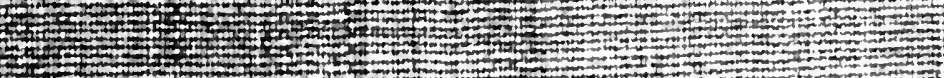

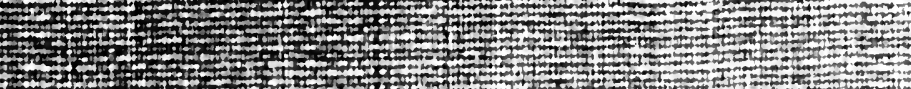

(4)

1)

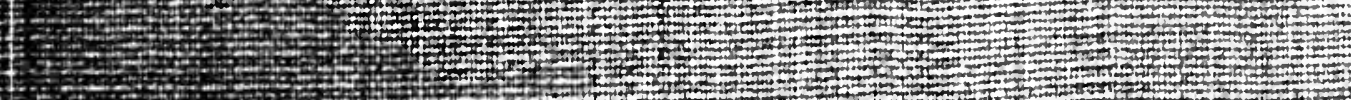

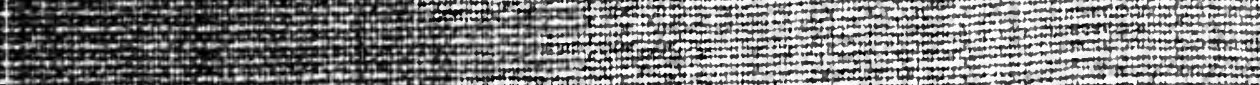

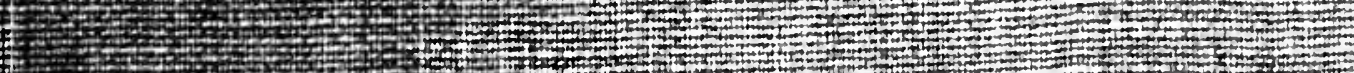

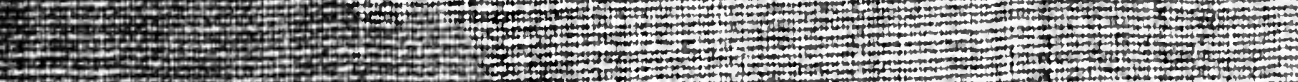

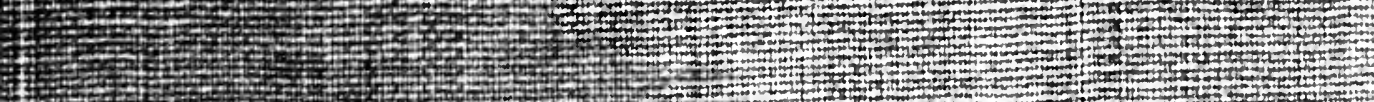

$+\frac{1}{2+1}$

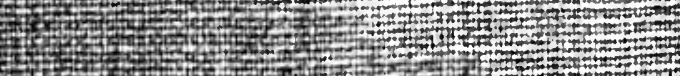

(1)

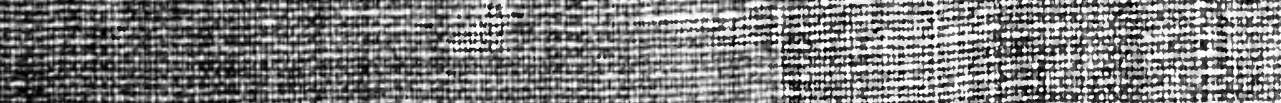

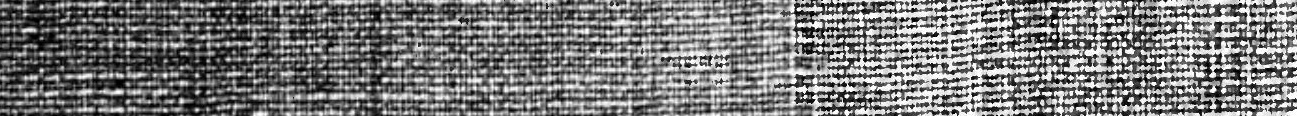

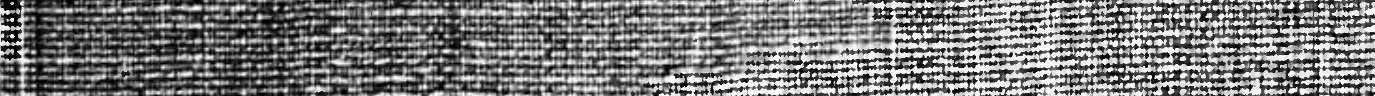

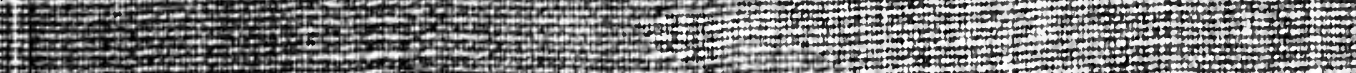

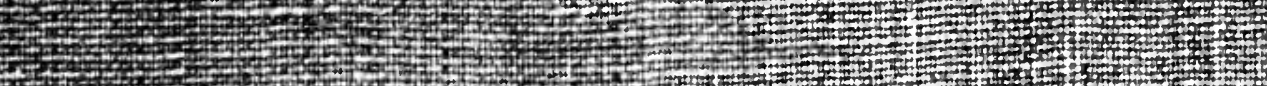

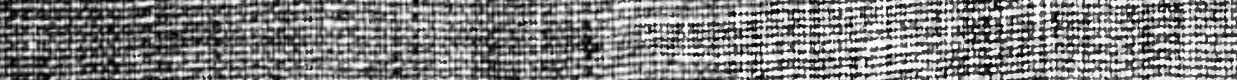

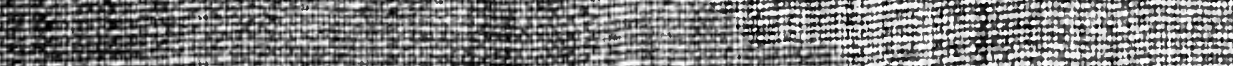

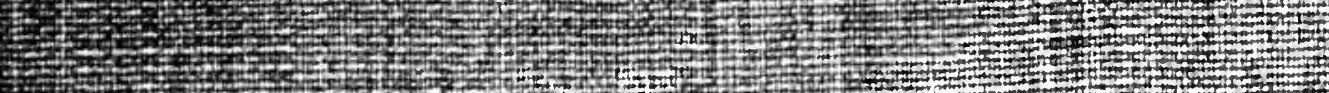

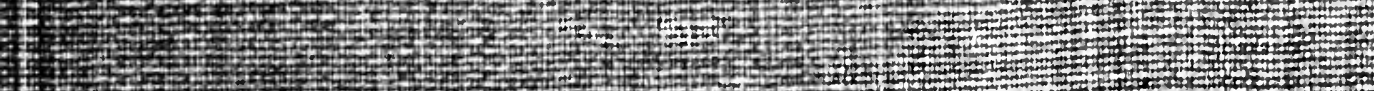

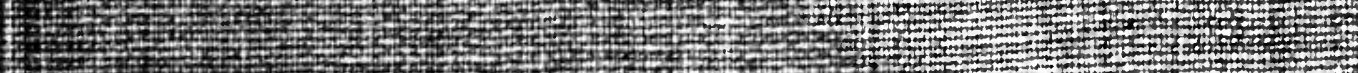

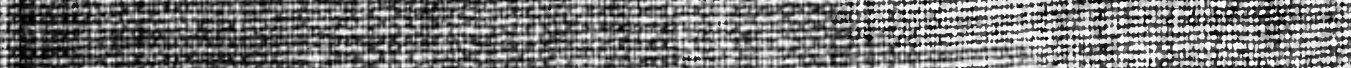

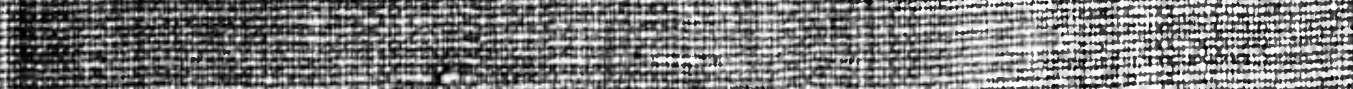

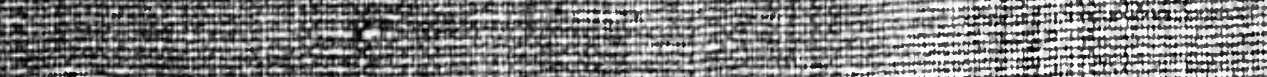

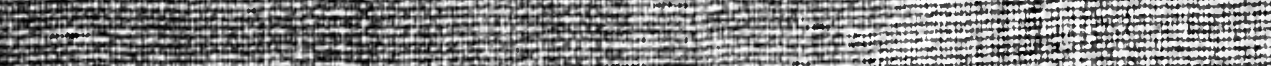

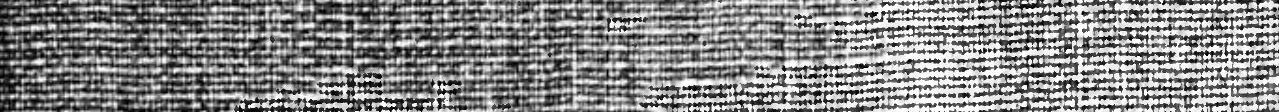

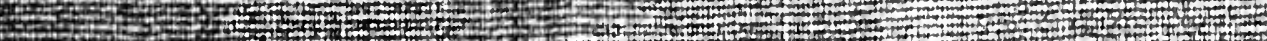

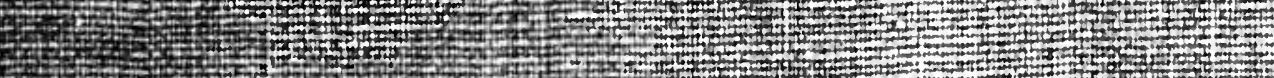

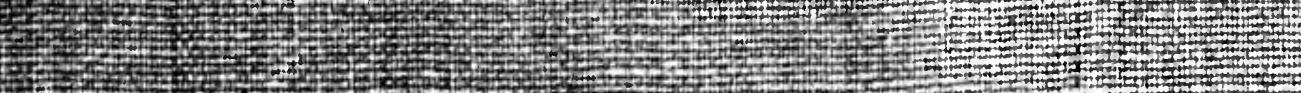

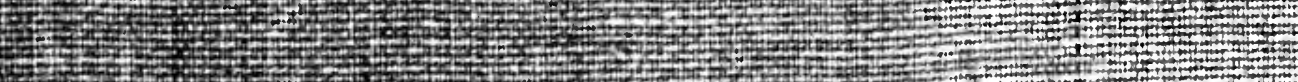

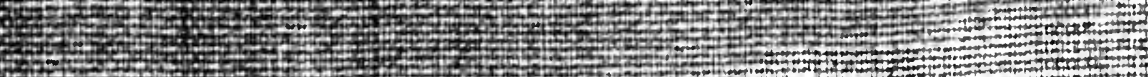

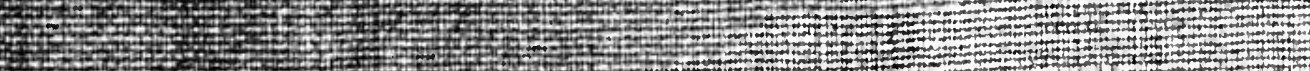
4.7.

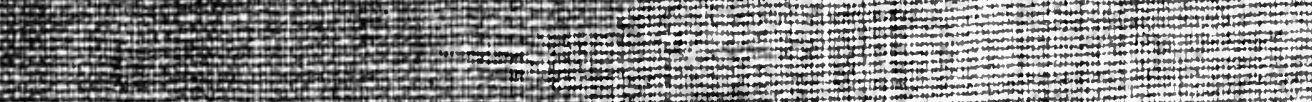

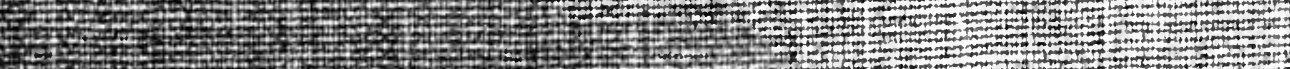

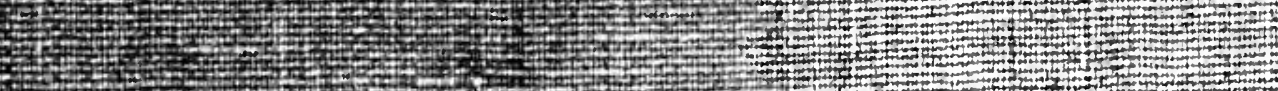

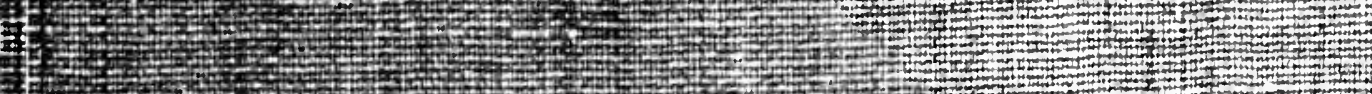




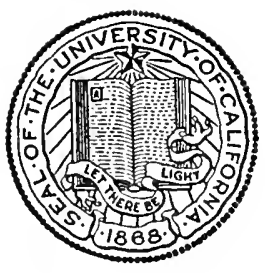

THE LIBRARY OF

\section{THE UNIVERSITY OF CALIFORNIA LOS ANGELES}

SCHOOL OF LAW

GIFT OF

Harold E. Ives 




$$
\begin{aligned}
& 1: 1 \cdot ? \\
& \text { y. }
\end{aligned}
$$

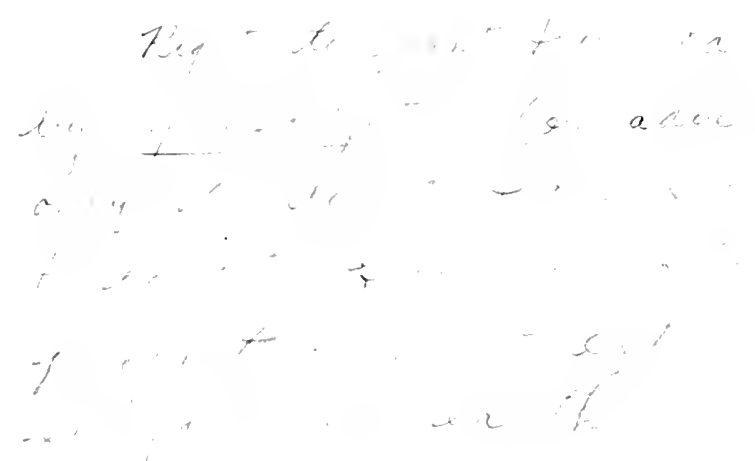

e 








\section{CASES ON THE LAW OF PROPERTY}

VOL. I. PERSONAL PROPERTY.

By Harry A. Bigelow, Professor of Law in the University of Chicago.

VOL. II. RIGHTS IN LAND.

By Harry A. Bigelow.

VOL. III. TITLES TO REAL PROPERTY.

By Ralph W. Aigler, Professor of Law in the Unirersity of Michigan.

VOL. IV. FUTURE INTERESTS.

By Albert M. Kales, of the Chicago Bar, formerly Professor of Law in Harvard Uiversity.

VOL. V. WILLS, DESCENT, AND ADMINISTRATION.

By George P. Costigan, Jr., Professor of Law in Northwestern University. 


\title{
CASES ON THE LAW OF PROPERTY
}

\author{
VOLUME 2
}

\section{INTRODUCTION TO THE LAW OF REAL PROPERTY}

\section{RIGHTS IN LAND}

\author{
BY HARRY A. BIGELOW
}

PRUFESSOR OF LA W IN THE ONIVERSITY OF CHICAGO

AMERICAN CASEBOOK SERIES

WILLIAM R. VANCE

GENERAL EDITOB

ST. PAUL

WEST PUBLISHING COMPANY 
Coprbight, 1919

BY

WEST PUBLISHING COMPANY

(2 Big.Prop.) 


\section{THE AMERICAN CASEBOOK SERIES}

THE first of the American Casebook Series, Mikell's Cases on Criminal Law, issued in December, 1908, contained in its preface an able argument by Mr. James Brown Scott, the General Editor of the Series, in favor of the case method of law teaching. Until 1915 this preface appeared in each of the volumes published in the series. But the teachers of law have moved onward, and the argument that was necessary in 1908 has now become needless. That such is the case becomes strikingly manifest to one examining three important documents that fittingly mark the progress of legal education in America. In 1893 the United States Bureau of Education published a report on Legal Education prepared by the American Bar Association's Committee on Legal Education, and manifestly the work of that Committee's accomplished chairman, William G. Hammend, in which the three methods of teaching law then in vogue-that is, by lectures, by text-book, and by selected cases-were described and commented upon, but without indication of preference. The next report of the Bureau of Education dealing with legal education, published in 1914, contains these unequivocal statements:

"To-day the case method forms the principal, if not the exclusive, method of teaching in nearly all of the stronger law schools of the country. Lectures on special subjects are of course still delivered in all law schools, and this doubtless always will be the case. But for staple instruction in the important branches of common law the case has proved itself as the best available material for use practically everywhere. *** The case method is to-day the principal method of instruction in the great majority of the schools of this country."

But the most striking evidence of the present stage of development of legal instruction in American Law Schools is to be found in the special report, made by Professor Redlich to the Carnegie Foundation for the Advancement of Teaching, on "The Case Method in American Law Schools." Professor Redlich, of the Faculty of Law in the University of Vienna, was brought to this country to make a special study of methods of legal instruction in the United States from the standpoint of one free from those prejudices necessarily engendered in American teachers through their relation to the struggle for supremacy so long, and at one time so vehemently, waged among the rival systems. From this masterly report, so replete with brilliant analysis and discriminating comment, the following brief extracts are taken. Speaking of the text-book method Professor Redlich says:

"The principles are laid down in the text-book and in the professor's lectures, ready made and neatly rounded, the predigested essence 
of many judicial decisions. The pupil has simply to accept them and to inscribe them so far as possible in his memory. In this way the scientific element of instruction is apparently excluded from the very first. Even though the representatives of this instruction certainly do regard law as a science-that is to say, as a system of thought, a grouping of concepts to be satisfactorily explained by historical research and logical deduction-they are not willing to teach this science, but only its results. The inevitable danger which appears to accompany this methed of teaching is that of developing a mechanical, superficial instruction in abstract maxims, instead of a genuine intellectual probing of the subject-matter of the law, fulfilling the requirements of a science."

Turning to the case method Professor Redlich comments as follows:

"It emphasizes the scientific character of legal thought; it goes now a step further, however, and demands that law, just because it is a science, must also be taught scientifically. From this point of view it very properly rejects the elementary school type of existing legal education as inadequate to develop the specific legal mode of thinking, as inadequate to make the basis, the logical foundation, of the separate legal principles really intelligible to the students. Consequently, as the method was developed, it laid the main emphasis upon precisely that aspect of the training which the older text-book school entirely neglected-the training of the student in intellectual independence, in individual thinking, in digging out the principles through penetrating analysis of the material found within separate cases; material which contains, all mixed in with one another, both the facts, as life creates them, which generate the law, and at the same time rules of the law itself, component parts of the general system. In the fact that, as has been said before, it has actually accomplished this purpose, lies the great success of the case method. For it really teaches the pupil to think in the way that any practical lawyer-whether dealing with written or with unwritten law-ought to and has to think. It prepares the student in precisely the way which, in a country of case law, leads to full powers of legal understanding and legal acumen; that is to say, by making the law pupil familiar with the law through incessant practice in the analysis of law cases, where the concepts, principles, and rules of Anglo-American law are recorded, not as dry abstractions, but as cardinal realities in the inexhaustibly rich, ceaselessly fluctuating, social and economic life of man. Thus in the modern American law school professional practice is preceded by a genuine course of study, the methods of which are perfectly adapted to the nature of the common law."

The general purpose and scope of this series were clearly stated in the original announcement:

"The General Editor takes pleasure in announcing a series of scholarly casebooks, prepared with special reference to the needs and limi- 
tations of the classroom, on the fundamental subjects of legal education, which, through a judicious rearrangement of emphasis, shall provide adequate training combined with a thorough knowledge of the general principles of the subject. The collection will develop the law historically and scientifically; English cases will give the origin and development of the law in England; American cases will trace its expansion and modification in America; notes and annotations will suggest phases omitted in the printed case. Cumulative references will be avoided, for the footnote may not hope to rival the digest. The law will thus be presented as an organic growth, and the necessary connection between the past and the present will be obvious.

"'The importance and difficulty of the subject as well as the time that can properly be devoted to it will be carefully considered so that each book may be completed within the time allotted to the particular subject. *** If it be granted that all, or nearly all, the studies required for admission to the bar should be stiidied in course by every student-and the soundness of this contention can hardly be seriously doubted-it follows necessarily that the preparation and publication of collections of cases exactly adapted to the purpose would be a genuine and by no means unimportant service to the cause of legal education. And this result can best be obtained by the preparation of a systematic series of casebooks constructed upon a uniform plan under the supervision of an editor in chief.

"'The preparation of the casebooks has been intrusted to experienced and well-known teachers of the various subjects included, so that the experience of the classroom and the reeds of the students will furnish a sound basis of selection."

Since this announcement of the Series was first made there have been published books on the following subjects:

Administrative Lare. By Ernst Freund, Professor of Law in the University of Chicago.

Agency. By Edwin C. Coddard, Professor of Law in the University of Michigan.

Bills and Notes. Second Edition. By Howard I. Smith, Professor of Law in the University of $\mathrm{Misconsin,} \mathrm{and} \mathrm{Lnderhill} \mathrm{Moore,} \mathrm{Pro-}$ fessor of Law in Columbia Lniversity.

Carricrs. By Frederick Green, Professor of Law in the University of Illinois.

Conflict of Lau's. By Ernest G. Lorenzen, Professor of Law in Yale University.

Constitutional Laa'. Py Tames Parker Hall, Dean of the Faculty of Law in the University of Chicago.

Contracts. By Arthur L. Corbin, Professor of Law in Yale Lniversity. 
Corporations. By Harry S. Richards, Dean of the Faculty of Law in the University of Wisconsin.

Criminal Laze. By William E. Mikell, Dean of the Faculty of Law in the University of Pennsylvania.

Criminal Procedure. By William E. Mikell, Dean of the Faculty of Law in the University of Pennsylvania.

Damages. By Floyd R. Mechem, Professor of Law in the University of Chicago, and Barry Gilbert, of the Chicago Bar.

Equity. By George H. Boke, formerly Professor of Law in the University of California.

Equity. By Walter Wheeler Cook, Professor of Law in Yale University. Volume 1. Volumes 2 and 3 in preparation.

Eicidence. By Edward W. Hinton, Professor of Law in the University of Chicago.

Insurance. Py William R. Vance, Professor of Law in Yảle University.

International Lazc. By James Brown Scott, Lecturer on International Law and the Foreign Relations of the United States in the School of Foreign Service, Georgetown University.

Legal Ethics, Cases and Other Authorities on. By George P. Costigan, Jr., Professor of Law in the University of California.

Partnership. By Eugene A. Gilmore, Professor of Law in the University of Wisconsin.

Persons (including Marriage and Divorce). By Albert M. Kales, late of the Chicago Bar, and Chester G. Vernier, Professor of Law in Stanford University.

Pleading (Common Law). By Clarke B. Whittier, Professor of Law in Stanford University, and Edmund M. Morgan, Professor, of Law in Yale University.

Property (Future Interests). By Albert M. Kales, late of the Chicago Bar.

Property (Personal). By Harry A. Bigelow, Professor of Law in the University of Chicago.

Property (Rights in Land). By Harry A. Bigelow, Professor of Law in the University of Chicago.

Property (Titles to Real Property). By Ralph W. Aigler, Professor of Law in the University of Michigan.

Property (IVills, Descent, and Administration). By George P. Costigan, Jr., Professor of Law in the University of California.

Quasi Contracts. By Edward S. Thurston, Professor of Law in Yale University.

Sales. By lirederic C. Woodward, Professor of Law in the University of Chicago. 
Suretyship. By Crawford D. Hening, formerly Professor of Law in the University of Pennsylvania.

Torts. By Charles M. Hepburn, Dean of the Faculty of Law in the University of Indiana.

Trade Regulation. By I Ierman Oliphant, Professor of Iaw in Columbia University.

Trusts. By Thaddeus D. Kenneson, Professor of Law in the University of New York.

It is earnestly hoped and believed that the books thus far published in this series, with the sincere purpose of furthering scientific training in the law, have not been without their influence in bringing about a fuller understanding and a wider use of the case method.

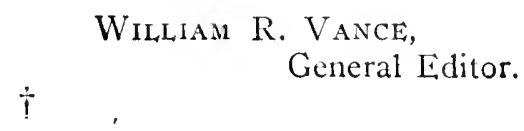


$-28$ 


\section{INTRODUCTION}

TO

\section{THE LAW OF REAL PROPERTY}

\section{BY HARRY A. BIGELOW}

PBOFEssor OF LA. W IN THE UNIVERSITY OF CHICAgO

AMERICAN CASEBOOK SERIES

WILIMAI R. VANCE

GENCRAL EDITOR

ST. PAUL

WEST PUBLISHING COMPANX

1919 
Copyright, 1919

$\mathrm{BY}$

WEST PUBLISHING COMPANT

(Big.Int.) 
TO

THE SILENT PARTNER

(i1i) 


\section{AUTHOR'S PREFATORY NOTE}

Tris treatise has been written with the thought constantly in mind that it is to serve as the medium by which students, either wholly ignorant of law or at best with a slight knowledge of it, are to begin the study of one of its most difficult branches. Such students require above all else simplicity of statement and an easily understandable outline, that will furnish a background against which the instructor can fill in details and refinements as the capacity of the class permits. Consequently the doctrines of the older law have been stated simply, and as far as possible in nontechnical language. The extent to which they are to be expanded is a matter that the instructor will settle for himself.

The treatise is only an introduction to the law of real property in another sense, viz., it stops substantially with the 18th century law. No attempt has been made to do more than hint at the modern developments of the law of property. To go further would be to encroach upon the function of the various volumes that make up the series to which this is a preface.

Tine University of Chicago Law School,

HARRY A. BighLow. July 17, 1919.

(iv) 


\section{TABLE OF CONTENTS}

\section{CHAPTER I}

The H'teudal System

Section

1. Introduction $\ldots \ldots \ldots \ldots \ldots \ldots \ldots \ldots \ldots \ldots \ldots \ldots \ldots \ldots \ldots \ldots \ldots \ldots \ldots$

2. Military Tenure............................... 4

3. Socage Tenure.............................. 8

4. Frankalmoyn Tenure.... $\ldots \ldots \ldots \ldots \ldots \ldots \ldots \ldots \ldots \ldots$

5. Copyhold Tenure................................ 10

6. Statutory Changes in the Feudal System................... 11

7. Tenure in the United States....................... 17

\section{CHAPTER II}

\section{Estates}

1. Introduction $\ldots \ldots \ldots \ldots \ldots \ldots \ldots \ldots \ldots \ldots \ldots \ldots \ldots \ldots \ldots \ldots \ldots \ldots \ldots \ldots$

2. Fees Simple.................................. 19

3. Fees Conditional and Fees Tail...................... 22

4. Determinable Fees............................. 25

5. Estates for Life................................ 26

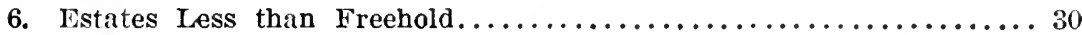

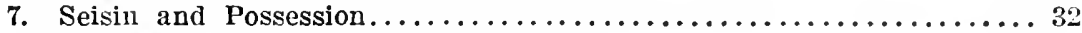

8. Transfer on Seisin and Possession..................... 34

\section{CHAPTER III}

\section{NONPOSSESSORY INTERESTS IN LAND}

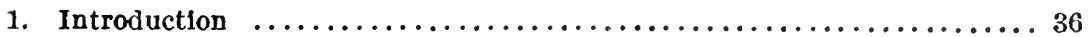

2. Reversions and Remainders........................ 38

3. Conditional Limitations and Rights of Entry...............43

4. Incorporeal Hereditaments..........................44

5. Conveyance of Incorporeal Interest...................... 44

6. Other Species of Conveyances......................... 46

\section{CHAP'TER IV}

JOINT OWNERSHIP

\section{CHAPTER V}

Disseisin and the Remedies Therefor.................. 5s

\section{CHAPTER VI}

Uges and TBUSTB................................66

Big.INT.

(v) 


\section{TABLE OF STATUTES}

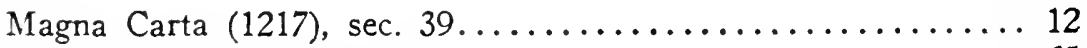

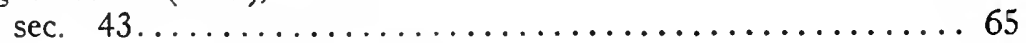

13 Edw. I, c. 1, De Donis (1285) ................... 22

$18 \mathrm{Edw}$. I, c. 1, 3, Quia Emptores (1290).............. 12

15 Rich. II, c. 5, Mortmain Statute (1391)...............66 66

1 Rich. III, c. 1, Statute of Uses (1483)............... 71

27 Hen. VIII, c. 10, Statute of Uses (1536)............ 72

27 Hen. VIII, c. 16, Statute of Enrollments (1536).......... 76

12 Car. II, c. 24, Statute Abolishing the Court of Wards and Liv-

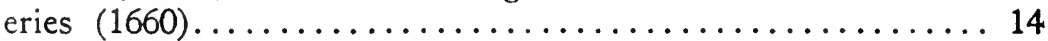

29 Car. II, c. 3, Statute of Frauds (1676) secs. 1, 2........ 35

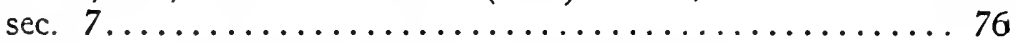

4 Anne, c. 16, sec. 9, Statute of Attornment (1705).......... 45

8 \& 9 Vict. Statute Regulating Conveyances (1845).......... 35

Bia.INT.

(vi) 


\section{TABLE OF CASES}

[TITLES OF CASES CITED IN FOOTNOTES ARE INDICATED BY ITALICS. WIERE SAALL CAPITALS ARE USED, THE CASE IS REFERRED TO IX THE TEXT]

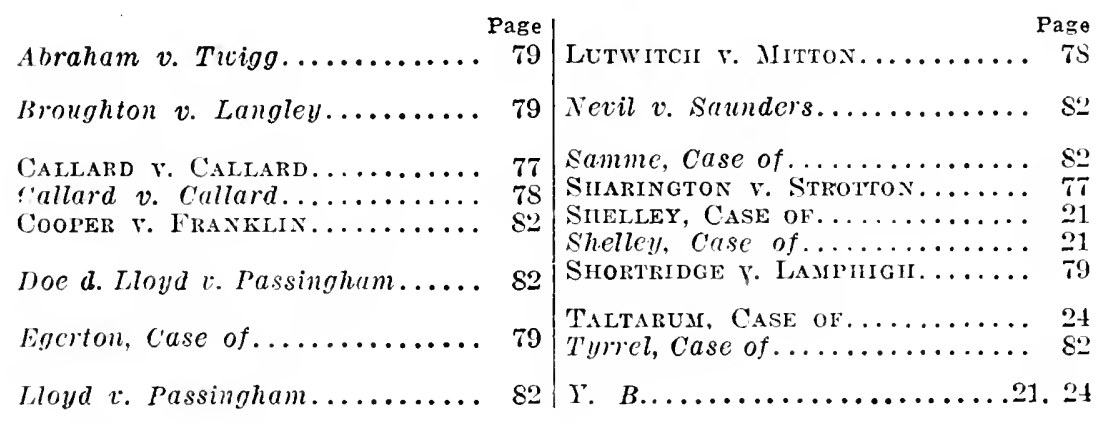

Brg.INT.

(vii) 
ious to the new ruling classes, were probably for the most part not at all affected so far as their physical occupation of the soil was concerned. At the same time it is true that as a result of the Conquest, with the killing off of a considerable part of the higher English landowning classes, large blocks of land came into the immediate possession of the king. Furthermore, he succeeded by right of conquest to all the lands owned by the Saxon king, and other large amounts came into his possession by forfeiture, following the unsuccessful rebellions of the English nobility. These lands aggregated an amount which it was clearly impossible for the king to keep in his immediate personal possession. It was also desirable that such an organization should be put on foot as would enable him to retain the conquest that he had made. As a consequence of these facts the king parceled out large tracts of land among his immediate personal followers. These men, in turn, parceled out the large tracts so allotted to them, in smaller tracts, among their immediate personal followers; and this process was repeated in a descending scale. Naturally these holdings would be allotted upon terms, the most needful provisions in which would be that the one to whom the allotment was made would assist the one from whom the allotment was received in keeping control of his other property, or render him some other service therefor. The allotter in turn would promise to help the allottee in retaining his land so long as he kept faith, and to give him other lands if he were ousted from those given. These reciprocal relations of help and service culminated, as has been already said, in the king. The allotments thus made in the manner above outlined were technically known as fiefs, or feuds.

Another element that entered into the formation of the English feudal system was the fact that in a state of society where life and property were none too secure the small landholder would find it almost imperative to put himself under the protection of some more powerful individual. Consequently, where there was no forfeiture of land, it is probable that in many cases the small landowner would "commend" himself to some neighboring lord. This involved the acknowledgment of the fact that the person so commending himself became "the man" of the lord and that he held his lands under him.

The effect of these two forces. was that by the time of Henry II (1154-1189) the system of landholding in England was fairly definitely established. It may, roughly, be compared to a pyramid: At the summit of the pyramid was the king, who was, in legal theory, the owner of all land in England. Immediately under him were the great lords of the kinglown, holding the large tracts of land in the manner already mentioned. These tenants immediately under the king later received the name of "tenants in capite." Under the tenants in capite were various grades of intermediate or mesne tenants, and at the bottom of the pyramid may be said to be the tenants who were in actual occu- 
pation of the land, either personally or by their servants. Just what the relation was between these tenants in occupation and the actual tillers of the soil will be considered more in detail subsequently. Thus it may be said that, except for the highest and lowest grades, each person occupied a double relation. With respect to the person below him he was a lord; with respect to the person under whom he was holding he was a tenant, owing fealty and faith and feudal services, and entitled to receive protection from his lord.

The creation of this relation of lord and tenant was accompanied by certain formalities which seem to have been regarded as of great significance, viz., the doing of homage and the swearing of fealty. In the former ceremony the tenant knelt unarmed, ungirt, and bareheaded before his lord, put his hands in the hands of his lord, and acknowledged that he became the lord's man, and that he held his land of him and would faithfully perform his obligations as such tenant. Swearing fealty was a less ceremonious performance. The tenant stood before his lord and solemnly swore that he would bear faith and perform his obligations as a loyal tenant. Turning from the formalities of the creation of lord and tenant to the nature of the rights created thereby in the land which the tenant received from his lord, it is to be noticed, and this is one of the striking peculiarities of the feudal system of landholding, that each tenant and lord, although there might be with respect to any given piece of land four or five individuals in an ascending scale from the tenant to the king, was regarded as having a property interest in the land. The one in possession was said to be seised in his demesne. The others under whom he held were said to be seised in service. This relation between the lord and the tenant with respect to the land was technically known as tenure. There were various species of tenure, and these it is now necessary to examine. The first distinction that is to be noticed in this regard is the distinction between free tenure and villain or servile tenure. The free ten. ures were of three sorts: Military; socage; frankalmoyn. ${ }^{1}$

1 On the introduction of the feudal system into England, see 2 Blackstone, Commentaries, ch. IV ; 1 Pollock \& Maitland, History of the English Law (2d Ed.) pp. 66-73; 2 Id. pp. 232-240; Digby, Hist. of the Law of Real Prop. (5th Ed.) pp. 29-38. 


\section{SECTION 2.-MILITARY TENURE}

Military tenure was considered to be at once the most onerous and the most honorable form of tenure. The most common form of military tenure was tenure by knight service. It could exist only if the tenant held at least a minimum amount of land, called a knight's fee, and the holding involved the obligation upon the part of the tenant to serve the king in battle for a certain number of days per year, dependent upon the extent of his holding. The fundamental characteristic of knight service, and indeed of all military tenures, was the uncertainty of the obligation. In practice, this obligation of personal service by the tenant in knight service was, after a comparatively short time, found to be unsatisfactory from a military point of view, and in the time of Henry II the obligation was commuted into a money payment, called scutage, proportioned to the amount of land held. The tenure is sometimes referred to as scutage tenure for this reason.

In addition to this fundamental obligation of military service, there were a number of other obligations, or incidents, as they were technically called, which belonged to military tenure. These various incidents are well described by Blackstone:2

"This tenure of knight service $* * *$ was perfected by homage and fealty. It also drew after it these seven fruits and consequences, as inseparably incident to the tenure in chivalry, viz. aids, relief, primer seisin, wardship, marriage, fines for alienation, and escheat: All which I shall endeavour to explain, and to shew to be of feodal original.

"1. Aids were originally mere benevolences granted by the tenant to his lord, in times of difficulty and distress; but in process of time they grew to be considered as a matter of right, and not of discretion. These aids were principally three: First, to ransom the lord's person, if taken prisoner; a necessary consequence of the feodal attachment and fidelity: insomuch that the neglect of doing it, whenever it was in the vassal's power, was by the strict rigour of the feodal law an absolute forfeiture of his estate. Secondly, to make the lord's eldest son a knight; a matter that was formerly attended with great ceremony, pomp, and expense. This aid could not be demanded until the heir was fifteen years old, or capable of bearing arms: the intention of it being to breed up the eldest son and heir apparent of the seignory, to deeds of arms and chivalry, for the better defence of the nation. Thirdly, to marry the lord's eldest daughter, by giving her a suitable portion. 
“2. Relief, relevium, was before mentioned as incident to every feodal tenure, by way of fine or composition with the lord for taking up the estate which was lapsed or fallen in by the death of the last tenant. But though reliefs had their original while feuds were only life estates, yet they continued after feuds became hereditary; and were therefore looked upon, very justly, as one of the greatest grievances of tenure: especially when, at the first, they were merely arbitrary and at the will of the lord; so that, if he pleased to demand an exorbitant relief it was in effect to disinherit the heir. *** But afterwards $* * *$ the composition was universally accepted of 100s. for every knight's fee; as we find it ever after established. But it must be remembered, that this relief was only then payable, if the heir at the death of his ancestor had attained his full age of one-and-twenty years.

"3. Primer seisin was a feodal burthen, only incident to the king's tenants in capite, and not to those who held of inferior or mesne lords. It was a right which the king had, when any of his tenants in capite died seised of a knight's fee, to receive of the heir (provided he were of full age) one whole year's profits of the lands, if they were in immediate possession: and half a year's profits, if the lands were in reversion expectant on an estate for life. This seems to be little more than an additional relief, but grounded upon this feodal reason: That by the ancient law of feuds, immediately upon the death of a vassal, the superior was entitled to enter and take seisin or possession of the land, by way of protection against intruders, till the heir appeared to claim it, and receive investiture: during which interval the lord was entitled to take the profits; and unless the heir claimed within a year and a day, it was by the strict law a forfeiture. This practice however seems not to have long obtained in England, if ever, with regard to tenure under inferior lords; but as to the king's tenures in capite, the prima seisina was expressly declared, under Henry III and Edward II, to belong to the king by prerogative. in contradistinction to other lords. The king was entitled to enter and receive the whole profits of the land, till livery was sued; which suit being commonly made within a year and day next after the death of the tenant, in pursuance of the strict feodal rule, therefore the king used to take as an average the first fruits, that is to say, one year's profits of the land.

"4. These payments were only due if the heir was of full age; but if he was under the age of twenty-one, being a male, or fourteen, being a female, the lord was entitled to the wardship of the heir, and was called the guardian in chivalry. This wardship consisted in having the custody of the body and lands of such heir, without any account of the profits, till the age of twenty-one in males, and sixteen in females. For the law supposed the lieir male unable to perform knight service till twenty-one; but as for the female, she was sipposed capable at fourteen to marry, and then her husband might per- 
form the service. The lord therefore had no wardship, if at the death of the ancestor the heir male was of the full age of twentyone, or the heir female of fourteen; yet, if she was then under fourteen, and the lord once had her in ward, he might keep her so till sixteen, by virtue of the statute of Westm. I, Edw. I, c. 22, the two additional being given by the legislature for no other reason but merely to benefit the lord.

"This wardship, so far as it related to land, though it was not nor could be part of the law of feuds, so long as they were arbitrary, temporary, or for life only; yet when they became hereditary, and did consequently often descend upon infants, who by reason of their age could neither perform nor stipulate for the services of the feud, does not seem upon feodal principles to have been unreasonable. For the wardship of the land, or custody of the feud, was retained by the lord, that he might out of the profits thereof provide a fit person to supply the infant's services, till he should be of age to perform them himself. And if we consider the feud in its original import, as a stipend, fee, or reward for actual service, it could not be thought hard that the lord should withhold the stipend, so long as the service was suspended. ***

"When the male heir arrived to the age of twenty-one, or the heir female to that of sixteen, they might sue out their livery or ousterlemain; that is the delivery of their lands out of their guardian's hands. For this they were obliged to pay a fine, namely, one half a year's profit of the land; though this seems expressly contrary to Magna Carta. However, in consideration of their lands having been so long in ward, they were excused all reliefs, and the king's tenants also all primer seisins.

"5. But, before they came of age, there was still another piece of authority, which the guardian was at liberty to exercise over his infant wards; I mean the right of marriage (maritagium, as contradistinguished from matrimony), which in its feodal sense signifies the power, which the lord or guardian in chivalry had of disposing of his infant ward in matrimony. For, while the infant was in ward, the guardian had the power of tendering him or her a suitable match, without disparagement or inequality; which if the infants refused, they forfeited the value of the marriage, valorem maritagii, to their guardian; that is, so much as a jury would assess, or any one would bona fide give to the guardian for such an alliance; and, if the infants married themselves without the guardian's consent, they forfeited double the value, duplicem valorem maritagii. This seems to have been one of the greatest hardships of our ancient tenures. There were indeed substantial reasons why the lord should have the restraint and control of the ward's marriage, especially of his female ward; because of their tender years, and the danger of such female ward's intermarrying with the lord's enemy; but no tolerable pre- 
tence could be assigned why the lord should have the sale or value of the marriage.

"6. Another attendant or consequence of tenure by knight service was that of fines due to the lord for every alienation, whenever the tenant had occasion to make over his land to another. This depended on the nature of the feodal connexion; it not being reasonable or allowed, as we have before seen, that a feudatory should transfer his lord's gift to another, and stbstitute a new tenant to do the service in his own stead, without the consent of the lord: and, as the feodal obligation was considered as reciprocal, the lord also could not alienate his seignory without the consent of his tenant, which consent of his was called an attornment. This restraint upon the lords soon wore away; that upon the tenants continued longer. * * *

"7. The last consequence of tenure in chivalry was escheat; which is the determination of the temure, or dissolution of the mutual bond between the lord and tenant from the extinction of the blood of the latter by either natural or civil means: if he died without heirs of his blood, or if his blond was corrupted and stained by commission of treason or felony; whereby every inheritable quality was entirely blotted out and abolished. In such cases the lands escheated, or fell back to the lord of the fee: that is, the tenure was determined by breach of the original condition expressed or implied in the feodal donation. In the one case there were no heirs subsisting of the blood of the first feudatory or purchaser, to which heirs alone the grant of the feud extended; in the other, the tenant, by perpetrating an atrocious crime, shewer that he was no longer to be trusted as a vassal, having forgotten his duty as a subject: and therefore forfeited his feud, which he held under the implied condition that he should not be a traitor or a felon. The consequence of which in both cases was, that the gift, being determined, resulted back to the lord who gave it."

Another species of military tenure was tenure by grand serjeanty. The tenant so holding was bound to attend personally upon the king for some service, such as carrying his banner or bearing his sword. ${ }^{3}$

3 On military tenures see 2 Poll. \& Mait. op. cit. pp. 252-290, 307-329; Williams, Real Prop. (20th Ed.) pp. 45-50; Coke's Iittleton, 74b-S5a. 


\section{SECTION 3.-SOCAGE, TENURE}

Just as the tenure already discussed was a military tenure, based on the rendering of military services and existent chiefly among the nobility, or what would in later years have been called the landed gentry, so it may be said, broadly speaking, that socage tenure was an agricultural tenure, and was, for the most part confined to the lower grades of society. The term "socage tenure" has been variously derived from the old French "soc," meaning a plow, or from the AngloSaxon "socn," meaning jurisdiction.

For a better understanding of the scope and nature of the socage tenure it will be necessary to consider briefly the place occupied in the feudal law by the institution of the manor. The manorial organization in substance, if not under that name, was undoubtedly very much older than the Norman Conquest. In a simple and largely agricultural organization of society, where means of communication were few and imperfect, and where a large part of the population lived and died in the same place in which it was born, the natural unit, outside of the family, would tend to be the village or township center, ordinarily controlled and protected by some lord. It was these units to which the name "manor" was subsequently given, and the legal aspects of which were worked out by the Anglo-Norman lawyers.

A complete manor in the technical sense of the word may be said to have two aspects: A territorial, and a jurisdictional. On the territorial side it may be said that the lands embraced in a given manor were of various sorts. There was, first, the demesne, upon which dwelt the lord of the manor or his bailiff. The demesne land also embraced a certain portion of arable land upon which were raised the crops for the lord's own use and profit. Next, there were large tracts of land upon which dwelt the tenants of the manor. These tenants were freemen. They held their tracts under the lord of the manor and owed him services and fealty therefor; but only in the same sense that their lord in turn held from his overlord in the way that has already been described. In some cases these tenants held by military tenure. In others the services or returns that the freeholders had to render to their lord for the lands so held under him consisted of agricultural services of a fixed character, on the demesne land; in other cases of a payment in kind; and in others, of a money payment, the former not infrequently being commuted into the latter. These are the origins and fundamental characteristics of tenancy in socage, and the distinguishing feature of this tenancy, as contrasted with military tenancy, is the certainty of the services which had to be rendered as a return for the land held.

A third portion of the manor consisted of the so-called common 
land. In these the tenants of the manor had certain rights of pasturing their cattle, of cutting firewood, and the like. It is in this aspect of manorial life that we find the beginnings of the modern law of easements and profits.

In addition to the freehold tenants above described, there were also, upon many manors, a class of unfree, or servile, tenants. The characteristics of their holding will be referred to subsequently in another connection.

Turning to the jurisdictional aspect of the manorial organization, it should be noticed that there were two manorial courts. There was, first, the court baron. This was presided over by the lord of the manor and attended by the freeholders of the manor, whose duty it was to act as jurors and judges in the cases brought before them. The activities of the court were concerned mainly with the settlement of disputes relating to the land of the freeholders comprised in the manor. In the manors on which were found the servile tenants, to which reference has already been made, there existed a second and lower branch of the court baron. This is ordinarily called the customary court baron, to distinguish it from the freeholders' court. The functions of the customary court were to settle the land rights of the servile tenants and other similar questions. In addition to what may be called these civil manorial courts, there was also the court leet. which had a jurisdiction over crimes committed within the manor. ${ }^{4}$

After this digression into the subject of the manor we may return to a consideration of socage tenure. As regards the feudal incidents attendant upon socage tenure, only this need be said. The tenant owed fealty to the lord; homage was rarely an incident of socage tenure. Aids and relief were incidents, but their amount was fixed at one year's rent of the land. Tenants in capite in socage were also subject to primer seisin; and the incident of escheat also obtained in this tenure. The most important difference in this regard betwcen military and socage tenure, and the one that made socage tenure distinctly more advantageous to the tenant, was that the incident of marriage did not exist at all. The incident of wardship existed, but the guardian was accountable to the ward for all the profits derived from the land.

While socage tenure was largely an agricultural tenure, there were nevertheless other socage tenures, so classified because of the certainty of the services to be rendered. These should be briefly noticed:

In many of the towns in England the tenants held from their lord by a species of socage tenure called "burgage tenure," or "borough English." The characteristic feature of borough English was that the lands descended to the youngest son, instead of either to the oldest or to all the sons equally. Another species of socage tenure was the so-called "gavelkind tenure." The characteristics of this tenure are

4 On the manor see Digby, op. cit. pp. 43-45, 49-56; 1 Poll. \& Mait. op. cit. pp. $59 t-634$. 
four: The lands (1) descended to all the sons equally; (2) were devisable by will; (3) did not escheat in case of attainder for felony; (4) could be aliened by the tenant when he reached fifteen.

Another form of socage tenure was "petty serjeanty." The holder under this form of tenure had the obligation to render annually to the king some article, such as a horse or a spear, in return for the land held by him. ${ }^{5}$

\section{$\underline{-}^{\cdot}$ \\ SECTION 4.-FRANKALMOYN TENURE 2ireed}

This tenure was a religious tenure. It antedates the Conquest, and was the tenure upon which many of the monasteries and religious houses in England held their lands. There were no feudal incidents attached thereto. As a result of the statute of Quia Emptores, referred to later, no tenancy in frankalmoyn could be created after the date of that statute, except by the king. ${ }^{\circ}$

\section{SECTION 5.-COPYHOLD TENURE}

In the discussion of the manor it was mentioned that, in addition to the free tenants upon the manors, there was another class of tenants. This other class of tenants held by a servile tenure. The essence of the tenure seems to have been that the extent of their obligation was originally undefined and largely dependent upon the will of the lord. Another characteristic was that originally their lands were held at the will of the lord and they could be at any time turned out of them. In the course of time, however, the extent of their obligation became more or less exactly defined by custom, and their rights to retain possession of the land so long as they fulfilled their obligations also became recognized. The only evidence, however, of the nature of their obligations or the extent of their interest in their land, was in the copy of the rolls of the manor. Hence the origin of the term "copyhold," which is applied to this species of tenure. The only method whereby the copyhold tenant could transfer his land was to surrender his land to his lord, with the request that his purchaser be inducted into the land. A certain amount of land is

${ }_{5}^{5}$ On socage tenure see 2 Bl. op. cit. pp. 79-92; Digby, op. cit. pp. 47-49); 2 Poll. \& Mait. 291-307; Williams, op. cit. pp. 49-53; Coke, littleton, S5b-93b.

6 On frankalmoyn see Co. Lit., 93b-100b; 2 Poll. \& Jait. op. cit. pp. 240251; 2 Bl. op. cit. pp. 101, 102. 
still held in England by copyhold tenure, although at the present time all servile incidents or uncertainties of obligation in respect thereto have long since passed away. ${ }^{\text {? }}$

\section{SECTION 6.-STATUTORY CHANGES IN THE FEUDAL SYSTEM}

The earlier history of the growth of the law with respect to the power of the tenant to alien his lands is a matter with respect to which considerable doubt exists. It is by no means certain whether for the first two hundred years after the Norman Conquest the growth was toward a restriction of the power of alienation, or toward a development of freedom in the power of alienation. It seems reasonably certain that by the time of Henry II the power of the tenant to alien his lands, subject to the payment of the ordinary fines, was definitely established.

Land may be alienated in one of two ways: For example, if A. is the lord and $\mathrm{B}$. is the tenant, $\mathrm{B}$. may alienate his complete interest to C. This may be calied alienation by substitution. Since the services were regarded as being due from the land, an alienation of this sort would not deprive A., as cverlord, of any of his feudal dues. At the same time, however, he might be prejudiced in the personality of the tenant by the change from one favorably disposed to him to one not so favorably disposed. More than this, if B. alienated his land to several different persons, instead of to one person, there would be more difficulty on the part of $\mathrm{A}$. in collecting his feudal dues.

In comparison with the case just above put, B., the feudal tenant of A., instead of conveying to $\mathrm{C}$. all his possible interests in the land, and thereby substituting $\mathrm{C}$. in his place, might convey the land to $\mathrm{C}$. in perpetuity, but at the same time reserve from $\mathrm{C}$. certain obligations to himself; $\mathrm{B}$. thereby interposing himself as a mesne lord between A. and $\mathrm{C}$., so that $\mathrm{C}$. would hold his lands and be in a tenure relation, not to A., but to B. This is known as alienation by subinfeudation. It would not affect the personal relations between $A$. and B., nor would it cut off the feudal obligations owed to A. by the linrl. But it nevertheless might seriously prejudice $A$. in the niost valuable of his feudal rights. Suppose, for example, that B. should convey the land to C.. subject only to the obligation to pay one penny yearly. If, now, B. should die, leaving only a minor heir, A. would have his right of wardship. But, instead of being entitled under it to take possession of the land and get what he could from it, all he would be entitled

7 On ropyhold see 1 Poll. \& Mait. on. cit. pp. 356-38u; Digby, op. cit. Ill. $152,153,258-295 ; 2$ Bl. op. cit. pp. 90-101. 
to would be the one penny per annum. So, again, if B. died without heirs, so that his interest would escheat to A., the only subject-matter of the escheat would be the reservation of one penny per annum.

The first legislation that seems to have been passed directed against this state of affairs is found in Magna Carta (1217), which provides (section xxxix): "No freeman from henceforth shall give or sell any more of his land, but so that of the residue of the lands the lord of the fee may have the services due to him which belong to the fee."

Apparently this provision was not regarded as an adequate settlement of the matter. The subject was definitely settled by legislation in the reign of Edward I. - In the year 1290 was passed the statute of Quia Emptores. It read as follows:

"Forasmuch as purchasers of lands and tenements of the fees of great men and other lords have many times heretofore entered into their fees, to the prejudice of the lords, to whom the freeholders of such great men have sold their lands and tenements to be holden in fee of their feoffors and not of the chief lords of the fees, whereby the same chief lords have many times lost their escheates, marriages, and wardships of lands and tenements belonging to their fees, which thing seems very hard and extreme unto those lords and other great men, and moreover in this case manifest disheritance, our lord the king in his parliament at Westminster after Easter the eighteenth year of his reign, that is to wit in the quinzine of Saint John Baptist, at the instance of the great men of the realm granted, provided, and ordained, that from henceforth it should be lawful to every freeman to sell at his own pleasure his lands and tenements or part of them, so that the feoffee shall hold the same lands or tenements of the chief lord of the same fee, by such service and customs as his feoffor held before.

"c. 2. And if he sell any part of such lands or tenements to any, the feoffee shall immediately hold it of the chief lord, and shall be forthwith charged with the services for so much as pertaineth or ought to pertain to the said chief lord, for the same parcel, according to the quantity of the land or tenement so sold; and so in this case the same part of the service shall remain to the lord, to be taken by the hands of the feoffee, for the which he ought to be attendant and answerable to the same chief lord according to the quantity of the land or tenement sold for the parcel of the service so due.

"c. 3. And it is to be understood that by the said sales or purchases of lands or tenements, or any parcel of them, such lands or tenements shall in no wise come into mortmain, either in part or in whole, neither by policy ne craft, contrary to the form of the statute made thereupon of late. And it is to wit that this statute extendeth but only to lands holden in fee simple, and that it extendeth to the time coming. And it shall begin to take effect at the Feast of Saint Andrew the Apostle next coming." 
The effects of this statute may be briefly summarized as follows:

1. It allowed complete alienation by way of substitution upon the payment of a fine, even though the lands were thereby divided.

2. It abolished subinfeudation, making the feoffee hold of the feoffor's overlord upon the same terms upon which the feoffor had held of the feoffor's overlord.

3. It did not affect the rights of the king against the tenants in capite, because of the general principle that the rights of the king are not affected by a statute unless he is specially named therein.

4. It applied only to conveyances in fee simple.

So long as English society continued on what might fairly be called a military basis, so long as protection to property and life through legal process was not very direct and adequate, and the need for protection and assistance between the lord and the tenant was immediate and close, the feudal organization of society, with its onerous incidents, might nevertheless be regarded as a not unfair working arrangement. In the course of time, however, the feudal element in English economic life ceased to have any real value, the agricultural element became more pronounced, and then gradually a commercial aspect developed. The king's courts asserted their jurisdiction over all the country, and life and property became secure. With this growth of society the justification for the feudal incidents disappeared. They became a mere source of profit upon the part of the lord, with no corresponding beneilt to the tenant. An element that operated to make this burden all the more heavy was the fact that, with the breaking down of the feudal system, the relation of lord and tenant was no longer kept sharply in mind, and the doctrine gradwally arose that every tenant was presumed to be a tenant in capite, unless it appeared that he was a mesne tenant. It has already been pointed out that the feudal burdens of the tenants in capite were distinctly more onerous than those of the mesne tenants. The effect of Quia Emptores was also to work the holding of any given tenant toward the top of the feudal pyramid. When feudalism was definitely terminated as a real factor in English economic organization by the War of the Roses, and the establishment of the Tudors, the objection to these burdensome incidents became constantly stronger. Blackstone thus describes the situation. ${ }^{8}$

"For the present I have only to observe, that by the degenerating of knight service, or personal military duty, in escuage, or pecuniary assessments, all the advantages (either promised or real) of the feudal constitution were destroyed, and nothing but the hardships remained. Instead of forming a national militia composed of barons, knights, and gentlemen, bound by their interest, their honor, and their oaths, to defend their king and country, the whole of this system of tenures now tended to nothing else but a wretched means of raising money to

82 Bl. op. cit. p. 75. 
pay an army of occasional mercenaries. In the meantime the families of all our nobility and gentry groaned under the intolerable burthens, which (in consequence of the fiction adopted after the Conquest) were introduced and laid upon them by the subtlety and finesse of the Norman lawyers. For, besides the scutages to which they were liable in defect of personal attendance, which however were assessed by themselves in parliament, they might be called upon by the king or lord paramount for aids, whenever his eldest son was to be knighted, or his eldest daughter married; not to forget the ransom of his own person. The heir on the death of his ancestor, if of full age, was plundered of his first emoluments arising from his inheritance, by way of relief and primer seisin; and if under age, of whole of his estate during his infancy. And then, as Sir Thomas Smitho very feelingly complains, "when he came to his own, after he was out of warship, his woods decayed, houses fallen down, stock wasted and gone, lands let forth and ploughed to be a barren,' to reduce him still farther, he was yet to pay half a year's profits as a fine for suing out his livery; and also the price or value of his marriage, if he refused such a wife as his lord and guardian had bartered for, and imposed upon him; or twice that value if he married another woman. Add to this, the untimely and expensive honour of knighthood, to make his proverty more completely splendid, And when by these deductions his fortune was so shattered and ruined, that perhaps he was obliged to sell his patrimony, he had not even that poor privilege allowed him without paying an exorbitant fine for a license of alienation."

In the reign of James I a proposal was made to abolish all these incidents, but this proposal was defeated. On the overthrow of Charles I, steps were taken to do away with these feudal obligations, and a statute to that effect was enacted in 1656 . On the restoration of Charles II, in 1660 , the statute was re-enacted in order to put its validity beyond question. The statute provides as follows:

St. 12 Car. II (1660) c. 24-"An Act taking away the Court of Wards and Liveries and Tenures in Capite, and by Knight Service, and Purveyance, and for settling a Revenue upon his Majesty in lieu thereof.

"Whereas it hath been found by former experience that the Court of Wards and Liveries and tenures by knight service either of the king or others, or by knight service in capite, or socage in capite of the king, and the consequents upon the same, have been much more burthensome, grievous and prejudicial to the kingdom than they have becn beneficial to the king; and whereas since the intermission of the said court, which hath been from the four and twentieth day of February, which was in the year of our Lord one thousand six hundred forty and five, many persons have by will and otherwise made dis-

๑ Commonwealth of England, bli, 3, ch. 5. 
posal of their lands held by knight service, whereupon divers questions might possibly arise unless some scasonable remedy be taken to prevent the same; be it therefore enacted by the King our Sovereign Lord, with the assent of the Lords and Commons in Parliament assembled, and by the authority of the same, and it is hereby enacted, That the Court of Wards and Liveries, and all Wardships, liveries, primer seisins and ousterlemains, values and forfeitures of marriages, by reason of any tenure of the King's Majesty, or of any other by knight service, and all mean rates, and all other gifts, grants, and charges, incident or arising for or by reason of wardships, liveries, primer seisins, or ousterlemains be taken away and discharged, and are hereby enacted to be taken away and discharged, from the said twenty-fourth day of February one thousand six hundred forty-five; any law, statute, custom, or usage to the contrary hereof in any wise notwithstanding: And that all fines for alienations, seizures, and pardons for alienations, tenure by homage, and all charges incident or arising for or by reason of wardship, livery, primer seisin, or ousterlemain, or tenure by knight service, escuage, and also aide pur file marrier, et pur faire fitz chivalier, and all other charges incident thereunto, be likewise taken away and discharged from the said twentyfourth day of February one thousand six hundred forty and five: any law, statute, custom, or usage to the contrary hereof in any wise notwithstanding: And that all tenures by knight service of the king, or of any other person, and by knight service in capite, and by socage in capite of the king, and the fruits and consequence thereof, happened or which shall or may hereafter happen or arise thereupon or thereby, be taken away and discharged; any law, statute, custom, or usage to the contrary hereof in any wise notwithstanding. And all tenures of any honours, manors, lands, tenements, or hereditaments, of any estate of inheritance at the common law, held either of the king or of any other person or persons, bodies politick or corporate, are hereby enacted to be turned into free and common socage, to all intents and purposes, from the said twenty-fourth day of February one thousand six hundred forty-five, and shall be so construed, adjudged and deemed to be from the said twenty-fourth day of February one thousand six hundred forty-five, and forever hereafter, turned into free and common socage; any law, statute, custom, or usage to the contrary hereof in any wise notwithstanding.

" 2 . And that the same shall forever hereafter stand and be discharged of all tenure by homage, escuage, voyages royal, and charges for the same, wardships incident to tenure by knight's service, and values and forfeitures of marriage, and all other charges incident to tenure by knight service, and of and from aide pur file marrier, and aide pur faire fitz chivalier; any law, statute, usage, or custom to the contrary in any wise notwithstanding. And that all conveyances and devises of any manors, lands, tenements, and hereditaments, made since the said twenty-fourth day of February, shall be expounded to 
be of such effect as if the same manors, lands, tenements, and hereditaments had been then held and continued to be holden in free and common socage only; any law, statute, custom or usage to the contrary hereof in any wise notwithstanding.

" 3 . And be it further ordained and enacted by the authority of this present Parliament, That an Act made in the reign of King Henry the Eighth, intituled An Act for the Establishment of the Court of the King's Wards ; and also one Act of Parliament made in the thirtythird year of the reign of the said King Henry the Eighth, concerning the officers of the Courts of Wards and Liveries, and every clause, article, and matter in the said Acts contained, shall from henceforth be repealed and utterly void.

" 4 . And be it further enacted by the authority aforesaid, That all tenures hereafter to be created by the King's Majesty, his heirs or successors, upon any gifts or grants of any manors, lands, tenements, or hereditaments, of any estate of inheritance at the common law, shall be in free and common socage, and shall be adjudged to be in free and common socage only, and not by knight service, or in capite, and shall be discharged of all wardship, value and forfeiture of marriage, livery, primer seisin, ousterlemain, aide pur faire fitz chivalier and pur file marrier; any law, statute or reservation of the contrary thereof in any wise notwithstanding.

"5. Provided nevertheless, and be it enacted, That this Act, or anything herein contained, shall not take away, nor be construed to take away, any rents certain, heriots, or suits of court, belonging or incident to any former tenure now taken away or altered by virtue of this Act, or other services incident or belonging to tenure in common socage due or to grow due to the King's Majesty, or mean lords, or other private person, or the fealty and distresses incident thereunto; and that such relief shall be paid in respect of such rents as is paid in case of a death of a tenant in common socage.

"7. Provided also, and be it further enacted, That this Act, or anything herein contained, shall not take away, or be construed to take away, tenures in frankalmoign, or to subject them to any greater or other service than they now are; nor to alter or change any tenure by copy of court roll, or any services incident thereunto; nor to take away the honorary services of grand serjeanty, other than of wardship, marriage, and value of forfeiture of marriage, escuage, voyages royal, and other charges incident to tenure by knight service; and other than aide pur faire fitz chivalier, and aide pur file marrier."

The result of this statute, although the language of it is confusing, and the statute is poorly drawn, is clear. It abolished military tenure. It turned all tenure into free and common socage and discharged most of even the slight burdens incident to that tenure.

It is to be noticed that neither Quia Emptores nor the statute abolishing the court of wards and liveries affected the doctrine of tenure as such. The theory of English law is to-day what it was eiglit hun- 
dred years ago, namely, that the owner, even when he has the largest possible rights in his land that the law recognizes, is not the owner of his land in the same sense that he is, for example, the owner of his watch. He holds his land in tenure under the sovereign.

\section{SECTION 7.-TENURE IN THE UNITED STATES}

The question now remains for consideration as to the nature of land ownership in the United States. Does a man own his land, to use the illustration just given, in the same completeness of ownership that he owns his watch? This species of ownership as applied to land is termed allodial. Or, on the other hand, does tenure still prevail, at least in legal theory, in the states in this country? This question may be of importance in two aspects: First, as to the right of escheat; second, as involving the possibility of subinfeudation.

The doctrine of escheat, strictly speaking, depends on tenure. If the owner of land owned allodially dies without having disposed of his land and without leaving heirs, unless the sovereign has made provision by statute for disposing of the title to it, it would seem that any person who obtained possession of the land could retain it simply because no one could show a right to put him out. If the owner of land held in tenure dies under the same state of facts, the land will escheat to the overlord.

The question of subinfeudation is, of course, closely associated with the question as to whether Quia Emptores is law in this country. If the land is owned allodially, of course, there can be no question of subinfeudation. If tenure exists in this country, then subinfeudation is possible unless the doctrine of Quia Emptores is to be deemed a part of our law.

When the charters were granted by the British crown for the various settlements in the United States, most of them contained provisions that the land should be held in socage tenure. Upon the Revolution, it would seem that the various state governments succeeded to the rights of the sovereign, and that consequently there would be a tenure relation between the owner of the land and the sovereign, in the character of the state. In a considerable number of the states, the matter has been settled, either by a constitutional provision or by legislative enactment. Closely allied with this question is the question as to whether or not Quia Emptores is in force in the United States. Professor Gray ${ }^{10}$ states the matter thus:

"In this condition [i. e, with tenure no longer obtaining] are at

10 The Rule against Perpetuities (3d Ed.) p. 23.

BIG.INT.-2 
least Connecticut, New York, Maryland, Virginia, Ohio, Wisconsin, West Virginia, Kentucky, Minnesota, and Arkansas. * * * In all of the United States, with the exception of South Carolina and perhaps Pennsylvania, land, if held, at all, can be held of none but the state; for in all the states, with the two exceptions, either there is no tenure, or, if there is tenure, the statute of Quia Emptores is in force." 11

11 On tenure in the United States see Gray, op. cit. \$\$ 22-28; 3 Kent, Commentaries, pp. 509-514. 


\section{CHAPTER II}

\section{ESTATES \\ SECTION 1.-INTRODUCTION}

Up to the present time we have been considering the English law so far as it related to the framework or skeleton upon which the general system of landholding was constructed. We now take up the question as to the extent of the interest that might be had by any particular individual in a given piece of land, or, as it is technically called, the extent of his estate in the land.

The English law divides estates in land into freehold, and nonfreehold. This distinction is historical rather than logical, and the reason for it will be pointed out later. The freehold estates are the fee simple, the fee tail, other qualified fees, and the life estate. The nonfreehold estates are the estate for years, from year to year, at will, and at sufferance.

\section{SECTION 2.-FEES SIMPLE}

Without an attempt at an exact definition, it may be said that a person who holds land in fee simple possesses the totality of rights that a man may have with respect to a piece of land. Among these rights he has the privileges of doing as he sees fit with his land and the right to be protected in the exercise of these various privileges; the limit of these rights and privileges being the point where the exercise of them is regarded as being socially unjustifiable. just where the law draws the line as to the privileges that a man may exercise with respect to the soil is a question of policy and expediency that need not at present be considered. The owner in fee simple further has the fullest powers of disposition over his land that the law recognizes, and complete immunity from any control by a third person, subject to the legislative and constitutional powers of the state.

While the exact nature of the right that the tenant had in his land immediately after the Norman Conquest is not entirely clear, it is probable that the land was given to him by his overlord only for his life. The personal relation and confidence that existed between the lord and the tenant would make this likely and this conclusion is corrob- 
orated by the existence of some of the feudal incidents. If, however, the heir of the tenant was a person in whom the lord could repose confidence, it would be natural that upon the death of the original tenant the land should be continued by the lord in the possession of the heir. Where the tenure was agricultural, and lacking the personal element that existed in military tenure, such 'would be even more likely to be the case. As the practice became confirmed, and partly as tending to confirm it, the custom gradually grew up of indicating in the gift of the land to the first tenant that it should go on his death to his heirs. It is at this point that we see the beginnings of an interesting and technical doctrine of our laws. If the lord by such a conveyance gave the land expressly to $\mathrm{B}$. and his heirs, and if $\mathrm{B}$. during his life aliened the land to $\mathrm{C}$., the natural construction to be put upon the terms of the gift would be that $\mathrm{B}$. had an interest in the land only for liis own life. This interest he might conceivably enongh transfer to C., but C.'s interest could be no larger than B.'s, and consequently, after the death of B., B.'s heirs would be able to regain the land from C. Such was apparently the earlier law. Later, however (that is, by the 13th century), we find the rule of law to be pretty definitely established otherwise. This result is expressed in a doctrine and formula of a highly technical nature, but of so mich importance in the law of real property as to require some consideration.

As has already been said, it would seem that the natural construction of the phrase "to B. and his heirs" would be that the subject-matter of the conveyance was given to B. for his life and after his death to his heir; in other words, that the heir would take the land after B.'s death, not as taking something coming to him from B., but because he was the person intended by the original lord to be the next one to have the land. To state this idea in technical language, it is necessary to call attention to the precise meaning of two legal terms, "descent" and "purchase." A person is said to take land by descent when a title to the land passes to him by operation of law; he is said to take by purchase when the title passes to him by act of the parties. Now, to state technically the natural construction to be put upon the phrase under consideration, it would seem that the heir after the death of $B$. would take the property by purchase; that is, because he is indicated by $A$. as the person to take it. As has already been said, however, by the 13 th century, the doctrine seems to have been definitely established that, if $\mathrm{B}$. conveyed the estate during his life, the heir would get no interest in it after B.'s death; that is, the function of the phrase "to his heirs" was construed as being, not to indicate the person who would take the land after B.'s death, but to mark out or delimit the size of the estate that B. had, as the largest possible estate that could be given. In other words, to put it technically, the phrase "to his heirs" was treated as a phrase of limitation, and not of purchase.

Once this construction of the phrase in question had been definitely 
established as a part of the law of fees simple, it led to consequences far-reaching and important. Suppose the terms of the gift, instead of being to $B$. and his heirs, are to B. for life and on B.'s death to B.'s heirs. This limitation, though longer, in fact says nothing more than would the shorter phrase already considered, if the shorter phrase were to receive its natural construction. Since the two phrases were in natural construction identical, and since it had been definitely established with respect to the shorter phrase that the phrase "to his heirs" was a phrase of limitation, and not of purchasc, the same reasoning was applied to the longer phrase; that is, it was construed to vest a fee simple in $B$. Of course, if $B$. died without having aliened the land, it would go to B.'s heirs; but it would go io them by descent, and not by purchase. The doctrine just outlined was first established by a decision in $1324,{ }^{1}$ and illustrates the simplest form of the Rule in Shelley's Case, so called after a decision in Lord Coke's time in which the doctrine was reasserted. ${ }^{2}$ The rule may be formulated thus: Where an estate is given to the ancestor for life, and by the same instrument an immediate estate is given to his heir in fec, the result is to give the ancestor a fee simple. The artificial character of this reasoning is clear; and of course the application of it will frequently operate to defeat the intention of the person making the conveyance. At the same time the idea that is worked out in it seems to represent a fundamental principle of the policy of the English law with respect to ownership of land, namely, that the owner of it should be able freely to alienate it. The struggle in English law between the two conflicting principles of freedom of alienation and restriction of alienation still continues.

One other consequence that should be noticed in respect to the doctrine which we have been considering is this: Since a conveyance to $B$. and his heirs gives B. a fee simple, the converse is also true. With a few rare exceptions, the only method under English law whereby an estate in fee simple could be created was by a conveyance in terms to B. and "his heirs." No other phrase would take the place of this nagic formula.

1 Y. B. 18 Edw. II, 577. See 7 Man. \& G. 941 , note. It has been sugqested (see Tiedeman, Real Prop. [2d Ed.] \& 483) that the origin of the doctrine is to be accounted for thus: In the 14th century it would not have been nos. sible to regard the phrase "to the heirs" as creating any legal interest in them, for the reason that since the heirs of the grantee could not be knowis until his death, this would be a contingent remainleri (see post, p. 39), and in the 14th century such a remainder was not recomnized as a legally possible interest. Consequently, to give any effect at all to these words of the grantor, it was necessary to put unon them the construction that was adopted.

- Shelley's Case, 1 Co. 9?a (15\$1).

3 On the fee simple see Litt. $\$ \$ 1,2 ; 2$ BI. op. cit. $101-109 ; 2$ Poll. \& Mait. op. cit. pp. 13-16; Williams, op. cit. ch. II; Leake, Digest of the Law of Property in Land (2d Ld.) pp. 22-24. 


\section{SECTION 3.-FEES CONDITIONAL AND FEES TAIL}

Another very old form of limiting the size of the estate which was given to the tenant was this: "To B. and the heirs of his body." After the courts had held that the tenant in fee simple had complete powers of alienation and had adopted the construction of the phrase "to B. and his heirs" as stated in the preceding section, it might still be possible to limit the freedom of alienation of $B$. and to keep the estate in a definite line of descent by using the narrower form of limitation above given. The same liberalizing tendencies, however, on the part of the courts, were at work also in regard to this narrower limitation. By the middle of the 13th century the construction that was put upon the phrase was that the conveyance was to $\mathrm{B}$. upon condition that he should have heirs to his body. Once the condition was satisfied by the birth of an heir, B. then had the power to create a fee simple in a third person by conveying the estate to him. This construction, of course, defeated the aim of the overlord to keep the estate in a particular line of descent. It was to check this tendency, and force the retention of an estate given to a man and the heirs of his body in the line of descent marked out by the terms of the gift, that there was passed in the year 1285 the statute De Donis Conditionalibus. The statute is as follows:

St. 13 E.dw. I-St. of Westm. II (1285) c. 1, De Donis Conditionalibus:

"First, concerning lands that many times are given upon condition, that is, to wit, where any giveth his land to any man and his wife, and to the heirs begotten of the bodies of the same mar and his wife, with such condition expressed that if the same man and his wife die without heir of their bodies between them begotten, the land so given shall revert to the giver or his heir; in case also where one giveth lands in free marriage, which gift hath a condition annexed, though it be not expressed in the deed of gift, which is this, that if the husband and wife die without heirs of their bodies begotten, the land so given shall revert to the giver or his heir; in case also where one giveth land to another and the heirs of his body issting, it seemed very hard and yet seemeth to the givers and their heirs, that their will being expressed in the gift was not heretofore nor yet observed. In all the cases aforesaid after issue begotten and born between them, to whom the lands were given under such condition, heretofore such feoffees had power to aliene the land so given, and to disinherit their issue of the land, contrary to the minds of the givers, and contrary to the form expressed in the gift: and further, when the issue of such feoffee is failing, the land so given ought to return to the giver or his heir by form of gift expressed in the deed, though the issue, if any were, had 
died; yet by the deed and feoffment of them to whom land was so given upon condition, the donors have heretofore been barred of their reversion of the same tenements which was directly repugnant to the form of the gift: wherefore our lord the king, perceiving how necessary and expedient it should be to provide remedy in the aforesaid cases, hath ordained, that the will of the giver according to the form in the deed of gift manifestly expressed shall be from henceforth observed, so that they to whom the land was given under such condition shall have no power to aliene the land so given, but that it shall remain unto the issue of them to whom it was given after their death, or shall revert unto the giver or his heirs if issue fail either by reason that there is no issue at all, or if any issue be, it fail by death, the heir of such issue failing. Neither shall the second husband of any such woman from henceforth have anything in the land so given upon condition after the death of his wife, by the land of England, nor the issue of the second husband and wife shall succeed in the inheritance, but immediately after the death of the husband and wife, to whom the land was so given, it shall come to their issue or return unto the giver or his heir as before is said. *** And it is to wit that this statute shall hold place touching alienation of land contrary to the form of gift hereafter to be made, and shall not extend to gifts made before. And if a fine be levied hereafter upon such lands it shall be void in the law, neither shall the heirs or such as the reversion belongeth unto, though they be of full age, within England, and out of prison, need to make their claim."

The language of the statute requires no extended comment. The result of it was that the old common-law conditional fee could no longer be created and in the place of it there came into being, as a result of the statute, the fees tail, from the old French, "talliare," meaning to cut or limit. Estates tail are classified as general or spccial tail. An estate tail general is to A. and the heirs of his body. An estate tail special may be to A. and the heirs male of his body, or to A. and the heirs female of his body, or to A. and the heirs of his body by a particular wife. With regard to any of the estates tail the property will continue in the line of the descent indicated by the terms of the gift so long as that line continues. If the line runs out, the property will then pass to the next person legally entitled to it according to the terms of the original grant, such person being known as a remainderman, or if there is no legal estate in remainder the property will then return to the original creator of the estate, or to his heirs. Estates in remainder and cognate matters will be considered in detail subsequently.

The policy of thus restraining alienation in estates of this character. as established by De Donis, continued to be effective for about 200 years. There were, however, numcrous objections to it, and these objections constantly grew in force. It was unsafe for a person to buy land, or to take a long-term lease of it, since there was always the pos- 
sibility that the land was entailed, and, if such was the case, the purchaser, regardless of his good faith, would be ousted at the end of the life of the tenant from whom he purchased. The king also objected to this sort of estate, for the reason that the treason of a tenant in tail would result merely in forfeiting his life interest in the premises.

The result of these various objections against the estate tail was that in 1472 (12 Edw. IV) the judges sanctioned a method of evading the effect of the statute, by means of fictitious litigation. The fictional character of the whole proceeding is so obvious that it is clear that there must have been strong feeling of policy to have induced the judges to permit it. The case in which this possibility was first recognized is Taltarum's Case. ${ }^{4}$ The common recovery was a very old form of action, used, as its name would indicate, to recover the possession of land. The steps by which it was allowed to bar the entail were these: The principle had already become established that a tenant in tail could convey a fee simple and so bar his heirs, providing he left assets equal in value to the land. This was then enlarged into the proposition that he could so convey if he left for his heirs a judgment for the value of the land so conveyed. These principles were combined in the common recovery in this fashion. If $\mathrm{B}$., the tenant in tail, wished to convey the land to $\mathrm{C}$. in fee, $\mathrm{C}$. would bring by agreement a common recovery against $\mathrm{B}$. B. would allege that he had derived title in the land from $\mathrm{X}$., and would ask that X. be called in to defend the case. X., upon being called in, would, in accordance with the agreement between himself and B., admit that he had conveyed the land to B., but that he had no defense to C.'s action. Judgment would thereupon be given that $\mathrm{C}$. should recover the land in accordance with the terms of his allegation that he was entitled to it in fee simple. B. and B.'s heirs would be given what in legal theory was an adequate recompense in the shape of a judgment against $X$. for other lands of equal value in respect of which A.'s interest as reversioner would also theoretically attach. Since, however, X. was always chosen for the part that he played, for the very reason that he was entirely irresponsible financially, the judgment against him, although adequate on the face of it, was, as was intended from the beginning, in fact worthless, and the net result of the transaction was that C. obtained the land in fee simple and that the entailed line and the rights of the original donor of the land were barred.

It will be noted that in De Donis it is provided that the rights of the heirs in tail or of the donor shall not be prejudiced by the levying of a fine. The fine was another form of lawsuit frequently used in order to transfer title to land. After the doctrine had been established that an estate tail could be transformed into a fee simple by a common recovery, a somewhat similar effect was given by statute to the levying of a fine. The difference was that a common recovery barred both the entail and the donor, whereas a fine barred only the entail.

4. B. 12 Edw. IV, 19 (1472). 
Estates tail may now be barred in England by a deed in ordinary. form, and a fee simple thereby vested in the grantee.

In the United States fees tail are possible, although rare. Roughly speaking, it may be said that three different methods have been adopted in dealing with them: In some of the states a conveyance to $\mathrm{A}$. and the heirs of his body gives A. a life estate, followed by an estate in fee to the first heir who at common law would take under the entail. In some states such a limitation operates merely to create a fee simple in A. In other states the result is to create a true estate tail, but any tenant in tail may destroy it by an ordinary deed conveying the premises in fee simple.

\section{SECTION 4.-DETERMINABLE FEES}

A question which is too difficult to do more than touch on in the present treatise should be briefly mentioned. That is whether it is possible to create a fee (that is, an estate which may last forever) with a limitation other than as a fee tail. It seems clear that at least one fee of this character can be created. In referring to the possibilities of conveying an estate in fee simple by the levying of a fine by the tenant in tail, attention was called to the fact that the fee so created would last only as long as the entailed line lasted. This fee is what is technically known as a "base fee."

The following situation raises a more doubtful question: A. conveys land to $\mathrm{B}$. and his heirs for so long as they continue to occupy it in person. If at any time they cease so to do, may $\mathrm{A}$. then re-enter into the land? If this conveyance is covered by Quia Emptores, it is clear that A. cannot do so. His right can exist only if there is a relation of tenure between him and B., and the effect of the statute would be to cut off any such relation between himself and B., and B. would seem consequently to have a fee simple absolute in the land. If, on the other hand. the statute applies only to the case of a fee simple absolute, then A. would still retain such an interest in the land as would authorize him to enter upon the violation of the terms on which it was held. Some decisions seem to indicate that the statute does not apply to this case, and that consequently that it is still possible to create this fee which is technically called a determinable fee. The natter, however, cannot be deemed free from doubt. ${ }^{\mathrm{e}}$

s On fees conditional and tail sce 2 Bl. op. cit. pp. 109-120; 2 Poll. \& Mait. op. cit. pp. 16-20; Co. Litt. \$\$ 13-19, 21-24; Willians, op. cit. cli. III; Leake, op. cit. pp. 24-28; Challis, lieal Iroperty (3d Nd.) ch. XVIII.

6 On determinable fees see Challis, op. cit chs. XVII, XIX, App. IV; Gray, op. cit. $\delta \S 31-41$, App. E. 


\section{SECTION 5.-ESTATES FOR LIFE}

With the estate for life we take up the most limited of the freehold estates. The owner of a fee simple or a fee tail, convertible either by a common recovery or otherwise into a fee simple, has the utmost privileges that can be exercised by any person in respect to land. He may cut down the timber, destroy the houses, or in any other manner deal with the property as he pleases. This is not true of the tenant for life. His privileges of user and his powers of disposal of the property are limited.

Estates for life are ordinarily divided into two sorts, viz.: Estates created by act of the party, and estates created by operation of law. Ve shall deal with each in turn.

Estates for life created by act of the parties may be either an estate for the life of the tenant, or an estate for the life of some third person or persons. The simplest case is where A., owning in fee, grants to B. for B.'s life. When B. dies, his estate naturally comes to an end. If the estate is granted to B. for any indeterminate period, so that the earliest possible moment at which the estate must terminate is B.'s death, this is also a life estate; as, for example, where the estate is given to $B$. so long as he remains unmarried.

If $\mathrm{A}$. grants to $\mathrm{B}$. to hold during the life of $\mathrm{C}$., this is what is technically known as an estate d'autre vie. If $\mathrm{C}$. dies while $\mathrm{B}$. is still alive, B.'s estate, of course, comes to an end, and A. is entitled to re-enter the land. A more difficult problem arises if B. dies first. Suppose that, after the death of B., X., a stranger, takes possession of the land. A. cannot evict him because, by the terms of his grant to B., A. would have no right to enter until the death of C. A.'s overlord cannot claim it on the ground of escheat, because there is no escheat, except in the case of a fee simple. C. cannot ciaim it, because his life is used merely as a means of measuring the duration of the estate, and not to confer any beneficial interest. B.'s heir cannot enter, because B.'s estate was not an estate of inheritance. The result is that X. is enabled to hold the land as long as C. -lives, merely because there is no one legally able to put him out. C. is technically known as a general occupant. This common-law doctrine has now been changed by statutes. B. may leave the land by will, and, if he does not do so, it goes under some statutes as his real property, and under other statutes as his personal property. If the land is conveyed by A. to B. and his heirs for the life of C., the heir would take in that case after B.'s death as special occupant, taking by purchase and not by descent. ${ }^{7}$

The life estates created by operation of law are of three sorts:

7 See Co. Litt. 41b-42b; Leake, op. cit. 144-149; Williams, op. cit. 110-116. 
Curtesy, dower, and tenant in special tail with possibility of issue extinct. The estates of dower and curtesy and their various incidents are well described by Blackstone. ${ }^{8}$

"Tenant by the curtesy of England, is where a man marries a woman seised of an estate of inheritance, that is, of lands and tenements in fee simple or fee tail; and has by her issue, born alive, which was capable of inheriting her estate. In this case he shall, on the death of his wife hold the lands for his life, as tenant by the curtesy of England.

"There are four requisites neccssary to make a tenancy by the curtesy: Marriage, seisin of the wife, issue, and death of the wife. 1. The marriage must be canonical and legal. 2. The scisin of the wife must be an actual seisin, or possession of the lands; not a bare right to possess, which is a seisin in law, but an actual possession, which is a seisin in deed. And therefore a man shall not be tenant by the curtesy of a remainder or reversion. $* * *$ If the wife be an idiot, the husband shall not be tenant by the curtesy of her lands; for the king by prerogative is entitled to them, the instant she herself has any title; and since she could never be rightfully seised of the lands, and the husband's title depends entirely upon her seisin, the husband can have no title as tenant by the curtesy. 3. The issue must be born alive. Some have had a notion that it must be heard to cry; but that is a mistake. Crying indeed is the strongest evidence of its being born alive: but it is not the only evidence. The issue also must be born during the life of the mother: for if the mother dies in labour, and the Cæasarean operation is performed, the husband in this case shall not be tenant by the curtesy; because at the instant of the mother's death he was not clearly entitled, as having had no issue born, but the land descended to the child while he was yet in his mother's womb; and the estate being once so vested, shall not afterwards be taken from him. In gavelkind lands, a husband may be tenant by the curtesy, without having any issue. But in general there must be issue born: and such issue as is also capable of inheriting the mother's estate. Therefore, if a woman be tenant in tail male, and hath only a daughter born, the husband is not thereby entisled to be tenant by the curtesy; because such issue female can nerer inherit the estate in tall male. And this seems to be the principal reason why the husband cannot be tenant by the curtesy of any lands of which the wife was not actually seised: because, in order to entitle himself to such estate, he must have begotten issue that may be heir to the wife: but no one, by the standing rule of law, can be heir to the ancestor of any land whereof the ancestor was not actually seised: and therefore, as the husband hath never begotten any issue that can be heir to those lands, he shall not be tenant of them by the curtesy. And hence we may observe, with how must nice'y and consideration

в 2 Com. 126 et seq. See, also, Co. Lit. 29a-30a, 31a-33b. 
the old rules of law were framed; and how closely they are connected and interwoven together, supporting, illustrating, and demonstrating one another. The time when the issue was born is immaterial, provided it were born during the coverture: for, whether it were born before or after the wife's seisin of the lands, whether it be living or dead at the time of the seisin, or at the time of the wife's decease, the husband shall be tenant by the curtesy. The husband by the birth of the child becomes (as was before observed) tenant hy curtesy initiate and may do many acts to charge the lands; but hi 3 estate is not consummate till the death of the wife; which is the fourth and last requisite to make a complete tenant by the curtesy.

"Tenant in dower is where the husband of a woman is seised of an estate of inheritance, and dies; in this case, the wife shall have the third part of all the lands and tenements whereof he was seised at any time during the coverture, to hold to herself for the term of her natural life.

"In treating of this estate, let us, first, consider who may be endowed; secondly, of what she may be endowed; thirdly, the manner how she shall be endowed; and fourthly, how the dower may be barred or prevented.

" 1 . Who may be endowed? She must be the actual wife of the party at the time of his decease. If she be divorced a vinculo matrimonii, she shall not be endowed; for ubi nullum matrimonium ibi nulla dos. But a divorce a mensa et thoro only, does not destroy the dower; no, not even for adultery itself by the common law. Yet now by the statute Westm. 2, if a woman voluntarily leaves (which the law calls eloping from) her husband, and lives with an adulterer, she shall lose her dower, unless her husband be voluntarily reconciled to her. It was formerly held, that the wife of an idiot might be endowed, though the husband of an idiot could not be tenant by the curtesy; but as it seems to be at present agreed, upon principles of sound sense and reason, that an idiot cannot marry, being incapable of consenting to any contract, this doctrine cannot now take place. $* * *$

"2. We are next to inquire, of what may a wife be endowed? And she is now by law entitled to be endowed of all lands and tenements, of which her husband was seised in fee simple or fee tail, at any time during the coverture; and of which issue, which she might have had, might by possibility have been heir. Therefore, if a man seised in fee simple, hath a son by his first wife, and after marries a second wife, she shall be endowed of his lands; for her issue might by possibility have been heir, on the death of the son by the former wife. But if there be a donee in special tail who holds lands to him and the heirs of his body begotten on Jane his wife; though Jane may be endowed of these lands, yet if Tane dies, and he marries a second wife, that second wife shall never ve endowed of the !ands entailed; for no issue that she could have, could by any possibility inherit them. A seisin in law of the husband will be as effectual as a 
seisin in deed, in order to render the wife dowable; for it is not in the wife's power to bring the husband's title to an actual seisin, as it is in the husband's power to do with regard to the wife's lands: which is one reason why he shall not be tenant by the curtesy, but of such lands whereof the wife, or he himself in her right, was actually seised in deed. The seisin of the husband, for a transitory instant only, when the same act which gives him the estate conveys it also out of him again (as where, by a fine, land is granted to a man, and he immediately renders it back by the same fine), such a seisin will not entitle the wife to dower; for the land was merely in transitu, and never rested in the husband, the grant and render being one continued act. But if the land abides in him for the interval of but a single moment, it seems that the wife shall be endowed thereof. $* * *$

" 3 . Next, as to the manner in which a woman is to be endowed. * * *

"By the old law, grounded on the feudal exactions, a woman could not be endowed without a fine paid to the lord; neither could she marry again without his license: lest she should contract herself, and so convey part of the feud, to the lord's enemy. This license the lords took care to be well paid for; and, as it seems, would sometimes force the dowager to a second marriage, in order to gain the fine. But, to remedy these oppressions, it was provided, first by the charter of Henry I, and afterwards by Magna Carta, that the widow shall pay nothing for her marriage, nor shall be distrained to marry afresh, if she chooses to live without a husband; but shall not however marry against the consent of the lord; and farther, that nothing shall be taken for assignment of the widow's dower, but that she shall remain in her husband's capital mansion house for forty days after his death, during which time her dower shall be assigned. These forty days are called the widow's quarantine, a term made use of in law to signify the number of forty days, whether applied to this occasion, or any other. The particular lands, to be held in dower, must be assigned by the heir of the husband, or his guardian; not only for the sake of notoriety, but also to entitle the lord of the fee to demand his services of the heir, in respect of the lands so holden. For the heir by this entry becomes tenant thereof to the lord, and the widow is immediate tenant to the heir, by a kind of subinfeudation, or undertenancy.completed by this investiture or assignment; which tenure may still be created, notwithstanding the statute of Quia Emptores, because the heir parts not with the fee simple, but only with an estate for life. If the heir or his guardian do not assign her dower within the term of quarantine, or do assign it unfairly, she has her remedy at law, and the sheriff is appointed to assign it. Or if the heir (being under age) or his guardian assign more than she ought to have, it may be afterwards remedied by writ of admeasurement of dower. If the thing of which she is endowed be divisible, her dower 
must be set out by metes and bounds; but if it be indivisible, she must be endowed specially; as the third presentation to a church, the third toll dish of a mill, the third part of the profits of an office, the third sheaf of tithe, and the like. $* * *$

"4. How dower may be barred or prevented. A widow may be barred of her dower $* * *$ by elopement, divorce, being an alien, the treason of her husband. *** A woman may also be barred of her dower by levying a fine, or suffering a recovery of the lands, during her coverture. But the most usual method of barring dowers is by jointures. ***

"But then these four requisites must be punctually observed: 1 . The jointure must take effect immediately on the death of the husband. 2. It must be for her own life at least, and not pur autre vie, or for any term of years, or other smaller estate. 3. It must be made to herself, and no other in trust for her. 4. It must be made, and so in the deed particularly expressed to be, in satisfaction of her whole dower, and not of any particular part of it. If the jointure be made to her after marriage, she has her election after husband's death, as in dower ad ostium ecclesiæ, and may either accept it, or refuse it and betake herself to her dower at common law; for she was not capable of consenting to it during coverture. And if, by any fraud or accident, a jointure made before marriage proves to be on a bad title, and the jointress is evicted, or turned out of possession, she sliall then (by the provisions of the same statute) have her dower pro tanto at the common law."

The tenancy in special tail with possibility of issue extinct is of rare occurrence. This estate may arise in this fashion. A. grants land to B. and the heirs of his body by his wife C. C. dies, not having had issue. It is obvious that this estate, since the special limitation, can no longer be satisfied, must necessarily terminate with the life of $\mathrm{B}^{\mathrm{\theta}}$

\section{SECTION 6.-ESTATES LESS THAN FREEHOLD}

Before entering into a consideration of nonfreehold estates, attention should be called to the various meanings of the term freehold. The term has at least three distinct meanings: It may be used to describe the quantity of the estate, the sense in which it is being used in this present discussion; the term may be used to indicate the character of the tenure upon which land is held, thus contrasting a freehold tenure with a servile tenure; the term may be used to indicate possession of the land, as distinguished from an interest that is not possession, as where one speaks of the freeholders, meaning

จ 2 B1. op. cit. 121-126; Co. Lit. 27b-28b. 
thereby, the ones in actual possession of the soil, with or without a frechold estate, and irrespective of the nature of the tenure.

The distinction between the estates that are classified as freehold in the sense in which we are at present using the term and the nonfreehold estates is one that is historical in its nature rather than logical. If 'we go back to the centuries immediately following the Norman Conquest, we find that at that time the normal method of holding land was either by estates for life, or by larger estates of the sort already described; the putting out of land on leases for years, although not unknown, was rare. It is possible, although not certain, that at a very early date a lease for more than forty years was void. In any event, the person having a lease for years was regarded as having a right that was in the nature of a contract right against the lessor rather than in the nature of a property right in the land. If he was ejected from the land by the lessor, his remedy against the lessor was more analogous to an action of contract than to an action to assert a property right in the land. If the eviction was by a third person, the only recourse of the lessec so evicted was through his lessor, by virtue of the obligation of his lessor to see that he should quietly enjoy the leased lands, or, if that could not be done, to provide him with other lands. As a corollary of the conception of the right of the lessee for years as being essentially contractual, it was treated as personalty, and not as realty, and it therefore had the incidents of personal property; that is, it could be left by will, which was not true of real property until a much later date, and in the event of intestacy the transmission of the title would be governed by the laws relating to personal property.

During the 13 th century the precarious position of the lessce for years, so far as the nature of his interest in the land was concerned, was ameliorated. In the year 1235 the action of quare ejecit was created, by which the lessee was allowed to assert his possessory right in the land as against the lessor or a purchaser from the lessor who wrongfully ejected him, by a judgment which restored him to possession. By the end of the 13 th century the action of trespass quare clausum fregit was definitely established, so that the lessee for years could recover damages against anyone interfering with his possession. Later a specialized form of trespass, de ejectione firma, was developed, by which the termor was enabled to regain possession of the land from any person wrongfully evicting him. 'This latter action gradually became the accepted form of action for determining the right to the possession of the land, not only in case of tenancies for years, but generally.

Despite these developments in the protection of the property aspect of the interest of the lessee for years, with the result that for the last 500 years he has been just as completely protected in the possession and enjoyment of the land for the duration of his term as is 
the tenant in fee, the interest is still treated as personal property, and is technically known as a chattel real. In some jurisdictions the incongruity of treating leases for long terms of years as chattels has been recognized and done away with by statutes, which provide that leases for more than a specified period shall be treated as realty.

Another species of nonfreehold estate is the tenancy at will, as where the land is leased by A. to B., to hold at the will of A. As the name implies, the lease may be terminated by $\mathrm{A}$. at any time. In the event of such termination, $\mathrm{B}$. has a reasonable time to remove his property and is entitled to the annual crops then growing on the land. A correlative of the right of termination by the lessor is that the lease is also terminable at the will of the lessee. It should be noticed, however, that a lease which is to terminate solely at the will of B. is a tenancy, not at will, but for life.

For a long time the undesirability of the strict tenancy at will, its unfairness to both lessee and lessor, has been recognized, and from the strict tenancy at will has developed the tenancy from year to year. This is a tenancy which can be terminated by either party only upon the giving of a half year's notice of the desire to terminate.

The tenancy at sufferance, so called, is, properly speaking, not a tenancy at all. The situation to which the term is applied is where the lessee, whose estate has terminated, nevertheless continues to remain in the possession of the land. He cannot properly be classified as a trespasser, because his entry was lawful, and to that slight extent he has the characteristic of a tenant. His retention of possession, however, since it is not with the consent of the landlord, either express or implied, is unlawful, and makes the application of the term "tenant" to him a misnomer. The landlord may at any time turn him into a tenant by treating him as such. ${ }^{10}$

\section{SECTION 7.-SEISIN AND POSSESSION an senstige)}

The distinction that the law makes between freehold and nonfreehold estates, which has already been referred to, is of importance in another regard, namely, in the distinction between seisin and possession. The word "seisin" is a very old one in the English law. In the first one or two centuries after the Conquest, it was used merely to indicate possession, either of land or of chattels. Thus the old writers speak indifferently of a man being seised of land or of a horse. Gradually, however, the term "seisin" began to take on a

10 On estates less than freehold see 2 Bl. op. cit. ch. IX; Lit. $\$ 58$; 2 Poll. \& Mait. op. cit. 106-117; Digby, op. cit. 176, 177. 
more technical meaning, and to be distinguished from the word "possession." 11

In discussing the origin of the nonfreehold estates it has been pointed out that the estate for years was in the beginning regarded as giving the lessee for years only a contract right against his lessor, that his occupation of the land was merely in the nature of a servant or bailee to the lessor, and that for the purposes of determining feudal relations and obligations the freehold lessor of the tenant for years was the only one looked to by the overlord. Gradually the term "seisin" was applied only to denote the possession of a tenant holding a freehold estate, and the interest of a tenant holding a nonfreehold estate was designated as possession, and this difference in the terms is now definitely established. Consequently, if A., owning in fee, leases to B. for years, B. has the possession, but A. still retains the seisin, even though, of course, the de facto occupant of the land is B.

The next step in the development of the doctrine of seisin may be illustrated by the following case: Suppose A., the owner in fee, grants to B. for life. B., now having a freehold estate, has the seisin. B., however, owes A. the feudal obligations of homage, fealty, and the like. Consequently the feudal lawyers said that $\mathrm{A}$. also was seised in respect of these rights. They distinguished between the two by saying that $B$. was seised in his demesne and that $A$. was seised in his services. This idea of a seisin that was not in fact accompanied by an actual possession was applied in another type of case. Thus, if A. had a right to rent from B.'s land, and A.'s estate in the rent was a freehold (i. e., in fee or for life), A. was said to be seised of the rent to which he is thus entitled; and if A. was deprived of the rent by the tortious act of B. or of a third person, A. was said to be disseised of the rent, and he could bring an action to recover the rent that was almost identical with the action that he would bring to recover the seisin of land from which he had been tortiously ousted. It is not necessary to follow further these interesting questions of the somewhat refined doctrines of seisin. Our concern at present is only with the seisin of the demesne; that is, with the actual possession of the land under a freehold title. In connection with the idea of seisin in this most elementary sense one other aspect of the doctrine, of extreme importance in the law of conveyances of interests in land and of the creation of future estates in land which are next to be consid- ered, requires to be specifically stated. The purpose of the feudal organization of society and the whole theory upon which it was constructed were that all land should always be in the possession of some tenant having a freehold interest therein - that is, a seisin-who should be responsible for the performance of the feudal obligations. From this principle follows the doctrine that the seisin of land can never

11 See 1 Maitland, Coll. Pap. 329-3St.

BIG.INT. -3 
be in abeyance, or, to state the same thing in a different form, that some one must always be seised of any given piece of land. There were a few minor exceptions to this rule, but they are of so slight importance as not to require further mention. ${ }^{12}$

\section{SECTION 8.-TRANSFER OF SEISIN AND POSSESSION}

The most natural and obvious way of transferring rights in any tangible object is by delivering that object to the person to whom it is desired to transfer the rights in it. Indeed, if the rights are conceived of as inhering in the object, this would seem to be almost the only way by which the rights could be transferred. One of the oldest and the most commonly used methods of conveying estates in land was based upon this conception. To be sure, the land could not be physically picked up like a book and handed to the grantee. But the nearest approximation to that would be equally satisfactory, namely, to put the grantee physically into the possession of the land, under such circumstances as would make it manifest that the intent was thereby to transfer to him a freehold interest in the land. This was in fact, as has already been said, the most common way of transferring seisin of land under the early English law. It was technically called livery of seisin, or feoffment. It was done by A., the feoffor, taking B., the feoffee, to the land in question and there handing him a branch or a piece of turf as a symbolical delivery of the land. No deed was required; the physical act of delivery was the operative act to transfer the title. As a matter of security this always took place in the presence of witnesses, and, if the transaction was of any importance, a formal document was ordinarily drawn up, stating the fact of the livery, and what land was given, and for what estates. This document was called the charter of feoffment. From the nature of livery of seisin it follows that it was a present act-that is, the seisin could be passed out of the feoffor only by an act of present delivery; an attempt to make a livery of seisin to take effect at some future date was a nullity. This doctrine appears to have been qualified somewhat by the so-called livery in law. Under this latter doctrine the feoffor could take the feoffee to the neighborhood of the land, point it out to him, and declare to him that he thereby gave him livery. This was effectual if the feoffee entered into the land during the life of the feoffor.

The method adopted for the transfer or creation of nonfreehold interests was analogous to livery of seisin. Of course, since the tenant for years had only a possession, and not seisin, the transaction 
was not technically a livery of seisin. But the same fundamental idea of a physical installation on the land prevailed. It was a less ceremonious affair, partly, doubtless, for the reason that the estate created was of not so long a duration. There was one important difference between the creation of a freehold estate and a nonfreehold estate. Since the nonfreehold estate was in its origin a contract rather than a property right, the doctrine that the estate could not be cre ated to begin in futuro had no application. Consequently, A. could make a lease to B. of Blackacre to begin at a specified future date. On that date it was merely necessary for B. to enter into possession. He was not regarded as having a leasehold interest in the interval, but he was regarded as having a right to the lease, and this right was technically called an interesse termini.

If A., the owner in fee, wished to convey his land to B. in fee, subject to a contemporaneous three-year lease in favor of $\mathrm{C}$., this required a combination of livery of seisin and possession; the seisin clearly could not be delivered directly to B., for that would mean putting him into the land to the exclusion of C.'s leasehold interest. On the other hand, C. could not talie a livery of seisin to himself, since he had a nonfreehold interest. The creation of these estates was accomplished by putting $\mathrm{C}$. into the possession of the land and delivering seisin to him for $\mathrm{B}$., who was thus considered as having been vested with the seisin subject to C.'s three-year possessory interest.

These methods of creating freehold and nonfreehold estates continued in England unchanged by statute until the latter part of the 17 th century. In the Statute of Frauds it was provided, among other things that "all leases, estates, interests of freehold, or terms of years, or any uncertain interest of, in, to or out of any messuages, manors, lands, tenements or hereditaments made or created by livery and seisin only, or by parol, and not put in writing and signed by the parties so making or creating the same, or their agents thereunto lawfully authorized by writing, shall have the effect of leases or estates at will only, and shall not, either in law or equity be deemed or taken to have any other or greater force or effect; $* * *$ except nevertheless all leases not exceeding the term of three years from the making thereof."

The law as thus outlined continued substantially unchanged until the 19 th century, at which time, after various pieces of legislation, it was finally provided in 1845 ( 8 \& 9 Vict. c. $106, \S 2$ ) that after October 1,1845 , all corporeal tenements and hereditaments should, as regards the conveyance of the immediate freehold thereof, be deemed to lie in grant as well as in livery.

1329 Car. II $(1676)$ c. $3, \$ \S 1,2$.

On livery of seisin and possession see Co. Lit. 4Sa, 4Sb; 2 Bl. on. cit. $: 810-31 \mathrm{ti}$. 


\section{CHAPTER III}

\section{NONPOSSESSORY INTERESTS IN LAND}

\section{SECTION 1.-INTRODUCTION}

Up to the present time, in discussing the nature of the interests or estates that might be created in land, the discussion has been confined to a consideration of the larger or smaller group of rights that might be had by the person in the occupation of the land, whether this occupation be technically described as seisin of a freehold estate or possession of a nonfreehold estate, and whether the group of rights was the complete group embraced in the term fee simple or the comparatively limited group of rights embraced in the idea of a tenancy for years. Regardless of these variations, the rights have always been those relating to the physical occupation of the land. Rights of this nature are technically classified under the English law as corporeal rights.

English law, however, has always recognized that there may be rights in land held by those who are not entitled to the actual occupation thereof. These have to a certain extent already appeared by inference in the matters that have been considered. Thus, where A. grants to B. for life or for years, the seisin or possession of the land is in B., but it is clear that A. nevertheless retains rights in the land which may be of as great or even greater importance than those of B. So, again, B. may own land in fee simple, but A. may have a right to rent from the land, or a right of going over the land. In these cases, also, it is clear that A. has some legal interests in the land, although they are not of a possessory nature. Interests of this second sort are termed incorporeal rights.

It is worth while to pause for a moment to point out that this terminology, "corporeal" and "incorporeal" rights, is not a scientifically sound one. The law is never concerned with a physical object as such. The sole subject-matter of law is rights, and rights are in all cases relations between individuals. The relation may be purely between individuals, or it may be between individuals with respect to physical objects, such as chattels or land. But rights as such in every case are mercly intellectual concepts. It would seem that the distinction between corporeal and incorporeal rights would be more accurately expressed as a distinction between possessory and nonpossessory rights, The difficulty has been explained by Digby as follows: ${ }^{1}$

1 Op. cit. p. 306 , note 2. Compare Challis, op. cit. p. 49 et seq. 
"The division of hereditaments into corporeal and incorporeal, though deeply rooted in our legal phraseology, is most unfortunate and misleading. The confusion is inherited from the Roman lawyers (see Justinian, Inst. ii, tit. 2), but has been made worse confounded by our own authorities. The Ronans, misled by the double sense of res, unhappily distinguished res corporales and res incorporales; the former being things 'quæe tangi possunt, veluti aurum, vestis,' the latter mere rights, 'quæ in jure consistunt.' It is obvious that this is mere confusion; the two ideas not being in pari materia, or capable of being brought under one class, or of forming opposite members of a division. Following the Romans, our lawyers distinguished between hereditaments as meaning the actual corporeal land itself, and another kind of hereditaments as not being the land itself, but 'the rights annexed to or issuing out of the land.' A moment's reflection is sufficient to show that the distinction is untenable. The lawyer has nothing whatever to do with the material corporeal land, except so far as it is the subject of rights. It is the distinction between different classes of rights, and not between land on the one side and rights on the other, that he is concerned with. In such phrases as 'the land descends to the heir,' what is meant is, not that something happens to the land itself, but that a particular class of the ancestor's rights in relation to the land descends to the heir. The names 'corporeal' and 'incorporeal' are most unfortunate, because, if by 'corporeal' is meant 'related to land,' then a large class of incorporeal hereditaments are also entitled to the name; if by 'incorporeal' is meant that they are mere rights, then all hereditaments are incorporeal, because the lawyer is only concerned with different classes of rights.

While the justice of this criticism seems clear, the phrases in question are firmly established as a part of the English legal vocabulary, and so long as their meaning is understood their inexactness is no serious bar to their usefulness.

Incorporeal rights may be divided into two different classes. There are, first, those that may ultimately develop into corporeal or complete possessory interests. Such is the nature of A.'s interest where he has leased to B. for a term of years. During the contintance of B.'s lease, A.'s interest is incorporeal or nonpossessory. At the end of the term his interest will once more become possessory the second group of nonpossessory rights is those which do not have this characteristic. The right of way or the right to rent mentioned above are sufficient illustrations of this species of incorporeal rights. Rights of this second sort are grouped by Blackstone under the head of incorporeal hereditaments, and will be discussed in detail later on. For the present we shall confine ourselves to the first group of incorporeal riglits. 


\section{SECTION 2.-REVERSIONS AND REMAINDERS}

If A., owning land in fee simple, conveys to B. in fee simple, A. thereby disposes of his entire interest in the land. Under Quia Emptores B. now holds the land, not under A., but under A.'s overlord. If B. dies, not having disposed of the land and leaving no heirs, the land will escheat to the overlord by virtue of the fact that the estate has terminated and that there is a tenure relation between the overlord and $B$. If, on the other hand, A., being seised in fee, conveys to B. for life, B. has not acquired all of A.'s interest in the property. The relation between A. and B. in this case is not affected by Quia Emptores. A. still owns the fee of the land, subject to the life estate which he has created in B., and after B.'s death or the other earlier termination of the life estate, the land will revert to A., and he will be entitled to resume possession thereof. The same thing is true if $\mathrm{A}$. conveys land to $B$. in tail, and the entailed line runs out, or the estate is otherwise terminated; A.'s right, of course, being subject to the possibility of being barred by B.'s suffering a common recovery. This undisposed-of interest that remains in A. after the creation in B. of what is technically called the particular estate, is the reversion. It is to be noted that it is not created by any act of A., but is merely the undisposed of residue of his estate. If B.'s estate is for years, instead of for life or in tail, the same general relation is created; but, since B.'s interest is now a nonfreehold interest, A.'s interest is not technically a reversion, although the term is frequently used somewhat loosely to cover this case. The same general situation may exist, even though A. does not have a fee simple. Thus, a person who has a life estate may carve out of it a smaller estate in another person for years, and the interest thus left in the tenant for life may again loosely be described as a reversion.

Suppose A., owning in fee, conveys the land to B. for life, and after B.'s death to go to C. for life. Several questions may arise in connection with a conveyance of this sort. First, as to how this conveyance would be made. A. would make a livery of seisin to $B$. for his life, which would operate to put the seisin in B., at the same time declaring by his charter of feoffment or otherwise the extent of the interests that B. and C. respectively were to have in the land. Then, after B.'s death, the seisin would pass to C. for life, and after C.'s death would revert to A. The passage of the seisin from $\mathrm{B}$. to $\mathrm{C}$. is not a violation of the doctrine that there can be no livery of seisin to begin in futuro, because of the fact that the seisin is put out of $A$. once for all for the entire set of limitations at the time of the original livery to $B$. Notice the difference between C.'s interest in this case, and A.'s reversionary intcrest. C.'s interest, like B.'s is created by the act of A., and 
is not merely an undisposed-of residue of the estate of the original creator. C.'s interest is what is technically called a renuainder.

The principle illustrated by the case just given is capable of many applications. For example, A., owning in fee, may enfeoff B. for life, remainder to $\mathrm{C}$. for life, remainder to $\mathrm{D}$. in tail. In this case, as in the one just cited, C. and D. have remainders, and back of them is a reversion in fee in $\mathrm{A}$. It is to be noticed that the particular tenant and the remaindermen have no relation of tenure between themselves. They all derive their title from A., and all stand in a relation of tenure to him. If now, A. by a later conveyance transfers his reversion to X., $\mathrm{X}$. is not a remainderman, but an assignee of the reversion, and now occupies the same tenure relation toward B., C., and D. that was formerly occupied by A. A. may also execute this series of limitations: To B. for life, remainder to $\mathrm{C}$. for life, remainder to $\mathrm{D}$. in fée. This will dispose of all of A.'s interest in the land, since he can give no greater estate than a fee. This is expressed in the doctrine that there can be no remainder after a remainder in fee. Another consequence of creating the remainder in fee in $D$. is that, since $A$. has now disposed of all his interest in the land, there can be no tenure between him and B., C., and D. It is equally clear, however, that B., C., and D. have no tenure relation between themselves. Quia Emptores applies in this case, with the result that all three of them hold under A.'s overlord.

In all the cases liitherto discussed the estate of the remainderman was of such a sort that, whenever the preceding estate terminated, the estate in remainder was ready to take up the seisin. It is true, of course, that in the limitation last given $\mathrm{C}$., the tenant for life, may die before $\mathrm{B}$. dies. If that happens, it merely means that on the death of $B$. the seisin will pass to $D$. The fact that $D$. himself may have died before B. is immaterial, since his estate is one of inheritance, and his right to the seisin will pass to his heir. We now, however, have to consider a different species of remainder. Suppose that A., being seised in fee, enfeoffs B. for life, remainder to C. for life if C. shall pay A. $£ 100$. The feudal rule requiring that the seisin should always be vested in some definite person is satisfied, at least for the time being, since B. has a freehold estate. This case, however, differs from those hitherto considered, in that in the present case it is impossible, at the time of the creation of these limitations, to say where the seisin will go upon B.'s death. It may or may not go to C., depending upon whether he has or has not paid the $f 100$. The remainder to $C$. in this case is what is technically called a contingent remainder, as contrasted with the vested remainders in the limitations hitherto given. Under the older law contingent remainders were not recognized. By the 15th century, however, the possibility of creating them, subject to certain limitations now to be discussed, was definitely established. If, therefore, in the example given, $\mathrm{C}$. shall pay the $£ 100$. at or before the termination of B.'s life estate, the seisin will, upon the termination of such 
life estate, pass to $\mathrm{C}$. If $\mathrm{C}$. has not paid, the seisin will revert to $\mathrm{A}$. or to A.'s heirs. The general principle is that a contingent remainder is good, if it becomes vested at or before the termination of the preceding estate. If, in the illustration given, the contingent remainder in C. had been followed by a remainder to D., and C. had not satisfied the contingency at or before the termination of B.'s estate, the seisin would then have passed to the next vested estate in remainder, that is, D.'s, and C.'s contingent remainder would have been destroyed. The same result follows if, through the nonperformance of the contingency, the seisin reverts to $A$.

There are various kinds of contingent remainders. Mr. Fearne, in his work on Contingent Remainders, ${ }^{2}$ divides them as follows:

"1. Where the remainder depends entirely on a contingent determination of the preceding estate itself-

"As if A. makes a feoffment to the use of B. till C. returns from Rome, and after such return of $\mathrm{C}$. then to remain over in fee; here the particular estate is limited to determine on the return of $\mathrm{C}$., and only on that determination of it is the remainder to take effect; but that is an event which possibly may never happen, and therefore the remainder, which depends entirely upon the determination of the preceding estate by it, is dubious and contingent. So where a fine was levied to the use of $A$. and the heirs male of his body, until he, the said A., should do such a thing, and after such a thing done by the said $A$. to the use of $\mathrm{B}$. in tail: A. died without issue, and without performing the condition; and it was adjudged the remainder was contingent, and never took place.

"2. Where some uncertain event, unconnected with and collateral to the determination of the preceding estate, is, by the nature of the limitation, to precede the remainder-

"As if a lease be made to A. for life, remainder to B. for life, and if $B$. die before $A$. to $C$. for life; here the event of B.'s dying before A. does not in the least affect the determination of the particular estate, nevertheless it must precede and give effect to C.'s remainder ; but such event is dubious, it may or may not happen, and the remainder depending on it is therefore contingent. So if lands be given to $\mathrm{A}$. in tail, and, if B. come to Westminster Hall such a day, to B. in fee ; here B.'s coming to Westminster Hall has no connection with the determination of A.'s estate; but as it is an uncertain event, and the remainder to B. is not to take place unless it should happen, such remainder is therefore a contingent remainder.

" 3 . Where a remainder is limited to take effect upon an event, which, though it certainly must happen some time or other yet may not happen till after the determination of the particular estate-

"As if a lease be made to J. S. for life, and after the death of J. D. the lands to remain to another in fee; now it is certain that J. D. must

210 th Ed., pp. 3 to 9. 
die some time or other, but his death may not happen till after the determination of the particular estate by the death of J. S., and therefore such remainder is contingent. So in case of a lease for life to A., and after the death of $A$. and M., the remainder to B. in fee, this is a contingent remainder; for the particular estate being only for the life of A., and the remainder not to commence till after the death of A. and M., if A. die before M., the particular estate will end before the remainder can commence; which is very possible, and therefore such remainder is contingent. So if a feoffment be to the use of $\mathrm{A}$. for 21 years if he shall so long live, and after his death to the use of $B$. in fee; here A. may survive the 21 years; if he should, the particular estate would determine before the remainder could commence, and therefore such remainder is contingent, and, being so, is void, for want of a preceding freehold to support it, as will appear hereafter.

"4. Where a remainder is limited to a person not ascertained, or not in being at the time when such limitation is made-

"As if a lease be made to one for life, remainder to the right heirs of J. S.; now there can be no such person as the right heir of J. S., until the death of J. S. (for nemo est hæres viventis), which may not happen till after the determination of the particular estate by the death of tenant for life, therefore such remainder is contingent. So where a remainder is limited to the first son of $B$., who has no son then born; here B. may never have a son, or, if he should, the particular estate may determine before the birth of such son, therefore this estate is contingent. So if an estate be limited to two for life, remainder to the survivor of them in fee, the remainder is contingent, for it is uncertain who will be the survivor."

These illustrations are given merely as indicating the various possibilities in the creation of these estates.

A., being seised in fee, conveys to $B$., for ten years, remainder to C. in fee if C. pays A. $£ 100$. This remainder is intrinsically bad. The seisin cannot be in B., for the reason that he has a nonfreehold estate. It cannot be in $\mathrm{C}$., because he is not yet entitled to it. To say that when C. pays the $£ 100$. the seisin then passes to him is to violate the common-law doctrine that there cannot be a livery of seisin operating in futuro. The principle exemplified in this case is embodied in the doctrine that a contingent remainder is bad unless supported by a preceding vested estate of freehold.

A., being seised in fee, enfeoffs B. for life and one year after B.'s death to C. in fee. This limitation to C. is also intrinsically bad. Upon the death of B., the seisin cannot go to $\mathrm{C}$., for such is not the limitation. It must therefore revert to $\mathrm{A}$., and, once being back in $\mathrm{A}$., it cannot thereafter be taken ont of him, except by a new conveyance, for the reason already stated.

It has already been mentioned that it was necessary that a contingent remainder should vest at or before the termination of the pre- 
ceding estate, and that if it did not do so by that time it was irretrievably lost. Thus, if $\mathrm{A}$. was a tenant for life, with a contingent remainder to B. for life, it would be sufficient if B. satisfied the contingency at or before A.'s death. At common law it was possible that A.'s estate might terminate before the death of A., if A. engaged in a course of action that forfeited his estate, as for example, enfeoffing $\mathrm{X}$. of the land in fee. Since this was in violation of A.'s feudal obligations with respect to the land, it resulted in destroying whatever estate he had, with the consequence that the next estate must then take the seisin and be ready to assume the burdens of feudal tenure. If B.'s estate had not at that time become vested by the performance of the contingency, it would drop out, the seisin would pass to the next vested estate of freehold, and B.'s estate be destroyed. Contingent remainders might also be lost in ways other than by the destruction of the particular estate. These other methods will be considered in a later connection.

This easy destructibility of contingent remainders led to a device to preserve them for the benefit of the contingent remainderman, by providing that after the termination of the tenancy for life for any reason the seisin should go to certain specified persons, their heirs and assigns, as trustees for the life of the tenant for life and for his benefit. These persons, being specified and their estate being therefore ready to come into possession on any termination of the particular estate, had a vested remainder. Consequently, if the tenant for life forfeited or otherwise terminated his estate, the vested remainder in the trustees for the life of the tenant for life would then come in. By thus interposing another vested estate until the termination of the natural life of the tenant for life, a further chance was given for the contingent remainderman either to come into being or to satisfy the contingency upon which his estate depended, if he was already in being. Of course it would have been possible for the trustees, acting in collusion with the next vested remainderman, to destroy the contingent remainder; but they were prevented from doing this by the orders of the Chancellor. By later legislation contingent remainders were made indestructible, and consequently the need for trustees to preserve contingent remainders was done away with. ${ }^{3}$

3 On reversions and remainders see 2 bl. op. cit. 163-176; Challis, op. cit. 72-S5, 11.9-151; Digby, op. cit. 262-275 ; Leake, op. cit. 226-246; Williams, op. cit. $323-365$. 


\section{SECTION 3.-CONDITIONAL LIMITATIONS AND RIGHTS OF ENTRY}

The next type of nonpossessory interest in land that requires consideration may be illustrated by the two following limitations: A., being seised in fee, enfeoffs B. to hold for B.'s life or until C. pays A. $£ 100$, and thereupon to C. in fee; A., being seised in fee, enfeoffs $B$. for life, subject to the condition that, if C. pays A. $\notin 100$., then C. may enter and terminate the estate of $\mathrm{B}$. The limitation to $\mathrm{C}$. contained in the first illustration is good. B. has a life estate; that is, an estate of uncertain duration, that may terminate in one of two ways, either by his death, or by the payment of the $£ 100$. The proviso for the termination of his estate in favor of $\mathrm{C}$. by the payment of the $f 100$. is a conditional limitation, and C.'s estate is an ordinary remainder. The limitation given to $\mathrm{C}$. in the second illustration is bad. It is not couched as a conditional limitation upon B.'s estate; that is, B.'s estate does not automatically come to an end upon the payment of the $£ 100$. What is attempted is to give C. the power to terminate B.'s estate after C. has paid the $£ 100$ to A. 'This power on C.'s part is what is technically' known as a right of entry. A right of entry was not regarded under the common law as being in the nature of an estate in the land. It was regarded as a personal right or power, and in the type of right of entry that is now being considered it could exist only in the person creating the estate with respect to which the power was created, or in his heirs. It could not be assigned, even as a part of the reversion back of the particular estate which was made subject to the right of entry. In general, the question as to whether a given phrase is to be regarderl as a conditional limitation or as a condition with power of entry is one of the intent of the parties rather than of the exact language used; the general tendency is to treat it, if possible, as a conditional limitation. The doctrine of the common law with respect to conditions was changed as regards certain classes of leases in the time of Henry VIII (32 Hen. VIII, c. 34), and it has been changed by statute in similar cases in all of the states in this country as well."

4 On conditional limitations and rights of entry see Co. Lit. 214a-215u: Challis, op. cit. 219, 253 ; Leake, op. cit. 161-175. 


\section{SECTION 4.-INCORPOREAL HEREDITAMENTS}

We pass, now, to the other group of incorporeal interests. Blackstone enumerates ten so-called incorporeal hereditaments, namely, advowsons, tithes, commons, ways, offices, dignities, franchises, corodies, annuities, and rents. Of these the only ones that possess importance for our present purposes are commons, ways, and rents. All three of these found their origin in the feudal system, and the first two probably go back to the ante-Conquest days, when the manor was in its formative stage. Common was the right of pasturage that the tenants of the manor had upon the waste lands of the manor, and is one species of the broader group of rights known as profits. A profit may be defined as the right which one person has to take some substance from the soil of another without being entitled to the possession of the soil from which the substance is taken. A way is one species of the broader group of rights known as easements, which may be defined as the right to make a limited specified use of the land of another without taking any of the substance therefrom or having jossession thereof. Rent was the return reserved by the grantor of land from the grantee thereof. ${ }^{5}$

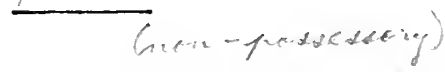

SECTION 5.-CONVEYANCE OF INCORPOREAL INTEREST

If $A$. has the reversion of a piece of land in fee, subject to an estate in B. for years or for life or in tail, and A. wishes to convey his reversionary interest to C., how is this to be done? Clearly under these circumstances A. cannot give C. livery of seisin. To attempt to do so would result in an illegal disturbance of B.'s interest in the land. Whether B.'s interest be for life or in tail, which would give him a seisin, or whether his interest be for years, which would give him technically only a possession, any attempt by A. to take C. to the land and go through the formality of livery would be an ouster of $\mathrm{B}$. and a disturbance of his legal rights. So, also, if B. is tenant for life and $\mathrm{C}$. has a remainder for life, which he wishes to convey to D., it is equally impossible for $\mathrm{C}$. to give livery of seisin. The same difficulty arises if A., the owner of land, wishes to create in B. an easement or a profit or a right to a rent. Thesę all, being incorporeal-that is to say, nonpossessory-interests, cannot be created by a method the essence of which is a dealing with the physical possession of the land.

5 On incorporeal hereditaments see 2 Bl. op. cit. ch. III; Digby, op. cit. 181-210. 
It is in this type of case that we encounter the second main method of conveyancing known to the common law; that is to say, by deed, a formal instrument sealed and delivered by the grantor to the grantee, describing the interest to be conveyed to the grantee. Conveyance by deed was used in all cases at common law where conveyance by livery was impossible, owing to the nature of the right to be conveyed. Hence the common-law adage that corporeal interests lie in livery and incorporeal interests lie in grant.

In the case where the incorporeal interest to be conveyed was a reversion or remainder, another essential step to complete the conveyance was the assent of the particular tenant to the transfer of the reversionary or remainder interest to the grantee. This was known as the attornment by the tenant. It consisted of a formal acknowledgment by him of the transfer, and a recognition that the right so transferred was vested in the grantee. The reason for requiring the attornment of the tenant that is ordinarily given is that in the feudal system the relation of lord and tenant was so personal that it was regarded as unfair to the tenant that his lord should be changed, save by his consent. That this cannot be the sole reason for the requirement is manifest from the fact that attornment was also necessary in the case of the transfer of a remainder, although in that situation there is, of course, no relation of tenure between the particular tenant and the remainderman. It has been suggested that another explanation for the doctrine of attornment is that the incorporeal interest transferred was regarded as having one end localized in the soil, and that consequently this transfer could not be made except, as the tenant permitted it by his formal consent. ${ }^{6}$

This doctrine of attornment on the part of the tenant was done away with by statute in the time of Anne. The statute provides as follows:

St. 4 Anne (1705) c. 16, § 9: "And be it further enacted by the authority aforesaid, That from and after the said first day of Trinity term (1706), all grants or conveyances thereafter to be made, by fine or otherwise, of any manors or rents, or of the reversion or remainder of any messuages or lands, shall be good and effectual, to all intents and purposes, without any attornment of the tenants of any such manors, or of the land out of which such rent shall be issuing, or of the particular tenants upon whose particular estates any such reversions or remainders shall and may be expectant or depending, as if their attornment had been had and made."

This same statute has in substance been re-enacted in many states in this country. In those states where it has not been formally re-enacted, the courts would doubtless hold that the idea of attornment was so foreign to present policy as to have no place in our law. ${ }^{7}$

- See 1 Maitland, Coll. Pap. 374-379.

7 On grant and attornment see 2 bl. op. cit. 317; Co. Lit. 309a-310a, 315b316b; Digby, op. cit. 260-262; Lealie, on. cit. 37-38. 


\section{SECTION 6.-OTHER SPECIES OF CONVEYANCES}

The more important methods of conveyancing, viz., the feoffment for freehold, and the lease for nonfreehold, possessory interests, and the deed for nonpossessory interests, have already been discussed. In addition to these conveyances, there are certain others that require mention.

The release is a special form of conveyance by deed. It could be given only by a person out of possession of land to a person in possession. There were four kinds of releases:

1. Per mitter le droit. This was the form of release that was executed by the disseisee of lands to the one who had disseised him, the result being to pass to the disseisor in possession the rights that the disseisee still retained.

2. Per mitter l'estate. This was the form of release that was executed by one joint tenant or coparcener to another.

3. Per enlarger l'estate. This release was the form used by a reversioner or remainderman in conveying his interest to the tenant of a particular estate.

4. Per extinguishment. This was the form of release used by the holder of an incorporeal hereditament, such as a rent or easement, to release to the owner of the land the right to the rent or the easement.

A release per enlarger, in connection with a lease of the land in question, was sometimes used as a method of conveying in fee simple, instead of a feoffment. Thus, A. would execute a lease of the premises to B. for one year, and B. would go into possession, whereupon A. would execute to him a release, which would operate, of course, to vest a fee simple in $B .^{8}$

Surrender is just the reverse of release; the surrender being a giving up by the holder of the estate in possession to the next vested estate in reversion or remainder. No livery of seisin or deed was necessary. The mere expression of the giving up by the particular tenant to the remainderman or the reversioner and the acceptance by the latter was sufficient to operate as a surrender of the particular estate. There could not be a technical surrender, except where the legally smaller estate was surrendered to the larger estate. Thus a tenant for life in possession could not technically surrender to a remainderman having an estate for years, irrespective of the length of the term. On the other hand, a tenant for 100 years in possession could surrender to a remainderman for life, and A., a tenant for life in possession, could

8 On release see $2 \mathrm{Bl}$. op. cit. 324 ; Littleton, $\$ \$ 444-447,449-451,459-461$, $465-471,479-480$. 
surrender to B., a remainderman for life, for the reason that A.'s estate was from B.'s point of view an estate d'autre vie, and an estate d'autre vie was an estate legally smaller than an estate for one's own life.

Closely associated with the doctrine of surrender is the doctrine of merger. In the event of a surrender by the particular tenant to the remainderman or reversioner, the surrenderee did not thereupon have two estates. The smaller, or surrendered, estate was held to be lost or merged in the larger estate of the surrenderee. This result was due to the common-law rule that it was legally impossible for a man, except in a few cases, to have at the same time in hinself two separate and immediate estates. If between the estate of the tenant for life in possession and the estate of the remainderman or reversioner there was an outstanding vested estate in another remainderman, then there could technically be no stirrender. The conveyance would have to be by livery or other corresponding methods, and for the same reason there would be no merger of estates in the one to whom the conveyance was made.

If the outstanding interest was mercly a contingent remainder, this would not be regarded as sufficient to prevent the doctrine of merger from applying, and the necessary result would be that the contingent remainder would be destroyed. This destruction of a contingent remainder followed in any case where the particular estate was conveyed to the person who had the next vested estate in remainder, whether by surrender or release or otherwise. This rule of the common law has now been largely changed by statute, and the contingent remainder preserved from destruction by this method. ${ }^{\circ}$

Mention has already been made of the fictitious lawsuits known as the fine and the common recovery in discussing the barring of estates tail. These two fictitious lawsuits were also used as regular methods of conveying interests in land during the older period of English law. They had the advantage of publicity, and of establishing a permanent record as to the state of the title.

Another common-law method of conveyance of limited use was the method of exchange. This could be utilized only where the estates to be exchanged were equal. Neither delivery nor deed was required. It was enough if the possession of the exchanged pieces was taken during the life of the two persons making the exchange. By the statute of frauds, if the estates so exchanged were of more than three years' duration, the exchange must be in writing.

The principles of the feudal law did not admit the power of the holder of land to transmit it by will. As has already been pointed out, the first tendency was to cause the land to go to the heir of the original donee under the terms of the original gift from the overlord. When it became established that the first grantee took a fee simple, the land would nevertheless go to the heir, unless disposed of by the ancestor in

9 On surrender and merger see 2 Bl. op. cit. 326 ; Co. Lit. $337 \mathrm{~b}$; Challis, op. cit. 136 ; Fearne, Conting. Lems. 340-348; Ieake, op. cit. 235. 239. 
his lifetime. The right to leave by will existed in the case of gavelkind land and in some of the English boroughs.

This common-law rule was changed by statute in the reign of Henry VIII. By 32 Hen. VIII, chs. 1 and 35, and 35 Hen. VIII, ch. 5, the power was given to devise all lands held in socage tenure and twothirds of the land held in knight service. When by the $12 \mathrm{Car}$. II, ch. 24 , all land was declared to be held in socage, it thereby automatically became devisable. 


\section{CHAPTER IV}

\section{JOINT OWNERSHIP}

Up to the present, as a matter of convenience, questions of the estates in land have been considered as though the estates were owned by a single individual. Such, however, was not necessarily the case under English law. All rights, whether corporeal or incorporeal, might be owned either by a single person or by two or more persons. There were several species of ownership of this nature. They are described by Blackstone as follows: ${ }^{1}$

"An estate in joint tenancy is where lands or tenements are granted to two or more persons to hold in fee simple, fee tail, for life, for years, or at will. In consequence of such grants an estate is called an estate in joint tenancy, and sometimes an estate in jointure, which word as well as the other signifies an union or conjunction of interest; though in common speech the term jointure is now usually confined to that joint estate, which by virtue of Statute $27 \mathrm{Hen}$. VIII, c. 10, is frequently vested in the husband and wife before marriage, as a full satisfaction and bar of the woman's dower.

"In unfolding this title, and the two remaining ones, in the present chapter, we will first inquire how these estates may be created; next, their properties and respective incidents; and lastly, how they may be severed or destroyed.

"1. The creation of an estate in joint tenancy depends on the wording of the deed or devise, by which the tenants claim title; for this estate can only arise by purchase or grant, that is, by act of the parties, and never by the mere act of law. Now, if an estate be given to a plurality of persons, without adding any restrictive, exclusive, or explanatory words, as if an estate be granted to A. and B. and their heirs, this makes them immediately joint tenants in fee of the lands. For the law interprets the grant so as to make all parts of it take effect, which can only be done by creating an equal estate in them both. As therefore the grantor has thus united their names, the law gives them a thorough union in all other respects. For,

" 2 . The properties of a joint estate are derived from its unity, which is fourfold: The unity of interest, the unity of title, the unity of time, and the unity of possession; or in other words, joint tenants have one and the same interest, accruing by one and the same conveyance, commencing at one and the same time, and held by one and the same undivided possession.

$12 \mathrm{Com} .180$ et seq.

BIG.INT. -4 
"First, they must have one and the same interest. One joint tenant cannot be entitled to one period of duration or quantity or interest in lands, and the other to a different; one cannot be tenant for life, and the other for years; one cannot be tenant in fee, and the other in tail. But if land be limited to A. and B. for their lives, this makes them joint tenants of the freehold; if to $A$. and B. and their heirs, it makes them joint tenants of the inheritance. If the land be granted to A. and B. for their lives, and to the heirs of A., here $A$. and $B$. are joint tenants of the freehold during their respective lives, and $A$. has the remainder of the fee in severalty: or if land be given to A. and B., and the heirs of the body of A., here both have a joint estate for life, and $A$. hath a several remainder in tail.

"Secondly, joint tenants must also have an unity of title; their estate must be created by one and the same act, whether legal or illegal ; as by one and the same grant, or by one and the same disseisin. Joint tenancy cannot arise by descent or act of law; but merely by purchase or acquisition by the act of the party: and unless that act be one and the same, the two tenants would have different titles; and if they had different titles, one might prove good and the other bad, which would absolutely destroy the jointure.

"Thirdly, there must also be an unity of time; their estates must be vested at one and the same period, as well as by one and the same title. As in case of a present estate made to $A$. and $B$., or a remainder in fee to A. and B. after a particular estate; in either case $A$. and B. are joint tenants of this present estate, or this vested remainder. But if, after a lease for life, the remainder be limited to the heirs of A. and B., and during the continuance of the particular estate A. dies, which vests the remainder of one moiety in his heir; and then $B$. dies, whereby the other moiety becomes vested in the heir of B.: now A.'s heir and B.'s heir are not joint tenants of this remainder, but tenants in common; for one moiety vested at one time, and the other moiety vested at another.

"Lastly, in joint tenancy there must be unity of possession. Joint tenants are said to be seised per my et per tout, by the half or moiety, and by all; that is, they each of them have the entire possession, as well of every parcel as of the whole. They have not, one of them a seisin of one-half or moiety, and the other of the other moiety; neither can one be exclusively seised of one acre, and his companion of another; but each has an undivided moiety of the whole, and not the whole of an undivided moiety.

"Upon these principles, of a thorough and intimate union of interest and possession, depend many other consequences and incidents of the joint tenant's estate. If two joint tenants let a verbal lease of their land, reserving rent to be paid to one of them, it shall enure to both, in respect of the joint reversion. If their lessee surrenders his lease to one of them, it shall also enure to both, because of the 
privity or relation of their estate. On the same reason, livery of seisin, made to one joint tenant, shall enure to both of them: and the entry, or re-entry, of one joint tenant is as effectual in law as if it were the act of both. In all actions also relating to their joint estate, one joint tenant cannot suc or be sued without joining the other. *** Upon the same ground it is held, that one joint tenant cannot have an action against another for trespass, in respect of his land; for each has an equal right to enter on any part of it. But one joint tenant is not capable by himself to do any act which may tend to defeat or injure the estate of the other; as to let leases, or to grant copyholds: and if any waste be done, which tends to the destruction of the inheritance, one joint tenant may have an action of waste against the other, by construction of the Statute Westm. II, c. 22. So, too, though at common law no action of account lay for one joint tenant against another, unless he had constituted him his bailiff or receiver, yet now by the Statute 4 Anne, c. 16, joint tenants may have actions of account against each other, for receiving more than their due share of the profits of the tenement's held in joint tenancy.

"From the same principle also arises the remaining grand incident of joint estates; viz.: The doctrine of survivorship, by which when two or more persons are seised of a joint estate, or inheritance, for their own lives, or pur anter vie, or are jointly possessed of any chattel interest, the entire tenancy, upon the decease of any of them remains to the survivors, and at length to the last survivor; and he shall be entitled to the whole estate, whatever it be, whether an inheritance or a common freehold only, or even a less estate. This is the natural and regular consequence of the union and entirety of their interest. The interest of two joint tenants is not only equal or similar, but also is one and the same. One has not originally a distinct moiety from the other; but, if by any subsequent act (as by alienation or forfeiture of either) the interest becomes separate and distinct, the joint tenancy instantly ceases. But, while it continues, each of two joint tenants has a concurrent interest in the whole; and therefore, on the death of his companion, the sole interest in the whole remains to the survivor. For the interest which the survivor originally had is clearly not divested by the death of his companion; and no other person can now claim to have a joint estate with him, for no one can now have an interest in the whole, accruing by the same title, and taking effect at the same time with his own; neither can any one claim a separate interest in any part of the tenements; for that would be to deprive the survivor of the right which he has in all, and every part. As therefore the survivor's original interest nust now be entire and several, and that he shall alone be entitled to the whole estate (whatever it be) that was created by the original grant.

"This right of survivorship is called by our ancient authors the jus accrescendi, because the right upon the death of one ioint tenant ac- 
cumulates and increases to the survivors; or, as they themselves express it: 'Pars illa communis accrescit superstitibus, de persona in' personam, usque ad ultimam superstitem.' And this jus accrescendi ought to be mutual; which I apprehend to be one reason why neither the king, nor any corporation, can be a joint tenant with a private person. For here is no mutuality; the private person has not even the remotest chance of being seised of the entirety, by benefit of survivorship; for the king and the corporation can never die.

"3. We are, lastly, to inquire how an estate in joint tenancy may be severed and destroyed. And this may be done by destroying any of its constituent unities: 1 . That of time, which respects only the original commencement of the joint estate, cannot indeed (being now past) be affected by any subsequent transactions. But, 2 . The joint tenants' estate may be destroyed, without any alienation, by merely disuniting their possession. For joint tenants being seised per my et per tout, every thing that tends to narrow that interest, so that they shall not be seised throughout every part, is a severance or destruction of the jointure. And therefore, if two joint tenants agree to part their lands, and hold them in severalty, they are no longer joint tenants: for they have now no joint interest in the whole, but only a several interest respectively in the several parts. And for that reason, also, the right of survivorship is by such separation destroyed: By common law all the joint tenants might agree to make partition of the lands, but one of them could not compel the other so to do; for this being an estate originally created by the act and agreement of the parties, the law would not permit any one or more of them to destroy the united possession without a similar universal consent. But now by the Statutes 31 Hen. VIII, c. 1 , and 32 Hen. VIII, c. 32, joint tenants, either of inheritances or other less estates, are compellable, by writ of partition to divide their lands. 3. The jointure may be destroyed by destroying the unity of title. As if one joint tenant alienes and conveys his estate to a third person: here the joint tenancy is severed, and turned into tenancy in common; for the grantee and the remaining joint tenant hold by different titles (one derived from the original, the other from the subsequent grantor), though, till partition made, the unity of possession continues. But a devise of one's share by will is no severance of the jointure: for no testament takes effect till after the death of the testator, and by such death the right of the survivor (which accrued at the original creation of the estate, and has therefore a priority to the other) is already vested. 4. It may also be destroyed by destroying the unity of interest. And therefore, if there be two joint tenants for life, and the inheritance is purchased by or descends upon either, it is a severance of the jointure; though, if an estate is originally limited to two for life, and after to the heirs of one of them, the freehold shall remain in jointure, without merging in the inheritance; because, being created by one and the same conveyance, they are not 
separate estates (which is requisite in order to a merger), but branches of one entire estate. In like manner, if a joint tenant in fee makes a lease for life of his share, this defeats the jointure: for it destroys the unity both of title and of interest. And, whenever or by whatever means the jointure ceases or is severed, the riglit of survivorship or jus accrescendi, the same instant ceases with it. Yet, if one of three joint tenants alienes his share, the two remaining tonants still hold their parts by joint tenancy and survivorship: and if one of three joint tenants release his share to one of his companions, though the joint tenancy is destroyed with regard to that part, yet the two remaining parts are still held in jointure; for they still preserve their original constituent unities. But when, by any act or event, different interests are created in the several parts of the estate, or they are held by different titles, or if merely the possession is separated; so that the tenants have no longer these four indispensable properties, a sameness of interest, and undivided possession, a title vesting at one and the same time, and by one and the same act or grant; the jointure is instantly dissolved.

"An estate held in coparcenary is where lands of inheritance descend from the ancestor to two or more persons. It arises either by common law or particular custom. By common law: As where a person seised in fee simple or in fee tail dies, and his next heirs are two or more females, his daughters, sisters, aunts, cousins, or their representatives; in this case they shall all inherit, as will be more fully shown when we treat of descents hereafter; and these co-heirs are then called coparceners; or, for brevity, parceners only. Parceners by particular custom are where lands descend, as in gavelkind, to all the males in equal degree, as sons, brothers, uncles, \&c. And in either of these cases, all the parceners put together make but one heir, and have but one estate among then.

"The properties of parceners are in some respects like those of joint tenants; they having the same unities of interest, title and possession. They may sue and be sued jointly for matters relating to their own lands; and the entry of one of them shall in some cases enure as the entry of them all. They cannot have an action of trespass against each other; but herein they differ from joint tenants, that they are also excluded from maintaining an action of waste; for coparceners could at all times put a stop to any waste by writ of partition, but till the statute of Henry the Eighth, joint tenants had no such power. Parceners also differ materially from joint tenants in four other points: 1. They always claim by descent, whereas joint tenants always claim by purchase. Therefore, if two sisters purchase lands, to hold to them and their heirs, they are not parceners, but joint tenants; and hence it likewise follows that no lands can be held in coparcenary, but estates of inheritance, which are of a descendible nature; whereas not only estates in fee and in tail, but for life or years, may be held in joint tenancy. 2. There is not unity of 
time necessary to an estate of coparcenary. For if a man hath two daughters, to whom his estate descends in coparcenary, and one dies before the other; the surviving daughter and the heir of the other, or when both are dead, their two heirs are still parceners; the estates vesting in each of them at different times, though it be the same quantity of interest and held by the same title. 3. Parceners, though they have a unity, have not an entirety of interest. They are properly entitled each to the whole of a distinct moiety; and of course here is no jus accrescendi, or survivorship between them; for each part descends severally to their respective heirs, though the unity of possession continues. And as long as the lands continue in a course of descent, and united in possession, so long are the tenants therein, whether male or female, called parceners. But if the possession be once severed by partition, they are no longer parceners, but tenants in severalty; or if one parcener alienes her share, though no partition be made, then are the lands no longer held in coparcenary, but in common.

"Parceners are so called, saith Littleton, because they may be constrained to make partition.

"The estate in coparcenary may be dissolved, either by partition, which disunites the possession; by alienation of one parcener, which disunites the title, and may disunite the interest; or by the whole at last descending to and vesting in one single person, which brings it to an estate in severalty.

"Tenants in common are such as hold by several and distinct titles, but by unity of possession; because none knoweth his own severalty, and therefore they all occupy promiscuously. This tenancy, therefore, happens where there is a unity of possession merely, but perhaps an entire disunion of interest, of title and of time. For if there be two tenants in common of lands, one may hold his part in fee simple, the other in tail, or for life; so that there is no necessary unity of interest; one may hold by descent, the other by purchase; or the one by purchase from A., the other by purchase from B.; so that there is no unity of title; one's estate may have been vested fifty years, the other's but yesterday; so that there is no unity of time. The only unity there is, is that of possession: and for this Littleton gives the true reason, because no man can certainly tell which part is his own; otherwise even this would be soon destroyed.

"Tenancy in common may be created, either by the destruction of the two other estates in joint tenancy and coparcenary, or by special limitation in a deed. By the destruction of the two other estates, I mean such destruction as does not sever the unity of possession, but only the unity of title or interest: As, if one of two joint tenants in fee alienes his estate for the life of the alienee, the alienee and the other joint tenant are tenants in common; for they have not several titles, the other joint tenant by the original grant, the alienee by the new alienation; and they also have several interests, the former joint 
tenant in fee simple, the alience for his own life only. So, if one joint tenant gives his part to $\mathrm{A}$. in tail, and the other gives his to $\mathrm{B}$. in tail, the donees are tenants in common, as holding by different titles and conveyances. If one of two parceners alienes, the alienee and the remaining parcener are tenants in common; because they hold by different titles, the parcener by descent, the alience by purchase. So likewise, if there be a grant to two men, or two women, and the heirs of their bodies, as might have been the case had the limitation been to a man and woman, and the heirs of their bodies begotten: and in this, and the like cases, their issue shall be tenants in common; because they must claim by different titles, one as heir of $\mathrm{A}$., and the other as heir of B.; and those two not titles by purchase, but descent. In short, whenever an estate in joint tenancy or coparcenary is dissolved, so that there be no partition made, but the unity of possession continues, it is turned into a tenancy in common.

"A tenancy in common may also be created by express limitation in a deed; but here care must be taken not to insert words which imply a joint estate; and then if lands be given to two or more, and it be not joint tenancy, it must be a tenancy in common. But the law is apt in its constructions to favor joint tenancy rather than tenancy in common; because the divisible services issuing from the land (as rent, \&c) are not divided, nor the entire services (as fealty) multiplied by joint tenancy, as they must necessarily be upon a tenancy in common. Land given to two, to be holden the one moiety to one, and the other moiety to the other, is an estate in common; and, if one grants to another half of his land, the grantor and grantee are also tenants in common: because, as has been before observed, joint tenants do not take by distinct halves or moieties; and by such grants the division and severalty of the estate is so plainly expressed, that it is impossible they should take a joint interest in the whole of the tenements. But a devise to two persons to hold jointly and severally, is said to be a joint tenancy; because that is necessarily implied in the word 'jointly,' the word 'severally' perhaps only implying the power of partition; and an estate given to A. and B., equally to be divided between them, though in deeds it hath been said to be a joint tenancy for it implies no more than the law has annexed to that estate, viz., divisibility, yet in wills it is certainly a tenancy in common, because the devisor may be presumed to have meant what is most beneficial to both the devisees, though his meaning is imperfectly expressed. And this nicety in the wording of grants makes it the most usual as well as the safest way, when a tenancy in common is meant to be created, to add express words of exclusion as well as description, and limit the estate to $A$. and $B$., to hold as tenants in common, and not as joint tenants.

"As to the incidents attending a tenancy in common: Tenants in common (like joint tenants) are contpellable by the statutes of Hentry VIiI and William III, before nentioned, to make partition of their 
lands; which they were not at common law. They properly take by distinct moieties, and have no entirety of interest; and therefore there is no survivorship between tenants in common. Their other incidents are such as merely arise from the unity of possession; and are therefore the same as appertain to joint tenants merely upon that account; such as being liable to reciprocal actions of waste, and of account, by the statutes of Westm. II, c. 22, and 4 Anne, c. 16. * * *

"Estates in common can only be dissolved in two ways: 1. By uniting all the titles and interests in one tenant, by purchase or otherwise; which brings the whole to one severalty. 2. By making partition between the several tenants in common, which gives them all respective severalties. For indeed tenancies in common differ in nothing from sole estates but merely in the blending and unity of possession.

Tenancy by entirety is only incidentally mentioned by Blackstone, and then not under that name. It is a species of joint tenancy peculiar to the relation of husband and wife. It can be created only by a conveyance and to persons who are at the time of the conveyance husband and wife. Any conveyance to husband and wife operates to vest in them a tenancy by the entirety, unless specified to be otherwise. The doctrine of survivorship obtains in tenancy by the entirety as in joint tenancy. It differs, in that it cannot be defeated by a conveyance of either one of the tenants. A conveyance to the husband and wife and a third person operates to give the husband and wife one half the land as tenants by the entirety and to vest the other half in the third person as a joint tenant or tenant in common, according to the language of the conveyance.

The rights which the husband had at common law to the control and disposition of his wife's real property during their joint lives should not be confused with the rights under tenancy by entirety. Thus if $\mathrm{H}$. and W., husband and wife, are seised in fee as tenants by entirety, and $\mathrm{H}$. conveys to $\mathrm{X}$. in fee, $\mathrm{X}$. may or may not get a fee simple. He has the privilege of enjoying the land during the joint life of $H$. and W. because of H.'s power of disposition over W.'s undivided interest during coverture. If $H$. survives $W$., the whole title will pass to him by the doctrine of survivorship, and he will be estopped to assert his title as against $\mathrm{X}$., who will thus obtain an indefeasible fee simple. On the other hand, should W. survive $H$., then, H.'s power of control being terminated, the doctrine of survivorship will put the whole fee in W.

The right of marital control by a husband over his wife's real estate has been very largely abolished by modern statutes; and in many states the doctrine of tenancy by entirety has also been done away with.

Another form of joint ownership entirely unknown to the common law is that of community property. Under this species of ownership all property acquired by husband and wife by their own efforts dur- 
ing marriage, as distinguished from gifts to either one of them, belongs to them jointly. Ordinarily the husband is given the management of such property during marriage. On the death of either spouse, one half of the property goes to the heirs or devisees of the deceased spouse, and the other half to the surviving spouse. ${ }^{2}$

2 On joint ownership see Digbr, op. ctt. 275-2\$1; Litt. $\$ \$ 241-248,250,254$. $265,277,280,281,283,285,287,285.290-292,294,295,298,299,302-304,309$, $319,321,322$; Williams, op. cit. 134-141. 


\title{
CHAPTER V
}

\section{DISSEISIN AND THE REMEDIES THEREFOR}

\begin{abstract}
1
The importance of the seisin of the land, the freehold possession of it, in the earlier law, has already been referred to. This doctrine of seisin remains to be considered from still another point of view, viz., as to the effect produced upon the rights of persons having an interest in land by a wrongful ouster or disseisin ${ }^{1}$ therefrom.

Suppose that A. is seised of land in fee simple, and that B. wrongfully enters upon him and puts him out. The effect of this act by B., technically called a disseisin, is to divest A. of the seisin of the land and to vest a tortious seisin in B. Or, again, suppose that $\mathrm{A}$. has a reversion in fee, subject to a life estate in B., and B. wrongfully enfeoffs $X$. in fee. This also operates as a disseisin of $A$. The same result follows if the tenant for life should enfeoff $X$. in tail. This would give $\mathrm{X}$. a tortious seisin in tail, with a tortious reversion in fee in B., the tenant for life. The effect of a disseisin, if connmitted against a tenant in fee, was necessarily to deprive him of all
\end{abstract}

1 Beside disseisin in the narrow sense there are other ousters or dispossessions of land. Blackstone mentions the following: Abatement, intrusion, discontinuance, deforcement.

"An abatement is where a person dies seised of an inheritance. and before the helr or devisee enters, a strnnger who has no right makes entry, and gets possession of the freehold; this entry of him is called an abatement, and he himself is denominated an abator.

"Intrusion is the entry of a stranger, after a particular estate of freehold is determined, before him in remainder or reversion. And it happens where a tenant for term of life dieth seised of certain lands and tenements, and a stranger entereth thereon, after such death of the tenant, and before any entry of him in remainder or reversion. This entry and interposition of the stranger differ from an abatement in this; that an abatement is alwas to the prejudice of the heir, or immediate devisee; an intrusion is always to the prejudice of him in remainder or reversion.

"Discontinuance happens when he who hath an estate tail maketh a larger estate of land than by law he is entitled to do, in which case the estate is good, so far as his power extends who made it, but no farther. As if a tenant in tail makes a feoffment in fee simple or for the life of the fooffee, or in tail; all which are beyond his power to make, for that by the common law extends no farther than to make a lease for his own life; in sich case the entry of the feoffee is lawful during the life of the feoffor, but if he retains the possession after the death of the feoffor, it is an injury, which is tormed a discontinuance: the ancient legal estate, which ought to have survired to the heir in tail, being gone, or at least suspended, and for a while discontinued.

"Deforcement, in its most extensire sense, is nomen generalissimum; a much larger and more comprehensive expression than any of the former: it then signifying the holding of any lands or tenements to which another person hath a right."

3 Bl. Com. 167 et seq.

See further, on the old law of disseisin. Challis, op. cit. 89, 91. 405 ; Leabe, o1) (it. th-1:; 1 Maitlank, op. cit. $107-457$; 2 Poll. \& Mait. op. cit. 40-80. 
his interest in the land and to vest a tortious seisin in the disseisor, which might be divided into smaller tortious estates in the manner above indicated. A.'s interest was no longer an estate; after the disseisin, all he possessed was a right of entry or a right of action. These rights were peculiarly personal to himself. They could descend to his heir, but they could not be alienated.

A.'s remedies after a disseisin of the sort above indicated were three:

He had, first, the right of self-help. If within a short time after his disseisin (under the older law, apparently five days) he made a reentry upon the disseisor, he might thereby successfully re-establish himself in the seisin of the land. At a later date this period was probably somewhat lengthened, but it was always brief, and by the Statute 3 Rich. II, ch. 8 , it was provicled that no entry should be made, even by disseisee, if it involved a breach of the peace. If the circumstances were such that $\mathrm{A}$. could not safely make this re-entry upon the land, he could keep alive his right of entry by making once a year as near the land as possible a definite assertion of his right thereto and a demand for the repossession thereof. This was known as keeping alive the right of entry by continual claim. Even under these circumstances, however, the right of entry was lost if the disseisor clied in the wrongful seisin of the land, so that the wrongful seisin thereof descended to his heirs. In this case the right of entry was said to be tolled by descent cast.

If the disseisee, for one reason or another, lost his right of entry, he was then driven to bring his action. Actions for the assertion of rights in land were of two sorts: Droitural and possessory. The purpose of the droitural action, as the name indicates, was to determine, as between the plaintiff and the defendant, who had the right to the land. The droitural actions, however, were very slow, very expensive, and gave a great advantage to the defendant, because of the mere fact that he was in the possession of the land with respect to which the action was being brought. Consequently in the reign of Henry II (1154-1189) the so-called possessory actions first made their appearance. The purpose of these actions was to determine, not the question of the ultimate right to the land, but who was entitled to the immediate possession thereof. That is to say, in the hypothetical case under discussion, if A. had lost his right of entry, his next step would be to bring a possessory action based upon the fact that he had been in possession of the land. In this action neither $A$. nor B. would be allowed to raise the question of the ultimate ownership of the land; the only question that would be decided would be whether A. had been in the seisin of the land and B. had put him out without any judgment justifying $B$. in so doing. If so, $A$. would have judgment for a restoration to possession and for damages. After A. had bcen thus revested with the seisin of the land, B. might, as plaintiff, litigate the question of who was really entitled to the land. 'The 
purpose and limited scope of this possessory action made it necersary that it should be brought within a short time after the disseisin complained of. The form of possessory action first devised was the novel disseisin; later other forms were invented to meet varying situations.

If the plaintiff, A., delayed too long in the bringing of his possessory action, so that this method of procedure was no longer open to him, or if he was defeated in his possessory action through some technical reason, he would still be able to bring his droitural action. He would no longer be able to rely upon his right to immediate possession, but despite the fact that the defendant would have the benefit of the actual seisin of the land, the plaintiff would still have it open to him to show that he nevertheless had the better right to the land than the defendant, and if he ultimately succeeded in obtaining a judgment in the droitural action, he would then be restored to the land from which he had been disseised.

By the beginning of the 17 th century both the writs of entry and writs of right had become practically obsolete, and the action of ejectment, of which mention has been made in the discussion of leasehold estates, had become the almost universal method of settling the right to both possession and title of land. The use of fictions by which this action was enlarged from its original narrow purpose is characteristic of the method by which the common-law judges accomplished desirable results by the adoption of means that were originally intended for no such purpose. The development of the old action of quare ejecit into the modern action of ejectment is thus described: ${ }^{2}$

"As the plaintiff did not possess a freehold interest, his title to the lands was only so far acknowledged in this action [quare ejecit] as to give him damages for the injury he had sustained, but not to restore to him the possession of his term.

"Whilst the feudal system continued in its vigour, and estates for years retained their original character, but little inconvenience resulted to tenants from this imperfect remedy. But when the feudal policy declined, and agriculture became an object of legislative regard, the value and importance of estates of this nature considerably increased, and it was necessary to afford lessees for years a more effectual protection. It then became the practice for leaseholders, when disturbed in their possessions, to apply to courts of equity for redress, and to prosecute suits against the lessor himself, to obtain a specific performance of the grant, or against strangers for perpetual injunctions to quiet the possession; and these courts would then compel a restitution of the land itself to the party immediately injured.

"The courts of common law soon afterwards adopted this method of rendering substantial justice; not indeed by the invention of a new writ, which perhaps would have been the best and most prudent

${ }^{2} \Lambda$ dams, Ejectment ( $3 d$ Ed.) p. 8 et seq. 
method, but by adapting the one already in existence to the circumstances of the times; and introducing, in the prosecution of a writ of ejectment, a species of remedy neither warranted by the original writ, nor demanded by the declaration, namely, a judgment to recover the term, and a writ of possession thereupon.

"It is singular that neither the causes which led to this important change, nor the principles upon which it was founded, are recorded in any of the legal authorities of those times. It is difficult, if not impossible, to ascertain with accuracy the precise period when the alteration itself took place; although it certainly must have been made between the years 1455 and 1499 , since in the former year it is said by one of the judges that damages only can be recovered in ejectment : and an entry of judgment is still extant, given in the latter of those years, that the plaintiff in ejectment shall recover both his damages and his term. It is said, indeed, in argument as early as the year 1458 , that the term may be recovered in ejectment, but no reason is assigned for the assertion, nor is any decision upon the point on record until the time of the entry already mentioned.

"But, whatever might be the causes which occasioned this alteration, the effects they produced were highly important. A new efficacy was given to the action of ejectment, the old real actions fell into disuse, and in the subsequent periods of our history the action of ejectment became the regular mode of proceeding for the trial of possessory titles.

"That an action of ejectment, by means of this alteration in its judgment, might restore termors to possession who had been actually ejected from their lands, is sufficiently obvious; but it is not perhaps so evident how the same proceeding could be applicable to a disputed title of freehold, or why, as soon after happened, the freeholder should have adopted this novel remedy. No report of the case, in which this bold experiment was first made, is extant; but from the innumerable difficulties which attend real actions, it is not surprising that the freeholder should take advantage of a fiction which enabled him to avoid them; and as the Court of Common Pleas possessed an exclusive right of judicature in matters of real property, it is probable that the experiment originated in the Court of King's Bench, as an indirect method of giving to that court a concurrent jurisdiction with the Common Pleas. But, however this may be, the experiment succeeded, and the uses of the action, as well as its nature, were changed.

"When first the remedy was applied to the trial of disputed titles, the proceedings were simple and regular, differing but little from those previously in use, when an ejectment was brought to recover the damages of an actual trespass. The right to the frechold could only be determined in an indirect manner. It was a term which was to be recovered by the judgment in the action, and it was therefore necessary that a term should be created; and as the injury complained of 
in the writ was the loss of possession, it was also necessary that the person to whom the term was given, should be ejected from the lands.

"In order to obtain the first of these requisites, namely, a term, the party claiming title entered upon the disputed premises, accompanied by another person, to whom, whilst on the lands, he sealed and delivered a lease for years. This actual entry was absolutely necessary; for, according to the old law of maintenance, it was a penal offence to convey a title to another, when the grantor himself was not in possession. And, indeed, it was at first doubted, whether this nominal possession, taken. only for the purpose of trying the title, was sufficient to excuse him from the penalties of that offence.

"It is from the necessity of this entry, also, that the remedy by ejectment is confined to cases in which the claimant has a right to the possession. When only a right of property or a right of action remained to him, the entry would be illegal, and consequently not sufficient to enable the party making it tc convey a title to his lessee; and as the principles of the action still remain the same, although its proceedings are changed, the right to make an entry continues to be requisite, though the entry itself is no longer necessary.

"The lessee of the claimant, having acquired all right to the possession, by means of the lease already mentioned, remained upon the land, and then the person who came next upon the freehold, animo possidendi, or, according to the old authorities, even by chance, was accounted an ejector of the lessee, and a trespasser on his possession. A writ of trespass and ejectment was then served upon the ejector by the lessee. The cause regularly proceeded to trial as in the common action of trespass; and as the lessee's claim could only be founded upon the title of his lessor, it was necessary to prove the lessor's interest in the land, to enable the plaintiff (the lessee) to obtain a verdict. The claimant's title was thus indirectly determined; and although the writ of possession must of course have been issued in the plaintiff's name, and not in his own, yet as the plaintiff had prosecuted the suit only as the lessor's friend, he would immediately give up to him the possession of the lands.

"In the infancy of the experiment, this mode of proceeding could be attended with no ill consequences. As the party previously in possession, must in contemplation of law be upon the lands, and certainly, animo possidendi, the friend of the claimant was allowed to consider him as an ejector, and make him the defendant in the action. When, however, the remedy became more generally used, this simple method was found to be productive of considerable evil. It was easy for the claimant to conceal the proceedings from the person in possession, and to procure a second friend to enter upon the lands, and eject his lessee immediately after the execution and delivery of the lease. The lessee would then commence his suit against this ejector, and the party in possession might consequently be ousted of his lands, without any 
opportunity of defending his title. To check this evil, a rule of the court was made, forbidding a plaintiff in ejectment to proceed against such third person without giving a previous notice of the proceedings to the party in possession; and it was the practice for such party, on the receipt of this notice, if lhe had any title to the lands, to apply to the court for permission to defend the action; which application was uniformly granted, upon his undertaking to indemnify the defendant (the third person) from the expenses of the suit. The action however proceeded in the name of such defendant, though the person in possession was permitted at the trial to give evidence of his own title.

"A considerable alteration in the manner of proceeding in the action was occasioned by this rule, although it was only intended to remedy a particular evil. It became the general practice to have the lessee ejected by some third person, since called the casual ejector, and to give the regular notice to the person, instead of making him, as before, the trespasser and defendant. A reasonable time was allowed by the courts, for the person in possession, after the receipt of the notice, to make his application for leave to defend the action, and if he neglected to do so, the suit proceeded against the casual ejector, as if no notice had been necessary.

"The time when this rule was made is unknown, but as the evil it was intended to remove must soon have been discovered, it probably was adopted shortly after the remedy grew into general use. It seems also to have been the first instance, in which the courts interfered in the practice of the action, and is therefore remarkable as the foundation of the fictitious system, by which it is now conducted.

"In this state, with the exception of a few practical regulations, not necessary to be here noticed, the action of ejectment continued until the time of the Commonwealth. Much trouble and inconvenience, however, attended the observance of the different formalities. If several persons were in possession of the disputed lands, it was necessary to execute separate leases upon the premises of the different tenants, and to commence separate actions upon the several leases. Difficulties also attended the making of entries, and the action of ejectment had by this time grown into such general use, as to make these inconveniences generally felt. A remedy, however, was discovered for them by Lord Chief Justice Rolle, who presided in the Court of Upper Bench during the Protectorate; and a method of proceeding in ejectment was invented by him, which at once superseded the ancient practice, and has by degrees become fully adapted to the modern uses of the action.

"By the new system, all the forms which we have been describing are dispensed with. No lease is sealed, no entry or ouster really made, the plaintiff and defendant in the suit are merely fictitious names, and in fact all those preliminaries are now only feigned, which the ancient practice required to be actually complied with. 
"A. the person claining title, delivers to $B$. the person in possession, a declaration in ejectment, in which C. and D., two fictitious persons, are made respectively plaintiff and defendant; and in which C. states a fictitious demise of the lands in question from A. to himself for a term of years, and complains of an ouster from them by D. during its continuance. To this declaration is annexed a notice, supposed to be writien and signed by D., informing $\mathrm{B}$. of the proceedings, and advising him to apply to the court for permission to be made defendant in his place, as he, having no title, shall leave the suit undefended. Upon receipt of this declaration, if $B$. do not apply within a limited time to be made defendant, he is supposed to have no title to the premises; and upon an affidavit that a declaration has been regularly served upon him, the court will order judgment to be entered against $\mathrm{D}$. the casual ejector, and possession of the lands will be given to A. the party claiming title. When, however, B. applies, pursuant to the notice, to defend the action, the courts annex certain conditions to the privilege. Four things are necessary to enable a person to support an ejectment, namely, title, lease, entry, and ouster; and as the three latter are only feigned in the modern practice, $\mathrm{C}$. (the plaintiff) would be nonsuited at the trial if he were obliged to prove them. The courts therefore compel B. if made defendant, to enter into a rule, generally known as the consent rule, by which he undertakes, that at the trial he will confess the lease, entry, and ouster to have been regularly made, and rely solely upon the merits of his title; and, lest at the trial he should break his engagement, another condition is also added, that in such case, he shall pay the costs of the suit, and shall allow judgment to be entered against D. the casual ejector. These conditions being complied with, the declaration is altered, by making B. the defendant instead of D., and the cause proceeds to trial in the same manner as in other actions." 


\section{CHAPTER VI}

\section{USES AND TRUSTS}

The system of rights, powers, privileges, and immunities as outlined in the preceding chapters constituted the measure of interests in land as developed and recognized by the courts of common law. Then, however, as now, men for economic or social or religious reasons frequently desired to engage in courses of action or to achieve results which either were actually forbidden by the law or which at least the law would not recognize or protect. It was for reasons of this sort that the doctrine of uses made its appearance in England. In its essence the idea of a use was extremely simple. A. puts the title to land in $\mathrm{B}$., with the understanding that $\mathrm{C}$. is to have the enjoyment or use of the land. B. in such a case is the only one who has any legal title; C. is entirely dependent upon B.'s honesty and good faith for the protection of the interest in the land which $\mathrm{A}$. intended that $\mathrm{C}$. should have. It is evident therefore, that the desire of $\mathrm{A}$. to achieve the result and his trust in B.'s good faith must be strong to induce him to engage in such a course of action.

The historical origin of uses is obscure. There is some reason for believing that traces of them can be found as far back as the 12th century. One of the earliest and most potent influences in the creation of uses was the desire to evade the mortmain statutes. Within a century after the Norman Conquest the large accumulation of land in the hands of the religious corporations began to be a source of considerable trouble in English law and policy. The conveyance of land in mortmain was forbirden by Magna Carta, section 43 (1217), which provided as follows:

"It shall not be lawful from henceforth to any to give his lands to any" religious house, and to take the same land again, to hold of the same house. Nor shall it be lawful to any house of religion to take the lands of and to lease the same to him of whom they were received to be holden. If any from henceforth so give his lands to any religious house, and thereupon be convict, the gift shall be utterly void, and the land shall accrue to the lord of the fee."

After the adoption of Magna Carta the broad construction that was put upon this section rendered it impossible for a monastery to receive the legal title to land. This being the situation, if a person wished to convey land to a monastery, some indirect method became inevitable. The following device was the one that was resorted to: The grantor A., would make a livery of seisin of the land in question to $B$. in fee, with a direction to $B$. to allow the monastery to have the occupation

Big.INT.-5 
and use of the land; B.'s legal title being purely nominal, for the purpose of evading the statutory provision. In a court of law $B$. was the only person having an interest in the land. But B., in accordance with the terms of his understanding, would permit the monastery to take possession of the land. Its only standing at law was that of a tenant at will, and if $\mathrm{B}$. violated his pledge and turned the monastery out it was helpless legally. In such a case some other means must be found to coerce $\mathrm{B}$. into performing his obligation. This means was found at an early date in the spiritual authorities. If $B$. refused to abide by his agreement, the parish priest or possibly the abbot of the monastery or some other religious authority would threaten the spiritwal punishment of interdict, or excommunication, and, in a time when the religious influences were as powerful and widespread as they were in England in the 12th century, such a threat was potent, and in many cases quite sufficient to compel $\mathrm{B}$. to perform his obligation and to protect the beneficiary in the enjoyment of the property. This device of evading the mortmain statute by means of uses was abolished in 1391 by 15 Rich. II, ch. 5 , which provides as follows:

"It is agreed and assented, that all they that be possessed by feoffment or by other manner to the use of religious people, or other spiritual persons, of lands and tenements, fees, advowsons, or any manner of other possessions whatsoever, to amortise them, and whereof the said religious and spiritual persons take the profits, that betwixt this and the feast of St. Michael next coming they shall cause them to be amortised by the licence of the king and of the lords, or else that they shall sell and aliene them to some other use, between this and the said feast, upon pain to be forfeited to the king and to the lords, according to the form of the said Statute of Religious, as lands purchased by religious people; and that from henceforth no such purchase be made, so that such religious or other spiritual persons take thereof the profits, as afore is said, upon pain aforesaid; and that the same statute extend and be observed of all lands, tenements, fees, advowsons, and other possessions purchased or to be purchased to the use of guilds or fraternities."

By this time, however, the desirability of uses for purposes other than those of evading the mortmain statute had become so manifest that the practice grew in spite of the forbidding of uses for religious purposes. One of the most important of the other sources of uses was the facility it afforded in evading the onerous feudal obligations. This may best be illustrated by a concrete case. Suppose that A., a tenant in fee simple, is likely to die within a year or so leaving a minor son as his heir. If $\mathrm{A}$. dies seised of the lands, the overlord (the king, if $\mathrm{A}$. is a tenant in capite) will be entitled to wardship and marriage in the land, with the prejudicial results to the interest of A.'s heir that have already been pointed out. If now, A., during his life, enfeoffs B., a young man, of the land in fee simple for the benefit of A.'s minor son in fee simple, 
A. will have to pay the customary fine for alienation, which is slight: but the legal title of the land will then be in B., and A.'s later death will have no effect upon B.'s legal title. At the same time the heir, for whose use the legal title has been put in B., will be protected in the enjoyment of the land, and the profit of it will be accumulated for him and not go into the pocket of the overlord, and he will also be free from the feudal burden of the lord's right of marriage. There are certain drawbacks. Against these advantages must be put the fact that, since the legal title is in B., the land will be subject to dower in favor of B.'s wife, if he has one, and if B. should die seised of the lands his overlord would be entitled to whatever feudal incidents might accrue as a result of that death. These possibilities can be reduced to a minimum if A., instead of enfeoffing B. alone, enfeoffs B., C., and D. as joint tenants of the land in fee. In this case the doctrine of survivorship will cut out dower rights and any rights on the part of the overlord, so long as any of the joint tenants survive. When the title becomes vested in a single joint tenant, the process can be repeated by a convevance by him to other joint tenants upon the same uses. The technical name that is given to the one who holds the legal title in the manner above described is feoffee to uses; the beneficiary is technically known as the cestui que use.

Another advantage that the doctrine of uses offered was in the facility with which equitable titles could be conveyed. The commonlaw methods of conveying legal title have already been discussed. These common-law doctrines had no application to the interests of the beneficiary, and a mere parol transfer or creation of a beneficial interest was sufficient. Again, as has been pointed out, the legal title to land held in knight service could not be left by will. This was evaded by the device of $\mathrm{A}$. enfeoffing $\mathrm{B}$. of land in fee simple, to hold to the use of such persons as A. should designate by his will.

Other causes that contributed to the development of the doctrine of uses was the desire of debtors to defeat creditors in their rights in the debtor's land and to render more difficult the forfeiture of the land for treason. The first of these two purposes was prevented by statute at a rather early date.

Whether the doctrine of uses would have grown to the extent that it did, if the protection of the cestui que use had been merely the religious one that has already been referred to, may perhaps be doubted. But in time another coercive power was dereloped for the protection of the beneficiary in the juriscliction of the King's chancellor. The chancellor, in the 11 th and 12th centuries, was known as the "keeper of the King's conscience." At a time when the distinction between the legislative and executive and judicial powers of the government was not sharply defined, and the king was regarded as the source of all power, it was the common custom for persons who were aggrieved and found themselves in a situation where either the courts 
of law were powerless to protect them or where there was no right that the common law recognized, to petition the king for redress from the hardship of their particular case. These petitions were customarily referred by the king to the chancellor for his action, and by the middle of the 14th century the jurisdiction of the chancellor to deal with such cases as a matter of course was definitely established. The position of the cestui que use would make a particularly strong appeal, since the unfairness of allowing the feoffee to uses to take advantage of the fact that he had the legal title and to exercise it in violation of the terms of his trust was so obvious that the chancellor would not hesitate to give relief in such a case. By the end of the 14th century petitions to enforce uses of lands begin to appear in the records, and from that time on they grow steadily in number.

The method by which the chancellor operated is worth noticing. The legal title to the land was in the feoffee to uses and that legal title could not be directly affected by the chancellor. Indeed, he made no attempt to deal with or change the legal title as such. His method of procedure was based upon a recognition of the fact that the legal title to the land was in the feoffee to uses, and it took the form of commanding the feoffee to uses so to deal with the land which he thus owned that the cestui que use should be allowed to enjoy it in accordance with the will of the creator of the use. If the feoffee refused to do this, the chancellor would fine him, or, more commonly, imprison him, until he was ready to comply with the order. The writ by which the chancellor summoned the feoffee to uses bisan with the Latin words "Sub pœna," and consequently the process in chancery to enforce a use was frequently referred to as the subpœna.

Once the general principle had been definitely established of protection by the chancellor of the rights of the cestui que use, the law of uses began to take definite shape and various questions in connection therewith began to arise. Naturally one of the first questions would be as to who would be bound by the terms of the use.

Clearly the original feoffee to uses, B. wottld be bound to abide by his agreement. If $\mathrm{B}$. died, leaving an heir, D., to whom the legal title of the land would pass, the chancellor at first refused to enforce the use against him. The reason for this was that the right of the cestui was regarded as being not so much a property right, a right in the land, as a personal right against the feoffee to uses as an individual. Since the confidence had been reposed only in B., the original feoffee, it seemed that there was no good reason for charging the conscience of B.'s heir with respect to the land to which he had the legal title, where he had personally made no promises with respect thereto. By the middle of the 15 th century, however, it was established that B.'s heir would take the land subject to the use. Since he had paid nothing for the land, the justice of this result seems clear. On the same principle, if $\mathrm{B}$. during his life enfeoffed $\mathrm{X}$. of the land as a gift, the chancellor had 
no hesitation in enforcing the terms of the use against $\mathrm{X}$. Again, if $\mathrm{X}$. paid a consideration for the land, but at the time that he took it knew of the fact that it was held subject to a use in favor of C., there would seem to be no good reason why X., the purchaser, should complain if the use was also enforced against him. On the other hand, if the purchaser had paid value for the land and took the legal title in ignorance of the fact that any third person was supposed to have a beneficial interest in the land, it seemed unfair to permit the beneficiary to subject $\mathrm{X}$. to his claim. In this situation both the beneficiary and the purchaser were equally innocent, and the purchaser had the added advantage over the beneficiary that he had the legal title to the land, and as such would naturally be entitled to enjoy it as he saw fit, unless the beneficiary could successfully sustain the burden of affirmatively establishing that he should be allowed to have the beneficial enjoyment despite the fact of X.'s legal title. The principle involved in this latter type of case is embodied in the proposition that a purchaser in good faith and for a valuable consideration of the legal title to land cuts off equitable rights therein.

It will be noticed that in the various situations so far dealt with the person who succeeded to the title of the land with respect to which the cestui claimed, did so either as heir or donee or purchaser of the title of the original feoffee to uses; that is to say, he took through the feoffee, and he was subject to the equities that were good against the feoffee, except in the case already mentioned of his being a purchiaser in good faith for a valuable consideration. If the feoffee to uses forfeited his estate, so that it went to his overlord by escheat, or if he was disseised of the land, or if he died leaving a wife, who was allotted dower in the land, the cestui que use lost his right as against the person so taking title. The reason for this difference was that in the cases last mentioned the persons taking title took it after the feoffee to uses, but not through the feoffee to uses; their title being considered as being separate from and independent of, that of the feoffee. 'This doctrine is technically expressed in the statement that the interest of the cestui que use may be enforced against a person taking title in the per, but not against a person taking in the post.

Another problem that has to be considered is as to when a use was raised. If $\mathrm{A}$. enfeoffed $\mathrm{B}$. in fee, and declared that the use of the land was to be in $\mathrm{C}$., there could be no question. It was not necessary to employ any particular terms in order to declare the use; any language that made it clear that a specified person was to have the beneficial interest in the land was sufficient. Where the use was not expressly declared, there was more doubt in the matter; the problem then being to ascertain the intent of the feoffor from other circumstances. If the feoffee paid a consideration for the land, the inference would seem clear that he was not taking the title merely to benefit some one else, and the beneficial interest would be regarded as being in hin, together 
with the legal title. This doctrine prevailed in the lack of any other evidence showing the one entitled to the beneficial interest to be other than the feoffee to uses, even where the consideration was a merely nominal one. If $\mathrm{A}$. conveyed the land to $\mathrm{B}$. for life or for years, and nothing was said as to who should have the use of the land, it was considered that the feudal obligations that would be due from B. to A. by virtue of the tenure existing between them would be a sufficient consideration to keep the use of the land in B. In either of these two last mentioned cases if the use was expressly declared to be in a third person, such express declaration would prevail.

Another situation was this. A. might enfeoff $B$. of the land in fee simple, and there be neither a consideration nor any statement as to who was to have the beneficial use of the land. To understand the construction that the chancellor put upon this state of affairs, it must be remembered that it has been said that by the 15th century in England "the use [custom] of the country to deliver land to be safely kept has made a mere delivery of possession no evidence of right without valuable consideration." 1 This being the practice, the chancellor would come to the conclusion that the purpose of the conveyance was merely to put the legal title in B., but that A. intended to keep the beneficial interest in the land in himself. In these circumstances the use was technically said to result to A. A similar doctrine would be applied in the case of a feoffment to B. in fee, where the use was declared only for a smaller estate than a fee, as, for example, to C. for life. In this case the use after the termination of C.'s life estate would result to $\mathrm{A}$. in fee, and this result would follow even though a consideration was paid; the presumption being that the consideration was paid for the use declared.

So far, as a matter of convenience, we have considered uses raised on a feoffment. It should be noticed, however, that a use might be raised upon any other form of common-law conveyance, such as a fine, or a recovery, or a lease and release.

Up to here we have been considering cases in which the use was raised in connection with a conveyance of the legal title by the creator of the use to some third person for the benefit of the cestui que use; that is, the use has always been raised in connection with a change of the posscssion of the land from the original creator of the use to the grantee of the legal title. It was entirely possible, however, to raise a use without such transmutation of possession. Thus A., the owner of land in fee simple, might merely sell to B. for a valuable consideration, the use of the land either for years or for life or in fee. In such case A. would still retain the legal title, but B.'s equity and his right to the protection of the chancellor would be just as clear, and the protection would be just as freely given, as in the cases which have hitherto been considered. The chancellor would by his orders compel A. to permit

1 Gilbert, Uses and Trusts, 125. 
B. to have the use of the land in accordance with the terms of their bargain, so that $A$. would have only the bare legal title, and $B$. the beneficial interest. This transaction was technically known as a bargain and sale. Since it was not a dealing with the legal interest in the land, it did not have to satisfy any of the common-law formalities as to conveyances. A mere informal agreement between the parties was sufficient, if the chancellor was satisfied as to what the terms of the bargain were. On the other hand, the chancellor would not assist B., unless B. had paid a valuable consideration for the use of the land. While in the common-law courts a promise under seal was just as binding on A. as though it was supported by a valuable consideration, and, while the deed was one of the established methods of conveying common-law interests in land, these mere formalities were not regarded by the chancellor as being sufficient to entitle $\mathrm{B}$. to enforce against $\mathrm{A}$. a promise which was not supported by a valuable consideration. This doctrine was modified in the 16th century in one type of case which will be subsequently considered.

With the growth of uses the possibility of creating in the cestui estates of various sizes, similar to the legal estates, but with much more flexibility in their creation, became recognized. Use estates might be created for years, for life, in tail or in fee, in reversion or in remainder, and otherwise. This will be considered at greater length subseguently.

The custom of raising uses in land grew constantly in England, and by the end of the 15th century a large part of English lands were held subject to uses, so that the legal title to the land was in one person. and the beneficial title to the land in another. While this custom had the advantages that have been mentioned above, it also had certain disadvantages. Titles, for example, were necessarily in an uncertain condition. The strongest objection to the prevalence of uses came from the crown, because of the serious encroachments that were made on the feudal rights of the crown as a result of the creation of equitable titles which were entirely free from the common-law feudal obligation. Several attempts were made to meet this situation. One of them, passed in 1483 , was as follows:

St. 1 Rich. III (1483) c. 1: "Forasmuch as by privy and unknown feoffments, great unsurety, trouble, costs, and grievous vexations daily grow among the King's subjects, insomuch that no man that buyet any lands, tenements, rents, service, or other hereditaments, nor women that have jointures or dowers in any lands, tenements, or other hereditaments, nor men's last wills to be performed, nor leases for term of life, or of years, no annuities granted to any person or persons for their services for term of their lives or otherwise be in perfect surety, nor without great trouble and doubt of the same, because of the said privy and unknown feoffments: (2) For remedy whereof, be it ordained, established, and enacted, by the advice of the Lords Spiritual and 'Temporal, and by the Commons in this present Parliament assem- 
bied, and by authority of the same, that every estate feoffment, gift, release, grant, leases and confirmations of lands, tenements, rents, services, or hereditaments, made or had, or hereafter to be made or had by any person or persons being of full age, of whole mind, at large, and not in duress, to any person or persons; and all recoveries and executions had or made, shall be good and effectual to him to whom it is so made, had or given, and to all other to his use, (3) against the seller, feoffor, donor, or grantor thereof, (4) and against the sellers, feoffors, donors, or grantors, and every of them, his or their heirs, claiming the same only as heir or heirs to the sellers, feoffors, donors, or grantors and every of them, (5) and against all other having or claiming any title or interest in the same, only to the use of the same seller, feoffor, donor or grantor, sellers, feoffors, donors or grantors, or his or their said heirs at the time of the bargain, sale, covenant, gift, or grant made, (6) saving to every person or persons such right, title, action or interest, by reason of gift in tail thereof made, as they ought to have had, if this Act had not been made."

The effect of this statute was to give to the cestui que use power to pass to his grantee both his own estate and the legal estate of the feoffee to uses. But this was merely a privilege, the exercise of which lay in the discretion of the cestui. The statute did very little toward doing away with what was, from the point of view of the crown, the fundamental evil, viz., the existence of the separate equitable title. Some fifty years later, upon the insistence of Henry VIII, the so-called Statute of Uses was passed for the purpose of definitely doing away with the system of double ownership, legal and equitable. ${ }^{2}$

St. 27 Hen. VIII (1536) c. 10: "Where by the common law's of this realm, lands, tenements and hereditaments be not devisable by testament, (2) nor ought to be transferred from one to another, but by solemn livery and seisin, matter of record, writing sufficient made bona fide, without covin or fraud; (3) yet nevertheless divers and sundry inaginations, subtle inventions and practices have been used, whereby the hereditaments of this realm have been conveyed from one to another by fraudulent feoffments, fines, recoveries, and other assurances craftily made to secret uses, intents and trusts; (4) and also by wills and testaments, some time made by nude parolx and words, cometimes by signs and tokens, and sometimes by writing, and for the most part made by such persons as be visited with sickness, in their extreme agonies and pains, or at such time as they have scantly had any good memory or remembrance; (5) at which times they being provoked by greedy and covetous persons lying in wait about them, do many times dispose indiscreetly and unadvisedly their lands and inheritances; (6) by reason whereof, and by occasion of which fraudulent

2 On uses prior to the statute of uses see $2 \mathrm{Bl}$. op. cit. 327-332; Challis, op. cit. :55, 3SG; Digby, op. cit. ch. VI; Leake, op. cit. 7S-S2; Williams, op. cit. $10.5-170$. 
feoffments, fines, recoveries, and other like assurances to uses, confidences and trusts, divers and many heirs have been unjustiy at sundry times disinherited, the lords have lost their wards, marriages, reliefs, harriots, escheats, aids pur fair fils chivalier \& pur file marier, (7) and scantly any person can be certainly assured of any lands by them purchased, nor know surely against whom they shall use their actions or executions for their rights, titles and duties; (8) also men married have lost their tenancies by the curtesy, (9) women their dowcrs, (10) manifest perjuries by trial of such secret wills and uses have been committed; (11) the King's Highness hath lost the profits and advantages of the lands of the persons attainted, (12) and of the lands craftily put in feoffments to the uses of aliens born, (13) and also the profits of waste for a year and a day of lands of felons attainted, (14) and the lords their escheats thereof; (15) and many other inconveniences have happened and daily do increase among the king's subjects, to their great trouble and inquietness, and to the utter subversion of the ancient common laws of this realm; (16) for the extirping and extinguishment of all such subtle practiced feoffments, fines, recoveries, abuses and errors heretofore used and accustomed in this realm, to the subversion of the good and ancient laws of the same, and to the intent that the King's Highness, or any other his subjects of this realm, shall not in any wise hereafter by any means or inventions be deceived, damaged or hurt, by reason of such trusts, uses or confidences: (17) it may please the King's most royal majesty, That it may be enacted by his Highness, by the assent of the Lords Spiritual and 'Temporal, and the Commons, in this present Parliament assembled, and by the authority of the same, in manner and form following: that is to say, That where any person or persons stand or be seised, or at any time hereafter shall happen to be seised, of and in any honours, castles, manors, lands, tenements, rents, services, reversions, remainders or other hereditaments, to the use, confidence or trust of any other person or persons, or of any body politick, by reason of any bargain, sale, feoffment, fine, recovery, covenant, contract, agreement, will or otherwise, by any manner or means whatsoever it be; that in every such case, all and every such person and persons, and bodies politick that have or hereafter shall have any such use, confidence or trust in fee simple, fee tail, for term of life or for years or otherwise, or any use, confidence or trust in remainder or reverter, shall from henceforth stand and be seised, deemed and adjudged in lawful seisin, estate and possession of and in the same honours, castles, manors, lands, tenements, rents, services, reversions, remainders, and hereditaments, with their appurtenances, to all intents, constructions and purposes in the law, of and in such like estates as they had or shall have in use, trust or confidence of or in the same; (19) and that the estate, title, right and possession that was in such person or persons that were, or hereafter shall be seised of any lands, tenements or hereditaments, to the use, 
confidence, or trust of any such person or persons or of any body politick, be from henceforth clearly deemed and adjudged to be in him or them that have, or hereafter shall have such use, confidence or trust, after such quality, manner, form, and conditions as they had before, in or to the use, confidence or trust that was in them.

"II. And be it further enacted by the authority aforesaid, That where divers and many persons be, or hereafter shall happen to be, jointly seised of and in any lands, tenements, rents, reversions, remainders or other hereditaments, to the use, confidence, or trust of any of them that be so jointly seised, that in every such case those person or persons which have or hereafter shall have any such use, confidence or trust in any such lands, tenements, rents, reversions, remainders or hereditaments, shall from henceforth have, and be deemed and adjudged to have only to him or them that have, or hereafter shall have any such use, 'confidence or trust, such estate, possession and seisin, of and in the same lands, tenements, rents, reversions, remainders and other hereditaments, in like nature, manner, form, condition and course, as he or they had before in the use, confidence or trust of the same lands, tenements, or hereditaments; (2) saving and reserving to all and singular persons and bodies politick, their heirs and successors, other than those person or persons which be seised, or hereafter shall be seised, of and lands, tenements or hereditaments, to any use, confidence or trust, all stich right, title, entry, interest, possession, rents and action, as they or any of then had, or might have had before the making of this Act.

"III. And also saving to all and singular those persons, and to their heirs, which be, or hereafter shall be seised to any use, all such former right, title entry, interest, possession, rents, customs, services and action as they or any of them might have had to his or their own proper use, in or to any manors, lands, tenements, rents or hereditaments, whereof they be, or hereafter shall be seised to any other use, as if this present Act had never been had nor made; any thing contained in this Act to the contrary notwithstanding.

"IV. And where also divers persons stand and be seised of and in any lands, tenements, or hereditaments, in fee simple or otherwise, to the use and intent that some other person or persons shall have and perceive yearly to them, and to his or their heirs, one annual rent of $x$. li. or more or less, out of the same lands and tenements, and some other person one other annual rent, to him and his assigns for term of life or years, or for some other special time, according to such intent and use as hath been heretofore declared, limited and made thereof:

"V. Be it therefore enacted by the authority aforesaid, That in every such case the same persons, their heirs and assigns, that have such use and interest, to have and perceive any such annual rents out of any lands, tenements, or hereditaments, that they and every of them, their heirs and assigns, be adjudged and deemed to be in possession and seisin of the same rent, of and in such like estate as they had in the title, 
interest or use of the said rent or profit, and as if a sufficient grant, or other lawful conveyance had been made and executed to them, by such as were or shall be seised to the use or intent of any such rent to be had, made or paid, according to the very trust and intent thereof, (2) and that all and every such person and persons as have, or hereafter shall have, any title, use and interest in or to any such rent or profit, shall lawfully distrain for non-payment of the said rent, and in their own names make avowries, or by their bailiffs or servants make conisances and justifications, (3) and have all other suits, entrics and remedies for such rents, as if the same rents had been actually and really granted to them with sufficient clauses of distress, re-entry, or otherwise, according to such conditions, pains, or other things limited and appointed, upon the trust and intent for payment or surety of such rent."

Stated in general terms, the effect of the Statute of Uses was that in any case where a person was seised of a freehold estate in land to the use of another person, the use estate of the second person was transformed into a legal estate of the same size as his prior use estate, the legal title of that amount being carried from the holder of the legal title to the holder of the equitable title, by operation of the statute. The more detailed effects of the statute may be considered from three points of view. 1. As to its effect on methods of conveying title to land. 2. As to its effect on the law relating to the creation of estates in land. 3. As to its effect on the modern law of trusts.

It will be recalled that under the common law a possessory title in land could be passed either by livery of seisin, by lease and release, by fine, or by recovery. In the first two of these methods, the transaction necessarily involved, in the case of the livery, a formal entry upon the land and a formal transfer of the frcellold interest; in the case of a lease and release, the formalities were not so great, but an actual taking of possession by the lessee was necessary before the release could be executed. In the case of the fine and recovery, the transfer of the title was a matter of judicial record. After the passage of the Statute of Uses, if A. should enfeoff B. in fee, to the use of C. in fee, the legal title would pass to $B$. by virtue of the feoffment. Since he stood seised to the use of $\mathrm{C}$. in fee, the statute would operate to carry to $C$. the legal estate in fee, leaving $B$. no interest in the land; $\mathrm{B}$. being what is technically known as a conduit to uses. No formalities were necessary, it is to be noticed, in the declaring of the use, and consequently the effect of the statute was to create a legal title in C., entirely unaccompanied by any formality; that is, the legal title in $\mathrm{C}$. might rest purely upon a parol declaration of the use. This was true, not only where the use was raised upon a feoffment; it applicd to a use raised upon any of the common-law conveyances. This situation continued until the last half of the 17 th century, when the seventh section of the Statute of Frauds destroyed the possibility of creating by 
parol a legal title by raising a use upon a common-law conveyance. It provided as follows:

St. 29 Car. II (1676) c. 3: "§ 7. And be it further enacted by the authority aforesaid, That from and after the said four and twentieth day of June [1677] all declarations of creations of trusts or confidences of any lands, tenements, or hereditaments, shall be manifested and proved by some writing signed by the party who is by law enabled to declare such trust, or by his last will in writing, or else they shall be utterly void and of none effect.

"§ 8. Provided always, That where any conveyance shall be made of any lands or tenements by which a trust or confidence shall or may arise or result by the implication or construction of law, or be transferred or extinguished by an act or operation of law, then and in every such case such trust or confidence shall be of the like force and effect as the same would have been if this statute had not been made; anything hereinbefore contained to the contrary notwithstanding."

In these cases at least one step in the passage of the title, to wit, the common-law conveyance, either involved a change in the actual possession of the land, or was a matter of judicial record. Neither of these facts was true in the case where the owner of the land, A., bargained and sold the use of it to C. In such a case there would be no conveyance at all, and the mere informal bargain and sale of the use would be sufficient, under the operation of the statute of uses, to vest the legal title in C. The possibility of unlimited and secret transfers of the legal title by this method became clear shortly after the passage of the Statute of Uses. To remedy this weakness, the same session of Parliament that passed the Statute of Uses passed also the Statute of Enrollments. This was as follows:

St. 27 Hen. VIII, c. 16-St. of Enrollments (1536): "Be it enacted by the authority of this present Parliament, That from the last day of July, which shall be in the year of our Lord God 1536, no manors, lands, tenements, or other hereditaments, shall pass, alter or change from one to another, whereby any estate of inheritance or freehold shall be made or take effect in any person or persons, or any use thereof to be made, by reason only of any bargain and sale thereof, except the same bargain and sale be made by writing indented, sealed, and inrolled in one of the King's courts of record at Westminster, (2) or else within the same county or counties where the same manors, lands, or tenements, so bargained and sold, lie or be, before the Custos Rotulorum and two justices of the peace, and the clerk of the peace of the same county or counties, or two of them, at the least, whereof the clerk of the peace to be one; (3) and the same enrollment to be had and made within six months next after the date of the same writings indented; $* * *(6)$ and that the clerk of the peace for the time being. within every such county, shall sufficiently enroll and ingross in parchment the same deeds or writings indented as is afore- 
said; (7) and the rolls thereof at the end of every year shall deliver unto the said Custos Rotulorum of the same county for the tirne being, amongst other records of every of the same counties where any such enrollment shall be so made, to the intent that every party that hatis to do therewith, may resort and see the effect and tenor of every such writing so enrolled.

"II. Provided always, That this Act, nor any thing therein contained, extend to any manor, lands, tenements, or hereditaments, lying or being within any city, borough or town corporate within this realm, wherein the mayors, recorders, chamberlains, bailiffs or other officer or officers have authority, or have lawfully used to enroll any evidences, deeds, or other writings within their precinct or limits; any thing in this act contained to the contrary notwithstanding."

The requirements of this statute gave a certain degree of publicity to the creation of titles by means of a bargain and sale, and thus rendered the entirely secret creation of them in this manner impossible. It was still possible to create a use on a common-law conveyance by means of a parol declaration which the statute would then transform into a legal estate.

One other method of creating a legal title also received recognition as a direct result of the statute of uses. In discussing the creation of uses prior to the statute, it was stated that the chancellor would not enforce a gratuitous use, and the mere fact that the promise was under seal would not alter the situation. Shortly after the passage of the statute of uses, this doctrine was modified in the case of Sharington v. Strotton, ${ }^{3}$ decided in the Queen's Bench. In that case the owner of land in fee executed a deed in which he stated that, in order to preserve his family stock and that of his brothers, he covenanted for these reasons and for the affection that he bore his brothers that he would stand seised of the land in question to his own use for his own life, then to the use of his brother and his wife for their lives, with other similar limitations. The court held that this consideration of blood and brotherly love was sufficient to make the covenant valid. and that consequently the uses were executed under the statute into corresponding legal estates. This is the so-called covenant to stand seised, and it is limited in its scope to cases of family settlement in favor of near relatives.

About thirty years later, in Callard v. Callard, the court of Queen's Bench held that these limitations for family purposes could be raised only by deed, thus for reasons of public policy giving at least a certain degree of definiteness in the creation of legal titles. It will be noticed that the covenant to stand seised is not embraced within the Statuie of Enrollments.

The covenant to stand seised and the bargain and sale may be combined in one instrument, as where A., in consideration that B. is his

8 Plowd. 298 (1505).

- Moore, 6St (1593). 
son and that $\mathrm{C}$. has paid him $£ 100$, covenants that $\mathrm{B}$. shall have the use of his land during his life, and after his death that $\mathrm{C}$. shall have it in fee.

In the 17 th century a still further method of conveying title to land was worked out, and, once it had been sanctioned by the courts, became the most popular method of transferring title. It had the advantages of requiring neither the formality or publicity of the common-law conveyances, nor was it recordable under the Statute of Enrollments. This was the method of conveying known as the lease and release. The lease and release has already been mentioned as one method of conveying used at common law. When so used, however, it was necessary that the lessee should enter the land before he could take a release. The new method under the statute of uses was for A. to execute to B. a bargain and sale for one year of the land in question which it was desired to convey. Since the statute of enrollment applied only to bargains and sales of freehold interests, the bargain and sale for a year did not require recording. It had been held in Lutwitch v. Mitton ${ }^{5}$ that a bargain and sale of this kind gave the bargainee by virtue of the statute a legal title without his making any entry on the land. Thus having a legal title, by operation of law, he could immediately take a common law release in fee of the grantor's reversionary interest. This became ultimately the commonly used method of conveying title; the bargain and sale for a year and the release ordinarily being written on the same piece of paper, the release being dated one day later than the bargain and sale.

These two methods of conveying - that is, the common-law method, with a declaration of the use to the person taking the legal title under the conveyance, and conveyances operating either in whole or in part under the Statute of Uses-continued to exist side by side till the 19th century. For the first few years after the Statute of Uses, the courts were extremely narrow in their attitude, and if a conveyance was intended to operate as a conveyance at common law and was for some reason ineffective as such, they would refuse to give it any efficacy under the Statute of Uses even though all the elements of a good conveyance under the statute existed. ${ }^{8}$ Later on, their attitude changed, and the rule was definitely established that, if a conveyance could be made to operate either at common law or under the Statute of Uses, it would be held effective.

The most far-reaching effect of the Statute of Uses is to be found in the changes that were produced in the law relating to estates. It is to be borne in mind that the statute operated to transform into legal estates those estates which prior thereto the chancellor would have protected as equitable estates. In deciding what interests he would

5 Cro. Jac. 604 (1620).

6 Sep Callard v. Callard, Moore, $6 S 7$ (1593).

7 Sce Roe v. Tranmer, 2 Wils. 75 (1757). Compare Taylor v. Vale, Cro. Eliz. 166 (1589). 
so protect, the chancellor did not feel himself bound by the strict common-law rules which have been discussed in considering the method of creating estates at common law and the kinds of estates that could be created. To a certain extent when, after the Statute of Uses, these former equitable estates now became legal estates, and so were brought within the cognizance of the common-law courts, these courts did apply the stricter conmon-law principles. Thus the phrase "to his heirs" was necessary to create a fee simple. A mere declaration of the use to B. would result in giving him only a life estate, and a limitation of the use to B. and the heirs of his body, after the Statute of Uses, would give him a legal estate in tail. ${ }^{8}$ In general, however, the law courts recognized as valid legal estates those limitations which, prior to the statute, had been equitable estates. Certain particular cases, however, should be noticed. If A. enfeoffed B. in fee to the use of A. for life, after the statute A. would clearly have a legal estate for life. If the undisposed of residuum of the use was allowed to result to $\mathrm{A}$. in fee, this would give him a reversion in fee which would swallow up and destroy his life estate by the doctrine of merger. Consequently, in order to preserve the life estate, in accordance with the express terms of the creation of the use, the court held that the reversion did not result to $A$. in fee, but that, after A.'s death, B. had a legal remainder in fee. On the other hand, if $A$. enfeoffed B. in fee to the use of A. in tail, which after the statute would give him a legal estate in tail, the use was also held to result to him in fee; De Donis in this case keeping the two estates apart, so that the common-law doctrine of merger had no application. Doubt was also raised in the case of Shortridge v. Lamplugh ${ }^{9}$ whether or not the use would result on a lease and release in fee. It seemed, however, finally to be settled that there was no essential difference between this method of conveying and any other, and that a use would result in this case where it would result in the case of a conveyance by livery.

It is in the law relating to the creation of future estates that the greatest changes in the law were produced by the Statute of Uses. The common-law rules with respect to the creation of common-law remainders have already been stated. Under the Statute of Uses the possibilities in the creation of future estates werc greatly enlarged. These changes can best be illustrated by examples:

If A. enfeoffs B. in fee from the 1st of January next, this conveyance would be bad at common law, for the reason that a freehold estate of possession cannot be created to begin in futuro. However, A. could bargain and sell the use of his land to B. in fee or in tail or for life, to begin two years from date, or on A.'s death, or when B.

8 See Abraham v. Twigg, Cro. Ellz. 478 (1590): Egerton's Case, Cro. Jac. 525 (1619); Broughton v. Langley, 2 Salk. 679 (1703).

o 2 Salk. 67 S (170'). 
paid A. $£ 100$. The chancellor would have enforced any one of these uses before the statute, and after the statute they were all good legal estates. Both the use and the complete legal title would remain in A. until the contingency happened upon which they were to go to $B$.; that is, A.'s estate would not be a particular estate, but would be the complete fee of the land, subject to the estate over in favor of B. This estate in $\mathrm{B}$. is what is technically known as a springing use; the use comes into being without there having been created any preceding use estate. The same general principle applied to the creation of uses raised on transmutation of possession, as where $A$. enfeoffs $X$. in fee to the use of $B$. two years from date, etc.

Another estate which could be created under the Statute of Uses, which was impossible at common law, was a limitation after a fee to a third person. Thus $\mathrm{A}$. could bargain and sell to $\mathrm{B}$. in fee, and if $\mathrm{B}$. died without issue living at his death, or if C. paid B. $£ 100$, then to C. in fee. This case, where the second use estate operates to cut off the first use estate, is technically known as a shifting use. Here, also, the same set of estates may be created by a use raised on a common-law conveyance, as where A. enfeoffs X. in fee to the use of $\mathrm{B}$. in fee, with the limitation over to $\mathrm{C}$. in fee, as well as on a bargain and sale.

In connection with this limitation, mention should be made of the highly technical doctrine of scintilla juris. In the case last put, since the limitation of the use was to B. in fee, when that was executed by the statute that would seem to carry from X., the feoffee to uses, all his legal estate. If later the contingency was satisfied by C., so that the use was shifted to him, the question arose as to what seisin that use was based on. The theory was then evolved that, despite the fact that X.'s entire seisin had been carried to B. to serve the first use, there still remained in $X$. a possibility of a right sufficient to carry the second use to $\mathrm{C}$. This possibility of right received the name "scintilla juris." The only practical aspect of the question lay in the possibility of B.'s being able to deal with the scintilla juris in such a way as to prejudice C.'s rights. The whole doctrine was abrogated by statute, and C.'s rights definitely put beyond possibility of prejudice. ${ }^{10}$

At common law, as has already been pointed out, it was impossible to create a contingent remainder unsupported by a preceding vested estate of freehold. Under the statute, however, A. might bargain and sell to $B$. for ten years, and then to the son of $B$. in fee, even though $B$. had no son at the date of the bargain and sale. Although one or two old cases intimated that the estate in A.'s son would be bad, it is probably good. ${ }^{11}$

1023 \& 24 Vict. c. 38 , \& 7.

11 See Gray, Rule against Perpetuities (3d Ed.) \$§ 58-60. 
Another possibility in the creation of future estates, that takes its origin in the Statute of Uses, is the doctrine of powers. Since the legal title is carried to the use estate, when the use estate comes into being, it is possible to create the following limitation: A. may bargain and sell to $\mathrm{C}$. for life, and then to such person as X. may appoint, and, when $\mathrm{X}$. does appoint, his appointee will, by virtue of the statute, have his use estate executed into a corresponding legal estate. Here, as before, the same result may be achieved by the raising of the use upon a conmon-law conveyance.

At common law it is impossible for a man to convey to himself. Under the Statute of Uses A. may enfeoff B. in fee to the use of A. for life, which will result in giving $A$, a life estate under the conveyance, as a purchaser.

These are but illustrations of the possibilities of creating future estates under the statute. In every case where the use is undisposed of, either by declaration or consideration or tenure, it results to the creator of the use, and always in fee, although, of course, it may later be cut off by some expressly declared use: A case that is not expressly covered by the statute is the following: A., a tenant for life, bargains and sells to $B$ in fee. In this, case it will be noticed that the legal estate, A.'s, out of which the use estate in B. is created, is smaller than is the estate in B. The utmost that the statute can do is to carry A.'s life estate to B. Consequently B. can get a fee only for the life of $\mathrm{A}$.

Mention has been made in another connection of the destructibility of contingent remainders, except where preserved by trustees or protected by statutory enactment. In this regard there was a marked difference between contingent remainders and springing or shifting uses and executory devises. Regardless of what might be done with the particular estate, when the contingency happened upon which the declared use was to come into being, the legal estate was thereby automatically created by action of the statute. This nondestructibility of estates created under the Statute of Uses led to the growth of a new doctrine in the law of property, the so-called rule against perpetuities. The situation that it was designed to reach can best be shown by a concrete illustration: Suppose A. enfeoffs B. in fee to the use of C. in fee, but if C.'s direct descendants ever become extinct then to the then oldest living descendant of $\mathrm{D}$. in fee. It is evident that in this case the estate after C.'s may not vest until the lapse of an indefinitely long time. Consequently, since a shifting use is indestructible, it is evident that in no way can a clear title be obtained to this land. Such a situation, and there are many others, variations of the same principle, is open to most serious objections upon the grounds of public policy. Beginning with the 17th century, the doctrine was evolved, and now is definitely recognized which may be stated as follows: "No interest is good unless it must vest, if at

Big.INT. -6 
all, not later than twenty-one years after some life in being at the creation of the interest." 12

We now come to a consideration of cases not covered by the statute.

The statute in terms purported to apply only to a case where one person was seised to the use of another. Consequently, if A., a tenant for years, bargains and sells to C., or if A., the owner in fee, leases to B. for years to the use of C., in neither case is C.'s interest affected by the statute. His rights, after the statute, as before, are purely equitable.

A. enfeofis B. in fee to the use of B. in fee. B.'s estate in this case is not created by the statute, but by virtue of the common-law conveyance, and the declaration of the use in $\mathrm{B}$. merely prevents the use resulting to $A .{ }^{13}$ If, on the other hand, A. enfeoffs $B$. in fee to the use of B. and C. in fee, B. as well as C. in this case gets his estate by operation of the statute. ${ }^{14}$

In Cooper v. Franklin ${ }^{15}$ it was held that it was impossible to raise a use on an estate tail; the reason for this being that De Donis definitely fixed the beneficial interest in the tenant in tail, and it was impossible to raise a use in contravention to the purpose of that statute.

Another use not executed by the statute is the active use. Thus A. enfeoffs B. in fee, to sell the land in question and pay the proceeds to C., or to collect the rents and profits and pay them to C. Since in these cases the feoffee to uses had active duties to perform, and was not merely to serve as a passive conduit to uses to $C$., the case was not regarded as coming within the operation of the statute. Consequently C.'s rights still remained equitable. ${ }^{16}$

The final case of the use unexecuted by the statute is the use on the use, as where A. enfeoffs B. in fee. to the use of C. in fee, to the use of D. in fee, or A. bargains and sells to $\mathrm{C}$. in fee, to the use of $\mathrm{D}$. in fee. Before the passage of the Statute of Uses the chancellor would have enforced only the first use in $\mathrm{C}$.; the use orer to $\mathrm{D}$. being regarded as repugnant to the already declared use in C., and therefore void. The same situation obtained after the statute; since C.'s use was the only one that the chancellor would have recognized, C. was regarded as having the legal estate after the statute, and the use to D. was disregarded. ${ }^{17}$ Care should be taken to distinguish between a use on a use and a shifting use. In the former case the attempt is to make the first cestui que use hold contemporaneously for the benefit of the second cestui que use. In the second case the attempt is

12 Gray, op. cit. § 201.

13 See Doe d. Lloyd r. Passingham, 6 Barn. \& C. 305 (1827).

14 See Samme's Case, 13 Co. 54 (1609).

15 Cro. Jac. 400 (1616).

18 Nevil v. Saunders, 1 Vern. 415 (1686).

17 Tyrrel's Case, Dyer, 155a (1557). 
to make the interest of the second cestui que use come in on a certain contingency and cut off the interest of the first cestui que use.

The interest of the second cestui que use in the case of the use on the use was apparently entirely ignored both by the law courts and by the chancellor for about 100 years after the passage of the Statute of Uses. By the middle of the 17th century, however, the doctrine that a use on a use could not be enforced was regarded as a mere legal technicality, and the chancellor began to protect in equity the interest of the second cestui. With this recognition by the chancellor of the possibility of an equitable estate, distinct from and impose. upon the legal estate in the land, and protected by equitable processes. the situation was brought back in many respects to substantialiy what it was before the passage of the Statute of Uses. The statement of the interest of the old cestui que use, the only one, as has been aiready said, that the chancellor would have recognized, having become by statute and the passage of time merely a step in the creation of a legal estate, this legal estate, in turn, becomes the foundation for a new equity. It is in this connection that the statement has been made that the total effect of the Statute of Uses was to add three words to a common-law conveyance.

This is the beginning of the modern law of trusts. The only difference is that the feoffee to uses, or holder of the legal estate, is now called a trustee, and the old cestui que use, or holder of the equitable estate, is now called the cestui que trust. The doctrines of the modern law of trusts, while bearing a general resemblance to those of the old law of uses, differ widely therefrom in other regards, and form a large and independent branch of modern law. ${ }^{18}$

I 8 On uses subsequent to the statute of uses see $2 \mathrm{Bl}$. op. cit. $333-340$ : Challis, op. cit. 386-392; Digby, op. cit. ch. VII. Leake, op. cit. 82-96; Williams, op. cit. $170-179,366-371$.

See, in general, on uses, Ames, 21 Harr. Law Rer. 261. 



\section{INDEX}

[THE FIGUHES REFER TO PAGES]

ABATEMENT, $58 \mathrm{n}$.

ALIENATION,

By subinfeudation, 11, 17, 1 .

By substitution, 11.

Restricted by De Donis, 22. 23.

By Quia Emptores, 12, 13.

Under the statute of uses, $77-79$.

ALLODIAL OWNERSHIP, 17.

ATTORNMENT,

Abolition of, 45 .

Requirement of, 7,45 .

BLRGAGE TENURE, 9.

CONDITIONAI, LIMITATIONS, 43.

CONVEYANCE,

See Alienation.

COPYHOLD TENURE. 10.

See Servile Tenants.

CORPOREAL AND INCORPOREAL RIGHTS, 36, 37.

CURTESY,

See Life Estates.

DEFORCEMENT, $58 \mathrm{n}$.

DESCENT AND PURCHASE, 20.

DISCONTINLANCE, $5 S \mathrm{n}$.

DISSEISIN, REMHEDIES FOR, 59, 60.

What is, 5 s.

DOWER,

See Life Estates.

EJECTMENT,

Action of, 60-64.

ENTRY,

Right of, 43.

EXCHANGE,

Conveyance by, 47.

FEE CONDITIONAL. 22.

FEE DETERMINABLE, 25.

FEE SIMPLE,

How created, 20, 21.

Origin of, $19,20$.

Subinfeudation of, $11,13,17,18$.

Eig.Ixt. 
FEE TAIL,

Methods of barring, 24, 25 .

Orimin of, 23.

United states, in. 25.

FEOFFMENT,

Charter of, 34.

Converance by, 34, 35. See Seisin.

FINIE,

Conrerance by, $4 \pi$.

Entail barred by, 24.

Feudal incident of, 7 .

FRANKALMOYN TENURE, 10.

FREEHOLD,

Nleanings of, 30.

GAVELKIND TENURE, 9.

INCORPOREAL HEREDITAMENTS, 44.

See Corporeal and Incorporeal Rights

INTRUSION, $5 S$ n.

JOINT OWNFRSHIP,

Community property, 56.

Coparceny, 53, 54.

Joint tenancy, 49-53.

Tenancy bs entirets, 56.

Tenancy in common, 55,56

JOINT TENANCY.

How created. 49.

Properties of, 50́-0.2.

Termination of, 52, 53.

LEASE.

How created, 34, 35.

See Tenant.

LEASE AND RELEASE, 78.

LIFE ESTATES,

Curtesr, 27.

D'autre vie, 26.

Dower, 2S-30.

General occupant in, $2 \boldsymbol{a}$.

Special occupant in, 26 .

Varieties of, 26.

LINITATION,

Words of, 20.

LORD AND TENANT, 3.

MANOR,

Dirisions of, 8.

Jurisdiction of, 9.

MERGER, 47. 
MILITARY TENURE,

Abolition of, 14-17.

Incidents of,

Aids, 4.

Escheat, 7.

Fines, 6.

Marriage, 6.

Primer seisin, 5.

Relief, 5.

Wardship, 5.

In Lnited States, 17.

NORMAN CONQUEST,

Effect of, 1, 2 .

PERPETUITHES,

Rule against, $\$ 1, \$ 2$.

POSSESSION.

Distinguished from seisin, 32,33

Transfer of, 34, 35.

REAI PROPERTI LAW, Origin of, 1.

RECOVERY,

Common,

Bars entail, 24.

Form of conveyance by, 47 .

RELEASES, 46.

REMAINDERS,

Contingent, 39-41.

Destructability of, $41,42,47$.

Transfer of, 44,45 .

Trustees to preserve, 42.

Vested, $38,39$.

REVERSIONS, 38, 39.

SEISIN,

Distingnished from possession, 32, 33

Meaning of, $32,33$.

Transfer of, 34, 35, 38, 39, 41, 42 .

SERJEANTY $7,10$.

SERVILE TENANTS, 9, 10.

See Copyhold.

SOCAGE TENURE, 8, 9.

STATUTE OF USES, $72-75$.

Conveyances under, $75,77-79$.

Estates creited unter, $7:-\$ 1$.

Relation of, to law of trusts, 83 .

Scintilla juris, under, so.

ilses not executed by, s2, s3. See Uses.

SURIENDER, 46. 47.

TENANT,

At sufferance, 32 .

At will, 32.

For years, 31.

From year to year, 32. 
TENURES,

Abolition of, 14-17.

Burage. 9.

Conyhold, 10.

Frankalmoyn, 10.

Gavelkind. 9.

Military, 4- 7 .

Socage, $8,9$.

United States, in, 17, 18.

Varieties of, 3.

TRUSTS,

Relation of, to uses, $\$ 3$.

LSES,

Bargain and sale of, 70 .

Chancellor's protection of, 67,68 .

Consideration, when necessary, 69,70 .

Donee of feoffee, bound br, 69 .

Feoffee to, bound by, 67, 68 .

Feudal obligations, evaded by, 66, 67 .

Heir of feoffee, bound by, 67 .

Iortmain statutes, eraded by, 65,66 .

Not executed by the statute, 82 .

On a use, 82,83 .

Purchaser from feoffee, when bound by, 69.

Raised by parol, 71, 75,76 .

Resulting, 69, 70 .

Raised without transmutation of possession, 70, 77, 78 .

Statutes affecting, 65, Magna Carta. $\$ 34: 66,15$ Rich. II, c. 5: 71. 1 Rich. III, c. $1 ; 72,27$ Hen. VIII, c. $10 ; 76,29$ Car. II, c. $3, \& 7 ; 76,27$ Hen. VIII, c. 16.

See Statute of Uses.

WILL OF REAL ESTATE.

Not allowed at common law, 47.

Power to make, given by statute, 48. 




\section{CASES}

\section{ON \\ RIGHTS IN LAND}

BY HARRY A. BIGELOW

PROFESSOR OF LAW IN THE UNIVERSITY OF CHICAGo

\section{AMERICAN CASEBOOK SERIES \\ WIILIAM R. VANCE \\ GENERAL EDITOR}

ST. PAUL

WEST PUBLISHING COMPANY

1919 
Copraight, 1919

BY ।

WEST PUBLISHING COMPANY

(BIG.RIGHTS) 


\section{TO MY COLLEAGUES}

$$
\text { OF THE }
$$

LAW FACULTY

(iii)* 



\section{AUTHOR'S PREFATORY NOTE}

THE title of this volume is at best an approximation. The powers and immunities that form so important a part of rights relating to land are touched on only to a slight extent; for the most part those aspects of property rights are taken up elsewhere. To attempt to catalogue in detail the privileges that the owner of land has, whether his ownership be absolute or qualified, would be to attempt a list of human activities which take place on the soil; to attempt to consider the relation between these privileges and the right not to be disturbed in the enjoyment of them, or the further question as to how far these privileges may be abridged, is the proper field for a work on Jurisprudence or Constitutional Law. The aim of the present volume is more limited. It is to present first, the law of the more important rights that are normal incidents of the ownership of soil; and, second, the law of certain more or less stereotyped forms of rights and privileges with respect to land in which a third person has an interest, either absolute or qualified. Hence the division of the volume into two parts: Rights Incidental to Ownership, and Rights in the Land of Another.

How far cases in equity ought to be included is a question upon which reasonable men may well differ. In the present collection the aim has been this: Where the courts of equity have developed a substantive law peculiar to thenselves, as in the enforcement of contracts affecting the use of land and in waste, the attempt has been made to show the development of those doctrines with the same fullness as any other branch of the law within the scope of the volume. Where the courts of equity have merely protected the owner in rights that a common-law court would also enforce, the aim has been to indicate the peculiarities, if any, of the protection given by a court of equity; but not to go into the question of what prerequisites such as the establishment of a right at law, or repeated violations of the right or similar matters, must exist before a court of equity will act. Nor has it seemed necessary, in dealing with the extent to which equity would act, to cover all aspects of equitable relief in each topic taken up in the volume. The considerations that do or do not affect a court of equity in giving relief in some situations (as for example, the doctrine of balance of convenience in nuisances), must be understood as applicable, mutatis mutandis, to other situations corered by the volume.

The traditional and almost universal method of dealing with the subject-matter of this volume and that of Professor Aigler is to take up the former first. Consequently the numerical order of the volumes has naturally and properly been arranged with this custom in mind, and in the present volume the attempt has been made to have the material in a shape available for first ycar students. 
In the statement that the teaching of the subject-matter of Volume II before that of Volume III is traditional, there is no implication that this order has only tradition to justify it. At the same time it is the opinion of the editor of the present volume that, while the subject-matter of both Volume II and Volume III, as well as that of the other volumes in this series, must of course be taken up at one time or another, if the student is to have an adequate understanding of the whole field of property law, there is much to be said in favor of an order which combines the subject-matter of Volume III, with certain introductory material, as a first-year course, and postpones the subject-matter of Volume II to the second year. Few teachers of Real Property will plunge beginning students at once into the cases of either Volume II or Volume III. There must be some introduction to this general subject. Whichever order is adopted, the starting point will be the material covered in this series under the title "Introduction to the Law of Real Property," either in the form there given or in some other form. The most important topics dealt with in this introductory matter are disseisin, feoffments, grants, estates, and the doctrine of uses. After this material has been deait with, if it is to be really assimilated, and correlated with living law, so as to be more than a more or less nebulous acquaintance with legal antiquities, the transition must be to branches of the law where the information that has been acquired can be kept alive and steadily made use of, either by comparison, or by analogy, or as furnishing a historical explanation for modern doctrines. It is the belief of the writer that this correlation and vivifying of the law is more likely to be accomplished by the use of a casebook that deals with adverse possession, estates and the form and effect of a modern conveyance, rather than a casebook that deals with easements, covenants, and rents. Furthermore, while one cannot be dogmatic on the point, questions of the making of deeds, of the relation of landlord and tenant involved in leases and surrenders, and of adverse possession, seem to be of a sort more likely to have come within the experience of the beginning law student than questions of easements, profits, and restrictive covenants.

So far as the intrinsic difficulty of the subject-matters of the two volumes is concerned, both present problems of law that are not easy. If Volume II has covenants and rents, Volume III has reservation of easements and title by estoppel. But here, too, on the whole, the subject-matter of Volume III seems more adapted to first-year work than that of Volume II.

No person who has had the advantage of Professor Gray's teachings and writings can fail to acknowledge the influence and help that they furnish. The author is glad to make that acknowledgment.

\section{HARry A. Bigelow.}

The U.xiversity of Cincago I,ain School, July 17, 1919. 


\section{TABLE OF CONTENTS}

PART I

Rights INCIDENTAL to Possession

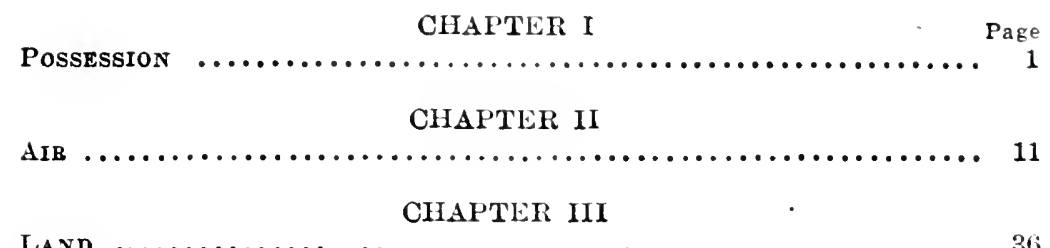

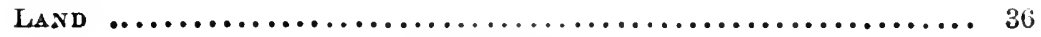

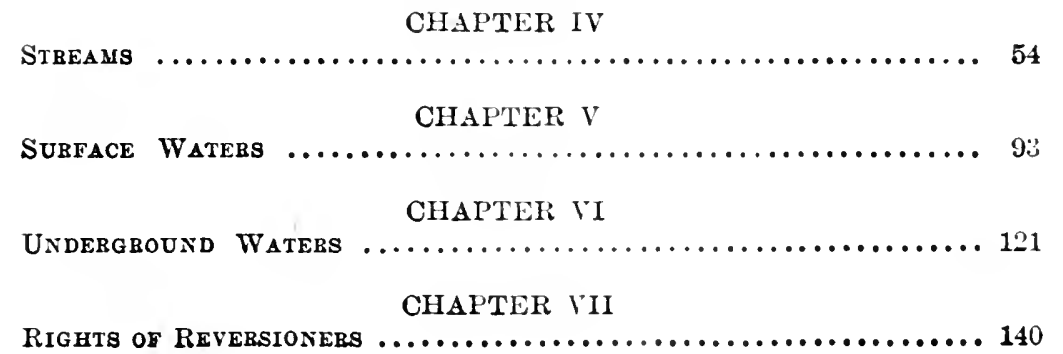

\section{PART II}

Rights in the LAND of ANother

CHAITER 1

Pвofits

153

\section{CHAPTER II}

\section{Section}

EAsejexts

1. General Principles of Easements....................... 180

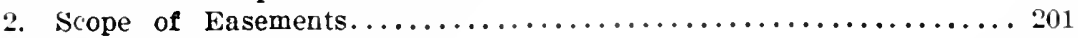

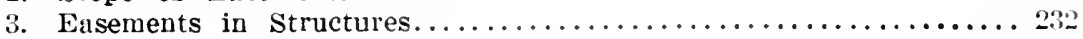

4. Easements in Artificial Water Courses.................... $25 \%$

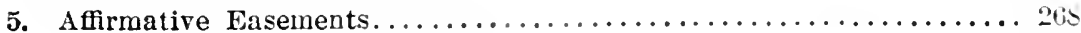

6. Extinguishment of Easements...........................

\section{CHAPTER III}

LICENSES 303

\section{Bio.Rights}

(vii) 


\section{CHAPTER IV}

Section

\section{Legal Enforcement of Covenants Running with the Land}

1. As between Landlord and Tenant....................... 338

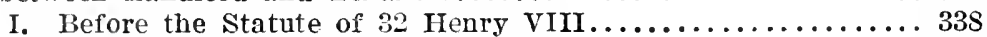

II. Under the Statute of 32 Ifenry VIII................. 339

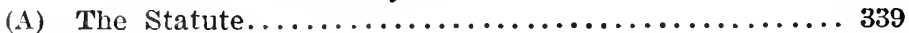

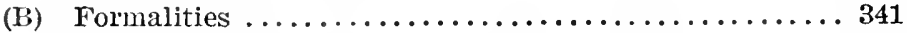

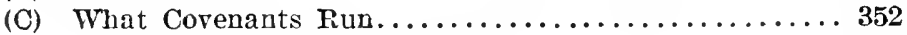

(a) Covenants by the Lessee................. 352

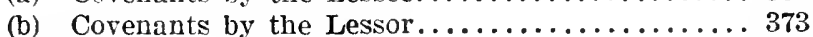

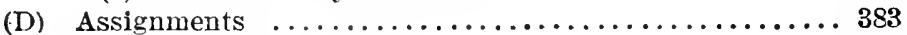

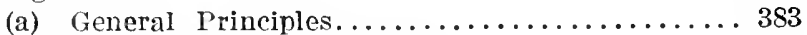

(b) Assignment of Part Interests........... 395

III. Not Under the Statute 32 Henry VIII............... 410

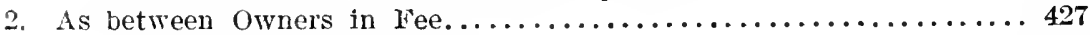

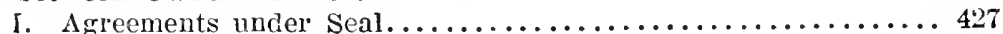

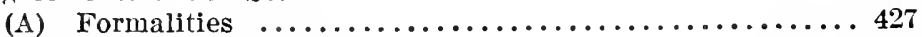

(B) What Covenants Run......................446

(C) Party Wall Covenants.....................4 471

II. Agreements not Under Seal......................489

\section{CHAPTER V}

Equitable Enforcenent of Agreements Running with the Land

1. General Principles ................................... 494

2 Running of Benefit and Burden....................... 511

\section{CHAPTER VI}

\section{RENTS}

1. General Nature of Rents............................ 549

2 Suspension and Apportionment of Rents.................. 575

3. Failure to Obtain Possession...........................617

4. What Payments are Rents...........................6 632

\section{CHAPTER VII}

WASTR

1. General Principles of Waste...........................6. 639

2. Remedies for Waste...............................6. 6 .

3. Equitable Waste.................................68 68

\section{CHAPTIER VIII}

PUBLIC RIgHTS

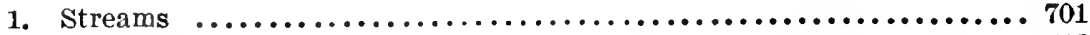

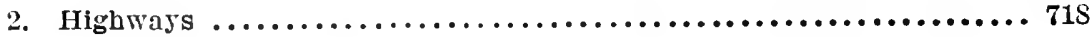




\section{TABLE OF STATUTES}

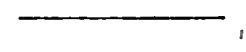

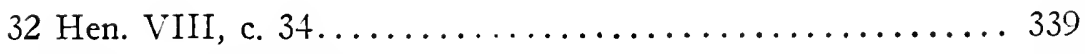

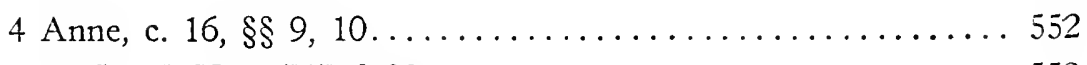

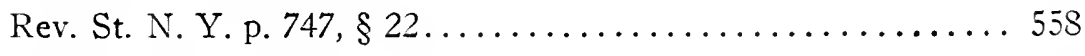

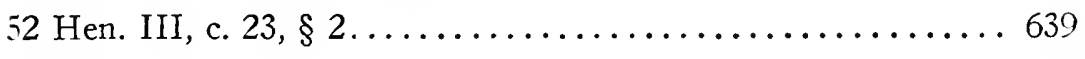

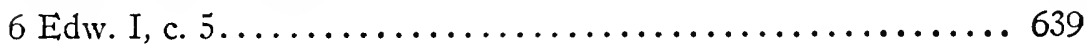

Big.Rights (ix)* 



\section{TABLE OF CASES}

[TITLES OF CASES PRINTEd heREIN ARE SET IN ORDINARY TYPE. CASES CITED IN FOOTNOTES ARE INDICATED BY ITALICS. WHERE SMALL CAPITALS ARE USED, THE CASE IS REFERRED TO IN THE TEXT]

v. Cooper.........

Abbot r. Weekly................. 150 Abuott v. Kansas City, St. J.\&C.

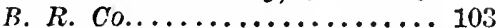
Ackroyd v. Smith............ 185 Acton r. Blundell............ 121 Adams $v$. Toble.............442 ADAMS v. VAN ALSTYNE....... 73 Albright $v$. Cortright.........717 Aldritt $v$. Fleischaucr.......... 114 Allcock $v$. Moorhousc..........415 Allen r. Culver.............4 420 dllen $r$. San Jose Land \& Water

ro. ......................... 205 Allen v. sechinam........... 495 Amcrican Strawboard Co. v. Haldeman Paper Co............ 355

Ames v. Kendall............. 398 Ames v. Shat................2s

Arigus r. Dalton........... 33

Anomymous ..............6.

Anoximous Case............699

Applcgate L. Franklin......... 99

Ards v. Watkins........... 561

Arnold $v$. stetens.............

Ashby $v$. 11 ilson........... 513

ASILET v. WOLCOTT.......... 96

ATkins r. Bordanax.........2:3

Atlanta, K. \& N. IR. Co. v. McKin-

mey ...............4 455

Atlintic Coast Line r. Co. v.

Bunting ................ 230

Attoe $v$. Hemmings........... 404 Attorncy Gencral r. Condnit Co... \$1

Attorney General v. Williams.... 202

A ustcrberiy $\imath$. Oldhum........ 462

$A$ ris $r$. Newman.................661

Bacon v. Sandbcrg..........547

НА(iOT $г$. BAGOT.............650

Bailey v. Stephens.......... 176

. Bakeman v. 'talbot...........207

Baker $v$. Scbright..........669

Ball v. Herder'. ........... 705

Ballard $v$. Dyson............205

Ballard $v$. Titus................

BALly v. Wells...........

Baltimore City v. Fairieled

IMr. Co.................

BIg.Rrguts
Pạ̣e

Battigore \& P. R. Co. v. Fifril Baptist Cilurch............ 19

BaMforb v. TURNLEY......... 15 Banli of British North America $v$. Miller ................... 197 Bank of Pennsylyania v. Wise... 55: BANNING, CASE OF........... ISt Barber v. Penley............. 7.: Barliley v. IVilcox........... 10:3 Barncs v. City of Lonilon K. $E$. Co. ...................... Barringer $v$. Firginia Trust C'o... 46t Barrington, In re.......... Baryow v. Richard........... Barry v. Ealutiten................ Barton 1. Slifer............. 517 Baskerville v. MaYo......... 556 Bass $\nabla$. Rollins............ 610 BASSETt $y$ SAlisBlry Mrg. Co... 12t; Bateman v. Hotchkin........6.67 Bates v. Dunewn.......... 316 BATES v. INHAMITANTS OF WESTBOROUgh .............. 119

Baxter v. Tavlor.............. 140

Beach v. Barons............. 39 Beach 2. Jlorgan............717 Beach v. Sterling Iron d Zinc Co. $\$ 7$ Peal v. Hoston Car Spring Co.... 57:bennett v. Fittle........... 591 Berry 2 . Godfrey.............. Bickford v. P'ilrson...........4 41ti Bidlle $\vee$ Hussminu. .......... 5st Biduell v. Holden............. sot Bingham v. Snlene............... 16.; Bish v. Hecling............ Fitello v. J ipson. . . . . . . . . . . Blatehford $v$. Cole........... 5. BLEWTT Y. TrEgovisisg...... 179

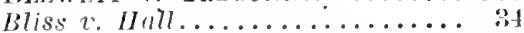
Bloch. v. lsham........... 475 BLy $r$. EDISON Electric hlluMINativa Co............ 148, 151 Ioatman v. Ialsley........... 157 Bonomi v. Backhouse.......... ; Boston Ferrule Co. v. Hills....... :9 Boston \& $P$. R. Corporation $v$. nerty ................. 291

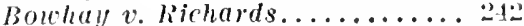
22 Bowles (Lewis), Case of........ 65s 
Bowlsby $\nabla$. Speer............ 114

Bradford $v$. Pickles............ 129 Bradford Oil Co. v. Blair....... 352 Braleley v. Thade............ 559 Brett $\nabla$. Cumberland.......... 383 Brewer v. Malishall. . ........ 448 Brewer v. Marshall.........510 Brewster v. Eidgill..........5566 Brislol Hydraulic Co. v..Boyer... 93 BroAdDENT V. RaysiothaM. . .96, 99 BROCK v. DoLE.............. 657 Broder v. Salllard.......... 117

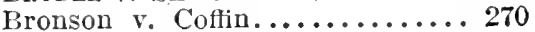
Bronson v. Coffin............. 272 Brooks v. Curtis............. 232 Brown v. Chadbourne.........701 Brown v. Illius............. 134 Brown $\nabla$. Southern Pac. Co...... 442 Browne $v$. Trustees of Methodist Episcopal Church in City and Precincts of Laltimore........ 295 Brulcy v. Garvin........... 316 Buckworth v. Simpson \& Benner 410 Bulkley v. Dolleare...........6S6 Burbank v. Pillsbury......4439, 459 Burr v. Maclay Water Co........ 129 Bussman $v$. Ganster.........6.635 Butler v. Frontier Telephone Co. BUTLER $\nabla$. KYN NERSLEY.........

Cadwalader . Bailey......... 194 Caldwell v. Fulton............ 158 Campbell v. Miesier..........247

CaMpbell $v$. Race........... 729

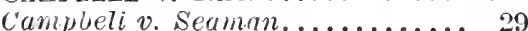

Capron v. Grecnuay........... 302

Carrell v. Read.............. 592

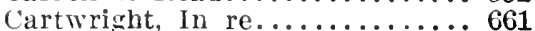

Castuer v. Riegel...........273

Chalmers v. Swith...........667

Chapman v. Smith........... 352

Charless v. Raukin........... 49

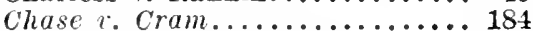

Cimasemore v. Richardos....... 33

rhatjicld v. Wilson.......... 125

Checseburough v. Green....... 242

Chester v. Alker \& Elmes........7 718

Cibel \& Hills, Case of.......... 591

Cincimati, H. \& D. R. Co. v.

Wachter ................ 232

City of Canton $\nabla$. Schock........

Cily of Emporia $v$. Soden........

Citl of MANSEIELD $v$ BaLLIETT City of Quincy v. Jones........ Craflin v. Carpenter..........

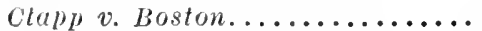
Clark v. McGee............... Clavering v. Claverivg......... 'legg v. Hands.............. Clement $\nabla$. Wheeler............

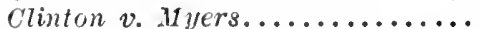
Crun, Case of...............
Clun v. Fisher................ 55

Cobb v. Bennett............. 709

Cobb v. Johnson..............4418

Cockson v. Cock............. 352

Codman v. Evans........... 723

Cort v. OWEnby..........230, 231

Cole v. Bellasis............ 557

Cole $\nabla$. Foxman.............. 164

Cole v. Green................ 642

Cole v. Hugines. . . . . . . . . . 484

Collins v. Chartiers Valley Gas

Co. ................... 134

Conduitt . Ross............. 475

Congham . . King............ 395

Conner v. Woodfill........... 119

Constantine v. Wake..........63s

Consumers' Gas Trust Co. $v$. American Plate Glass Co..... 232

Cook v. Jones............... 379

Cook v. Mayor of Bath.........2s

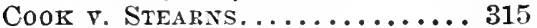

Cooke v. Chrlcott........... 461

Cooper v. Crabtree........... 144

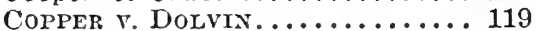

Comish v. Stubbs............ 314

Corporation of Birmingham v. Allen .................. 42 Cotting v. Boston.......... 243 Countess of Salop $\nabla$. Crompton.. 659 Countryman . Deck.......... 505 Crain v. Fox................. 280 Crawford v. Krollpfeiffer....... 482 Crawford v. Ramio.......... 100 Crescent Co. v. Silver King Co.... 10 Cronin v. Watkins..........343, 420 Crossley \& Sons, Limited, $v$. Lightowier ............. 88

Crowe v. Riley............. 355 Cubitt v. Porter. . . . . . . . . . 239

Damren $\nabla$. American Light \&

Power Co................ 559

Damron $v$. Justice............ 228

Dana v. Valentine........... 35

Davis $\nabla$. Gilliam............. 646 Davis v. Niagara Falls Touer Co. 120

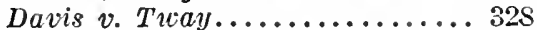

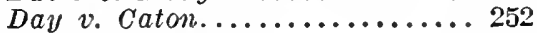
Demarest v. Willard.......... 407 Denman v. Prince............ 460 Derby (Earl of) $\nabla$. Tąylor....... 396 Devlin v. SNELLENiBURG....... 143 Dewar v. Goodman............ 380 Dickinson $v$. Baltimore........ 682 Dill v. Board of Education of City of Camden............... 29. Dillman v. Hoffman.......... $2 S 2$ Dix v. JaquaY............. 676

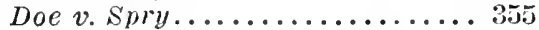

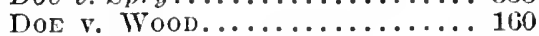
Doe v. Wood................. 157 Doe d. Bish v. Keeling. ........ 355 
Page

Doherty v. Allman...........6S2

Dolph v. Barry.............. 609

Dooly v. Stringham.......... G5s

Dority v. Dumning............. 302

Dorr v. Ilarkness........... 672

Douglas v. Coonley........... 243

Dowglass v. Kiendal............ 154

Drake . Hewins............. 313

Drake v. Lady Ensley Coal, Iron

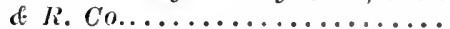

Drake v. Wells............. 313

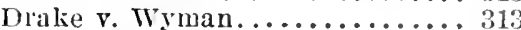

Drury v. Kent............. 164

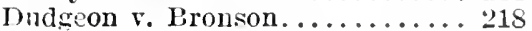

Duhain v. Mermod, Jaccard \& king Jewelry co..........6.600

Dumont . ISellogg.............. 61

Dumean v. Central Pass. R. Co... 546

Durfee v. Garvey............. 221

Duross v. Singer.............22s

Duval v. Becker............. 302

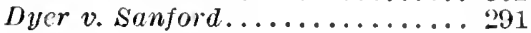

Dyett v. Pendleton..........6600

Earl of Derby v. Taylor........ 396 Earl of Sandwich v. Great North-

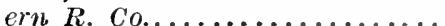

Earle v. Arbogast...........6670

Edgerton v. Page.............606

Edgett v. Douglass............ 216

Edmison $v$. Lowry............ 597

Eells v. Morse............. 559

Elias v. Griffith...........650

Elliot v. Fitchburg R. Co....... 75

Elliston $v$. Reacher.......... 529

Emans v. Turingulu.......... 166

Embrey $\nabla$. Owen............. 54

Emerson v. Shores...........316

Emmott . Cole.............682

WNo v. DeL Vecchio............ 234

Ensminger v. People......... 715

Eulrich v. Richter............

Farmers' \& Merchants' Irr. Co. v. Hill ..................

Farner v. Tennessee Copper Co...

Fentiman v. Simth...........

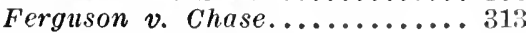

Filbert v. Dechert........... 77

First Nat. Bank of Sioux City $v$.

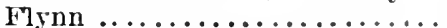

Fiteh $v$ Johnson.............. 455

Fitcliburg Cotton Manufactory Corporation v. Melren......... 5s1

Fitzpatrick v. Boston \& i. Ii, R. 298

Fitzpatrick v. Welch..........119

Flaherty $v$. Fleming...........2s

Flamang, Case of............

Flanagan v. Philadelphia...... 703

Flect v. Metropolitan Asylum

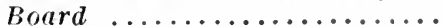

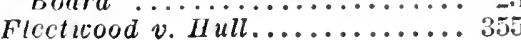

Page

Flint v. Siveenet...........610

Foley v. Wyeth.............. 46

Ford v. Orcgon Electrie R. Co.... 4.:-

Ford $v$. Whitlock.............2 26;

Formby v. Barker............. 591

Fouler v. Bott............ 5Tt

Fresno Canal Co. v. Fouell..... till

Friend v. Oil Well Supply Co.... 624

Frogley r. Earl of Iovelace...... 316

Frogley v. Lovelace (Earl of)... 316

Frye v. I'artridge.......... 510

Fuller $v$. Wason............6.6.

Gagnon v. French Lick Springs

Hotel Co.................. 129

Gaines v. Green Pond Iron Min-

ing Co................. 649

Gallatin v. Corning Irr. Co...... 102

Gamlen v. Lron............... 69s

GanNon r. Hargadon......... 96

Gardinef v. Williamson...... 620

Gardner v. Keteltas........... 631

Garner $\imath$. Hannah...........63s

Garwood 5 . New York Cent. \& H

R. R. Co............... $6 \mathrm{~S}$

Gerst v. St. Louis............ 5:

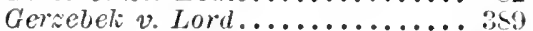

Gibson v. Holden............ 4 . 1

Gimson v. Wells.............66 64

Gilbert v. Shoucrman........ 21

Gilderslecve v. Hammond....... 58

Gillhay r. Madisox County Ii.

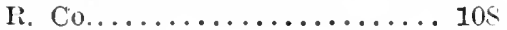

Gillis v. Chase............. 69

Gilmer v. Mobile \& M. R. Co..... 45:

Gilmore v. Driscoll........... 4!

Glenin v. Canby............

Glidilen $v$ Sccond Ave. Inv. Co... BS?

Goonale v. Tuttie............. 104

Goodhort v. Hyctt............21s

Goodman v. Jayor of Saltash.... 176

Goodson v. Richardson......... 10

Goodtitle ex dem. Chester r. Al-

ker \& Elmes............... 71 s

Gormley v. Sanford.......... 107

Gower r. Postmaster General... 367

Graham v. Walker........... 181

Grates v. Berdan............ 579

Gray v. Cambridge.......... 21:

Green $v . \operatorname{sun}$ Co............. 14i

Greene v. Commy.............25

Grcenlcaf v. Fruncis........... 124

Gregory v. BUSII............ 111

Grey v. ruthbertson.......... 348

Grubb v. Bayard............ 15é

Grubis v. Gulliord.......... 17

Hagur v. Buek............. $37 s$

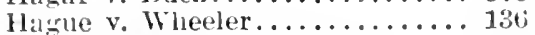

Il MII. v. HAKEW LODGE. . . . . . 24:

Ilaldeman v. Bruckhurt........ 1:it;

Hale v. McIea............. 195 
Hall v. Brewing Co........... 200

Hall v. Ewin............... 498

Hall v. Lawrence............. 167

Hall $v$. Norfolk............... 40

Hall v. Sterling Iron \& Ry. Co... 215

Hanbury v. Jcnkins........... 200

Ifancoek v. Austin.............. 636

II annabalson $v$. Sessions..........

Hamicker $v$. Lepper............

HaNSEX $\checkmark$. MEYER............ 350

Harber v. Evans............. 236

Hard $v$. Boise City Irrigation \&

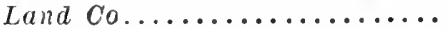

Ha rmer v. Bean............... Harrison v. Rutland........... 723 Ilarshn v. Reid.............. 442 Ilarrood v. Benton........... 130 Hathorn v. Natural Carbonic Gas Co. ...................... 131

Hauley $v$. Sheldon............ 97 Hayden v. Tucker............ 23 Hayes $v$. New York Gold Mining Co. of Colorado.............4 423 Hayes $r$. Waldron............. Ss Hayford $v$. Spokcsficld.......... 282 Haytrood v. Brunswick Permanent Benefit Bldg. Soc........ 496 Heartt $v$. Kruger............. 242 Heflin v. Bingham............ 316 HeNdricks v. STARK......... 295 Hennessy v. Carmony........... Herman v. Roberts..............

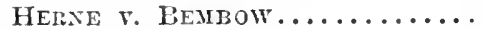
Hewlins v. Shippam........... 301 Heyuood v. Fulmer............ 162 Hicliman v. Maisey...........723 Hilt v. Burgess............687 Hill v. Huron............... t78 Hill v. Tupner.............. 197 Hill v. 'TUPPER.............. 90 Hinsdale v. Humphrey.......... 412 Houre $r$. Board of Work. ...... 200 Hodgkins v. Farrington......... 314 IIoffman v. Sarage............. 200 Hole y. Barlow............ 15 Holfotd v. Hatch............. 395 Hollander v. Central Metal \& Sup-

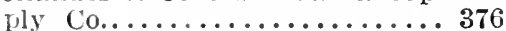
Holmcs v. Goring............. 302 Home Life Ins. !'o. of Brooklyn v. sherman ................ 5s3 Hope $v$. Osborn............. 154 Holn v. Miller.............. 435 Iloskins $v$. liobins............. 164 Howell $\nabla$. King.............. 201 Hubbard v. Bctl.............. 706 IIUBBARD $\vee$ CoxCORD......... S7 II udson v. Cripps.............. 524 II umphries $v$. brogden. . . . . . . 49 Hunt v. Gas Co................ 13 IIuntington v. Asher.......... 173 Hurd v. Curtis............. 432
Fage urdman v. North Eastern R. Co. 116 Hurst v. Picture Theaters....... 331 Hurxthal v. St. Lawrence Boom \& Lumber Co..................43s

\section{Ilo Oil Co. v. Indiana Natural Gas}

\& Oil Co.................. 140 Indiana Natural Gas \& Oil Co. v. Hinton ................. 426 Irving $v$. Turnbull............ 486 IVINS v. ACKERSON........... 276

Jackson v. Bruns............ 242 JACKSON $v$. PESKED............ 140 Jackson \& Shark v. Philadelphia W. \& B. R. R. Co............. 323 James $v$. Stevenson............. 293 Jenkins $v$. Lykes.............. 316 Jennison $\nabla$. Walker............ 293 Johnson v. Barton............ 381 Johnson v. Johnson...........64s Johnson $v$. Sherman............ 38T Johnstoun Iron Co. v. Cambria Iron Co.................. 168 Jones v. Chappel............. 147 Joues v. Conn............... 71 JoNES v. EARL OF TANRERVILLE.. 335 Jones v. Grover............. 3s7 JoNES v. HILI................ 664 Jones v. Parker.............. 3St Jonces v. Pritchard............. 218 JoNes v. TANkerville (EARL OF) 335 Jordeson v. Gas Co............ 54 Jourdain v. Wilson............... 373 Joyner $v$. Weeks............. 405

Kastner v. Benz............... 331

Kavanagh v. Barber.......... 11

Keeper's \& Gorernors of the Possessions, etc., of Harrow School v. Alderton...............643 KELLLOG v. ROBINSON.......... 443 Kelly $v$. Keys................ 16:3 Fenuedy r. Owen............. 490 KEPPEll v. BaIley............ 90 herpochan v. New York EleVATÉD R. R. Co............. 148 Kettle River R. Co. v. Eastern R. Co. of Minnesota........... 510 Kimpton v. Wood............. 161 King $v$. Allen................ 316 King, The, v. Hermitage........ $\$ 02$ Kinnaird v. Standard Oil Co...... 132 Klie $v$. Von Broock........653, 681 Innolle, Case of.............. 562 Innoules v. Dow............... 180 Krvay v. Huggli.............. 262

Lappan v. Glunz.............237 Lawrence $\nabla$. French. .......... 6:2 Lawrence v. White............ 5s? LAWSON . HIOWLY.......... 710 
Page

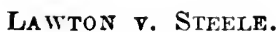

717

Leishman $v$. White........... 599

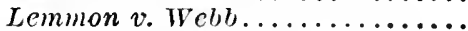

LePrell $\nabla$. KLEINSCHMIDT.......

I.ewis v. Gollner............ 538

Levis $x$. Jones.............. 728

I ewis Bowles, Case of. ........6 68s

LEXIXGTON BANK $v$. SALLANG....440

Lexington Lodge $v$. Bcul. ....... 240

Lide $v$. Hadley.............302

Liggins $v$. Inge............ 305

Lincoln $\nabla$. Burrage...........448

Lincoln v. Davis............ 718

Little Rock \& Ft. S. R. Co. v. Chapman ............... 120

IATTLEWOOD $\vee$. JACKSON........ $40 \mathrm{~S}$

London v. Fiiggs............. 209

London County Council v. Allen.. 535

Lord StráfFord v. Ladd WextWORTH .............. 557

Lothrop $v$. Thayer...........660

Loud v. Pender ast........... 545

Loyd v. Langford. . . . . . . . . . . . 564

Lunwell $\nabla$. NewMa . . . . . . . . 629

Lund $\imath$. Nevo Bedford.......... 145

Luslington . Boldero..........694

Luther v. Wiñisimiet Co...... 105

Lybbe v. Hart. . . . . . . . . . . 358 Lydick v. Baltimore \& O. R. R. Co. 420 Lyon v. Parker. . . . . . . . . . 442

McAdam $\tau$. Benson Logging \& Lumbering Co............. 282

Mc:artney $v$. Londonderry, etc.,

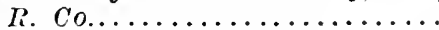

McClure $v$. Leaycraft.........

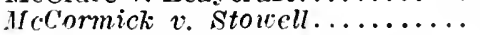

Merrea $v$. Marsh . . . . . . . . 313

McCullough ₹. Board Exchange

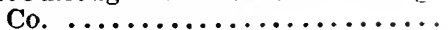

Mclonald $v$. May...........

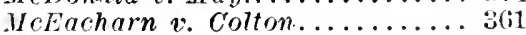

McGhee v. Tennessee Copper Co.

ILKenna v. Eaton............

Mackin v. Haven........... 475

McNurphy r. Minot...........5699

McNeil v. Kendall........... B. Bs

Macomber v. Golfrey.......... 9.

McPheters $v$. MoOs\% Riv $\mathrm{Cr}$ Log Driving Co................

Madison v. Incktown sulphur, Copper \& Iron Co............

Magoon $v$. Eastman...........

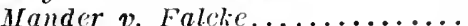

Manteufel v. Wetzel...........111

Manufacturers' Gas of Oil 'o. v. Indiana. Futurul Gas d Oil ('o... 140

Marshall $v$. Mosely.......... 5.s

Martin $v$. Jartin............. 55t

Martyn v. Williams..........

Maryland \& P. R. Co. i. Silver... 44.

Mascal, Case of............ ül Big.RIGHTS-b
Mason $\nabla$. Shrewsbury \& H. R. Co 25 Mason v. Smitl.............. ;s? Massot $v$. Moses............. 16.

Master $v$. II

Masury v. Southworth......... .

Matheson $r$. Ward............ 25:

Matures $v$. Westrood.......... 35:

Jayor, etc., of Cougleton v. Patti-

son .......................

Meelier r. East Oranqu. . . . . . . 125

Melnts v. Pabst Brewing Co...... Ger

Ments v. Coffey............. tit

Meng $v$. Cofficy.............. 万.

Merrick Water Co. v. Proolilyn. . 160

Messinger. Appeal of .........

Hiddleficld v. Church Enitting

Hills ro............... 269

Middenteld v. KNitTi.g Co..... 4ST

Middleton v. Boomisg Co...... T0S

Miller v. Clary..............45s

Miller v. Edison Electric Illuni-

nating Co............. 147

Miller. Greenwich Tp.......... 336

Jiller $v$. Prescott.......... 502

Milne, Appeal of ............236

Minucsota Loan of Trust Co. v. St.

Anthony Falls Water-Pouer Co. 70

Irinshull $r$. Onlics............ 35ँ

Mogg v. Mogg............. s

Mooers $v$. Thait...............6st

Moore $r$. Mansfield.................6.

Moore r. Rawson............. 27

Moone v. SAxBorse........... T0

IIorey v. Fitzrerald........... 729

Morris v. Cairncross.........66ti.

Jorris v. Lennedy............. 3ss

Horrow $v$. Massclman........ 5.s

Morse v. Aldrich............ 424

Joss Point Lamber Co. $v$. Iíari son County..............649

MotT $v$ GPPEXHEIMER. ........4\$ 4

Mountjos. Case of........... $15 \%$

Jurphy Chair Co. v. American

liadintor Co.....................

National Lnion Banli at Jover $\nabla$.

Segur ................ 446 Tare $v$ Bcrry..............67:

. Veale $v$. Jackentie.......... bit

Negus $\imath$. Berker............. 28.

Newcomb v. Harver........... 50

Xechofi v. Mallo...........

Newnall v. Anderton..........6.,:;

rereton v. Wilson........... 6.

Now lork IRubher Co. r. ILothery

Tirhols $v$. reck.............

Nickliñ v. Wihtiams..........

Nitarll $\vartheta$ I'oschull...........

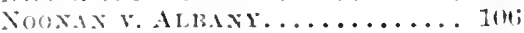

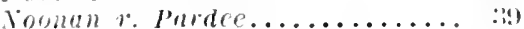

Norctus $v$ Jalles............ jut 
Norman v. Wells............... $\begin{array}{r}\text { Page } \\ 379\end{array}$

Northern Pac. R. Co. v. McClure. . 369

Nuttal v. Bracewell........... 92

O'Connell v. East Tennessee, $\boldsymbol{\nabla}$. \&

G. F. Co................ 103

ogilvie v. Hull............. $60 \mathrm{~s}$

Original Hartlepool Co.v. Gibbs.. 715

Oruenod v. Mild Co........... 70

Oster v. Broe............. 323

опеn v. Hyde................6644

Pachington r. Packington. . . . 692

Page v. Parr................. 593

Pakenham, Case of........... 427

Palmer v. Edwards........373, 396

Parisil v. Wimtney.......... 492

Park . White............. 145

Parlier . Nightingale.......... 521

Parks r. Bishop............... 203

Parks v. Boston............. 585

Parrott $r$. Barncy..........6.672

Partridge v. Gilmert.......... 234

Partkidge v. Scott........... 51

Patten v. Deshon........... 402

Paul v. Hazelto............ 336

Pa.rton $x$. Kenned!............638

Peabody Heights Co. of Baltimore

City v. Wilson............. 529

Pearson v. Rolfe............ T09

Peck v. Herrington........... 113

Pence v. Carney............. 129

Pendleton r. Drett...........600

Pennsyliania Coal Co.v. Sander-

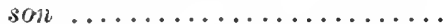

Pexnsylvania $\mathrm{S}$. $\mathrm{V}$ R. Co.

ReAding PAPER Mills........

Percival $v$. Colonial Inv. Co.......

Perrot v. Perrot.............6679

Peter $v$. Casicll.............261

Pfeiffer v. Grossman.......... 1

Phillips r. Rhodes............ 165

l'icliering v. Rudd............

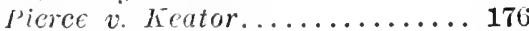

Pitts v. Lancaster Wills........ 61

Pittsburgh, Ft. W. \& C. Ry. v.

Peet ...................

Jixley v. Clark. .............. 130

Pohlman v. Chicago, is. \& st. $\ddot{P}$.

R. I.................. 113

Pollock v. Cleveland Ship Bldg.

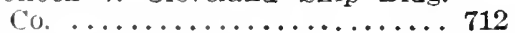

Ponfret v. Ricroft............. 219

Pope $y$. Devereux. . . . . . . . . . 299

Poppleacll v. Hodkinson........ 54

Post v. Learney. . . . . . . . . . . 369

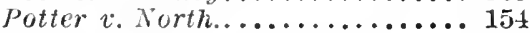

Potts v. Clarke............... 144

Potts-Thompson Liquor Co. v.

Capital City Tobacco Co.......

Poull v. Mockley.............. 19:
Pase

Pratt $\nabla$. Sweetser.............. 286

Pridgeon v. Excelsior Boat Club. . 596

Pue v. Pue.................. 2s2

Purvis v. Shuman............. 349

Putzel v. Drovers' \& Mechanies'

Nat. Bank................237

Pynchon v. Stearns............644

Queen. The, v. Chorley......... 280

R. จ. BUCKNALL (SiR J.) . . . . . . . 269

R. v. Sir J. Bucknall. . . . . . . 269

Race $\nabla$. Ward.............. 177

Raudall $\nabla$. Latham............ 502

Rawstrom v. Taylor........... 107

Rea v. Algren..............6 613

Red River Roller Hills v. Wright S6

Reilly v. Booth............. 230

Renals v. Cowlishaw.......... 513

Rerick . Kern............... 318

Reynolds v. Union Sav. Bank..... 236

Richards v. Dower........... 8

Fichardson v. Pond........... 200

Richardson $v$. Tobcy.........4486

Ricletts v. Enfield Church $\mathbf{W a r}$

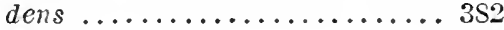

Rider v. Smith..............26s

Ring v. Walker.............. 193

Ritger v. Parker............. 300

Roath $v$. Driscoll.............. 124

Roberts v. Guyrfai Dist. Council 76

Rouins v. Cox............... 562

Robinson v. Hartopp.......... 165

RocHE v. Ul.MAN............4475

Rockingham v. Penrice........ 556

Rogers v. Atlantic, G. \& P. Co.... 672

Rogers $v$. Hosegood............ 521

Rogers .. Stewart............ 291

Rolt v. IORD SOMERVILle... .6S1, 697

RoLT T. SoMERivilLe (LORD). .6S1, 697

Romer v. St. Paul City R. Co..... 17

Ross. Butler.............. 13

Rotherham v. Green...................... 163

Ruldick v. St. Louis, K. \& N. W. R. Co................444

Rust v. Low................ 271

Rushmer v. Polsue........... 21

Russman $v$. Ganster.............6. 635

Rylands $v$. Fletcher.......... 130

St. Helen's Swertixg Co. $\nabla$.

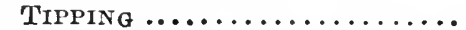
St. Louis, I. M. \& S. Ry. v.

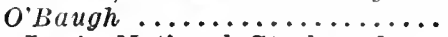

St. Louis National Stockyards $\mathbf{v}$.

Wiggins Ferry Co.......... 323

Salmon v. Matthews...........6. 635 Salop (Countess) v. Crompton.... 659 SAMPSON v. EAsterby..........3S2 Sampson v. Easterly........... 3S2 SANDERS v. MakTiN.......... 251 
Sandwich (Earl) v. Great North. ern $R . C o . \ldots \ldots \ldots \ldots \ldots \ldots \ldots$ Sayres $v$. Collyer............. 545

Schaefer v. Marthaler........ 97

Schermerhorn v. Buell..........684

Scholes $v$. Hargreaves.......... 165

Schuster v. Albrecht.......... 111

Seabrook v. Moyer...........583

Selby v. Graves...........686

Sharp v. Ropes............. 527

Shaughnessey v. Lcary........ 205

shepardson v. Perlins.......... 266

Sherred v. Cisco............. 246

Shirley v. Crabb.............. 240

Simpson v. Godmanchester....... 200

Simpson v. Savage........... 141

Skally v. Silute............ 599

SkElton v. Shelton.........693

Skull v. Glenister...........208

Sloan $v$. Hollidau............ 205

SMelting Co.. Tipping........ 26

Smiley $\nabla$. Van Tirlile........ 571

smith v. Andreus........... 717

Smith v. Barber............628

Smith r. Boston \& M. R. I........ 295

Smith v. Dall.............. 559

Smith v. Gatewood.......... 176

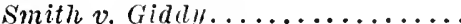

Smith $v$. Mr.Enany.......... 598

Smith v. Raleigh........... 599

Smith r. Sinith.............

Smith v. Thaclierah..........

Smith v. Youmans............

SNow v. Parsons...........

Sodth Metropolitan R. Co. v.

EDEx ................ 202

Southworth v. Perring. ........ 479

Spaulding $\vee$ Grundy.......... 249

Spencer's Case..............

Sposato v. New Tork......... 152

springer $v$. Darlington......... 2966

Springer $v$. De Wolf...........: :91

Stackpole v. Healy...........719

standard Oil Co. v. Buclii....... 190

Standen $v$. Clirismas......... 414

Stanislaus Water Co. v. Pinchman ¿gs

Starr $v$. Jaclison............. 145

State v. Roberts.......... T16

Steiner v. Peterman...........200

Stevenson $v$. Lumbard......... 5. 5.

Stewart $v$. Winters...........;

Stewart v. Childs Co.......... till

Stewart r. Finkelstone....... 5 . 6

Stockport Waterworks Co. v. Pot-

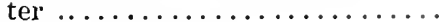

Stoddard r. Emery............

stolies $r$. Cooper............. 593

Stokoe 2 Singers.................

Storandt $r$. Fogel \& Binder Co.... 37;

Stotler v. Rochelle.......... 21

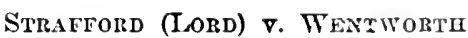
(TADY) ................ 557 Strong $v$. Benedict..........216 Stugeon $v$. Wingfield......... 373 Sturges v. Briderman......... 32 Sullens $v$. Chicago, R. I. \& $P$. R. Co. .................. 103 Susquehanna Fertilizer Co. $v$.

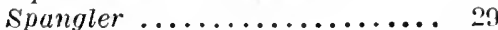
Sucansca v. Thomas......... 56? SwetT $v$. CutTs............. 12 Sucinden W. W. Co. v. Wilts, etc., Cunal Co.................... s3

Talbott $v$. Grace............. 179

Tallman v. Coffin.............84:3

T'apting v. Jones...............290

Tatem v. Chaplin...........

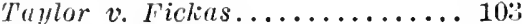

Taylor v. Ouen..............................

Taylor v. Thliteherd..........219

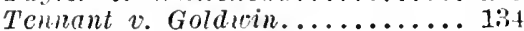

Thomas r. Hayward........... 379

Thomas $v$. Thomas.......... 30:

Thomas $v$. Wightman........... 559

Thompson v. Wralsen . . . . . . . 299

Thompson . New Haven Water

Co.................... 99

Thompson v. Rosc.........343, 419

Thorn v. Wilson............. 24"

Threer $x$. Barton............ 56!

Thunder Bay River Booming Co.

v. speechly............. 706;

Thurston v. Minke............ 355

TIPPING $r$. Sr. Helen's SMelt-

ING Co.................. 15

Tomlinson v. DAY. . . . . . 6 21,624

Tottle v. Howell............. 155

Trinidad Asphalt Co. $v$. Ambard. . 54

Trulock v. Herte........... 23

Trustees of Columbia Collcge $v$.

Lynch .............. 496

Trustees of Columbia College

r. Thacher............. 5t2

rucker $r$. Eldred............ 726

Tulk v. Mroxliay.............4 491

Tuner v. Wright........... (9)

Twynam $v$ Pickald........... 405

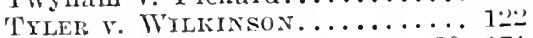

Truirigilam, Case or.......170, 171

Tyringham, c'ase of.......... 1it

[da] $\vee$ Udal.............. 6is

Underliood $v$. Waldron......... 120

University v. Tucker..........

Univelsity Clul of Chicatso r. Deal-

lin ................613

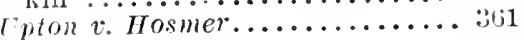

Vane r. Bariard (Lord) ....... 692 
VANE $\nabla$. Lord Barnard........ 692

Van Rensselaer v. Hays....... 441

Tan Rensselacr $v$. Radcliff....... 17.

Tan Rensselaer v. Rcad........ 566

Van Sant v. Tose. ............ 535

Veghte $v$. Ravitan Water Pouer

Co. ..................... 309

Termilyn v. Chicago, $\boldsymbol{M}$. \& $\mathrm{st}$. $P$.

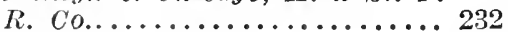

Ternon v. Smith............. 361

Verplanck $v$. Wright............ 353

Villuge of Duight $v$. Haycs..... 309

Vyryan v. Arthur............. 364

TIaite v. O'Neil.............. 581

Walker's Case............... 549

Wall v. Hinds................. 384

Wall v. Pittsburgh Harbor Co... 715

Villaks v. Pfeil............ 51

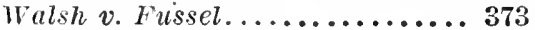

Walsh v. Packard............. 424

Ward v. Edesheimer........... 632

Ware v. Allen................ 75

Warr v. London County Council. . 313

Washington Natural Gas Co. v.

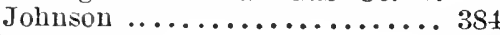

Watson v. Bioren............. 205

Watson v. Hunkins............ 562

Wattles v. South Omaha Ice \& Coal Co.................. 577

Webe v. Bird............... 33

Webt v. Bird................200

Webb v. Russell.............566

Webb v. Portland Mrg. Co...... 58

WEEKLx v. WiLdMaN.......... $17 \mathrm{~S}$

Tieil. Hill................ 517

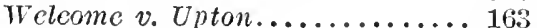

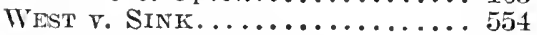

West $v$. Taylor.............. 95

Westphal v. New York.......... 129

IVIIALEY v. LAING............ 90

Wheatley v. Chrisman........ ¿15

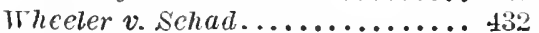

Wheelock v. Jacobs............ 200

White r. Grand Hotel, Eastbourne 207
Page

White v. Molyneux...........555

White v. Southern Hotel Co....... 379

White's Bank of Buffalo v. Nichols 2 S5

Whitney v. Union R. Co........ 357

Whittenton Mfg.Co.v. Staples...

270,505

Whittier $v$. Winkley.......... 209

WICKHAM v. HaW KER. . . . . . . . 179

Wiggins v. Water Co......... 72 Wiggins Ferry Co. v. Ohio \& M.

R. Co................. 462

Willey v. Laraway........... 677

Williams v. Earle............. 358

Williams $v$. Ilayuard......... 563

Williams $\vee$. James............. 201

Willoughby v. Laurence.......... 194

Willow River Club v. IVade..... $\mathbf{7 1 6}$

Wills v. Summers............ 393

Wilmartu v. Woodcock........ 5

Wilmot v. Үazoo \& M. V.R. C'o... 232

Wilson v. Edmonds...........662

Wilson v. Hart............... 495

Wilson v. Maekiet............ 168

Wilston v. Pilkney.............. 563

Wimfield v. Henning. . . . . . . . . . 529

Winslow v. Vallejo............ 220

Winter v. Brockwell............ 290

Winterield v. Stauss. ....... 370

Wiseman $v$. Luclisinger. ......... 328

Wombell v. Belasyse........... 693

Wood v. Lake............... 303

Wood $v$. Leadbitter. . . . . . . . . . 309

Wood v. Saunders............. 209

WOOD v. VEAL.............. 141

Wood v. Waud.....................................

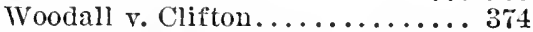

Woodin $v$. Wentworth..........6. 63

WOODWARD v. SEELY. . . . . . . 325, 326

Wooliscroft v. Norton..........444

WYatT $\nabla$. Harman............ 50

Yellowly v. Gower. . . . . . . . 664

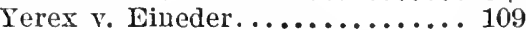

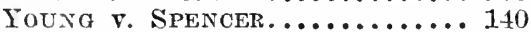

Ioung v. Star Co.............. 293 


\title{
CASES ON RIGHTS IN LAND
}

\section{PART I}

\section{RIGHTS INCIDENTAL TO POSSESSION}

\author{
CHAPTER I \\ POSSESSION
}

\section{PFEIFFER v. GROSSMAN. \\ (Supreme Court of Illinois, 1553.15 Ill. 53.)}

This cause was tried before Underwood, Judge, at the March term, 1853, of the St. Clair Circuit Court.

TREAT, C. J. This was an action of trespass quare clausum fregit, brought in 1853, by Pfeiffer against Grossman. The plea was, not guilty. It appeared in evidence, that the plaintiff had title to a certain tract of land; that according to a survey made in 1851, a fence claimed by the defendant was on this tract; the fence inclosed about half an acre of the tract, part of which was in timber, and the rest in cultivation; the fence was built by McGuire, who was in possession previous to the defendant; prior to the survey there was some difficulty between the plaintiff and defendant as to the boundary line, the latter claiming to the fence; the defendant was dissatisfied with the survey, and continued in possession of the ground up to the fence, although notified by the plaintiff to remove the fence; after the suit was brought, the defendant caused another survey to be made, which agreed with that made in 1851. It was stated by the plaintiff's counsel, that the suit was brought for the purpose of establishing the boundary line between the parties. The court refused to give these instructions: "That the putting a fence or letting it stay on the land of another is a trespass in the eye of the law, for which the aggrieved person is entitled to at least nominal damages; that the ploughing up of another man's land and cultivating it, although the land may thereby be improved, is still a trespass in law, for which the person aggrieved is

Big.Rigits-1 
entitled to at least nominal damages." The jury found the issue for the defendant, and the court rendered judgment on the verdict.

The instructions not only asserted correct legal principles, but they were strictly applicable to the case. If a party puts a fence on another's land, or plows up the soil, he is liable as a trespasser. Such acts are a violation of the owner's right of possession, to redress which the law gives him an action. And the action is maintainable, although the owner is not substantially injured. He is entitled to nominal damages for the intrusion upon his possession. The defendant cannot defeat the action, by showing that the plaintiff is not materially prejudiced, or even that he is actually benefited. A right is invaded, and a wrong committed, and that is a sufficient basis for an action. Every unathorized entry on the land of another is a trespass, for which an action will lie. The law implies damage to the owner, and in the absence of proof as to the extent of the injury, he is entitled to recover nominal damages. Especially is this the case, where the suit is brought for the purpose of settling a question of right. Dixon v. Clow, 24 Wend. (N. Y.) 18S; Pastorius v. Fisher, 1 Rawle (Pa.) 27 ; Bagby v. Harris, 9 Ala. 173; Plumleigh v. Dawson, 1 Gilman, 544, 41 Am. Dec. 199; Polivar Manuf. Co. v. Neponset Manuf. Co., 16 Pick. (Mass.) 241; Whipple v. Cumberland Manuf. Co., 2 Story, 661, Fèd. Cas. No. 17516.

The judgment is reversed, and the cause remanded. Judgment reversed.

\section{SMITH v. SMITH.}

(Supreme Judicial Court of Massachusetts, 1872. 110 Mass. 302.)

Tort. The declaration alleged that the defendant forcibly entered the plaintiff's close and broke down a fence, and also built a part of a barn upon the close, and thereby expelled and put out the plaintiff from possession and occupation of a part of the close, and kept and continued him so kept out and expelled from said part of the close. Trial in the Superior Court, before Bacon, J., who, after a verdict for the defendant, allowed the following bill of exceptions:

"The plaintiff offered to prove that the eaves or jet of a barn, alleged to have been built and erected upon the plaintiff's close by the defendant, extended over on to the close from fifteen to eighteen inches, but the judge excluded the evidence.

"The jury returned a verdict for the defendant, and the plaintiff alleged exceptions."

MORTON, J. ${ }^{1}$ This is an action of tort in the natufe of trespass quare clausum fregit. The plaintiff in his declaration, among other acts of trespass, alleges that the defendant built a part of his barn

1 The statement of facts is abridged and part of the opinion is omitted. 
upon the plaintiff's close, and thereby put and kept plaintiff out of the possession and occupation of $a_{e}$ part of the close. We think it was competent for the plaintiff to prove that the eaves of the defendant's barn projected over the plaintiff's close. Projecting his eaves over the plaintiff's land is a wrongful act on the part of the defendant which, if continued for twenty years, might give him a title to the land by adverse occupation. It is a wrongful occupation of the plaintiff's land for which he may maintain an action of trespass. Codman v. Evans, 7 Allen, 431; Carbrey v. Willis, Id. 364, 83 Am. Dec. 688. $* *$ * *

Exceptions sustained. ${ }^{2}$

\section{BUTLER v. FRONTIER TELEPHONE CO.}

(Court of Apreals of New York, 1906. 186 N. Y. 486 , 79 N. E. 716, 11 L. R. A. [N. S.] 920,116 Am. St. Rep. 563, 9 Ann. Cas. S5s.)

Appeal from a judgment of the Appellate Division of the Supreme Court in the Fourth Judicial Department, entered December 6, 1905 , affirming a judgment in favor of plaintiff entered upon a decision of the court at a Trial Term without a jury.

This is an action of ejectment, which was tried by consent before the court without a jury. The trial judge found as facts that "the defendant on or about January 1, 1903, without the consent of the plaintiff and without lawful authority, entered upon" his premises in the city of Buffalo "and stretched a wire over and across the same in the manner described in the complaint and maintained said wire upon said premises until January 10, 1903, when the defendant re-

$2 \mathrm{~A}$. thrust his arm over the division fence between his lot and B.'s. Held, A. is guilty of a trespass. Hannabalson $\mathrm{v}$. Sessions, 116 Iowa, $457,90 \mathrm{~N}$. W. 93, 92 Am. St. Rep. 250 (1902).

"I recollect a case, where I held that firing a gun loaded with shot into a field was a breaking of the close. The learned judge on the eircuit with me doubted upon the point, but many with whom I a terwards conversed on the subject thought I was right; and the judge himself, who at filst dilfered from me, was afterwards of the same opinion; but I never yet heard that firing in vacuo could be considered as a treslass. No doubt, if you could prove any inconvenience to have been sustained, an action might be maintained; but it may be questionahle whether an action on the case would not be the proyer form. Would trespass lie for passing through the air in a balloon over the land of anothel"?" Ellenbolough, C. J., in Pickering v. Ludd, 1 Stark. N. I. 56, 5S (1S15).

Compare Clifton v. Niury, 4 Times law Rep, 8 (1SS7); Whittaker v. Stang. vick, 100 Minn. 886,111 N. W. 295,10 L. R. A. (N. S.) 921, 117 Am. St. Rep. 703, 10 Ann. Cas. 52s (1907).

The branches of trees growing on $A$.'s land lirojested over H.'s land. $B$. cut the projecting part without notice to $A$. Ileld, $A$. has no cause of action against B. Ifmmon v. Welb, [1895] A. C. 1.

"If trees projecting orer the boundary are not in fact doing any damage it may be that the planintit's only right is to cut back the overhanging portions; but where they are actually loing danage I think there nust be a right of action." liennedy, .J., in simith v. Giddy, [1904] 2 K. B. 44S, 451. Compare Fay v. Inentice, 1 C. B. 523 (1545). 
moved the said wire entirely from plaintiff's said premises." According to the allegations of the complaint the wire was strung "about 30 feet from the surface of the ground on the easterly side and slanting to about 20 feet on the westerly side," reaching "across the entire width of said premises." The trial judge further found that "the plaintiff has been in possession of the premises described in the complaint at all times mentioned therein and since, except that portion thereof occupied by the defendant with said wire during the period specified." The damages sustained by the plaintiff were assessed at six cents for "the withholding by the defendant of that portion of the premises occupied by said wire for the period above specified." There was neither allegation nor evidence that the wire was supported by any structure standing upon the plaintiff's lot. The action was commenced on the 5th of January, 1903. The court found as a conclusion of law that the plaintiff, as the owner in fee of the premises in question, "was entitled at the commencement of this action to have said wire removed from said premises, and is entitled to judgment against the defendant so declaring, and for six cents damages for withholding said property and for the costs of this action. * * * " The judgment entered accordingly was affirmed on appeal to the Appellate Division by a divided vote, and the defendant now comes here.

VANN, J. (after stating the facts). The question presented by this appeal is whether ejectment will lie when the soil is not touched, but part of the space a few feet above the soil is occupied by a telephone wire unlawfully strung by the defendant across the plaintiff's premises? This question has never been passed upon by the Court of Appeals, nor by the Supreme Court, except in the decision now before us for review. Questions similar, but not identical, as they related to overhanging eaves, projecting cornices, or leaning walls, were decided in favor of the defendant in Aiken v. Benedict, 39 Barb. 400 , and Vrooman v. Jackson, $6 \mathrm{Hun}, 326$, and in favor of the plaintiff in Sherry v. Frecking, 11 N. Y. Super. Ct. 452. In Leprell v. Kleinschmidt, 112 N. Y. 364, 19 N. E. 812, the question as to the effect of projecting eaves was alluded to, but not decided, because there was in that case "a physical entry by the defendant upon the land of the plaintiffs and an unlawful detention of its possession from them."

The precise question before us does not appear to have been passed upon in any other state, and upon the cognate question relating to projecting cornices and the like the authorities are divided. Some hold that ejectment will lie because there is an actual onster or disseisin. Murphy v. Bolger, 60 Vt. 723, 15 Atl. 365, 1 L. R. A. 309; McCourt v. Eckstein, 22 Wis. 153, 94 Am. Dec. 594; Stedman v. Smith, 92 Eng. C. L. 1. Others hold that there is not such a disturbance of possession as to sustain an action in that form. Norwalk H. \& L. Co. v. Vernam, 75 Conn. 662, 55 Atl. 168, 96 Am. St. Rep. 246; Rasch v. Noth, 99 Wis. 285, 74 N. W. 820, 40 L. R. A. 577, 67 Am. St. Rep. 858. 
The case last cited does not overrule the earlier case in Wisconsin, but proceeds upon the theory that the aerial space was occupied by the projecting eaves of both parties, one above the other, on opposite sides of the boundary line. Some of the cases hold that a court of equity may order the removal of a projection without deciding whether ejectment will lie or not. Thus, in Wilmarth v. Woodcock, 58 Mich. 482, 485, 25 N. IV. 475, it was decided that equity would require the removal of a projecting cornice, because "no remedy at law is adequate, owing to the incertainty of the measure of damages, to afford complete compensation." But, as the learned court continued: "No person can be permitted to reach out and appropriate the property of another, and secure to himself the adverse enjoyment and use thereof, which, in a few years, will ripen into an absolute ownership by adverse possession." See, also, Plummer v. Gloversville Electric Co., 20 App. Div. 527, 47 N. Y. Supp. 228.

While some of the cases may be harmonized by resort to the distinction between "disseisins in spite of the owner and disseisins at his election," the main question is open, and must be determined upon principle. The defendant concedes that the plaintiff has a remedy, but insists that it is an action for trespass, or to abate a nuisance, while the plaintiff claims that ejectment is a proper remedy and one of especial value, as it entitles him, if he needs it, to a second trial as a matter of right and to costs, even if he recovers less than $\$ 50$ damages. Code Civ. Proc. $\S \S 1525,3228$.

An action of ejectment, ascording to the Code, is "an action to recover the immediate possession of real property." Code Civ. Proc. $\S 3343$, subd. 20 . While the statute to some extent regulates the procedure, it did not create the action, and for the principles which govern it resort must be had to the common law. Code Civ. Proc. $\$ \$$ 1496 to 1532; Real Property Law, Laws 1896, pp. 560, 594, c. 547, $\S \S 1,218$; Rev. St. (2d Ed.) p. 303, pt. 3, c. 5, tit. 1, § 3. Without entering into the somewhat involved and perplexing learning upon the subject, it is sufficient to say that, as all the authorities agrce, the plaintiff must show that he was formerly in possession, that le was ousted or deprived of possession, and that he has a right to re-enter and take possession. It is admitted by the pleadings that when the wire was put up the plaintiff was in possession of the entire premises, and that he was entitled to the immediate possession thereof as owner when the action was commenced. The serious question is whether he was deprived of possession to the extent necessary to authorize ejectment. While ouster is essential to the maintenance of the action, it need not be entire or absolute: for it is sufficient if the defenciant is in partial possession of the premises while the plaintiff is in possession of the remainder. Sullivan v. Legraves, 2 Str. Cases, 695; Doe v. Durt, 1 T. R. 701 ; Lady D'Acres Case. 1 Ler. 58; Rowan v. Keisey, 18 Barb. 484; Otis v. Snith, 26 Mass. (9 Pick.) 293; Gilliam v. Bird, 30 N. C. 280, 49 Am. Dec. 379; Reynolds v. Cook, 83 Va. 817 , 
3 S. E. 710, 5 Am. St. Rep. 317; McDowell v. King, 4 Dana (Ky.) 67 ; Adams on Ejectment, 27; Newell on Ejectment, 38; Warvelle on Ejectment, 22. Mines, quarries, mineral oil, and an upper room in a house are familiar examples. Is the unauthorized stringing of a wire by one person over the land of another an ouster from possession to the extent that the wire occupies space above the surface as claimed by the plaintiff, or a mere trespass or interference with a right incidental to enjoyment as claimed by the defendant? Was the plaintiff in the undisturbed possession of his land when a portion of the space above it was occupied by the permanent structure of the defendant, however small? Was the space occupied by the wire part of the land in the eye of the law?

What is "real property"? What does the term include so far as the action of ejectment is concerned? The answer to these questions is found in the ancient principle of law: "Cujus est solum, ejus est usque ad coelum et ad inferos." The surface of the ground is a guide, but not the full measure; for within reasonable limitations land includes not only the surface but also the space above and the part beneath. Co. Litt. 4a; 2 Blackstone's Comm. 18; 3 Kent's Com. (14th Ed.) *401. "Usque ad cœlum" is the upper boundary, and, while this may not be taken too literally, there is no limitation within the bounds of any structure yet erected by man. So far as the case before us is concerned, the plaintiff as the owner of the soil owned upmerds to an indefinite extent. He owned the space occupied by the wirc, and had the right to the exclusive possession of that space, which was not personal property, but a part of his land. According to fundamental principles and within the limitation mentioned, space above land is real estate the same as the land itself. The law regards the empty space as if it were a solid, inseparable from the soil, and protects it from hostile occupation accordingly. If the wire had touched the surface of the land in permanent and exclusive occupation, it is conceded that the plaintiff would have been dispossessed pro tanto. A part of his premises would not have been in his possession, but in the possession of another. The extent of the disseisin, however, does not control; for an owner is entitled to the absolute and undisturbed possession of every part of his premises, including the space above, as much as a mine beneath. If the wire had been a huge cable, several inches thick and but a foot above the ground, there would have been a difference in degree, but not in principle. Expand the wire into a beam supported by posts standing upon abutting lots without touching the surface of plaintiff's land, and the difference would still be one of degree only. Enlarge the beam into a bridge, and yet space only would be occupied. Erect a house upon the bridge, and the air above the surface of the land would alone be disturbed. Where along the line of these illustrations would dispossession begin? What rule has the law to measure it by? How much of the space above the plaintiff's land must be subjected to the dominion of the defendant in order 
to effect a dispossession? To what extent may the owner be dispossessed and kept out of his own before there is a privation of seisin? Unless the principle of "usque ad colum" is abandoned, any physical, exclusive, and permanent occupation of space above land is an occupation of the land itself and a disseisin of the owner to that extent.

The authorities, both ancient and modern, with some exceptions not now important, agree that the ability of the sheriff to deliver possession is a test of the right to maintain an action of ejectment. Jackson v. Buel, 9 Johns. 298; Woodhull v. Rosenthal, 61 N. Y. 382, 389; Patch v. Keeler, 27 Vt. 252, 255; Warvelle on Ejectment, 34; Crabb on Real Property, 710; Butler's Nisi Prius, 99. "The rulc now is that when the property is tangible, and an entry can be made and possession be delivered to the sheriff, this action will lic." Nichols $v$. Lewis, 15 Conn. 137. The defendant insists that the sheriff cannot give possession of space any more than he can deliver water in a running stream or "air whirled by the north wind." When the space over land is unoccupied, there is no occasion for delivery, because there is nothing to exclude the owner from possession. The sheriff, however, can deliver occupied space by removing the occupying structure. All that he does to deliver possession of the surface of land, or of a mine under the surface, is to remove either persons or things which keep the owner out. He does not carry the plaintiff upon the land and thus put him in possession, but he simply removes obstructions which theretofore had prevented him from entering. So, in this case, that officer can deliver possession by removing the wire, the same as he would if one end happened to be imbedded in the soil, when no question as to the right to bring ejectment could arise. Where there is a visible and tangible structure by which possession is withheld, to the extent of the space occupied thereby ejectment will lie, hecause there is a disseisin measured by the size of the obstruction, and the sheriff can physically remove the structure and thereby restore the owner to possession. The smallness of the wire in question does not affect the controlling principle, for it was large enough to prevent the plaintiff from building to a reasonable height upon his lot. The prompt removal of the wire after the suit was brought could not def eat the action because the rights of the parties to an action at law are governed by the facts as they existed when it was commenced. Wisner v. Ocumpaugh, 71 N. Y. 113.

The judgment should be affirmed, with costs. Judgment affirmed. 


\section{RICHARDS v. DOWER.}

(Supreme Court of California, 18S3. 64 Cal. 62, 28 Pac. 113.)

Appeal from a judgment of the Superior Court of Nevada County.

The action was brought to enjoin the defendant from constructing a tunnel through a lot owned by the plaintiff in the city of Nevada. The construction of the tunnel was in progress at the commencement of the action, and extended about fifteen feet into the lot. It was twenty feet below the surface, and would pass when completed one hundred and fifty feet through the lot. The dimensions of the tunnel do not appear, but the court finds that it was being constructed for the purpose of working and developing a quartz ledge, and conveying away the rock and other matter therefrom. A preliminary injunction was granted, but on the final hearing, the injunction was dissolved, and a judgment rendered for the defendant. The additional facts are sufficiently stated in the opinion of the court.

Sharpstein, J. The court found that at the time of the commencement of this action the defendant had excavated and projected a tunnel under the lot of the plaintiff a distance of $15 \mathrm{feet}$, and was engaged in the further extension thereof, and threatened to continue the same, but that said tunnel has not affected, and will not, if completed, affect, injuriously or otherwise, the surface ground of plaintiff's said lot. There is a further finding "that the driving of the tunnel was not, and will not, if completed, cause the plaintiff irreparable injury, or injure said lot in any way." And another "that the defendant is not insolvent." And, as a conclusion of law from the foregoing facts, the court found that the defendant was entitled to a dissolution of an injunction previously granted, and ordered judgment to be entered to that effect. From that judgment the plaintiff appealed, and the questions which the record presents are: (1) Did the court err in its said conclusion of law? (2) Was the continuation or dissolution of the injunction by the court which granted it so much a matter of discretion as to preclude any interference here with the action of that court in the premises?

As late as Mogg v. Mogg, Dick. 670, Lord Thurlow was unable to find a precedent for granting an injunction to restrain a mere trespasser from cutting timber on another person's land. But in Flamang's Case, where a landlord of two closes had let one to a tenant, who took coal out of that close, and also out of the other, which was not demised, the difficulty was whether the injunction should go as to both, and Lord Thurlow ordered it as to both; and on the authority of that case Lord Eildon, in Mitchell v. Dors, 6 Ves. 147, granted "an injunction against the defendant, who, having begun to get coal in lis own ground, had worked into that of the plaintiff." In Thomas v Oakley, 18 Ves. 1S4, I ard Eldon expressed the opinion that it had 
then been settled in England that an injunction would be granted to restrain a mere trespasser from cutting timber or taking coal or learl ore from another person's land, and in that case he granted an injunction to restrain the defendant from removing stone from the plaintiff's quarry, on the ground that the defendant was taking the substance of the inheritance,-removing that which was the plaintiff's estate. He said the difference in value between stone and coal or stone and lead ore could not be considered in that case. From which we infer that in his opinion the right to an injunction in such a case did not depend on the value of the substance which was threatened with removal, but upon the fact of its constituting the inheritance or estate of its owner; and, in that light, the kind or quality of the substance would be quite as immaterial as the value of it.

And such we understand to be the rule in this state. In More v. Massini, 32 Cal. 594, the court says: "The gravamen is a threatened trespass upon land. The trespass is in the nature of waste, and it will be committed unless the defendant is restrained. Should the threat be fulfilled, the plaintiff would be deprived of a part of the substance of his inheritance, which could not specifically be replaced. In the class to which this case belongs no allegation of insolvency is necessary. The injury is irreparable in itself." Citing Mining Co. v. Fremont, 7 Cal. 322, 68 Am. Dec. 262; Hicks v. Michael, 15 Cal. 116; Leach v. Day, 27 Cal. 646; People v. Morrill, 26 Cal. 360. The findings show that the tunnel which the defendant is constructing through the plaintiff's land is of a permanent character. It disturbs the plaintiff's possession, and, if permitted to continue, will ripen into an easement. That, of itself, is sufficient to entitle him to an injunction. Poirier v. Fetter, 20 Kan. 47 ; Johnson v. City of Rochester, 13 Hun, 285; Williams v. Railroad Co., 16 N. Y. 97, 69 Am. Dec. 651. The finding that the injury is not irreparable is inconsistent with the findings which describe the character of the work which it is sought to have enjoined. "The injury is irreparable in itself," and the solvency of the defendant is an immaterial circumstance.

The findings leave no room for doubt as to the plaintiff's title to the premises, and that, coupled with the fact that the threatened injury is per se irreparable, entitles the plaintiff to the relief demanded in his complaint; and we think the error committed by the court in dissolving the injunction should be corrected. Cases of palpable error or abuse of discretion are excepted from the rule under which this court declines to interfere with the granting, refusing, continuing, or dissolving of injunctions; and that rule applies more especially, if not exclusively, to preliminary injunctions. IVe do not think that it applies to a case in which an injunction is continued or dissolved after trial and findings upon all the material issues. In that case, as in any other in which the findings do not support the judgment, it should be reversed. Judgment reversed, and cause remanded, with directions 
to the court below to enter judgment on the findings that the injunction issued in the first instance be perpetual, and that the plaintiff recover his costs.

Myrick and Thornton, JJ., concurred. ${ }^{3}$

3 See, further, as to equitable relief against trespass, Goodson v. Richardson, L. R. 9 Ch. App. 221 (1874) ; N. Y., etc., R. Co. v. Scovill, 71 Conn. 136, 41 Atl. 246, 42 L. R. A. 157, 71 Am. St. Rep. 159 (1898); Norwalk Heating Co. v. Vernam, 75 Conn. 662, 55 Atl. 168, 96 Am. St. Rep. 246 (1903) ; Council Bluffs v. Stewart, 51 Iowa, 385, 1 N. W. 628 (1879); Hunter v. Carroll, 64 N. H. 572, 15 Atl. 17 (1Ss8); Crescent Co. v. Silver King Co., 17 Utah, 444, is Pac. 244, 70 Am. St. Rep. 810 (1S9S). 


\section{CHAPTER II}

\section{AIR}

\section{KAVANAGH v. BARBER.}

(Court of Appeals of New York, 1592, 181 N. Y. 211, 30 N. E. 235, 15 L. R. A. 6S9.)

This was an action to recover damages alleged to have been sustairred by plaintiff by reason of an alleged nuisance created by defendant in operating a factory for the manufacture of asphalt for paving purposes.

ANDREws, $J$. The trial judge instructed the jury that, if they found that the vapors arising from the manufactory of the defendant constituted a nuisance, the plaintiff was entitled to recover to the extent of the damages sustained by him in the diminished enjoyment of the premises he occupied. The evidence justified a finding that the fumes arising from the asphalt penetrated the house, and subjected the plaintiff and his family to great annoyance and discomfort. The air of the neighborhood was tainted with the odor, and there is some evidence that the plaintiff's wife and daughter became ill in consequence. The main damage, however, sustained by the plaintiff, according to the proof, was in the personal discomfort to which he was subjected in the occupation of the house.

The case, in its legal aspects, is novel. The house was owned by the plaintiff's wife, and had been occupied for 14 years by the plaintiff and his family, and was so occupied when the manufactory of the defendant was built. The plaintiff, so far as appears, had no lease or other interest in the realty. The family, as is to be inferred, lived in the house by sufferance of the wife. The possession of the house followed the legal title. Both the occupation and the possession, in a legal sense, was that of the wife, and not of the husband. Martin v. Rector, 101 N. Y. 77, 4 N. E. 183. The husband supported the family. The question presented is whether, under these circumstances, a private action can be maintained by the husband for the discomfort caused by the offensive vapors. We find no precedent for such an action by a person so situated. Mr. Justice Blackstone defines a private nuisance to be "anything done to the hurt and annoyance of the lands, tenements or hereditaments of another," (3 Comm. 215), which definition, as said by Julge Cooley, (Cooley, Torts, p. 565,) embraces not a mere physical injury to the realty, but any injury to the owner or possessor as respects his dealing with, possessing, or enjoying it. Interferences with public and common rights, creating a public nnisance, when accompanied with special damage to the owner of land, also gives a right of private action. The public nuisance as to the person who is specially injured thereby in the enjoyment or vilue of 
his lands becomes a private nuisance also. Upon the evidence in this case on the part of the plaintiff, the defendant maintained a public nuisance. The air of the neighborhood was, for a long distance, infected with the disagreeable odor of the asphalt, and rendered residence within the area uncomfortable, and life therein less enjoyable. Upon these facts, the plaintiff's wife, who owned and lived in the premises, sustained an actionable injury. Mills v. Hall, 9 Wend. 315, 24 Am. Dec. 160; Francis v. Schœllkopf, 53 N. Y. 152. The trial judge charged the jury that the plaintiff could not recover for any injury to the premises, or for diminished rental value, for the reason that the title was in the wife. But the wife, who both owned and "occupied the realty, had her action for damage for the special injury in being deprived of the reasonable enjoyment of her property as her dwelling by reason of the nuisance.

The judgment in this case adjudges that the husband also can maintain an action for the interference with his enjoyment of the premises. The principle upon which the judgment proceeds, if sustained, will greatly extend the class of actionable nuisances. We have found no case where a private action has been maintained for corruption of the air by offensive odors, except by a plaintiff who was the owner of, or had some legal interest, as lessee or otherwise, in, land, the enjoyment of which was affected by the nuisance. The cases are numerous of actions on the case for nuisance created by a noxious trade, producing offensive and noisome odors, smoke, or noises, but, from the case of Morley v. Pragnell, Cro. Car. 510, down, they have been brought and maintained (so far as we can discover) by the owner or lessee of the realty affected by them. See Wood, Nuis. p. 577. We perceive no legal distinction between the plaintiff's situation and that of a lodger or guest in the house; or why, if the plaintiff can maintain an action, each member of the household cannot maintain one likewise for her or his separate injury of the same kind. The plaintiff's situation appeals more strongly, perhaps, than the others for an extension of the rule as heretofore understood. But there was a public remedy open to him by public prosecution, and we think the public interests would not be subserved by opening the door to actions of this character, where the claimant has no property right to be protected from infringement. The language of Chief Justice Shaw in Quincy Canal v. Newcomb, 7 Metc. (Mass.) 276, 39 Am. Dec. 778, is appropriate here: "He cannot have an action, because it would lead to such a multiplicity of suits as to be itself an intolerable evil." We think the judgment is erroneous.

Judgment reversed, and new trial granted. All concur, except MAYNARD, J., absent. ${ }^{1}$

1 Acc.: Ellis v. Kansas City, St. J. \& O. B. R. Co., 63 Mo. 131, 21 Am. Rep. 436 (1876).

A. was a visitor in B.'s house and was made seriously 11 by gas escaping from the defendant's main. In an action by $\mathbf{A}$. against the defendant for 


\section{ROSS v. BUTLER.}

(Court of Chancers of New Jersey, 1ses. 19 N. J. Eq. 294, 97 Am. Dec. 65t.)

Argued on a rule to show cause why an injunction should not issue.

The Chancelior (Zabriskie). $* * * 2$ For the purposes of this application, it must be taken as established, that the defendant is about to erect upon his lot, on the west side of Burnet street, a brick building with a fire proof roof, forty feet front by sixty feet deep, and three stories high; that the building is to be placed on the line of Burnet street upon the front of the lot, which is one hundred feet wide and two hundred feet deep, and has on its rear a small pottery, which has been used for several years; that the building will be constructed with two kilns, each containing one furnace for burning earthenware, having each one chimney; that it is intended when the building is finished, to use these kilns and to burn pine wood, which will cause large volumes of dense smoke to issue from the chimneys, which, with the cinders emitted with it, will fall in the yards and upon the houses in the vicinity, and penetrate the dwellings of the complainants, injure their goods and make their homes uncomfortable. These fires will not be kindled more than twice in each month, and after the first twelve hours will not emit large volumes of smoke, and in certain states of the atmosphere the smoke will be carried off without penetrating the houses of the complainants.

It must also be taken as established, that Burnet street, in this locality, and the adjoining parts of the city, are, if not continuously, thickly built up, and have been so built up for years; that these buildings have been, and now are, used for dwellings; that the complainants all occupy dwellings on Burnet street, between New and Oliver streets, and that the dwelling house of the complainant, Agnew, is on the opposite side of Burnet street, and within forty feet of the proposed pottery; that this part of the city is used for business and mechanical purposes, and is in the neighborhood of the canal and river, and of the wharves, docks, and coal and lumber yards on it, and is not the residence of the more wealthy and luxurious inhabitants, but it is occupied by business men and mechanics of moderate means.

The question is, whether this factory, and the business proposed to be carried on in it in the manner stated, will be, in that neighbor-

the damage so caused, an instruction that $A$. could recover, if he was in. jured by the gas and the defendant was gullty of negligence and $\mathbf{A}$. was not, was sustained. Hunt $\nabla$. Gas Co., 8 Allen (Mass.) 169, $85 \mathrm{Am}$. Dec. 697 (1564).

Compare: Ft. Worth, etc. Co. v. Glenn, 97 Tex. 5s6, so S. W. 992. (i5 1. R. A. 818,104 Am. St. Rep. $\$ 94,1$ Ann. Cas. 270 (1904); Herman v. Buffalo, 214 N. Y. 316,108 N. E. 451 (1915).

2 Part of the opinion is omitted. 
hood and to these complainants, a nuisance such as this court ought to prevent and restrain.

The defendant contends that it will not be a nuisance: First, because the annoyance will not be great, and only occasional, principally in the night, when it will not be much noticed, and will not be injurious to health; secondly, because it is in an old part of the town, now deserted by the better class of residents, and given up principally to trade and manufactures, and on which there are not many valuable buildings; and, thirdly, because it is near the canal and river, where there is an abundant supply of water to extinguish any fires which may be occasioned by the business.

The law takes care that lawful and useful business shall not be put a stop to on account of every trifling or imaginary annoyance, such as may offend the taste or disturb the nerves of a fastidious or over refined person. ${ }^{3}$ But, on the other hand, it does not allow any one, whatever his circumstances or condition may be, to be driven from his home, or to be compelled to live in it in positive discomfort, although caused by a lawful and useful business carried on in his vicinity. The maxim, "Sic utere tuo ut alienum non lædas," expresses the well established doctrine of the law.

It is not necessary, to constitute a nuisance, that the matter complained of should affect the health or do injury to material property. It is sufficient, in the language of Sir Knight Bruce, if it is "an inconvenience materially interfering with the ordinary comfort, physically, of human existence, not merely according to elegant and dainty modes and habits of living, but according to plain and sober and simple notions among the English people."

The law, then, must be regarded as settled, that when the prosecution of a business, of itself lawful, in the neighborhood of a dwelling house, renders the enjoyment of it materially uncomfortable, by the smoke and cinders, or noise or offensive odors produced by such business, although not in any degree injurious to health, the carrying on such business there is a nuisance, and it will be restrained by injunction.

That large quantities of dense smoke produced by burning pine wood, with the cinders floating in it, falling upon the houses and yards in the vicinity, and penetrating the dwellings, would cause material discomfort, there can be no doubt. In this case, it is contended that as the burning will be but twice in a month, and for twelve hours only, and that principally at night, it will be so slight as not to be a material discomfort.

A nuisance of this kind may possibly occur so seldom that it will not be held to produce a material discomfort. Where the occurrence was only accidental and not produced by the regular course of busi-

3 See Akers v. Marsh, 19 App. D. C. 29 (1901); Wade v. Miller, $18 s$ Mass. 6. 7? N. E. 849,69 L. R. A. 820 (1905). 
ness, and recurring only three or four times a year, and not intended to be again permitted, it was held not to be a proper cause for an injunction to stop a lawful business, but that the party must be put to his action for damages.

But I am not aware of any authority or established principle, holding 'that a clear unmistakable nuisance, which it is intended to commit periodically, will be permitted because it does not exist the greater portion of the time, but only for a small portion of it. This court will not determine that a family shall have their dwelling house made uncomfortable to live in for twelve hours, once in two weeks, or that they shall protect themselves by closing the house tightly, and remaining indoors for that time. It is surcly no justification to a wrongdoer, that he takes away only one twenty-eighth of his neighbor's property, comfort, or life.

Another question raised is, whether this business, although in some places it might be a nuisance, is not lawful here, on the ground that this is a part of the city deroted to such business, and therefore a convenient and proper place for it. The defendant is about to erect his pottery in a part of the city where there are no costly dwellings, and inhabited by persons in moderate circumstances, some of whom are mechanics, and some tradesmen, and carry on their trades and business on their own premises, but none of whom cause any annoyance in kind or degree like the smoke of such a pottery.

The doctrine that a business which of itself was a nuisance to dwellings in its vicinity, might be carried on lawfully if in a convenient and suitable place, has been applied to justify such business to the discomfort of the inhabitants in their own dwelling houses, on the ground that such trade and business must be carried on somewhere, and that certain places should be considered proper for, and dedicated to, such purposes. This position has been supported by many dicta, and some authorities.

In England, it was founded on a dictum of Baron Comyns in his Digest, title, "Action upon the Case for a Nuisance, (C)," in which he says: "So it does not lie for a reasonable use of any right, though it be to the annoyance of another; as if a butcher, brewer, \&c., use his trade in a convenient place, though it be to the annoyance of his neighbor." And on this authority, the Court of Common Pleas, in the case of Hole v. Barlow, 4 C. B. (N. S.) 334, held that it was no misdirection for the judge at Nisi Prius, to submit it to a jury, whether the burning of brick, the nuisance there complained of, was in a proper and convenient place.

But this case was expressly overruled in Bamford v. 'Turnley, first in the King's Bencl, and then on error in the Exchequer Chamber, 3 Best \& Smith, 62. Afterwards, the question was again raised in the case of Tipping v. The St. Helen's Smeiting Company [11 H. L.

4 See Swain v. G. N. Ry. Co., 4 De G., J. \& S. 211 (1564). 
C. $642(1865)]$, by which the law is considered as finally settled in England.

I find no authority that will warrant the position that the part of a town which is occupied by tradesmen and mechanics for residences and carrying on their trades and business, and which contains no elegant or costly dwellings, and is not inhabited by the wealthy and luxurious, is a proper and convenient place for carrying on business which renders the dwellings there uncomfortable to the owners and their families by offensive smells, smoke, cinders, or intolerable noises, even if the inhabitants are themselves artisans, who work at trades occasioning some degree of noise, smoke, and cinders. Some parts of a town may, by lapse of time, or prescription, by the continuance of a number of factcries long enough to have a right as against every one, be so dedicated to smells, smoke, noise, and dust, that an additional factory, which adds a little to the common evil, would not be considered at law a nuisance, or be restrained in equity.

There is no principle in law, or the reasons on which its rules are founded, which should give protection to the large comforts and enjoyments with which the wealthy and luxurious are surrounded, and fail to secure to the artisan and laborer, and their families, the fewer and more restricted comforts which they enjoy.

But the question remains, what degree or amount of discomfort is necessary to constitute a nuisance. It is clear that every thing that renders the air a little less pure, or is to any extent disagreeable, is not necessarily a nuisance. The smoke that may, in certain conditions of the atmosphere, descend from a neighbor's chimney, the fumes that may sometimes be wafted from his kitchen, though not desirable or agreeable, are not a nuisance. Between them and the dense smoke from a kiln or factory, that renders breathing difficult and painful, and smells offensive to the verge of nauseating, there is debatable ground, on which it may be difficult to fix the exact point at which the smoke or smell becomes a nuisance in the eye of the law.

The word "uncomfortable" is not precise, nor does the phrase of Vice Chancellor Bruce, "according to plain and sober and simple notions among the English people," add much to making it definite. In fact, no precise definition can be given; each case has to be judged of by itself.

Here the question is, whether a dense smoke laden with cinders, caused by the burning of pine wood, and continued for twelve hours, twice in each month, falling upon and penetrating the houses and premises of the complainants, at distances varying from forty to two hundred feet, would cause such injury, annoyance, and discomfort, as would constitute a legal nuisance. I am of opinion that it would. The building of the pottery would be no nuisance. It is possible that the burning of earthenware may be conducted with other fuel than pine wood, not emitting large quantities of dark, dense smoke or cinders; and equity will not interfere against a nuisance that is only contingent. 
The defendant may, if he sees fit, finish his building. But it was proper for the complainants, as soon as they knew of his intention to use the building for a purpose objectionable to them, to apply in equity for relief. This court would be very reluctant to interfere, if they had stood by, without objection, and allowed him to expend his money.

An injunction must issue against using the building for burning earthenware, or any manufacture with pine wood, or any fuel that may emit large quantities of dense smoke. The injunction, of course, may be removed or modified, if, upon the final hearing of the cause, it appears that the consequences on which this decision is founded, will not follow from such use of the premises. ${ }^{5}$

\section{ROMER v. ST. PAUL CITY RY. CO.}

(Supreme Court of Minnesota, 1899. 75 Minn. 211, 77 N. W. 825, 74 Am. St. Rep. 455.$)$

START, C. J. ${ }^{6}$ This was an action for damages against the defendant for so maintaining and operating its street-car barn, and switching the cars in and out of it, as to constitute a nuisance, whereby the rental value of the plaintiff's real estate was impaired. At the close of the evidence the trial court directed a verdict for the defendant, and the plaintiff appealed from an order denying his motion for a new trial.

Competent evidence was introduced on the trial, which was sufficient, taking the most favorable view of it for the plaintiff, to establish the following facts: Ramsey street and Smith and Thompson avenues are public streets within the city of St. Paul. The plaintiff has owned for some years, and still owns, the real estate described in the complaint, abutting upon the street and avenues named, which is occupied by dwelling houses and flats, as stated in the complaint. The defendant is a corporation for the purpose of operating street-railway lines in the city of St. Paul, and has been so engaged since 1872, and for the past nine years it has been engaged in operating a general system of electric street railways in the city, composed of various lines; but each line is practically a part of every other line, so that a passenger boarding the car on any particular line can, by means of a transfer. required by ordinance, on payment of one fare, ride to any point on any other line embraced within the system. One of the lines of this system is operated along Ramsey street, and is known as the "Grand

5 Acc.: Walter r. Selfe, 4 le G. \& $\$ 315$ (1S51); Hurlbut v. McKone, 55 Conn. 31, 10 Atl. 164, 3 Am. St. Rep. 17 (1S57); Euler r. Sullivan, 75 Md. 616, $23 \mathrm{Atl}$. 845. $32 \mathrm{Am}$. St. Rep. 420 (1S9); Stevens r. Rockport Granite Co., 216 Mass. 4S6. 104 N. E. 371 , Ann. Cas. 1915L, 1054 (1914); Robinson $r$. Baugh, 31 Mich. 290 (1S75).

6 The statement of facts and part of the opinlon are omitted.

Big.Rights-2 
Avenue Line," which connects with or crosses all the other lines of the system. The defendant is the owner of the land, bounded by Ramsey street and Thompson and Smith avenues, upon which is located the car barn in question, which fronts on Ramsey street. It has been the owner of this land, and has maintained a car barn thereon, and operated its cars in and out of it, for many years. Since 1890 electricity has been the motive power used on the defendant's lines, and since that date it has operated on Ramsey street its Grand avenue line in front of the plaintiff's property, at which point it has used a cross switch. ***

The location of the barn is practically a residence district, but it is within a few blocks of the business part of the city, with a lumber yard and several shops and stores in its immediate vicinity. The defendant's employés begin about 4 o'clock in the morning to take the cars out of the barn with the switching motor, and put them in position on the streets around the barn for distribution over the system. The cars are brought back in the evening, and are taken into the barn up to 1 o'clock in the morning. In switching and distributing the cars a great noise is made, which is heard every morning from 4 to 6 o'clock, and again in the evening to 1 o'clock in the morning. The cars are taken out of the barn on Thompson avenue, and around the curves to Ramsey street, and run over the switches in front of the plaintiff's brick block. The cars, in running around the curves, produce a sharp, grinding noise, and in making up the trains and pulling them out there is a bumping noise. The alleged nuisance consisted of the loud and disagreeable noises caused by the defendant so switching its cars in and out of the barn, and running them over and across the curves on Thompson and Sinith avenues, and over the switch in front of the plaintiff's block on Ramsey street; also, by the ringing of the gongs on the cars, the loud talking of the defendant's employés in charge of them, and the hammering in cleaning and repairing of the cars in the street. The noises so produced were such as to disturb the rest and comfort of the plaintiff, his tenants, and other property owners in the vicinity of the car barn, by keeping them awake until late at night, and rousing them in the early hours of the morning. And, further, in the obstruction of the streets in front of plaintiff's property by permitting its cars to stand thereon, and by bringing coal, wood, sand, and other material to be used in the operation of its electric line, and unloading them upon the street at or near the barn. The rental value of the plaintiff's property has been in some measure reduced by the alleged nuisance. It was substantially admitted by the plaintiff on the argument of this appeal that the defendant was not guilty of any negligence in the construction, maintenance, and operation of its street-railway tracks, curves, switches, cars, and barn at the point in question. It was also conceded on the trial that no negligence in the premises had been proven. As to the repairs of the cars in the street, the evidence shows that they were such as were occasionally necessary to put them in a condi- 
tion to be moved. The obstruction of the streets by the cars was temporary. ***

The real question, then, in this case, is whether the loud and disagreeable noises necessarily occasioned by the defendant in running its cars over its switches and curves in the streets, late at night and early in the morning, whereby the plaintiff is disturbed in the enjoyment of his property, is an actionable nuisance. 'The plaintiff, while conceding that the defendant has a right to maintain its car barn at the intersection of these streets, and to construct side tracks and switches on Ramsey street, claims it has no such right on Smith and Thompson avenues, and no legal right to switch its cars in and out of its barn over the tracks and curves upon the avenues.

We find in these ordinances no express grant to the defendant to maintain the curves and switches in the avenues in question for the purpose of taking its cars in and out of its barn, but the right to do so was given by necessary implication.

This conclusion, however, does not dispose of this appeal; for while it is true, as a general proposition, that what is authorized to be done by law cannot be a public nuisance, yet it may be a private nuisance, as to individuals who are specially injured thereby. 2 Wood, Nuis, 557. The question still remains whether the loud and disagreeable noises occasioned by the running of the defendant's cars in and out of its barn over the curves and switches on the strects at the place and at the hours in question, although authorized by the city ordinances, constitute an actionable nuisance, as to the plaintiff. The answer to this question-there being no negligence in the case-depends on whether the location of the defendant's car barn was a reasonable and proper one, and whether the use of the streets at the times and in the manner they were used by the defendant in running its cars over the curves and switches, whereby the noises complained of were produced, was one of the reasonable uses or purposes for which the streets were acquired. The plaintiff cites and relies on a class of cases to the effect that, where a party is carrying on a lawful business on his own land without negligence, yet if it is a business which is attended with loud and disagreeable noises, or produces noisome smells or noxious vapors, whereby the property and comfort of those divelling in the neighborhood are materially injured and disturbed, the business is a nuisance per se. Such cases, however, are not particularly in point; for this is not the case of carrying on an offensive trade or business on one's own premises which may be carried on at places removed from the occupied parts of a city, or beyond its limits.

The case of Baltimore \& P. Ry. Co. v. Fifth Baptist Church, 10\& U. S. 317, 2 Sup. Ct. 719, 27 L. Ed. 739, also relied on by the plaintiff, is more nearly in point than any other cited. But that case is clearly distinguishable from the one at bar. It was a case where a commercial railway company, whese motive power was steam, located its engine house and machine shop immediately adjoining a then existing churct 
edifice, which was, and had been for some years prior to such location, continuously used by the church as its house of worship. The hammering in the shop, the passing of the engines in and out of the roundhouse, the blowing of whistles, the sounding of the bells, and the cinders and offensive odors, created a constant disturbance of the religious exercises of the church. Such acts were held to constitute an actionable nuisance, and it was held that the church was entitled to damages in the premises. This was clearly a case of an improper and unreasonable location of its roundhouse and machine shop by the railway company, with reference to which the court, in its opinion, said, "There are many places in the city sufficiently distant from the church to avoid all cause of complaint, and yet sufficiently near the station of the company to answer its purposes." But there is a radical difference between an ordinary commercial railway, operated by steam, and a surface street railway, operated by electricity, as to the selection of its roundhouses and machine shops by the one, and its car barns by the other. In each case the selection must be made with reference to the rights of property owners in the neighborhood; also, those of the railway company and of the public. The rights and convenience of property owners cannot alone be considered, for one living in a city must necessarily submit to the annoyances which are incidental to urban life, and individual comfort must in many cases yield to the public good.

Now, the only ground for claiming in this case that the location of the defendant's car barn was an improper one is that it is in the residence portion of the city. But the exclusive business of the defendant is the carrying of passengers within the limits of the city and in its streets. Its lines traverse the streets of the residence portion of the city. Its business is there. It takes on and discharges passengers in all parts of the city. It must have its car barns so located that it can promptly get its cars upon its lines for the purpose of enabling the people of the city to seasonably get from their homes to their respective places of business or labor. It cannot locate its barns outside of the city, because it is only authorized to build and operate its lines within the city limits and upon its streets; and, if it had the authority to do otherwise, it would be impractical and detrimental to public interests to do so. Again, if it locates its barns at points where there are at present no dwelling houses, it is only a matter of time when some property owner will be disturbed by the loud and disagreeable noises necessarily occasioned by taking its cars in and out of the barns. The rights of such an owner are the same as those of the plaintiff. The barn in question is only one of five barns located and used by the defendant for the same purpose in different parts of the city, and the evidence conclusively shows that its location is not an improper or unreasonable one.

The further question, whether the maintenance and use by the defendant of the switches and curves in question are a proper street use, is settled adversely to the plaintiff by the previous decisions of this 
court. Such maintenance and use are a necessary incident to the operation of its street-car system, which derives its business from the streets, is intended for the convenience of the travel therein, and is in aid of the identical use for which the streets were acquired; hence the maintenance and operation of these switches and curves are a proper street use, and not an additional burden thereon. Newell v. Railway Co., 35 Minn. 112, 27 N: W. 839, 59 Am. Rep. 303. The discomfort and injury sustained by the plaintiff from the loud and disagreeable noises produced by taking the cars of the defendant in and out of its barn over the switches and curves at the place and at the times in question are the same, except in a greater degree, as are sustained by property owners at the street corners where its cars are operated over curves. The acts of the defendant complained of do not constitute a private nuisance for which the plaintiff is entitled to recover damages.

Order affirmed. ${ }^{7}$

\section{STOTLER v. ROCHELLE.}

(Supreme Court of Kansas, 1910. 83 Kan. 86, 109 Pac. 788, 29 L. R. A, [N. S.] 49.)

MAson, J. ${ }^{8}$ A hospital for the treatment of patients afflicted with cancer was about to be established in Kansas City, Kan., in a building formerly used as a dwelling house. The owner and occupant of adjacent premises brought an action to enjoin its establishment upon the ground that in view of the character of the neighborhood its presence there would render it in legal contemplation a nuisance. A permanent injunction was granted, and the defendants appeal.

The home of the plaintiff is 78 feet from the main building which it is proposed to use as a hospital. The two houses face in the same direction, and each has a number of windows looking toward the other. A 15 -foot alley runs between them, near which is a small building belonging to the hospital property, formerly used for a billiard room.

7Acc.: Daris v. Whitney, 6S N. H. 66, 44 Atl. 7S (1S91); Ladd v. Brick Co., 68 N. H. 1S5, 37 Atl. 1041 (1S91). See Sanders-Clark v. Grovesnor Mansions Co., [1900] 2 Ch. 373.

A. lived in a neighborhood in whlch there wero several printing establishments as well as allied trades. F. had for several years conducted a large printing establishment in an adjoining building. IIe installed additional machinery which he ran at niglit. The day operatlons added somewhat to the noise of the neighborhood; the night operatlous were an innovation and seriously disturbed A.'s sleep. Held, A. was not entitled to enjoin the running of the additional machinery in the daytlme; he was entitled to enjoin its running at night. Kushmer $v$. L'olsue, [1906] 1 Ch. 1 . 234. Compare Austin r. Converse, 219 I'a. 3, 67 Atl. 921 (1907).

A. was almost the only resident in a block otherwise devoted to business and manufacturing purposes. An adjoluing building was used as a flour mill, causing dust, steam, ashes, and soot to permeate $\mathbf{A}$.'s dwelling, and calusing marked noise and vibration. Hold. 1 . was not entitled to an injunction.' Gilbert r. Showerman, 23 Mich. 44 (1871).

- Part of the opinion is omitted. 
Two other residences are situated about 90 feet from the hospital building, and three others at a distance of about 150 feet. All the houses in the vicinity are used solely as dwellings.

Witnesses for the plaintiff who were familiar with real estate values testified that in their judgment the establishment of the hospital would cause a material depreciation in the rental and market value of the surrounding property. Several physicians expressed the opinion that there would be some danger of the communication of the disease. through transmission by means of insects, and perhaps in other ways. There was also evidence that offensive odors resulting from the disease itself and from disinfectants used on account of it might reach the occupants of neighboring dwellings. On behalf of the defendants, there was testimony that none of the anticipated evils had resulted from a cancer hospital formerly maintained by them under somewhat similar conditions; that under proper management there need be no offensive odors about such a place; and that cancer is not contagious or infectious. Perhaps the court may take notice of the prevailing view in the medical profession upon the last proposition. From the current literature of the subject, it appears that while it has not been proved to the satisfaction of the profession generally that cancer can be communicated from one individual to another, except by the process of grafting or transplanting cancerous tissue, competent investigators are not lacking who believe that it is of parasitic origin and in some degree infectious. ***

In Baltimore City v. Fairfield Imp. Co., 87 Md. 352, 364, 365, 39 Atl. 1081, 1084 (40 L. R. A. 494, 67 Am. St. Rep. 344), an injunction against the placing of a leper for care and restraint in a residence neighborhood was justified in part upon grounds thus stated in the opinion: "Leprosy is and always has been, universally regarded with horror and loathing. *** The horror of its contagion is as deep-seated to-day as it was more than 2,000 years ago in Palestine. There are modern theories and opinions of medical experts that the contagion is remote and by no means dangerous; but the popular belief of its perils founded on the Biblical narrative, on the stringent provisions of the Mosaic law that show how dreadful were its ravages and how great the terror which it excited, and an almost universal sentiment, the result of a common concurrence of thought for centuries, cannot in this day be shaken or dispelled by mere scientific asseveration or conjecture. It is not, in this case, so much a mere academic inquiry as to whether the disease is in fact highly or remotely contagious; but the question is whether, viewed as it is by the people generally, its introduction into a neighborhood is calculated to do a serious injury to the property of the plaintiff there located."

Much the same reasoning may be applied here. The question is not whether the establishment of the hospital would place the occupants of the adjacent dwellings in actual danger of infection, but whether they would have reasonable ground to fear such a result, and whether, 
in view of the general dread inspired by the disease, the reasonable enjoyment of their property would not be materially interfered with by the bringing together of a considerable number of cancer patients in this place. However carefully the hospital might be conducted, and however worthy the institution might be, its mere presence, which would necessarily be manifested in various ways, would make the neighborhood less desirable for residence purposes, not to the oversensitive alone, but to persons of normal sensibilities. The court concludes that upon these considerations the injunction was rightfully granted. ${ }^{\circ}$

\section{HENNESSY v. CARMONY.}

(Court of Chancery of New Jersey, 1892. 50 N. J. Eq. 616, 25 Atl. 374.)

PI'NEY, V. C. ${ }^{10}$ The object of the bill is to restrain a private nuisance. The complainant is the owner of a small lot of land, about 18 feet front and rear by about 96 feet deep, in the city of Camden, fronting on the west side of South Eighth street, about midway between Spruce street on the north and Cherry street on the south. Upon this lot is situated a small dwelling house, composed of a main or front part of brick, about 15 feet front by 30 feet deep, two stories high, leaving a passageway of 3 feet on the northerly side, and having a wooden extension or kitchen about 10 by 35 feet, two stories high, in

9Acc.: Haggart v. Stehlin, 197 Ind. 49,35 N. F. 997,22 L. R. A. 577 (1892) (licensed saloon); Saier v. Jog, 195 Mich. 295, 164 N. W. 507 , L. R. A. 1918A, 825 (1917) (undertaker); Barth . IIospital, 196 Mich. 642, $163 \mathrm{~N}$. W. 62 (1917) (insane asylum); Everett r. Paschall, 61 Wash. 47, 111 Pac. \$79, 31 L. R. A. (N. S.) S27, Ann. Cas. 1912B, 112S (1910) (sanitarium): Densmore v. Evergreen Camp. 61 Wash. 230, 112 l'ac. 255, 31 L. R. A. (N. S.) 60.s, Ann. Cas. 1912B, 1206 (1910) (undertaker).

A. sought an injumction to prevent B. from establishing a smallpox hospital within 2,000 feet of $A . ' s$ house. The injunction was refused. "The" question to be decided was whether there was an appreciable injury to the healthiness of the plaintiff's property. The plaintitis must make out that there was a real danger, otherwise, however much they might feel the hospital to be an annoyance, they rould not ret an injunction." Fleet v. Metropolitan Asylum Board, 2 T. L. R. 261 (1S66). Ace.: Westcott $\mathbf{v}$. Middleton, $4: 3$ N. J. Eq. 47S, 11 Atl. 490 (158T) (undertaker); City of Northifeld v. Loart, etc., 85 N. J. Eq. 47, 9. Atl. 745 (1915) (tulerenlosis hospital); Ieaton v. Packer, 131 App. Div. 812, 116 X. Y. Supp. t6i (1909) (insane asylum).

A. maintained within 50 fert of B.'s house, and in full view rom the windows thereof, a breeding ulace for stallions and jacks, where the animals were engaged daily. Held, $\mathbf{B}$. is entitled to enjoin the conduct of this business by $A$. in this place. Hayden r. Tucker, ;i Mo. 214 (1866); Farrell $v$. Cook, 16 Neb. $48.3,20$ N. W. $7: 0,49$ Am. Iiep. 721 (1584).

A. erected on his land, inmediately opposite the windows of $B$.'s parlor, and about 50 feet therefrom, a stalle, pig sty, and privy, all of which he used. Held, B. was not entitled to enjoin their use, except in so far as the noise or swells therefrom amounted to a nuisance. 'Trulock v. Merte. T:' Iowa, 510,34 N. W. 307 (1S87). See, also, Quintini v. Board of Allermen, $; i$ Miss. 483, 1 Sonth. 625, $60 \mathrm{Am}$. Rere. 62 (1SS6); Lane v. Concord, 70 N. $I$. 455,49 Atl. 687,55 Am. St. Iiel. 643 (1900).

10 Part of the opinion is omitted. 
the rear. The rear of this structure is $311 / 2$ feet from the rear line of the lot. The ground lying to the north anci west of this lot is owned by the defendants, or one of them, and is used for a dye works for coloring cotton and other materials. In the process of dyeing, it, of course, becomes necessary to diry those materials, and in order to hasten this process use is made of two machines, called in the evidence "whizzers," into which the wet material is placed, and which, by being revolved at great speed, drive out the water by centrifugal force. These machines are driven by two small engines attached to them directly, without intermediate gearing, so that the engines must make the same number of revolutions as do the whizzers, and the more rapid the revolution, the more rapid the process of drying.

The principal subject of litigation was as to the effect upon the complainant's premises of these machines. There were other matters complained of, some of which were remedied about the time the bill was filed, and such as were not remedied are capable of being remedied without serious inconvenience to the defendants.

Fourth. Complainant contends that the running of the centrifugal machines before mentioned has the effect of making a disagreeable noise, and also of jarring and shaking the house, so that the windows and doors rattle, the pieces of table crockery rattle and move upon one another on the shelves, and the walls are more or less cracked. * * *

With regard to the alleged noise and vibration, and the right of the complainant to relief on that score if the vibrations be established, more troublesome questions arise. The proof is clear that when these machines, called in the evidence "whizzers," were first put in, some years ago, they did produce a serious vibration in the neighbòring buildings. The factory is situate in the easterly center of the block, which is oblong, and bounded north by Spruce street, east by Eighth street ancl south by Cherry street, and the engines are about equidistant-say 110 feet to 120 feet-from each of these streets, and about 30 feet from the rear of complainant's lot. On the west of the factory is a church and a public schoolhouse, and the latter is more than 150 feet distant from the machines. So great was the vibration they produced at the schoolhouse that complaint was made by the school authorities, and the defendants attempted to remedy the nuisance by constructing a solid foundation of masonry, extending some six feet below the surface, and placing the machines upon it. It is also proven by one of the defendants' witnesses, who lived in the complainant's house at and before the construction of this foundation, that complainant's house was seriously shaken by the machines. This solid foundation, put in about three years before bill filed, seems to have remedied the difficulty so far as the schoolhouse was concerned, and, under ordinary circumstances, one would suppose that the result would be general, and include buildings as near as complainant's dwelling. But the evidence compels me to come to a contrary conclusion. 
The evidence of the complainant and his family is strong as to the noise and vibration in his house, and its effect, as above stated, in cansing the windows to rattle and the dishes to rattle and move upon their shelves, the doors to swing open, and the walls to crack. ***

The serious and troublesome question in the case is as to whether the vibration established is of such a degree as to entitle the complainant to the aid of this court. Upon reason and authority I think there is a clear distinction between that class of nuisances which affect air and light merely, by way of noises and disagreeable gases, and obstruction of light, and those which directly affect the land itself, or structures upon it. Light and air are elements which mankind enjoy in common, and no one person can have an exclusive right in any particular portions of either; and, as men are social beings, and by common consent congregate, and need fires to make them comfortable and to cook their food, it follows that we cannot expect to be able to breathe air entirely free from contamination, or that our ears shall not be invaded by unwelcome sounds. Thus, ny neighbor may breathe upon my land from his, and the smoke from his house fire and the vapor from his kitchen may come onto my land, or he may converse in audible tones while standing near the dividing line, and all without giving me any right to complain. So my neighbor and I may build our houses on the line between our properties, or have a party wall in common, so that we are each liable to hear and be more or less disturbed by the noise of each other's family, and cannot complain of it. In all these matters of the use of the common element air we give and take something of injury and annoyance, and it is not easy to draw the line between reasonable and unreasonable use in such cases, affecting, as they do, mainly the comfort, and, in a small degree only, the health, of mankind. In attempting to draw this line, we must take into consideration the character which has been impressed upon the neighborhood by what may be called the "common consent" of its inhabitants. But when we come to deal with what is individual property, in which the owner has an exclusive right, the case is different. While my neighbor may stand by my fence on his own lot, and breathe across it over my land, and may permit the smoke and smell of his kitchen to pass over it, and may talk, laugh, and sing or cry, so that his conversation and hilarity or grief is heard in my yard, he has no right to shake my fence ever so little, or to throw sand, earth, or water apon my land in ever so small a quantity. To do so is an invasion of property, and a trespass, and to continue to do so constitutes a minsance; and, if he may not shake my fence or my house by force directed immediately against them, I know of no principle by which he may be entitled to do it by indirect means.

I think the distinction between the two classes of injury is clear. At the same time it would scem that it has, in appearance at least, becn frequently overlooked by able and careful judges, and the sante rules as to the degree of the injury which will justify judicial interference 
applied to each class. The distinction between the two classes of injuries was pointed out by Lord Westbury in Smelting Co. v. Tipping, 11 H. L. Cas. 642, 11 Jur. (N. S.) 785, 116 E. C. L. 1093. The charge of the judge under review is given in full in the report in the Jurist, and in the addenda to 4 Best \& S., printed in 116 E. C. L. 1093, while a mere abstract is given in the report in the queen's bench, (4 Best \& S. 608 ), and in the official report in the house of lords, (11 H. L. Cas.) One of the headnotes of the official report (11 H. L. Cas.) is this: "There is a distinction between an action for a nuisance in respect of an act producing a material injury to property and one brought in respect of an act producing personal discomfort. As to the latter, a person must, in the interest of the public generally, submit to the discomfort of the circumstances of the place, and the trades carried on around him. As to the former, the same ruling would not apply."

Lord Westbury, in moving the judgment of affirmance, said: "In matters of this description it appears to me that it is a very desirable thing to mark the difference between an action brought for a nuisance upon the ground that the alleged nuisance produces material injury to the property and an action brought for a nuisance on the ground that the thing alleged to be a nuisance is productive of sensible personal discomfort. With regard to the latter, namely, the personal inconvenience and interference with one's enjoyment, one's quiet, one's personal freedom, anything that discomposes or injuriously affects the senses or the nerves, whether that may or may not be denominated a 'nuisance,' must undoubtedly depend greatly on the circumstances of the place where the thing complained of actually occurs. If a man lives in a town, it is necessary that he should subject himself to the consequences of those operations of trade which may be carried on in his immediate locality which are actually necessary for trade and commerce, and also for the enjoyment of property, and for the benefit of the inhabitants of the town and of the public at large. If a man lives in a street where there are numerous shops, and a shop is opened next door to him, which is carried on in a fair and reasonable way, he has no ground for complaint because to himself individually there may arise much discomfort from the trade carried on in that shop. But when an occupation is carried on by one person in the neighborhood of another, and the result of that trade or occupation or business is a material injury to property, then there unquestionably arises a very different consideration. I think that in a case of that description the submission which is required from persons living in society to that amount of discomfort which may be necessary for the legitimate and free exercise of the trade of their neighbors would not apply to circumstances the immediate result of which is sensible injury to the value of the property." This opinion was expressly concurred in by the other judges who sat in that case.

The sole question before the court was whether the defendant below (the plaintiff in error) had any reason to complain of the charge of the 
judge, and not whether, if the verdict had been for the defendant, the plaintiff below might not have taken exception to it; and the effect oi the judgment of Lord Westbury was-as it seems to me-to hold that the charge was too favorable to the defendant below, who was plaintiff in error. This aspect of the case was noticed and pointed out by Lord Cockburn in the queen's bench, who said (4 Best \& S. 615) that, if the summing up of the judge "was wrong in any respect, the error is one of which the other side is the only party entitled to complain." It is not quite safe, therefore, as it seems to me, to rely upon the charge of the judge there under review as an accurate statement of the law, without taking into consideration this circumstance. In my judgment, the distinction taken by Lord Westbury in that case is founded in reason, and should be observed; and, in looking at the language used by the judges in other cases, we ought to observe whether it was used in reference to a case of injury through the air by noise or offensive odor, or whether it was one affecting the land itself. Thus, in Sturges v. Bridgman, $(1879) ,11 \mathrm{Ch}$. Div. 852 , where the injunction was granted, the case was one mainly of noise, and, although the element of vibration was mentioned, the judges dealt altogether with the matter of noise. The same may be said of Gaunt v. Fynney, (1872,) L. R. \& Ch. App. 9, where the injunction was refused.

The question here, then, is not so much whether the effect of the noise and vibration caused by the rapid revolution of the defendants' machines is to render complainant's house less comfortable to live in: (though that is a matter to be considered,) but rather whether the complainant's land and dwelling is sensibly and injuriously affected by the vibration. If it be so, then it seems to me he ought, in the absence of any equitable defense, to be entitled to relief. The familiar ground on which the extraordinary power of the court is invoked in such cases is that it is inequitable and unjust that the injured party should be compelled to resort to repeated actions at law to recover damages for his injury, which, after all, in this class of cases, are incapable of measurement; and I presume to add the further ground that in this country such recovery must result in giving the wrongdoer a power not permitted by our system of constitutional government, viz., to take the injured party's property for his private purposes upon making, from time to time, such compensation as the whims of a jury may give. This ground of equitable action is of itself sufficient in those cases where the injury, though not irreparable, promises to be repeated for an indefinite period, and so is continuous in the sense that it will be persevered in indefinitely. See Ross v. Butler, 19 N. J. Eq. 302, 97 Am. Dec. 654 .

Several matters have at various times and on various occasions been held to stand in the way of granting an injunction in this class of cases. The principal one is what may be callcd the "de minimis." "balance of injury," and "discretion" doctrine. It has been said and held on some occasions that, where the injury to the complainant by the con- 
tinuance of the nuisance is small, and the injury to the defendant by its discontinuance is great, the court will consider that circumstance, and, if the balance is greatly against the complainant, will, in the exercise of a sound discretion, refuse the injunction, and leave the complainant to his remedy at law.

I have never been able to see how the question of the right of the complainant to an injunction on final hearing could ever be a matter properly resting in the "discretion" of the chancellor, as I understand the force of that word in that connection. If by "discretion" is here meant that the judge must be discreet, and must act with discretion, and discriminate, and take into consideration and give weight to each circumstance in the case in accordance with its actual value in a court of equity, then I say that that is just what he must do in every case that comes under his consideration; no more and no less; and that is the sense in which I understand the word is used in Demarest v. Hardham. But if the word "discretion," in this connection, is used in its secondary sense, and by it is meant that the chancellor has the liberty and power of acting, in finally settling property rights, at his discretion, without the restraint of the legal and equitable rules governing those rights, then I deny such power. It seems to me that the true scope of the exercise of this latter sort of discretion in the judicial field is found in those matters which affect procedure merely, and not the ultimate right. ${ }^{11} * * *$

The result of a careful review of the evidence upon my mind is to lead me to the conclusion that the degree of injury is such as to entitle the complainant to damages in an action at law, with the result that he is entitled to an injunction in this court. The injury, to be actionable, must be sensible and appreciable, as distinguished from one merely fanciful, and in a case like this I assume, for present purposes, that it must have the effect of rendering the premises less desirable, and so less valuable for ordinary use and occupation. Now, it seems to me that a vibration that causes the windows and doors of a house to rattle in their casings, and dishes on the shelves to rattle and move on one another, and the walls to crack, and is distinctly felt by persons in the house, would have such effect, and is therefore actionable; while smoke and noise might have a similar effect in rendering the house less desirable without being actionable, because the degree of discomfort would not be sufficiently great to reach the standard (if, indeed, any standard has been established) applied to that class of injuries. See Walter v. Selfe, 4 De Gex \& S. 318, 20 Law J. Ch. 434, 15 Jur. 416; Ross v. Butler, 19 N. J. Eq. 294, 299, 306, 97 Am. Dec. 654. There is evidence tending to show that complainant made little or no complaint with regard to this vibration until about the time the bill was filed, when the invasion of his property rights by hanging the stay wire over his land, by driving the filthy steam from the sewer into his kitchen, and 
the sprinkling of spray over his back yard, seemed to combine to exasperate him. This apparent acquiesccnce can only be used as evidence that the complainant did not consider the vibration as serious, but I think that is not sufficient in that regard to overcome the weight of the evidence that his house is injured.

I will advise a decree that the defendant be restrained from so using his machines as to cause the complainant's house to vibrate, and also from allowing the water and spray from the exhaust of his engines to come onto the complainant's lands. ${ }^{12}$

\section{MADISON et al.v. DUCKTOIVN SULPHUR, COPPER \& IRON CO. et al.}

McGHEE et al. v. TENNESSEE COPPER CO. et al.

FARNER v. TENNESSEE COPPER CO.

(Supreme Court of Tennessee, 1904. 113 Tenn. 331, 83 S. W. 658.)

Bill for an injunction. [The defendants were large copper smelting companies. The complainants were small farmers.]

NEIL, J. ${ }^{13} * * *$ All of the complainants have owned their several tracts since a time anterior to the resumption of the copper industry at Ducktown in 1891, and have resided on them during this period, with the exception of Avery McGhee, who worked for one of the defendant companies a considerable time, and Margaret Madison, who removed to Snoddy, in Rhea county, two or three years ago.

The general effect produced by the smoke upon the possessions and families of the complainants is as follows, viz.:

Their timber and crop interests have been badly injured, and they

12 For other cases, where the damage to property was held to constitute a nuisance, see Susquehanna Fertilizer Co. v. Spangler, S6 Md. 562, 39 Atl. $270,63 \mathrm{Am}$. St. Rep. 533 (1S9S) (action at law); Campbell $\nabla$. Seaman, $63 \mathrm{~N}$. Y. 568, $20 \mathrm{Am}$. Rep. 567 (1876) (granting an injunction).

Compare: Downing v. Elliot, 152 Mass. 2S, 64 N. E. 201 (1902).

"The fair interpretation of the plaintife's bill is that the floor above its rooms naturally and properly has holes in it, and that the defendants knowingly carry on their business in such a way as to send fumes of aeid and large quantities of sand through these holes upon the plaintiff's premises, and thereby to corrode and spoil its machinery and goods.

"As between adjoining proprietors, one of them has no right as against the others to do what is complained of here, and it would be no answer to an action to say that the plaintiff might liave shut lis windows. There would be no need to allege in terıns that the business was unsuitable to be carried on in that place, or that thers was negligence in the mode of carrying it on. As the damage was a manifest consequence of the defenciant: business, the fact that they could not help it if lley carried on that busines: would be immaterial. See the form of declaration in Tipping v. St. Helen's Smelting Co., 4 B. \& S. 60S. and st. Helen's Smelting Co. $\Gamma$. Tinring, 11 H. L. Cas. 642." Holmes, J., in Poston Ferrule Co. v. Hills, 159 Mass. 147, 149, 34 N. E. S5, 20 L. IR. A. $84 t$ (1893).

13 Part of the opinion is onitted. 
have been annoyed and discommoded by the smoke so that the complainants are prevented from using and enjoying their farms and homes as they did prior to the inauguration of these enterprises. The smoke makes it impossible for the owners of farms within the area of the smoke zone to subsist their families thereon with the degree of comfort they enjoyed before. They cannot raise and harvest their customary crops, and their timber is largely destroyed.

The Court of Chancery Appeals finds that the defendants are conducting and have been conducting their business in a lawful way, without any purpose or desire to injure any of the complainants; that they have been and are pursuing the only known method by which these plants can be operated and their business successfully carried on; that the open-air roast heap is the only method known.to the business or to science by means of which copper ore of the character mined by the defendants can be reduced; that the defendants have made every effort to get rid of the smoke and noxious vapors, one of the defendants having spent $\$ 200,000$ in experiments to this end, but without result.

It is to be inferred from the description of the locality that there is no place more remote to which the operations referred to could be transferred. ***

'There can be no doubt that the facts stated make out a case of nuisance, for which the complainants in actions at law would be entitled to recover damages.

The following general propositions seem to be established by the authorities: If the case made out by the pleadings and evidence show with sufficient clearness and certainty grounds for equitable relief it will not be denied because the persons proceeded against are engaged in a lawful business $(* * *$ Tipping v. St. Helens Smelting Co., 11 H. L. Cas. 642; Atty. Gen. v. Colny Hatch Lunatic Asylum, 4 L. R. Ch. App. 478; Crossly v. Lightowler, 3 L. R. Eq. 279, 2 L. R. Ch. App. 478; *** Robinson v. Baugh, 31 Mich. 291; Susquehanna Fertilizer Co. v. Malone, 73 Md. 268, 282, 20 Atl. 900, 9 L. R. A. 737, 25 Am. St. Rep. 595), or because the worlss complained of are located in a convenicnt place, if that place be one wherein an actionable injury is done to another (Susquehanna Fertilizer Co. v. Malone, 73 Md. 268, 277, 278, 20 Atl: 900, 9 L. R. A. 737, 25 Am. St. Rep. 595, and cases cited; Tipping v. St. Helens Smelting Co., supra); nor will the existence of another nuisance of a similar character at the same place furnish a ground for denying relief if it appear that the defendant has sensibly contributed to the injury complained of (Crossly v. Lightowler, supra ****).

But there is one other principle wlich is of controlling influence in this department of the law, and in the light of which the foregoing principle must be weigled and applicd. This is that the granting of an injunction is not a matter of absolute right, but rests in the sound discretion of the court, to be detcrmined on a consideration of all of 
the special circumstances of each case, and the situation and surroundings of the parties, with a view to effect the ends of justice.

A judgment for damages in this class of cases is a matter of absolute right, where injury is shown. A decree for an injunction is a matter of sound legal discretion, to be granted or withheld as that. discretion shall dictate, after a full and careful consideration of every element appertaining to the injury.

The question now to be considered is, what is the proper exercise of discretion, under the facts appearing in the present case? Shall the complainants be granted, in the way of damages, the full measure of relief to which their injuries entitle them, or shall we go further, and grant their request to blot out two great mining and manufacturing enterprises, destroy half of the taxable values of a county, and drive more than 10,000 people from their homes? We think there can be no doubt as to what the true answer to this question should be.

In order to protect by injunction several small tracts of land, aggregating in value less than $\$ 1,000$, we are asked to destroy other property worth nearly $\$ 2,000,000$, and wreck two great mining and manufacturing enterprises, that are engaged in work of very great importance, not only to their owners, but to the state, and to the whole country as well, to depopulate a large town, and deprive thousands of working people of their homes and livelihood, and scatter them broadcast. The result would be practically a confiscation of the property of the defendants for the benefit of the complainants-an appropriation without compensation. The defendants cannot reduce their ores in a manner different from that they are now employing, and there is no more remote place to which they can remove. The decree asked for would deprive them of all of their rights. We appreciate the argument based on the fact that the homes of the complainants who live on the small tracts of land referred to are not so comfortable and useful to their owners as they were before they were affected by the smoke complained of, and we are deeply sensible of the truth of the proposition that no man is entitled to any more rights than another on the ground that he has or owns more property than that other. But in a case of conflicting rights, where neither party can enjoy his own without in some measure restricting the liberty of the other in the use of property, the law must make the bcst arrangement it can between the contending parties, with a view to preserving to each one the largest measure of liberty possible under the circumstances. We sce no escape from the conclusion in the present case that the only proper decree is to allow the complainants a reference for the ascertainment of damages, and that the injunction must be denied to them. ${ }^{14} *{ }^{*} *$

14 Acc.: Richard's Appeal, 57 Pa. 105. 9S Am. Dec. 202 (1S6S); Rliss 5. Anaconda Conper Co. (C. C.) 167 Fel. 34: (1909). Compare Daniels v. Keo. kuk Waterworks. 61 Iowa, 549, 16 N. W. 705 (1Ss3); Shelfer v. London Electric Lighting Co., [1 1595$]$ Ch. D. 20. 


\section{STURGES v. BRIDGMAN.}

(Chancery Division, 1879. L. R. 11 Ch. Div. 852.)

TIIESIGER, L. J., ${ }^{15}$ delivered the judgment of the Court (JAmES, Baggallay, and Thesigeir, L. JJ.) as follows:

The defendant in this case is the occupier, for the purpose of his business as a confectioner, of a house in Wigmore street. In the rear of the house is a kitchen, and in that kitchen there are now, and have been for over twenty years, two large mortars in which the meat and other materials of the confectionery are pounded. The plaintiff, who is a physician, is the occupier of a house in Wimpole street, which until recently had a garden at the rear, the wall of which garden was a party wall between the plaintiff's and the defendant's premises, and formed the back wall of the defendant's kitchen. The plaintiff has, however, recently built upon the site of the garden a consulting room, one of the side walls of which is the wall just described. It has been proved that in the case of the mortars, before and at the time of action brought, a noise was caused which seriously inconvenienced the plaintiff in the use of his consulting room, and which, unless the defendant had acquired a right to impose the inconvenience, would constitute an actionable nuisance. The defendant contends that he had acquired the right, either at common law or under the Prescription Act, by uninterrupted user for more than twenty years.

In deciding this question one more fact is necessary to be stated. Prior to the erection of the consulting room no material annoyance or inconvenience was caused to the plaintiff or to any previous oćcupier of the plaintiff's house by what the defendant did. It is true that the defendant in the seventh paragraph of his affidavit speaks of an invalid lady who occupied the house upon one occasion, about thirty years before, requesting him if possible to discontinue the use of the mortars before eight o'clock in the morning; and it is true also that there is some evidence of the garden wall having been subjected to vibration, but this vibration, even if it existed at all, was so slight, and the complaint, if it could be called a complaint, of the invalid lady, and can be looked upon as eridence, was of so trifling a character, that, upon the maxim "De minimis non curat lex," we arrive at the conclusion that the defendant's acts would not have given rise to any proceedings either at law or in equity. Here then arises the objection to the acquisition by the defendant of any easement. That which was done by him was in its nature such that it could not be physically interrupted; it could not at the same time be put a stop to by action. Can user which is neither preventible nor actionable found an easement? We think not. The question, so far as regards this particular easement claimed, is the same question whether the defendant endeavours to assert his right by

15 The statement of facts is omitted. 
conmon law or under the Prescription Act. That act fixes periods for the acquisition of easements, but, except in regard to the particular easement of light, or in regard to certain matters which are immaterial to the present inquiry, it does not alter the character of easements, or of the user or enjoyment by which they are acquired. This being so, the laws governing the acquisition of easements by user stands thus: Consent or acquiescence of the owner of the servient tenement lies at the root of prescription, and of the fiction of a lost grant, and hence the acts or user, which go to the proof of cither the one or the other, must be, in the language of the civil law, "Nec vi nec clam nec precario;" for a man cannot, as a general rule, be said to consent to or acquiesce in the acquisition by his neighbour of an easement through an enjoyment of which he has no knowledge, actual or constructive, or which he contests and endeavours to interrupt, or which he temporarily licenses. It is a mere extension of the same notion, or rather it is a principle into which by strict analysis it may be resolved, to hold, that an enjoyment which a man cannot prevent raises no presumption of consent or acquiescence.

Upon this principle it was decided in Webb v. Bird, 13 C. E. (N. S.) 841 , that currents of air blowing from a particular quarter of the compass, and in Chasemore v. Richards, 7 H. L. C. 349, that subterranean water percolating through the strata in no known channels, could not be acquired as an easement by user; and in Angus v. Dalton, 4 Q. B. D. 162 , a case of lateral support of buildings by adjacent soil, which came on appeal to this court, the principle was in no way impugned. although it was held by the majority of the court not to be applicable so as to prevent the acquisition of that particular easement. It is a principle which must be equally appropriate to the case of affirmative as of negative easements; in other words, it is equally unreasonable to imply your consent to your neighbour enjoying something which passes from your tenement to his, as to his subjecting your tenement to something which comes from his, when in both cases you have no power of prevention. But the affirmative eascment differs from the negative easement in this, that the latter can under no circumstances be interrupted except by acts done upon the servient tencment, but the former, constituting, as it does, a direct interference with the enjoyment by the servient owner of his tenement, may be the subject of legal proceedings as well as of physical interruption. To put concrete cases - the passage of light and air to your neighbour's windows may be physically interrupted by you, but gives you no legal grounds of complaint against him. The passage of water from his land on to yours may be physically interrupted, or may be treated as a trespass and made the ground of action for damages, or for an injunction, or both. Noise is similar to currents of air and the flow of subterranean and uncertain streams in its practical incapability of physical interruption, but it differs from them in its capability of grounding an action. W Webb 
v. Bird and Chasemore v. Richards are not, therefore, direct authorities governing the present case. They are, however, illustrations of the principle which ought to govern it; for until the noise, to take this case, became an actionable nuisance, which it did not at any time before the consulting room was built, the basis of the presumption of the consent, viz., the power of prevention physically or by action, was never present.

It is said that if this principle is applied in cases like the present, and were carried out to its logical consequences, it would result in the most serious practical inconveniences, for a man might go-say into the midst of the tanneries of Bermondsey, or into any other locality devoted to a particular trade or manufacture of a noisy or unsavoury character, and, by building a private residence upon a vacant piece of land, put a stop to such trade or manufacture altogether. ${ }^{16}$ The case also is put of a blacksmith's forge built away from all habitations, but to which, in course of time, habitations approach. We do not think that either of these hypothetical cases presents any real difficulty. As regards the first, it may be answered that whether anything is a nuisance or not is a question to be determined, not merely by an abstract consideration of the thing itself, but in reference to its circumstances; what would be a nuisance in Belgrave Square would not necessarily be so in Bermondsey; and where a locality is devoted to a particular trade or manufacture carried on by the traders or manufacturers in a particular and established manner not constituting a public nuisance, judges and juries would be justified in finding, and may be trusted to find, that the trade or manufacture so carried on in that locality is not a private or actionable wrong. As regards the blacksmith's forge, that is really an idem per idem case with the present. It would be on the one hand in a very high degree unreasonable and undesirable that there should be a right of action for acts which are not in the present condition of the adjoining land, and possibly never will be any annoyance or inconvenience to either its owner or occupier; and it would be on the other hand in an equal degree unjust, and, from a public point of view, inexpedient that the use and value of the adjoining land should, for all time and under all circumstances, be restricted and diminished by reason of the continuance of acts incapable of physical

16 "In this cise the declaration alleges that the defendant injuriously carried on, in messuages contiguous to the messuage of the plaintiff, tlre trade and business of a candlemaker, by which noxious vapors and smells plocceded from the messuane of the defendant and diffused themselves over the messuace of the plaintilf; and all that the defendant says in answer is, that he carried on the husiness for three years before the plaintiff became possessed of the messuige he inhabits. That is no answer to the complaint in the declaration; for the plaintiff came to the house he occupies with all the rights which tlie common law affords, and one of them is a right to wholesome air. Unless the defendant shows a prescliptive right to carry on his business in the palticular place the plaintiff is entitled to judgment." Tindal, C. J., in liliss v. IIall, + Bing. N. C. 153,156 (1S3s). Ace.: Hayden v. Tuclier, 37 Mo. $21 \pm$ (1Sti), ante, 1). 23. 
interruption, and which the law gives no power to prevent. The smith in the case supposed might protect himself by taking a sufficient curtilage to ensure what he does from being at any time an annoyance to his neighbour, but the neighbour himself would be powerless in the matter.

Individual cases of hardship may occur in the strict carrying out of the principle upon which we found our judgment, but the negation of the principle would lead even more to individual hardship. and would at the same time produce a prejudicial effect upon the development of land for residential purposes. The Master of the Rolls in the court below took substantially the same view of the matter as ourselves and granted the relief which the plaintiff prayed for, and we are of opinion that his order is right and should be affirmed, and that this appeal should be dismissed with costs. ${ }^{17}$

17 A. owned a slaughterhouse that for over 20 rears had been emitting stenches. B. and C. orned adjacent land; B.'s being unocrupied, and C.'s occupied. Thes sought an injunction against $A$. A. claimed a prescriptive right. Held, the act was of a charicter to anomit to a nuisance. The court then said:

"Another objection to the defendant's title by prescription is, that until lately the plaintiffs suffered no damage from the alleged nuisance, ancl thelefore could not interpose to prevent its continuance. But it is very clear that. where a party's right of properts is invaded. he may maintain an action for the invasion of lis right, without proof of actual dimage." Daua r. Valentine. 5 Metc. (Mass.) \& (1842).

Compare Churchill v. Burlington Water Co., 94 Iowa, \&9, 62 ․ W. 646 (1S95) ; Matthews v. Stillwater Gas \& Electric Co., 69 Mimn. 49:3, 6. X. W. 947 (1S96); Mills r. Hal], 9 Wend. (N. Y.) 815,24 Am. Dec. 160 (15:32). 


\section{CHAPTER III}

LAND

2 ROLLE'S ABRIDGMENT, 564: If A. be seised in fee of copyhold land next adjoining the land of $\mathrm{B}$., and $\mathrm{A}$. erect a new house upon his copyhold land and part of the house is built upon the confines of his land next adjoining B.'s land, if B. afterwards excavates his land near to the foundation of A.'s house but no part of the land of A., by which the foundation of the house and the house itself fall into the pit, still no action lies by A. against B. ; for it was the fault of A. himself that he built his house so close to the land of B., for he cannot by his own act prevent B. from making the best use of his own land that he can. P. 15 Car. B. R. [1639] between Wilde and Minsterley, by the court after a judgment for the plaintiff.

But, semble, a man who has land next adjoining my land cannot excavate his land so close to mine that thereby my land falls in his pit. And so if the action had been brought for this, it would lie.

\section{BONOMI v. BACKHOUSE.}

\section{(Exchequer Chamber, 1859. E., Bl. \& El. 646.)}

VILIES, $J$. This is a proceeding in error upon a judgment of the Court of Queen's Bench, and was brought to question the decision in that case and a judgment of the Court of Exchequer in Nicklin v. WVilliams. In the Court of Queen's Bench Mr. Justice Wightman differed from the majority of the Court; some of whom expressed their opinion with very great doubt.

The question argued before us may be stated in a very few words. The plaintiff was owner of the reversion of an ancient house. The defendant, more than six years before the commencement of the action, worked some coal-mines 280 yards distant from it. No actual damage occurred until within the six years.

Question: Is the Statute of Limitations an answer to the action? Or, in other words, did the cause of action accrue within the six years? The majority of the Court of Queen's Bench thought it did not.

The right to support of land and the right to support of buildings stand upon different footings as to the mode of acquiring them, the former being primâ facie a right of property analogous to the flow of a natural river, or of air; Rowbotham v. Wilson, S E. \& B. 123 (E. C. I. R. vol. 92); though there may be cases in which it would be sustained as matter of grant (see The Caledonian Railway Company v. Sprot, 2 Macq. Sc. App. 449); whilst the latter must be founded upon 
prescription or grant, express or implied: but the character of the rights, when acquired, is in each case the same. The question in this case depends upon what is the character of the right; viz., whether the support must be afforded by the neighbouring soil itself, or such a portion of it as would be beyond all question sufficient for present and future support, or whether it is competent for the owner to abstract the minerals without liability to an action unless and until actual damage is thereby caused to his neighbour. The most ordinary case of withdrawal of support is in town property, where persons buy small pieces of land, frequently by the yard or foot, and occupy the whole of it with buildings. They generally excavate for cellars, and in all cases make foundations; and, in lieu of support given to their neighbor's land by the natural soil, substitute a wall. We are not avare that it has ever been considered that the mere excavation of the land for this purpose gives a right of action to the adjoining owner and is itself an unlawful act, although it is certain that if damage ensued a right of action would accrue. So also we are not aware that, until the case of Nicklin v. Williams, 10 Exch. 259, it had ever been supposed that the getting coal or minerals, to whatever extent, in a man's own land was an unlawful act, although, if he thereby cansed damage to his neighbour, he was undoubtedly responsible for it. 'The right of action was supposed to arise from the damage, not from the act of the adjoining owner in his own land. The law favours the exercise of dominion by every one upon his own land, and his using it for the most beneficial purpose to himself.

As we have already said, the defendant's proposition is that the adjoining owner is entitled to have the adjacent land remain in its natural condition; he does not and cannot contend that an artificial substitute would prevent a cause of action. For, if he did, if he admitted that a man might excavate the natural soil to an extent dangerous to the adjoining owner, provided he applied a remedy in time to prevent damage, as by putting props or a wall, this consequence would follow: that he must have time within which to do it; and that time would be any time until damage resulted; which, in effect, would be to say that there was no cause of action till actual damage. If the defendant is right, these consequences follow: whenever a mine or quarry is worked, the worker may be subjected to actions by all surrounding owners: nay, they would in self-defence be compclled to bring them, if there was any reasonable ground to suppose that the working would in time produce damage to their property. It wonld be in vain that the worker should say: "You will not be injured; the workings are not injurious; if they turn out likely to be so, I will take means to prevent it : at all events wait till you are injured." Vexatious and oppressive actions might be brought, on the one hand; and, on the other, an unjust immunity obtained for secret workings of the most mischievous character, but the result of which did not appear within six years. The inquiry in such cases would be little better than speculative. The character of the soil, the inclination of the strata, the depth and extent of the 
works, the distance and nature of the land supposed to be in danger, and other considerations, would make the inquiry of such a character that the only prudent verdict would be "Not proven." In many cases, damages would be given where none could be sustained; while they would, in other cases, be given where they ought to be withlield.

There is no doubt that for an injury to a right an action lies: but the question is, What is the plaintiff's right? ls it that his land should remain in its natural state, unaffected by any act done in the neighbouring land, or is it that nothing should be done in the neighbouring land from which a jury would find that damage might possibly accrue? There is no doubt that in certain cases an action may be maintained, although there is no actual damage. The rule laid down by Serjeant IVilliams, in note (2) to Mellor v. Spateman, $1 \mathrm{Wms}$. Saund. $346 \mathrm{~b}$, is that, whenever an act injures another's right, and would be evidence in future in favour of the wrongdoer, an action may be maintained for an invasion of the right, without proof of any specific damage. This is a reasonable and sensible rule; but it has no application to the present case; for the act of the defendant in getting the coal would be no evidence in his favour as to any future act: getting the coal was an act done by him in his own soil by virtue of his dominion over it. If the question were unaffected by decision, we cannot but think that the contention on the part of the plaintiffs in error is correct. That on behalf of the defcrdant is, that the action must be brought within six years after the excavation is made, and that it is immaterial whether any actual clamage has occurred or not. The jury, according to this view, would have therefore to decide upon the speculative question, Whether any damage was likely to arise; and it might well be that in many cases they would, upon the evidence of mineral surveyors and engineers, find that no damage was likely to occur, when the most serious injury afterwards might in fact occur, and in others find and give large sums of money for apprehended damage, which in point of fact never might arise. This is certainly not a state of the law to be desired. On the other hand, the plaintiffs in error rely upon the ordinary rule that damnum and injuria must concur to confer a right of action, and that, although only one action could be maintained for damage in respect of such a claim, nevertheless it would be essential that some damage should have happened before a defendant was made liable for an act done in his own land. Actions upon contract and actions of trespass for direct injuries to the land of another are clearly distinguishable.

No authority is cited in Nicklin v. Williams, 10 Exch. 259, for the judgment there given: and, although the judgment in that case is distinct upon the point, it neverthcless was extrajudicial; for before the former action was commenced it is obvious that actual damage had been sustained; in which case another principle applies, viz., that no sccond or fresh action can under such circumstances be brought for subsequently accruing clamage: all the damage consequent upon the 
unlaw ful act is in contemplation of law satisfied by the one judgment or accord. We are not insensible to the consideration that the holding damage to be essential to the cause of action may extend the time during which persons working minerals and making excavations may be made responsible; but we think that the right which a man has is to enjoy his own land in the state and condition in which nature has placed it, and also to use it in such manner as he thinks fit, subject always to this: that, if his mode of using it does damage to his neighbour, he must make compensation. Applying these two principles to the present case, we think that no cause of action accrued for the mere excavation by the defendant in his own land, so long as it caused no damage to the plaintiff; and that the cause of action did accrue when the actual damage first occurred.

We should be unwilling to rest our judgment upon mere grounds of policy; but we cannot but observe that a rule of law, or rather the construction of a Statute of Limitation, which would deprive a man of redress after the expiration of six years, when the act causing the damage was unknown to hin, and when in very many instances he would be in inevitable ignorance of it, would be harsh, and contrary to ordinary principles of law.

The judgment must therefore be reversed, and judgment given for the plaintiffs.

Judigment reversed. ${ }^{1}$

1 The judgment of the Court of the Exchequer Chamber was affirmed in the House of Lords. 9 H. of I. 503 (1S61).

Acc.: Smith v. Seattle, 18 Wash. 4S4, 51 Pac. 1057, 63 Am. St. Rep. 910 (1S98). See Darley Main Colliery Co. v. Mitchell, L. R. 11 A. C. 127-(1S86j): West Leigh Colliery Co. v. Tunnicliffe \& Hampson, [1908] A. C. 27 (1907).

A. was the owner of the surface of a certain liece of land, and $\mathbf{B}$. of the underlying adjacent coal strata. B. so mined that later the surface ot A.'s land subsided. The subsidence took place more than six years atter the mining. The court held that $A$. could not recover from B., saying, inter alia:

"The adjacent owner in this case at some time failed in duty to the owner of the surface of this lot. The mere fact that it caved in because the coal had been mined underneath demonstrates this failure. When the coal was removed without leaving sufticient pillars, or without sulplying sufficient artificial props, was the time when the subjacent owner failed in an absoIute duty he owed to his neighbor above. And from that dates the cause of action. Unless, when the coal was mined, the miner left no pillars, or too few, or of too small dimensions for such a mine, or did not replace the coal with ample artificial durable props, there was no canse of action."

"The date of the care-in and partial destruction of the house is not the date of the cause of action; that was only the consequence of a previous cause, whether one month or twenty sears before. It is argued that in some cases the surface owner could not know by the most careful observation whether the mine owner had neglected his duty within six years. We answer, that is only one of the incidents attending the purchase of land over coal mines. It is not improluable that this risk enters largely into the commercial value of all like surface land in that regicn. But, however this may be, we hold that the miner is not forever answerable fol even his own default. Further. in no case is he answerable for the default of his prederes. sor before his possession." Noonan v. Pardee, $200 \mathrm{~Pa} .474,483$, 4S4, 50 Atl. 255. 55 L. R. A. 410, S6 Am. St. Rep. 722 (1901).

$A$. and $B$. were adjacent landowners. B. excavated the coal under his 


\title{
SMITH v. THACKERAH.
}

\author{
(Court of Common Pleas, 1866. L. R. 1 C. P. 564.)
}

Declaration that the plaintiff was possessed of certain land, and the land received lateral support from certain land adjoining thereto, and the defendants dug and made on this adjoining land an excavation or well near to the land of the plaintiff, and the defendants thereby, and for want of keeping and continuing the sides of the well shored up, or otherwise preventing the consequences hereinafter mentioned, wrongfully deprived the land of the plaintiff of its support, whereby the land of the plaintiff sank and gave way, and divers walls, buildings, and premises of the plaintiff on the land sank and were damaged, whereby the plaintiff was put to great expense, \&r.

Pleas: Not guilty, and not possessed.

At the trial before Erle, C. J., at the last Surrey spring assizes, it was proved that the plaintiff was pessessed of a piece of land on which a building had been recently erected, and that the defendants, who were neighbouring landowners, dug a well on their own land near to that of the plaintiff, and afterwards filled up the well with such loose earth that the ground round it sank, and the plaintiff's building was injured, causing damage to the amount of $£ 15$.

The jury found, in answer to questions by the Chief Justice, that the land of the plaintiff would have sunk if there had been no building on it, and that some particles of sand from it would have fallen on to the defendants' property, but that the plaintiff would have suffered no appreciable damage.

$A$ verdict was entered for the defendants, with leave to the plaintiff to move to enter the verdict for such sum under $£ 15$. as the Court should direct, on the ground that the facts proved at the trial entitled the plaintiff to a verdict without proof of any pecuniary damage.

Robinson, Serj., obtained a rule nisi pursuant to the leave reserved.

ERLE, C. I. I am of opinion that this rule should be discharged. There is no doubt that a right of action accrues whenever a person interferes with his neighbour's rights, as, for example, by stepping on his land, or, as in the case of Ashby v. White, $1 \mathrm{Sm}$. L. C. (5th Ed.) 216 , interfering with his right to vote, and this though no actual damage may result. But for a man to dig a hole in his own land is in itself a perfectly lawful act of ownership, and it only becomes a wrong if it injures his neiglibour; and since it is the injury itself which gives rise to the right of action, there can be no right of action unless the damage is of an appreciable amount. A person may build a chimney in front of your drawing room, and the smoke from it may annoy you, or

land. Later B. died, devising the land to G. C. did not work the mines. Thereafter A.'s land subsided; this subsidence being caused by the workings done by B. Held, $A$. has no cause of action against $C$. Hall v. Norfolk, [1900] 2 Ch. 493. See, also, Greenwell v. Coal Co., [1S97] 2 Q. B. 165. 
he may carry on a trade next door to your house the noise of which may be inconvenient; but unless the smoke or noise be such as to do you appreciable damage, you have no right of action against him for what is in itself a lawful act. In the case of St. Helen's Smelting Company v. Tipping, $11 \mathrm{H}$. L. C. $642,35 \mathrm{~L}$. J. (Q. B.) 66 , in which the defendant had set up some chemical works, the Fiouse of Lords held that, if the noxious vapours did not cause material damage to the plaintiff, he had no cause of action. In the present case the digging the well and filling it up again were in themselves perfectly lawful acts, and the jury have found that they did no sensible damage to the plaintiff, and he has therefore no right of action.

BYLES, J. I am of the same opinion. In actions for a trespass the trespass itself is a sufficient cause of action. But in actions for indirect injuries like the present, the judgment of the House of Lords in Bonomi v. Backhouse, 9 H. L. C. 503, 34 L. J. (Q. B.) 181, shews that there is no cause of action if there be no damage, and I cannot distinguish between no appreciable damage to the land in its natural state and no damage at all.

Montague Smith, J. I am of the same opinion. The mere subsidence of the surface of the soil is not necessarily an injury, and we are bound by the verdict of the jury, who found that in fact no appreciable damage would have occurred if these new buildings had not been on the land.

Rule discharged. ${ }^{2}$

2 A coal company so mined as to cause a public highway and adjacent land gradually to sink to a depth of 10 feet. No actual damage was done to the highway nor was it rendered thereby less conrenient. In an action against the coal company, Collins, J., said: "I have no doubt whaterer that such an action would lie without proof of pecuniary loss. I think the principle at the root of the matter is, that the owner is entitled to have his land "remain in its natural state, unaffected by any act done in the neighbouring land": see per Willes, J., delivering the judgment of the Exchequer Chamber in Bonomi v. Backhouse, E., B. \& E. 622, at page 657, and that as soon as the condition of the plaintiffs' land has been in fact changed to a substantial extent by the withdrawal of lateral support, the plaintiff has sustained an injuria for which he may maintain an action without proof of pecuniary loss. In the same case, Willes, J., compares the right to that in the flow of a natural river-a right which is unquestionably invaded where a sensible alteration has been produced in the character of the water where it passes the plaintiff's land, although there is no money damage. Another source of some confusion is that damage not measurable in money has been treated as equivalent to a physical alteration so small as to amount to nothing in contemplation of law-an observation which may perhaps explain Smith $\mathrm{r}$. Thackerah, Law Rep. 1 C. P. 564, which is the only case, so far as I know, which might seem to throw doubt on the principle which I have stated." Attorner General ₹. Conduit Co., [1895] 1 Q. B. 301, 311, 313 (1844).

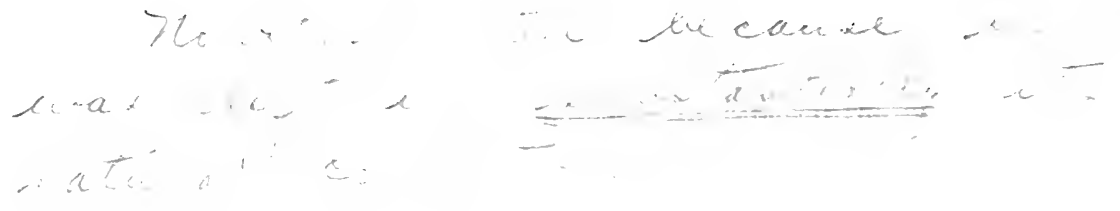




\section{CORPORATION OF BIRMINGHAM v. ALLEN.}

(Chancery Division, 1877. L. R. 6 Ch. Div. 284.)

This was an action by the Corporation of Birmingham, who were the owners of gasworks called the Swan Village Gasworks, to restram the Defendants, T. H. Allen and T. E. Holden, who were proprietors of Swan Farm Colliery, in the neighborhood of the gasworks, from working their coal in such a manner as to cause subsidence of the surface of the plaintiffs' land.

The plaintiffs purchased the gasworks from the Birmingham \& Staffordshire Gaslight Company in the year 1875 .

The gas company purchased the land on which the works were erected together with the minerals under the same, in the year 1824. They afterwards purchased the minerals under various pieces of land adjoining their property, for the purpose of preventing the surface of their own land from being shaken or disturbed. Among others they purchased, in 1872, the minerals under a piece of land belonging to Messrs. Pershore \& Gregory which adjoined the western boundary of the gasworks. The defendants' colliery lay to the west of this piece of land, to which it adjoined, so that the piece of land lay between the properties of the plaintiffs and the defendants.

The seams of coal under the district were as follows: The brooch coal, 3 ft. 9 in. thick, about ninety yards from the surface.

The thick coal, $28 \mathrm{ft} .9 \mathrm{in}$. thick, about 156 yards from the surface.

The heathen coal, 3 ft. 6 in. thick, about 156 yards from the surface.

The new mine coal, $5 \mathrm{ft} .6$ in. thick, about 185 yards from the surface.

The thick coal under the picce of land purchased by the gas company in 1872 had been worked out more than thirty years before they purchased it, and the superincumbent earth was propped by pillars in the usual way.

The thick coal under the gasworks had not been worked out when the company purchased the site in 1824; but in the year 1834 they granterl the thick coal under a small portion of the surface to Messis. Pagnall \& Haynes, who worked it out. Some of the area thus granted was cxactly under the retorts of the gas company.

The defendants were now engaged in working the lowest vein, or new mine coal, under their land. 'They worked from west to east, and in doing so approached within a few yards of the western boundary of land purchased by the gas company in 1872 .

The plaintiffs claimed that the working of the new mine coal by the defendants had already caused a subsidence of the surface of their land and the buildings thercon crected, and would, if persisted in, cause them great injury and they brought this action for an injunction accordingly. 
The defendants pleaded that, if any subsidence of the plaintiffs' land had taken place, it had been caused partly by the excavations of thick coal under the plaintiffs' own land by the lessees of the gas company, and partly by the erection of buildings within the last twenty years over such excavated portions; and they denied that they were under any liability to the plaintiffs in respect of any injury they had sustained.

Both sides went into evidence at great length. The trial came on before the Master of the Rolls on the 15th of March, 1877, and witnesses were examined on both sides.

The result of the evidence is stated in the judgment of the Master of the Rolls.

JESSEL, M. R. I am of opinion that the plaintiffs' case entirely fails. We have had a most careful and, I think, a most exhaustive investigation into the facts, and, as far as I am concerned, I have no doubt upon any of the facts necessary to be decided.

I think it is plain that if the land adjoining the plaintiffs land had not been undermined, the defendants might work the new mine seam as well as the thick coal seam up to their boundary. [His Lordship then referred to the evidence on this point.?

Now, looking to this evidence, and considering that it is for the plaintiffs to prove their case, I an of opinion that it is proved satisfactorily that, supposing the land between the plaintiffs' and the defendants' land had remained in its natural state, if the defendants' workings should be prosecuted up to the boundary of their property, they would nut, as far as the new mine is concerned, cause any injury whatever to the plaintiffs' works.

Then there is a second question, which is a question of fact I think I ought to give my opinion upon. Has the working of the defendants new mine at all actually injured the plaintiffs' buildings? I am clear it has not. [IIis Lordship then considered the evidence on this part of the case, and considered that there was no evidence of injury atready received.]

Then comes the question, Will it occasion injury? As to that, the evidence is very conflicting. Mr. Cooksey puts the safe distance as 100 yards, and although there is a little variation, the plaintiffs experts substantially agree in putting the safe distance at 100 yards, or fiftyfive yards from the defendants' boundary. 'The defendants' four experts also substantially agree, and they put it at sixty yards, or fifteen yards from the defendants' boundary. Here, again, it is for the plaintiffs to make out their case, and it seems to me to be mere surmise nn both sides. However, I must say, if it were necessary to decide the case on that ground, that it is not proved to my satisfaction that more than sixty yards is required, that is, more than fifteen yards from the boundary.

[His Lordship, after considering certain subordinate questions of fact, continued:] 
I now come to a point of very great difficulty indeed, on which the evidence is in a very singular condition. The plaintiffs themselves, or their predecessors in title, had allowed a portion of their land to be undermined, that is, had allowed coal to be extracted from under that land, and the question was, whether the extraction of that coal in any way interfered with the support of the retort houses. Now the odd part of the matter is, that the experts for the plaintiffs said that it would interfere with the support, and increase subsidence; and the experts of the defendants said it would not. Under these circumstances I think it is only fair to say that, as against the plaintiffs, they cannot reject the evidence of their own experts, and therefore I must consider that it does affect it to some extent, but considering the evidence of the defendants' experts, not to a material extent. That is the way that matter appears to me.

Now, having so far dealt with the facts, let me consider the law. As I understand, the law was settled by the House of Lords, confirming the decision of the Court of Exchequer Chamber in the case of Backhouse v. Bonomi, 9 H. L. C. 503, that every landowner in the lingdom has a right to the support of his land in its natural state. It is not an easement: it is a right of property. That being so, if the plaintiffs' land had been in its natural state, no doubt the defendants must not do anything to let land slip, or go down, or subside. If they were doing an act which it could be proved to me by satisfactory expert evidence would necessarily have that effect, I have no doubt this court would interfere by injunction on the ground upon which it always interferes, 11 amely, to prevent irreparable damage when the damage is only threatened. Of course they must have a much clearer and much stronger case to call for the interference of this court by injunction where the damage is merely threatened and no damage has actually occurred, than when some damage has actually occurred, because in the one case you have no facts to go by, but only opinion, and in the other case you have actual facts to go by. If some damage has occurred it makes it manifest and certain that further damage will occur by reason of the prosecution of the works.

Now in this case, if it stands at all, it may well stand merely on opinion evidence, which would be sufficient ground for interference, if all the experts agreed and the court were satisfied that damage liad occurred; and I think when I compare the evidence of these various experts, I must take it for this purpose as proved that if the defendants work within fifteen yards of their boundary, and in their new mine coal, damage, and serious damage, will accrue to the plaintiffs' buildings. But the question I have to decide is whether in law that entitles them to an injunction. I think it does not. In this case it is true the plaintiffs or their predecessors acquired the mineral area, and acquired some of the land after the thick coal had been worked out and not before; but for the present purpose I lay out of consideration the fact of their ownership of anything, and I will treat the case. 
as if the portions under which they possess the minerals, and the land so subsequently acquired, did not belong to them, and it appears as the result of the evidence that if that thick coal had not been extracted from under these portions of land, the intended operations of the defendants would certainly not cause any substantial injury.

But it is said that, inasmuch as these operations have occurred in what I will call the intervening land, and have thereby weakened the support, it will entitle the plaintiffs to prevent the owners of the land on the other side of this intervening land from working their mines in the way they could otherwise have worked them. But the first question one asks is, Why? Why should the act of the intervening owner, that is, the owner of the intermediate land, deprive men of their rights to their mines? It strikes one at once as a most extraordinary proposition. The act of the intervening owner for this purpose is rightful as regards the mine owners whose mines are asked to be confiscated; for that is what it comes to. If they cannot work them they are confiscated. The plaintiffs ask for the confiscation of their property, not because they have done any wrong, for they have done no wrong-not because the intervening owner has done any wrong, for he only worked his mines, and when he worked them he occasioned no injury to the person who owned the property on the other side; but it is said that inasmuch as he has taken out his coal first, the defendants are deprived of the right of getting their mines. I say it is a startling proposition, and one which appears to me so unfounded in reason that I should be very loth indeed to believe it was founded in law.

Now, what is the right of the adjoining owner? As I said before, it is to the support of his land in his natural state-support by whom? The Judges have said, "Support by his neighbour." What does that mean? Who is his neighbour? It was contended that all the landowners in England, however distant, were neighbours for this purpose if their operations in any remote degree injured the land. But surely that cannot be the meaning of it. The ncighbouring landowner to me for this purpose must be the owner of that portion of land, whether a wider or narrower strip of land, the existence of which in its natural state is necessary for the support of my land. As long as that land remains in its natural state, and it supports my land, I have no rights beyond it, and therefore it seems to me that he is my neighbour for this purpose. There might be land of so solid a character consisting of solid stone, that a foot of it would be enough to support the land. There might be other land so friable and of such an unsolid character that you would want a quarter of a mile of it. But whatever it is, as long as you have got enough land on your boundary, which left untouched will support your land, you have got your neighbour's land whose support you are cntitled to. Beyond that it would appear to me you have no rights.

Well, that being so, it is clear upon the evidence that the intervening portions of land between the boundary of the plaintiffs' and the boundary of the defendants' land was sufficient in its natural state for 
the support of the plaintiffs' building. Therefore it appears to me that the plaintiffs have no rights as against the landowners on the other side of that intervening space, and that they acquire no rights whatever the owner of the intervening land may have done; and, if the act of the intervening owner has been such as to take away the support to which the first landowner who complains is entitled, then, for whatever damage occurs from the act which he has done, the first owner may have an action, but an action against the intervening owner, not an action against the owner on the other side; and it appears to me that it would be really a most extraordinary result that the man upon whom no responsibility whatever originally rested, who was under no liability whatever to support the plaintiffs' land, should have that liability thrown upon him without any default of his own, without any misconduct or any misfeasance on his part. I cannot believe that any such law exists or ever will exist. It appears to me, therefore, that the plaintiffs are not entitled to damages for the acts of the defendants, and that the only order I ought to make is to dismiss the action with costs. ${ }^{3}$

\section{FOLEY v. WYETH.}

(Supreme Judicial Court of Massachusetts, 1861. 2 Allen, 131, 79 Am. Dec. 771.)

Merrick, J.4 The declaration alleges that the plaintiff was seized and possessed of the parcel of land described therein, together with a right of way in common with other persons, in two passage ways adjoining and appurtenant thereto; and that the defendant dug a large and deep pit in her own land, whereby a considerable portion of his land caved in and was removed, and the said passage ways were made useless and impassable. And, from the statement of facts reported, it appears that the plaintiff had contracted in writing to purchase the premises for a valuable consideration to be subsequently paid, and that in the mean time he was in the possession and occupation of the premises by the license of Erastus Hutchinson, the owner with whom the contract of sale was made. Proof of the alleged excavation and injury to his land and passage ways having been adduced by the plaintiff, the presiding judge ruled that this was sufficient to entitle him to maintain his action, and that for this purpose it was not incumbent on him to show also that the excavation was made by the defendant in a careless, negligent and unskilful manner.

This ruling was correct. If the owner of land makes an excavation

3 The decision was aflimed by the Court of Appeal. L. R. 6 Ch. Dir. $\because 92(1877)$.

Compare Brown v. Rohins, 4 Hurls. \& N. 186 (1859), Murrar r. Pannaci, 64

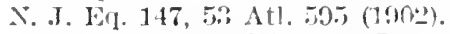

Thr opinions of James, Baggallay, and Brett, L. J., are omitted.

t Part of the opinion is omitted. 
in it so near to the adjoining land of another proprietor that the soil of the latter breaks away and falls into the pit, he is responsible for all the damage thereby occasioned. Few principles of the law can be traced to an earlier or to a more constant recognition, through a long series of uniform and consistent decisions, than this. It is distinctly stated in 2 Rol. Ab. 56t. In Gale \& Whatley on Easements, 215, it is said that "the right to support from the adjoining soil may be claimed either in respect of the land in its natural state, or land subjected to artincial pressure by means of buildings or otherwise." In the former case the right is not an casement, but is a right of property as being necessarily and naturally attached to the soil. Id. 216. And in the recent case of Humphries v. Brogden. 12 Ad. \& El. (N. S.) 739, where the law upon the subject appears to have been fully and carefully investigated and considered, it is affirmed that the right to lateral support from the adjoining soil is not like the support of one building upon another, supposed to be gained by grant, but is a right of property which passes with the soil, so that if the owner of two arljoining closes conveys away one of them, the alienee, without any grant for that purpose, is entitled to the support of the other close the very instant when the conveyance is executed. "And this doctrine," said Lord Campbell, C. J., after an examination of the authorities in which it is recognized, and by which it is sustained, "stands on natural justice, and is essential to the protection and enjoyment of property in the soil."

The same principle is asserter by this court in the opinion given by Parker, C. J., in the case of Thurston v. Hancock, 12 Mass. 220, 7 Am. Dec. 57. The decision in the case of Lasala v. Holbrook, 4 l'aige $(\mathbb{N}$. Y.) $169,25 \mathrm{Am}$. Dec. 524, is to the same effect. Radeliff v. Mayor, \&c., of Brooklyn, 4 N. Y. 195. 53 Am. Dec. 357: Richardson v. Vermont Central Railroad, 25 Vt. 465,60 Am. Dec. 283; Solomon v. The Vintners' Company, 4 Hurlst. \& Norm. 585. It is a necessary consequence from this principle that, for any injury to his soil resulting from the removal of the natural support to which it is entitled, by means of cxcavation on an adjoining tract, the owner has a legal remedy in an action at law against the party by whom the work has been clone and the mischief therehy occasioned. This does not depend upon negligence or unskilfulness, but upon the violation of a right of property which has been invaded and disturbed. ${ }^{5}$ 'This unqualified rule is limited to injuries caused to the land itself, and does not afford relief for damages by the same means to artificial structures. For an injury to buildings, which is mavoidably incident to the depression or slide of the soil on which they stand, caused by the excavation of a pit on adjoining land, an action can only be maintained when a want of due care or skill, or positive negligence, has contributed to produce it.

The jury were therefore correctly advised that, if the defendant. by excavations in her own land, and by carrying away large quantities of

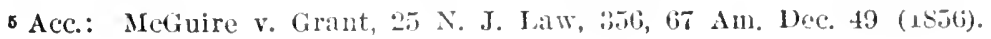


earth and clay therefrom, caused the adjoining land to fall and sink into the pit which she had dug, she was liable for the injury done to the soil of the plaintiff; and that this action might be maintained to recover damages for the interruption and disturbance of his right of way in the passage ways, as well as for depriving him, or lessening the value, of the use of the land to which they were appurtenant. But it was erroneous, in the absence of any proof of carelessness, negligence or unskilfulness in the execution of the work, to add that they might take into consideration as an element of damage for which compensation could be recovered, the fact that the foundation of his house had been made to crack and settle. ****

The defendant excepts to the refusal of the court to instruct the jury, in conformity to his request, that, if the injury complained of was in any degree caused by, or would not have occurred but for, the additional weight of buildings erected on their land by persons other than the plaintiff, he could not recover in this action. But this instruction was properly withheld. Whether, if the pressure of the weight of artificial structures which the owner has placed upon his own land for a lawful purpose and in its reasonable use, contributes to cause a slide or crumbling away of his soil into a pit excavated in an adjoining close by another proprietor, this will deprive him of the right to remuneration for the injury sustained, may be considered to be at least open to denial. It may be determined when the precise question arises. It does not arise here.

But as to the much broader proposition asserted by the defendant in her request, we think there is no room for doubt. The absolute and unqualified right of property which vests in the owner of land cannot be diminished or lawfully affected by the acts or proceedings of strangers in the use and appropriation of that which belongs to them; and therefore he who, in the execution of an enterprise for his own benefit, changes the natural condition of the parcel of territory to which he has title, and thereby takes away the lateral support to which the owner of the adjoining estate is entitled, cannot exonerate himself fron responsibility by showing that the particular injury complained of would not have occurred if other persons had never made alterations in or improvements upon their respective closes. Brown v. Robbins, 4 Hurlst. \& Norm. 186. His right of dominion over his own land is not without some limitations. To make a justifiable use of his own, he must have a proper respect to the appropriation which has already been made by other owners of the surrounding territory. And therefore, when one undertakes to make an excavation on his land, he must con-

BAcc.: Moellering v. Erans, 121 Ind. 195,22 N. E. 959, 6 L. R. A. 449 (18\$9); Winn v. Aheles, 35 Kan. S5, 10 Pac. 443, 57 Am. Rep. 138 (1S86) : Matulys v. Philadelphia \& Reading Coal \& Iron Co., 201 Pa. 70, 50 Atl. Sæ: (1902).

Contra: Brown v. Robbins. 4 H. \& N. 186 (1859) ; Stearns v. City of Richmond, $8 S$ Va. 992,14 S. E. 847,29 Am. St. Rep. 758 (1S92). 
sider how it will be likely, in view of the existing and actual occupation of others, to affect the soil of his neighbor.

For the reasons stated, it is apparent that the verdict cannot be affirmed for the sum which the jury have found as the damages sustained; and accordingly it must be set aside and a new trial granted. ${ }^{7}$

\section{CHARLESS v. RANKIN.}

(Supreme Court of Missouri, 1856. 22 Mo. 566, 66 Am. Dec. 642.)

This was an action to recover damages for injuries alleged by plaintiff, Joseph Charless, in his petition to have been sustained by him in consequence of the "negligent, unskillful and improper manner" in which defendant, David Rankin, made certain excavations upon a lot adjoining that of plaintiff, which, by undermining the foundations of plaintiff's building, caused the walls thereof to fall.

The defence set up was substantially a denial of the negligence alleged in the petition. ***

On motion of the plaintiff, the court gave the following instructions to the jury, to the giving of which the defendant excepted: "If the jury believe from the evidence that the digging for the foundation of defendant's building was performed in a reckless, negligent, or improper manner, and that by reason thereof plaintiff's house was thrown down, then plaintiff is entitled to recover such damage as he has sustained by the throwing down of his house. (2) If the jury believe from the evidence, that the fall of plaintiff's building might have been prevented by the exercise of reasonable care and skill on the part of those who were digging defendant's cellar, and that, owing to their failure to exercise such care and skill, damage resulted to

i Where A. by excavating caused B.'s land to sink the court said, as to B.'s measure of damages:

"It is agreed that the "damages occasioned to the plaintiff, by loss of and injury to her soil alone, caused by the acts of the defendant, amount to ninety-five dollars.' We are of opinion that she is entitled to recover that sum, and no more. She is clearly not entitled to recover the cost of putting her land into and maintaining it in its former condition, because that is no test of the amount of the injury. McGuire v. Grant, 1 Dutcher [25 N. J. Law] $356[67 \mathrm{Am}$. Dec. 49]. She cannot recover the difference in market value, because it does not appear that that difference is wholly due to the injury to her natural right in the land; it may depend upon the present shape of the lot. upon the improrements thereon, or upon other artificial circumstances which hare nothing to do with the natural condition of the soil." Gilmore v. Driscoll, 122 Mass. 199, 209. 23 Am. Rep. 312 (1877). Acc.: Schult\% v. Bower, 64 Minn. 122, 66 N. W. 139 (1S96). Compare Wednesbury v. The Iodge Holes Co., [1907] 1 K. B. $i 8$.

The principles of lateral support also apply to subjacent support, where the strata are separately owned. See Ilumphries v. Brogden, 12 A. \& E. (N. S.) 739 (184S); Yandes Y. Wright. 66 Ind. 319, 32 Am. Rep. 109 (1S79); Noonan v. Pardee, ante, p. 39.

Big.Rights-4 
plaintiff's building, then plaintiff is entitled to recover in this action such an amount of damages as he may prove he has sustained by the fall of his building. (3) In excavating by the side of another's building, it is the duty of the person having the excavating done to use such care and caution, to prevent injury to such building, as a sensible and prudent man, experienced in such work, would exercise, if he were the owner of the building; and the omission of such care and cattion is cuipable negligence, and renders the person having the excavating done liable for all the damages resulting therefrom. (6) The measure of damages in this case is the amount of money required to rebuild plaintiff's house as it was before the fall, and the value of the house thrown down to plaintiff during the time necessarily taken to rebuild it, with the interest on those amounts from the time when the house was completed, after its fall, to the present time." * * *

LEONARD, Judge. The right to support from the adjoining soil may be claimed either for the land in its natural state, or for it subjected to an artificial pressure by means of building or otherwise. The right in the former case would seem to be a natural servitude or easement belonging to contiguous lots, and accordingly it was recognized and protected in the Roman law by specified regulations, and similar provisions have been introduced into the civil code of France. (Code Civil, art. 614.) We are not aware of any express common law decision upon this subject; but we find it said of old, in Rolle's Abr. 564, tit. Trespass: "It seems that a man who has land closely adjoining my land, cannot dig his land so near mine that mine would fall into his pit, and an action brought for such an act would lie;" and in Wyatt $\mathrm{v}$. Harman, (3 Barn. \& Adol. S74), Lord Tenterden remarked, in delivering the judgment of the court of king's bench: "It may be true that, if my land adjoins that of another, and I have not, by building, increased the weight upon my soil, and my neighbor digs in his land, so as to occasion mine to fall in, he may be liable to an action."

When, however, the lateral pressure has been increased by the crection of buildings, it seems to be well settled at common law by authorities, that no man has a right to an increased support unless he has acquired such a servitude by grant or prescription. It is so laid down in the early case of Wilder v. Minsterly (2 Rolle's Abr. 564). *** And Lord Tenterden, in delivering the judgment of the court in the case before cited, said: "The question reduces itself to this: if a person builds to the utmost extremity of his own land, and the owner of the adjoining land digs the ground there, so as to remove some part of the soil which formed the support of the building so erected, whether an action lies for the injury thereby occasioned. Whatcver the law might be, if the damage complained of were in respect of an ancient messuage, possessed by the plaintiff, at the extremity of his own land, which circumstance of contiguity might im-

8 Parts of the statement of facts and part of the opinion are omitted. 
ply the consent of the adjoining proprietor at a former time to the erection of the building in that situation, it is enough to say in this case that the building is not alleged to be ancient, but may, as far as appears from the declaration, have been recently erected, and if so, then, according to the authorities, the plaintiff is not entitled to recover." In the more recent case of Partridge v. Scott, $(3$ Mees. \& Wels. 220,) which involved the same question, it is said: "If a man builds his house at the extremity of his land, he does not thereby acquire any right of easement, for support or otherwise, over the land of his neighbor. He has no right to load his own soil so as to make it require the support of that of his neighbor, unless he has some grant to that effect;" and the American cases are, it is believed, to the same effect. ('Thurston v. Hancock, 12 Mass. 221, 7 Am. Dec. 57.)

Although not altogether in good taste, I repeat, as applicable to the present case, what I had occasion to say in a former case. It is a logical consequence from legal principles, that to the extent to which a person has a right to act, others are bound to suffer; and that any damage that may accrue to them, while a person thus exercises his own rights, affords no valid ground of complaint. The loss occasioned in such cases is "damnum absque injuria." Every person, however, who is performing an act is bound to take some care in what he is doing. He can not exercise his own indisputable rights without observing proper precaution not to cause others more damage than can be deemed fairly incident to such exercise. In Wallars v. Pfeil, (Mood. \& Malk. 364 ,) the plaintiff lad neglected to take any precaution by shoring up their own houses within, or in any other way against the effect of pulling down the defendant's adjoining house; and it appeared that this might have been so done that the accident would not have happened to the same extent. There was also evidence to show that the accident was owing to the bad foundation of the plaintifl's house; but there was conflicting evidence as to whether, by due care on the part of the defendant's workmen, the mischief might have been entirely avoided. ${ }^{3}$ In summing up, the chief justice of the queen's bench stater it to be now settled that the owner of premises adjoining those pulled down, must shore up his own in the inside, and do every thing proper to be done upon them for their preservation; but, although that had not been done, still the omission did not necessarily defeat the action, and that if the pulling down were irregularly and improferly done, and an injury were produced thereby, the person so acting would be liable, notwithstanding the omission of the plaintiff; and the jury were accordingly charged, that, if the defendant's house was pulled rown in a wasteful, negligent and improvident manner, so as to occasion greater risk to the plaintiff than in the ordinary course of doing the work he would have incurred, then the defendant was liable to make compensation for the consequences of his want of ciution; but

9 See Rass v. West, 110 lia, (a), 86 S. E. 241 (1900(1). 
that if they thought fair and proper caution had been exercised, then the defendant would be entitled to a verdict. The result of the cases, we think, is, (and such would seem to be the reasonable doctrine,) that, if a man in the exercise of his own rights of property do damage to his neighbor, he is liable, if it might have been avoided by the use of reasonable care; and it seems to be usual in England for a party intending to make alterations that may affect his neighbor's premises, to give notice of his intention; but whether any such duty be imposed by law (Town v. Chadwick, 8 Scott, 1) need not be inquired into here, as the present plaintiff knew of the digging and took measures to protect himself against the consequences of it. ${ }^{10}$

These principles require us, we think, to reverse the judgment, and s.nd the case back for a second trial. We do not think there is any err $r$ in the refusal of the defendant's first and fourth instructions. A party may subject himself to responsibility by the want of reasonable care, although his digging be confined to his own ground and do not exceed a reasonable depth; nor is he protected by the fact that he used such care as his builder, who was a skillful and careful person, deemed necessary. The question is, as to the fact of negligence, whether the work were done in a careless and improvident manner, so as to occasion greater risk to the plaintiff than in the reasonable course of doing the work he would have incurred, and not whether, in the opinion of the superinendent, no matter how skillful he may have been, every thing was done that he deemed necessary. His opinion may be proper evidence to be considered by the jury, but it does not conclude the matter, constituting of itself a bar to the plaintiff's recovery. But the error is in plaintiff's third instruction, where an attempt is made to define, with precision, the degree of care that must be used in a case like the present, in order to exempt a party from liability; and the standard there adopted is substantially that care that a prudent man, experienced in such work, would have exercised, if he had been himself, the owner of the injured building. Now it is quite evident, we think, that this is going beyond the care that the law exacts upon such occasions. It is to be observed that the defendant was upon his own ground, and in digging upon it, exercised an undoubted right of property, which the plaintiff had no right, either by express grant or prescription-by statute or local ordinance-in any way to interfere with or prevent; and although, in exercising his rights, it was certainly

10 "It is the duty of one who makes an excavation on his own land, deeper than the foundation of a building on an adjoining lot, and so near to such building as to endanger it, to notify the adjoining owner of the proposed excavation, and affold him a reasonable opportunity to protect his property, and a failure to discharge such duty is negligence, for which an action may be maintained for the injury resulting therefrom, unless the adjotning owner had actual knowledge c? such proposed excaration." Gerst v. St. Louis, 185 Mo. 191, 209, 84 S. W. 34, 105 Am. St. Rep. 580 (1904).

Acc.: Schultz v. Byers, 53 N. J. Law, 44:2 22 Atl. 514, 13 L. R. A. 563, 26 Am. St. Rep. 455 (1891) ; Davis v. Summerfield, 131 N. C. 352,42 S. E. 818 , 63 L. R. A. $49_{2}^{2}, 92$ A.m. St. Rep. 781 (1902). 
his duty to his neighbor to use ordinary care in order to avoid doing him harm, he was not bound to observe the same care that he would have taken, as a wise and sensible man, if he had been the owner of both buildings - the one erected and the one about to be erected. He would, of course, in that event, have shored up and would have submitted to many inconveniences, and, indeed, would have incurred considerable additional expense in doing the new work, rather than expose the buildings already erected to any risk. Every prudent person, in such a situation, would take precautions-subject himself to inconveniences, and forego the exercise of every right that would endanger his present building, if he found it for his interest to do so. In the present case, if the laying of the new foundation, in very short sections, would have been attended with increased expense and with danger to the sufficiency of the new wall, and the defendant had been the owner of the plaintiff's building, he might have found it for his interest to have submitted, and most probably would have submitted, to this inconvenience and risk, and even increased expense, to avoid all hazard to his own property; yet the law does not exact of him the same forbearance and care and expense for the security of his neighbor's property that he would have found it for his interest to have taken for his own. We do not know that the instruction was intended, or indeed understood by the jury in the sense we impute to it. It may, however, have been so understood, and if so, could not but have misled them; and we shall therefore reverse the judgment, that the case may be retried upon a fuller understanding of the facts and of the law applicable to them.

The judgment is reversed, and the cause remanded. ${ }^{11}$

11 "It is required of the owner of the soil, having the right to excarate, notwithstanding there are buildings upon adjacent soil, that he shall exer(ise his right with reasonable skill and care in view of the character of the buildings and the nature of the soil, so as to avoid doing unnecessary injury to the buildings." City of Quincy v. Jones, 66 111. $231,241,20$ Am. Rep. $243(1875)$.

"If he [the excavating owner] fails to take such reasonable precautions to protect his neighbor's soil and to preserve it in its natural state, he is liable for the injury to both the land and the superstructure, if the pressure of the superstructure did not cause the land to fall and it fell in consequence of the failure to take such reasonable precautions." Gildersleeve v. Hawmond, 109 Mich. $431,439,67$ N. W. 519,33 I. R. A. 46 (1596).

See, also, Covington v. Geyler, $93 \mathrm{Ky.} \mathrm{275,} 19 \mathrm{~S}$. W. 741 (1592); Shafer v. Wilson, 44 Md. 265 (1S76) ; White v. Nassau Trust Co., 168 N. Y. 149, 61 N. F. 169,64 L. R. A. 275 (1901); Sjohn v. Dives, 174 Pa. 474,34 Atl. 192 (1s96). For liability under statutes, sec Aston v. Nolan, 63 Cal. 269 (1853); McMillen v. Watt, 27 Ohio St. $30 t$ (1575).

A. excavated on his lot, leaving a strip adjoining B.'s land. B.'s house did not fall until, by the action of rain and wind upon the retaining strip. brought ahout by A.'s not finishing bis eellar, it was gradually eroded and finally became insufficient to retain B.'s land and house. lleld, B. Las a cause of artion against $A$. for the damage eaused to the bouse. Hannicker v. Irepper, 20 S. D. 371,107 N. W. 202,6 L. K. A. (N. S.) 243,129 Am. St. Rel. 935 (1906). See Austin v. Hudson liver I. Co., 25 N. Y. 334 (1S62). Com- 


\section{CHAP'TER IV.}

\section{STREAMS}

\section{EMBREY v. OWEN.}

(Court of Exchequer, 1S51. 6 Exch. 353.)

The plaintiffs were occupiers of a water grist-mill situate on the banks of the river "Rhiew," a mountain stream, in the parish of Berriew, in that county. The defendant Mrs. Owen was the owner of land on both sides of that river above the mill; and this action was brought against her for diverting part of the water of the river, for the purpose of irrigating certain meadows on the northern bank, which were in the occupation of her tenant John Jones. The water was diverted by means of an iron trough or aqueduct placed near a waste weir, from whence the surplus or waste water was carried into the trough or aqueduct, and by it over the river into the main and floating gutters of the meadows, when required for irrigation; at other times such surplus water was discharged from the trough or aqueduct direct into the bed of the river by means of an iron flap or sluice in the middle side of the trough, so constructed as to be opened for the latter purpose at pleasure. A portion of the water was lost by absorption and evaporation in the process of irrigation; the working of the plaintiffs' mill, however, was not in the least impeded; and the

Jare Gilmore $v$. Driscoll, ante, p. 49: Witherow r. Tannehill, 194 Pa. 21, 44 Atl. 1085 (1Sn9); compare U. S. v. Peachy (D. C.) 36 Fed. 160 (1SSs).

A. and $B$. were adjacent landowners. A. started to build; the land was swampy; and, in excarating a large amount of water worked from B.'s land to A.'s excaration. As a consequence of the withdrawal of this water support B.'s house and land sunk and were damased. B.'s land would have -mink, eren had there been no building on it. Held, B. has no right of action arainst .1. Popplewell v. Hodkinson, L. R. 4 Excl. $24 S$ (1869). Acc.: New lork Continental Jewell Filtration Co. v. Jones, 37 App. D. C. 511, 37 L. Li. A. (N. S.) $19:$ (1911). Compare Elliot v. N. E. Ry. Co., 10 H. L. Cas. $33 ;$ (186i3).

A., in excaling on his own land, encombtered a stratum of quicksand or water-logred soil. which ran from under B.'s land as fast as dug away by A. As a conserpuence B.'s land and house sumk and were damaged. Held, $\dot{B}$. has a right of action against $A$. Jordeson v. Gas Co., [1899] 2 Clı. "217. Acc.: Cahot $\vee$ Kingman, 166 Mass. 403,44 N. E. 344,33 L. R. A. 45 (1s46).

A. and L. Were adjacent owners of lands, the value of which lay in extensive substrata of asplualt. B. excarated on his land immediately up to A.'s boundary. The asphalt oozed from A.'s land to B.'s, causing A.'s land and cheap frame buildinss theroon to sink. Held, A. may enjoin B. from further excarating. and may recover for the damige caused by the subsidenct: and the value of the asphalt so obtained by B. Trinidad Asphalt Co. v. Anbard, [1S99] A. C. 594 . See, also, Salt Union v. Brunner, [1906] 2 K. B. S*2; llendricks v. Spring Valley Min. \& Irr. Co., 5 S Cal. 190, 41 Am. liep, 257 (1ऽS1). 
quantity thus lost was differently calculated by scientific witnesses on both sides, a witness for the plaintiffs estimating it at four or five per cent., and a witness for the defendant at only one-seventh per cent., even in summer. All the witnesses concurred, that there was no sensible diminution of the stream by reason of the diversion, that is to say, none cognizable by the senses, and that the amount of loss was ascertainable only by inference from scientific experiments on the absorption and evaporation of water poured out on the soil.

The learned Judge, with reference to the first issue, left to the jury the question, whether there was any sensible diminution of the natural flow of the water by means of the diversion; and with refercnce to the other issues, he left it to them to say, in the terms of the pleas, whether the quantities of water absorbed and evaporated in the process of the defendant's irrigation were small and inappreciable cuantities; intimating, howcver, that he felt great difficulty in fixing a legal meaning on this latter term, but suggesting that it might mean "so inconsiderable as to be incapable of price or value." Both the questions left to the jury having been answered by them in favour of the defendant, the former in the negative and the latter in the affrmative, the learned Judge directed that the verdict should be entered on the above issues for the defendant, reserving leave to the plaintiffs to move to enter it for them, with nominal danages. ${ }^{1}$

PARKE, B. *** The important question is that which arises on the plea of not guilty, the jury having found that no sensible diminution of the natural flow of the stream to the plaintiff's mill was caused by the abstraction of the water. That the working of the mill was not in the least impeded was clear on the evidence. On that finding we think the verdict was properly ordered to be entered for the defendant.

It was very ably argued before us by the learned counsel for the plaintiff, that the plaintiffs had a right to the full flow of the water in its natural course and alundance, as an incident to their property in the land through which it flowed; and that any abstraction of the water, however inconsiderable, by another riparian proprictor, and though productive of no actual damage, would be actionable, because it was an injury to a right, and, if continued, would be the foundation of a claim of adverse right in that proprietor.

We by no means dispute the truth of this proposition, with respect to every description of right. Actual perceptible damage is not inclispensable as the foundation of an action; it is sufficient to show the violation of a right, in which case the law will presume damage: injuria sine damno is actionable, as was laid down in the case of Ashby v. White, 2 Ld. Raym. 938, by Lord IloLT, and in many subsequent cases, which are all referred to, and the truth of the proposition powerfully enforced, in a very able judgnicnt of the late Mr. Justice Story

1 The statement of facts is abridged and part of the opinion is omited. 
in Webb v. The Portland Manufacturing Company, 3 Sumn. Rep. 189. But in applying this admitted rule to the case of rights to running water, and the analogous cases of rights to air and light, it must be considered what the nature of those rights is, and what is a violation of them. $* * *$

The right to have the stream to flow in its natural state without diminution or alteration is an incident to the property in the land through which it passes; but flowing water is publici juris, not in the sense that it is a bonum vacans, to which the first occupant may acquire an exclusive right, but that it is public and common in this sense only, that all may reasonably use it who have a right of access to it, that none can have any property in the water itself, except in the particular portion which he may choose to abstract from the stream and take into his possession, and that during the time of his possession only. See 5 B. \& Ad. 24. But each proprietor of the adjacent land has the right to the usufruct of the stream which flows through it.

This right to the benefit and advantage of the water flowing past his land is not an absolute and exclusive right to the flow of all the water in its natural state; if it were, the argument of the learned counsel, that every abstraction of it would give a cause of action, would be irrefragable; but it is a right only to the flow of the water, and the enjoyment of it, subject to the similar rights of all the proprietors of the banks on each side to the reasonable enjoyment of the same gift of Providence.

It is only therefore for an unreasonable and unauthorized use of this common benefit that an action will lie; for such an use it will; even, as the case above.cited from the American Reports shows, though there may be no actual damage to the plaintiff. In the part of Kent's Commentaries to which we have referred, the law on this subject is most perspicuously stated, and it will be of advantage to cite it at length: "Every proprietor of lands on the banks of a river has naturally an equal right to the use of the water which flows in the stream adjacent to his lands, as it was wont to run (currere solebat), without diminution or alteration. No proprietor has a right to use the water to the prejudice of other proprietors, above or below him, unless he has a prior right to divert it, or a title to some exclusive enjoyment. $\mathrm{He}$ has no property in the water itself, but a simple usufruct while is passes along. 'Aqua currit et debet currere' is the language of the law. Though he may use the water while it runs over his land, he cannot unreasonably detain it, or give it another direction, and he must return it to its ordinary channel when it leaves his estate. Without the consent of the adjoining proprietors, he cannot divert or diminish the quantity of water which would otherwise descend to the proprietors below, nor throw the water back upon the proprietors above, without a grant, or an uninterrupted enjoyment of twenty years, which is evidence of it. This is the clear and settled general doctrine on the subject, and all the difficulty that arises consists in the applica- 
tion. The owner must so use and apply the water as to work no material injury or annoyance to his neighbour below him, who has an equal right to the subsequent use of the same water; nor can he, by dams or any obstruction, cause the water injuriously to overflow the grounds and springs of his neighbour above him. Streams of water are intended for the use and comfort of man; and it would be unreasonable, and contrary to the universal sense of mankind, to debar every riparian proprietor from the application of the water to domestic, agricultural, and manufacturing purposes, provided the use of it be made under the limitations which have been mentioned; and there will, no doubt, inevitably be, in the exercise of a perfect right to the use of the water, some evaporation and decrease of it, and some variations in the weight and velocity of the current. But de minimis non curat lex, and a right of action by the proprietor below would not necessarily flow from such consequences, but would depend upon the nature and extent of the complaint or injury, and the manner of using the water. All that the law requires of the party by or over whose land a stream passes, is, that he should use the water in a reasonable manner, and so as not to destroy, or render uscless, or materially diminish or affect the application of the water by the proprietors above or below on the stream. He must not shut the gates of his dams and detain the water unreasonably, or let it off in unusual quantities, to the annoyance of his neighbour. Pothier lays down the rule very strictly, that the owner of the upper stream must not raise the water by dams, so as to make it fall with more abundance and rapidity than it would naturally do, and injure the proprietor below. But this rule must not be construed literally, for that would be to deny all valuable use of the water to the riparian proprietors. It must be subjected to the qualifications which have been mentioned, otherwise rivers and streams of water would become utterly useless, either for manufacturing or agricultural purposes. The just and equitable principle is given in the Roman law: 'Sic enim debere quem meliorem agrum suum facere, ne vicini deteriorem faciat." "

In America, as may be inferred from this extract, and as is stated in the judgment of the Court of Exchequer in Wood v. Waud, a very liberal use of the stream for the purposes of irrigation and for carrying on manufactures is permitted. $* * *$ It is entirely a question of degree, and it is very difficult, indeed impossible, to define precisely the limits which separate the reasonable and permitted use of the stream from its wrongful application; but there is often no difficulty in deciding whether a particular case falls within the permitted limits or not; and in this we think, that as the irrigation took place, not continuously, but only at intermittent periods, when the river was full, and no damage was done thereby to the working of the mill, and the diminution of the water was not perceptible to the eye, it was such a reasonable use of the water as not to be prohibited by law. If so, it was $n o$ infringement of the plaintiffs' right at all; it was only 
the exercise of an equal right which the defendant had to the usufruct of the stream.

We are therefore of opinion that there has been no injury in fact or law in this case, and consequently that the verdict for the defendant ought not to be disturbed.

The same law will be found to be applicable to the corresponding rights to air and light. These also are bestowed by Providence for the common benefit of man; and so long as the reasonable use by one man of this common property does not do actual and perceptible damage to the right of another to the similar use of it, no action will lie. A man cannot occupy a divelling and consume fuel in it for domestic purposes, without its in some degree impairing the natural purity of the air; he cannot erect a building, or prant a tree, near the house of another, without in some degree diminishing the quantity of light he enjoys; but such small interruptions give no right of action; for they are necessary incidents to the common enjoyment by all.

\section{IVEBB v. PORTLAND MFG. CO.}

(Circuit Court of the United States, D. Maine, 1S3s. 3 Sumn. 189, Fed. Cas. No. 17,322.)

Bill in equity for an injunction by the plaintiff to prevent the defendant from diverting a watercourse from the plaintiff's mill, and for further relief.

The facts admitted on all sides were, that at the Saccarappi Falls, on the river Presumpscut, there were two successive falls, upon which there are erected certain mills and milldams, the latter being called the upper and the lower milldams, and the distance between them is about forty or fifty rods; and the water therein constituted the mill-pond of the lower dam. The plaintiff is the owner of certain mills and mill privileges, in severalty, upon the lower dam, and the defendants are entitled to certain other mills and mill privileges on the same dam, also in severalty. As to a portion of one of the mills, there was a controversy between the parties in regard to title; but that controversy in no essential degree affected the question presented to the court. The defendants are the owners of a cotton-factory mill near the left bank of the river, and opened a canal for the supply of the water necessary to work that mill, into the pond immediately below the upper dam; and the water thus withdrawn was returned again into the river immediately below the lower dam. The defendants insisted upon their right so to divert and withdraw the water, by means of their canal, upon the ground, that it was a small part only, (about one fourth) of the water, to which, as mill owners on the lower dam, they were entitled; and that there was no damage whatsoever done to the plaintiff's mill by this diversion of the water. * * * 
STORy, Circuit Justice. ${ }^{2}$ The question, which has been argued upon the suggestion of the court, is of vital importance in the cause; and, if decided in favor of the plaintiff, it supersedes many of the inquiries, to which our attention must otherwise be directed. It is on this account, that we thought it proper to be argued, separately from the general merits of the cause. The argument for the defendants then presents two distinct questions. 'The first is, whether, to maintain the present suit, it is essential for the plaintiff to establish any actual damage. The second is, whether, in point of law, a mill owner, having a right to a certain portion of the water of a stream for the use of his mill at a particular dam, has a right to draw off the same portion, or any less quantity of the water, at a considerable distance above the dam, without the consent of the owners of other mills on the same dam. In connection with these questions the point will also incidentally arise, whether it makes any difference, that such drawing off of the water above, can be shewn to be no sensible injury to the other mill owners on the lower dam. [The court answered the first question in the negative. $]^{3}$

But I confess myself wholly unable to comprehend, how it can be assumed in a case, like the present, that there is not and cannot be an actual damage to the right of the plaintiff. What is that right? It is the right of having the water flow in its natural current at all times of the year to the plaintiff's mills. Now, the value of the mill privileges must essentially depend, not merely upon the velocity of the stream, but upon the head of water, which is permanently maintained. The necessary result of lowering the head of water permanently, would seem, therefore, to be a direct diminution of the value of the privileges. And if so, to that extent it must be an actual damage.

Again, it is said, that the defendants are mill-owners on the lower dam, and are entitled, as such, to their proportion of the water of the stream in its natural flow. Certainly they are. But where are they so entitled to take and use it? At the lower dam; for there is the place, where their right attaches, and not at any place higher up the stream. Suppose, they are entitled to use, for their own mills on the lower dam, half the water, which descends to it, what ground is there to say, that they have a right to draw off that half at the head of the mill-pond? Suppose, the head of water at the lower dam in ordinary times is two feet high, is it not obvious, that by withdrawing at the head of the pond one half of the water, the water at the dam must be proportionaliy lowered? It makes no difference, that the defendants insist upon drawing off only one fourth of what, they insist, they are entitled to; for, pro tanto, it will operate in the same manner: and if they have a right to draw off to the extent of one fourth of their privilege, they have an equal right to draw off to the full extent

2 The statement of facts is abridged and part of the opinion is omitted.

3 See post, pp. 75,76 . 
of it. The privilege, attached to the mills of the plaintiff, is not the privilege of using half, or any other proportion merely, of the water in the stream, but of having the whole stream, undiminished in its natural flow, come to the lower dam with its full power, and there to use his full share of the water power. The plaintiff has a title, not to a half or other proportion of the water in the pond, but is, if one may so say, entitled per my et per tout to his proportion of the whole bulk of the stream, undivided, and indivisible, except at the lower dam. * * *

A suggestion has also been made, that the defendants have fully indemnified the plaintiff from any injury, and in truth have conferred a benefit on him, by securing the water by means of a raised dam, higher up the stream, at Sebago Pond, in a reservoir, so as to be capable of affording a full supply in the stream in the dryest seasons. To this suggestion several answers may be given. In the first place, the plaintiff is no party to the contract for raising the new dam, and has no interest therein ; and cannot, as a matter of right, insist upon its being kept up, or upon any advantage to be derived therefrom. In the next place, the plaintiff is not compellable to exchange one right for another; or to part with a present interest in favor of the defendants at the mere election of the latter. Even a supposed benefit cannot be forced upon him against his will; and, certainly, there is no pretence to say, that, in point of law, the defendants have any right to substitute, for a present existing right of the plaintiff's, any other, which they may deem to be an equivalent. The private property of one man cannot be taken by another, simply because he can substitute an equivalent benefit.

Having made these remarks, upon the points raised in the argument, the subject, at least so far as it is at present open for the consideration of the court, appears to me to be exhausted. Whether, consistently with this opinion, it is practicable for the defendants successfully to establish any substantial defence to the bill, it is for the defendants, and not for the court, to consider.

I am authorized to say, that the district judge concurs in this opinion. Decree accordingly. ${ }^{4}$

4 See Blue Ridge Interurban R. Co. . Hendersville Light \& Power Co., 169 N. C. 471, S6 S. E. 296 (1915). 


\section{DUMONT v. KELLOGG.}

(Supreme Court of Michigan, 1574. 29 Mich. 420, 18 Am. Rep. 102.)

COOLEY, J. ${ }^{5}$ The grievance complained of by Kellogg in the court below was that Dumont had constructed a dam across a natural water course, and by means thereof wrongfully detained the water in the stream to the prejudice and injury of the plaintiff, who was proprietor of a mill previously erected on the stream below. The reservoir created by defendant's dam was quite a large one, and plaintiff gave evidence that the flow of water in the stream below was considerably diminished by the increased evaporation and percolation resulting from the construction of this dam. The plaintiff had judgment in the court below, and the case comes here upon exceptions, the errors principally relied upon being assigned upon the instructions to the jury, and involving the relative rights of riparian proprietors to make use of the waters of a running stream which is common to both, and to delay its flow for that purpose.

The instructions given were numerous, and the most of them were unexceptionable. Others appear to be based upon a view of the law which is not to be reconciled with the authorities. Of these are the following :

"Every proprietor of lands on the banks of a stream, and every mill owner, has an equal right to the flow of the water in the stream as it was wont to run, without diminution or alteration; no proprietor has the right to use the water to the prejudice of the proprietors below hin, without the consent of the proprietors below; he cannot divert or diminish the quantity which would otherwise descend to the proprietors below.

"He must so use the water as not materially to affect the application of the water below or materially diminish its quantity.

"If the jury find, from the evidence, that Dumont's dam and pond have diminished, by the increased evaporation and soakage occasioned by it, the flow of the water in the Dumont creek one-third, or any other material amount, and that the plaintiff has sustained damages thereby, then the plaintiff is entitled to recover in this action.

"The rights of a riparian proprietor are not to be measured by the reasonable demands of his business. His right extends to the use of only so much of the stream as will not materially diminish its quantity, so that in this case the question whether defendant needs the water as he uses it in his business is entirely immaterial.

"The defendant had the right to build a dam upon his land, but he must so construct the dam and so use the water as not to injure the plaintiff below in the enjoyment of the same water, according to its natural course."

$s$ Part of the ovinion is omitted. 
In endeavoring to determine the soundness of these instructions, we may dismiss from the mind the fact that the plaintiff had first put the waters of the stream to practical use, since that fact gave him no superiority in right over the defendant. The settled doctrine now is that priority of appropriation gives to one proprietor no superior right to that of the others, unless it has been continued for a period of time, and under such circumstances as would be requisite to establish rights by prescription. *** It is not claimed that any question of prescription is involved, and the case is consequently to be regarded as only presenting for adjudication the relative rights of the parties at the common law to make use of the flowing waters of the stream, unaffected by any exceptional circumstances.

And in considering the case it may be remarked at the outset that it differs essentially from a case in which a stream has been diverted from its natural course and turned away from a proprietor below. No person has a right to cause such a diversion, and it is wholly a wrongful act, for which an action will lie without proof of special damage. It differs, also, from the case of an interference by a stranger, who, by any means, or for any cause, diminishes the flow of the water; for this also is wholly wrongful, and no question of the reasonableness of his action in causing the diminution can possibly arise. And had the instructions which are excepted to been given with reference to a case of diversion, or of obstruction by a stranger, the broad terms in which the responsibility of the defendant was laid down to the jury might have found abundant justification in the authorities.

But as between two proprietors, neither of whom has acquired superior rights to the other, it cannot be said that one "has no right to use the water to the prejudice of the proprietor below him," or that he cannot lawfully "diminish the quantity which would descend to the proprietor below," or that "he must so use the water as not materially to affect the application of the water below, or materially to diminish its quantity." Such a rule would be in effect this: That the lower proprietor must be allowed the enjoyment of his full common-law rights as such, not diminished, restrained, or in any manner limited or qualified by the rights of the upper proprietor, and must receive the water in its natural state as if no proprietorship above him existed. Such a rule could not be the law so long as equality of right between the several proprietors was recognized, for it is manifest it would give to the lower proprietor superior advantages over the upper, and in many cases give him in effect a monopoly of the stream.

Cases may unquestionably be found in which the rule of law is laid down as broadly as it was given by the circuit judge in this case, but an examination of them will show either that the facts were essentially different, or that the general language was qualified by the context. Thus the language employed in the first instruction as above given seems to have been quoted from Lord Tenterden in Mason v. Hill, 3 B. \& Adol. 312. But there it had reference to a case of diver- 
sion of water, and was strictly accurate and appropriate. The same language substantially is made use of in Twiss v. Baldwin, 9 Conn. 291; Wadsworth v. Tillotson, 15 Conn. 373, 39 Am. Dec. 391; Arnold v. Foot, 12 Wend. (N. Y.) 331: and probably in many other cases, and is adopted by Chancellor Kent in his Commentaries (volume 3, p. 439). See, also, Bealey v. Shaw, 6 East, 20S; Agawam Canal Co. v. Edwards, 36 Conn. 497 ; Williams v. Morland, 2 B. \& C. 913 ; Mason v. Hill, 5 B. \& Adol. 1; Tillotson v. Smith, 32 N. H. 95, 64 Am. Dec. 355. But as between different proprietors on the same stream the right of each qualifies that of the other, and the question always is, not merely whether the lower proprietor suffers damage by the use of the water above him, nor whether the quantity flowing on is diminished by the use, but whether under all the circumstances of the case the use of the water by one is reasonable and consistent with a correspondent enjoyment of right by the other.

It is therefore not a diminution in the quantity of the water alone, or an alteration in its flow, or either or both of these circumstances combined with injury, that will give a right of action, if in view of all the circumstances, and having regard to equality of right in others, that which has been done and which causes the injury is not unreasonable. In other words, the injury that is incidental to a reasonable enjoyment of the common right can demand no redress.

We think the court erred also in declining to instruct the jury on defendant's request that in determining the question of reasonable use by the defendant they might consider, among other things, the general usage of the country in similar cases. As was said in Gould v. Boston Duck Co., 13 Gray (Mass.) 452: "Usage is some proof of what is considered a reasonable and proper use of that which is a common right, because it affords evidence of the tacit consent of all parties interested to the general convenience of such use." And see Thurber v. Martin, 2 Gray (Mass.) 394, 61 Am. Dec. 468; Snow v. Parsons, 28 Vt. 459, 67 Am. Dec. 723. Indeed in most cases this proof is the most satisfactory and conclusive that could be adduced, being established by the parties concerned, who understand better than any others what is reasonable and convenient, and who would not be likely to acquiesce in any thing which was not so.

These errors render it necessary to order a new trial. Some of the rulings on the admission of evidence seem to have been very liberal, but we are not satisfied that they exceeded the bounds of judicial discretion.

The judgment will be reversed, with costs, and a new trial ordered. The other Justices concurred. ${ }^{\circ}$

6 A. was an upper, B., a lower, riparian. B. had a water wheel mill. A. kept back the river by a dam to aecumulate suflicient water to carly his lows down by flood, releasing the water at intervals. This detention of the water made it impossible for $B$. to the his miil. Heht, b. has a right of ale-

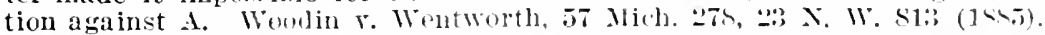

A., an upper ripurian, raised his dam, and to get his poud tilled sllut wh 


\section{MENG v. COFFEY.}

(Supreme Court of Nebraska, 1903. 67 Neb. 500, 93 N. W. 713, 60 L. R. A. 910, 108 Am. St. Rep. 697.)

Pound, C.' This suit was brought in 1893 to enjoin the defendants, upper riparian owners upon Hat creek and its several tributaries, from diverting the waters of said streams for irrigation purposes to such extent as to deprive the plaintiff, a lower owner, of the use of the stream. Upon trial a decision was announced orally adverse to the plaintiff. On appeal to this court it appeared that no final decree had been entered in accordance with such announcement, and the appeal failed. Thereafter a decree dismissing the cause and following the findings originally announced was duly entered, from which the present appeal is prosecuted.

The defendants justify their diversions of the waters of said streams upon these grounds: (1) Prior appropriation; (2) that irrigation of meadow land to produce forage for their stock is a "domestic" use of the water, for which, if necessary, they may consume the whole. * * *

The first two positions are clearly untenable if this court is to adhere to its repeated pronouncements that the rules of the common law as to the rights and duties of riparian owners are in force in this state. *** $*$

A great deal of what has been urged upon us as demonstrating the inapplicability of the rules of the common law upon this head to conditions in Nebraska proceeds upon an erroneous impression of the nature and purpose of such rules. Thus, in a brief in which the subject is most elaborately and exhaustively discussed, counsel say: "No riparian proprietor in Nebraska to-day is entitled to the full flow of the stream through his premises just for the pleasure it may give him to see the stream filling its banks. * * * The use of the water belongs to the people." And throughout that brief, and in all the arguments we have examined, it is assumed that at common law any taking of water from a stream is an injury to the riparian proprietor, and that the latter may insist that no water whatever shall go out. The common law does not hold to so unreasonable a rule. On the contrary, it considers running water publici juris, and, while it will not permit any one man to monopolize all the water of a running stream when there are other riparian owners who need and may use it also, neither does it grant to any riparian owner an absolute right to insist that every drop of the water flow past his land exactly as it would in a state of nature.

the water entirely for two days in June and for four days in July. During these days B., a lower riparian, was unable to operate his mill. Held. $\boldsymbol{R}$. has no cause of action against A. Pitts v. Lancaster Mills, 13 Metc. (Mass.) 156 $(1 S 4 \bar{\tau})$.

i Part of the oninion of the Commissioner is omitted. 
When, therefore, counsel tell us that their clients have a natural right to irrigate, and that reasonable use of the water is necessary in exercise of that right, they urge nothing against the rules of the common law, since the latter merely insist that others along the streams in question have the same natural right, and permit every reasonable use by each consistent with like use by all. The apparent modifications of the common-law rules in the semiaricl or arid states in that courts of such states are more liberal in their construction of what is a reasonable use, are no departure from the principles on which the rules are founded. On the contrary, they carry them to their logical conclusion in view of the special conditions of such regions.

For the reasons indicated, we are of opinion that the former holdings of the court must be adhered to, and that, except as altered by statutes, the common-law rules are in force in every part of the state. The details of such rules with respect to irrigation, however, and their ap. plication to irrigation in the semiarid portions of the state, have not, a. yet, received careful consideration by this court. It is generally resognized that at common law a riparian owner may take water from a stream for purposes of irrigation. Embrey v. Owen, 6 Exch. 353; Elliot v. Fitchburg R. Co., 10 Cush. (Mass.) 191, 57 Am. Dec. 8.5; Gillett v. Johnson, 30 Conn. 180; Ulbricht v. Eufaula Water Co., 86 Ala. 587, 6 South. 78, 4 L. R. A. 572, 11 Am. St. Rep. 72; Gould on Waters, $\S 617$. At an early day there was a tendency to class irrigation among those uses of a stream which might be carried even to entire consumption of its waters. But another view has long prevailed, and is now well established, not only in the eastern portion of the country, but even in the arid and semiarid states (so far as such states recognize the common-law doctrine as to riparian rights), to the effect that irrigation is one of those uses which must be exercised reasonably with due regard to the rights of others. Low v. Schaffer, 24 Or. 239, 33 Pac. 67S; Gillett v. Johnson, 30 Conn. 180; Black's Pomeroy, Water Rights, $\S 151$; Gould on Waters, $\S \S 205,217$. This subject has been confused needlessly by the unfortunate use of the words "natural" and "ordinary" in this connection to distinguish those uses which the common law does not attempt to limit, and "artificial" or "extraordinary" to designate those which are required to be exercised within reasonable bounds. It is no donbt true that irrigation is a very natural and a very ordinary want, and that use of a stream for such purpose is natural and ordinary in semiarid regions. Wut such is not the question. The law does not regard the needs and desires of the person taking the water solely to the exclusion of all other riparian proprietors, but lookrather to the natural effect of his use of the water upon the stream and the equal rights of others therein. The true distinction appears to lie between those modes of use which ordinarily involve the taking of small quantities, and but little interference with the stream, such as drinking and other household purposes, and those which necessarily in-

BIG.RIGHTS-5 
volve the taking or diversion of large quantities and a considerable interference with its ordinary course and flow, such as manufacturing purposes. ***

It would doubtless be impolitic to give an arbitrary or hard and fast meaning to the word "reasonable" in this connection. The use of water for irrigation always involves some loss, and we do not think it would be wise to declare every perceptible diminution of the waters of a stream to be unreasonable. The necessity of a liberal view of what constitutes a reasonable use of water for irrigation has been judicially recognized (Harris v. Harrison, 93 Cal. 676, 29 Pac. 325; Bathgate v. Irvine, 126 Cal. 135, 58 Pac. 442, 77 Am. St. Rep. 158), and we think caution in that respect entirely proper. If the rights of the upper owner in the water are no more than those of the lower owner, they are at the same time no less. His right to reasonable use of the water for irrigation ought not to be rendered nugatory by requiring it to be exercised in an impossible manner. ***

The uses which an upper riparian owner may make of a stream for purposes of irrigation must be ịdged, in determining whether they are reasonable, with reference to the size, situation, and character of the stream, the uses to which its waters may be put by other riparian owners, the season of the year, and the nature of the region. These circumstances differ in different cases, and what use is reasonable must be largely a question of fact in each case. Lux v. Haggin, 69 Cal. 255, 4 Pac. 919, 10 Pac. 674; Baker v. Brown, 55 Tex. 377; Harris v. Harrison, 93 Cal. 676, 29 Pac. 325; Minnesota Loan \& Trust Co. v. St. Anthony Falls Water Power Co., 82 Minn. 505, 85 N. W. 520; Embrey v. Owen, 6 Exch. 353 ; Pitts v. Lancaster Mills, 13 Metc. (Mass.) 156. Some things, however, are clearly unreasonable, and it may be laid down absolutely that the upper owner, in using the svater for irrigation, must not waste, needlessly diminish, or wholly consume it, to the injury of other owners, nor so as to prevent reasonable use of it by them also. Union Mill Co. v. Dangberg, 2 Sawy. 450, Fed. Cas. No. 14,370; Lux v. Haggin, 69 Cal. 255, 4 Pac. 919, 10 Pac. 674; Harris v. Harrison, 93 Cal. 676, 29 Pac. 325; Gould v. Eaton, 117 Cal. 539, 49 Pac. 577, 38 L. R. A. 181; Coffman v. Robbins, 8 Or. 279; Gillett v. Johnson, 30 Conn. 180.

Judged in this way, we think the use made of the streams in question by three of the defendants may not be said to be reasonable. Hat creek is a small stream, about 10 feet wide where it passes the plaintiff's lands, formed by the junction of a number of similar streams a few miles above. Of these, IVarbonnet creek, after gathering several small tributaries, flows into Mrunroe creek, which is received by Sowbelly crcek, and the latter soon joins Hat creek, into which, some distance above, a number of smaller streams have been united.

The defendant Brewster maintains a dam on Warbonnet creek, and a ditch, by means of which he irrigates some 300 acres. The capacity of this ditch is sufficient to contain the entire stream. It takes the wa- 
ter away from the creck to a point about a mile off, where the dip is but very slightly toward the creek, and there discharges it, so that practically all that is not used in irrigation will, in hot weather, evaporate, and not return to the creek. On one occasion, when the season was very dry in that vicinity, and a number of Mr. Brewster's neighbors below him were complaining because they could get no water, it appears that he was turning the water upon a meadow of 80 to 100 acres, so that it stood there from one to one and one-half inches deep; and, as we have seen, what was not used was substantially wasted. This is obviously unreasonable. The defendant Wilcox maintains a ditch on Munroe creek, with which he irrigates 150 acres. This ditch also is sufficient to carry the whole stream, and the water is so discharged that none gets back into the creek, since the ground slopes in another direction at the point of discharge. With respect to the defendant Coffey, who maintains a ditch on Hat creek, with which he irrigates 160 acres, the case is not so clear. But at the time the writs were served in this case, while there was an abundance of water in his ditch, the sheriff found the creek dry a mile and a half below, and the bed of the creek opposite the plaintiff was so dry that dust blew in it. ***

With respect to the defendant Steele, however, who is on Middle Hat creek, above Coffey, the evidence is that all of the water taken out by him, except what is consumed by evaporation, goes back to the creek, and there is no evidence of unreasonable use or of injury to the plaintiff. [The Commissioner found that until 1893 there was no undue user by any of the defendants.]

PER CURIAx. For the reasons set forth in the foregoing opinion, the decree of the district court is affirmed as to the defendant Steele, but reversed as to the defendants Coffey, Brewster, and Wilcox, with directions to make new and further findings of fact in conformity with said opinion, and to enter a decree enjoining the defendant Wilcox from wasting or unreasonably diminishing the waters of Munroe creek, and enjoining the defendants Brewster and Coffey from consuming all the waters of Warbonnet and Hat creeks, respectively, in the irrigation of their lands, or permanently diverting in any year a greater proportion of the water in such streams for the time being than they were accustomed to take out prior to 1893 , having regard to the nature of the season and the condition of the stream at the time; that proportion and other questions of fact necessary to the rendition of such decree to be ascertained from the evidence already taken, or by taking further evidence at the discretion of the district court. ${ }^{8}$

8 See Mud Creek Irrigation Agr. \& Mfg. Co. v. Virian, 74 Tex. 170, $11 \mathrm{~s}$. W. $107 \mathrm{~s}$ (1SS9). 


\section{G.ARWOOD v. NEW YORK CENT. \& H. R. R. CO.}

(Court of Appeals of New York, 1Ss1. 83 N. I. 400, 38 Am. Rep. 45i.)

[The defendant at a point where its roadbed crossed a stream installed pipes and drew away water for use in its locomotives. This diversion perceptibly reduced the water in the stream and materially diminished the grinding power of the plaintiff's mill lower down on the stream. He asked for damages and an injunction. He obtained both in the court below, and the defendant appealed.]

DANFORTH, $\mathrm{J}^{\circ} * * *$ Each [riparian proprietor] has a right to the ordinary use of water flowing past his land, that is, ad lavandum et ad potandum, for domestic purposes and his cattle, although some portion may be thereby exhausted; and this is so, without regard to the effect which such use may have upon the lower owner. The water may also be used for irrigation or for manufacturing purposes. The cases cited by the appellant are abundant to show this, but in every one the irrigation is of the land to which the right to use the water is an incident, or with which the manufacturing purpose is connected, but even this privilege cannot be exercised if thereby the lawful use of the water by a lower proprietor is interfered with to his injury. Miner v. Gilmour, 12 Moore, 156; Tyler v. Wilkinson, 4 Mason, 397, Fed. Cas. No. 14,312. Now in the case before us the defendant has done something more; it has not been content with exercising this privilege; it has diverted a considerable portion of the stream not for any use upon the land past which it flows, but for the transaction of its business in other places and for purposes in no respect pertaining to the land itself. The pipes and reservoirs of the defendant are not laid or constructed for the mere purpose of detaining the water a short time, or applying it to machinery or other object upon the land itself, and afterward restoring it, but for facility in filling the defendant's locomotives, in order that they, with power generated from it, may pass as the interest of the defendant may require, to the east or west, returning no portion of it, even in the form of vapor, to the stream from which it was taken. So far as the plaintiff is concerned, it has carried away from his premises the water as effectually as if it had been turned into another channel and discharged at Albany or Buffalo; and from this, as the jury has found, he has sustained damage. Not only this, but it has been done under a claim of right by the defendant, which, if acquiesced in by the plaintiff, would in course of time ripen into a realty and destroy the incident of his propertythe right of the plaintiff as riparian owner to have the water fiow as it had theretofore been accustomed to flow. For in that case, although the defondant could not claim the right as riparian proprietor, it might claim it by prescription; and to prevent this result also, the

- The statement of facts is rewritten and part of the opinion is omitted. 
plaintiff had a clear right to an injunction. The terms of the one granted are sufficiently well guarded. The defendant is "restrained" only "from diverting the water to the injury of the plaintiff."

But the learned counsel for the appellant contends that inasmuch as both plaintiff and defendant require the water for artificial as distinguished from natural uses--the one as a power for mill purposes, the other as material or the means of producing power for railroad purposes, it may be abstracted by the defendant, even to the other's injury, although he concedes the rule would be different if the plaintiff required the water for natural purposes. It is difficult to see how such a distinction can be maintained. The plaintiff requires the current because its momentum supplies power. The defendant, as riparian owner, has no right to remove the water and so diminish it. If the defendant's use was for natural purposes there might be some reason for giving it priority; but this is not pretended. To justify a use beyond that a grant or license would be necessary. The defendant exhibits neither, but in its answer asserts that its use has been adverse to the plaintiff for more than twenty years. The evidence does not sustain the claim. As to it therefore the case presents no exception to the rule, that a riparian proprietor has no right to divert any part of the water of the stream into a course different from that in which it has been accustomed to flow, for any purpose, to the prejudice of any other riparian owner. This is the doctrine both of the common and civil law ( 3 Kent Com. 585), and it stands upon the familiar maxim, sic utere tuo ut non lædas alieno. In substance the defendant's claim is that it has a right to use all the water it pleases; but it does not show the origin or foundation of the right. As the case stands then the defendant has diverted the water without right and to the plaintiff's injury; its use therefore could not be reasonable, and the inquiry desired by the defendant, as to whether it was or not, would not be applicable.

Judgment appealed from affirmed, with costs. ${ }^{10}$

\section{GILLIS v. CHASE et al.}

(Supreme Court of New Hampshire, 1S91. 67 N. H. 161, 31 Atl. 18. (6s Am. St. Rep. 645.)

Case, for diverting water and diminishing the flow upon the plaintiff's land. Facts found by the court.

The plaintiff and one J. S. Winn are riparian owners, Winn's land being above the plaintiff's. About fifteen years ago Winn built a dam to hold back the water, thus forming a reservoir from which by

10Acc.: Even though the diversion might not have substantialls damaged the plaintiff's mill. McCartney v. Londonderry, etc., Ry. Co.. [1904] A. I'. 301, overruling Earl of Sandwich v. Gt. Northeru Ry. Co., L. R. 10 Ch. Dir. 707 (1578). 
an aqueduct he supplied water to his farm buildings. He also permitted the defendants, who are not riparian owners, to connect aqueducts with the reservoir and thereby supply their buildings with water, conveying to them by deed a right to such use. The defendants all claim the right to take the water from the reservoir under J. S. Winn, the owner of the land where the reservoir is located, and the owner of a part of the meadow from which the water is collected. The use of the water made by the several defendants is reasonable as to the quantity used, and the sale of the water by Winn to them is a reasonable use of it. The water used does not return to the stream, but the amount is so small as to make no difference that would probably be perceptible in the stream flowing through the plaintiff's land.

BLODGETT, J. The case finds that "the defendants all claim the right to take the water from the reservoir under J. S. Winn, the owner of the land where the reservoir is located, and the owner of a part of the meadow from which the water is collected."

In virtue of this ownership, Winn's right to divert the water for use to a reasonable extent was incident to the land; and, as the plaintiff has failed to show any actual damage, it is only for an unreasonable and unauthorized diversion that the law will imply damage to him, because each riparian proprietor having the right to a just and reasonable use of the water as it passes through and along his land, it is only when he transcends his right by an unreasonable and unauthorized use of it that an action will lie against him by another proprietor whose common and equal right to the flow and enjoyment of the water is thereby injuriously affected. And as the reasonableness of the use is, to a considerable extent, a question of degree, and largely dependent on the circumstances of each case, it is to be judged of by the jury, and must be determined at the trial term as a mixed question of law and fact. Jones v. Aqueduct, 62 N. H. 4SS, 490; Rindge v. Sargent, 64 N. H. 294, 295, 9 At1. 723. This question having been found adversely to the plaintiff by the trial court, the finding is conclusive against him (Jones v. Aqueduct, supra), and consequently the only question now open to him is as to the right of Winn, in his character as a riparian proprietor, to sell the non-riparian defendants any of the water belonging to him as incident to his land.

The English rule is understood to be, that "A riparian owner can$110 t$, except as against himself, confer on one who is not a riparian owner any right to use the water of the stream, and any user by a nonriparian proprietor, even under a grant from a riparian owner, is wrongful." Ormerod v. Mill Co., L. R. 11 Q. B. 155; Swindon Water Works Co. v. Wilts \& Berlss Canal Nav. Co., L. R. 7 H. L. 697 ; Nuttal v. Bracew ell, I. R. 2 Ex. 1. But the rule is otherwise in this jurisdiction, for it is held here to be a question of fact, whether the use of the water made by a riparian owner for his own purposes, or for sale to others, is, under all the circumstances, a reasonable use. Jones v. Aqueduct and Rindge v. Sargent, supra. And in view of the finding 
that the sale of the water to the defendants by Winn is a reasonable use of his right as a riparian owner, the plaintiff has no standing on this branch of the case.

Judgment for the defendants.

ZLARK, J., did not sit; the others concurred. ${ }^{11}$

\section{JONES et al. v. CONN.}

(Supreme Court of Oregon, 1901. 39 Or. 30, 6t Pac. 855, 65 Pac. 1068, 54 L. R. A. $630,87 \mathrm{Am}$. St. Rep. 634.)

BEAN, C. J. ${ }^{12}$ This is a controversy between riparian proprietors upon a natural water course. There is virtually but one question involved in the case, and that is whether the lands which the defendant seeks to irrigate are riparian in character. It is practically conceded that up to the commencement of the suit the plaintiffs had not been substantially injured or damaged on account of the use of the water by the defendant, and, as a consequence, are not entitled to an injunction if the lands are riparian; but the contention is that they are nonriparian, and therefore the plaintiffs are entitled to an injunction restraining the use of the water thereon without proof of damage. ***

The plaintiffs admit the rule that, after the natural wants of all the riparian proprietors have been supplied, each is entitled to a reasonable use of the water for irrigating purposes, but insist that the exercise of the right must be limited to the tract of land through which the stream flows as first segregated and sold by the government of the United States, and that, even in such a case, where there are natural barriers within the tract which would prevent a portion of the land from deriving any benefit from the flow of the stream, the portion lying beyond the barrier should be excluded. But, as we understand the law, lands bordering on a stream are riparian, without regard to their extent. After a considerable search, we are unable to find any rule determining when part of an entire tract owned by one person ceases to be riparian.

It would seem, that any person owning land which abuts upon or through which a natural stream of water flows is a riparian proprietor,

11 Contra: Ormerod v. Toumorden Mill Co.. L. R. 11 Q. B. D. 155 (1SS:3). See Elliot v. Fitchbur: R. R. Co., 10 Cush. (64 Mass.) 191, 57 Am. Dec. 85 (1S52).

In many of the semi-arid states of the West the common-law doctrines relating to rights in streams have been done away with in favor of the socalled appropriation doctrine, viz, that the use of the stream belongs to the person who first appropriates it to lis own use, to the extent that he so appropriates. See Wiel. Water Rights in the Western States (3d Ld.) parts I, II, III : part IV, c. 40.

12 The statement of facts and part of the opinion are owitted. 
entitled to the rights of such, without regard to the extent of his land, or from whom or when he acquired his title. The fact that he may have procured the particular tract washed by the stream at one time, and subsequently purchased land adjoining it, will not make him any the less a riparian proprietor, nor should it alone be a valid objection to his using the water on the land last acquired. The only thing necessary to entitle him to the right of a riparian proprietor is to show that the body of land owned by him borders upon a stream.

The case of Boehmer v. Irrigation Dist., 117 Cal. 19, 48 Pac. 908, would seem to make the extent of riparian rights depend upon the source of title, rather than the fact of title; but in Water Co. v. Hancock, 85 Cal. 219, 24 Pac. 645, 20 Am. St. Rep. 217, it was expressly held that all land bordering upon a stream which is held by the same title-in that instance consisting of 1,280 acres-is riparian, and no distinction was made on account of the source of title. Again, in Wiggins v. Water Co., supra [113 Cal. 182, 45 Pac. 160, 32 L. R. A. 667], and Bathgate v. Irvine, 126 Cal. 135, 58 Pac. 442, 77 Am. St. Rep. 158 , the right of a riparian proprietor to use the waters of a stream for irrigation was limited to the water shed. But, as we understand these cases, the court in each instance was determining the rights of the parties then before it, and not attempting to lay down an inflexible rule as a guide in all cases. Nothing more was held or decided than that under the claim alone of riparian rights the owner of land cannot, to the injury of another riparian proprietor, take the water beyond the water shed, or onto lands held by a title different from the title of those through which the stream flows; and this all will concede. The right to make a reasonable use of the water of a stream is a right of property, depending on the ownership of the land abutting on or through which the stream flows; and whether a given use is reasonable or not is a question of fact, to be determined under the circumstances of each particular case. The right to use the water belongs to the owner of the land, and the extent of its exercise is not to be determined by the area or contour of his land, but by its effect upon other riparian proprietors.

It is suggested that the court ought to ascertain and determine the rights of the respective parties, and fix them in the decree, so that hereafter there may be no controversy concerning the matter. In the very nature of things, however, it is impossible in a case of this character to make such a decree. The rights of the several riparian proprietors are equal, each being entitled to but a reasonable use of the water for irrigating purposes, and what constitutes such use must necessarily depend upon the season, the volume of water in the stream, the area and character of the land which each riparian proprietor proposes to irrigate, and many other circumstances; so that it seems to us there is no basis upon which the court could frame any other decree than one enjoining and restraining the defendant from diverting the water from 
the stream to the substantial injury of the present or future rights of the plaintiffs, and, as the decree of the court below is to that effect, it will be affirmed. ${ }^{13}$

\section{Appeal of MESSINGER.}

(Supreme Court of Pennsylvania, 1Ss5. 109 Pa. 285, 4 Atl. 162.)

[Bill for an injunction to restrain defendants from using the water of a stream. Bill was dismissed, and plaintiff appeals.]

MERCUR, C. J. ${ }^{14}$ This is an attempt to enjoin the appellees against the use of the water of a small stream which flows through their land. It unites with another stream of about the same size in forming the larger one, on which the appellants own lands and mills, some six miles below the junction of the two smaller streams. The complaint is that the appellees so use the water of the stream on their lands as to greatly lessen the fiow thereof during a portion of the year to the mills of the appellants, to their injury. That such is now the effect of the appellees' use of the water in a dry season, when the streams are low, is undoubtedly correct.

What, then, are the controlling facts found by the master? They are that about 40 years before this bill was filed the predecessors in title of the appellees built a low dam across the stream, and cut a sluice or ditch therefrom by which the water was led into their meadows adjoining. A gate was put at the entrance of the ditch by which the quantity allowed to flow could be checked or shut off when desired. This use of the water, under a claim of right, had continued for about 40 years, whenever the owners of the meadows thought they needed watering. It did not flow constantly over the meadows, as there were times when for several months they did not need the water; yet, during that portion of each and every year when the growth of the grass, would be promoted by irrigation, the water was so used. Such use of the water was continuous and uninterrupted except when they did not want it and closed the gates. He further found that the dam is no higher, the ditches no larger, nor the quantity of water diverted any greater, than when the dam was originally constructed. On the contrary, that three acres less of meadow land are now irrigated than while it was in possession of the former owners; that a number of ditches through which the water formerly flowed for irrigating purposes are now abandoned and closed; that the water now taken from the creek is less than was formerly taken, but it has not decreased proportionately with the diminution of water in the creek.

At the time the water was first diverted from the stream, and for many years thereafter, it does not appear to have caused any injury to

13 In addition to cases cited in text, see Crawford Co. v. Hathaway, 67 Neb. 325, 353,93 N. W. 751,60 L. R. A. SS9, 108 Am. St. Rep. 647 (1903).

14 The statement of facts and part of the opinion are oinitted. 
the property now owned by the complainants. The injury results from the gradual diminution of the volume of water flowing in the stream, which has been the case for several years. ${ }^{15}$ While the dam which diverts the water remains no higher, and the ditches which led the water from the stream and returned it thereto are unchanged, and the appellees use less water than formerly, yet the appellants claim, in consequence of the diminished flow of water in the stream, the effect of the diversion, at first harmless, has now become injurious, and therefore the use of the water should be enjoined against. In support of this view, the gencral rule, as declared in Washb. Easem. $\S 49$, is invoked, that the time from which the period is to be reckoned in computing the duration of a continuous enjoyment is when the injury or invasion of right begins, and not the time when the party causing it began that which finally creates the injury.

The correctness of this rule may be conceded, yet it is not applicable to the facts of the present case. If the injury here was caused by a change of the dam or of the ditches; or by suffering the latter to become filled up or clogged, (Polly v. McCall, 37 Ala. 20;) or by applying the water to a different use; or if injury was caused by any late act, cither of omission or of commission, on the part of the appellees,it might be said they had previously only begun the work which caused the injury; but such is not this case. Here the whole action and work of the appellees is a continuance only of that which was done on the ground 40 years ago, and the water continues to be used for the same purpose now as then.

The work on the ground was not only under a claim of right, but it was open, visible, and notorious. 'The parties who owned the property below could foresee and anticipate the ultimate effect of the diversion of the water, as well as the parties who caused it. The fact that they may not have foreseen the probable diminution of the quantity of water which would flow in the stream cannot deprive the appellees of any of their rights arising from their possession and enjoyment of the water for nearly twice the number of years necessary to give a right thereto by prescription.

Judigment affirmed. ${ }^{16}$

15 The stream had shrunk to one-half its former size and it was alleged that in dry seasons the defendints took practically all the water.

16 "The plaintiff settled upon his land in 1886, fire years after colfey began his ditch, and from that time until 1893 there is abundant evidence that he had water in the creck at all times except for a day or two in 1890. No right to divert and dissipate the whole stream was acquired by making such use thereof as would still leave water for the plaintitf. So long as the water Was suticient for all, there was no adverse user. *** One of the elements to he considered in determining what is a reasonable use of the water of a stream is the season of the year. and its eficct upon the stream. Riparian owners are not to be debarred from use of water because the season is dry and the stream low. But at such time they must take care 'to do no imaterial injury to the common right, having regard to the then stage of the river." *** The testimony is that the season of 1893 was unusnally dry. Hence what might have been a rcasonable use of the water, or at least such 
NEW YORK RUBBER CO. v. ROTHERY et al.

(Court of Appeals of New York, 1592. 132 N. Y. 293, 30 N. E. 841, 28 Am. St. Rep. 575.)

[The appellant was a lower, the respondents, upper, riparian proprietors. The respondents had a valuable mill upon their land and erected a dam to get water power for the mill, by which means the normal flow of the river was diverted, and not returned to the channel until it reached a point below the appellant's land. The appellant's land was not used for manufacturing purposes. The appellant brought an action at law for the diversion of the water. Judgment below for the defendants.]

LAANDON, J. ${ }^{17} * * *$ The court charged the jury that if the defendants used and diverted the water to a degree that materially and appreciably lessened its flow along the lots of the plaintiff the plaintiff was entitled to recover nominal damages. But the court also charged: "These defendants have the right to use this water to run their wheel, provided they do not interfere with the stream to an extent which you can say is both appreciable and material. That question will, of course, be determined with reference to the land as it was, and not with reference to the future, for an instant. Be sure as to that. Do not change the question from just what it is: Have the Rotherys, by this water course, diverted the water so as to leave the stream, to it material and appreciable extent, insufficient for the purposes of plaintiff's business? Now, gentlemen, that is all there is of the case." The plaintiff excepted to this portion of the charge, and requested the court to charge "that the plaintiff's right to maintain this action, and to recover a verdict for nominal damages, does not depend at all upon the plaintiff's showing any actual or any perceptible damage, but solely upon the question whether the defendants have, by the use of their

use as gave the plaintiff no ground of complaint, in other 5cars, became highly unreasonable when it had the effect of giving Coffey and Brewster all the water, and leaving none for other owners. Only a contimuous and adverse user of the whole stream could give a right to talie out a greater proportion of such water as was in the stream at the time than they had habitually talien in former years." Meng v. Coffey, 67 Neb. 500, 520, 9: N. WV. 713, 720, 60 T. R. A. $910,10 S$ Ain. St. Rep. 697 (1903). Hor the facts of this case see ante, p. 61.

A., an upper riparian, built a dam and excarated for a reservolr. In so doing he opened two or three springs on his own land and tapped a lare spring on adjoining land, the watcrs of which he piped to his reservoir. In an action by a lower riparian for intelference with the flowage of the stream, A. contended that as a conscruence of these new somes and the further facts of the leakage and overtlow from the dam and the occasionil raising by him of the sluice gate, as mull water lan down to the plaintitl"s: land as formerly. Feld, if the defendant lad interfered with the natulat water flow, these facts constituted no defense. Ware $v$ Allen, 140 Mass. 513,5 N. F. 629 (1SS6). Compare Elliot v. Fitchuulg R. R. Co., 10 Cusi. (64 Mass.) 191, 57 An. Dec. 85 (1S52).

17 The statement of facts is rewitten and yart of the opinion is omited." 
race, at any season of the year, diverted water from Matteawan creek, and thereby have reduced, perceptibly and materially, the volume or current of water which otherwise would have flowed by the plaintiff's premises." This was refused.

Both the charge and refusal were erroneous. The plaintiff's right to recover nominal damages was substantial, though the quantity of damages was not. The defendants probably did leave water enough in the stream for the purposes of the plaintiff's business, as that business had been conducted. But the plaintiff's title to its water rights, and its right to redress for their invasion, were not conditional upon the beneficial user of them. $* * *$ The plaintiff may, however, lose its title by the defendants' prolonged adverse user of the water of the stream, and this is the more probable if such adverse user is protected by the verdict of the jury. It is not improbable that this action was brought to prevent the defendants from acquiring a prescriptive right to divert the water. The charge, which makes "the purposes of the plaintiff's business" material to its right to recover, and cautions the jury to regard plaintiff's land "as it was, and not with reference to the future," tended to lead the jury to disregard the inviolable character of the plaintiff's property rights, or at least expose them to sacrifice, if plaintiff's actual and immediate pecuniary damages were inappreciable. The plaintiff might thus lose its right to the beneficial use of the water as it was accustomed to flow before defendants began to divert it simply because it had not as yet found it convenient to use it. In such a case, nominal damages given confirm the plaintiff's right, but withheld, impeach and may destroy it.

The judgment should be reversed, new trial granted, costs to abide event. All concur, except FOLLET'T, C. J., not voting. ${ }^{18}$

18 The plaintiff was a riparian proprietor owning a water mill upon a small stream. The defendants acquired land on the lake whence the stream flowed, and installed a dam for the purpose of obtaining a water supply for certain villages, thereby changing the natural flow of the stream. The dam was so arranged, howerer, that the amount of water for the plaintiff's mill was entirely sufficient and flowed with a more regular volume than it had before the installation of the dam. Held, the plaintiff was entitled to an injunction preventing the defendant from changing the natural flow of the stream. Roberts v. Gwyrfai District Council, [1899] $1 \mathrm{Ch} .583$.

A. was an upper, B. a lower, riparian proprietor. A. put in a dam that diverted the bulk of the river from B.'s side of the stream to the other. B. alleged that the effect of this change was to destroy a water power of his land aud asked an injunction to compel the restoration of the natural flow of the river. The court found that in fact B.'s land had no water power possibilities. Held, B. is not entitled to an injunction. Minuesota Loan \& 'I'rust Co. v. St. Anthony Falls Water-Power Co., 82 Minn. 505, 85 N. W. 520 (1901). See Modoc Land \& Live Stock Co. v. Booth, 102 Cal. 151, 36 Pac. 431 (1891).

A. erected a dam across a stream through his land, and used it to detain the water in the pond which formed the source of the stream, during the autumn and spring when his factory, which was situated on other land that he owned lower down the stream and situated below that of B., was adequately supplied with water from another source. When that failed, the deficiency was made up from the reservoir thus created. B. opened the 


\section{FILBERT v. DECHERT.}

(Superior Court of Pennsylrania, 1903. 22 Pa. Super. Ct. 362.)

PORTER, J. ${ }^{18}$ The plaintiff is the owner in fee of a tract of land through which flows Furnace creek, an unnavigable stream, upon which is erected a gristmill and sawmill operated by the water power. The corporation defendant is an agent of the state to which has been committed the possession and management of the property used as an asylum for the chronic insane, the title to the property being in the commonwealth. Act of June 22, 1891, P. L. 379. The land of which the defendant, as the representative of the commonwealth, is in lawful possession consists of a tract containing 540 acres, through which for a distance of about a mile flows Asylum creek, a stream which falls into Furnace creek, at a point above the land of the plaintiff. The state has erected upon its land extensive buildings, suitable as a place of residence for the insane, and has for a number of years there maintained the unfortunate of this class to the number of 800 , the nurses and officers necessarily employed about the buildings increasing the total population living upon the land to about 900 . Asylum creek enters the property of the defendant at a point nearly 100 feet higher than the asylum buildings, and the water used about the buildings has been conveyed from the creek through a six inch pipe. The plaintiff brought this action alleging a deprivation of her right to the use of the water of said stream. The only injury to the property of the plaintiff suggested by the evidence was the diminution of the water power.

The riparian rights of the commonwealth are the same which would have been incidental to ownership by a private individual: Union Mill, etc., Co. v. Ferris, 2 Sawy. 176, Fed. Cas. No. 14,371. * * * The learned judge of the court below charged the jury that the use of the water made by the defendant was not a proper use of the stream by a riparian owner; and that "if the amount of water taken from the channel of this stream sensibly or materially diminished the flow, then the defendant has subjected itself to an action for an excessive use or diversion of the water." "No matter what the necessities of the asylum may have been, no matter how useful the institution may be, how praiseworthy it may be, it had no right to convey the water out of its course to the prejudice of the plaintiff's right." This language has the merit of being free from ambiguity. The learned judge of the court below determined as matter of law that the defendant had no right to furnish to the inmates of the buildings upon the riparian land water for drinking, culinary and cleansing or any other purpose usually considered necessary to the preservation of life and health.

gates and let off the accumulated water. Held, A. could not get an injunction against B., although there was no showing that the retention of the water damaged B. Clinton V. Myers, 46 N. Y. 511, 7 Am. Rep. 373 (1871).

10 The statement of facts and part of the opinion are omitted. 
This conclusion seems to have been reached because of the frequent recurrence of the term "ordinary domestic purposes" in the authorities dealing with the rights of riparian owners. The learned judge, in his opinion refusing a new trial, says: "The principal question is whether the use of the water by the defendant is domestic in its nature." He then refers to the definitions of the word "domestic" found in several dictionaries, and thus states the result: "The central idea of both these definitions seems to be a family, home interest, something for the benefit of the family and home." Having thus reasoned out that there must be a home and a family upon the land before riparian rights become incidental to it, the learned judge proceeds to investigate the character of the residence of the insane patients upon the property of the state. Having satisfied himself that this public institution "is an asylum, not a home; a house of detention; a place of treatment for the chronic insane, a hospital," the process of excluding these divellers upon the margin of the stream from all riparian rights is complete. Even if the spirit of a legal principle and the relations out of which it arises are to be disregarded, the meaning of the word "domestic" cannot be arbitrarily assumed to be always thus narrow. One of the declared purposes of ordaining the constitution of the United States was to "insure domestic tranquility." As here used the term can hardly be said to imply an intention to preserve the peace of private families: it refers rather to the regulation of internal public affairs, not foreign interests. The term ordinarily means pertaining, to one's place of residence, or to the affairs which concern it, or used in the conduct of such affairs. The authorities do not leave us without a definition of the term. In Philadelphia v. Gilmartin, supra [71 Pa. 140], Mr. Justice Agnew said, in referring to the use of water for manufacturing purposes: "These uses are not domestic, that is, such as are for the preservation of the life and health of the population and their creatures." Chief Justice Paxson said, in Haupt's Appeal, supra [125 Pa. 211, 17 At1. 436, 3 L. R. A. 536]: "If there was a tenant thereon he could use it for watering his stock and for household purposes, for any useful, necessary and proper purpose incident to the land itself and essential to its enjoyment." * * *

The word as used in the authorities cited by the learned judge of the court below refers to the purposes for which the inhabitants may use the water, and not to the social status of the individuals occupying the buildings which may be upon the land. The right is a natural one, recognized as growing out of the natural wants of man; it is inherent in the ownership of the land, and is to be enjoyed by all who lawfully dwell upon the premises to the ownership of which it is an incident, without regard to the duration or purpose of such residence. All those who lawfully occupy the riparian lands have a right to the ordinary use of the water for the purpose of supplying their natural wants, including drinking, washing, cooking, and about their habitations for such things as are necessary to the preservation of life and health. 
This natural right is not dependent upon whether the dwellers by the stream occupy homes or hospitals, are sheltered by tents or live in the open. The state might lawfully ordain that the National Guard should encamp upon this tract of land and take water for their use while there, from this stream. The ordinary use of the water, for the purpose of supplying the natural wants of those who inhabit the riparian lands, may involve an exhaustion of the stream without incurring liability to lower riparian proprietors: Attorney General v. Gt. Eastern Ry. Co., 23 L. 'T. N. S. 344. When the use is extraordinary, for the supply of artificial wants, such as manufactures, those whose supply of water is thereby sensibly diminished, have a right of action: Gould on Waters (3d Ed.) § 205; Black's Pomeroy on Water Rights, $\S \S 138$, 140 , and cases there cited.

This agent of the state, the defendant, had an unquestionable right to take from the stream so much water as was reasonably necessary to supply the natural wants of those living upon this tract of land. The evidence does not indicate any necessity for the use of the water to operate a fountain. The defendant was not warranted in taking water for the manufacture of ice to be sold away from the premises. The first and second specifications of error are sustained.

The judgment is reversed and a venire facias de novo awarded. ${ }^{20}$

\section{CITY OF CANTON" SCHOCK.}

(Supreme Court of Ohio. 1902. 66 Ohio St. 19. 63 N. E. 600, 58 L. R. A. 637, 90 Am. St. Rep. 5j7.)

The city of Canton is a municipal corporation, and is situated between the east and west forks of Nimishiller creek; the forks meeting at or near the sonth line of the city, and thus forming that creek. The entire natural drainage of the city is toward and into these two forks of the creek, which is a natural water course. The city has established its system of waterworks on the west branch of the creek, on a lot of land adjoining said branch; and it takes its water supply from said creck, and from certain wells near the same, and from Miyers' Lake, near by. The city uses so much of the water supply thus passing through its waterworks as it needs for its use as a city, and supplies its inhabitants with water for domestic, comnercial, and manufacturing purposes, at a price fixed by the city, so as to produce an income about sufficient to pay the expenses of said waterworks. The defendants in error own a water-power gristmill, located on the creek, a short distance downstream, south of the city, and have used the water of the creek for many years-over 50-as power to run their mill, and until about the year 1887 there was sufficient water to supply both the city

20 See Wadsworth r. Tillotson, 15 Conn. 866, 39 Am. Dec. 391 (1S43): Evans v. Merriweather, 3 scam. (4 Ill.) 492 , 35 Am. Dec. 106 (1S42). 
and the mill; but as the city grew, and extended its waterworks, it used larger quantities of water, and thereby the supply to the mill besame reduced to such an extent that in dry seasons of the year there was not sufficient water to run the mill all the time, and it became necessary to shut down at nights. Thereupon, in the year 1898, the defendants in error (plaintiffs below) commenced an action against the city in the court of common pleas, seeking to recover damages from the city for thus using the water, and thereby diminishing the supply to the mill.

The city saved exceptions to part of the charge, and to the charge as a whole. A verdict was returned in favor of plaintiffs below, motion for new trial overruled, judgment entered on the verdict against the city, and a bill of exceptions allowed, signed, and made part of the record. The circuit court affirmed the judgment, and thereupon the city filed its petition in error here, seeking to reverse the judgments below.

BURKET, J. ${ }^{21}$ As this is an action against the city for damages, no question as to eminent domain, or appropriation of private property for public uses, is involved in the issue; the controlling issue being as to whether the city, as a municipal corporation, is a riparian proprietor having the right to use the waters of the creek for its own purposes, and to supply them to its inhabitants for the ordinary purposes of life, and as to whether the right to use water from a stream by one riparian proprietor for manufacturing purposes, such as running a gristmill, is inferior or equal to the right to use the water from the same stream by an upper proprietor for domestic purposes.

It is urged by counsel for defendants in error that a municipality situated on a natural water course is not, in its corporate capacity, a riparian proprietor, and that only those inhabitants whose lots or lands border on the stream are such proprietors; and some cases are cited which seem to.take that view of the law.

It was held by this court at this term in City of Mansfield v. Balliett, 65 Ohio St. 451,63 N. E. 86, 58 L. R. A. 628, that a city situate on a stream is liable in its corporate capacity to a lower proprietor for polluting the water of such stream by running the sewage of such city and its inhabitants into such stream. This case holds the city, in its corporate capacity, and as an upper proprietor, liable to a lower proprietor for polluting the water of the stream; and if the city is liable not only for its own acts, but also for the acts of its inhabitants, in flowing sewage into the stream, it must be upon the principle that, as upper riparian proprietor, it has violated its duty toward a lower riparian proprietor on the same stream, and that therefore the city, in its corporate capacity, is a riparian proprietor on the stream, and must bear the burdens of such position. While the inhabitants own their lots individually, the city owns the streets, the fire department, and all other public

21 Part of the opinion is omitted. 
property and public works, and, in its corporate capacity, provides for the convenience and welfare of its inhabitants as to strcets, fire protection, lighting, and supplying water; and in such and other like matters the city overshadow's the individuals, and stands in its corporate capacity as a single proprietor extending throughout its entire limits, and entitled, as such, to all the rights, and subject to all the liabilities, of a riparian proprictor on the stream upon which it is situated. Sound reason, the weight of authority, and the present advanced state of municipal government, rights, and liabilities, require that a municipality should be held and regarded, in its entirety, as an individual entity, having in its corporate capacity the rights, and subject to the liabilities, of a riparian proprietor; and we so hold in this case.

The bringing of the action against the city for damages is of itself an implied admission that the city, in its corporate capacity, is an upper proprietor, liable for the wrongful diversion or use of the water of the stream upon which it is situated. Being charged with the liability of such upper proprictor, as conceded by bringing the action, and as was rightly held in the City of Mansfield Case, it must also be accorded the rights and benefits of such proprietor.

As such proprietor, the city uses the water of the stream, through its waterworks, in extinguishing fires, sprinkling streets, and other public purposes, and supplies water to its inhabitants for domestic use and manufacturing purposes.

As the right of the city to supply water to manufactories within its bounds for power purposes is only equal to the right of a lower proprietor to use water for the same purpose, the question arises in this case as to the rights of the parties to use the water of the stream for such purposes. $* * *$ Where there is not sufficient water in a stream to supply fully the needs of all the proprietors on the stream for power purposes, no one has the right to use all the water, and thereby deprive those below him from the use of any: nor can those below rightly insist that those above shall use no water for power, and thereby save it all for those below. Each should use the water reasonably, and so as to do as little injury to the others as circumstances will permit. As a loss must fall upon one or the other of such proprietors, neither should be compelled to bear the whole loss, but the water should be so divided and used that each one may bear his reasonable proportion of the loss. ***

This being so, the city of Canton, in supplying water to its inhabitants for power purposes, had the right to use the water of the stream to a reasonable extent only, and so as to do as little injury as might be, under all the circumstances, to the lower proprietor; each party bearing an equitable share of the loss caused by the shortage of water. Dry seasons are not caused by either party, but are the act of God, and each party must bear the losses resulting to him therefrom. * * *

All water powers on a stream are established subject to the superior big.Ricints-6 
right of all upper proprietors to use water out of the stream for domes. tic purposes, and, if the upper proprietors have grown so large or become so numerous as to consume most or all of the water, the lower proprietors have no cause of complaint, because it is only what they should have reasonably expected in the growth and development of the country, and subject to which contingency they established their water powers.

In addition to taking water from the stream for its own uses, and supplying the same to its inhabitants for domestic and manufacturing purposes, the amended petition avers that the city supplied water to its inhabitants for commercial purposes. If this means only that the city received pay for the water so supplied, and thereby made the water an article of commerce, the averment is of no force. The city having the right to supply water to its inhabitants for domestic and manufacturing purposes, it can make no difference in that right that the supply is for pay, rather than for nothing. The injury, if any, to the lower proprietor, arises from the taking of the water, and not from the pay received therefor.

It is also averred in the amended petition that the city supplies water to people outside of the city for domestic, commercial, and manufacturing purposes. If such supply to outsiders, or to be transported away from the city for commercial purposes, is sufficient in quantity to materially injure defendants in error, taking into consideration the size of the stream and water supply, the city, to that extent, is exceeding its right as a riparian proprietor.

The city having no right to materially diminish the flow of the water in the stream to the injury of defendants in error by supplying water to outsiders, or for commercial purposes to be transported to other parts, or to supply to its inhabitants for power purposes an unreasonable quantity, as above pointed out, it follows that if the city has materially diminished the flow of the water in the stream by so supplying water to outsiders or for transportation, or unreasonably for purposes of power, it is liable to respond in damages to the party injured thereby; but for the water consumed by the city for its own purposes, or so supplied to its inhabitants for domestic use, even though it received pay therefor, it is not liable.

'The water taken by the city from the stream for its own use, and so supplied to its inhabitants, is taken by virtue of its rights as a riparian proprietor, and not by virtue of the right of eminent domain, and therefore no compensation need be made therefor. * * *

The circuit court erred in affirming the judgment of the common pleas. Both judgments will be reversed, and the cause remanded for further proceedings.

Judgments reversed. ${ }^{22}$

22 Compare Barre Water Co. v. Carnes, 65 Vt. 626, 27 Atl. 609, 21 L. R. A. 769, 36 Am. St. Rep. 891 (1898).

\% An incorporated city purchased a piece of land on a river and sunk a 


\section{HAYES v. WALDRON.}

(Supreme Court of New Hampshire, 1863. 44 N. H. 580, 84 Am. Dec. 105.)

Case by Simon F. Hayes against Jeremiah W. Waldron, for discharging saw-dust and shavings from the defendant's mill into the Cochecho river, which ran through the plaintiff's meadows below the mill, and was accustomed to overflow them in times of high water, whereby the saw-dust and shavings, in times of high water, were carried and deposited on these meadows. The defendant's saw-mill, situate on his land on the river, was a belt mill, driven by water, and prior to 1847 the saw-dust had been carried by a belt and box into the wheel pit, whence it passed off through the tail race into the river. About 1857 the belt and box were changed so as to carry the saw-dust directly into the river opposite and back of the mill, which is some twenty feet from the river. At the river bank there is a bank wall some six feet high from the water, and the belt and box are some twelve or fifteen feet above the water, and extend just beyond the wall, so as to drop the saw-dust into the bed of the river. About 1852 the defendant put in a planing machine, and the shavings from it were carried away and burnt till July 4, 1958, when the defendant put in a belt and box similar to the other, and discharged the shavings into the river some twelve or fifteen feet below where the saw-dust was discharged. If there had been no belts and boxes to carry off the saw-dust and shavings, they would have fallen into a room under the mill, and not into the water. In the winter the saw-dust and shavings accumulated where they fell into the river, and were from time to time shoveled into the river directly, or through holes cut in the ice, 'if frozen. The testimony was somewhat corflicting as to the extent of the accumulations and the frequency of the removals. As bearing on the question whether such discharge of saw-dust and shavings into the river was a reasonable use of the stream by the defendant, he offered to show a uniform, long continued, uninterrupted and undisputed usage for water saw-mills, planing machines and shingle and clapboard machines to discharge their

large well within 100 feet of the stream in sandy soil. It does not clearly appear whether this land was within the eity limits. This well drew it: water from the river in such quantities as to interfere seriously with the mill of a lower riparian. The water was nsed by the city for municipa! purposes and for supplying its inhabitants for domestic and manufacturing purposes. Held, the lower rivarian may enjoin the withdrawal of the watter. The court, Brewer, J., said: "I city cannot be considered a riparian proprietor within the scope of the exrefition namerl [as to user for domes!ic purposes]. * * * The eity, as a corporation, mat own land on the banks, and thus in one sense, be a rifarian owner. Lut this loes not nake each citizen a riparian owner. And the corlolation is not talking the water tor its own domestic purposes: it is not an inrlividual; it has no natural wants: it is not taking for its own use but to supply a multitude of individuatis; it

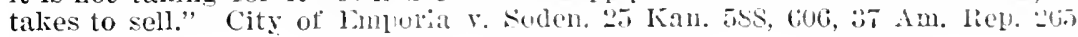
(1SS1).

See Swinden W. W. Co. r. Wilts, rtr.. I'anal Co., I, R. T Kuglish \& Irish

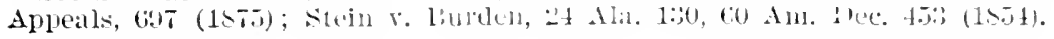


saw-dust, chips and shavings into the stream; to which the plaintiff objected, but the court overruled the objection.

Then a considerable number of witnesses, acquainted with saw-mills, some with many, others with few, in that vicinity, and also in other parts of the State, testified that in all the water saw-mills they ever knew the saw-dust was discharged into the streams. ***

[The jury returned a verdict for the defendant. The plaintiff moved to set it aside.]

BELLows, J.23 The charge was in substance that the defendant, being a riparian proprietor, was entitled to a reasonable use of the stream for manufacturing purposes; and whether it was a reasonable use to throw into the stream the saw-dust resulting from the process of manufacture, was a question of fact for the jury; and in determining that question the jury were required to keep in view that the plaintiff had a sinilar right to the reasonable use of the stream, which the defendant could not lawfully infringe; and they were further instructed that, in deciding whether the use by the defendant was reasonable, they were to take into consideration all the circumstances of the case, including the size and character of the stream, the nature and importance of the use claimed and exercised by the defendant, together with the inconvenience or injury to the plaintiff.

To these instructions we think there can be no objection; on the contrary, they are sustained by the general current of authority upon that subject.

But the plaintiff urges that, in accordance with his request, the court should have charged the jury that the defendant had no right to conduct his saw-dust and shavings into the river, if they did any injury to the plaintiff's lands below, and also, that he had no right to discharge them into the river, unless such discharge was necessary to the running of his mill; and it appears that the court declined to charge the jury in these terms, but did instruct them that each proprietor might use and apply the water, as it runs over his land, to domestic, agricultural, or manufacturing purposes, provided he uses it in a reasonable manner, and so as to work no actual or material injury to the others; and by actual or material injury is meant infringement of the right of others; and again, that the test is, not whether it produces some inconvenience or detriment to him, but whether it impairs the full and reasonable enjoyment of the stream that he is entitled to equally with the proprietor above.

Of these instructions we think the plaintiff has no cause to complain; nor do we perceive any error in declining to give the instructions prayed for, in the terms suggested.

As it is in respect to the abstraction, detention, and diversion of the water, so it is and must be in respect to the deposit of waste, or other

23 Part of the oplinion is omitted. 
substances in the stream, as incidental to its use in the various modes before described. In many or most of these modes of use such deposits are to some extent necessarily made. In the construction and repair of mills and dams, in the excavations required for their foundations, and in the frequent removal of the gravel used for tightening such dams. the water must for a time, and necessarily, be rendered so impure as to cause inconvenience occasionally to persons engaged in a kind of manufacture requiring pure water. But if such building and repairs are reasonably conducted, the inconvenience must be borne just the same, and for the same reasons, as the inconvenience caused by the temporary and reasonable detention of the water while filling the dam. So in the use of a stream for purposes of agriculture, such as wasliing sheep, crossing it with teams, allowing cattle and swine to traverse it, - the same principles will apply. So in the use of many kinds of mills, such as saw-mills, fulling-mills, cotton and woolen factories,there must be thrown into the stream more or less of the waste, such as saw-dust, soap-lees, and other impurities, and no ordinary care or prudence could prevent it. In the other cases such disposition of the whole waste, although not absolutely indispensable, would add great!y to the productive value of the mill power.

Whether, in either case, it may be rightfully done must depend upon. the question whether, under all the circumstances of the case, it is or is not a reasonable use of the stream; and in determining that question the extent of the benefit to the mill owner, and of inconvenience or injury to others, may, as stated in the charge, very properly be considered. So in respect to the size and character of the stream, it being obrious that an amount of diminution or pollution which would be insignificant in a large stream, might, in a snall one, be wholly destructive of the common right. So also, in determining the reasonableness of suffering the manufacturer's waste to pass off in the current, nuch must depend upon the use to which the stream below can be or is applied; whether as a mere highway alone, or for purposes of manufacture, requiring pure water, or for the supply of an aqueduct to a large city, as in the case of the Croton river; and in respect to the lands below adjacent to the river, the character of the banks, whether they are usually overflowed or not in high water, should be considered.

But it is urged that the court should have charged the jury, as requested by the plaintiff, that the defendant "had no right to discharge his saw-dust and shavings into the river, unless such discharge was necessary to the running of his mills." The question, however, was not whether the acts complained of were necessary to the enjoyment of the defendant's right, in the sense that without them it could not be enjoyed at all, but whether such acts were done in the reasonable use of the stream; and of course in deciding that question the jury should consider the necessity or importance of the right claimed so to discharge 
the waste, as well as the extent of the injury likely to be caused to the plaintiff. ${ }^{24}$

The plaintiff's counsel regards this discharge of the waste as an act by itself, distinct from the use of the mill, and likens it to the case of depositing the waste directly upon the plaintiff's land by means of teams or machinery provided for that purpose. To this view we are unable to assent, because the discharge of the waste into the streani, so far as it is reasonable, must be regarded as an incident of the right to use the stream for the manufacture which produces such waste, otherwise the act, if calculated to injure the proprietors below, could not be justified. In this respect it stands upon the same ground as the retardation or acceleration of the current in the proper and reasonable use of the mills.

Upon this point the court charged the jury to consider how far the use, if important, could be of practical value without the right claimed, and also the extent of the detriment, inconvenience, or injury to the owner below; and this we think goes as far as the plaintiff could rightfully ask.

The remaining question touches the admission of evidence of usage, as bearing upon the reasonableness of discharging the saw-dust and shavings into the stream. There are cases where the customs and usages of trade may be proved to aid in the construction of contracts, and in defining the obligations arising out of such trade. 1 Greenl. Ev., sec. 292; 2 Stark. Ev. 453, 456, and notes; Dunham v. Day, 13 Johns. (N. Y.) 40; Cutter v. Powell, 6 T. R. 320; Noble v. Kenoway, Doug. 510; Dolby v. Hiest, 1 P. \& B. 224; Renner v. Bank of Columbia, 9 Wheat. 581, 6 L. Ed. 166.

24 "Defendant shows that his mill is so constructed that the sardust and refuse cannot be otherwise disposed of, except by permitting it to fall into the stream, without practically destroying its value as a water-power mill; that owing to the construction of buildings adjacent to said mill, and the formation of the land thereabout, there is no other available method of disposing of this refuse without rendering the mill, as it now stands and is constructed, useless as such. Now, if he had gone one step further and shown that this was a proper way in which to locate and construct a sawmill, and that there was no other feasible and practical method of doing it, we would probably not have felt warranted in disturbing the decision of the trial court; at least, if it appeared that this stream was adapted to and useful for such saw-mill purposes. But we look in vain either in the evidence or special findings of the court for anything tending to show that this mill was properly located or constructed, or that there was any necessity for locating or constructing it as it now is. In the location and construction of his mill defendant was bound to anticipate and hare regard for any reasonable use to which others might or could put the stream. For anything that appear's in the erillence this mill conld have been so constructed as to render the casting of this refuse into the water wholly unnecessary. The necessity for doing so now may be wholly the result of defendant's own wrong or negligence in constructing this will in the manner or place he did. If so, it will not avail him to show that he cannot use the mill as now located and construrtrol in any other was." Red River Roller Mills v. Wright, 36 Minn. 249, 25t, 15 ‥ W. $16 \overline{6}, 169,41 \mathrm{Am}$. Rej. 194 (1853). 
But whether such customs and usages may or may not be proved to bear upon the question of reasonableness in a case jot growing out of any contract, upon which we give no opinion, we are satisfied that the court erred in admitting the proof of usage in the ease before us; upon the ground that the jury may be presumed to be already sufficiently informed as to what is a reasonable use of a water-course, as they are supposed to be as to what shall constitute a reasonable state of repair of a lighway; Itubbard v. Concord, 35 N. H. 60, 69 An. Dec. 520; Patterson v. Colebrook, 29 N. H. 94; or ivhat shall be considered a reasonable use of it by the traveller.

Our opinion therefore is that this does not belong to that elass of cases concerning navigation, trade, or manufactures, about which the jury may be supposed to require the aid arising from the proof of ctustoms or usages; but we think the admission of such evidence would be to open an extensive field of enquiry in this and similar cases, upon the same principle, that would tend greatly to increase the expenses of litigation, without affording in general any substantial aid to the jury.

The direction to the jury upon this point appears to have been based upon the highly respectable authority of Snow v. Parsons, 28 Vt. 459, $67 \mathrm{Am}$. Dec. 723, but upon a careful examination of the authorities we are unable to reconcile it with the course of our own courts upon that subject.

There must, therefore, be a new trial. ${ }^{25}$

25 B. was a riparian engaged in the mannfacture of white paper, in which process lie used the waters of the stream. A., 'ul upler riparian, dischilrged into the stream discolored water from his mine, which prevented $B$. from using the water for mamfacturing purposes. Ileld, B. may enjoin A. Beach r. Sterling Iron \& Zinc Co., 54 N. J. W. (i5, .3. Ati. 266 (1595). Acc.: Young v. Bankier Distillery, [159:] A. C. 6:01.

Acc., where the dischare from the mino roules the water mmosalo for domestic or aericultural purposis: Intae $v$ Lady Eusley Coal. Iron de lay.

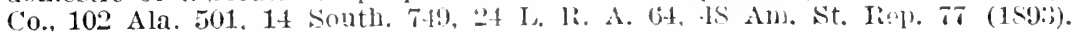

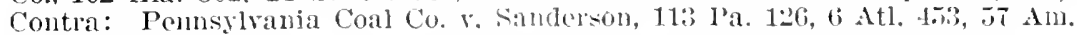
Rep. 445 (1S\&f).

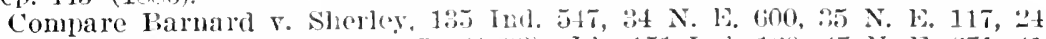

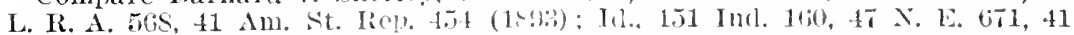
L. R. A. 7:7T (189S); Merriticlel v. City of Woreceter, 110 Mass. 216, 14 Am.

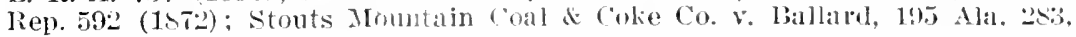
TO south. $172(1915)$.

"But the defemants contend that the lubintilis lave no risht to complain

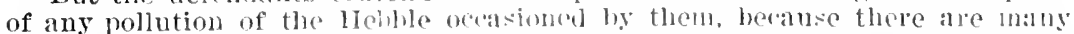

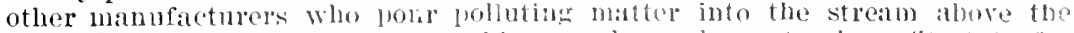
plaintiffs' works, so that they conld nerer have the water in a tit state for use, even if the defondinte allowether cessed to foul it. The rase of st.

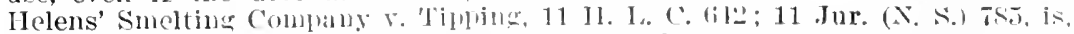

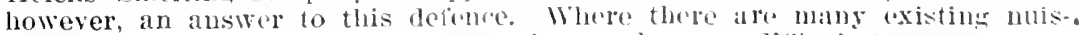
ances, either to the air, or to water. it mily be rery diflicult to lyace to its source the injury ocosioned by any une of them; but if the difondants ath

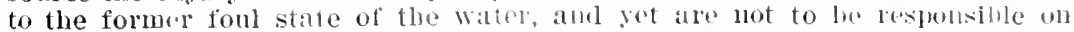
account of its previons comblition. this consugunder womla follow. that it the plaintiffs were to make terms with the ofher folluters of the straim so ats

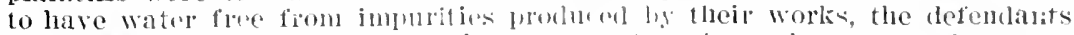
wight say: "We began to foul the strean at al time wheil, as aginst you, 


\section{STOCKPORT WATERIVORKS CO. v. POTTER.}

(Court of Exchequer, 1864. 3 Hurl. \& C. 300.)

[Action for fouling the water of the river Mersey.

For about fourteen years prior to 1853 the owners of the Woodbank estate, a riparian tract, had been in the habit of drawing water from what was called the Nab Pool weir, this being part of the riparian tract. The water so drawn was carried by tunnels and conduits to, and used to supply the town of, Stockport. In 1853 the owners of the Woodbank estate executed to the plaintiffs a deed under which the Stockport waterworks and the use of the conduits and tunnels were ceded to the plaintiff. The latter continued to draw the water in the same way up to the time of the bringing of this action, so that the user had been continuous for over 20 years. It was asserted by the plaintiffs and denied by the defendant that the right to take the water from the stream was also granted to the plaintiffs by the above mentioned deed.

That the defendant had unduly fouled the stream was to be taken for granted for the purposes of this decision.]

Brairwell, B. ${ }^{26} * * *$ Can a grantee from a riparian proprietor of land, part of the former riparian estate, but separated from the stream by land of the grantor not included in the grant, with a grant from the grantor of a right to lay pipes from the stream to the granted land and take water by means of them from the stream to such granted land, maintain an action against a person who fouls the stream? It is strange that this question should arise for the first time. There can be no doubt that the grant as between the riparian grantor and the grantee is good. And there is this to be said in favour of supporting the present claim, that we must suppose that the grantor and grantee have found the arrangement to be to their mutual advantage, that the stream can be more beneficially used this way than otherwise. Consequently that such an arrangement is for the public good. Why, then, should it not be effectual against a person, who as against the riparian proprietor is a wrongdoer? It imposes no additional burden on the riparians or others above. If they are wrongdoers by fouling now, so were they before. They could be restrained by injunction before if they can now. No doubt they might be made liable to larger damages than they would have been before, but their rights are not altered. It was said that innumerable actions might be brought if the

it was lawful for us to do so, inasmueh as it was untit for your use, and you eannot now, by getting rid of the existing pollutions from other sources, prevent our continuing to do what, at the time when we began, you had no right to objeet to." " Chelmsford, L. C., in Crossley \& Sons, Limited, v. Lightowler, L. R. 2 Ch. App. 478, 481 (1867).

Compare Ferguson v. Nirmenich Mfg. Co., 77 Iowa, 576, 42 N. W. 448, 14 Am. St. Rep. 319 (1Ss9).

26 The statement of facts is rewritten and parts of the opinions are omitted. 
law were as the plaintifis contend. But there are two answers to this, one practical, viz., that they would not be brought, the other that the same might happen now if the smallest portion of the bank was granted with the right. A similu answer may be given to the supposed difficulty of the riparian proprietors above desiring to buy up rights below. The power to make such a grant tien is for the benefit of the grantor and grantee, and the public; and the only prejudice by it to the riparian or wrongdoer above is the liability to greater damages anl to an action and injunction at the suit of persons additional to the riparians below. But this consideration could not preclude a covenant by the grantor that the grante misht apply in his name for an injunction or sue in his name, nor would it preclude a grant of the part of the bank where the water was taken, in which case it is clear the grantee might maintain an action or obtain an injunction. And this suggests to me the remark that what may be done indirectly ma be directly. Further, it does seem strange that if a man has an estate on the bank of a stream extending a mile from it, he may build houses on the land, conduct water from the stream to them, and maintain an action and recover substantial damages for the injury to each house: that his tenants of each, if he let them, might do the same even though he demised them for 1000 years at a peppercorn rent, but that if he grants away the house in fee with the right of water, such grantee can maintain no action. What is to happen if he does so and repurchases? What would be the case if a riparian proprietor added to his estate another, to which water had been so conducted? Suppose a riparian proprietor on both sides for a great length wholly alters the course of the stream, could he not effectually complain of a fouling of the water in the new course? Suppose besides the new course he allowed the old one to continue, the stream running in both, could he not then maintain actions for the damage done to either? If he could, could not his grantee of lands on the new stream, and if such grantee could, why cannot the plaintiffs?

If the defendants' argument is well founded, it will follow that where the owner of land on a stream has built a mill alongside the stream with a cut or lead to it, and sells the mill, but not the natural watercourse, the owner of the mill can maintain no action against a riparian owner above who abstracts the water. I cannot think this is so. Further, suppose the person fouling the water was not a riparian proprietor but a mere wrongdoer, why should not an action lie against him? I can see no reason, nor can I see that his being such proprietor makes any difference. Upon these various considerations it seems to me this action is maintrinable. I think it may fairly be asked to what extent I would carry the principle upon which I decide this: My answer is, to the extent to which the analogous case extends of a grantee of a right of way. Where a grantec of a right of way conld maintain an action for distullance of his way, so do I think the grantee of a right of water might. This case of the right of way, and 
cases of right of common, seem to me analogous to this case and authorities for my opinion. I am of course aware of the case of Keppeli v. Bailey, 2 Myl. \& K. 516, and agree that new rights of property cannot be created, but I think that rule does not interfere with the present case. There, an owner of land was resisting a burden put on it by a former owner, and it was held that burden could not be attached to the land in the hands of the assignee. Here, no doubt, it can be, that is to say, on the lands of the riparian proprietors, the Marsdens. The question is not with them, but with one who would be a wrongdoer if he had no riparian estate or occupation, and is not the less so because he has. Nor is Hill v. Tupper, 2 H. \& C. 121, any authority against the maintenance of this action. 'That case decided that in respect of what was no estate, and which gave no possessian, but merely a right of action, against a covenantor, that right could not be enforced against a third party. On the other hand, Whaley v. Laing, 3 H. \& N. 675, 901, seems a strong authority in favour of the plaintiff; for all the Judges seem to have considered that had the water been taken as of right the action would have been maintainable. I have only to add that, to my mind, this is not a question of easement or of dominant and servient tenement. The plaintiffs rely on the possession and enjoyment as of right, and charge the defendant as a wrongdoer, not the less because he is a riparian owner. I think the plaintiffs are entitled to judgment.

Port_ock, C. B. I am about to deliver the judgment of my Brother Channeli and myself. My Brother Wilde, being no longer a member of the Court, takes no part in the judgment; but it may be satisfactory to the profession to know that he had prepared a judgment founded on the principles which I am about to state. * * *

There is no doubt that if the plaintiffs have such rights in reference to the stream as to be entitled to insist upon its purity for practical purposes, the acts of the defendants constitute a cause of action.

But the defendants contend that, whatever others may have, the plaintiffs have no such rights. And they raise a variety of very formidable objections.

In the first place, the defendants argue that, although the right to pure water is the right of a riparian proprietor, the plaintiffs are not riparian proprietors at all. Nor are the plaintiffs the assignees of a riparian proprietor.

For, first, the law knows of no such right as the subject of assignment separate from the land in respect of which it arises, and, secondly, no such assignment has in fact been made.

And the defendants say there is no authority for the proposition that these rights in respect of water, which, in Embrey v. Owen, 6 Exch. 353 , and other modern cases have been for the first time defined and attributed to the ownership of land by the side of a river, can be dealt with in gross and assigned in any way except in conjunction with such land. 
And further, that if such rights could be the subject of transfer they have not been in fact transferred.

The defendants also say that the rights even of a riparian proprietor himself would not extend to the abstraction from the stream of water for the use of a populous town situated on land in no way comnecte? with such stream, and the conveyance of it away from the riverside to a considerable distance for that purpose without returning it into the stream.

But then the plaintiff's case, thus driven from a more exact basis, is placed upon the fact that he and those under whom he claims have done the same thing for twenty years.

To this the defendants answer that the mere doing of a particular thing for twenty years will not necessarily give a right of action against anybody who interferes with its being done as beneficially as it hitherto has been.

The plaintiffs, thus pressed, contencled before us that the right they claimed of having pure water come down the stream for them to abstract and use was an "easement" acquired by more than twenty years user, in which the Stockport Waterworks were the dominant tenement and the defendant's land the servient tencment.

But a conclusive answer as it seems to us, was given to such an easement.

The defendant's land is far higher up on the stream than the conduit or tunnel at Nab Pool Weir by which the plaintiffs abstract the water.

No amount of water abstracted by the plaintiffs or those under whom they claim could possibly be felt by the defendants. If the water was abstracted unlawfully or in excessive quantities, or not returned into the river the proprietors below might have cause to complain, but the defendants could not, because they could not be affected by it. They had neither the will nor the power to interfere with the plaintiffs' use nor to take legal proceedings against them.

No grant could therefore be presumed by the defendants because no user ever existed adverse to their full cnjoyment of the water. And Sampson v. Hoddinott, 1 C. B. N. S. 590, 611, was cited as an express authority for this proposition.

We have thus recapitulated these arguments of the defendants hecause they appear to us to contain a perfect answer to the plaintiffs' claim in whatever light it can be put.

It is difficult to perceive any possible legal foundation for a right to haie the river kept pure, in a person situated as this Company is.

There seems to be no authority for contending that a riparian proprietor can keep the land abutting on the river the possession of which gives him his water rights, and at the same time transfer those rights or any of them, and thus create a right in gross by assigning a portion of his rights appurtenant. 
It seems to us clear that the rights which a riparian proprietor has with respect to the water are entirely derived from his possession of land abutting on the river. If he grants away any portion of his land so abutting, then the grantee becomes a riparian proprietor and has similar rights. But if he grants away a portion of his estate not abutting on the river, then clearly the grantee of the land would have no water rights by virtue merely of his occupation. Can he have them by express grant? It seems to us that the true answer to this is that he can have them against the grantor but not so as to sue other persons in his own name for an infringement of them. The case of Hill v. Tupper, 2 H. \& C. 121, recently decided in this Court, is an authority for the proposition that a person cannot create by grant new rights of property so as to give the grantee a right of suing in his own name for an interruption of the right by a third party.

The case where a riparian proprietor makes two streams instead of one and grants land on the new stream, seems to us analogous to a grant of a portion of the river bank, but not analogous to a grant of a portion of the riparian estate not abutting on the river. In the case of a grant of land on a new stream, the grantee obtains a right of access to the river, and it is by virtue of that right of access that he obtains his water rights.

We think then that in this case the right claimed cannot be the subject of a grant so as to enable the plaintiffs to sue in their own name for an infringement.

Nor is the supposed easement founded on user much more defensible.

The dominant and servient tenements have no apparent connexion with one another.

The abstraction of the water from the stream took place at a spot situated on other land than that now called the dominant tenement, and in no sort of way affected the enjoyment of the water at what is now called the servient tenement.

Judgment for the defendants. ${ }^{27}$

$27 \times$. Was the lessec of a mill situated on riparian land, but not immediateIf on the stream. C., X.'s lessor, had an unsealed agreement with B., the riparian next ahove $C$., whereby in consideration of an annual payment, $C$. had dug and maintained a sluiceway through B.'s land to the mill on C.'s land, the water boing suhsequently riturned to the stream. The mill while in $\mathrm{I}$.'s possession continued to derive its water power from this source. A., a riparian above $13 .$, diverted stream. Held, $\mathbf{X}$. may maintain an action in bis own name against A. Nuttal v. Bracewell, L. R. 2 Exch. 1 (1S66).

X., a non-ripalian, drew water from the stream through a sluiceway to his mill. whence it was discharged into the stream by another sluice. $\mathrm{C}$., a riparian, elected a dam that backed the water into the lower sluice and stopped the mill wheel. $X$. brought action against $C$. The court said:

"The principln settled hy these and other decisions is, that one having the possession of property may maintain an action against a wrongloel for an injury thereto, which cannot be defeated by showing the title to be in some one else than the plaintiff.

"We sce no good reason why the principle should not be applicable to such a case as the present. The plaintift's action ought not to be barred, as we think. on the arnund that he had not aequired the right from the 


\title{
CHAPTER V
}

\section{SUREACE WATERS}

\author{
ELLRICH v. RICHTER. \\ (Supreme Court of Wisconsin, 15i5. 37 Wis. 226.)
}

Appeal from the Circuit Court for Winnebago County.

Action for damages for the alleged erection of a dam across a brook or water course, whereby it was alleged, that the defendant had caused the water to set back and overflow the plaintiff's land. Answer, a general denial. The testimony taken on the trial, for the most part, tended to show that the alleged brook was a ravine, through which surface water, which had gathered on the higher lands, ran during the melting of snows, and-after heavy rains, and sometimes during a large portion of the summer, but in no regular or defined channel, nor generally so as to hinder the growing of crops in the ravine on plaintiff's land; that the plaintiff had dug or plowed two ditches, one up and down the ravine, and one from his cellar, and run them under the line fence upon the defendant's land; that, thereupon, the plaintiff [defendant] had erected a dam to prevent the discharge of the waters from such ravine and ditches upon her land. The court instructed the jury in substance that, there being no substantial conflict in the testimony, as to the character of the stream, as a proposition of law, upon the testimony, the locus in quo is a water course; and the defendant owning land upon it, had no riglit to dam it up, and set the water back upon the upper proprietors, and was liable for the resulting damages.

COLE, J. We think the learned circuit court erred in charging as a proposition of law, that the locus in quo was a natural water course. The jury were told that there was no substantial conflict in the testimony with reference to the character of the stream, and that as a matter of law it was a water course, which the defendant had obstructed.

The definition of a water course, as given by Mr. Angell, and which has been substantially adopted by this court, is, a stream of water consisting of a bed, banks and water; though the water need not flow continually, and there are many water courses which are sometime!

riparian owners mentioned, to divert the water from its natural chamel He may be called upon by such owntus to respond in damiges for doing so But, whether he shall be or not. it is a matter that does not in the leas! concern the defendants." Eristol Hydraulic Co. v. Boyer, 67 Ind. :36, 240 (1S79).

Compare Williams r. Wadsworth, 51 Conn. 277 (1SS3); Wyman r. Oliver. 75 Me. 421 (1S83); St. Anthony Falls Water-lower Co. v. Mimneapolis. 41 Minn. 270,43 N. T. $56(1 \leqslant \varsigma 9)$. 
dry. There is, however, a distinction in law between a regular flowing stream of water, which at certain seasons is dried up, and those occasional bursts of water, which, in times of freshet, or melting of snow and ice, descend from the hills and inuridate the country. To maintain the character of a water course, it must appear that the water usually flows in a certain direction, and by a regular channel, with banks or sides. It need not be shown that the water flows continually; the stream may at times be dry; but it must have a welldefined and substantial existence. Angell on Watercourses, §4; Hoyt v. City of Hudson, 27 IVis. 656, 9 Am. Rep. 473; Fryer v. Warne, 29 Wis. 511.

According to our understanding of the testimony, there is considerable doubt whether it proves a water course, within this definition; or whether it did not appear that the water was mere surface water, descending from higher to lower ground, in no defined channel, in times of rain or the melting of snows and ice in the spring. If it was mere surface water, caused by rain or snow, which naturally flowed down the hollow or ravine, but in no defined natural channel having a bed and banks, then it was not a water course, and the defendant had the right to use such means as she might deem necessary to keep it off her land. For this court has adopted the common law rule, that the owner of the superior or higher ground has no natural easement or servitude to discharge mere surface water, such as falls or accumulates by rain or the melting of snow on his land, upon and over the land of his neighbor which may happen to be on a lower plane (Pettigrew v. Village of Evansville. 25 Wis. 223, 3 Am. Rep. 50; Hoyt v. City of Hudson, sunra); but that such neighbor has the right to obstruct or change the flow of such water by preventing it from coming within his boundaries.

There was testimony which tended to show that the flow of water down the hollow or ravine from the plaintiff's to the defendant's land was not in any regular channel; that it was only occasional, and did not prevent the cultivation of the ravine, or the growing of grass there. The plaintiff's land was rolling, and considerably higher than the defendant's, and of course all surface water caused by rains or the melting of snow was discharged from the higher through the lower ground. But there was testimony from which the jury might have found that this flow of water did not constitute a water course within the sense of the law; that it had no well-defined channel with a bed and banks, which extended from the land of the plaintiff upon and across the land of the defendant. And this question, whether there was a water course there or not, should, we think, have been submitted to the jury upon the evidence, instead of being decided as a proposition of law. Had there been no dispute as to the facts, nor any testimony which tended to show that the locus in quo was not a water course, and that the rights and duties of proprietors on such a stream had no application, the charge of the court might have been proper. But, upon the 
testimony, the question should have gone to the jury to determine whether there was a water course within the legal definition.

We shall go into no examination of the evidence at the present time, nor express any opinion as to what inference should be drawn from it. The facts of the case are not so clcar and undisputed as to warrant the court in withdrawing from the jury the question, whether the locus in quo was a natural water course.

We therefore think there must be a new trial.

By THE .Cour'T. The judgment of the circuit court is reversed, and a new trial awarded. ${ }^{1}$

\section{MACOMBER v. GODFREY.}

(Supreme Court of Massachusetts, 1871. 10S Mass. 219.)2

Tort for the diyersion of a water course by the defendant, whereby the water was prevented from flowing through the plaintiffs' land and irrigating their crops. Trial in the superior court, before Scudder, J., who made the following report thereof:

"The plaintifis' counsel, in his opening to the jury, stated that the evidence would show that from time immemorial a natural stream of water had flowed from a southerly direction across the road and upon the defendant's land, taking a northwesterly course across the defendant's land; that for a part of the way across the same it ran in a well-defined channel, but when it reached a point within about five rods of the plaintiffs' adjoining land the water spread out over the surface of the ground, covering a space a few rods in width, and so ran upon and across the plaintiffs' land, which was a level meadow, covering the same for several rods in width, and irrigating it in a valuable manner through its whole length: about seven rods, and thence on to other land of other owners beyond; that from the point where it so spread out over the surface on the defendant's land there was no defined channel either on the defendant's land or through the whole length of the plaintiffs' land, and not until a short distance beyond the plaintiffs' land, where it again formed a small brook, and ran off in a westerly direction to the river; that the plaintiffs' and defendant's lands

1 A creek furnishing the outlet to a lake was blocked by sand. Thereafter the waters of the lake, starting at the lowest part of the bank of the lake in a general northerly direction, worked over the flat marshy lands cut by low ridges, and overgrown by bushes to another creek. There was no defined waterway, but for most of the rear the water had a sufficient morement so that, if not interrupted, it would reach the second creek. The defendant erected a dike, as a consequence of which the water was kept off from his Tand and worked over onto land of the plaintiff, where it would not have gone but for the dike. Held, the plaintiff is entitled to an injunction asainst the maintenance of the clike. West v. Taylor, 16 Or. 165, $2: 5$ Pac. 665 (18ss). See, also, Gillett v. Johnson, 30 Conn. 180 (1861); Earl r. De Hart, 12 ‥ J. Eq. 250, 72 Am. Dec. 395 (1550); Boynton v. Gilman, 58 vt. 17 (1Ss0).

2 The statement and opinion on new trial are omitted. 
formerly belonged to the same ancestor, and the division was made after his death by quitclaim deeds; and that the defendant diverted this stream on his own land near to the road, where it was a water course running in a defined channel, turning it in a northerly direction so that it ceased to flow upon the plaintiffs' land, thus injuring their land and crops.

"Upon this opening statement, the judge ruled that the plaintiffs" action could not be maintained, and with the consent of parties reports the case before verdict for consideration by the supreme judicial court. If the above ruling is correct, judgment is to be entered for the defendant; if it is incorrect, the case to be sent back for trial."

Chaprian, C. J. The defendant admits the well-established principle, that, where there is a natural water course, each successive riparian proprietor has a right of property in it, and may maintain an action against one who diverts it from coming down to his land. But he contends that the facts stated in the report are not sufficient to establish the existence of such a water course. This is the only point now presented to us.

Ve cannot doubt that water which has flowed from time immemorial in a well-defined channel tiil it comes upon the defendant's land, and again after it has passed a short distance beyond the plaintiffs' land forms a brook, and thus runs across the land of several proprietors to a river, into which it empties, is a natural water course when it thus flows. But the defendant contends that because, at a point on his land about five rods above the plaintiffs' land, the water spreads out over the surface, covering a space of a few rods in width, and thus runs upon and across the plaintiffs' land, which is a level meadow, and covers the same for several rods in width, irrigating it in a valuable manner through its whole length, being about seven rods, and during this whole length of twelve rods has no defined channel, it ceases to be a water course, and is to be regarded as mere surface water, to the flow of which the plaintiffs have no right.

If the whole of the stream had sunk into the defendant's soil, and no water remained to pass to the plaintiffs' land except under the surface, it would have ceased to be a water course, and the plaintiffs would have had no right to it. Broadbent v. Ramsbotham, 11 Exch. 602. Buffum v. Harris, 5 R. I. 243. Or if the water had only flowed in temporary outbursts, caused by melting snow or by rain, it would have been surface water, as in Ashley v. Wolcott, 11 Cush. 192; the defendant might have diverted it, and the plaintiffs might have raised barriers on their land to prevent its flowing upon their lot below. Gannon v. Hargadon, 10 Allen, 106, 87 Am. Dec. 025; Franklin v. Fisk, 13 Allen, 211, $90 \mathrm{Am}$. Dec. 194. But where, owing to the level character of the land, it spreads out over a wide space without any apparent banks, yet usually flows in a continuous current, and passes over the surface to the lands below, it still continues to be a water course. Gillett v. Johnson, 30 Conn. 180. If the plaintiffs had erected 
a barrier to keep it from their land, it would evidently have accumulated, by its natural and regular flow, upon the defendant's land, not merely when there were melting snows or rains, but at all ordinary seasons. We cannot doubt that not only the defendant, but all the lower proprietors, could have maintained an action against the plaintiffs for any damage caused by such obstruction. For it has a regular and natural flow from a permanent source; and its usual course is in a channel, with a well-defined bed and banks, and neither upon the land of the plaintiffs or of the defendant does it entirely lose this character.

Case to stand for trial. ${ }^{3}$

\section{SCHAEFER v. MARTHALER.}

(Supreme Court of Minnesota, 18s6. 34 Minn. 487, 26 N. W. 726, 57 .Am. Rep. 73.)

Gilfillan, C. J. Action to enjoin defendant from draining a small lake or pond. The parties own and occupy adjoining lands. There is situated partly on the plaintiff's land and partly on defendant's land a body of water, four and one-fourth acres in extent, in a natural depression, forming a basin, fed solely by surface waters produced by rains and melting snows falling upon higher adjacent lands, and running naturally into such basin. The greater depth of the water in the basin, at the deepest place, is, at an ordinary stage, five feet, and at the same stage its greatest depth on the line between the lands of the parties is two and nine-tenths feet. The character of the soil under the basin is such that it retains the water, so that the only waste is from evaporation, except during ligh water, for six or eight weeks in the year, when it overflows through a natural channel situate on defendant's land. There is another natural channel on defendant's land, through which, during heavy rains, and when there is an accumulation of water on the high lands from melting snow, the water flows into the basin. The parties have owned and occupied their respective lands for 30 years, and the body of water has never, so far as known, been dry except at a time of extreme drought in the year 1864. In winter the water freezes to the bottom, but, by cutting through the ice, and digging into the mud at the bottom, water for stock can be obtained, in which manner plaintiff has often procured water for his stock.

There must be in this state a great number of bodies of water similar to this-some larger, some smaller-situate upon lands of different owners; so that the question involved is one of considerable im-

3Acc.: Mitchell v. Bain, 142 Ind. 604, 42 N. E. 230 (1895). Utherwise where the water spreads ont, but does not again form itself into a stream. Hawley v. Sheldon, 64 Vt. 491, 24 Atl. 717,33 Am. St. Rep. 941 (1892).

Big.RIghts-7 
portance. The question has never been before this court. In Bennett v. Murtaugh, 20 Minn. 151, (Gil. 135), an injunction against draining a small lake was sustained, but the point here raised was not presented.

The defendant claims the right to drain the lake or pond, on the proposition that it is surface water, (because coming into the basin, over the surface of adjacent lands, from rains and melting snows,) and that the rule applicable to surface waters applies. It is somewhat strange that, so far as we are able to ascertain, there is no case reported which decides the rights, with respect to such a body of water, of the different owners of the land on which it lies. The cases most nearly analogous are those relating to water courses. Under the common law there is a marked difference in the rules governing in cases of surface waters and those applicable to water courses; for one owner is under no obligation to receive upon his own land surface waters from the land of another, nor to permit them to flow from his land to that of another, nor to retain them on his land for the benefit of other lands. Such waters belong to or are a part of the land on which they happen to be at the time, and the owner may ordinarily do what he will with them while on his land, doing no unnecessary harm to others. But a natural water course is the common property of the lands through which it flows, to this extent: that no owner may arrest its passage, either to prevent its coming upon his own land or going to the land of another. It is regarded as an advantage or element of value to each piece of land through which it flows, which nature has bestowed upon it, and which belongs as much to one piece of land through which it runs as to another. When surface waters reach and become part of a natural water course, they lose their character of surface waters, and come under the rules governing water courses. Broadbent v. Ramsbotham, 11 Exch. 602; Earl v. De Hart, 12 N. J. Eq. 280, 72 Am. Dec. 395; Jones v. Hannovan, 55 Mo. 462; Swett v. Cutts, 50 N. H. 439, 9 Am. Rep. 276; Gibbs v. Williams, 25 Kan. 214, 37 Am. Rep. 241; Palmer v. IVaddell, 22 Kan. 352. But before they reach the water course, while they are still surface waters, - that is, while they are oozing through the soil, or diffusing or squandering themselves over the surface, following no defined course,the owner of the soil on which they happen to be may appropriate or divert them in the ordinary and reasonable use of his land. $\mathrm{He}$ is under no obligation to keep his land as a watershed, to feed the stream; nor to keep it as a receptacle to receive and retain the overflow from the stream. The waters pass beyond his right of appropriation as soon as they reach, even on his own land, the natural water course. His right in respect to the waters is then qualified, and must be exercised wilh due regard to the rights of others in the stream. And such waters, when they nave ceased to spread and diffuse over the surface or percolate through the soil; when they have lost their casual and vagrant character, and have reached and come to rest in a permanent mass or body, in a natural receptacle or reservoir, not spreading over or soak- 
ing into the soil, forming mere bog or marsh,-cannot be regarded as surface waters any more than they can be after they have entered into a stream. The mass or body of water constituting a lake or pond is an advantage or element of value to the land upon which nature has placed it, of the same kind as is the water course to the lands through which nature has caused it to flow. There is no reason which can be suggested why the stream should be the property of each on his own land, of all the lands through which it flows, and why one owner should not prevent its flow, as nature caused it to flow, upon the land of another, that is not equally applicable to a body of water like this; and none can be suggested why the rights of the owners of the lands upon which nature has placed it should not be equal to the rights in respect to a stream.

Applying the same rules that apply in respect to a water course, it would follow that no one is bound to keep his land as a watershed, to feed such a body of water; nor as a receptacle to retain the overflow from it; but that, in the reasonable and ordinary use or improvement of his land, he may interfere with or arrest the surface waters before they reach such body, or may drain off any bog or marsh on his land formed by the overflow, although the doing of either may incidentally affect the amount of water in the lake or pond. We therefore hold that defendant has not the right to drain off the lake.

Judgment affirmed. ${ }^{4}$

\section{THOMPSON v. NEW HAVEN WATER CO.}

(Supreme Court of Connecticut, 1913. S6 Conn. 597, 86 Atl. 555.)

[The defendant was an upper riparian proprietor; the plaintiff owned meadow land below the defendant, situate about 600 feet back from the river. In the spring freshets, the flood water of the river would frequently run down from the defendant's land to the plaintiff's meadow, fertilizing it by the sedimentary deposits. These freshets occurred only in winter and spring, and in some years there were none at all. Their frequency, when they did occur, varied from year to year. The defendant built a low dike and constructed a conduit upon its own land, which intercepted the freshet water and diverted it to the defendant's reservoir, thereby depriving the plaintiff's land of the benefit of these freshets. He sued to recover the damages so caused, and to enjoin the defendant from maintaining the embankment.

Judgment for the plaintiff; defendant appeals.]

4 The dissenting opinion of Perry, J., is omitted. Acc.: Alcorn v. Sadler, t6 6 Miss. 221, 5 Soutl. 694 (1S 59 ). See Hebron Gravel Road Co. v. Harvey, 90 Ind. $192,46 \mathrm{Am}$. Rep. 199 (18s3).

In Applegate v. Franklin, 109 Mo. App. 298, S4 S. W. 347 (1904), a body of water covering 2,500 acres and rarying in depth from 3 to 6 feet was held surface water. which an abutting owner might drain, even though so doing damaged another abutting owner. 
PRENTICE, C. J. ${ }^{5} * * *$ These definitions [of a water course] necessarily imply, what is more directly stated in others, that it is a distinguishing mark of a water course that there be "a supply which is permanent in the sense that similar conditions will always produce a flow of water, and that the conditions recur with some degree of regularity, so that they establish and maintain, for considerable periods of time, a running stream." Farnham on Waters and Water Courses, $\S 457$.

"Surface water" is a term which has been defined or used variously. A few of the definitions embody statements which would imply that it is a term appropriate to be applied to all fresh water upon the surface of the earth, not ponded, which is not that of a water course. Other authorities while giving a definition which affords no logical foundation for such a broad use of the term, act upon the assumption that all nonponded fresh water is either surface or stream water. The better and more generally stated definitions and those which permit a consistent application productive of just results confine surface water within more definite limits.

For instance, Amer. \& Eng. Ency. of Law (volume 30, p. 323) says: "Surface water may be defined as waters on the surface of the ground which are of a casual or vagrant character, following no definite course, and having no substantial or permanent existence, and which are lost by being diffused over the surface of the ground, through percolation into the soil or evaporation." Farnliam treats it as water appearing upon the surface of the ground in a diffused state, with no permanent source of supply or regular course, and then disappearing by percolation or evaporation. Section 878. Water is surface water while it is oozing through the soil or diffusing and squandering itself over the surface, following no defined course. Schaefer v. Marthaler, 34 Minn. 487,.26 N. W. 726, 57 Am. Rep. 73. These definitions are doubtless open to criticism, as where the means of disappearance are limited to percolation and evaporation, and natural drainage into water courses is ignored. But they serve to indicate that water moving in volume, whose source is a stream, is excluded, and that conditions presenting the general appearance upon the surface of the earth of those created by rain or snowfall are those intended to be embraced. There are cases which appear to limit the term to water which had its immediate source in rains or melting snow. Crawford v. Rambo, 44 Ohio St. 287, 7 N. E. 429. Others have properly included, as possible sources of surface water, springs upon or underneath the ground. Grand Junction Canal Co. v. Shugar, 6 L. R. Ch. App. 483, 486; Gray v. McWilliams, 98 Cal. 157, 32 Pac. 976, 21 L. R. A. 593, 35 Am. St. Rep. 163.

A considerable number of our cases have dealt with surface water.

* * * A study of these cases is convincing that the accepted con-

$\checkmark$ Part of the opinion is omitted. 
ception of surface water in this jurisdiction is one which is not sufficiently comprehensive to embrace flood water escaped from channels in large volume and flowing in masses to its destination in some larger and more permanent body.

Looking at the various phases which the freshet overflow of streams may assume, it is apparent that it may present the unmistakable indicia of either a water course or of surface water. The water which has overleaped the banks, confining the normal flow of the stream, may still go on its way in a well-defined channel. Its line of movement may present all of the recognized indications of a water course. The bed, banks, and flow may be there, so that the water clearly deserves to be regarded as either a part of the stream from whose main course it was turned aside, or, at least, an independent stream. On the other hand, the escaped water may have become so scattered and diffused over the adjoining territory and there taken on such a character as to present all the recognized characteristics of surface water. It is equally evident that this overflow may appear under such conditions that the requisites of a water course, according to our definition, are not present, and at the same time the characteristics of surface water, according to our accepted notions, are not discoverable.

We are thus presented with the important practical question as to whether we shall change our definitions so that the limits of the fields of the two classes shall be brought together, and the two be made comprehensive enough to include all nonponded fresh water, or shall recognize a third class between the two, to be dealt with independently, and with a sole regard for the conditions it may present. In substantially all, if not all, jurisdictions where there has been occasion to deal with conditions arising from flood water, the courts have felt under the necessity of finding a place for it, in one or the other of the two classes referred to, by some sort of expedient and at whatever cost of inconsistency. The result has been a most perplexing mediey of decisions which refuse to yield a satisfactory working rule. In some cases flood water has been made to masquerade as surface water; in more as a water course. The great struggle has been to so classify it that justice to the rights of parties under the given conditions might be done. When the classification has once been thus established, the difficulty has arisen that it fails, under another set of conditions, to lead to results consonant with justice, if accepted principles applicable to the class where the new conditions find themseives placed are observed. Then has come the necessity for legal gymnastics, if palpably right results were to be attained. A good illustration is furnished by ccrtain English cases. They have held that there was no good basis for distinction between the ordinary water of a stream and flood water. Menzies v. Breadalbone, 3 Bligh N. S. 414; Rex v. Trafford, 1 Barn. \& Adol. 874: And yet in the latter case, on appeal, the court did not hesitate to say that a landowner might raise the banks of a stream so 
that its waters might not escape as it had been accustomed to do. Trafford v. The King, 8 Bing. 204. ***

The questions which have arisen, where flood water conditions were involved, have usually grown out of the raising of the bank of the stream to prevent overflow, or the obstruction or diversion of the flood flow whereby it was cast back or thrown over upon the land of another proprietor in accumulated or accelerated volume to his damage. The rights of parties in such cases are not hard to find, and would not be difficult of definition, as applied to flood water alone. We have here, however, a very different question. It involves the right of a lower proprietor to have the natural flood flow continued to his land for the benefit which will be derived from it. This general subject is one which might be presented in various aspects. We have no occasion to attempt to anticipate all of them and formulate a rule applicable thereto. The case presents a comparatively simple situation, and we may well confine our 'attention to that.

The evidence discloses that the defendant, the upper proprietor, has not attempted to appropriate the flood water reaching its land in the improvement or enjoyment of such land, or to interfere with or affect the flow of the water for any purpose connected with that land. The embankment, in so far as appears or can be imagined, neither serves, nor was intended to serve, any useful purpose. The conduit, as it was when the damage for which recovery was permitted, was equally tiseless for any present purpose, except as it may have carried surface or flood water into the defendant's reservoir some distance away, and there made it available for sale. Whatever prospective purpose it had was, in connection with the defendant's business, carried on elsewhere, and the embankment was created as an incident of the conduit's construction. We thus have a situation in which the plaintiff was damaged in his property by an act of the defendant in interfering with the natural flow of the flood water, which had no justification in the improvement, use, enjoyment, or protection of its land. Damage done under such circumstance cannot, with due regard for property rights, be regarded as absque injuria. ***

There is no error. In this opinion the other Judges concurred. ${ }^{6}$

6 A., who had lawful access to a river, erected a diverting conduit, through which he proposed to conduct water to non-riparian land. The conduit was so constructed that it would not divert the ordinary thow of the stream or ordinary freshets, but only extraordinary floods in the rainy season. Held, B., a lower riparian, has no right of action in the lack of a showing that this diversion will damage him. Gallatin v. Corning Irrig. Co., $163 \mathrm{Cal}$. 405, 126; Pac. S6t, Ann. Cas. 1914A, 74 (1912).

B. owned land bordering on the Ohio river below that of A. B. had planted a thick row of trees along the boundary between the two tracts. Prior to the growth of these trees the annual flood water of the Ohio river would sweep over the land of $\mathrm{A}$. unobstructedly. As the trees increased in size, they formed a barrier l,y means of which floating timber and other trash carried down by these floods were arrested and kept back on the land of $\mathrm{A}$. As a consequence of the barrier so formed, the flood waters stayed longer on the land, and trash and sand were deposited there, so that much of the 


\section{BARKLEY v. WILCOX.}

(Court of Appeals of New York, 18s1. S6 N. Y. 140, 40 Am. Rep. 519.)

Appeal from a judgment entered below in favor of defendant.

This action was brought to recover damages for injuries alleged to have been sustained by the obstruction of the natural flow of surface water from plaintiff's lot over and across that of defendant.

ANDREwS, J. ${ }^{7}$ This is not the case of a natural water course. A natural water course is a natural stream flowing in a defined bed or channel, with banks and sides, having permanent sources of supply. It is not essential to constitute a water course that the flow should be uniform or uninterrupted. The other elcments existing a stream does not lose the character of a natural water course, because in times of drought the flow may be diminished or temporarily suspended. It is sufficient if it is usually a stream of rumning water. Ang. Water Courses, $\S 4$; Luther v. Winnisimmet Co., 9 Cush. (Mass.) 171.

The parties in this case own adjacent lots on a street near a village, but not within the corporate limits. The findings are that the natural formation of the land was such that surface water from rains and melt- ing snows would descend from different directions and accumulate in the street in front of the plaintiff's lot, in varying quantities, according to the nature of the seasons, sometimes extending quite back upon the plaintiff's lot; that in times of unusual amount of rain, or thawing snow, such accumulations, before the grading of the defendant's lot, were accustomed to run off over a natural depression in the surface of the land across the defendant's lot, and thence over the lands of others, to the Neversink river; that when the amount of water was small it would soak away in the ground; that in 1871 the defendant built a house on his lot, and used the earth excavated in digging the cellar to

land was ruined. Held, these flood waters are surface waters and $A$. has no cause of action. Taylor v. Fickas, 64 Ind. 167, 31 Am. Rep. 114 (1S78). Acc.: Cass v. Dicks, 14 Wash. 75,44 Pac. 113, 53 Am. St. Rep. 859 (1846). Contra: Pinkstaff v. Steffy, 216 Ill. 406, 75 N. E. 163 (1905).

A railroad built a bridge across a river passing through low country. Culverts in the embankment built by it for its roadbed were not of sulficient size to permit ordinary flood waters to get back to the river, and as. a result the flood waters were backed up against upper rilurians to their damage. Held, the railroad is liable to the upper riparians for the damage so caused. Sullens v. Chicago, R. I. \& P. Ry. Co., 74 Iowa, 659, 35 N. W. 545, 7 Am. St. Rep. 501 (1SSs); Abbott v. Kansas City, St. J. \& C. B. Ry. Co., S3 Mo. 271. 53 Am. Iep. 581 (1S54) (ovelruling and discussing earlier Mis. souli cases); Fordham v. Nortlern Pac. Ry. Co., 30 Mont. 421, 76 Pac. 1040, 66 I. R. A. 556,104 Am. St. Rep. 729 (1904) ; Uhl v. Ohio River R. Co., 56 W. Va. 494, 49 S. E. 378,68 L. R. A. 13S, 107 Am. St. Rep. 968, 3 Ann. Cas. 201 (1904).

See Missouri Pacific Ry. Co. v. Keys, 55 Kan. 205, 40 Pac. 275, 49 Am. St. Rep. 249 (1895).

As to the liability of a railroad in case of extraoldinary flood waters, see O'Connell v. East Temnesser, V. \& G. Hy. Co., S7 Ga. 246, 13 S. E. 489, 13 L. R. A. 394,27 Am. St. Rep. 246 (1891).

7 Part of the opinion is omitted. 
improve and better the condition of his lot, by grading and filling up the lot and sidewalk in front of it, about twelve inches, and on a subsequent occasion he filled in several inches more; that in the spring of 1875 there was an unusually large accumulation of water from melting snow and rains in front of and about the plaintiff's premises, so that the water ran into the cellar of his house and occasioned serious damage; that the filling in of the defendlant's lot had the effect to increase the accumulation of water on the plaintiff's lot, and contributed to the injury to his property.

There was no natural water course over the defendant's lot. The surface water, by reason of the natural features of the ground, and the force of gravity, when it accumulated beyond a certain amount in front of the plaintiff's lot, passed upon and over the lot of the defendant. The discharge was not constant or usual, but occasional only. There was no channel or stream in the usual sense of those terms. In an undulating country there must always be valleys and depressions, to which water, from rains or snow, will find its way from the hill-sides and be finally discharged into some natural outlet. But this does not constitute such valleys or depressions water courses. Whether, when the premises of adjoining owners are so situated that surface water falling upon one tenement naturally descends to and passes over the other, the incidents of a water course apply to and govern the rights of the respective parties so that the owner of the lower tenement may not, even in good faith and for the purpose of improving or building upon his own land, obstruct the flow of such water to the injury of the owner above, is the question to be determined in this case.

This question does not seem to have been authoritatively decided in this state. It was referred to by Denio, Ch. J., in Goodale v. Tuttle. $29 \mathrm{~N}$. Y. 467, where he said: "And in respect to the running off of surface water caused by rain or snow I know of no principle which will prevent the owner of land from filling up the wet and marshy places on his own soil, for its amelioration and his own advantage, because his neighbor's land is so situated as to be incommoded by it. Such a doctrine would militate against the well-settled rule that the owner of land has full dominion over the whole space above and below the surface." The case in which these observations were made did not call for the decision of the question, but they show the opinion of a great judge upon the point now in judgment. Similar views have been expressed in subsequent cases in this court, although in none of them it seems was the question before the court for decision. Vanderwiele v. Taylor, 65 N. Y. 341 ; Lynch v. Mayor, 76 N. Y. 60, 32 Am. Rep. 271.

The question has been considered by courts in other states, and has been decided in different ways. In some, the doctrine of the civil law has been adopted as the rule of decision. By that law, the right of drainage of surface waters, as between owners of adjacent lands, of different elevations, is governed by the law of nature. The lower proprietor is bound to receive the waters which naturally flow from the 
estate above, provided the industry of man lias not created or increased the servitude. Corp. Jur. Civ. 39, tit. 3, §§ 2, 3, 4, 5; Domat (Cush. Ed.), 616; Code Napoléon, art. 640; Code Louisiana, art. 656. The courts of Pennsylvania, Illinois, California and Louisiana have adopterl this rule, and it has been referred to with approval by the courts of Ohio and Missouri. Martin v. Riddle, 26 Pa. 415, note; Kauffman v. Griesemer, id. 407, 67 Am. Dec. 437; Gillham v. Madison Co. R. Co., 49 I1l. 484, 95 Am. Dec. 627; Gormley v. Sanford, 52 Ill. 158; Ogburn v. Connor, 46 Cal. 346, 13 Am. Rep. 213; Delahoussaye v. Judice, 13 La. Ann. 587, 71 Am. Dec. 521; Hays v. Hays, 19 La. 351; Butlerv. Peck, 16 Ohio St. 335, 88 Am. Dec. 452; Laumier v. Francis, 23 Mo. 181. On the other hand, the courts of Massachusetts, New Jersey, New Hampshire and Wisconsin have rejected the doctrine of the civil law, and hold that the relation of dominant and servient tenements does not by the common law apply between adjoining lands of different owners, so as to give the upper proprietor the legal right, as an incident of his estate, to have the surface water falling on his land. discharged over the land of the lower proprietor, although it naturally finds its way there; and that the lower proprietor may lawfully, for the improvement of his estate and in the course of good husbandry, or to make erections thereon, fill up the low places on his land, although by so doing he obstructs or prevents the surface water from passing thereon from the premises above, to the injury of the upper proprietor. Luther v. Winnisimmet Co., 9 Cush. (Mass.) 171; Parks v. Newburyport, 10 Gray (Mass.) 28; Dickinson v. Worcester, 7 Allen (Mass.) 19; Gannon v. Hargadon, 10 Allen (Mass.) 106, 87 Am. Dec. 625; Bowlsby v. Speer, 31 N. J. Law, 351, S6 Am. Dec. 216; Pettigrew v. Evansville, 25 Wis. 223, 3 Am. Rep. 50; Hoyt v. Hudson, 27 Wis. 656, 9 Am. Rep. 473; Swett v. Cutts, 50 N. H. 439, 9 Am. Rep. 276. It may be observed that in Pennsylvania, house lots in towns and cities seem to be regarded as not subject to the rule declared in the other cases in that state, in respect to surface drainage. Bentz v. Armstrong, 8 Watts \& S. 40, 42 Am. Dec. 265.

Upon this state of the authorities, we are at liberty to adopt such rule on the subject as we may deem most consonant with the demands of justice, having in view on the one hand individual rights, and on the other the interests of society at large. Upon consideration of the question, we are of opinion that the rule stated by Denio, C. J., in Goodale v. Tuttle, is the one best adapted to our condition, and accords with public policy, while at the same time it does not deprive the owner of the upper tenement, of any legal right of property. The maxim, aqua currit et debet currere ut currere solebat, expresses the general law which governs the rights of owners of property on water courses. The owners of land on a water course are not owners of the water which flows in it. But each owner is entitled by virtue of his ownership of the soil to the reasonable use of the water as it passes his premises, for domestic and other uses, not inconsistent with a like reasonable use of the 
stream, by owners above and below him. Such use is inciden to his right of property in the soil. But he cannot divert or unreasonably obstruct the passage of the water, to the injury of other proprietors. These familiar principles are founded upon the most obvious dictates of natural justice and public policy. The existence of streams is a permanent provision of nature, open to observation, by every purchaser of land through which they pass. The multiplied uses to which in civilized society the water of rivers and streams is applied, and the wide injury which may result from an unreasonable interference with the order of nature, forbid an exclusive appropriation, by any individual, of the water in a natural water course, or any unreasonable interruption in the flow.

It is said that the same principle of following the order of nature should be applied between coterminous proprietors, in determining the right of mere surface drainage. But it is to be observed that the law has always recognized a wide distinction between the right of an owner to deal with surface water falling or collecting on his land, and his right in the water of a natural water course. In such water, before it leaves his land and becomes part of a definite water course, the owner of the land is deemed to have an absolute property, and he may appropriate it to his exclusive use, or get rid of it in any way he can, provided only that he does not cast it by drains or ditches, upon the land of his neighbor; and he may do this, although by so doing he prevents the water reaching a natural water course, as it formerly did, thereby occasioning injury to mill-owners, or other proprietors on the stream. So also he may by digging on his own land, intercept the percolating waters which supply his neighbor's spring. Such consequential injury gives no right of action. Action v. Blundell, $12 \mathrm{M}$. \& W. 324; Rawstron v. Taylor, 11 Exch. 369 ; Phelps v. Nowlen, 72 N. Y. 39, 28 Am. Rep. 93.

Now in these cases there is an interference with natural laws. But those laws are to be construed in connection with social laws and the laws of property. The interference in these cases with natural laws is justified, because the general law of society is, that the owner of land has full dominion over what is above, upon or below the surface, and the owner in doing the acts supposed is exercising merely a legal right. The owner of wet and spongy land cannot, it is true, by drains or other artificial means, collect the surface water into channels, and discharge it upon the land of his neighbor to his injury. This is alike the rule of the civil and common law. Corp. Jur. Civ. 39, tit. 3, $\S \S 2,3,4,5$; Noonan v. Albany, 79 N. Y. 475, 35 Am. Rep. 540; Miller v. Laubach, $47 \mathrm{~Pa}$. 154, $86 \mathrm{Am}$. Dec. 521. But it does not follow, we think, that the owner of land, which is so situated that the surface waters from the lands above naturally descend upon and pass over it, may not in good faith, and for the purpose of building upon or improving his land, fill or grade it, although thereby the water is prevented from reaching it, and is retained upon the lands above. 
There is a manifest distinction between casting water upon another's land, and preventing the flow of surface water upon your own. Society has an interest in the cultivation and improvement of lands, and in the reclamation of waste lands. It is also for the public interest that improvements shall be made, and that towns and cities shall be built. To adopt the principle that the law of nature must be observed in respect to surface drainage would, we think, place undue restriction upon industry and enterprise, and the control by an owner of his property. Of course in some cases the opposite principle may cause injury to the. upper proprietor. But the question should, we think, be determined largely upon considerations of public policy and general utility. Which rule will on the whole best subserve the public interests, and is most reasonable in practice? For the reasons stated, we think the rule of the civil law should not be adopted in this state. The case before us is an illustration of the impolicy of following it. Several house lots (substantially village lots) are crossed by the depression. They must remain unimproved if the right claimed by the plaintiff exists. It is better we think to establish a rule which will permit the reclamation and improvement of low and waste lands, to one which will impose upon them a perpetual servitude, for the purpose of drainage for the benefit of upper proprietors. We do not intend to say that there may not be cases which, owing to special conditions and circumstances, should be exceptions to the general rule declared.

But this case is within it, and we think the judgment below should be affirmed. All concur.

Judgment affirmed. ${ }^{8}$

\section{GORMLEY v. SANFORD.}

(Surreme Court of Illinois, 1869. 52 Ill. 15s.)

LAWRENCE, J. ${ }^{9}$ This was an action on the case, brought by Sanford against Gormley, for wrongfully obstructing a channel by which, as claimed by plaintiff, his land was drained. Sanford owned certain lots in block 3, in the city of Morris. Grundy county, numbered 11, 12 and 13 , and Gormley owned lots 5,6 and 7 , in the same block, situated south of Sanford's lots, and separated from them by an alley. In Nay, 1867, Gormley deposited upon the rear part of his lots, near the

sAcc.: Gibbs v. Williams. 25 Kin. 214.37 Am. Rep. 241 (1Ss1); Bates v. Smith, 100 Mass. 181 (1Sts).

Acc., as to railroad embankments: Walker v. New Mexico \& S. P. R. R., 165 U. S. 593, 17 Sup. Ct. 4D1, 41 L. Ed. S37 (1S97); Morrison v. Bucksport \& B. R. R., 67 Me. $.5 \%$ (1S77). See, also, eases cited in note to Thompon. $\checkmark$ New Haven Water Co.. ante, p. 1"'.'.

A. drained his land, thereby cutting off surface water, which formery flowed over and irrigated B.'s land. Ifeld, B. has no cause of action. even though his land is damaged by the cutting off of the water. Rawstrom $r$. Taylor, 11 Exch. 369 (1555) ; Broadhent v. Ramsbotham, 11 Exch. 602 (1556).

9 The statement of facts and part of the opinion aíe omitted. 
alley a quantity of earth, which he had taken from an adjoining coal shaft. At that time Sanford had upon his lots a large number of grape vines which had been planted two years before, about two hundred of which, together with a few young fruit trees, died in the spring of 1867, and he insists, their death was caused by the water thrown back on the rear of his lots by the deposit of earth on Gormley's lots, across which he claims a right of drainage, as being what the civil law terms the lower or servient heritage. The jury found a verdict for the plaintiff, allowing him $\$ 1,500$ damages, and the defendant appealed.

It is admitted that the water which flowed from Sanford's to Gormley's land, the obstruction of which is the basis of the action, is wholly surface water, consisting of rain which fell upon the land itself, or of snow falling and melting there, and much of the argument has been addressed to the question, whether the same law in regard to drainage, which applies to well-defined water courses, is applicable to cases of this character.

This question has already been decided by this court in Gillham v. Madison County R. R. Co., 49 I11. 484, 95 Am. Dec. 627, not reported. and probably not within the knowledge of counsel, when this case was argued. In the opinion filed in that case, we said, although there was a conflict of authorities among the courts of this country, yet the rule forbidding the owner of the servient heritage to obstruct the natural flow of surface waters, was not only the clear and well-settled rule of the civil law, but had been gencrally adopted in the common-law courts, both of this country and of England. Various cases bearing upon each side of the question are cited in that opinion, and it is not necessary to cite them again. This rule was thought by this court, in that cause, to rest upon a sound basis of reason and authority, and was adopted. We find nothing in the argument, or authorities presented in the present case, to shake our confidence in the conclusion at which we then arrived. In our judgment, the reasoning which leads to the rule forbidding the owner of a field to overflow an adjoining field by obstructing a natural water course, fed by remote springs, applies, with equal force, to the obstruction of a natural channel through which the surface waters, derived from the rain or snow falling on such field, are wont to flow. What difference does it make, in principle, whether the water comes directly upon the field from the clouds above, or has falleri upon remote hills, and comes thence in a running stream upon the surface, or rises in a spring upon the upper field and flows upon the lower? The cases asserting a different rule for surface waters and running streams, furnish no satisfactory reason for the distinction.

It is suggested in the a'rgument, if the owner of the superior heritage has a right to have his surface waters drain upon the inferior, it would follow that he must allow them so to drain, and would have no right to use and exhatsst them for his own benefit, or to drain them in a different direction. We do not perceive why this result should follow. The right of the owner of the superior heritage to drainage is based 
simply on the principle that nature has ordained such drainage, and it is but plain and natural justice that the individual ownership arising from social laws should be held in accordance with pre-existing laws and arrangements of nature. As water must flow, and some rule in regard to it must be established where land is held under the artificial titles created by human law, there can clearly be no other rule at once so equitable and so easy of application as that which enforces natural laws. There is no surprise or hardship in this, for each successive owner takes with whatever advantages or inconveniences nature has stamped upon his land. We find no error in the instructions of the court upon this branch of the case.

It is urged, however, that this rule, even if justly applicable to agricultural lands, should not be applied to city lots. Where a city has established an artificial grade, and provided an artificial sewerage, of which property owners can reasonably avail themselves, we should probably hold it their duty to do so, and so the court substantially instructed in the present case. But this was not the state of facts in reference to this property, so far as disclosed by this record. The lots lie in a very thinly populated addition to the city of Morris, and those belonging to plaintiff were used for the purpose of fruit growing, while defendant mined coal upon his. ${ }^{10} * * *$

[The judgment was set aside upon other grounds.]

\section{YEREX v. EINEDER.}

(Supreme Court of Michigan, 1891. S6 Mich. 24, 48 N. W. S75, 24 Am. St. Rep. 113.)

Morse, J. ${ }^{11}$ The plaintiff owns the E. $1 / 2$ of the S. W. $1 / 4$ of section 22 , township $8 \mathrm{~N}$., of range $12 \mathrm{E}$., in Lapeer county. The defendant owns the IV. $1 / 2$ of the same quarter, same section, township, and range. It was claimed by plaintiff that the water from the lowlands of defendant - a marsh or swamp-was diverted from its natural flow, and carried upon the lands of plaintiff, to his damage, by means of a ditch dug upon defendant's premises. The action was commenced in justice court, where plaintiff had judgment. Upen appeal to the circuit court, verdict and judgment passed for the defendant. The plaintiff brings error.

The testimony showed that the swamp on defendant's land was a part or neck of a large swamp, which contained over 300 acres. The

10Acc.: Farkas v. Towns, 103 Ga. 150, 29 S. E. 700, 68 Am. St. Rep. z8 (1S97) ; Boyd v. Conklin, 54 Mich. 5S2, 20 N. W. 595, 52 Am. Rep. S31 (1SSt); Garland v. Aurin, 103 Tenn. 555,53 S. W. $940,4 S$ L. R. A. 862 , 76 Am. St. Rep. 699 (1S99).

Compare Little Rock \& Ft. S. Ry. Co. v. Chapman, 39 Ark. 463, 43 Am. Rep. 280 (1S82), and Morlissey v. Chicago, B. \& Q. R. Co., 38 Neb. 406, 56 N. W. 946,57 N. W. 522 (1893).

11 Part of the opinion is omitted. 
natural outlet of this swamp was into Little brook, and from thence into Mill creek, away from plaintiff's land. The testimony on the part of the plaintiff was to the effect that, although the neck of the swamp upon defendant's land came within about 20 rods of his premises, there was a ridge between such premises and the swamp, which, in the absence of the ditch, prevented any water from the swamp overflowing, even in times of high water, upon plaintiff's land. After passing this ridge, the land of defendant sloped towards plaintiff's land, which, adjoining defendant's premises, was lower than the land of defendant. It was conclusively shown that there was never any natural water course, with defined banks, running from the swamp to plaintiff's land. $* * *$

The defendant introduced testimony tending to show that, in a state of nature, the water from the neck of this swamp flowed upon plaintiff's land, especially in seasons of high water; that the defendant built a dam at the lowest place in the swamp, where this water ran towards plaintiff's land, which confined the waters more closely to the swamp: that the ditch did not quite come up to this dam, and that the water which ran into the ditch flowed around the dam, and thus reached the ditch; and that no more water went upon plaintiff's premises from the swamp, with the dam and ditch in existence, than flowed there before without them; and some of the witnesses testified that the quantity of water reaching plaintiff's land was less than it would have been had not the dam and ditch been constructed. But there was no testimony disputing the fact that this ditch collected the water, and precipitated it upon plaintiff in such a manner that it prevented a large amount of it from soaking into or spreading out over defendant's land, when without the ditch the water could not reach plaintiff's premises, except as it did so by spreading out and overflowing defendant's land, and until by such spreading and overflow it reached the land of plaintiff. In other words, it is practically undisputed in the record that the digging of this ditch carried the water from this swamp in a different and unusual manner from which it possibly could have reached it naturally, and that the water thus thrown upon it damaged his land, while it reclaimed some of defendant's. The defendant testified that he made the ditch in the first place so that he would be enabled to work the rest of the place to cultivate it. "Until I made the ditch, I could not work it. The ditch kept the water together, so that I could get a chance to work the rest of the land." "I couldn't work it till I cut the ditch, because it would overflow the whole place. $* * *$ Question. After that ditch was dug, wouldn't it take the water from the overflow of the swamp at once onto Yerex's land, and prevent it from overflowing on your land, and soaking him? Answer. Yes, sir. Q. And that was the object of digging the ditch, wasn't it, on your part? A. Yes; that was the object on my part."

Such being the record, it was error to permit the defendant to show that the digging of this ditch was an act of good husbandry. The de- 
fendant, as said in Gregory v. Bush, 64 Mich. 42, 31 N. IV. 90; 8 Am. St. Rep. 797, could not, "by artificial drains or ditches, collect the waters of stagnant pools, sagholes, basins, or ponds upon his premises, and cast them in a body upon the proprietor below him, to his injury." And he could not reclaim his land by transferring the overflow from his land to that of plaintiff's. "He could not collect and concentrate such waters, and pour them in an artificial ditch, in unusual quantities, upon his adjacent proprietor." Id., 64 Mich. 44, 31 N. W. 94, 8 Am. St. Rep. 797. What the defendant did, by his own showing, was to transfer his wet and untillable land to his neighbor by the digging of an artificial ditch, and carrying the water at once upon plaintiff's land, so that it would not overflow or percolate his own soil. This he had no right to do under any circumstances, and whether or not it was good husbandry upon his part to do so was entirely immaterial. We are at a loss to understand how the jury, under the evidence and charge of the court, which was mainly correct, could have found for the defendant, unless they were prejudiced by the admission of this testimony, which had no business in the case.

The court, we also think, should have given the plaintiff's second request, as follows: "(2) From the undisputed evidence in this case, the fact has been established that, by means of the dead furrow and ditch constructed by defendant, the water has been prevented from percolating through and settling in the lowlands of defendant next to the swamp, and has been caused to flow through the dead furrow and ditch onto plaintiff's lands in quantities at times greater than it would have flowed on plaintiff's lands if there were no ditch or dead furrow, and that said plaintiff was damaged thereby, and your verdict, therefore, will be for the plaintiff."

The judgment is reversed, and a new trial granted, with costs of this court to plaintiff. The other justices concurred. ${ }^{12}$

\section{MANTEUFEL v. WETZEL.}

(Supreme Court of Wisconsin, 1907. 133 Wis. v19, 114 N. W. 91, 19 L. R. A. [N. S.] 16T.)

Timlin, J. ${ }^{13}$ Only one question is necessary to be considered. It is established by the findings that the parties own adjoining lands. There is on the defendant's land and about 700 feet west of the plaintiff's land a sink hole, or depression, which in wet seasons and before the construction of the ancient ditch contained about three acres of

12Acc.: Livingston v. McDonalel. 21 Iowa, 160, 89 Am. Dec. 563 (1866i); Miller v. Laubach. 47 Pa. 154, 86 Am. Dec. 521 (1864). A fortiori is such throwing off of surface water actionable when there is no natural drainage to the plaintiff's land. Schuster v. Albrecht, 9S Wis. 241, 73 N. W. 990, 67 Am. St. Rep. So4 (1898).

13 Part of the opinion is omitted. 
water 'of the average depth of $1 \frac{1 / 2}{2}$ feet, and between this sink hole or depression and the land of the plaintiff there is upon the land of the defendant at a point distant from the common boundary an elevation of about three feet. More than 20 years prior to the commencement of this action the predecessor in title of the defendant cut through this elevation by a ditch, so that the surface water which formerly collected in such depression passed through said ditch and to a point upon defendant's land about 150 feet west of the common boundary, where it spread over defendant's land and escaped by the natural course of surface water on to the land of the plaintiff. The said sink hole or depression is a natural basin or reservoir without natural outlet which is capable of holding, and which, in fact, did collect, receive, and hold, large quantities of surface water which fell and gathered upon lands of the defendant and adjacent land in the vicinity of said depression. and the surface water so collected remained standing in said depression until the same disappeared by evaporation, absorption by the earth, or was removed therefrom by means of said ancient ditch or artificial outlet to the point aforesaid upon the defendant's land. In May, 1904, the defendant, following the natural course of the surface water, excavated on his own land a shallow ditch from the termination of said ancient ditch to the common boundary between plaintiff and defendant, and, as a direct result thereof, the surface water from said depression has passed through the ancient ditch and through the extension thereof just mentioned to the plaintiff's land, and has been deposited on the plaintiff's land in greater quantities and with much greater rapidity and force thambefore, and has thereby rendered about four or five acres of the plaintiff's land too wet for ordinary use as agricultural land, and of less value than formerly, and in the year 1904 caused a washout upon the lands of the plaintiff of about 45 feet in length by 7 feet in width, and 3 feet in depth. Upon these facts, the court below held that the ancient ditch extending from the sink hole or depression on defendant's land to a point on defendant's land about 150 feet from the common boundary should be allowed to be and remain as it was, apparently upon the grounid that this outlet had been maintained more than 20 years prior to the commencement of the action. That ruling is not excepted to, and is not before us for review. But the court decreed on these facts that the plaintiff recover $\$ 100$, and that the defendant be ordered to close and fill up the extension of ditch above described made by him in May, 1904, and thereafter to keep, the same closed.

We have considered the cases, *** and do here determine that where the upper proprietor does no more than collect in a ditch, which ditch follows the course of the usual flow of surface water, the surface water which formerly took the same course toward the land of the lower adjacent proprietor, and causes to pass through this ditch the surface water which formerly took the same course but spread out over the surface, he has committed no actionable legal wrong of which the 
lower proprietor can complain, or upon which such lower proprietor can maintain an action. In other words, causing surface water to flow in its natural direction through a ditch on one's own land instead of over the surface or by percolation as formerly, where no new watershed is tapped by said ditch and no addition to the former volume of surface water is caused thereby, except the mere carrying in a ditch what formerly reached the same point on defendant's land over a wider surface by percolation through the soil or by flowing over such wider surface, is not, when not negligently done, a wrongful or unlawful act. It follows that, upon the findings of fact of the court below, the conclusion of law should have been that the defendant was entitled to judgment dismissing, the complaint and judgment accordingly.

The judgment of the circuit court is reversed, and the cause remanded, with directions to enter judgment for the defendant dismissing the plaintiff's complaint. ${ }^{14}$

14 Acc.: Hughes $\nabla$. Anderson, 6S Ala. 280. 44 Am. Rep. 147 (1880). See Jessup r. Bamford, 66 N. J. Law, 641. 51 Atl. 147, 5S L. R. A. 329, SS Am. St. Rep. 502 (1901).

Peck and Helrington orned adjacent farms. There was a natural depression leading through Peck's farm across Herrington's farm to a river. Sulface water and the spring orerflow from three small surface water ponds on Peck's farm worked off down this deplession. Peck put in a loose tile drain from these ponds all the way down the depression to the boundary of Herrington's farm. As a result, the ponds were drained and the amount of water flowing through the depression on Herrington's farm was greatly incleased. The court held that Herrington had no cause of action against Peck. saying: "It may be true that the owner of a tract of land would have no right to drain a lake or large body of water upon the land of an adjoining owner, and thus destroy it; but such is not this case. These small ponds rendered much of the land of Peck unfit for cultivation. and good hushandry required that ther should be drained, and so long as the water was discharged in the regular channel leading from the land of Peck to that of Herrington, he has no legal ground of complaint. The natural flow of the surface water was not changed by the drainage. It may hare been increased. but such increase of water was a burden which the location of the two tracts of land demanded should be borne by the owner of the lower tract of land. As was said in Kauffman F. Griesemer, supra: "Because water is descendible by nature. the owner of a dominant or superior heritage has an easement in the servient or inferior tenement for the discharge of all waters which by nature rise in, or flow or fall upon. the superior.'” Peck v. Herrington, 109 Ill. 611, 620. 50 Am. Rep. 627 (1S8t). Acc.: Todd r. Yolk Countr, 72 Neb. 20T. 100 N. IV. 299. 66 I. R. A. 561 (1904). Compare: Jacobson v. Van Boening. $4 \mathrm{~S}$ Neb. $50.66 \mathrm{~N} . \mathrm{W} .093,32 \mathrm{~L}$. R. A. 2*y. $5 S$ Am. St. Rep. 6S4 (1S96); Waftle r. New Yolk Cent. R. R., 53 N. Y. 11, 1:; Am. Rep. 467 (1873) : Butler r. I'eck, 16 Ohio St. 334, SS Am. Dec. 452 (1S65).

A., B., and C. owned three adjoining pieces of land; the general slope anc: the run of the surface water was from A. to C. C. constructed a ditch on his land to carry off the surface water. As a result, the course of the water over A.'s land was so accelerated that it rlamaged his land bs washing away the soil. Held, admitting the lule to be that the lower owner is under an obligation to receive the naturill flow from the upper, $A$. has nc cause of action against C. Pohlman r. Chi॰ago. MI. \& St. P. R. I., 131 Iowa, st, 107 N: W. 1025,6 J. R. A. (N. S.) $14 t i(1906)$.

A surface water pond of 25 to 10 acres with a maximum depth of $\because$ feet stood partly on the land of $A$. and partly on that of $\mathbf{B}$. The pond liad 
BOWLSBY v. SPEER.

(Supreme Court of New Jelsey, 1S65. 31 N. J. Law, 351, S6 Am. Dec. 216.)

This action was brought for diverting a water course from its bed into the lands of the plaintiff. The circumstances as they appeared on the trial were these, viz.: There was a pond on the side of a hill, and below this pond was the stable lot of the defendant, and still lower down was the lot and dwelling house of the plaintiff. The pond was not fed by a spring nor from any subterranean source, but was formed altogether from rains and melting snows, and occasionally it was entirely dry-never ran over except in times of heavy showers, and then with the other surface water falling on the contiguous land, it passed down in a slight hollow or depression over the premises of the defendant, and so on to other lands below them. This water, in its natural condition, did not go upon the lot of the plaintiff. The defendant, a short time before the commencement of this suit, built a stable on his lot, and located it over this hollow, through which the water before mentioned was discharged, and this obstacle turned the course of the water, so that it ran on to the lot and into the cellar of the dwelling house of the plaintiff. For the damage thus occasioned this suit is brought. The questions involved came before this court on a motion for a new trial.

BeAsLey, C. J. ${ }^{15}$ It is not one of the legal rights appertaining to land that the water falling upon it from the clouds shall be discharged over land contiguous to it; and this is the law, no matter what the conformation of the face of the country may be, and altogether without reference to the fact, that in the natural condition of things, the surface water would escape in any given direction. "The consequence is, therefore, that there is no such thing known to the law as a right to any particular flow of surface water, jure naturæ. The owner of land may, at his pleasure, withhold the water falling on his property from passing in its natural course on to that of his neighbor, and in the same manner may prevent the water falling on the land of the latter from coming on to his own. In a word, neither the right to discharge nor to receive the surface water, can have any legal existence except from a grant, express or implied. The wisdom of this doctrine will be ap-

no natural outlet. A few rods from the pond and on A.'s land began a natural depression, which continued over C.'s land to a creek. A. dug a ditch from the pond to the depression, thereby discharging all the water over C.'s land and rendering the depression untillable. The lowest point in the bank of the pond was on a side other than that where the ditch was cut. Held, C. has no right of action against A. Aldritt v. Fleischauer, 74 Neb. 66, 103 N. W. 1054,70 L. R. A. 301 (1905). Acc.: Sheehan v. Flynn, 59 Minn. 436,61 N. W. 462,26 L. R. A. 632 (1894).

15 Part of the opinion is omitted. 
parent to all minds upon very little reflection. If the right to run in its natural channels was annexed to surface water as a legal incident, the difficulties would be infinite indeed; unless the land should be left idle it would be impossible to enforce the right in its rigor; for it is obvious every house that is built and every furrow that is made in a field, is a disturbance of such right. If such a doctrine prevailed, every acclivity would be and remain a water shed, and most low ground become reservoirs. It is certain that any other doctrine but that which the law has adopted, would be altogether impracticable.

This subject, until a comparatively recent date, does not appear to have received the attention of the courts. No ancient authority can, therefore, perhaps be produced, but the topic has of late been discussed both by the Barons of the Exchequer and by the courts of Massachusetts, and the doctrine placed upon a footing which, as it seems to me, should receive the assent of all persons. Upon an examination of these cases, it will be found that the conclusion is reached that no right of any kind can be claimed in the mere flow of surface water, and that neither its retention, diversion, repulsion, or altered transmission is an actionable injury, even though damage ensues. How far it may be necessary to modify this general proposition in cases in which, in a hilly region, from the natural formation of the surface of the ground. large quantities of water, in times of excessive rains or from the melting of heavy snows, are forced to seek a channel through gorges or narrow valleys, will probably require consideration when the facts of the case shall present the question. It would seem that such anomalous cases might reasonably be regarded as forming exceptions to the general rule.

Applying, then, the doctrine above indicated to the facts of the present case, the conclusion must be that upon the proof made at the trial, the plaintiff was not entitled to recover. The water diverted by the building of the defendant was altogether surface water, and he, therefore, had a legal right to obstruct and to turn aside its course. If the plaintiff has suffered from such act it is damnum absque injuria. Nor is her case helped by the circumstance that a portion of the water in question came from the pond which was proved to exist, because no more waste water was discharged by reason of this reversion than there would have been if it had not been there. It was merely the rain water flowing from surface of the pond, as it would have done if the superficies had been land instead of water. Nor does it seem to me that there is any significance in the fact, that there was an appreciable channel for this surface water over the land of the defendant and into which it naturally ran. 'On every hill side numbers of such small conduits can be found, but it would be highly unreasonable to attach to them all the legal qualities of water courses. I am not willing to adopt a doctrine which would be accompanied with so much mischief.

In my opinion the existence of a water course was not proved in the 
present case, and as this is the ground work of the plaintiff's action, I think a new trial should be granted.

Rule made absolute: ${ }^{16}$

\title{
HURDMAN v. NORTH EASTERN RY. CO.
}

\author{
(Court of Appeal, 1S7S. L. R. 3 C. P. D. 16S.)
}

Appeal from the judgment of Manisty, $J$., in favour of the plaintiff on demurrer to a statement of claim.

Claim: At the time of the damage hereafter mentioned the plaintiff was, and is still, possessed of a house, No. 16, Lodge Terrace, Sunderland.

2. The defendants then were, and still are, possessed of a certain close of land adjoining the house of the plaintiff.

3. The defendants placed and deposited in and upon the close of the defendants, and upon and against a wall of the defendants which adjoins and abuts against the house of the plaintiff, large quantities of soil, clay, limestone, and other refuse, close to and adjoining the house of the plaintiff, and thereby raised the surface of the defendants' land above the level of the land upon which the plaintiff's house was built.

4. The rain which fell upon the soil, clay, limestone, and other refuse so placed as aforesaid oozed and percolated through the wall of the defendants into the house of the plaintiff, and the plaintiff's house thereby became wet, damp, unwholesome and unhealthy, and less commodious for habitation.

5. By reason of the acts of the defendants the walls of the house of the plaintiff became and were very much injured, and the paper upon the walls has been destroyed.

6. In the alternative the plaintiff alleges that the defendants negligently and improperly placed and deposited the soil, clay, limestone, and refuse upon the defendants' land, and that the rain water falling thereon oozed and percolated through and into the plaintiff's house, whereby the plaintiff's house was damaged as before mentioned.

7 . In the alternative the plaintiff alleges that the defendants were guilty of negligence in this, that the wall of the defendants against which the defendants so placed the soil, clay, limestone, and refuse was not sufficiently and properly constructed and built so as to prevent the

16Acc.: Gannon $\nabla$. Hargadon, 10 Allen (Mass.) 106, S7 Am. Dec. 625 (1S65); Contra: (Semble) Adams v. Walker, 34 Conn. 466, 91 Am. Dec. 742 (1867); Rhoads v. Daridheiser, 133 Pa. 226, 19 Atl. 400, 19 Am. St. Rep. 630 (1890). See Mayor v. Sikes, 94 Ga. 30, 20 S. E. 257,26 L. R. A. 653, 47 Am. St. Rep. $132(1894)$.

Compare: Cedar Falls $\mathrm{v}$. Hansen, 104 Iowa, 1s9, $73 \mathrm{~N}$. W. 585, $65 \mathrm{Am}$ St. Rep. 439 (1897), and Waverly v. I'age, 105 Iowa, 225, it N. W. 93S, 40 L. R. A. 465 (189\$). 
water from falling upon the soil, clay, limestone, and refuse from oozing and percolating through the wall and into the plaintiff's house, and that the defendants were guilty of negligence in placing the soil, clay, limestone, and refuse against the wall being so insufficient to prevent the water falling upon the soil, clay, limestone, and refuse from oozing and percolating through and into the plaintiff's house, whereby the plaintiff's house was damaged.

Demurrer to the claim, on the ground that the acts, matters, and things alleged to have been done by the defendants do not give rise to any right of action on the part of the plaintiff.

The judgment of the Court (BRAMwELl, BretT, and Cot'Ton, L. JJ.) was delivered by

Co'ron, L. J. In this case the plaintiff has brought an action for injury alleged to have been caused to his house, which abuts on a wall of the defendants, by certain acts done by the defendants on their own land. The question is raised on demurrer to the statement of claim. and the question therefore is whether that alleges a good cause of action. [The Lord Justice read the statement of claim, except paragraph 7.] It is unnecessary to read the seventh paragraph, because it is based on a supposed obligation of the railway company to make their wall water-tight, but in our opinion there is no such obligation, and if the statements contained in the preceding paragraphs do not shew a cause of action, the statements of the seventh paragraph do not enable the plaintiff to sustain this action.

For the purposes of our decision, we must assume that the plaintiff has sustained stibstantial damage, and we must construe the statement as alleging that the surface of the defendants' land has been raised by earth and rubbish placed thereon, and that the consequence of this is that rain-water falling on the defendants' land has made its way through defendants' wall into the house of the plaintiff, and has caused the injury complained of. The question is, are the defendants, admitting this statement to be true, liable to the plaintiff? and we are of opinion that they are. The heap or mound on the defendants' land must, in our opinion, be considered as an artificial work. Every occupier of land is entitled to the reasonable enjoyment thereof. This is a natural right of property, and it is well established that an occupier of land may protect himself by action against any one who allows any filth or any other noxious thing produced by him on his own land to interfere with this enjoyment. We are further of opinion that, subject to a qualification to be hereafter mentioned, if any one by artificial erection on his own land causes water, even though arising from natural rainfall only, to "pass into his neighbor's land, and thus substantially to interfere with his enjoyment, he will be liable to an action at the silit of him who is so injured, and this view agrees with the opinion expressed by the Master of the Rolls in the case of Broder v. Saillard, $2 \mathrm{Ch}$. D. at page 700 . I have limited this statenent of liability to 
liability for allowing things in themselves offensive to pass into a neighbour's property, and for causing by artificial means things in themselves inoffensive to pass into a neighbour's property to the prejudice of his enjoyment thereof, because there are many things which when done on a man's own land (as building so as to interfere with the prospect, or so as to obstruct lights not ancient) are not actionable, even though they interfere with a neighbour's enjoyment of his property.

But it is urged that this is at variance with the decision that if, in consequence of a mine-owner on the rise working out his minerals, water comes by natural gravitation into the mines of the owner on the deep, the latter mine-owner cannot maintain any action for the loss which he thereby sustained. But excavating and raising the minerals is considered the natural use of mineral land, and these decisions are referable to this principle, that the owner of land holds his right to the enjoyment thereof, subject to such annoyance as is the consequence of what is called the natural user by his neighbour of his land, and that when an interference with this enjoyment by something in the nature of nuisance (as distinguished from an interruption or disturbance of an easement or right of property in ancient lights, or the support for the surface to which every owner of property is entitled), is the cause of complaint, no action can be maintained if this is the result of the natural user by a neighbour of his land. That this is the principle of these cases appears from the case of IVilson v. Waddell, 2 App. Cas. 95, and from what is said by the Lord Chancellor in Fletcher v. Rylands, Law Rep. 3 H. L. C. 330 . Moreover, the cases referred to have laid down that a mine-owner is exempt from liability, for water which in consequence of his works flows by gravitation into an adjoining mine, only if his works are carried on with skill and in the usual manner; and in the present case it is stated that the defendants have conducted this operation negligently and improperly. The decisions, therefore, as regards the rights of adjoining mine-owners, do not enable the defendants to discharge themselves from liability.

It was also argued that a land-owner, who by operations on his own land drains the water percolating underground in the property of his neighbour, is not liable to an action by the man whose land is thus deprived of its natural moisture, and this it was argued was inconsistent with a judgment for the plaintiff on a statement alleging as a cause of action an alteration in the percolation of water. It is sufficient to say. that no one can maintain an action unless there is some injury to something to which the law recognizes his title, and the law does not rec-. ognize any title in a land-owner to water percolating through his prop-erty underground and in no definite channel.

We are of opinion that the maxim "Sic utere tuo ut alienum non lædas" applies to and governs the present case, and that as the plaintiff by his statement of claim alleges that the defendants have by artificial erections on their land caused water to flow into the plaintiff's 
land, in a manner in which it would not but for such erection have done, the defendants are answerable for the injury caused thereby to the plaintiff.

Judgment affirmed. ${ }^{17}$

\section{FITZPATRICK v. WELCH.}

(Supreme Judicial Court of Massachusetts, 1S99. $17 \pm$ Iass. 4S6, 55 N. L. 178, 4S L. R. A. 27S.)

Holmes, J. 'The plaintiff's case was that water flowing from the roof of the defendant's stable into a gutter along the side of the stable was discharged upon the plaintiff's land in large quantities through an aperture in the gutter, and thus did the damage for which suit is brought. If these were the facts, a ruling that the defendant was bound to use only ordinary care properly was refused.

One who arranges a roof and gutter in such a way that the first wili collect water, and the second manifestly will discharge it upon a neighbor's land unless prevented, has notice that the threatens harm to his neighbor of a kind which the law, in its adjustment of their conflicting interests, does not permit him knowingly to inflict. Bates v. Inhabitants of Westborough, 151 Mass. 174, 181, 23 N. E. 1070, 7 L. R. A. 156. The danger is so manifest, so constant, and so great that although, no doubt, a possibility of harm does not always require more than the exercise of ordinary care to prevent it (Quinn v. Crimmings, 171 Mass. 255, 50 N. E. 624, 42 L. R. A. 101, 68 Am. St. Rep. 420), and although in some states only ordinary care is required in cases like this (Underwood v. Waldron, 33 Mich. 232, 238, 239, Garland v. Towne, 55 N. H. 55, 20 Am. Rep. 164), the requirement here and elsewhere is higher, and sometimes is stated as absolute, to prevent at one's peril the harm from coming to pass (Shipley v. Fifty Associates, 105 Mass. 194, 199, 8 Am. Rep. 318; Jutte v. Hughes, 67 N. Y. 267, 272).

If the defendant is liable, she is liable for damage to artificial structures upon the plaintiff's land (Copper v. Dolvin, 68 Iowa, 757, $28 \mathrm{~N}$. W. 59, 56 Am. Rep. S72; Martin v. Simpson, 6 Allen, 102, 105; and cases below): and, if the discharge of water caused the wall to fall, she is liable for it, whether the wall was well constructed or not. The request which was refused would have exonerated the defendant if the wall was ill constructed, even though the bad construction did not contribute to the damage. It is not necessary to consider this question more nicely, as it appears that full instructions were given, and the

17 Ace.: Rainwater thrown on adjacent premises from houses. Conner v. Woodfill, 126 Ind. 85, 25 N. E. 876,22 . Am. St. Iep. $56 \mathrm{~S}$ (1590); Beach v. Gaylord. 43 Minn. 476,45 N. W. 1095 (1890); Bellows v. Sackett, 15 Barb. (N. Y.) 96 (185:3). 
only exception is to the refusal of the defendant's request. Underwood v. Waldron, 33 Mich. 232, 236, 237 ; Gould v. McKenna, $86 \mathrm{~Pa}$. 297, 27 Am. Rep. 705.

Exceptions overruled. ${ }^{13}$

18 See Davis v. Niagara Falls Torer Co., 171 N. Y. 336,64 N. E. 4, 57 I. R. A. 545, \&9 Am. St. Rep. $\$ 17$ (1902).

The wall of A.'s house was built on loose soil and in a careless fashion. $B$. negligently allowed the water from his roof to fall on A.'s land, to the damage of A.'s wall. Held, A.'s negligence in building, assuming it to be one of the causes of the destruction of the wall, will not bar an action against B. Underwool v. Waldron, 33 Mich. 232 (1876). Compare Copper v. Dolvin. GS Iowa, 757, 28 N. W. 59, 56 Am. Rep. 872 (1S86); Gould v. ICKenna, S6 Pa. 297, 27 Am. Rep. 705 (187S).

See, also, on the question of how far the defendant's liability is affected by his negligence, Little Rock \& Ft. S. Ry. Co. v. Chapman, 39 Ark. 463, 4: Am. Rep. $2 S 0$ (1SS2); Missouri Pac. Ry. Co. จ. Keys, 55 Kan. 205, 40 Pac. 275, 49 Am. St. Rep. 249 (1895), ante, p. 103; Morrissey v. Chicago, B. \& Q. R. R., 38 Neb. 406,56 N. W. 946, 57 N. W. 522 (1S93); Abbott v. Kansas City, st. J. \& C. B. Ry. Co., \&3 Mo. 271, 53 Am. Rep. 581 (1884) ante, p. 103; Crawford v. Rambo, 44 Ohio St. 279,7 N. E. 429 (1886). 


\section{CHAPTER VI}

\section{UNDERGROUND WATERS}

ACTON v. BLUNDELL.

(Court of Exchequer Chamber, 18t3. 12 Mees. \& W. 324.)

TINDAL, C. J. ${ }^{1}$ The question raised before us on this bill of exceptions is one of equal novelty and importance. The plaintiff below, who is also the plaintiff in error, in his action on the case, declared in the first count for the disturbance of his right to the water of certain underground springs, streams, and water courses, which, as he alleged, ought of right to run, flow, and percolate into the closes of the plaintiff, for supplying certain mills with water; and in the second count for the draining off the water of a certain spring or well of water in a certain close of the plaintift, by reason of the possession of which close, as he alleged, he ought of right to have the use, benefit, and enjoyment of the water of the said spring or well for the convenient use of his close. The defendants by their pleas traversed the rights in the manner alleged in those counts respectively.

At the trial the plaintiff proved, that, within twenty years before the commencement of the suit, viz. in the latter end of 1821, a former owner and occupier of certain land and a cotton mill. now belonging to the plaintiff, had sunk and made in such land a well for raising water for the working of the mill; and that the defendants, in the year 1837. had sunk a coal pit in the land of one of the defendants at about threequarters of a mile from the plaintiff's well, and about three years after sunk a second at a somewhat less distance; the consequence of which sinking was, that, by the first, the supply of water was considerably diminished, and by the second was rendered altogether insufficient for the purpose's of the mill. The learned Judge before whom the cause was tried directed the jury, that, if the defendants had proceeded and acted in the usual and proper manner on the land, for the purpose of working and winning a coal mine therein, they might lawfully do so, and that the plaintiff's evidence was not sufficient to support the allegations in his declaration as traversed by the second and third pleas. Against this direction of the Judge the counsel for the plaintiff tendered the bill of exceptions which has been argued before us. And after hearing such argument, and consideration of the case, we are of opinion that the direction of the learned Judge was correct in point of law.

The qucstion argued before us has been in substance this: Whethe-

1 Part of the opinion is omitted. 
the right to the enjoyment of an underground spring, or of a well supplied by such underground spring, is governed by the same rule of law as that which applies to, and regulates, a watercourse flowing on the surface. ***

The ground and origin of the law which governs streams running in their natural course would seem to be this, that the right enjoyed by the several proprietors of the lands over which they flow is, and always has been, public and notorious; that the enjoyment has been long continued-in ordinary cases, indeed, time out of mind-and uninterrupted; each man knowing what he receives and what has always been received from the higher lands, and what he transmits and what has always been transmitted to the lower. The rule, therefore, either assumes for its foundation the implied assent and agreement of the proprietors of the different lands from all ages, or perhaps it may be considered as a rule of positive law, (which would seem to be the opinion of Fleta and of Blackstone,) the origin of which is lost by the progress of time; or it may not be unfitly treated, as laid down by Mr. Justice Story, in his judgment in the case of Tyler v. Wilkinson, in the courts of the United States, 4 Mason's (American) Reports, 401, Fed. Cas. No. 14,312, as "an incident to the land; and that whoever seeks to found an exclusive use must establish a rightful appropriation in some manner known and admitted by the law." But in the case of a weil sunk by a proprietor in his own land, the water which feeds it from a neighbouring soil does not flow openly in the sight of the neighbouring proprietor, but through the hidden veins of the earth beneath its surface: no man can tell what changes these underground sources have undergone in the progress of time: it may well be, that it is only yesterday's date, that they first took the course and direction which enabled them to supply the well: again, no proprietor knows what portion of water is taken from beneath his own soil: how much he gives originally, or how much he transmits only, or how much he receives; on the contrary, until the well is sunk, and the water collected by draining into it, there cannot properly be said, with reference to the well, to be any flow of water at all. In the case, therefore, of the well, there can be no ground for implying any mutual consent or agreement, for ages past, between the owners of the several lands beneath which the underground springs may exist, which is one of the foundations on which the law as to running streams is supposed to be built; nor, for the same reason, can any trace of a positive law be inferred from longcontinued acquiescence and submission, whilst the very existence of the underground springs or of the well may be unknown to the proprietors of the soil.

But the difference between the two cases with respect to the consequences, if the same law is to be applied to both, is still more apparent. In the case of the running stream, the owner of the soil merely transmits the water over its surface: he receives as much from his higher neighbour as he sends down to his neighbour below: he is nei- 
ther better nor worse: the level of the water remains the same. But if the man who sinks the well in his own land can acquire by that act an absolute and indefeasible right to the water that collects in it, he has The power of preventing his neighbour from making any use of the spring in his own soil which shall interfere with the enjoyment of the well. He has the power, still further, of debarring the owner of the land in which the spring is first found, or through which it is transmitted, from draining his land for the proper cultivation of the soil: and thus, by an act which is voluntary on his part, and which may be entirely unsuspected by his neighbour, he may impose on such neighbour the necessity of bearing a heavy expense, if the latter has erected machinery for the purposes of mining, and discovers, when too late, that the appropriation of the water has already been made. Further, the advantage on one side, and the detriment to the other, may bear no proportion. The well may be sunk to supply a cottage, or a drinking place for cattle; whilst the owner of the adjoining land may be prevented from winning metals and minerals of inestimable value. And, lastly, there is no limit of space within which the claim of right to an underground spring can be confined: in the present case, the nearest coal pit is at the distance of half a mile from the well: it is obvious the law must equally apply if there is an interval of many miles.

Considering, therefore, the state of circumstances upon which the law is grounded in the one case to be entircly dissimilar from those which exist in the other; and that the application of the same rule to both would lead, in many cases, to consequences at once unreasonable and unjust; we feel ourselves warranted in holding, upon principle, that the case now under discussion does not fall within the rule which obtains as to surface streams, nor is it to be governed by analogy therewith.

No case has been cited on either side bearing directly on the subject in dispute. $* * *$

The Roman law forms no rule, binding in itself, upon the subjects of these realms; but, in deciding a case upon principle, where no direct authority can be cited from our books, it affords no small evidence of the soundness of the conclusion at which we have arrived, if it proves to be supported by that law, the fruit of the researches of the most learned men, the collective wisdom of ages, and the groundwork of the municipal law of most of the countries in Europe.

The authority of one at least of the learned Roman lawyers appears decisive upon the point in favour of the defendants; of some others the opinion is expressed with more obscurity. In the Digest, lib. 39, tit. 3, De æequâ et aquææ pluviæe arcandie, s. 12, "Denique Marcellus scribit, Cum eo, qui in suo fodiens, vicini fontem avertit, nilil posse agi: nec de dolo actionem, et sane non debet habere; si non animo vicini nocendi, sed suum agrum meliorem faciendi, id fecit."

It is scarcely necessary to say, that we intimate no opinion whatever as to what might be the rule of law, if there had been an uninterrupt- 
ed user of the right for more than the last twenty years $;^{2}$ but, confin. ing ourselves strictly to the facts stated in the bill of exceptions, we think the present case, for the reasons above given, is not to be governed by the law which applies to rivers and flowing streams, but that it rather falls within that principle, which gives to the owner of the soil all that lies beneath his surface; that the land immediately below is his property, whether it is solid rock, or porous ground, or venous earth, or part soil, part water; that the person who owns the surface may dig therein, and apply all that is there found to his own purposes at his free will and pleasure; and that if, in the exercise of such right, he intercepts or drains off the water collected from underground springs in his neighbour's well, this inconvenience to his neighbour falls within the description of damnum absque injuriâ, which cannot become the ground of an action.

We think, therefore, the direction given by the learned judge at the trial was correct, and that the judgment already given for the defendants in the Court below must be affirmed.

Judgment affirmed. ${ }^{3}$

2 "The lots of the plaintiff and defendant adjoin each other. And the case finds, that the plaintiff's cellar was dug fourteen years ago, and water was then found, and in about two years afterwards an excavation was made in the earth, in the place where the well now stands, about three feet deep. and a barrel was inserted, and the water rose to the surface. Afterwards the defendant dug to obtain water in his own soil, and in a place where it was convenient for him, near to the well of the plaintiff, and after the defendant's well was dug, the water ceased to flow into the plaintift's well, so copiously as it did before. $\overline{\mathrm{It}}$ is for this alleged injury that the action is brought. Then it is to be considered, whether the plaintiff has proved any such easement, as she claims to have in the soil of the defendant. She does not pretend, that there has been any written grant from the defendant. She relies upon the use, as evidence from which a jury should presume a grant; and there is no other circumstance to be relied upon. But by our law, the right of the plaintiff to control the operations of the defendant on his own soil must, in the absence of a written agreement, be made out by an adverse possession continued peaceably under a claim of right for twenty years at the least. In the present case such proof is wanting. There is not evidence of any adverse use or possession at all. For the defendant had no means of knowing that the plaintiff's well was supplied by springs in the (lefendant's soil, until the defendant dug for water there for his own use." (ireenleaf v. Francis, 18 Pick. (Mass.) 117, 122 (1836). See, also, Wheatley v. Baugh, 25 Pa. 528, 64 Am. Dec. 721 (1S55).

3 Acc.: Wheatley v. Baugh, ante, p. 124.

A. had a well on his own land, whence he drew water for domestic and other purposes; B. dug a well on his land near to A.'s well to get water for' liis domestic purposes. Thereafter, and in consequence of B.'s digging, the water in A.'s well was insuficient for his purposes. Held, A. has no cause of action against B. Roath v. Driscoll, 20 Conn. 533, 52 Am. Dec. 352 (1850). See, also, Bloodgood v. Ayers, $10 \mathrm{~S} \mathrm{N.} \mathrm{Y.} \mathrm{400,} 15$ N. E. 433, 2 Am. St. Rep. 443 (1SST); Frazier v. Brown, 12 Ohio St. 294 (1861).

A. and B. were adjacent landowner's. A well on A.'s land was supplied by percolating water from B.'s land. B. dug a ditch on his own land, so as to prevent the percolation to A.'s well. An instruction was given that if the jury found that the acts of $B$. prevented the usual and natural flow. of the water underground to A.'s soil, and that these acts were done by 1 ; solely with the purpose of injuring $A$. and depriving him of water, and not with any purpose of usefulness to himself, $\mathbf{B}$. would be liable to $\mathbf{A}$. for 


\section{MEEKER v. CITY OF EAST ORANGE.}

(Court of Errors and Appeals of New Jersey, 1909. 77 N. J. Law, 623, it Atl. 379,25 L. R. A. [N. S.] 465, 134 Am. St. Rep. 79S.)

Pitney, Ch. ${ }^{*}$ Plaintiff brought two actions in one of the district courts of the city of Newark to recover damages for the diversion by the defendant of percolating underground water. In each case the district court rendered judgment in favor of the defendant, and upon appeal to the Supreme Court the judgments were affirmed. By writs of error the records are brought here for review.

The cases were submitted to the trial court upon agreed statements of fact. In one case it is stipulated that plaintiff owns and occupies a farm of about 100 acres, situate in the valley of Canoe brook, in the townships of Millburn and Livingston, in the county of Essex. He is a milkman, and has for a number of years used his farm for the pasture and support of his cows and horses. Canoe brook and two small streams tributary thereto flow through his farm. Upon the farm there is also a spring, inclosed by a springhouse, the water of which has for years been used by the plaintiff for drinking purposes and for the storing and keeping of his milk. His cattle in pasture have for years resorted to the brook and its tributaries for drinking water. The defendant, the city of East Orange, under the authority of "An act to enable cities to supply the inhabitants thereof with pure and wholesome water," approved April 21, 1876, and the acts supplemental thereto and amendatory thereof (P. L. 1876, p. 366; Gen. St. 1895. pp. 646-650, $\S \S 902-917)$, acquired a tract of land containing about 680 acres situate in the valley of Canoe brook and in the township of Millburn, and installed thereon a water plant consisting of about 20 artesian wells, situate further down the stream than plaintiff's farm and distant upwards of a mile therefrom. In the construction of these wells, and of the works, mains, and reservoirs connected therewith, the city has expended more than $\$ 1,000,000$. A few years prior to the commencement of the action, the city began to take water from the wells, and has thus taken percolating underground water, which, but for its interception, would have reached the plaintiff's spring or stream. No water other than percolating water has been taken, and no water has been taken out of any surface stream or from the spring of the plaintiff after it (the water) has appeared upon the surface or in any surface or stream. In this action the plaintiff seeks damages $f(x i$

any damage sustained hr A. Held. the instruction was incorrect. Chatfield v. Wilson, 28 Vt. 49 (1855). Contra: Barclay v. Abraham, 121 Iowa. 619,96 N. W. 1080,64 L. R. A. 255, 100 Am. St. Rep. 365 (1903); Stillwatr Wateŕ Co. v. Farmer, 89 Minn. 58, 93 N. W. 907,60 L. R. A. S75, 99 Am. S.. Rep. 541 (1903). Compare Phelps r. Nowlen, 72 N. Y. 39, 2s Am. Rep. 9:: (1878).

+ Part of the opinion is omitted 
the diversion of the underground water that otherwise would have reached his spring and streams.

In the other action the agreed statement of facts differs only in that it shows the existence upon plaintiff's farm of a well which for years had provided water for the various purposes of the plaintiff, and that as a result of the defendant's operations it had taken percolating underground water which otherwise would have reached this well, and had also taken percolating underground water from beneath the surface or soil of the plaintiff's land to such an extent that his crops will not now grow as they did formerly, and the taking of such percolating water has damaged the plaintiff's hay and crops, and also has reduced the level of the water in his well. For this diversion damages are sought.

The judgments under review are based upon the theory that the city has an absolute right to appropriate all percolating water found beneath the land owned by it, and to use the water for purposes entirely unconnected with the beneficial use and enjoyment of that land, to the extent, indeed, of making merchandise of the water and conveying it to a distance for the supply of the inhabitants of East Orange, and that although by such diversion the plaintiff's spring, well, and stream are dried up, and his land rendered so arid as to be untillable, it is damnum absque injuria. The judgments are attacked upon the ground that the law recognizes correlative rights in percolating subterranean waters, that each landowner is entitled to use such waters only in a reasonable manner and to a reasonable extent beneficial to his own land, and without undue interference with the rights of other landowners to the like use and enjoyment of waters percolating beneath their lands, or of water courses fed therefrom.

The law respecting the rights of property owners in percolating subterranean waters is of comparatively recent development; the first English decision bearing directly upon the question having been rendered in 1843. Acton v. Blundell, 12 M. \& W. 324, 13 L. J. Exch. 289. This was followed by Chasemore v. Richards (1859) 7 H. L. Cas. 349, 29 L. J. Exch. 81, 5 Jur. N. S. 873, 1 Eng. Ru1. Cas. 729. These cases may be taken as establishing for that jurisdiction the rule upon which the judgments under review are based. They were followed by a considerable line of decisions in this country, in which the English rule was adhered to, and which will be found discussed in Washburn on Easements, 363-390: Angell on Water Courses, §§ 109-114p; $30 \mathrm{Am}$. \& Eng. Encye. Law (2d Ed.) 310-313.

The soundness of the English doctrine was, however, challenged by the Supreme Court of New Hampshire in a well-considered case decided in 1862 (Bassett v. Salisbury Mfg. Co., 43 N. H. 569, 82 Am. Dec. 179), where it was elaborately reasoned that the doctrine of absolute ownership is not well founded in legal principles, and is not so commended by its practical application as to require its adoption, that the true rule is that. the rights of each owner being similar, and 
their enjoyment dependent upon the action of other landowners, their rights must be correlative and subject to the operation of the maxim sic utere, etc., so that each landowner is restricted to a reasonable exercise of his own rights and a reasonable use of his own property, in view of the similar rights of others. This decision was followed by Swett v. Cutts (1870) 50 N. H. 439, 9 Am. Rep. 276, where the court again laid down that the landowner has not an absolute and unqualified property in all such water as may be found in his soil, to do what he pleases with it, as with the sand and rock that form part of the soil, but that his right is to make reasonable use of it for domestic, agricultural, and manufacturing purposes, not trenching upon the similar rights of others. The doctrine, thus enunciated, has come to be known in the discussion of the topic as the rule of "reasonable use." * * *

A review of the reasoning upon which the English doctrine respecting percolating underground waters rests will demonstrate, as we think, that this reasoning is unsatisfactory in itself and inconsistent with legal principles otherwise well established. Thus, in Acton v. Blundell, 12 M. \& W. Exch. 349, Tindal, C. J., in undertaking to show the inapplicability to percolating waters of the law that governs running streams, declared that the ground and origin of the law respecting the latter would seem to be that the riglit enjoyed by the several proprietors of the lands over which they flow is, and always has been, public and notorious, that the enjoyment has been long-continued and uninterrupted, and therefore based upon the implied assent and agreement of the proprietors of the different lands from all ages, while underground waters, being concealed from view, there can be no implied mutual consent or agreement between the owners of the several lands respecting them; but, as has been since repeatedly pointed out, the right of the riparian owner to the flow of a natural stream arises ex jure naturæ, and not at all from prescription or presumed grant or acquiescence arising from long-continued user. See remarks of Parke, B., in Broadbent v. Ramsbotham, as reported in 25 L. J. Exch., at page 121; and remarks of Lord Wensleydale in Chasemore v. Richards, 7 H. L. Cas., at pages 382, 383, 29 L. J. Exch. 87, 1 Eng. Rul. Cas. 752, 753, and cases cited.

Again, in Acton v. Blundell, 12 M. \& W. 351, the Chief Justice said: "If a man who sinks a well in his own land can acquire by that act an absolute and indefeasible right to the water that collects in it, he has the power of preventing his neiglibor from making any use of the spring in his own soil which shall interfere with the enjoyment of the soil." Obviously he failed to note that there is a middle ground between the existence of an absolute and indefeasible right and the absence of any right that the law will recognize and protect. There is room for the existence of qualified and correlative rights in both landowners. The English rule seems to be rested at bottom upon the maxim, "Cujus est solum, ejus est usque ad cœlum et ad inferos." 
Thus, in Acton v. Blundell, 12 M. \& WV. 354, Tindal, C. J., said that the case fell within "that principle which gives to the owner of the soil all that lies beneath his surface; that the land immediately below is his property, whether it is solid rock, or porous ground, or venous earth, or part soil, part water; that the person who owns the surface may dig therein, and apply all that is there found to his own purposes at his free will and pleasure." Here the impracticability of applying the rule of absolute ownership to the fluid, water, which by reason of its nature is incapable of being subjected to such ownership, is apparently overlooked. If the owner of Whiteacre is the absolute proprietor of all the percolating water found beneath the soil, the owner of the neighboring Blackacre must, by the same rule, have the like proprietorship in his own percolating water. How, then, can it be consistent with the declared principle to allow the owner of Whiteacre to withdraw, by pumping or otherwise, not only all the percolating water that is normally subjacent to his own soil, but also, and at the same time, the whole or a part of that which is normally subjacent to Blackacre? Where percolating water exists in a state of nature generally throughout a tract of land, whose parcels are held in several ownership hy different proprietors, it is, in the nature of things, impossible to accord to each of these proprietors the absolute right to withdraw ad libilum all percolating water which may be reached by a well or pump upon any one of the several lots, for such withdrawal by one owner necessarily interferes to some extent with the enjoyment of the like privilege and opportunity by the other owners.

Again, the denial of the applicability to underground waters of the general principles of law that obtain with respect to waters upon the surface of the earth is in part placed upon the mere difficulty of proring the facts respecting water that is concealed from view; but experience has demonstrated in a multitude of cases that this difficulty is often readily solved. When it is solved in a given case, by the production of satisfactory proof, this reason for the rule at once vanishes. It is sometimes said that, unless the English rule be adopted, landowners will be hampered in the development of their property because of the uncertainty that would thus be thrown about their rights. It seems to us that this reasoning is wholly faulty. If the English rule is to obtain, a man may discover upon his own land springs of great value for medicinal purposes or for use in special forms of manufacture, and may invest large sums of money upon their development; yet he is subject at any time to have the normal supply of such springs wholly cut off by a neighboring landowner, who may with impunity sink deeper wells and employ more powerful machinery, and thus wholly drain the subsurface water from the land of the first discoverer.

In the case before us, the city of East Orange might have its underground water supply cut off or materially impaired by the estab- 
lishment of deeper wells and more powerful pumps upon some neighboring tract-even upon the tract owned by the plaintiff. ***

Upon the whole, we are convinced, not only that the authority of the English cases is greatly weakened by the trend of modern decisions in this country, but that the reasoning upon which the doctrine of "reasonable user" rests is better supported upon general principles of law and more in consonance with natural justice and equity. We therefore adopt the latter doctrine. This does not prevent the proper user by any landowner of the percolating waters subjacent to his soil in agriculture, manufacturing, irrigation, or otherwise; nor does it prevent any reasonable development of his land by mining or the like, although the underground water of neighboring proprietors may thus be interfered with or diverted; but it does prevent the withdrawal of underground waters for distribution or sale for uses not connected with any beneficial ownership or enjoyment of the land whence they are taken, if it thereby result that the owner of adjacent or neighboring land is interfered with in his right to the reasonable user of subsurface water upon his land, or if his wells, springs, or streams are thereby materially diminished in flow, or his land is rendered so arid as to be less valuable for agriculture, pasturage, or other legitimate uses.

It follows that the judgments of the district court and of the Supreme Court must be reversed. ${ }^{5} * * *$

5Acc.: Katz v. Walkinshaw, 141 Cal. 116, 70 Pac. 663, 74 Pac. 766. 6.t L. R. A. 236,99 Am. St. Rep. 35 (1903) : Forbell r. New York, 164 N. Y. 522, 55 N. E. 644,51 L. R. A. 095,79 Am. St. Rep. 666 (1900). Contra: Chasemore v. Richards, 7 H. L. Cas. 349 (1859). Compare Houston \& T. C. R. Co. v. East, 98 Tex. 146, 81 S. W. 279, 66 L. R. A. 738, 107 Am. St. Rep. 520, 4 Ann. Cas. 827 (1904).

See Erickson v. Crookston Waterworks, Power \& Light Co., 105 Minn. 1S:z, 117 N. W. 435,17 L. R. A. (N. S.) 650 (1908).

As to the form of relief to which plaintiff is entitled, compare Westphal v. New York, 177 N. Y. 140,69 N. E. 369 (1904).

As to protecting a possible future user of water for local purposes against non-local user, see Burr r. Maclay Water Co., 15+ Cal. 42S, 98 Pac. 260 (1908).

A. had a valuable mineral spring on his land; B., in the process of developing on his own land a supply of the same water, temporarily pumped and wasted so much of the water as to lower A.'s spring, to his damage. Held, A. has no cause of action. Pence v. Carnev, 58 W. Va. 296, 52 S. E. 702, 6 L. R. A. (N. S.) 266, 112 Am. St. Rep 963 (1905).

B. installed a pump on his land, and pumped and wasted valuable mineral water, thereby draining A.'s springs, at which A. had erected an expensive hotel and built up a large business. B. did this for the purpose of compelling A. to buy him out. Held, A. may enjoin B. from so wasting the waters. Gagnon v. French Lick Springs Hotel Co., 163 Ind. 657, 72 N. L. S49, 68 L. R. A. 175 (1904). Contra: Bradford . Pickles [1595] A. C. 587.

Defendant bought from the plaintiff a narrow strip of land along a stream and then built a dam on his land below. He made an embankment on the strip to protect the plaintiff's land from being flooded, but the water percolated through the natural banks of the creek and made the plaintilt's land wet. The defendant was held liable, though he had built the embankment with dne care and skill. The court said: "It is not that the defendants have unreasonably, negligently, unintentionally, unnecessarily, or unexpectedly flowed the plaintift's land, to his injury, for their benefit, that they are Big.RIGHTS -9 


\section{MERRICK WATER CO. v. CITY OF BROOKLYN.}

(Supreme Court of New York, Appellate Division, Second Department, 1898. 32 App. Div. 454, 53 N. Y. Supp. 10, Affirmed [1S99] 160 N. Y. 657, 55 N. E. 1097.)

HATCH, J. ${ }^{6}$ The plaintiff is a corporation engaged in the business of collecting water, and selling the same to its various customers throughout the neighborhood where it has its principal place of business. The complaint avers that the land occupied by the plaintiff, and from which it obtains its water supply, is located on a subterranean stream supplied from a water shed, which is particularly described; that such underground stream rises to the surface on the plaintiff's land, and flows into ponds owned by it. The complaint further avers that the defendant has acquired a considerable strip of land lying north of the plaintiff's pumping station and its wells, upon which land it intends to sink about 80 wells, and draw therefrom a water supply for the city of Brooklyn, and that, if it carries out such purpose, it will draw the water from the plaintiff's wells and the underground strean, and also from the surface stream and said ponds, whereby the plaintiff will be deprived of its water, its business will be destroyed, and the locality in which it seeks to carry on its business will be checked in its growth. The complaint demands judgment that the defendant be restrained from sinking its wells or establishing a pumping station, or doing any other act upon its land which will diminish the flow of water upon the plaintiff's lands. At the time of the trial the defendant had sunk its wells, established its pumping stations, was engaged in operating the same, and was carrying the water thus obtained to the city of Brooklyn. The proof tended to establish, and the referee found, that the effect of the defendant's pumping had been to permanently lower the water in plaintiff's well from seven to eight feet; that such lowering was caused by the defendant's pumps in drawing the water from under the plaintiff's well and the land on which it is situated. The evidence failed in support of the averment that there existed a subterranean stream of water which supplied the

liable. It is simply because they have done it in fact; they have done it by their works, and it cannot be charged to extraordinary floods. In the language of the old books, 'the defendants' exaltavunt stagnum by which the plaintiff's meadow was flooded,' and they are liable therefor. Godbolt, 58. The necessity, motive, knowledge, or care of defendants forms no element of this action. Not the peculiar mode or manner of the injury, but the fact of the injury caused by the dam, in any mode or manner, is the ground of the action." Pixley v. Clark, 35 N. Y. 520, 531, 91 Äm. Dec. 72 (1866). See, also, Wilson v. City of New Bedford, 108 Mass. 261, 11 Am. Rep. 352 (1871). When the effect of the reservoir was to prevent the underground waters on B.'s land passing along by percolation, $A$. was held to have no liability. Harwood v. Benton, 32 Vt. 724 (1860), But see Bassett v. Salisbury Mfg. Co., 43 N. H. 569, S2 Am. Dec. 179 (1S62). In general, as to the extent of liability for damage caused by accumulated water, see Rylands v. Fletcher, I. R. 3 II. L. 330 (1868), and other cases in Hepburn's Cases on Torts, 776 et seq.

6 Part of the opinion is omitted. 
plaintiff's well. Upon this subject the proof was that the interruption, by the act of the defendant, was of percolating water, and as a consequence the water in the well was diminished in quantity, as was the flow of the small surface stream running to the ponds, which was practically, if not entirely, dried up, and the quantity of water in the ponds diminished.

In the present case both corporations seek to obtain water in a similar manner, for a precisely similar purpose; i. e. for transportation and sale. Neither party intends to make use of its land for any other purpose than will facilitate the gathering and distribution of water. In this respect their rights are equal, one as great as the other; and we see no reason why the rule should not be applicable as would apply in case either owner desired to improve its land for purposes of use. Then, as we have seen, neither party would be liable for the diversion of percolating water, because each is engaged in the exercise of a legal right, and the rights of each are equal in the use and enjoyment of the land. When both seek to use their land for exactly the same purpose, and neither seeks to improve it for the purpose of beneficial enjoyment, but to make a profit from the business carried on, the right to such use must also be equal. Under such circumstances, if one gets more than the other we think there can be no more ground of complaint than would exist if both sought to improve their own land, and one secured more than the other, or one was damaged and the other not. As applied to such obligations, the doctrine of reasonable use and relative rights has never been adopted by any of the courts in this state, nor in any other state, so far as our research has discovered, except in New Hampshire. We are not able to see, therefore, that the act of the defendant has infringed upon any legal right which the plaintiff possessed. So far as the diversion of the small brook is concerned, we do not think that the facts warrant its separation from the rule applicable to percolating water. There'was little proof to show that its source, character, or use was such as to make the rule of the Smith Case applicable. It is not every rivulet or small stream to which such rule can be applied, as it is evident, if such were the rule, then an adjoining owner might be unable to improve his property, or might improve, and find himself liable for exercising his legal right. The destruction must be unreasonable when the rights of both parties are considered, and, as applied here. we think it was not sufficient to create a subject-matter of legal damage.

These views call for a reversal of the judgment. ${ }^{\text {? }}$

TAcc.: When neither party used a pump. Ocean Grove v. Asbury Park, 40 N. J. Eq. 447,3 Atl. 168 (1SS5).

A. had a natural mineral spring, the waters of which he bottled and sold. B. installed a pump and pumped the waters, extracted the carbonic acid gas, which he sold, and let the waters go to waste. This pumping diminished the waters in A.'s spring, to his damage. Held, A. may enjoin B. Hathorn v. Niatural Carbonic Gas Co. 194 N. Y. 326, 87 N. E. 504, 23 L. R. A. (N. S.) $4: 36$, $12 S$ Am. St. Rep. 555, 16 Ann. Cas. 989 (1909). 


\section{KINNAIRD v. STANDARD OIL CO.}

(Court of Appeals of Kentucky, 1S90. \$9 Ky. 468, 12 S. W. 937, 7 L. R. A. 451, 25 Am. St. Rep. 545.)

PRYOR, J. ${ }^{8}$ The appellant, Kinnaird, is the owner of a small tract of land containing about four acres, lying adjacent to or within the boundary of the town of Lancaster, in the county of Garrard. On this land is a valuable and never-failing spring, that appears upon the surface of the ground at the foot of a hill, and had been used as such for a long period of time. In November of the year 1886 the appellee, the Standard Oil Company, leased from the Kentucky Central Railroad Company a site upon which to build a warehouse for the storage of its coal oil. They erected the warehouse, and placed in it their coal oil, that leaked from the casks, and saturated the ground, both on the inside and outside of the building. The floor of the house consisted of a bed of cinders about 12 inches in depth, that supplied the place of plank, that, as the proof shows, would become very inflammable when saturated with the oil. The bed of cinders, therefore, rendered the property much more secure than if a floor had been laid in the building. The spring of the appellant is located about 200 yards from the oil-house of the appellee, with a hill or rise in the ground between the two, and the proof conduces to show that water on the surface of the ground at the oil-house would naturally flow in an opposite direction from the spring, because it is lower than the ground where the spring emerges from the hill. After the oil had been deposited in the building erected for that purpose, it is manifest that it leaked from the casks, and, being of such a penetrating character, it passed into the ground, and polluted the water or stream from which the spring of appellant was supplied.

While it is argued that the proof on this subject is by no means satisfactory, we think it apparent from the testimony that the oil mingled with underground currents of water that fed the spring of the appellant, and caused the injury. The court below, on hearing the testimony, gave a peremptory instruction to the jury, on the ground that no action could be maintained for contaminating the subterranean water that flowed into the spring of the appellant, as the appellee had the right, in the exercise of its legitimate business, to build the house, and store the oil within it, on its own land, although the property of its neighbor was injured by it. * * *

It seems to us, after a careful review of the authorities referred to by counsel for the corporation, all of which are entitled to great weight, that there is a manifest distinction between the right of the owner of land to use the under-ground water upon it, that originates from percolation or is found in hidden veins, and the right to contaminate it 
so as to injure or destroy the water when passing to the adjoining land of his neighbor.

It is a familiar doctrine that one must so use his property as not to injure his neighbor, and because the owner has the right to make an appropriation of all the under-ground water, and thus prevent its use by another, he has no right to poison it, however innocently, or to contaminate it, so that when it reaches his neighbor's land it is in such condition as to be unfit for use either by man or beast. One may be entitled by contract with his neighbor to all the water that flows in a stream on the surface that passes through the land of both, and, while he can thus appropriate it, he has no right to pollute the water in such a manner as, when it passes to his neighbor, its use becomes dangerous or unhealthy to his family, or to the beast on his farm. As soon as the water leaves the land of the one who claims the right to use it, and runs on the land of another, the latter has the same right to appropriate it, and, if property, it then becomes as much the property of the last as the first proprietor. The owner of land has the same right to the use and enjoyment of the air that is around and over his premises as he has to use and enjoy the water under his ground. He is entitled to the use of what is above the ground as well as that below it, and still it will scarcely be insisted that he can poison the atmosphere with noxious odors that reach the dwelling of his neighbor, to the injury of the health of himself or family. If not, we see no reason why he should be permitted to so contaminate the water that flows from his land to his neighbor's, producing the same results, and still escape liability for the damages sustained, and whether the water escapes the one way or the other is immaterial.

The simple question is, can the owner, with a knowledge of the penetrating character of its oil, and the effects following its leakage, store large quantities of it near the spring of the plaintiff, when the oil is seen in puddles outside of the building, the result of leakage of the casks on the inside, and resist the claim of the plaintiff on the ground that it did not know the water was affected by it? The injury has been done, and can it be said that it presents a case of damnum absque injuria? We think not.

The entire dominion of the defendant over its property in the present case is undenied, but it had no right, while enjoying its use, although in a legitimate way, to violate, by the manner of its use, the rights of others. It seems to us unreasonable to adjudge that the erection and operation of gasworks, or buildings for the storage of oil, with the noxious and injurious substances, by reason of the deposit on the surface permeating the ground, and injuring or destroying the taste or use of water belonging to and on the property of others, is such a legitimate use of one's property, and his dominion over it, as to preclude any recovery for an injury to the property of his neighbor, however great, and to require a notice that the injury has, been inflicted before the action can be maintained would be to destroy the theory or 
the principle upon which a recovery in the case is permitted. It is argued that the appellee was ignorant of the existence of the nuisance or injury to appellant's spring, and had no right to suppose that its oil was affecting the water in the spring of the plaintiff. This may be so, and still the defendant is responsible for the injury, although it was not aware that its neglect in permitting the oil to leak from the casks, and stand in pools outside the building, had or would work an injury to the plaintiff. If a nuisance, whether neglect or not, the appellee is liable.

We have assumed, in the consideration of the questions presented, that the injury complained of resulted from the manner in which the oil was kept in the store-house of the defendant, but we are not to be understood as taking that question from the jury on the return of the case.

Judgment reversed and remanded, with directions to award a new trial, and for proceedings consistent with this opinion. ${ }^{\circ}$

9Acc: Tennant v. Goldwin, 1 Salk. 360 (1704) ; Ballard v. Tomlinson, 1. R. 29 Ch. Div. 115 (18s5); Ball v. Nye, 99 Mass. 5S2, 97 Am. Dec. 56 (1S68). See Patrick จ. Smith, 75 Wash. 407, 134 Pac. $1076,4 S$ L. R. A. (N. S.) 740 (1913).

The defendant drove a gas well on its own land about 50 feet from the plaintiff's spring. As a result the spring was affected and rendered worthless by pollution from a stratum of salt water encountered in sinking the gas well. The plaintilf was allowed to recover for the damage so caused. The court said: "The defendant is liable, not becsuse it has necessarily in. jured the plaintiffs in the exercise of its own legal right, but because it has injured them unnecessarily by the neglect of such reasonable precautions as might and should have been taken to protect them. According to the testimony, this gas well was arilled with the knowledge of the fact that salt water was to be encomntered; that it could be confined to its own bed; that. if it was not, the 'whole neighborhood nould be snoiled;' and that there were many wells near by in the borongh of Glenfield to be affected by their want of care of it in this particular. Iet no effort whatever was made to shut off the calt mater, or to avoid the destruction of the wells which it was practicable to sare. The ground of the defendant's liability is negligencethe want of reusonable care, under the circumstances, for the rights of others." Collins v. Chartiers Yal. Gas Co., 139 Pa. 111, 21 Atl. 147 (1S91).

A. built a gas retort on his own land, and there deposited the refuse matter resulting from the manufacture; part of it was carried by surface water or shallow subsurface percolation into B.'s well; part of it worked into the ground and polluted the deejer underground waters by which B.'s rell was sunplied. B. brought action for the pollution. Held, A. is liable for the pollution resulting from the surface and shallow subsurface direct percola. tion, but for the indirect pollution of the well only if his conduct is mali. cious, and knowledge that these consequences are being produced is not sufficient. Brown v. Illius, 27 Conn. S4, 71 Am. Dec. 49 (1858).

See, also, Dillon v. Acme Oil Co., 49 Hun, 565, 2 N. Y. Supp. 289 (18s8); Beatrice Gas Co. v. Thomas, 41 Neb. 662, 59 N. W. 925, 43 Am. St. Rep. 711 (1894). 


\section{HALE v. McLEA.}

\section{(Supreme Court of California, 1879. 53 Cal. 578.)}

[The plaintiff and the defendant owned adjacent tracts of land. On the plaintiff's tract near the boundary was a small, never-failing spring of water which the plaintiff used for domestic purposes. On defendant's land a line of bushes, usually found nowhere except on a water course, extended up to the boundary line at the point near which the spring appeared. The defendant, on his own land and just inside the boundary, began at some distance from the line of bushes and at right angles to it a trench, which deepened to a depth of nine feet where it intercepted the line of bushes. At this point a stream of water made its way into the trench and was piped away by the defendant to his house, where part of it was used and the rest allowed to go to waste. Immediately after this was done the plaintiff's spring ceased to flow and has since remained dry. The defendant was not actuated by malice. The plaintiff brought action for the diversion of the water. $\mathrm{He}$ had judgment below and defendant appealed.] ${ }^{10}$

CrocketT, J. An examination of the English and American decisions on the questions of law involved in this appeal leads us to the conclusion that, on the facts admitted by the pleadings or found by the court, the right of the defendant as against the plaintiff to use the water of the subterranean stream, which is the subject of the action, is at most no greater than if it was a surface stream, on which the defendant was the upper and the plaintiff a lower riparian owner. Tested by this rule, the utmost that can be claimed for the defendant on the facts is, that he is entitled to take from the stream as much water as he needs for watering his cattle and for domestic uses, such as cooking, washing, and the like, leaving the surplus to flow to the spring of the plaintiff in its natural channel. But the findings show that the defendant has diverted the whole body of the stream through pipes, in such a manner that no portion of the water can reach the spring; and the surplus at the commencement of the action was running to waste, as appears from the admissions in the pleadings. If it were a surface stream, the plaintiff would be entitled to have it flow to and across his lands, in its natural channel, subject only to the right of the defendant to use so much of the water as is necessary to supply his natural or primary wants as above indicated; nor, on the facts found, can the defendant exercise any greater right in respect to a subterranean stream. Assuming, therefore, that the rights of the defendant are precisely the same as though it was a surface stream, he has exceeded them by diverting the whole body of the water from its natural channel, instead of allowing the surplus to flow to the spring in its accustomed bed.

10 The statement of facts is rewritten and the concurring opinion of Rhodes, J., is omitted. 
But the exigency of the case does not require us to decide that the defendant has the same right in respect to a subterranean stream as though it was a surface stream flowing across his land; and our decision is only to the effect that, if it be assumed his rights are the same, he has, nevertheless, exceeded them by diverting the whole body of the stream, instead of allowing the surplus to flow to the spring in its natural channel.

There is no question in this case involving the right of a riparian owner to the use of water for purposes of irrigation; nor is the point before us whether or not a land-owner may be restrained from diverting or obstructing the flow of an underground current, running in a defined channel across his land, and which supplies a spring or well on the adjoining lands, if it become necessary to divert or obstruct the stream in the prosecution of the business of mining, or any other legitimate enterprise on his own land; nor to what extent, if at all, it would affect the question if the underground current was not known to exist until the fact was discovered in the prosecution of the work. These are grave questions, which the exigency of the present case does not require us to decide.

Judgment affirmed. ${ }^{11}$

\section{HAGUE v. WHEELER.}

(Supreme Court of Pennsylvania, 1893. 157 Pa. 324, 27 Atl. 714, 22 L. R. A. 141, 37 Am. St. Rep. 756.)

Wilimams, J. ${ }^{12} * * *$ In the treatment of this case it is a matter of first importance to get a clear apprehension of the facts on which the questions are raised. 'There are two plaintiffs who join in the bill, whose interests, while like in kind, are nevertheless several and distinct. There are several defendants, but their interests appear to be joint. The two plaintiffs hold separate leases on parts of tracts in Warren and Foster counties, Nos. 5,202, 5,203, 5,207, and 5,209, aggregating about 2,200 acres. The gas company began drilling on its leases in 1887. Hague began in 1888. Each has a gas well or wells furnishing gas in sufficient volume to enable the owner to utilize it by transportation to and sale in towns in the vicinity. The defendants are

11 Acc.: Keeney r. Carillo, 2 N. M. 480 (1883). See, also, Willis v. City of Perry, 92 Iowa, 297, 60 N. W. 727,26 L. R. A. 124 (1S94); Strait v. Brown, 16 Nev. 317, 40 Am. Rep. 497 (1881); Whetstone v. Bowser, 29 Pa. 59 (1S57). Compare City of Los Angeles v. Hunter, 156 Cal. 603, 105 Pac. 755 (1909).

A., in mining on his own land, unexpectedly intercepted an underground stream that supplied a spring on B.'s land, used by B. for domestic purposes. By the pumping necessary to render his mine workable, A. destroyed this stream, with the result that the spring went dry. Ileld, B. has no right of action against A. Haldeman v. Bruckhart, 45 Pa. St. 514, 54 Am. Dec. 511 (1S63). Acc.: Chase $\nabla$. Silverstone, 62 Me. 175, 16 Anl. Rep. 419 (1873).

12 The statement of facts and part of the opinion are omitted. 
owners and lessees of part of tract No. 5,207, which adjoins the lands of the gas company, and is not far from the lands of Hague. In 1890 they drilled a well on their tract, and obtained gas in considerable volume, but not sufficient to enable them to utilize it by transportation and sale. They have therefore allowed it to escape into the open air. 'The plaintiffs allege that the "geological formation in that locality" is such that the gas-bearing sand rock underlying all these tracts and forming the common reservoir or deposit from which the gas is obtained "is subject to drainage by the drilling of wells on any part thereof." For this reason they assert that "the flow of gas from the said well of defendants is so great that it will, if allowed to go to waste, seriously and irreparably injure the wells of the plaintiffs by drainage from the lands adjoining and near to said defendants' wells. To prevent this they state that they entered on the defendants' land, and at a cost of about $\$ 200$ shut in the gas and closed the well. The defendants then threatened to remove the cap or plug and permit the gas to escape again into the air. Upon these facts the plaintiffs asked the court below to enjoin the defendants from removing the cap or plug from the casing or tubing in the well, and from "permitting the gas therefrom to flow into the air, or otherwise go to waste." The injunction was granted, and from that decree this appeal was taken.

The affidavits show that the defendants drilled their well in 1890, at the suggestion and request of the gas company, and that negotiations for its purchase by the gas company have been conducted at some length, but without resulting in a bargain. This fact-that the well in controversy had been drilled at considerable cost by the defendants, ar the request of the gas company-the learned judge rightly regarded as a significant one. In the opimion filed by him, which is an able one. he says that this fact "might defeat this application so far as the gas company is concerned;" but he regarded it as of no consequence so far as the other plaintiff was concerned, for he immediately added: "But, as it cannot affect the plaintiff Hague, it is not necessary to consider it at this time." He then proceeds to state and consider the question on which his decree was based, upon a state of facts such as might arise where an adjoining owner was guilty of malice or negligence in the conduct of operations on his land resulting naturally in injury to his neighbor. But is this conclusion of the learned judge that Hague stood on higher ground than the gas company a correct one? 'The acts complained of were the drilling of the well in 1890 , when the wells of both the plaintiffs were in full operation, and the subsequent failure to utilize or shut in the gas. 'The drilling of the well was accounted for, and the suggestion of malice or negligence therein negatived by proof that it was done at the instance of the gas company. This company had a considerable gas plant, and was engager in the supply of gas to its customers for fuel. It was interested in the development of the region, and evidently expected to buy the defendants' well if it was of sufficient size to be capable of utilization. The defendants and the gas 
company could not agree upon the price of the well after it was drilled, but the fact that it was drilled at the request of the company, and not of the mere motion of the defendants, was an answer to any allegation of malice or negligence on the part of Hague as well as on the part of the company, since it accounted for the act of drilling by assigning a motive therefor, both lawful and neighborly. It will not do to say that an act thus accounted for as to one plaintiff may be assumed to be the result of malice or negligence as to the other, in the absence of proof to sustain the assertion. These plaintiffs stand on common ground. Neither of them can complain of the defendants for the act of drilling the well on their land on any other ground than the existence of malice or negligence. When the act is accounted for in such a manner as to show that it was not done with malice, or in negligence, but in good faith, as an act of ownership, and at the solicitation of the gas company, the character of the act is established, and as a basis of relief it falls out of the case.

What have we then? Three landowners owning considerable holdings in the same basin, or overlying the same gas-bearing sand rock, each having an open gas well or wells on his land, drilled without malice or negligence, in a lawful manner, and for a lawful purpose. Two of these owners have been able to utilize the gas from their respective lands and find a market for it. One of them has not been so fortunate. He has gas from his well, but up to the time of the filing of this bill he has not been able to utilize or dispose of it, and his gas has gone to waste for that reason. His more fortunate neighbors come into a court of equity, and ask that he shall not be permitted to let his gas run, because, while this gas is his own, underlying his tract, and finding its way to the surface through his well, it has a tendency to drain the sand rock, and so to reduce ultimately the flow of gas from their wells. This would be equally true if the defendants were able to utilize their gas; yet it is conceded that in that case their right to the gas from their well would be as incontestable as the right of the plaintiffs to use the gas from theirs. How is that right lost? By their inability to find a purchaser? If they can find a purchaser, or turn the gas to any useful purpose, their right to the gas that flows from their well is conceded. If they cannot, their right is denied. Their well must be shut in, while their successful neiglibors drain the entire basin through their open wells, and receive pay for the gas. This is a proposition to limit the power of the owner over his own by the use he is able to make of it. If he can sell his gas or his oil, or turn it to some practical purpose, his power over it as owner is unabridged. If he cannot find a purchaser, or a practical purpose to which to apply his yield of gas or oil, then his power as owner is gone. This would be an adaptation to actual business of the spiritual truth that "to him that hath shall be given; but from him that hath not shall be taken away, even that which he seemeth to have." * * * 
An owner of land may have a deposit of coal under some portion of it so small in extent, or with such an inclination, as to make it impossible for him to mine through his own tract without a greater cost to him than the value of the mined coal when brought to the surface. His neighbor may have an open mine that reaches it, and through which it could be brought at a fair profit. These circumstances do not affect the title of the owner of the coal, or confer any right on the adjoining mine owner; but it is said that the oil and gas are unlike the solid minerals, since they may move through the interstitial spaces or crevices in the sand rocks in search of an opening through which they may escape from the pressure to which they are subject. This is probably true. It is one of the contingencies to which this species of property is subject. But the owner of the surface is an owner downward to the center, until the underlying strata have been severed from the surface by sale. What is found within the boundaries of his tract belongs to him according to its nature. The air and the water he may use. The coal and iron or other solid mineral he may mine and carry away. The oil and gas he may bring to the surface and sell in like manner, to be carried away and consumed. His dominion is, upon general principles, as absolute over the fluid as the solid minerals. It is exercised in the same manner, and with the same results. He cannot estimate the quantity in place of gas or oil, as he might of the solid minerals. He cannot prevent its movement away from him, towards an outlet on some other person's land, which may be more or less rapid, depending on the dip of the rock or the coarseness of the sand composing it; but so long as he can reach it and bring it to the surface it is his absolutely, to sell, to use, to give away, or to squander, as in the case of his other property. In the disposition he may make of it he is subject to two limitations: he must not disregard his obligations to the public, he must not disregard his neighbor's rights. If he uses his product in such a manner as to violate any rule of public policy or any positive provision of the written law, he brings himself within the reach of the courts. If the use he makes of his own, or its waste, is injurious to the property or the health of others, such use or waste may be restrained, or damages recovered therefor: but, subject to these limitations, his power as an owner is absolute, until the legislature shall, in the interest of the public as consumers, restrict and regulate it by statute.

The decree of the court below is reversed, and the injunction is dissolved. ${ }^{13}$

13 "The acts of 1891 and 1893 are an express recognition by the legislature of the qualified ownership of the common owners in the gas in the common reservoir, and any act therein forbidien may be, according to the circumstances, the subject of a suit at law or a proceeding in equity by the persou injured. as well as the foundation of a public prosecution. Independently, however, of any statute, for the reason already stated, the common owners of the gas in the common reservoir, separately or together, have the right to enjoin any and all acts of another owner which will materially injure, or 


\title{
CHAPTER VII
}

\section{RIGHTS OF REVERSIONERS}

\author{
BAXTER v. TAYLOR. \\ (Court of King's Bench, 1832. 4 Barn. \& Adol. 72.) \\ * * At the trial before Parke, J., at the last assizes for the
} county of York, it appeared that the plaintiff was seised in fee of the closes mentioned in the declaration, which he had demised to tenants; that the defendant had with his horses and cart entered upon the close called Stoney Butts Lane; and that after notice had been given him by the plaintiff to discontinue so doing, he claimed to do so in exercise of a right of way. The learned Judge was of opinion, that although that might be good ground for an action of trespass by the occupier of the plaintiff's farm, it was not evidence of any injury to the reversionary estate, and therefore that the action was not maintainable; and he nonsuited the plaintiff, but reserved liberty to him to move to enter a verdict. ***

Tauntox, J. ${ }^{1}$ I think there should be no rule in this case. Young v. Spencer. 10 B. \& C. 145 , is not in point. That was an action on the case in the nature of waste by a lessor against his own lessee. Here the action is by a reversioner against a mere stranger, and a very different rule is applicable to an action on the case in the nature of waste brought by a landlord against his tenant, and to an action brought for an injury to the reversion against a stranger. Jackson v. Pesked, 1 M. $\&$ S. 234. shews, that if a plaintiff declare as reversioner, for an injury done to his reversion, the declaration must allege it to have been done to the damage of his reversion, or must state an injury of such permanent nature as to be necessarily prejudicial thereto, and the want of such an allegation is cause for arresting the judgment. If such an al.. legation must be inserted in a count, it is material, and must be proved. Here the evidence was, that the defendant went with carts over the close in question, and a temporary impression was made on the soil by the

which will involve the destruction of, the property in the common fund, or supply of gas." Manufacturers' Gas \& Oil Co. v. Indiana Natural Gas \& Oil Co., 155 Ind. 474,57 N. E. 912,50 L. R. A. 768 (1900).

A. and B., owners of oil lands, each had a pump; B.'s being more powerful. A. filed a bill for an injunction against B., alleging that by the use of B.'s pump the oil was being drawn away from the strata of A.'s land, to his great damage. Held, injunction denied. Ilo Oil Co. v. Indiana Natural Gas \& Oil Co., 174 Ind. 635, 92 N. E. 1, 30 L. R. A. (N. S.) 1057 (1910). See Kelley v. Ohio Oil Co., 57 Ohio St. 317, 49 N. E. 399, 39 L. R. A. 765, 63 Am. St. Rep. 721 (1897).

1 The statement of facts is abridged and the opinions of Patterson and ['arke, JJ, are omitted. 
horses and wheels; that damage was not of a permanent but of a transient nature; it was not therefore necessarily an injury to the plaintiff's reversionary interest. Then it is said that the act being accompanied with a claim of right, will be evidence of a right as against the plaintiff, in case of dispute hereafter. But acts of that sort could not operate as evidence of right against the plaintiff, so long as the land was demised to tenants, because, during that time he had no present remedy by which he could obtain redress for such an act. He could not maintain an action of trespass in his own name, because he was not in possession of the land, nor an action on the case for injury to the reversion, because in point of fact there was no such permanent injury as would be necessarily prejudicial to it; as therefore, he had no remedy by law for the wrongful acts done by the defendant, the acts done by him or any other stranger would be no other evidence of right as against the plaintiff, so long as the land was in possession of a lessee. In Wood v. Veal, 5 B. \& A. 454, it was held, that there could not be a dedication of a way to the public by a tenant for ninety-nine years, without consent of the owner of the fee, and that permission by such tenant would not bind the landlord after the term expired. I think therefore that the plaintiff cannot maintain the present action; and there is not doubt sufficient to induce me to think that there ought to be a rule nisi for a new trial.

\section{SIMPSON v. SAVAGE.}

(Court of Common Pleas, 1S56. 1 C. B. [N. S.] 347.)

The plaintiff was the owner of a plot of ground in King's Lynn, in the county of Norfolk, upon which he built several houses in 1850, which were let to tenants at rents varying from $£ 40$ to $£ 44$ per annum. The defendant is an agricultural implement maker occupying premises consisting of workshops with a forge and chimney and yard closely adjoining the back yards of the plaintiff's houses. The workshops, forge, and chimney were erected (not by the defendant) in 1851, and were a few feet only from the back windows of the plaintiff's houses. The nuisance complained of consisted in the emission of smoke from the forge chimney, to such an extent that great quantities of soot entered the windows in the rear of the plaintiff's houses, dirtying and spoiling the furniture in the rooms, and of noises from the hammering, and offensive smells from the burning of old wood in the yard. It was proved, on the part of the plaintiff, that, in consequence of the nuisance, which was of a serious character, some of the plaintiff's tenants had given him notice to quit (though it did not appear that any of them had actually quitted); and that, in consequence of the nuisance, the plaintiff's houses would not realize as much rent as they would otherwise have done. 
CRESSWELl, J. ${ }^{2}$ This was an action for an injury to the plaintiff's reversion by erecting a manufactory on land adjoining the plaintiff's houses, and causing smoke to issue from a chimney, and making loud noises. The plaintiff also complained of a nuisance arising from the lighting of wood fires in the yard adjoining the factory.

The cause was tried before Lord Campbell, at the last assizes for Norfolk, when his lordship ruled that the nuisances merely of a temporary nature, such as the wood fires and the noises, would not support the action: but, with reference to the smoke issuing from the foundry chimney, he thought the case distinguishable from Mumford v. The Oxford, Worcester, and Wolverhampton Railway Company, 1 Hurlst. \& Norm. 34, and that there was evidence to go to the jury to prove injury to the reversion: but he reserved leave to the defendant to move to enter a nonsuit, if the court should be of opinion that there was no injury to the reversion.

A rule nisi having been obtained accordingly, cause was shown in the course of the last term, before my Brothers Williams and Crowder and myself.

The only point reserved for our consideration, was, whether there was evidence for the jury of any injury to the reversion in the premises of which the plaintiff was owner, but not the occupier, they being let to tenants. ***

On the argument, it was insisted that the injury done by the defendant need not be of a permanent nature, and that it was sufficient if proved to be of such a description as would cause the reversion in the premises to sell for a smaller sum if brought into the market.

After considering the authorities, we are of opinion, that, since, in order to give a reversioner an action of this kind, there must be some injury done to the inheritance, the necessity is involved of the injury being of a permanent character.

The earliest instances of such an action are, cutting trees, subverting the soil, and erecting a dam across a stream so as to cause it to flow over the plaintiff's land. In the two former cases, the thing done was not removable or remediable during the term: in the third, it was; but, being of a permanent character, it was to be assumed that it would remain, and therefore was treated as an injury to the inheritance.

The decision in Jessel v. Gifford, 4 Burr. 2141, falls within the same principle. A window was obstructed; the obstruction was of a permanent character, and would remain, unless something was done to remedy the evil. Tucker v. Newman, 11 Ad. \& E. 40 (E. C. L. R. vol. 39), 3 P. \& D. 14, belongs to the same class.

Now, the building erected in this case did not injure the plaintiff's inheritance: but it is said that the use made of it did. The real subject-matter of complaint, therefore, is, not the erection of the building, but causing smoke to issue from it. If the fires had not been made by

s Part of the opinion is omitted. 
the defendant, he could not have been sued for an injury either to the possession or the inheritance: Rich v. Basterfield, 4 C. B. 783 (E. C. L. R. vol. 56). Now, making the fires and causing smoke to issue, was not an act of a permanent nature. It is very like the case of Baxter v. Taylor, 4 B. \& Ad. 72 (E. C. L. R. vol. 24), where a person trespassed, asserting a right of way; and not distinguishable from Mumford v. 'The Oxford, Worcester, and Wolverhampton Railway Company, where the action was brought against the defendants as occupiers of certain sheds, for making noises therein, which caused the plaintiff's tenants to give notice to quit.

The real complaint by the reversioner is, that he fears the defendant, or some other occupier of the adjoining premises, will continue to make fires and cause smoke to issue from the chimney: and, if the reversion would sell for less, that is not on account of anything that has been done, but of the apprehension that something will be done at a future time.

According to the authorities, we feel bound to say that this is not such an injury as will enable the reversioner to maintain an action. The rule for entering a nonsuit must, therefore, be made absolute.

Rule absolute. ${ }^{3}$

\section{GREEN v. SUN CO.}

(Superior Court of Pennsylrania, 1907. 32 Pa. Super. Ct. 521.)

Trespass to recover damages for injuries to real estate resulting from fumes from an oil refinery.

Henderson, J.4 One of the plaintiff's complaints was that the defendant wrongfully and injuriously constructed its works and negligently maintained and carried on its business, as a result of which the plaintiff's buildings were damaged. No evidence of negligence was introduced, however, the plaintiff relying on testimony tending to establish the existence of a nuisance in the business which the defendant conducted. There is also an averment that the atmosphere was made unwholesome and injurious to the plaintiff's tenants. The latter charge, however, was eliminated from the case by the court, together with all the evidence relating thereto, the issue being confined to the inquiry whether the defendant maintained a nuisance and whether that nuisance was injurious to the buildings occupied by the plaintiff's tenants. * * *

The plaintiff does not seek to recorer damage for the injury to the tenants. His allegation was that there was a physical injury to the property. The damage was to the freehold and not to the tenants' occupancy. For such an injury the landlord may maintain an action notwithstanding the occcupancy by a tenant. Devlin v. Snellenburg, 132

3Acc.: Mumford v. Oxford etc., Ri. Co., 1 H. \& N. 34 (1850); Mott v. Shoolbred, L. R. 20 Eq. Cas. 22 (1875).

4 The statement of facts and part of the opinion are omitted. 
$\mathrm{Pa} .186,18$ At1. 1119. There is no evidence that the tenants were bound to repair, and certainly no obligation rested on them to make reparation of the injury alleged to have been caused by the defendant. Earle v. Arbogast, $180 \mathrm{~Pa} .409,36 \mathrm{Atl}$. 923. The plaintiff is none the less entitled to recover even if he has not actually made the repairs. The value of his property is reduced to the extent of the injury whether he should determine to apply the amount of his damages to the improvement of his property or keep the money in his pocket. If his property had been wholly destroyed by the unlawful and injurious act of the defendant he would be entitled to compensation whether he rebuilt or not.

The declaration charged negligence, but, it was not necessary that the plaintiff offer evidence in support of this averment. A nuisance is sufficiently charged and the question of negligence is not necessarily involved. Hauck v. Tidewater Pipe Line Co., $153 \mathrm{~Pa}$. 366, 26 At1. 644, 20 L. R. A. 642, 34 Am. St. Rep. 710 ; Stokes v. Penna. R. R. Co., 214 Pa. 415, 63 At1. 1028. * * *

The assignments are all overruled and the judgment affirmed. ${ }^{5}$

5Acc.: Shelfer v. City of London Electric Co., [1S95] 1 Ch. 287.

Plaintiff complained "that the defendant by means of certain erections and obstructions caused the water of a certain stream to run out of its natural course, into and upon land of plaintiff, and to overflow same, and thereby rotted, spoiled, damaged, washed away, and destroyed the grass and herbage of the plaintiff and also made the land boggy, miry and rotten, and greatly deteriorated in value: by means of which plaintiff has been injured in his reversionary estate of said lands." The court held this declaration to be good on demurrer and said:

"If the plaintiff had only averred that the defendant had turned the water upon and overflowed his land, and thereby rotted, destroyed, and washed away the grass there being and growing, he might have proved on the trial such an extent of injury to his land and meadow grounds, as seriously affected his reversionary estate. It is no argument to say that the tenant, if the action had been lrought by him, might hare declared in the very language used in this declaration. This is certainly true. There are many injuries that may be done to lands, which affect, as well the landlord as the tenant, and for which the former may have an action on the case, and the latter an action of trespass; and in which the wrongful acts may be, and sometimes must be, described in the same way. For instance, digging up the soil, cutting down fruit, or timber or ornamental trees; or breaking $o l^{\circ}$ destroying the dwelling house; and in short. whatever amounts to waste, is an injury to both, and may be described by both in the same way. There are other injuries that, from their very nature, can only be prejudicial to the possession;-such as cutting or trampling down the grass or grain growing; or gathering and carrying a ray fruit from the orchard; and therefore, if the landlord were to declare for such injury, it would be had on demurrer, even though he should aver that it was done to the prejudice of his reversion, since such averment would be inconsistent with, and in fact contradictory to his own statement of the trespass." Potts v. Clarke, $20 \mathrm{~N}$. J. Law, 536, 543 (1845).

Injuries to the reversion were found in Tucker v. Newman, 11 Adol. \& El. 40 (1S39) ; Kankakee \& S. R. Co. v. Horan, 131 Ill. 2S8, 23 N. E. 621 (1890) ; Armeson v. Spawn, 2 S. D. 269, 49 N. W. 1066, 39 Am. St. Rep. 7 S3 (1891).

The reversioner was denied relief in Cooper $v$. Crabtree, $20 \mathrm{Ch}$. Dir. 589 (18s:).

A. Was the owner of a mill and mill privilege on a certain river. B. had constructed a dam abore A.'s mill for the purpose of raising a pond as a 


\section{PARK v. WHITE.}

(Chancery Division of the High Court of Ontario, 1893. 23 Ont. 611.)

This was an appeal by the defendants from the judgment at the trial, in an action brought by William Park against Thomas L. White and Sarah White, his wife, to restrain a nuisance occasioned by smells arising from privy pits located near the walls of the plaintiff's house.

It appeared that about seven years ago, when the locality was not so thickly settled, the defendants built a row of cottages on the rear of their lot, and common closets were constructed for the use of the occupants. Subsequently the plaintiff became the owner of the lot immediately adjoining, and constructed a row of cottages with the rear wall 18 inches from the privy pits. The plaintiff complained that the pits were a nuisance to the occupants of the cottages belonging to him; and that some of his tenants had left, and some were threatening to leave on account of the bad smells arising therefrom. ***

Boyd, C. ${ }^{6}$ The plaintiff's pleadings are grounded on his ownership of land which is injuriously affected by disagreeable and noxious odours arising from privy pits on the land of the defendant. He does not sue as reversioner, but alleges that his tenants have from time to time vacated his houses, and that by the frequent remarks of tenants, his houses are getting an ill repute, and that he fears he will be unable to rent them, all on account of the filthy condition and foul smells of and from the said privy pits, and he further alleges that the tenants now in occupation threaten to leave if the said nuisance is not abated.

The chief ground of contention was on the issue, nuisance or no nuisance, and the plaintiff has succeeded. Questions were submitted and answered, and on the answers merely and only, the defendant now moves against the judgment directed to be entered for the plaintiff. $* * *$

It is urged again that the plaintiff had no right of action. Some cases were cited to the effect that a reversioner pure and simple would have no right of action in respect of a mere temporary nuisance. The most notable case on this head is Jones v. Chappel, L. R. 20 Eq. 539. But

storage reservoir for its waterworks. The water was taken from this dam by the conduits of $B$. under a clatim of right and to such an extent as to damage the mill privilege. In an' action of tort by A. against $B$. for so diverting the water, held, although $\Lambda$.'s mill is in possession of a tenant, $A$. call recover for such constant withdrawals of water as an injury to his reversion. Lund v. City of New Bedford, 121 Mass. 286 (1S76): Acc.: Heil. bron v. Last Chance Water Ditch Co., 75 Cal. 117, 17 Pac. 65 (1S88).

Where there is a damage to the reversion, as by cutting down trees, where the land is in the possession of a tenant at will, the reversioner may maintain trespass quare clausum fregit. Starr v. Jackson, 11 Mass. 519 (1S14).

6 The statement of facts is abridged and part of the opinion of Bosd, C., and the opinion of Meredith, J., are omitted. 
the neat point in that was, the plaintiffs in an action to restrain a nuisance of a temporary nature must be the occupiers, and not merely the reversioners of the property affected by the nuisance. Had a tenant been added as coplaintiff, the action would have succeeded. This course was taken during the course of the trial in Broder v. Saillard, $2 \mathrm{Ch}$. D. at page 698, and the trial judge in this case held in suspense a similar application, which he did not deem necessary to act upon. But as a matter of precaution the permission to amend should now be given as the whole matter in controversy was as to the existence of a nuisance.

I should deem the nuisance here to be not of a temporary character, but of such a recurring nature as to be practically continuous and permanent. Draper v. Sperring, 4 L. T. N. S. 365. If so, the reversion is prejudicially affected because the injury was likely to last in the ordinary course of things down to the time when the reversion would come into possession. In fact, it was said that some of the short tenancies had determined; and as to the damages given, it was in respect of a vacant house.

The frame of action without amendment seems justified by such cases as Wilson v. Townsend, 1 Dr. \& Sm. 324; Tucker v. Newman, 11 A. \& E. 40; Swain v. The Great Northern R. W. Co., 4 DeG. J. \& S. at p. 215: Smith v. Humbert, 2 Kerr (New Brunswick) 602; and Cleeve v. Mahany, 9 IV. R. 882. This last case is similar to the present, and Kindersley, V. C., said "the plaintiff had not suffered personally, except that he said he could not let his house; and if that loss ensued by reason of the continuance of the operation (of brickburning) then he might be entitled to the injunction." Page 883.

The motion should be dismissed with costs. ${ }^{\top}$

z "It appeared in evidence, as far as I could gather, that at the time when the bill was filed. but certainly shortly before, the two houses were let to weekly tenants, and they are both still so let and fully occupied. Now, as I unlerstand the doctrine in Simjsson v. Savage, 1 C. B. (N. S.) 347 (1856), the landlord in such a case cannot bring an action. The injury is a temporary nuisance, because the saws might be stopped and the steam engine might cease working at any moment. It is only an injury to the occupier, and the landlord cannot bring an action, because before his estate comes into possession the muisance may have ceased, or the person committing it may choose to make it cease the monent the estate comes into possession.

"Another ground of action on the part of the landlord might be that the existence of a nuisance of a temporary character would rénder it more difticult for him to let to a future tenant or to sell. But that is said not to be a good ground of action, because the theoretical diminution of the value of the property cammot be taken into account, inasmuch as the purchaser or the new occupiel would have a right to stop the nuisance, so that he ought not to give less on that account than he otherwise would. It appears to me I am not able to overrule Simpson $r$. Savage, and that the principles upon which it was decided apply as much to weekly tenancies as to any other tenancies.

"But then it is said that, if that is so, no relief at all can be obtained, and Mr. Jason Smith said that there was some doctrine of this court by which it weekly tenant could not have an injunction. So far as I am aware, that zas never been decided, but I should not find the slightest difficulty myself, 


\section{MILLER v. EDISON ELECTRIC ILLUMINATING CO.}

(Court of Appeals of New York, 1906. 184 N. Y. 17, 76 N. E. 734.)

The plaintiffs, by the institution of this action, have sought to restrain the defendant from continuing a nuisance, created through the maintenance and operation of a plant for the supply of electric light and power, whereby their property in neighboring dwelling houses has been injuriously affected. They, further, demanded judgment for damages already sustained. The property was in the occupancy of a tenant, holding under a lease by the plaintiffs. The trial court formulated its decision in findings of facts and conclusions of law, and the judgment recovered by the plaintiffs thereupon was affirmed by the Appellate Division. The facts found, so far as they need to be mentioned, show that the plaintiffs became the owners of the premises in question some years prior to 1888; in which year the defendant constructed, upon premises adjacent to those of the plaintiffs, a power house, equipped with machinery and appliances necessary for the purpose of generating electricity to be supplied to the public for lighting, or for power. In 1890, the plaintiffs leased their property for a term of five years; receiving a rental of $\$ 15,000$ a year and certain privileges. Shortly prior to the expiration of the term of this lease, the premises were again leased to the same tenant for another term of five years from May 1, 1895, at the rental of $\$ 12,000$ a year, with the reservation of the same privileges as in the previous lease. In 1900, the premises were, again, leased at a less rental, with the reservation of some additional privileges, and with a right to the lessors to share in the profits of the hotel business conducted by the lessee.

After the construction of its power house, the defendant's operations caused "soot, cinders, ashes, steam, or water condensing from steam," to be discharged upon plaintiffs' premises. Noises, jars, and vibrations resulted from the operation of the machinery, which impaired the peaceful enjoyment of the premises and affected their rental value. The court, further, found that, as the machinery was used at the time of the trial, no injury was being worked to the plaintiffs' property and "that it was improbable that it would be so used as to work injury in the future," but that, as the plaintiffs wert entitled to the equitable relief prayed for when the action was commenced, the court would retain the case and award to them their damages. Judgment was directed for the plaintiffs for such damages, in the amount of $\$ 4,500$. The court decided that the plaintiffs failed to establish that they suffered any damage after the year 1900 and, though the rental for the premises, reserved to them in the new lease of that year, was less than

if an occupier, being a weekly tenant, and his landlord were to join in a suit to restraip a nuisance, in granting them an injunction."

Jessel, M. R., in Jones v. Chappel, 1. R. 20 Eq. Cas. 539, 543 (1575). See Bell v. Jifland Iiy. Co., 10 C. B. N. S. 287 (1861). 
that for the prior term, the difference could be accounted for otherwise than by charging it to the defendant's acts. This was explained in the changed character of the locality, and in the fact that the lease provided, not only that the plaintiffs should have a share of the profits, but that they should enjoy greater privileges than formerly. These findings of the trial court have sufficient support in the evidence.

Cullen, C. J: (after stating the facts). I adopt Judge Gray's statement of facts, and I agree with him in the position that this action was properly brought in equity, that it was triable by the court, and that the defendant was not entitled to a jury trial as of right. I am unable; however, to concur in the view that the plaintiffs were properly awarded damages for diminution in the rental value of the property. The plaintiffs were in possession of the premises during no part of the period for which damages have been recovered, but the same were in the occupation of their tenants under a lease for a term of years. One of these leases expired during the existence of the nuisance, and, as the trial court has found, by reason of the nuisance the plaintiffs were compelled to rent the premises for a new term at a reduced rent. It is for this loss of rent that damages have been awarded. The question as to which party, the landlord or his tenant, is entitled to recover for depreciation of the rental value by the existence of a nuisance has involved the conrts in much perplexity. In the elevated railroad cases it has been settled that, in the case of a lease made after the erection and operation of the railroad, the landlord, not the tenant, is entitled to recover for such depreciation. Kernochan v. N. Y. Elevated R. R. Co., 128 N. Y. 559, 29 N. E. 65.

In the Kernochan Case there is an elaborate discussion of the question by Chief Judge Andrews. A careful analysis of the opinion of the learned judge will show that the decision proceeded on the ground that the elevated road was a permanent structure and intended to be so maintained; that it was constructed in the street under legislative authority; and that as ample authority was granted to condemn any property rights on which it might trespass, the lessor had "no absolute remedy to compel the removal of the structure, since the right of condemnation can at any time be exercised by the defendants." The learned judge said: "It is also a necessary deduction from the circumstances attending the making of ordinary leases of improved property, executed after the construction of the elevated railroad, that the right to recover damages is vested exclusively in the lessor." To the doctrine of that case the court has steadily adhered. When, however, the doctrine was invoked to defeat the right of a tenant to recover damages against the present defendant for the very same acts which constitute a nuisance in the case now before us, it was held that the rule in the elevated railroad cases did not apply. In Bly v. Edison Electric III. Co., a tenant, hiring after the nuisance was created, recovered the depreciation in the rental value of the premises.

The Appellate Division, citing the authority of the Kernochan Case, 
reduced the award to a nominal sum, holding that the tenant was not entitled to recover diminution in rental value. 54 App. Div. 427, 66 N. Y. Supp. 737. On appeal to this court the judgment of the Appellate Division was reversed, though a new trial was ordered because the trial court had awarded damages for a period anterior to 6 years hefore the commencement of the action. $172 \mathrm{~N}$. Y. 1, 64 N. E. 745, ss L. R. A. 500. This court said, per Werner, J.: "WVe think the Kernochan Case has no application to a case like the one at bar, and this without reference to the fact that it appears affirmatively that the rental paid by the plaintiff was the same during the existence of the nuisance as it was before. The elevated railroad cases, to which class the Kernochan Case belongs, are sui generis. They are governed by principles which apply to no other class of cases." The elaborate discussion of the question by Judge Werner leaves nothing to be now added. It is sufficient to say that that case expressly held that a tenant under a lease made during the existence of the nuisance was entitled to recover the depreciation of the value of the occupation of the premises.

It is said to be the settled rule of law "that where the wrongful act affects different interests in the same property, the owner of each interest may have his separate action against the wrongdoer. Landlord and tenant have separate assets, and each, if injured therein, may have redress, the one for the injury to the reversion, the other for the injury inflicted in diminishing his enjoyment of the premises." This statement is doubtless correct, but under this rule "to entitle a reversioner to maintain an action, the injury must be necessarily of a permanent character, and that a presumed intention to continue the nuisance is not sufficient, even where there is evidence that the premises would sell for less if the nuisance were continued." Mott v. Shoolbred, opinion of Sir George Jessel, M. R., 20 Eq. Cases, 22. See, also, cases cited in Judge Werner's opinion. Here the only injury found by the trial court is to the enjoyment and occupation of the premises. That does not affect the reversioner. Had the trial court found that the operation of defendant's light plant cracked the walls or injured the structure, such damage would be of a permanent character and the reversioner entitled to recover. In the present case, however, not only is there no permanent injury to the plaintiffs' buildings, but the defendant's plant did not constitute the nuisance, but its operation, and such operation was not necessarily or inherently injurious because the trial court found that at the time of the trial its operation did not damage the plaintiffs. Judge Andrews said in the Kernochan Case: "We should be very reluctant to make a decision which would expose the defendants to a double action in cases like this," and I imagine that the reluctance still continues. Nevertheless if the judgment before $u s$ is affirmed the defendant will be subjected to a double recovery against it, for under the Bly Case the tenant is also entitled to recover, if in fact he has not already recovered, the diminution in the 
rental value during the same period for which the plaintiffs are awarded damages for such diminution. It is not a case like that suggested where the same act has caused injury to different persons and each recovers for the injury to himself; but here two parties will recover for exactly the same injury.

I may suggest this further distinction between the elevated railroad cases and that of a casual temporary nuisance. In the Kernochan Case the defendant upon satisfactorily compensating the landlord could continue the operation of its road despite the complaint of his tenant. Here, no release from, or settlement with, the landlord could have prevented the tenant from restraining the operation of the defendant's plant. Moreover, the lease by the plaintiffs was for a term of years. The rights of the tenant and landlord then became fixed, and the damage to the plaintiffs accrued at once. It was the diminished rent during the demised term. Had the defendant ceased the operation of its plant the day after the lease, the plaintiffs' injury would have been as great as if it had maintained the operation during the whole demised term. Yet I apprehend no one will contend that the defendant would have been liable for the whole period. But if we should assume that such a contention would be well founded the result would be that the day after the lease the operation of the plant might be stopped at the suit of the tenant, and yet the defendant remain liable to the landlord for the loss of rent for the whole term of the lease. In other words, the defendant's liability would depend not on the injury done by its trespass or nuisance, but on the manner in which the owner might deal with his property. The decision in the Bly Case did not pass this court without discussion. On the contrary, there was a vigorous dissent by Judge Haight (concurred in by two other members of the court), who contended that the loss in rental value went to the landlord, not to the tenant. The force of this position was appreciated by the majority of the court which, when it decided that the tenant could recover for that loss, substantially decided that the landlord could not.

I think the judgment should be reversed, and a new trial granted, costs to abide event.

Gray, J. (dissenting). ${ }^{8}$ In my opinion, the right of the plaintiffs to bring and maintain this action is clear, and the defendant's appeal should not be sustained. The plaintiffs were shown to have been injured by the defendant's acts in the depreciation of the value of the property, as shown by the diminished amount of the rent for the premises reserved by the lease of 1895 . For the prior term of five years from 1890 , they had been receiving $\$ 15,000$ a year as rent; while, for the succeeding term of five years from 1895, they were to receive only $\$ 12,000$ a year. That represented a total loss to the owner of $\$ 15,000$ for the new term and furnished a basis of injury, upon which this action was commenced in 1898.

8 Part of the dissenting opinion of Gray, J., is omitted. 
1 consider it to be a settled rule of law that, where the wrongful act affects different interests in the same property, the owner of each interest may have his separate action against the wrongdoer. Lessor and tenant have separate estates and each, if injured therein, may have redress; the one for the injury to the reversion, the other for the mjury inflicted in diminishing his enjoyment of the premises. This rule and its reason have been, heretofore, discussed with such care, that I deem it necessary, only, to refer to the recent cases of Kernochan v. N. Y. Elevated R. R. Co., 128 N. Y. 559, 29 N. E. 65; Hine v. Same, 128 N. Y. 571, 29 N. E. 69; Kernochan v. Manhattan Ry. Co., 161 N. Y. 345, 59 N. E. 906; and Bly v. Edison Electric Ill. Co., 172 N. Y. 1,64 N. E. $745,58 \mathrm{I}$. R. A. 500 . If it be a nuisance, which is the subject of complaint as injuring adjacent property interests, the question is, when the owner not in possession sues, whether it has diminished the rental value of his property; the difference in that respect being the measure of his right to damages. When the tenant sues, his right to recover rests upon the ground that his occupancy is disturbed and the full enjoyment of his possession of the premises is prevented by the common nuisance. Francis v. Schoellkopf, $53 \mathrm{~N}$. Y. 152; Hine v. N. Y. Elev. R. R. Co., supra; Bly v. Edison Electric I11. Co., supra. In the Bly Case the question discussed was that of the tenant's right to maintain an action to abate a nuisance and for damages, when in under a lease made during the existence of the nuisance. It was held, upon a careful review of the authorities, in effect that as there was no justification for the maintenance of that which was a nuisance and, hence, an unreasonable and a wrongful use by the defendant of its property, the tenant of the property injuriously affected was not deprived of the right to bring an action by reason of having acquired the lease thereof, during the existence of the nuisance, at a diminished rental. The right to have compensation for injuries actually sustained and to have the nuisance abated could not thereby be affected. It was upon that proposition that the judges of this court divided in opinion. As to the right of the owner of property, though not in possession, to maintain an action to restrain the continuance of a nuisance, which threatens injury to his reversionary rights, and to recover for any damage which he may be able to show that he has already sustained in that respect, I think there should be no doubt.

It is argued that, as the nuisance arises from the method of defendant's operation of the power house, presumptively, it is but casual and temporary. That is to say, though the defendant's building and mechanical plant were permanent structures, the operation of the machinery in a way intolerable and injurious to others, as complained of, would not be presumed to continue. Assuming the correctness of the proposition, how does it affect the principle upon which the legal right of the plaintiffs was founded? They, certainly, had the right to protect their reversionary interest against injury. A casual, or temporary, trespass, or nuisance, if the latter is of a casual nature, it is true, usual- 
ly affects the possession of the property, and therefore gives a right of action to the lessee. But for a wrongful act, which diminishes the rental value of the property, and which, from the circumstances, may, fairly, be regarded as likely to continue, whether it be in the nature of a trespass, or of a nuisance, an action will lie by a reversioner to redress the wrong; although the lessee may, equally, have his action to redress the wrong inflicted upon his right to peaceable and comfortable possession. See Kernochan Case, 128 N. Y. 559, 566, 29 N. E. 65, and the English cases cited in the opinion, as well as the Bly Case, supra.

In this case the rental value of the plaintiffs' property, when the second lease was made in 1895 , was diminished to the extent of $\$ 3,000$ a year, under conditions of lease similar to those of the preceding, and, according to the findings of the trial court, the damage to the plaintiffs from defendant's operations, only, ceased to be inflicted in 1900 . Thus, the defendant's use of its power house, in a way injurious to others, had continued for many years after its construction. It had so seriously affected the rental value of the plaintiff's property as to compel them to accept a reduced rental in 1895 for a further term and when this action was commenced, in 1898, the threat in the situation was the same. However, technically, the nuisance may be termed casual, as caused by the methods of the defendant in operating its power house, it was a very real menace to the plaintiffs' interests as property owners. The case, in my judgment, came within the established rule which allows an action to a lessor, whose reversion is injuriously affected, to abate the nuisance, by restraining its continuance. To say that the nuisance was a casual or a temporary one is an answer no more satisfactory than it is complete, legally, to the statement of the owners that they had suffered injury in the past by its maintenance and would suffer in the future unless it was restrained.

For these reasons, I advise the affirmance of the judgment.

Judgment reversed, etc. ${ }^{9}$

9 See, in addition to the cases cited in opinions, Rust v. Victoria Dock Co., 36 Ch. D. 113 (1886) ; Central R. Co. v. English, 73 Ga. 366 (1S84); Baker v. Sanderson, 3 Pick. (Mass.) 34 (1S25) ; Sumner v. Tiletson, 7 Pick. (Mass.) 198 (1S2S); Eno v. Del Vecchio, 13 N. Y. Super. Ct. 17 (1856).

The city of New York in $18 S 5$ placed a pumping station on land owned l,y it. In $189 \mathrm{~S}$ the plaintiff took a lease of a tract of land near by for a term of fire years. He now sues the city for damages to his land caused by the action of the pumps in drawing water from the surface and subsurface of his premises. Held he has no cause of action. Sposato v. City of New York, 75 App. Dir. 304 . 78 N. Y. Supp. 168 (1902), affirmed 178 N. Y. 583, 70 N. E. 1109 (1904). Compare Halsey v. Lehigh Val. K. Co., 45 N. J. Law, 26 (1S\&3). 


\title{
PART II
}

\section{RIGHTS IN THE LAND OF ANOTHER}

\author{
CHAPTER I
}

\section{PROFITS}

\section{MOUNTJOY'S CASE.}

(Common Pleas, 15S3. Co. Lit. 164b.) 1

The Lord Mountjoy, seised of the mannor of Canford in fee, did by deed indented and inrolled bargaine and sell the same to Browne in fee, in which indenture this clause was contained. Provided alwayes. and the said Browne did covenant and grant to and with the said Lord Mountjoy, his heires and assignes, that the Lord Mountjoy, his heires and assignes, might dig for ore in the lands (which were greate wasts) parcell of the said mannor, and to dig turfe also for the making of allome. And in this case three poynts were resolved by all the judges. First that this did amount to a grant of an interest and inheritance to the Lord Mountjoy, to digge, \&c. Secondly, that notwithstanding this grant, Browne his heires and assignes might dig also, and like to the case of common sauns nomber. ${ }^{2}$ Thirdly, that the Lord Mountjoy might assigne his whole interest to one, two, or more; but then, if there be two or more, they could make no division of it, but work together with one stock; neither could the Lord Mountjoy, \&c. assigne his interest in any part of the wast to one or more, for that might worke a prejudice and a surcharge to the tenant of the land; and therefore if such an incertaine inheritance descendeth to two coparceners, it cannot be divided betweene them. ${ }^{3}$

1 S. c. 1 And. 307 ; Godbolt. 17.

2Acc: Chatham v. Williamson, 4 East, 469 (1804).

s.tec: Leyman v. Abeel, 16 Johns. (N. Y.) 30 (1s19).

(153) 


\section{DOWGLASS v. KENDAL. \\ (Court of King's Bench, 1609. Cro. Jac. 256.)}

Trespass, for taking and carrying away thirty loads of thorns of the plaintiff's, by him cut down, and lying upon his land at Chippingwarden, in a place called the Common Waste.

The defendant justifies, because the place where, \&c. is an acre, and that he is seised in fee of a messuage and three acres of land in Chippingwarden aforesaid; and that he and all whose estate it was, \&c. have used from time to time to cut down and takes omnes spinas crescentes upon the said place, to expend in the said house, or about the said lands, as pertaining to the said house and lands; and so justifies, \&c.

The plaintiff shews, that Sir Richard Saltington was seised in fee of the manor of Chippingwarden, whereof the place where, \&c. is parcel, and granted license to him to take the thorns; whereupon he cut them down, and the defendant afterwards took them.

Upon this plea it was demurred; and, after argument at the Bar, adjudged for the defendant: for, as this case is, the lord may not cut down any thorns, nor license any other to cut them down; for the defendant prescribeth to have all the thorns growing upon that place, and this prescription excludes the lord to take any thorns there: but if he had claimed common of estovers only, then if the lord has first cut down the thorns, the commoner might not take them; and if he had cut down all the thorns, the commoner might have had an assise; but here he prescribes to have all, which is admitted by the replication, and is well enough; and so hath been resolved in one Kentick's Case, Cro. Jac. 208; that one may prescribe to have the sole pasturage in such a place, from such a time to such a time, against the owner of the soil, who shall not meddle therewith during that time. It was also held, aithough he doth not prescribe that it was an ancient house to which, \&c. yet it is good enough; and so is the usual prescription for common, and shall be so intended.

Wherefore it was adjudged for the defendant. ${ }^{4}$

4 "It has been long since settled, that a man may prescribe to have the sole and several pasture, vesture, or herbage for a limited time in every year, in cxclusion of the owner of the soil. Fitz. Prescription, 51 Co. Litt. 122. a. 2 Roll. Abr. 267 (L), pl. 6. Winch's Rep. 6. Sil George Spanke's case. S. C. Hutt. 45. Pitt v. Chick. But it was for some time a question whether a prescription for a sole and several pasture, Sc. in exclusion of the owner of the soil for the whole year was good. In Vaugh. 251. North $v$. Coe. S. C. 1 Lev. 253. the court of Common Pleas was equally divided upon it; but in the principal case, the court of $K$. B. inclined to think the prescription might be supported; and in Hopkins v. Robins, 2 Saund. 324. S. C. 2 Lev. 2. Pollexf. 13. 1 Mod. 74. it was adjudged that the prescription was good; for it does not exclude the lord from all the profits of the land, as lie is entitled to the miues, trees, and quarries: and the law has been so considered ever since." Potter v. North, 1 Wm. Saund. 353, note 2 (1669).

The latter part of the note by Serjeant Williams contains a discussion of the right of self-redress by the commoner. See, also, Hope v. Osborn, [1913] 2 Cl. 349. 


\section{TOTTEL v. HOWELL. \\ (Court of Common Pleas, 1595. Noy, 54.)}

It was held by the Court, that herbagium for years, cannot be grant. ed without deed. Note 17 E. $4,6 .^{5}$

\section{GRUB்B v. BAYARD.}

(Circuit Court of the United States. E. D. Pennsylvania, 1S51. 2 Wall. Jr. S1, Fed. Cas. No. 5s49.)

David Foree, by deed of indenture made in 1769 , reciting his title to 302 acres of land, grants, bargains and sells 20 acres of it which are described, to William Bennet; leaving 282 acres still his own property, in regard to which the indenture contained the the following covenant: "And the aforesaid David, for himself, his heirs, executors and administrators, doth covenant, promise, grant and agree to and with the aforesaid William, his heirs and assigns, that he, the said Willian, his heirs and assigns, shall and may, from time to time, and all time hereafter, dig, take and carry away all iron ore to be found within the bounds of the said David's tract of land containing 282 acres, provided he, the said William, his heirs and assigns, pay unto the said David, his heirs or assigns, the sum of six pence, Pennsylvania currency, per ton, for every ton taken from the premises of 282 acres aforesaid." The deed was a technically and well drawn instrument containing all the formal or orderly parts of a deed enumerated by Lord Coke (Co. Litt. 6a); and the covenant above quoted followed after the habendum and tenendum. Bennet being dead, the plaintiff purchased the interests of ninety-four of ninety-nine of his representatives, and the defendant having become owner of the 282 acres reserved, and having taken away many thousand tons of iron ore, this action on the case was brought by the plaintiff against him.

It was admitted that the ore taken by the defendant was found, mined and dug by himself or his servants: and it appeared that neither Bennet nor his heirs, nor the plaintiff had ever had actual possession, use, occupation or enjoyment of the right granted by the deed of 1769 , nor been in any way hindered in the enjoyment of it otherwise than by the defendant's taking ore in the manner just stated. The declaration which contained numerous counts, founded the plaintiff's right to recover on his being "lawfully possessed of a certain right and privilege to dig, take, and carry away iron ore to be found within the bounds of a certain tract of land to the exclusion of the defendant," or as being "lawfully possessed of a certain exclusive right or several privi-

5Acc.: Gardner v. Williamson, 2 B. \& Ad. 336 (1S:1).

See Hoskins v. Robins, 2 Saund. 324 (1671); Somerset v. Fogwell, 5 B. \& C. 875 (1826). 
lege to dig, take and carry away iron ore to be found within the bounds of a certain tract of land;" and charged the defendant with unjustly hindering and preventing the plaintiff from digging, taking away the iron ore to be found within the bounds of the tract, and also wrongfully taking large quantities of ore from said tract, \&c. All the counts asserted in some form a right which was several or exclusive in the plaintiff: none of them representing him as a tenant in common with others: and none of them alleging a "surcharge" by defendant.

The plea was "Not guilty": there being no plea of any sort in abatement for the nonjoinder of the remaining representatives of Bennet, whose rights the plaintiff had not acquired. Upon these facts, a verdict having been given for the defendant, the following questions came before the court on a motion for a new trial:

I. What was the nature of the right granted by Foree to Bennet?

II. Was this right-whatever it was-exclusive? so making it unlawful for the owner of the land to dig in it for ore, as well as the assignee of Bennet.

III. Was this right divisible or susceptible of apportionment; so that the plaintiff having but 94-99ths of it could maintain this action?

GRIER, Circuit Justice. Assuming, for the argument, the plaintiff to be the assignee of the whole right which was vested in Bennet, and that it is a grant upon sufficient consideration, let us inquire, what is granted? Not the iron ore. This the plaintiff properly admits in his declaration, where he defines his interest under the deed, as a "right and privilege to dig, take, and carry away iron ore to be found" in the land of defendant. If it had been a grant of an absolute property in all the iron ore in the tract, the deed would have been insufficient to confer tithe without livery of seisin, and the statute of limitations a bar to the claim. A right or privilege to dig and carry ore from the land of another, is an incorporeal hereditament, - a right to be exercised on the land of another. It is a license irrevocable, when granted on sufficient consideration. It may be demised for years or granted in fee: it is assignable. The grantee or assignee of such a license, right or privilege to be exercised in the land of another, has no such title to the ore that he can support trover against the owner of the land for ore or coal raised by him. Chetham v. Williamson, 4 East, 469. ***

2. Is the right granted, one that is exclusive of the owner of the soil? Much stress has been laid upon the word "all" in this grant, as having the effect of making it exclusive. But so important a restriction cannot be deduced from so equivocal an expression. The deed has been drawn by a very able conveyancer. He seems to have had Lord Mountjoy's Case in his mind at the time. He employs none of the apt and well known terms or phraseology to indicate an intention of giving an exclusive right as against the grantor himself. The grant of a right to dig, take and carry away "all" iron ore to be found within the bounds, \&c. shows the extent of the license, but not its exclusiveness. The grantee may dig, take, \&c. of any or all the ore he can find on the land, but he 
has no exclusive right in any of it till he finds it and digs it. It is a right without stint as to quantity, and Lord Mountjoy's Case likens it to the grant of a right of common sans nombre which does not exclude the owner. This is a point decided in Lord Mountjoy's Case as reported by Coke, Leonard and Godbolt.

3. Did the evidences given by the plaintiff support the allegation that he was possessed of the exclusive right to dig, \&c, assuming that the deed in question conferred an exclusive right on Bennet to dig, take, and carry away the iron ore on this tract of land? The right, license or liberty granted to Bennet is in its nature one and indivisible. Unless the plaintiff is clothed with the whole he has nothing. As for other things indivisible, it may be held by one or more as joint tenants. But they hold per my et per tout, (not as Blackstone has erroneously interpreted it, "by the half or moiety and by all,") but "by nothing and by all" (7 Man. \& S. 452, in note), or, in the language of Bracton, "Quilibit totum habet et nihil habet, scilicet totum in communi et nihil separatim per se." As a right to be exercised in the land of another it is an indivisible unit. Whether the plaintiff has 1-99th or 94-99ths makes no difference. If he has not the whole he has nothing. It is a question of title and not of pleading.

The Case of Lord Mountjoy is conclusive on this point also.

New trial refused. ${ }^{6}$

- Kane. District Judge, delivered a concurring opinion. Part of the opinion of May 13, 1S51, and all of the opinion of Sentember 8,1851 , of Grier, Circuit Justice, are omitted.

A. grauts to B. "bis partner's, fellow adventurers, executors, administrators, and assigns, free liberty, license, power, and authority to dig, work, mine, and search for tin, tin ore, etc., and all other metals and minerals whatsoever throughout all that part of the land of the said A. commonly called Crinnis, * * * and the tin, tin ore, etc, and other metals and minerals there found to raise and bring to grass. *** And dispose of to their own use at their pleasure. $* * *$ To have, hold, use, exercise, and enjoy the said sereral liberties, licenses, etc., for the term of twenty-one years." $B$. covenanted to pay one-eighth share of all ore to $\mathrm{A}$. and effectually to work the premises. Subsequently, within 21 years, C., under license from A., opened mines on other parts of the specified land, but not interfering with the mines opened by B. Held, B. cannot maintain ejectment against C. Doe v. Wood, 2 B. \& Ald. 724 (1819). Acc.: Harlow v. Lake Superior Iron Co., 36 Mich. 105 (1877). 


\section{CALDIVELL v. FULTON.}

(Supreme Court of Pemnsyliania, 1558. $31 \mathrm{~Pa} .475,72 \mathrm{Am}$. Dec. 760.)

This was an action of trespass, for taking coals from the land of the plaintiff. He claimed the locus in quo, by devise from his father, James Caldwell. The defendants justified under George Greer, to whom James Caldwell made a deed, in his lifetime, for the coals taken, and as the judgment to be entered in this case must depend on the construction of that deed, it is important to obtain, at the threshold, a clear and comprehensive view of its terms.

The deed was dated on the 27th May, 1831; acknowledges a consideration of one thousand eight hundred dollars, is to George Greer, his heirs and assigns, for all the therein "described property, situate on the east side of the Youghiogheny river," and then describes by metes and bounds, two parcels of land, one of which contains six acres and forty-seven perches, the other ten acres and fifty perches. The grant of coal then follows, in these terms: "Also, the full right, title, and privilege of digging and taking away stone coal, to any extent the said George Greer may think proper to do, or cause to be done, under any of the land now owned and occupied by the said James Caldwell; provided, nevertheless, the entrance thereto, and the discharge therefrom, be on the foregoing described premises." In the habendum the property conveyed is called two lots or parcels of land, and the "aforesaid right to the stone coal," and is so designated again in the covenant of warranty. Such was the original grant.

On the 23d March, 1842, Greer and wife conveyed an undivided half of the premises to Butler Case, and the other half to John B. McCune. January 20th, 1844, Butler Case conveyed to IVilliam McCune. December 5th, 1844, John B. McCune conveyed his moiety to Thompson Bell. By deeds, bearing date the 7 th June and the 30th August, 1848, Bell and William McCune made partition between themselves of the sixteen acres, according to agreed lines, and of the coal lying back of said lots, under the Caldwell farm, in a manner corresponding with the partition of the lots.

In August, 1852, William McCune leased to Fulton and the other defendants his several part, both of the lots and the coal; and it was the entry upon the coal, under this lease, for which the suit was brought. It does not appear, from the record, whether any opening had been made into the coal, on the part of the premises set off to McCune, but it is stated that the opening on Bell's portion of the ten acre piece has not been worked since Fulton commenced working the coal on McCune's part. $^{7} * * *$

Strong, J. [after stating the substance of the deed]. The consideration mentioned is single for the entire subject conveyed by the deed.

; This statement of fact is taken from the first opinion of the court in this case by Woodward, J. Part of the opinion of Strong, J., is omitted. 
It is to be observed in the description of the thing granted, that there are no limits fixed upon the extent to which coal might be taken from the land then owned and occupied by the grantor. The grantee's right was coextensive with his will; not necessarily to be exercised by himself, but one which might be enjoyed by others whom he should authorize. No form of words other than those employed could have given him larger dominion.

Coal and minerals in place are land. It is no longer to be doubted that they are subject to conveyance as such. Nothing is more common in Pennsylvania than that the surface right should be in one man, and the mineral right in another. It is not denied, in such a case, that both are landowners, both holders of a corporeal hereditament.

If then the ownership of the coal or other minerals in a tract of land may be vested in one person, while the right to the surface belongs to another, the next inquiry is, by what words it may be granted. There are two modes in which the subject-matter of a deed may be described, both equally potential. The one is by a description of the thing itself, as of land by metes and bounds, or by a known name, and the other is by a designation of its usufruct, or of the dominion over it. Thus a grant of the rents, issues, and profits of a tract of land is uniformly held to be a grant of the land itself. Co. Litt. 4 b. Judgments abound to this effect in regard to devises, and though in wills and deeds the rules of construction difier relative to words limiting the estate granted, yet they are the same of words describing the subject-matter of the grant. There are also cases of the same character to be found in regard to deeds. Thus it has been held that by the grant of a boilery of salt the land passes, for that is the whole profit, Co. Litt. 4 b.; or a mine of lead, Id. 6 a. So by the grant of all growing trees, Cro. Eliz. 522. See, also, Clap v. Draper, 4 Mass. 266; Fish v. Sawyer, 11 Conn. 545. The reason is that the grant of a thing can be no more than the grant of the full and unlimited use of it. So too the general power of disposal without liability to account is equivalent to ownership itself, it being the highest attribute of ownership, and a gift of the one necessarily carries with it the other. This is the doctrine of Morris v. Phaler, 1 Watts, 389.

Applying these principles to the case in hand, why was not the deed of Caldwell to Greer a conveyance of the coal in the land owned and occupied by the grantor? Because, says the plaintiff in error, it is not a grant of the thing itself, but of a right to take it, and until it is seized or taken the property in the thing remains in the grantor. But if the conveyance of the whole use of a thing, and of the absolute dominion over it, is a grant of the thing itself, only differing in the mode of describing the subject, it is not easy to see what more Caldwell could have sold than he did. If in another form of words he had described the coal as the subject of the grant, Greer would have possessed no greater beneficial rights than were given to him by the form adopted. The ownership of the coal in the ground is but a "full right, title, and priv- 
ilege" to dig and carry it away, nothing more, nothing less. The words employed in the deed express absolute dominion, and complete enjoyment. These constitute property, and all that is understood in proprietorship.

Again, says the plaintiff in error, this is but a grant of a right to take and carry away part of the profits, and that while a grant of a right to take all the rents, issues, and profits of a tract of land is equivalent to a conveyance of the land itself, because it embraces their whole usufruct, a grant of a right to take part, such as "iron ore, coals," or "minerals," is not. It is said that in such a case the grantee can only take in common with the grantor.

The argument is based upon a misconception. The subject alleged to have been granted here is not the tract of land, but the coal in it, which, as we have seen, is capable of a separate conveyance, and which may be vested in one person, while the ownership of the tract of land, as such, may be another's. The alleged subject of the grant then being the coal in the land, the substratum, the argument is inapplicable. The whole usufruct of that, as well as the entire dominion over it, was granted. The deed is not a conveyance of part of the usufruct, nor of the usufruct of part of the coal, but of the entire enjoyment. As already said, there was no limit to the grantee's right but his own will. He could take out coal to any extent. He could cause it to be taken out to any extent, and at all times under any of the land. He was accountable to no one. His entrance to it and his exit from it were indeed required to be on his own land; but the right to take the coal itself was absolutely unlimited. It would seem, therefore, that, according to well-established rules of construction, the deed of Caldwell to Greer was a conveyance of the coal itself, and not of a mere easement, or incorporeal hereditament.

It is contended, however, that such a construction is in conflict with the authorities, and we are referred to Lord Mountjoy's case as the leading and principal one.

Unlike the case we have under consideration; it was not a grant of unlimited dominion over the ores and turf. It was not a grant of a right to dig, take, and carry away without stint, but only sufficient for a single specified purpose, viz.: the manufacture of alum and copperas. It was very aptly likened to a grant of common sans nombre, but was not an exclusive right. Surely there is very little resemblance between that case and the present. It is not at all in conflict with the construction we place upon Caldwell's deed to Greer.

We are next referred tö Doe v. IVood, 2 Barn. \& Ald. 719, where the grant was called a license, and where the privilege was to dig, work, mine, and search for tin, \&c., and dispose of what might be found during a term of twenty-one years. The court held it to be a license on the ground, among others, that it was a right to dig, search for, \&c., "the minerals that should within that term there be found," and not a grant of the entire subject. The indenture also contained covenants of 
the grantee to render a share of the ore he might find, and to allow the grantor himself to drive adits. The case is no authority in support of the argument of the plaintiff in error.

The only other case to which we are referred is Grubb v. Bayard, 2 Wallace, Jr. 81, Fed. Cas. No. 5,849. There the grant was to dig, take, and carry away all iron ore to be found within the bounds of a tract of land of the grantor, provided the grantee should pay unto the grantor, his heirs and assigns, the sum of sixpence for every ton taken from the premises. This was held to be an incorporeal hereditament. It will be observed, that there was no present consideration passed, nor was there a covenant of the grantee to search for or take any ore. He might never have taken any. In that event, if the deed had been held a conveyance of the iron ore, there would have been a sale without a consideration. Nor was it a grant of the whole, but, said Mr. Justice Grier, of the iron ore that should be found within the term, and on that account was but a license. He also remarked that "if it had been a grant of an absolute property in all the iron ore in the tract, the deed would have been insufficient to convey title without livery of seisin." This observation goes beyond the English cases, and is not necessary to the judgment rendered. In Grubb v. Bayard, Judge Kane delivered a concurring opinion. In it, he refers to the absence of a covenant by the grantee to work the mines, and thus make the rent reserved of value, as a circumstance of much importance in determining the intentions of the parties. That it is so, is obvious, for without it the contract might have proved entirely fruitless to the vendor, while in the present case, Caldwell has received all that he ever can receive. The ${ }^{\text {? }}$ right, whatever it is, is one for which all the consideration has been paid.

These are all the cases addiuced to sustain the doctrine that a conveyance of a right to dig, take, and carry away the coal or minerals in a tract of land, though the grant be unlimited in quantity, time, or purpose for which the minerals may be taken, conveys no interest in the coal or minerals until they are taken, passes only an incorporeal hereditament. None of them were decided upon the ground of any supposed distinction between a right to take all the coal and carry it away, and a right to the coal itself. They are all cases in which there was no unrestricted power of taking and disposition conferred upon the grantee. The coal or minerals was to be taken either for a limited purpose, or in restricted quantities, and generally was not to be paid for until taken. And in most of them it is easy to see that the supposed necessity of livery of seisin, in order to pass a corporeal interest in land, was a controlling consideration in the minds of the judges. Even in Grubb v. Bayard, it seems not to have been without influence. The impossibility of making livery is, however, in Pennsylvania, no reason for refusing to give a construction to a deed accordant with the intention of the parties. When the intent is to give the entire usufruct and pow- 
er of disposal, the legal title must be held to pass. Even in England, livery of seisin is no longer indispensable to the grant of a corporeal hereditament. Unopened mines may be conveyed, and the grantee takes more than a right issuing out of land, or exercisable therein. $\mathrm{He}$ takes the mines themselves. In Stoughton v. Leigh, 4 Taunt. 402, a widow was held entitled to dower of mines, not only in lands in which her husband had been seised in his lifetime and during coverture, but also in those which were in the lands of other persons, the minerals or substratum of which had been conveyed to him. It was also ruled, that in assigning her dower, the sheriff should set off to her not onethird of the profits, but one-third of the mines themselves, and that the partition might be made either by metes and bounds, or by directing separate alternate periods of enjoyment. ***

Thus, after a careful review of the question, we are constrained to hold that, by the deed from Caldwell to Greer, the title to the coal in the lands then owned and occupied by the grantor was conveyed, and not a mere license, or incorporeal right. Such was the opinion of this court in 1855, when the same deed was here for construction, and the very able argument of the counsel for the plaintiff in error, has failed to convince us that the court was then mistaken. * * *

The judgment is affirmed. ${ }^{8}$

$8 \mathrm{~A}$, in consideration of $\$ 2,000$ executed a deed to one Moses by which he granted, sold, and conveyed unto the said Moses, "his heirs, executors and assigns, the right and privilege of entering, by himself and his agents, in and upon all or any part of the said tract of land, for the purpose of searching for minerals and fossil substances and conducting mining operations, to any extent the said Moses might deem advisable, and for working, removing, selling, using and applopriating, as the property of the said Moses, for the term of ten years, all organic or unorganic minerals, rocks, fossils, marls or so-called phosphates that might be found on, by any person or persons, or contained in, any part of the said plantation," which said privilege was, howerer, subject to the proviso, "that the said O. A. Moses should not, at any one time, during the aforesaid term of ten years, engage in working over one-third part of the said tract. The third to be so worked to be selected by the said $O$. A. Moses, and such selection to be made as often as the said O. A. Moses might desire." Within the ten years A. licensed others to mine phosphates within the said land. Held, Moses is entitled to an ac counting and to an injunction against further mining. Massot v. Moses, 3 S. C. 168, 16 Am. Rep. 697 (1ST1).

A. executed the following instrument: "receired of B. $\$ 175$ in parment of sand bar on Fall creek *** for the year 1S90. This is for the exchusive right to all gravel and sand for the year above named and excluding all other parties from the said premises. [Signed] A." Within the year A. conveyed the premises to $\mathrm{C}$., who bought with no knowledge of this instrument. Held, C. cannot enjoin P. flom taking away gravel; the instrument is a lease. Heywood v. Fulmer, 155 Ind. 65S, 32 N. E. 574, 18 L. R. A. 491 (1892).

A. executed to B. a deed which contained, among others, the following clause: "The said $A$. further aglees to give to the said $B$. the privilege of raising iron ore in his fields at twenty-five cents per ton * * * and to give the privilege to none else." B. conveyed all his interests to $\mathrm{X}$. A. conveyed the land owned by hin to $Y$., subject to any rights that $B$, or his assigns might bave by virtue of the above grant. Held, $\mathbf{X}$. cannot enjoin $\mathbf{I}$. 


\section{ROTHERHAM v. GREEN.}

(Court of Common Pleas, 1597. Cro. Eliz. 593.) ${ }^{9}$

Trespass. The defendant pleads, that William Green, his father, was seised in fee of a tenement in L. and that he and all his ancestors, and all those, \&c. in the said tenement, from time whereof, \&c. have used to have common in the place where, \&c. for all their beasts levant et couchant upon the said tenement; and that it descended unto him, \&c. Issue was taken upon the prescription, and a special verdict found, viz. that Edward Green, grandfather to the defendant, was seised of the tenement; and that he and all his ancestors, and all whose, \&c. from time whereof, \&c. had used common, \&c. (according to the prescription); and he being so seised, released to Sir Thomas Rotherham, the plaintiff's ancestor, all his right, and his common in part of the land, where he had the common, and died; and the tenement descended to William Green, and from him to the defendant. Et si, \&c.-Drew prayed judgment for the plaintiff. For by release of the common in part of the land, the whole common is gone, and extinct; for otherwise the tenant of the residue of the land should be charged with all the common, which is not reasonable. And thereupon it is, that if a lord releaseth his signiory in one acre, all is gonè as $21 \mathrm{Edw} .3$. "Scire Facias," 112. is.-Spurling é contra; because the common is appurtenant, and it is for the manturance of the land, and stands with common right.-Anderson. This is not a common of common right; for it is for swine and sheep, and it is not like to Dyer, 339. where the lord improved part of the common, leaving sufficient to the commoner, and infeoffed a commoner of that part improved: for there the common is not extinct; because the land improved was discharged of common before the feoffment. But this is like to Rampton's case, which was adjudged in this Court; where one having common in a great field, wherein many men liad land, he purchased an acre from one of them, it was adjudged that all this common was extinct, \&c.

from mining coal in the land in question. Johnstown Iron Co. v. Cambrii Iron Co.. 32 1'a. 241, 72 Am. Dec. 783 (1858).

See, also, Funk v. Haldeman, 53 Pa. 2209 (1866).

A. by deed granted to B., bis heir's and assigns, the "sole and exclusive right and privilege" of shooting and taking wild fowl on A.'s land. Held, B. cannot indiscriminately license other persons to shoot wild fowl on A.'s land. Bingham v. Salene, 15 Or. 208, 14 Pac. 523, 3 Am. St. Rep. 152 (1SS7).

An exclusive profit in gross may be acquired by prescription. Welcome v. Upton, 6 M. \& W. 536 (1840); Melvin v. Whiting, 10 Pick. (Mass.) 295, 20 Am. Dee. 524 (1830).

is to the form of action maintainable by the owner of an exclusive profit, see Anon., Dyer, 285b, pl. 40 (15f9) : Wilson v. Mackret, 3 Burr. 1824 (1766); Cox v. Ghue, 5 C. B. 539 (18ts) ; Claj v. Draper, 4 Mass. 266, 3 Am. Dec. 215 (1808); Hartford Iron Mining Co. v. Cambria Mining Co., 93 Mich. 90, $53 \mathrm{~N}$. W. 4, 22 Am. St. Kep. 4SS (1892) ; Kelly v. Keys, 213 1'a. 295, 62 Atl. 911, 110 Am. St. Rep. 547 (1906).

$\because$ S. c. 2 And. $59 ;$ Noy, $6 \pi$. 
So here the common also is intire through the whole land: wherefore a release in part shall discharge the whole. The prescription also is general, to have common in all the place, where, \&c. and the jury have found a release in part of the land, and therefore the prescription is found against the defendant.-Beaumond and Owen agreed with him in both points: but Walmsley held, that the common was not gone for the residue; because this release went in benefit of the ter-tenant, and it was an improvement by him: but, as touching the prescription, he agreed, that it was found against the defendant, for the reason abovesaid.-Wherefore they all agreed against the defendant. And it was adjudged accordingly. ${ }^{10}$

\section{DRURY v. KENT.}

(Court of King's Bench, 1603. Cro. Jac. 14.)

Replevin. Upon a special verdict, the case was, a man prescribes to have common appurtenant to the manor of $\mathrm{B}$. for all his beasts levant \& couchant: he grants this common to A. Whether this grant were good or no? was the question.-And adjudged, that he could not grant it over, for he hath it quasi sub modo, viz., for the beasts levant \& couchant; no more than estovers to be burnt in a house certain: but common appurtenant for beasts certain may be granted over. Wherefore it was adjudged ut supra. ${ }^{11}$

\section{COLE v. FOXMAN.}

(Court of Common Pleas, 1618. Noy, 30.)

In an action upon the case by a commoner against I. S. for charging of the common, see 9 Rep. 112. The point was, A. seized of 5 acres, and of a common appurtenant to them, aliens one acre, if the common be extinct, for part or in the whole. And by the Court it is not extinct, for any part, but it shall be apportioned, and no prejudice to the terretenant. And Hubbard, Chief Justice, who gave the rule said, the sole reason is, that otherwise a grand inconvenience and mischief

10 A. had 50 acres of land, with common appurtenant for cattle levant and couchant thereon in two other tracts, one owned by $\mathbf{B}$. and one by $\mathrm{C}$. $\mathbf{B}$. bought the piece owned by A. Held, B. has no right of pasturage in C.'s land, the court stating that if the common had been appendant instead of appurtenant it would have been apportioned. Tyrringham's Case, 4 Co. 36b (15St).

so the common is extinct in the piece owned by $C$. if $A$. buys the piece owned by B. Kimpton v. Wood, 1 And. 159 (15S6).

11 Acc.: Daniel v. Hanslip, 2 Lev. 67 (1672).

A., the owner of a tract of copyhold land, had by prescription the sole and several pasturage of a certain piece of land for the whole year at his will, as belonging to his said tenement. He licensed $X$., a stranger, to pasture his cattle on the servient piece. Held, the owner of the servient piece cannot justify the taking of X.'s cattle as damage-feasant. Hoskins $v$. Robins, 2 Saund. 324 (1671). Compare Jones r. Richard, (5 A. \& E. 530 (1837). 
would ensue. For by that all commons in England shall be extinct, and salus populi est summa lex, \& apices juris non sunt jura. And the great dispute in that case was, for the certainty what shall be said to be cattle levant and couchant. And Serjeant Attee said, that Cook, Chief Justice in his circuit in Norff. said, that so many of the cattle that the land, to which the common is appurtenant, may maintain in the winter, so many shall be said levant and couchant. To which Warberton and Hutton agreed. ${ }^{12}$

\section{PHILLIPS v. RHODES.}

(Supreme Judicial Court of Massachusetts, 1813. 7 Metc. 322.)

The parties submitted this case to the court on agreed facts, all of which appear in the opinion of the court.

HUbBaRd, J.13 This is an action of trespass for breaking and entering the plaintiff's close, and taking and carrying away sea weed. The defendant pleaded the general issue, with notice that he was the lessee or servant of Mary Ann Balch and her husband; said Mary Ann being a part owner of the locus in quo, or an owner of a privilege in the same. The taking of the sea weed mentioned in the declaration is admitted.

The plaintiff claims title to the locus in quo under the will of her late husband, Benjamin H. Phillips, deceased, whose title was derived by deed from Jonathan Phillips and others, children and heirs at law of Gideon Phillips and Rebecca his wife, dated December 12th, 1797, and a deed from said Rebecca, dated December 11th, 1797. This deed of Jonathan Phillips and others conveys to Benjamin H. Phillips, among other parcels of land, the following: "All that part of the home field, so called, excepting thirteen poles laid out to said Jonathan Phillips, that lieth southerly and westerly of a line running southerly eighteen rods from said Jonathan Phillips's land down the field to a stake; thence easterly ten and four tenth rods to a stake; thence southerly to the beach; and contains four acres and forty poles, with the mansion house that was our said father's and mother's on the premises."

The title under which the defendant justifies is by a deed of the same date, from Jonathan Phillips and others to Rebecca Collins, wife of Jacob Collins, Jr.; and the description of one of the parcels of land is the following: "Also two acres and nine poles of land in Nahant, so called; also a privilege of getting what is called sea dung on the

12Acc.: Wild's Case, 8 Co. 781. (1609). See Day v. Spooner, Cro. Car. $4 \% 2$ (1636).

As to the meaning of levant and couchant, mmpare Scholes $v$ Harcreares. 5 T. R, 46 (1792); Whitelock r. Hutchinson, 2 Moo. \& R. 205 (1839); Robinson v. Har'topp, L. R. 43 Ch. Dir. $4 S t$ (1S\$9).

13 Palt of the opinion is onited. 
beach below the home field, that our mother Rebecca Phillips hath granted unto us; with all other privileges and appurtenances thereunto belonging."

The above deeds were made by the heirs, in the division of the estate of Gideon and Rebecca Phillips. The other lands of said Gideon were assigned to his other children, by deeds of division, and a privilege in the beach was granted to all of them except those who had part of the home field. The said Rebecca Collins survived her husband, and died leaving her estate by will, after certain legacies, to her son Phillips Collins, and to her daughter Mary Ann Collins, and if either should die leaving no issue, the survivor was to inherit the whole. The said Mary Ann Collins married John C. Balch, and she claims a privilege to take sea manure from the beach, and has leased or sold her right to the defendant.

The land, to which the defendant carried the manure from the locus in quo, was no part of the estate formerly belonging to said Gideon or Rebecca Phillips. There are about eighty direct descendants from the six children of Gideon and Rebecca Phillips, who claim each a right to take manure from said beach by virtue of the grants to their ancestors of privileges in the division deeds.

The right granted to the ancestor of Mary Ann Balch was a privilege of getting sea manure on the beach below the home field, which field belonged to the plaintiff. The sea weed which is thrown up belongs to the owner of the beach; Emans v. Turnbull, 2 Johns. (N. Y.) 322, $3 \mathrm{Am}$. Dec. 427; and so is the subject of grant. The question presented for consideration is, whether the grant thins made to Rebecca Collins (similar grants having been made to other children of Gideon and Rebecca Phillips) is a right in gross, to be enjoyed by all the grantees and their heirs, or whether it is a right appurtenant to the particular parcel of estate conveyed in the deed to which it is annexed.

As a right or common in gross passes by deed, it is necessary to consider the terms of the grant, to ascertain the nature of the estate intended to be conveyed. And we think it is obvious, from the language of the deed, that the object of the grant was to benefit the owner of the particular estate, by furnishing her with a valuable dressing for her land, and not to give a personal right to her and all her heirs and their assigns, as many as there might be. The privilege, thus subdivided, would be of no personal use or advantage; but as appurtenant to the particular estate, so that it might be used thereon, it would always enhance its value. We are therefore of opinion, that the grant created by this deed is an incorporeal hereditament, appurtenant to the estate to which it is annexed, and passes with it; and consequently, it is a right which cannot be severed and sold separate from the estate, and thus subdivided ad infinitum. Such a sale of the right to a stranger would either be a void grant, or would extinguish the right.

But we do not consider, though the privilege is appurtenant to the estate, that the owner is confined, by the terms of the grant to use the 
dressing on the particular estate. Having taken the manure from the beach, by virtue of the privilege, she may use it on other lands of her own, or dispose of it to others; or she can lease her share of the privilege while she remains an owner in common of the particular estate. If it is said that the privilege may in this manner be subdivided, and the same evils follow as would or might flow from a sale of the privilege independent of the land to which it is appurtenant; yet it must be remembered that its subdivision can only be such as the piece of land to which it is attached is subject. One person having a right or privilege may also obtain more than his just share of the dressing cast up during the season. But such inequality in the division is almost inevitable from the nature of the property itself, thrown up as it is on the beach, in greater or less quantities, by the constant heaving of the sea. But it is also true, that if one proprietor should be obstructed by another proprietor in the enjoyment of his privilege, he would not be without a remedy for the obstruction of his right. ***

We notice, in the report of the case, that the said Mary Ann Balch either leased or sold her right to the defendant Rhodes. In the opinion we have expressed, it becomes important to settle the fact whether the defendant is the lessee of said Balch's interest, or has made an absolute purchase of the same. If the former, the defendant may justify, as acting under the owner, by virtue of her lease to him. But if he justifies the entry and taking under a sale of the right to himself, he takes nothing by the purchase, and is liable in this action to the plaintiff. And if the fact cannot be agreed, the canse must be sent to a jury to ascertain it.

\section{HALL v. LAWRENCE.}

(Supreme Court of Rhode Island. 1S52. 2 R. I. 218, 57 Am. Dec. 715.)

[Submission for determination of the rights of the parties under their respective conveyances.

On November 7, 1776, Nicholas Taylor and Joseph Wanton Taylor were owners in common of a farm abutting on the ocean. On that day they executed a deed of partition by which the south part adjoining the ocean was conveyed to Nicholas, and the north part to Joseph.

Other facts appear in the court's opinion.]

BrayTon, J. ${ }^{14}$ The plaintiff claims in this case a right to enter upon the land of the defendant, being the farm set off to Nicholas Taylor in the deed of partition of 1776 , and to take and carry away from the shore thereof, mentioned in the deed of partition, sea-weed, gravel and stone in any quantity without limit at his will and pleasure and to make merchandise thereof for his profit, and a right of way to pass and repass to and from said shore over the defendant's land for that purpose.

14 The statement of facts is abridged and part of the opinion is omitted. 
This right he claims as a right in gross, though, by the deed of partition, he claims that it was originally made appurtenant to the North farm set off in said deed to Joseph IV. Taylor, under whom he claims.

The argument both for plaintiff and defendant, proceed upon the assumption that the right of taking sea-weed, gravel and stone, whatever it was, was originally appurtenant to the estate of Joseph W. Taylor, and, indeed, if it were not appurtenant, it is evident the plaintiff has no title, for his deed from Armstrong describes no such right, and unless it was appurtenant at the time, he takes nothing by his deed.

In order to ascertain what the rights of the plaintiff now are, it is necessary to inquire. first, what were the rights originally granted in said deed to Joseph IV. Taylor.

By the terms of the deed, after setting off to Nicholas the south part of the original farm upon which portion was all the beach, and setting off to Joseph the north part, which was less in quantity, and we may presume without a beach privilege less in value, the deed then proceeds and says: "And the said Nicholas Taylor, doth grant free liberty of carrying away gravel and sea-weed off the beach, belonging to his part of said farm, and also, stones below high-water mark on said beach, to the said Joseph W. Taylor, his heirs and assigns, and, also, liberty to tip the sea-weed on the bank on his part of said land."

This grant is made doubtless to equalize the partition, to render the north part, which had no shore where sand and sea-weed might be obtained for improving and fertilizing the land, and, it may be, less facilities for obtaining stone for building and fencing, equal in value with the south part.

It will be seen also, that the grant is not limited in terms as to quantity, nor is it defined in terms to what uses it shall be applied or for what purposes taken, so as to furnish a just measure of the amount which Joseph might take.

We must however presume that it is not to be entirely without limit, extending to the entire quantity of gravel, sea-weed or stone upon the shore and thereby excluding Nicholas; but that the right of Joseph was to be a right in common with Nicholas. So it must have been the intent of the parties, that, as the right was created for the benefit of the north shore, and as it must have some linit as to the amount, it should be limited in extent to the uses of the land set off to Joseph, and so it must necessarily become appurtenant; Joseph would not, however, be confined to so much only as might be necessary of necessity to the estate, but as the grant was liberal- "free liberty"-might take so much as he might have occasion to use for any purpose upon the estate.

The plaintiff's counsel contends that under this grant, upon a just construction of it, Joseph originally had a right to take for sale and profit, without regard to any use, and the case of Phillips v. Rhodes, 7 Metc. (Mass.) 322, is cited to that point, in which it is held, that unJer a right of common to take sea-weed appurtenant to the estate and intended for a dressing for the land, it might when taken be applied 
to that use or sold. No reason is given nor authority cited, and we are left upon the authority of the case alone. It is not easy to perceive the reason, if the extent of the right were to be measured by the use and purposes of the estate. But without determining whether when once taken for use, the party might not forego the benefit of it to his estate and sell to another, the conclusion we think is warranted that the sale would not give him a right to take more than reasonably he might have taken had he thought fit to use it upon the estate.

The effect of the grant in the deed of partition is to create a right of common for sea-weed, gravel and stone, in favor of the north farm set off to Joseph, and as appurtenant thereto, to be exercised on the shore of the estate set off to Nicholas, giving a right to take so much as the owner of the north shore might think proper or profitable to use on the estate.

There passed also, as incident to this grant, a right of passing and repassing to and from the shore over the land of Nicholas, in some convenient place for the purpose of taking the profit. This was necessary to the enjoyment of the right of common granted, and would therefore pass by an implied grant, and accompany and follow the principal grant so long as it existed, and only became extinguished with the extinction of the common itself.

Did these rights pass to the plaintiff? George Armstrong, by his deed of July 4th, 1835, conveyed to the plaintiff all the land originally set off to Joseph W. Taylor, in the deed of partition of 1776, with the appurtenances, and whatever rights of common were then appurtenant to the lands conveyed or to any portion of them passed to the plaintiff. Our inquiry then must be directed to the title which Armstrong had to the common.

Armstrong's title to the land is derived to him by two separate conveyances. By the deed from Joseph W. Taylor, of August 12, 1813, he acquired title to nineteen and three-quarters acres, a portion of the land originally set off to Joseph, "and all the privileges and appurte.nances which I, the grantor, now have of taking and carrying away gravel and sea-weed and all stones below high water mark on said beach, and also to tip the sea-weed on the beach of the said Nicholas 'Taylor's land." Such are the words of the grant.

But whether any right of common then remained appurtenant to the nineteen and three-quarters acres, must depend upon the effect which is to be given to the conveyance of Joseph W. Taylor to his brother Nicholas of March 12, 1803. By that deed Joseph conveyed to Nicholas thirty acres, part of the shares set off to him, to which the whole right of common was made appurtenant. ${ }^{15}$

The defendant's counsel claims that the effect of the conveyance of

15 On March 19,1819 , the title to this 30 acres was conveyed to Armstrong subject to an equity of redemption in Nicholas Taylor and the dower right of his wife. 
the thirty acres portion of the dominant estate is the extinguishment of the whole common.

The first question here raised is whether this right of common was divisible and might or not be apportioned to the several parts of the dominant estate upon a severance of the estate. In regard to rights of common which by law are indivisible, a conveyance of any portion of the dominant estate will extinguish the whole, as in the case of common of estovers, Van Rensselaer v. Radcliff, 10 Wend. (N. Y.) 639, 25 Am. Dec. 582; Livingston v. Ketcham, 1 Barb. (N. Y.) 592, and the reason assigned is that the service is entire and appurtenant to an entire estate, and not being divisible it cannot be appurtenant to part of the estate as an entire service.

There are, however, other rights of common which are in law divisible, and in all such cases it may be apportioned to the several parts of the dominant estate upon its severance by different conveyances. A right of pasture for cattle san nombre is of this kind. In such case it is held that though the right be unlimited in terms, yet it is intended for the use of the estate and limited to such cattle as may be kept upon the dominant estate or upon any portion of it, and equally upon any portion, so that, upon a division of the dominant estate and upon apportionment of the service to the several parts, the servient estate is not charged to any greater extent than before or with more cattle. And the rule is that wherever the common is admeasurable the common is apportionable. Tyrringham's case, 4 Co. 35 . But the right being measured by the uses of the estate cannot be severed from the estate and granted over. Drury v. Kent, Cro. J. 15.

This right in the present case is of the same nature. It is intended for the use of the estate and for every acre of it, and that equally and whether the right be divided or not, the measure is the same. It may therefore be divided, and, by a conveyance of a part of the dominant estate, it would be apportioned to the part conveyed and so much might well pass with it under the term appurtenance.

This conveyance may be affected by another rule, for although the common may be in its nature divisible and apportionable, yet, if the effect of the conveyance is to surcharge the servient estate, it shall not only not be apportioned, but shall become extinct for the whole.

And for the same reason it is, that a release of a portion of the servient estate or purchase of part of the servient by the sole owner of the dominant shall extinguish. In Rotherham v. Green, Cro. E. 593, there was a release of part of the land in which, \&c. In Kimpton v. Bellamyes, Leonard, 43, the owner of the dominant purchased two acres of forty of the servient estate. In these cases the effect was to surcharge the residue. So, in Tyrringham's case, 4 Co. $35 . * * *$

And the rule deducible from all the cases is, as before stated, that if the effect of the conveyance is to surcharge the common and burthen to a greater extent the servient estate, it shall extinguish; if otherwise, 
there shall be an apportionment and such portion will pass as appurte11ant.

By this rule the portion of common belonging to the thirty acres would become severed from the residue, which would remain appurtenant to the nineteen and three-quarters acres retained by Joseph Taylor, and the thirty acres would become a distinct dominant estate.

But inasmuch as the title to the dominant estate, by virtue of the conveyance, became united in the hands of Nicholas with the servient estate, all the common appurtenant to the thirty acres thereby became extinguished by unity of title. It has not been revived by any of the conveyances so as to pass by the term appurtenance in the deed of Armstrong to the plaintiff.

The defendant's counsel claims that, although such would be the effect of the deed to a stranger, who immediately conveys to the servient owner, yet, if made directly to the servient owner, the whole is extinguished.

Now, bearing in mind the reasoning on the cases generally upon the subject and the rules deducible from them, we should not expect to find a case in which it should be held that, where the conveyance does not directly surcharge the common remaining, and where the servient owner can in no wise suffer injury, the whole common should become extinguished and that against the apparent intent of the parties, but that effect would be given in such case to the clear intent.

There is, however, in Tyrringham's case, the annunciation of such a rule as the defendant's counsel claims. It is this: That common appurtenant cannot be extinct in part and in esse for part by act of the parties, for that common appurtenant was against common right. Taken in the broad sense which counsel gives it, and independent of the connection in which it is used, it might support the ground which the counsel assumes. But taken with its connection, it is evident that it was not applied or intended to apply to such a case as is now before us. The same rule exists in relation to rent charge, which is said to be against common right as distinguished from rent-service which is deemed of common right.

Now Tyrringham's case when carefully examined, it will be seen, does not come up to the point made by the defendant's counsel. ***

Now, the case was: The owner of part of the servient became owner of the whole dominant and so interested in surcharging the residue of the servient.

But, in order to fully understand the case and the point immediately before the court, it must be borne in mind that so far as the severance and apportionment of the common to the dominant estate is concerned, there is no difference in the rule of law applicable to the common appurtenant or conmmon appendant. In either case, upon severance of the dominant estate the common was apportionable. The difference between the two related to the servient estate, and the court in a preceding part of the case had resolved that common appendant being $c$, f 
common right, might not only be apportioned to the land to which, \&c., but would also be apportioned upon the severance of the estate in which, \&c., and they say, that as to this kind of common, if the commoner aliene part the land in which, \&c., yet the common shall be apportioned. But it was not so with common appurtenant. In such case there could be no apportionment to the servient estate. And, therefore, the court was obliged to say, referring particularly to the part of the case before them, that by this purchase the common was extinct for the whole, for in such case common appurtenant could not be extinct in part and in esse for part by act of the parties.

There never was any difficulty in releasing a portion of the service charged upon the servient estate. 'The only difficulty was in releasing any portion of the servient estate wholly from all service, and that, because it could not be apportioned. * * *

We are then, upon the whole, of the opinion that the deed from Joseph W. Taylor to Nicholas Taylor, of the thirty acres, operated as a severance and apportionment of the common, and that the part apportioned to the thirty acres became extinguished and lost, but that the conveyance did not operate to extinguish the residue of the common apportionable to the nineteen and three-quarters acres, and that so much passed by Armstrong's deed of July 4th, 1835, to the plaintiff, with a right of way as incident of it and necessary to the enjoyment.

Had the plaintiff remained owner of the whole of this lot of nineteen and three-quarters acres, he would still have been entitled to the common appurtenant. But his right has again been affected by his conveyance to Robert $H$. Ives, of nine and three-quarters acres, part of the nineteen and three-quarters acres. ${ }^{16} \mathrm{Had}$ he made no reservation of the common in that deed, there would have been an apportionment. and Ives would have taken the portion belonging to nine and threequarters acres, for though such common may be apportioned, it could not be severed from the estate and granted over, (Drury v. Kent, Cro. I. 15,) and, because it could not be severed, the plaintiff could not retain it to himself. If it exist at all, it must exist with the estate, the uses of which it is to attend and minister to.

The plaintiff, then, at the time of filing his bill in this case, had a right of common to take from the shore of the defendant's estate seaweed and gravel, and stones below high-water mark, at all times at his will and pleasure, for such purposes as he might think proper to use them upon his estate; but this right did not extend to the thirty acres. to which Armstrong derived title under the mortgage of Nicholas Fry to the Bank of Rhode Island, all right being extinguished as to that. but was limited to that portion of the nineteen and three-quarters acres

${ }_{16}$ This conveyance to Ives by the plaintiff expressly reserved "the privi. leges of sand, gravel and sea weed upon the south shore of the Taylor farm and of tipping the sea weed on the bank thereof as appurtenant to the residue of the said Joseph WV. Taylor farm retained by" the plaintiff. 
conveyed by Joseph W. Taylor to Armstrong, by deed of August 12th, 1813 , which the plaintiff has not conveyed to Robert $\mathrm{H}$. Ives; and he had, also, a right of way to and from his said land to the shore for the purpose of exercising this right as incident and necessary to its enjoyment.

This is the extent of his right in our view upon the deeds and conveyances put before us. ${ }^{17}$

\section{HUNTINGTON v. ASHER.}

(Court of Appeals of New York, 1884. 96 N. Y. 604, 48 Am. Rep. 652.)

One Hogan owned a tract of land on which was a large pond. On November 3, 1869, he conveyed to one J. H. Asher a half acre of land adjoining the pond. The deed contained the following provision:

"And the party of the first part, as incident to this conveyance, also grants and conveys to the party of the second part, his heirs and assigns, the exclusive right to take ice from the pond of the party of the first part, with the right and privilege of access for that purpose to and from the pond to the ice-house to be erected on the lot hereby conveyed.

"In consideration of which said grant, as aforesaid, the party of the second part hereby covenants and agrees for himself and his heirs and assigns to furnish and deliver to the party of the first part (so long as he shall continue to occupy his present residence), free of charge, all the ice which he shall require for his own family use, and also to furnish and deliver to the purchaser or purchasers of the pond and mill privilege and their heirs and assigns, free of charge, all the ice which they shall require for their own family use, so long as they continue to reside in the village of Rhinebeck."

The residue of Hogan's land came by mesne conveyances to the plaintiff, each conveyance being expressed to be subject to Asher's right. Subsequently J. H. Asher conveyed to the defendant, Emeline Asher, his half acre with the appurtenances, but made no mention of the right to cut ice. The plaintiff contended that the defendant had no right to cut ice and brought this bill for an injunction.

FINCH, J.18 The contract of purchase and sale between the original parties contemplated the creation of a right to take ice from the unsold lands of the grantor as an incident to the conveyance of the half acre

${ }^{17} \mathrm{~A}$. conveyed a farm to $\mathrm{B}$. in fee, "together with the free liberty * * * of cutting timber ** * for building, fencing, and fuel * * * for the use of the said hereby released lands only" in certain land still belonging to A. Part of B.'s farm came to C. Held, C. has no right to cut timber for the above mentioned uses of his farm. Van Rensselaer v. Radcliff, iv Wend. (N. Y.) 639, 25 Am. Dec. 582 (1833).

18 The statement of facts is abridged and part of the opirion is omitted. 
and an appurtenance of the land conveyed. It is impossible to study the arrangement in its details and arrive at a different conclusion. The half acre of land was purchased for the known and declared purpose of erecting thereon an ice-house to store the product of the pond, and as a means of conducting the ice business. The terms of the deed substantially so declare, and the fact is not denied by the findings of the trial court. The right thus given was a natural, appropriate, and necessary adjunct of the land conveyed, having in view the purpose for which it was purchased, on the one hand, and sold, on the other. There was no sale of the right in gross for its own sole and separate consideration, but the price of the land paid and to be paid covered the land with its right attached. The arrangement was meant to be continuous, and to follow the two estates irrespective of their ownership. The conveyance of the right, like that of the land, was to the grantee and his assigns, and the former was declared in terms to pass as "incident" to the grant of the latter. And then the grantee, "for himself, his heirs and assigns," covenants to furnish ice to the successive grantees of the pond and mill privilege so long as they reside in the town of Rhinebeck. The contract thus contemplated a dominant and servient estate. If a mill, dependent upon water-power, had stood upon the half acre, the right to draw from the pond would have passed with the land as an appurtenant easement, if such had been the actual situation of the premises, or the express agreement of the parties. If no mill and no raceway were there, but the purchase was for the purpose of erecting them and the deed gave the water-right accordingly and as incident to the conveyance, such right would become an appurtenance, at least when exercised, and pass with the land. But the right in question here is of a somewhat different character, and upon that difference is founded the conclusion of the General Term, and much of the argument before us.

The opinion below asserts that the right under consideration was not an easement attached to a dominant estate, and not an appurtenance of the latter. The reason assigned is in these words: "A right by which one person is entitled to remove and appropriate for his own use any thing growing in, or attached to, or subsisting upon the land of another for the purpose of the profit to be gained from the property thereby acquired in the thing removed, has always been considered in law a different species of right from an easement. Such right is a privilege, and so is an easement; but the latter is a privilege without profit, and is merely accessorial to the rights of property in land, while the former is the reverse. If granted to one in gross it is so far of the character of an estate or interest in the land itself that it is treated as such." * * *

It must be admitted that the strict and technical definition of an easement excludes a right to the products or proceeds of land, or, as they are generally termerl, profits a prendre But that such a right is in 
the nature of an easement, and although capable of being transferred in gross, may also be attached to land as an appurtenance and pass as such, is shown by the authorities to which the General Term refer. In Post v. Pearsall, supra [22 Wend. 425], the language of the chancellor is, "for a profit a prendre in the land of another, when not granted in favor of some dominant tenement, cannot properly be sffrr to be an easement, but an interest or estate in the land itself." That it may be so granted by the terms of the grant as to become an appurtenant right in the nature of an easement is implied in the citation. Washburn, to whose discussion of the subject we are referred, says distinctly, "this right of profit a prendre, if enjoyed by reason of holding a certain other estate, is regarded in the light of an easement appurtenant to such estate;" (WVash. on Eas. 8, § 7); and alluding also to rights acquired by custom or dedication, the author adds: "it would be difficult to treat of easements or servitudes, without embracing these rights, as well as that of taking profits in another's land which one may enjoy in connection with the occupancy of the estate to which such right is united." It seems, therefore, to be the law, that a right to take a profit from another's land, although capable of being transferred in gross, may also be so attached to a dominant estate as to pass with it by a grant transferring the land with its appurtenances.

An instructive case on this point is that of Grubb v. Guilford, 4 Watts (Pa.) 223, $28 \mathrm{Am}$. Dec. 700. There, on sale of twenty acres of ore-bank, a right was also given to the grantee to enter upon other lands of the grantor and search for iron ore, and mine and carry it away. The question was whether such right was appurtenant to the twenty acres, and it was held that it was not. Among the reasons given were that a separate consideration for the ore mined was to be given, and that the right was in no manner necessary to the use or occupation of the twenty acres, and did not concern or affect it at all. The furnace to be supplied was on other lands, and the court said that the argument tended only to show that the right was appurtenant to the furnace, and not to the twenty acres, because while it was needed for the one, it was not for the other, and in no manner concerned it.

The whole question, thus, turns upon the inquiry whether the privilege granted was of such a character as to be in the nature of an easement and become, when exercised, an appurtenance. It does not concern or inhere in the land precisely like a right of way which is essential or convenient irrespective of the use to which the land is put, but does do so relatively to that use, as in the case of land used for a mill or for the manufacture of iron. In those cases, as in this, the use for which the land was bought, and which characterized the contract of purchase, became the essential element by which the privilege granted was to be measured and judged. The right to take ice from the pond was the one essential thing leading to the purchase of the half acre, justifying the building put upon it, and making possible the perform- 
ance of the covenants for supply. We think that right passed to the present defendant.

The judgment should be reversed and a new trial granted, costs to abide the event. All concur.

Judgment reversed. ${ }^{19}$

\section{SMITH v. GATEWOOD.}

(Court of King's Bench, 1607. Cro. Jac. 152.)

Trespass in a place called Horsington Holms. The defendant justifies, for that Stixwold is an ancient vill adjoining to the place where, \&c. and that within the said vill is, and time whereof, \&c. hath been such a custom; that every inhabitant within any ancient messuage. within the said vill, by reason of his commorancy therein, hath had common in the place where, for all his great beasts, at all times of the year, \&c. ; and so justifies as an inhabitant. And it was thereupon demurred, whether such a prescription and usage in a vill for the inhabitants for common and matter of profit be good?

After argument at Bar and Bench, it was resolved, that it was not good; for inhabitants, unless they be incorporated, ${ }^{20}$ cannot prescribe to have profit in another's soil, but only in matters of easement, as in a way or causey to church, or such like: so in matters of discharge, as to be discharged of toll, or of tythes, or in modo decimandi, or the like: but to have interest it cannot be ; for that ought to be by persons inabled, who are always to have continuance: for if there should be such prescription, then, if any of the inhabitants depart from their ancient houses, and the house continues empty, the inheritance of the common should be suspended; which cannot be. Nor can such a common be released; for if one inhabitant should release, another which succeeded him might clain it; which is against the rules of law, that an inheritance in a profit should not be discharged: and by such prescription a maid servant or child who resides in the house is said to be an

19Acc.: Grubb v. Grubb, 74 Pa. 25 (1873).

A. claimed, by prescription of himself and his predecessors in title of a certain piece of land, as appurtenant thereto, the right to go on the adjacent land of B. and there cut down and carry away for all purposes the trees there growing. Held, A. cannot assert such a right by virtue of his ownership of the land. Bailey v. Stephens, 12 C. B. N. S. 91 (1862); see Heyward v. Cannington, 1 Siderfin, 354 (1668).

A. owned a farm; he conveyed in fee a strip to a ralload company. The deed contained the following clause: "Said parties of the first part to have the privilege of mowing aud cultivating the surplus ground of said strip of land not required for railroad purposes." The farm was subsequeutly conreved to $B$. Held, $B$. does not have the right to cultivate the strip. Pierce v. Keator, 70 N. Y. 419, 26 Am. Rep. 612 (1877).

20 See Boteler r. Bristow, Y. B. 15 E. 4, 129, pl. 7, (1475); White $\nabla$. Coleman, Freem. 134 (1673). Compare Sale v. Pratt, 19 Pick. (Mass.) 191 (183i).

See, also, Goodman v. Mayor of Saltash, L. R. 7 A. C. 633 (1882) ; Johuston v. O'Neil, [1911] A. C. 552 ; Harris r. Chesterfield, [1911] A. C. 623. 
inhabitant, and to have the benefit of the common; which would be inconvenient. Wherefore they all resolved, that such a custom alledged by way of usage (not otherwise) is not good; and adjudged it for the plaintiff. It was said to be so resolved in Trinity Term, 33 Eliz. Roll 422. Lawrence v. Hull; and Coke cited, that in 19 Hen. 8, in Spelman's Reports, it was adjudged accordingly in this court. Vide 7 Edw. 4 pl. 26. 15 Edw. 4 pl. 29. 18 Edw. 4 pl. 3. 20 Edw. 4 pl. 10. 9 Hen. 6 pl. 62.18 Hen. 8 pl. $1 .{ }^{21}$

\section{RACE v. WARD.}

(Court of Queen's Bench, 1555. 4 El. \& Bl. 702.)

Lord Campbeil, C. J. ${ }^{22}$ The first count of the declaration is for breaking and entering the plaintiff's close in the township of Horbury, and committing various trespasses therein. The defendants justify under an immemorial custom in the said township for all the inhabitants for the time being in the said township to have the liberty and privilege to have and take water from a certain well or spring of water in the said close in which, \&c., and to carry the same to their respective dwelling-houses in the said township, to be used and consumed therein for domestic purposes.

The plaintiff demurs: and it has been argued before us that the plea is bad, because it claims a right for all the inhabitants of the township to take a profit à prendre in alieno solo.

But we are of opinion that no such right is claimed by the alleged custom. The action is not for taking water the property of the plaintiff; and no such action could be supported unless the water were contained in a cistern or some vessel in which he had placed it for his private use. The defendants have to answer the charge of having unlawfully broken and entered the plaintiff's close, and trampled and injured his grass growing there, \&c. In doing so they certainly claim a right by immemorial custom, in all the inhabitants of the township, to take water from a spring issuing from the close, and to carry it to their dwelling-houses for domestic purposes: but this claim is made with the view of excusing the alleged trespasses in entering the close and injuring the grass, \&c.

The water which they claim a right to take is not the produce of the plaintiff's close; it is not his property; it is not the subject of property. Blackstone, following other elementary writers; classes water with the elements of light and air. Vol. 2, p. 14. Afterwards, having

21 Acc.: Grimstead v. Marlowe, 4 T. R. 717 (1792); Smith v. Andrews, [1891] $2 \mathrm{Ch}$. $67 \mathrm{~S}$ (fishing); Hill v.'Lord, $48 \mathrm{Me} . \$ 3$ (1S61), taking seaweed.

22 Part of the opinion is omitted.

Big.RIGHTS-12 
stated that a man cannot bring an action to recover possession of a pool or other piece of water, either calculating its capacity, as for so many cubical yards, or by superficial measure for twenty acres of water, he gives the reason: "For water is a movable wandering thing, and must of necessity continue common by the law of nature." Ib. p. 18. It is not disputed that this would be so with respect to the water of a river or any open running stream. We think it is equally true as to the water of a spring, when it first issues from the ground. This is no part of the soil, like sand, or clay, or stones; nor the produce of the soil, like grass, or turves, or trees. A right to take these by custom, claimed by all the inhabitants of a district, would clearly be bad; for they all come under the category of profit à prendre, being part of the soil or the produce of the soil: and such a claim, which might leave nothing for the owner of the soil, is wholly inconsistent with the right of property in the soil. But the spring of water is supplied and renewed by nature; it must have flowed from a distance by an underground channel; and, when it issues from the ground, till appropriated for use, it flows onward by the law of gravitation. While it remains in the field where it issues forth, in the absence of any servitude or custom giving a right to others, the ewner of the field, and he only, has a right to appropriate it; for no one else can do so without committing a trespass upon the field; but, when it has left his field, he has no more power over it, or interest in it, than any other stranger.

For these reasons it has been considered that the inhabitants of a district may, by custom, have a right to go upon the soil of another to take or to use water. On examining the Yearbook, Trin. 15 Ed. 4, fol. 29 A. pl. 7 , cited at the bar, it would appear that Genney, as counsel, says it would be a good prescription that all the inhabitants in such a vill have used from time immemorial to have the water in such a pond to drink, \&c. Catesby, then a judge, assents to this, and he likens it to a custom for all the fishermen, inhabitants in a particular vill, to have a right to dry their nets on a particular close. There the word "prescription" is used; but there is no prescription stated in a que estate; and a customary right by reason of inhabitancy in a particular district is evidently described and intended.

In Weekly v. Wildman, 1 Ld. Raym. 407, we find certain obiter dicta upon this subject which are entitled to some weight. "Blencowe, J. Inhabitants may have a custom to have pot water, which is an interest, and not barely an easement. But Powell, J., denied that, and said that it is only an easement." Both these learned Judges agree that inhabitants may have a right to enter the soil of another to take pot water; and only differ as to the name to be given to it.

The authorities relied upon by $\mathrm{Mr}$. Unthank are not inconsistent with this doctrine. His quotation from Bracton does not prove that the right to take watcr when flowing in its natural course is a profit à prendre; and the learned author of that treatise, by the words he uses immediately after, shows that he was well aware of the distinction 
between such water and water in a cistern, which is the subject of private property.

In Wickham v. Hawker, 7 M. \& W. 63, the Court of Exchequer held that a "liberty, with servants or otherwise, to come into and upon" lands, "and there to hawk, hunt, fish, and fowl," is a profit à prendre within the prescription act, $2 \& 3$ W. 4, c. 71 : but that liberty and a liberty to take water are so different that they furnish no safe analogy to guide us in this case.

In Blewett v. Tregonning, 3 A. \& E. 554 (E. C. L. R. vol. 30), this Court held an alleged custom to be bad for all the inhabitants occupying lands in a district to enter a close, and take therefrom reasonable quantities of sand which had drifted thereupon, for the purpose of manuring their lands. The reason was that the drifted sand had become part of the close, so that the claim was to take a profit in alieno solo: but the water to be taken never had become part of the close; nor was it the produce of the close.

The plaintiff's counsel lastly referred to the recent decision of the House of Lords in Dyce v. Lady James Hay, 1 Macqueen, 305, in which the Lord Chancellor said that neither by the law of Scotland or of England can there be a prescriptive right, in the nature of a servitude or easement, so large as to preclude the ordinary uses of property by the owner of the lands affected. But no such consequence will follow from the customary easement claimed in the present case; and it does not interfere with the ordinary uses of the plaintiff's close so much as the custom would which was held to be valid in Tyson $\mathrm{v}$. Smith, 6 A. \& E. 745 (E. C. L. R. vol. 33), 9 A. \& E. 406 (E. C. L. R. vol. 36), that, at fairs holden on the waste of a manor, every liege subject exercising the trade of a victualler might enter, at the time of the fairs, and erect a booth, and continue the same a reasonable time after the fairs, for the more convenient carrying on his calling.

As to customary rights claimed by reason of inhabitancy, the distinction has always been between a mere easement and a profit à prendre. A custom for all the inhabitants of a vill to dance on a particular close at all times of the year, at their free will, for their recreation, has been held good, this being a mere easement; Abbot v. Weekly, 1 Lev. 176; and we held, last Term, that, to a declaration for breaking and entering the plaintiff's close and taking his fish, a custom pleaded for all the inhabitants of the parish to angle and catch fish in the locus in quo was bad, as this was a profit à prendre, and might lead to the destruction of the subject-matter to which the alleged custom applied.

Judgment for the defendants. ${ }^{23}$

23 The privilege of piling lumber upon the land of another cannot be obtained by custom. Talbott v. Grace, 30 Ind. 389, 95 Am. Dec. 704 (156is); Iittlefield v. Maxwell, 31 Me. 134, 50 Am. Dec. 65: (1S50); Ackerman v. Shelp, 8 N. J. Law, $12 \bar{J}$ (1825); Post v. Pearsall, 2.2 Weld. (N. Y.) $4: J$ (1839!. 
CHAPTER II

EASEMENTS

\title{
SECTION 1.-GENERAL PRINCIPLES OF EASEMENTS
}

\author{
ABBOT v. WEEKLY. \\ (Court of Iring's Bench, 1665. 1 Lev. 176.)
}

Trespass for breaking his close; the defendant prescribes, that all the inhabitants of the vill, time out of memory, \&c. had used to dance there at all times of the year at their free will, for their recreation, and so justifies to dance there: issue was on the prescription, and a verdict for the defendant, and to save his costs the plaintiff moved in arrest of judgment, that this prescription to dance in the freehold of another, and spoil his grass, was void, especially as it is laid, viz. at all times of the year, and not at seasonable times; and that 'twas also ill laid in the inhabitants, who although they may prescribe in easements, as 6 Co. Gateward's case, and some other books are, yet they ought to be easements of necessity, as ways to a church, \&c. and not for pleasure only, as this case is. Secondly, If it be good, it ought to have been laid by way of custom in the town, and not by prescription in the persons, and a case was cited, where 'twas so adjudged on a demurrer: but by the Court, this is a good custom, and it is necessary for inhabitants to have their recreation. And as to the second, that though perhaps it had been ill on a demurrer, yet issue being taken there on and found for the defendant, 'tis good; and judgment was given for the defendant. $^{1}$

1Acc.: Knowles $\checkmark$. Dow, 22 N. H. 387, 55 Am. Dec. 163 (1851), on the ground that twenty years' use justifies the finding of immemorial use. A custom "for all persons for the time being, being in a certain parish," to play games upon a specified close, was held bad in Fitch $\nabla$. Rawling, $2 \mathrm{H}$. B1. 393 (1795). See, also, Jousney v. Ismay, 1 H. \& C. 729 (1863). 


\section{GRAHAM v. WALKER et ux.}

(Supreme Court of Connecticut, 1905. 78 Conn. 130, 61 Atl. 98, 2 L. K. A. [N. S.] 983, 112 Am. St. Rep. 93, 3 Ann. Cas. 611.)

Action in the nature of trespass qu. cl. fr., brought by appeal from a judgment of a justice of the peace to the court of common pleas in New London county, and tried by jury before Noyes, J.; verdict and judgment for the plaintiff for one cent damages, and appeal by the defendants. Error and new trial ordered.

BALDWIN, J. 'The answer contained three separate defenses-a general denial; an entry in the exercise of a prescriptive right of way to and from Taftville, appurtenant to a close of the defendants situated in a quarter of the town of Lisbon known as "Blissville"; and an entry in the exercise of a right of way to and from Taftville, belonging by immemorial local custom to all the inhabitants of Blissville. It was admitted that the land over which the way was alleged to exist was bounded by a highway, on the opposite side of which, at a distance of about half a mile, the defendants owned a house and farm, which was the close to which they claimed the way to be appurtenant. The defendants introduced evidence which, as they claimed, proved the existence of each of the rights of way set up in their answer-the former by a contintous, uninterrupted, and adverse user for more than 15 years by them and their predecessors in title in connection with the occupation, use, and enjoyment of their close, and the latter by a like user for more than 15 years by all the landowners and inhabitants of Blissville generally, and their tenants and employés.

With respect to the third defense, the jury were instructed that if a substantial portion of the inhabitants of Blissville for an entire period of at least 15 years had uninterruptedly, continuously, adversely, and under a claim of right in behalf of all the inhabitants, passed over the land in question, to and from Taftville, with the knowledge of the owner of the land, a right of way in favor of all the inhabitants was thereby acquired, founded on custom, which attached to every one who for the time being was such an inhabitant, while he continued to be such; that, if such a user was open, notorious, and visible, the owner of the land was charged with notice of it; that a user would be continuous and unintermpted, if it were substantially such, although it were more or less frequent, according to the nature of the way and the occurrence of occasions for traveling over it; and that certain testimony which had been introduced by the plaintiff as to the existence of other paths and their use by the inhabitants in going to and from Taftville tended in a measure to show that their use of the way claimed was not continuous, uninterrupted, and customary.

These instructions are made a ground of appeal by the defendants. They were too favorable to the defense. A right of way by custom in favor of the inhabitants of a particular locality might be set up by the 
common law of England. It could be proved by immemorial usage. From such proof a presumption was deemed to arise that the usage was founded on a legal right. This right was not assumed to arise from a grant by an owner of land of an easement in it. No grant of that nature can subject the tenement of the grantor to an easement which will outlast the life of the grantee, unless it be made in such a way as to become appurtenant to some other tenement. A right of way by custom appertains to a certain district or territory, but not to any particular tenement forming part of that territory. Nor is it confined to owners of land within that territory. It belongs to the inhabitants of that territory, whether landowners or not. To a fluctuating body of that kind no estate in lands can be granted. If, therefore, an easement be claimed to exist in their favor, a title cannot be made out by prescription, on the theory of a lost grant. It must have come, if at all, from some public act of a governmental nature.

The theory of English law was that, if there had been a usage from time immemorial (that is, so far as could be ascertained, from the coronation of Richard I), affecting the use of real estate by those not able to show any paper title to warrant it, it might fairly be presumed that it arose under an act of Parliament or other public act of governing power, the best evidence of which had perished. A charter from some feudal lord or ecclesiastical corporation might be such an act. Of such charters there were no public records. That the accidental destruction of the parchment on which one was written should annul the privileges which it gave would be plainly unjust.

The political and legal institutions of Connecticut have from the first differed in essential particulars from those of England. Feudalism never existed here. There were no manors or memorial rights. A recording system was early set up, and has been consistently maintained, calculated to put on paper, for perpetual preservation and public knowledge, the sources of all titles to or incumbrances affecting real estate. Nor have we all the political subdivisions of lands which are found in England. An easement by custom may exist there in favor of the inhabitants of a city, county, town, hamlet, burgh, vill, manor, honor, or hundred. Co. Litt. 110b, 113b, 115b. Most of these terms denote forms of communities that are unknown in this state. Under our statute of limitations, also, rights of way may be established by a shorter user than that required by the English law. Coe v. Wolcottville MIfg. Co., 35 Conn. 175; Gen. St. 1902, § 1073.

During the greater part of the colonial era the common law of England was not deemed to form a part of the jurisprudence of Connecticut, except so far as any part of it might have been accepted and introduced by her own authority. Stat. (Ed. 1769) 1; Swift's System, I, 44. Later the doctrine received the sanction of this court that it was brought here by the first settlers, and became the common law of Connecticut so far as it was not unadapted to the local circumstances of shis country. Card v. Grimman, 5 Conn.164, 168. This court has never 
affirmed the recognition by our law of personal rights of way or other easements resting on local custom. In view of all the considerations named, we are of opinion that such rules of the English common law as gave them sanction were unadapted to the conditions of political society existing here, and have never been in force in Connecticut. ${ }^{2}$

It follows that the trial court erred in directing the jury to disregard the second defense. They were told in the first place to disregard it because the evidence of user introduced in its support was equally relevant to support the third defense, and if the defendants, as inhabitants of Blissville, had a personal right of way by local custom, their user, being consistent with that, could not be claimed to indicate the assertion and enjoyment of a way by prescription appurtenant to their particular close. See Blewett v. Tregonning, 3 Adolphus \& Ellis, 554. There being no such thing in Connecticut as a personal right of way established by custom, the evidence in question could only be pertinent to the second defense, and, if sufficient to support that, the defendants would have been entitled to a verdict. The defendants had themselves used the way in question only since they purchased their close, seven years before. To make out a prescriptive right, it was therefore necessary to tack the user by their predecessors in title.

The trial court further instructed the jury particularly with regard to the second defense, that there had been no evidence that the use of the way by the defendants or their predecessors in title had any connection with the defendants' land, nor any direct relation to its use and enjoyment, since it differed in no respect from the use of the way by their neighbors, and therefore that no way appurtenant to their close had been made out. In this there was error. An easement may be appurtenant to land although the servient tenement is separated by other lands from the dominant tenement. *** A right to convey water from a distant source of supply may be appurtenant to a tenement separated from that on which such source of supply is situated by several intervening parcels of land, each belonging to a different proprietor. Cady v. Springsville Waterworks Co., 134 N. Y. 118, 31 N. E. 245. In like manner, a way from one close to and through another is none the less appurtenant to the former if it run over the intervening lands of numerous proprietors. Guthrie v. Canadian Pacific Railway Co., 27 Ont. App. 64, 69; Horner v. Keene, 177 Ill. 390, 52 N. E. 492 . See Fisk v. Ley, 76 Conn. 295, 56 At1. 559.

No reason is apparent why the same principles should not govern when a way is prescribed for as an appurtenance, which commences at a highway. In an early English case the plaintiff declared on a way to his close in D "in, by, or through a certain way in Sale," and in overruling a motion in arrest of judgment the court held that assuming the term "way," as thus used, to mean highway, while the plaintiff was

2Acc.: Ackerman v. Shelp, 8 N. J. Law, 125 (1825). See Coolidge v. Learned, 8 Pick. (Mass.) $50 \pm$ (18*9). 
in the exercise of a public right when on the highway he might prescribe for a way over adjoining ground reached from and by means of the highway. Banning's Case, Noy, 9. This is cited by Comyn as authority for the position that a private way may exist to the close of anothur, through or across the highway. Com. Dig., III, 37 "Chemin," D. So it has been held that a way may be appurtenant to a close though separated from it by a navigable river. Case of Private Road, 1 Ashmead, 417,421 . That a way cannot be appurtenant to a close at which it neither begins nor ends has been often asserted by text-writers, and is not without countenance from judicial decision. Washburn on Easements, *161; 23 Am. \& Eng. Encyclop. of Law, 6, "Private Ways"; Whaley v. Stevens, 21 S. C. 221 ; Id., 27 S. C. $549,558,559,4$ S. E. 145.

The better reason scems to us to lead to a contrary conclusion, and to be supported by the rules of common law. An appurtenant way ordinarily does touch the close to and from which it leads, and that it should is commonly essential to its enjoyment; but it is not always thus essential, and, when not, the dominant may be separated even at a long distance from the servient tenement. ${ }^{3}$ The use, however, of any easement, which can be claimed as an appurtenance by prescription, must be so related to the use of the dominant tenement that its particular connection with the beneficial enjoyment of that tenement is not merely conjectural, but direct and apparent. A claim to a way by prescription appurtenant to a particular close being founded on the presumption of a lost grant, none can be so gained unless the prescriptive use was such as to make it reasonable to presume that the owner of the land over which the way was used knew that such use was in connection with and furtherance of the enjoyment of such close. He might be willing to concede a claim to a personal right of way which would cease with the life of the claimant, when he would dispute a claim to a right of way appurtenant to another's close, which would endure forever.

The fact that the respective closes of the parties were half a mile apart, and that the way was only accessible by the highway on which each of these closes abutted, did not conclusively bar a claim that the way was an appurtenance to that of the defendants. The testimony which they had introduced tended to show a long, adverse, and contin-

3 In addition to the cases cited in the opinion, see Thorpe v. Brumtit, L. R. 8 Ch. App. 650 (1S73) ; Louisville \& N. R. R. v. Koelle, 104 Ill. 455 (1882); Winston $\mathrm{v}$. Johnson, 42 Minn. 398,45 N. W. 958 (1890).

Compare Garrison v. Rudd, 19 Ill. 558 (1858).

A. owned a farm upon which was a spring. He conveyed a part of the farm to his son B. in fee, together with the right "to take water from my spring for his family use"; he later conveyed another portion to his daughter C. in fee, together with "a privilege to take water from the spring on my farm as occasion may require." Held, C.'s easement was appurtenant to the land conveyed to her. Chase v. Cram, 39 R. I. 83,97 Atl. 481, I. R. A. 1918 F, 444 (1916). Compare Coatsworth . Hayward, 78 Misc. Rep. 194, $13 y$ ․ Y. Supp. 331 (1912). 
uous user by the successive owners of their close, in connection with their use, occupation, and enjoyment of it in going thence to Taftville and back. Such a user, if proved to the satisfaction of the jury, might sufficiently establish a direct connection between the use of the close and the use of the way to bring it within the definition of a way appurtenant. That some or all of their neighbors might have a similar way, appurtenant to their closes, was immaterial. Kent v. Waite, 10 Pick. (Mass.) 138.

Other reasons of appeal require no discussion, as the questions presented are not likely to recur on another trial.

There is error, and a new trial is ordered. The other Judges concurred.

\section{ACKROYD v. SMI'TH et al.}

(Court of Common Pleas, 1850. 10 C. B. 164.)

[Trespass qu. cl. fr. for breaking and entering a certain close of the p)laintiff, which consisted of a road or lane running between the Bradford and Thornton turnpike road on one side and a certain other road known as Legram's Lane on the other side. The plaintiff was the owner subject to a mortgage to one Lister, and in possession of the locus in quo. He had also owned, subject to the same mortgage, certain other adjacent parcels. He and the mortgagee by deed had conveyed these other parcels in fee to one John Smith "together with all ways, paths, passages, particularly the right and privilege to and for the owners and occupiers, for the time being, of the said close, pieces, or parcels of land, or any of them, and all persons having occasion to resort thereto, of passing and re-passing, with or without horses, cattle, carts, and carriages, for all purposes, in, over, along, and through a certain road running between the Bradford and Thornton turnpike road and Legram's Lane."

The defendants in their plea set out the above-mentioned conveyance and deduced a title in themselves by mesne conveyances of the above granted lands "and appurtenances," and alleged that thus being the owners of the parcels conveyed and having occasion for their own purposes to use the right so granted they had passed over the road oyer which the way had been granted, and so justified the trespasses complained of.

The plaintiff demurred, assigning for causes that the plea did not show that the trespasses justified were committed in going to or from the premises conveyed, or that they were in any manner connected with the enjoyment of these premises.]

CRESTELL, J. ${ }^{4} * * *$ In support of the demurrer, it was contended, first, that the road granted was only for purposes connected

4 The statement of facts is abridged and part of the opinion of (jressvel J.. and the opinion of Wilde, C. J., are omitted. 
with the occupation of the land conveyed, and therefore was not sufficient to support the justification pleaded, and, secondly, that, if the grant was more ample, and gave to the grantee a right of using the road for all purposes, although they might not be in any way connected with the enjoyment of the land, it would not pass to an assignee of the land, and therefore the defendants could not claim it under a conveyance of the land; with the appurtenances. On the other hand, it was contended that the right created by deed might be assigned by deed, together with the land, and was large enough to maintain the justification pleaded.

Upon consideration, we have come to the conclusion that the plaintiff is entitled to our judgment on the demurrer.

If the right conferred by the deed set out, was only to use the road in question for purposes connected with the occupation and enjoyment of the land conveyed, it does not justify the acts confessed by the plea. But, if the grant was more ample, and extended to using the road for purposes unconnected with the enjoyment of the land-and, this, we think, is the true construction of it-it becomes necessary to decide whether the assignee of the land and appurtenances would be entitled to it. In the case of Keppell v. Bailey, 2 Mylne \& K. 517, the subject of covenants running with the land, was fully considered by Lord Chancellor Brougham; and the leading cases on it are collected in his judgment. He there says: ${ }^{5}$ "The covenant (that is, such as will run with the land) must be of such a nature as 'to inhere in the land,' to use the language of some cases; or, "it must concern the demised premises, and the mode of occupying them,' as it is laid down in others: 'it must be quod ammodo annexed and appurtenant to them,' as one authority has it; or, as another says, "it must both concern the thing demised, and tend to support it, and support the reversioner's estate." Now, the privilege or right in question does not inhere in the land, does not concern the premises conveyed, or the mode of occupying them; it is not appurtenant to them. A covenant, therefore, that such a right should be enjoyed, would not run with the land. Upon the same principle, it appears to us that such a right, unconnected with the enjoyment or occupation of the land, cannot be annexed as an incident to it: nor can a way appendant to a house or land be granted away, or made in gross; for, no one can have such a way but he who has the land to which it is appendant: Bro. Abr. Graunt, pl. $130{ }^{\circ}$ If a way be granted in gross, it is personal only, and cannot be assigned. So, corpmon in gross sans nombre may be granted, but cannot be granted over - per Treby, C. J., in Weekly v. Wildman, 1 Ld. Raym. 407. It is not in the power of a vendor to create any rights not connected with

52 Mylne \& K. 537.

o Citing 5 H. 7,7 (II. 5 H. 7 , fo. 7, pl. 15): "Note, that it was said by Fairfax (Justice of C. P.) for law, that, if one has a way appendant to his manor, or to his house by prescription, that way cannot be made in gross; because no man can take profit of that way, except he have the manor or the house to which the way is appendant." 
the use or enjoyment of the land, and annex them to it: nor can the owner of land render it subject to a new species of burthen, so as to bind it in the hands of an assignee. "Incidents of a novel kind cannot be devised, and attached to property, at the fancy or caprice of any owner." Per Lord Brougham, C., in Keppel v. Bailey.

This principle is sufficient to dispose of the present case. It would be a novel incident annexed to land, that the owner and occupier should, for purposes wholly unconnected with that land, and merely because he is owner and occupier, have a right of road over other land. And it seems to us that a grant of such a privilege or easement can no more be annexed, so as to pass with the land, than a covenant for any collateral matter.

The defendants cannot, therefore, as assigns, avail themselves of the grant to John Smith; and our judgment must be for the plaintiff.

Judgment for the plaintiff.

\section{BOATMAN v. LASLEY.}

(Supreme Court of Ohio, 1873. 23 Ohio St. 614.)

Motion for leave to file a petition in error to the District Court of Gallia county.

The original action was brought in the Court of Common Pleas of Gallia county by Matthew Lasley against Isaac Boatnan and wife, to foreclose a mortgage executed by the defendants to secure the payment of purchase money of the lands mortgaged. The mortgaged premises had been conveyed by the plaintiff to defendant, Isaac Boatman, on the 15th of March, 1870, by a deed containing a covenant that the demised premises were free and clear of all incumbrances. The defendant answered, and by way of counterclaim, alleged damages resulting from a breach of this covenant against incumbrances. The alleged incumbrance consisted of a private right of way over the warranted premises, outstanding at the date of the conveyance in one Alexander Logue. This right of way had been granted by deed, on the 7th day of June, 1862 , by the warrantor, to "Logue, his heirs and assigns, and the tenants or occupiers for the time being of the lands now (then) owned and occupied by the said Alexander Logue, in section 15, town 5, of range 14, in the Ohio Company's Purchase. It is also alleged in the answer, that, before the 15th of March, 1870 (the date of the covenant), said Logue had conveyed his lands in section 15 , town 5 , of range 14 , in the Ohio Company Purchase, to one George IV. Roush. It is not alleged, however, that Logue, at the time the right of way over the warranted premises was granted to him by the plaintiff, was the owner or occupier of any land in said section 15, or elsewhere, nor is it alleged that the right of way complained of became appendant or appurtenant to anv land whatever, or that said Roush had any interest in said right 
The plaintiff, in his reply, denied that Roush had an easement or right of way on the premises granted to the defendant, and also denied that the defendant had sustained any damage by reason of the right of way complained of.

The cause was submitted to a jury, who assessed the defendant's damages, by reason of the existence of the right of way, at $\$ 100$, which sum was deducted from the mortgage debt, and decree entered in favor of the plaintiff for the balance.

During the trial the defendant took a bill of exceptions, from which it appears that the defendants offered in evidence the deed for the right of way from Lasley to Logue, a copy of which is attached, marked "A." They also gave evidence tending to prove that said right of way was still in the occupation of said Alexander Logue, and those claiming under him, who were then occupying the lands to which said right of way was intended to be made appendant. "And the plaintiff, to maintain the issue on his part, gave evidence tending to show at the time said deed of right of way was executed by him to Alexander Logue, the said Logue did not own the land to which the right of way was intended to be appendant, and that said Logue had, prior to the execution of the deed of right of way, conveyed said lands to one George W. Roush."

The evidence being closed, the court charged the jury as follows: "If the jury shall find from the evidence that at the date of the deed made by Lasley to Logue, marked 'A,' the said Alexander Logue, grantee therein, was not the owner in fee or otherwise of some real estate adjoining the farm through which said right of way is granted, or situate in the neighborhood, so that said right of way may become appurtenant to the same, then the said deed conveys a right of way personal to himself alone-one which can not descend to his heirs, and one which he can not assign or release to another person, except such other person be the owner of the farm through which said way was granted."

The judgment of the Common Pleas was afterward, on petition in error, affirmed by the District Court of Gallia county.

Leave is now asked to file a petition in error in this court to reverse the judgment below, for alleged error in the charge to the jury as above set forth.

MCILVAine, $J$. Is a private right of way over the lands of another, in gross, such an interest or estate in land, as may be cast by descent, or may be assigned by the grantee to one who has no interest in the land? These are the only questions in this case. If such a right be inheritable or assignable, the Court of Common Pleas erred in its charge; otherwise there is no error in the record.

The terms of the deed from Lasley to Logue plainly import an intention to make the right of way therein granted appendant and appurtenant to other lands, but the record does not disclose either the facts or the law given to the jury, whereby it could determine whether 
or not that intention was accomplished. It simply shows that the jury was instructed that if the right of way granted did not and could not, under the circumstances, become appurtenant to lands other than those over which it was granted, then it was a mere personal right in the grantee, which could not be inherited from him, or transferred by him to a stranger.

The correctness of this instruction does not depend upon a construction of the deed by which it was granted, for the terms of the grant are "to Alexander Logue, his heirs and assigns." The real question is, whether or not a private right of way in gross is, in law, capable of being transferred or transmitted.

It is strongly insisted upon, in argument, that a right of way in gross may be conveyed to the grantee "and to his heirs and assigns forever," because an owner in fee may carve out of his estate any interest less than the whole and dispose of the less estate absolutely; and this because the power to dispose of the whole estate includes a power to dispose of any part of it.

This argument assumes the affirmative of the very question in controversy, to wit, that such a right of way is an interest or estate in the land.

A mere naked right to pass and repass over the land of another, a use which excludes all participation in the profits of the land, is not, in any proper sense, an interest or estate in the land itself. Such a right is in its nature personal; it attaches itself to the person of him to whom it is granted, and must die with the person.

If such right be an inheritable estate, how will the heirs take? In s.everalty, in joint tenancy, coparcenary, or as tenants in common? If not in severalty, how can their interests be severed?

If it be assignable, what limit can be placed on the power of alienation? To whom and to how many may it be transferred? Why not to the public at large, and thus convert into a public way that which was intended to be a private and exclusive way only?

Where the way is appendant or appurtenant to other lands, very different considerations arise. There the right attaches to the lands to which the way is appurtenant, because it is granted for the convenience of their occupation without respect to the ownership or number of occupants. In such case the right of way passes with the dominant estate as an incident thereto. A right of way appendant cannot be converted into a way in gross, nor can a way in gross be turned into a way appendant.

A very marked distinction also exists between a way in gross and an easement of profit à prendre; such as the right to enter upon the lands of another, and remove gravel or other materials therefrom. The latter so far partakes of the nature of an estate in the land itself, as to be treated as.an inheritable and assignable interest. Post v. Pearsall, 22 Wend. (N. Y.) 432. 
Both upon principle and authority, we think there was no error in the charge of the court below. Mr. Washburn in his work on Easements, page 8, par. 11, states the law upon this subject as follows: "A man may have a way in gross over another's land, but it must, from its nature, be a personal right not assignable or inheritable; nor can it be made so by any terms in the grant, any more than a collateral and independent contract can be made to run with the land." See also Ackroyd v. Smith, 10 C. B. 164; Garrison v. Budd, 19 Ill. 558; Post v. Pearsall, 22 Wend. (N. Y.) 432; Woolrych on Ways, 20; 2 Black Com. 35; 3 Kent's Com. 420, 512.

Leave refused. ${ }^{7}$

\section{STANDARD OIL CO. v. BUCHI et ux.}

(Court of Chancery of New Jersey, 1907. 72 N. J. Eq. 492, 66 Atl. 427.)

Pitney, Advisory Master. ${ }^{8}$ The object of the bill is to obtain judicial restraint preventing the defendant from interfering by strong hand and serious threats of violence with the complainant's work in laying across the lands of the defendant in Bergen county a line of pipe for the transportation of oil. ***

The complainant claims the right in question by virtue of a deed dated the 30th day of October, 1882, and duly recorded on the 6th day of December, 1882, in the clerk's office of Bergen county, where the lands lie, between James $\mathrm{H}$. Kingsland, predecessor in title of the defendant and then the owner of the lands in question, and one John B. Barbour, under whom the complainant claims. That deed, or so much of it as is necessary for present purposes, is as follows: "Witnesseth: That for and in consideration of five dollars in hand paid, the receipt of which is hereby acknowledged and the further sum of twenty dollars to be paid before any pipe is laid, the party of the first part, his heirs and assigns, hereby grants to the party of the second part, his heirs and assigns, the right of way to lay pipes for the transportation of petroleum; and operate the same on, over and through his lands in said County of Bergen, in said State of New Jersey, described in a certain deed dated Sept. 13th 1881, and recorded in the County Clerk's office of Bergen County, in book Z-10 page 542 of deeds, together with all the rights and privileges incident and necessary to the enjoyment of this grant, and the removal of said pipes. *** $*$ It is understood and agreed between the parties hereto that said pipe lines are to be laid within ten feet of the southerly lines of the above described property, excepting where there are angles in said property lines at which points such deflections shall be made therefrom as the surveyor

7 Contra: Shreve $\nabla$. Mathis, 63 N. J. Eq. 170, 52 Atl. 234 (1902).

See Hall v. Armstrong, 53 Conn. 554, 4 Atl. 113 (18S5); Wilder v. Wheeler, 60 N. H. 851 (1SS0).

8 l'art of the opinion is omitted. 
of the party of the second part may decide to be necessary. Witness our hands and seals the day and year first above written. [Signed] Jas. H. Kingsland. [Seal.] J. B. Barbour. [Seal.]"

The bill alleges, and in this respect is supported by the affidavits, or at least is not disputed on this motion, that the grantee, Barbour, was a mere agent or trustee for procuring the right of way (and land for pumping stations) for a continuous underground series of pipes conducting petroleum from Pennsylvania and other oil-bearing regions to tide water. That in 1880 he purchased certain land in Bergen county from a Mrs. Zabriskie, and an adjoining tract from one Knowles, for the purpose of a pumping station, which he immediately conveyed to the Standard Oil Company, and that the deed above mentioned from Kingsland was also taken by said Barbour as a part of the right of way for a great pipe line system for conducting oil from the oil regions to tide water, and shortly afterwards was assigned and conveyed to the complainant and a continuous line of oil-bearing pipe was laid over it, including the Kingsland strip, and pumping stations erected and the pipe line put in use for the purpose of conveying oil, and has been in use ever since; that later on, in 1894, a second pipe line was laid alongside the first along the entire length of the Kingsland property and put in immediate use, and that the object of the present proposed interference with the soil of the defendant is to lay a third pipe line over the whole right of way close beside the first.

The justification set up by the defendant amounts to a demurrer to the bill, and the argument in its support may be briefly stated as follows: That the grant contained in the Kingsland deed amounted to no more than the grant of an easement without the naming of any dominant tenement, and therefore amounted to no more than an easement in gross, which was not assignable, and hence amounted to a mere license, and was determinable at the will of the licensor; that the license was in law immediately abandoned by the assignment thereof, and that it was also formally determined by a notice of revocation given by the defendant Buchi to the complainant, dated March 5, 1907, and annexed to the bill of complaint.

The first inquiry naturally is: what is the true character of the grant in question? Is it properly classified either as a mere easement or as a mere revocable license? It is to be observed, in the first place, that it is an instrument under seal, and expresses to be for a valuable consideration presently paid, with the provision for the ascertainment of a further consideration in a mode, the reasonableness of which seems to me to be quite apparent and which has not been attacked in the argument. In the next place, it is not a mere promise to do something in the future, nor is it a mere permission, but it is a grant in præsenti, and it is not a mere privilege given to the grantee which can be considered as merely personal to him, such as a privilege to wander over ground with or without the privilege of hunting or fishing, but it is 
made to the grantee, his heirs and assigns. Then it is not the mere privilege to walk or pass over land without the right to disturb the soil, as is a right of way, but it is a "right to lay down pipes for the transportation of petroleum and to operate the same over" the lands, "together with all the right and privileges incident and necessary to the enjoyment of the grant and the removal of the pipes." This grants rights in the soil in perpetuo.

Now just here the defendant attempts to meet this aspect of the case by setting up that he does not propose to dispute or disturb what has already been done under the so-called license, or to interfere with the complainant in the enjoyment of its works already on his land, but he claims the right to prevent any further exercise of the rights mentioned in the grant. Nor does he contend that the right to lay the third line of pipes is not included in the terms of the grant. Nor does he contend that there is anything inequitable in the complainant's standing before the court. On the contrary, he puts himself on the bold, bare ground that, because there was no dominant tenement mentioned in the grant to which what would have been an easement was appurtenant or appendant, the easement so called became one in gross and not assignable, and by its attempted assignment ceased to exist in law, or at least degenerated into a mere license revocable so far as not acted upon.

Now, is it possible to treat the document in question as having no greater force than that? The doctrine contended for, if logically applied, leads to this result: If Mr. Barbour had paid Mr. Kingsland $\$ 1,000$ in cash for this grant, and had the next day assigned it to the complainant, it would have been possible for Kingsland to have immediately destroyed the value in the law of his grant by a formal revocation of it, and the complainant would have had no relief in equity by showing that Barbour was acting merely as its agent; for it is not contended by the defendant that the Standard Oil Company has not the capacity in law of holding the title to and operating a pipe line such as that described and in actual use. And it is to be observed that the question is not whether in the then present condition of the law the Standard Oil Company had the right to acquire by condemnation proceedings the lands and rights of way for its pipe line and pumping stations from the western oil fields to tide water, but the question is whether, having first purchased the lands and rights of way through agents, by means of divers conveyances which did not disclose, so far as relates to mere rights of way, any termini or dominant tenement, it could have been prevented by any one of the grantors from proceeding to lay its pipe across the grantor's land, or, rather, whether, having acquired title in that manner, by grants which provided in effect the right to add to its pipe line from time to time, and having acted upon those grants so obtained, and having built a great trunk line and being in possession and use thereof, it may be prevented from adding thereto on the ground here taken. 
The idea underlying the ordinary easement is that it is at the $€ x$ pense of one tenement, called the "servient" tenement, and for the henefit especially of another tenement, called the "clominant" tenement. Clearly the right granted by the deed in this case was not of that character, and hence it must be construed by rules not applicable to those of ordinary easements. There was in this case, and could in the nature of things be, no dominant tenement. Nor is it, in its essential nature a license, nor can it be reduced in its nature in that respect. It by its terms granted a permanent riglit to lay the pipe, to maintain the same and to remove the same. It gave an interest in the land quite as positive and as permanent as that in which a deed is given granting the right to lay a line of water pipes or to erect a line of telephone poles across the grantor's land, where the circumstances indicate that the work done thereunder was to be permanent. From these considerations, based on general and familiar principles, I come to the conclusion that the defendant's position is untenable, especially when urged in a court of equity. ${ }^{9} * * *$

I think the present grant is something more than an easement, al though undoubtedly it includes easements, and I think that it is a great deal more than a license, in that it gives an irrevocable interest in the land and creates, by apt words, an estate, is expressed to be upon $a$ consideration, and is sealed by the seal of the grantor. I can find no authority in any of the treatises or in any of the adjudged cases for holding that it is revocable.

As in my judgment the right of the complainant is entirely clear and not subject to revocation, $I$ think it is entitled to relief by way of immediate injunction. ${ }^{10} * * *$

9 The court here discussed the following cases: Ackroyd $\nabla$. Smith, $10 \mathrm{C}$. B. 164 (1850); Goodrich v. Burbank. 12 Allen (Mass.) 459, 90 Am. Dec. 161 (1S66) ; Mayor, etc., of City of New York v. Law, 125 N. Y. 380, 26 N. E. 471 (1891); East Jersey Iron Co. $\nabla$. Wright, 32 N. J. Eq. 248 (1S50); Eckert $r$. Peters, 55 N. J. Eq. 379, 36 Atl. 191 (1896) ; Mitchell . D'Olier, 65 N. J. Law, 375,53 Atl. 467, 59 L. R. A. 949 (1902); Wilkins v. Irvine, 33 Ohio St. $13 \mathrm{~s}$ (1877); Wood v. Leadbitter, 13 M. \& W. 845 (1515); Wood V. Manley, 11 A. \& E. 34 (1839) ; Berry r. Potter, 52 N. J. Eq. 664, 29 Atl. 223 (1S94); șed v. Pennington, 72 N. J. Eq. 599, 65 Atl. 713 (1907).

10 Acc.: Goodrich v. Burbank, 12 Allen (Misss.) 459 (1s66).

A. conveyed to $B$. in fee a piece of land between two virers, "reserving the right of erecting a $\log$ sluice and flume between my mill and the mill of said grantees." Held, A. could conrey this right in fee to C., the owner of another mill, who could use it for fluming logs to his mill as against B.'s grantee of the servient tract. Ring v. Walker, 87 Me. 550, 33 Atl. 174 (189J).

A. granted to B., "his heirs and assigns forever," the right "to take water for his family and for any other purpose" out of a specified well on $A$. 's land. Held, assuming the right to be in gross, B. could convey it in fee to C., who could enforce it against A.'s grantee of the serrient piece. Poull $\mathbf{v}$. MLokles, 33 Wis. 482 (1ST3).

A. had a lease of a tract of land. He made a contract under seal with $F$.. by which he corenanted that $B$. should have the right to the exclusive use of the fences surrounding the tract for adrertising purposes so long as $A$. or his assigns should occupy the land. A. assigned the lease of the tract Big.RIGIITs-13 


\section{CADWALADER v. BAILEY et al.}

(Supreme Court of Rhode Island, 1S91. 17 R. I. 495, 23 Atl. 20.)

I3ill in equity for an injunction.

The bill shows that Joseph I. Bailey and Alfred Smith were tenants in common of a piece of land known as Bailey's Beach. They conveyed a portion of it in fee to one George Cadwalader, together with the right to place a bathing car on the remaining part of the beach. The deed also contained the following clause:

"And we, the said Joseph I. Bailey and Alfred Smith, for ourselves, our heirs, executors, and administrators, do hereby covenant to and with the said George Cadwalader, his heirs and assigns, that no building, excepting bathing-cars, shall ever be placed upon the marsh or beach called 'Bailey Beach'; that no building shall ever be placed to the westward of a line drawn southerly from Bellevue street, parallel to and distant five hundred and thirty-one feet westerly from the Ledge road, and that none shall be placed on a knoll overlooking said beach, and just north of the lower end of Bellevue street." "* * *

The bill further shows that the said George Cadwalader entered upon and took possession of the land to lim conveyed, and thereafterwards, on the 1Sth day of August, 1864, by deed duly executed, sold and conveyed to one William IV. Tucker, his heirs and assigns, the land which the said George Cadwalader had received as grantee in the said deed of October 15, 1S52; but that the said deed from Cadwalader to Tucler contains the clatuse: "It is understood and agreed that the grantor reserves to himself, his heirs and assigns, the corenants and stipulations contained in a deed from J. I. Bailey and A. Smith, dated October 15, 1852, against building on certain sites near the bathing beach, and the right of bathing on said beach."

The bill further shows that the respondents are now seised and possessed of said marsh or beach called "Bailey's Beach," and of the land adjacent thereto, as heirs of the said Bailey and Smith, both of whom are decensed, or as heirs or devisees of the said Bailey, and as heirs of the said Snith, and have been so seised and possessed since the deaths, respectively, of said Bailey and of said Smith; that the said George Cadwalader died February 3, 1879, testate, leaving his wife, Frances Cadwalader, his sole devisee and legatee;- that she died testate, January 9, 1SSO, leaving the complainant, John Cadwalader, her residuary devisee and legatee. The bill further shows that the respondents, notwithstanding said covenants in said deed of October 15 , 1852 , contained, did, in the year 1890 , erect, on the marsh or beach

to C., who bouglht with notice of B.'s contract. Held, B. may enforce against C. the right to use the fen e for advertising purposes. Willoughby v. Lawrence, 116 Ill. 11,4 N. is. 856,56 Am. Rel. T5s (1856).

See, also, II:ll v. Ionia, 38 Mich. 49:3 (15T): Columbia Water Powel Co. v. Columbia Electric Street liailway, light \& Power Co., 43 s. C. 154, 20 s. k. $1002(1894)$. 
called "Bailey's Beach," a permanent building of large size, and not bathing-cars, which building was plaged, and is by the respondents still maintained, on said marsh or beach, to the detriment of the complainant, and in violation of his rights under the said covenants, and without his consent, and in defiance of his protests.

The prayer of the bill is that the covenants contained in said deed of October 15, 1852, may be declared valid and existent obligations upon the respondents; that they may be required to make specific performance thereof; that said covenants may be declared in favor of the complainant, his heirs and assigns, as valid restrictions upon said marsh and beach; and for an injunction. A plat of the premises is attached to and made part of said bill.

The answer admits the material allegations in the bill to be true, except as to any wrongful or unlawful acts therein charged; but avers and sets up that the complainant has no title to the easements granted in and by said deed of October 15, 1852-First, because the same were wholly severed and extinguished by the reservation in the deed from George Cadwalader to said William W. Tucker of August 18, 1864; or, second, because said easements were appurtenant to the land conveyed by said deed to Cadwalader, of which land no portion is owned or possessed by the complainant; or, third, because said easements were not appurtenant to said land, (nor any land,) but were rights in gross belonging to said George, and not assignable nor inheritable nor devisable. A ground plan of the bualding is attached to and made part of the answer.

Tilringhast, I. ${ }^{11} * * *$ These covenants, in so far, at any rate, as they constitute a restriction against building upon the remaining land of the grantors-and this is as far as we are called upon to consider them in this case-we think were manifestly intended by the parties to be restrictions in favor of the estate granted; or, in other words, that said covenant against building created a negative easement appurtenant to the premises conveyed. We cannot see that the parties in making this restriction could reasonably have had any other object in view than that of securing and preserving to the granted premises an unobstructed prospect or view of the beach and sea-a most desirable right, in connection with summer residents in Newport. Said restrictions were well adapted to the accomplishment of that object. It was a useful and desirable object. Between the granted premises and the sea was the land of the grantors, out of which this estate was carved, and there was nothing to obstruct the view of the beach on which the grantee had stipulated for the right to place a bathing-car. It is apparent, from an inspection of the premises, that buildings placed upon that part of the land included in the restrictions mentioned, and particularly upon the "knoll," would, to a greater or less extent, obstruct the prospect seaward from the granted premises. It was the

11 Part of the opinion is omitted. 
possibility of such an obstruction, we think, which it was the intention of the parties to guard against.

Furthermore, we fail to see that this restriction could have been intended for the purpose of making the bathing rights granted by said. deed "available and pleasant," as is contended by the complainant. For such buildings as might be constructed upon the restricted premises would not, so far as we are able to discover, in any way interfere with said bathing rights. Said "knoll," in particular, is so situated that no building placed thereon could by any possibility obstruct or prejudice said right. Moreover, the building which has been erected by the respondents upon the restricted premises (a large and commodious bathing pavilion) does not in any manner whatever interfere with said bathing right. The complainant is not the owner of any of the land conveyed by the respondents' ancestors in title to George Cadwalader in October, 1852, and has no interest in the execution of the covenant in suit; for, as already stated, said George Cadwalader conveyed the premises to which the easement in question was appurtenant to William W. Tucker in August, 1864, reserving to himself, his heirs and assigns, the covenants and stipulations contained, in the deed from Bailey and Smith of 1852, against building on certain sites near the bathing beach, and the right of bathing on said beach. We think it not improbable that the purpose of said George Cadwalader in severing the easement from the estate was to prevent said Tucker and his successors in title from setting up the same against his (said Cadwalader's) right to build upon a lot of land which he purchased in October, 1852, which, as the record shows, was a part of the restricted premises, and upon which he subsequently built and occupied a house, which house the complainant is now occupying.

But, however this may be, the easement, being a negative easement appurtenant to the land conveyed, was extinguished by operation of law upon being severed therefrom, and hence is no longer in existence. The easement, being appurtenant to the land, cannot exist alone. It has no.standing apart from the dominant estate to which it was attached. Thus, as stated in Woolrych on Ways, 13; "A way appendant cannot be turned into a way in gross, because it is inseparably united to the manor or land to the which it is incident." And, as stated in Washb. Easem. (4th Ed.) 26: "Though a man may acquire an easement in gross, like a right of way over another's land, separate and distinct from the ownership of any other estate to which it is appendant, yet, if his right to such way result from his ownership of a parcel of land to which it is appendant, he cannot by grant separate the easement from the principal estate to which it is appendant, so as to turn it into a way in gross in the hands of his grantee." See, also, Garrison v. Rudd, 19 I11. 558, 564, and cases cited; 3 Greenl. Cruise, 83; Ackroyd v. Smith, 10 C. B. 164; Hall v. Lawrence, 2 R. I. 218, 242, $57 \mathrm{Am}$. Dec. 715. Furthermore, as stated in Trustees of Columbia College v. Lynch, 70 N. Y. 440, 26 Am. Rep. 615: "A negative 
easement, by which the owner of lands is restricted in their use, can only be created by covenant in favor of other lands not owned by the grantor and covenantor." See, also, Hills v. Miller, 3 Paige (N. Y.) 254, $24 \mathrm{Am}$. Dec. 218. But for the reservation in the deed from Cadwalader to Tucker, the easement created would doubtless have passed to the latter, whether the grant in terms had embraced it or not, and this would also be so whether such grant, in terms, embraced privileges and appurtenances or not. Washb. Easem. (4th Ed.) p. 40, and cases cited.

It follows, then, that the complainant, never having owned the dominant estate described in the bill, has no standing in a court of equity to enforce rights which were appurtenant thereto. So far as the bathing rights are concerned, no question is made in this case concerning the right of enjoyment thereof by the complainant. For the reason above stated we are of the opinion that the complainant has not made out a case which entitles him to relief. The bill must therefore be dismissed. ${ }^{12}$

\section{HILL v. TUPPER.}

(Court of Exchequer, 1S63. 2 Hurl. \& C. 121.)

Declaration.-For that, before and at the time of the committing by the defendant of the grievances hereinafter mentioned, the plaintiff was entitled to, and had and was possessed of, the sole and exclusive right or liberty to put or use boats on a certain canal called the Basingstoke Canal, for the purposes of pleasure and to let the same boats for hire on the said canal for the purposes of pleasure. Yet the plaintiff says that, whilst he was so entitied and possessed as aforesaid, the defendant, well knowing the premises, wrongfully and unjustly disturbed the plaintiff in the possession, use, and enjoyment of his said right or liberty, by wrongfully and unjustly putting and using, and causing to be put and used, divers boats on the said canal for the purposes of pleasure, and by letting boats on the said canal for hire, and otherwise for the purposes of pleasure. By means of which said premises

12Acc.: Blood v. Millard, 172 Mass. 65, 51 N. E. 527 (189s), right to draw water; Reise v. Enos, if Wis. 634. 45 N. W. 414, 8 L. R. A. 617 (1S90), right of way. Compare McKenna 5 . Brooklyn Lnion Elerated R. Co., 181 N. $Y$. 391,77 N. E. 615 (1906).

Mater rights in irrigation ditches under the Idabo statutes have been held transferable to the owners of other lands. Hard v. Boise City Irrigation \& Land Co., 9 Idaho, 5\$9, 76 Pac. 331, 65 L. R. A. 407 (1904).

A. owned in fee a right in gross to a specified amount of water porver. For twelre years he used it exclusively and continuously in connection with a mill also owned by him, and then mortgaged the mill to B., describing the property by metes and bounds, and not mentioning the water power. The property with the power was worth $\$ 5,000$ more than the mortgage debt; without the nater power, it was worth $\$ 4,000$ less than the mortgage debt. Held, the water power passed to the mortgagee. Bank of British North America v. Miller (C. C.) 6 Fed. 5t5 (1881). See, also, Fisher v. Fair, 24 S. C. 203.13 S. E. 470,14 L. R. A. 383 (1890). 
the plaintiff was not only greatly disturbed in the use, enjoyment, and possession of his said right and liberty, but has also lost great gains and profits which he ought and otherwise would have acquired from the sole and exclusive possession, use, and enjoyment of his said right or liberty, and was otherwise greatly aggrieved and prejudiced.

Pleas.-First: not guilty. Secondly: that the plaintiff was not entitled to, nor had he, nor was he possessed of, the sole and exclusive right or liberty to put or use boats on the said canal for the purposes of pleasure, nor to let the said boats for hire on the said canal for the purposes of pleasure as alleged.-Issues thereon.

At the trial, before Bramwell, B., at the London Sittings, after last Hilary Term, the following facts appeared:-Under the 18 Geo. 3, c. 75, the Company of Proprietors of the Basingstoke Canal Navigation were incorporated with perpetual succession and a common seal, for the purpose of making and maintaining a navigable canal from the town of Basingstoke, in the county of Southampton, to communicate with the river Wey in the parish of Chertsey, in the county of Surrey. The lands purchased by the company of proprietors, under their parliamentary powers, were by the Act vested in the Company.

By the 100th scction of the Act it is enacted: "That it shall and may be lawful for the owners and occupiers of any lands or grounds adjoining to the said canal, to use upon the said canal any pleasure-boat or boats, or any other boat or boats, for the purpose of husbandry only, or for conveying cattle from one farm, or part of a farm, or lands, to any other farm or lands of the same owner or occupier, without interruption from the said company of proprietors, their successors or assigns, agent or agents, and without paying any rate or duty for the same; and so as such boat or boats be not above seven feet in breadth, and do not pass through any lock to be made on the said navigation, without the consent of the said company of proprietors, their successors or assigns, or be employed for carrying any goods, wares, or merchandise to market or for sale, or any person or persons for hire; and so as the same shall not obstruct or prejudice the said navigation, or the towing-paths, or obstruct any boats passing upon the said navigation liable to pay the rates or duties aforesaid; and the owner of all such pleasure-boats, or other boats, shall in his own lands or grounds, make convenient places for such boats to lie in, and shall not suffer them to be moored or remain upon the said canal."

The defendant was the landlord of an inn at Aldershot adjoining the canal, and his premises abutted on the canal bank. The plaintiff, who was a boat proprietor, also occupied premises at Aldershot on the bank of the canal, which he held under a demise from the company of proprietors, and by virtue of the demise claimed the exclusive right of letting out pleasure-boats for hire upon the canal, which was the riglit the defendant was alleged to have disturbed.

The lease under which the plaintiff claimed this right was dated the 29 th of December, 1860 , and by it, in consideration of the rents, cove- 
nants, and agreements therein contained, the said company of proprietors demised to the plaintiff, under their common seal, for the term of seven years from the 24 th of June, 1860 , at the yearly rent of $£ 25$., "All that piece or parcel of land containing nineteen poles or thereabouts, adjoining Aldershot wharf, situate in the parish of Aldershot aforesaid, and the wooden cottage or tenement, boathouse, and all other erections now or hereafter being or standing thereon, \&c." (describing the premises by boundaries, and by reference to a plan), "together witl the appurtenances to the same premises belonging; and also the sole and exclusive right or liberty to put or use boats on the said cana!, and let the same for hire for the purposes of pleasure only." The lease contained various covenants framed with the object of preventing any interference by the plaintiff's pleasure-boats with the navigation of the canal, and a proviso for re-entry for any breach of the covenants.

The evidence of the defendant was at variance with that adduced on behalf of the plaintiff upon the question whether the defendant had ever let out boats upon the canal for hire, in the sense of a direct money payment. The defendant did not deny that he kept pleasure-boats, and used them upon the canal, but stated that he kept them for the use of his family; he admitted, however, that gentlemen had come from time to time to his inn and used these boats for fishing and bathing.

The learned Judge reserved leave to move to enter a nonsuit or verdict for the defendant, and left to the jury the question whether the defendant had obtained any pecuniary advantage from the boats. The jury found a verdict for the plaintiff; damages, a farthing.

POLLOCK, C. B. ${ }^{13}$ IVe are all of opinion that the rule must be absolute to enter the verdict for the defendant on the second plea. After the very full argument which has taken place, I do not think it netessary to assign any other reason for our decision, than that the case of Ackroyd v. Smith, 10 C. B. 164 (E. C. L. R. vol. 70), expressly decided that it is not competent to create rights unconnected with the use and enjoyment of land, and annex them to it so as to constitute a property in the grantee. This grant merely operates as a license or covenant on the part of the grantors, and is binding on them as between themselves and the grantee, but gives him no right of action in his own name for any infringement of the supposed exclusive right. It is argued that, as the owner of an estate may grant a right to cut turves, or to fish or hunt, there is no reason why he may not grant such a right as that now claimed by the plaintiff. The answer is, that the law will not allow it. So the law will not permit the owner of an estate to grant it alternately to his heirs male and heirs female. A new species of incorporeal hereditament cannot be created at the will and pleasure of the owner of property; but he must be content to accept the estate and the right to dispose of it subject to the law as settled by decisions or controlled by Act of Parliament. A grantor may bind himself by cove-

18 The opinion of Bramwell, J., is onitted. 
nant to allow any right he pleases over his property, but he cannot annex to it a new incident, so as to enable the grantee to sue in his own name for an infringement of such a limited right as that now claimed.

Martin, B. I am of the same opinion. This grant is perfectly valid as between the plaintiff and the canal Company; but in order to support this action, the plaintiff must establish that such an estate or interest vested in him that the act of the defendant amounted to an eviction. None of the cases cited are at all analogous to this, and some authority must be produced before we can hold that such a right can be created. To admit the right would lead to the creation of an infinite variety of interest in land, and an indefinite increase of possible estates. The only consequence is that, as between the plaintifi and the canal Company, he has a perfect right to enjoy the advantage of the covenant or contract; and, if he has been disturbed in the enjoyment of it, he must obtain the permission of the canal Company to sue in their name. The judgment of the Court of Common Pleas in Ackroyd v. Smith, 10 C. B. 164 (E. C. L. R. vol. 70), and of Lord Brougham, C., in Keppell v. Bailey, 2 Myl. \& K. 517, 535, are, in the absence of any case to the contrary, ample authority for our present decision. ${ }^{14}$

14 Compare Schmoele v. Betz, 212 Pa. 32, 61 Atl. 525, 108 Am. St. Rep. 845 (1905).

It has been held that there can be no easement right to a breeze, Webb v. Bird, 13 C. B. N. S. 811 (1S63); Chastey v. Ackland, [1S95] 2 Ch. 389; nor to percolating water, Wheelock v. Jacobs, 70 Vt. 162,40 Atl. 41,43 L. R. A. 105, 67 Am. St. Rep. 659 (1897).

The following rights in addition to those considered in the other sections of this chapter have been recognized as easements. To maintain a signboard, Hoare v. Board of Works, L. R. 9 Q. B. Ca. 296 (1874); Moody v. Steggles, $12 \mathrm{Ch}$. Div. 261 (1S79); to have light and (through delined passages) air from the premises of another, Hall v. Brewing Co., 49 L. J. Ch. N. S. 655 (18s0); to open a sluiceway on servient's land to relieve the dominant land from flood water, Simpson $\nabla$. Godmanchester, [1S96] $1 \mathrm{Ch}, 214$; to pile and hoist merchandise and to swing a projecting shutter, Richardson v. Pond, 15 Gray (Mass.) 387 (1860) ; to stretch a clothesline and hang clothes, Steiner v. Peterman (N. J. Ch.) 63 Atl. 1102 (1906). See, further, part I, chapters II to VI, ante, and chapters IV and V, post.

A. had a lease for years of a building. He assigned his interest in part of the building to B., reserving a right of passage in certain halls in that part of the building so assigned for the benefit of the part kept by him. Subsequently A.'s interest passed to $\mathrm{X}$. and B.'s to $\mathrm{Y}$., the lease meanwhile having been renewed. Held, $\mathrm{X}$. may exercise the right of passage duringr the life of the lease and the renewal. Newhoff v. Mayo, 48 N. J. Eq. 619, 23 Atl. 265, 27 Am. St. Rep. 455 (1S91).

An easement may be appurtenant to an estate for life, in which case it terminates with the life estate. Hoffman v. Savage, 15 Mass. 130 (1818). Compare Rymor v. McIlroy, [1897] 1 Ch. 52S.

An easement may be appurtenant to a profit. Hanbury v. Jenkins, [1901] 2 Ch. $401,421$. 


\title{
SECTION 2.-SCOPE OF EASEMENTS
}

\author{
HOWELL v. KING. \\ (Court of Common Pleas, 1674. 1 Mod. 190.)
}

Trespass, for driving cattle over the plaintiff's ground. The case was, A. has a way over B.'s ground to Black-Acre, and drives his beasts over B.'s ground to Black-Acre, and then to another place lying beyond Black-Acre. And, whether this was lawful or no? was the question, upon a demurrer.

It was urged, that when his beasts were at Black-Acre, he might drive them whither he would.

On the other side it was said, that by this means the defendant might purchase a hundred or a thousand acres adjoining to Black-Acre, to which he prescribes to have a way; by which means the plaintiff would lose the benefit of his land: and that a prescription presupposed a grant, and ought to be continued according to the intent of its original creation.

The whole Court agreed to this.-And judgment was given for the plaintiff. ${ }^{15}$

\section{WILLIAMS v. JAMES.}

(Court of Common Pleas, 1867. L. R. 2 C. P. 577.)

Declaration for trespass to land.

Fifth plea, that one Ann Morgan was owner in fee of certain land, and was entitled by immemorial user to a right of way over the plaintiff's land, on foot, and with waggons, carts, and horses, to a public highway from her said land, for the more convenient occupation thereof; that Ann Morgan demised this land with its appurtenances to one Jenkins; and that the alleged trespasses were the use of the right of way by the defendant, as the servant of Jenkins.

Issue and new assignment of excess in the user of the way.

At the trial before Pigott, B., at the spring assizes for Monmouthshire, the following facts were proved:-Ann Morgan was owner in fee of a field called the Nine acre field, and of two other fields adjoining, called Parrott's land. 'These three fields were in the occupation of R. Jenkins. There was from time immemorial a right of way on foot, and for waggons, carts, and horses, from the Nine acre field over the plaintiff's land to a public highway. There was no right of

15 $\Lambda$ cc.: Iawton v. Ward, 1 Ld. Raym. 75 (1696). Compare Tuttle r. Kilroa, 177 Mass. 146 , 58 N. E. $682(1900)$. 
way over the plaintiff's land from Parrott's land. In the summer of 1866, Jenkins mowed the Nine acre field and Parrott's land, and stacked all the hay upon the Nine acre field. In September, 1866, Jenkins sold the hay to the defendant, who carted it over the plaintiff's land to the highway, which was the alleged trespass.

The jury found, first, that there was an immemorial right of way from the Nine acre field to the highway; secondly, that the stacking of the hay was done honestly, and not to get the way further on; third$1 y$, that there was no excess in the user of the way by the defendant, apart from the question of defendant's right to cart the hay grown on Parrott's land over the plaintiff's land; fifthly, if Parrott's land hay could not be legally carried over the plaintiff's land, then damages 40s.

Pigott, B., directed a verdict for 40s. to be entered for the plaintiff, with leave to the defendant to move to enter the verdict for him.

A rule having been obtained accordingly-

WILLF:S, J. The distinction between a grant and prescription is obvious. In the case of proving a right by prescription the user of the right is the only evidence. In the ease of a grant the language of the instrument can be referred to, and it is of course for the Court to construe that language; and in the absence of any clear indication of the intention of the parties, the maxim that a grant must be construed most strongly against the grantor must be applied. Accordingly, in South Metropolitan Railway Company v. Eden, 16 C. B. 42, where a grant was produced without stating the object of the gkant, it was the opinion of the judges that the grant was general, and that the way in that case might be used to any part of the land to which the way was granted.

I agree with the argument of Mr. Jelf that in cases like this, where a way has to be proved by user, you cannot extend the purposes for which the way may be used, or for which it might be reasonably inferred that parties would have intended it to be used. The land in this case was a field in the country, and apparently only used for rustic purposes. To be a legitimate user of the right of way, it must be used for the enjoyment of the Nine acre field, and not colourably for other. closes. I quite agree also with the argument that the right of way can only be used for the field in its ordinary use as a field. The right could not be used for a manufactory built upon the field. The use must be the reasonable use for the purposes of the land in the condition in which it was while the user took place. A right of way by user was here proved, and I think the verdict of the jury excludes the excess of the user charged by the plaintiff. Honest user of the Nine acre field must have been understood by the jury in the large sense of bona fide and reasonable, not a 11 er in order to get an advantage to which the defendant was not entitled. The finding of the jury was, that the land was used honestly, and not in order to get a right of way further on. This is equivalent to finding that the stacking of the liay on the Nine acre field was in the reasonable and ordinary use of it as a field: 
also that the carting was from the Nine acre field and not from Parrott's land. I think both these propositions are included in the finding.

I think, therefore, that the rule must be made absolute. We could not refuse this without splitting straws on a subject which ought to be dealt with substantially. The case has been well argued on both sides; and Mr. Jelf has said all that could be said for the plaintiff. ${ }^{16}$

\section{PARKS v. BISHOP.}

(Supreme Judicial Conrt of Massichusetts, 1S76. 120 Mass. 340, 21 Am. Rep. 519.

Bill in equity alleging that the plaintiff was the owner of the fee in the soil and of a right of way in a passageway leading from Purchase Street by land of the plaintiff to a shop of the defendant, which adjoined the rear of a store of the defendant on Atlantic Avenue; and praying that the defendant might be restrained from using the way as appurtenant to the land on which that store was built, or for the purpose of passing, or of carrying merchandise or other things, between that store and Purchase Sireet. The answer alleged that the defendant had acquired a right to such use by adverse possession.

Hearing before Wells, J., who ordered an injunction to issue, and reserved the case for the consideration of the full court, upon a report, the material part of which is stated in the opinion.

Gray, C. J. The report of the judge, before whom this case was heard in the first instance, states the facts proved at the hearing, and his decision that the use of the way in question by the defendant, in the manner and for the purpose complained of, was not justified by any right acquired by Lakin (under whom the, defendant claims) through the use of the way by him as stated in the report, and that an injunction should isste, stibject to the revision and determination of the full court upon the question, among others, "whether Lakin, upon the facts stated, had acquired such a right of way as to constitute a gond defence." The report, being on the equity side of the court, submits to our revision all inferences of falct, as well as conclusions of law.

16 Borill, C. J., and Smith, J., delivered concurring opinions.

See Finch v. Railway Co., L. R. 5 Exch. Div. 254 (1879).

A. owned a piece of land, appurtenant to which was a right of way over a private road on B.'s land. $X$. owned a tract of lind adjoining $A$.'s, on which he was desirous of building. He rented A.'s piece by a parol lease at a rental of $£ 1$. per annum and hauled his building material over the private road, depositing it temporarily on the $A$. piece. The july found that the way was really being uséd merely as a means of getting to the $\mathrm{X}$. piece. Heli, B. may recover against $X$. in trespass. Sliull v. Glenister, 16 C. 13. N. S. S1 (1864). See McCullough v. Broad Exch. Co., 101 App. Dir. 566, 9: N. 1. Supp. 533 (1905), post. p. 2S7. Compare Kretz r. Firelloof Storage Co., 1:7 Minn. 304, 149 N. W. 648, 955 (1914). 
Wright v. Wright, 13 Allen, 207, 209; Stockbridge Iron Co. v. Hudson Iron Co., 102 Mass. 45, 47.

When a right of way to certain land exists by adverse use and enjoyment only, although evidence of the exercise of the right for a single purpose will not prove a right of way for other purposes, yet proof that it was used for a variety of purposes, covering every purpose required by the dominant estate, in its then condition, is evidence from which may be inferred a right to use the way for all purposes which may be reasonably required for the use of that estate while substantial$1 \mathrm{y}$ in the same condition. Ballard v. Dyson, 1 Taunt. 279; Cowling v. Higginson, 4 M. \& W. 245; Dare v. Heathcote, 25 L. J. (N. S.) Exch. 245; Williams v. James, L. R. 2 C. P. 577 ; Sloan v. Holliday, 30 L. T. (N. S.) 757. But if the condition and character of the dominant estate are substantially altered-as in the case of a way to carry off wood from wild land, which is afterwards cultivated and built upon; or of a way for agricultural purposes, to a farm, which is afterwards turned into a manufactory or divided into building lots-the right of way cannot be used for new purposes, required by the altered condition of the property, and imposing a greater burden upon the servient estate. Atwater v. Bodfish, 11 Gray, 150; Willes, J., in L. R. 2 C. P. 582 ; Wimbledon Commons v. Dixon, 1 Ch. D. 362.

In the present case, the report states that for more than twenty years Lakin had, in the shop abutting upon the passageway in question, a steam engine, which was driven by boilers in the larger building on the lot behind, and was used for operating the machinery in that building, the three stories of which were respectively occupied for a blacksmith's shop, a carriage shop, and a paint shop; that there was a door in the wall between the two buildings, which was constantly used for the purpose of passing between them through the engine room and over the passageway; that the space in the passageway was occasionally used for the purpose of setting tires upon wheels, in connection with the work in the shop; that all the coal for use under the boilers was brought in through the passageway, and deposited in the basement or cellar under the engine room, until used in the regular course of business; and that the way was used generally as a back entrance or thoroughfare, as convenience required, in connection with the shops occupied by Lakin, without question or objection, for more than twenty years.

These facts appear to the court to justify and require the conclusion that Lakin had acquired by prescription a right of way for all purposes reasonably necessary for a manufactory upon the two lots, and which, upon the buildings being destroyed by fire and rebuilt for a manufactory and storehonse, he was entitled to use for the purpose of bringing goods into the smaller building abutting upon the passageway, to be thence hoisted up into the larger building, for storage and use therein; that there has been no substantial alteration in the condition or character of the dominant estate, and no change, except in 
degree, in the exercise of the easement, and that for this reason the defendant has not exceeded his rights in the use of the passageway. Bill dismissed. ${ }^{17}$

\section{WATSON v. BIOREN.}

(Supreme Court of Pennsylvania, 1814. 1 Serg. \& R. 227, 7 Am. Dec. 617.)

This was an action on the case for disturbing the plaintiff in his right of way, and for stopping his water course.

The cause was tried at Nisi Prius, before Tilghman, C. J., in February, 1814, when a verdict was found for the plaintiff, subject to the opinion of the court in bank, upon the following facts:

By deed, dated December 18th, 1805, Elisha Gordon and wife, conveyed to the plaintiff a lot of ground, on the south side of Chesnut street, containing ten feet in front on Chesnut street, and running back seventy-seven to a three feet wide alley, which leads into Orphan's court or Carter's alley, with free and uninterrupted ingress, egress, and regress, \&c. in common with the owners and occupiers of the lots adjoining the same, and of a water course over and along the said three feet wide alley, from the premises to Orphan's court. On the 14th of July, 1810, the plaintiff conveyed to John Conyers, all the said lot of ground, except a small piece three feet wide by thirteen feet long, at the southwest corner of the lot, adjoining the said alley. Conyers afterwards sold this lot to the defendant, who owned the adjoining ground on the east, and was proprietor of the alley. The house and lot

17 In addition to the cases cited in the court's opinion, see Baldwin $\nabla$. Boston \& M. R. R., 181 Mass. 166, 63 N. E. 428 (1902).

A. claimed by prescription a right of way in a narrow passage over B.'s land, for the purpose of driving horned cattle to a building now used as a slaughterhouse, before that as a stable, and much earlier as a barn A. had been accustomed to drive a cart through the passage, ordinarily drawn by a horse, on one or two occasions drawn by an ox; the preceding occupier had driven hogs down the passage to the slaughterhouse. Held, a verdict against A.'s claim will not be disturbed. Ballard v. Dyson, 1 Taunt. 279 (1808).

For over 20 years A., and his friends visiting him, had used a path over B.'s yard to the back door of A.'s house. A. then opened a shop in the front of his house, and some few customers came by the path at the rear. Held, this is not a misuse of the easement. Sloan v. Holliday, 30 L. T. N. S. 757 (1874). See, also, Cowling v. Higginson, 4 MI. \& W. 245 (1838) ; Wimbledon Conservators v. Dixon, L. R. 1 Ch. Div. 362 (1S75).

From 1866 to $1878 \mathrm{~A}$. wrongfully discharged through a pipe in B.'s land his sink drainage, there being until then no bathroom in A.'s house. in $1878 \mathrm{~A}$. installed a bathroom, and from then until 1858 discharged both sink and water-closet drainage through the pipe. In 1858 B. stopped the pipe. Held, A. has a right to discharge sink drainage, but not water-closet draillage. Shaughnessey $\vee$. Leary, 162 Mass. 108, 38 N. E. 197 (1894). Compare Baxendale v. Mclurray, L. R. 2 Ch. App. 790 (1S67).

A. had acquired by prescription a right to maintain an irrigation ditch over B.'s land. Held, he cannot substitute an underground pipe of the same capacity, even though this would be less of a burden on the servient estate. Allen v. San Jose Land \& Water Co., 92 Cal. 138, 28 Pac. 215, 15 L. R. A. 93 (1891). 
adjoiling the first mentioned lot on the west, and extending back fiftyeight feet from Chesnut street, were also the property of the plaintiff, as well as another lot in Third street, running east fifty feet to the small piece of ground, which he retained out 'of the lot granted by him to Conyers, and by Conyers to Bioren. The Chesnut street and Third street lots belonging to the plaintiff were contiguous; the south line of the former, constituting part of the north line of the latter. Thus the plaintiff had access from all the above mentioned lots to the alley in question. It was admitted, that the defendant had disturbed the plaintiff in the use of the alley, and had stopped the water course.

Two questions arose: 1 . Whether the plaintiff, notwithstanding he had parted with the whole of the lot to which the alley was appurtenant. except the sniall piece of ground above described, retained the privilege of the said alley? 2. Whether the plaintiff had a right of way through the alley to his other lots?

Tilghman, C. J. ${ }^{18}$ After having stated the different deeds, proceeded as follows: The defendant, who is proprietor of the alley, contends, that the plaintiff has no rights to the use of it, because he has parted with all the lot to which the right of way was appurtenant, except the small piece last mentioned. It may be remarked in the outset, that at all events, the plaintiff must recover in this action, because the defendant has obstructed the water course, and no argument whatever has been urged to show that the right to the water course is lost, by selling part of the lot. As to the right of way, the argument is, that the deed should be construed according to the intent of the parties, and that it must have been supposed by the grantor, that this small lot conveyed by Gordon to the plaintiff (only ten feet wide) would have been ahways occupied by one person; therefore the cutting it up into several parcels, and giving a right of passage to several persons, will subject the grantor, and those claiming under him, to greater inconvenience than was contemplated. But we are to judge of the intentions by the words of the deed. When land is conveyed with a right to the grantec, his heirs, and assigns, to pass over other land, the right is appurtenant to all and every part of the land so conveyed, and consequently every person to whom any part is conveyed, is to enjoy the right of passage. It must not be supposed, that either party was ignorant, that the grantee had a right to alien a part, nor that it was the intention (unless clearly expressed) that by such alienation, the right of way should be extinguished. Now, if the defendant's argument is just, the right of way is totally extinguished, by an alienation of part of the premises, because it cannot be said that the owner of one part has better right than the owner of the other, consequently as both cannot have the right, the whole is gone. We must decide this case on general principles: the same law that is applied to a lot of ten feet wide must be applied

.8 Part of the opinion of Tilghman, C. J., and the opinion of Yeates, J., dre omitted. 
to one of the width of an hundred feet. And it is obvious, that such a principle cannot prevail in a city without intolerable grievance, because it would force every person who has a right of way to preserve his property entire, in order to preserve his passage. Generally speaking, covenants that run with the land extend to assignees of every part of the land. This is the case with covenants to warrants, \&c., although by multiplying the assignees, the actions against the covenantor may be multiplied. The defendant has produced no authorities distinguishing this case from the general principle. I am, therefore of opinion, that the plaintiff was entitled to the use of the alley in question, as appurtenant to the ground retained by him. But the plaintiff has another claim. *** I do not think that the facts stated in the record make it proper to decide that point at present. $* * *$ On the whole I am of opinion, that judgment should be entered for the plaintiff.

Judgment for plaintiff. ${ }^{19}$

\section{WHITE v. GRAND HOTEL, EASTBOURNE, Limited.}

(Chancerg Division, 1912. [1913] L. R. 1 Ch. 113.)

Appeal from a decision of Joyce, J.

This was an action by the owner in fee simple and his tenant of stables and mews and a private road leading from the mews to a public road called Silverdale Road at Eastbourne, against the owners of adjoining property, for an injunction to restrain them from using the private road as a carriageway for the passage of motor cars or other vehicles, and for an order that the defendants should rebuild part of a wall which had been pulled down.

'The defendants' premises formerly consisted of a private dwellinghouse and garden known as St. Vincent Lodge. The only passage to the plaintiffs', mews was by a lane running into Silverdale Road. In 1883 the predecessors in title of the plaintiffs and defendants (Mr. Peerless and MIr. Ford) entered into an arrangement whereby the lane was to be eniarged and Mr. Ford, the owner of St. Vincent Lodge, was to have a right of way over it and through a gateway nine feet in width into his premises, thus obtaining a means of access to Silverdale Road. There was no documentary evidence of this agreement, and the question whether there was any express restriction or limitation upon the right of way was in dispute. The defendants had recently acquired St. Vincent Lodge and made use or it in connection with the business of their hotel; a covered yard between the stable and the house being used as a garage for notor cars belonging to visitors stay-

19 Yeates and Brackenridge, J.T., concurred. Acc.: Newcomen v. Coulson, L. R. 5. Ch. Div. 133 (1S7T); Underwood v. Calneg, 1 Cush. (Mass.) 2Sj (194S); Lansing v. Wiswall, 5 Denio (X. Y.) 213 (1Sts); ses Dawsou Y. St. Paul Fire \& Marine Ins. Co., 15 Minn. 136 (Gil. 102), 2 Am. Rep. 109 (1570). 
ing at the hotel, and the drivers being lodged in St. Vincent Lodge itself. These drivers were in the habit of using the right of way, and the defendants altered the gateway to facilitate their passage. The plaintiffs brought this action; a good deal of evidence was adduced and several questions argued, but the only point which calls for a report is the first question, namely, whether the use of the right of way must be restricted so as no longer to enure for the benefit of the owners of St. Vincent Lodge and its stables unless the same continued to be used and occupied precisely as they were in 1883 , when the agreement was made, that is to say, as a private dwelling house. On this point Joyce $\mathrm{J}$. said "a great many authorities were cited before me, not all quite consistent, but the result of the argument is that in my opinion the authorities cited at pages 90 and 91 of Theobald's Law of Land do support the proposition there stated, namely: 'Where there is an express grant of a right of way to a particular place to the unrestricted use of which the grantee of the right of way is entitled, the grant is not to be restricted to access to the land for the purposes for which access would be required at the time of the grant.' Then all the cases are there cited, and in my opinion that statement is correct and I think the law is so settled; in other words I hold that the defendants had an unrestricted right of way to or from the gateway nine feet wide in the new wall as erected by Ford and that nothing has happened to determine such right of way." His Lordship accordingly dismissed the action.

The plaintiffs appealed.

Cozens-HARDY, M. R. ${ }^{20}$ This is an action in which the plaintiffs claim an injunction to restrain the defendants from using and enjoying a right of way, which I shall have more particularly to deal with. The plaintiffs' main point was this: They said that the right of way, which was granted under circumstances which I shall state hereafter, was limited in its nature; that it was only a right of way for what I may call domestic purposes as distinct from trade purposes; and that it was only for such use as could reasonably be expected to be in the contemplation of the parties at the time when the defendants' house, St. Vincent Lodge, was a private residence, and ought not to be altered now that St. Vincent Lodge is turned into a garage. We heard that point fully argued by counsel for the appellants and we have come to the conclusion that there is no ground for limiting the right of way in the manner suggested. It is not a right of way claimed by prescription. It is a right of way claimed under a grant, and, that being so, the only thing that the Court has to do is to construe the grant; and unless there is some limitation to be found in the grant, in the nature of the width of the road or something of that kind, full effect must be given to the grant, and we cannot consider the subsequent user as in any way sufficient to cut down the generality of the grant.

20 The opinions of Farwell and Hamilton, Lords Justices, are omitted. 
I do not propose to go into the authorities, many of which were cited to us. I think that the law is settled clearly and conclusively by the decision of the Court of Appeal in United Land Co. v. Great Eastern Ry. Co., L. R. 10 Ch. 586. I, therefore, do not differ in any way from the view taken by Joyce, J., that the right of way is not to be restricted to access to the land merely for such uses as were reasonably. required at the date of the grant. So far this action, I think, fails. ${ }^{21}$

[His Lordship then considered the facts of the case and held that the defendants had no right to any access except through a gate in the position of the nine-foot gate which formerly stood there, and that the plaintiffs were entitled to an injunction to restrain them from exer. cising a right of way through a new and wider gate recently erected.]

\section{WOOD v. SAUNDERS.}

\section{(Court of Chancery, 1875. 23 Weekly Rep. 514.) 22}

[One L. B. Knight-Bruce, owner in fee of a large tract of land, made an agreement in writing with defendant whereby the latter was to erect various mansion houses upon the said land, and leases of the said houses were to be granted to the defendant. Later, by an indenture of lease dated June 9, 1870, L. B. Knight-Bruce and the defendant leased to the plaintiff one of the mansion houses, known as the Priory, and two acres of land, for a term of two years from December 25, 1869.।

The description of the parcels was followed by these words: "Together with the free passage and running of water and soil in and to the existing cesspool, and in and through all the drains, sewers, and water courses now constructed, or hereafter to be constructed, through the adjoining property of the said L. B. Knight Bruce, his heirs or assigns." The lease contained a covenant by the plaintiff not to use the premises for any trade or business, or for any purpose or in any way which might be, or grow to be, a nuisance to the said L. B. Knight Bruce or his tenants, and not without the consent of the said L. B. Knight Bruce to erect any walls, building, or erection whatever, upon the demised premises, or alter the elevation thereof; also a proviso that the plaintiff should have an option of purchasing the fee simple of

21Acc.: Parson v. New York, N. H. \& H. R Co., 216 Mass. 269,'103 N. E. 693 (1913) ; Kretz v. Fireproof Storage Co., 127 Minn. 304,149 N. W. 618 , 955 (1914); Arnold v. Fee, 148 N. Y. 214,42 N. E. $58 S$ (1S96).

See United Land Company v. Great Eastern Ry. Co., L. R. 10 Ch. App. $5 S 6$ (1875).

A way of necessity is only for the purpose of the dominant piece in the condition in which it was at the time of the creation of the easement. London V. Riggs, L. R. 13 Ch. Dir. 795 (1S80). implied reservation; compare Serff v. Acton, L. R. 31 Ch. Dir. 679 (1SS6). Contra: Myers v. Dunn, 49 Conn. 71 (1Ss1), implied grant; Whittier v. Winkles, 62 N. H. $33 S^{\circ}$ (1Ss:).

22 The case is also reported in L. R. $10 \mathrm{Ch} .582$.

BIG.RIGHTS-14 
the demised premises for $\notin 10,000$, on giving three calendar months' notice in writing of his desire to do so.

The plaintiff gave due notice of his desire to purchase, and by an indenture dated the 21st day of May, 1872, L. B. Knight Bruce conveyed the fee simple to him accordingly in consideration of $£ 10,000$.

The conveyance granted a right of drainage in precisely the same words as were used in the lease, and contained the usual general words, "together with all buildings, yards, gardens, trees, fences, hedges, ditches, ways, sewers, drains, water courses, liberties, privileges, easements, and appurtenances whatsoever to the said messuage and premises belonging, or in any wise appertaining, or then or usually occupied or enjoyed therewith, or reputed as appurtenant thereto."

It appeared that the object of the plaintiff (who was a physician) in acquiring the property was to use it as a private lunatic asylum. After the plaintiff had declared his option to purchase, but before the property was conveyed to him, he stated his desire to make additions to the house, and requested a license from the lessor, L. B. Knight Bruce, in order to enable him to proceed to build immediately; and although no license was given the alterations and additions were partially completed before the date of the conveyance. The premises, as altered, afforded accommodation for a large number of patients, and it was admitted by the plaintiff that from ninety to a hundred persons were usually resident therein. In consequence of this fact there was a greatly augmented user of the right of drainage conferred by the lease and the conveyance.

[The defendant threatened to cut the drain, and the plaintiff brought this bill for an injunction.]

HALL, V. C. ${ }^{23}$ The important question for me to determine in this case is the construction of the grant which is contained in the lease; for it has been admitted by the plaintiff at the bar that the conveyance is to be construed as conveying exactly what was given by the lease and nothing more; and I think that it was a very fair, and reasonable, as well as a sound way of putting the case, to admit that the plaintiff's right as grantee under the conveyance could not be carried farther than his right as it existed as lessee. ***

That being so, the next question is, What is the extent of the easement which is granted? and for the purpose of determining that, I do not think it is proper to stop at the point in the deed where I have already read to; but I think that you must go through the deed and examine its further provisions, so as to ascertain, by a perusal and consideration of the whole of the instrument, the way in which the parties contemplated that the property in question would be used and enjoyed. It is not necessary for me to state the different provisions in cletail, but suffice it to say that it is clearly stipulated that the property shall remain in the same state and condition as it was at the time when

23 The statement of facts is abridged and part of the opinion is omitted. 
the lease was made. No building was to be erected upon the property, and the elevation of the mansion house was not to be altered without license from the lessor. Therefore, the substantial thing was the preservation of the property in its then existing state, subject to any alterat:ons being made in it with the consent of the lessor. 'The lessor's consent was never given to any alteration whatever. If it had been given, it might have been qualified with reference to its effect on the right of passage of water. It might or it might not; but no license was ever given, and therefore I must take it that when this property was conveyed and taken under the option matters stood exactly as they were, and that there was no existing right of user of the easement of free passage of soil and water other than that which existed immediately after the lease itself was made, whatever that may be. Now the righi which existed at the time of the lease being made was not an unrestricted general right in respect of this house and nine acres of land. It was a right attaching to this house and land subject to this, that they could only be enjoyed in a limited and special and peculiar manner. Therefore, there was no grant of right of passage of water and soil in respect of any buildings which might thereafter be erected, but only a right in respect to the actual building as it stood and existed at the time the lease was made, and from what I have already said it was consequently that right only which passed by the conveyance.

It was said, however, that consistently with the authority, the grant ought to be measured with reference to the size of pipes, and not with reference to the size of the building. I do not know of any authority for any such proposition. I am not aware that in construing a grant of a right of way or road (which I do not know how you can, for this purpose, distinguish from a grant of a right of water course), and in ascertaining the extent of the right to a user of that road when there has been an alteration in the property in respect of which it was granted, you are to consider that the grant extends to the altered state oi circumstances, simply because there is plenty of room to allow persons to go along the road.

As I understand it, you must measure the right by the existence of the thing which is to have the use of the right, and I adopt for that purpose what is stated by Mr. Justice Willes in the case of Williams v. James, 15 IV. R. 928, L. R. 2 C. P. 577, which has been referred to. Mrr. Justice Willes there says, "The use must be the reasonable use for the purpose of the land in the condition in which it was while the user took place." I consider, therefore, that the user here must be a user consistent with the use of the mansion as a mansion in the state and condition in which it was at the time the grant was made. I do not mean to say that any small alterations which might be made in the buildings, such as the addition of a single water-closet, or anything else in the nature of a small addition to the house--even were it the building of another room-would effect the right. You must look at it in a reasonable point of view; you must not, as Mr. Justice Willes says, be 
splitting straws upon these questions, but you must take it in a reasonable point of view; and taking it in a reasonable point of view, you have here a case where there has been accommodation added to this house so as to render it capable of being used as a lunatic asylum for a hundred or more inmates, instead of as a private dwelling house. For this purpose it is just as if it were a user for a manufactory, except that the character of the manufacture might be such as to make the quantity of soil and water or other matter much larger than it is at present. But upon the evidence here it is clear that there has been a very large increase indeed to the quantity of water and soil which has been passed through these drains down into the moat or ditch.

Another suggestion of Mr. Lindley's was that the true measure might be taken to be the quantity which the moat or ditch itself would contain. That view seems to me to be entirely without any authority to support it, and might raise very awkward questions indeed as to the quantity of water and sewage which the grantor himself was still entitled to put in, and as to how the rights of the parties should be adjusted in case of a dispute as to the quantity which each was to put in. The same question no doubt to a certain extent might arise under the view which I take, because even the limited user might be forestalled by the grantor sending in such a quantity from his own premises as not to leave sufficient space for what might come from the grantee's premises. But an unlimited right, or some greater right than a right limited to the mansion, would be much more likely to create difficulties, and would have been much more likely to have been made the subject of special provision, if there had been any intention to grant it, than a mere limited right of passage of water and soil from a private dwelling house, the quantity of which both parties might well conceive would be really not of much importance in reference to the use of the moat or ditch. Therefore, I consider that that argument is not tenable. * * *

The order made was as follows: "Order that an injunction be awarded to restrain the defendant, his servants and workmen, from cutting off or stopping up the drains in the bill mentioned, or in any way preventing the free passage and running of water and soil in and to the existing cesspool in the bill mentioned, such cesspool being in the judgment of the court the moat or ditch in the bill mentioned, but this order is only to protect the plaintiff in the reasonable use of such cesspool having regard to the extent to which the same was being used prior to the date of the lease." 24

24 See Elser v. Village of Gross Point, 223 Ill. 230, 79 N. E. 27, 114 Am. st. Rep. 326 (1906). 


\section{GRAY et al. v. CITY OF CAMBRIDGE.}

(Supreme Judicial Court of Massachusetts, 1905. 189 Mass. 405, 76 N. K. 195, 2 I. R. A. [N. S.] 976.)

['This is a bill in equity by the executor of Edward W. Hooper to enjoin the defendant from causing or allowing water to run thru certain pipes laid in Hooper's land under a grant from one Stearns, Hooper's predecessor in title.

In 1865 Stearns, the then owner of the land in question, granted in fee to the defendant "the right to enter upon a strip of land fifteen feet wide, situate in said Cambridge, and lying between Reservoir Street and the land of Josiah Coolidge for the purpose of laying one or more water pipes for conveying water from Fresh Pond to the city reservoirs on said street and of examining, repairing, and relaying the same whenever necessary." The plan at that time was to pump the water from Fresh Pond thru pipes laid in the strip in question to the city reservoirs mentioned and thence to distribute it by gravity to various parts of the city. In pursuance of this plan, a twelve inch pipe was first laid in the strip from the pond to the reservoir; later this was taken up, and a twenty-four inch pipe was substituted. Several years later a second, a thirty inch supply pipe, was laid, and still later a third twelve inch pipe. Contemporaneously with the laying of the thirty inch pipe and the twelve inch pipe, the city altered its plans and in the next ten years gradually changed the use of the pipes in the strip in question so that instead of pumping the water to the reservoir, the city pumped the water thru these pipes under greater pressure into other pipes connecting with them in the vicinity of the reservoir and so directly to the consumers. In 1896 a new reservoir was built on a different site, the old reservoir razed and the land whereon it stood sold. The pipes in question were thereafter used solely as distributing mains in connection with the new reservoir system.]

LORING, J. ${ }^{25}$ We are of opinion, first, that the master's construction of the Stearns grant in the main is correct; and, second, that pipes laid under this grant can be used as supply pipes only and cannot be used as distribution pipes. What are the terms of the grant? They are (1) "to enter upon a strip of land fifteen feet wide," which strip of land is (2) "situated in said Cambridge, and lying between Reservoir street and land of Josiah Coolidge," (3) "for the purpose of laying one or more pipes," which pipes are to be used (4) "for conveying water from Fresh Pond to the city reservoirs on said street [Reservoir street]," and (5) "of examining, repairing, and relaying the same whenever necessary?" The question comes down to this: For what purpose were the words inserted "for conveying water from Fresh Pond to the city reservoirs on said street?" and what effect is to bs given to them? They were not inserted to describe the termini of thro

25 The statement of facts rewritten and part of the opinion is omitted. 
15-foot strip. 'That was fully stated elsewhere. There is the previous description of the 15-foot strip as "lying between Reservoir street and land of Josiah Coolidge," and the subsequent delineation of it in the plan referred to in the deed. Moreover, as a description of the terminus ad quem it is inaccurate, Mr. Stearns' ownership extended only to Reservoir street. It did not extend across the street to the reserroir.

In the second place, these words were not inserted to state the use to be made of the 15 -foot strip. That is stated by the words immediately preceding the clause in question, to wit, "for the purpose of laying one or more water pipes" in it, the 15 -foot strip. We see no escape from the conclusion that these words were inserted as a description of the use to be made of the pipes to be laid in the strip. That use is "for conveying water from Fresh Pond to the city reservoirs on said street"; that is to say, these pipes are not for general use in the water system of the city, but for the narrower use of conveying water from the supply to the reservoir, which is the initial point of distribution. Pipes which are to convey water from the source of supply on a low level to a reservoir on a higher level, which reservoir includes a standpipe to enable the water to reach houses higher than the level of the reservoir, for convenience may be termed, as they have been termed in this opinion, supply pipes. Those which take the water from the reservoir, including the standpipe as part of the reservoir, are or may be termed distributing pipes. The limitation "for conveying water from Fresh Pond to the city reservoirs" is, in effect, a provision that the "water pipes" to be laid in the 15-foot strip are to be used as supply pipes, thereby excluding their being used as distributing pipes as they are now exclusively used.

The defendant city in effect claims that, in spite of the words "for conveying water from Fresh Pond to the city reservoirs on said street," it can use these pipes for any purpose in the water system of the city, that the reservoir was a mere resting place for the water on its way from the supply to the consumer, and the pipes can be used to convey water to the consumer. So far as we can see, no effect is given to those words if that construction is adopted; and, unless we can read the words "for the purpose of conveying water from Fresh Pond to the city reservoirs" on Reservoir street to mean or to include "for the purpose of conveying water from the city reservoirs, wherever situated, to the consumers," the use now made is not covered by the grant. In our opinion the words cannot be so read. 'The explanation of the whole matter seems to be found in a suggestion of the plaintiffs' counsel that ordinarily distribution mains are laid in public streets and in public streets oniy. The mexpected, however, turns out to be the event in the case at bar, and it has become convenient now for the city to utilize these supply pipes as a link in the distribution system starting from the new reservir. This remote contingency did not occur to the city when it made its bargain with Mr. Stearns in 1866, and by the 
terms of what was then agreed upon as the trade struck between them such a use was not included. ***

Finally, the defendant argues that, if the grantor had intended that the easement should cease in case the city ceased to use the reservoir, it should have said so. But in that event the easement did not cease unless it was made appurtenant to the land on which the reservoir was built, upon which we do not find it necessary to express an opinion. The easement continues in legal contemplation, to wit, the easement to maintain pipes in the 15 -foot strip for the purpose of conveying water from Fresh Pond to the reservoir. So long as the defendant has no reservoir, nothing can be done under the easement, but the easement continues. The city may hereafter erect a new reservoir on the same site. Whether the city can continue the pipes after razing the reservoir to the ground under this continuing easement is another matter.

There must be a decree for the plaintiffs on terms to be settled by a single justice. The interests of the public are concerned in the peremptory shutting off of the water asked for by the plaintiffs. Subject to such modification as may be called for by those public interests, the plaintiffs are entitled to a decree, with costs in accordance with the prayer of their bill.

So ordered. ${ }^{2 e}$

26 A.. through whose land ran a creek, granted to $B$. the right to erect and maintain a dam and ditch in A's land and draw water thence to P.'s land for the purpose of irrigating B.'s meadow. B. built the dam and ditch, but used the water for the pumose of watering his stock as well as irrigating. He kept this up for over twenty years. Feld, he has, as against A.'s successor in title, the right to use the water for both purposes. Wheatley v. Chrisman, 24 Pa. 29S, 64 Am. Dec. 657 (185.5).

See Colchester v. Rolerts, 4 M. \& W. 769 (1S:9); Northam v. Hurley, 1 \&. \& B. 665 (1553); Rolens v. City of Hutchinson, 83 Kan. 618, 112 Pac. 1:!) (1910) : Cheney r. Pease, 99 Mass. 448 (1sGs).

On the 25th day of June, 1S11, one Peter Townsend and wife, in cousideration of the sum of five dollars, to them in hand paid, conveyed to olle Henry McFarlan "all the right or privilege of using or drawing off tle water from a certain pond called 'Mit. Bashan Pond,' situate in the town of Momroe. in the county of Orange, near a gristmill and nail manufactory of the said Henry McFarlan and others, called the 'Monroe Works, for the purpose ni carrying on the said rorks, in such quantity as rould be sufficient for carrying on and working the furmace, situate between said nail manufactory and the said pond, called 'Southfield Furmace,' occupied and owned by the said Feter Townsend and others, and for which pulpose said water is now usci, and no further or greater quantity: I'ovidcd, alwass, that the right so as aforesaid glanted to the said Henry IICFallan, his heirs and assigns, of drawing off said water as aforesaid. shall cease at all times whenerer said furnace, called the 'Southfield Furnace,' is in blast or making irou." 'The plaintiff had succeeded to the right of McFarlan, and the defendant to the right of Townsend. The nail factory was destroyed by fire in the vicinity of 50 years ago, and had never been rebuilt; the gristmill was converted intio a basket factory, which afterwards gare place to a shoddy mill, and then to a manufactory of wooden articles, which business was still conducted therein. Held, the plaintifi is entitled to continue to use the amonnt of water specilied in the deed of 1811 . Hall r. Ster.ing Iron \& R. Co., 1-1s $N$. Y. 432, 42 X. E. 1056 (1s96). Ace.: Suttrel's Case, 4 Co. Sla (1601); Garland 


\section{EDGETT v. DOUGLASS.}

(Supreme Court of Pennsylvania, 1891. 144 Pa. 95, 22 Atl. 868.)

On June 14, 1889, A. J. Edgett filed a bill in equity against C. I. Douglass, charging in substance (1) that the defendant, without any authority, had entered upon a tract of seven acres owned by the plaintiff, for the purpose of constructing a dam to restrain the flow of Tunungwant creek and divert it from its natural course, and threatened to continue $2 u$ make such entries; and (2) that the defendant was construcing a dam below the plaintiff's property in such manner as to overflow, not only said seven acres, but also another tract of the plaintiff containing thirty acres, to the plaintiff's irreparable damage; praying that the defendant be enjoined from entering on the seven acres for the purpose of changing or diverting the channels of said creek, and from maintaining said dam "other than it now is;" and for general relief. *** *

The dam mentioned in the pleadings was built in 1844 by W. R. Fisher, and from that time until the purchase by the defendant of the gristmill and water rights mentioned below, was maintained substantially in the same condition as when first erected. From 1844 to 1866 Fisher owned the dam, and the land on each side thereof. There were erected prior to 1866 , on land owned by Fisher, a sawmill, situated on the west side of the creek, and a gristmill situated on the opposite side. Both were supplied with water from said dam. In 1866, Fisher conveyed to Henrietta Peterson a parcel of land upon which the sawmill stood, and also the seven acres now owned by the plaintiff, the deed containing the following reservation:

"Reserving, however, to the party of the first part sufficient water to run a gristmill on the same milldam, and the right at all times to maintain a dam across the Tunungwant creek where the dam now is, and the right to flow the land hereby conveyed so far as may be necessary for the use of the water privilege." ***

The plaintiff's title to the seven acres was derived, through intermediate conveyances, from Henrietta Peterson. The defendant owned at the time of the hearing the Fisher gristmill, and had succeeded by grant to all the rights which Fisher had in the mill property, dam, wa-

v. Hodsdon, 46 Me. 511 (1859) ; Adams v. Warner, 23 Vt. 395 (1851); see Coburn v. Middlesex Co., 142 Mass. 264, 7 N. E. 849 (1886).

A., being the owner of a tract of riparian land and a water power, granted to B. in fee a part of the land with "the privilege of building a fulling mill, together with the privilege of drawing water from Long Pond Ithe source of the power], so much as shall be necessary to carry a well-built overshot fulling nili at any time when he, the said $B$., shall have occasion to use his said fulling mill." B. built his fulling mill; it subsequently burned, and later an oil mill was erected on the same site by B.'s successor in title, who attempted to use the same amount of power for his oll mill. Held, he is not entitled to use the water power for the oil mill. Strong $\nabla$. Penerlict, 5 Conn. 210 (1824). Acc.: Clement v. Gould, 61 vt. 573, 18 Atl. $45{ }^{\circ}$ (1889). Compare Toodring v. Hollenbach, 202 Pa. 65, 51 Atl. 318 (1902). 
ter privilege and appurtenances, the same having been conveyed to him by deed of Fisher and wife, dated July $27,1886$.

As originally built, the dam in question extended across Tunungwant creek. The break, which the defendant was claiming the right to repair, was up the stream from the dam and about 150 feet above it, and with the exception of about three feet, was wholly on the tract of seven acres belonging to the plaintiff. It was contended by the defendant that, soon after the construction of the dam in 1844, a dyke extending along the stream from the dam to a point beyond the break, was built for the purpose of restraining the water from flowing over a portion of the seven acres and of thus increasing the height of the water in the dam, and it was a break in this dyke the defendant was seeking to repair. $* * * 27$

Paxson, C. J. This case involves some questions of fact which could have been more appropriately settled at law. Indeed, had this point been made below, we would have been inclined to sustain it. But where parties submit to the jurisdiction, and take their chances of a decree in their favor, the objection here comes with a bad grace, and will not, as a general rule, avail, unless the want of jurisdiction is so plain that we would feel justified in dismissing the bill of our motion. Aside from this, in the view we take of the case, the disputed facts are not of special importance, as it turns in a great measure upon the prop. er construction of the reservation in the deed of October 16, 1S66, fron. IVilliam R. Fisher and wife to Henrietta Peterson. The language of said reservation is as follows: "Reserving to the party of the first part sufficient water to run a gristmill on the same milldam, and the right at all times to maintain a dam across the Tunungwant creek where the dam now is; and the right to flow the land hereby conveyed so far as may be necessary for the use of the water privilege."

We think the master and the court below took a narrow view of this reservation. Their construction of it was, in the language of the former, "simply to give him [Fisher] the right to flow this land and to maintain a dam across the Tunungwant creek where the same now is. He reserved no right to enter upon his grantee's land for any purpose, although this land was the subject-matter of the trade." The master's view, as we understand it, was that the right to maintain the dam consisted solely in the right to keep up the breastwork across the creek and to overflow the seven acres; but he has failed to enlighten us how the dam is to be maintained if the bank by the side of the creek is washed away, so as to allow the water to escape. In such case, repairing the bank which crosses the creek would be of no avail.

In this case there was a break in the side of the dam, and admittedly on the plaintiff's land. This break could only be repaired by going upon the land of the latter, and it was in doing this that the alleged trespasses occurred. It is to be observed that the reservation is

27 'The statement of facts is abridged. 
"to maintain a dam across the Tunungwant creek where the dam now is"; that is to say, the right was reserved to maintain the dam in its length and breadth as it existed at the time of the reservation. This included all the banks by which the water was confined. The right to maintain the dam means the right to keep up the banks, and, if they are washed away, to repair them. The right to repair necessarily involved the right to go upon the land for that purpose, and must have been so understood by the parties to the reservation at the time it was made. Were it otherwise, the reservation would have been worthless, and we are not to presume that the parties intended a vain thing. We are of opinion that the defendant has the right to go upon the plaintiff's land for the purpose of making any repairs to the bank necessary to maintain his dam.

The decree is reversed, and the bill dismissed, at the costs of the appellee. ${ }^{28}$

\section{DUDGE.ON v. BRONSON et al.}

(Supreme Court of Indiana, 1902. 159 Ind. 562,64 N. E. 910 , 65 N. E. 75:, 95 Am. St. Rep. 315.)

Dowling, C. J. Mary C. Bronson, the plaintiff below, with whom was joined her husband, sued the appcllant for a way of necessity over lands owned by him. The court overruled a demurrer to the amended complaint. A special finding of facts was made, and conclusions of law were stated thereon. The appellant excepted to each conclusion. Motions for a new trial and for a venire de novo were also made and overruled. These decisions of the court are assigned for error.

The complaint shows that in 1875 one Stone owned two tracts of land in Allen county, one of which contained 160 acres, and the other 40 acres. Stone sold the larger tract in 1875 to one Benninghoff, and in the same year conveyed the smaller to the appellee Mary C. Bronson. The 160-acre tract bordered upon a highway, but the 40-acre tract had no outlet. The appellant is a remote grantee of Benninghoff. The successive owners of the larger tract have recognized the right of the appellee to a way over the same to the public highway, and such way is in use by the appeliee, but, on account of the character of the location of the said way, which is low and wet for a large part of the year, and

28 Sec Vermilya v. Chicago, M. \& St. P. Ry. Co., 66 Iowa, 606, 24 N. W. 234, 55 Am. Rep. 279 (1SS5); Prescott v. White, 21 Pick. (Mass.) 341, $32 \mathrm{Am}$.

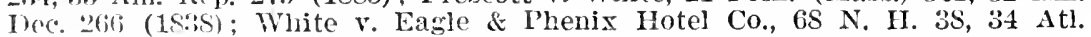
672 (1491); Central Christian Cluurch v. Lennon, 59 Wash. 425, 109 Pac. 1027 (1910). Compare Thompson v. Uglow, 4 Or. 369 (1S73).

A. had an easement in fee orer B.'s land for water pipes. B. started to build a house on his land in such a way that the repairing of the pipes, if necessary, would be much more dificult and expensive. Held, A. may enjoin B. from so building. Goodhart v. Ilyett, L. I. 25 Ch. D. 182 (18s3).

As to the liability of the dominant to the servient owner for damage anser by the non-negligent exercise of the casement, see Jones v. I'ritchard, [100s] 1 Ch. 630. 
the nature of the soil, which is soft, the appellee cannot pass over the said way without inconvenience and difficulty. In its present condition, the said way is useless to the appellee for ingress and egress to and from her land, and an additional strip 4 feet in width, running the whole length of said way, is required to render said way passable and useful. The appellant refused to let the appellee use such additional strip, and has forbidden her to enter upon the same. The relief prayed for is that the width of the way be fixed at 20 feet.

The case stated in the complaint is one in which the appellee was originally entitled to a way of necessity. Stone owned both the outer and larger tract bordering on the highway, and the inner and smaller one, which had no outlet. If the smaller tract was first sold, the right of access to the highway over the lands of the grantor was appurtenant to the grant. If the larger was first sold, then a way of necessity was impliedly reserved by the grantor for the benefit of the 40-acre tract. Eut it appears from the complaint that, after the conveyance of the two tracts by Stone, a way 16 feet in width was granted to and accepted and used by the appellee, and that she still continues to use it. She does not allege that she has no outlet from her land to the public highway, but says that the way (which we must presume was agreed upon between the appellee and the appellant, or his grantors) has become wet and inconvenient, and therefore useless. Having accepted a way of a certain width, and over a particular part of the lands owned by the party holding the servient estate, the appellee has no right to change it, but must be confined to the way thus selected. The grounds of the complaint are mere matters of inconvenience. That the way once selected and agreed upon is too steep or too narrow or too wet does not entitle the appellee to demand a new way, or to increase the width or change the direction of the old one.

The right of way from necessity over the land of another is always of strict necessity, and nothing short of this will create the right. It is said in Ritchey v. Welsh, 149 Ind. 214, 221, 48 N. E. 1031, 1033, 40 L. R. A. 105, that: "When the way is once selected, it cannot be changed by either party without the consent of the other. Nichols v. Luce, 24 Pick. [Mass.] 102, 35 Am. Dec. 302; Holnes v. Seely, 19 IVend. [N. Y.] 507, 510; Morris v. Edgington, 3 Taunt. 24; Godd. Easen. (Bennett's Ed.) 351." See, also, Washb. Real Prop. (4th Ed.) 306; Vashb. Easem. 163-168. "The grantee is bound to keep the way in repair, ${ }^{29}$ and is not permitted to go extra viam, as a traveler upon a public highway is allowed to do, when the way is impassable, except, it seems, when the private way is temporarily or accidentally obstruct-

29 " $\mathrm{By}$ common law, he who has the use of a thing ought to repair it," Mansfield, C. J., in Taylor $r$. Whitelend, 2 Doug. T15 (17S1). Ace.: Dana จ. Smith, 114 Me. 262,95 Atl. 1034 (1915).

A. leased a house to $B$. torrether with the use of a pump on other land belonging to $A$. A. allowed the mump to get out of repair. Holn, B. has no cause of action against $A$. Pomfret $v$. Ricrolt, 1 saund. 321 (1titi). 
ed." Holmes v. Seely, supra. "Where the right to an easement is granted without giving definite location and description to it, the exercise of the easement in a particular course or manner, with the consent of both parties, renders it fixed and certain, and the dominant owner has no right afterwards to make changes affecting its location, extent, or character." $10 \mathrm{Am}$. \& Eng. Enc. Law (2d Ed.) 430, and cases cited in note 3 .

The situation of the appellee is the same as if her deed from the owner of the servient tract had expressly granted and described a way, 16 feet wide, from her 40 -acre lot over the 160-acre tract to the highway, along the route followed by the way she now owns. In that case she certainly could not have compelled the appellant to give her a new way, or to increase the width of the old one. As it appears from the complaint that the appellee can get to her property from the highway over a way already belonging to her, and as that way must have been selected or agreed upon by her, no ground is shown for her claim to an additional strip as a way of necessity. The demurrer to the complaint should have been sustained. The other errors assigned need not be considered.

For the error of the court in overruling the demurrer to the complaint, the judgment is reversed, with directions to sustain the demurrer, and for further proceedings in accordance with this opinion. ${ }^{30}$

30Acc.: Oahu R. \& L. Co. v. Armstrong, 18 Haw. 258 (1907); Jennison v. Walker, 11 Gray (Mass.) 423 (1S60) ; Outhank v. Lake Shore \& M. S. R. Co. 71 N. Y. 194, 27 Am. Rep. 35 (1877).

A. granted the city of V. a right of way orer A.'s land "for any water pipes or mains which may be laid by the said city of Vallejo * * * and the right to maintain such water pipes and mains *** and also the use of so much land as is necessary in the laying down and maintaining of said water pipes." V. laid down a 10 -inch pipe. Twelve vears later it sought to lay a second and 14-inch pipe within 3 feet of the first pipe. Held, it cannot do so. Winslow v. City of Vallejo, 148 Cal. 723, 84 Pac. 191, 5 L. R. A. (N. S.) 851,113 Am. St. Rep. 349, 7 Ann. Cas. 851 (1906). Contra: Standard Oil Co. v. Buchi, 72 N. J. Eq. 492, 66 Atl. 427 (1907), ante, p. 190. Compare Sked v. Pennington Spring Water Co., 72 N. J. Eq. 599,65 Atl. $71: \vdots$ (1907); Moorhead v. Snyder, 31 Pa. 51t (1S58).

"It is settled law that where an unlocated right of way is granted or reserved, the owner of the servient estate may in the first instance designate a reasonable way, and if he fails to do so, the owner of the dominant estate may designate it. Jones on Easements, § 337 ; Kripp v. Curtis, 71 Cal. 62. 65, 11 Pac. 879 (1S86) ; Blum v. Weston, 102 Cal. 362, 369, 36 Yac. 778. 41 An. St. Rep. 1SS (1S94). Findings sufficiently sustained by evidence establish that there was no such failure in this case as to entitle plaintiff to make the selection. But had she been so entitled, she would still hare been required to select a route that was reasonable as to both parties, in view ot all the circumstances, one that will not unreasonably interfere with the grantor in the enjoyment of his estate.' Jones on Lasements, \& 337. 'The trial court was warranted in concluding that the route selected by plaintitt was unreasonable, in view of all the circumstances. The case before us is simply one where the parties have been unable to agree upon a reasonable route in which event the location may be determined in equity. Jones on Easements, § 354; Gardner ₹. Webster, 64 N. H. 520, 522, 15 Atl. 144 (18s8)." Angellotti. J., in Ballard v. Titus, 157 Cal. GS3, 110 Pac. 122 (1910). See Ifuore r. White, 159. Mich. 460, 124 N. W. 62, 134 Am. St. Rep. 735 (1909). 


\section{DURFEE v. GARVEY.}

(Supreme Court of California, 18s9. 78 Cal. 546, 21 Pac. 302.)

[The plaintiff claimed the right to drain his land by means of a ditch running through the defendant's land.]

Betcher, C. C. ${ }^{31} * * *$ Prior to 1882 , a part of defendant's land was cultivated, but in that year he ceased to cultivate it, and has since used it only for pasturing stock. He has kept on it horses, mules, and cattle, and these animals, by feeding along the ditch, and frequently passing over it, have broken in its sides, and have thereby filled it up and obstructed the flow of water through it. This obstruction interfered with the drainage of plaintiff's land, and prevented his cultivating 20 to 25 acres of it on which he could otherwise have raised good crops. ***

1. The theory of plaintiff, developed at the trial, in reference to his first cause of action, was that he had acquired a prescriptive right to the use of the ditch leading from his lower line to the arroyo, and that defendant had no right to make any use of his land which would cause an obstruction of the ditch, and that if he did so he must keep it cleared out, or be liable for any damages caused by the obstruction. On the other hand, the theory of defendant was that plaintiff. had acquired no prescriptive right to the use of the ditch, and that, if he had, defendant had a right to use his land for any legitimate and ordinary purpose, and if, while so using it, the ditch was injured or obstructed the burden was upon the plaintiff to remove the obstructions and keep it in repair. ***

The question then presented for decision on this branch of the care, conceding that plaintiff had acquired an irrevocable right to have $k_{i}$ is ditch maintained over defendant's land, is, to what extent does that right interfere with and limit defendant's right to use his land? Must defendant, if he would use his land for the pasturage of stock, fence in the ditch, or cover it over so that the stock cannot tread down its sides? And, if he so uses it, is the burden cast upon him to keep the ditch clear and unobstructed, so that water will continuously flow through it? It must be admitted that the use of land for pasturage is a common and legitimate use of it, and there is no pretense that defendant did not exercise ordinary care over his stock. ***

Now, if the plaintiff's theory be correct, the defendant cannot use his land as a pasture, though that may be the best and perhaps only profitable use he can make of it, unless he employs men to patrol the ditch and keep the cattle away from it, or goes to the expense of fencing it in or covering it with bridges. It does not seem to us that the plaintiff's easement on the land can impose any such burden as that on

81 Part of the opinion is omitted. 
the defendant. The general rule is that any man may use his own land in his own way, provided he does not use it negligently, so as to injure his neighbor; and the rule is, also, that, where one man has an easement over the land of another, the duty of keeping the easement in repair rests upon its owner, and when repairs are necessary he may enter on the servient tenement to make them. God. Easem. 285; Gale \& W. Easem. 215; Prescott v. Williams, 5 Metc. (Mass.) 435, 39 Am. Dec. 688. It does not appear that plaintiff was ever denied the privilege of making any repairs upon his ditch, and it would be going to an extreme and unwarranted length, as it seems to us, to hold that in a case like this defendant is made liable. In our opinion the court erred in giving the instruction above quoted for plaintiff and in refusing to give, without modification, that asked by defendant.

PER CURIAM. For the reasons given in the foregoing opinion the judgment and order are reversed, and the cause remanded for a new trial, unless the plaintiff shall, within 30 days after the going down of the remittitur, file in the court below a release of $\$ 150$, and his costs in that court, and if he does file such release that the judgment and order stand affirmed. ${ }^{32}$

\section{ATTORNEY GENERAL v. WILLIAMS.}

(Supreme Judicial Court of Massachusetts, 1Ss5. 140 Mass. 329, 2 N. E. S0, 3 N. E. 214,54 Am. Rep. 468.)

Information in equity, at the relation of the Harbor and Land Commissioners, to restrain the erection of bay windows or projections extending into or over a passageway in the rear of the defendant's house on the corner of Boylston Street and Exeter Street in Boston. Hearing before Devens, J., who reserved the case for the consideration of the full court. The facts appear in the opinion.

C. Allen, $\mathrm{JJ}^{33}$ The first question which we have considered is, whether an information in the name of the Attorney. General can be maintained to enforce the stipulations in respect to the passageway. ***

[The Court answered this question in the affirmative.]

32 Acc.: City of Bellerue v. Daly, 14 Idaho. 545. 94 Pac. 1036, 15 L. R. A. (N. S.) 992,125 Am. St. Rep. 179. 14 Ann. Cas. 1136 (100S).

A. had a right of way orer B.'s farm to his summer home. He built a carriage road at an expense of $\$ 700$ b. drew heary loads of agricultural proflucts over the road from one part of his farm to another and seriously damaged the road. Held A. may enjoin B. from so doing. Ilerinan v. Roberts, 119 N. Y. $37,2: 3$ N. F. $4 \frac{12}{2}$, T L. R. A. 226,16 Am. St. Rep. 800 (1890).

See Rockland Water Co. v. Tillson, 75 Me. 170 (1SS3); Draper v. Varnerin, 220 Mass. fit, 107 N. E. $3 \pi 0$ (1911): Kansas City Southern Ry. Co. v. Sandlin, 173 Mfo. App. 344. 1 \% S S. W. 857 (1913); Haley $v$. Colcord, 59 N. H. 7,47 Am. Rep. 176 (1S79); Williams r. Safforel. T Barb. (N. Y.) 209 (1S49); Mof-

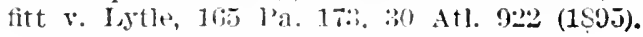

3 s Iart of the (pinion is ornitted. 
The principal ground of objection to the maintenance of the information is, that the defendant has not infringed upon the stipulation referred to. Before considering this question in the light of the particular stipulation, it may be well to review some of the principal authorities cited at the argument. The leading case upon this subject is Atkins v. Bordman, 2 Metc. 457, 37 Am. Dec. 100, where it was held that the owner of land, over which his grantor had reserved a passageway, might, under the peculiar circumstances of that case, law fully cover such passageway with a building, if he left a space so wide, high, and light that the way was substantially as convenient as before for the purposes for which it was reserved. There, from the language of the reservation, construed in the light of the existing facts and circumstances, the right reserved was held to be that of "a suitaole and convenient footway to and from the grantor's dwelling house, of suitàble height and dimensions to carry in and out furniture, provisions, and necessaries for family use, and to use for that purpose wheelbarrows, hand sleds, and such small vehicles as are commonly used for that purpose, in passing to and from the street to the dwelling in the rear, through a foot passage, in a closely built and thickly settled town." It was a use which was individual to the occupant of that house, and not for the public. It was limited to certain simple uses, connected with getting things into and out of the house. It is obvious that the rights of the single person entitled under such circumstances to a passageway are not necessarily identical with the rights involved in the present case. ***

It is necessary now to look at the terms of the bond in which the stipulation relied on in the present case is contained, in order to see what it means. In the first place, it is to be borne in mind that the place in question is a part of a great scheme of improvement of waste land in a city, for streets and dwelling. The description of the land carefully defines the width and lines of the passageway: "Running one hundred and twelve feet to a passageway sixteen feet wide; thence westerly on the line of said passageway; $* * *$ also all that part of said passageway sixteen feet wide that lies southerly of its centre line, and between the easterly and westerly lines of said premises extended; reference being had to the plan accompanying the fifth annual report of the commissioners on the Back Bay." A reference to the plan shows a system of streets, covering an extensive territory, with passageways for the accommodation of the houses on two streets, and for access to their rear entrances. "Any building erected on the premises shall be at least three stories high for the main part thereof, and shall not in any event be used for a stable or for any mechanical or manufacturing purposes." There were also other provisions showing that dwellinghouses of a high class were contemplated. Afterwards followed the particular stipulation relied on, "that a passageway sixteen feet wide is to be laid out in the rear of the premises, the same 
to be filled in by the commonwealth, and to be kept open and maintained by the abutters in common."

It was contemplated that buildings might be erected on both sides of this passageway. Each owner might build up to the line of it. The defendant has done so, and has built bay windows from a point eight feet above the sidewalk, and extending from three to four feet into the passageway, to the top of his house, six stories high. If the opposite owner should do the same, the passageway between the buildings, extending upwards from a point beginning eight feet above the surface of the ground, would be eight feet, instead of sixteen, in width. It would be half closed up, so far as light and air and prospect are concerned. And, if this may be done, it is difficult to place any practical limit to what might be done in this manner. The passageway was designed as a thoroughfare for the accommodation of many persons. In appearance, it is on the plan indistinguishable from a narrow street. It is connected at each end with broad and important streets. It was to be kept open. No gates could be put at the ends of it. It was to be "maintained," that is, kept in good order for use. Its width shows that it was designed for vehicles drawn by horses, as well as for travellers afoot. The supplies for all the houses on both sides of it, for its entire length, would be chiefly deliverable, and all refuse matter removable, by its means. Thus we have a passageway of defined dimensions; in the rear of all the houses on two broad streets, designed for use by all who may have occasion to seek the rear entrance of any houses on either street,- - a passageway available also for police purposes and for use in the extinguishment of fires,-a passageway which is to be maintained, and kept open, and designed for horses and wagons, in a part of a large city which is designed to be wholly occupied by dwellings of a high class, to which air and light and prospect are not only desirable, but essential, in the rear as well as in the front, with no limitation to the use which may be made of it or of the persons by whom it may be used.

In view of these considerations, we think the language of the stipulation was designed to signify a separation of sixteen feet at least between the rear portions of the buildings abutting on the passageway. A passageway sixteen feet wide was not merely to be kept open at both ends, but open to the sky throughout its entire length, for the general convenience and benefit. It is easy to see that the rights of others would be lessened, upon any other construction. The opposite owner, who might not wish in like manner to build into the passageway, would have in the rear of his house a space just so much narrower. The adjacent owner on the same side, who did not wish to occupy a part of the passageway with his building, would have light, air, and prospect cut off. The right themselves to occupy the passage in this manner would be no equivalent to owners who did not wish to build their houses so as to extend back to the line of it. 
There is nothing in the facts proved at the hearing and reported to us which in any way controls the construction thus put upon the language of the stipulation. The result is, that a decree must be entered for the removal of the projections.

Decree accordingly. ${ }^{34}$

\section{BITELLO v. LIPSON.}

(Supreme Court of Connecticut, 1908. S0 Conn. 497, 69 Atl. 21, 16 L R. A. [N. S.] 193, 125 Am. St. Rep. 126.)

Action to restrain the obstruction of a passway, and for damages, brought to and tried by the court of common pleas in New Haven county, Wolfe, J.; facts found and judgment rendered for the plaintiff, and appeal by the defendant. Error and cause remanded.

HALL, J. ${ }^{35}$ Anson Brown owned a tract of land on the northerly side of Washington avenue in New Haven, about 89 feet wide and 230 feet deep. In October, 1901, Brown conveyed the northerly end of said tract, a lot some 70 feet on the east and west, and 89 feet on the north and south, to the plaintiff, and also by the same deed granted the plaintiff a right of way over the east side of the remainder of the grantor's tract, in the following language: "And the use of a right of way in common with myself, heirs, and assigns, forever, over a strip of land ten (10) feet wide and one hundred and sixty (160) feet more or less deep, from Washington avenue to the above-described land." At the time of said conveyance there was a dwelling house on the lot conveyed, and there is now also a small barn and sheds upon it. [The title to the dominant and servient pieces had passed by mesne conveyances to the plaintiff and defendant respectively.] In De-

34 See Crocker v. Cotting, 181 Mass. 146, 63 N. E. 402 (1902); Schmoele $\nabla$. Betz, 212 Pa. 32, 61 Atl. 525, 10S Am. St. Rep. $\$ 45$ (1905). Compare Swift v. Cocker, 83 Ga. 789.10 S. E. 442,20 Am. St. Rep. 347 (1SS9).

A. laid out a small parcel of land in seven house lots, which he convesed in fee to various purchasers. All the lots bad access to a 7 -foot alley and some of the lots had no other access; a right of way over the alley was made appurtenant to each lot, and it was stipulated that the owners of the seven lots should bear the entire cost of the upkeep of the alley. The purchaser of one lot, who owned other adjacent land, secured from $A$. a release of all bis interest in the land under the alley, and then attempted to use the alley for the benefit of his other land. Held, he may be enjoined by the owners of the other dominant lots from so doing. Greene v. Carny, 137 Mass. 64 (1854). See Wilson v. Ford, 209 N. Y. 1S6, 102 N E. 614 (1913); Kirkham v. Sharp, 1 Whart. (Pa.) 323, 29 Am. Dec. 57 (1S82); Stephen Putney Shoe Co. v. Richmond, F. \& P. R. Co., 116 Va. 211. 81 S. E. 93 (1914)

$A$. Conveyed a parcel of land to $B$. in fee, with a right of way over a 30 -foot strip still owned by A. A. subsequently conveyed another parce: ro C. in fee, with a right of way over the same strip. Held, B. cannot enjoin $C$. from building a switch track over the said strip. Murphy Chair Co. v. American Radiator Co., 172 Mich. 14, 137 N. IV 791 (1912). Acc.: Forsyth $v$. American Maize Products Co., 59 Ind. App. 634, 108 N. E. 622 (1915).

35 Part of the opinion is omitted.

Big.Rights-15 
cember, 1906, the defendant commenced constructing on the east side of his dwelling house, which fronts on Washington avenue and adjoins said driveway, a bay window 11 feet and 6 inches above the ground, extending about 16 feet north from the southeast corner of the house, and projecting over said driveway 2 feet and 6 inches.

Upon the question of the possible interference of this bay window with the plaintiff's use, of the driveway these facts are found: The plaintiff is engaged in the ice business and keeps his ice wagon, which is 5 feet and 4 inches high, upon said premises. A two-horse covered ice wagon is 8 feet and 6 inches high and 6 feet and 2 inches wide. The highest furniture van used in New Haven is 10 feet 6 inches high and 7 feet 4 inches wide. The highest two-horse canvas covered truck is 10 feet 11 inches high. The ordinary two-horse truck, loaded with furniture, is not higher than 11 feet. If a high furniture van were to be driven through the driveway into the plaintiff's premises, it could not be turned around on account of the buildings. A two-horse load of loose hay is from 8 to 10 feet wide and from 10 to 12 feet high. The plaintiff purchases his hay by the bale, and has never carted anything over said driveway with which said bay window would interfere. The finding states that in addition to the above facts found, as stipulated by the parties, the court personally viewed the premises, and that, "in the light of all the surrounding circumstances, and from a view of the premises," reached the conclusion that "the plaintiff is not only entitled to an unrestricted right of way over the strip of land described in the grant to him for the purpose of passage, but is also entitled to the right of uninterrupted access of light and air over and across the same, and that the erection of the structure in question is an improper and material interference with, and obstruction of, such rights, thus rendering the right of way less beneficial and useful."

By this language, as well as from the judgment rendered upon the facts found, it seems clear that the court intended to hold that any material interference by the defendant with the "access of light and air over and across" the strip of land was an obstruction of the plaintiff's right, even though it did not interfere with the reasonable and ordinary use of the right of way. This ruling was erroneous.

By his deed from Brown the defendant acquired the fee to land over which he was building the bay window, incumbered by a right of way previously granted by Brown to the plaintiff, which was a right of passage over the 10-foot strip. Hart v. Chalker, 5 Conn. 311-314. The deed from Brown to the plaintiff contained no express grant of an easement of light and air. Implied grants of such easements not reasonably necessary for the enjoyment of the rights expressly granted are not favored in this state. Section 4046, Gen. St. 1902. There was no. implied grant to the plaintiff of a right to have light and air pass over the driveway to any greater extent than was necessary for the reasnnable enjorment of the right of passage granted. Puorto v. Chieppa, 78 Conn. 401-404, 62 Att. 654 ; Robinson v. Clapp, 65 Conn. 365, 32 
Atl. 939, 29 L. R. A. 582; Atkins v. Bordman, 2 Metc. (Mass.) 457, 37 Am. Dec. 100; Gerrish v. Shattuck, 132 Mass. 235. We are unable to see how the projection $21 / 2$ feet over the driveway of a bay window $111 / 2$ feet from the ground could so diminish or affect the supply of light and air in the driveway as to prevent those persons who have the right to use it, or those vehicles which are permitted to be driven over it, from passing along it with comfort, safety, and convenience, and the trial court has not found that it would. The driveway is not to be kept supplied with light and air for the benefit of the public. The way granted to the plaintiff is appurtenant to his land, and is a private one. That this lane is known as "Washington Place" does not make it a public court or highway or thoroughfare. The deed to the defendant describes it as "leading to and from Washington Place." The grant to the plaintiff gives no right to any person to use it for any other purpose than in passing to and from the plaintiff's premises.

It follows from what we have said that the judgment was erroneous, unless it appears that the bay window itself would constitute a physical obstruction to the proper use of the driveway, permitted by the deed to the plaintiff. The court has not found that it would, and the facts found show that it would not. The top of the highest loaded vehicle described in the finding, a two-horse load of loose hay, which never has passed and probably never will pass through the driveway, might extend 6 inches above the bottom of the bay window. If there should ever be any occasion to drive such a loaded vehicle by the bay window, it evidently could be done without any inconvenience. In inquiring whether an injunction ought to be granted upon the ground that the bay window may directly interfere with the plaintiff's use of the driveway the proper question is, not what use the plaintiff might possibly attempt to make of it, but what uses can he reasonably be expected to have occasion to make of it. ${ }^{36}$. Such uses would seem to be covered by those, the measurements required for which are given in the finding.

There was error, and the judgment is set aside, and the case remanded, with directions to render judgment for the defendant. In this opinion the other Judges concurred. ${ }^{37}$

$36 \mathrm{~A}$. had a right of way to and from his wood lot orel three adjoining tracts of land belonging to B. B. put up fences between the tracts, with movable rails at A.'s right of way. In an action by A. against $B$. to compel him to remore these obstructions, the court held that $\mathrm{B}$. could not be compelled so to do, saying: “**** The plaintift's lot is still wood lot. It may remain so for many sears. * * * There is nothing inconsistent in holding that the present arrangements are suitable and sufficient under existing circumstances; and after these circumstances shall have changed and the question shall arise as to what shall then be proper, to determiue that a passage perpotually op $* * *$ shail be required of the defendant." Bakeman r. Talhot. 31 N. Y. 366, ss Am. Dec. 275 (1865).

37 Acc.: Atlins r. Bordman, 2 Metc. (Mass.) 45T, 37 Am. Dec. 100 (1841); Grafton v. Moir, 130 N. Y. 46.5, 29 ×. 1. 974. 27 Am. St. Rep. 533 (1592).

A. owned two adjoining city hots, there being an alley on the east side of 


\title{
PITTSBURGH, F'T. W. \& C. RY. v. PEET.
}

\author{
(Supreme Court of Pennsylvania, 1892. 152 Pa. 488, 25 Atl. 612, 19 L. R. A. \\ 467.)
}

\section{Ejectment for a lot of ground on the south side of Robinson street} in the city of Allegheny.

At the trial, before Stowe, P. J., plaintiff claimed title to the land in controversy by virtue of condemnation proceedings in 1855. Part of the land condemned was used by the railroad company for its tracks and abutments; but the lot in suit was not in actual occupation of the company. At the time of the condemnation proceedings, the assistant engineer of the railroad company which condemned the land testified that the property was not to be used for sidings or depot purposes, but it was intended eventually to be used to build protection walls upon it on either side and fill them in. Defendants averred that they bought the land without any actual notice that the railroad company claimed it, and they were about to build a warehouse upon it when this action was brought.

[Verdict and judgment for plaintiffs. Defendants appeal.]

Paxson, C. J. ${ }^{38}$ This was an action of ejectment in the court below. The plaintiffs showed title to the locus in quo by certain deeds,

the west lot. A. granted the east lot to $B$. in fee, "together with the free use $*_{*}^{*}$ of the said alley for free ingress **** and of a water course therein, reserving to the owner of said lot adjoining to the westward the right of building over the said alley at the same height and of the same depth as the same is now built over." A. later conrejed the west lot to C. in fee, who built over for a greater depth than at the time of the abore deed. It was admitted that B.'s use of the ally as a way and water course was not prejudiced. Held, B. has no cause of action against C. Duross v. Singer, $224 \mathrm{~Pa} .573,73$ Atl. 951 (1909).

A. grants B. "the free and undisturbed right to the use" of a way orer A.'s land. Held, A. may later put a gate across the way. Boyd v. Bloom, 152 Ind. 152 , 52 N. E. 751 (1S98); Brill จ. Brill, 108 N. Y. 511,15 N. E. 539 (18s7). Otherwise where the way was over a private alley in a city. Flaherty $\mathrm{v}$. Fleming, 5 S W. Va. 669,52 S. E. 857,3 L. R. A. (N. S.) 461 (1905). Compare Ballinger v. Kinney, 87 Neb. 342, 127 N. W. 239 (1910).

"It is true that a way gained by adverse use gives rights commensurate with the adrerse use. But, if the use be for agricultural purposes only, then the way becomes a way for that use-a use to be exercised in a reasonable manner: and reasonable use of a way for agricultural purposes, whether created by grant or adverse user, may properly be subjected to gates and bars not unreasonably established. The way may be gained without being so obstructed at all, but it is, nevertheless, a way for a particular use; and, in the enjoyment of that use, unreasonable obstructions only are probibited. The nature of the easement gained determines its character, and not the particular manner of the use that created the right." Haskell, J., in Ames v. Shaw, S2 Me. 379,19 Atl. 856 (1890). Acc.: Luster v. Garner, 128 Tenn. 160,159 S. W. 604 , 48 L. R. A. (N. S.) 87, Ann. Cas. 1914D, 769 (1913). Contra: Fankboner v. Corder, 127 Ind. 164, 26 N. E. 766 (1891). Compare McMillan v. Cronin, 75 N. Y. 474 (1878); Bolton v. Murphy, 41 Utah, 591, 127 Pac. 335 (1912).

If the gate is a proper one, the dominant is under the duty of keeping it closed. Damron v. Justice, $162 \mathrm{Ky} .101,172 \mathrm{~S}$. W. 120 (1915).

38 The statement of facts is abridged and part of the opinion is omitted. 
and by proceedings to condemn it for railroad purposes. The defendants contended that, if the plaintiffs did actually condemn the strip of ground in question, they could not recover in ejectment, for the reason that they did not acquire a fee in the ground, but only an easement, and that ejectment will not lie for a mere right of way. The vice of this argument consists in treating the plaintiff's right as a mere easement or right of way. It is a great deal more than a right of way. They have the actual possession of the property, and that possession is exclusive, at all times and for all purposes, except where a way crosses it. Railway Co. v. Hummell, 44 Pa. 375, 84 Am. Dec. 457; Railroad Co. v. City of Philadelphia, S8 Pa. 424. The estate acquired by a railroad company by a condemnation of land is often spoken of as an "easement," but the term is used in a loose way, for the purpose of distinguishing it from a "fee."

In the recent case of Pennsylvania S. V. R. Co. v. Reading Paper Mills, 149 Pa. 18, 24 At1. 205, it was said by our Brother Mitchell: "Such title is sometimes called an 'easement,' but it is a right to exclusive possession,- to fence in, to build over the whole surface, to raise and maintain any appropriate superstructure, including necessary foundations, and to deal with it within the limits of railroad uses as absolutely and as uncontrolled as an owner in fee. There was no such easement at common law, and it may well be doubted if it is not a misnomer to extend to this newly-invented interest in land the name of 'easement,' perhaps appropriate enough to the railroad's ordinary right of way for its tracks. It would seem to be rather a fee in the surface and so much beneath as may be necessary for support, though a base or conditional fee, terminable on the cesser of the use for railroad purposes. But, whatever it may be called, it is, in substance, an interest in the land, special and exclusive in its nature, and which may be the subject of special injury by the obstruction of access to the abutting street, and therefore within the rule which governs the application of equitable relief. The right of exclusive possession includes the right of ingress and egress from the street, and in this respect the injury is exactly the same as to a tenant for life or for years, whose right to relief would be unquestionable, and is entirely different from the general right of the public to pass along the street." * * *

By the appellants' second point, the court below was asked to instruct the jury as follows: "That, there being no evidence in the case of any necessity for the use of the property in question, or of any interference by its present use with the operations of their railroad company, the railroad company cannot recover in an action of ejectment." This point was properly refused. When a railroad company condemns land, it is of necessity the judge of how much is required for its use. If this question were submitted to a jury in every case, the right of eminent domain would be of little practical value. The company had a right, when it condemned the property, to regard and 
make provision for its future, as well as its present needs. This is settled law. It is sufficient to refer to Pittsburgh Junction R. Co.'s Appeal, $122 \mathrm{~Pa}$. 530, 6 At1. 564, 9 Am. St. Rep. 128. If it condemns for future use land which it does not need at the time, the nonuser of a portion for present purposes cannot be held to be an abandonment. We are of opinion that, under the evidence in the case, the court below was justified in directing a verdict in favor of the plaintiffs.

Judgment affirmed. ${ }^{39}$

\section{ATLANTIC COAST LINE R. CO. v. BUNTING.}

(Supreme Court of North Carolina, 1915. 16S N. C. 579, 84 S. E. 1009.)

Appeal from Superior Court, Pitt County; Peebles, Judge.

Action by the Atlantic Coast Line Railroad against J. R. Bunting. From a judgment for plaintiff, defendant appeals. Reversed.

Civil action to enjoin erection of a brick building on plaintiff's right of way, heard on return to preliminary restraining order. On the hearing, the restraining order was made permanent, and enjoining defendant from further proceeding with the building, whereupon defendant excepted and appealed.

HokE, J. Our decisions are to the effect that a railroad right of way, when once acquired, may be occupied and used by the company to its full extent, whenever the proper management and business necessities of the road may so require, and the company is made the judge of such necessity. Railroad v. MicLean, 158 N. C. 498, 74, S. E. 461; Earnhardt v. Railroad, 157 N. C. 358, 72 S. E. 1062; Railroad v. Olive, 142 N. C. 273,55 S. E. 263 . And, further, that, to "the extent that the land covered by the right of way is not presently required for the purposes of the road, the owner may continue to occupy and use it in a manner not inconsistent with the full and proper enjoyment of the easement." Lumber Co. v. Hines, 126 N. C. 254, 35 S. E. 458 ; Railroad v. Sturgeon, 120 N. C. 225,26 S. E. 779. Both positions will be found stated and approved in the more recent cases of Coit v. Oxvenby, 166 N. C. 136-138, 81 S. E. 1067, and Hendrix v. Railroad, 162 N. C. 9, 77 S. E. 1001, and it is further established in this state, both by statute and precedent, that, when the company has acquired and properly entered on the enjoyment of its easement, the further appropriation and use of the right of way, as indicated, may not be destroyed or sensibly impaired by reason of the occupation of

39 Acc.: Kansas \& C. P. Ry. r. Burns, 70 Kan. 627, 79 Pac. 238 (1905).

A. owned a house fronting on a street with a stable and yard in the rear, the rard being connected with the street by an arched passigeway under the house. A. conveyed the rear lot to $\mathrm{B}$. in fee. "together with the exclusive use of the said gateway" or passageway, describing it by metes and bounds. B. later lined the passageway with boards, and converted it into a book shop. Held. A: has no canse of action. Reilly r. Booth, I. R. 44 Ch. D. 12 (1S90). 
the owner or other person. Revisal, $\S 388$; Beattie v. Railroad, 108 N. C. $4 j 2,433,12$ S. E. 913 ; Railroad v. McCaskill, 94 N. C. 746.

A correct application of these principles to the facts in evidence, about which there is no substantial dispute between the parties, is, in our opinion, against the ruling of the court below on the question presented. From these facts, it appears that plaintiff is now operating a railroad through or by the town of Bethel, and that, under its various charters, its right of way extends for 100 feet each way from the center of its track; that formerly the town was some further away, but soon after the completion of the road, about 1885 , the business portion was moved towards the southern side of the track, and a substantial block of business buildings, including a bank, two hotels, and some large brick stores, were erected along said track and fronting the same, leaving a space of 65 feet between said buildings and the track, which space was used as a public street known as Railroad street, the principal business street of the town, and had been since the before mentioned date, 1885 ; that defendant, owning one of the lots on this street, had bought an old warehouse from the company and placed it on the lot and had used it as a business house or warehouse for several years, till the fall of 1914, when he tore it down with intent to erect on the lot a brick business building, this being substantially in line with the buildings already along the street and situate, for some distance, on plaintiff's right of way.

In making our present decision, we must not be understood as holding that, under usual or ordinary circumstances, the owner of property, subject to such an easement, would be justified in building a permanent brick structure on the plaintiff's right of way, but there is nothing in this record which shows or tends to show that plaintiff company has any present purpose of putting in a double track, or that the proposed building will tend to interfere with the proper and efficient operation of the road, or that it will sensibly increase the hazards incident to its operation, and, in the absence of some such evidence, we must hold, as stated, that, on the facts presented, there is nothing to indicate that the proposed building or its contemplated use will, in any way, tend to interfere with the "full and proper enjoyment of plaintiff's easement," the test suggested in Coit v. Owenby, supra, and the authorities cited in its support. It was only a business building in line with the other buildings on the block, and, so far as appears, it did not even sensibly increase the obstruction to the view, at times desirable for the safe operation of plaintiff's trains.

The case of Coit v. Owenby was cited on the argument as authority for the position that, on the facts in evidence, the plaintiff might have some proprietary interest in that portion of defendant's lot on the right of way, which it might rent or lease for warehouse or other business purposes to some patron of the road. Owing to the fact that the testimony on that point in Coit v. Owenby, supra, was somewhat obscurely stated, in the case on appeal, the decision may, in some 
aspects of the evidence, permit of such an interpretation and we deem it well, therefore, to say that, in the case referred to, the court never intended to hold that a railroad had the right to rent out the right of way to an individual for strictly personal or private business purposes. The decision was made to rest on that aspect of the testimony which permitted the interpretation and tended to show that the right of way had been let to a patron of the road as a terminal facility for receipt and shipment of freight, and it was held that the company might do this to the extent that it did not interfere with the facilities for serving the public. A railroad company would not be permitted to sell or farm out any portion of its right of way to an individual for any purposes extraneous to its chartered rights and duties.

We find there was error in the judgment rendered, and, on the record, the same must be reversed.

Reversed. ${ }^{40}$

WALKER and Brown, JJ., dissenting.

\section{SECTION 3.-EASEMENTS IN STRUCTURES}

\section{BROOKS v. CURTIS et al.}

(Court of Appeals of New York, 1872. 50 N. Y. 639, 10 Am. Rep. 545.)

Appeal from judgment modifying judgment in favor of defendants, entered upon the decision of the court at Special Term, and affirming judgment as modified.

Action to compel defendants to remove encroachments alleged to have been placed by defendants upon the premises of plaintiff, and to restore the property to its former condition.

The parties own adjoining premises in the city of Rochester. In 1846 Everett Peck owned both premises. He deeded to plaintiff in July of that year. At that time Peck had begun the construction of a three-story brick building upon the lot. The easterly line of the premises conveyed to plaintiff is thus given in the deed: "Beginning

40 It has been held that the owner of the land subject to a railroad right of way may not make cattle guards under or along the roadbed, Alton \& S. R. Co. v. Baugh, 14 Ill. 211 (1852); may excavate sand so. far as it does not interfere with the use of the land for railroad purposes, Vermilya $\mathbf{v}$. Chicago, M. $\&$ St. P. Ry. Co., 66 Iowa, 606, 24 N. TV. 234, 55 Am. Rep. 279 (18s5); may not cultivate cotton along the right of way against the objection of the railroad, Wilmot v. Yazoo \& M. V. R. Co., 76 Miss. 37t, 24 South. 701 (189S) ; may install a private crossing from one part of his farm to another, Cincinnati, $H$. \& D. R. Co. v. Wachter, 70 Okio St. 113, 70 N. E. 974 (1904).

A railroad company has no right, as against the owner of the land through which the right of way runs, to sink oil wells in the right of way. Consumers' Gas 'Trust Co. ₹. American Plate Glass Co., 162 Ind. 393, 68 N. E. 1020 (1903). 
at a point on the north of Buffalo street * * * opposite the center of the brick wall which said party of the first part is now erecting as the west wall of a block of stores; thence northwardly through the center of said brick wall seventy-nine feet." In $185 \overline{5}$ plaintiff erected a three-story building: using the wall for the east wall. In 1856 the defendants acquired title from the executors of Peck to the other lot. In 1866 they added two stories to their building-raising the party wall for that purpose. They also lowered the ceiling of the upper story of the building, as it was, some six feet, letting the joists into the old wall, and passed iron anchors through the wall, fastened on the west face of the wall by nuts and plates. The anchors were inserted with the verbal consent of plaintiff. The latter gave no consent to raising the wall. After the addition was completed, ice and snow from the roof of defendants' building fell upon plaintiff's roof, doing some damage. The trial court dismissed the complaint.

The judgment of the General Term was as follows: "Judgment modified so as to restrain the defendants from maintaining their roof in such manner and of such construction that the water and snow from it, and the ice formed from the waters falling from it, descend upon the roof of the plaintiff's adjoining building. As thus modified, judgment affirmed, without costs of this appeal to either party."

Rapallo, J. The deed from Everard Peck to the plaintiff states that the wall in controversy was, at the time of the conveyance, being erected by Peck as the west wall of a block of stores. The center line of the wall is, by the deed, made the easterly boundary of the land conveyed, which includes the land on which the westerly half of the wall stands. It appears that Peck's stores were afterward completed, and the plaintiff erected a building upon his own lot, using the wall as a party wall, and inserting in it the joists of his building. Peck afterward conveyed to the defendant, who made the addition to the height of the wall.

We think that the language of the deed and the acts of the parties show that it was their intention that the wall should be a party wall for the common use of both lots. The deed states that Peck was at the time erecting the wall, half of which was conveyed, and that it was to be the west wall of his block. This implies that the wall was not then completed, and that Peck was to have the right to complete it and use it as the west wall of his block. If the deed is to be treated as an absolute conveyance, free from any reservation, easement or privilege in the co-owner of the wall, Peck would have had no right to proceed to complete it, or at least that part which was beyond his line, after. the conveyance. It cannot be supposed that such was the intention of the parties. Subsequently to this conveyance the wall has been used for more than twenty years as a party wall.

Although land covered by a party wall remains the several property of the owner of each half, yet the title of each owner is qualified by 
the easement to which the other is entitled; and an important question in this case is, whether such easenent includes the right to increase the height of the wall, provided such increase can be made without detriment to the strength of the wall or to the property of the adjacent owner.

This question, in the absence of statutory regulations upon the subject, does not seem to have been distinctly settled by authority; but the fact appears in several of the cases relating to party walls that the height had been increased, and there is no intimation that such increase was unlawful. Watt v. Hawkins, 5 Taunt 20, was an action of trespass. The plaintiff had added to the height of a party wall, and the defendant tore down the addition, for which injury the plaintiff brought trespass. The only point decided was, that the parties were not tenants in common of the land, and therefore the action of trespass could be maintained. In Campbell v. Mesier, 4 Johns. Ch. 335, 8 Am. Dec. 570, a party wall, standing equally on two lots, having become ruinous, the owner or one side, against the will and in spite of the prohibition of the adjacent owner, pulled down the wall and rebuilt it ligher than it was originally. It was held that the adjacent owner was bound to contribute to the expense of the new wall, but not to the extra expense of making it higher than the old. There is no intimation in the case that the increase of height was wrongful. In Partridge v. Gilbert, 15 N. Y. 601, 69 Am. Dec. 632, the new wall built by the defendant was not only higher, but its foundations were deeper than the old wall which it replaced. The right to make these additions was not however discussed in the case, and perhaps there was no occasion to discuss it, the action being brought by the tenant of the adjacent lot, whose goods were injured in making the repair, and not by the owner.

In Eno v. Del Vecchio, $11 \mathrm{~N}$. Y. Super. Ct. 53, it was held that the owner on one side of a party wall might, for the purpose of improving his own premises, underpin the foundation of the wall and sink it deeper if he could do so without injury to the building on the adjoining lot; also, that he might increase, within the limits of his own lot, the thickness, length or height of the wall, if he could do so without injury to the building on the adjoining lot. Whether he could raise the whole party wall higher, or whether any additional elevation must be wholly within the limits of his own lot, the court expressly declined to decide.

We think that the right of either of the adjacent owners to increase the height of a party wall, when it can be done without injury to the adjoining building, and the wall is clearly of sufficient strength to safely bear the addition, is necessarily included in the easement. No adjudication adverse to that right has been referred to by counsel or found by us. "The party making the addition does it at his peril; and if injury results he is liable for all damages. He.must insure the 
safety of the operation. But when safe it should be allowed. ${ }^{41}$ The wall is devoted to the purpose of being used for the common benefit of both tenements. In Hendricks v. Stark, 37 N. Y. 106, 93 Am. Dec. 549 , it is held that a party wall is in no sense a legal incumbrance upon either property; that the mutual easements of adjoining proprietors in such walls are a mutual benefit to each, and not a burden, but a valuable appurtenant which passes with the title to the property. This is undoubtedly correct, provided each party is allowed to derive from the wall all the benefit which it is capable of affording without detriment to the other. But if, though of sufficient strength, it cannot be used by either party in increasing the height of his building, it may prove a serious injury to the property of one desiring to make that improvement; an improvement which is very usual and often very necessary in crowded cities. The fairer view, and the one generally adopted in legislative provisions on the subject in this and other countries, is to treat a party wall as a structure for the common benefit and convenience of both of the tenements which it separates, and to permit either party to make any use of it which he may require, either by deepening the foundation or increasing the height, so far as it can be done without injury to the other. The party making the change, when not required for purposes of repair, is absolutely responsible for any damage which it occasions (Eno v. Del Vecchio, 13 N. Y. Super. Ct. 17); but in so far as he can use the wall in the improvement of his own property without injury to the wall or the adjoining property, there is no good reason why he should not be permitted to do so.

The judge has found that the wall was sufficiently strong to be of the increased height without any injury thereto. He has further found that the carrying up of the wall, under claim of right, was with the

41 One of two adjoining party wall owners employed a contractor to carry the party wall up another story. During the process of construction that part of the wall which was being so carried up fell on the roof of the bullding of the other party wall owner, who thereupon brought action against the owner so causing the wall to be carried up. There was no evidence that the falling of the wall was due to any negligence in construction, or that the wall was not proper for the purpose. The plaintiff relied upon Brooks v. Curtis. The court said (Gray, J.): "The argument is that this language formulated the rule of liability for this case. The respondent, in his brief, says: 'Under the principle there enunciated, the appellants had a legal right to increase the height of the wall. But this was a conditional, and not an absolute, right. The condition is that he insures the safety of the operation.' We think the opinion in Brooks $\mathrm{r}$. Curtis [50 N. Y. 639, $10 \mathrm{Am}$. Rep. 545 (1572)] has been quite misapprehended in deducing from it any such rule of absolute liability, and that the language quoted, which is relied upon as furnishing the rule, should receive no such reading. In connection with the facts, it was appropriate. Ihe 'safety' there alluded to, which the building party insures, has reference to the strength of the wall to support the addition, or to the manner of its construction, as furnishing thereafter a possible source of danger or of luisance to the adjoining owner. It did not mean safety against uncontrollable accidents or the results of some third party's negligence. This is clear from. the reading of the balance of the opinion, as well as from a fair consideration of the question" Negus v. Becker, $143 \mathrm{~N}$. Y. 303, 305, $38 \mathrm{~N}$. E. -90, 25 L. R. A. 66T, 42 Am. St. Rep. 724 (1894). 
knowledge of and without objection from the plaintiff; and that the anchors were inscrted with his verbal assent. We think the judge was right in his conclusion of law that the plaintiff was not entitled to relief, so far as the carrying up of the wall and insertion of the anchors were concerned.

The court at General Term however modified the judgment in respect to the roof, so as to restrain the defendants from maintaining it of such construction as to cause water, snow and ice to fall upon the roof of plaintiff's building. This modification is not appealed from. In making it, the General Term necessarily held that the Special Term should not have dismissed the complaint, but should have granted that part of the relief prayed for which is embraced in the modification, and should have denied the residue; and it is claimed that the judgment of the General Term is erroneous in affirming the dismissal of the complaint with the modification referred to. The appellant is technically correct in this claim. The more proper form would have been simply to modify the judgment, and render such judgment as the Special Term should have rendered. But the objection is one of form merely, except so far as the question of the costs awarded at Special Term is concerned. This being an equitable action, costs were in the discretion of the court below; and it had power, either at Special or General Term, to decree costs in favor of the defendants, although some part of the relief prayed for was granted. We will not therefore disturb the judgment on that ground.

The judgment should be affirmed, with costs. All concur.

Judgment affirmed. ${ }^{42}$

42Acc.: Tate v. Fratt, 112 Cal. 613, 44 Pac. 1061 (1896); Fleming $\nabla$. Cohen, 186 Mass. 323,71 N. E. 563, 104 Am. St. Rep. 572 (1904); Dauenhauer v. Devine, 51 Tex. 480, 32 Am. Rep. 627 (1879). Compare Watson v. Gray, 14 Ch. 192 (1880); Field v. Leiter, 118 11l. 17, 6 N. E. 877 (1886); Fidelity Lodge, No. 59, I. O. O. F., of New Castle, v. Bond, 147 Ind. 437, 45 N. E. 338,46 N. E. 825 (IS96); Johnson v. Minnesota Tribune Co., 91 Minn. 476, 98 N. W. 321 (1904); Calmelet v. Sichl, 48 Neb. 505, 67 N. W. 467, 58 Am. St. Rep. 700 (1896).

A. and B. were owners of adjoining lots. A wall stood wholly on A.'s land and about 9 inches from the boundary. B. had for over 20 years used this wall to support his house. A. erected a new wall on his own land, but nearer the boundary, cut B.'s joists slightly, and inserted them in the new wall. The new wall was higher than the old, and $B$. later raised his house, using the higher part of the wall. Held, B. has no right to use the added height. He has a right of action if he can show that the new wall is nearer the boundary than the old wall. Barry $\nabla$. Edlavitch, 84 Md. 95, 35 Atl. 170, 33 I. R. A. 294 (1896).

A party wall means a solid wall; consequently, if elther owner attempts to open windows, the other may get damages, Milne's Appeal, 81 Pa. 54 (1S76); or enjoin him from so doing, Harber v. Evans, 101 Mo. 661, 14 s. W. 750,10 L. R. A. 41, 20 Am. St. Rep. 646 (1S90); or compel him to close the openings, Springer v. Darlington, 207 Ill. 23S, 69 N. E. 946 (1904). Contra: That plaintiff can get relief in equity, only if he wlshes to use the wall. Reynolds v. Union Savings Bank, 155 Iowa, 519, 136 N. W. 529, 49 l. R. A. (N. S.) 194 (1912); Witte v. Schasse (Tex. Civ. App.) 54 S. W. 275 (1899).

Whether either of the adjoining owners can use the wall for other purnoses, as advertising, depends upon the ownership of the wall; if the one 


\section{PUTZEL v. DROVF.P.S' \& MECHANICS' NAT. BANK.}

(Court of Appeals of Marjland, 1894. 78 Md. 349, 28 Atl. 276, 22 L. R. A. 632, 44 Am. St. Rep. 298.)

Bryan, J. ${ }^{43}$ Selig G. Putzell filed a bill in equity against the Drovers' \& Mechanics' National Bank of Baltimore. It was alleged that the defendant, without right or justification, was about to tear down the rear wall of the complainant's dwelling house, and thereby render it untenantable, and do him irreparable damage. The bill prayed an injunction to restrain the defendant from proceeding as alleged, and it was accordingly granted before answer. There was also a prayer for general relief. After answer the defendant moved a dissolution of the injunction. Testimony was taken on both sides, and when the cause came to final hearing the injunction was dissolved, and the bill dismissed. Complainant appealed.

We think that a statement of the material facts of the case as they appear to us will sufficiently show the grounds of our opinion, without the necessity of a discussion of the testimony of the different witnesses. Putzell, the complainant, is the owner of a leasehold interest for 99 years, renewable forever, in a lot of ground in the city of Baltimore, on the west side of Eutaw street, between Fayette and Lexington streets. He acquired this property in the year 1866 . For many years before his purchase, and ever since then, there has been on this lot a substantial brick dwelling house, which extended back to its westernmost boundary. The Drovers' \& Mechanics' Bank, in the year 18s8, became the owner of a leasehold interest in a lot of ground fronting on Fayette street, and running back northerly to Marion street, and binding, for a portion of its easterly line, on the westernmost boundary of Putzell's lot. It is not distinctly stated in the record, but this leasehold interest is evidently for 99 years, renewable forever. The bank's lot and Putzell's lot are separated by a division brick wall, which, by the measurements proved in the case, is shown to be built partly on the ground of one of these parties, and partly on the ground of. the other. This wall has been standing for a very long time, certainly for more than 30 years before the transactions which are the subject of complaint in this case.

As far as we can ascertain from the testimony, Putzell's house, as originally built, had this division wall as its rear wall, but the rear wall was not built higher than the top of the division wall. In 1870, Putzell put an additional story on the back building, placing its rear wall

so using owns that part of the wall, he has all the privileges of an owner, save those that interfere with the other's easement. Lappan $\mathbf{v}$. Glunz, 140 Mich. 609, 104 N. W. 26 (1905) ; Shiverick v. R. J. Gunning Co., 58 Neb. 29, 78 N. W. 460 (1899). If he has only an easement, he can do nothing outside the scope of his easement. Berry v. Godfrey, 198 Mass. 228, 84 N. E. 304, 16 I. R. A. (N. S.) 434 (1908).

4 Part of the opinion is omitted. 
on the top of the division wall. This division wall was used by the owners and occupants of the lot now owned by the bank for the purpose of designating the boundary line between it and the Putzell lot. There was evidence of the use of it, also, for a series of years, as a support for the frame of a grape arbor. The bank, in the year 1892, commenced the erection of a large six-story building for the purposes of its business, and in the prosecution of the work proposed to take down the entire wall separating the two lots, and erect on the same line another wall of sufficient strength and thickness to support the. new building, not encroaching on Putzell's lot, and offering to give him the benefit of the new wall as a partition wall for the benefit of any building to be erected on his lot. The question in the case is whether this action on the part of the bank would be a legitimate exercise of its rights of property.

No one seems to know when the wall in question was built. In all probability, the time was beyond the limit of living memory. There is some reason to think so from the fact that the deeds which created the leasehold interests in these lots were executed towards the close of the last century, and early in the beginning of the present. It seems to have been erected for the purpose of making the boundary between the lots, and to have been always used for that purpose. The soil of the respective owners was covered by it; and this was the use of his soil which each owner elected to make for his own benefit. Each one owned the portion of the wall which was on his own ground. There seems to have been no cessation of the use of it, in the way in which it was intended to be used,- - that is, to mark the boundary line. There was no ouster of the possession of the soil. Each coterminous proprietor owns the portion of the wall which rested on his own ground, as he had continued to own it from the beginning, and he has actual and beneficial possession of the soil by reason of the occupation and use of it by means of his portion of the wall. Surely, there could not be a more distinct and unequivocal exercise of the right of ownership than to build on one's own land a house or a wall, and to use it continuously for the purposes to which it was suitable. ***

$\mathrm{But}$, although there was no amotion of the possession of the owners of the bank lot, it does not follow that Putzell had not acquired some rights to the use of the division wall. He had used this wall for more than 20 years as a support to his house: the enjoyment of it for this purpose had been notorious, peaceable, uninterrupted, and "as of right." Under these circumstances, the law considers that he had a prescriptive title to the use of it in the manner in which he had enjoyed it. $* * *$

The bank retained all its rights in the division wall which are not inconsistent with the enjoyment of the easement. It was bound to permit it to be used as a support for Putzell's house in the accustomed manner; but this is the limit of its obligation. It would be unreasonable to deny to it the right to improve its own property ac- 
cording to its interests and inclinations, provided it did not infringe the rights of other persons. In fact, the wall which it proposed to take down was insufficient to support the building which it desired to erect. If this should be taken down, and another larger and stronger one built in its stead, it would thereby exercise its own legitimate rights of property; and, if it gave to the adjoining house the same right of support in the new wall which it had in the old one, it would not injure its neighbor. This seems to us the just settlement of this controversy. Putzell may be put to some inconvenience while the building is going on, but this is one of the unavoidable consequences of living in a closely-built city.

We have said that each portion of this division wall belonged in severalty to the proprietor on whose ground it stood; but, even if these proprietors had been tenants in common of this wall, the result would not have been practically different. In Bank v. Stokes, 9 Ch. Div. 72, Sir George Jessel cites, with marked approval, Cubitt v. Porter, 8 Barn. \& C. 257 . He quoted as follows from the opinion of $\mathrm{Mr}$. Justice Bayley: "There is no authority to show that one tenant in common can maintain an action against the other for a temporary removal of the subject-matter of the tenancy in common, the party removing it having at the same time an intention of making a prompt restitution. It was not a destruction. The object of the party was not that there should be no wall there, but that there should be a wall there again as expeditiously as a wall could be made." And in a subsequent part of his opinion he says: "As I have read the law from the statements of eminent judges, he [that is a tenant in common] has a right to pull down when the wall is neither defective nor out of repair, if he only wishes to improve it, or put up a better or handsomer one." * * *

The allegations of the bill of complaint were sufficient to give a court of equity jurisdiction, and they justified the preliminary injunction. The complainant has not proved the precise title to the wall which he alleged, although he has proved a title to a portion of it, and an interest in the other portion by way of easement. For the reasons which we have stated, we approve of the dissolution of the injunction, and to that extent the decree below will be affirmed. But the right to take down the wall is not absolute and unconditional; it is qualified in the manner which we have explained in a previous part of this opinion. The bank is bound to finish the division wall at its own expense, and to allow to Putzell's house the same right of support which it had in the old wall, and to indemnify him for the necessary expenses which he has incurred, and may incur, in protecting his property from the consequences of the removal of the old wall. For failure to do these things it would be liable to an action at law. But as a court of equity had jurisdiction of this case, although it could not give the precise relief prayed, it was proper, according to well-settled principles, to do complete justice between the parties, and thus avoid multiplication of 
suits it, the future. It ought to have retained the bill for the purpose of settling and adjudicating any claim which may arise in favor of Putzell against the bank, in accordance with the principles which we have stated. We disapprove of that portion of the decree which dismisses the bill.

Decree affirmed in part, and reversed in part, and cause remanded for further proceedings; the costs in this court to be equally divided between the parties. ${ }^{4}$

\section{SHIRLEY et al. v. CRABB.}

(Supreme Court of Inüiana, 1S9t. 138 Ind. 200, 37 N. E. 130, 46 Am. St. Rep. 376.)

Hackney, J. ${ }^{45}$ This action was by the appellants, and its object was to quiet title to an easement. The only question in the case arises upon an exception to one conclusion of law stated upon the facts specially, found. From the special finding it appears that, in the year 1873. Homan and Piersol owned, as joint tenants, a part of lot 17 , block 19, in the town of Danville, fronting east $421 / 2$ feet on a public street, and extending west to an alley, with an additional width upon said alley. While so owning the same, they erected thereon a double building two stories high, the division wall between the two parts of said building being so constructed that the center thereof was $211 / 2$ feet south of the north line of said part lot, and 21 feet north of the south line thereof. On the south side of said division wall was constructed a stairway from said street to a landing upon the second floor of said building, and another stairway from the rear of that part of the building on the south of said division line, and on the south of said division wall, was so constructed as to reach said landing. From said landing was made an entrance to the second story of that part of said building on the north of said line, and through said entrance, and by said stairways, was supplied the only means of ingress and egress to and from the second story of the part of said building north of said division line. By numerous conveyances the appellee became the owner of that part of said property lying south of said division line, subject to a reservation in each deed of conveyance of such right of way over the front and rear stairways so constructed, and in a hall running north and south through the second story of

44 Contra: Partridge v. Lyon, 67 Hun, 29, 21 N. Y. Supp. 848 (1893). See Wallis v. First Nat. Bank of Racine, 155 Wis. 306, 143 N. W. 670 (1913).

A. and B. were owners of adjoining buildings with a party wall. A.'s building was destroyed by fire; the wall was still adequate to support B.'s building, but, owing partly to the fire, and partly to original faulty construction, was not adequate to support the building $\mathbf{A}$. wished to erect. Held, $\mathbf{A}$. may tear down and replace the wall by a new party wall, being liable to $\mathbf{B}$. only for negligence. Lexington Lodge v. Beal, 94 Miss. 521, 49 South. 833 (19u9).

45 Part of the opinion is omitted. 
said building, for the proper use and occupancy of the second story of that part of said building on the north of said division line. By deeds of conveyance the appellants became the owners of the real estate north of said division line, together with said right of way; and before and after such conveyances said stairways were continuously used openly and freely for the benefit of the appellants' part of said building until the 28th day of August, 1891, when said building, and the parts thereof owned by both the parties herein, together with said stairways, were wholly destroyed by fire, without the fault of either of the parties. Since the destruction of said building the appellee has erected upon his part of said real estate a two-story brick building, occupying the entire width of his said real estate, excepting one inch along the north line thereof, or along the said dividing line between his property and that of the appellants. On the north side of the building so constructed the appellee has erected a stairway from said street to the second story of said building. The appellants contemplate the erection, at an early date, of a two-story building of the character of that so owned by them and so destroyed, and they desire to avail themselves of the use and privileges of stairways of the character, and for the purposes, of those so existing prior to the destruction of the former building. The right so desired is denied by the appellee.

Upon the facts found, the court stated, as conclusions of law: First, that the appellants, by their purchase and the conveyance to them, acquired an easement in the nature of a right of way over said stairways and hall as they existed before the destruction of said building; and, second, that by the destruction of said building said easement was wholly lost and extinguished. It is to this second conclusion that the appellants except, and insist that they held an easement not to be lost by the destruction of the building. This position necessarily involves the claim that the appellants' rights were more than a license to use the stairways and halls, and that their interest in the property of the appellee was an easement attaching to the real estate, and continuing until extinguished by some act of the owner of that dominant estate. $* * *$

We feel entirely certain that the reservation, in the form in which it is brought to us, was not intended to create an interest in the soil; and if it possessed the quality of an easement, in that it became an interest in real estate, it was only to the extent of affording the use of the stairways and hall in the building as it existed, and independently of any right to or interest in the soil. If this was the extent of the interest, it follows that the destruction of the building destroyed the right as effectually as if the interest had been in the soil, and the floods had carried away the soil; nothing would remain upon which the right could operate. A new structure would not recreate the right, for such right had been destroyed, and not simply suspended, as would probably have been the case if the right had attached to the land.

Big.RIghts-16 
The case of Hahn v. Baker Lodge, 21 Or. 30, 27 Pac. 166, 13 L. R. A. 158, 28 Am. St. Rep. 723, presents a stronger claim to a reviving right than that of the appellants. There the plaintiff owned a lot upon which was erected a two-story building, the middle room or hall in the upper story of which was owned by the defendant, and used as a lodge. The building was destroyed by fire. The conveyance to the defendant contained no provision, in case of such destruction, giving the right to rebuild. No interest in the land having been conveyed, it was held that all right was extinguished. We say the claim was stronger because there the interest was an absolute ownership; here, at most, it is but an easement; and in neither case does it appear that the right extends to the subjacent soil. The distinction here marked was established by this court in the case of Thorn v. Wilson, 110 Ind. 325, 11 N. E. 230, 59 Am. Rep. 209. It was there held that a contract under which one became the owner of an upper story of a building gave no interest in the land. It was said: "The instrument before us, however, grants a mere use, and not a proprietary interest in the corpus of the property; and upon such a grant a proprietary interest in the real estate itself cannot be recovered." It was also suggested that, in case of the destruction of the building, all rights under the contract would terminate.

We conclude, therefore, that the right of the appellants did not extend beyond the use of the stairways and hall, and did not consist of an interest in the soil; that no obligation rested upon the appellee to rebuild or maintain for appellants' use another stairway in the event of the destruction of those in which the interest was held; and that, by the destruction of the building without the fault of the appellee, the interest of the appellants was extinguished. The judgment of the lower court is affirmed. ${ }^{4} \quad-t<$. te $f$

46 The destruction of a party wall by fire terminates the easement. Bowhay v. Richards, 81 Neb. 764, 116 N. WV. 67T, 19 L. R. A. (N. S.) SS3 (190\$); Sherred v. Cisco, 6 N. Y. Super. Ct. 480 (1851); for another part of this case, see post, p. 246. Compare Brondage $\nabla$. Warner, 2 Hill (N. Y.) 145 (1S41). Conseguently, if either orrner rebuilds the wall partly upon the land of the other owner, the latter may maintain ejectment. Heartt $\mathbf{r}$. Kruger, $121 \mathrm{~N}$. I. 386,24 N. E. $\$ 41,9$ L. R. A. 135,18 Am. St. Rep. $\$ 29$ (1S90). See Wigford ․ Gill, Cro. Fliz. 269 (1591).

An easement of user or support in a building or party wall ends when the structure becomes so decrepit that it is reasonably torn down because of its condition. McKenna v. Eaton, 182 Mass. 346,65 N. E. 35*, 9t Am. st. Rep. 661 (1902) ; Partridge v. Gilbert, 15 N. Y. 601, 69 Am. Dee. 632 (1857); Fewell v. Kinsella ('Tex. Cir. App.) 144 S. W. 1174 (1912). Compare Ballald v. Butler, 30 Me. 94 (1S49) ; Riley v. Pearson, 120 Mimu. 210, 139 N. W. 361, L. R. A. $1916 \mathrm{D}, 7$ (1913).

A. was the owner of the upper story of a building and $\mathbf{B}$. of the lower; $\mathbf{A}$. having an easement of support in B.'s part. B.'s part became ruinous through the action of the elements. to the damage of $\mathrm{A}$. The court, in Cheeseborough $r$. Gleen, 10 Conn. 319, 26 Am. Dec. 396 (1834), held that $A$. had no cause of action against $B$. for not repairing, but suggested that $A$. rould have relief in equity. In Jackson v. Bruns, 129 Iowa, 616, $106^{\circ} \mathrm{N}$. W. 1, 3 L. R. A. (N. S.) 510 (1906), it was held that A. could not compel B. to repair. See also Pierce v. Dyer, 109 Mass. 374, 12 Am. Rep. 716 (1872).

A. owned two adjoining lots, on each of which was a two-story building, 


\section{DOUGLAS v. COONLEY.}

(Court of Appeals of New York, 159S. 156 N. Y. 521,51 N. E. 283, 66 Am. St. Rep. 5s0.)

Appeal from an order and a judgment of the late General Term of the Supreme Court in the Third Judicial Department, entered February 27 and March 8, 1895, respectively, reversing a final judgment entered upon the decision and order of the court at Special Term, sustaining plaintiffs' demurrer to the defendants' answer.

This action was brought to recover the use and occupation of a certain stairway in common with the defendants, and to restrain them from interfering with such use and occupation.

The facts, so far as material, are stated in the opinion.

PARKER, C. J. ${ }^{47}$ By his will, Henry B. Smith conferred upon executors named therein the power to sell and convey his real estate. It consisted in part of a three-story building that had three stores on the ground floor. The executors conveyed the middle store to Margaret $\mathrm{A}$. Cantwell, and the store next adjoining it on the west to this defendant Coonley and one John Hughes and Hughes' title has since been acquired by the defendant Sophronia C. Smith. Between the said middle and west stores was a wall that the conveyance made a party wall, and from the street to the upper rooms of the building, immediately adjoining this party wall on the west side, there was a stairway that was used by the occupants of both buildings, it being the only mode of access between the upper and lower floors of either building. After Coonley and Hughes had become the owners of the west store, they undertook to confirm the alleged right of Margaret A. Cantwell to use this stairway in common with themselves as a means of ingress and egress to and from the two floors above her store, and to that end executed a deed of conveyance, by

with stores below and rooms above. He granted one to $B$. in fee in the following langnage: "A certain lot of land with the store thereon standing," and, after" describing the land, concluding as follows: "With a privilege in the passage of the adjoining store, for the purpose of passing and repassing to the chambers of the store hereby conveyed." B.'s store came to $\mathrm{X}$., and A.'s to $\mathbf{Y}$. $X$. tore down the old store and erected another building of the same size, conneeting with the passage in Y.'s store, just as the old one had. It was admitted that $X$. did not intend to abandon his easement. Held, he has no right of passage to and from the new building. Cotting $r$. Boston, 201 Mass. 97, 87 N. E. 205 (190S). Acc: Day v. Walden, 46 Mieh. 575,10 N. W. 26 (1SS1); Taylor . Hampton, 4 MeCord (S. C.) 96,17 Am. Dec. 710 (1S27). Contra, as to ancient lights: Currier's Co. v. Corbett. :Dr. \& Sm. 355 (1S65); Ecclesiastical Com'rs v. Kino, L. R. 14 Ch. D. 21: (1Ss0). Compare, as to the construction of the deed, Bangs r. Harker, 71 IIe. 458 (1Ss0).

In general, as to the loss of easement by destruction of the dominant structure, see National, etc., Co. v. Donald, 4 H. \& N. S (18.9); Weis r. Meyer, 55 Ark. 1S, 17 S. W. 399 (1s.1): Riefle \& sons r. Wayne storage Water Power Co., 232 Pa. 2\$2. \$1 Atl. 200 (1911); Southern Ry. Co. v. Memphis, 97 Fed. \$19, 38 C. C. A. 498 (1s99).

47 Part of the opinion is omitted. 
which, as the complaint recites, was "granted, sold, and conveyed to the said Margaret A. Cantwell, her heirs and assigns, the right of way to pass and repass up and down the passageway or stairway between the store owned by Margaret A. Cantwell and of the parties of the first part hereto at all times, in common with the parties of the first part hereto, for the purpose of going and returning to and from the rooms in the upper part of said stores; the party of the second part to pay one-half of the expense of keeping the stairway in repair." Subsequently, these plaintiffs succeeded to the title of Margaret A. Cantwell in and to the middle store; and thereafter, and on the 11th day of January, 1893, the entire building was destroyed by fire. The parties at once reconstructed the buildings on the same foundation as before, and united in the construction between the two stores of a party wall similar to the one formerly existing, except as to the doorway leading from the head of the stairway to the second floor of the plaintiffs' building. The plaintiffs put in a frame for such doorway when the wall was being constructed, but afterwards defendants tore the frame out, and built that portion of the wall up solid, thus preventing the plaintiffs from obtaining access to their premises by means of the stairway. The defendants, though frequently requested, refused to permit the plaintiffs to enjoy the stairway in common with them.

It is conceded that, prior to the destruction of the building by fire, the plaintiffs had a legal right to use, as they did, this stairway and the doorway in the party wall as well, in common with the defendants. But it is contended that the effect of the destruction of the building by fire was to destroy this easement. The diligence of counsel has not succeeded in bringing to light a similar case, in this country, nor have we been more fortunate. The appellate division regarded the case as controlled by Heartt v. Kruger, $121 \mathrm{~N}$. Y. 386, $24 \mathrm{~N}$. E. 841, 9 L. R. A. 135, 18 Am. St. Rep. 829. That case is certainly authority for the proposition that these plaintiffs had no right to insist upon a reconstruction of the party wall or of the stairway. The buildings having been destroyed without fault on the part of the defendants, it was their right thereafter to make such use of the land as should seem to them most conducive to their interests. They could not by their own act affect the plaintiffs' easement, but, an outside force beyond the defendants' control having destroyed the buildings and the major part of the party wall, it was within their power thereafter to so use the land that the plaintiffs' easements should not be revived. Had they done so, a situation would have been presented within the doctrine of Heartt v. Kruger, supra. But this they did not do. Instead, they united with the defendants in constructing a party wall, anci rebuilt the stairway in precisely the same place as before; and thus within a comparatively short period of time the buildings, so far at least as the stairway and party wall are concerned, were exactly the same as if the fire had never taken place. And 
the question is, did this conduct of the parties operate to revive the easement that was suspended by the destruction of the property? If such be the effect of this action, the result is certainly equitable and in accordance with good conscience. The plaintiffs' predecessor in title, in purchasing the middle store, acquired the right to use the stairway and the doorway through the party wall as a necessary incident to her enjoyment of the second and third stories of her building.

Apparently, for the purpose of further assuring her right to use the stairway and the doorway as well, a grant of such right, presumably upon a good and sufficient consideration, was made to her by these defendants. The grant was not intended to be a temporary matter, or one purely for her personal convenience, for it ran to her, her heirs and assigns. Why should she or her assigns be deprived of it now, inasmuch as the situation of the property is precisely the same as it was then? No good reason has been suggested by counsel for relieving the defendants from the easement which they undertook to confirm, if not create. The law afforded them an opportunity for the destruction of the suspended easement by an entirely different method of construction; and the reason of the law is that, in case of the destruction of an easement by the act of God, then a party ought to be at liberty to make the best possible use of his property, and should not be burdened with the necessity of a reconstruction along the same lines. Presumably, these defendants found that a reconstruction of the building upon the old plan was the best possible use to which they could put the land, and now, that such reconstruction is accomplished, they insist that the other parties shall not enjoy the easement. The plaintiffs need not have united with the defendants in the construction of the party wall, but did so with the expectation, undoubtedly, of enjoying the right supposed to be secured to them of access to the upper stories of the building. It certainly seems but just under all the circumstances that these expectations should be realized, and hence it becomes the duty of a court of equity to work out that result, provided it can be done within established equitable principles.

Mr. Washburn, in his work on the Law of Easements and Servitudes, says, at page 568 (page 686, 3d Ed.): "It may be observed as a well-settled rule of the civil law, which would doubtless be regarded as a part of the common law, that if a house, a wall, a water spout, or anything of that kind with which or by which a servitude exists or is enjoyed, is destroyed, and the same is afterwards, within the period of prescription, reconstructed or restored, whatever may have been the servitudes connected therewith, they are, by such restoration, revived." * * *

This rule, well founded in reason, is applicable to this case, and therefore it becomes the duty of the court to hold that the effect of the 
reconstruction of the buildings, including the party wall and the stairway as they were before, operated to revive the easement that had been for a time suspended by the destruction of the former buildings by fire. $* * *$

The order appealed from should be reversed, and the judgment of the special term affirmed, with costs. All concur, except GraY and BarTleitT, JJ., dissenting, and Haight, J., absent. Order reversed.

\section{SHERRED v. CISCO.}

(Superior Court of City of New York, 1S51. 6 N. Y. Super. Ct. 480.)

This was bill in equity, filed in the supreme court, from whence the cause was transferred to this court. An answer was put in, a replication filed, and evidence was introduced at the hearing of the cause. The facts disclosed by the pleadings and proofs were as follows:

For several years prior to 1845 , the mmplainant, Sarah Sherred, was seised in fee of a lot known as No. 31, on the easterly side of Broad street, in the city of New York; and Richard Duryee, in his lifetime, and after his death, his heirs, were seised in fee of the adjoining lot on the north side, known as No. 29. Each lot was covered by a store or warehouse. The buildings were separated by a single brick wall, resting on a stone foundation, one half of which was upon the land of Sherred, and the other half on the land of Duryee. The beams of the two stores rested upon this common or party wall. Duryee had executed several mortgages on lot No. 29, which were duly recorded. Prior to July 19, 1845, Duryee died, and the mortgagees to whom three of the mortgages were executed, commenced proceedings for their foreclosure against Duryee's heirs and the subsequent mortgagees. While the foreclosure was pending, on the 19th of July, 1845, both of the stores, 29 and 31 Broad street, were destroyed by fire, and nothing was left of the party wall except the stone foundation.

Immediately after the fire, Sherred proceeded to rebuild the store on lot No. 31, extending it a little further in depth than the former building. In rebuilding, her contractors commenced on the stone foundation of the former wall between the stores on 29 and 31 , and after raising it with stone about a foot higher than the stone wall was before, built upon it with brick, the side wall of her store, four stories. high. The new wall, built at the sole expense of Sherred, thus stood one half on her lot, and the other half on the Duryee lot. Her store was finished in the fall of $18+5$.

The bill charged that she built this wall after applying to Duryee's heirs to unite with her in so doing, with their assent and approval, and on their agreeing to pay half the expense, if they could obtain the money to rebuild their store. These statements were put in issue, and were not proved. 
The foreclosure of Duryee's mortgages resulted in a decree for a sale, under which the defendant Cisco became the purchaser of lot 29 , for $\$ 15,600$, at a sale made by a master in chancery on the 27 th of January, 1847. The master conveyed the lot to him on the 15 th of February, 1847. 'The defendant, soon after his purchase, built a warehouse or store on lot 29, and used the wall so built by Sherred for one of the side walls of his store, inserting therein his timbers and beams. 'The first story of his store extended to the same depth as Sherred's new store, but the upper stories did not extend as far back from the street, by about fourteen feet, as Sherred's store extended. As to those stories, the portion of the party wall not used by the defendant, was shown to be a detriment to him, rather than a benefit.

Sherred applied to the defendant to pay half the value of the wall as used by both parties, which he declined to do, on the ground that he purchased and paid for the half of it standing on his lot, at the master's sale. There was no proof that the defendant had any notice, till after he commenced building, that Sherred had built the party wall at her sole expense, or that she had not been paid for half of it, or that she claimed payment therefor. It was proved that the value of the half of that part of the party wall which the defendant made use of in constructing his store, was $\$ 459.14$. The value of the entire wall built by Sherred between upon the two lots, was $\$ 1,146$.

SANDFORD, J. ${ }^{48}$ The plaintiff relies entirely on the case of Campbell v. Mesier, 4 Johns. Ch. 334, 8 Am. Dec. 570, and 6 Johns. Ch. 21, to sustain this suit. It was there decided, that where there was an old party wall standing between two houses, which had become ruinous, and the owner of one of the houses being desirous to rebuild his house, after notice to the owner of the other, and a request to him to unite in the work, took down the old wall and rebuilt it on the same site, with and for his new house, the owner of the adjoining house was bound to contribute ratably to the expense of the new wall; but not beyond the extent of the height and quality of the old wall. It was in effect held also, when the case was before the chancellor on the equity reserved in 6 Johns. Ch. 21 , that a purchaser of the house from the owner thus liable, took it subject to the charge upon it for contribution. But we suppose this was on the ground that the purchaser was aware of the claim of his neighbor for contribution when he purchased, as was apparent from his taking a covenant of indemnity in respect of the use of the party wall, in his deed of the house.

We think this case differs from Campbell v. Mesier, so far that the decision of the latter is not controlling. In the first place, the defendant bought his lot with the new wall upon it without notice of the plaintiff's claim. Next, when the wall in question was built by the plaintiff, there mas no party wall in existence. There had been a wall, which served as a partition between the two stores, (whether properly called

48 Fart of the opinion is onitted. 
a party wall or not, in the sense used by the chancellor in the case cited, we will not here inquire) but it was destroyed with those stores. The stone foundation that remained does not alter the matter. Either party could remove so much of it as rested on his ground, with the rubbish on his lot, on preparing to rebuild. Then the plaintiff on one side, and the mortgagees on the other, Duryee's heirs really having no interest in the subject, owned two adjoining vacant lots in severalty, where there had once been a partition wall forming the mutual support of two adjoining buildings. The plaintiff, without notice to the mortgagees, ind without their assent or knowledge, rebuilt her store, and placed the partition wall on the site of the former one. There was no "equality of right and interest" in an existing wall, which it was necessary, for the two houses then supported by it, should be rebuilt, and in which wall the parties "had an equal interest," as was the chancellor's view of the facts in Campbell v. Mesier. These parties had no such interest, for they had no joint or common interest whatever. Each owned in severalty the half of the ground on which the former wall stood. Neither was under any obligation or duty to build upon his lot, or to suffer the other party to place part of a division wall upon it. The principle of contribution applicable to tenants in common of a mill, and to the discharge of a common burthen or charge upon lands held in common, is therefore not applicable to this case; and we think it is not governed by the principle of the chancellor's decision in the authority relied upon by the plaintiff.

By the common law, every owner of land is his own judge of the propriety of building upon it or leaving it vacant; and when he does build, of the manner and extent of his buildings. In the absence of statutory provisions, he may build with what material he pleases, and he is under no obligation to give to his neighbor any use or advantage of his land, by way of support, drip, or easement of any description. If a stranger dispossess him, or enter upon his unoccupied property, erect buildings, and make valuable permanent improvements upon it, he is not under the slightest obligation to recompense such stranger for any portion of the expense, on recovering the possession of the land. $* * *$

We perceive no ground upon which the plaintiff can maintain her suit, that will not give a like remedy for all permanent valuable erections made in good faith, by all persons on lands which they do not own. It ivas argued that the fact of there having formerly been a partition wall, (which we will call a party wall,) gives the right to have it continued for all time to come.

[After pointing out the objections to this contention:] It suffices to say, that when two owners of adjoining city lots unite in building two stores with a party wall, we have no right to infer, from that act, an agreement binding upon them and their heirs and assigns to the end of time, to erect another like party wall at their mutual expense, when 
that one is casually destroyed, and so on, as often as the new one shares the same fate.

But it is said the defendant made use of the new wall when he built on his lot, and thus ratified it as a party wall; and it will be unjust to permit him to have the benefit of it without making compensation.

As to the injustice alleged, it is very well answered that the defendant bought this lot at a judicial sale; and, so far as we know, paid for it all that it was worth, including the half wall then standing upon it, and a judgment in this suit compelling him to pay the plaintiff for the same half, will make him pay for it twice. But whether that be the result of our decision, or it have the effect to give him the half of the wall for nothing, it cannot change the rule of law which governs the case.

Then what is the effect of his using the party wall? He found it on his land, on taking possession. He wanted to build. Was he to tear it down, or insist on the plaintiff's removing the half wall, so that he could occupy his whole land? This he might have done, (Wigford v. Gill, Cro. Eliz. 269,) to her great injury, and with probably no advantage to himself. Or was he not entirely at liberty to use as his own, an erection on the land he had bought, without subjecting himself to pay for work done without his request or knowledge. We think he was. We do not see how the defendant is liable to pay for half of this wall, because he used it, any more than he would have been liable, if the Duryees had rebuilt before he bought, and had put their beams into the wall, without paying the plaintiff for it. Yet the proprsition would be at once scouted, that the purchaser of a house in this city, having paid to the owner the price, in good faith and without notice, would be liable to the owner of an adjoining house, for the unpaid half of the cost of the party wall which separated the two tenements. $* * *$

Upon the whole, we are clear that the plaintiff is not entitled to re cover, and her bill must be dismissed with costs. ${ }^{49}$

\section{SPAULDING et al. v. GRUNDY.}

(Court of Appeals of Kentucky, 1907. $126 \mathrm{Ky} .510,104$ S. W. 293, 13 L. R. A. (N. S.) 149,128 Am. St. Rep. 32S, 15 Ann. Cas. 1105.)

CArroliL, J. ${ }^{50}$ Appellants are the owners of a lot, with a store building thereon, in the city of Lebanon. Appellee owns the adjoining lot. Both lots were formerly owned by one Ben Spaulding, and the parties to this litigation acquired their respective lots by various conveyances. For a considerable time, the buildings on both lots extended back the same distance from Main street; the dividing wall between

40 Acc.: Antomarchi's Fx'r v. Russell, 63 Ala. 356. 35 Am. Rep. 40 (1879); Orman v. Day, 5 Fla. 385 (1853). See List v. Hornbrook, 2 W. Va. 340 (1867) 50 Part of the opinion is omitted. 
them being recognized as a joint or partnership wall. Afterwards, appellants' vendors increased the depth of their store building by extending the division wall on the line between the lots, and erected a wall two stories in height above the ground. The extension of the partnership wall between the two buildings was made by the appellants' vendors at their own expense, with the expectation, belief, and assurance that, when appellee or his vendors should extend their building and use the wall erected by appellants' vendors for the purpose of building on or to it, they would contribute their share of the expense of erecting it, or pay to appellants one-half of the value of the wall so taken and used at the time it should be used. Appellee acquired title to his lot in 1881, and since then at various times he has extended the store building on his lot, until the storeroom now reaches to the end of the wall erected by appellants' vendors, and is using and utilizing the wall as the eastern wall of his building. Appellee refusing to contribute anything to the expense of erecting the wall made by appellants' vendors, or pay any part of the value of the wall used by him, they brought this action, seeking to recover from appellee one-half the value of the wall erected by their vendors and used by him. To their petition a demurrer was sustained, and judgment entered dismissing it.

The statement of the facts heretofore made is taken from the petition, and for the purposes of this appeal must be accepted as true. There was no written or other agreement between any of the parties concerning the erection or use of this partition wall, and the point to be decided may be thus stated: Will a person, who uses for his own convenience and benefit an adjoining wall erected by another person, be required to contribute to the vendee of the person erecting the wall onehalf, or his fair proportion of the cost thereof? The center of the wall erected by appellants' vendors was the dividing line between their lot and the adjoining lot, now owned by appellee, and it may be conceded that, at any time before appellee took possession of the wall or commenced to use it as a party or partnership wall, it might have been removed by the persons who erected it or their vendees. Appellants, under the conveyances, became entitled to all the rights in the wall that their vendors had; in other words, their status was the same as if the wall had been erected by them. Acçurately, the question, narrowed down, resolves itself into this: If A. erects a wall, the center line of which is the dividing line between his property and that of B.'s and afterwards $B$. uses the wall without any agreement or arrangement, written or otherwise, to contribute to the expense of erecting the wall, will the mere fact that $B$. is using it as one of the walls of the building erected by him entitle $\mathrm{A}$. to recover from $\mathrm{B}$. his proportionate cost of the wall?

When appellee built up to this wall, and used it as one of the exterior walls of his building, appropriating to himself the use of the wall, and enjoying the benefits of the labor and money expended by the persons who erected it, it would seem fair and just that he should be re- 
quired to contribute toward the cost thereof. Numerous questions concerning party walls have come before the courts, and in many material particulars there is wide conflict and difference in the opinions concerning the rights and liabilities of the persons who erect the walls and those who use them. Generally, party walls are erected under an agreement as to their use, and in many states are regulated by statute, and often an issue has arisen as to whether these agreements are personal to the parties or covenants running with the land and enforcible by and against remote vendees of the persons who made the agreement at the time the wall was built. There was no privity of contract respecting this wall between appellants and appellee; nor can it fairly be said that appellee had any connection with the "expectation, assurance, and belief" existing in the mind of appellants' remote vendor when he erected this wall. But, back of this, there stands out in support of appellants' claim the substantial fact that appellee has appropriated to his own use a part of this party wall erected by appellants' vendors, without having paid anything therefor. So that, aside from any of the distinctions that involve the law of party walls in obscurity and doubt, there remains the proposition strongly put in behalf of appellants that justice and fair dealing demand that appellee should contribute towards the payment of a wall that he has used to his advantage and benefit. ***

In Sanders v. Martin, 2 Lea ('Tenn.) 213, 31 Am. Rep. 598, the facts were very similar to those here presented. Sanders and Martin owned adjoining lots in the city of Memphis, separated by a party wall. The houses were two stories high without any cellar. Sanders erected a three-story brick house on his lot, and used the party wall, raising it one story higher. He also, with the consent of Martin, made a cellar, which necessitated underpinning the party wall by a wall of the same thickness, one half on his lot and the other half on the lot of Martin. Sanders expected that, when Martin came to use the cellar and raise his house higher, he would contribute one-half the actual cost of these improvements. Afterwards Martin erected a building on his lot, using in its construction the wall erected by Sanders. Thereupon Sanders brought an action for contribution against Martin. In the opinion, the court said: "The common law is singularly obscure on this subject, and the decisions few, conflicting, and unsatisfactory. It seems certain that the common law does not recognize the right of the owner of land to compel the owner of an adjoining lot to build a party wall; nor can either demand contribution from the other for a wall erected in whole or in part on the land of such other nerson, nor for any incidental benefit the latter may derive from a wall erected entirely on the land of the builder. The authorities stop short of the case before us, and that is, whether, after the wall has been underpinned and raised in height by one for his own convenience, he can claim contribution from tie coowner when the latter actually uses these additions. In the forum of conscience the answer would at once be that the latter ought to pay the 
former for the benefit received by his.labor and expenditure. The argument of the learned counsel for the defendants is that this court is governed by the law, not by principles of abstract right; that the defendant Martin is not entitled to treat any erection made by a third party on his own land as his own; and, in fine, that the client stands upon the letter of the law, and claims all he can get. If one owner can rebuild a party wall, which has become dangerous, and compel contribution, it is clearly upon the equitable and moral principle that the expenditure is for the benefit of both, and that the right of easement is a sufficient basis upon which to justify interference and raise an implied contract. The same basis exists where a wall is added to and actually used. If both of these parties had dug their cellars and added additional stories to their houses at the same time, although only one of them built the addition to the party wall, a promise by the other to pay for the moiety of the wall would be implied. Is there any reason in law why the same implied promise would not arise where, after the addition had been made by one, the wall was used by the other? The relation of the parties created by the joint easement in the new wall would seem to be as efficient in the case of an addition to the wall as in the case of rebuilding the same wall. Upon the case made in the bill, if established by the testimony, the complainant is entitled to relief. * * * "

The conclusion we have reached is not free from doubt, and is contrary to the views held by a respectable number of courts; but we are of the opinion that a person who uses a wall erected on the dividing ine by the owner of the adjacent lot should pay a reasonable and fair price for the use thereof, estimated as of the time when the user takes place. And this, although neither he nor his vendor was a party to the erection of the wall, and made no agreement, express or implied, concerning it.

The judgment is reversed, with directions to proceed in conformity with this opinion. ${ }^{51}$

B1 "If a party, however, voluntarily accepts and avails himself of valuable serrices rendered for his benefit, when he has the option whether to accept or reject them, even if there is no distinct proof that they were rendered by his authority or request, a promise to pay for them may be interred. His knowledge that they were valuable, and his exercise of the option to avail himself of them, justify this inference. Abbot $v$. [Inhabitants of Third School Dist. in] Hermon, 7 Greenl. (Me.) 118 (1S30). Hayden v. Madison, 7 Greenl. (Me.) 76 (1830). And when one stands by in silence and sees valuable services rendered upon his real estate by the erection of a structure, (of which he must necessarily avail himself afterwards in his proper use thereof,) such silence, accompanied with the knowledge on his part that the party rendering the services expects payment therefor, may fairly be treated as evidence of an acceptance of it, and as tending to show an agreement to pay for it." Devens, J., in Day v. Caton, 119 Mass. 513, 515, 20 Am. Rep. 347 (1870).

See, also, Huck v. Flentye, 80 Ill. 258 (1S75) ; Bright v. J. Bacon \& Sons, 131 Ky. 848, 116 S. W. 268, 20 L. R. A. (N. S.) 386 (1909); Walker v. Stetson, 162 Mass. 86,38 N. E. 18, 44 Am. St. Rep. 350 (1894). 


\title{
SECTION 4.-EASEMENTS IN ARTIFICIAL WATER COURSES
}

\author{
WOOD et al. v. WAUD et al.
}

\author{
(Court of Exchequer, 1849. 3 Exch. 748.)
}

[A mine owner had for over sixty years pumped and discharged the surplus water from his mines through two underground conduits or "soughs," known as Bowling Sough and Low Moor Sough. They ran through, first, the land of the defendant, and then that of the plaintiff, and then discharged into a natural stream, called the Bowling Beck, which also ran through the plaintiff's land. The plaintiff had used the water for manufacturing purposes. The defendant so fouled, heated, and abstracted the water that it was rendered unusable in quality and insufficient in quantity for the use of the plaintiff. The plaintiff brings action for the damages so caused. Further facts are stated in the opinion.]

Pollock, C. B. ${ }^{52} * * *$ The remaining questions relate to the two soughs called Bowling Sough and Low Moor Sough, and are very important, and also novel. Both of these differ from the Bowling Beck in three respects: that was an immemorial stream, a natural stream, and flowing above ground; these are not immemorial, they are artificial, and flowing under ground. They differ, also, between themselves in one respect: that one, the Bowling Sough, was constructed in the land now belonging to the plaintiffs, and part of the water thereof was used by them, by a direct communication between the sough and the plaintiffs' reservoirs, for the purposes of the mill, before the alleged diversion by the defendants; the other, the Low Moor Sough, only communicated with the Bowling Beck, and not in the plaintiffs' land. Both agreed in one respect, that they were diverted before the waters flowing along them became part of the Bowling Beck
stream. $*_{*}$

The Bowling Sough and the Low Moor Sough being neither of them natural watercourses,-being under ground, and not immemorial,-a question of some nicety and difficulty arises as to the rights of the riparian proprietors upon these streams, or below their junction with the Beck. This question is not with respect to their rights as against the owners of those collieries which those soughs relieve from water, but as to the rights of those proprietors inter se; and it will be better to consider, in the first place, how they would stand if the streams were not under ground. With respect to a claim of right as against the colliery owners, if it be true that a right was gained to these streams by the riparian proprietors as against them, in consequence of their acquiescence for twenty years, by virtue of the presumption of a grant, or of I,ord Tenterden's Act ( $2 \& 3$ Will. 4, c. 71), there would be no diffi-

52 Part of the opinion is omitted. 
culty as to the right of the riparian proprietors as against each other, or other persons. But Mr. Cowling admitted that a grant could not be presumed, and that he should have great difficulty in establishing the right under Lord Tenterden's Act.

This Court, as then constituted, much considered that subject in the case of Arkwright v. Gell, 5 M. \& W. 231. We have again considered it, and are satisfied that the principles laid down as governing that case are correct, and were properly acted upon in it, by deciding that no action lay for an injury by the diversion of an artificial watercourse, where, from the nature of the case, it was obvious that the enjoyment of it depended upon temporary circumstances, and was not of a permanent character, and where the interruption was by the party who stood in the situation of the grantor. The Court of Queen's Bench, in a subsequent case, Magor v. Chadwick, 11 A. \& E. 571, supported a verdict for the plaintiff, for the disturbance of a right to the enjoyment of a stream, under circumstances somewhat similar; but in that case the action was not brought against the party in whose land the artificial watercourse commenced, nor any one claiming under him, and he had not put an end to it by altering the mode of working his mines; but, what is more important, the action was not brought for abstracting, but for fouling the water, a species of injury which does not stand on the same footing; for, though the possessor of the mine might stop the stream, it does not follow that he, or any other, could pollute it whilst it continued to run; and besides, from the course which the cause took at Nisi Prius, the precise question which we have now to consider does not appear to have called for decision. The two cases are, therefore, distinguishable: and the expressions used by the learned Judges in that case, as to the similarity of natural and artificial streams, are to be understood as applicable to the particular case.

We entirely concur with Lord Denman, C. J., that "the proposition, that a watercourse, of whatever antiquity, and in whatever degree enjoyed by numerous persons, cannot be enjoyed so as to confer a right to the use of the water, if proved to have been originally artificial, is quite indefensible"; but, on the other hand, the general proposition, that, under all circumstances, the right to watercourses, arising from enjoyment, is the same whether they be natural or artificial, cannot possibly be sustained. The right to artificial watercourses, as against the party creating them, surely must depend upon the character of the watercourse, whether it be of a permanent or temporary nature, and upon the circumstances under which it is created. The enjoyment for twenty years of a stream diverted or penned up by permanent embankments, clcarly stands upon a different footing from the enjoyment of a flow of water originating in the mode of occupation or alteration of a person's property, and presumably of a temporary character, and liable to variation.

The flow of water for twenty years from the eaves of a house could not give a rigint to the neighbour to insist that the house should not be pulled down or altered, so as to diminisl the quantity of water flowing from the roof. The flow of water from a drain, for the purposes of agricultural improvements, for twenty years, could not give a right to 
the neighbour so as to preclude the proprietor from altering the level of his drains for the greater improvement of the land. The state of circumstances in such cases shows that one party never intended to give, nor the other to enjoy, the use of the stream as a matter of right. If, then, this had been a question between the plaintiffs and the colliery owners, it seems to us that the plaintiffs could not have maintained an action for omitting to pump water by machinery (and in this the Court of Queen's Bench and Exchequer entirely agree in the case above cited). Nor, if the colliery proprietors had chosen to pump out the water from the pit, from whence the stream flowed continuously, and caused what is termed the natural flow to cease, could the plaintiffs, in our opinion, have sued them for so doing.

But this case is different. The water has been permitted to flow in an artificial channel by the colliery owners, and for sixty years. And the question is one of more difficulty, whether the plaintiffs can sue another person, a proprietor and occupier of the land above and through which the sough passes, not claiming under or authorized by them, for diverting the water.

The case of the Bowling Sough differs from the Low Moor Sough in this, that the plaintiffs, in 1838, used the water of the Bowling Sough where it passes through their land, by making a communication to their reservoir, for working the mill. Have the plaintiffs a right to the water of this sough, as described in the third count of the declaration? It appears to us to be clear, that, as they have a right to the use of the Bowling Beck, as incident to their property on the banks and bed of it, they would have the right to all the water which actually formed part of that stream, as soon as it had become part, whether such water came by natural means, as from springs, or from the surface of the hills above, or from rains or melted snow, or was added by artificial means, as from the drainage of lands or of colliery works; and if the proprietors of the drained lands or of the colliery augmented the stream by pouring water into it, and so gave it to the stream, it would become part of the current; no distinction could then be made between the original natural stream and such accessions to it.

But the question arises with respect to an artificial stream not yet united to the natural one.

The proprietor of the land through which the Bowling Sough flows has no right to insist on the colliery owners causing all the waters from their works to flow through their land. These owners merely get rid of a nuisance to their works by discharging the water into the sough, and cannot be considered as giving it to one more than another of the proprietors of the land through which that sough is constructed; each may take and use what passes through his land, and the proprietor of land below has no right to any part of that water until it has reached his own land,- -he has no right to compel the owners above to permit the water to flow through their land for his benefit; and, consequently, he has no right of action if they refuse to do so. 
If they polluted the water, so as to be injurious to the tenant below, the case would be different.

We think, therefore, that the plaintiffs have no right of action for the diversion of that water. The question as to the Low Moor Sough is less favourable to the plaintiffs, for this sough does not pass through their land at all.

We are of opinion, that, if the plaintiffs would not be entitled to the water of these soughs if above ground, their being below ground in this case would probably make no difference. It does not certainly make a difference in favour of the plaintiffs.

The issues on the seventh and ninth pleas ought, therefore, to be found for the defendants.

[Judgment on other pleas was given for the plaintiff.] ${ }^{\text {ss }}$

\section{MASON v. SHREWSBURY \& H. R. CO.}

(Court of Queen's Bench, 1871. L. R. 6 Q. B. Cas. 578.)

Cockburn, C. $\mathrm{J}^{54} * * *$ The plaintiff is the owner of lands to which a stream called the Ashton Brook flows in its natural course. Shortly before the commencement of the present century a canal company obtained power of an act of Parliament to divert, and under that power did in fact divert, at a point in the course of the stream above the plaintiff's land, the greater part of the water, while the rest continued to flow in its natural channel. In 1847 the defendants, a railway company, being empowered by act of Parliament, purchased the canal; and being likewise authorized by the act to discontinue the use of the canal, and to fill up and sell the bed, they, in 1853, exercised the power thus given, discontinued the use of the canal, discharged the water into the Ashton Brook, and adopted measures whereby the water diverted from the brook was again returned to it at a point above the plaintiff's land. The effect of this was to restore the flow of the water, so far as the plaintiff was concerned to its pristine condition, with one important exception - the bed of the stream had, owing to the diminished scour of the water during so many years, become partially silted up, so as to be insufficient to carry off, not indeed the water ordinarily flowing down it, but the water coming down in times of extraordinary flood. In 1866 such a flood occurred; the water overflowed the plaintiff's land, and did damage to his crops; and in respect of the damage thus done this action is brought.

The question is, whether, under these circumstances, the plaintiff is

63Acc.: Greatrex v. Hayward, 8 Exch. 291 (1S53); Hanson v. McCue, 42 Cal. 303, 10 Am. Rep. 299 (1871); Mitchell v. Parks, 26 Ind. 354 (186i).

"4 I'art of the oplinion and the judgments read by Blackburn, J., are omitted. 
entitled to recover. I agree with my learned Brothers in thinking that he is not. I differ from them in thinking that the question, whether the plaintiff has acquired any right as against the defendants, turns on the Prescription Aet ( $2 \& 3$ Wm. 4, c. 71$)$ alone. It appears to me to depend on a prineiple of the law relating to easements, which would have been equally applicable if the Act in question had never been passed.

The right of diverting water which in its natural course would flow over or along the land of a riparian owner, and of conveying it to the land of the party diverting it, the servitus aqux ducendx of the civilians is an easement well known to the law of this as of every other country. Ordinarily such an easement can be created, according to the law of England, only by grant, or by long continued enjoyment, from which the existence of a former grant may be reasonably presumed. But such a right may, like any other right, be created in derogation of a prior right by the action of the legislature. It was thus ereated in the present instance. But, however it may be called into existence, the right is essentially the same. The legal incidents connected with it are the same, whether the easement is created by grant or by statutory enactment. Now, it is of the essence of such an easement that it exists for the benefit of the dominant tenement alone. Being in its very nature a right created for the benefit of the dominant owner, its exercise by him cannot operate to create a new right for the benefit of the servient owner. Like any other right, its exercise may be discontinued, if it becomes onerous, or ceases to be beneficial, to the party entitled. An easement like the present, while it subjects the owner of the servient tenement to disadvantage by taking from him the use of the water, for the watering of his cattle, the irrigation of his land, the turning of his mill, or other beneficial use to which water may be applied, may, on the other hand, no doubt, be attended incidentally with equal or greater advantage to him, as for instance, by rendering him safe from the danger of inundation. But this will give him no right to insist on the exercise of the easement on the part of the dominant owner, if the latter finds it expedient to abandon his right. In like manner, where the easement consists in the right to discharge water over the land of another, though the water may be advantageous to the servient tenement, the owner of the latter cannot acquire a right to have it discharged on to his land, if the dominant owner chooses to send the water elsewhere, or to apply it to another purpose. And upon this principle, as it appears to me, might the case of Wood v. Waud, 3 Ex. $748 ; 18$ L. J. (Ex.) 305, have been decided without reference to the Prescription Act $(2 \& 3 \mathrm{Vm} .4$, c. 71$)$, or to the question as to whether there had been an enjoyment "as of right," so as to satisfy that statute. I prefer to rest my judgment on the principle-as it appears to me, a fundamental one-that an easement exists for the benefit of the dominant owner alone, and that the servient owner acquires 
no right to insist on its continuance, or to ask for damages on its abandonment.

I am far from saying that the grant of an easement might not be accompanied by stipulations on the part of the grantor; as, for instance, that the easement should not be discontinued without his consent, or that on its discontinuance certain things should be done. I am far from saying that such a stipulation would not give a right of action. My observations are intended to apply to a case in which nothing appears beyond the existence of an easement. In such a case, it appears to me beyond doubt that the servient owner acquires no right to the continuance of the easement and the incidental advantages arising to him from it, if the dominant owner thinks proper to abandon it.

If, in the present case, the Canal Act had made it incumbent on the company to continue the use of the canal, or had attached any specific obligations to the contingency of its disuse, the case would have been different. But nothing of the sort is to be found in the Act. The powers conferred by it are permissive; no conditions are attached to the discontinuance of the canal; the company acquire the right to take the water, without more. The exercise of the right is not compulsory. The company may abandon its exercise if they choose. I am at a loss to see how, under such circumstances, the plaintiff, in derogation of whose prior right the right of the company was given, can be said to have acquired a right to insist on the continuance of the easement.

The defendants, having been authorized to abandon the use of the canal and having in fact abandoned it, had, as it secms to me, no alternative but to allow the water to flow, undiminished in quantity, down the brook, in its natural course to the plaintiff's land. Their right to take the water being limited to taking it for the use of the canal, they could not have taken it for a different purpose, or so as to allow it to run to waste. So soon as they discontinued the use of the canal, their right to take the water ceased, and the plaintiff and the riparian owners lower down the stream again became entitled to have the whole of the water descend to them in its natural course; and, if the defendants had continued to divert the water, would have had legal ground of complaint and action; while the defendants could not have justified, inasmuch as they could not have alleged that the water was taken for the purpose of feeding and mairtaining the canal. It appears to me, therefore, quite clear that the defendants were right in restoring the water to its natural quantity before it reached the land of the plaintiff.

It is true that the proximate cause of the damage complained of, namely, the silting up of the channel, so as to render it less capable of carrying off the water at a time of flood, was brought about by the act of the defendants in diverting the water of the brook. But as this was the natural and necessary consequence of the diversion of the water, as authorized by act of Parliament, it follows that this result cannot bc imputed to the defendants as wrongful. If it be said that, having 
brought about this result, it was incumbent on them to have recourse to some engineering contrivance to prevent any damage in times of flood, or to restore the channel of the stream to its original condition, the general reasoning I have before set forth in respect of the obligations of a dominant owner apply, as shewing that no such duty was cast on the defendants either by the local act or by implication of law. In addition to which, as regards the restoration of the channel, it may be further observed that the defendants could not have entered on to the plaintiff's land, for the purpose either of ascertaining the condition of the channel or of restoring it, except by the leave and license of the plaintiff. No such leave and license was ever given. Far from calling on the defendants to repair the bed of the stream, the plaintiff acquiesced in the existing state of things from the year 1853, when the change took place, till 1866, when an extraordinary flood caused the overflow of the stream. Till that time neither he nor any one else appears to have entertained any doubt of the capacity of the channel to carry off the water at all times. The defendants, therefore, were not only not called upon to do anything to the channel, but would not have been justified in doing so.

The result is that the plaintiff is not entitled to recover, and that our judgment must be for the defendants.

Judgment for the defendants. ${ }^{55}$

\section{MATHESON et ux. v. WARD et al.}

(Supreme Court of Washington, 1901. 24 Wash. 407, 64 Pac. 520, 85 Am. St. Rep. 955.)

Mount, J. ${ }^{56}$ The Dungeness river rises in the Olympic Mountains, and flows in a northerly course through Clallam county into the Straits of Fuca. It is a rapid stream, and at time of freshets, which occur semiannually, frequently overflows its banks, and floods the surrounding low land, and does great damage to cultivated lands. Especially is this true near its mouth. About four miles south of its mouth, at a place known as "Potter's Crossing," the river forks into three branches. The east branch is known as "Hurd's Creek Channel," the central or main branch being known as the "East Channel," and the one further west as the "West Channel." Neither plaintiffs nor defendants own any of the land at these forks, nor within one or two miles thereof, but all own lands further to the north, which are subject to the overflow at times of high water; plaintiffs' land being some two miles from these forks, and along Hurd's creek channel, east of the main channel,

55 Compare Burk v. Simonson, 104 Ind. 173, 2 N. E. 309, 3 N. E. Sact, 54 Am. Rep. 304 (1585).

so lart of the opinion is omitted. 
and defendants' lands being about the same distance north, and on the west side of the main channel. Some time prior to the year 1865 one Le Balister built a wing dam somewhere near Potter's crossing, and about opposite the head of Hurd's creek channel, which diverted all the flow of water into the East channel and Hurd's creek channel, so that for a period of 30 years no water ran into the West channel, except probably at times some seepage; and this West channel thereby became obliterated as an active channel, and near its head trees and brush grew in the same, and banks were formed, so that no water ran out of the river into this channel except during very high water. In 1895 the owners of lands on the east side of said river and on Hurd's creek channel some two miles north of Potter's crossing, without the knowledge of those living on the west side, excavated at or near said crossing, which is the place at which the river forks as aforesaid, a channel of from 10 to 40 feet wide, from 2 to 4 feet deep, and 40 to 120 feet in length, and placed a wing dam in the main channel, so that thereafter almost the entire stream was thereby diverted from Hurd's creek channel and the East channel into the West channel. At times of high water the lowlands, including the lands of defendants, were flooded and badly damaged thereby. In January, 1900, defendants, who.own lands along and near this West channel to the north, attempted to clear out the driftwood and débris at and near the forks as aforesaid, in the East channel, and to close up the West channel, and thereby turn the water again into Hurd's creek and the East channel. "This action was brought by plaintiffs to restrain defendants from so doing. After a trial by the lower court, and findings in favor of the defendants, and judgment dismissing the complaint and giving defendants affirmative relief, plaintiffs appealed.

It is admitted in the cause that the Hurd's creek channel and the East channel are natural channels, in which the waters of the Dungeness river have been accustomed to flow from time immemorial. It is also admitted that from 1865 down to 1895 no water flowed in the West channel except a seepage, and at extreme high water, when the Dungeness river overflows it banks. *** Even if the West channel was a natural channel prior to 1865 , and was then dammed up, and the water diverted to the East and Hurd's creek channels, where it was confined for 30 years, and this flow was acquiesced in by the riparian owners and others along the channels of said river, this would make the East and Hurd's creek the natural channels; and defendants and others purchasing and improving lands along the old channel, and relying upon the flow continuing in the channels thereby formed, could not now have their lands damaged by reason of the water being turned back by artificial means after that lapse of time. After the lapse of 30 years the channels known as the "East" and "Hurd's Creek" became natural channels, and the attempt of riparian or other owners to change the flow at this late day to the injury of persons on the old channel would be unlawful. 
According to the evidence it is probably true that in the year 1865 one L.e Balister, by means of a dam or embankment, changed the flow of water out of the West channel. Conceding it to be so, the acquiescence by plaintiffs and their grantors and all riparian owners below the point of divergence for a period of 30 years has now lost them the right to change the flow from the new into the old channel. $28 \mathrm{Am}$. \& Eng. Enc. Law, p. 964; Woodbury v. Short, 17 Vt. 387, 44 Am. Dec. 344; Ford v. Whitlock, 27 Vt. 265; Ang. Water Courses, § 1081 . Gould, Waters, $\S 159$, says: "When a stream flowing through a person's land is diverted into a new channel, either artificially or by sudden flood, affecting the rights of other riparian proprietors favorably, and the owner acquiesces in the new state of the stream for so long a time that new rights accrue, or may be presumed to have accrued, such acquiescence is binding, like a public dedication, and the stream cannot be lawfully returned to its former channel." No doubt the plaintiffs, within a reasonable time after such diversion, could have removed the obstruction placed across the West channel by Le Balister; but when, after 30 years, they undertook to do so by virtually making a new channel, they were invading the rights of those below, who had purchased lands and improved the same. Hurd's creek and East channels having become the natural channels, defendants had the right to the natural flow through the same. Likewise, if the West channel had been opened without consent of the lower owners by artificial means, and these lower owners thereby suffered injury to their lands which were under cultivation by reason of the floods which would not naturally flow over their lands, they might replace the embankments, and restrain plaintiffs from interfering with the same. Ang. Water Courses, $\S \S 333,334,428$, 429; Gould, Waters, § 413; Mathewson v. Hoffman, 77 Mich. 420, 43 N. W. 883, 6 L. R. A. 349; Manufacturing Co. v. Brush, 43 Vt. 528. IVe have carefully examined the record, and are convinced that the findings of the lower court are correct, and in accordance with the weight of the evidence. ${ }^{57} * * *$

57 Acc.: Stiuson $\nabla$. Inhabitants of Brookline, 197 Mass. 568, 83 N. E. S9̈̈, 16 L. R. A. (N. S.) 2S0, 125 Am. St. Fiep. 3S2, 14 Ann. Cas. 907 (190S); Mathewson $\nabla$. Hoffman, 77 Mich. 420, 43 N. W. S79, 6 L. R. A. 349 (1Ss9). See Woodbury $\nabla$. Short, 17 Vt. 357, 44 Am. Dec. 344 (1845). Otlerwise where the actions of the upper riparian do not show an abandonment of the right to have the water flow through the natural channel. Peter 5 . Caswell, 38 Oliio St. 518 (1SS2).

The defendant, a lower riparian, dicerted the water into an artificial channel so that it flowed more rapidly. The plaintiff, an upper riparian, then built a mill upon the stream. The defendant subsequently restoled the stream to its original channel, so that the plaintiff's mill was rendered useless by the backed up water. The court held that the plaintiff could maintain an action for the damages so caused, saying:

"Where such diversion affects those above or below unfavorably, it requires fifteen years to give the right to continue the stream in the new channel. But if the diversion affects other proprietor's favorably, and the party on whose land the diversion is made acquiesces in the stream running in the new channel, for so long a time that new rights may be presumed to have accrued, or have in fact accrued, in faith of the new state of the 


\section{KRAY v. MUGGLI et al.}

(Supreme Court of Minnesota, 1901. $8+$ Minn. 90, 86 N. W. 882,54 L. R. A. 473,87 Am. St. Rep. 332.)

Brown, J. ${ }^{58}$ This was an action to restrain and enjoin defendants from removing or destroying a certain milldam across Sauk river at Cold Springs, in Stearns county. The defendants recovered in the court below, and plaintiff appeals from an order denying a new trial. A former appeal in the case is reported in 77 Minn. 231, 79 N. W. 964, 1026, 1064, 45 L. R. A. 218. The facts are substantially as follows: In 1856 a dam was built and constructed across Sauk river at Cold Springs, Stearns county, by the Cold Springs Mill Company, which has ever since, except during a short period in 1865 , when out of repair, been maintained for the purpose of developing water power to propel and operate mill machinery. No authority was obtained to so construct or maintain the dam by application or resort to legal proceedings, but the same was so built and constructed without special or granted right, and subsequently maintained by the mill company and its successors for over 40 years, with the acquiescence and consent of the owners of riparian property affected thereby, by reason of which continued maintenance, and the consequent raising of the level of the water, and the adverse, uninterrupted, and exclusive use of the dam for said period of 40 years, the mill company and its successors, Muggli and his grantors, acquired the right by prescription to perpetually maintain the same. The effect of the dam was to raise the level of the waters of the river to a height of $71 / 2$ feet, cause the same to set back and overflow large tracts of adjacent land to a distance of about 16 miles up the river, and the formation of several lakes and ponds along its course. By the construction of the dam, and the consequent raising of the level of the waters of the river, the greater part of the land described in the complaint has since that time been overflowed and rendered valueless for agricultural purposes.

The defendants, other than defendant Muggli, own land abutting upon the river, and are residents and freeholders of the towns through which the river runs and flows. Nearly all of said defendants and their grantors have for more than 40 years owned and occupied the lands so adjacent to said river and the lakes, and have cultivated and improved the same with reference to the conditions created and caused by the dam and the increased quantity of water occasioned thereby. Some of the defendants owned and occupied land bordering on the river prior to the construction of the dam, and so far as the record in the case shows at no

stream, the party is bound by such acquiescence, and cannot return the stream to its former channel." Tiedfield, C. J., in Ford v. Whitlock, $27 \mathrm{Vt}$. $265,267(1855)$.

Acc.: Delaney v. IBoston, 2 Har. (Del.) 4 S9 (1839).

38 Part of the oprinion is omitted. 
time did they object to the dam or to its maintenance. At the time of the construction of the dam the public domain in this section of the state was unsurveyed. It was subsequently surveyed, and with reference to the conditions existing, with the waters of the river raised above its natural level $71 / 2$ feet, and the lakes formed thereby were meandered in all respects as though natural bodies of water. Some time prior to the commencement of this action defendant Muggli, who owns the mill property, entered into a contract with the other defendants by which he attempted to sell and transfer to them the right to take out and remove the dam; such other defendants paying him for that right and privilege the sum of $\$ 5,000$. It is claimed by such defendants that by the removal of the dam large tracts of submerged land will be reclaimed and made valuable for agricultural purposes. Acting under this contract, such defendants threatened to take out and remove the dam, and this action was brought to restrain them from doing so.

Plaintiff in this action is in the actual possession, under claim of title, of land bordering on the river, and has improved the same with reference to the conditions existing subsequent to the construction of the dam. His improvements were made in reliance upon the continuance of such conditions, and that the level of the waters in the lakes would remain as it had existed for years prior thereto, and for purposes of a pleasure resort, and for boating, fishing, and other amusements, in and about which improvements he expended a large sum of money, which will be practically a total loss if the dam is taken out. A portion of the land has been used for the pasture of stock, and the stage of water as made by the dam is necessary to be maintained in order that he may fully enjoy his property. He placed a steamboat in the river at Cold Springs, which boat is used for transporting passengers from that point to a distance of about 20 miles up the river; and, if the waters are lowered to their stage before the erection of the dam, the river will be made nonnavigable, and the lakes almost wholly destroyed. $*^{*} *$

What right in law or equity has the plaintiff to insist upon the continued maintenance of the dam? The right to maintain it on the part of the mill company was acquired by prescription. The mill company, in erecting it, obtained no express grant to do so from the riparian owners; but the erection and maintenance thereof for more than 40 years created a prescriptive right to continue its maintenance perpetually. The inquiry is, what right, if any, accrued to the plaintiff and his grantors, and the other owners of property bordering on the river and the lakes formed thereby, as a result from the acts of the mill company and the acquisition by it of the prescriptive right to maintain the dam? The riparian owners improved their property, erected their buildings and fences with reference to the artificial stage of the water as made by the erection of the dam, and acquiesced in its maintenance during the time necessary to create and establish in the mill company and its successors the perpetual right to do so. 
It is contended on the part of plaintiff that there grew out of the relations between the parties, with respect to the construction and maintenance of the dam, reciprocal rights and privileges,- the right on the part of defendants to maintain it, and the right on the part of plaintiff to insist that it be maintained; while it is contended on the part of defendants that the only rights or privileges resulting from such relations accrued to them, that they may maintain the dam so long as they feel inclined to do so and then destroy it, regardless of the consequences to plaintiff and other riparian owners, and that the only right or benefit which accrued to plaintiff is the very valuable privilege of quietly submitting to the wishes and pleasure of defendants. We adopt the contention of plaintiff as most in consonance with the equity and justice of the case. If plaintiff and his grantors acquired a reciprocal right to have the dam maintained, it is not material that its removal will result in less injury and damage to them than to defendants. Prescriptive rights find no support in pecuniary considerations. It is a right or privilege appurtenant and incident to realty, and passes with the title thereto. ****

Snith v. Youmans, 96 IVis. 103, 70 N. W. 1115, 37 L. R. A. 285, 65 Am. St. Rep. 30, is also directly in point. It is there held that it is but a fair inference that riparian owners, in view of advantages that might or would accrue to them by raising the level of the waters of the lake on which their lands border, were induced to consent and acquiesce therein, and in the use of the dam and waters as raised thereby, in view of which it was held that the relations and interests of the parties thus originated and created became fixed by prescription, and imposed upon each reciprocal rights and duties. The court said: "It has long been settled that the artificial state or condition of flowing water, founded upon prescription, becomes a substitute for the natural condition previously existing, and from which a right arises on the part of those interested to have the new condition maintained. The water course, though artificial, may have originated under such circumstances as to give rise to all the rights riparian proprietors have in a natural and permanent stream, or have been so long used as to become a natural water course prescriptively; and when a riparian owner has diverted the water into an artificial channel, and continues such change for more than 20 years, he cannot restore it to its natural channel, to the injury of other proprietors along such channel, who have erected works or cultivated their lands with reference to the changed condition of the strcam, or to the injury of those upon the artificial water course who have acquired by long user the right to enjoy the water there flowing." See, also, Canton Iron Co. v. Biwabik Bessemer Co., 63 Minn. 367, 65 N. W. 643.

The dam in question, having been erected for the purpose of developing power to operate mill machinery, must be taken to be a permanent obstruction; and, it having existed and been maintained as such for so 
great a length of time, the artificial conditions created thereby must be deemed to have become the natural conditions. There is no suggestion in the evidence that the dam was placed in the river for temporary purposes, and, even though it may at one time have been out of repair, it was nevertheless originally intended as a permanent structure. The authorities all hold, as far as our examination has extended, that in such cases the conditions arising from the permanent obstruction, though artificial to begin with, become by long lapse of time the natural conditions, and interested parties are bound by the rules of law applicable to such conditions. Magor v. Chadwick, 11 Adol. \& E. 571; Beeston v. Weate, 5 El. \& Bl. 986; Roberts v. Richards, supra [50 Law J. Ch. 297]; Mathewson v. Hoffman, supra [77 Mich. 420, 43 N. W. 879, 6 L. R. A. 349] ; Finley v. Hershey, 41 Iowa, 389; Murchie v. Gates, 78 Me. 300, 4 Atl. 698.

In the case at bar even nature herself became adapted to the new surroundings. A native growth of hard-wood timber sprang up along the shores of the lakes formed by the raise of the river, thus giving a natural effect and appearance to the conditions created by the dam. The government, in the survey of the lands in that vicinity, recognized the artificial as the natural state, and surveyed the public lands with reference to the lakes, meandering them precisely as other natural bodies of water are surveyed and meandered. There can be no difference on principle between cases where the natural channel of a stream is changed and diverted, and those where a permanent obstruction is placed therein. In either case the rights of the parties are essentially the same.

An examination of the books discloses that this same doctrine is applied to public highways and public parks. Where a highway or public park has been laid out by lawful authority, or acquired by dedication or prescription, the owners of property abutting thereon acquire a special right in the continuance of the park, street, or highway, as the case may be, of which they cannot be deprived except by due process of law. * * *

Something was said on the argument with reference to the right of a mill owner to abandon his mill and permit the dam to become out of repair and finally destroyed by the elements, and the question was suggested as to whether he could be compelled to repair the same or be required to maintain the dam after its abandonment; and it is further mooted whether or not the riparian owners would have the right to enter upon the mill owner's property, in the case of his failure or neglect to keep the dam in repair, and put it in order and maintain it at their own expense. These questions are not involved in the case, and we do not decide them. When they are presented in any proper case, they will be taken up and disposed of in the usual way. It may be doubted whether the mill owner could be compelled to maintain the dam in good repair. No principle of law making it his duty to do so now occurs to us. But it is not so clear but that the riparian owners, having acqui- 
esced in the maintenance of the milldam for such a length of time as to create a perpetual right in the mill owner to maintain it, out of which, within the authorities we have cited, grew the reciprocal right to insist that it be not disturbed, and that the water as raised by the dam be maintained at its artificial height, would have the right to enter upon the property and repair any defects in the dam, and keep and maintain it in order and repair at their own expense. But these questions are not before the court, and we do not decide them, nor do we wish to be understood as expressing any opinion with reference thereto. The action is to restrain and enjoin defendants from taking any active or affirmative steps looking to the removal of the dam, and whether they may be compelled by law to keep it in repair is not involved in the determination of the case. We hold that they may be restrained from committing any overt act, and from taking any affirmative steps looking to the removal of the dam. Perhaps the apparent difficulties in the matter of keeping the dam in repair after abandonment by the mill owner may be relieved and obviated by an application of the provisions of chapter 88, Laws 1897.

We have not considered the question whether defendants could be restrained from taking out the dam because of the statutes prohibiting the draining of meandered lakes. The disposition of the case on the other question renders it unnecessary. The order appealed from is reversed.

START, C. J., dissents. ${ }^{50}$

50 A riparian cut a channel to cut off a loop in a stream flowing through his land. A large part of the stream flowed for over 30 years through the artificial channel, at which time an owner on the lower part of the channel elected a mill thereon. Held, the owner of the upper end of the channel cannot, 27 vears after the erection of the mill, turn the water back into the natural channel to the prejudice of the lower owner. Shepardson $\nabla$. Perkins, 58 N. H. 354 (1S7S). Acc.: Hollett v. Daris, 54 Wash. 326, 103 Pac. 423 (1909). See, also, Burrows v. Lang, [1901] 2 Ch. 502 ; Baily v. Clark. [1902] 1 Ch. 649; Murchie v. Gates, 78 Me. 300, 4 Atl. 69S (1ss6); Lake Drummond Canal \& Water Co. . Burnham, 147 N. C. 41, 60 S. K. 650, 17 L. R. A. (N. S.) 945,125 Am. St. Rep. 527 (190S); Fox River Flour \& Paper Co. v. Kellev, 70 Wis. 287,35 N. W. 744 (1887).

The Stanislaus \& San Joaquin Water Company owned the right to take water from the Stanislaus river for irrigation purposes, and also a distributillg canal. It made a contract with one Threlfall, the owner of 400 acres of land, whereby it agreed to furnish him with water for the said land for irrigation purposes at the annual price of $\$ 1.50$ per acre. Ditches were dug, connecting the canal with the land, and proper gates installed. The Stanislaus Water Company then succeeded to the title of the origmal company, and Bachman became the onner of the land. The Stanislaus Water Company furnished the water, but demanded a higher price, aud brought action therefor. The court held that the plaintiff was bound by the agreement. In the course of the opinion it said (per Shaw, J.):

"We have assumed that the right conferred on Threlfall by the agreemen with the canal company was real property. This is controverted by plaintiff, and its argument is, for the most part, founded on the assumption that it was either personalty, or that the agreement constituted nothing more than a personal covenant of that company which does not bind the plaintiff, as its successor. The think neither of these prolositions is corlect. That water in 
its natural situation upon the surface of the earth, whether as a flowing stream, as a lake or pond, or as percolations in the soil, is real property will not be disputed. That it may become personalty by being severed from the land and confined in portable receptacles is also evident. There is a remark in the opinion of Field, J., in People ex rel. Heyneman v. Blake, 19 Cal. 595 (1S62), which has apparently given rise to the notion that when water is confined in artificial channels it thereupon becomes personal property. The learned jurist there says: "Water when collected in reservoirs or pipes and thus separated from the original source of supply is personal property, and is as much the subject of sale-an article of commerce-as ordinary goods and merchandise.' The law then authorized the formation of corporations to engage in 'any species of trade or commerce.' 'The corporation in question was organized to ellgage in the business of distributing and selling water to the inhabitants of a city for their use. The question under discussion was the authority to organize such a corporation under that law. The language quoted from the opinion is apt for the disposition of the question to which it was addressed, but it is by no means tantamonnt to a decision that water becomes personalty as soon as it is diverted from its natural channel or situation. No such question was involved in that case. The earth is composed of land and water and the water is not different in this respect from other material substances composing a part of the earth. Trees when felled and cut into logs and lumber; coal, iron, gold, and silver when taken from the mine; rocks when quarried from their bed; oil when pumped from its depths; clay when burned into bricks or converted into cement-all are real property before tine change, but upon severance forthwith become personalty. The business of collecting water in reservoirs, conducting it in pipes to houses of a eity, and there selling and delivering it to the occupants of such houses, is a process of severing the water from its connection with the earth and changing it into Iersonal property. The person engaged therein is as much engaged in trade and commerce as is the miner, the oil producer, the brickmaker, or the cement manufacturer who sells his product. But the substances in which these persons deal do not become personalty until the severance is complete. The right to the water in the pipes and the pipes themselves, usually constitute an appurtenance to real property in such cases, and, if so, the water usually retains its character as realty until severance is completed by its delivery from the pipes to the consumer. The right in water which has been diverted into ditches or other artificial conduits, for the purpose of conducting it to land for irrigation, has been uniformly classed as real property in this state. "The right to water must be treated in this state as it has always been treated, as a right running with the land and as a corporeal privilege bestowed upon the occupier or appropriator of the soil; and as such, has none of the characteristic's of mere personalty.' Hill v. Newman, 5 Cal. 446, 63 Am. Dee. 140 (1S55). The risht to have water flow from a river into a ditch is real property; and so also is the water while flowing in the ditch. Lower Kings River Water Ditch Co. v. Kings River \& F. Canal Co., 60 Cal. 410 (1852). A wronglul diversion of water flowing in a ditch is an injury to real property. Last Chance Water Ditch Co. v. Emigrant Ditel Co., 129 Cal. 275. 61 Pac. 960 (1900). The right to take water from a river and conduct it to a tract of land is realt.v. South Tule Independent Ditch Co. v. King, 144 Cal. 454, 77 Pac. 1032 (1904). The right to have water flow through a pipe from a reservoir to and npon a tract of land is an appurtenance to the land. Standart v. Round Valley Watel Co., 77 Cal. 40:, 19 Pac. 689 (1SSS). An undivided interest in a ditch and in the water flowing therein is real property. Hayes v. Fine, 91 Cal. 398. 27 Pac. 772 (1891). A ditch for carrying wate is real estate. Smith v. O'IIara, 43 Cal. 376 (1872); Bradley v. Harkness, 26 Cal. 77 (1S64). And, where one person has water flowing in a ditch and another has the right to have a part of such water flow from the ditch to his land for its irrigation, the right of the latier is a servitude upon the ditch, and is real property. Dorris v. Sullivall, 90 Cal. 286, 27 Pac. 216 (1891). So, in the case at bar, the right of Threlfall and his successor, Bachman, under the agreement, to have the water flow flom the plaintift"s canal through the lateral ditch, to the land, for its irrigation, is a servitule upon the ditch and upon the canal, is an appurtenance to the land, and is 


\title{
SECTION 5.-AFFIRMATIVE EASEMENTS 0
}

\section{RIDER v. SMITH.}

\author{
(Court of Kïing's Bench, 1790. 3 Term R. 766.)
}

This was an action on the case for not repairing a private road leading through the defendant's ground. 'The declaration stated that the plaintiff on \&c, and long before, was and from thence hitherto hath been and still is possessed of a certain messuage \&c, and by reason of his possession thereof was entitled to a certain way from the said messuage unto into through and over a certain close of the defendant \&c unto and into the king's common highway \&c and so back again \&c from the said king's common highway unto into \&c to go pass and repass \&c; that the defendant now is and during all the time aforesaid hath been lawfully possessed of and in the said close called \&c, and of and in divers, to wit, two other closes of land in the parish of Manchester aforesaid, with the appurtenances, contiguous and next adjoining to the said close, \&c to wit, \&c. And that the defendant, by reason of his possession of the said close called \&c, and the said two closes of land with the appurtenances, contiguous and next adjoining thereto, during all the time aforesaid of right ought to have maintained and repaired and still ought to maintain and repair at his own proper costs and charges, when and so often as the same hath been necessary the said way leading \& $\mathrm{c}$, yet that he had wrongfully and injuriously permitted it to be ruinous and out of repair \&c; per quod \&c.

To this declaration there was a general demurrer, and joinder in demurrer.

Chambre, in support of the demurrer, objected to the declaration, because it did not shew by what right or obligation the defendant was bound to repair the road; he is not bound of common right, merely as occupier. Declaring generally on possession is not sufficient against the owner of the soil, tho' it is against a wrong doer. Strode v. Byrt, 4 Mod. 420. Kenrick v. Taylor, 1 Wils. 326. Waring v. Griffith, 1 Burr. 443. In Keilw. 52, p1. 4, a distinction was taken between the mode of charging the owner of the inheritance, and the occupier only, with the repair of a road; against the latter it is necessary to allege a prescription, though not against the former. So in R. v. Sir T. Fanshaw, 1 Ventr. 331, an indictment for not repairing a bridge against the de-

real property." Stanislaus Water Co. จ. Bachman, 152 Cal. 716, 725, 9:3 Pac. 858,15 L. R. A. (N. S.) 359 (1908).

60 For the most part obligations which impose a duty of affirmative action upon the part of an owner of land do not come within the category of what were recognized by the common-law courts as easements; moreover, they are ordinarily created by language of promise rather than by language of grant. See post, chapter's $I V$ and $V$. 
fendant ratione tenuræ was held good. But in Sty. 400, such an indictment by reason of his tenements was quashed. This latter authority therefore is directly in point.

Wood, contra. Formerly a distinction was taken between a charge against a wrong-doer, and against the owner of the land: but it is now sufficient to declare generally on the possession of the defendant, and to charge him in respect of that possession. The precedents for above this last century have been in that form, and no objection has hitherto been made to them. And in Blockley v. Slater, 1 Lutw. 119, it was held sufficient. Sands v. Trefuses, Cro. Car. 575. So in an action for not grinding at the plaintiff's mill, it is sufficient to say that the inhabitants ought of right to grind their corn there. Chapman v. Flexman, 2 Ventr. 291. It seems admitted that if the defendant had been charged by reason of his tenure it would have been sufficient: now this amounts to the same thing; for the onus prima facie goes with the possession.

The Court were clearly of opinion that the declaration sufficiently charged the defendant by reason of his possession. And

BULLER, J. said the distinction was between cases where the plaintiff lays a charge upon the right of the defendant, and where the defendant himself prescribes in right of his own estate. In the former case, the plaintiff is presumed to be ignorant of the defendant's estate, and cannot therefore plead it, but in the latter the defendant, knowing his own estate in right of which he claims a privilege, must set it forth. In R. v. Sir J. Bucknall, 2 Ld. Raym. 804, Lord Holt said "where a man is obliged to make fences against another, it is enough to say omnes occupatores ought to repair \&c, because that lays a charge upon the right of another, which it may be he cannot particularly know." And notwithstanding two out of three of the judges were of a different opinion in Holback v. Warner, Cro. Jac. 665 ; yet several subsequent cases have been determined on the above distinction. In 1 Ventr. 264, there is the report of an action on the case against the defendant for not repairing a fence, where the alleyation was that the tenants and occupiers of such a parcel of land adjoining the plaintiff's have time out of mind maintained it \&c; Holt moved in arrest of judgment "that the prescription is laid in occupiers, and not shewn their estates; and that hath been judged naught in 1 Cro. 155, and 2 Cro. 665." But the Court said "it is true there have been opinions both ways; but 'tis good thus laid, for the plaintiff is a stranger and presumed ignorant of the estate: but otherwise it is if the defendant had prescribed." So in Tenant v. Goldwin, Salk. 360, in an action on the case for not repairing a wall "debuit reparare" was held sufficient. The case of Winford v. Woollaston, 3 Lev. 266, is also to the same effect.

Judgment for the plaintiff. ${ }^{61}$

61 In Middlefield v. Church Knitting Mills Co., 160 Mass. 267,35 N. E. $780^{\circ}$ (1S94), the plaintiff brought action to recover moneys expended in repairing 


\section{BRONSON v. COFFIN et al.}

(Supreme Judicial Ccurt of Massachusetts, 1871. 10S Mass, 175, 11 Am. Rep. 335).

Contract upon the covenant against incumbrances, contained in a deed from the defendants to the plaintiff, dated May 24, 1866. Writ dated September 28, 1868. Trial in the superior court, before Putnam, J., who made the following report thereof:

"The land in question was situated in New Bedford, and came to the defendants under the will of the late Timothy G. Coffin, and was a portion of his farm.

"On April 6, 1839, the said Coffin conveyed a strip of land fiftyfive rods in length and four and three tenths rods wide, running through the land in question, to the New Bedford \& Taunton Railroad Company, by a deed which contained the following clause: ' $I$, the said $T$. G. Coffin, hereby covenant that I and my heirs and assigns will make and maintain a sufficient fence through the whole length of that part of the railroad which runs through my farm; this covenant of maintaining the fence to be perpetual and obligatory upon me and all persons who shall become owners of the land on each side of said railroad.'

"The defendants contended that this clause did not constitute an incumbrance on the land, but created merely a personal obligation. But the judge, for the purposes of the trial, ruled that it did constitute an incumbrance upon the whole of the land now owned by the plaintiff, and which he held under said deed. To this ruling the defendants excepted.

GraY, J ${ }^{62}$ [After quoting the language of the deed from Coffin to the railroad:]

The principal question in the case is, whether the obligation thus expressed, to maintain a division fence between the land granted and the adjoining lands of the grantor, created a charge upon those lands, binding upon any assignee thereof, either by way of covenant running with the lands, or grant of an interest in the nature of an easement

a bridge. The declaration alleged that the defendant and its predecessors in title of a certain piece of land were, as owners thereof. under a duty to the llaintiff town to keep the bridge in repair and had failed so to do. In sustaining the action of the lower court in overuling a demurrer to the declaration. the court said, per Holmes, J. (160 Mass. p. 271, 35 N. E. 782): "It is true that, in general, active duties cannot be attached to land and that aflimative covenants only bind the covenantor, his heirs, executors, and adninistrators. But there are some exceptions, and most conspicuous amongr them is the obligation to repair fences and highways."

See Perley v. Chandler, 6 Mass. 454, 4 Am. Dec. 159 (1810).

In Whittenton Mfg. Co. v. Staples, 164 Mass. 319,41 N. L. 441, 29 L. K. A. $500(1895)$, the court enforced against land owned by the defendant a prescriptice obligition to pay a proportionate part of the annual cost of keeping up a dam supplying water power to land so owned.

62 The statement of facts is abridged and part of the opinion is omitted. 
therein, which constituted an incumbrance, within the meaning of the covenant against incumbrances in a subsequent deed thereof from the grantor or those claiming title under him.

"On general principles," said Chief Justice Parsons, "every right to or interest in the land granted, to the diminution of the value of the land, but consistent with the passing of the fee in it by the conveyance, must be deemed in law an incumbrance." Prescott v. Trueman, 4 Mass. 627, 629, 3 Am. Dec. 246.

Words sounding in covenant only may operate by way of grant of an easement, wherever it is necessary to give them that effect in order to carry out the manifest intention of the parties. Bro. Ab. Covenant, 2; Holmes v. Seller, 3 Lev. 305; Rowbotham v. Wilson, 8 H. L. Cas. 348; Greene v. Creighton, 7 R. I. 1; Norfleet v. Cromwell, 64 N. C. 1.

In the general definitions of easements in the text books, it is indeed sometimes said that they consist either in suffering something to be done, or in abstaining from doing something, upon the servient tenement. 3 Kent, Com. (6th Ed.) 419; Washburn on Easements (2d Ed.) 4, 5; Gale on Easements (4th Ed.) 5. But the obligation to maintain a fence by prescription or agreement is classed by the same writers with easements, though Mr. Gale calls it a "spurious easement," and one of his editors "a right in the nature of an easement." 3 Kent, Com. 438; Washburn on Easements, 524; Gale on Easements, 117, $460,487,488,524$, note. See also Hunt on Boundaries and Fences (2d Ed.) $49,51,99$.

In England, it has been well settled from very early times, and never denied, that an obligation of the owner of land to fence against land adjoining may be established by prescription, and if so established is a charge upon his land. Had this not been so, the point, formerly much mooted, whether such a charge was extinguished by unity of possession and title of the two closes, could not have arisen. Fitz. N. B. 128, note; Anon., Dyer, 295 b; Sury v. Pigot, Pop. 166, 170, 172; s. c. Noy, 84; Latch, 153, 154 ; Polus v. Henstock, 1 Ventr. 97 ; s. c. 2 Keb. 686, 707; T. Raym. 192; Star v. Rookesby, 1 Salk. 335; Vin. Ab. Fences, pl. 164, 166; Boyle v. Tamlyn, 9 D. \& R. 430 ; s. c. 6 B. \& C. 329; Barber v. Whiteley, 34 L. J. N. S. (Q. B.) 212. In Boyle v. Tamlyn, Mr. Justice Bayley said: "Such a right to have fences repaired by the owner of adjoining land is in the nature of a grant of a distinct easement, affecting the land of the grantor." 9 D. \& R. 437, and 6 B. \& C. 338, 339. And Justices Littledale and Holroyd appear to have concurred in his vicw. 9 D. \& R. 439, 440.

In Massachusetts, the doctrine has always been recognized, that the owner or occupier of land may be bound by prescription to a more extensive obligation to keep up and repair the division fences than would be imposed upon him by the common law or by the statutes of the commonwealth. Rust v. Low, 6 Mass. 90, 94, 97; 2 Dane, Ab. 659, 660; Minor v. Deland, 18 Pick. 266, 267; Thayer v. Arnold, 
4 Metc. 589, 590. In Binney v. Hull, 5 Pick. 503, 506, it was adjudged that the owner of one of two adjoining lots of land might be bound by prescription to maintain the fence between them; and Chief Justice Parker spoke of the right to have him do so, as an easement in his land. ***

In the deed now before us, the covenant to maintain a fence upon the line of division between the land granted to the railroad corporation and the lands retained on either side thereof is made by the grantor, and is in terms declared to bind his heirs and assigns and to be intended to be perpetual and obligatory upon him and all persons who shall become owners of the lands on each side of the railroad, and this obligation is imposed upon all of them only as owners and by virtue of their ownership. It would be difficult to express more clearly an intention that the duty of maintaining the fence should be a charge upon these lands into whose hands soever they should come. The manifest purpose was to regulate the mode of occupying the lands retained, for the purpose of securing to the grantees the full beneficial use of the land granted, by establishing a permanent barrier to prevent all persons and cattle from straying upon it. The necessary conclusion is, upon principle and authority, that the terms of Coffin's deed conveyed to his grantees an interest in the nature of an easement in his adjoining lands, and thus created a sufficient privity of estate between them and his assigns, to support the covenant to maintain the fence as a covenant running with the lands adjoining; and that such easement and covenant constituted an incumbrance, which was a breach of the covenant against incumbrances in the subsequent deed to the plaintiff, upon which this action is brought. It was therefore rightly ruled at the trial, that the clause in Coffin's deed did not create a merely personal obligation, but constituted an incumbrance upon his adjoining lands.

[A new trial was ordered for misdirections upon another point.] ${ }^{63}$

63 Acc.: Hazlett v. Sinclair, 76 Ind. 485, 40 Am. Rep. 254 (1881). Compare Louisville \& N. R. Co. v. Webster, 106 Tenn. 5S6, 61 S. W. 1018 (1901).

Upon a second trial of Bronson v. Coffin the defendant requested an instruction in substance that if the plaintiff should diride the land in question into lots learing one narrow lot contiguous to the railroad and should sell the other lots, the purchasers of the lots not contiguous to the railroad would take free from the obligation to feuce. Held, the instruction should have been given. Bronson v. Coflin, 118 Mass. 156 (1875). 


\section{CASTNER v. RIEGEL et al.}

(Supreme Court of New Jersey, 1892. 54 N. J. Law, 498, 24 At1. 484.)

Certiorari at the prosecution of Emmeline Castner against John $\mathrm{F}$. Riegel and others to review an order by two of the township committee of Washington township, determining and directing that a part of certain line fences should be made and maintained by prosecutor and another portion by defendant Riegel. Order set aside.

Argued at November term, 1891, before ScudDER and Magre, JJ.

MAGIE, J. Prosecutrix attacks the order brought before us by this writ, upon the ground that the members of the township committee were without jurisdiction to make it. Her contention is that the defendant Riegel is bound by law to make and perpetually maintain a fence along the whole of the line in question dividing his lands from hers, and that consequently the provisions of the fence act relative to the determination of the part of a division fence to be made and maintained by each of two owners bound to make and maintain it equally cannot apply. The fence act imposes on the owners of adjoining lands the duty of making and maintaining a just proportion of the partition fence, except such persons as shall choose to let their adjoining lands lie vacant and open. The act provides that under certain circumstances two of the township committee nay determine what part of the partition fence shall be maintained by each owner. But if one of the owners is under obligation to make and maintain the whole fence, it is obvious that the statute is inapplicable, and there will be no power to divide the fence. Such was the interpretation given to a similar law in New York. Adams v. Van Alstyne, 25 N. Y. 232. It becomes necessary, therefore, to inquire whether the obligation to make and maintain the whole of the partition fence in question rests upon the defendant Riegel.

The contention of prosecutrix is that he, and those under whom he claims, owners of the lands adjoining hers, and separated by the fence, have, for the period of about 38 years, continually mended and maintained said fence, and that thereby a right in the nature of an easement has been acquired in favor of her lands, and a duty has been imposed upon the lands now owned by him and its owners, to continually amend and maintain the fence. That an obligation to maintain partition fences might arise by prescription, which could be enforced by the writ curia claudenda at common law, does not admit of doubt: This right was said by Gale \& Whatley to be a spurious kind of easement. Gale \& IV. Easem. 201, 202. The easement seems to be founded upon the duty which at common law required the owner of a close, at his peril, to keep his cattle thereon, and to prevent them from trespassing on an adjoining close; and when the owner of the latter erected a fence for his protection, and maintained it for the prescriptive period, he was 
deemed to have discharged his neighbor from his original duty, and to have become bound to protect his own close by some grant or argument the evidence of which was lost by lapse of time. But in whatever way the right arose, there can be no question that it did arise by prescription at common law. Com. Dig. Droit, M 1 and M 2; Vin. Abr. "Fences," E; Washb. Easem. 634; Ivins v. Acherson, 38 N. J. Law, 220; Lawrence v. Jenkins, L. R. 8 Q. B. 274.

Did this feature of the common law become a part of the law of New Jersey, and has it been modified or repealed by our legislation concerning fences? Those questions do not seem to have been hitherto mooted in our courts. In other states with similar laws such questions have been dealt with. The earliest case is Rust v. Low, 6 Mass. 90, and the opinion is by Chief Justice Parsons. It was held that since, at the original settlement of the country, no prescription to fence could exist, the common law authorizing the writ of curia claudenda, being inapplicable to the state of the colony, was never introduced into Massachusetts. But it was also held that since, under their statute, (which closely resembles our fence act,) adjoining owners were bound to make and maintain an equal part of the division fence, and could agree upon the parts to be made and maintained by each respectively, or, in default of an agreement, could procure an assignment of the part each should make and maintain, and since the country had then been settled long enough to allow the time necessary to prove a prescription, and ancient assignments or agreements might have existed and been lost, a right by prescription (which at common law was presumed to stand on a lost grant) might be set up and proved by ancient usage. The doctrine of that case was applied in Binney v. Proprietors, 5 Pick. (Mass.) 503, and approved in Thayer v. Arnold, 4 Metc. (Mass.) 589, and in Bronson v. Coffin, 108 Mass. 175, 11 Am. Rep. 335. Evidence that a fence was originally erected by one owner of the land it adjoined, and maintained for 30 years by his grantees, was held to require a presumption of an original grant or agreement establishing a division of the fence, and imposing an obligation to maintain. Knox v. Tucker, 48 Me. 373, $77 \mathrm{Am}$. Dec. 233. A charge that, if the owners of land, or those from whom they derived title, had, for a sufficient period, severally maintained well-defined portions of a division fence, each repairing a part, and recognizing his obligation to do so, a division by prescription was established, was held correct. Harlow v. Stinson, 60 Me. 347.

A valid prescription, by which an owner of land would become bound to maintain perpetually the whole of a division fence between him and an adjoining owner, was recognized by Judge Denio in the New York court of appeals, but it was held that no obligation to maintain would be established by proof that one owner had maintained for any length of tine an equal or just proportion of a division fence. Adams v. Van Alstyne, ubi supra. In the courts of New Hampshire and Connecticut the power to acquire such a right in the maintenance 
of a division fence by user or prescription is denied, but in the latter state the common-law obligation of owners to keep upon their own land their cattle no longer exists. Glidden v. Towle, 31 N. H. 147; Wright v. Wright, 21 Conn. 330. The true doctrine upon this subject, in my judgment, lies between the extremes indicated by the decisions referred to. A right in favor of the owner of one of two adjoining tracts of land to have the division fence perpetually maintained for the whole or a specified part of the boundary line by the owner of the other tract may undoubtedly be created by grant or agreement. Such a right is in the nature of an easement, and is a burden imposed on a servient tenement in favor of a dominant tenement. Easements may be established by proof of a continuous, uninterrupted, and adverse user in this state for that period of time which by analogy now suffices for what may yet be called "prescription," viz., 20 years. Railroad Co. v. McFarlan, 43 N. J. Law, 605. Such user affords, in general, a conclusive presumption of a lost grant. The difficulty in applying to the case of a boundary fence the doctrine of easements acquired by user is obvious. The common-law rule respecting the protection of lands by fences has been here modified by the statute, which imposes on owners of lands lying adjacent an obligation and duty to maintain each a just proportion of a division fence. What part each should make and maintain may be determined by their mutual agreement, or by the determination of two of the township committee, made in the manner prescribed. When for a period of over 20 years the owner of one of two adjoining tracts has continuously, without interruption, and as of duty, repaired and maintained the whole of the division fence. in my judgment a presumption would arise that he or those under whom he derived title were, as owners of a servient tenement, bound to perpetually make and maintain the fence. ${ }^{64}$ The existence of a former and lost agreement to do so may be inferred, and no other inference would be consistent with the circumstances.

But the difficulty arises when the owrer of one tract has maintained in the manner mentioned only a part of the division fence. An obligation to perpetually maintain a specific portion of such a fence may be acquired and imposed by grant or agreement. But will the continuous maintenance for 20 years of only a part of the division fence-no grant or agreement being actually in existence-justify a presumption of an obligation to perpetually maintain that portion? If, by the statute, the determination of two of the township committee fixing the portion of the division fence to be maintained by each owner is designed to fix the obligations of the owners forever, without reference to subsequent changes in ownership and the introduction of new divi-

64Acc.: Titus v. Pennsylvania R. Co., st న. J. Law, 157, 92 Atl. 944, Amn. Cas. 1917B, 1251 (1914).

As to how far the servient is responsible for lreaches in the fences occurring without negligence on his part, see Lawrence r. Jenkins. L. R. 8 Q. Is. 274 (1873). Compare Bell v. Twentyman, 1 A. E E. N. S. 766 (1841). 
sion lines, then a 20-years maintenance of a part of the fence would justify the presumption of an obligation to maintain it, arising by an agreement or grant in respect to that part. But such a construction of the fence act would, in my judgment, be indefensible. The subject of the act is the boundary fence of adjoining lands of different owners. It obliges them to maintain such a fence in just proportion, to be fixed by agreement or determination of the township committee. When one of two such adjoining tracts is subdivided by grant, so that the boundary of the granted tract adjoins that of the tract undivided, there arises a new subject for the operation of the act, viz., the boundary fence of adjoining lands of different owners. And since the act requires the fixing of a just proportion of fence to be maintained, it is plain that the original agreement or determination must cease to operate, to be replaced by a new agreement or determination in respect to the boundary which remains between the original owners. Any other construction would be opposed to the spirit of the act, and would produce great confusion and injustice. The construction does no violence to the language of the act. The result is that the continued maintenance for any length of time of a part only of a division fence must be deemed to be referable-in the absence of proof of an express agreement-to an agreement or an assignment made under the statute, and no presumption will arise of a perpetual obligation to maintain that portion of the fence. This was the conclusion arrived at in Adams v. Van Alstyne, ubi supra. The construction given to the fence act harmonizes with the view that the agreement of adjoining owners respecting division of the fence between them may be by parol. Ivins v. Ackerson, 38 N. J. Law, 222.

The contention of prosecutrix that defendant Riegel is shown by the evidence to be under a perpetual obligation to maintain the fence, which was divided by the determination of the township committee, cannot prevail. The evidence shows that the lands of prosecutrix and Riegel adjoin for a distance of about 183 perches. The fence which the committee divided extends for less than 118 perches. It is therefore only a part of the fence which the statute requires both adjoining owners to maintain. The proof that Riegel and those under whom he claims have continuously, and as if under duty to do so, maintained for over 30 years this part of the fence, does not establish a right in the nature of an easement for the continued maintenance thereof. The proofs raise only a presumption that previously, by agreement or determination, the whole boundary line had been divided, and the part which is now in question had been taken by or assigned to the owner of the land now Riegel's. Nor is this presumption affected by the fact that the part so maintained considerably exceeds the remainder of the boundary fence. The act requires each owner to make and amend a just proportion of the fence, and in declaring that it shall be equally divided requires regard to be had to the quantity of fence necessary, and other conveniences of fencing. But the conclusion arrived at on 
the proofs is fatal to the jurisdiction of the township committee, for they establish either an agreement on the part of the owners of the Riegel tract to make and maintain the fence in question as the just proportion of the whole boundary fence, or a previous determination to that effect under the statutes. In either case, the committcemen had no right to act.

In my judgment, jurisdiction to make any determination in respect to this fence is also shown not to exist by the mere proof that it comprises only a part of the whole division fence between the lands of the parties. The act plainly contemplates a division of the whole fence, and neither party can invoke its aid to divide it by piecemeal.

\section{SECTION 6.-EXTINGUISHMENT OF EASEMENTS}

\section{MOORE v. RAWSON.}

(Court of King's Bench, 1824. 3 Barn. \& C. 332.)

Case for obstructing lights. Plea, not guilty. At the trial before Hullock, B., at the last Spring assizes, for the county of Derby, it appeared, that the plaintiff was seised in fee of a messuage and building, with a yard, garden, and appurtenances, situate at Ripley, in that county, in the occupation of a tenant from year to year. The defendant was the owner of other messuages and premises next adjoining the plaintiff's, on the northern side thereof. The plaintiff's messuage was an ancient house, and adjoining to it there had been a building formerly used as a weaver's shop. The old shop had ancient windows, for the convenience of light to the weavers who worked looms there. About seventeen years ago the then owner and occupier of the premises took down the old shop, and erected on the same site a stable, having a blank wall next adjoining to the premises of the present defendant. This building had latterly been used as a wheelwright's shop. About three years ago, and while the plaintiff's premises continued in this state, the defendant erected a building next to the blank wall, and the plaintiff then opened a window in that wall, in the same place where there had formerly been a window in the old wall, and the action was brought for the obstruction of this new window by the building so erected by the defendant. The learned Judge directed the jury to find a verdict for the plaintiff, but reserved liberty to the defendant to move to enter a nonsuit.

Аввотт. C. J. I am of opinion, that the plaintiff is not entitled to maintain this action. It appears that many years ago the former owner of his premises had the enjoyment of light and air by means of certain windows in a wall of his house. Upon the site of this wall he built a 
blank wall without any windows. Things continued in this state for seventeen years. The defendant, in the interim, erected a building opposite the plaintiff's blank wall, and then the plaintiff opened a window in that which had continued for so long a period a blank wall without windows, and he now complains that that window is darkened by the buildings which the defendant so erected. It seems to me that, if a person entitled to ancient light, pulls down his house and erects a blank wall in the place of a wall in which there had been windows, and suffers that blank wall to remain for a considerable period of time, it lies upon him at least to show, that at the time when he so erected the blank wall, and thus apparently abandoned the windows which gave light and air to the house, that was not a perpetual, but a temporary abandonment of the enjoyment; and that he intended to resume the enjoyment of those advantages within a reasonable period of time. I think that the burthen of showing that lies on the party who has discontinued the use of the light. By building the blank wall, he may have induced another person to become the purchaser of the adjoining ground for building purposes, and it would be most unjust that he should afterwards prevent such a person from carrying those purposes into effect. For these reasons I am of opinion, that the rule for a nonsuit must be made absolute.

LITTLEDALE, J. According to the present rule of law, a man may acquire a right of way, or a right of common, except, indeed, common appendant) upon the land of another, by enjoyment. After twenty years' adverse enjoyment, the law presumes a grant made before the user commenced, by some person who had power to grant. But if the party who has acquired the right by grant ceases for a long period of time to make use of the privilege so granted to him, it may then be presumed that he has released the right. It is said, however, that as he can only acquire the right by twenty years' enjoyment, it ought not to be lost without disuse for the same period; and that as enjoyment for such a length of time is necessary to found a presumption of a grant, there must be a similar non user, to raise a presumption of a release. And this reasoning, perhaps, may apply to a right of common or of way. But there is a material difference between the mode of acquiring such rights and a right to light and air. The latter is acquired by mere occupancy; the former can only be acquired by user, accompanied with the consent of the owner of the land; for a way over the lands of another can only be lawfully used, in the first instance, with the consent, express or implied, of the owner. A party using the way without such consent would be a wrong doer; but when such a user, without interruption, has continued for twenty years, the consent of the owner is not only implied during that period, but a grant of the easement is presumed to have taken place before the user commenced. The consent of the owner of the land was necessary, however, to make the user of the way (from which the presumption of the grant is to arise) lawful in the first instance. But it is otherwise as to light and air. Every man 
on his own land has a right to all the light and air which will come to him, and he may erect, even on the extremity of his land, buildings with as many windows as he pleases. In order to make it lawful for him to appropriate to himself the use of the light, he does not require any consent from the owner of the adjoining land. He therefore, begins to acquire the right to the enjoyment of the light by mere occupancy. After he has erected his building, the owner of the adjoining land may, afterwards, within twenty years, build upon his own land, and so obstruct the light which would otherwise pass to the building of his neighbor. But if the light be suffered to pass without interruption during that period to the building so erected, the law implies, from the non-obstruction of the light for that length of time, that the owner of the adjoining land has consented that the person who has erected the building upon his land shall continue to enjoy the light without obstruction, so long as he shall continue the specific mode of enjoyment which he had been used to have during that period. It does not, indeed, imply that the consent is given by way of grant; for although a right of common (except as to common appendant) or a right of way being a privilege of something positive to be done or used in the soil of another man's land, may be the subject of legal grant, yet light and air, not being to be used in the soil of the land of another, are not the subject of actual grant; but the right to insist upon the non-obstruction and non-interruption of them, more properly arises by a covenant which the law would imply not to interrupt the free use of the light and air. The right, therefore, is acquired by mere occupancy, and ought to cease when the person who so acquired it discontinues the occupancy. If, therefore, as in this case, the party who has acquired the right once ceases to make use of the light and air which he had appropriated to his own use, without showing any intention to resume the enjoyment. he must be taken to have abandoned the right. I am of opinion, that as the right is acquired by mere user, it may be lost by non user. It would be most inconvenient to hold, that the property in light and air, which is acquired by occupancy, can only be lost where there has been an abandonment of the right for twenty years. I think, that if a party does any act to show that he abandons his right to the benefit of that light and air which he once had, he may lose his right in a much less period than twenty years. If a man pulls down a house, and does not make any use of the land for two or three years, or converts it into tillage, I think he may be taken to have abandoned all intention of rebuilding the house; and, consequently. that his right to the light has ceased. But if he builds upon the same site, and places windows in the same spot, or does any thing to show that he did not mean to convert the land to a different purpose, then his right would not cease. In this case, I think that the owner of the plaintiff's premises abandoned his right to the ancient lights, by erecting the blank wall instead of that in which the ancient windows were; for he then indicated an inten- 
tion never to resume that enjoyment of the light which he once had. Under those circumstances. I think that the temporary disuse was a complete abandonment of the right.

Rule absolute. ${ }^{65}$

\section{CRAIN v. FOX.}

(Supreme Court of New York, 1853. 16 Barb. 184.)

GRIDLEY, J. ${ }^{60}$ This was an action to recover the possession of a piece of land that had been laid out as a private road, through the farm of the plaintiff, near fifty years ago. It is immaterial whether the road was legally laid out or not; as even if it was illegally laid out, it would form the basis on which an adverse use and a prescriptive right to the easement might be founded. It was used as such private way more than twenty years, by the defendant's grantor, and thus became a private way. The plaintiff relied on an abandonment and obstruction of the easement, for a number of years past, and an occupation of it utterly inconsistent with and destructive of its use as a way, by the defendant; and consequently a loss of the right to enjoy it for the general purposes of agriculture. He proved that there was formerly a house at one end of the way, with no other egress to the public road than through this way. This house had been moved off some twelve years ago; and a barn, belonging to the owner of the house, had been removed six or seven years. For the last six or seven years, the land had been plowed up and planted with potatoes; and it had been mowed, some seasons, and used for general agricultural purposes, like the rest of the farm. It had been fenced up at each end; thus presenting a permanent obstruction to its use as an easement, while the fence con-

os Bayley and Holroyd, JJ., delivered concurring opinions.

"But we apprehend that, as an express release of the easement would destroy it at any moment, so the cesser of use coupled, with any act cleariy indicative of an intention to abandon the right would have the same effect without any reference to time. * * It is not so much the duration of the cesser as the nature of the act done by the grantee of the easement, or of the adverse act acquiesced in by him, and the intention in him which either the one or the other indicates, which are material for the consideration of the jury." Lord Denman, C. J., in The Queen v. Chorley, 12 Q. B. 519 (1848).

[Erle, J.:] "In Moore r. Rawson, 3 B. \& C. 332 (E. C. L. R. vol. 10), it seems to be said that an intention to abandon it [the easement] permanently destroys it, unless a contrary intention be manifested within a reasonable time, which is not defined. I should feel inclined to say that the intention permanently to abandon it would destroy it as soon as it was communicated to the owners of the servient tenement, without the lapse of any time." Iord Campbell, C. J.: "I doubt whether the communication of that intention destroys the right until the communication is acted upon. 'Then it certainly does." Stókoe v. Singers, 8 El. \& Bl. 37 (1857).

Malins, V. C.: "It is clear that if [in Moore v. Rawson] there had been no building erected before the expiration of the screnteen years, the plaintiff' might have resumed his windows." Cook v. Major of Bath, 18 L. T. R. N. S. 123 (186S).

B $B$ The statement of facts and part of the opinion are omitted. 
tinued. The present defendant had resolved to sell, and offered to sell it to the plaintiff; thus indicating his intention to abandon its use as an easement.

After the testimony was closed, the defendant moved for a nonsuit, on the ground that there was no period of nonuser proved to have existed for twenty years; and no act proved showing a permanent obstruction and an intention to abandon it as an easement. 'The judge denied the motion; and we think he decided that question right.

After the trial was closed, the judge before whom the cause was tried, without a jury, decided all the questions of fact and law, for the plaintiff, and ordered judgment for the possession. And the question now is, whether that decision was correct. He found, as a question of fact, "that the road had become unnecessary and useless for the purpose of a way; that the defendant had appropriated the premises for six or seven years, to uses entirely inconsistent with their use as a road, and with the intention to abandon it as a private way." Now unless the decision of this cause in favor of the plaintiff was erroneous, on these grounds thus found, we must affirm the judgment; because there was some evidence to support the finding, and that cannot be questioned, any more than the verdict of a jury. The counsel for the defendant, therefore, insists that where there has not been a nonuser for twenty years, proof must be given of some permanent obstruction, manifesting an absolute intention to abandon the easement, or the right is not extinguished. And it must be confessed, that the language of some of the elementary writers does, indeed, favor such a principle. But the rule, as established by the latter authorities, is less rigorous than this. Whenever the facts are such as to show clearly an intention to abandon the easement, as such, it is sufficient, though the obstruction be not of a more permanent character than that created by a board or a rail fence.

So, too, it is enough that a way is plowed up and cultivated for agricultural purposes, if there be evidence of an intention to make the occupation perpetual, for a purpose inconsistent with an enjoyment of the easement. Chancellor Kent says, "If the act which prevents the servitude, be incompatible with the nature or exercise of it, and be by the party to whom the servitude is due, it is sufficient to extinguish it; and when it is extinguished for a moment, it is gone forever." (3 Kent, 552.) A fence, like that erected by the defendant at each end of this lane or way; the use of the land for agricultural purposes, for a series of years; the removal of the house, for the accommodation of whose occupants the way was originally granted, with the declared intention of the defendant, to sell the premises, showing a fixcd and absolute dctermination to abandon the easement, afford evidence of as strong a character as would be furnished by the erection of a stone wall across it. * * *

It is, however, enough to say that the facts in the case furnished evidence which tended to show an absolute intention permanently to aban- 
don the easement. These facts were passed on by the justice; and his finding is as decisive, on a question of fact, as the verdict of a jury. Had we less doubt of the correctness of the decision than we have, it would be impossible for us to disturb the finding of the justice, without subverting the principles on which a decision upon questions of fact has for the wisest reasons been made to rest.

Judgment affirmed. ${ }^{67}$

\section{DILLMAN et al. v. HOFFMAN.}

\section{(Supreme Court of Wisconsin, 1875. 38 Wis. 559.)}

Appeal from the County Court of Milwaukee County.

In 1849, James Kneeland was the owner in fee simple of the whole of a certain lot in the city of Milwaukee, on the west side of East Water street, having a front of sixty feet on that street, and running back about a hundred feet to the Milwaukee river. In that year he erected a building on said lot, covering the whole width thereof; the lower story containing three stores fronting on East Water street, of about equal size. Between the north and middle stores was constructed a stairway about five feet wide, leading from the sidewalk up to the second story of the building; about one-third of which stairway was north, and two-thirds south, of the division line between said two stores. In the second story of the building was a hall about forty feet long from north to south, and twenty feet wide; the north end of which was bounded by the north wall of the building. From this hall doors opened into offices on the east, west and south sides thereof. The landing of the front stairway already described was in this hall; and immediately opposite this landing, on the west side of the hall, was a rear stairway, leading down from the hall by one flight to a landing on the main floor, and thence by another flight to the ground in the

67Acc.: Crossley v. Lightowler, L. R. 2 Ch. App. 478 (1867), prescriptive easement; King v. Murphy, 140 Mass. 254. 4 N. L. 566 (1855); Norton v. Duluth Transfer Co., 129 Minn. 126, 151 N. W. 907, Ann. Cas. 1916E, 760 (1915): Snell v. Levitt, 110 N. Y. 595, 18 N. E. 370, 1 L. R. A. 414 (1S88), eascments created by deed. Compare Mathews Slate Co. of New York v. Advance Industrial Supply Co., 185 App. Div. 74, 172 N. Y. Supp. 830 (1918).

$A$. had a right of way for a logging railroad orer B.'s land. He took up the rails in order to $\log$ in another district, and then fell into financial difficulties, so that he did not attempt to replace the rails on B.'s land for ten years. IIcld, he has not lost his easement. McAdam v. Benson Logging \& Lumbering Co., 57 Wash. 407, 107 Pac. 187 (1910).

A. had a right of way across B.'s land. He lought another piece of land that Gave him for part of the way a more convenient access. He then put a board fence across the opening to the first passage. 'This situation continued for seven years. Held, a subsequent purchaser from A. may use the original passage. Hayford v. Spokestield, 100 Nass. 491 (186S). See, also, Watts $v$ C. I. Johnson \& Bowman Real Listate Corp., 105 Va. 519, 54 S. E. $306(1906)$.

"A right of way, once established by prescription (which presupposes a grant) or by grant, cannot be extinguished by a parol agreement." Johmson, Chancellor, in l'ue v. I'ue, 4 Mad. Ch. 386, 390 (1848). 
rear of the building, and being on both sides of the division line between the north and middle stores. A small office over the front stairway connected the offices on the east side of the hall, which would otherwise have been separated by the width of said stairway; and a like office over the rear stairway made a similar connection between the other offices on the western side of the hall. The hall and offices occupied the whole of the second story. The hall was open to the roof, and lighted by a sky-light; but over the offices of the second story were similar ones in the third story, which were entered from a gallery running around the east, west and south sides of the hall; and this gallery was reached by a stairway in the north end of the hall, which lea up several steps to the north wall, and then divided and led up east and west to said gallery. Said hall was built by Kneeland for the common benefit and accommodation of the occupants of the second and third stories of the whole building.

On the list of August, 1855, Kneeland conveyed the south forty feet of said lot to one Berliner, and the deed was recorded the next day. On the 25th of the same month he conveyed the north twenty feet of said lot with the appurtenances, to Charles Geisberg. Both conveyances were by warranty deed, with full covenants, including a covenant that the premises conveyed were free of all incumbrances. By subsequent conveyances, Dillman, one of the plaintiffs in this action, succeeded to the rights of Geisberg, and Hoffman, the defendant, to those of Berliner.

In December, 1865, and January, 1866, or some weeks later, Geisberg inclosed the north part of the hall by a partition wall, reaching from the north line of the front stairway west, and parallel to the north wall of the building. This partition extended upward from the floor to the ceiling of the hall, and cut off access to the third story by means of the stairway in the north end of the hall, above described; but, during the progress of the work, Geisberg took down said stairway and placed it "at the south end of the hall, over the middle store, connecting it with the gallery, so as to give access to the upper rooms" [in the third story]. Geisberg at the same time constructed a stairway over his own store, from the second to the third stories, for lis private use. The object of this alteration was to convert the whole second and third stories in the north twenty feet (except the strip between said partition and the division line) into a book bindery.

Within a year before the commencement of this action, and while Geisberg owned the north twenty feet, the defendant erected a partition on the division line, in the rear stairway, and in the hall, nearly to the front stairway; and he threatened to extend this partition to and through said front stairway, along said division line, to the front sidewalk. Dillman, having in the meantime acquired Geisberg's title to the north twenty feet, brought this action to maintain his right to the free and unimpeded use of the stairways, and the passages through said 
hall between the same, and to enjoin the defendant from obstructing them. ***

The court included in its finding of facts nearly all those above stated. It also made the following additional findings as to matters of fact; and to these exceptions were taken.

4. That Geisberg objected to the construction of defendant's partition on the division line, while he owned the north twenty feet, and plaintiff had also objected since his purchase. 5. That plaintiff's premises would be necessarily injured and their value impaired by the obstruction of the stairway as proposed by defendant; that said stairway, constituting the only access at present to the second and third stories of his building, would be reduced to a width of twenty inches, which would be wholly inadequate; and that Dillman and his tenants would thereby practically be shut out from a free and sufficient access to the upper stories of his building.

[Judgment was given in favor of the plaintiff, substantially to the effect that he was entitled to the use of all stairways and halls as they were before the defendant made the erections complained of; and enjoining the defendant from interfering with the enjoyment thereof by the plaintiffs. Defendant appealed.]

Ryan, C. $\mathrm{J}^{68} * * *$ Whether upon such a conveyance of part of a structure dependent for access above on common stairs, passages and halls, the doctrine of easements in ways of necessity applies, as held in Thompson v. Miner, 30 Iowa, 386, Morrison v. King, 62 Ill. 30 , and perhaps other cases, or whether in such a case the conveyance of part should not be held to determine the common use of stairs, passages and halls,-we need not, in our view of this case, determine.

For, granting the easement, each stair, passage and hall was not a separate easement, but together constituted one entire, mutual easement: parts of one common way. And the common stairs, passages and halls being in part upon the estate of each party, it appears very certain, upon principle and authority, that neither party could insist upon such an easement in the estate of the other, and at the same time obstruct the easement in invitum on his own estate. Either party, relying for himself on a mutual easement, would be bound to concede it to the other; and an adverse, permanent exclusion of one by the other upon the estate of the latter, would, at the election of the former, operate as an extinguishment of the mutual easement by the latter. Washburn on Eas. ch. $5, \S 5$, and the cases there cited, particularly Corning v. Gould, 16 Wend. (N. Y.) 531. That case proceeds upon obstruction by one party of a mutual way, and appears to be directly applicable to the present case. See also Partridge v. Gilbert, $15 \mathrm{~N}$. Y. 601, 69 Am. Dec. 632; Dyer v. Sanford, 9 Metc. (Mass.) 395, 43 Am. Dec. 399.

88 The statement of facts is abridged and part of the opinion is omitted. 
The respondent's grantor, while seized, several years before this suit was brought, built a permanent partition, ever since maintained, inclosing within his own premises a great part of the common halls and passages in the upper stories upon his own estate, and removed a stairway between the second and third,stories, part of the common way, from his own premises to those of the appellant. This worked a substantial change in the economy of the common way, and went far to relieve the respondent's premises from the burthen of the mutual eascment which he clains. It is immaterial that this change left a common way. It did not leave the same common way, nor one apparently as advantageous to the appellant. And there can be no serious question that the change was an obstruction of the common way established by Kneeland, within the rule stated, if it was made in invitum. The respondent, however, claims that it was made by consent of the owners of both estates. We think that the evidence fails to establish such consent. ***

What might then have been the rights or remedies of the appellant to maintain the common way, we need not now inquire. He had a right to insist on the extinguishment of the respondent, as he did and does. The mutual easement, if there were one, is now clearly extinguished by the permanent obstruction of the one party and the ratification of it by the other. The appellant's partial forbearance to enforce his right could not affect the right itself, until the new way should ripen into a way by prescription. And the respondent cannot have equitable interposition to enforce against the appellant a mutual way in both of their estates, from which in a great measure he excludes the appellant on the respondent's own estate.

Other questions were discussed at the bar, which, in this view of the case, it is unnecessary to decide.

By the Court.-The judgment of the court below is reversed, and the cause remanded with instructions to dismiss the complaint. ${ }^{69}$

69Acc.: Steere v. Tiffany, 13 R. I. 568 (1882). See Monaghan v. Memphis Fair \& Exposition Co., 95 Tenu. 108, 31 S. W. 497 (1895); Tuttle v. Sowadskî. 41 Utah, 501, 126 Pac. 959 (1912).

A. laid out a tract of land in city lots with streets. He sold one lot to $\mathrm{X}$. He later conveyed the fee of the streets to $\mathrm{B}$. Subsequently, by order of the city council. the street was narrowed, the center line remaining the same. $\mathrm{X}$. fenced in the land between the old and new line of the streer, claiming it as his own. Held, the strip belongs to $B$., but $X$. still has an easerrent over it. White's Bank of Buffalo v. Nichols, 64 N. Y. 65 (ISi (j). See Chew $\nabla$. Cook, 39 N. J. Eq. 396 (1885). 


\section{PRATTT v. SWEETSER.}

(Supreme Judicial Court of Maine, 1878. 68 Me. 344.)

On exceptions from the superior court.

Trespass quare clausum.

The defendant set up a right of way over the locus in q110, which was the upland mowing field of the plaintiff, for taking off marsh hay from his marsh adjoining the premises on which the trespass was alleged to have been committed, and introduced evidence tending to show that such right of way had been acquired by him and those under whom he claimed, by prescription.

The plaintiff claimed that there had never been an adverse or continuous use of the way in question for said purpose, for twenty consecutive years, and introduced evidence tending to show non-user, an abandonment and an interruption of use of the way, and that the line of travel over which the hay had been taken off was not the same each year.

The presiding justice instructed the jury as in the opinion appears; and the defendant alleged exceptions.

VIRGIN, J. The defense set up was a prescriptive right of way across the locus. To this the plaintiff replied that, if the defendant had acquired such a right, he subsequently lost it by abandonment. Upon this point the presiding justice instructed the jury as follows:

"The question is whether, at any period in the past, the owners of the marsh, by such use as I have described, had obtained a right of way by prescription. Such a right of way, if once obtained, would continue until it was voluntarily abandoned with an intention to abandon it, or until it had ceased to be used for a period of twenty years.

"If you should find at some time there was such a right of way, then, upon the question whether it continued or not down to the trespass, this would be the rule. It could be destroyed in two ways; and these two ways are all it is necessary for me to consider. First, by voluntary abandonment of it. If at any time the owners of the marsh had another right of way, and gave up this right of way with the intention to abandon it,--if that is proved, their right would cease at once. On the other hand, if there is no proof of that, notwithstanding they did not intend to abandon, but did not use it, then that non-use must continue for twenty years before the right by prescription fails. Having once obtained a right of way, they may abandon it at any time they see fit, and if the intention is proved, that is the end of it; or if they cease to use it for twenty years, then their right terminates in that way."

By giving this unqualified statement as to the effect of non-user, though some of the authorities sustain it, we think the learned judge erred. For, even if, as suggested by some of the authorities, there is any sound distinction between easements created by deed and those acquired by prescription, the right is not necessarily lost by mere non- 
user for twenty years. The better doctrine seems to be that non-user for the period mentioned is evidence of an intention to abandon; but it is open to explanation, and it may be controlled by evidence that the owner had no such intention while omitting to use it. Wash. Easements, 673; 3 Kent, Com. (12th Ed.) 449, and notes; Farrar v. Cooper, 34 Me. 394.

Exceptions sustained.

New trial granted. ${ }^{70}$

\section{McCULLOUGH et al. v. BROAD EXCHANGE CO. et al.}

(Supreme Court of New York, Appellate Division, First Department, 1905. 101 App. Div. 566, 92 N. Y. Supp. 533.)

[The defendant was the owner of a parcel of land known as $52 \mathrm{Ex}-$ change Place, and of several other adjacent parcels. The first parcel had a right of way over the premises known as 51 and 53 Beaver Street, owned by the plaintiff. The other parcels owned by the defendant had no such easement. The defendant erected upon the parcels owned by it a single large office building, twenty stories high, with a single heating and power plant, and accommodations for about 7,000 occupants. It was built without regard to the original lot lines, and was designed as one structure, with connecting halls and stairways throughout, and with interdependent relations between its various parts. All the coal used in the power plant of the entire building, amounting to over twenty tons a day, was taken in over the way in question; all the ashes and waste paper were so removed, and the way was used by the tenants and employees from all parts of the building.

[The plaintiff brought action to obtain a decree forfeiting and extinguishing the easement of the defendants.]

LAUGHLIN, $\mathrm{J}^{71} * * *$ The trial court has found that by thus constructing and using the office building the appellant owner has "so materially changed the condition of the original dominant tenement as to increase the burden of the servitude upon the subservient tenement of the plaintiffs, and to subject the servient tenement to the services of premises other than the premises originally dominant, and to render it

70Acc.: Ward v. Ward, 7 Exch. S3S (1852).

Acc., as to easements created by deed: Edgerton v. Mcllullan. ว̄5 Kan. 90. 39 Pac. 1021 (1595); Earnes v. Lloyd, 112 Mass. 224 (1573); New lork Cent. \& Il. R. R. Co. v. City of Chelsea, 213 MIass. 40, 99 N. E. 455 (1912); Lathrol v. Elsner, $93 \mathrm{Mich} .599,53 \mathrm{~N}$. W. 791 (1892). Acc., as to a profit: Seaman v. Vaudrey, 16 Vez. 390 (1810); Arnold v. Stevens, 24 Pick. (Mass.) 106, 30 Am. Dec. 305 (1839).

"It is certainly true that a right of enjoyment may be lost in the same way it has been gained; and when acquired by an adverse possession for twenty years, it may, I should suppose, be lost by non-user for the same period." Gibson, C. J., in Nitzell v. Paschall, 3 Iiawle (Pa.) 76, 81 (1s31).

71 Part of the opinion of Laughlin, J., and the opinion of O'Brien, J., are omitted. 
impossible to separate the enjoyment of the original right from the enjoyment of the excess beyond the original right, and to make impossible the legitimate use of said easement." It has accordingly been decreed that the appellant owner has forfeited all its rights to the enjoyment of the easement, and that the same is forever forfeited and extinguished, and it is perpetually enjoined from using the same.

Vie find no definite evidence indicating that it would be feasible or practicable to alter the building in such manner that the tenants of that part of it which is constructed on the premises formerly known as 52 Exchange Place might be separated from the others, and, in the exercise of the lawful-rights of the appellant owner, be permitted to use the alley and areaway for ingress and egress or that the power plant and other use of which complaint is made might be likewise separated. However, it is not impossible to make this separation, and, if the owner wishes to do so, we see no reason why it should not be permitted. Moreover, the office building may be destroyed or otherwise demolished or removed at any time, and in that event it would seem that the owner should be permitted to enjoy the easement in connection with that part of his premises to which the easement was appurtenant. The erection of the building upon its own land was lawful, and does not work a forfeiture of the easement. Rexford v. Marquis, 7 Lans. 249262; Greene v. Canny, 137 Mass. 64; Topling v. James, 13 C. B. N. S., 876. An unlawful or excessive use of an easement may be enjoined, but it is difficult to see upon what principle of law the court is authorized to declare it forever and altogether forfeited and extinguished because of an unauthorized or excessive use. It is a valuable property right, and we know of no authority for transferring its title, against the will of the owner, except by due process of law, involving just compensation.

It is also conceivable that an authorized and unauthorized use may be so intermingled as to justify enjoining any use until the circumstances have so changed that the authorized use may be permitted without affording opportunity for the unauthorized use which it would be difficult to discover or prove. If this be the rule a situation is here presented justifying an injunction, not against the excessive use, but restraining any use until the building is so altered or changed that that part of it which is on the dominant tenement may enjoy the easement without permitting its enjoyment by the tenants and occupants of other parts of the building who have no right thereto." Where the nature and extent of the use of the easement is, as here, unrestricted, the use by the dominant tenement might, of course be enlarged or changed. Allen v. Gomme, 11 Ad. \& El. 759; Arnold v. Fee, 148 N. Y. 214, 42 N. E. 588; Gillespie v. Weinberg, 148 N. Y. 238, 42 N. E. 676; Dand? v. Ringscote, 6 M. \& W. 173; Sloom v. Holliday, 30 Law Times, 757. But the owner of the dominant tenement may not subject the servient tenement to servitude or use in connection with other premises to which the easement is not appurtenant. 
It is to be borne in mind that this right of way and easement were acquired by deed, and the rule is that such an easement is not extinguished by nonuser, but only by grant or adverse possession. Sinyles v. Hastings, 22 N. Y. 217 ; Welsh v. Taylor, 134 N. Y. 450,31 N. E. 896, 18 L. R. A. 535; Parker v. City of St. Paul, 47 Minn. 317, 50 N. W. 247. Here there was no adverse possession, and notling has been done with the intention of relinquishing the easement; but, on the contrary, it has been constantly enjoyed, and the complaint mercly is of a use unauthorized in part. It was formerly held in England that the easement of "ancient lights" might be lost or suspended until the premises were restored to their original condition by enlarging or changing the position of the window, but it is doubtful whether that rule still prevails (Tapling v. Jones, 13 C. B. [N. S.] 876); and, moreover, it was never given place in our jurisprudence (Parker v. Foote, 19 Wend. 319), and would not be applicable to this case if it had. The appellant and those using the easement without authority would doubtless be liable to the plaintiffs in damages. Dennis v. Sipperly, 17 Hun, 69; Rexford v. Marquis, supra, 249, 262; Davenport v. Lamson, supra; Shroder v. Brenneman, $23 \mathrm{~Pa}$. 348; French v. Marstin, $32 \mathrm{~N}$. H. 316.

But it is manifest that it would be next to impossible to show the damages or to enforce the rights of the plaintiffs under an injunction conrining the use to the tenants of and those using the dominant tenement. Although equity abhors forfeitures and will in a proper case relieve against their enforcement, it will not aid their enforcement even where it would interfere against the same at law. 1 Pomeroy's Eq. Jur. (2d Ed.) $\S \S 450,459$. Yet the appellant owner is responsible for the situation which enables its tenants and employés to use the easement, and render it impossible for the plaintiffs to know which have and which have not a right to such use. Therefore, while equity will not destroy the appellant owner's easement, it will grant the relief necessary to preserve the rights of the plaintiffs. It is manifest that these rights can only be effectively preserved by enjoining the appellant owner from using the easement while its premises remain in their present condition.

The judgment should therefore be modified by striking out all provisions relating to a forfeiture of the easement, and modifying the injunction so as to enjoin and restrain the appellant owner, its officers, agents, and employés, from using the easement, and from furnishing occasion or extending, by implication or otherwise, any invitation to the tenants or persons having business with the tenants to use the easement, until such time as the building shall be so changed, altered, or arranged as to permit the enjoyment of the easement for the advantage of the dominant tenement only, with leave to the appellant owner to apply to the court, at the foot of the judgment, on notice to the plaintiffs or their successors in interest, when that time shall have arrived 
to vacate the injunction as to the dominant tenement, leaving the injunction, however, to stand permanently as to the remaining premises; and, as thus modified, the judgment should be affirmed, without costs of the appeal to either party.

Van Brunt, P. J., and Patterson and Hatch, JJ., concurred. O'BRIEN, J., dissented. ${ }^{72}$

\section{WINTER v. BROCKWELL.}

(Court of King's Bench, 1807. \& Last, 308.)

This was an action on the case for a nuisance, wherein the plaintiff complained, that being lawfully possessed of a dwelling house with the appurtenances in Long Acre, \&c. (Westminster), into which the light and air entered by means of a window from a certain open area between the said window and an adjoining house; by means of which open area also noisome smells which came from the adjoining house evaporated, without occasioning any nuisance to the occupier of the plaintiff's house; the defendant wrongfully placed a skylight over the area above the plaintiff's window, by means of which the light and air were prevented from entering the plaintiff's window into his house, and noisome smells arising from the adjoining house were prevented from evaporating, and entered the plaintiff's dwelling-house, \&c. Plea, the general issue. At the trial before Lord Ellenborough, C. J., at the last sittings at Westminster, the defence set up was, that the area which belonged to the defendant's house had been inclosed and covered by a skylight in the manner stated, with the express consent and approbation of the plaintiff, obtained before the inclosure was made, who also gave leave to have part of the frame-work nailed against his wall. But some time after it was finished the plaintiff objected to it, and gave notice to have it removed. But his lordship was of opinion, that the licence given by the plaintiff to erect the sky-light, having been acted upon by the defendant, and the expense incurred, could not be recalled, and the defendant made a wrong-doer; at least, not without putting him in the same situation as before, by offering to pay all the expenses which had been incurred in consequence of it: and under this direction the defendant obtained a verdict.

Wigley, (in the absence of the Attorney General) now moved for a new trial: but after stating the point (a),

72 Sce Harvey v. Walters, L. R. 8 C. P. 162 (1873); Masonic Temple Ass'n v. Harris, 79 Me. 250,9 Atl. 787 (18s7); McMillan v. Cronin, 75 N. Y. 474 (1878).

A. had an easement of light for certain ancient windows orerlooking B.'s land. He enlarged these windows. $B$. built so as to shut off the light from both the new and the old part of the windows, this being a practically unaroidalle consequence of his building in such a way as to cut off the light from any part of the windows. Held, A. may maintain an action for obstructing ancient lights. Tapling v. Jones, 11 H. of L. 290 (1865). Compare Heath v. Buckinall. I. R. 8 Eq. 1 (1S69). 
Lord Ellenborough, C. J., said, that the Attorney General, who led the cause at the trial, had himself mentioned this case at the beginning of the term, in the argument of the case of the Quarriers in the isle of Purbeck; certainly without intimating any disapprobation of the opinion which had been delivered at the trial, but insisting upon it in support of his argument. His lordship added, that the point was new to him when it occurred at the trial; but he then thought it very unreasonable, that after a party had been led to incur expense in consequence of having obtained a licence from another to do an act, and that the licence had been acted upon, that other should be permitted to recal his licence, and treat the first as a trespasser for having done that very act. That he had afterwards looked into the books upon this point, and found himself justified by the case of Web v. Paternoster best reported in Palmer 71, but reported also in other books (b), where Haughton, J., lays down the rule, that a licence executed is not countermandable; but only when it is executory. And here the licence was executed.

Wigley thereupon waived his motion. ${ }^{3}$

\section{ROGERS v. STEWART et al.}

(Supreme Court of Vermont, 1833. 5 Vt. 215, $26 \mathrm{Am}$. Dec. 296.)

This was an action on the case for the obstruction of a private way of the plaintiff. There was a jury trial in the County Court, and a verdict for the plaintiff. Several exceptions were taken to the instructions given to the jury. These, including some points not urged before this Court, appear in a long bill of exceptions, allowed by the Judges of the

7.3 "An easement may be lost by abandonment, and whether there is an abandonment is ordinarily a question of intention. If the extinguishment of an easement by the execution by the owner of the servient estate of a license which prerents the further enjovment of the easement rests on the ground that the owner of the easement intentionally abandoned it,- and where there is a complete extinguishment it may well rest upon that ground, -his intention is conclusirely presumed in favor of the owner of the servient tenement who executed the license, hecause, between these parties, where one acts upon the license of the other, the manifest and apparent intention which is acted upon must control their rights, whatever the secret intention of the licensor may be. $* * *$ The exccution of the license worlied an extinguishment of the defendant's easement. As against the plaintiffs, he must be conclusively presumed to have intended to abandon his easement on the performance of the condition when he gave the license; and the Iicense having been acted on, and heing irrerocable, the abandonment became complete." Knowlton, J., in Poston \& P. R. Corp. v. Doherty, 154 Mass. 314. 317,28 N. E. 277,278 (1891).

A tenant for life of lind, haring an easement of light over an adjoining tract. br parol authorized the owner thereof to ereet a building thereon, which was done. In an action for obstructing the light, brought by the remainderman in fee, who had subsequently come into possession, held, the fact that the defenlant had acted on the faith of the license was no defense. Dyer v. Sinford, 9 Mretc. (Mass.) 395, 43 Am. Dec. 399 (1S45). See Vogler v. Geiss. 51 MIt. 407 (1879). 
County Court. The material facts in which, and the arguments of counsel, sufficiently appear in the following opinion of the Court, delivered by

Hutchinson, C. J.74 It appears by the Bill of Exceptions in this case, that the plaintiff owned a piece of land, lying northwestwardly of the common, in Middlebury, and had used and occupied, for thirty or forty years, a foot-way and cart-way from this land, in a southeastward direction, across a small piece of land, long owned by Gamaliel Painter and his heirs, and coming out into the highway, or common, near where the church now stands. The erection of a fence on the line of the highway, with gates for foot-passengers only, said fence extending across this private way of the plaintiff, was the obstruction complained of in the declaration. In this, the plaintiff complains of the obstruction of this way as a cart-way-not as a foot-way. * * *

Stephens, who was made defendant, but has since deceased, erected this fence as a door-yard fence to a house near by. This was in 1825 or 1826. Afterwards Stephens leased these premises, together with a factory owned by him, to the defendant, Hough, for five years; and afterwards assigned this lease to the defendants, Stewart and Phelps. And said Hough underlet the house, to accommodate which this fence was erected, to the defendant Morrison.

The defendants' counsel contended in argument, that the plaintiff had abandoned this way, before the injury complained of; and this destroyed his right of recovery, if such right would otherwise exist. This argument is urged upon the following facts: When Stephens erected said fence, he moved a house on to the premises, and extended it about nine links to the north-east over his line, and into this way of the plaintiff; leaving only ten links for a passage, which is not sufficient for a carriageway. Since which time it could not be, and has not been used for a cart-way; though there was proof of the plaintiff's drawing stone in the rear of the buildings, which it would have been more convenient for him to have drawn through this cart-way, had it been open.

The defendants' counsel argued, that this cart-way, or right of way, was for the use and benefit of Rogers' property, in the rear of the Stephens' buildings, and the plaintiff suffering the obstruction to remain on his own land, must be considered an abandonment of the way. And further, that, while the house stands on the plaintiff's own land, and wholly obstructs the way, the plaintiff can suffer no damage from any other obstruction. While the plaintiff's counsel contend, in the first place, that, the whole of the different obstructions being put the:e at once by the same individual, neither he, nor any person claiming from him, can justify one part of them on the ground that another part would alone have produced the same effect. It is sufficient, that the part complained of, produces the effect. In the second place, the plain-

74 Part of the opinion is omitted. 
tiff's counsel contend, that finding both the house and fence in his way, it became his business to cause both to be removed. When he gets the fence removed, he may, if he pleases, remove the house by his own act, and open the way at once. The Court consider, that, if the plaintiff himself, had placed this house where it was placed by Stephens, extending on the plaintiff's land, so as wholly to obstruct this way, as a cart-way, the evidence of this would have been pertinent in proving an abandonment; but the plaintiff's neglecting to bring an appropriate action for the placing and continuing the house there, is no evidence of such abandonment, until a longer period has elapsed, than the one now proved; especially as the front fence, of which he now complains, was an entire obstruction of the same way. Any right the plaintiff may have, to bring trespass or ejectment for the placing and continuing the house partly upon his land, does not interfere with his right to maintain this action for the obstruction of the way.

The judgment of the County Court is affirmed. ${ }^{75}$

\section{JENNISON v. WALKER.}

\section{(Supreme Judicial Court of Massachusetts, 1858. 11 Gray, 423.)}

Action of tort for breaking and entering the plaintiff's close in Newton. Answer, a right to enter for the purpose of constructing and maintaining an aqueduct and reservoir for conducting water from a spring thereon to land of the defendant.

At the trial in the court of common pleas, the following facts were proved: In 1800 Phinehas Jennison (under whom the plaintiff claimed) conveyed to Stephen Dana, the owner of land adjoining, (whose title the defendant had,) his heirs and assigns forever, "the right and privilege of laying an aqueduct from the principal spring and springs, fountain or fountains of water in" the close in question; "likewise the privilege of digging and sinking sufficient reservoirs for the purpose of the aqueduct, and at all times hereafier the privilege of going on the land for the purpose of repairing said aqueduct; reserving to

$75 \mathrm{~A}$. owned land to which was appurtenant an easement of war orer b.'s land. The way remained unused for many years by $A$. and bis successor's in title, they having no occasion to use the same, and $B$. cultivated that part of his land orer which $A$. had the right of way. Held, A. is still entitled to the way. James v. Stevencon, [1S93] A. C. 16. Acc.: Johnson v. Stitt, 21 I. I. 429, 44 Atl. 513 (1899); Boyd v. Hunt, 102 Tenn. 495, 52 s. W. 13i (1S99). Compare Bowen v. Team, 6 Rich. (S. C.) 298,60 Am. Dec. 1:7 (18:i:3).

A. had a right of way ten feet whte orer B.'s land. It had been used only for a footpath for many years, and A. had built is summerhouse that projected two feet into the strip. B. erected a stable that largely covered the strip. Eight months later $A$. hrought action for an injunction to compel the removal of the stable. Held, under the circumstances of the case, ho is not entitled thereto. Young v. Star Co., SG L. T. R. 41 (1902). 
myself, my heirs and assigns, as much water as will be necessary for watering the cattle which shall or may be kept in said pasture."

Before 1816 there was a reservoir at the principal spring on the servient estate, and an aqueduct of cedar logs laid under ground, leading therefrom across the close in question to the defendant's land. After 1818 that aqueduct was not used for any purpose, and between 1818 and 1824 the plaintifif's grantors removed and destroyed portions of these logs, and from 1818 to 1855 the defendant and his grantors made no use of this spring or aqueduct, nor attempt to lay any aqueduct.

In 1855 the defendant entered upon the plaintiff's close, cleared out and walled up the spring, and laid lead pipes therefrom across the plaintiff's land to his own, in a different direction from the old log aqueduct, the change being necessary in consequence of the construction of a railroad across the line of the former aqueduct, and in order to go through a culvert in the embankment of the railroad.

Upon these facts Sanger, J., ruled that the defendant had not shown a defence; the jury found a verdict for the plaintiff for nominal damages, and the defendant alleged exceptions.

BIGELOW, $J^{76}$ We can see no sufficient reason for disturbing the verdict in this case.

The evidence at the trial not only proved a non-user of the easement of laying and maintaining an aqueduct through the land now owned by the plaintiff by the owners of the dominant tenement for more than thirty years, but also established a possession and use of the servient estate by the plaintiff and his grantors during the same period, entirely inconsistent with and adverse to the existence of the easement. The right or easement in question having been acquired by grant and not by use, there might have been difficulty in showing a loss or extinguishment of it by proof of a mere omission during twenty years or more to exercise the right by an actual enjoyment of the easement. But the removal by the plaintiff's grantors of the logs which conveyed the water through the land now owned by the plaintiff rendered the enjoyment of the easement impossible. It was an act in its nature essentially adverse. It effectually hindered the exercise of the right and operated to annihilate it. After this removal took place, no means were adopted to renew the enjoyment of the privilege. It was a continuous disturbance for more than thirty years. The non-user of the easement by the owners of the dominant estate united with a use of the servient estate inconsistent with and adverse to the existence of the easement during this period of time. Upon this proof, there was sufficient to justify the inference that the right originally conveyed by grant had been released and extinguished by a subsequent non-appearing deed. The doctrine on this subject is fully explained and illustrated in Ar-

76 I'art of the opinion is omitted. 
nold v. Stevens, 24 Pick. 111, 35 Am. Dec. 305. The defendant did not claim to go to the jury at the trial, and the evidence was in our judgment sufficient to warrant a verdict for the plaintiff.

Exceptions overruled. ${ }^{77}$

\title{
BROWNE v. TRUSTEES OF METHODIST EPISCOPAL CHURCH IN CITY AND PRECINCTS OF BALTIMORE.
}

(Court of Appeals of Maryland, 1S72. $37 \mathrm{Md}$. 108.)

\begin{abstract}
[Action to recover damages for the obstruction of an alleged right of way.

The plaintiff appellant became the owner of Font Hill, the dominant estate, in 1855 , upon the death of his aunt, a tenant for life. The way was in existence at least as early as 1814 , at which time the life tenant had acquired her interest. The servient tract now owned by the defendant appellees, was formerly owned by one Patterson. Further facts are given in the opinion.]
\end{abstract}

77 Acc.: Bauman v. Wagner, 146 App. Div. 191, 120 N. Y. Supp. 1016 (1911)

A. had a riglit by deed to mine ore in B.'s land. For forty rears B. and his predecessors in title continued in the exclusive and uninterrupted oc"upation of the land, cultivating it as they saw tit. At the end of that time $A$. exercised his right to mine, and $B$. blought trespass. The court held that the right had not been lost l.g B.'s possession, saying (per Molton, J.): "In the ease at bar there was no adverse possession. The oceupation of the owners in fee was consistent with the rights of the owners of the easement. * * * Here, although the oceupation of the predecessors of the plaintiffs was not comsistent with the exercise of the right claimed by the defendant, yet it was no infringement of that right. They did not dig any ore, they did not preclude any othed persons from digsing, nor exclude them from the land. Until the owners of the easement chose to exercise the right granted to them it was inoperative, and left the owners of the soil free to make such use of it as their interest might require. Thompson v. Gregory, 4 Johns. (N. Y.) S1, 4 Am. Dec. 255 (1809). Hy the principles of law governing easements of this kind, the owners of the soil had a perfect right to make every use of it which could be done without inflinging the servitude. And as long as this remained unused they were entitled to the whole benefit of the laud as much as if it did not exist." Alnold v. Sterens, 24 Pick. (Mass.) 106, 111, 35 Am. Dec. 305 (1539).

A. laid out a tract of land in town lots with an alley. He sold to $\mathrm{X}$. and $\mathrm{I}$., respectively, lots on either side of the alley. The alley was never accepted by the public. $\mathrm{X}$. enclosed the alley in his lot by a board fence and lielt exclusire possession of ${ }^{\circ}$ it for over twenty years as a public school ground. $\Gamma$. now ploposed to erect a school house upon the alley in such a way as to cut off the light coming to Y.'s house. In a bill by Y. to enjoin such ereetion, held, that $I$. acquiled by his conveyance from $A$. an easement of way, light and air over the alley; and, assuming that $Y$. has lost his easement of way in the alley, he has not lost his easement of light and air. 1 ill F. Toard of Foncation of City of Camden, 47 N. J. Eq. 421, 20 Atl. 739, 10 L. R. A. $276(1890)$.

See, also, Reed v. Gasser, 130 Iowa, 87, 106 N. W. 383 (1906); Welsh v. Taylor, 134 N. Y. 450. 31 N. L. 896,18 L. R. A. 53i (1892); Bombaugh v. IIiler, 82 Pa. 203 (1ST6). 
STENART, J. ${ }^{78 * * *}$ It seems from the evidence, that the road in question, if it ever existed as a reservation at the sale of Mrs. Lawson's property, or was otherwise acquired as a servitude on the property now claimed by the appellees, was closed by Patterson, who had purchased the lots, in the year 1829; and was then opened or closed by him, as it suited his convenience. Mr. Browne, the appellant, states that when he visited the premises in the year 1842, the road was closed, and he was obliged to take another route to get to Font Hill. He told his aunt holding the life interest, about it; and she said it had not been done by her consent. No steps, however, seem to have been taken by any of the parties to have the road opened. The appellees became entitled to the property in the year 1849, at which time the road was closed; and there is no evidence that they were aware of any right or claim to the road.

It appears there was no record of the road, to which they could resort, for the purpose of ascertaining if there was such an easement on the property.

The appellant, according to his own statement, had some information, or belief, as to the right of way through the property of the appellees to Font Hill.

He states, he knew the property quite intimately since 1848 . He knew that the road was closed in 1842, but don't recollect that he told his aunt the road was closed, until after his visit in 1848, when she resided in Baltimore, about 1849-50. He thinks he notified the appellees, in 1858-59, of his intention to claim the road. Don't recollect of giving them written notice, or informing the Board officially of his intention.

It thus appears, that although the company had purchased the property in 1849, when the road was closed, and when they were ignorant (from any thing shewn) of any intention to assert a right to the road, or that there was any dormant right, and after the life tenancy had terminated in 1855, the appellant gave no formal notice to the Board of his intention to claim the road. John Morrow, one of the trustees of the company and of the committee to take charge of the cemetery, testifies, that many dead are buried on the property-most thickly in the centre, near the appellant's property; and that he never heard of a right of way, claimed by the appellant, prior to this suit.

If the property of the appellees ever was incumbered with the servitude of this road through it, enuring to the benefit of the appellant, as the proprietor of the dominant estate, he certainly has shown great remissness and want of due vigilance in the assertion of his rights; more especially, as against the appellees, who have been preparing and using the property, including the bed of the road, for a cemetery, the receptacle of the dead, whose right of peaceable and quiet asylum has, incidentally, if not primarily, become involved in this question.

78 Part of the opinion is onitted. 
The company occupying and employing the property for such laudable purpose, and under the peculiar circumstances, so well calculated to arrest the attention of all parties having claims upon it, and to prompt them, if so inclined, to the earliest assertion and notice of them, is certainly entitled to the most liberal construction of the sound doctrine of estoppel in pais, if applicable; because of the use to which the property was being devoted and dedicated.

The appellees have in charge the remains of the dead, whose right of sepulture should not be disturbed, except upon most unequivocal legal grounds; and the appellant, in undertaking to invade their domain, and to dispossess the trustees, ought to be able and prepared to vindicate his claim, and to show by clear and unmistakable proof, that he has been guilty of no laches.

Their possession and the appropriation of the property, after their purchase in 1849 , when the road had been long discontinued, and without notice of the claim of the appellant, was, certainly, not that sort of "encroachment on the soil, or rights of the appellant, as amounted to an acknowledged tort, equally known and open to the notice of both parties, which confers no right, until it has continued for such length of time, without interruption as to give effect to the limitation of the right of action for the disturbance," to use the language adopted in Tongue's Lessee v. Nutwell, 17 Md. 230, 79 Am. Dec. 649, but comes within the principle, with its qualification, recognized in the above case, and also in the case of Casey's Lessee v. Inloes et al., 1 Gill, 502, 39 Am. Dec. 658.

The principle is this, where one stands by and sees another laying out money upon property, to which he has some claim or title, and does not give notice of it, he cannot afterwards, in good conscience, set up such claim or title; except where the encroachment is on land, the title to which is equally well known or equally open to the notice of both parties; where the claim is under some trust, lien or other right, not equally open and apparent to the parties, the principle applies in favor of one who would be deceived by such want of notice. In such case the doctrine of estoppel in pais affords a protection to the party misled by the conduct of the other party.

The prayer of the appellees assumes this theory of the facts, and if the circumstances of the parties, in regard to the road in question, sustain the proposition of the prayer, the appellant is precluded from recovery for the obstruction of the road, even if the evidence were sufficient to establish the easement through the property, by long antecedent user and enjoyment.

After the termination of the life tenancy in the property, if the appellant, as the proprietor of the inheritance of the alleged dominant estate, acquiesced in the abandonment of the road, and allowed the appellees to make the improvements suitable for the burial of the dead. without the earliest and amplest notice of his rights, he is precluded from the resumption of the easement; because, by his laches, he has 
induced others to expend their money; and in this case for a sacred purpose. It is just he should suffer loss, rather than those deceived and misled by his neglect. ,Under such circumstances he will be considered as waiving and abandoning his claim.

Judgment reversed and new trial ordered. ${ }^{70}$

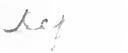

FITZPATRICK v. BOSTON \& M. R. R. SMITH v. SAME.

(Supreme Judicial Court of Maine, 1891. Sf Me. 33, 24 Atl. 432.)

Two actions of trespass for wrongfully placing and maintaining obstructions across the plaintiffs' right of way across the defendant's land. * * *

WhiterHouse, J. ${ }^{80}$ The plaintiffs had a right of way across the defendant's railroad. In 1881 the defendant obstructed it by digging four cellars, and placing houses upon them, and in 1888 disturbed it at another point by making excavations for the purpose of laying a spur track to a gravel pit. November 30,1889 , the plaintiffs commenced these actions for damages.

1. With respect to the obstruction caused by digging the cellars and erecting the houses in 1881, the facts are undisputed. A public highway 50 feet wide was established and opened to travel in 1876, leading from a point near the beginning of plaintiffs' private way, in the dividing line between Berwick and South Berwick, northerly about 800 feet across the defendant's location; and the houses in question were erected by the defendant across the private way, and fronting on the public way. At the same time the defendant prepared for the use of the plaintiffs, as a substitute for that part of the old way thus obstructed, a new and equally good, but slightly circuitous, way leading over the highway described, and returning to the original private way. The effect of this change of location was to divert the course of travel about 20 feet to the north of the old way. The defendant corporation owned in fee simplc all the lands covered by the houses; the location of the highway and the plaintiffs' present private way substituted for the old way; also the lands purchased for the gravel pit; and all lands within its location from South Berwick station easterly beyond the

roAcc.: Arnold v. Cornman, 50 Pa. 361 (1865).

A. had a prescriptire way over B.'s land. An intending purchaser of B.'s land asked $\mathbf{A}$. if he had a "regular way" over B.'s land. A. said, "No." A. did not know the purpose of the inquiry, and it did not appear that the purchaser relied on the answer in buying the land. Held, A. may still assert his easement. Nichols v. Peck, 70 Conn. 439, 39 Atl. 803,40 L. R. A. 81, 66 Am. St. Rep. 122 (189S). Compare Sterens v. Dennett, 51 N. H. 324 (1872).

See, also, Manning v. Port Reading R. Co., $5 \pm$ N. J. Eq. 46, 33 Atl. 802 (1895).

80 The statement of facts is abridged and part of the opinion is omitted. 
farm crossing fixed by the commissioners at the time of the location of the road at or near stations 24 and 39.

In the case at bar, the obstruction in 1881 was unquestionably of a permanent character. Four cellars were dug and completed across the way, and houses of a substantial and permanent character erected upon them. It must have been understood by all the parties interested that the result of this act was not merely a temporary obstruction, but a practical extinguishment of so much of the way as was covered by the houses. It was a completed act in 1881. There was no expectation that the houses would be removed or the cellars filled up. The interruption was manifestly final. The plaintiffs then had a cause of action for an invasion of a riglit. The conditions were fixed and enduring, and were not expected to change.

It is evident that the plaintiffs made no serious objection, if any, to the change in the way thus caused by the erection of the houses. They made no claim for damages. For seven years they used the substituted way as occasion required without complaint, and in consideration of the advantage of being connected with the highway, made safe and convenient at public expense, they evidently accepted the new way in lieu of that destroyed by the cellars and buildings. Their conduct for seven years succeeding this interruption sufficiently indicates that there was no intention on their part to raise any question in regard to it until the excavation in 1888. It appears to have been mutually understood that that portion of the way covered by the houses was finally abandoned. The plaintiffs silently acquiesced in the change, and intentionally surrendered the old way in consideration of the dedication of and an agreement for the new one opened for their benefit. "It is not the duration of the cesser to use the easement, but the nature of the act done by the owner of the easement, or of the adverse act acquiesced in by him, and the intention which one or the other indicates, that is material." Pope v. Devereux, 5 Gray (Mass.) $412 .{ }^{81}$

[The plaintiffs recovered nominal damages for the obstructions caused in 18S8.]

81Acc.: Pope v. Derereux, 5 Gray (Mass.) 409 (1S56).

"If. then, the predecessors of the defendants, in consideration of the closing of said portion of the north and south alley, granted to plaintiffs and to their predecessors a right of waly over the east and west alley in lieu thereof, which was accepted by the plaintiffs and their predecessors, the defendants will not now be allowed to close the new or substituted alley without first restoring the old one; and the fact that such grant was oral matters not, if ${ }^{-1}$ the faith of it rights have been acquired or relinquished and acted unon. *** And where the owner of a right of way. whether acquired by prescription or otherwise. consents to the closing of the said right of way in consideration of substituting and granting to him a new one, th" right to the use of such new way at ince attaches, and he is not required to use the new way for a period of time to give him title by prescription." Straup, J.. in Thompson y. Miadsen, 29 Ttah, 326, 332, 81 Pac. 160 (1905). See, alco, Ilorne v. Widlake, Yelv. 141 (160S); Reirunds v. Edwards. Willes. $2 S 2$ (1741): Lorell v. Snith, 3 C. B. N. S. 120 (1557); Wright v. Willis, (iis S. W. 991, 2:; Ky. Law Iien. 505 (1901); Davidson v. Kretz, 127 Mim. 313, 149 N. W. 652 (1914); Iramilton r. White, 5 N. Y.9 (1S51). 


\section{RITGER v. PARKER.}

(Supreme Judicial Court of Massachusetts, 1851. 8 Cush. 145, 54 Am. Dec. 744.)

This was an action of trespass quare clausum fregit. The defendant, in justification of the alleged trespass, relied on a right of way over the plaintiff's close, as appurtenant to an adjoining lot of land, belonging to the defendant. At the trial in the court of common pleas, before Mellen, J., the following facts were proved or admitted:

Abel Corey on the 11th of June, 1836, conveyed to James Gardner the lot now held by the defendant; James Gardner, on the 24th of September, 1836, mortgaged it to Margaret Gardner; who took possession to foreclose on the 5th of April, 1841; and on the 26th of September, 1842, conveyed the same to Gilbert Parker; the mortgage was foreclosed on the 23d of April, 1844; and on the 15th of September, 1847, Gilbert Parker conveyed to the defendant.

The plaintiff's title to the locus in quo was as follows: Isaac Perry conveyed to James Gardner on the 10th of December, 1839; James Gardner on the 11th of December, 1839, mortgaged to Margaret Gardner, who took possession on the 5th of April, 1841, for the purpose of foreclosing this mortgage; and the same was actually foreclosed on the 23d of April, 1844; and Margaret Gardner, on the 10th of May, 1844 , conveyed to the plaintiff.

On these facts, the presiding judge ruled, that if any right of way existed, as appurtenant to the defendant's close, over the close of the plaintiff, prior to the 10th of December, 1839, such right of way was extinguished before the defendant's close was conveyed to him. Whereupon the jury returned a verdict for the plaintiff, and the defendant alleged exceptions. * * *

Silaw, C. J. ${ }^{82}$ To an action of trespass quare clausum, the defendant sets up a right of way, to pass on and over the close of the plaintiff; and insists, that as he entered in the exercise of that right, such entry was no trespass.

It appears from the report that the plaintiff and the defendant own estates adjoining each other, and the defendant, as such owner, claims a right of way, as annexed to his estate. The plaintiff insists, that even though such right did formerly exist by grant or prescription, for the owner of the estate now owned by the defendant, in and over the estate now owned by the plaintiff, such easement has been extinguished, by unity of title and possession of the two estates, in one and the same person at the same time. To determine this, it is necessary to examine the facts furnished by the report.

But upon principle it seems to us, that in order to extinguish an easement, by the unity of title and possession, both of the dominant and servient tenements, in the same person, he should have a perma-

82 Part of the opinion is omitted. 
nent and enduring estate, an estate in fee in both. This results from the consideration of a few obvious principles. An easement or servitude is a right, which one proprietor has to some profit, benefit, or beneficial use, out of, in, or over the estate of another proprietor. An owner of land, therefore, cannot have an easement in his own estate in fee, for the plain and obvious reason, that in having the jus disponendi-the full and unlimited right and power to make any and every possible use of the land-all subordinate and inferior derivative rights are necessarily merged, and lost in the higher right. He may use every part of the surface for a way, if he chooses, and therefore has no occasion to claim any particular way; and so of every other use, to which land may be subjected. If, therefore, after such merger, the owner grants away a portion of his estate, it is the creation of a new estate, and not the revival of an old one. And although he may make a grant of that particular land, which formerly constituted one of the separate estates, which coalesced in him, yet it is not with its former incidents, unless it is done by force of the grant itself, by such words of description. as could bring them into being, by way of new grant. ***

This, of course, does not extend to watercourses and such natural incidents as belong to the land itself, and are inseparable from it.

From this view of the subject it seems manifest, that the merger of the easement, arising from unity of title and possession, which will extinguish and put an end to such easement, arises from that unlimited power of disposal, which will enable the owner to grant any part of the soil with the former incidents, or to grant it without the former incidents or create and annex to it or subject it to new incidents in favor of another estate, at his own will and pleasure. Such a power of disposal can only exist when the same proprietor has a permanent estate in both tenements, not liable to be defeated by the performance of a condition or happening of any event beyond his control, and where the estates cannot again be disjoined by operation of law.

And it seems equally clear, that the two estates did not merge, whilst held by Mrs. Gardner, as mortgagee only, although mortgagee in fee. So long as she held them, they were both defeasible, and defeasible upon different conditions, (the payment of distinct debts,) and for aught that appears, conditions to be performed by different persons, because the respective equities of redemption might be held by different persons. So long as she held them, one might have been redeemed and the other foreclosed without any act of hers; and a foreclosure or redemption or either would have entirely effected a separation of the two, each retaining its own incidents. But she conveyed one before foreclosure; and when foreclosed, the estates were in different persons; the defendant's was then held by Gilbert Parker, and the plaintiff's by Margaret Gardner. 
The court are therefore of opinion, that if the defendant and those whose estates he holds had a right of way over the plaintiff's tenement prior to the conveyances to James Gardner, such right was not extinguished by any unity of title and possession set forth in the report.

New trial ordered. ${ }^{83}$

${ }^{83} \mathrm{~A}$. owned in fee a tract of land to which was appurtenant a right of way over an adjoining tract owned by $\mathbf{X}$. in fee. $\mathbf{A}$. mortgaged to $\mathbf{B}$. the dominant land, the right of way being specifically included. $\mathrm{X}$. then bought the dominant land subject to the mortgage; he onened a new way from the dominant tract over another piece of land owned by him, closed the original way and built a terrace over it upon the original servient tract. This latter tract he then conveyed to $\mathrm{Y}$. in fee, the deed making no mention of any easement. Later $C$. bought the dominant piece under a foreclosure sale. Held, C. has the original right of way over the tract now owned by $\mathbf{Y}$. Duval v. Becker, 81 IId. 537, 32 Atl. 308 (1S95).

The easement is not extinguished where the dominant and servient estates are held by one person-as a fee simple and as a base fee respectively: The King v. The Inhabitants of Hermitage, Carth. 239 (1692); in fee and under a 500-year lease, Thomas v. Thomas, 2 C., M. \& R. 34 (1S35); in sev. eralty and in common, Dority v. Dunning, 78 Me. 381,6 Atl. 6 (1886). See, also, James v. Plant, 4 Ad. \& E. 749 (1836); Kilgour v. Gaddes, [1904] 1 K. P. 457; Richardson V. Graham, [1908] 1 K. B. 39 ; In re Bull, 15 R. I. 584,10 Atl. 481 (1SST).

The easement was held to be extinguished by merger in Capron v. Greenway. 74 Md. 289, 22 Atl. 269 (1891); Morgan v. Meuth, Co Mich. 238, 27 N. W. 50 ? (1SS6).

A way of necessity ceases when the necessity ceases. Holmes v. Goring, 2 Bing. 76 (1S24); Pierce v. Selleck, 18 Conn. 321 (1847); Oliver v. Hook, $47 \mathrm{Md} .301$ (1ST7).

Where the new access is permissive only, the way of necessity is not extincuished. Lide v. Hadley, 36 Ala. 627, 76 Am. Dec. 335 (1860); Yalmer v. Palmer, 150 N. Y. 139,44 N. E. 966,55 Am. St. Rep. 653 (1S96).

For other cases in which the easement ceases, see Shirley v. Crabb, ante, p. 240. 


\section{CHAPTER III}

\section{LICENSES}

\section{WOOD v. LAKE.}

(Court of King's Bench, 17j1. Sayer, 3.)1

In a case reserved, in an action upon the case, it was stated; that the defendant had agreed, by a parol agreement, that the plaintiff should have the liberty of stacking coals upon part of a close belonging to the defendant, for the term of seven years, and that, during this term, he should have the sole use of that part of the close, upon which he was to have the liberty of stacking coals; and that, after the plaintiff had, pursuant to this agreement, enjoyed the liberty of stacking coals three years, the defendant locked up the gate of the close.

The question was, whether this agreement was good for seven years?

LEE, C. J., and DENison, J., were of opinion, that it was.

And by them.- In the case of Webb v. Paternoster, Palm. 71, it is laid down, that the grant of a license to stack hay upon land does not amount to a lease of the land; and, although it be in that case said, that such a license, provided the grant be for a time certain, is irrevocable, it by no means follows, that an interest in the land does thereby pass. As the agreement in the present case was only for an easement, and not for an interest in the land, it did not amount to a lease, and consequently it was, notwithstanding the Statute of Frauds and Perjuries, good for seven years.

WRIGHT, J., was absent.

Foster, J., concurred in opinion, that the agreement did not amount to a lease; but he inclined to be of opinion, that the words in the Statute of Frauds and Perjuries, any uncertain interest in land, do extend to this agreement, and consequently that it was not good for more than three years.

LEE, C. J., and Denison, J., inclined to be of opinion, that the words in that statute, any uncertain interest in land, do relate only to interests, which are uncertain as to the time of their duration.

After taking time to consider, it was holden that the agreement was good for seren years.

1.S. c., 13 M. \& W. S4s, note. 


\section{HEWLINS v. SHIPPAM.}

(Court of King's Bench, 1826. 5 Barn. \& C. 221.)

[Case for wrongfully obstructing a drain.]

The piaintiff was a lessee of the Swan Inn, at Chichester, under W. and E. Humphrey. In May, 1819, W. and E. Humphrey rebuilt the Swan Inn, at Chichester, and being desirous to construct a drain in the adjoining premises (in the possession of the defendant) applied to Wills, the landlord, who said he had no objection if his tenant had not. 'The Humphreys further agreed to repair the defendant's premises, to raise his chimnies, and to pave his yard. The defendant assented to the making the drain upon these terms, and they raised the defendant's chimnies and paved his yard, and thereby incurred an expense of $100 l$. The drain was constructed, it was paved at the bottom, and covered with solid stone, and the sides were brick. Upon these facts, Graham, 33., was of opinion that the right claimed under the license granted by the defendant and his landlord, to have the drain in the soil of another, was an uncertain interest in the land, within the first section of the statute of frauds, and not being granted by any instrument in writing, the plaintiff acquired under it a right at will only, which was determined by the defendant's stopping up the drain. He therefore directed a nonsuit, with liberty to the plaintiff to move to enter a verdict.

Taddy, Serjt., in last Easter term, obtained a rule nisi for that purpose.

BAYLEY, J. ${ }^{2} * * *$ It appeared in evidence upon the trial that the drain was made in 1819 , at the expense of the Humphreys, with the consent of the defendant and Mr. Wills, and that the Humphreys laid out some money in improving the defendant's premises, but nothing was said as to how long the drain was to continue, nor was any thing in writing between any of the parties; and when the inconveniences such a drain may occasion from smells, and the necessity of cleaning it are considered, it is almost impossible to suppose that Wills and the defendant meant to run all risks, and allow the parties an absolute interest so long as the defendant should continue in possession, or so long as it should be requisite, \&c. But suppose this had been the intention, can such an interest be created by parol? A right of way or a right of passage for water, (where it does not creatc an interest in the land,) is an incorporeal right, and stands upon the same footing with other incorporeal rights, such as rights of common, rents, advowsons, \&c. It lies not in livery, but in grant, and a freehold interest in it cannot be created or passed, (even if a chattel interest may, which I think it cannot,) otherwise than by deed. ***

In Fentiman v. Smith, 4 East, 107, where the plaintiff claimed to have passage for water by a tunnel over defendant's land, Lord Ellen-

2 The statement of farts is abridged and part of the opinion is omitted. 
borough lays it down distinctly: "The title to have the water flowing in the tunnel over defendant's land could not pass by parol license without deed." Upon these authorities we are of opinion, that although a parol license might be an excuse for a trespass till such license were countermanded, that a right and title to have passage for the water, for a freehold interest, required a deed to create it, and that, as there has been no deed in this case, the present action, which is founded on a right and title, cannot be supported. The case of Winter v. Brockwell, 8 East, $309,{ }^{3}$ which was relied upon on the part of the plaintiff, appears clearly distinguishable from the present. All that the defendant there did, he did upon his own land. He claimed no right or easement upon the plaintiff's. The plaintiff claimed a right and easement against him, viz. the privilege of light and air through a parlor window, and a free passage for the smells of an adjoining house through defendant's area; and the only point decided there was, that as the plaintiff had consented to the obstruction of such his easement, and had allowed the defendant to incur expense in making such obstruction, he could not retract that consent without reimbursing the defendant that expense. But that was not the case of the grant of an easement to be exercised upon the grantor's land, but a permission to the grantee to use his own land in a way in which, but for an easement of the plaintiff's, such grantee would have had a clear right to use it. Webb v. Paternoster, Palm. 71; Wood v. Lake, Sayer, 3 ; and Taylor v. Waters, 7 Taunt. 374, were not cases of freehold interest, and in none of them was the objection taken that the right lay in grant, and therefore could not pass without deed. These, therefore, cannot be considered as authorities upon the point; and on these grounds, therefore, that the right claimed by the declaration is a freehold right, and that if the thing claimed is to be considered as an easement, not an interest in the land, such a right cannot be created without deed; we are of opinion that the nonsuit was right, and that the rule ought to be discharged.

Rule discharged.

\section{LIGGINS v. INGE et al.}

(Court of Common Pleas. 1S31. 7 Bing. 68.9.)

TINDAL, C. J. ${ }^{4}$ It will be unnecessary on the present occasion to consider more than one of the questions which have been argued at the bar, namely, whether the present action, upon the facts stated in the award of the arbitrator, is maintainable against the defendants.

The action is, in point of form, an action of tort, and charges the defendants with wrongfully continuing a certain weir or fletcher, which the defendants had before erected upon one of the banks of

8 Ante, p. 290.

4 The statement of facts is omitted.

Big.Iilgnis-20 
the river, and by that means wrongfully continuing the diversion (If the water, and preventing it from flowing to the plaintiff's mill in the manner it had been formerly accustomed to do.

It appeared in evidence before the arbitrator, that the bank of the river, which had been cut down, was the soil of the defendants; and that the same had been cut down and lowered, and the weir erected, and the water thereby diverted by them, the defendants, and at their expense, in the year 1822, under a parol license to them given for that purpose by the plaintiff's father, the then owner of his mill; and that in the year 1827, the plaintiff's father represented to the defendants, that the lowering and cutting down the bank were injurious to him in the enjoyment of his mill, and had called upon them to restore the bank to its former state and condition; with which requisition the defendants had refused to comply.

The question, therefore, is, whether such non-compliance, and the keeping the weir in the same state after, and notwithstanding the countermand of the license, is such a wrong done on the part of the defendants as to make them liable to this action.

The argument on the part of the plaintiff has been, that such parol license is, in its nature, countermandable at any time, at the pleasure of the party who gave it. That to hold otherwise, would be to allow to a parol license the effect of passing to the defendants a permanent interest in part of the water which before ran to the plaintiff's mill; which interest, at common law, could only pass by grant under seal, being an incorporeal hereditament, and which, at all events, would be determinable at the will of the grantor since the statute of frauds, as being "an interest in, to, or out of lands, tenements, and hereditaments."

If it was necessary to hold, that a right or interest in any part of the water, which before flowed to the plaintiff's mill, must be shown to have passed from the plaintiff's father to the defendants under the license, in order to justify the continuance of the weir in its original state, the difficulty above suggested would undoubtedly follow. For it cannot be denied that the right to the flow of the water, formerly belonging to the owner of the plaintiff's mill, could only pass by grant, as an incorporeal hereditament, and not by parol license.

But we think the operation and effect of the license, after it has been completely executed by the defendants, is sufficient, without holding it to convey any interest in the water, to relieve them from the burthen of restoring to its former state what has been done under the license, although such license is countermanded; and, consequently, that they are not liable to an action as wrongdoers, for persisting in such refusal.

The parol license, as it is stated in the award of the arbitrator, was a license to cut down and to lower the bank, and to erect the weir. Strictly speaking, if the license was to be confined to those terms, it was at once unnecessary and inoperative; for the soil being the property of the defendants, they would have the right to do both those 
acts without the consent of the owner of the lower mill. But as the diversion of part of the water which before flowed to that mill would be the necessary consequence of such acts, it must be taken that the object and effect of such license was to give consent, on the part of the plaintiff's father, to the diverting of the water by means of those alterations.

IVe do not, however, consider the object, and still less the effect, of the parol license, to be the transferring from the plaintiff's father to the defendants any right or interest whatever in the water which was before accustomed to flow to the lower mill, but simply to be an acknowledgment, on the part of the plaintiff's father, that he wanted such water no longer for the purposes of his mill; and that he gave back again and yielded up, so far as he was concerned, that quantity of water which found its way over the weir or fletcher, which he then consented should be erected by the defendants. And we think, iftcr he has once clearly signified such relinquishment, whether by words or acts, and suffered other persons to act upon the faith of such relinquishment, and to incur expense in doing the very act to which his consent was given, it is too late then to retract such consent, or to throw on those other persons the burthen of restoring matters to their former state and condition.

Water flowing in a stream, it is well settled, by the law of England. is publici juris. By the Roman law, running water, light, and air, were considered as some of those things which had the name of res cominunes and which were defined "things, the property of which belong to no person, but the use to all." And, by the law of England, the person who first appropriates any part of the water flowing through his land to his own use, has the right to the use of so much as he thus appropriates, against any other. Bealy v. Shaw and Others, 6 East, 207. And it seems consistent with the same principle, that the water, after it has been so made subservient to private uses by appropriation, should again become publici juris by the mere act of relinquishment. There is nothing unreasonable in holding that a right which is gained by occupancy should be lost by abandonment. Suppose a person, who formerly had a mill upon a stream, should pull it down, and remove the works, with the intention never to return. Could it be held, that the owner of other land adjoining the stream, might not erect a mill and employ the water so relinquished? Or that he could be compellable to pull down his mill, if the former mill-owner should afterwards change his determination, and wish to rebuild his own?

In such a case it would undoubtedly be a subject of inquiry by a jury, whether he had completely abandoned the use of the stream, or had left it for a temporary purpose only; but that question being once determined, there seems no ground to contend that an action would be maintainable against the person who erected the new mill, for not plìling it down again after notice. And if, instead of his intention remaining uncertain upon the acts which he had done, the former pro- 
prietor had openly and expressly declared his intention to abandon the stream,- - that is, if he had licensed the other party to erect a mill,the same inference must follow with greater certainty. Or suppose A. authorizes B., by express license, to build a house on B.'s own land, close adjoining to some of the windows of A.'s house, so as to intercept part of the light; could he afterwards compel B. to pull the house down again, simply by giving notice that he countermanded the license? Still further, this is not a license to do acts which consist in repetition, as to walk in a park, to use a carriage way, to fish in the waters of another, or the like: which license, if countermanded, the party is but in the same situation as he was before it was granted; but this is a license to construct a work, which is attended with expense to the party using the license; so that, after the same is countermanded, the party to whom it was granted may sustain a heavy loss. It is a license to do something that, in its own nature, seems intended to be permanent and continuing. And it was the fault of the party himself, if he meant to reserve the power of revoking such a license, after it was carried into effect, that he did not expressly reserve that right when he granted the license, or limit it as to duration. Indeed the person who authorizes the weir to be erected becomes, in some sense, a party to the actual erection of it; and cannot afterwards complain of the result of an act which he himself contributed to effect.

Upon principle, therefore, we think the license in the present case, after it was executed, was not countermandable by the person who gave it, and consequently that the present action cannot be maintained. And, upon authority, this case appears to be already decided by that of Vinter v. Brockwell, which rests on the judgment in Webb v. Paternoster. We see no reason to doubt the authority of that case, confirmed, as it since has been, by the case of Tayler v. Waters in this Court, and recognized as law in the judgment of Mr. Justice Bayley, in the case of Hewlins v. Shippam, in the Court of B. R.

We therefore think the rule for setting aside the award of the arbitrator must be made absolute.

Rule absolute. ${ }^{5}$

5 "A license to a person to do or erect something on his own land, by which a right or easement of the licensor may be affected, if once executed cannot be revoled. 3 Kent, 4i2; Angell on Water Courses, $\$ \S 296,308$; Washb. on Easements, 559, § 1; Liggins v. Inge, 7 Bing. 6S2 [1891]; Winter v. Brockwell, S East, 30 [1807]; Dyer v. Sanford, 9 Metc. 395 [43 Am. Dec. 399 (1845)]; Morse v. Copeland, 2 Gray, 302 [1854].

"This effect giren to a license by parcl or by writing without seal, seemingly contrary to the principle of law that a right to an easement can arise or pass by deed only, is said by some to be founded on the doctrine of abandonment. It is settled, that an easement or right in the estate of another, acquired by grant or prescription, may be lost by actual abandonment, that is, by a non-user for twenty years, or even for-less time, accompanled by acts which show an intention not to resume it. And it is sald that the effect of a license to do an act on the land of the licensee, can only extinguish such easement as may be abandoned, that is, easements or rights acquired by grant or prescription, and coes in no case affect easements or in- 


\section{WOOD v. LEADBIT'TER.}

(Court of Exchequer, 185. 13 Mers. \& W. S39.)

AldERSOx, B. ${ }^{6}$ This was an action tried before my Brother Rolfe at the sittings after last Trinity Tem. It was an action for an assault and false imprisonment. The plea (on which alone any question arose) was, that at the time of the alleged trespass the plaintiff was in a certain close of Lord Eglintoun, and the defendant, as the servant of I.ord Eglintoun, and by his command, laid his hands upon the plaintiff in order to remove him from the said close, using no unnecessary violence. Replication, that, at the time of such removal, the plaintiff was in the said close by the leave and license of Lord Eglintoun. The leave and license was traversed by the defendant, and issue was joined on that traverse. On the trial it appeared that the place from which the plaintiff was removed by the defendant was the enclosure attached to and surrounding the great stand on the Doncaster race-course; that Lord Eglintoun was steward of the races there in the year 18+3; that tickets were sold in the town of Doncaster at one guinea each, which were understood to entitle the holders to come into the stand, and the enclosure surrounding it, and to remain there every day during the races. These tickets were not signed by Lord Eglintom, but it must be assumed that they were issued with his privity. It further appeared, that the plaintiff, having purchased one of these tickets, came to the stand during the races of the year 1843, and was there or in the enclosure while the races were going on, and while there, and during the races, the defendant, by the order of Lord Eglintoun, desired him to depart, and gave him notice that if he did not go away, force would he used to turn him out. It must be assumed that the plaintiff had in no respect misconducted himself, and that, if he had not been re-

corporeal hereditaments, which are, lo law, amexed to the land of the licensor. Angell on Water Courses, 303 ; Fentiman v. Smith, 4 Fast, 107 [1503]. of this kind, is the right to ruming water passing orer or along his land in a natural stream or water course. It is creating an easement in, or parting with a right annexed by law, not giving u! or ahandoning a right acquired by grant or prescription. I an much inclined to think that the last is the correct doctrine." Zabriskie, Chancellor, in Voghte v. Raritan Watol lower Co., 19 N. J. El. 142. 15: (1sfis). Sue Sildison r. 1lack, 2 Gill (Ird.) 221, $41 \mathrm{Am}$. Dec. 421 (1.4. I).

A. was a riparian proprietor. 1le verbally anthorized an incorporated village to discharge its drainage, by a drainage system, into the creek above his land in a way that without such consent would amount to a nulsance. The rillace, in reliance upon this permission, expended money in the prepa. ration of plans, and incurred other liabilities, and the contrators had started upon the building of the sewer. .1 . then revoled his license and songht to enjoin the village from so dischatrging its sewerage. Ileld, he is

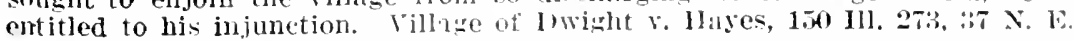
221s, 41 Am. St. liep. 367 (1591).

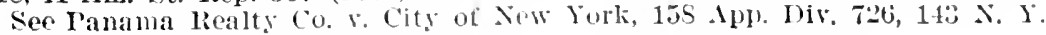
Supl. S98 (1915).

6 The statement of facts and part of the opinion are omitued. 
quired to depart, his coming upon and remaining in the enclosure would have been an act justified by his purchase of the ticket. The plaintiff refused to go, and thereupon the defendant, by order of Lord Eglintoun, forced him out, without returning the guinea, using no unnecessary violence.

My Brother Rolfe, in directing the jury, told them, that, even assuming the ticket to have been sold to the plaintiff under the sanction of Lord Eglintoun, still it was lawful for Lord Eglintoun, without returning the guinea, and without assigning any reason for what he did, to order the plaintiff to quit the enclosure, and that, if the jury were satisfied that notice was given by Lord Eglintoun to the plaintiff, requiring him to quit the ground, and that, before he was forcibly removed by the defendant, a reasonable time had elapsed, during which he might conveniently have gone away, then the plaintiff was not, at the time of the removal, on the place in question by the leave and license of Lord Eglintoun. On this direction the jury found a verdict for the defendant. In last Michaelmas Term, Mr. Jervis obtained a rule nisi to set aside the verdict for misdirection, on the ground, that, under the circumstances, Lord Eglintoun must be taken to have given the plaintiff leave to have come into and remain in the enclosure during the races; that such leave was not revocable, at all events without returning the guinea; and so that, at the time of the removal, the plaintiff was in the enclosure by the leave and license of Lord Eglintoun. Cause was shown during last term, and the question was argued before my Brothers Parke, and Rolfe and myself; and on account of the conflicting authorities cited in the argument, we took time to consider our judgment, which we are now prepared to deliver.

That no incorporeal inheritance affecting land can either be created or transferred otherwise than by deed, is a proposition so well established, that if would be mere pedantry to cite authorities in its support. All such inheritances are said emphatically to lie in grant, and not in livery, and to pass by mere delivering of the deed. In all the authorities and text-books on the subject, a deed is always stated or assumed to be indispensably requisite.

And although the older authorities speak of incorporeal inheritances, yet there is no doubt but that the principle does not depend on the quality of interest granted or transferred, but on the nature of the subject-matter: a right of common, for instance, which is a profit a prendre, or a right of way, which is an easement, or right in nature of an easement, can no more be granted or conveyed for life or for years without a deed, than in fee simple. Now, in the present case, the right claimed by the plaintiff is a right, during a portion of each day, for a limited number of days, to pass into and through and to remain in a certain close belonging to Lord Eglintoun; to go and remain where if he went and remained, he would, but for the ticket, be a trespasser. This is a right affecting land at least as obviously and extensively as a right of way over the land,-it is a right of way and 
something more: and if we had to decide this case on general principles only, and independently of authority, it would appear to us perfectly clear that no such right can be created otherwise than by deed. The plaintiff, however, in this case argues, that he is not driven to claim the right in question strictly as grantee. He contends, that, without any grant from Lord Eglintoun, he had license from him to be in the close in question at the time when he was turned out, and that such license was, under the circumstances, irrevocable. And for this he relies mainly on four cases, which he considers to be expressly in point for him, viz. Webb v. Paternoster, reported in five different books, namely, Palmer, 71; Roll. 143 and 152; Noy, 98; Popham, 151, and Godbolt, 282; Wood v. Lake, Sayer, 3; Tayler v. Waters, 7 Taunt. 374, and IVood v. Manley, 11 Ad. \& E. 34; 3 Per. \& D. 5.

As the argument of the plaintiff rested almost entirely on the authority of these four. cases, it is very important to look to them minute$1 y$, in order to see the exact points which they severally decided.

Before, however, we proceed to this investigation, it may be convenient to consider the nature of a license, and what are its legal incidents. And, for this purpose, we cannot do better than refer to Lord C. J. Vaughan's elaborate judgment in the case of Thomas $v$. Sorrell, as it appears in his Reports. The question there was as to the right of the Crown to dispense with certain statutes regulating the sale of wine, and to license the Vintners' Company to do certain acts notwithstanding those statutes.

In the course of his judgment the Chief Justice says, Vaughan, 351, "A dispensation or license properly passeth no interest, nor alters or transfers property in any thing, but only makes an action lawful, which without it had been unlawful. As a license to go beyond the seas, to hunt in a man's park, to come into his house, are only actions which, without license had been unlawful. But a license to hunt in a man's park, and carry away the deer killed to his own use; to cut down a tree in a man's ground, and to carry it away the next day after to his own use, are licenses as to the acts of hunting and cutting down the tree, but as to the carrying away of the deer killed and tree cut down, they are grants. So, to license a man to eat my meat, or to fire the wood in my chimney to warm him by, as to the actions of eating, firing my wood, and warming him, they are licenses; but it is consequent necessarily to those actions that my property may be destroyed in the meat eaten, and in the wood burnt. So as in some cases, by consequent and not directly, and as its effect, a dispensation or license may destroy and alter property."

Now, attending to this passage, in conjunction with the title " $\mathrm{Li}$ cense" in Brooke's Abridgment, from which, and particularly from paragraph 15 , it appears that a license is in its nature revocable, we have before us the whole principle of the law on this subject. A mere license is revocable: but that which is called a license is often something more than a license; it of ten comprises or is connected with a 
grant, and then the party who has given it cannot in general revoke it, so as to defeat his grant, to which it was incident.

It may further be observed, that a license under seal (provided it be a mere license) is as revocable as a license by parol $;^{7}$ and, on the other hand, a license by parol, coupled with a grant, is as irrevocable as a license by deed, provided only that the grant is of a nature capable of being made by parol. But where there is a license by parol, coupled with a parol grant, or pretended grant, of something which is incapable of being granted otherwise than by deed, there the license is a mere license; it is not an incident to a valid grant, and it is therefore revocable. Thus, a license by A. to hunt in his park, whether given by deed or by parol, is revocable; it merely renders the act of hunting lawful, which, without the license, would have been 'unlawful. If the license be, as put by Chief Justice Vaughan, a license not only to hunt, but also to take away the deer when killed to his own use, this is in truth a grant of the deer, with a license annexed to come on the land: and supposing the grant of the deer to be good, then the license would be irrevocable by the party who had given it; he would be estopped from defeating his own grant, or act in the nature of a grant. But suppose the case of a parol license to come on my lands, and there to make a watercourse, to flow on the land of the licensee. In such a case there is no valid grant of the watercourse, and the license remains a mere license, and therefore capable of being revoked. On the other hand, if such a license were granted by deed, then the question would be on the construction of the deed, whether it amounted to a grant of the watercourse; and if it did, then the license would be irrevocable. ['The court discussed IVebb v. Paternoster, Palmer, 71, Rolle, 143, 152, Wood v. Lake, Sayer, 3, Tayler v. Waters, 7 Taunt, 374, and Wood v. Manley, 11 Ad. \& E. 34.]

It was suggested that, in the present case, a distinction might exist, by reason of the plaintiff's having paid a valuable consideration for the privilege of going on the stand. But this fact makes no difference: whether it may give the plaintiff a right of action against those from whom he purchased the ticket, or those who authorized its being issued and sold to him, is a point not necessary to be discussed; any such action would be founded on a breach of contract, ${ }^{8}$ and would not be the result of his having acquired by the ticket a right of going upon the stand, in spite of the owner of the soil; and it is sufficient, on this point to say, that in several of the cases we have cited, (Hewlins v. Shippam, for instance, and Bryan v. Whistler,) the alleged license had been granted for a valuable consideration, but that was not held to make any difference. We do not advert to the cases of Winter v: Brockwell, 8 East, 308, and Liggins v. Inge, 7 Bing. 682, or other cases

iAcc.: Fish v. Capwell, 18 R. I. 667, 29 Atl. S40, 25 I. R. A. 159, 49 Am. St. Rep. 807 (1894).

8Acc.: Kerrison r. Smith, [1897] 2 Q. B. 445. See Elswick v. Lamey, 157 Ky. 6.99, 168 S. W. 751 (1914). 
ranging themselves in the same category, as they were decided on grounds inapplicable to the case now before us, and were, in fact, admitted not to bear upon it.

We have come to the conclusion, that the direction given to the jury at the trial was correct, and that this rule must be discharged.

Rule discharged. ${ }^{9}$

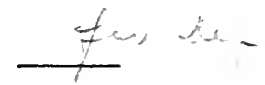

DRAKE v. WELLS. SAME v. WYMAN. SAME v. HEIVINS.

(Supreme Judicial Court of Massachusetts, 1865. 11 Allen, 141.)

Three actions of tort in the nature of trespass quare clausum.

At the trial in the superior court, before Rockwell, J., the following facts appeared: In November, 1863, Manley Drake put up and sold at auction the standing wood on the close described, in several parcels, and the defendants each became the purchaser of one or more of said parcels; and at the auction the auctioneer stated publicly, and as one of the terms of sale, that the purchasers might have until the middle of the following June to cut and remove the wood from the land.

At the same auction, and after the sale of the wood had been completed, the land was put up by the same auctioneer for sale, in two lots: and the plaintiff, through an agent who was present at the sale of both wood and land, and heard the terms of sale stated by the auctioneer, bid off and became the purchaser of one of the lots, and Azel Drake purchased the other. Subsequently in the same month deeds of the lots were executed by Manley Drake to Emma R. Drake and Azel Drake; and on the 12th day of February, 1864, Azel Drake sold and conveyed by deed the lot purchased by him to the plaintiff. All the deeds above mentioned were entered for record on the 14th of June, 1864; but it was not contended, at the argument in this court, that the defendants were ignorant of the sale of the land by Manley Drake, and the execution of the deeds thereof, at the time when the trees were cut.

'Acc.: Where the ticket holder had not taken the seat to which the ticket entitled him. McCrea v. Marsh, 12 Gray (Mass.) 211, 71 Am. Dec. 745 (185S); Burton r. Scherpf, 1 Allen (Mass.) 133. 79 Am. Dec. 717 (1861) ; Horney v. Nixon, $213 \mathrm{~Pa} .20,61$ Atl. 10SS, 1 L. R. A. (N. S.) 1184, 110 Am. St. Ken. 520, 5 Ann. Cas. 349 (1905), distinguishing Drew จ. Peer, 93 Pa. 234 (1850).

Contra: Tayler v. Waters, 7 Taunt. 3.74 (1S17). Contra, where the ticket holder had taken the seat to which his ticket entitled him: Hersuson v. Chase, 28 Wash. L. Rep. 797 (1900). Contra. by statute: Greenberg $r$. Western Turf Ass'n, 140 Cal. 357, 73 Pac. 1050 (1903); Cremore v. Huber, is App. Div. 231, 45 N. Y. Supp. 947 (1S97).

$A$. was the lessee of a theater. He made a contract with $B$. whereby $A$. "let" and B. "took *** the exclusive right to sell refreshments at the * * *" theater, for the term of A.'s leãse, "with the necessary use of the refreshment rooms, bar, cloak rooms, and wine cellars $*_{*}^{*}$ and the free and exclusive right of supplying visitors and other people wines, spirits, cigars," etc. B. was to pay a weekly "rental" of $£ 35$. Held, B. has no interest that entitles him to compensation in condemnation proceedings to take over the land and theater building. Warr $v$. London County Council, [1904] 1 K. B. 713. See, also, White v. Maynard, 111 Mass. 250, $15 \mathrm{Am}$. Rep. 28 (1872). 
The deeds from Manley Drake to the plaintiff and Azel Drake, and the deed from said Azel to the plaintiff, were warranty deeds, containing no reservation of standing wood, or of any right to enter upon the land to cut or remove the same; and all the acts of trespass complained of consisted in cutting and carrying away the wood sold, and were committed by the several defendants prior to the 15 th of June, 1864.

Upon these facts, the judge instructed the jury that the plaintiff was not entitled to recover in either of said actions, and verdicts were accordingly rendered for the defendants. The plaintiff alleged exceptions.

Bigelow, C. J. The doctrine is now well settled that a sale of timber or other product of the soil, which is to be severed from the freehold by the vendee under a special license to enter on the land for that purpose is, in contemplation of the parties, a sale of chattels only, and cannot be regarded as passing an interest in the land, and is not for that reason required to be in writing as being within the statute of frauds. Such license to enter on the land of another, so far as it is executed, is irrevocable; because, by the severance of the timber or other growth of the soil from the freehold, in execution of the license, it becomes personal property, the title to which is vested in the vendee absolutely, and the rule applies that where chattels belonging to one person are placed or left on the land of another, with the permission or assent of the latter, the owner of the chattels has an implied irrevocable license to enter and remove them. ${ }^{10}$ In such case the owner of land cannot, by withdrawing his assent to enter on his premises, deprive the owner of chattels of his property, or prevent him from regaining possession of them. The law will not lend its aid to the perpetration of a fraud. But it is otherwise where the contract has not been executed by a severance of the subject matter of a contract of sale from the freehold. So long as the timber or other product of the soil continues in its natural condition, and no act is done by the vendee towards its separation from the soil, no property or title passes to the vendee. The whole rests in contract. A revocation of the license to enter on the land does not defeat any valid title; it does not deprive an owner of chattels of his property in or possession of them. The contract being still executory, no title has passed to the vendee, and the

10.Arc: Tood v. Manley, 11 A. \& E. 34 (1889); Long v. Buchanan, 27 Mu. 502, 92 Am. Dec. 653 (1867) ; Sterling v. Warden, $51 \mathrm{~N} . \mathrm{H} .217,12 \mathrm{Am}$. Rep. 80 (1871); Barnes v. Barnes, 6 Vt. 388 (1834).

That the licensee has a reasonable time after the rerocation of the license within which to remove his property, see Cornish v. Stubbs, L. R. C. P. 394 (1570); Parsons v. Camp, 11 Conn. 525 (1836); Rogers v. Cox, 96 Ind. 157, $49 \mathrm{Am}$. Iiep. 152 (1SS4); Great Falls Waterworks Co. v. Great Northern R.y. Co., 21 Mout. 487, 54 Pac. 963 (1S98); Western North Carolina R. ('o. v. Deal, 90 N. C. 110 (18s4).

If the licensee does not remove within a reasonable time, the licensor may do so. Hodgkins v. Farrington, 150 Mass. 19, 22 ‥ E. 73, 5 L. L. A. 209, 15 Am. St. Rep. 168 (1ऽ১9). 
refusal of the vendor to permit the venclee to enter on the land for the purpose of disconnecting from the freehold the property agreed to be sold is only a breach of contract, the remedy for which is an action for damages, as in the common case of a failure or refusal to deliver ordinary chattels in pursuance of a contract of sale.

These principles have been recognized and established as the law of this commonwealth in several adjudicated cases. In Claflin v. Carpenter, 4 Metc. .580, 582, $38 \mathrm{Am}$. Dec. 381, it was held that a contract for the sale of standing wood to be cut and severed from the freehold was to be construed "as passing an intcrest in the trees when they are severed," and that a license to enter on the land under such contract could not be countermanded after it had been acted on. So in Nettleton v. Sikes, 8 Metc. 34 , it was said by the court that a beneficial license to be exercised on land, "when acted upon under a valid contract cannot be countermanded." To the same effect are Nelson v. Nelson, 6 Gray, 385, and Douglas v. Shumway, 13 Gray, 49S. In these cases it appeared that the license had been acted on by the vendee, who had entered on the land and cut the timber which was the subject of the contract of sale, and had thereby acquired a title to the wood as personal property. In Giles v. Simonds, 15 Gray, 441, 77 Am. Dec. 373. a case was presented where a vendee had entered on land under a contract of sale of standing wood, and had cut down a part of those which was agreed to be sold, when he was forbidden by the vendor, the owner of the land, from proceeding any further in the execution of the contract, and also from removing those which had been severed from the freehold. He nevertheless did go on the land and take away such of the trees as had been previously cut down. It was held that the vendor had a right to terminate the contract and revoke the license as to the trees left standing, but that he could not do so as to those which had been already cut, and that an action of trespass would not lie for entering and taking away the latter. See also Burton v. Scherpf, 1 Allen, 135, 79 Am. Dec. 717.

The application of the principles established by these cases is decisive of the rights of the parties to these actions. Taking the most favorable view of these cases in behalf of the defendants, they had acquired no title to the wood standing on the land of the plaintiff. They had only an executory contract for the purchase of the trees growing on the premises, with a license from the plaintiff's grantor to enter and cut and remove the same. This license, not having been acted on, was revocable. And it was revoked by the deed of the land to the plaintiff by the licensor, by which it was conveyed absolutely and free of all incumbrances to the plaintiff. In Cook v. Stearns, 11 Mass. 533. 538 , it was held that the transfer of land to another, or even a lease of it, without any reservation would, of itself, be a countermand of a license. Clearly it must be so, bccause an unqualified grant of land carries with it the title to everything. which is part of the realty or annexed to the freehold, and is inconsistent with a right in any other per- 
son than the grantee to enter on the land and remove therefrom trees growing thereon or other products of the soil. Coleman v. Foster, 1 Hurlst. \& Norm. 3\%.

It follows that the ruling of the court was erroneous at the trial of this cause. The defendants were trespassers, and were liable to the plaintiff for entering her close and cutting and removing wood therefrom.

Exceptions sustained. ${ }^{11}$

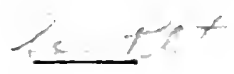

\section{FROGLEY v. EARL OF LOVELACE.}

(Court of Chancery, 1859. Johns. Ch. 3:3̈̈.)

By an indenture of lease, dated the 24th of February, 1844, made between the defendant of the one part, and the plaintiff of the other part, the defendant demised to the plaintiff two farms, in the county of Surrey, for twenty-one years, from Michaelmas, 1842, at the rent therein mentioned.

11Acc.: That a mere license is personal, and is consequently terminated by a converance of the land with respect to which the license is giren. Emerson r. Shores, 95 Me. 237, 49 Atl. 1051, 85 Am. St. Rep. 404 (1901); Cook r. Stearns, 11 Mass. 533 (1S14); Ward v. Rapp, 79 Mich. 469, 44 N. W. 934 (1890) ; Bridges v. Purcell, 18 N. C. 492 (1S36).

A. owned a tract of land; B. made a verbal contract with $A$. to purebase the timber standing thereon; before $B$. could cut the timber $A$. made a binding contract to sell the land to $C$. B. had no notice of this contract and entered and cut the timber. C. had no notice that B. claimed anv interest in the timber until after he (C.) took possession of the land. C. took possession of the timber so cut. Held, B. cannot maintain an action of trover against C. for the timber so taken. Bruley r. Garrin. 105 Wis. 625, 81 న. W. 1038, $48 \mathrm{~L}$. R. A. $\$ 39$ (1900). See White ₹. King, 87 Mich. 107, 49 N. W. $51 S$ (1591).

A. orned a piece of land on which it was proposed to erect a building. Br written contract A., "the licensor," gare B., "the licensee," exclusire pelmission to affix adrertisements upon the walls of building so to be erectert for a period of four years from the erection thereof. $B$. to pay therefor a "rent" of $£ 12$ per annum. The licensor agreed that he would not, while the license remained in force, permit any otber person to afiix adrertisements. $A$. then leased the land to $\mathrm{C}$. by indenture for 40 vears. C. corenanting to erect a building. C. had notice of the contract with $B$. C. erected the building and refused to allow B. to affix advertisements. Held. B. has an action for breacn of contract against A. King v. Allen, [1916] 2 A. C. $\overline{4} 4$. Com. rare Lery $v$. Louistille Gunning System, $121 \mathrm{Ks}$. 510, $\$ 9 \mathrm{~S}$. W. 528, 1 I. R. A. (N. S.) 349 (1905); Eorough Bill Posting Co. v. Lery, 1t4 App. Div. TSt, 12y N. Y. Supp. $i+0$ (1911).

An assignment of the license br the licensee also terminates it, Bates $v$ Duncan, 64 Ark. 339, 42 S. IT. 410, 62 Am. St. Rep. 190 (1597): Prince v. Case, 10 Conn. 375. 27 Am. Dec. 675 (1835); Dark $\vee$. Johnston. 55 Pa. 164 $93 \mathrm{Am}$. Dec. 782 (1697); Nunnelly $\nabla$. Southern Iron Co., 94 Tenn. 39\%. S. W. $361,2 \&$ L. R. A. 421 (1S94).

As to the richts of the holder of a license "coupled with an interest" against a grantee of the land, see Jenkins v. Lykes, 19 Fla. 14S, $45 \mathrm{Am}$. Rep. 19 (1SS2); Shipley v. Fink, 102 IId. 219, 62 Atl. 360, 2 L. R. A. (N. S.) 1002 (1905).

A license "coupled with an interest" is assignable. Heflin v. Binghrm, ar; Ala. J66. $28 \mathrm{Am}$. Rep. 76 (1STe); Ingalls v. St. Paul. M. \& I. Ry. ('o.. ::: Minn. 479. 40 ‥ $\pi .524 .12 \mathrm{Am}$. St. Rep. 676 (1sss). See Ely v. Caranaugh, S: Conn. B81, it Atl. 1122 (1910). 
Preyiously to the execution of the said indenture the following memorandum was indorsed thereon: "It is hereby agreed that the said Ralph Frogley," meaning the plaintiff, "shall have the exclusive right of sporting over, and killing the game upon, the lands included in the within-written lease, and also upon the lands adjacent thereto belonging to the said earl," meaning the defendant (describing such adjacent lands), "during the continuance of the said term, if the said Ralph Frogley shall so long live; he undertaking to keep and leave a fair stock of game thereupon, and not to keep such an excessive quantity of hares and rabbits as to do damage to the said earl or his under-tenants in the neighbourhood."

The lease was executed by both plaintiff and defendant; but the memorandum was executed by the plaintiff only.

On the 9th of February, 1859, the defendant caused a notice to be served on the plaintiff, whereby, after reciting the memorandum indorsed on the lease of February, 184, the defendant gave the plaintiff notice that, from and after the date thereof, he reroked, rescinded and entirely put an end to the agreement expressed in the said memorandum, and each and every right, license, liberty, permission or authority thereby given.

The bill stated these facts, and further stated, as the fact was, that, between the 9 th and the 12th of February, 1859, the defendant sent bodies of men upon the property comprised in the said indenture to destroy the hares and rabbits thereon, thereby disturbing and driving away the pheasants and game which the plaintiff had been preserving upon the property.

The bill prayed that the defendant might be decreed specifically to perform the agreement indorsed on the lease of February, 184t; and for that purpose to make and execute to the plaintiff a proper and legal grant of the exclusive right to sporting over, and killing the game upon, the lands included in the said lease, and upon the lands adjacent thereto, in accordance with the terms of the said agreement: and that the defendant, his agents. \&c., might be restrained from disturbing, driving away and destroying, or in any manner interiering with, the pheasants, game, hares and rabbits in and upon the premises comprised in the said agrcement, during the term of years granted or agreed to be granted in respect of the said premises, if the plaintiff should so long live. ${ }^{12} * * *$

The Vice-Chaxcelior ${ }^{13}$ commenced his judgment by examining the evidence as to the circumstances under which the memorandum of agreement was indorsed upon the lease of February, 1St4, and as to the circumstances attending the execution of that indenture: which led the Court to the conclusion that the agreement expressed in the memorandum so indorsed upon the deed formed an essential part of

12 The statement of facts is abridged.

13 Sir W. Page Wood. 
the consideration upon which the plaintiff was induced to take the lease of the property comprised in the indenture; and that the memorandum, though not signed by the defendant, was binding upon him. His Honour then proceeded as follows:

In this state of things, if the whole transaction had rested upon a deed, if the agreement expressed in the memorandum indorsed upon the lease had been also entered into, as the lease itself was by an instrument under seal, I should have felt a good deal of difficulty as to whether I ought not to leave both parties to their rights at law. But that is not the case. The memorandum is a mere writing not under seal, and the case of Wood v. Leadbitter, 13 Mee. \& W. 838, has decided that, in order to acquire a right such as that which is here claimed by the plaintiff, an instrument under seal is necessary; and that at law an instrument purporting to grant such a right, though given for a valuable consideration, is revocable at any time and without paying back the money. At law, therefore, the plaintiff has no remedy until the defendant shall have executed a deed containing a proper and legal grant of the exclusive right of sporting in accordance with the terms of the agreement.

Then I observe that the defendant clairrs to kill not rabbits onlyas to which it seems to have been decided by the very recent case which was cited (Spicer v. Barnard, 1 El. \& El. 874) that they may be killed by the tenant, notwithstanding an express reservation to the landlord of the exclusive right of sporting-but hares also, which are clearly game. In the face of his own express agreement that the plaintiff shall have "the exclusive right of sporting over, and lilling the game upon, the lands" in question, the defendant kills the hares himself, instead of leaving it to the plaintiff to kill them.

Under these circumstances, it appears to me that the plaintiff is clearly entitled to an injunction, in the interval, until the defendant shall have executed a proper legal grant of the right claimed by the plaintiff. I hope, however, that such a grant will be shortly executed, so that the injunction will not long be wanted. ${ }^{14}$

\section{RERICK v. KERN.}

(Supreme Court of Pennsylvania, 1826. 14 Serg. \& R. 267, 16 Am. Dec. 497.)

On the return of a writ of error from the Common Pleas of Union county, it appeared from the record, that this was a special action on the case, brought by Henry Kern, the defendant in error, against Henry Rerick, the plaintiff in error, for diverting a water course, in consequence of which he lost the use of his sawmill; the defcudant pleaded not guilty.

14Ace.: Deyonshire v. Eglin, 14 Beav. 530 (1851); Hervey v. Smith, 22 Beav, 299 (1856). 
The material facts, proved on the trial, were, that some years before the institution of the suit, Henry. Kern, the plaintiff below, being about to erect a sawmill on a stream which was designated by the witnesses as the right-hand stream, a better seat for the mill was found by his millwright on what was termed the left-hand stream. Kern thereupon applied to Rerick for permission to turn the water into the left-hand stream, which was granted; in consequence of this permission, he built the sawmill upon the left-hand stream. Without the aid of the right-hand stream, the water of the left-hand stream would have been wholly insufficient, but the right-hand stream alone would have served the purposes of the mill three or four months during the year; by a union of the two streams, the mill was rendered about a third more valuable than it would have been, with the right-hand stream alone. No deed was executed, nor was any consideration given, but Kern, in consequence of the permission given by Rerick, built a very good mill, which did a great deal of business, and which he would not have built on the left-hand stream, if the permission had not been given. When the water was turned away by Rerick, the mill was in good order, and it was further proved, that, at the time the trial took place, there was as much or more water in the left-hand stream, than there had been before the erection of the sawmill.

The President of the court of common pleas (Chapman) charged the jury as follows:

"Two questions arise in this cause; the first is, whether Henry Rerick, after permitting and agreeing that Henry Kern should turn the water from the right-hand stream to the left-hand stream, when, if he had not given that permission, he would have built his mill upon the right-hand stream, can he, Henry Rerick, afterwards withdraw his permission, and thereby destroy the use of Kern's sawmill. His withdrawing that permission after the mill was built, by removing the stones laid for the purpose of turning the water, if the jury believe these facts, would be a fraud and imposition upon Henry Kern, and he would have no right to remove them; but, if he had withdrawn his: permission, and removed the dam, before Henry Kern was at the expense of building a mill, he would have been justifiable in so doing; or, if the permission was, by parol, to enjoy a right which could only pass by grant, for a consideration, it would be within the statute of frauds and perjuries, and not good in law. But if the jury believe the act was fraudulent in Henry Rerick, he is liable to pay damages to Henry Kern for the injury done him. Of the amount of damages the jury are the judges.

"Ihe second question, if the jury believe that no fraud has been committed by Henry Rerick, is, did Rerick, by removing the dam, divert the water from the left-hand stream, so as to leave less water running in the left-hand stream than there was formerly before the dam was erected? This is a fact for the jury, and if the jury believe that Rerick has diverted the water from the ancient channel, which he 
had no right to do, to the injury of Kern, and that Kern has suffered damage thereby, the jury are to deternine to what amount if any damage the plaintiff has suffered."

The court was requested, by the counsel for the defendant, to instruct the jury in the following manner:

"1. That if Rerick, about the year 1811, did allow the plaintiff, as proved by William Teats, to place an obstruction in the natural channel of one branch of the stream, on Rerick's own land, yet that being without any consideration, and merely by parol, no legal right to the stream, or the use thereof, passed thereby to Kern, but Rerick had a right, at any time, to remove the said obstruction, so that the water could flow at any time in its natural channel."

Answer: "In answer to the first question: He would have a right to remove the said obstructions, before Kern had incurred the expense of building a sawmill, on the faith of Rerick's promise, or he would have had a right, if the permission or promise had been after the building of the mill, but not, after he had induced Kern to be at the expense of building the mill.

"2. That an action for diverting an ancient water course, does not, lie, for removing an artificial obstruction from the natural channel, whereby the water was made to flow as it used to do from time immemorial."

Answer: "That is the general principle of the law; but to this there are exceptions, where, by so doing, the party commits a fraud, and an action will lie."

" 3 . That if the jury believe the whole evidence exhibited by the plaintiff in this cause, Rerick could, legally, in the fall of 1821, remove the dam placed in the forks of the stream, by Kern, on Rerick's land, and for removing the same no action lies, whether Kern sustained thereby loss or not."

Answer: "If the jury believe that there was no fraud in Rerick's removing the dam, in which case he would have a legal right to do it, no action would lie."

" 4 . That if the jury believe the water, ever since the removal of the obstruction at the forks, has run, and continues to run in its natural channel, as it used to do from time immemorial, their verdict should be for the defendant."

Answer: "If the jury so believe, and that no fraud was committed by removing this obstruction or dam, then your verdict should be for the defendant."

The counsel for the defendant excepted to the opinion of the court, both in their charge to the jury, and in their answers to the several propositions submitted to them.

The opinion of the Court was delivered by

Gibson, J. To the objection, that an action for diverting an ancient water course, is not supported by evidence of the removal of an artificial obstruction, it is sufficient to answer, that in the case before us, 
the right depends, not on the antiquity of the water course, but on the agreement of the parties; and the question, therefore, is, would equity carry this agreement into effect?

That such an agreement may be proved by parol, was settled in Le Fevre v. Le Fevre, 4 Serg. \& R. 241, 8 Am. Dec. 696, which, in this respect, goes as far as the case before us. The defence there was, that the right, being incorporeal, and therefore, lying in grant, could pass only by deed; but, as the agreement was for a privilege to lay pipes, it is evident, that the right acquired under it was no further incorporeal than that which passes by the grant of a mine, or of a right to build, which indisputably vests an interest in the soil. A right of way, which has been thought to approach it more nearly, in fact, differs from it still further. But the defence in this case is put on other ground, it being contended, that a mere license is revocable, under all circumstances, and at any time.

But a license may become an agreement on valuable consideration; as, where the enjoyment of it must necessarily be preceded by the expenditure of money; and when the grantee has made improvements or invested capital in consequence of it, he has become a purchaser for a valuable consideration. Such a grant is a direct encouragement to expend money, and it would be against all conscience, to annul it, as soon as the benefit expected from the expenditure is beginning to be perceived. Why should not such an agreement be decreed in specie? That a party should be let off from his contract, on payment of a compensation in damages, is consistent with no system of morals, but the common law, which was, in this respect, originally determined by political considerations, the policy of its military tenures requiring that the services to be rendered by the tenant to his feudal superior, should not be prevented by want of personal independence. Hence, the judgment of a court of law operates on the right of a party, and the decree of a court of equity on the person. But the reason of this distinction has long ceased, and equity will execute every agreement, for the breach of which damages may be recovered, where an action for damages would be an inadequate remedy. How very inadequate it would be in a case like this, is perceived, by considering that a license which has been followed by the expenditure of $\$ 10,000$, as a necessary "qualification to the enjoyment of it, may be revoked by an obstinate man who is not worth as many certs. But besides this risk of insolvency. the law, in barely compensating the want of performance, subjects the injured party to risk from the ignorance or dishonesty of those who are to estimate the quantum of the compensation. In the case under consideration, no objection to a specific, performance can be founded on the intrinsic nature of the agreement, nor, having been partly executed, on the circumstances of its resting in parol; but it is to be considered as if there had been a formal conveyance of the right, and nothing remains but to determine its duration and extent.

BIG.RIGIITS-21 
A right under a license, when not specially restricted, is commensurate with the thing of which the license is an accessory. Permission to use water for a mill, or anything else that was viewed by the parties as a permanent erection, will be of unlimited duration, and survive the erection itself, if it should be destroyed or fall into a state of dilapidation; in which case, the parties might perhaps be thought to be remitted to their former rights. But having had in view an unlimited enjoyment of the privilege, the grantee has purchased, by the expenditure of money, a right, indefinite in point of duration, which cannot be forfeited by non-user, unless for a period sufficient to raise the presumption of a release. The right to rebuild, in case of destruction or dilapidation, and to continue the business on its original footing, may have been in view as necessary to his safety, and may have been an inducement to the particular investment in the first instance. The cost of rebuilding a furnace, for instance, would be trivial, when weighed with the loss that would be caused by breaking up the business, and turning the capital into other channels; and therefore, a license to use water for a furnace would endure for ever. But it is otherwise, where the object to be accomplished is temporary; such usually is the object to be accomplished by a sawnill, the permanency of which is dependent on a variety of circumstances, such as an abundance of timber, on the failure of which the business necessarily is at. an end. See Hepburn v. McDowell, 17 Serg. \& R. 383, 17 Am. Dec. 677. But, till then, it constitutes a right for the violation of which redress may be had by action. With this qualification, it may safely be affirmed, that expending money or labor, in consequence of a license to divert a water course or use a water power in a particular way, has the effect of turning such license into an agreement that will be executed in equity. Here, it was not pretended that the license had expired, and we are unable to discover an error in the opinion of the court, on the points that were propounded.

Judgment affirmed. ${ }^{15}$

15 Acc.: Stonel v. Zueker, 148 Cal, 516, 83 Pac. 808,113 Am. St. Rep. 301, 7 Ann. Cars. $70 t$ (1906) : Brantley v. Perry, 120 Ga. 760,48 S. E. 332 (1904); Ruthren r. Famer's' Co-onerative Creamery Co., 140 Iowa, 570, $11 \mathrm{~s}$ N. W. 915 (190S), (distinguishing Jones v. Stover, 131 Iowa, 119, $108 \mathrm{~N}$. W. 112, 6 L. R. A. [N. S.] 154 [1906]; Lee v. Meleod, 12 Nev. 280 (1877); Risien r. Brown, 73 Tex, 135, 10 S. W. 661 (1Ss9); Clark v. Glidden, 60 Vt. 702, 15 Atl. 358 (1S87).

See, also, Chamberlin v. Myers (Ind. App.) 120 N. E. 600 (1918).

"But it is argued that a contract may be implied from the acts of the parties. And the principle sought to be applied at this point of the argument was one imnonnect by Gibson, C. J., in the I'ennsylvania cases of Rerick v. Kern, 14 Serg. \& R. (Pa.) 267, $16 \mathrm{Am}$. Dec. 497 (1826), and Swart\% v. Swartz, 4 l'a. 358,45 An. Dec. 697 (1846), that the grant of a privilege which is accessory to a permanent business is presumed to be commensurate in duration with the business, and although at first but a license and as such revorable, yet that when acted unon in fle expenditure of money it becomes a contract for a valuable consideration, to be executed by a Court of Equity as a contract part performed. It will be observed, that this principle must depend, for its application to any narticular case, upon the 


\section{ST. LOUIS NATIONAL S'TOCKYARDS v. IVIGGINS. FERRY CO.}

(Supreme Court of Illinois, 18St. 112 Ill. 384, 5t Am. Rep. 243.)

Appeal from the Appellate Court for the Fourth District; heard in that court on appeal from the Circuit Court of St. Clair county; the Hon. Amos Watts, Judge, presiding.

The bill of complaint exhibited in this case by the St. Louis National Stockyards, in the circuit court of St. Clair county, on February 10,1882, sets out that the complainant, being the owner of United States survey No. 627, containing four hundred acres of land adjacent to East St. Louis, upon which tract its stock yards were situated, was desirous of having a connecting railway track as near as might be to the East St. Louis stations of divers railroads; that the Wiggins Ferry Company, being the owner of land between said survey 627 and sairl railroads, on or about May, 1875, offered to give complainant, for the purpose of a right of way for said contemplated connecting track, a strip of land sixty feet wide, (part of said ferry company's land,) extending from complainant's survey 627 to the main track of the Wabash railway, on the condition that complainant would locate and construct the track upon the ferry company's land north of Stockyard avenue, an improved highway leading froni the stock yards to Front street, on the Mississippi river, at East St. Louis, and so as to enable the ferry company to lay out the land between Stockyard avenue and the proposed track, into lots, of sufficient depth for manufacturing purposes, and to permit holders of lots abutting the track to connect therewith; that complainant accepted the proposal so made, and thereupon, in pursuance of the agreement, laid out a sixty feet right of way upon and across the ferry company's land, in July, 1875 , and within sixty days thereafter, with the knowledge and consent of such company, constructed said projected connecting track on said right of way; that the entire length of the connecting track was three thousand one hundred and fifty feet, permanently built, at a cost to complainant of $\$ 12,000$, - one

presumed intent of the parties that the privilege granted in such case should be commensurate with the business to which it might be accessory as a right in all events, and not as an arraugement depending upon the will of the parties for its continuance. Ordinarily, such a presumption may be a reasonable one. In the Pennsylvania cases it was clearly so. But after all, this presumption, or to spenk more accurately, this inference as to the intent of the parties, is one controlled by the circumstances of the particular aise and may be wholly countervailed by evidence demonstrative that the privilege in question was in fact granted and accepted not as a perpetual. indefeasible right, but as a voluntary accommodation, to abide the gond will and mutual interests of the parties." Jackson \& Shark r. I'hiladelphia, IV. \& B. IR. R. Co., 4 Del. Ch. 1S0, 157 (1S71).

A. gave $\mathbf{B}$. a license to build a drain through his land. $B$. did so at a large expense. A. later broke the drain. B. recovered as damages the cost of the construction of the drain. B. later sought to enjoin A. from interfering with the drain. Held, he is not entitled to the injunction. Uster v. Broe, 161 Ind. 113, 64 N. E. 918 (1903). 
thousand seven hundred and fifty feet of it being upon this right of way, the other one thousand four hundred feet being upon complainant's survey 627 , and including a permanent bridge built across Cahokia creek; that the part of the track upon survey 627 including the bridge, cost $\$ 7,000$ out of the total of $\$ 12,000$, and would not have been built, and was and is of no use to complainant without the other one thousand seven hundred and fifty feet, each being a necessary part of the entire connecting track; that ever since the completion of the track, in the fall of 1875 , it was, with the knowledge and acquiescence of the ferry company, maintained and operated by complainant, for more than five consecutive years; that in 1876 complainant applied to the ferry company for a deed of said right of way, and the latter promised to make it as soon as it could have a survey made of the sixty feet wide strip, and thereafter, on a subsequent application, refused to make a deed; that on April 17, 1881, the ferry company commenced suit in an action of forcible detainer, against complainant, to recover possession of the middle twenty feet of said sixty feet wide right of way, one thousand seven hundred and fifty feet in length, containing said connecting track, and on June 1, 1881, the ferry company made a lease for ten years for said middle twenty feet, for $\$ 250$ per annum, to the East St. Louis Connecting Railway Company; that thereafter the ferry company recovered judgment in the forcible detainer suit, which judgment was affirmed by the Appellate and Supreme Courts, whereupon, on January 30,1882, a writ of restitution was issued. The bill prays that the ferry company may be enjoined in the premises, that it be required to make a conveyance of the right of way to complainant, and that the lease to the connecting railway company be cancelled. The circuit court, on the hearing, denied the relief prayed for, and ordered the bill to be dismissed. On appeal to the Appellate Court for the Fourth District, the decree was affirmed, and complainant appealed to this court.

Mr. Justice SheldoN ${ }^{16}$ delivered the opinion of the Court:

The arrangement under which the embankment and railroad track in question were constructed, was made with S. C. Clubb, the superintendent of the Wiggins Ferry Company. Question is made as to what was the character of that arrangement, it being contended on the side of the appellant that it was a contract of sale of the right of way. But that we do not regard as now an open question, under the decision of this court in the action of forcible detainer referred to in the bill which was brought by the ferry company, against the appellant, wherein it recovered judgment for the possession of this railroad track, and which came before this court on appeal from the Appellate. Court for the Fourth District. (See St. Louis National Stockyards v. Wiggins Ferry Co., 102 I11. 514.) We there held that it was a controverted question of fact, in the case before the Appellate Court, whether such

16 Part of the opinion is omitted. 
agreement was a contract of sale of the right of way, or but a mere license, and that it nust be taken that that court had determined it to be a Ticense, which was a finding of fact that was conclusive upon the Supreme Court, and leaving as the only question for its decision, whether the ferry company was estopped from revoking the license, and if so, whether the estoppel could be made available in the action at law. Only the latter branch of the question was decided,--that such an estoppel could not be availed of in an action at law, but only in a suit in equity,-and the judgment was affirmed, without in any way passing upon whether there was such an estoppel in this case or not. We must take it, then, as an adjudicated fact not liable to be controverted again, that there was here but a mere license to construct this railroad track, and the question presented for determination is, whether, under the circumstances of this case, after the execution of the license by the construction of the railway track at a considerable expenditure of money, the ferry company is estopped from revoling the license.

The evidence on the part of appellant tends to show that in giving the license there was in view the benefit of the connecting track to the ferry company in having lots of two hundred and fifty feet in depth running back from Stockyard avenue to the track, which might be valuable for manufacturing purposes. The embankment and connecting railway track were constructed, at considerable cost, upon the faith of the license from Clubb, and although he was without authority to dispose of the ferry company's lands, it must be taken, under the proofs, that the track was constructed and operated with the knowledge and acquiescence of the company, and there is evidence tending to show that anticipated benefit to the ferry company's land, from having lots to abut on the connecting track, somewhat entered into the consideration for giving the license. The circumstances might well, under the decisions of some courts, constitute an estoppel in pais against the revocation of the license, on the ground that to revoke it would be a fraud, after such an expenditure of money upon the faith of the license, and there would be compelled specific performance, by deed of the right of user, as of a contract in part executed. But there was a contrary rule established in this State in the case of WVoodward v. Seely, 11 Ill. 157, $50 \mathrm{Am}$. Dec. 445, where it was decided that a license coupled with an interest in land must be in writing; that a license perpetually to overflow one's land would create an interest in the land, and the license could not be granted by parol; that a court of equity would not enforce a parol license to overflow the lands of the licenser, even in favor of a party who had acted in good faith upon the parol license, and made valuable improvements upon his own land, which would become worthless if the license was revoked. * * * Woodward v. Seeley has never been overruled or directly questioned by this court, that we are aware of, and we think it must govern this case. It has stood so long as the rule in this State that we are disposed to adhere to it, without entering upon consideration of whether or not it night 
be the proper one to adopt were the question now an original one be. fore this court.

The judgment of the Appellate Court will be affirmed.

Judgment affirmed.

WALKER, DickEy and Craig, JJ., dissenting.

Subsequently, upon an application for a rehearing, the following additional opinion was filed:

Mr. Justice Mulkey. After a very careful reconsideration of this case a majority of the court adhere to the conclusion reached upon the former hearing, as expressed in the opinion already filed in it.

The case of Woodward v. Seely, 11 I11. 157, 50 Am. Dec. 445, can not be distinguished from the present one, and the authority of that case, standing, as it does, in line with the decided weight of authority, has been too long recognized by this court as a correct exposition of the law upon the question involved, to be now overruled without any special reason for doing so. A contrary conclusion can not be placed upon any grounds, however plausible, which are not fully met by the Woodward-Seely Case, and many others adopting the same view of the law. Moreover, the conclusion reached is in harmony with other well settled principles of law. The contrary view is not. The right to build a railroad track and operate it upon the land of another is an interest in land which can only pass by grant, and an agreement to convey such a right, if not in writing, is clearly within the Statute of Frauds. If, however, a party, verbally contracting for such right, enters upon the land and expends money in building the track, upon the faith of the owner's verbal promise to convey, and he otherwise performs or offers to perform his part of the agreement, such performance or partial performance will, as in other cases, take the case out of the statute, and a court of equity will decree a specific performance of the agreement; but in this case we start out with the proposition conceded there was neither a conveyance nor a promise to convey. Specific performance, as an equitable remedy, by its very terms presupposes the existence of a contract between the parties to the controversy, of between those through whom they claim, for it were absurd to talk of the specific performance of an agreement that has no existence. In the case before us it has been solemnly adjudicated that the railroad track in question was not constructed under any contract, promise or agreement on the part of the Wiggins Ferry Company to convey the right of way to the appellant, and that in building the track the latter was acting under a mere license. It follows, therefore, that so much of appellant's argument as is based upon the assumption there was such an agreement, is not warranted by the record, and as this assumption has no foundation in fact, the argument based upon it must necessarily fail.

The only matcrial question in this suit not settled by the former case between the parties, (reported on 102 Ill. 514,) is, whether conceding, as we must, appellant entered appellee's premises and built the track in guestion under a mere parol license from the Wiggins Ferry Company, 
the latter has at any time been guilty of such conduct as to estop it from asserting its right to the possession of the land upon which the track is built. If any such estoppel exists, it is what is known as an estoppel in pais, and consists in appellee having said or done something whereby appellant has been misled to its injury if the license is revoked. Now, it is clear that outside of the fact of revoking the license there is no ground for the claim that appellant has in any way been deceived or misled by appellee. Permission was given to build the track at the place it was bitilt, and it was probably built about as both parties supposed it would be. No deception was practiced, so far as we can perceive, by either of the parties, and none has been suggested. It was a plain, common business transaction. No compensation on the one hand was asked for the right of way, nor was any guaranty asked on the other side as to the length of time this right of way should be enjoyed. Probably both parties supposed the operation of the road would be mutually beneficial, and that that would be ample security against appellee revoking the license on the one hand, and against appellant removing its track on the other. If appellant saw proper, as it did, to enter upon appellee's land and spend money in constructing its track, upon a mere parol license, which, as matter of law, it is conclusively presumed to have known was revocable at the pleasure of appellee, it was its own folly. The case in this respect does not differ in principle from any other where the licensee has expended money in connection with his entry upon land of the licenser. Indeed, this most generally occurs. Suppose, under the circumstances, appellant had concluded it was to its interest to take up the track altogether, it unquestionably would have had the right to do so, however much appellee may have been injured in consequence of it. On principle it would seem there ought to be some mutuality in this respect. The only thing about which appellant can have the slightest pretence for the charge that it has been misled to its injury, is the bare fact that appellee has exercised the right of revocation, when it was, perhaps, thought it never would. It is hardly accurate, under the eircumstances, to say appellant was misled, for unless the mere grant of the license to build the track was an implied undertaking to never, exercise the right of revocation, appellant was not warranted in assuming appellee would never exercise such right, and if appellant's expectations in this respect have not been realized, it was simply disappointed, rather than deceived, by the revocation. To say that the license is irrevocable because the thing permitted to be done necessarily involved the expenditure of money, would be going beyond the most extreme views on the subject, and nuke most licenses irrevocable. 'The practical effect of such a doctrine would be to make most licenses conveyances of an interest in land by mere estoppel in pais. Ultra as this view manifestly is, if we stop short of it the present appeal can not be maintained. Such a decision would establish the rule that all licenses founded upon a valuable consicleration, or necessarily involving the expenditure of money, would be irrevoca- 
ble, which would practically destroy the distinction between a license and a grant. To go to this extent would be to overrule all this court has ever said on the subject, and place it in direct antagonism with the overwhelming current of authority. This we are not prepared to do.

Rehearing denied. ${ }^{17}$

\section{WISEMAN et al. v. LUCKSINGER.}

(Court of Appeals of New York, 1Ss1. 84 N. Y. 31, is Am. Rep. 479.)

Appeal from judgment of the General Term, fourth department, entered upon an order affirming a judgment in favor of plaintiff, entered upon a decision of the court on trial at a Special Term.

This action was brought to restrain defendant from interfering with plaintiff's right of drainage acress defendant's premises, and for damages, etc.

The facts appear in the opinion. Judgment for plaintiff.

DANFORTH, J. ${ }^{18}$ Although the action is in equity the plaintiffs sought compensation in damages as well as equitable relief. 'The former was denied to them, but the latter has been granted to the full extent asked for. I can discover no ground upon which it can be approved.

The parties are owners of adjoining city lots in the city of Syracuse. The defendant built an underground drain or sewer of plank from the basement of his house, through his own lot and that of one Stern, to Jefferson street sewer, and afterward "and more than twenty-five years last past, the plaintiff," as the trial court finds, "purchased of the defendant the right and easement to drain his premises, by an under-

13Acc.: Profile Cotton Mills v. Calhoun Water Co., 189 Ala. 181, 66 South. 50 (1914); Foot v. New Haven \& Northampton Co., 28 Conn. 214 (1854); Stratton's Independence v. Midland Terminal R. Co., 32 Colo. 493, 77 Pac. $247(1904)$; Hodgkins v. Farrington, 150 Mass. 19,22 N. E. 73, 5 L. R. A. 209, 15 An. St. Rep. 168 (18s9); Nowlin Lumber Co. v. Wilson, 119 Mich. 406, 78 N. W. 338 (1899); Minneapolis Mill Co. v. Minneapolis \& St. L. Ry. Co.. 51 Minn. 304, 53 N. W. 639 (1892), with which compare Munsch v. Stelter, 109 Minn. 403, 124 N. W. 14, 25 L. R. A. (N. S.) 727, 134 Am. St. Rep. 785 (1910); Belzoni Oil Co. v. Yazoo \& M. V. R. Co., 94 Miss. 58, 47 South. 468 (1908): Lewis v. Patton, 42 Mont. 52S, 113 Pac. 745 (1911) ; Houston v. Laffee, 46 N. H. 505 (1S66) ; Lawrence v. Springer, 49 N. J. Eq. 289, 24 Atl. 933, 31 Am. St. Rep. 702 (1S92); Crosdale v. Lanigan, 129 N. Y. 604,29 N. F. $\$ 24,26$ Am. St. Rep. 551 (1892); Kivett v. MCKeithan, 90 N. C. 106 (1884); Yeager r. Tuning, 79 Ohio St. 121,86 N. E. 657,19 L. R. A. (N. S.) 700,128 Am. St. Rep. 679 (1908); Yeagar Y. Woodruff, 17 Utah, 361, 53 Pac. 1045 (189S); Hathaway v. Yakima Water, Light \& Power Co., 14 Wash. 469, 44 Pac. \$96, 53 An. St. Ren. 874 (1S96); Pifer v. Brown, 43 W. Va. 412, 27 S. E. 399 (1897). And see note to same case in 49 L. R. A. 497.

Compare Girard v. Lehigh Stone Co., 280 Ill. 479, 117 N. E. 695 (1917).

A. gave $B$. permission to construct and maintain an irrigation ditch through A.'s land, "until the Reclamation Service shall provide other means tor conducting irrigation water." B. so built. Held, A. may reroke the license at any time. Davis v. Tway, 16 Ariz. 566, 147 Pac. 750, L. K. d. $1915 \mathrm{E}, 604$ (1915).

28 Part of the opinion is omitted. 
ground drain and covered sewer, through the defendant's premises, for the consideration of $\$ 7$, which the plaintiff paid and the defendant accepted;" and thereupon the plaintiff, partly upon his own premises and partly on those of the defendant, built an underground sewer of plank to connect with the sewer of the defendant. The connection was made a short distance from the line dividing the respective lots. It is further found that "the plaintiff for over twenty-five years enjoyed the privilege as of right of draining his own premises through this sewer, until July 22,1876 , when the connection was cut off by the defendant on his own land." At that time, he denied the plaintiff's right, obstructed the flow of water, "and refused to allow the plaintiff to go upon his premises to maintain and repair the said sewer." It is also found that "before this, and in 1873, the plaintiff caused his old sewer to be taken up and replaced with a tile sewer of a capacity greater than that of defendant's sewer, with which it was connected." The plaintiff had also made changes in the form of his privy vault, and the court found that "after this change, and the alteration and enlargement of his sewer by the plaintiff, the filth and foul water from his privy flowed back into the cellar of the defendant, creating stench and a great nuisance to defendant, rendering his house unfit to live in, and that to prevent such injury to his premises the defendant tore up said sewer."

The learned court also found as a fact that "no deed of conveyance of said easement or right to drain through said defendant's premises was ever executed by defendant to plaintiff, nor was any written contract agreeing to convey ever executed by defendant or any one for him, except the receipt for $\$ 7$ for the right to drain through defendant's premises." The receipt referred to was not produced upon the trial, but after proving its loss, the plaintiff was allowed to show its contents by his witnesses. Neither of them had seen the paper for many years, and there was some difference as to its form. It is not stated by the court in any'other way than in the above finding, but it is given by one witness in these words: "Received of Joseph Wiseman, seven dollars, for the right to drain through my premises:" and this, he says, bore the signature of the defendant. It is adopted by the learned counsel for the respondents in his points, and is the form most favorable to his contention. The trial court found, "as conclusion of law and equity, that the plaintiff acquired the right of draining his premises on the defendant's premises more than twenty-five years before the said obstruction, and during all that time enjoyed the same as of right; that the plaintiff is entitled to judgment declaring his said right and easement on the defendant's premises and restraining him from interfering with the plaintiff's enjoyment of such casement; and that the plaintiff is entitled to go upon the defendant's premises to rebuild and repair the same." Judgment was entered accordingly, and it having been affirmed by the General 'Term, the defendant has appealed to this court. 
The right awarded to the plaintiff to have his drain pass through the defendant's land is in the terms of the judgment an easement, and for its enjoyment requires that the plaintiff shall have an interest in the defendant's land.

It is therefore within the statute "of fraudulent conveyances and contracts relative to land," and could neither be created, granted or declared, except by deed or conveyance in writing ( 2 R. S., tit. 1, chap. 7 , part $2, \S 6$, p. 134); so that consent, although in writing, will be of no more avail than it would be if given by word of mouth. Indeed this is conceded by the learned counsel for the plaintiff to be so at law; but he contends, that in equity the case is otherwise, and says, that "courts of equity give effect to parol agreements for the grant of an easement when founded upon a valuable consideration." Assuming that to be so, we may inquire whether there is any thing in this case to call for the exercise of such extraordinary jurisdiction. And first, the contract which equity will regard as equivalent to the grant required at common law or by the statute must be a complete and suffcient contract, founded not only on a valuable consideration, but its terms defined by satisfactory proof, and accompanied by acts of part performance unequivocally referable to the supposed agreement. In such a case the application of the statute is withheld, lest by its interposition the mischief would be encouraged which the Legislature intended to prevent.

There is, I think, little danger of that in the present case. If we look at the situation of the parties at the time the contract was entered into, it will be difficult to infer that they considered the arrangement indicated by the writing to be a permanent one. The lots of both parties fronted upon a public street-in it there was no sewer. If there had been, it cannot be doubted that as the easiest, cheapest and most natural way of drainage, they would have used it. As it was, the defendant was obliged not only to carry his drain the whole length of his lot, but first by license, and then by purchase, acquire the right to cross another lot before an outlet for his drain could be had. His drain was built of plank, at little expense and soon perishable. While in this condition the plaintiff applies, according to his own testimony, for the privilege of draining his lot into the defendant's drain, and obtains it by the payment of $\$ 7$. So much the receipt indicates. There is nothing more. Its language is equivocal. It would be satisfied by drainage during the pleasure of the defendant, or during the life of the plaintiff, or until a public sewer should be constructed in the street by which the lot was bounded. There is nothing said as to how long it should continue. And when we consider the heavy imposition that would rest upon the defendant's lot, the annoyance from smells, the perpetual lien and incumbrance, necessarily rendering the land unsalable or of less value in the market-less available for improvement-compelling the defendant so to build that his structure should not interfere with the plaintiff's right of drainage, of inspection, of rebuilding and repara- 
tion, we find nothing which permits the inference that the permission indicated by the receipt was intended to be in perpetuity. The nature and character of the easement, the purpose which it was intended to serve, and other circumstances above adverted to, must be taken into account. The effect of the judgment is to deprive the defendant of the full enjoyment of his property, and subject it to the control of another. I am unable to find, in the words of the parties, any intention to produce that result. It is not expressed in the receipt, nor is it fairly to be implied. Full effect may be given to it by regarding it as a temporary arrangement; and it should, I think, be so construed. * * *

The plaintiff has made out no case against this appeal; and the judg. ments of the General and Special Terms should therefore be reversed and a new trial granted, with costs to abide the event. ${ }^{19}$

All concur, except EARL, J., dissenting; FINCII, J., concurring in result.

Judgment reversed.

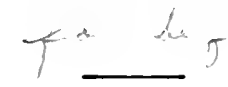

\section{HURST v. PICTURE THEATRES, Limited.}

\section{(Court of Appeal, 1914. [1915] 1 K. B. 1.)}

Appeal of the defendants from a decision of Channell, J., at the trial with a special jury.

The plaintiff sued to recover damages for an alleged assault and false imprisonment.

The plaintiff stated in his evidence that, being attracted by an advertisement announcing that a picture of Lake Garda was being shewn

19Acc.: Cook v. Ferbert, 145 Mo. 462, 46 S. W. 947 (1S9S). See Thoemke v. Fiedler, 91 Wis. 386,64 N. W. 1030 (1895).

A. and B. Were owners of adjoining city lots. A., for a valuable consideration, gave $\mathbf{B}$. oral permission to get access to the second story of his: building by meaus of a staircase in A.'s building. B." altered his building to conform to this plan. Held, B. may enjoin A. from preventing B. from so using the staircase. Kastner v. Benz, 67 Kan. 4S6, 73 Pae. 67 (1903). Acc.: Sumpter Ry. Co. v. Gardner, 49 Or. 412, 90 Pac. 499 (1907); Meetze v. Charlotte, C. \& A. R. Co., 23 S. C. 1 (1S55).

See Western Union Tel. Co. v. l'ennsylrania Co., 129 Fed. 849, 861, 64 C. C. A. $2 S 5$, tS L. I. A. !) (1904).

Compare Morton Lrewing Co. v. Morton, 47 N. J. Eq. 15S, 20 Atl. $2 S 6$ (1S90).

1. and $B$. orally agreed to sink a well upon what was believed to be the dividing line between the land of $A$. and of $B$. It was also agreed that, it the woll should not be upon the line. the ownership of it should remain unchanged. The well was sunk as agleed upon, each party paying his share of the expense. and a windmill was also erected at their joint expense. later it was found that the well was wholly upon B.'s land. B. obstructed A.'s access to the well. On a bill by $A$. to enjoin B. from interfering with his use of the well, held, A.'s bill to be dismissed upon B.'s paying $A$., within a time to be fixed by the trial court, an amount equal to A.'s contribution to the sinling of the well and his share of the value of the wind1uill; if $B$. does not so pay, he to be enjoined from interfering with $A$. 's use of the well until payment, or the disuse of the well by both parties. Johnson v. Barton, 23 N. D. 629, $1: T$ N. W. 109\%, 44 L. K. A. (X. S.) $5: i$ (1912). See Wyun v. Garland, 19 Ark. 23, 68 Am. Dec. 190 (1557). 
at the defendants' cinema theatre at High Street, Kensington, he went to that theatre on March 17, 1913, for the purpose of seeing it. At the pay office he tendered a florin and asked for a sixpenny seat, and was given a metal check and the change; the check entitled him to an unreserved seat. He gave up his check at the door leading into the theatre, and was shown into a seat by a young woman with an electric torch. After the performance had proceeded for some little time, a girl came up and asked plaintiff if he had come in with a ticket, and, on his replying that he had, the girl went away. Shortly afterwards another girl came up and asked him to come out and see the manager, but he refused. Then a man in evening dress came up and asked him to come and see the manager, but he again refused. Then the manager himself came up and asked the plaintiff to come outside, and, on his refusing, said, "Then we shall have to compel you." A porter or doorkeeper, who was sent by the manager, then asked the plaintiff to go out, which he refused to do. The porter went out and returned with a policeman, whom he asked to put the plaintiff out. This the policeman refused to do, suggesting that the porter should do it himself. The porter then made his way into the row of seats and, taking hold off the plaintiff under the arms, lifted him out of his seat. The plaintiff then walked quietly out. No unnecessary violence was used in thus ejecting the plaintiff.

The defendants justified their conduct on the ground that the plaintiff had not taken a ticket for that performance. They also contended that they were entitled, without assigning any reason, to call on the plaintiff to leave the theatre, and, if he declined, to forcibly remove him, relying on the authority of Wood v. Leadbitter, 13 M. \& W. 838.

Channizi, J., was of opinion that Wood v. Leadbitter, 13 M. \& W. 838 , was no longer good law, and held that a visitor to a theatre who had paid for his seat had a right to retain his seat so long as the performance lasted, provided he behaved quietly and complied with the regulations laid down by the management. He left to the jury the question whether the plaintiff had paid for his seat, and the jury found that he had, and assessed the damages at $£ 150$.

The defendants appealed.

BuckLEY, L. J. ${ }^{20}$ We have listened in this case to a very ingenious and interesting argument from Mr. Mackinnon, but, if I may borrow the words of Lord Esher in Butler v. Manchester, Sheffield \& Lincolnshire Railway (188S) 21 Q. B. D. 207, 211, it may have been quite right for the appellants' counsel to suggest the point, but when considered it is contrary to good sense. I may add that I think it is not only contrary to good sense, but contrary also to good law as administered since the Judicature Act in this Court. The proposition which $\mathrm{Mr}$. Mackinnon sets out to affirm is that if a man has paid for his seat at

20 Part of the opinion of Buckley, L. J., and the opinions of Kenuedy and I'hillimore, L. JJ., are omitted. 
the opera, or the theatre, and has entered and taken his seat, and is behaving himself quite properly, it is competent to the proprietors of the theatre, merely because they choose so to do, to call upon him to withdraw before he has seen the perfornance for the enjoyment of which he has paid; that what he has obtained for his money is a mere revocable license to come upon the land of the proprietor of the theatre, and that the proprietor may, simply because he chooses, say, "I revoke your licence; go." If that proposition be true, it involves startling results. Kennedy, L. J., has suggested one. Suppose that there be sitting in the stalls a man who is a constant patron of the opera or the theatre, to whom the management pay great deference, whether from his rank or his habit of attendance: he goes to the management and says, "I do not like the person sitting in front of me or next to me; ask him to go." It would be competent to the management to go to that person and say, "Please go; you cannot have your money back; go." Further, if the proposition is right, it follows that, having let the seat to A., the management may come to A. at the end of the first act or before and say, "I revoke your licence; go," and he has to go. The management may let the seat to $\mathrm{B}$. for the rest of the performance, and at the end of the second act or sooner they may come to $\mathrm{B}$. and say "I revoke your licence; go." He will have to go, and they may let the seat a third time to $\mathrm{C}$. Those consequences ensue from this proposition if it be well founded. It was for that reason I said at the outset of my remarks that it seems to me, when the point comes to be considered, it is contrary to good sense.

Next it is to my mind contrary also to good law. The proposition is based upon the well-known decision in Wood v. Leadbitter, 13 M. \& W. 838. Let me at the outset say what Wood v. Leadbitter, 13 M. \& W. 838 , seems to me to have decided. It affirmed that a mere licence, whether or not it be under seal, by which I mean a licence not coupled with an interest or a grant whether it be under seal or not, is revocable. It affirmed also that if there be a licence coupled with an interest or coupled with a grant, it is not, or at any rate in general is not, revocable. For those two propositions, I read these two sentences from the case of Wood v. Leadbitter, 13 M. \& W. at page 844: "A mere licence is revocable; but that which is called a licence is often something more than a licence; it often comprises or is connected with a grant, and then the party who has given it cannot in general revoke it, so as to defeat his grant, to which it was incident. It may further be observed, that a licence under seal (provided it be a mere licence) is as revocable as a licence by parol; and, on the other hand, a licence by parol, coupled with a grant, is as irrevocable as a licence by deed, provided only that the grant is of a nature capable of being made by parol." Those are propositions with which, as it seems to me, no one quarrels or can quarrel. Wood v. Leadbitter, 13 M. \& W. 838, rested, I think upon one of two grounds-I will indicate them both-but I think it was the second of those which I am going to mention. The first ground is that 
the man who bought his ticket for the race meeting had not obtained any grant of the right to come during the currency of the meeting to see any particular spectacle from its commencement to its termination. If that were the ground, it would, I think, be erroneous. I conceive he had the right to see what was to be seen during the days covered by his ticket. But I do not think that was the ground on which the Court decided it. They decided it upon the ground, which will be found at page 842 and onwards, that no incorporeal inheritance affecting land can be created or transferred otherwise than by deed, a proposition which was discussed with some elaboration in the course of the judgment. What Alderson, B., was saying there was: this man has got no deed; he had got nothing under seal; he has therefore not got a grant; he cannot in this Court be heard to say he is a grantee, and because he is not a grantee he is a mere licensee, and being a mere licensee (whether it is under seal or not under seal does not make any difference) the licence is revocable.

Let me for a moment discuss this present case upon the footing that Wood v. Leadbitter, 13 M. \& W. 838, stands as good law at this date. I am going to say presently that to my mind it does not, but suppose it does stand as good law at this date. What is the grant in this case? The plaintiff in the present action paid his money to enjoy the sight of a particular spectacle. He was anxious to go into a picture theatre to see a series of views or pictures during, I suppose, an hour or a couple of hours. That which was granted to him was the right to enjoy looking at a spectacle, to attend a performance from its beginning to its end. That which was called the licence, the right to go upon the premises, was only something granted to him for the purpose of enabling him to have that which had been granted him, namely, the right to see. He could not see the performance unless he went into the building. His right to go into the building was something given to him in order to enable him to have the benefit of that which had been granted to him, namely, the right to hear the opera, or see the theatrical performance, or see the moving pictures as was the case here. So that here there was a licence coupled with a grant. If so, Wood v. Leadbitter, 13 M. \& W. 838, does not stand in the way at all. A licence coupled with a grant is not revocable; Wood v. Leadbitter, 13 M. \& W. 838, affirmed as much.

So far I have been treating it as if Wood v. Leadbitter, 13 M. \& W. 838, were law as now administered in every Court. Let us see how that matter stands. Wood v. Leadbitter, 13 M. \& W. 838, was a case decided in a Court of law before the Judicature Act; it was a case to be decided, therefore, simply upon the principles which are applicable in a Court of law as distinguished from a Court of Equity. What was the principle which would have been administered in a Court of Equity in the year 1845, the date of Wood v. Leadbitter, 13 M. \& W. 838, or subsequently? For that I lnok at the decision of Wood, V. C., in Frog. ley v. Earl of Lovelace (1859) John. 333. * * * 
The position of matters now is that the Court is bound under the Judicature Act to give effect to equitable doctrines. The question we have to consider is whether, having regard to equitable considerations, Wood v. Leadbitter, 13 M. \& W. 838, is now law, meaning that Wood v. Leadbitter, 13 M. \& W. 838, is a decision which can be applied in its integrity in a Court which is bound to give effect to equitable considerations. In my opinion, it is not. Cozens-Hardy, J., as he then was, the present Master of the Rolls, in the case of Lowe v. Adams, said this ([1901] 2 Ch. 598, at page 600): "Whether Wood v. Leadbitter, 13 M. \& W. 838, is still good law having regard to Walsh v. Lonsdale," 21 Ch. D. 9-which is a decision of the Court of Appeal"is very doubtful." The present Lord Parker, then Parker, J., in the case of Jones v. Earl of Tankerville, says this ([1909] 2 Ch. 440, at page 443): "An injunction restraining the revocation of the licence, when it is revocable at law, may in a sense be called relief by way of specific performance, but it is not specific performance in the sense of compelling the vendor to do anything. It merely prevents him from breaking his contract, and protects a right in equity which but for the absence of a seal would be a right at law, and since the Judicature Act it may well be doubted whether the absence of a seal in such a case can be relied on in any Court." What was relied on in Wood v. Leadbitter, 13 M. \& W. 838, and rightly relied on at that date, was that there was not an instrument under seal, and therefore there was not a grant, and therefore the licensee could not say that he was not a mere licensee, but a licensee with a grant. That is now swept away. It cannot be said as against the plaintiff that he is a licensee with no grant merely because there is not an instrument under seal which gives him a right at law.

There is another way in which the matter may be put. If there be a licence with an agreement not to revoke the licence, that, if given for value, is an enforceable right. If the facts here are, as I think they are, that the licence was a licence to enter the building and see the spectacle from its commencement until its termination, then there was included in that contract a contract not to revoke the licence unil the play had run to its termination. It was then a breach of contract to revoke the obligation not to revoke the licence, and for that the decision in Kerrison v. Smith, [1897] 2 Q. B. 445, is an authority. So far I have dealt with the law.

I think that the appeal which has been brought before us, and which is founded simply upon the question of law which I have discussed at the beginning of this judgment, fails and must be dismissed with costs. 


\section{MILLER v. INHABITANTS OF GREENWICH TP. et al.}

(Court of Errors and Appeals of New Jersey, 1598. 62 N. J. Law, 7i1, 4: Atl. 735.)

Coluns, J. A verdict was directed, at the circuit, in favor of the defendants, in an action of tort, brought to recover damages for injury to real property; and, upon the consequent judgment, this writ of error was brought. The complaint in the declaration was of the cutting down of a public street in front of the plaintiff's house, and the destruction of a sewer or drain laid across it for the use of the plaintiff. In form, the allegation was trespass quare clausum fregit. To the plea of not guilty, two special pleas were added,- - one, that the defendant Rambo, who was a member of the township committee of the township of Greenwich, did the injury complained of, in the amending and repairing of the street by direction of the township committee; and the other, that he did the injury by virtue of an ordinance of the township. To these pleas the replication de injuria was interposed, and the issue came on to be tried. It appeared that the plaintiff's title ran only to the side of the street upon which his land abutted, and that the sewer existed by parol license from one Paul, the owner of the fee of the land in the street and on the opposite side. The direction of verdict was upon the idea that the plaintiff had no property rights in the premises. It is not necessary to consider his rights in the street, but he surely had a right to his sewer.

The learned trial judge seems to have based his contrary decision upon the case of Wiseman v. Lucksinger, 84 N. Y. 31, 38 Am. Rep. 479, which holds that an easement to drain through the lands of an adjoining owner can only be created by deed. Granting this, still an unrevoked license has value; and, as against every one but the licensor or those claiming under him, an action ought to lie for injury to the licensee. For mere disturbance of an easement, the remedy at common law was an action on the case (1 Chit. P1. 142); but trespass was always proper where there was an exclusive right of possession, as there must have been of the sewer in question (Id. 174). Under our rules of pleading, trespass and case are now both styled actions of tort, and the form of declaring is not very important. It has long since been adjudged in the supreme court that an injury by a stranger, to an exclusive possession, in lands, of a mere licensee, is actionable. A pertinent case is Paul v. Hazelton, 37 N. J. Law, 106. It was there held that, although the exclusive right given by statute to a riparian owner to plant oysters in the bed of a navigable stream adjacent to his land is a mere license suljject to revocation, yet that an action of trespass quare clausum fregit will lie for an invasion of that right.

We entirely apfrove of the doctrine underlying this case, and think it applicable to that now before us. It was proved that the defendant Rambo cut down the street, and destroyed the sewer. He proved no 
authority from the township. Against him, therefore, a right of action was established, and the judgment in his favor must be reversed, and venire de novo awarded. As there was not a scintilla of evidence connecting the township with the transaction, the judgment in its favor must stand. If, on the new trial, Rambo can justify under the township, questions will arise not open for present discussion in this cause. ${ }^{21}$

21 Acc.: Case r. Weber, 2 Ind. $10 \mathrm{~S}$ (1550). Compare New York Steam Co. v. Foundation Co.. 195 N. Y. 43, 87 N. E. 765, 21 L, R. A. (N. s.) 470 (1909). A. licensed B. to dig a well and install a ram on A.'s land. B. did so. Later part of A.'s land was condemned, and the part where the well and ram were was lawiully flooded. Held, $B$, has no right to reimbursment against the condemning party. Clapp v. City of Boston, 133 Mass. 367 (1.8\%). See, also, Warr $r$. London County Council, ante, p. 313, note 9; Sabine \& l. T. Ry. Co. v. Johnson, 65 Tex. 389 (18S6).

Bie.Rights-22 


\section{CHAPTER IV}

\section{LEGAL ENFORCEMENT OF COVENANTS RUNNING WITH THE LAND}

\section{SECTION 1.-AS BETWEEN LANDLORD AND TENANT}

\section{BeFore the Statute of 32 Henry VIII}

A man leases a house and land for years and the lessee covenants that he and his assigns will repair the house, and then the lessee grants over his term and the assign does not repair; action of covenant lies against the assign, for this is a covenant which runs with the land; and it also clearly lies against the lessee after he has assigned over his term, and it appears that if the lessor brings several writs of covenant against each, there is no remedy until he takes out execution against one and then it appears that if he proceeds against the other, he shall have Audita querela; and in the new Natura Brevium it is said that the assignee shall have an action of covenant against the lessor by reason of the fact that the assignee is mentioned in the deed, and so it appears reasonable that the lessor shall have an action of covenant against him: and H. 48 E. 3 the assignee of the lessee shall have a writ of covenant against the lessor where the assign was not named in the deed; quare, for it is not in the printed report.

Brook's Abridgiment, Covenant, 32 (1533).

* * * The better opinion seems to be that the assignee of the reversion could not bring an action of corenant at common law, but it is given by the statute of $32 \mathrm{H} . \mathrm{S}, \mathrm{c} .34$. * * *

$* * *$ The action of debt lay for the assignee of the reversion at common law; for the rent being incident to the reversion, and the lessee being in the possession of the lands and in the perception of the profits, the law therefore created such a privity between them as would support this action for the rent. $5 \mathrm{H} .7,18 \mathrm{~b}, 19 \mathrm{a}$. Bro. Dette, 141. * * * For the same reason of privity of estate, the lessor may have debt or covenant for rent or for not repairing, etc., against the assignee of the term at the common law. 5 H. 7, 19a.

Williams' Notes (3 and 6) to Thursby v. Plảnt, 1 Saund. 237. 
It is said that an assignee of a reversion might at common law have maintained an action of covenant for anything agreed to be done upon the land itself $;^{1}$ and Coke was of opinion that an assignee of the reversion could maintain an action of covenant for the rent at common law, for the rent goes with the reversion, and so by consequence the covenant also; ${ }^{2}$ and in a modern case, where the assignee of the reversion brought covenant against the personal representative of the lessee upon a demise of land for years, doing suit to the mill of the lessor his heirs and assigns, by grinding all such corn there as should grow upon the land demised, which was held to amount to an implied covenant which ran with the land, Mr. Justice Bayley said, that an action at the suit of the assignee of the reversion was maintainable in some cases at common law, in others under the statute $32 \mathrm{H} .8$; he rather thought this case belonged to the former class. ${ }^{3}$ But speaking generally, we may observe that at common law the action of covenant did not lie for the assignee of the reversion. ${ }^{4}$

Sugden, V. \& P. (14th Ed.) p. 582, par. 17.

Perhaps the best way of reconciling the case is by considering that at common law covenants ran with the lind. but not with the reversion, therefore the assignee of the lessee was held to be liable in covenant, and to be entitled to bring covenant, but the assignee of the lessor was not.

Patterson's note (a) to 'Thursby v. Plant, supra.

\section{Under Thi: Statute of 32 Henry VIII}

\section{(A) The Stainte}

ST. $32 \mathrm{HEN}$. VIII, c. 34.-Where before this time divers, as well temporal as ecclesiastical and religious persons, have made sundry leases, demises and grants to divers other persons, of sundry manors, lordships, ferms, meases, lands, tenements, meadows, pastures, "or other hereditaments, for term of life or lives, or for term of years, by writing under their seal or seals, containing certain conditions, covenants and agreements to be performed, as well on the part and behaif of the said lessees and grantees, their executors and assigns, as on the behalf of the said lessors and grantors, their heirs and successors; (2) and forasmuch as by the common law of this realm, no stranger to any

1 Barker v. Damer, 3 Mod. $33 S$ (16S9); Wey v. Rally, 6 Mod. 194 (1705).

2 Athowe v. Heming, 1 kolle R. 81 (1615), Laulres Justices rient disont al cest point.

3 Vyvyan v. Arthur, 1 B. \& C. 410 (1\&23), post. p. $36+4$.

- Barker v. Damer, ubi supra; Thrale v. Cormwall, 1 Wils, 165 (17t7). 
covenant, action or condition, shall take any advantage or benefit of the same, by any means or ways in the law, but only such as be parties or privies thereunto, by the reason whereof, as well all grantees of reversions, as also all grantees and patentees of the King our sovereign lord, of sundry manors, lordships, granges, ferms, meases, lands, tenements, meadows, pastures, or other hereditaments late belonging to monasteries, and other religious and ecclesiastical houses dissolved, suppressed, renounced, relinquished, forfeited, given up, or by other means come to the hands and possession of the King's majesty since the fourth day of February the seven and twentieth year of his most noble reign, be excluded to have any entry or action against the said lessees and grantees, their executors or assigns, which the lessors before that time might by the law have had against the same lessees for the breach of any condition, covenant or agreement comprised in the indentures of their said leases, demises and grants: (3) be it therefore enacted by the King our sovereign lord, the lords spiritual and temporal, and the commons, in this present parliament assembled, and by authority of the same, That as well all and every person and persons, and bodies politic, their heirs, successors and assigns, which have or shall have any gift or grant of our said sovereign lord by his letters patents of any lordships, manors, lands, tenements, rents, parsonages, tithes, portions, or any other hereditaments, or of any reversion or reversions of the same, which did belong or appertain to any of the said monasteries, and other religious and ecclesiastical houses, dissolved, suppressed, relinquished, forfeited, or by any other means come to the King's hands since the said fourth day of February the seven and twentieth year of his most noble reign, or which at any time heretofore did belong or appertain to any other person or persons, and after came to the hands of our said sovereign lord, (4) as also all other persons being grantees or assignees to or by our said sovereign lord the King, or to or by any other person or persons than the King's highness, and the heirs, executors, successors, and assigns of every of them, (5) shall and may have and enjoy like advantages against the lessees their executors, administrators and assigns, by entry for non-payment of the rent, or for doing of waste or other forfeiture; (6) and also shall and may have and enjoy all and every such like, and the same advantage, benefit and remedies by action only, for not performing of other conditions, covenants or agreements contained and expressed in the indentures of their said leases, demises or grants, against all and every the said lessees and farmers and grantees, their executors and administrators and assigns, as the said lessors or grantors themselves, or their heirs or successors, ought, should, or might have had and enjoyed at any time or times, (7) in like manner and form as if the reversion of such lands, tenements or hereditaments had not come to the hands of our said sovereign lord, or as our said sovereign lord, his heirs and successors, should or might have had and enjoyed in certain cases, by virtue of the act made at the first session of this present par- 
liament, if no such grant by letters patents had been made by his Highness.

II. Noreover be it enacted by authority aforesaid, That all farmers, lessees and grantees of lordships, manors, lands, tenements, ronts, parsonages, tithes, portions, or any other hereditaments, for term of years, life or lives, their executors, administrators and assigns, shall and may have like action, advantage and remedy against all and every person and persons and bodies politic, their heirs, successors and assigns, which have or shall have any gift or grant of the King our sovereign lord, or of any otlier person or persons, of the reversion of the same manors, lands, tenements, and other hereditaments so letten, or any parcel thereof, for any condition, covenant or agrecment contained or cxpressed in the indentures of their lease and leases, as the same lessees, or any of them might and should have had against the said lessors and grantors, their heirs and successors; (2) all benefits and advantages of recoveries in value by reason of any warranty in deed or in law by voucher or otherwise only excepted."

\title{
(B) Formalitics
}

\section{SPENCER'S CASE.}

\author{
(Court of King's Bench, 1583. 5 Coke, 16a.) *
}

Spencer and his wife brought an action of covenant against Clark, assignee to J., assignee to S., and the case was such: Spencer and his wife by deed indented demised a house and certain land (in the right of the wife) to S. for term of 21 years, by which indenture S. covenanted for him, his executors, and administrators, with the plaintiffs, that he, his executors, administrators, or assigns, would build a brick wall upon part of the land demised, \&c. S. assigned over his term to J. and I. to the defendant; and for not making of the brick wall the plaintiff brought the action of covenant against the defendant as assignce: and after many arguments at the Bar, the case was excellently argued and debated by the Justices at the Bench: and in this case these points were unanimously resolved by Sir Christopher Wray, Chief Iustice, Sir Thomas Gawdy, and the whole Court. And many differences taken and agreed concerning express covenants, and covenants in law, and which of them run with the land, and which of them are collateral, and do not go with the land, and where the assignee shall be bound without naming him, and where not; and where he shall not be bound, although he be expressly named, and where not.

The substance of this statute is generally law in the United States, either bs expless re-enactment or as a part of our common law. See sims. covenants Which Run with the Land, Other than Covenants for Title, p. 74 and fol.

- I'art of the opinion is omitted. 
1. When the covenant extends to a thing in esse, parcel of the demise, the thing to be done by force of the covenant is quodammodo annexed and appurtenant to the thing demised, and shall go with the land, and shall bind the assignee although he be not bound by express words: but when the covenant extends to a thing which is not in being at the time of the demise made, it cannot be appurtenant or annexed to the thing. which hath no being; as if the lessee covenants to repair the houses demised to him during the term, that is parcel of the contract, and extends to the support of the thing demised, and therefore is quodammodo annexed appurtenant to houses, and shall bind the assignee although he be not bound expressly by the covenant; but in the case at Bar, the covenant concerns a thing which was not in esse at the time of the demise made, but to be newly built after, and therefore shall bind the covenantor, his executors, or administrators, and not the assignee, for the law will not annex the covenant to a thing which hath no being.

2. It was resolved that in this case, if the lessee had covenanted for him and his assigns, that they would make a new wall upon some part of the thing demised, that for as much as it is to be done upon the land demised, that it should bind the assignee; for although the covenant doth extend to a thing to be newly made, yet it is to be made upon the thing demised, and the assignee is to take the benefit of it, and therefore shall bind the assignee by express words. So on the other side, if a warranty be made to one, his heirs and assigns, by express words, the assignee shall have a warrantia chartæ. F. N. B. 135, \& 9 E. 2, Garr' de Charters 30; 36 E. 3, Garr. 1; 4 H. 8, Dyer 1. But althougli the covenant be for him and his assigns, yet if the thing to be done be merely collateral to the land and doth not touch or concern the thing demised in any sort, there the assignee shall not be charged. As if the iessee covenants for him and his assigns to build a house upon the land of the lessor which is no parcel of the demise or to pay any collateral sum to the lessor, or to a stranger, it shall not bind the assignee, because it is merely collateral, and in no manner touches or concerns the thing that was demised, or that is assigned over; and therefore in such case the assignee of the thing demised cannot be charged with it, no more than any other stranger.

See the statute of 32 H. 8, c. 24, 34, which Act was resolved to extend to covenants which touch or concern the thing demised and not to collateral covenants. ${ }^{7}$

${ }^{\top}$ Acc.: Frools va Smith, Thomp. Unrep. Tenn. Cas. 226 (1860).

Contra: Anon. XIoo. 159, pl. 300 (158t).

See Hyde \%. Windsor, Cro. Eliz. 552 (1597); Smith v. Arnold, 3 Salk, 4 (1703); Bally r. Wells, 3 Wils. 25 (1769).

A. leased to $X$. and covenanted with $x$. and his assigns, for himself, bis executors and administrators, to pay $\boldsymbol{X}$. or his assigns the ralue of any shrublery that they might plant on the leased premises. A. assigned to $\dot{H}$. who refused to pay $\mathbf{X}$. for the shrubbery planted by $\mathbf{X}$. Held, $\mathbf{X}$. has no 


\title{
MASURY v. SOUTHIVORTH et al.
}

\author{
(Supreme Court of Ohio, 1859. 9 Ohio St. 340.)
}

In Error to the District Court of Cuyahoga County.

The plaintiff in error brought an action against the defendants in error, in the court of common pleas of Cuyahoga County. The petition in that action stated, that on the 25 th day of February, $1854, \mathrm{~S}$. A. Powers and Joseph C. Foster executed a lease, which was duly acknowledged and recorded. By this lease, a lot in the city of Cleveland was demised by Powers to Foster, for a term beginning on the 1st day of April, 1854, and ending the 1st day of July, 1867. The petition alleged "that, by one of the covenants in said lease, the said Foster was to keep said leasehold premises fully insured for the benefit of Powers, and that, if at any time the said Foster should fail to keep the same so insured, that the said Powers might cause an insurance to be made on said premises at the expense of said Foster, and in the name and for the benefit of said Powers. And by a further stipulation in said lease, it was further agreed that, in case that said building should burn down during the continuance of said lease, that the said Foster should have the benefit of said insurance money for the purpose of rebuilding said premises, in case he should elect to rebuild the same." The petition further stated, that on the 14th of October, 1854, "Powers assigned and sold to plaintiff all his interest in said lease ;" and "that the interest of Foster in said premises and lease was sold under. an order of court to satisfy judgments against said Foster, and that the defendants became the purchasers of said Foster's interest in said premises at said sale. It is also stated, that the defendants went into possession of the said premises; that at the "time they went into possession, a policy procured by Foster was running; that when it expired the plaintiff notified the defendants to insure the premises, which

cause of action against B. Grey $\mathrm{r}$. Cuthbertson, 2 Chitty, 482 (17S5). Acc.: Hansen v. Miever, 81 Ill. 321, 25 Am. Rep. 282 (1876).

"The authorities are not, however, altogether clear upon the point whether, although the obligation of the covenant will not bind the assignee of the land or the reversion, as the case may be, where the assigns are not named and the covenant extends to a thing not in esse. the benefit of the covenant will not pass to the assignee although he be not named. But, upon principle, there would seem to be no distinction between the burden and the benefit in the application of the rule, the mutuality incident to the contract requiring that the one should not be separated from the other; and that a party who is not bound to perform an agreenent should not be entitled to exact nerformance." Cooper, Ch., in Cronin v. Watkins, 1 Temn. Ch. 119, 126 (1ST:).

Where the covenant relates to a thing not in esse, the principles of spencer's Case have been applied to an action: By the assignee of the lessee against the lessor, Thompson v. Rose, S Cow. (N. Y.) 266 (1828); Cronin v. Watkius (supra); by the assignee of the lessee against the assignee of the lessor, Tallman v. Coftin, 4 N. Y. 134 (18J0); Bream v. Dickerson, 2 Humph. (21 Tenn.) 126 (1S40). 
they neglected and refused to do, The amount which the plaintiff claims to recover is what it had cost him to procure an insurance on the premises.

The lease is referred to as a part of the petition. It states that the lease of the lot is made "at and for the rents and conditions hereinafter specified; to have and to hold the leased and demised premises upon the terms and conditions hereinafter specified." Among the terms and conditions so specified is found the covenant to insure, stated in the body of the petition. In connection with that covenant, and preceding it, was one that the lessee "will erect upon said premises a good and substantial brick building, the heighth of which shall be equal to that of the building on Bank street, known," etc.; which covenant contained a description of the size and style of the building, and the use to which it was to be put-the rooms on the ground floor to be "used and kept for storerooms, during the continuance of this lease." It is this building, by the terms of the lease, which is to be kept fully insured.

To the petition of the plaintiff, the defendants filed a demurrer, upon the ground that it did not contain facts sufficient to constitute a cause of action.

This demurrer was sustained by the court of common pleas, and judgment entered against the plaintiff.

To reverse this judgment a petition in error was filed in the district court, where the judgment was affirmed.

To reverse the judgment of affirmance in the district court, upon leave obtained, a petition in error was filed in this court.

GHolson, J. ${ }^{8}$ In consequence of the rule of the common law, that a chose in action was not assignable, the assignee of a reversion could not maintain an action upon a covenant contained in a lease, against the lessee, though the covenant might run with the land. There was a distinction made between the assignee of the reversion, and the assignee of the lease; and while the latter might maintain, and be liable to, an action upon such a covenant, it was different as to the former. To remedy this, the statute of $32 \mathrm{H}$. 8, cap. 34, was enacted, which gave, generally, to the assignee of the reversion the same right of action that the lessor had, upon the covenants in the lease. But this statute did not extend to mere personal and collateral covenants; it embraced those only which touched and concerned the thing demised.

It has been decided by this court, that the statute of $32 \mathrm{H}$. 8, cap. 34 , is not in force in this state, and that an assignee of the reversion cannot maintain an action upon the covenants in the lease. ${ }^{9}$ But if the covenant be assignable in equity, so that an action might have beer; maintained in the name of the assignor, or relief obtained by a suit in

8 Part of the opinion is omitted.

- Compare Newbur: ve Weare, 44 Ohio St. 604, 9 N. E. 845 (1887). 
equity, our code of civil procedure operates upon the remedy, even more extensively, that the statute of $32 \mathrm{H}$. 8, cap. 34. For whether the covenant be collateral, or inhere in the land, if it be assigned, the assignee not only may, but, as the party beneficially interested, must sue in his own. name. For example, if there be a contract by a lessee to build a house or a wall upon the land, at any time, and whether to be used by the lessee or not, the lessor, in selling the reversion, may also assign the benefit of such a contract, and the action of the assignee for a breach would, under the code, be in his own name.

In the present action, it may be inferred from the pleadings that the lessor, Powers, has assigned to the plaintiff the covenant to keep the house insured for the benefit of the lessor and lessee. This covenant Powers might well assign; and the plaintiff, being the assignee of the reversion, and entitled also to the benefit of the covenant, might bring an action for its breach, in his own name, against the lessee of Powers. But does this right of action extend to the assignee of the lessee? It may be, that the lessee would be liable on the covenant, but not the assignee of the lessee. There is a manifest difference betiveen assigning a right of action, and creating, by assignment, a liability to an action. The latter must, generally, assume the shape of a contract to indemnify, and could not usually affect the rights of the party holding the original claim. It would be really a new contract, and not in the nature of an assignment of another contract. In this view of the liability of an assignee of the lease to the assignee of the reversion the principle governing the assignment of a chose in action, or the benefit of a covenant, must be thrown out of view, and the inquiry be made on other principles and considerations.

The covenant must run with the land-must be so connected with, be attached to, and inhere in the land, that the assignee of the reversion or the assignee of the lease, as the case may be, would have a right to the advantage of it, or be bound to perform it. Such is the general principle; but whether a covenant so runs with the land, must depend, in the first place, upon the nature and character of the particular covenant and of the estate demised, as connected with the respective rights of lessor and lessee in reference to the subject-matter of the covenant; and, in the next place, upon the intent of the parties in the creation of the estate, as shown by the language of the instrument creating it, construed with reference to the relative position of the parties, and to the subject-matter to which their contract and conreyance is to be applied. The nature and character of the covenant may be such, that it may run with the land; and yet, if it be clearly the agreement of the parties that it shall not so run, it would not be annexed, in spite of the agreement so expressed. And, on the contrary, however clearly and strongly expressed may be the intent and agreement of the parties, that the covenant shall run with the land, yet, if it be of such a character that the law does not permit it to be attached. 
it cannot be attached by the agreement of the parties, and the assignee would take the estate clear of any such covenant.

From this view, it is obvious that, as to the first point, the nature and character of a covenant which may inhere in the land, we are to look at the reason and policy of the law; and, as to the second point, whether it does so inhere as to give a right and create an obligation in the case of assignees, we must look at the intent of the parties creating the estate. The law must say that it may inhere, and the parties must say that it shall inhere. *** [The court held that the covenant was of such a character that it might be made to run with the land.]

The second point is one which, in its application to the present case, in view of the decisions and dicta in England and in this country, presents considerable difficulty. When any effect, such as to pass an estate or create an obligation, is dependent upon the intent of parties as expressed in a writing, it is an important inquiry whether the law has prescribed certain words or expressions as essential to be used to indicate that intent. If it be so, those words must be used, and none others will suffice. The word "heirs," in the case of a conveyance to create an estate in fee simple, is an instance. But where the law has prescribed no such words, then the intent of the parties must be ascertained from the whole instrument, interpreted and construed by just and proper rules. In the latter class of cases, as a general rule, whether the intent be very clearly and plainly expressed, or be ascertained after some difficulty by the rules of construction, can make no difference. It is not a question of degree. The intent is either expressed or it is not, and the effect is the same without reference to the degree of clearness.

In determining whether a particular covenant was intended to run with the land, the fact that its particular subject-matter was not in existence at the time the estate was created, is undoubtedly very important and material, and in many instances might be regarded as a controlling consideration. In such a case, though the subject-matter be connected with the land, as a house or wall to be built upon it at a future day during the term, yet if nothing more appeared to indicate the intent, it might be regarded as a personal covenant, and not running with the land. If, however, an intent be shown that the covenant shall run with the land, by binding the "assigns" in so many words, then the covenant does run with the land, and the assignee of the lease is bound. Thus it was resolved, in the leading case upon this subject: "If the lessee had covenanted for him and his assigns that they would make a new wall upon some part of the thing demised, that forasmuch as it is to be done upon the land demised, that it should bind the assignee; for although the covenant doth extend to a thing to be newly made, yet is to be made upon the thing demised, and the assignee is to take the benefit of it, and therefore shall bind the assignee by express words." Spencer's Case, 5 Coke, 16 b. 
In the first resolution of the same case it had been said: "When the covenant extends to a thing in esse, parcel of the demise, if the thing to be done by force of covenant is in any manner annexed and appurtenant to the thing demised, it shall go with the land and bind the assignee, although he be not bound by express words; but where the covenant extends to a thing which is not in being at the time of the demise made, it cannot be appurtenant or annexed to the thing which hath no being." And it was further said as to the case at bar: "The covenan? concerns a thing (a wall) which was not in esse at the time of the demise made, but to be newly built after, and therefore shall bind the covenantor, his executors and administrators, and not the assignee, for the law will not annex the covenant to a thing which hath no being."

Between the first and second resolutions in Spencer's Case, there is an apparent inconsistency, and the unsatisfactory character of the second resolution has been a subject of remark and comment. In the first resolution it seems to be considered that the law will not permit such a covenant as the one under consideration-a covenant to build a wall upon the land demised - to be annexed to the estate and run with the land. And if this be so, on the ground that it is to be regarded as a collateral covenant, not proper to be annexed to the land, then the conclusion part of the second resolution shows that the agreement of the parties, whether expressed by the word "assigns," or otherwise, could not make it a covenant running with the land and binding upon the assignee. Yet, in the second resolution, it is said, of a supposed case, if the lessee had covenanted for him and his assigns, it would bind the assignee by express words: and thus showing, apparently, in a case in which it had been before said, that the covenant could not be appurtenant or annexed to the land, that the parties might make it so. It is to be observed, however, that in the second resolution an element is introduced, not found in the statement of the case in the first resolution, viz.: That the building of the wall would be beneficial to the estate demised, and the assignee would have the benefit of it. The result, then, would be, that if the thing to be done upon the land, though not existing at the time of the demise, would be of a permanent nature, connected with the use and enjoyment of the land, and beneficial to the assignee, an intent that it should run with the land and bind the assignee, shown by naming him in the deed, would be effectual.

Thus understood, the two resolutions are not inconsistent, and there may have been some omission in expressing the second resolution which has led to the apparent inconsistency. The question then arises. whether an intent to bind the assignee, in the case of such a covenant, may be effectual without the word "assigns?" Whether that word is used in the technical sense, and cannot be supplied by other words. If, for example, in the case stated, instead of "for him and his assigns," it was said "for him and any other person or persons to whom the estate demised shall be conveyed," or other equivalent words. 
Our conclusion is, that the word "assigns" is not used in a technical sense and as the only word appropriate for the purpose, but that equivalent words, or any clear manifestation of intent will suffice. We think the real question must be, the covenant being one which may be annexed to the estate and run with the land, whether such was the intention of the parties, as expressed in the deed. The important consideration is, whether the covenant is annexed to the estate and runs with the land. If this be so, the rights and liabilities of those who take the estate and possess the land during the term, flow from a privity of estate, and not from any assignment of right or contract. If the covenant cannot, or does not, run with the land, no words of assignment can create a privity of estate; if a privity of estate be created, no words of assignment are necessary. The word "assigns" could only show that the covenant was intended to run with the land, for if the covenant were otherwise attached to the land and the privity of estate created, as in the ordinary case of covenant to repair, that word is shown by all the authorities not to be requisite to bind the assignee of the lease.

Upon the principle and authority, "the law does not require any particular form of words to constitute such a covenant which shall run with the land." Trull v. Eastman, 3 Metc. (Mass.) 121-124 (37 Am. Dec. 126). "Any words in a deed, which show an agreement to do a thing, make a covenant." Williams v. Burrell, 1 M., G. \& S. 402-429; Comyn's Dig. Tit. Covenant. "To charge a party with a covenant, it is not necessary that there should be express words of covenant or agreement. It is enough if the intention of the parties to create a covenant be apparent. Wolveridge v. Steward, 3 M. \& S. 561 (30 E. C. L. 312); Courtenay v. Taylor, 6 M. \& G. 851 ; Williams v. Burrell, 1 C. B. 402-430; Great N. Railway Co. v. Harrison, 12 C. B. 576609; Savage v. Mason, 3 Cush. (Mass.) 500-505.

In the present case, that the covenant to keep the building fully insured, was intended to accompany the estate in the event of any assignment, is, we think, shown as well by the immediate object in view as by the language. The land demised was a vacant lot to be rendered more productive and valuable by an improvement corresponding with those on other lots in the neighborhood. It was to be improved with a view to permanent and continuous business-the rooms were to be kept and used for stores. That the lot might lie unimproved, or the building after its erection be burned and not be rebuilt, either by lessor or lessee, was never contemplated by the parties. The language in the instrument is, that the lease was made "at and for the rents and conditions" specified; and it was to be held "upon the terms and conditions" expressed. We feel, therefore, authorized, for the reasons given and for others on which it is not necessary to enlarge, to use an expression of the American annotators on Spencer's case, and say, that the covenant to insure in this case did not relate solely to something nut 
in esse at the time it was made, but related to the land so directly and in such manner that it may bind an assignee of the lessee. 1 Smith's Leading Cases, Am. Ed., 177. Judgment reversed. ${ }^{10}$

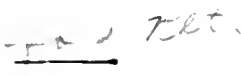

\section{PURVIS v. SHUMAN.}

(Supreme Court of Illinois, 1916. 273 Ill. 2S6, 112 N. E. 679, L. R, A. 1917 A. 121, Ann. Cas. 191SD, 1175.)

CARTwRIGnT, J.11 The appellant, Lawrence Purvis, filed his declaration in this case in the circuit court of Moultrie county against the appellee, Irving Shuman, grantee of the reversion in premises leased to the appellant by Sam T. Miller, to recover from the appellee 75 per cent. of the cost of improvements placed on the leased premises by.virtue of a covenant of the lessor contained in the lease. The court sus tained a demurrer to the declaration and rendered judgment against the appellant for costs. An appeal was taken to the Appellate Court for the Third District, where the judgment was affirmed and a certificate of importance and a further appeal were allowed.

The facts alleged in the declaration and admitted by the demurrer are as follows: On April 9, 1907, Sam T. Miller, owner of the north half of the northwest quarter of the southeast quarter of section 1 , town 13, range 5 , in Moultrie county, leased the same to the plaintiff from March 1, 1907, to March 1, 1912, at a rental of $\$ 200$ per annum. It was agreed that the plaintiff should not sublet the premises without the consent of the lessor, and the lease contained the following provisions:

"It is further mutually agreed between the parties hereto that the party of the second part has leased said premises as an amusement park, and that the party of the second part is entitled to all rents and privileges that he may be able to receive from the parties desiring to use the same for a ball park, race meetings or other similar forms of anusement. It is further agreed between the parties hereto that any and all improvements that may be put on said premises by the party of the second part for the purpose of carrying out the provisions of this lease will at the expiration of this lease be purchased by the party of the first part at seventy-five per cent. of the original cost of said improvements. * * * The covenants herein shall extend to and be binding upon the heirs, executors and administrators of the parties to this lease."

The lease was recorded, and the plaintiff took possession and constructed the improvements for the purpose of carrying out the provi-

10Acc: Frederick v. Callahan, to Iowa, 311 (1875); Vue v. Fetzer. (ia) Wis. 55.26 N. W. 266 (1SSt): Hunt v. Danforth, 2 Curt. 392 , Fed. Cas. No. $6 S 57(185)$.

11 Part of the opinion is omitted. 
sions of the lease that the premises should be used for an amasement park, and the improvements cost $\$ 8,255.95$. During the term, on August 10, 1909, Sam T. Miller, the lessor, having platted the premises into lots, sold and conveyed a portion to the defendant and another portion to the defendant and D. L. Enslow, and on January 3, 1910, Enslow conveyed all his interest to the defendant. On March 1, 1912, the defendant notified the plaintiff that he was the owner of the premises and requested the plaintiff to remove the improvements. The plaintiff refused to comply with the request, and demanded from the defendant 75 per cent. of the original cost of the improvements, which the defendant refused to pay. Afterward the defendant obtained a judgment against Sam T. Miller, the lessor, caused an execution to be issued and levied upon the improvements as the property of Miller and sold them by virtue of the execution. The Appellate Court was of the opinion that, the improvements not being in existence at the time the lease was executed, the covenant of Miller to pay at the termination of the lease 75 per cent. of their original cost was personal and collateral to the demise, and did not run with the land so as to bind the grantee of the lessor, under the decision in Spencer's Case, 5 Coke, 16 (1 Smith's L. C. 145), and subsequent cases following that one. The decision of this case will turn upon the question whether that view of the law was correct.

The statutory provision giving lessees a right of action against grantees of the reversion is section 15 of chapter 80 of the Revised Statutes of 1874, relating to landlord and tenant, and is as follows:

"The lessees of any lands, their assigns or personal representatives, shall have the same remedy, by action or otherwise, against the lessor, his grantees, assignees or his or their representatives, for the breach of any agreement in such lease, as such lessee might have had against his immediate lessor: Provided, this section shall have no application to the covenants against incumbrances, or relating to the title or possession of the premises demised."

The previous statute, included among those adopted as the law of this state, was enacted in the thirty-second year of the reign of Henry VIII (St. 32 Henry VIII, c. 34). * * * That section [the second section of 32 Henry VIII, c. 34] provided that all lessees should have the same rights and remedies against the grantees of the reversion as they might have had against the lessors, and section 15 of our statute is a substantial re-enactment of section 2 of the former statute. ***

In the case of Hansen v. Meyer, 81 Ill. 321, 25 Am. Rep. 282, the suit was brought to recover damages for the breach of a covenant of the lessor to buy from the lessee, at a reasonable price, counters and shelving to be put in a storeroom on the first floor of a hotel building by the lessec. 'The court cited Spencer's Case, and held that the grantee of the lessor was not bound because the counters and shelving were not in esse and had not yet become a part of the land when the lease was made. 'The appellant claimed a right to maintain the action un. 
der section 15 of our statute, before referred to, but the court declined to consider that question because the statute was enacted after the lease was executed. It does not appear, however, that there was any restriction upon the use of the premises which required counters and shelving, or that they were necessary to the enjoyment of the leasehold estate. The court, therefore, did not consider that question and the case came exactly within the first resolution in Spencer's Case.

Neither the Hansen Case nor Spencer's Case is authority for the doctrine that if the lessee is restricted to a particular use of the lands demised, requiring improvements without which the land could not be used for the special purpose, a covenant relating to such improvements does not run with the land and bind assigns not expressly named. The covenant in this case did directly affect the mode of enjoying the leasehold estate which could not be otherwise enjoyed. Surely such a covenant is annexed to the land itself and the privity of estate which is the foundation of the rumning of covenants with the land is present. The improvements, when made, would not only tend to the support of the thing demised, but would be essential to its use. The provisions of the lease amounted to an express covenant not to use the premises for any other purpose than as an amusement park. The naked land without the improvements could not be used for that purpose, and the lessee agreed to create the very thing which would enable him to use the land for the specified purpose. Stalls, paddocks, seats for the people, stands for the judges, fences with gates, offices for the sale of tickets, and other improvements, were absolutely essential to effect the purpose of the lease and to give the lessee the benefit of it. The grantee to Miller unquestionably had a right to enforce the covenant of the lease that the premises should be used for an amusement park, and having the benefits of the covenant the burden and benefit ran together with the land. The defendant, as grantee of the reversion, might have enforced against an assignee of the plaintiff the provision of the lease that the demised premises should be used for an amusement park, and such use necessitated the making of the improvements. The mutual covenants related to the manner of use and enjoyment of the premises, and were inherent in the demise, and not personal or collateral. Whether there was ever any rational ground for a distinction between things which are or are not in esse when the covenant is made where they do not concern the use and enjoyment of the demised premises, there certainly is none where the covenant directly concerns such use and enjoyment.

The judgments of the Appellate Court and circuit court are reversed, and the cause is remanded to the circuit court.

Reversed and remanded. ${ }^{2}$

12 Covenunt against the assignee of a lessee "on a demise to the lessee, his executors, administrators, and assigns, in consideration of the rents and corenants on the part and behalf of the lessee and his assigns to be raid, done, and performed, of a messuage and lands, with liberty to the lessee, 


\section{(C) What Covenants Run}

\section{(a) Covenants by tue Iesssee}

\section{COCKSON v. COCK.}

(Court of King's Bench, 1606. Cro. Jac. 125.)

Covenant against the defendant as the assignee of Dalton; for that upon an indenture of demise Dalton covenanted for himself, his executors, and administrators, to leave fifteen acres every year for pasture absque cultura; and that he granted his estate to the defendant, and that the defendant non reliquit quindecim acras ad pasturam, but such a day and year ploughed up all. And upon this count it was demurred, because the assignee not being named, it is not any covenant which shall bind the assignee, for it is collateral.

But all the Court held, that this covenant is to be performed by the assignee, although he be not named; because it is for the benefit of the estate, according to the nature of the soil; but to perform a collateral covenant, as to build de novo, or such like, shall not bind him, unless named. Wherefore it was adjudged for the plaintiff. ${ }^{13}$

his executors, administrators, and assigns, to make any erections or buildings. The lessee covenanted for himself, his heirs, executors, and administritors (not saying assigns), * * * that he, his executors or administrator's, would repair the messuage and farm, cuthouses, barns, stable, and all other erections and buildings which should or might be thereafter erected, * * aud the same being so repaired, he, the lessee, his executors, administrators, and assigns, at the end of the term would yield up. There was a breach alleged, in non-repair and not yielding up in repair. The third plea was pleaded to a part of this, viz., to so much as complained in respect of a water corn-mill, cottages, and other buildings erected and built during the term, and showed that they were buildings erected during the term, and not erected in place of others previously existing." The court per Yollock, C. B., held the defendant liable, saying: "In the present case we think it sutficient to say, that as the corenant is not a covenant absolutely to do a new thing, but to do :something conditionally, riz., if there are new buildings, to repair them; as when ruilt they will be part of the thing demised, and subsequently the covenant extends to its support, and as the covenant clearly binds the assignee to repair things in esse at the time of the lease, so does it also those in posse, and consequently the assignee is bound. There is only one corcnant to repair; if the assignee is included as to part, why not as to all? On these grounds we think the third plea bad." Minshull v. Oakes, 2 Hurl. \& N. 79? (1S5S).

See, also, Conover v. Smith, 17 N. J. Eq. 51, S6 Am. Dec. 247 (1S64).

Cases dealing with the question as to whether a covenant to pay for improvements redutes to a thing not in esse are collected in a note to Willcox v. Kiehoe, 4 L. R. A. (N. S.) 466 (1905).

13 Acc.: Covenant to reside on the land, Tatem v. Chaplin, 2 H. Bl. 133 (1793); to sink oil wells in the land, Bradford Oil Co. v. Blair, 113 ra. 83, 4 Atl. 21S, 57 Am. Rep. 442 (18s6).

The following coreuants have been held enforceable: By the assignee of the lessor against the lessee-to deliver up the premises in good condition, IIatures v. Westwood, Cro. Eliz. 599 (1598); Sihelby v. Hearne, 6 Yerg (14 'Tenn.) 512 (1534); to use on the premises all manure produced thereon, Chapman v. Smith, [1907] $2 \mathrm{Ch}$. 97. By the assignee of the lessor against 


\section{MAYOR, ETC., OF CONGLETON v. PATTISON et al.}

(Court of King's Bench, 1808. 10 East, 130.)

The plaintiffs declared in covenant upon an indenture, made the $23 \mathrm{~d}$ November, 1752, whereby they demised to John Clayton a piece of ground in Congleton, called the Byflat, and a certain slip of land, through which a watercourse was intended to be made, with liberty for making and repairing the same, and with liberty for Clayton, his executors, administrators, or assigns, to erect in the Byflat a silk mill, \&c. habendum, the said piece of ground and premiscs, \&c. to Clayton, his executors, administrators, and assigns, for 300 years from the date of the indenture; yielding and paying, as therein mentioned. And Clayton covenanted for himself, his executors, adninistrators, and assigns, with the corporation, that he, his executors, \&c. would at all times during the term, before any persons should be received as servants, workmen, or apprentices, in such silk. mill, give notice of their names to the town-clerk of the borough for the time being; and if he should immediately give satisfactory information to Clayton, his executors, \&c. or to the then owner or occupier of the silk mill, that any of the persons in such notice were legally settled in any other parish or township, and not in Congleton, then they should not be received to work in the business of such silk mill, before a certificate of the settlement of such person under the Stat. 8 \& 9 W. 3, c. 30, should be given to Congleton. The declaration then stated the entry of $J$. Clayton, and the building of the silk mill; and that on the 1st of January 1790, all the estate and interest, \&c. of J. Clayton in the premises duly came to and vested in the defendants by assignment, by virtue of which they entered and were possessed, \&c.: and then assigned as a breach, that after the defendants became so possessed, and while they were working the silk mill, and during the continuance of the term, they received divers persons as servants, workmen and apprentices to work in the said mill, without giving the previous notice before mentioned to the town-clerk of Congleton, and that the persons so received worked in the said mill without any such notice, and that they had not previously gained any settlement in Congleton; by reason of which the township of Congleton had become liable to relieve them and their families, and had expended a large sum in the same, and continued liable to the burden, \&c.; and that the plaintiffs had also incurred great expence in the premises, and their estates and property in the township had bcen lessened in value.

the assignee of the lessee-condition not to sell off timber. Verplanck $r$.

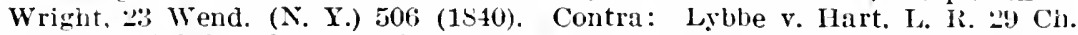
Div. S, 19 (1ss3). Compare Clegre v. Hands, L. R. 44 Ch. Div. 503, 512 (1590). see Allen r. Culver, 3 Denio (N. Y.) $2 \$ 4$ (1S46), post, p. 420.

Hig.RIgIts-28 
The defendants, after craving oyer of the indenture, by which it appeared further, that the term was granted by the corporation in consideration of $£ \subseteq O$. paid, and of a nominal yearly rent, demurred generally to the declaration.

Lord Eltengorough, C. J. ${ }^{14}$ This is a covenant in which the assignee is specifically named; and though it were for a thing not in esse at the time, yet being specifically named, it would bind him, if it affected the nature, quality or value of the thing demised, independently of collateral circumstances; or if it affected the mode of enjoying it. But this covenant does not affect the thing demised, in the one way or the other. It may indeed collaterally affect the lessors as to other lands they may have in possession in the same parish, by increasing the poor's rate upon them; but it cannot affect them even collaterally in respect of the demised premises during the term. How then can it affect the nature, quality, or value of the thing demised? Can it make any difference to the mills, whether they are worked by persons of one parish or another: or can it affect the value of the thing at the end of the term, independently of collateral circumstances? The settling an additional number of persons in this place may indeed, by means of the increased population, bring an increased burden at the end of the term on those who are to pay the rates: but that increase of population may also be an increased benefit to the land owners, as it has happened within our own experience in many parts of this kingdom, the seats of manufactures, where the value of land has, in consequence, risen in a great proportion. But the covenant in question does not affect the thing demised immediately, but only, if at all, in respect of collateral circumstances; that is through the medium of an increased population, and the increased expence of providing for them on the one hand, with the increased value of the lands to be set against it on the other hand. How then does it affect the mode of occupation? The carrying on of a particular trade on the premises may be said to do that; but where the work to be done is at all events the same, whether it be done by workmen from one parish or another, cannot affect the mode of occupation. The covenant, therefore, not directly affecting the nature, quality, or value of the thing demised, nor the mode of occupying it, is a collateral covenant, which will not bind the assignee of tile term, though named; and this is a question with the assignee, and not with the original lessee who entered into the covenant. In the case of Bally v. Mells [3 IVils. 25, and Vilmot's Rep. 341] the covenant might affect the thing demised; for if the lessee of the tithes suffered any of the farmers of the parish to take their own tithes, such union of the land with the tithe might lay a foundation for claiming a modus, which might affect the future value of the tithes, and would immedi-

14 The opinions of Le Blanc and Bayley, JJ., are omitted. 
ately affect the occupation. But we cannot say that this covenant does either: and therefore it does not run with the land so as to bind the assignees.

Judgment for the defendant. ${ }^{15}$

\section{THRUSTON v. MINKE et al.}

(Court of Appeals of Maryland, 1570. 32 Md. 487.)

Bar'Tol, C. J., ${ }^{16}$ delivered the opinion of the Court.

It appears from the record, that before the 24th day of October, 1867, the appellant and Frederick Minke, (the appellee,) were seized in fee as tenants in common, of a lot of ground in the town of Cumberland, on the north-west corner of Baltimore and George streets; the appellant owning one-fourth, and Minke three-fourths thereof. The lot was improved by a three story building known and occupied as "St. Nicholas Hotel." The building was situated on the corner of the streets mentioned, leaving on the west thereof a part of the lot fronting on Baltimore street vacant or unimproved.

On the 24th day of October, 1867, the appellant leased to Minke, for the term of ninety-nine years, renewable forever, his undivided fourth part of a portion of the vacant or unimproved part of the lot; commencing at the westerly wall of the hotel and binding thereon; the parcel so leased is described in the lease, and need not be more particularly noticed here.

After describing the parcel demised, the lease contains, among others, the following provisions:

"With the privilege to said lessee, his representatives and assigns to use so much of said westerly wall of said hotel building, as binds along the first line of the property hereby demised, as a party wall, to the height of the third-story floor of said hotel building only: Provided, however, and this lease is on this condition, that said lessee and his assigns shall not at any time hereafter erect, build or construct, on the part of the lot hereby demised, which fronts eleven feet on Baltimore street next to said hotel building, and runs back — feet in the depth, any building or tenement, any portion or part of which shall be

15 The following covenants have been held enforceable by the lessor against the assignee of the lessee: Not to conduct a business, Doe d. Bish v. Keeling, 1 Maule \& S. 95 (1S13); not to open a butcher shop, Doe r. Spry, 1 B. \& Ald. 617 (1818); not to manufacture a specitied hind of product, American stramboard Co. v. Haldenan Paper Co., \$3 Fed. 619, 27 C. C. A. 634 (1897); to conduct the premises as a saloon in an orderly and legal manner, Crowe v. Riley, 63 Ohio St. 1,57 N. E. 950 (1900); Granite building Corp. v. Greene, 25 R. I. $586,57 \mathrm{Atl}$. 649 (1904). Acc., as to the last covenant, by the assignee of the lessor against the lessee: Fleetwood v. Hull, L. R. 23 Q. B. L. 35 (1SS!)).

1 l'art of the opinion is omilted. 
higher than the present level of said third story floor of said hotel building; and provided further, that in using such part of said westerly wall of said hotel building as a party wall as aforesaid, the said lessee and his assigns shall not weaken or materially injure or affect the same."

The bill of complaint filed by the appellant states that the above conditions were put in the lease "for the express purpose of preventing Minke, or his assigns, from shutting up, or excluding the light from the west window in the third story hall of the main hotel building, and other windows on the west side of said hotel building, in the third story, and also to prevent Minke from building any tenement or house higher than the third story floor of said hotel building, for the space of eleven feet westerly therefrom."

And the bill charges "that Minke has directly violated and broken said condition."

That "said Minke, without any agreement on the part of the complainant, or waiver or release of said condition, and in opposition to the repeated remonstrances of the complainant, is now proceeding to erect and construct a building, and is actually constructing the same of brick, to a height several feet above the roof of the main hotel building, and shutting up the whole space of eleven feet in width on Baltimore street, for the whole depth of thirty-two and a quarter feet, by occupying the whole thereof with such building."

The bill further charges that Minke is proceeding to construct a large wooden cornice on and against the westerly wall of the hotel building, at and near the front thereof, on Baltimore street, and putting the same far over and above the roof of the main hotel building, thereby, as alleged, increasing the dangcr to the same in case of fire. And the effect of such violation of the conditions of the lease is alleged to be to shut out and obstruct the light and ventilation from the hall of the third story of the hotel, and greatly to injure and impair the value of the same and of the complainant's interest therein.

An injunction was issued to prevent and restrain Minke from proceeding with the construction of the proposed building, contrary to, and in violation of the covenant and conditions contained in the lease.

The appellee, Minke, answered the bill, and proof was taken, and the Circuit Court, on hearing the cause upon the pleading and proofs, passed an order dissolving the injunction. From that order the present appeal was taken.

In the progress of the case in the Court bclow, the fact was disclosed that the appellant, Thruston, after making the lease, on the 30th day of October, 1867, conveyed to John B. H. Campbell all his reversionary interest and estate in the property demised, and assigned the covenants therein, and the respondent contended that the effect of such conveyance and assignment was to confer upon Campbell the exclusive right to enforce the particular covenant or condition under con- 
sideration, and to divest the complainant of the right to maintain any action at law or in equity for the breach or violation thereof. This defence was ruled good by the Circuit Court, and its decree dissolving the injunction appears to have rested mainly on that ground.

In this view we do not concur. It is plain, from the nature of the condition, that it was inserted, as alleged in the bill, only for the benefit and protection of the hotel property, in which the lessor retained his estate, and that it was not in any respect intended for the benefit of the lessor as owner of the reversion in the property leased. It was, in its nature, an independent covenant or condition, made with Thruston, as owner of the contiguous property, for the benefit and protection of which it was intended; it was not a covenant running with the land demised, and did not pass to the assignee of the reversion.

The effect of the condition was to create a right or interest in the nature of an incorporeal hereditament or easement appurtenant to the contiguous hotel property, and arising out of the parcel of land demised by the lease. The principle is correctly stated by the Court in Whitney v. Union R. Co., 11 Gray (Mass.) 359, 71 Am. Dec. 715, as follows:

"When it appears, by a fair interpretation of the words of the grant, that it was the intent of the parties to create or reserve a right in the nature of a servitude or easement in the property granted, for the benefit of the other land owned by the grantor, and originally forming, with the land conveyed, one parcel, such right shall be deened appurtenant to the land of the grantor, and binding on that conveyed to the grantec, and the right and burden thus created will respectively pass to and be binding on all subsequent grantees of the respective parcels of lands." * * *

The appellant, as partner of the hotel property, is entitled to the benefit of the condition in the lease, and that it did not pass to Campbell by the assignment of the reversion. Is he entitled to relief by a writ of injunction to prevent its violation? ***

In 2 Story's Eq. Jur. $\S 927$, it is said: "Where easements or servitudes are annexed, by grant or covenant or otherwise to private estates **** the due enjoyment of them will be protected against encroachments, by injunction."

That is the nature of the right that has been encroached upon here. In this case the covenant or condition in the lease is express and positive, and, as we have before said, the appellant, as part owner of the hotel property, for the protection or benefit of which it was made, has a right to insist on its observance by the lessee.

The consequence of its violation in the manner charged in the bill, as shown by the evidence, is, to shut out, or materially obstruct the light and ventilation of the third story of the hotel.

For such dannage and injury, an action at law would not, in our opinion, afford an adequate and complete remedy, and, therefore, the appellant is entitled to relief by injunction. 
For the reasons stated, the order of the Circuit Court dissolving the injunction will be reversed, with costs to the appellant, and the cause will be remanded.

Reversed and remanded. ${ }^{17}$

\title{
IVILIIAMS v. EARLE.
}

\author{
(Court of Queen's Bench, 1868. L. R. 3 Q. B. Cas. 739.)
}

Brackiurn, J. ${ }^{18}$ This is an action by the lessor against the assignee of a lease for breach of covenants in the lease, and the rule has been well established ever since Spencer's Case, 5 Rep. 16a, $1 \mathrm{Sm}$. L. C. 6th Ed. 45, that when covenants are contained in a lease (at all events if, as in the present case, the covenants are on behalf of the lessee and his assigns), and the covenants touch or concern the land, although the original covenants are made by the original lessee with the lessor, yet they run with the land, and there being privity of estate between the assignee and the lessor, the lessor may sue the assignee for breach of any of them. But this is only in the case of a covenant which "touches or concerns" the land.

17 A. was a brewer and dealer in ale, owning his own brewery and a public house. He leased the latter to $\mathbf{X}$. by indenture; the lease provided that the word "lessor" should include A., his heirs, executor's, administrators, and assigns; with a corresponding provision as to the word "lessee." The lessee rovenanted to sell no ale in the leased premises except that purchased from the lessor. A. later conveyed to B., another brewer, A.'s brewery and business, his reversion in the public house, and the benefit of the corenant. A.'s brewery was dismantled. $X$. refused to buy his ale from $B$. $B$. sought an injunction restraining $X$. from selling on the leased premises any ale other than that bought from $B$. The court held that $B$. was entitled to his injunction. In considering whether the corenant would run at law, Cotton, L. J., said:

"Then it is said that this covenant does not run with the land. I think it does run with the laud. That is my opinion; but there are other points on which this case may be decided independently of that question. It is a contract relating to the way in which the business at a particular house is to be carried on, therefore it is a contract relating to the public house, just as much, in my opinion. as a contract as to the mode in which the cultiration of a particular bit of land is to be carlied on relates to the land. It affects the value of the reversion. it affects the louse, and in my opinion it is a contract running with the land. If that is so, that will enable the juclument to be supported, and will euable the present owner of the reversion in this case to sne."

Lopes, I. J., said:

"But then a question is raised as to whether the benefit of this covenant runs with the reversion. It was contended by Mr. Collins that it did not run with the reversion, and that it was purely collateral. The benefit to run with the reversion must touch or concern the demised premises. Now. does this corenant tuuch or conceln the demised premises" It relates to the mode of enjorment of a public house. The thing demised is a public house, and the corenant compels the covenantee to buy the beer of the covenantor and his arsigns. In my opinion. it touches and concerns the demised premises; it afiects the node of enjogment of the prenises, and therefore it runs with the reversion." Cloger r. IIands, L. R. 44, Ch. D. 503, 51S. 523 (1S90).

Ser, also, Manchestr Prewing Co. v. Coombs, [1901] 2 Ch. 60S.

18 The statement of facts ancl opinion of Lush, J., are omitted. 
Now the first and chief point to be determined here is, there being a covenant in the original lease by which the lessees, on behalf of themselves and their assigns, covenant with the lessor that neither they nor their assigns will assign the lease without the licence of the mortgagor and mortgagee, and the defendant the assignee having assigned without their licence, whether that is a covenant which touches or concerns the land, and therefore runs with it and binds the defendant.

I have been unable to perceive, after listening attentively to the argument of the counsel for the defendant, any reason why this covenant should not be considered a covenant touching and concerning the land. It is an express covenant as to who shall have and occupy the land, and it is inserted with a view that the landlord shall not be deprived of a voice as to who shall be substituted for the original lessee in the possession of the landlord's premises. It is certainly very material as touching the interest of the landlord and tenant, and touches and concerns the thing demised quite as directly as the many covenants that have been held to do so, such as a covenant to renew a lease, which has been held to run with the land in more than one case cited in the judgment of the Court in Roe v. Hayley, 12 East, at page 469; or a covenant to reside in the demised premises, which was held in Tatem $v$. Chaplin, $2 \mathrm{H}$. B1. 133, to bind the assignee though not named. Again, in Bally v. Wells, 3 Wils. 25, 33, a covenant not to let any of the farmers take the tithes demised without the consent of the lessor was held to run with the tithes and bind the assignee, assigns being mentioned in the covenant. And the expression made use of by the Court at the end of the judgment, which $\mathrm{Mr}$. Jones relied upon as shewing that a covenant to assign without a license could not run with the land, seems to have no such meaning, but the contrary. The expression is, "a covenant not to assign generally must be personal and collateral, and can only bind the lessor himself, there never can be an assignee;" but the Court adds, "whereas the present lease grants to executors, administrators, and assigns;" and what they seem to have meant is, that when the lessee covenants, not that he will not assign without licence, but that he will not assign at all, then the covenant of course does not run with the land, because the covenant is gone whether the assignment be with a licence or without. But when there is a covenant that the lessee and his assigns will not assign without licence, it is different, and the covenant may run with the land toties quoties. It seems to me, therefore, both upon principle and authority, that the present covenant not to assign without licence from the landlord from time to time, does run with the land, and consequently the defendant, the assignee, is liable for the breach.

But though there is a covenant binding on the defendant not to assign, the assignment is nevertheless operative, and the estate passed from the defendant to Banks, and the breaches of covenant which have occurred since are not breaches for which the defendant can be liable in the present form of action; anything done by the defendant on the 
premises since then he may be liable for in an action on the case: but the remedy on the covenants must be against the new tenant Banks. But the plaintiff is entitled to recover indirectly in the present action by way of damages for the breach of the covenant not to assign. For inasmuch as, if the covenant not to assign had not been broken, the assignee would have remained liable to the plaintiff to fulfil all these covenants, the breaches of which are mentioned in the first count, and there would have been, if he remained solvent, a complete and sufficient remedy in his liability, the defendant having assigned over to a person, who no doubt is selected because he has nothing to lose and so loses nothing by incurring the liability under the covenants, there has been damage sustained by the plaintiff by the defendant's breach of covenant not to assign, by reason of the plaintiff only having the liability of this inferior person, instead of the liability of the defendant, for the breaches of the other covenants; and the arbitrator, in assessing the damages on the second count, must put the plaintiff, as far as - possible, in the same position, so far as money will do it, as if the covenant had not been broken. The arbitrator will take into consideration low much the worse the plaintiff will be both in respect of breaches of covenant already incurred, as well as in respect of breaches which may in future be incurred. The arbitrator must see what sum of money will put the plaintiff in the same position as he would have been in if the covenant not to assign the lease had not been broken, and the plaintiff had retained the liability of the defendant instead of an inferior liability. I agree with Mr. Jones that this will be a matter of some difficulty, and the parties would do well to agree that the lease shall be surrendered to the plaintiff, and then the measure of damages will be by how much worse off the plaintiff is than he would have been had the defendant continued bound as lessee all the time, as he would have been had" he not broken his covenant not to assign.

There are some further questions for our consideration, which will be material for the arbitrator's guidance in assessing the damages, both on the first and second counts. In this form of action the defendant is only liable for a breach of covenant; and as has been already stated a covenant to run with the land must touch and concern the land; and it appears from the lease that there was demised, not only fixtures, but movable things, which are mentioned in the schedule-tools, utensils, and other things. And there is a covenant that the fixtures and other things should be kept in order and restored when worn out, and when restored kept in the same good working order. So far as that covenant relates to anything fixed to the land the covenant runs with the land, and for any breach committed during the defendant's time he will be liable on the first count; and any breach which may have been committed during Banks' time, after the assignment from the defendant, will be matter to be taken into account in assessing the damages against the defendant on the second count. But as to the movable things, the covenant does not run with the land, as the mode in which they were 
dealt with could not have affected the land, and for anything connected with them the plaintiff cannot recover in the present form of action. For instance, a boiler, fixed to the land, though the tenant might be able to remove it at the end of the term, yet the keeping it there during the term would relate to the occupation and enjoyment of the land, and the covenant for keeping it there would run with the land. But the covenants as to mere chattels cannot run with the land, and, as to such things, if the parties cannot wisely agree to refer all matters to the arbitrator, the mortgagor, who is the real plaintiff, will take advice as to bringing another action.

Judgment for the plaintiff. ${ }^{10}$

\section{VERNON v. SMITH.}

\section{(Court of King's Bench, 1821. 5 Barn. \& Ald. 1.)}

Covenant by the assignee of the lessor against the lessee. The declaration stated, that one J. Hance, the lessor, before the time of making the lease, was lawfully possessed of the tenements and premises for the residue and remainder of a certain term of years, whereof seven years were then unexpired; which tenements and premises, with the appurtenances, then were, and thence hitherto have been and still are situate within the weekly bills of mortality, mentioned in the $14 \mathrm{G}$. 3 , c. 78; and being so possessed thereof, he, the said J. Hance, by indenture, demised and leased to the defendant the tenements and premises, with the appurtenances, habendum, for seven years, at a certain rent therein mentioned; covenant by the defendant that he should and would forthwith, at his own expense, and from time to time during the term, insure in some of the public offices in London or Westminster, for the purpose of insuring houses from casualties by fire, the messuage, dwelling-house, coach-house, stable, and premises thereby demised or thereafter to be erected and built thereon, to the amount

${ }^{19} \mathrm{~A}$ reassignment without the consent of the lessor by an assignee to the original lessee is a breach of the corenant not to assign without the consent of the lessor. Mckacharn v. Colton [1902] A. C. 10t: Munro v. Waller, 28 Ont. Is (1597). Contra: McCormick v. Stowell, 138 Mass. 431 (1S\$5). A release by one joint lessee to his co-lessee is not' a breach of the covenant against assigning. Roosevelt v. Hoplins, 33 N. Y. 81 (1865). Contra: 'Tober v. Collins, 130 Ill. App. 333 (1906); Varley v. Coppard, L. R. 7 C. P. 505 (1572), joint assignees.

$\Lambda$. leased to $\mathrm{X}$. and covenanted to renew the lease. $\mathrm{X}$. covenanted not to assign without the consent of $A$. $X$. assigned to $Y$. with A.'s consent. Y. assigned to $Z$. without A.'s consent. Held, Z. has no action against $\Lambda$. for breach of the corenant to renew the lease. Upton v. Hosmer, $70 \mathrm{~N}$. H. 498,49 Atl. 96 (1900).

See, also, Randol $\vee$ Scott, 110 Cal. 590, 42 Pac. 976 (1S95) ; Postal Telegraph Cable Co. v. Western Cnion Telegraph Co., 155 Ill. 335,40 N. L. 557 (1595) ; Bockover v. l'ost, 25 N. J. Law, 285 (1S55); Gazlay v. Williams, 210 U. S. 41,28 Sup. Ct. 687,52 L. Ed. 950 (1908). As to the difference between an assignment and a sublease, see post, pp.
$396-405$. 
of $£ 800$, in the joint names of the defendant, his executors, administrators, or assigns, and of Robert Stone, the ground landlord of the premises, his heirs or assigns ; and should and would, at the request of Hance, or of the ground landlord, their heirs or assigns, produce the policy and receipts for such insurance. The declaration set out the proviso in the lease for re-entry, on breach of any of the covenants. It then stated the defendant's entry into the premises, and that, after the making of the indenture, the term was assigned by Hance to the plaintiff. The breach assigned was, that the defendant did not insure. The second count stated, that, before the making of the demise to the defendant, in the first count mentioned, and also before and at the time of the making of the demise thereinafter mentioned, Robert Stone was seized in fee of and in the said demised tenements, and by a certain indenture, demised the same to J. Hance, habendum, for 85 years and six months. And that $\mathrm{J}$. Hance, by that indenture, covenanted to insure the premises from fire, to the amount of three-fourths of the value thereof, in the joint names of himself and Stone, with a proviso for re-entry, in case of non-performance of the covenants. It then stated, that three-fourths of the value of the premises amounted to $£ 800$, and that, by reason of the said demised premises remaining uninsured, Stone brought an action of ejectment for the forfeiture, and the plaintiff was forced to pay the costs to him, amounting to $£ 500$, and also to sustain his own costs, amounting to $£ 1000$ breach, that the defendant had not kept the covenant made by him, as stated in the first count. To this declaration, there was a general demurrer and joinder.

Аввот'т, C. J. ${ }^{20}$ It is not necessary, on the present occasion, to give any opinion on the effect of a covenant to insure premises situate without the limits mentioned in the 14 Geo. 3, c. 78. These premises lying within those limits, the effect of that statute is, to enable the landlord, by application to the governors or directors of the insurance office, to have the sum insured laid out in rebuilding the premises. Now a covenant to lay out a given sum of money in rebuilding or repairing the premises, in case of damage by fire, would clearly be a covenant running with the land, that is, such a covenant as would be binding on the assignee of the lessee, and which the assignee of the lessor might enforce. Here the defendant does not covenant expressly in those words, but only that he will provide the means of having $f 800$ ready to be laid out in rebuilding the premises in case of fire, but, connecting that covenant with the act of parliament, the landlord has a right to say, that the money, when recovered, shall be so laid out. It is, therefore, as compulsory on the tenant to have the money laid out in rebuilding, and as beneficial for the landlord as if the tenant had expressly covenanted that he would lay out the money he received in respect of the policy upon the premises. For these reasons, I think that

2. Part of the opinion of Best, J., and the opinions of Bayley and Holroyd, JJ., are omitted. 
this is a covenant running with the land, for the breach of which the assignee of the lessor may sue; and, consequently, there must be judgment for the plaintiff

BEST, J. It has been argued from the preamble to the $83 \mathrm{~d}$ section of the 14 G. 3 , c. 78 , that this provision of the statute only applies to cases where fraud is suspected. But the enacting part of the clause goes beyond the mischief mentioned in the preamble, and is large enough to embrace this case. For, under the first branch of it, where the owner of the building requests the insurance company so to apply the money, no suspicion of fraud is necessary to make such request compulsory on the directors. Within the district, therefore, to which the building act applies, this covenant provides a fund for the rebuilding of the premises, which the owner has a right to require, shall be applied to that purpose; and then it is clear, that the assignee has a direct interest in having the insurance kept up. But I think, also, that if the premises were in any other part of the kingdom, this would be a covenant that would pass to an assignee. A covenant in a lease which the covenantee cannot, after his assignment, take advantage of, and which is beneficial to the assignee as such, will go with the estate assigned. If this were not the law, the tenant would hold the estate discharged from the performance of one of the conditions on which it was granted to him. The original corenantee could not avail himself of this covenant; he sustains no loss by the destruction of the buildings, and therefore has no interest to have them insured. $* * *$ This covenant is as beneficial to an assignee as it was to the covenantee. It secures to the tenant the means of performing his covenant, and to the landlord, a solvent instead of a ruined tenant. It is a covenant beneficial to the owner of the estate, and to no one but the owner of the estate; and therefore may be said to be beneficial to the estate, and so directly within the principle on which covenants are made to run with the land. * * * Lord Coke (Co. Litt. 215b) * * * adds, that the statute does not extend to "covenants for payment of a sum in gross, delivery of corn, wood, or the like." A sum in gross is in the nature of a fine which belongs to the lessor, and can never be intended for an assignee. By the deliveries of corn and wood were meant deliveries of those articles at the mansion-house of the lessor, and not rents payable in corn or wood, without any stipulations as to the place where the articles were to be delivered. These deliveries at the mansion-house were inconsiderable in value, and would be of no use to the assignee, unless he became the assignee of the mansion as well as the farm. In 5 Coke, 18, it is said, "that the $32 \mathrm{H}$. 8, was resolved to extend to covenants which touch or concern the thing demised, and not to collateral covenants." In Spencer's case, Moore, 159, the same doctrine is laid down in the same terms, and this case is put by Gawdy. J., and assented to by all the judges and serjeants, "that a covenant that a lessor will, at the end of the term, grant another lease, runs witl the land. The covenant here mentioned is not beneficial to the estate 
granted, in the strict sense of the words, because it has no effect until that estate is at an end, but it is beneficial to the owner, as owner, and to no other person. By the terms collateral covenants, which do not pass to the assignce, are meant such as are beneficial to the lessor, without regard to his continuing the owner of the estate. This principle will reconcile all the cases. In Webb v. Russell, 3 Term Rep. 402 , Lord Kenyon considers grantees or assignees to stand in the same situation, and to have the same remedy against the lessees, as heirs at law of individuals, or successors in the case of corporations, had before the statute. For these reasons, I am of opinion that the plaintiff is entitled to judgment.

Judgment for the plaintiff. ${ }^{21}$

\section{VYVYAN v. ARTHUR.}

(Court of King's Bench, 1823. 1 Barn. \& C. 410.)

Covenant by the devisee of the lessor against the administratrix of the lessee. The declaration stated, that at the time of making the lease Thomas Vyvyan the lessor was seised in fee of the demised tenements with the appurtenances, and also of a certain mill; and being so seised, on the 24th June, 1779, by indenture demised to N. D. Arthur, his executors, administrators, and assigns, a close of land together with certain common of pasture in the indenture described. Habendum for 99 years, if three persons therein mentioned should so long live, yielding and paying to the lessor, his heirs and assigns, certain rents, sums of money, payments, and returns; and also doing certain suits and services in the indenture mentioned; and also doing suit to the mill of the said 'Thomas his heirs and assigns, called Tregamere mill, by grinding all such corn there as should grow in or upon the close thereby demised during the term. The declaration then stated the entry of the lessee, and that the lessor being seised in fee of the reversion of the demised premises, by his will devised the same, and also the said mill unto three persons in the will mentioned, their heirs and assigns, to the use of the plaintiff for his life; that the lessor died; and that by force of the statute made for transferring uses into possession, the plaintiff became seised of the reversion in the demised premises and of the mill for the term of his life; that the lessee died intestate during the continuance of the term; and that administration was duly granted to the defendant; and that one of the persons for whose life the lease was granted was still living. Breach, that after the plaintiff became seised of the reversion of the demised premises and of the mill, and during the lifetime of the lessee, corn grew upon the demised premises which ought to have been ground at the mill; yet

21 Acc.: Masurey v. Southworth, ante, p. 343; Northern Trust Co. v. Snyder, 76 Fed. 34,22 C. C. A. 47 (1896). Compare Reid v. MeCrum, 91 N. í. 412 (1ะS3). 
the lessee in his lifetime, and the defendant since his death, did not do suit to the mill of the plaintiff, by grinding there the corn so grown upon the demised premises, but wholly neglected so to do. To this declaration there was a general demurrer.

BAYLEY, J. ${ }^{22}$ I am of opinion that this is a covenant which runs with the land so as to entitle the assignee of the reversion to maintain this action, which is brought against the defendant, not as assignee, but as personal representative of the lessee. An action at the suit of the assignee of the reversion is maintainable in some cases at common law; in others, under the statute of the 32 Hen. S. I rather think that this case belongs to the former class. The lease contains a reddendum, and whatever services or suits are thereby reserved partake of the character of rent. Now, one of the services to be rendered to the lessor in this case is, that the lessee shali grind all the corn grown upon the demised premises at the lessor's mill. It is true that rent goes with the reversion of the land in respect of which it is reserved. But in this case, at the time of granting the lease, the lessor was seised in fee of the mill, as well as of the reversion of the premises devised; and, therefore, so long as the property in the mill and the reversion of the demised premises continued to be in the same person, the suit to the mill would continue to be a suit due to the owner of the reversion of the devised premises, and would, therefore, in that respect, be in the nature of a rent. It is by no means unusual for the owner of a mansion and estate to stipulate with his tenants that they should carry coals to his mansion, and perform other similar services, as long as the ownership of the mansion and the estate continues in the same person, those services are in the nature of rent, to be rendered to the reversioner of the lands demised. Now, here, the plaintiff is the reversioner of the thing demised, and also owner of the mill. In the case cited from the $42 \mathrm{Ed}$. 3, the prior and his successors took no interest in the land, yet the covenant to sing in the chapel was held to run with the land. Here the covenantor is tenant of land to the covenantee, and the suit to be done to the mill is in respect of the land demised. It is not necessary for us to decide what the case would be if the ownership of the land demised and the mill had been severed. Here the lessor continued owner of the reversion of the demised premises and of the mill from the time of granting the lease till the time of his death, and the plaintiff, as his devisee, then became entitled to both, and now continues so. My judgment is founded entirely on the unity of title to the reversion of the land demised and to the mill.

Holroyd, J. The case cited from the Year-Books of the $42 \mathrm{Edw}$. 3 , seems to me to govern the present, and is much stronger. I think this is a covenant running with the land at common law. Here the close was leased to the lessee, his executors, administrators, and assigns, yielding the rents, and doing the suits and services therein men-

22 The opinion of Best, J., is omitted. 
tioned. The suits and services are to be rendered by the lessee, his executors, administrators, and assigns, to whom the lands are leased; and this suit is to be rendered to the mill of the lessor, his heirs and assigns; so that it appears to have been the intention that the assignees of the lessor and lessee should be bound, for they are expressly named, and that suit should be done to the mill as long as it continued to be the property of the lessor, his heirs or assigns. It has been said, that the thing to be done does not.affect the land. But it affects the profits of the land, and, generally speaking, they are considered the same thing as the land itself; for if the lessee in this case had had a mill of his own, he would still have been bound to grind the corn grown upon the demised premises at the lessor's mill, and the price paid for the grinding of such corn would be in the nature of a varying rent to the lessor, and a deduction from the profits of the lessee. But it is said that as the thing required to be done by the covenant is not to be done upon the land demised, but upon other land which might or might not continue to be the land of the lessor, it does not, therefore, respect the land demised, and, consequently, that the assignee cannot take advantage of the covenant. I am of opinion, however, that inasmuch as the thing to be done is to be done at a mill which belonged to the lessor at the time of making the lease, and which has always continued to belong to the owner of the reversion of the land demised, that the covenant to be implied from the reddendum is in the nature of a covenant to render a rent, and, consequently, that it is a covenant that runs with the land. It is said, that it is not in the nature of a rent, because it will not follow the reversion, for if the property in the mill and the reversion of the demised premises became severed, the service must be rendered to the owner of the mill, and not to the owner of the reversion of the demised premises. As long, however, as the mill and the reversion of the demised premises belong to the same person, the suit to the mill is a service to be rendered to the reversioner of the demised premises: and so long, therefore, it would follow the reversion, and in that respect partake of the nature of rent. Now here, at the time of granting the lease, the lessor was seised in fee of the land demised, and of the mill, and continued so seised of the latter, and of the reversion in the former, until his death, when his interest in both vested in the plaintiff, as devisee. From the time of granting the lease to the present time, the grinding of the corn at the mill was in the nature of a rent to the reversioner, issuing out of and rendered in respect of the demised premises. For these reasons, it appears to me that the assignee may, under the circumstances, take advantage of the covenant, and, consequently, that the plaintiff is entitled to the judgment of the Court. Judgment for the plaintiff. ${ }^{23}$

$23 \mathrm{~A}$ covenant to pay rent binds the assignees of the lessee and inures to the assignees of the lessor. Attoe v. Hemmings, Bulst: $2 S 1$ (1615), post, p. 404; Stevenson v. Lambard, 2 East, 575 (1802); Webster v. Nichols. 104 III. 160 (1Ss2): Jones $\nabla$. Gundrim, 3 Watts \& $S$. (Pa.) 531 (1S42). Compare In- 


\section{GOWER v. POSTMAS'TER GENERAL.}

(Chancery Division, 1S87. 57 Law T. N. S. 527.)

[Action of covenant by Mary H. Gower, Henry S. Sanderson, and W. E. Sanderson, as executors of Edward Henry Sanderson, who was the executor of Edward Sherman. Sherman had been the owner of a long-term lease, which on his death had passed to the respective personal representatives above mentioned. The leases to the Great Northern Railway Company, and to East, referred to in the court's opinion, had been made by Edward Henry Sanderson.]

KAY, J. This is a very short point, but a very curious one; and the argument has been an interesting one to me. I confess that I did not see the difficulty until it was put by the Attorney General and $\mathrm{Mr}$. Simpson. It seems that, on the Sth May, 1869, certain lessors granted a lease to a Mr. East of premises in the city of London, which are described as being messuages and tenements. In the description there is this exception: "Save and except out of the demise intended to be hereby made all such parts of the premises firstly hereinbefore described as are demised by an indenture of underlease, dated the 20th Dec., 1867, and expressed to be made between" the lessors and the Great Northern Railway Company. That was a lease for a term which would expire before the expiry of the term granted by the lease to which I am now referring-viz., the lease to Mr. East. But there can be no doubt whatever that these excepted parts are not included for any purpose of demise in that lease to Mr. East. I am told that they were some portions of the tenements, rather irregularly marked out, which jutted into the tenement which was let to Mr. East. The lease to Mr. East contained a covenant on which the present question arises. Mr. East thereby, for himself, his heirs, executors, administrators, and assigns, covenanted with Edward Henry Sanderson, one of the lessors, as such executor as aforesaid, his executors, administrators, and assigns. Pausing there, there can be no sort of doubt, as Mr. Simpson pointed out, that the word "assigns" there means assigns of the reversion of the demised premises, that is, the reversion of the premises demised to Mr. East, and not assigns of anything eise. That is beyond all power of argument. It seems to me too plain for anything. Then the covenant runs thus: That he, his executors, administrators, or assigns, would, during the several terms thereby granted, pay the yearly rent, and all taxes, etc., in respect of the demised premises, and also would, during the term thereby granted in respect of the premises firstly and secondly thereinbefore described and thereby demised, "pay all such sums (not exceeding in any one year the sum of $f 100$.) as shall for the time being be payable by the said Edward Henry San-

diana Nat. Gas. Co. v. Hinton, 159 Ind. 398, 64 N. F. 224 (1902), post, p. 426, note 65. Harbert $\nabla$. Hope Nat: Gas Co., 76 W. Va. 207, 84 S. E. 770, L. R. A. $1915 \mathrm{E}, 570$ (1915), post, p. 426 , note 65 . 
derson, as such executor as aforesaid, his executors, administrators, or assigns, on account of the like taxes, tithes, rates, assessments, and outgoings in respect of the premises comprised in and demised by the said indenture of underlease of the 20th Dec., 1867." That is to say, the premises which before were excepted and were not demised by this lease. Now, before I say anything more about the construction of the covenant, this is what has happened: Mr. East has assigned his interest in the lease to Her Majesty's Postmaster General, and the question is whether the Postmaster General is bound by this covenant at all. It is for the payment-for the moment I do not say by whom-of taxes, tithes, rates, assessments, and outgoings. The covenant is to pay all such sums as the lessor, his executors, administrators, or assigns, may have to pay on account of the like taxes, tithes, and so forth, in respect of the premises not thereby demised. That is to say, the lessor may have to pay taxes in respect of other premises which are not thereby demised, and the lessee covenants to pay-I do not say at present to whom-whatever the lessor may have to pay in respect of those taxes on other premises to the extent of $£ 100$. a year. Now, is that or is it not a collateral covenant-a covenant to pay a collateral sum of money? If it were meant to make that sum payable by whomsoever this lease may be assigned to, the matter would have been easy. It might have been reserved as rent, and then of course anybody to whom the lease was assigned would have to pay it. But it is not reserved as rent. A rent is reserved, and it is a very large one, and this is a mere covenant that the lessee will pay in respect of taxes, \&c. imposed upon other property not included in the lease, the amount of those taxes being, at least, $£ 100$. a year. I cannot conceive anything more entirely collateral. It is a collateral sum-a sum payable in respect of other property which the lessee says he will covenant with the lessor to pay. Does that run with the land or not? One cannot go to a better authority than Spencer's Case (5 Co. Rep. 16; 1 Sn. L. Cas.), where the proposition relied on was this: "Although the covenant be for him and his assigns"- that is, although assigns are expressed- "yet if the thing to be done be merely collateral to the land, and doth not touch or concern the thing demised in any sort, there the assignee shall not be charged. As if the lessee covenants for him and his assigns to build a house 11pon the land of the lessor which is no parcel of the demise, or to pay any collateral sum to the lessor, or to a stranger, it should not bind the assignee, because it is merely collateral, and in no manner touches or concerns the thing that was demised, or that is assigned over; and therefore in such case the assignee of the thing demised cannot be charged with it no more than any other stranger."

Now, it was attempted to be argued in the present case that these taxes, tithes, and so forth, although no doubt in respect of a part of the property which was not demised, yet they possibly might be charged on the whole tenement. That point, however, is not raised by the special case at all. What I have to deal with is distinctly a case in 
which the taxes, tithes, \&c., are separately payable in respect of the property which is not demised. That is the only case I have to deal with, so far as anything appears in the special case which I am asked to determine. The taxes, tithes, \&c., are separately payable by the occupier in respect of the undemised part of the tenement. I mean undemised by this lease. Therefore, it comes within the operation of the rule in Spencer's Case (ubi supra). Of course, the lessee covenanted, but he is not before me; the only person brought before me is his assign. That assign says that Spencer's Case decides, under circumstances like these (this being a covenant for payment of a sum entirely collateral to this particular demised property), that the covenant does not run with the land, and therefore that it does not bind him. I confess that he satisfies me; and I do not see any answer to it. It seems to me that that is conclusive. There are other questions, and certainly very formidable questions, and one is this, which was suggested by Mr. Simpson, that the word "assigns" in both parts of this lease has the same meaning. At present I see no answer to that. However, I ought not to prejudice those questions, because Mr. Ince has not replied on that part of the case, and therefore I do not express any opinion upon them. This being, as I have said, a case that is completely governed by the rule in Spencer's Case (ubi supra), the consequence is, that the Postmaster General is not liable under the covenant, because it does not run so as to bind him; and the plaintiffs must pay the costs of this special case.*

\section{NORTHERN PAC. RY. CO. v. MCCLURE et al.}

(Supreme Court of North Dakota, 1599. 9 N. D. 73, 81 N. W. 52, 47 L. R. A. 149.)

[The Northern Pacific Railroad Company on October 1, 1892, leased to the defendant McClure for a period of five years, a piece of land adjacent to its tracks at a rental of $\$ 10$ per annum. The lease contained the covenant which is stated in the opinion of the court. The Northern Pacific Railroad Company was reorganized, and transferred all its property to a new corporation, the Northern Pacific Railway Company. Certain machinery stored upon the leased premises with the consent of the lessee was destroyed by a fire caused by the plaintiff. The owner of the machinery recovered judgment against the plaintiff herein for the loss; the plaintiff defending the action after having requested the defendant herein so to do.]

Young, J. ${ }^{24}$ This action is brought, upon the indemnity covenant

*A corenant by the lessee to pay taxes or assessments on the demised premises is enforceable by the assignee of the lessor against the assignee of the lessee, Post r. Kearney. 2 N. Y. 394, 51 An. Dec. 303 (1S49). See, also, Wills v. Summers, post, p. 393 : Mason v. Sulth, post, p. 389.

24 Part of the opinion is omitted.

BIG.RIGITS-24 
in the lease from the Northern Pacific Railroad Company to the defendants, to recover the amount disbursed by plaintiff in paying the judgment referred to; also, the costs incurred in defending the action wherein the judgment was rendered. In the lease in question the Northern Pacific Railroad Company is named as the first party, and the defendants as second parties. The portion of said lease upon which plaintiff relies is in the following language: "The said parties of the second part shall, and do hereby, assume all risks of loss, damage, or destruction of any property, building or contents, coal, lumber, or material, that may be upon, or in proximity to, the grounds included in this lease, by the parties of the second part or by any other party, occasioned by fire or sparks from locomotive engines, or other cause, or by neglect, carelessness, or misconduct of any person in the employment or service of the said party of the first part; it being the intent hereof that the said parties of the second part shall and do release, forever discharge, save and hold harmless, the said party of the first part from all damages and claims for losses or injury suffered or sustained, or that may be suffered or sustained, to said property, or to any other property on or near said demised premises." No question is raised as to the validity of the contract of lease as a whole, or as to the foregoing covenant. On the contrary, counsel for defendants expressly concede in their brief that the agreement of defendants to save and hold the lessor harmless is a binding agreement, and that the lessor might have successfully maintained an action against them for recovery thereon for a breach of the same.

But it is contended that this covenant did not pass to the plaintiff, as the assignee and grantee of the lessor, and that it cannot, therefore, recover thereon. Defendants' whole contention is based upon the last proposition. Did the covenant to save the lessor harmless against claims for damages for losses of property upon the demised premises pass to the new corporation, the Northern Pacific Railway Company, the plaintiff in this action? If this covenant of the lessees did pass to the plaintiff by the transfer of the lease to it by the lessor, or by the grant to it of the right of way which is the subject of the lease, then it is patent that plaintiff has stated a cause of action entitling it to the relief demanded; for it is sufficiently alleged that it has suffered such a loss as entitles it to a recovery under the covenant referred to. The loss by fire occurred about eight months after the transfer of the land and lease by the old corporation to the plaintiff.

In this state some of the uncertainty as to the rights and remedies of grantees and devisees of a lessor against tenants of the latter is removed by direct legislation. * * *

The supreme court of Wisconsin, in construing their statute (which is substantially like sections 3366 and 3367 [of the North Dakota statute], supra, and wholly so, in effect, when the two sections are construed together) in Winterfield v. Stauss, 24, Wis. 394, said: "The effect of this statute is to cause the covenants entered into on the part 
of the lessee, or the conditions upon which he holds, to run with the land, and to pass by conveyance or assignment to the assignee of the lessor, or of the reversion, so that such assignee may at once, and without attornment by the lessee, take advantage of any covenant or condition contained in the lease, the same as the lessor himself might have done. The consent of the lessee, or what was called 'attorning, is no longer required, as at the common law, for this purpose; but the assignee succeeds immediately to all the rights and remedies which the lessor had, or might have had, if no assignment had been made. In other words, the assignee becomes himself the landlord, standing in the place of the lessor, and enjoying all his rights and privileges under and by virtue of the lease. $* * *$ The assignee here has all the rights and remedies of the lessor. He becomes the lessor by virtue of the assignment, and stands in the relation of landlord to the tenant in possession under the lease." We think the interpretation of the Wisconsin court, with the exception hereafter noted, is entirely sound, and evidently conforms to the legislative intention in enacting the remedial statutes; which was to place the assignees of both lessors and lessees in the same position relative to the lease which their assignors had, and to give to them the same rights and the same remedies.

Our conclusion is that the covenant in question in the case at bar passed to the plaintiff, and invested him with the same rights thereunder which the old-corporation had. In reaching this conclusion, we are not controlled by the fact simply that it is a covenant contained in a lease, for, in our opinion, that is not enough; and in this respect we think the language of the Wisconsin court in Winterfield v. Stauss, supra, is too broad, if it was intended to mean that all covenants of the lessee with the lessor passed to the assigns of the latter, regardless of the nature of the covenants. For it must be conceded that covenants and stipulations may be, and often are, inserted, which are wholly foreign to the subject-matter of the lease, and, while they are binding between the immediate parties thereto, are so disconnected with the estate that they do not pass by assignment, but remain as covenants between the original parties. But the covenant here involved is not of that nature. We think it is a covenant directly connected with the estate, and within the meaning of our statutes. While it is probably true that it is not an agreement to pay "rent," as that word is commonly understood, yet it has to do with determining the compensation which the lessor is to receive for the use of the premises. It is perfectly apparent that the agreement to pay $\$ 10$ per year as rent was merely a nominal sum, and that the real consideration for the use of the lands was this particular agreement that the lessor should not suffer loss from damage suits brought to recover for the destruction of property upon the premises so leased to the defendants.

If counsel's contention were true, that this covenant did not pass, then the only obligation the defendants would owe the plaintiff for the 
use of the property is the payment of the nominal rent of $\$ 10$ per year, and that would be the extent of their liability; for it is clear that they can incur no liability to the old corporation, in fact or in law. For, by reason of the sale of all of its property to the plaintiff, it cannot be the moving agent in negligently setting fire to property on the premises from which alone the liability would arise. Further, none of the covenants of the lease have been binding upon the lessor since August 18, 1896; for on that day all of its rights were transferred to the plaintiff, and the defendants attorned to it as their landlord under the lease in question. The legal effect of these acts was a surrender of all of the rights which the lessor had in the lease to the plaintiff which were connected with the estate, and an assumption of all of the obligations therein by the lessee as thereafter binding upon him in favor of his new landlord. Moreover, this was in accordance with the intention of the original parties, and their express agreement in the lease, contained in the following language: "It is further mutually" covenanted and agreed by and between the said parties hereto that the covenants, agreements, and conditions herein contained shall be binding upon the executors, administrators, and assigns of the said parties of the second part, and the successors and assigns of the said party of the first part."

The covenants and conditions which are thus expressly agreed to be binding upon the assigns of the lessor must be considered as binding upon the lessee, also, in order to effect mutuality; and such, without doubt, was the intention of the parties in making the stipulation. It would also seem that the covenant in question was one which directly affected the value of the property. It certainly would during the five years in which the lease run. For, without this covenant to save the lessor harmless, the lease of the property would, as this case shows, have been productive of loss, instead of profit, to the lessor or its assigns. So, too, the agreement to indemnify the lessor was one of the conditions, and the most important one, under which the defendants held the property, and was extremely valuable to the assignee of the lessor, and one which, as we have seen, was valueless to the lessor after its assignment of the lease, both in fact and by reason of its surrender. Covenants to indemnify and hold harmless, like that we have been considering, are not entirely new to the courts. They have been held to be legitimate provisions, and have been upheld as not against public policy. Hartford Fire Ins. Co. v. Chicago, M. \& St. P. Ry. Co., 17 C. C. A. 62, 70 Fed. 201, 30 L. R. A. 193. But we have not been able to find an adjudication upon the question whether this particular kind of a covenant runs with the land, and passes to the assigns of the lessor.

Our conclusion, however, is, for the reasons stated, that this covenant passed to the plaintiff, and invested it with the same rights of protection against losses by it, and to the same extent and in the 
same manner as the lessor might have asserted had there been no assignment of the lease. The demurrer was properly overruled. Judgment affirmed. All concur. ${ }^{25}$

(b) Covenants by the I,essor

\section{JOURDAIN v. WILSON.}

(Court of King's Bench, 1S21. 4 Biln. \& Ald. 266.)

Covenant by the assignee of the lessee against the reversioner. $\mathrm{By}$ the lease two messuages were demised. The breach assigned was upon the following covenant: "And the said William Inwood, the landlord, for himself, his executors, \&c. doth covenant, promise, and agree to and with the said lessee, his executors, \&c., to supply the said two messuages or tenements and premises with a sufficient quantity of good water, at the rate of three guineas per annum for each house." To this declaration there were several pleas, to some of which the plaintiff demurred; and the question argued was, whether this covenant ran with the land.

Аввот', C. J. By this lease the lessor covenants to supply the messuages and tenements demised with a sufficient quantity of good water at the rate of three guineas per annum for each house. 'The lease does not specifically point out the particular mode by which the water is to be supplied: whether by pipes, by collecting the water in cisterns, or by carrying it to the premises by buckets; but it is quite clear. that the covenant cannot be satisfied unless a sufficient quantity of good water is brought upon the premises during the term. This is, therefore, a covenant which respects the premises demised and the manner of enjoyment, and I have no doubt, therefore, that it is a covenant which runs with the land, and that the assignee may sue the reversioner for the breach of it.

Indgment for the plaintiff. ${ }^{26}$

$25 \mathrm{~A}$. leased land and a factory to $\mathrm{X}$. by indenture. $\mathrm{X}$. covenanted with . to save harmless the overseers of the poor of the parish from all charges incurred by reasom of bis hiring as laborers in the factory any persons who should thereby wain a settlement in the town. A. died. Later, during the ierru of the lease, $x$. broke the covenant. Held, $A$.'s executor has an action acainst $\mathrm{X}$. Walsh v. Fussel, 6 Bing. 163 (15:9).

26 Ace.: Covenant to supply wood, assignee of lessce against lessor, Palm. or v. Edwards. 1 Doug. 187n (1783); covenant to exterminate rabbits, lesset against assignee of lessol, Sturgcon v. Wingfield, 15 M. \& W. 224 (1816); 'ovenant to supply heat, lessee against assignee of lessor, Storandt v. Vogel \& Binder Co., 140 App. Div. 671. 125 N. Y. Supp. 568 (1910); covenant to sinply servant to care for demised premises, assignee of lessee against assigne of lessor, Barues v. City of London R. E. Co., [1918] 2 Ch. 18 (semble?. 


\section{WOODALL v. CLIFTON.}

\section{(Court of Appeal, 1905. [1905] 2 Ch. 257.)}

By a lease dated July 4, 1867, a piece of land of about six acres at Chislehurst was demised by the then owner in fee to the lessee for a term of ninety-nine years from June 24,1866 , at the yearly rent of 1142. The lease contained the following clause: "Provided always and it is hereby agreed and declared that in case the lessee, his heirs or assigns, shall at any time during the said term become desirous of purchasing the fee simple of and in the said lands and premises hereby demised, or any portion thereof not being less than one acre (unless by previous purchase the land remaining subject to this present demise shall be less than one acre), at and after the rate of $£ 500$ per acre, and such further sum for the timber thereon as shall be ascertained by a fair valuation thereof, and upon receipt of the amount of the purchase money for the same, the said [lessor], his heirs or assigns, shall and will execute a conveyance or other assurance of the said land and premises with the timber thereon in favour of the said [lessee], his heirs and assigns, upon the same terms as to title and otherwise as the said [lessee] and other purchasers of portions of the Camden Park estate have hitherto completed their purchases."

By another lease dated July 14, 1869, another piece of land of about four acres in Chislehurst and Bromley was demised by the same lessor to the same lessee for a term of ninety-nine years at the yearly rent of $£ 112$. This lease contained a proviso similar in its terms to that contained in the lease of 1867 , except that the option to purchase was reserved to the lessee, his "executors, administrators, or assigns," instead of to his "heirs or assigns," and that the price per acre was to be $£ 600$.

The lands comprised in and demised by these two leases were now vested in the plaintiff, an assign of the original lessee, for the residues unexpired of the terms thereby respectively granted, and he claimed that, as assignee of the two terms, he was entitled to the benefit of both the options, if the same were valid and subsisting options. Subject to the leases and the options therein contained the defendants, who were assigns of the lessor, were the owners in fee simple of the lands comprised in the leases.

Notice to purchase the whole of the premises demised by the two leases had, in pursuance of the terms of the options, been given by the plaintiff to the defendants, but the defendants, who were trustees, having been advised that the options were invalid as against them, declined to complete the purchase.

The plaintiff thereupon commenced this action against the defendants, and by his writ claimed a declaration that the two options to purchase "are valid and subsisting options and have been duly exercised 
by the plaintiff, and that the plaintiff is entitled to the benefit thereof, and to enforce the same against the defendants."

The writ also claimed that "the defendants may be ordered upon payment by the plaintiff to the defendants of the purchase money payable in accordance with the terms of the said two options respectively to execute a proper conveyance to the plaintiff of the premises subject to the said two options respectively."

[Judgment below was for the defendants. Plaintiff appealed.]

ROMER, L. J., read the following judgment of the Court (VAUGHaN Vil.liams, Romer and Stirling, L. JJ.):

A contract in a lease giving an option of purchase might be good, without regard to the provisions of the statute of Henry VIII, as. binding the land in the hands of the heirs or assigns, provided it did not infringe the law as to perpetuities. It would not be the less a binding contract because it was contained in a lease. But in the present case it is clear that the plaintiff cannot succeed on such a ground. Unless the covenant or proviso giving the option of purchase can be said to run with the land by virtue of the provisions of the statute, then the plaintiff must fail. Now undoubtedly the statute is in its wording very wide, but it has long been held that some limitations must be implied; as; for example, that the statute does not apply to covenants which do not touch or affect the land demised, or to assigns where the covenants relate to things not in esse, and "assigns" are not expressed to be bound. The question in the present case is whether the statute was intended to cover, or can be construed as covering, such a covenant or proviso as we have now to consider, so as to make the liability to perform it run with the reversion. We have come to the conclusion that that question must be answered in the negative.

The covenant is aimed at creating, at a future time, the position of vendor and purchaser of the reversion between the owner and the tenant for the time being. It is in reality not a covenant concerning the tenancy or its terms. Properly regarded, it cannot, in our opinion, be said to directly affect or concern the land, regarded as the subjectmatter of the lease, any more than a covenant with the tenant for the sale of the reversion to a stranger to the lease could be said to do so. It is not a provision for the continuance of the term, like a covenant to renew, which has been held to run with the reversion, though the fact that a covenant to renew should be held to run with the land has by many been considered as an anomaly, which it is too late now to question, though it is difficult to justify. An option to purchase is not a provision for the shortening of the term of the lease, like a notice to determine or a power of re-entry though the result of the option, if exercised, would or might be to destroy the tenancy. It is. to our minds, concerned with something wholly outside the relation of landlord and tenant with which the statute of Henry VIII was dealing, and allowing such a provision to come within the purview of the statute, and to be enforced as running with the land, would lead to 
very anomalous and, to our minds, most undesirable results as to perpetuities, conversion, and otherwise, which this Court should not validate unless it is obliged to do so. And we cannot think that the Court is so obliged on the true construction and effect of the statute. It is strange that there is no direct authority on the point. There are cases where the option has been exercised by the tenant and accepted by the landlord, and subsidiary questions have had to be decided which naturally would be dealt with on the footing that what had already been done could not or need not be questioned by the Court, as, for example, In re Adams and Kensington Vestry, 27 Ch. D. 394. But such cases are really of no assistance for the decision of the present case. In our judgment the appeal should be dismissed.

\section{HOLLANDER et al. v. CENTRAL, ME'TAL \& SUPPLY CO.}

(Court of Appeals of Maryland, 190S. 109 MId. 131, 71 Atl. 442, 23 L. R. A. [N. S.] 1135.)

Appeal from Circuit Court of Baltimore City; Thos. Ireland Elliott, Judge.

Suit by the Central Metal \& Supply Company of Baltimore City against Charles S. Hollander and others. From a decree for plaintiff, defendants appeal. Affirmed and remanded.

Thomas, J. ${ }^{27}$ The Central Metal \& Supply Company of Baltimore City, "a corporation duly incorporated under the laws of the state of Maryland," having purchased the leasehold estate in a certain lot of land in Baltimore city, brought this suit on the 31st day of May, 1907, against the appellants, as the present owners of the reversion in said lot, for a specific performance of the covenant in the lease of the lessor, "her heirs and assigns," upon payment of the amounts specified therein, to convey the fee to the lessees, their "heirs and assigns." The bill alleges that the defendants, Charles Hollander and Elsie Hollander, his wife, and Lee M. Hollander, are nonresidents, and that the plaintiff, in January, 1907, addressed a letter to these defendants notifying them of its desire to redeem the ground rent under the lease, and prepared and forwarded to them for execution a deed from them to the plaintiff of the fee in said lot, which they refused to execute on the ground that "the said rent is not redeemable." [The defendants demurred on various grounds.] * * *

The next ground of the demurrer is that the covenant to convey the fee to the lessees, "their heirs and assigns," is not a covenant running with the land. In Glenn v. Canby, $24 \mathrm{Md}$. 127, the court stated, as the established doctrine, "that a covenant to run with the land must extend to the land, so that the thing required to be done will affect the quality, value, or mode of enjoying the estate conveyed, and thus constitute a

27 I'art of the opinion is omitted. 
condition annexed or appurtenant to it; there nust also be a privity of estate between the contracting parties, and the covenant must be consistent with the estate to which it adheres, and of such a character. that the estate will not be defeated or changed by a performance of it." 'This is the doctrine asserted by Mr. Poe in 1 Poe's P. \& P. (1st E.d.) 253, and reiterated by this court in Whalen v. B. \& O. R. R. Co., 108 Md. 11, 69 Atl. 390, 17 L. R. A. (N. S.) 130, 129 Am. St. Rep. 423. In Taylor's Landlord and Tenant (7th Ed.) $\$ 261$, it is said that:

"In order that a covenant may run with the land, its performance or nonperformance must affect the nature, quality, or value of the property demised, independent of collateral circumstances, or must affect its mode of enjoyment. It must not only concern the land, but there must be a privity of estate between the contracting parties."

"In order that a covenant may run with the land-that is, that its benefit or obligation may pass with the ownership-it must respect the thing granted or demised, and the act covenanted to be done or omitted must concern the land or estate conveyed. Whether a covenant will or will not run with the land does not, however, so much depend on whether it is to be performed on the land itself, as on whether it tends directly or necessarily to enhance its value or render it more beneficial and convenient to those by whom it is owned or occupied, for if this be the case every successive assignee of the land will be entitled to enforce the covenant." 11 Cyc. 1080.

"Such covenants, and such only, run with land as concern the land itself, in whatsoever hands it may be, and become united with, and form a part of, the consideration for which the land, or some interest in it, is parted with, between the covenantor and covenantee." Washburn on Real Property, § 1205.

That the covenant in this case is within these requirements, as affecting the interest in the land demised, as enhancing the value thereof. and as forming a part of the consideration for the acceptance of the lease by the lessees, would seem to be free of doubt. The learned counsel for the appellants contend, however, that the performance of the covenant would defeat the estate of the lessor, and change the character of the estate of the lessee, and that it therefore falls within the restrictions of Glenn v. Canby, supra. But in Taylor's Landlord and Tenant, $\S 262$, it is said:

"The right of renewal constitutes a part of the tenant's interest in the land, and a covenant to renew is consequently binding upon the assignee of the reversion. So the grant of an additional term, or the right to purchase, is, for many purposes, to be considered a continuation of the former lease; and, if there is nothing in the lease to show that such right or renewal was intended to be confined personally to the lessee, they will inure to his assignees or executors, without their being particularly named."

In the case of Maughlin v. Perry, $35 \mathrm{Md} .352$, the covenant on the part of the lessor was as follows: 
"And the said party of the first part, for himself, his heirs and assigns, doth hereby covenant and agree with the party of the second part, his heirs and assigns, to sell and convey unto the party of the second part, his heirs and assigns, the above-described property and premises for the sum of fifteen hundred dollars at any time before the expiration of this lease or tenancy."

The lessor died after having sold the property, and suit. was brought by the assignees of the lessee against the assignee of the lessor for a specific performance of the covenant, and the court, in affirming a decree requiring the defendant to convey the property to the plaintiff in accordance with the terms of the covenant, said:

"As a part of the consideration of the lease constituting the contract between the parties, Wells, the lessor, covenanted to sell the property to Hynson, his lessee, for fifteen hundred dollars, at any time during the existence of the lease. This was a continual obligation running with the lease on the part of the lessor, with the option in the tenant to accept the same, or not, within that time. But it seems Wells, before the right of Hynson to make his election had determined, made sale of the property to Maughlin, and died. Maughlin, with notice of the recorded contract between the parties, can acquire no greater right than possessed by Wells."

The certain and definite rule deducible from the authorities cited, then, is that if the covenant, as in this case, touches and concerns the land or estate demised, enhances the value thereof, and forms a part of the consideration for the acceptance of the lease by the lessee, a court of equity will decree specific performance, not only as between the parties to the contract, but, in the absence of intervening equities controlling its conscience, also as between those claiming under them in privity of estate. 24 Cyc. 1026; Gear on Landlord and Tenant, § 84; Laffan v. Naglee, 9 Cal. 662, 70 Am. Dec. 678; Robinson v. Perry, 21 Ga. 183, 68 Am. Dec. 455; Kerr v. Day, 14 Pa. 112, 53 Am. Dec. 526; Hagar v. Buck, 44 Vt. 285, 8 Am. Rep. 368; Spencer's Case, 1 Smith's Leading Cases, 75.

[Decree for specific performance affirmed.] ${ }^{28}$

28 Acc.: Giving specific performance. Blakeman r. Miller, 136 Cal. 13S, tis Pac. 5S $7,89 \mathrm{Am}$. St. Rep. 120 (1902); Harper v. Runner, 85 Neb. 343, $123 \mathrm{~N}$. W. 313 (1909); Hagar v. Buck, 44 Vt. 285, 8 Am. Rep. 368 (1872). In the last case the court said (44 Vt. 290, S Am. Rep. 368):

"This consideration is sufficient to dispose of the question made by the defendants as to the right of the orator to stand upon this covenant in this suit. But if not, covenants that do not run with the land may be assigned in equity so as to pass the right to enforce them by action in the name of the covenantee to the assignee. 1 Smith's L. C., 179, Field, J.; Willard v. Tayloe, \& Wall. 571 [19 L. Ed. 501 (1S69)]. An assignee of a chose in action, who has the right to proceed at law upon it in the name of the assignor, has the riglit to proceed upon it in equity in his own name, in cases proper to be proceeded with in courts of equity. If this corenant had not passed with the estate in the land from Meringo to Mary Ann 'Turner, his conveyance would have operated as an equitable assignment of his interest in it and of his right to enforce it in his name to her; and a suit in equity in his name 


\section{THOMAS v. HAYWARD.}

\section{(Court of Excliequer, 1869. L. R. 4 Exch. 311.)}

Declaration by the assignee of a lease against the lessor, on a covenant in the lease, by which, the lessee having covenanted for himself his executors, administrators, and assigns, during the continuance of the term to use and continue the demised house for the sale of spirits, the defendant, for himself, his executors, administrators, and assigns, covenanted "not to build, erect, or keep, or be interested or concerned in building, erecting, or keeping, any house for the sale of spirits or beer within the distance of half a mile from the premises thereby demised, during the continuance of the said term."

Demurrer and joinder.

BRAMWELL, B. ${ }^{29}$ The covenant does not touch or concern the thing demised. It touches the beneficial occupation of the thing, but not the thing itself; and this becomes manifest when it is considered that, supposing the lessee's covenant to carry on the sale of spirits on the premises to be discharged by agreement between the lessor and lessee, or that without such discharge, the lessee, in fact, discontinued the business, the defendant's covenant would obviously in no way concern the land. This shows that the covenant relates only to the mode of occupying the land, not to the land itself. It does not, therefore, run with the land so as to enable the plaintiff to sue upon it. $* * *$

Judgment for the defendant. ${ }^{30}$

for such relief as is sought in this case would have been proper. The orator, being the personal representative of Mary Ann Turner, could maintain this suit in equity in his own name, as well as the original covenantee could have maintained it if no assignment or conveyance had been made."

A covenant to renew the lease runs: In favor of the assignee of the lessee, Cook V. Jones, $96 \mathrm{Ky} .283$, 2S S. W. 960 (1894); McClintock v. Jojner. 77 Miss. 678, 27 South. 837,78 Am. St. Rep. 541 (1900); asainst the assignee of the lessor, Isteed v. Stonely, 1 And. 82 (1580); Leominster Gaslight Co. v. Hillery, 197 Mass. 267, 83 N. F. S70 (1908). Compare Muller v. 'Traflord [1901] 1 Cl. 54.

A., a wine merchant, who owned a hotel, leased the hotel to $\mathrm{X}$., who corenanted to sell no wines there sare those purchased from A., his successors or assigns. The lease contained a proviso that so long as $\mathrm{X}$. ubserved this covenant the rent should be abated a specitied sum. A. died, devising all his real and personal estate to 13 . The wine business was sold by 13 . to ( The lease was assigned by $X$. to $Y$. Upon a submitted case, to liave determined the proper construction of the lease, held, so long as $Y$. sells no wines on the prenises save those purchased from C., he is entitled to the abatement in the rent. White v. Southern Hotel Co., [1S97] 1 Ch. 767.

20 'The opinions of Channell and Cleasby, BB., are omitted.

30 In Norman v. Wells, 17 Wend. (N. Y.) 136 (18:3), on substantially the same state of facts, the court held for the plaintiff, saying (page 151): "In the case at har the covemant is still more material. It is not to avoicl doing what wonld be a mere matter of inconvenience or offence to good taste; lut what might very materially impair the factory lot demised to Dulcroix, lor lusiness nurposes. 'The rent was doubtless lare in proportion; and the benefit would attend the lessee and all his assichees, whether immediate or remote, during the term. 'The covenant respected the premises; it regulat- 


\section{DEWAR v. GOODMAN.}

\section{(Court of Appeal, 1907. [1908] 1 K. B. 91.)}

[Action by the assignee of a lease against the assignee of the reversion for breach of the covenants contained in the lease. Judgment below was for the defendant and the plaintiff appeals.]

LORD Alverstone, C. J. ${ }^{31}$ In this case we are asked to reverse the judgment of Jelf, J., who has held that the action cannot be maintained. Speaking for myself, I wish to say that I am greatly indebted to $\mathrm{Mr}$. Copping for his very able argument, and I think that much that has been said by him would be strong ground for holding that a lessee in the circumstances of this case ought to be allowed by the law to have a remedy against the assignee of the lessor, but there is a strong line of authorities which, in my opinion, prevents us from giving effect to that argument. The question which we have to decide arises in this way. In 1820 a lease of certain land was granted, which contained a covenant on the part of the lessee to keep in repair all buildings erected on the land. Houses to the number of 211 were erected on the land. In 1886, Barns, in whom the lease of 1820 had become vested, sub-demised two of the houses to Humphrey, the underlease containing a covenant by Humphrey, to keep the two houses in good repair and covenants by Barns and his assigns for quiet enjoyment and for the performance of the covenants in the head lease, and for an indemnity against their non-performance. The underlease also contained a proviso which is not without significance as shewing that the parties had some doubt as to the effect of the covenants in the underlease, because it provided that the lessor, that is, Barns, should only be bound by the covenants whilst he held the reversion, and that it was the intention of the parties that the covenant should bind "so far as can be" any other persons for the time being entitled to the reversion. The plaintiff is the assignee of Humphrey, and the defendant is the assignee of Barns. The plaintiff was ejected by the head landlord for a breach of the covenant in the head lease to repair all the houses including the two demised by the underlease. In respect of that ejectment the plaintiff sues the defendant on the covenants contained in the underlease.

For the purpose of my judgment I will assume that, if the complaint

ed their ralue, it fixed the amount of rent, it was co-extensive with the estate, it benefited the ormer of the denised premises, and nobody but the owner. So far it would, I think, be a plain departure from the principle and analogy to deny the assignees' action on this covenant."

A., being the owner in fee of a town, leased a store to $\mathrm{X}$. and covenanted that he should have the exclusive privilege of selling merchandise in the town for ten years. A. leased another lot to B., who subleased to $\mathrm{C}$., who sold merchandise within the ten years. C. had notice of A.'s covenant with $\mathbf{X}$. before he took his sublease. Held, $\mathbf{X}$. has no rights, legal or equitable, against C. Taylor v. Owen, 2 Blackf. (Ind.) 301, 20 Am. Dec. 115 (1S:30): see Hebert . Dupaty, 42 La. Ann. 343, 7 South. 580 (1890).

si The opinions of Buckley and Kennedy, I. JJ., are omitted. 
as to non-repair had related only to the two houses occupied by the plaintiff, there would have been no ejectment of the plaintiff. I do not base my judgment in any way on any question as to whether the plaintiff, having himself been under covenant to keep those two houses in repair, is thereby precluded from maintaining this action. The real question which we have to consider is whether the lessor's covenants in the underlease are covenants which run with the land. It has been pointed out by Jelf, J., in his most carefully considered judgment that the law on this subject is fenced round with technicalities, but he suggested that it might be possible for this Court to take a, broader view of the matter than he felt bound to take, and to break through those technicalities. In my opinion it is not possible for us to deal with this case in the way contended for in the argument for the plaintiff without introducing entirely new principles, and overruling one if not two cases. It was said in argument that it was assumed in Doughty v. Bowman, 11 Q. B. 444 , that a covenant of the kind in question in this case would bind the assignee of the reversion, if assigns were named in the covenant. I was at first somewhat impressed with that, but I had not quite appreciated the facts of that case. There was in Doughty $v$. Bowman, 11 Q. B. 444, a covenant by the lessee to erect certain houses on the demised land; the lessee sub-demised to the plaintiff, and covenanted with him to perform all the lessee's covenants in the lease, but not naming assigns. The lessee afterwards assigned to the defendant, and the question was whether the lessee's covenant to perform the covenant as to building the houses was binding on the defendant. I agree that the judges asstumed that if assigns had been named in the covenant it would have been binding on them, but it is clear, I think, that the decision really turned on the distinction between the thing to be done on the land being in esse or in posse at the time of the demise, for Patteson, J., in his judgment said $(11$ Q. B. at page 448$)$ : "There are two sorts of covenants, the one binding the assignee of land whether named or not, the other not binding him unless he is named. If the covenant in question be considered as a covenant to build houses, then it relates to a thing not in esse at the time of demise, and does not bind the assignee of the land, as he is not named"; and Parke, B., said (Ibici. at page 454): "The first resolution in Spencer's Case, 5 Rep. 16, 1 Smith, L. C., applies here, and so does the first of the two answers given by my brother Patteson in the present case. Assigns are not named, and the covenant, concerning a thing not in esse at the time of the demise, does not pass to assigns unnamed."

It is quite clear from those passages that the Court there was not considering the question of a covenant to do something on land otiler than that demised. This view is borne out by the comments on Doughty v. Bowman, 11 Q. B. 444, made in Minshull v. Oakes, 2 H. \& \. 793, and both cases are referred to in Smith's Leading Cases, vol. 1, 11 th Ed., pp. 70, 71, as authorities for the proposition that covenants as to things not in existence at the time of the demise are not bindling 
on assigns if they are not named. The covenant in the present case is a covenant to do something on land which was not the subject of the demise, but it is contended for the plaintiff, that, as the performance of the covenant was for the benefit and protection of the sub-lessee and concerned his interest or estate in the land, that is sufficient to bind the assigns, and cases were cited for the purposes of shewing that the terms "estate" and "land" were in this connection to be treated as equivalent. But the important thing to observe with regard to the cases cited was that in every one of them the covenant did touch and concern the land demised in the strictest sense of the word, and moreover it must be remembered that observations as to covenants for quiet enjoyment must always be read as applying to the particular facts of each case.

The case of Sampson v. Easterby, 9 B. \& C. 505, 6 Bing. 644, was cited in reply as an instance of a covenant to do something on land other than the land demised which was held to run with the land. That was a case where there was a lease of minerals in or under certain moors or waste lands, and there was a covenant by the lessees to erect a new smelting mill on part of the waste. It was held that the covenant passed with the reversion, but the decision proceeded upon the ground that the erection of the new mill was a matter so closely connected with the working of the mines that it tended to the support and maintenance of the thing demised. The facts in that case were of such a very special character that the case cannot in my opinion be regarded as an authority in favour of the plaintiff's contention in the present case. $* * *$

In my opinion, having regard to the original foundation of the rule in Spencer's Case, 5 Rep. 16, 1 Smith L. C. 11 th Ed. p. 55, and to the way in which that rule has been applied in numerous cases, it is impossible to say that Jelf, J., came to a wrong conclusion in holding that this action failed. For these reasons the appeal must be dismissed. ${ }^{32}$

32 On appeal to the House of Lords the decision of the Court of Appeal was atfirmed. [1909] App. Cas. 72. Lord Collins said (page 77): "The reason why the covenant to do something on land other than that demised presumably does not run is not because there is not privity of estate in the land on which the covenant is to be performed, but because such a covenant is prima facie collateral, i. e., does not touch or concern the land demised. Lut instances may be imagined of covenants to do things on land other thin that demised which touch and concern so nearly the land demised as to run with it. Of this sampson v. Lasterby, 9 B. \& C. 505 [18\%9], 6 Bing. $644[1<: 30]$, is an instance, if it be assumed, as it seems to have been, that no denise was to be implied of the site on the waste where the mill was to be built. Vyryan $\mathrm{r}$. Arthur, 1 B. \& C. 415 [1:23]. is another instance where there was no privity of estate in the land on which the covenant was to be performed, but on special grounds the coveliant was held to run."

A. owned two adjoining lots. He leased one to $X$. and covenanted that he would not build on the adjacent piece within 30 feet of the street. $\mathbf{X}$. assigned the lease to $Y$. A. Duilt on the adjacent lot within 30 feet of the strcet. Held, the covenant runs with the land and $Y$. has an action against A. for damages for breach thereof. Riclietts v. Entield church Waroens, [1909] 1 Ch. 514. 


\section{(D) Assignments}

(a) General Principles

BRETT v. CUMBERLAND.

(Court of King's Bench, 1619. 2 Rolle, 63.)

The king leased three mills for years by his letters patent in which was this clause:

"And the aforesaid IV. C., the lessee, his executor and assigns from time to time during the aforesaid term, as often as shall be necessary, will well and truly keep up and repair the aforesaid mill and other premises." The lessee grants over his estate; the king accepts rent from the grantee; the first lessee dies; the king assigns his reversion; the assignee of the reversion accepts rent from the grantee; the mills become ruinous; the assignee brings action of covenant against the executors of the first lessee. ***

The court took the matter under advisement and it was finally resolved: 1. That this was an express covenant. ***2. That the king himself could clearly charge the lessee himself after the assignment of the term, for by no assignment that the lessee could make could he discharge himself from the express covenant. 3 . That the king could have charged the executors of the lessee after the assignment of the term, for they represent the person of the testator. 4. That the king could have charged each assignee of the term who had the estate, but if the king leased to $\mathrm{A}$ with such a covenant and $\mathrm{A}$ assigned to $B$, and $B$ to $C$, now the king could not charge $B$ for the repairs which have to be made; for although $B$ was the assignee of the estate, still he was not so at the time the repairs were made and his (the lessee's) executors can be made chargeable (as aforesaid). 5. The king could not recover for repairs suffered after his own assignment. 6. The assignee of the king in all the cases aforesaid shall have like remedy by action of covenant as the king himself could have, by the express words of the Statute of $32 \mathrm{H} .8$, ch. 34.

Whorefore judgment was given for the plaintiff. ${ }^{33}$

33 Ace. Norton v. Acklane, Cro. Car. 579 (16!0). 


\section{WALL v. HINDS.}

(Supreme Judicial Court of Massachusetts, 1555. 4 Gray, 256, 64 Am. Dec. 64.)

[Wall executed to Hinds a lease under seal of certain premises for a term of years, Hinds covenanting, among other things, to pay the rent. Six months later Hinds assigned the lease and Wall accepted rent from the assignee. Subsequently the assignee failed to pay the rent, and Wall brought this action against Hinds upon the covenant in the lease.]

BigELOW, J. ${ }^{34}$ 1. The assignment by the lessee of his entire interest in the estate under the lease, and the acceptance of rent by the plaintiffs from the assignees, do not constitute a valid defence to the present suit. It is the well settled rule of law that in such case the lessor cannot maintain an action of debt for rent against the lessee; but that an action will lie against him on the covenant for the payment of rent. The reason of the rule is, that, although by the assignment the privity of estate between lessor and lessee is terminated, there still remains the privity of contract between them, created by the lease, which is not affected by the assignment. The lessee still continues liable on his covenant, by virtue of the privity of contract. Bachelour v. Gage, Cro. Car. 188; Barnard v. Godscall, Cro. Jac. 309; Thursby v. Plant, 1 Saund. 240: Auriol v. Mills, 4 T. R. 94 . * * * Judgment for the plaintiffs. ${ }^{35}$

\section{WASHINGTON NATURAL GAS CO. v. JOHNSON et al.} (supreme Court of Pennsylrania, 1889. 123 Pa. 576, 16 Atl. 799, 10 Am. St. Rep. 553.)

Willialis, J. ${ }^{38}$ This action is brought to recover for a breach of covenant contained in an oil lease dated August 5, 1885. By the terms of the lease, Guffy \& Co., the lessees, acquired the exclusive right to drill and operate wells for oil and gas on about 75 acres of land for the term of 20 years. In consideration of the grant, they undertook to commence operations on the premises, and complete one well within six months from the date of the lease. They were also to commence a second well four months after the time for the completion of well No. 1. The royalty to be paid was fixed by the terms of the lease at one-fourth of all oil produced, if oil was found, and $\$ 800$ per annum for each gas well operated, if gas was found in sufficient quantities to be utilized. The lessees took possession, and drill-

34 Part of the opinion is omitted.

35Acc.: Consumers' Ice Co. v. Bixler, $8 \pm$ IId. 437, 35 Atl. $10 S 6$ (1S96). Compare Kimpton v. Walker, 9 vt. 191 (1S37).

36 The statement of facts and part of the opinion are omitted. 
ed one well in accordance with their covenant, which produced gas in sufficient quantities to be utilized. Three months before the time for putting down the second well, Guffy \& Co. assigned the lease to Robbins, who held it from the 18th March, 1886, till the 20th January, 1887, and then assigned to Washington Natural Gas Company. The second well should have been drilled, allowing three months to be a reasonable time in which to complete it, during the time when Robbins was the holder of the lease. The action, however, is against the assignee of Robbins, whose title was acquired some two months after the time when the well should have been completed, and at least five months after it should have been begun. The liability of the assignee was brought to the attention of the court by the sixth point submitted on the part of the defendant below, as follows: "It being a conceded fact that a reasonable time for drilling said second well had elapsed before defendant became assignee of the lease, the defendant cannot be held liable for a failure to drill said well." This point was refused.

The seventh point asked the further instruction that, "it being shown by the plaintiffs themselves that the covenant in the lease * * * to commence the second well * * * was broken before the defendant acquired any interest in the lease, the proper remedy for such breach was an action against the original lessee, or the holder of the lease at the time of the breach." This was also refused; and the learned judge told the jury in his general charge that the breach of covenant to drill a second well was not complete until the end of the 60 days after the well should have been finished, because that was the time when the rent for the second well would fall due. "The commencement of the breach," said the learned judge to the jury, "was the failure to begin a second well on or before October, 1886, and the consummation was in not paying the eight hundred dollars when it ought to have been paid, had a paying well been struck." The answers to the points and the foregoing instruction are assigned for error.

The covenant sued on is as follows: "And it is further agreed that the second well shall be commenced four months after May, 1886, the time stated for the completion of well No. 1." 'The plaintiffs allege a breach of this covenant, and state their cause of action to be that the defendant has failed to commence a second well upon said leased premises within the time mentioned in said lease; to-wit, within four months from May 1, 1886, or at any other time. The instruction of the learned judge that a covenant to commence a well at a fixed time was only partly broken by a failure to commence it is not in harmony with the plaintiff's claim, as stated in their narr., nor is it justified by the terms of the covenant. If the well had been drilled at the proper time, the covenant would have been fully performed. though neither gas nor oil had been found, and in that event no rent

BIG.RIGHTS-25 
would have been demandable. The duty to pay rent for the second well as for the first one was conditional upon actual production, and it ceased when the production ceased, or when the quantity of gas was to small to be utilized. The object of the covenant was to secure the development of the lessors' land by the putting down of two wells upon it for which rent was to be paid if the wells were successful. The breach was complete when the lessees failed to drill as they had agreed. Loss of rents and profits might or might not follow, depending on the productiveness of the field. This subject might have been considered by the jury in fixing the damages after the plaintiffs' right to recover was settled, but had no relation whatever to the question on which the liability of the defendant depended.

Turning, then, to the question raised by the points, we find the facts to be as assumed therein, and the liability of the gas company to depend upon the extent to which the covenants of Guffy \& Co. run with the land. That they continued liable notwithstanding their assignment to Robbins is very clear. The covenant was their own, and their privity of contract with their lessors continued notwithstanding their assignment of the lease. Their assignee, Robbins, who was in possession when the time for performance arrived, was also liable because of the privity of estate which arose upon his acceptance of the assignment. Acquiring the leasehold estate by an assignment of the lease, he is fixed with notice of its covenants, and he takes the estate of his assignors cum onere. But as his liability grows out of privity of estate, it ceases when the privity ceases. If he had assigned before the time for performance, his liability would have ceased with his title, and liability would have attached to his assignee by reason of privity of estate, and so on, toties quoties. Each successive assignee would be liable for covenants maturing while the title was held by him because of privity of estate, but he would not be liable for those previously broken, or subsequently maturing, because of the absence of any contract relation with the lessor. While he holds the estate, and enjoys its benefits, he bears its burdens, but he lays down both the estate and its burdens by an assignment, even though, as is said in some of the cases, his assignment be to a beggar. Negley v. Morgan, $46 \mathrm{~Pa}$. 281; Borland's Appeal, $66 \mathrm{~Pa} .470$.

It is clear, therefore, that, when Robbins made his assignment to the Vashington Natural Gas Company, the time fixed in the lease for the sinking of the second well had gone by, and the covenant was broken. Guffy \& Co. were liable upon their contract because, although their assignment had divested them of the lease, it could not relieve them from their contract. Robbins, who was the owner when the covenant matured, was liable because of the privity of estate, but the gas company had no relations with the lessor or the leasehold until after the covenant was broken. The covenant ran with the land until the breach. It then ceased to run, because it was turned into a cause of action. The case of Oil Co. v. Blair, 113 Pa. 83, 4 Atl. 218. 
57 Am. Rep. 442, has been cited as sustaining a contrary doctrine, but an examination' of it will show that it is clearly distinguishable from this case. The covenant which it is sought to enforce in that case was not for the completion of successive wells at successive dates, but it was for the commenccment of the work of developing Blair's farm at a time certain, and to continue with due diligence and without delay to prosecute the business to success or abandonment, and, if successful, to prosecute the same without interruption. Two wells were completed, and were successful oil wells. The assignee of the lease owned adjoining lands upon which it was operating, and it stopped work on the Blair farm. The action rested on the breach of the covenant to prosecute the business of producing oil from the land of the lessor with due diligence and "without interruption." 'The obligation of a covenant to prosecute the business of developing the land of the lessor without delay and without interruption is a continuing one. The breach for which the Bradford Oil Company was held liable was not that of some previous holder of title, but its own. * * *

Judgment reversed. ${ }^{37}$

\section{JONES v. PARKER et al.}

\section{SAME v. GROVER.}

(Supreme Judicial Court of Massachusetts, 1895. 163 Mass. 564, 40 N. E. 1044, 47 Am. St. Rep. 485.)

Holmes, J. ${ }^{38}$ The case of Jones v. Parker is a bill in equity brought by a lessee upon a lease purporting to begin on September 1, 1893, and to demise part of a basement in a building not yet erected. The lessor "covenants to deliver possession of the same to the lessee upon completion of said building, and thereafter, during the term of this lease, reasonably to heat and light the demised premises." It is alleged that the building has been completed, but that the defendants refused to complete the premises with apparatus sufficient to heat and light the same, and to deliver the same to the plaintiff. It also is alleged that the occupancy of the premises for the purpose contemplated in the lease was impossible without the construction in the premises of proper apparatus for heating and lighting them before delivery to the plaintiff. The prayer is for specific performance of the covenant quoted, and for damages. The defendant demurs.

The last objection taken is based on an allegation that the lessor, Parker, has conveyed the reversion to Blackall. It is not alleged that

37 Acc.: Grescot v. Green, 1 Salk, 199 (1700); Churchwardens v. Smith, 3 Burr. 1271 (1762). Acc. as to lessee's assignee's liability for rent accruing after an assignment by the assignee: Johnson $v$. Sherman, 15 Cal. 287, 76 An. Dec. 481 (1860).

s 8 The statement of facts and part of the opinion are omitted. 
Blackall had notice of Parker's covenant. But, as the lease is for less than seven years, it is valid without recording or notice (Pub. St. c. $120, \S 4$ ), and the assignment does not entitle Blackall to prevent the performance of the covenant. We need not consider whether the covenant runs with the reversion, by virtue of St. 32 Hen. VIII, c. 34, $\S$ 2,-a question not to be confused with the different one as to the covenants attaching a burden or a right to land at common law, irrespective of privity or the mention of assigns, after the analogy of commons or easements, or the yet different one as to the transfer of the benefit of warranties or covenants for title to assigns, when mentioned, being privies in estate with the original covenantees. Norcross v. James, 140 Mass. 188, 2 N. E. 946; Middlefield v. Knitting Co., 160 Mass. 267, 35 N. E. 780. This covenant is pretty near the line, as it has been drawn between covenants that will and those that will not pass under the statute, in respect of their nature. Assigns are not mentioned, and the plaintiff has not entered, but perhaps none of these objections would be fatal. Spencer's Case, 5 Coke, 16, and note to same case in 1 Smith, Lead. Cas. 137; Moore, 159; Plow. 300; Jourdain v. Wilson, 4 Barn. \& Ald. 266, 268; Doughty v. Bowman, 11 Q. B. 444 ; Minshull v. Oakes, 2 Hurl. \& N. 793, 808; Rawle, Cov. (5th Ed.) $\S \S$ 313, 31S; Williams v. Bosanquet, 1 Brod. \& B. 238; Simonds v. Turner, 120 Mass. 328. However this may be, the plaintiff is entiiled to his lease, and to his heat and light, notwithstanding the assignment; and whether the covenant passes, or not, he can hold the defendant, Parker, on his express contract. All the cases which have come under our eye are cases of covenants by lessees, but the reasoning is equally good for covenants by lessors. Wall v. Hinds, 4 Gray, 256, 266, 64 Am. Dec. 64; Mason v. Smith, 131 Mass. 510, 511; Barnard v. Godscall, Cro. Jac. 309; Brett v. Cumberland, Id. 521; Bachelour v. Gage, Cro. Car. 188; Pitcher v. Tovey, 4 Mod. 71, 76; Auriol v. Mills, 4 Term R. 94, 98, $99 . * * *$

Demurrer overruled. ${ }^{30}$

39Acc.: Stuart v. Jo5, [1904] 1 K. B. 362; Hazen v. Hoyt (Iowa) $75 \mathrm{~N}$. W. 647 (1S9S); Neal v. Jefferson, 212 Mass. 517, 99 N. E. 334,41 L. R. A. (N. S.) 3S7, Ann. Cas. 1913D, 205 (1912); Chamberlain v. Dunlop, 126 N. Y. 45,26 N. E. 966,22 Am. St. Rep. 807 (1S91). Compare Mansel v. Norton, I. R. 22 Ch. D. 769 (1S83).

A. leased land to $X$. on a long term lease. In the lease $A$. covenanted for himself, his heirs, executors, administrators, and assigns with $\mathrm{X}$., hís beirs, executors, administrators, and assigns, that $\mathbf{A}$. and his heirs, executors, administrators, and assigns, would within one year from the making of the lease build and finish a roadway upon A.'s land along the east boundary of the demised premises. A. did not so build within the year or at any other time, nor did any other person build the road. A.'s interests were subsequently conveyed to $B$., and X.'s interest to $Y$. Held, admitting the corenant to be of a sort that might run with the land, $Y$. had no cause of action against $B$, for the non-building of the road. Morris v. Kennedy, [1S96] 2 Ir. 247 (1S94). Ace. Cofhn v. Talman, 8 N. Y. 465 (1853).

A. leased a house to $X$. and covenanted for himself and his assigns that be would, as the court construed the corenants: (1) Paint the house within a reasonable time after the making of the lease; (2) during the lease, on 


\section{MASON v. SMITH.}

(Supreme Judicial Court of Massachusetts, 1S81. 131 Mass. 510.)

Contract for money paid. Trial in the Superior Court, without a jury, before Dewey, J., who allowed a bill of exceptions, in substance as follows:

On December 20, 1869, Nancy J. Fuller. leased to the plaintiff a parcel of land in Boston, for the term of fifteen years from January 1,1870 , by an instrument under seai and duly recorded, the lessee covenanting to pay rent and taxes. On April 8, 1870, the plaintiff assigned the lease to the defendant by an instrument under seal, written on the back of the lease, and signed by him, as follows: "Boston, April 8, 1870. In consideration of one dollar and other good and valuable considerations paid to me by $T$. $H$. Smith, the receipt whereof is hereby acknowledged, I do hereby assign to said Smith all my right, title and interest to the within written instrument." This assignment was recorded on the same day. On March 12, 1873, the defendant, by a similar indorsement on the lease, assigned the lease to John Carney. The plaintiff had no knowledge of this assignment, and it was not recorded until June 14, 1877.

On April 10, 1876, the heir at law of Nancy J. Fuller brought an action against the plaintiff upon the covenant in the lease, for the taxes assessed upon the demised premises for the years 1872, 1873, 1874 and 1875. The plaintiff requested the defendant to defend the action; but, as he did not do so, the plaintiff defended it, and judgment was recovered against him in the sum of $\$ 392$ damages, and $\$ 24.32$ costs.

'The plaintiff asked the judge to rule that the assignment of the defendant to Carney was not operative against the plaintiff in this action, he having no notice or knowledge of the same, and it not being recorded until June 14, 1877; and that the defendant was liable for all the taxes which the plaintiff had paid.

demand, repair the pipes. Two vears after the making of the lease A assigned the reversion to $\mathbf{B}$., A. having neither painted the house nor repaired the pipes. $X$. brings action against $B$. for breach of the two covenauts. Held, he cannot maintain his action on the first covenant; he cau on the second, no demand ever having been made on $\Lambda$., by showing a demand ou B. and a refusal by him. Gerzebek v. Lord, 33 N. J. Law, 240 (1869).

A. leased premises to $X$. for a term of years and corenanted to keep the premises properly heated. A. assigned the reversion to $B$., and $\mathbf{X}$. accepted B. as his landlord. Later there was a negligent failure to keep the premises properly heated and in consequence thereof, one of $X$.'s employés sulfered personal injury. In an action of tort by tle employé against $A$. settiln forth the abore facts. Held, admitting that the complaint would state at cause of action as against the landlord (Glidden v. Goodfellow, 124 Minu. 101,144 N. W. 428, L. R. A. 1916F, 1073 [1913]), it does not state a cause of action as against A. Glidden $r$. Second Ave. Investment Co., 125 Minn. 471, 147 N. W. 658 , L. R. A. 1915 C, 190 [1914].

See Wagner v. Van Schaick Realty Co., 163 App. Div. 632, 148 N. Y. Supp. 736 (1914). 
The judge refused so to rule; and ruled that the defendant was only liable for the tax for the year 1872; and ordered judgment accordingly. The plaintiff alleged exceptions.

ENDICOT', J. It is clear that the plaintiff was liable to the lessor upon the covenants of the lease for the payment of taxes for the years 1872, 1873, 1874, 1875; although he had assigned all his right, title and interest in the lease to the defendant in 1870, which assignment was under seal and duly acknowledged and recorded. The defendant, as assignee, would also be liable to the lessor for the taxes accruing during his term, by virtue of the privity of estate created by the assignment. In such a case, the liability of the original lessee does not depend upon privity of estate, for he has parted with his whole interest, but upon privity of contract, and continues during the whole term; while the liability of the assignee continues only during the time he holds the legal title to the leasehold estate under his assignment. When the privity of estate thus ceases, his liability to the lessor ceases. Farrington v. Kimball, 126 Mass. 313, 30 Am. Rep. 680, and cases cited. See Howland v. Coffin, 9 Pick. 52.

The plaintiff, being thus liable, was sued by the legal representative of the lessor for these unpaid taxes, and judgment having been rendered against him for the whole amount, he paid the same.

That a lessee can recover from his assignee, and also from a second assignee, the taxes accruing during their terms respectively and which the lessee has been obliged through their default to pay to the lessor, is well settled. Patten v. Deshon, 1 Gray, 325; Burnett v. Lynch, 5 B. \& C. 589; Moule v. Garrett, L. R. 5 Ex. 132; s. c., 7 Ex. 101; Farrington v. Kimball, ubi supra. The question presented in this case is whether the plaintiff is entitled to recover from the defendant, not only the taxes for 1872, when the defendant was actually in possession, but also the taxes for the following years, when Carncy was in possession, to whom the defendant had transferred the lease in 1873 by an assignment, not recorded until 1877. The lease was for the term of fifteen years from January 1, 1870.

The assignee of a lessee takes the whole estate of the lessee in the premises, subject to the performance on his part of the covenants running with the land, under the terms of the lease. By accepting and entering under the assignment, the law implies a promise to perform the duties thus imposed upon him. If through his neglect or refusal to perform them, the lessee is obliged to pay rent, taxes or other sums of money to the lessor under the covenants of his lease, he may recover the same from his assignee. Whether the lessee may recover from his assignee such sums as he has been obliged to pay, arising out of the default of a second assignee to whom the first assignee has assigned all his interest, presents a very different question, in the absence of an express agreement to do so in the instrument of assignment. For the implied promise to perform the duty imposed upon him by the acceptance of the assignment must be limited to the time 
while he holds the estate under the assignment, and while, by virtue of his privity of estate with the lessor, he is liable to him fur the performance of the covenants. In other words, the implied promise cannot include the payment of any sums, except those which as assignee he assumes, and for which, when he assigns the lease, he is no longer liable to the lessee. Wolveridge v. Steward, 1 Cr. \& M. 644.

The presiding judge, therefore, rightly ruled that the defendant was only liable to the plaintiff for the tax of 1872 .

It is immaterial that the assignment by the defendant to Carney was not recorded. The provisions of the Gen. Sts. c. $89, \S 3$, have no application here; and the failure of Carney to record the assignment cannot affect the rights or liability of the defendant in this case. See Parsons v. Spaulding, 130 Mass. 83.

Exceptions overruled. ${ }^{+0}$

\section{MASCAL'S CASE.}

(Court of Common Bench, 15st. 1 Leonard, 62.)

Mascal leased a house to $A$. for years by indenture, by which $A$. covenanted with Mascal to repair the house leased, and that it should be lawful for Mascal his heirs and assigns to enter into the house to see in what plight for matter of reparation the said house stood, and if upor any such view, any default should be found in the not repairing of it, and thereof warning be given to A. his executors, \&c. then within four months after such warning, such default should be amended: the house in the default of the lessee became ruinous: Mascal granted the reversion over in fee to one Carre, who upon view of the

40 See Burnett v. Lrnch, 5 B. \& C. $5 \$ 9$ (1526); Bender v. George, $92 \mathrm{~Pa}$. 36 (1579): State $v$. Martin, 14 Lea (Tenn.) 92. 52 Am. Rep. 167 (1s84). Compare Bonner v. Tottenham Building Soc., [1899] 1 Q. B. 161 (1S9S).

A. leased premises to $X$. by a long term lease, $X$. covenanting to pay the rent. A. assigned the reversion to $\mathrm{B}$. X. assigued the lease to $\mathrm{Y}$. by written assigninent under seal "in consideration of the assumption by the said" $Y$. "of all the obligations and liabilities of the lessee arising under said lease." B. dealt with Y. as his tenant. Y. assinned the lease to Z., but continlled to pay the rent for a time; he later ceased to pas; $Z$. made no payments. In an action of corenant by B. against $X$., Y., and Z., the trial court lield that $Y$. and $Z$. were both personally liable for the rent accruing suisequent to the assignment br $\mathrm{Y}$. to $\mathrm{Z}$. $\mathrm{Y}$. appealed. In aftirming the decision of the lower court with respect to the richt of $B$. (appellee) against Y. (appellant) and Z. (McGinniss), the court said:

"The appellant receired a converance of the leasehold estate, received possession of such estate, and assumed to pay the rent. There was thereby established between the appellant and the aljellee a privity of contract and a privity of estate. That privity of estate was terminated by the convevance and transfer of possession of the demised premises to McGinniss. But the privity of contract-the contractual liahility of the appellant-was not thus terminated. No valid reason is apparent to us why the appel'ant should not psy the rent he assumed." Springer v. De Wolf, 194 Ill, 224, 62 N. E. 5t2. 56 I. R. A. 465,88 Am. St. Rep. 155 (1901).

Compare Seventy-Eighth Street \& Broadway Co. v. Purcell Mfg. Co. jz Misc. Rey, 178, 15j x. Y. Supp. 259 (1915). 
house gave warning to A. of the default, \&c. which is not repayred, upon which Carre, as assignee of Mascal, brought an action of covenant against A. It was moved by Fenner, Serjeant, that the action did not lye, because the house became ruinous before his interest in the reversion; but the opinion of the whole Court was against him, for that the action is not conceived upon the ruinous estate of the house, or for the committing of waste, but for the not repayring of it within the time appointed by the covenant, after the warning, so as it is not material within what time the house became ruinous, but within what time the warning was given, and the default of the reparation did happen. ${ }^{41}$

\section{STODDARD v. EMERY.}

(Supreme Court of Pennsylvania, 1859. 128 Pa. 436, 18 Atl. 339.)

[On April 26, 1876, Stoddard leased land to Emery, the latter covenanting to sink one oil well within four months, and to sink a second well if the flow from the first one should be large enough to justify it. The first well was sunk within the time provided. On January 7, 1878, Stoddard conveyed his reversion to James. The second well was sunk in 1881 .

This was an action of covenant, brought by Stoddard for not sinking the second well within a reasonable time. The lower court ruled that the plaintiff was limited to showing that there was an unreasonable delay before January 7,1878 . The plaintiff excepted. Judgment for the defendant, and plaintiff appeals.]

GREEN, J. ${ }^{42} * * *$

We agree with the learned court below that there was no breach of the lease prior to the sale of the reversion by Stoddard, in January, 1878 , and that being so there was no right of action by Stoddard. If there were any breaches after the purchase of Janes, there would be no right of action in Stoddard, and there could be no recovery in an action brought in his name.

Judgment affirmed. ${ }^{43}$

41 See Vivian v. Champion, 2 Ld. Raym. 1125 (1705).

A. leased a farm to $\mathrm{X}$., who covenanted not to cut the wood. A. assigned the reversion to $B$. $X$. cut and carried away part of the wood. $B$. assigned the reversion to $C$. Held, $B$. may maintain an action of covenant against $\mathrm{X}$. for the wood cut prior to the assignment to C. Beach $\dot{v}$. Barons, 13 Barb. (N. Y.) 305 (1850).

42 The statement of facts and part of the opinion are omitted.

43 See Beely v. Parry, 3 Lev. 154 (16S4); Hares v. New York Gold Min. Co. of Colorado. 2 Colo. 273 (1871). Compare Payne v. James, 42 La. Ann. 230,7 South. 457 (1S90). 


\section{WILLS et al. v. SUMMERS.}

(Supreme Court of Minnesota, 1890. 45 Minn. 90, 47 N. W. 463. )

VANDERBURGH, J. The plaintiffs, owners of the real estate in controversy, leased the same to certain parties, and thereafter, on the $2 \mathrm{~d}$ day of February, 1885, the defendant became the assignee of the lease, and entered into possession of the leased premises thereunder, subject to the covenants and stipulations therein, and has since continued in such possession, and paid the rent agreed on. The lease contained a covenant requiring the lessees "to pay all rates, taxes, or assessments on the premises during the continuance of the lease." On the 1st day of January, 1889, the premises were subject to the payment of $\$ 501.74$ taxes, which became payable on the last-mentioned date. On the 21 st day of February, 1889, the plaintiffs, lessors, granted their entire interest and estate in the premises to one Murphy, by deed of general warranty, with covenant against incumbrances; and on the 26th day of March, 1889, the plaintiffs paid and satisfied the taxes above referred to in full. And thereafter, in December, 1889, they brought this action against the defendant assignee in possession, to recover the amount so paid. The trial court held that the action would not lie, because the estate had passed to Murphy, and plaintiffs had no longer any title or interest therein.

Conceding that, in the absence of more specific language in the covenant to pay the taxes, the tenant was entitled to delay the payment thereof until they became "delinquent" under the statute, this is no reason why the plaintiffs might not pay them sooner, because the covenant ran to them as owners, and it was inmmaterial to defendant whether he paid the sane to plaintiffs or the treasurer; and if the plaintiffs had a right to pay the taxes, or were bound to do so, by reason of their relation to the leasehold estate, they would be entitled to recover them back of defendant, in case of his ultimate default. The respondent, however, does not complain in this court that the taxes were prematurely paid by the plaintiffs, but contends that any payment by then after the sale to Murphy was intermeddling, and, in contemplation of law, a voluntary payment of the debt of another. To this proposition we are unable to assent.

It is not lisputed that the plaintiffs might have paid the taxes after January 1st, and prior to the sale to Murphy, and subsequently recovered the amount of the defendant; but it is argued that, upon their conveyance to Murphy, this right ceased, for the reason, before stated, that all their interest in the leased property had passed to him. If Murphy had assumed the payment of the taxes, and discharged the plaintiffs from liability, by reason of the lien thereof, or had taken a mes e quitclaim deed, an altogether different case would have been presented. But plaintiffs' relations to the property continued, as respects their liability to pay the taxes, by virtue of the covenant in their deed, 
and the statute making the same a lien as against the grantors from January 1,1889 . It was still their right and duty to pay the same as between them and their grantee, Murphy, though the primary liability to pay them rested upon the defendant, arising from his privity of estate created by the assignment of the lease which made the covenant to pay the taxes binding on him. Gas Co. v. Johnson, $123 \mathrm{~Pa} .576,16$ Atl. 799, 10 Am. St. Rep. 553, and notes. Plaintiffs were not, then, mere volunteers or intermeddlers in discharging the incumbrances on the leased premises by the payment of the taxes, which, as between them and Murphy, it was their duty to do immediately upon the delivery of the deed, as the covenant against incumbrances is in præsenti.

Where a lessee assigns a lease containing a covenant to pay taxes which the assignee becomes liable to pay by virtue of the assignment, and the former is afterwards obliged to pay the same, because of his privity of contract with the lessor, he may recover the same of the assignee, though his own interest in the estate has entirely ceased. Mason v. Smith, 131 Mass. 511.

Plaintiffs' right of action may be sustained under the equitable doctrine of subrogation, which is now recognized at law, as well as in equity, and which compels the ultimate payment of a debt by one who, in justice and good conscience, ought to pay it. Thus, it is admitted that defendant would be bound to pay these taxes to Murphy, but plaintiffs were also liable to him in presenti upon their covenant, and as the previous owners of the property, so that upon the payment thereof by the latter, a right to recover the amount thereof ultimately from the defendant accrued to the plaintiffs.

Under the terms of the lease, we are of the opinion that the covenant to pay the taxes would be satisfied by the payment thereof at any time before they became delinquent, June 1, 1889; but this is not material in this action, except as to the question of interest, because it was not commenced till long afterwards. The item of $\$ 72.83$ paid by plaintiffs in October, 1889, had not become due or payable when this action was brought, and cannot be recovered herein.

The order denying a new trial is reversed, and the case will be remanded, with directions to render judgment for the plaintiffs for the sum of $\$ 501.74$, with interest from June 1, 1889. 
(b) Assignient of Part Interests

CONGHAM v. KING.

(Court of King's Bench, 1631. Cro. Car. 221.)

Covenant against the defendant as assignee of an assignee, for not repairing of an house let inter alia.

The defendant takes issue upon the mean assignment of the lease laid in the declaration.

Wright, after verdict for the plaintiff, took divers exceptions to the declaration in arrest of judgment, that the plaintiff shows the lease to be to J. S. and by him devised to J. D. and made J. N. his executor, and that he virtute legationis entered and assigned to IV. S. and he entered and assigned one house, parcel of the premises, to the defendant, who entered and made spoil in an hall and chamber, parcel of the demised premises, \&c. * * *

The next exception alleged was, that the defendant is but assignee of parcel of the things demised; and then he is not chargeable with this covenant, no more than the assignee of parcel shall be charged in debt for the rent; but the action lies against the first lessee, as it is held Walker's case, 3 Co. 23 . Sed non allocatur; for this covenant is dividable, and follows the land, with which the defendant, as assignee, is chargeable by the common law, or by the statute of $32 \mathrm{Hen} .8$, c. 37 . Whereupon it was adjudged for the plaintiff. ${ }^{44}$

\section{HOLFORD v. HATCH.}

(Court of King's Bench, 1779. 1 Doug. 1S3.)

This was an action of covenant, for rent in arrear, brought against the defendant as assignee of one Saunders. The declaration stated, (in the common form, ) that the plaintiff demised to Saunders for seven years, by virtue whereof he entered and was possessed, and that afterwards, all the estate, right, title, and interest, of Saunders, in the premises, came to the defendant, by assignment thereof, by virtue whereof he entered and was possessed, and that, after the assignment, rent had become due, which the defendant had not paid. The defendant pleaded, that all the estate, right, title, and interest, of Saunders in the premises, did not come to him by assignment thereof in manner and form as the plaintiff had alleged.

On the trial, it appeared, that the defendant was in possession of the premises during the time when the rent in arrear became due, but that, by the deed under which he held, they were conveyed to him, by Saunders, for a day, or some days less than the original term, and that he had actually surrendered them before the action was brought. Some re-

44 Part of the opinion is omitted. 
ceipts also were produced for rent which had been paid by the defendant to the plaintiff, and which run thus: "Received of Saunders by the hands of Hatch."

Upon this evidence, it was contended, at the trial, which came on before Lord Mansfield, at the Sittings for Middlesex, in last Hilary Term ; 1. That, in point of law, a person holding of the first lessee, by an under-lease, like the present, is not liable to be sued by the original lessor, on the covenant for rent contained in the original lease; 2 . That the fact put in issue on the record, viz. that all the estate, \&c. of Saunders came to the defendant, was not proved.

A verdict was found for the plaintiff, but Lord Mansfield saved the points made by the defendant's counsel, for the opinion of the court. Accordingly, in Hilary Term, (Thursday, the 4th of February,) Davenport obtained a rule to shew cause why the verdict should not be set aside, and a nonsuit entered. He cited Poultney v. Holmes, M. 7 G. 3. at N. Pr. before Pratt, Ch. Just. 1 Str. 405, Crusoe v. Bugby, C. B. T. 11 G. 3, 3 Wils. 234, since reported 2 Blackst. 766, and Hare v. Cator, B. R. E. 18 G. 3 [† 58]. Vide infra, note (21), p. 184.

LORD MANSFIELD. It is fit that we should look into the authorities; therefore let the case stand over.

The court were understood to be for some time divided, and judgment was not given till this day, when Lord Mansfield delivered their unanimous opinion, as follows:

LORD MANSFIELD. This is an action of covenant by a lessor against an under-lessee, and the single question is, whether the action can be maintained against him, as being, substantially, an assignee. For some time, we had great doubts; we have bestowed a great deal of consideration on the subject, and looked fully into the books, and it is clearly settled, (and is agreeable to the text of Littleton,) that the action cannot be maintained, unless against an assignee of the whole term.

The rule made absolute. ${ }^{45}$

EARL OF DERBY v. TAYLOR and another, Executors of Twist.

(Court of King's Bench, 1801. 1 East, 502.)

This was an action for a breach of covenant, wherein the declaration stated, that the late Earl of Derby, whose grandson and heir the plaintiff is, being seised in fee of a messuage and other premises therein described, by indenture dated 14th December, 1756, made between the late earl of the one part, and Thomas Taylor of the other part,

$45 \mathrm{~A}$. leased a house and land to $\mathrm{X}$. for 30 years by deed at a rental of $£ 150$ per annum, and covenanted to supply wood to repair the house. A. asslgned his reversion to $B$. $X$. assigned to $Y$. for 30 years all his interest in that part of the premises including the house at an annual rental of $£ 30$ payable to $X$. 'The lease contained other corenants varying from those of the head lease. B. did not supply wood to repair the house. Held, Y. may' bring covenant against B. Palmer v. Edwards, 1 Doug. 186 (1783). 
demised to Taylor, his heirs and assigns, the said premises, \&c. for the lives of three persons therein named, all of whom are now dead. That Taylor covenanted for himself, his heirs, and assigns, with the late earl, his heirs and assigns, to repair and keep in repair the premises denised during the said term, and at the end of the term to deliver them up so repaired to the late earl, his heirs and assigns. The declaration further stated the entry and seisin of Taylor the lessee, the death of the late earl, and the descent of the reversion to the piaintiff. And that afterwards all the estate, right, title and interest, property, claim and demand whatsoever, of $\mathrm{T}$. Taylor, of and in the demised premises with the appurtenances came to and vested in $\mathrm{J}$. Twist by assignment; by virtue whereof Twist entered into and became seised of the demised premises for the remainder of the term demised to Taylor. The declaration further stated the death of the three persons for whose lives the estate was demised; and averred that Twist suffered the premises to be out of repair, and that at the end of the term they were delivered up to the plaintiff without being repaired. The defendants pleaded several pleas, but the only material one was that which denied that all the estate, right, title and interest, property, claim and demand whatsoever of $\mathrm{T}$. Taylor, of and in the demised premises, came to and vested in J. Twist by assignment thereof, in manner and form as alleged in the declaration.

The indenture [of assignment] in question, dated 24th of January, 30 Geo. 2, between $T$. Taylor and T. Harrocks of the one part, and James Twist of the other part, witnessed that in consideration of 2451. Taylor and Harrocks hath demised, granted, bargained, sold, assigned, transferred, and set over, and by these presents doth demise, \&c. to Twist, his executors, administrators, and assigns, all that messuage and tenement, \&c. held by lease, under Edward Earl of Derby, and now in possession of Twist, his assignees, \&c. and all the estate, right, title, interest, goodwill, and tenant right, sole power of leasing or renewing leases of the said premises, property, benefit, advantage, claim and demand whatsoever, both at law and in equity, of them the said Taylor and Harrocks, of, in, or to the same, every or any part or parcel thereof, to have and to hold the said messuage, tenement, \&c. and all and singular other the premises abovementioned, and intended to be hereby assigned, with their appurtenances; unto Twist, his executors, administrators, and assigns, from the day next before the day of the date of these presents, for and during and unto the full end and term of ninety-nine years from thence next ensuing and following, and fully to be complete and ended, if Harrocks, J. Twist, and T. Twist, the three lives in the indenture of lease thereof named, or any of them, should so long live: and that in as large, ample, and beneficial way, manner and form, to all intents, constructions and purposes, as they the said T. Taylor and T. Harrocks, their heirs, executors, or administrators, or any of them, can, may, might, or could, have held and enjoyed the same if these presents had not been made; yielding and 
paying therefore yearly during the said term unto the lord and owner of the reversion and inheritance of the said hereby assigned premises the yearly rent of 5s. 6d., \&c. Then followed the usual covenants for quiet enjoyment, for freedom from other incumbrances than the rent, and for further assurance; executed by the proper parties.

LoRd Kenyon, C. J. ${ }^{46} * * *$ The question at present before the Court is as to what estate passed to Twist under the indenture? It cannot be said that a term of 99 years is co-extensive in law with an estate of freehold: and here are no words by which the freehold of which the original lessees were seised was conveyed to the defendant's testator. Then how can we say that the whole interest in the lease passed to him. The conveyance of all the grantor's "estate, right, title interest," \&c. to a man and his executors for years cannot convey a freehold. Such words mean no more than all their interest, \&c. in the legal estate thereby granted; and we cannot give those words a larger operation than the parties themselves have declared they should have.

Per Curiam. Postea to the Defendant.

McNEIL v. KENDALL et al.

\section{AMES v. SAME.}

(Supreme Judicial Court of Massachusetts, 1SS0. 12S Mass. 245, 35 An. Rep. 373.)

EndicotT, J. In the first of these cases McNeil, the plaintiff, as assignee under a levy of sale of the leasehold estates of Samuel $\mathrm{T}$. Ames, created under cerfain indentures from Lucy Ann Harris, seeks to recover rent from the defendants, to whom Samuel T. Ames had leased, prior to the sale, a portion of the premises included in the indentures.

In the second case James B. Ames, the plaintiff, contends that the lease from Samuel T. Ames to the defendants operated in law' as an assignment of his entire term in the premises described therein, and not as an underlease; and that there was no estate or reversion in those premises remaining in Samuel T. Ames which could be levied upon and sold. Under an assignment, therefore, after the levy and sale, made to him by Samuel $T$. Ames of the rent reserved in the defendant's lease, James B. Ames seeks to recover the same from the defendants.

The cases were argued together as one case, and will be so considered by the court in determining which plaintiff is entitled to recover the rent from the defendants.

It appears from the record in these cases, that Lucy Ann Harris was, in 1866, the owner in fee of two estates in Boston, one on Summer Street, and the other on Lincoln Street. By an indenture dated

46 The statement of facts is abridged and part of the opinion is omitted. 
in September of that year, she demised to Samuel T. Ames, for the term of twenty years from January 1, 1867, the estate on Summer Street; and, at the same time, by another indenture, she demised to him for the same term the estate on Lincoln Street, which was bounded in part by the rear line of the estate on Summer Street. It is unnecessary to recite these indentures at length; with the exception of the amount of rent reserved, and certain provisions in regard to the removal and erection of buildings, they do not differ materially. Under the first named, the lessee was bound by his covenants to take down the building standing on the estate on Summer Street, and to erect thereon a good and substantial warehouse, of not less than a certain value, and to keep the same in repair, and insured for the benefit of the lessor. Under the second, he had the right to take down the buildings on the estate on Lincoln Street, and, if he did so, he was also required to build thereon a good and substantial warehouse. It was stipulated in this indenture that the lessee should keep the buildings standing thereon, or such as he might erect in their place, in good repair. Under these indentures, which were duly recorded, Samuel T. Ames went into possession of the whole estate. The city of Boston, in the exercise of the right of eminent domain, took a portion of each lot for the purpose of widening the street on which it fronted, and laid out the same as a highway before any of the instruments were executed which are the subject of this controversy.

Under the powers and in accordance with the covenants contained in these indentures, Samuel T. Ames took down all the old buildings on the demised premises, and, having full power and control over the same, treated them as one estate, and erected two warehouses thereon, obliterating the old lines of division. One warehouse was built on Summer Street, which covered all the land included in the first indenture, excepting that which was taken for the highway, and also covered a portion of the rear of the land demised by the second indenture. It was constructed of brick and stone and was four stories high. The other was built on Lincoln Street, as widened, of brick and stone, two stories high, and covered a portion of the land described in the second indenture. A space or area was left open between the two buildings, and a passageway was constructed five feet wide and planked, leading from Lincoln Street on the southerly side of the premises, in a direct line, under the last-named building, and across the area, to a door in the rear part of the building fronting on Summer Street. Each building had windows opening upon the area, and the building on Summer Street had windows overlooking the building on Lincoln Street. It is stated in the defendants' bill of exceptions, in the first case, that this passageway was left, constructed and designed for the use of the building on Summer Street, in connection with the door in the rear of the same, and was the only means of access from the highway to the area, and also to the door fronting thereon in the rear of the building on Lincoln Street. 
In July, 1873, Samuel T. Ames, by an indenture duly recorded, leased to the defendants for the remainder of his term "the store and warehouse Nos. 119 and 121 on Summer Street in Boston," giving no other description of the premises, and making no allusion to the area or the passageway in the rear, except in a clause which recites that "it is understood that the rear building on Lincoln Street shall not be carried up any higher, so as to obstruct the light during the continuance of this lease. Also agreed that the party occupying the small building on Lincoln Street shall have a right through the passageway." This lease is in the common form, and contains the provisions, that the lessor shall rebuild in case of fire, and remit during the time a fair proportion of rent; that the lessees shall pay the rent reserved and taxes, and deliver up the premises at the end of the term, and not make or suffer any waste; and that the lessor may enter to view and make improvements, and may expel the lessees if they fail to pay rent and taxes, or make or suffer any strip or waste.

Whatever may be the legal effect of this indenture, it is evident that the parties contemplated only a sub-lease of a portion of the whole estate, as improved by Samuel T. Ames.

Before giving this lease, Samuel T. Ames, in May, 1873, demised, by an indenture to $H$. P. Bambauer for the remainder of his term, "the two-story building, No. 2 Lincoln Street, in Boston," giving no other description, and not alluding to the area, but referring to the passageway in these words: "Passageway partly under the building is not included in this lease." This lease was surrendered in August, 1873, and at the same time Samuel T. Ames executed another lease of the same premises for the same term to Jacob Bambauer, which contains the same provision in regard to the passageway. Neither of these leases was ever recorded. The last was assigned by Samuel T. Ames to the plaintiff, McNeil, after he had purchased the leasehold interest of Ames in the Lincoln Street estate, which was sold at the sheriff's sale.

By neither of these indentures did Samuel T. Ames convey the lánd included within the area or the passageway. It is clearly to be implied from the language of the lease to the defendants, taken in connection with the fact that the passageway was then laid out from Lincoln Street to the door in the rear of the defendants' premises, that a right in that passageway passed by the indenture to the defendants in common with Samuel T. Ames and the occupants of the other building. It is also clear that the defendants acquired an easement for the light afforded to their building by the area, under the provision that the building on Lincoln Street should not be "carried up higher so as to obstruct the light during the continuance of this lease." These easements thus granted to the defendants, in the land not conveyed in either indenture and in the land occupied by the other building, constituted a portion of the premises demised to the defendants to be enjoyed 
in common with Samuel T. Ames, and such other persons as might occupy the building on Lincoln Street.

It was in this condition of the property, that all the right, title and interest of Samuel 'T. Ames, in the two estates, held by him under the two indentures from Lucy Ann Harris, were seized and sold, at a sheriff's sale in November 1S75, upon an execution issued against him in favor of the Lancaster National Bank. The plaintiff, McNeil, purchased the leasehold estate fronting on Summer Street, which was duly conveyed to him by the sheriff. One E. K. Harris purchased the other, and, having received a deed of the same from the sheriff, conveyed his interest therein to McNeil, who thus became assignee in law of the entire interest of Samuel T. Ames in the whole estate, to the same extent as if Ames had himself transferred all his leasehold interests therein. Sanders v. Partridge, 108 Mass. 556, 558. It was not contended at the argument that these sales were in any respect irregular or invalid.

'There is no question that some portion of the leasehold estates of Samuel T. Ames in the premises passed to McNeil by the levy and sale. The lease to Jacob Bambauer was not recorded, and cannot be treated as valid against the levy; and the subsequent assignment of it to McNeil cannot in any way operate to his prejudice. That portion of the premises therefore passed to him, as well as the area and passageway, subject to the defendants' easements therein; together with such interests and rights of reversion as Samuel T. Ames had in the strips of land taken for highway. Whether the remaining premises passed to him depends upon the question, whether the defendants hold, as assignees of a part of the premises for the whole term, or as sub-lessees.

Before dealing with that question, it is proper to allude to some difficulties which might have arisen on this state of facts. In improving the property, Samuel T. Ames disregarded the lines of division, as set out in the two indentures from Lucy Ann Harris, and erected the building on Summer Street partly on land included in the first, and partly on land included in the second indenture: and, in leasing this building to the defendants, he attached to the whole estate thus conveyed certain easements in the other land included in the second indenture. In selling his leasehold estates under both indentures, of course they must be sold separately, and if they had been bought and were now held by different persons, each purchaser would have acquired only a part of the building occupied by the defendants; and a very serious question would have arisen, in regard to their respective rights, as against the defendants, who hold the whole building, and the easements connected therewith, as one estate. But this question is not before us, for McNeil holds whatever passed by the sale of both. Nor is it denied that Samuel T. Ames had the right thus to disregard the old lines of division in improving the property, as one estate; and all parties claim interests under him in the entire prenises occu- 
pied by the defendants. As between them, therefore, we must assume that it is one estate, irfespective of all lines of division and of the fact that Samuel T. Ames obtained his interest by separate and distinct indentures; and the cases have been argued before us on this assumption.

It is unnecessary to cite authorities to the proposition, that to constitute an assignment by a lessee of the whole, or of a specific part, of his leasehold estate, the entire interest of the lessee in all the premises included in the assignment must pass to the assignee. Even if the instrument may be in form a sub-lease, yet if it conveys the whole estate it will operate as an assignment. In deciding, therefore, whether this lease to the defendants is in law an assignment, we must ascertain from all its provisions, as applied to the subject-matter, whether Samuel T. Ames conveyed his entire term and interest in the premises, which the defendants have the right to occupy and enjoy under their lease from him.

What then passed to the defendants from Samuel T. Ames? The land under the building, the building itself, the right to use the passageway in the rear extending to Lincoln Street, the right to enjoy the light in the area, secured by the provision that the space above the two-story building on Lincoln Street shall remain open and unobstructed. These were not mere personal rights, but easements appurtenant to and a part of the premises conveyed, and necessary for the complete enjoyment of that portion which opened on the area. Dennis v. Wilson, 107 Mass. 591; Peck v. Conway, 119 Mass. 546. And if Samuel T. Ames or those claiming under him had raised the building on Lincoln Street higher than two stories, the defendants would have been entitled to relief in equity to enforce the restriction. Parker v. Nightingale, 6 Allen, 341, 83 Am. Dec. 632. The defendants thus acquired the whole interest in the warehouse on Summer Street and the land on which it stood, and subordinate and limited interests in all the other land between the warehouse and Lincoln Street. These cannot be separated or divided, but form one estate, carved out of the whole leasehold estate of Samuel T. Ames, acquired from Lucy Ann Harris.

It is plain, therefore, that Samuel T. Ames, while he conveyed to the defendants his whole term for years, did not convey his whole interest in the premises, which the defendants had the right to occupy and enjoy under their lease; but retained in himself all the land, not covered by the warehouse on Summer Street, subject to the easements granted to the defendants. The interest which he conveyed to the defendants was a portion of the entire estate, and not his whole estate in a portion of the same. "For there is a diversity between the whole estate in part, and part of the estate in the whole, or of any part." Co. Lit. 385a; Shep. Touthst. 199.

While this case differs in many of its features from that of Patten 
v. Deshon, 1 Gray, 325, yet the point there determined is decisive of this, independently of the considerations stated above. In that case, one Walker, a lessee for years, had given a lease in a portion of the premises by metes and bounds, for his entire term, to the defendant, and afterwards assigned all his right, title and interest in his lease to the plaintiff; and it was held that the plaintiff could recover from the defendant the rent accruing upon his lease. Chief Justice Shaw in delivering the judgment said: "It would be too narrow a construction to hold that this was only an assignment of the instrument or document; it means all the right, title and interest, which he holds; or has title to hold, under the instrument. It clearly embraced the transfer of all right to the use and enjoyment, for the residue of the term, of all that part of the leased premises which had not been underlet to Deshon. Had the sublease to Deshon been surrendered, or forfeited by non-payment of rent, the assignment would have passed to the assignee the right to use and enjoy that part of the premises let to Deshon, for the residue of the term. It was therefore a substantial interest intended to be assigned." "And it is to be considered, that Patten, the plaintiff, by force of that assignment of Walker to him, for the whole term, had become assignee of the lessee, and as such liable to the action of the original lessor, for the entire rent. In order to enable him to meet that obligation, equity required that he should have the entire benefit of the term, including not only the use and occupation of the part not underlet, but also the rent accruing from sublessees, of all such parts of the premises as were held by them; and therefore it must have been the intention of the parties, in the assignment, that the assignee should take upon himself the burden of paying the whole rent, and be entitled to the benefit of the whole of the leased premises; and that Walker, the original lessee and assignor, being relieved from the payment of any rent to the original lessor, could have no right to receive rent of a sub-lessee."

In the case at bar, McNeil acquired under the levy and sale all the right, title and interest of Samuel T. Ames in a considerable portion of the leasehold estate not let to the defendants. By the terms of the lease to the defendants, Samuel T. Ames liad the right to re-enter if the defendants failed to pay rent, or committed strip or waste, and this right passed to McNeil under the conveyance from the sheriff of all the right, title and interest of Samuel T. Anes in the leasehold estates.

We are not aware that the decision in Patten $v$. Deshon has ever been judicially questioned; nor has any case been called to our attention, in which, upon the same state of facts, a different rule has been declared. It has been cited with approval in numerous cases in our own reports; it has been the law in Massachusetts for more than twenty years, and lays down a just and equitable rule, not inconsistent with the established principles of the law. Buffum v. Deane, 4 Gray, 
385, 393; Hunt v. Thompson, 2 Allen, 341; Way v. Reed, 6 Allen, 364 ; Sanders v. Partridge, 108 Mass. 558, 560; McNeil v. Ames, 120 Mass. 481; Porter v. Merrill, 124 Mass. 534; Farrington v. Kimball, 126 Mass. 313, 30 Am. Rep. 680. See, also, Shumway v. Collins, 6 Gray, 227.

The plaintiff, McNeil, entered upon the premises after the sale, notified Lucy Ann Harris of his assignment, and that he would pay rent to her; and also gave notice to the defendants that they must pay rent to him; and we are of opinion, for the reasons stated, that he is entitled to recover. It therefore becomes unnecessary to consider the other questions so ably argued at the bar, or to review the numerous cases cited by the counsel. By the terms of the report, in the first case the exceptions must be overruled; and in the second case the entry must be

Plaintiff nonsuit. ${ }^{47}$

\section{ATTOE v. HEMMINGS.}

\section{(Court of King's Bench, 1612. 2 Bulst. 281.)}

In an action of covenant, the case appeared to be this, Thomas Taverner, 1 Jac., made a lease for years unto Salisbury, who entered, and was thereof possessed; Taverner doth devise the reversion unto Mary his wife for her life, who grants this over to the three plaintiffs for forty years, if she shall so long live; Salisbury attorns, makes his wife executrix, and dies; in the first indenture divers covenants are contained, and upon which diverse questions were moved; Salisbury in the first indenture doth covenant to pay $\{37$. rent unto Thomas Taverner the lessor, for nonpayment of this $£ 37$. rent, the action of covenant is brought, by an assignee of an assignee of the reversion.

Coke, Chief Justice. ${ }^{48}$ This is as common as may be, that an assignee of a reversion for part, shall have the benefit of a covenant. * * * I do hold it clearly, that the grantee of part of the estate, being the plaintiffs, shall take benefit and advantage of this covenant here, in Leonard's case, in the C. B. it was adjudged, that a grantee for years of the reversion, should take advantage of a condition, within the statute of $32 \mathrm{H} .8$, cap. 24 , and it is very plain and clear, that such a grantee may have an action of covenant at the common law, the old

47 For other cases on the distinction between an assignment and a sublease, see Poultney v. Holmes, 1 Str. 405 (1720); Beardman v. Wilson, L. R. 4 U. P. 57 (1868); Cameron, etc., จ. Tobin, 104 Minn. 333, 116 N. W. 838 (190S); St. Joseph \& St. L. Ry. Co. v. St. Louis, I. M. \& S. Ry. Co., 135 Mo. 173, 36 S. W. 602.33 L. R. A. 607 (1896) ; Stewart v. Loug Island R. Co., 102 N. Y. 601,8 N. E. 200,55 Am. St. Rep. 844 (1886); Presby v. Benjamin, 169 N. Y. 377,62 N. E. 430,57 L. R. A. 317 (1902) : Davis v. Vidal, 105 Tex. 444, 151 S. W. 290,42 L. R. A. (N. S.) $10 S 4$ (1012).

48 The statement of facts is abridged and part of the opinion is omitted. 
difference was between a covenant personal and real; this appears in Spencer's Case, 5 pars. fol. 18, where divers cases are put to this purpose.

Judgment was given for the plaintiff. ${ }^{40}$

\section{TWYNAM v. PICKARD.}

(Court of King's Bench, 1818. 2 Barn. \& Ald. 105.)

Covenant. Declaration stated, that one H. N. Middleton being seised in fee of the premises, demised the same by lease to the defendant for fourteen years, and that the defendant covenanted to repair, \&c. The declaration then stated the entry of the defendant upon the premises, the reversion still remaining in Middleton; that the latter by lease and release conveyed his reversion to $W . H$. and $W$. T. in fee; that they became seised of the reversion in fee, and that they on the 15th day of February, 1810, by lease and release, conveyed to the plaintiff the reversion of part of the said demised premises, whereby he became seised of the reversion of that part of the premises in fee. The declaration then alleged breaches of covenant for not repairing that part of the premises, the reversion of which had been conveyed to plaintiff. General demurrer and joinder.

BAYLEY, J. ${ }^{50}$ Although it has never been expressly decided, that the assignees of the reversion of part of the demised premises can maintain this action against the lessee, yet, when the question comes fairly to be considered, I cannot entertain any doubt that covenant will lie both by and against the assignee of the reversion of part of the premises. The 32 H. 8. c. 34. s. 1., enacts, "that the grantees or assignees of any reversion or reversions, shall have the like advantages against the lessees by entry for non-payment of the rent, or for doing of waste or other forfeiture, and also shall have all such like and the same advantage, benefit, and remedies, by action only, for not performing of other conditions, covenants, or agreements contained and expressed in their leases, demises, or grants against the lessees, as the lessors or grantors themselves might have had at any time." The words therefore apply to conditions as well as to covenants, and are sufficiently large to include persons who are grantees of the reversion, either of the whole or part of the property, which is the subject of the lease.

4.Ace.: Wright $\nabla$. Burroughs, 3 C. B. 685 (1846).

A. leased a house to $X$., who covenanted to deliver it up in good repair at the termination of the lease. The lease expired on March 25, 1889. Before the expiration of the lease $A$. executed to $\mathbf{B}$. a lease of the same premises for 25 rears from March 25,1589 . $x$. delivered up the premises at the termination of the lease, but they were in bad condition. Held, $\mathbf{A}$. may maintain covenant against $\mathrm{x}$. Joyner v. Weeks, [1591] 2 Q. B. 31.

so Opinion of Abbott, J., is omitted. 
That part, however, which applies to conditions which in their very nature are entire, is necessarily confined to the assignees of the reversion of the whole premises. The authorities cited in the course of the argument, to shew that the assignees of the reversion of part are not within the act, were cases of conditions, and do not apply to covenants. I do not agree to the distinction taken in the argument, between the first and second sections of the act, for the words used in both sections are substantially the same, and must receive the same construction. The only difference is, that the words in the first section apply to the assignee of the reversion; those in the second section, to the assignee of the term. Then, except in cases where the construction of the statute is confined by the use of the word condition, and the nature of the thing, there is no good reason why the word assignee in the statute should not be held to extend to the assignee of the reversion in part. as well as of the whole of the premises. In Palmer v. Edwards, 1 Dougl. 187, it was held, that the assignee of part of the premises from the lessee might maintain covenant against the lessor; and there Buller, J., considered the remedies as mutual. In Congham v. King [Cro. Car. 222], it was held, that the lessor might maintain covenant against the assignee of part of the premises demised. These authorities seem to shew, that the severance of the estate demised does not take away the mutual remedies. I have always understood it to be clear law, that covenant was maintainable by the assignee of the reversion in part. ***

HOLROyd, J. I am also of opinion that this action is maintainable. The cases cited in argument apply only to conditions, with respect to which the statute expressly enacts, "that assignees shall have the like advantages against the lessees by entry for non-payment of rent, or for doing of waste or other forfeiture, as the lessors would have had." Now if the lessor assigned the reversion of part of the premises to another, his right of entry would be gone, for in Knight's Case, 5 Coke, $55 \mathrm{~b}$, it was expressly held that the severance of any part of the reversion destroyed the whole condition (which was entire, and the breach of which gave one entire right of entry into the whole premises on non payment of rent); that being so, the lessor at common law would have no right, in such a case, to vacate the lease by entry, and consequently his assignee would not have that right under the statute. But that does not apply to the case of covenants, for there, although the lessor has granted away part of the demised premises, still at common law he might maintain covenant against the lessee, and therefore it seems to me, that his assignee of part of the demised premises is entitled under the statute to maintain that action.

Judgment for plaintiff. ${ }^{51}$

51 See Leiter v. Pike, 127 Ill. 287, 326, 20 N. E. 23 (1889). 


\section{DEMAREST v. WILLARD. \\ (Supreme Court of New York, 1S2S. 8 Cow. 206.)}

Covenant on a lease, tried at the Saratoga circuit, November 28th, 1826, before Walworth, C. Judge.

At the trial, the following matters were in evidence: the plaintiff by lease under seal, dated March 29th, 1819, demised a house and lot to the defendant's testator, for two years from the 1st of May, then next, at an annual rent of $\$ 600$ payable quarterly. The lessee covenanted to pay the rent, and that no alterations, \&c., should be made in the house, or any nails or wooden pins driven into the floors, walls or ceilings, or any damage done, during the term; and that he would deliver up the premises in the same repair at the end of the term, as at the date of the lease, all reasonable wear excepted. The plaintiff claimed for rent arrear, $\$ 50.14$; for injury to the house by nails, pins, \&c.; and that the premises were not delivered up in good repair. Considerable damage was proved.

The defence was an assignment indorsed on the lease, dated April 29th, 1819, by the lessor to one Haswell, as follows: "For value received, I do hereby assign, transfer and set over unto John Haswell, of, \&c., his heirs and assigns, the within lease, and all the rents which may and shall from time to time become due and payable during the term," \&c., with an authority to Haswell to collect the rents, and a covenant to ratify and confirm what he might do in the premises:

The judge decided that this assignment was a bar to the plaintiff's recovery upon both branches of his claim.

The plaintiff then proved a re-assigniment from Haswell to the plaintiff, dated August 15th, 1821, thus: "The balance of rent and interest thereon due this day, is $\$ 36.48$, in consideration of which, I do hereby re-assign to Samuel Demarest, (the plaintiff,) all my right and interest of, in and to the within lease, and all the rent due and to become due thereon."

The judge decided that this did not revest a right of action: and non-suited the plaintiff, who excepted.

Curia, per SAvAGE, Ch. J. The question to be decided is, whether the plaintiff has a right to maintain an action in his own name, either on the covenant to pay rent, or the covenant to surrender the premises in good repair at the end of the term.

To ascertain the rights of the parties, it is necessary to examine the assignment to Haswell; and see what was conveyed to him. 'The plaintiff assigned the lease of Willard, and all the rents to become due during the term. No interest in the premises leased, except the rent issuing from them, is contained in this assignment. The reversion is not conveyed in terms, nor can it be by implication. When rent is reserved, it is incident, though not inseparably so, to the reversion. (Co. I.itt. 143.) The rent may be granted away, reserving 
the reversion; and the reversion may be granted away, reserving the rent, by special words. By a general grant of the reversion, the rent will pass with it as incident to it; but by a general grant of the rent, the reversion will not pass. The incident passes by the grant of the principal; but not e converso. (Co. Litt. 151; 2 Jac. L. D. Reversion.) The assignment to Haswell did not convey the reversion; and it, of course, remained in the plaintiff. It was perfectly within the power of the plaintiff to have assigned the rent to one, and the reversion to another; but he conveyed nothing beside the rent, unless something more passed by the words, "the within lease." It cannot be contended, that these words conveyed the fee of the house and lot. If anything was intended more than the instrument itself, it must be the plaintiff's interest in the premises during the term. But until the term was ended, the lessee could not be called upon to surrender the possession of the premises in good repair. All the interest and authority of the plaintiff during the term was to collect the rent. Authority for this purpose was given to Haswell, by the assignment; but it is altogether silent as to transferring any right to damages, which the plaintiff might be entitled to by reason of a breach of the other covenants in the lease.

That the right to prosecute upon a covenant to leave' the premises in repair, belongs to the assignee of the reversion, was decided in the case of Matures v. Westwood, (Cro. Eliz. 599, 617.) But there is a great difference between an assignee of the reversion, and an assignee of the rent. By an assignment, the assignor parts with his whole interest in the thing assigned; and puts the assignee in his place. (4 Cruise, 111.) There is no doubt of the correctness of this rule; but the question still recurs, what was the thing assigned? I am satisfied, and have endeavored to show, that nothing but the rent was assigned. Our statute to enable grantees of reversions to take advantage of conditions to be performed by lessees, which is substantially a copy of the 33 Henry 8, ch. 34, relates solely to grantees of reversions; and as the reversion has never been granted in this case, the statute has no application. That the assignee can take advantage of all covenants which run with the land, is perfectly settled, but not of such as are collateral. Glover v. Cope, (4 Mod. 81,) a case under the statute, decided that the assignee of the reversion might sue the lessee. The same point was held in Bally v. Wells, ( 3 Wils. 29,) and that on a covenant which runs and rests with the lands, an action lies for or against the assignee at the common law, although the assignees are not named in the covenant; quia transit terra cum onere. And it was held that a covenant to repair is one which concerns the land and runs with it. I agree, therefore, that if the reversion had been assigned to Haswell, this action could not be maintained; but we are constantly brought back to the assignment.

Littlewood v. Jackson, decided by this court, May term, 1820, is supposed to control this case. One Bailey had a term of 1590 years; 
and he demiscd to the defendant 1550 years of his term, reserving a rent of $£ 12.15 \mathrm{~s}$. $6 \mathrm{~d}$. Afterwards Bailey assigned to the plaintiff the rent and all remedies for its collection, and all the estate, \&c., claim and demand of Bailey to the rent, to have and to hold for the 1550 years. After the plaintiff became entitled to the rent, $£ 11 \mathrm{~S} .3 \mathrm{~s} .5 \mathrm{~d}$, being rent for 9 years and 3 quarters, fell due and was in arrear. 'The verdict being for the plaintiff, the defendant moved in arrest of judgment, on the ground that the plaintiff had not alleged that he was the assignee of the reversion. But the court denied the motion. As I understand this case, it decides that the assignee of the rent may recover it in that character, without being assignee of the reversion. It is an authority to show that Haswell might sue for and recover the rent in arrear; and consequently the plaintiff cannot; but it proves nothing as to the other covenants in the lease.

The re-assignment by Haswell to the plaintiff, was perfectly useless in respect to the maintaining of this suit. Arrears of rent are a chose in action; and not assignable like accruing rent. Haswell was assignee of the rent; and the whole became due before the re-assignment. If the plaintiff can recover the arrears, it must be in the name of Haswell.

My conclusion is, 1 . That the rents were assigned to Haswell; but not the reversionary interest in the premises; that the plaintiff, therefore, cannot recover, in this action, the arrears of rent; and 2. That the reversion having always remained in the plaintiff, and the covenant to surrender up the premises in good repair not being broken until the term ended, no one but the owner of the reversion can prosecute for the breach of that covenant; that, consequently, the plaintiff is entitled to recover upon the breach of that covenant; and for the injury generally done to the freehold.

The non-suit must be set aside; and a new trial granted, with costs to abide the event.

Rule accordingly. ${ }^{52}$

52 Acc.: Bordereaux v. Walker, 85 Ill. App. 86 (1899). Compare Allen v. Wooley, 1 Blackf. (Ind.) 148 (1821); Huerstel v. Lorillard, 29 N. Y. Super. Ct. 260 (1867). 


\section{Not under the Statute 32 Henry Vill}

\section{BUCKWORTH v. SIMPSON \& BENNER.}

\section{(Court of Exchequer, 1835. 1 Cromp., M. \& R. 834.)}

Assumpsit. The first count of the declaration stated that, by an agreement dated 6th December, 1805, M. M. Buckworth, J. C. Reeding, and P. Alaboine, as trustees and testamentary guardians of the plaintiff, let a messuage, land, and premises, in the county of Lincoln, to one William Barber to have and to hold, from the 6th day of April then next ensuing, for and during the term of one year from thence to be complete and ended, and thenceforward from year to year so long as all parties should think proper, either of them giving notice in writing to the other of his wish and intention to determine the said demise and tenancy, at least six months previous to the expiration of any one year, at the rent therein mentioned. The declaration then set out various undertakings by the said William Barber as to the management of the farm, and also a promise by him to keep the buildings and premises in complete repair, and to leave them in good and tenantable repair at the end of the year when they should be quitted. It then alleged that the plaintiff cane of age $22 \mathrm{~d}$ December, 1815; and that, in consideration that he had undertaken to let the premises to William Barber on the same terms as in the agreement made with his guardians, the said.William Barber undertook to perform the same in all things on his behalf to be performed; that, on the 5th of January, 1821, the said William Barber made his will, and authorized and directed the defendants, together with one C. M. Edmunds, to continue his business in trust for certain persons and purposes, and died on the $2 \mathrm{~d}$ of March, 1821: that the two defendants proved the will, and that all the estate, right, title, and interest of the said William Barber, of, in, and to the said demised premises came by assignment to the defendants. It then further alleged, that, in consideration of the premises, and that the plaintiff would permit them to continue in possession of the demised premises as such assignees, and would omit to give them six months' notice to quit at the proper time and according to the terms in the agreement mentioned, the defendants undertook to perform the agreement in all things to be performed on the behalf of the said William Barber. The declaration then averred that the said William Barber was tenant to the plaintiff until his deatle, and that after his death the defendants became and were the tenants, and continued as such tenants in possession to the plaintiff for a long space of time, to wit, until the 6th of April, 1833; and although the plaintiff suffered them to remain in possession, and omitted to give them six months' notice to quit at the proper time and according to the terms of the agreement, yet that the defendants, as such assignees as aforesaid, during the tenancy since the death of the said William. 
Barber until the 6th April, 1833, did not keep the premises in repair, but delivered them up on that day in a bad and untenantable state of repair.

[Defendant pleaded the general issue. Judgment for the plaintiff; defendant obtained a rule nisi for a new trial.]

PARKis, B. * * *53 The declaration states the facts of the case correctly [the learned Baron here read the declaration]; and the promise alleged to have been made by the defendants was, that, in consideration of the plaintiff permitting them to continue in possession of the premises, and omitting to give notice according to the terms of the agreenicnt, they would perform the agreement in all things to be performed on the behalf of Barber. The question is, whether this promise can be implied by law. I am of opinion that it is an implication of lav, arising from the situation of the parties; and, if it were not so, great inconvenience would be felt, for this species of holding is very common. The nature of the demise is this, that the party taking it is to hold on from year to year, so long as the parties shall please, with the power of notifying that dissent by giving a notice to quit. Suppose the land to descend to the heir-atlaw, and he omits to signify his dissent to its continuance by giving notice to quit, the tenancy will contintte. Again, if the tenant assigns, and the landlord do not give notice, the assignee must hold on the same terms. That contract the law will imply; otherwise the consequence would be, that no action could be brought on the original demise when there is an occupation from year to year, and the tenant assigns, for there is no contract whatever unless the original contract is transferred by operation of law. It is contended, however, that the executors of the original landlord, where he is dead, must bring an action against the personal representative of the original tenant. That would be very inconvenient ; and therefore it is better to hold that a new relation of landlord and tenant arises by implication from the situation of the parties, where there is a continuance of the occupation, and an omission by those who represent the original parties to give notice to quit.

Bolland, B., and Gurney, B., concurred.

Rule discharged.

ss Opinion of Jord Abinger. C. B., is omitted. 


\section{HINSDALE v. HUMPHREY.}

(Supreme Court of Connecticut, 1843. 15 Conn. 431.)

Hinman, J. ${ }^{54}$ The plaintiff, by deed poll, on the 10th day of October, 1827, leased certain premises to Ichabod Loomis, his heirs and assigns, for so long a time as a certain store standing thereon should continue, after the same had been repaired; and in the lease, is this clause: "After said five years expires, the said Ichabod is to pay, or his heirs or assigns, such rent as shall be considered a reasonable ground rent for the land on which the building stands, yearly; and if the lessor and lessee shall be unable to agree upon ground rent, then the amount thereof, from time to time, shall be left to two indifferent men to determine." On the 1st of November, 1831, Loomis assigned his interest in the unexpired term, to Chester Humphrey, who, on the $3 \mathrm{~d}$ of July, 1833, made a like assignment thereof to the defendant; who thus took, and still retains, possession of the premises. The rent being in arrear, the plaintiff has brought an action of covenant, to recover it; claiming, that Loomis, the original lessee, though he did not sign or seal the deed, yet, as he accepted it, and took possession of the premises under it, he thereby, so far, became a party to it; that he is liable in covenant, for the non-performance of such conditions and stipulations, as by the deed, it was made the duty of the lessee to perform, and as effectually, as if he had signed, sealed and delivered the instrument; and that the defendant, being the assignee of the premises, is also liable, in this action, for the non-performance of the covenants, during the time that he has had the possession of the premises.

The declaration being demurred to, the only question arising upon the demurrer is, whether covenant will lie against lessee, or assignee of lessee, for rent on a lease sealed only by the lessor, in other words, whether mutual covenants can arise upon a deed poll? The general rule, that covenant will not lie, except against him, who, by himself, or his duly authorized agent, has sealed and delivered a deed, has not been questioned-nor could it be. The very definition of a covenant, a contract or agreement under seal, or by deed, implies clearly, that to be binding, as a covenant, the agreement must be sealed by the obligor, or his agent; otherwise, it would not be his deed.

But, it is said, there are certain exceptions to the general rule; and that this case falls within one of them. And it is true, that several of the elementary writers do lay down the proposition, that the covenantee's acceptance of the deed, is such an assent to the agreement as will render it binding on him. 4 Cruise's Dig. c. 25, p. 393; Com. Dig. tit. Covenant, A. 1; 1 Sw. Dig. 571. If nothing more is meant by this, than the words, in their literal interpretation, imply, the prop-

-4 The statement of facts and part of the opinion are omitted. 
asition is not perhaps objectionable: but supposing the writers intend by it that the covenantee's acceptance of the deed, is such an assent to the agreement, as will render it binding on him as a covenant, it will be found to be unsupported by the authority of any adjudged case, and is clearly erroneous in principle. The cases usually referred to, in support of this doctrine, are Green v. Horne, 1 Salk. 197, and the case stated in Co. Litt. 231, a. The case in Salk. has no application to this case. The only principle decided there, was, that a person not named in an indenture, cannot have an action on it. And the case stated in Co. Litt. was not an action of covenant, but an action of debt. Platt on Cov. 3; Law Library, pp. 6 and 9. Indeed, all the authorities on this subject are very thoroughly examined, by Mr. Platt; and he says, that no instance can be found, of an action of covenant having been sustained by the courts, against one claiming under a deed poll. ***

The question, whether covenant can be maintained against lessee for rent, on a lease, sealed only by the lessor, has lately arisen in the supreme court of Ohio, in the case of Trustees of a section of land in Hocking County v. Spencer, 7 Ohio 2d pt. p. 149, and it was there held, that it could not. And Grimke, J., who delivered the opinion of the court, says, "Such a doctrine is unsustained, either on principle or authority, in England, and has never been asserted in any of the courts of America."

It is enough for the purposes of this case, that covenant will not lie; without attempting to furnish the plaintiff with another remedy. But, as the cases which go to show that another action may be brought, also show, that covenant cannot lie; as covenant and assumpsit, or covenant and case, are not concurrent remedies; it is not perhaps, improper to refer to the case of Goodwin v. Gilbert, 9 Mass. 510, in which it was held, that where certain duties were reserved, to be performed by the grantee of a deed poll, assumpsit may be sustained for the non-performance of them. And in the case of Burnett et al. v. Lynch, 5 B. \& Cres. 589 , (12 E. C. L. 327,) it was held, that case lay against the assignee by deed poll, who had taken possession under an assignment from the lessee, for breaches of covenant, committed during the time that the assignee was in possession; and $\mathrm{Ch} . \mathrm{J}$. Abbott, in giving his opinion, says, he thinks assumpsit would also lie.

We, therefore, advise the superior court, that the plaintiff's declaration is insufficient.

In this opinion the other Judges concurred.

Declaration insufficient. ${ }^{55}$

os See Johnson v. Muzzes, 45 Vt. 419, 12 Am. Rep. 214 (1872). 


\section{STANDEN v. CHRISMAS et al.}

(Court of Queen's Bench, 1847. 10 Q. B. 135.)

Assumpsit. The first count of the declaration stated that the defendants were tenants to the plaintiff of a messuage and premises, upon the terms that they should during their tenancy keep the interior of the messuage and premises in tenantable repair. Breach, non-repair. The second count stated that defendants were such tenants on the terms that they should use the premises in a tenantlike manner. Breach, that they had used the premises in an untenantlike manner. The third count was the ordinary indebitatus count for use and occupation.

Pleas. 1. To the whole declaration, Non assumpsit. 2. To the first count, a traverse of the alleged tenancy. 3. To the first count, performance. 4. To the second count, a traverse of the alleged tenancy. 5. To the second count, performance. Issues were joined on these pleas.

LORD DENman, C. J. ${ }^{56}$ in this vacation (February 25 th), delivered the judgment of the Court.

In this case, the plaintiff being entitled to five eighths, and one Richardson to three eighths, of certain copyhold premises, Richardson, by lease in writing, not under seal, demised them to the defendants in his own name for one year, at a rent payable half yearly, and under certain terms of repairing. Before the first half year's rent became due, Richardson surrendered his interest to the plaintiff, of which the defendants had notice, and afterwards paid the half year's rent to an agent employed both by Richardson and the plaintiff.

The present action is for non-repair, and for use and occupation, to recover the last half year's rent; and a verdict was found for the defendants. It was objected, at the trial, that no evidence was given of the existence of a manor of which the premises were copyhold. But surrenders purporting to be copies of the rolls of the manor, and which were admitted under a Judge's order, were given in evidence, and, we think, were abundant evidence on that point.

With regard to repairs, it was objected that Stat. 32 H. 8, c. 34, applies only to cases of demise by deed, and that the assignee of the reversion cannot sue in assumpsit on the contract made by the assignor. We are entirely of this opinion, and that the verdict on the first count is right. So on the second count, which is on an implied contract to repair arising out of the relation of landiord and tenant. No such implied contract arises where the tenant holds under an express contract which provides for the very matter Therefore, the verdict on the second count is also right.

58 The statement of facts is abridged and part of the opinion is omitted. 
The count for use and occupation requires more consideration. No doubt the plaintiff was landlord during the time that the rent in question accrued, and when it became due, and was entitled to receive it. He might, have distrained for it, supposing the tenancy to have continued; or he might have brought an action of debt for it. But the question is, whether an action of assumpsit will lie, in which he states that the defendants occupied by his sufferance and permission. It was said that a new tenancy might be inferred when the defendants had notice of the surrender to the plaintiff; but there is no ground whatever for any such inference. It is quite plain that the defendants held under the lease made by Richardson, and under that alone, and the plaintiff could not have prevented them from so holding. The permission to occupy emanated from Richardson, the grantor of the lease, and was complete when the lease was executed, and never could emanate from the person who subsequently became assignee of the reversion; unless, indeed, Richardson having granted for limself and his assigns, the permission of any person who might become assignee of the reversion during the lease can be said to be virtually included, so that the occupation became in point of law permissive on the part of the assignee as soon as his interest took place. We think that this is the right view of the case, and that, the occupation being in point of law by the permission of the plaintiff, the action is maintainable in its present form by virtue of the statute 11 G. 2 , c. $19, \S 14$. In most of the cases referred to on the argument the tenancy was from year to year. It is obvious that the assignee of the reversion has then the power of determining the tenancy by notice; and, if he refrains from so doing, the occupation may well be said to be by,his permission. * * * No case appears yet to have been determined, where, an absolute lease in writing, not under seal, for a fixed term of years, having been granted, and the landlord having assigned his reversion, it has been held that the assignee can maintain an action of assumpsit for use and occupation. We are however of opinion, for the reasons already given, that he can; and we think that the direction of the learned Judge on this part of the case was wrong, though right as to the question of repair.

The rule must be absolute for a new trial. Rule absolute. ${ }^{57}$

${ }^{37} \mathrm{~A}$. by parol leased premises to $\mathrm{X}$. as tenant from year to year. $\mathrm{X}$. later assigned his lease to $Y$. , but $A$. refused to deal with $Y$. as his tenant, although he continued in occupation. A. subsequently convered to $B$, all his estate in the demised premises. No rent was paid to either A. or B. after the assignment and $B$. brought action against $X$. for the rent in arrear sinct the conveyance from $A$. to $B$. Held, the action does not lie. Allcock $r$. Moorhouse, L. R. 9 Q. B. D. 366 (18S2). 


\section{BICKFORD v. PARSON.}

(Court of Common Pleas, 1S48. 5 C. B. 920.)

Assumpsit. The first count of the declaration stated, that, before the commencement of the suit, to wit, on the 25 th of June, 1825 , in consideration that the deferidants, at their request, had become and then were tenants to the plaintiff of a certain dwelling-house and premises, with the appurtenances, of the plaintiff, upon and subject to certain terms, (amongst others) to wit, the terms that the defendants should, during their said tenancy, keep all repairs thereon, the defendants then promised the plaintiff to use the said dwelling-house and premises in a tenant-like and proper manner during their said tenancy thereof, and also, during their said tenancy of the same, to keep all repairs thereon, according to the terms aforesaid; and that the said tenancy of the defendants of the said dwelling-house and premises, upon the terms aforesaid, continued for a long space of time, to wit, from the day and year aforesaid, hitherto; yet that the defendants, not regarding their said promises, did not nor would, during their said tenancy, use the said dwelling-house and premises in a tenant-like or proper manner, or keep such repairs thereon as aforesaid; but that, on the contrary thereof, the defendants, during all the time of their said tenancy, used the said dwelling-house and premises in an untenant-like and improper manner, and also, during all that time, wholly neglected to keep such repairs thereon as aforesaid, insomuch that, by reason of such default, \&c., of the defendants, the said dwelling-house and premises, while the defendants so continued tenants thereof as aforesaid, upon the terms in that behalf aforesaid, were and continued out of repair.

There was a further breach assigned,- that the defendants, during their said tenancy, wrongfully pulled dowin and carried away certain fixtures, parcel of the said dwelling-house.

The sixth plea stated, that, after the defendants had become tenants to the plaintiff, as in the said count alleged, and before the committing of the breaches in that count mentioned, or the accrual of the said causes of action in respect thereof, to wit, on the 1st of December, 1842, the plaintiff, by due course of law, conveyed, assigned, granted, and assured all his estate, right, title, and interest of and in the said demised premises, and of and in the reversion expectant upon the determination of the defendant's said tenancy, to a certain other person, to wit, one William Bickford; that the plaintiff thenceforward, and before the accrual of the causes of action in the said first count mentioned, ceased to have anything in the said demised premises and tenements; and that the defendants then ceased to be, and never since had been, tenants thereof to the plaintiff,--verification.

To this plea, the plaintiff demurred specially, assigning for causes, amongst others, that the promise of the defendants declared on, was according to its legal effect, a promise to keep in repair during the con- 
tinuance of the tenancy under the plaintiff and his assigns, and not under the plaintiff alone, and that the assignment and cessation of the tenancy under the plaintiff, as alleged in the plea, was no answer to the causes of action to which the plea was pleaded; and that the plea was an argumentative and informal traverse, either of the breaches, or else of the continuance or subsistence of the said tenancy at the time of the committing of the said breaches; and that the said traverse should have been in the ordinary form of a traverse, and have concluded to the country.

Joinder in demurrer.

WILDE, C. J. ${ }^{68}$ It seems to me that this plea is bad in substance; and therefore that it is not necessary to advert to the special causes of demurrer. The question turns upon the meaning of the ailegation in the declaration as to the tenancy of the defendants,- whether it imports a tenancy only between the plaintiff and the defendants, or a tenancy of the premises, which, although originally created between the plaintiff and the defendants, was not limited to the period of the plaintiff's possession. It seems to me that the declaration does not limit the defendants' promise to their tenancy under the plaintiff, but points to a tenancy for a term; and the plea treats the declaration as importing a tenancy to that effect. The declaration states, that, in consideration that the defendants had become, and were, tenants to the plaintiff, upon and subject to certain terms (amongst others), to wit, the terms that the defendants should, during the said tenancy, keep all repairs thereon, the defendants promised the plaintiff to use the premises in a tenantlike and proper manner during their said tenancy thereof, and also, during their said tenancy of the same, to keep all repairs thereon, according to the terms aforesaid; and that the said tenancy of the defendants of the premises, upon the terms aforesaid, continued for a long space of time, to wit, hitherto. There is, therefore, a distinct averment of a continuance of the tenancy down to the commencement of the action. And the breach is, that the defendants; whilst they continued tenants thereof as aforesaid, used the premises in an untenantlike manner, and suffered them to be out of repair. The question then is, whether, upon the face of the declaration, the plaintiff complains of a breach of the contract during the tenancy generally, or whether the declaration imports that the contract was to continue only so long as the plaintiff himself should remain the landlord. Taking the whole declaration together, it appears to me that it imports a tenancy generally between these parties. It is true, that, at the time of the contract, the defendants became tenants to the plaintiff. But there is nothing in the language of the declaration to limit it to the continuance of the plaintiff's interest. Applying one's general knowledge to the sub-

s Part of the opinion of Wilde, J., and the opinions of Maule, Coltman. and Cresswell, JJ.. are omitted.

Hig.Riguts-27 
ject-matter, and looking at the nature of the property, it is not to be inferred that a mere tenancy at will was intended, without words plainly showing that such was the contract between the parties. The plea commences by stating, that, after the defendants had become tenants to the plaintiff, as in the count alleged,--confessing the tenancy so alleged,- - and before the committing of the breaches, or the accrual of the catses of action in respect thereof, the plaintiff conveyed, assigned, \&c., all his estate and interest in the premises, and in the reversion expectant upon the determination of the said tenancy, to one William Bickford; that the plaintiff thenceforward ceased to have anything in the premises; and that the defendants then ceased to be, and never since had been, tenants thereof to the plaintiff. The plea treats the tenancy mentioned in the declaration, as a tenancy in respect of which there existed a reversion which was by the assignment conveyed to the person mentioned. If, therefore, the contract in the declaration was not limited to a tenancy under the plaintiff, but was to enure so long as the defendants continued tenants to whosoever might become possessed of the reversion, the only question is, whether, after the plaintiff had ceased to have anything to do with the premises,-inasmuch as this was a conveyance upon which the statute of $32 \mathrm{H}$. 8, c. 34, did not operate, - the right to maintain an action in respect of a breach of a contract, did not remain in the plaintiff. It appears to me that there is no reason, in point of law, why, if the right to sue for a breach did not pass with the reversion, it should not remain in the plaintiff. The privity of estate was destroyed by the conveyance of the reversion; but the privity of contract was not. That, it is plain, would not have passed with the reversion before the statute; and the statute has no operation where the conveyance is not by deed.

If, therefore, the privity of contract subsists for ever between the lessor and the lessee, assuming all that is alleged in the plea to be true, I see no reason why the plaintiff should not maintain this action. For these reasons. I think the plaintiff is entitled to judgment.

Judgment for the plaintiff. ${ }^{59}$

\section{COBB v. JOHNSON.}

(Supreme Court of Georgia, 1906. 126 Ga. 618, 55 S. E. 935.)

Error from City Court of Wrightsville; Wm. Faircloth, Judge.

Action by W. F. Johnson against A. T. Cobb. Trover. * * *

Johnson rented a place to Dudley for five years. The contract, which was in writing, stipulated that he should receive as rent one-fourth of all the corn, cotton, and fodder raised; and at the expiration of five years, or when the said J. D. Dudley shall leave the place, he is to leave the seed out of 16 bales of cotton on the place." Johnson sold the

8 s See Bridgham $\nabla$. 'Tileston, 5 Allen (Mass.) 371 (1S(i2). 
plantation in December, 1903, to Cobb, the present defendant, and made him a warranty deed thereto. He also indorsed on the contract of rent with Dudley, and signed the following: "W. 'T. Johnson having sold said land to A. T. Cobb, I hereby transfer the within contract to him. Dec. 11, 1903." Jolnnson testified that in the fall of 1904, Dudley said that he was thinking of leaving the place, and would deliver the seed, though the contract of rental would not expire by its terms till 1908; that Dudley told him to come to the place and get the seed, which were there in the seedhouse, and said he (Dudley) would deliver them, if Johnson would go for them. When plaintiff went for them, however, they were locked up, and the defendant declined to let him have them. He brought an action of trover to recover them. After a verdict in his favor, defendant moved for a new trial.

LuMPKin, $\mathrm{J}^{60}$ (after stating the facts). 1 . When the landlord sold and conveyed the plantation, and transferred to the purchaser the contract of lease or rent, without reservation, this included all of his rights under the contract, one of which was the right to have the seed from 16 bales of cotton left on the place at the expiration of the lease, or the removal of the tenant. As a part of the contract, the right to enforce this agreement passed to the purchaser under the assignment of the whole. Nothing was left the plaintiff to enforce; and no right to recover in trover existed in him. ***

Judgment reversed. ${ }^{61}$

60 The statement of facts is abridged and part of the opinion is omitted.

61 See Manchester Brewery Co. v. Coombs, [1901] 2 Ch. 608, 619; Isman v. Hanscom, $217 \mathrm{~Pa}$. 133, $66^{\circ}$ Atl. 329 (1907).

A. leased land to $\mathbf{X}$., and covenanted to pay for any improvements that $\mathrm{X}$. might put on the premises; the word "assigns" was not used. $\mathrm{X}$. convered his interest to $Y$., and $Y$. to $Z$. A., at the expiration of the lease, refused to pay for the improvements. In an action by $\mathrm{z}$. in the name of $\mathrm{X}$. against A., the comrt said: "It is clear that all the interest of Thompson in the leased prenises, not only his right to the unexpired term, but also to compensation for the improvements, passed by his assignment to Richard llarcourt. The assignment contains a special provision upon this point, and also a covenant that Thompson, the assignor, will consult Harcourt in the selection of the individual, to be named by him, according to the provisions of the lease, to ascertain the value of those improvements. It is equally clear that all the interest which Richard Harcourt thus accuired in the demised premises, and the improvements thereon, passed by his assignment to Benjamin IIarcourt, for whose benefit this action is brought. The terms in which the subject or interest intended to be assigned is deseribed are: 'All the right, title, interest, claim and demand, both in law and equity, and as well in possession as in expectancr, of the said yarty of the first part, of, in and to all that certain house and lot or piece of land, situate, \&c., with all and singular the hereditaments and aplurtenances therenno belonging, or in any wise appertaining.' 'The improvements or buildings for which compensation was sought by this action under the covenant in the lease, were the dwelling house, shed and blacksmith shop, which had been rected by Thompson. Now all the assignor's interest in the house, not only present, lout expectancy, is expressly assigned, and his interest in the other buildings passed, because they were appurtenint and belonged to the house anc lot." 'Thompson v. Rose, S Cow. (N. Y.) 266, 268 (1828).

Upon a similar state of facts it appeared that at the termination of the lease A. paid $X$. the value of the improvements in iguorance of the fact that 


\section{ALLEN et al. v. CULVER.}

(Supreme Court of New York, 1846. 3 Denio, 284.)

Motion to set aside the report of referees, and also in arrest of judgment. The action was covenant for the non-payment of rent and for the breach of covenants in the lease, brought by the grantees of the reversion against the defendant, who, by a separate instrument, became surety for the lessee. The declaration set out a lease dated February 17th, 1837, from Arthur Hirst and Ann his wife to William H. Culver, for certain premises described therein, situated in Brooklyn, with the buildings and fixtures thereon, known as the Nassau Whiting Factory, for the term of five years and one month from the first day of April ensuing, and ending May 1st, 1842, at an annual rent of $\$ 2751$, payable quarterly. The lessee covenanted to pay the rent, and that "on the last day of the said term or other sooner determination of the estate hereby granted the said party of the second part, his executors, administrators or assigns, shall and will peaceably and quietly leave, surrender and yield up unto the said parties of the first part, their heirs or assigns, all and singular the said demised premises in as good order and condition as the same are now in, ordinary wear and tear and damage by the elements excepted."

The parties also covenanted that there should be an inventory taken of the tools about the premises, and of certain chalk stones at the factory, which were used in the business of manufacturing whiting, which, it was agreed, should be "considered as part of the premises hereby demised and to pass therewith, and that the same are to remain in the possession of the said party of the second part, his executors, administrators and assigns, during the term hereby demised; and upon the expiration of the term of years hereby granted, the same to be and remain on the said demised premises, or replaced with others, or the same are to be paid for by the said party of the second part, his executors, administrators and assigns." The lease also contained the following clause, inserted after the covenant before mentioned: "And it is further mutually covenanted, promised and agreed, that in case of damage by fire to said buildings rendering the same or either of them untcnantable, the same shall be repaired by the said parties of the first part; and while the same shall so remain untenantable by reason of such fire, the rent shall cease for such part of the buildings as shall be so injured."

$\mathbf{X}$. had previously assigned the lease. In a subsequent aetion by $\mathbf{\Lambda}$. s assignee against $\mathrm{A}$. for the value of the improvements, held, $\mathrm{A}$. is not liable. Cronin v. Watkins, 1 Tenn. Ch. 119 (1873).

"As a bill of exchange or other negotiable paper in the hands of an assignee is free from the equities to which it was liable before assignment, so corenants runuing with land, when in the hands of a grantee of the land, are free from the equities which may have existed against the original covenhntor [eorenantee]." Green, P., in Lydiek v. Baltimore \& O. R. R. Co., 17 W. Va. $427,443(18 \$ 0)$. 
'There was an inventory of the tools and chalk stones at the foot of the lease with the respective values annexed; the tools being valued at $\$ 69$, and the chalk stones at $\$ 3000$.

The defendant's covenant was on the back of the lease; it bore the same date, and recited that the lease was executed by the lessors at the request of the defendant; in consideration of which and of one dollar, the defendant covenanted to "become surety for the punctual payment of the rent within reserved and faithful performance of the covenants within contained; and in case of default being made by the said William H. Culver, I promise and agree to and with the said Arthur Hirst, his heirs and assigns, owners of said demised premises within contained, to pay such sum or sums of money as will be sufficient to make up such deficiency in payment of rent, or default in performance of covenants, without requiring any notice of non-payment, or proof of demand being made."

After setting out the lease and covenant, the declaration stated that the lessors Hirst and wife afterwards, to wit, on the first day of June, 1837 , being seized of the reversion, granted and conveyed the same, "subject to and with the benefit of the lease," to the plaintiffs in fee. Breaches were assigned in the several counts of the declaration-1st, for the non-payment of the rent for the whole term; $2 \mathrm{~d}$, for not yielding up the premises at the end of the term in the condition required by the lease, but, on the contrary, having damaged and injured the fixtures; and "certain goods and chattels of the plaintiffs then being in and upon and a part of the said demised premises," being carrierl away and wholly lost to the said plaintiffs; and also that the tools and chalk stones did not remain on the premises, and have not been replaced or paid for as provided in the lease. * * *

JEWETT, J. ${ }^{62} * * *$ Unless the covenant, in relation to the tools and chalk stones, is one which runs with the estate in the land, the action for the breach of it cannot be sustained in the name of the plaintiffs, but must be brought by the lessors in whom the legal interest in the contract is vested. (1 Chitty's Pl. 11, 12, ed. 1812; Willard v. Tillman, 2 Hill, 274.) * * *

Although the parties agreed that the tools and chalkstones mentioned in the covenant, should be considered as part of the premises demised, and should pass therewith, they are nevertheless mere personal chattels, out of which the rent could not issue. It is true, that the yearly value of the demised premises may have been increased by the letting of these articles of personal property; still the rent reserved continwes to issue out of the land alone. In Spencer's case, (5 Co. 17,) it is resolved, thidt "if a man lease sheep, or other stock of cattle, or any other personal goods, for any time, and the lessee covenants for him and his assigns at the end of the time to deliver the like cattle or goods. as good as the things letten were, or such price for them, and the lessee

o2 The statement of facts is abridged and part of the opinion is omitien. 
assigns the sheep over, this covenant shall not bind the assignee; for it is but a personal contract;" and it is added,-_"The same law, if a man demises a house and land for years, with a stock or sum of money, rendering rent, and the lessee covenants for him, his executors, administrators and assigns, to deliver the stock or sum of money at the end of the term, yet the assignee shall not be charged with this covenant, for although the rent reserved was increased in respect of the stock or sum, yet the rent did not issue out of the stock or sum, but out of the land only, and therefore, as to the stock or sum, the covenant is personal and shall bind the covenantor, his executors and administrators who represent him, and not the assignee-and because it is not certain that the stock or sum will come to the hands of the assignee, for it may be wasted, or otherwise consumed or perished, through the lessee; and therefore the law cannot determine, at the time of making the lease, that such covenant shall bind the assignee." See also Newman v. Anderton, (2 New Rep. 226.) * * *63

The statute ( 1 R. S. $747, \S \S 23,24$,) does not make every covenant which may find a place in a lease assignable. The twenty-third section in terms provides that the grantees of any demised lands, tenements, rents, or other hereditaments, or of the reversion thereof, the assignees of the lessor of any demise, and the heirs and personal representatives of the lessor, grantee or assignee, shall have the same remedies by entry, action, distress or otherwise for the non-performance of any agreement contained in the lease so assigned, or for the recovery of any rent, or for the doing of any waste or other cause of forfeiture, as their grantor or lessor had or might have had if such reversion had remained in such lessor or grantor. This statute is but a reenactment of 32 Hen. 8, ch. 34. Spencer's case shows that the English statute was

63 See Smith r. Kellog. 46 V't. 560 (187t).

"The provision regarding the hay was, in substance, that the lessee should leave as much on the farm as was there when lie took possession. The defendant left the required amonnt of hay but some of it was not cut in proper season, and by reason of this was of less value than it otherwise would have been. It is claimed that the plaintiff as successor in interest to the lessor, was entitled to the required amount of hay properly and seasonably harvested according to the rules of good husbandry. This may be so; but the question hece is whether he can recover the damage in an action of covenant l, rongut in his own name. The diminished value of the hay is the only matter now in question. The injury to the soil is covered by another item. We think the defendant's obligation conecrning the hay is not one that touches or concerns the land. It is true that the has to be returned was potentially in the land, and that its quality and condition might depend somewliat on the character of the defendant's husbandry. But in its relation to the defendant's olligation it was nothing more than a personal chattel. The return of the hay was not the payment of rent in lind. It was to le returned to replace like properts which was delivered to the defendant to be consumed in its nse. The agreement to return it was a mere personal olingation. Ser Tilliny L. \& T. 894; Smith v. Kellogg, 46 Vt. 5tio |1s7t]; A]len r. Culver, : Denio (X. X.) 284 [1S46]; Willams r. Earle, L. R. 3 Q. B.

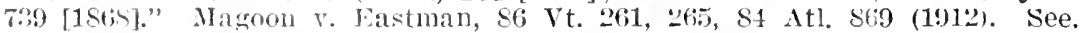

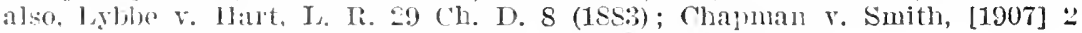
('ll. 97 ; Verlulandk v. Wright, 2:3 Wend. (N. Y.) 506 (1810). 
confined to covenants touching or concerning the thing demised, and did not extend to collateral covenants. The construction contended for here would make all covenants negotiable, or which is the same thing, assignable, if the parties would but insert them in any indenture of demise, which would confound all distinction between covenants real and personal. I think the statute does no more than to transfer the privity of contract of a covenant real, between the lessor and lessee, and does not affect a strictly personal covenant, although it be contained in a lease. (Norman v. Wells, 17 Wend. 136; Willard v. Tillman, 2 Hill, 274.)

It is insisted that the defendant's covenant to guaranty the payment of the rent, was not assignable, so as to enable the plaintiffs to sue in their own names for a breach of that covenant. It is not necessary that the defendant should have taken an interest in the land. In the case cited from the Year Book 42 Edw. 3, the prior and his successors took no estate in the land, yet it was held, that the covenant to sing in the chapel went with the land. When the thing to be done, or omitted, concerns the lands or estate, that is the medium which creates the privity between the plaintiff and defendant. I think the defendant's covenant respecting the rent run with the land, and that therefore the plaintiffs as grantees of the reversion could maintain this action for a breach of that covenant. ${ }^{64}$ (Norman v. Wells, 17 Wend. 136, 149.) The report must be set aside.

Motion granted.

64 Contra: Harbeck v. Sylvester, 13 Wend. (N. Y.) 605 (1S5j).

$\mathrm{X}$., a tenant in possession. executed to $A$., his inndlord, a bond conditioned on learing on the premises in good condition at the termination of the lease. certain specified fixtures; subsequently A.'s reversionary interest in the premises was sold to $\mathrm{B}$. At the termination of the lease. $\mathrm{X}$. failed to surrender the premises and fixtures in good condition. A. broucht action against $x$. on the bond. The court held that the action could not be maintained, saying: "At the time designated for performing the conditions, the estate had rassed to Ralston and Burke under the sheriff's deed. and therefore there was then no right of action in defendant in error. It is well settled that covenants real pass with the land to which they are annexed. to a purchaser at a sale under execution. Rawle on Covenants for Title, 35\%. I have not found any case in which the rule has been applied to a covenant which attached to the land after the sale, and hefore conreyance by the sheriff. as in this case. But it is believed that the principle is applicable to such covenants, and to whaterer estate is acquired by the judsment dehtor prior to the conveyance by the sheriff. Any other rule would divorce the covmant from the land for the benefit of which it was intenderl. and practically annul its obligation. The judgment debtor, not having the estate in the land. can suffer no injury from the breach, and if the grantree in the sheriffs deed cannot sustain an action upon the covenant, it would appear that no one would have such right. It is very certain that the jullyment rlobtor is divested of the right of action, and if it is not extinguisherl, it must lass to the assignee of the land." Hayes r. New Fork Gold IIin. ('o. of Colorado. 2 Colo. 278,280 (1874). 


\section{WALSH et al. v. PACKARD.}

(Supreme Judicial Court of Massachusetts, 1896. 165 Mass. 189, 42 N. L. 57 , 40 L. R. A. 321, 52 Am. St. Rep. 50S.)

Holares, $J$. This is an action upon a covenant appended to a lease, brought by the administrators of Walsh, the lessor and covenantee. 'The only objection urged to the plaintiffs' recovery is that, if the obligation of the covenant did not cease with the life of Walsh, his heirs, and not his administrators, were the proper persons to sue upon it. The covenant is as follows:

"In consideration of the letting of the above-described premises and one dollar to me paid, the receipt of which is hereby acknowledged, I do hereby become surety for the prompt and full payment of the rent and performance of the covenants as specified in the above lease to be paid by Ida E. Small to John Walsh. Witness my hand and seal, the twenty-eighth day of November, A. D. 1892.

"Wm. A. Packard. ......................... [Seal.]"

The contract raises a question of construction as well as a question of law when the construction is settled. It does not mention heirs, executors, administrators, or assigns, and courts are a little slower to enlarge by implication the undertaking of a surety or guarantor than they are to enlarge that of the principal party. But perhaps the word "surety," although seemingly inartificially used, coupled with the nature and object of the contract, makes the collateral indertaking as large as the principal one. We will assume that it is to be read in the broader sense. We have no doubt that it continues to run after the death of the original covenantee. But, supposing heirs, executors, and assigns to have been mentioned, it seems to be settled in this commonwealth that the instrument would not work like a letter of credit offering a new contract to the successors of Walsh (Saunders v. Saunders, 154 Mass. 337, 338, 28 N. E. 270; Abbott v. Hills, 158 Mass. 396,33 N. E. 592), if that would nrake any difference when there has been no purchase on the faith of it; and therefore, apart from other reasons, the only ground on which the heirs can be preferred to the administrators as the.proper plaintiffs is that the covenant runs with the land, or, more accurately, runs with the estate of the covenantee, and that the heirs are successors to that estate. The covenant is collateral to the lease (Virden v. Ellsworth, 15 Ind. 144), and is not affected by St. 32 Hen. I'III. c. 34; Harbeck v. Sylvester, 13 Wend. 608. See Jones v. Parker, 163 Mass. 564, 568, 40 N. E. 104t, 47 Am. St. Rep. 485.

In Allen v. Culver, 3 Denio ( $N$. Y.) 284, 301, a similar covenant was held by the supreme court of New York to pass to assigns, but the point was decided without discussion on the supposed analogy of Pakenham's Case (a covenant on the part of a convent that the convent should sing every week in a chapel in the plaintiff's manor), Y. B. 42 
Edw. III. p. 3, pl. 14. The reference to this case showed that the court did not have in mind the distinction pointed out by Lord Coke (1 Coke, 120a, 122b), and discussed in Norcross v. James, 140 Mass. 188, 2 N. E. 946, between those covenants which create, or follow the analogy of, easements, and go with the land even to disseisors, anci those pure contracts, like covenants for title, upon which no one can sue except parties and privies. Pakenhan's Case was of the former class. The argument for the plaintiff in that case of most weight in the mind of the court was that the plaintiff was tenant of the land, and that the service claimed was a thing annexed to the land, being of a kind that could be created by prescription, or, as it was stated by Fitzherbert, every one who has the land shall have the covenant. Fitzh. Abr. "Covenant," pl. 17. Those who are curious to verify the fact assumed in Pakenham's Case, that such services from a stationary ecclesiastical corporàtion might be due by prescription, may consult Y. B. 22 Hen. VI. p. 46, pl. 36; Id., 21 Hen. VII. p. 5, pl. 2; Williams' Case, 5 Coke, 72b, 73a; Slipper v. Mason, Nelson's Lutw. 43, 45; Rast. Ent. pl. 2b. See, further, Middlefield v. Knitting Co., 160 Mass. 267,35 N. E. 780.

The case at bar, on the other hand, is more analogous to the covenants for title; for, although rent savors of the realty, any warranty or insurance of rent is a purely personal contract, of which another than the original contractee can avail himself only on principles of contract. The true question is whether such a guaranty is wholly analogous to covenants for title. In the case of some of these, at least, assigns of the covenantee are treated as privy to the contract, and can sue in their own names; and, when this is so, heirs also can sue in their own names for breaches happening while they hold the estate of the covenantee. Lougher v. Williams, 2 Lev. 92; Rawle, Cov. (5th Ed.) $\S 316$.

But this right thus given to assigns only shortened up the old process by which, within certain limits, each purchaser looked in turn to his vendòr to make good the warranty imported by a sale. It is a doctrine of tradition and history (Norcross v. James, 140 Mass. 18? 2 N. E. 946), and cannot be extended to new cases by analogy without legislation. The old cases, so far as we know, even the most extreme, are all cases of warranties or covenants by owners of the land. Fitzh. Nat. Brev. 145c. Lord St. Leonard says that "there appears to be no direct authority that a stranger to the land can enter into covenants respecting it, which will run with the land in the hands of assignees." V. \& P. (14th Ed.) 587. And, although he seems to have missed the distinction between the two classes of covenants to which we have adverted, this statement we believe to be correct with regard to covenants for title and any others, if others there be, which are governed by the same rules. King v. Wight, 155 Mass. 444, 447, 29 N. E. $6+4$. 
We do not argue from the rule that new and unusual incidents are not to be annexed to land, because that rule seems to belong rather to the law of easements and the like than to the class under discussion. See Norcross v. James, 140 Mass. 188, 192, 2 N. E. 946.

It is true, no doubt, that the heirs are the only persons interested in the rent, and therefore are the only persons who suffer substantial damages by a failure to pay it. We assume that, if the administrators recover substantial damages, they will receive them as trustces for the heirs. We agree, as suggested by Lord Ellenborough in a different case, that a recovery by them would bar the heirs from recovering at all. But we do not agree to his further suggestion that they could recover, at most, but nominal damages. Kingdon v. Nottle, 1 Maule \& S. 355,362 . At the present day a trustee may recover damages to the extent of the interest of his cestui que trust. Drummond v. Crane, 159 Mass. 577, 580, 35 N. E. 90, 23 L. R. A. 707, 38 Am. St. Rep. 460; Lloyd's v. Harper, 16 Ch. Div. 290 . Executors or administrators represent the person of the deceased "more actually" than do the heirs. Co. Litt. 209a; Bullard v. Moor, 158 Mass. 418, 425, 33 N. E. 928. Unless we are prepared to hold that assigns could sue in their own names upon this contract, we ought to adhere to the general rule, and allow the administrators to maintain the action. For the reasons which we have given, we are of opinion that the plaintiffs can maintain this suit. In Harbeck v. Sylvester, 13 Wend. (N. Y.) 608, 609, not noticed in Allen v. Culver, an opposite decision was reached from that in Allen v. Culver. See, also, as to collateral covenants, Raymond v. Fitch, 2 Cromp., M. \& R. 588, 599, 5 Tyrw. 985, 996.

\section{Judgment for the plaintiffs. ${ }^{65}$}

65 See Webb v. Russell, 3 T. R. 393 (17๕9), nost, p. 566.

A., owning land in fee, granted to $\mathrm{X}$. for a term of years the right to dic clay in a specified part of the land. $X$. covenanted with $A$. and his assigns. inter alia, to pay compensation for all inclosed lands in the said specified nart that should be damaged by the digging and that he would keep the works in repair and deliver them up in good condition at the end of the term. A. then convered to B. all lis estate. Held, B. may maintain an action against $\mathrm{X}$. for breaches of the covenants occurring after the converance by A. to B.; the St. $32 \mathrm{H}$. S, c. 3t, covering incorporeal as well as corporeal interests. Martyn r. Williams, 1 H. \& N. S17 (1857). Acc.: Norral v. Pascoe. 34 J. J. N. S. Ch. 82 (1S61); Hastings v. R. R., [1898] 2 Ch. fitt; I ouisville \& N. R. Co. v. Illinois Cent. R. Co., 174 Ill. 448, 51 N. E. 824 (189S); Jordan v. Indianapolis Water Co., 159 Ind. 337,64 N. E. 650 (190:). if e Portmore r. Bunn, 1 B. \& C. 694 (1S2s).

A. "leaserl" to $X$. the privilege of sinking oil and gas wells in A.'s land and transporting thence the oil and gas; X. covenanting to supply gas to $\mathrm{A}$. for the use of A.'s house standing on the land. A. assigned all his interest to B., and $\mathrm{X}$. to $\mathrm{Y}$. Y. did not furnish gas as stipulated. Held, B. has a cause of action against $Y$. Indiana Natural Gis \& Oil Co. v. Hinton. 15? Ind. 398, 64 N. E. 2224 (1902). Accord, where B.'s house is situated upon another tract of lind never owned by A. Hamert v. IIole Natural Gas Co., 76 W. Ya. 207,84 S. E. 770 , L. R. A. $1915 \mathrm{E}, 570(1915)$. 


\title{
SECTION 2.-AS BETWEEN OWNERS IN FEE
}

\author{
I. AgreENENTS UNDER SEAL
}

\author{
(A) Formalities
}

\section{PAKENHAM'S CASE.}

(Court of Common Pleas, 1368. Y. B. 42 Edw. III, 3, pl. 14.)

One Lawrence Pakenham brought a writ of covenant as heir against a prior, and alleges by his writ that he does not keep a covenant made between one J., his ancestor, towit, the grandfather of the plaintiff, whose heir he is, and one of his predecessors, because the prior and the convent ought to sing every week in a chapel in his manor of $\mathrm{K}$., for himself and his servants, etc.

Belknap. The plaintiff and his servants are not living in the manor. Therefore judgment upon the writ.

Cavendish. This goes to the action, therefore if you wish this for your answer, we desire an imparlance.

Belknap. The deed which you have proffered states that he ought to sing for him and his servants and since he and his servants do not live in the manor, you cannot maintain this action.

Cavendish. Then this goes to the action. Therefore if you wish to answer thus, we desire an imparlance.

And then Belknap did not dare to demur, but said that the plaintiff had an older brother who was heir to the ancestor, to whom the action should be given, wherefore judgment, if you, who are the younger son, and not the heir, ought to have an action.

Cavendish. The plaintiff is tenant of the manor where the singing ought to be done; in which case it is reasonable that the action should be maintained by him. Wherefore judgment, and we demand our damages.

Belknap. And since you have brought your action as heir, and you have an older brother, judgment, if you have an action as heir, etc.

Ad alium diem :

Cavendish said that this same J., the great-grandfather of the plaintiff enfeoffed one G. of M. of the same manor; the said G. enfeoffed the plaintiff, and one Alice, his wife, of the same manor to themselves and the heirs of their two bodies begotten, and for default of issue, the remainder to J. and his heirs. So the plaintiff is tenant of the manor, and the action belongs to no one else except him. Wherefore judgment, and we pray our damages. And we also say that since the feoffment, the singing has been done from time whereof memory is not to the contrary: 
Belknap. And since you have brought this action as heir, and yet it is not denied by you that there is a nearer heir to him who made the covenant, to whom the action should rather be given than to you, we consequently pray that you should be barred.

Cavendish. And we, judgment; since we are tenant of the manor by purchase, and privy to the ancestor who made the covenant, and also the services have been done from time whereof memory is not to the contrary. Wherefore judgment.

Belknap. Altho he is privy in blood, and altho he has bought the land, since he has brought this action as heir, and he is not heir, and the action of covenant is not given to anyone except to him who made the covenant or his heir, therefore we do not understand that action, etc.

Finchden. I have seen this in terms adjudged here: That two parceners made a division of the land between them, and the one parcener made a covenant with the other to acquit her and her heirs of a suit which was due from the land, and the parcener aliened the land to a stranger, and then the suit was in arrear, and the stranger brought a writ of covenant against the parcener to acquit him of the suit. And the writ was maintained notwithstanding that he was a stranger to the covenant. And so here.

Belknap. I admit it in your case because the acquittance fell upon the land and not upon the person; and here the covenant is to the person.

Finchden. And if you admit that this is law, then all the more strongly in the other case, for in the case that I mentioned of the suit, this was maintained, because he was tenant of the land, from which the suit was due, and so it is here, he is tenant of the manor where the chapel is, and it ought to be done in the chapel. Wherefore, etc.

Wichingham. If the king grants warren to another, who is tenant of a manor, he shall have warren of all the manor, and if he aliens the manor, still the warren does not pass by the grant, because it is not appendant to the manor, and it seems no more so here, since the services are not appendant to the manor.

Thorpe to Belknap. There are some covenants upon which no one shall have an action except the party to the covenant or his heir, and other covenants have inheritance in the land, so that he who has the land by alienation or in any other manner shall have an action of covenant: and when you say that he is not heir he is privy in blood and may be heir; and so he is tenant of the land, and this is a thing which is annexed to the chapel, which is within the manor, and so annexed to the manor: and also he has said that the services have been done from time whereof memory is not to the contrary, by which it is reasonable that this action should be maintained.

Belknap. He never counted upon such a prescription, in his count. 
Thorpe. He did so count, and we remember it. And it was adjourned.

And it was said that if I lease land to a man for the term of his life rendering certain rent, and I grant the reversion of the same land to another and the tenant attorns, that the grantee shall have the rent notwithstanding that he has no specialty, and this was not denied, etc.

\section{MORSE v. ALDRICH et al.}

(Supreme Judicial Court of Massachusetts, 1837. 19 Pick. 449.)

This was an action of covenant. The cause was tried before Putnam, $J$.

In 1794, Stephen Cook, the defendants' ancestor, conveyed to William Hull, in fee, a tract of land in Watertown, containing about thirteen acres; with the privilege of using and improving the land and mill pond west of the same tract, for the purpose of fish ponds, baths, etc., within certain bounds described, including a portion of the grantor's mill pond; and the "full liberty of ingress, egress, and regress to and from any part of the said described land and water, to dig out and carry away the whole or any part of the soil, etc.; to build such causeways and dams as may be necessary to divide the same into six separate and distinct fish ponds."

Hull conveyed the same premises to the plaintiff.

Afterward, in November, 1809, an agreement under seal was made by and between Cook and the plaintiff, in which, in consideration of the covenants on the part of the plaintiff, Cook covenants with the plaintiff, his heirs and assigns, "that he will draw off his said pond when thereto requested by said Morse, in the months of August and September, not exceeding six working days in the whole, in each year, for the purpose of giving said Morse an opportunity of digging and carrying out mud, etc., as long as there may be mud in said pond, and no longer." It was upon this clause that the present action was brought. In the same agreement are other covenants, some concerning Morse's land and Cook's mill pond, and some concerning the discontinuance and costs of certain actions then pending between Cook and Morse. Cook does not covenant, in express terms, for his heirs or assigns.

It was contended by the plaintiff, that the covenant above recited was a covenant running with the land, and therefore binding upon the defendants, who derive their title to their estate as heirs of Cook, as to four fifths thereof, and as assignees by quitclaim, of one of his heirs: as to the other fifth. And this construction was supported at the trial, against the objection of the defendant. The plaintiff claimed the right to take the mud, etc., for the purpose of manuring his land. 
The plaintiff requested the defendants to draw off the pond in September, 1835, in order that he might get out the mud, but the defendants refused. ***

The questions reserved were, 1 . Whether the covenant ran with the land, and was binding upon the defendants as the heirs of the covenantor; 2. Whether the privilege extended to the whole pond, or was restricted to the plaintiff's own land under the pond. ${ }^{66}$

WiLDE, J., afterward drew up the opinion of the Court. The defendants are charged as the heirs of Stephen Cook, their ancestor, with the breach of a covenant made by him with the plaintiff, and the question submitted to the Court is, whether this covenant is such as is binding upon the heirs of the covenantor? And the decision of this question depends on another, namely, whether the covenant is a real covenant, running with the land, which the defendants inherit from their ancestor, the covenantor?

It is generally true, as has been argued by the defendants' counsel, that, by the principles of the common law, the heir is not bound by the covenant of his ancestor, unless it be stipulated by the terms of the covenant, that it shall be performed by the heir; and unless assets descend to him from his ancestor sufficient to answer the charge. Platt on Cov. 449; Dyer, 14a, 23a; Barber v. Fox, 2 Saund. 136. If therefore the heir be not named in the covenant, it will be binding only on the covenantor, his executors and administrators, although the heir may take by descent from the covenantor assets sufficient to answer the claim.

But this principle is not to be applied to real covenants running with the land granted or demised, and to which the covenants are attached for the purpose of securing to the one party the full benefit of the grant or demise, or to the other party the consideration on which the grant or demise was made. Such covenants are said to be inherent in the land, and will bind the heir or the assignee though not named. For as he is entitled to all the advantages arising from the grant or demise, it is but reasonable that he should sustain all such burdens as are annexed to the land. Platt on Cov. 65.

When a covenant is said to run with the land, it is obviously implied that he who holds the land, whether by descent from the covenantor, or by his express assignment, shall be bound by the covenant. The heir may be charged as an assignee, for he is an assignee in law, and so an executor may be charged as the assignee of the testator: Derisley v. Custance, 4 T. R. 75; Jac. Law Dict. Assigns. And a devisee may be charged in the like manner, and is entitled to the benefit of any covenant running with the land. Kingdon v. Nottle, 4 Maule \& Selw. 53.

If then the covenant in question runs with the land, it is clear that the defendants are liable; and it is immaterial whether the heirs and 
assigns of the covenantor are named in the covenant, or not, quia transit terra cum onere. Bally v. Wells, 3 Wils. 29.

To create a covenant which will run with the land, it is necessary that there should be a privity of estate between the covenantor and covenantee. Spencer's case, 5 Co. 16; Cole's case, Salk. 196; 3 IVils. 29 ; Webb v. Russell, 3 T. R. 402; Keppell v. Bailey, 2 Mylne \& Kees, 517; Kyryan v. Arthur, 1 Barn. \& Cressw. 410. In these cases, and in most of the cases on the same subject, the covenants were between lessors and lessees; but the same privity exists between the grantor and grantee, where a grant is made of any subordinate interest in land; the reversion or residue of the estate being reserved by the grantor, all covenants in support of the grant, or in relation to the beneficial enjoyment of it, are real covenants and will bind the assignee.

This principle is decisive of the present action. It appears by the deed of Stephen Cook, the defendants' ancestor, to William Hull, that the former conveyed to the latter a tract of land adjoining the mill pond in question, "with the full and free privilege of using and improving the said mill pond within certain limits, with the full liberty of ingress and egress, to dig out and carry away the whole or any part of the soil in said pond, and to divide the same pond, as described in the deed, into six separate and distinct fish ponds."

IVilliam Hull conveyed the premises to the plaintiff; after which, disputes arose between Cook and the plaintiff relative to their respective rights, and for settling the same they entered into sundry covenants in relation to said grant, and qualifying the same; for the breach of one of which this action was brought. At the time these covenants were made, there was a privity of estate between the parties in that part of the mill pond described in the grant to Hull. The covenant in question was made in reference to the plaintiff's right and interest under that grant, and was manifestly intended to confirm it, and to secure the plaintiff in the enjoyment thereof. This covenant therefore, upon the principles stated, is a real covenant, running with the land, and is binding on the heirs of the covenantor.

Judgment on the verdict. ${ }^{67}$

67 In Gilmer v. Mobile \& M. Ry. Co., 79 Ala. 560, 574 (5S Am. Rep. 628) (1S55) - for facts, see post, p. 452-Somerville, J., said: "We think, in this case, the plaintiff retained an interest in tire land conreged to the assignor of the defendant, which was in the nature of an easement. He not only imposed a servitude upon the land, by a prohibition against the sale of ardent spirits on the premises, but retained the right to cultivate it under certain conditions and circumstances; thus retaining an interest in the realty which would preserve the privity of estate in it and to which the covenant of defendant would attach, or become annexed."

A. owned land with a water privilege appurtenant thereto. He conveyed part of the land and a proportionate water privilege to $\mathbb{X}$. The race through which the water ran went first to $\Lambda$.'s mill, then to $X$.'s. Five dass after the conveyanee, $\mathbf{A}$. and $\mathbf{X}$. covenanted that for the improving of the water power they should ereet and maintain a dam and flume; that $\mathrm{X}$. would pay a proportionate part of the cost of election and repairs. A. so built. X.'s interest became rested in $\mathrm{Y}$. The dam needed revairs, which $\mathrm{A}$. made. He 


\section{HURD v. CURTIS et al.}

(Supreme Judicial Court of Massachusetts, 1837. 19 Piek. 459.)

Action of covenant. The declaration recites that in 1816, an indenture of four parts was made between. Simon Elliot and Solomon Curtis, of the first part, Moses Grant, of the second, Hurd, the plaintiff, and Charles Bemis, of the third, and John Ware, of the fourth, owners of the mills and mill privileges on the upper dam of Newton Lower Falls, to wit, two paper-mills and a saw-mill, with their mill privileges, on the Needham side of the river, and four paper-mills, one fulling-mill and one saw mill with their mill privileges, on the Newton side, for the purpose of fixing the quantity of water which the several parties should have a right to draw at their respective mills and mill privileges, to regulate the use of the same, and for some other purposes therein set forth, did for themselves, their heirs, administrators and assigns, respectively covenant and agree to and with each other and their respective heirs, administrators and assigns, that the six papermills and the fulling-mill, should have the first and exclusive right to the use of the water, when no more ran to the paper mills and fullingmill then erected and used, or that might be erected and used on the six paper-mill privileges and fulling-mill privilege, than should be necessary to work them to advantage, and that the saw-mill owned by Hurd and Bemis should have the second right of water, or the first right to the overplus water ; that all the paper-mills and the fulling. mill, then erected or that might be erected, should be altered and built with breast-wheels, each for a power equal to carrying two paper engines, in the paper-mills, and for a power equal to carrying a fulling and wool-carding machine, in the fulling-mill, that all the gates of all the mills or breast-wheels, should be drawn from the same level, and should be on a level with some permanent mark, to be made by consent of the parties; that the respective parties, and their heirs and assigns, should have a right to substitute and erect any other mills, works or

lrought action against $Y$. to recover his proportionate part of the cost thereof. Held, $\mathbf{I}$. is not liable. The court said: "Did the plaintiffs in thia rase have any estate in the land owned by the defendant at the time this acrement was entered into? It is not even claimed they had. Nor did the arreement itself create any such interest. 'There is no attempt in it to "onvey any estate to them, nor a wold of grant in the whole instrument. * * * is the grantors had no estate in the land owned by tile defend. ant when the agreement was entered into, but were mere strangers to it, the ease comes directly within the rule announced by Lord Coke, and very miformly followed both by the Fnglish and American courts since his time: Wehb r. Rusitell [3 Term, 393 (1789)] and Stokes r. Inussel], Id. 67s [1790]: Hurd v. Curtis, 19 Pick. [Mass.] 459 [18:3]; Inhabitants of Plymouth $v$. Carver, 16 Pick. [Mass.] 18. [1S:4]. See, also, an elaborate review of the jucstion in 1 Smith's Lead. Cas., note to Spencer's case, 2 Wash. I. Y. 16 Plck. 183 [1S:4]." Wheeler v. Schad. 7 Nev. 204, 210 (1871).

Siee, also. Evansille \& S. I. Traction Co. v. Evansville Belt R. Co., 44 Ind. Alp. 15j, 87 N. E. 21 (1909). 
machinery, in the place of those then erected, provided the new mills, works and machinery shouid require no greater power than the mills, works and machinery which the parties had a right to erect and use by virtue of the indenture. The declaration then avers that, at the time of the making of the indenture, the plaintiff was the owner of one undivided half of the saw-mill on the Newton side, and of the first right to the overplus water, and that Bemis was the owner of the other undivided half; that in 1817, Bemis conveyed his half to the plaintiff; that the two paper-mills and paper-mill privileges on the Newton side, which belonged to Elliot and Solomon Curtis, and the fulling-mill, with the privilege of water to work a fulling and wool-carding machine, which belonged to Ware, have, since the making of the indenture, been cunveyed to the defendants, and these two paper-mill privileges and the fulling-mill privilege have, for eleven years last past, been used and occupied by the defendants; that the defendants had due notice and full knowledge of the covenants, and agreements in the indenture set forth, on the part of Ware, Elliot and S. Curtis, and their respective heirs, administrators and assigns, to be kept and performed, and that the same are binding upon the defendants; yet that the defendants have erected and used and now use, on their two paper-mill privileges, breast-wheels constructed for a power much more than equal to carrying two paper engines in each of their paper-mills, to wit, for a power equal to carrying six paper engines in each of their paper-mills, and have actually carried the same, and on the fulling-mill privilege they have erected and used breast-wheels for a power more than equal to carrying one fulling and wool-carding machine, to wit, for a power equal to carrying four fulling and wool-carding machines, and have actually carried the same: and have also substituted and actually used in the place of the mills, works and machinery used on the two papermill privileges and the fulling-mill privilege, at the time of the making of the indenture. others which require a much greater power to carry the same than those which the defendants have a right to erect and use thereon by virtue of the indenture: whereby the plaintiff has lost the use and benefit of his saw-mill and of his first right to the overplus water, as secured to him by the indenture.

The defendants demurred.

Vir.DF, T., ${ }^{n s}$ afterward drew up the opinion of the Court. The plaintiff claims damages of the defendants for a breach by them of certain covenants contained in an indenture made by and between the plaintiff and several other persons, who were owners of mills on Charles river, at Newton Lower Falls, so called, the object and intent of the indenture being to limit and regulate the use of the waters of the river at their respective mills. The defendants were not parties to the indenture, but they have since purchased of two of the covenantors

68 Part of the opinion is onitted.

Big.Rights-2s 
their mills mentioned in the indenture, and the question is, whether they are bound as assignees by any of the covenants between the contracting parties, as is alleged in the declaration.

To make a defendant liable to an action of covenant, there must be a privity between him and the plaintiff. Bally v. Wells, 3 Wils. 29. As there is no privity of contract between the plaintiff and the defendants, it follows that the defendants are not liable in this action, unless there is a privity of estate between them. Where such a privity exists between the covenantor and the covenantee, and the covenantor assigns his estate, the privity thereby created between the assignee and the other contracting party, renders the former liable on all such covenants as regulate the mode of occupying the estate, and the like covenants concerning the same. And so if the covenantee assigns his estate, his assignee will have the benefit of similar covenants. These covenants are annexed to the land and run with it. But if there is no privity of estate between the contracting parties, the assignee will not be bound by, nor have the benefit of any covenants between the contracting parties, althongh they may relate to the land he takes by assignment or purchase from one of the parties to the contract. In such a case, the covenants are personal and are collateral to the land.

Covenants for title may be considered as an exception to the general rule, and the reason for the exception is very strong; for nothing can be more manifestly just, than that the party who loses his land by a defect of title, should have the benefit of the covenants which were intended to secure an indemnity for the loss. Such a covenant is dependent on the grant, is annexed to it, as part and parcel of the contract, and runs with the land in favor of the assigns of the grantee or covenantee; but there is no exception to the rule, that no covenant will run with the land so as to bind the assignee to perform it, unless there were a privity of estate between the covenantor and covenantee. "It is not sufficient," as Lord Kenyon remarks, in Webb v. Russell, 3 T. R. 402, "that a covenant is concerning the land, but in order to make it run with the land, there must be a privity of estate between the covenanting parties." And so the law has been laid down in all the cases turning on this point, ever since Spencer's case. * * *

Considering this principle as well established by the cases cited, and many others not adverted to, we are of opinion that this action cannot be maintained, as there was no privity of estate between the covenanting parties. Their estates were several, and there was no grant of any interest in the real estate of either party, to which the covenants could be annexed. The stipulations in the indenture cannot be construed as grants and covenants at the same time. If they were grants, then an action of covenant is not the proper remedy for the violation of them; and if covenants, the assignee is not bound, for want of privity of estate between the parties.

Nor can one covenant be considered as a grant, and the other as a covenant, for the stipulations are mutual, and if one is to be construed 
as a grant, the other should be construed in the same manner. If the stipulation that one party is to have the first preference of the use of the water for certain mills, is to be construed as a grant, the like stipulation, that the other party shall have the second preference, cannot consistently be construed as a covenant. And we ought not to give a strained construction to the indenture, for the purpose of extending the obligation of the contract to those who were not parties thereto. All the stipulations are covenants in form, were doubtless considered as such by the contracting parties, and must be so construed. As such they are mere personal covenants, according to all the authorities, and cannot be otherwise construed, without determining that all covenants concerning lands are real covenants, and binding on the assignee, however remote; which certainly cannot be maintained, either upon authority or upon principle. Such an extension of the obligation of covenants might be productive of great mischief and confusion of rights and obligations of the purchasers and owners of real estate.

Declaration adjudged insufficient. ${ }^{68}$

\section{HORN v. MILLER et al.}

(Supreme Court of Pennsylvania, 1890. 136 Pa. 640, 20 Atl. 706, 9 L. R. A. 810.)

Clark, J. ${ }^{70}$ This action was brought to recover damages for the diversion of the water of Wills creek, from the channel through which the plaintiff supplied the wheel of his grist-mill, near Hyndman, in Bedford county. It appears that the waters of Wills creek divide at a point about a mile above the plaintiff's land, (whether from artificial or natural causes does not appear,) and thence proceeds in two channels, one by the plaintiff's mill, and one by the defendants' mill, to a point a short distance below both mills, where a junction is again effected. It also appears that, in the year 1852, John Miller owned. the land now owned by the defendants, and also the land adjoining, upon which the stream divides, now owned by Jacob Evans, and that Enoch Cade was the owner of some 42 acres in two adjoining parcels, one containing 37 acres, more or less, part of the New Bridgeport tract, the other containing about 9 acres, known as the "Carpenter Lot."

The appellant's contention is that the extent of his right is fixed by an agreement dated July S, 1852, between John Miller and Enoch Cade, who were thus the predecessors in title to the respective premises involved in this controversy. In the year 1852, an action was pending in the court of common pleas of Bedford county in which Enoch Cade

6a See Lawrence v. Whitney, 115 N. Y. 410,22 N. E. 174,5 L. I. A. 417 (1859).

70 The statement of facts and part of the opinion are omitted. 
was plaintiff, and John Miller defendant. The action was brought to recover damages for the diversion by Miller of the water of Wills creek to his saw-mill, on one channel of the stream, to the prejudice of the right of Cade, who was the owner of a mill-site, on the other channel. The matters in controversy in this suit were settled according to the terms of the agreement mentioned. By this agreement it is provided, in substance, as follows: Cade, "his heirs, executors, administrators, or grantees," were conceded the right to use and enjoy the "water right or power" for two wheels, of any capacity and size he or they might see proper to construct, on either of the lots mentioned as belonging to him, "without let, hindrance, or diversion by said Miller, his heirs, executors, administrators, or grantees." When there was any surplus water, "over and above what may be needed for the full, free, and uninterrupted enjoyment of the two wheels," Miller was to have thereof what is sufficient for the full and free use of his sawmill, "not requiring, using, or diverting more" than was necessary for that purpose. The rest of the water of said creek (and there was to be no unnecessary waste of the water by either party) was to be used and enjoyed by Cade. The concluding clause of the contract is as follows: "Said Miller is to have a flood-gate erected at the mouth of his head-race, and shut the same down tightly and securely when the said creek does not furnish more than enough for the said two wheels of said Cade, as aforesaid, and also at all times else when he is not using his own mill, and at all times is not to interfere in any way with said two wheels, as aforesaid, or the rest of said, water, over and above his own, belonging to said Cade as aforesaid."

There is no dispute as to the proper construction of this agreement. There is no ambiguity of expression, or uncertainty of meaning, alleged, but the legal effect of it is what is most in dispute. It is certainly clear that the suit pending in 1852 was for redress of injuries for an invasion of Cade's right as a riparian owner. The agreement was made in adjustment of Cade's right as such. Miller had no right by artificial means, to withdraw the water from Cade's use. He was restricted in his use and enjoyment of the water to the natural flow, and the foundation of the action was that the natural condition of the stream had been interfered with. The agreement was virtually a recognition of the superior claim of Cade, for his right was distinctly recognized and entitled to a preference, and was intended to be protected under the terms of the agreement. But the right which was thus protected was nevertheless his right as a riparian owner, the extent of which, in view of all the facts and circumstances, was declared and established between the parties, their heirs, executors, administrators, and assigns, in the terms of the contract.

The right to reasonable use of water in its natural flow, without any diversion of it from its ordinary channel by artificial means, is incidental to the ownership of the land through which it flows, and the extent to which it may be used and applied affects the use and 
consequent value of the land itself. These covenants, therefore, relate to the land of the respective parties, or to the enjoyment of the land which they had in possession in fee, and were to be performed upon and in connection with its use and enjoyment. The present parties litigant have, in part at least, the same lands respectively to which the agreement relates, also in fee. The covenants were by the covenantors for the mutual benefit of themselves, their heirs, executors, administrators, or grantees, and the present owners, holding the land by conveyance from the covenantors respectively, under the law of this state, are in privity of estate with them respectively. There was no privity of estate between the contracting parties, but the covenants being in adjustment of their respective rights to the use of the water of Wills creek, must be construed as a mutual benefit to, and not as a burden upon, the lands of either.

We are of opinion, therefore, that the covenants in question run with the land, and define the rights not only of the parties thereto, but of their respective heirs and assigns. To the general rule that between the covenántor and covenantee there must be such privity of estate as would formerly have given rise to the rule of tenure, there are in this state, and perhaps in some of the other states, well-recognized exceptions. Covenants capable of running with an assignment of a present estate in land may, it seems, have that capacity in certain cases, although no estate passes between the covenantor and covenantee at the time of covenant made. The obligation of contracts is, in general, limited to the parties making them. Where privity of contract is dispensed with, there must ordinarily be privity of estate; but justice sometimes even requires that the right to enjoy such contracts should extend to all who have a beneficial interest in their fulfillment, not to impose a burden upon an ignorant and innocent third person, but to enable purchasers of land to avail themselves of the benefit to which they are in justice entitled. The character of a covenant of this kind must depend upon the effect of the entire agreement of which it is a part, and, where the benefit and the burden are so inseparably connected that each is necessary to the existence of the other, both must go together. The liability to the burden will be a necessary incident to the right to the benefit. ***

The effect of the agreement of 1852 was therefore to adjust and fix the rights of the parties thereto, and of their heirs and assigns. It is of no consequence that in the deeds constituting the chain of title from Cade to Horn no mention of this agreement is made, or of the rights accruing therefrom. The right passes as appurtenant to the land. As the assignee of the land from Cade in fee, Horn has a right to enjoy the bencfit of the contract which runs with it. This action is trespass upon the case, for diversion of the water to the prejudice of the plaintiff's rights as a riparian owner, which, in view of the alleged previous artificial diversion of the waters of the stream, were fixed and determined by the agreement of 1852 . Trespass was the proper 
zemedy. The agreement of 1852 established the rights of the parties, and the covenants were to that effect merely. The agreement was equivalent to a grant. Whatever may be conveyed by grant may be secured by covenant in this form. No one has ever supposed before, as was said in Lindeman v. Lindsey [69 Pa. 93, 8 Am. Rep. 219], supra, that upon a grant by deed of an easement or privilege upon land, or land covered by water, of one man to another, the remedy for disturbance of such easement or privilege was an action of covenant upon the deed. Take a common case of a grant or reservation of a right of way. Surely an action on the case may be maintained by the grantee for the obstruction of it, as well as against the grantor and those claiming under him as against strangers. The baoks are full of such cases, in which no such point was made. Citing Watson v. Bioren, 1 Serg. \& R. 227, 7 Am. Dec. 617; Kirkham v. Sharp, 1 Whart. 333, 29 Am. Dec. 57 ; Jamison v. McCredy, 5 Watts \& S. 129; Van Meter v. Hankinson, 6 Whart. 307 ; Ebner v. Stichter, 19 Pa. 19.

It is true that Horn is the assignee of part only of the 44 acres held by Cade, to which this covenant is applied, but his rights as a riparian owner are in no way impaired by this. If after the water leaves the tail-race of his mill others avail themselves of its power, we cannot see how this can affect Miller. But non constat that any other wheel will be placed on any other part of Cade's tract. One thing is certain,- that the mere apprehension of this cannot excuse Miller for diverting the water of the stream, in violation of the contract. It will be time enough to provide for this contingency when it happens. We are of the opinion that the learned judge of the court below erred in entering judgment for the defendant non obstante veredicto.

The judgment is therefore reversed, and judgment is now entered on the verdict for the plaintiff for $\$ 52 .{ }^{71}$

71 See Shaber v. St. Paul Water Co., 30 Minn. 179, 14 N. W. S74 (1SS3).

In Huxthal v. St. Lawrence Boom \& Lumber Co., 53 W. Va. S7, 44 S. E. 520. $97 \mathrm{Am}$. St. Rep. 954 (1903), the defendant had covenanted with one B. H. to maintain for five years certain dams that supplied water for a race that ran thru the lands of the defendant and of $\mathbf{B}$. H.; B. H. corenanting in return therefor to pay the defendant $\$ 75.00$ a year, "and the said obligation [to pay \$75.00] shall be * * * a covenant running with the land." An option was given to B. H. "his heirs, representatives, or assigns" to extend the agreement by giving notice to the clefeudant. B. H.'s interest lassed to J. H., who gave due notice of an extension of the agreement, and marle one subsequent annual payment of the $\$ 75.00$. The defendant then lefused to keep up the dams as provided in the covenant, and $\mathrm{J}$. $\mathrm{H}$. brought action for this breach. Brannon, J., said: "It is true that this corenant has one element of a corenant real in the fact that it benefits the estate of the covenantee, the mill property; but it lacks another material element -privity in estate-as the company convejed no interest in the mill, but merely made a personal obligation on the company touching the mill. So this coveluant is not, in its illherent nature, a real covenant. But loes its language make it such? The agreement makes the obligation of Hurxthal to pay for maintaining the dam one running with the land. It seems, under the law above stated, that this would not, perhaps, make it a corenant real; but it was rlearly a lien in its terns as an equitable mortgage. There is no such provision as to the covenants made by the company, and ne in- 


\section{BURBANK v. PILLSBURY.}

(Supreme Court of New Hampshire, 1869. 4S N. HI. 475, 97 Am. Bec. 6i3:)

This is an action of covenant broken, founded upon the covenant against incumbrances, the covenant of seisin, the covenant that the defendant had full power and lawful authority to sell and convey in the manner he assumed to do, and the covenant of general warranty, all contained in a warranty deed, executed by the defendant to the plaintiff and dated the seventh day of April, 1868, in common form, purporting to convey to the plaintiff a small tract of land in Haverhill; in which deed the land conveyed purported to be conveyed by metes and bounds in fee simple, without any reservation or exception, with all the privileges and appurtenances belonging to the same.

The same matter is relied on as a breach of each of said covenants, and consists of this, viz.: That on the 29th day of August, 1538, one Michael Johnston, Jr., was seized and possessed of the premises conveyed, which were surrounded on three sides thereof by other adjoining lands of said Johnston, and on that day said Johnston by his deed of that date conveyed the land in controversy to one Apphia Martin, with the following clause in said deed, to wit: "Said Apphia agrees for herself and her heirs and assigns that she and they will forever make and maintain a good, substantial, and lawful fence all

-

fer it was not so intended. But there is the clause in the agreement giving the right to the assignees of Hurxthal to continue the agreement for five years. What is the effect of that clause? It seems to be well settled in law that if a covenant is not, in nature and kind, a real covenant, the mere declaration of the parties that it shall run with the land will not make it a real corenant, though so stated. in the document. $8 \mathrm{Am}$. \& Eng. Ency. 1. 134 ; 2 Washb. R. Prop. \$§ 1203, 1205: Gibson v. Holden [115 Ill. 199, 3 N. l\%. 282 (1885)] 56 Am. Rep. 146, 149. Under this authority I do not see how it covenant not one of such nature as to run with land could, by declaration in the agreement, be made such, so as to place an obligation on the land in lhe hands of subsequent owners; but this corenant is one not placing a burden on the IIurxthal mill, but benefiting it, and the company agreed that benefit should go to the use of the assigns of Hurxthal. The point is not witlout difliculty, wut it does seem to me that under these circumstances this consent of the company, while it would not place a burden on the contlany property, would aive the mill molverty of llurxthal the benefit of the fovenant. so as to enable the plaintiff as alienee to sue upon it. I do not know that it will add anything to the strength of this position, in a legil loint of view, to rely upon the fact that the company accepted from the llaintiff pay for one rear's maintenance of the dam. If the corenant dors not give her right, it would be doubtful whether an oril agreement would w so under the statute of fraud, as being a contract not performable in one year, though the statute is not pleaded. This is not material, however, borause I hold that the plaintiff is entitled to sue for a breach of the cornant occurring during her ownership, by reason of the clanse giving the benctit of the agreement to the assignee of Bell IIurxthal. 'Tluce can be no question but that the plaintifi is a privy in estate with ben Hurxthal, and. an "assign" within the meaning of that word used in said agreenent; tor she mrchased at the judicial sale, which by law cast upon her the entire estate of Ben IIurathal. and she is as much an assignee of the property from Ien II rithal as if he had conveyed it to her." 
around said premises free from all costs and every expense to Michael Johnston, Jr., his heirs and assigns forever." 'This deed was seasonably recorded.

There is no record of any converance of the premises to any one by said Apphia Martin. But Robert French and others, being heirs of said Apphia Martin, conveyed the premises to the defendant, as such heirs, by full warranty deed in common form, dated May Sth, 1854, and said clause in said Johnston's deed to said Apphia Martin is not inserted, and in no manner referred or alluded to in this deed. In the deed from the defendant to the plaintiff, reference is made in the description, to the deed of the said Robert French and others to the defendant, as follows, after naming boundaries and abuttals: "Being all and the same land conveyed to me by Robert French and others by leed recorded in Grafton County Registry of Deeds, liber 226, folio 377." But no reference is made to said Johnston's deed or to any other conveyance.

The plaintiff relies upon the existence of said clause in said Johnston's deed to said Apphia as a breach of each of said covenants except that of general warranty, and in respect to the covenant of general warranty he relies on that clause, and the fact that said Johnstcn, by virtue of said clause, claims and exercises the right of turning his animals into his lands adjoining said premises without contributing to the repair of said fences, and the further fact that said animals have strayed from said Johnston's lands upon said premises and damaged the plaintiff's crops.

And it is agreed that, if upon the grounds hereinbefore stated the plaintiff can maintain an action of covenant broken against the defendant upon any of said covenants, judgment shall be rendered for the plaintiff for such sum in damages as the court, at a jury term, chall assess, unless the defendant elect to demur generally to the plaintiff's declaration, or shall confess judgment for such amount as he may deem expedient.

It was agreed that the writ and declaration, and copies of the records of any conveyances of the premises in question might be used in the arguments of this cause, the same as if fully set forth in the asreed case.

In the argument it was suggested that Apphia Martin is described in Johnston's deed as a married woman.

SMITII, J. ${ }^{22} * * *$ It has been asserted that covenants or agreements made by owners of land will not run with the land as a burden 1111less there is between the covenantor and covenantee a privity of estate arising upon the relation of tenure between them. Assuming that the statute of "quia emptores" is in force in this State, it is clear that no relation of tenure existed between Johnston and Apphia Martin, the original grantor and grantee, and if the doctrine just referred to

:L Lart of the urinion is umitted. 
is correct, it would follow that the agreement entered into between them would not run with the land. But we are not disposed to adopt the doctrine. It is inconsistent with the rule that certain covenants for title entered irto on a conveyance in fee will run with the land. There is no more privity of estate, in the sense of tenure, to support covenants which are a benefit to the landowner than there is to support those which are a burden to him. 'The suggestion that the running uf certain covenants for title with the land is an exception, may be met by the reply of Sir Edward Sugilen (just quoted) to a similar suggestion upon another topic. The doctrine that privity of estate, in the sense of privity arising upon tenure, is necessary to make the burden of it covenant run with the land, is also entirely at variance with the rule that if the owner of an estate for life conveys his whole estate reserving an annual rent which the grantee covenants to pay, the grantor may maintain covenant for rent against an assignee of the granter. McMurphy v. Minot, 4 N. H. 251, is exactly that case. It is there said by Richardson, C. T. (page 254): "Rent may be reserved upon a grant of a man's whole estate, in which case there can be no reversion." See other cases cited in Delafield v. Parish, 25 N. Y. 99. Considering the question on principle, it seems to us that in a case like the present there is such a connection between the parties that the agreement should run with the land, although no relation of tenure exists

Denio, J., said [in Van Rensselaer v. Hays, 19 N. Y. 6S, 91, 75 Am. Dec. 278]: "There is a certain privity between the grantor and grantee of the land. It is not the privity arising upon tenure, for there is no fiction of fealty annexed. It is, however, the same sort of privity which enables the grantee of a purchaser to maintain an action upon the covenants of title given to his vendor: and it is moreover a privity of the same nature with that which obtains between the grantor and grantee of terms for life and years. It is notorious that the grantee of a term is liable upon covenants which are in their nature capable of running with the land, such as covenants to pay rent, to repair and the like, which his grantor made with the owner of the reversion. In this case there is, it is true, a reversion, and that may be indispensable (1) cnable the covenantee to assign the obligation made to him; but it is not easy to see how, upon any kind of reasoning, the presence or absence of a reversion can affect the relations between the party primarily chargeable upon the covenants, and another to whom he convey: the land, charged with the performance of these covenants. It is obvious that the fiction of a feudal tenure has nothing to do with the case." * * *

The cases where the original covenanting parties stood in the relatim of landlord and tenant are not in point, because there the relation uf tenure existed; nor are the cases where covenants are entered into for the performance of acts on land. but no conveyance of land is male at the same time. In the latter class of cases "the covenantor 
takes nothing in the land at the time of the covenant made," and the equitable considerations which apply to a covenantor and his assigns who enjoy the land in fee under a conveyance which was a part of the same transaction with the covenant are wanting. ${ }^{73}$ Cases falling under these classes, not being in point, have not been cited here. $* * *$

Unless the defendant elects to demur, or confess, there must be Judgment for plaintiff. ${ }^{74}$

\section{BROWN v. SOUTHERN PAC. CO.}

(Supreme Court of Oregon, 1899. 36 Or. 12S, 58 I’ac. 1104, 47 L. R. A. 409,78 Am. St. Rep. 761.)

This is an action to recover damages resulting from the killing of four of plaintiff's cows by defendant's locomotive. The negligence alleged as constituting the cause of action is defendant's failure to place gates or bars at the intersection of its right of way with a private road crossing a farm cultivated by plaintiff, in consequence of which said cows got upon the track and were killed. The answer, after denying the material allegations of the complaint, avers that on November 10, 1870, Samuel Brown and Elizabeth Brown, his wife, executed a deed to the Oregon \& California Railroad Company, a corporation, conveying a strip of land 60 feet in width across said farm, and therein covenanted with said corporation, its successors, and assigns, to build and maintain a fence on each side of the railroad to be built through said premises; that said deed was duly recorded in the records of Marion county on November 11, 1870, and plaintiff had full notice and knowledge thereof; that defendant is the lessee of said corporation, and successor in interest of its right of way and of said covenant; that plaintiff is the son and successor in interest of Samuel Brown, and as such used and occupied said farm, and the private crossing thereon, subject to said covenant; that said cows got upon defendant's track at said crossing by reason of plaintiff's failure to place gates or bars thereat, and were killed without any fault upon defendant's part. The reply having put in issue the allegations of new matter contained in the answer, a trial was had, in which the jury, in pursuance of the court's instructions, returned a verdict for the defendant, and, a judgment having been rendered thereon, plaintiff appeals.

${ }^{73} \mathrm{~A}$. owned a mill and dam. B. covenanted with $\mathrm{A}$. and his grantees that he would keep the dam in repair. $A$. conveyed the property to $C$. Held, C. has no right of action against $B$. npon the covenant. Lyon $r$. Parker, 45 .lle. 474 (1S58).

A. covenants with 13. not to erect a mill on land owned by A. A. conveys the land to $C$. IIcld, $C$. is not liable to B. on the covenant. Harsha $r$. Reid, 45 N. Y. $415(1851)$.

74 Ace: Georgia Sonthern R. Co. v. lieeves, G1 Ga. 492 (18s0). 
MoorE, J.75 (after stating the facts). The question presented for consideration is as to whether the covenant in the deed of Samuel Brown and wife to the Oregon \& California Railroad Company created a charge upon their estate rumning with the land, and binding upon plaintiff. 'The said covenant is as follows: "And we further agree to build and maintain a fence on such side of said railroad through the premises herein, north of the town of Gervais, or not hold such railroad responsible for any damage done to stock belonging to us." The right to have a division fence built or repaired by an adjoining proprietor is a benefit to the dominant and a detriment to the servicnt estate, which is in the nature of a distinct easement, affecting the lands of the proprictor upon whom the burden is imposed. Tyler, Bound. 343; Washb. Easem. (2d Fd.) 601; Bronson v. Coffin, 108 Mass. 175, $11 \mathrm{Am}$. Rep. 335. It has been held that a covenant to build or maintain a division fence creates an incumbrance upon the wrenantor's estate, which runs with the land, if so intended by the parties to the deed. $12 \mathrm{Am}$. \& Eng. Enc. Law (2d Ed.) 1049: Beach v. Crain, 2 N. Y. 86, 49 Am. Dec. 369: Burbank v. Pillsbury, 48 N. H. $475,97 \mathrm{Am}$. Dec. 633. In order to determine whether a clause in a deed conveying real property is to be construed as a covenant ruming with the land, or a condition personal to the parties, it is necèssary to consider two subordinate questions: First, whether the right granted or the burden imposed is connected with the land affected by the conveyance, or collateral to it: and, second, if found to be the former, whether the situation of the parties and the condition of the subjectmatter enable the court to say, from an inspection of the language of the deed, that it was the intention of the parties thereto that the covenant should run with the land. Masury v. Southworth, 9 Ohio St. 340. In Kellogg v. Robinson, 6 Vt. 276, 27 Am. Dec. 550, Mir. Justice Phelps, after speaking of those covenants which necessarily run with the lanl, says: "There is another class of covenants of a doubtful or equivocal character, and which may be treated either as merely personal, or as annexed to and running with the land. With respect to these, it is doubtless competent for the contracting parties to make them either the one or the other, as they think expedient. When, therefore, the party covenants for himself and his assizns, it evinces an intent to bind the land, and the obligation becomes connected with and qualifies his estate." An examination of the covenant in the deed of Samuel Brown and wife shows that it does not include their "assigns" in express words, and, inasmuch as the fence along the right of way was not in esse at the time the deed was executed, it is contended that the onission in this particular manifests an intention that the covenant should be personal only. ***

The word "heirs" is not now necessary to create or convey an estate in fee simple. All of the grantor's estate passes by his deed, un-

75 lart of the opinion is onitted. 
less the intent to convey a less estate appears by express terms, or is necessarily implied from the language of the deed. Hill's Ann. Laws Or. $\S 3005$. The statute not having prescribed that the word "assigns," or other words of like import, shall be necessary to make a covenant run with the land, the omission of such words from a deed by which a right is connected with the dominant estate, or an obligation inheres in the servient estate, does not necessarily evidence an intention that the clause conferring the right or imposing the burden is a condition personal to the party charged with its performance. An examination of the language of the deed for the purpose of ascertaining the intention of the parties, shows that the grantors stipulated, in effect, that, if they neglected to build or maintain the fence agreed upon, the grantee should not be held responsible for any damage resulting from such neglect to stock belonging to them. This exemption from liability is the legal result of the grantors' failure to comply with the terms of their deed, and necessarily follows their neglect to build and maintain the fence, without being recited in the deed; for the rule is well settled that, if an adjoining landowner agree with a railroad company to build and maintain a fence along its right of way, the company is not liable to such proprietor, or to his assigns, who take his estate with notise thereof, for injury resulting from neglect to perform or keep such agreement. 12 Am. \& Eng. Enc. Law (2d Ed.) 1071; Railway Co. v. Washburn, 97 I11. 253; Duffy v. Railroad Co., [2 Hilt. (N. Y.) 496], supra. No agreement, however, entered into between a railroad company and an adjoining proprietor, whereby he stipulates to build and maintain division fences, will absolve the company from liability to persons not parties to the contract, or in privity with them, for injury resulting from the land owner's failure to keep his engagement in this respect. $12 \mathrm{Am}$. \& Eng. Enc. Law (2d Ed.) 1072; Railway Co. v. Williamson, 104 Ind. 154, 3 N. E. 814 ; Warren v. Railroad Co., 41 Iowa, 484; Thomas v. Railroad Co., 82 Mo. 538; Gilman v. Railway Co., 60 Me. 235. A tenant who enters upon land with notice of his landlord's covenant with a railroad company to build and maintain a division fence along the right of way, can acquire by the demise no greater estate in the premises than his landlord possessed therein, and lience he has no remedy against the company for injury to his stock resulting from the landlord's failure to build or repair such fence. Easter v. Railway Co., 14 Ohio St. 48: Duffy v. Railroad Co., supra; Railway Co. v. Petty, 25 Ind. 413; Railway Co. v. Washburn, supra. If Samuel Brown and his wife had leased their land, their tenant's stock could not, in any sense, be regarded as their own. The right conferred by their deed upon the railroad company was, so far as they were concerned, to permit it to operate its trains without fencing its right of way, and by exempting it from liability for injury to stock belonging to them they would, in such case, thereby impliedly reserve the right to their tenant, which he could enforce, of compelling it to fence its track across their premises, or be responsible to him for any 
injury to his stock in conseguence of a failure to do so ; for by exempting the company from liability for stock belonging to them only they restricted its right to use the track without fencing to the time in which they had possession of the premises, and made it responsible to their tenant for damage done by it to his stock in consequence of its failure to fence the track through said premises; and what is true of their tenant's stock must apply with equal force and reason to the stock of their successor in interest. The failure to include the word "assigns" in the deed is not controlling if it can reasonably be inferred from the language of the instrument that the parties intended that the covenant should run with the land ; $; 6$ but the absence of such word, or other words of like import, may be considered in connection with the context of the deed in arriving at the intent of the parties in this respect. Giving to the deed such construction, we think the parties thereto never intended that the stipulation to build and maintain the fence should be regarded as a covenant running with the land, but that such clause was meant to be a condition personal to the grantors, and binding upon them only.

It follows that the judgment is reversed, and a new trial ordered. ${ }^{77}$

76 Acc.: Doty r. Chattanooga Union Ry. Co., 103 Tenn. 564, 53 S. W. 94. 48 L. R. A. 160 (1S99).

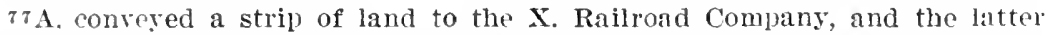
corenanted to erect a station on the land comvered and to stop its trains there. The rest of A.'s adjacent land came to B., and the X. Railroad Company was succeeded by the Y. Railroad Company. B. brought aetion against the Y. lialload for breach of the covenant. The court (Worthington, J.) salid: "In the case at bar the covenant was made with reference to something not then in esse. and there are no words of limitation to the heirs and assigns of the grantor. It is contended. however. that since Aets $1856, p$. 2-13. c. 154 (Code Pub. Gen. Laws 1904, art. 21, \$ 11), as words of inheritance are unnecessary to create a fet, the covenant in this case being in the 11:ture of a reconvesance of an interest in the lands conveyed, such words are unnecessaly hele. * * * Here the right was cleated by way of a corenant which * * * extended to something not in existence at the date of the deed. and the words 'heirs and assimn' are not expressed. Ender the circumstances we do not think the act of 1856 does away with the necessit? for the use of these words in order to pass the right ereated by the covenint in question to an issignee of the crantor." Maryland \& I. R. Co. v. Silver. 110 .ld. 510, 516, 73 Atl. 297 (1909). See Gulf, C. \& S. Rr. Co. v. Smith. T:

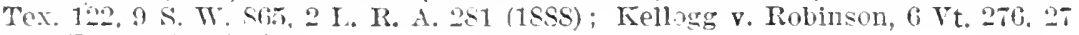
Am. Dec. 550 (1834). 
(B) What Covenants Run

\section{NATIONAL UNION BANK AT DOVER v. SEGUR.}

(Supreme Court of New Jersey, 1877. 39 N. J. Law, 173.)

On demurrer to the declaration.'

The articles of agreement, sued on, commenced in these words, viz.: "Agreement made this, \&c., between Anson G. P. Segur, of, \&c., of the first part, and Hudson Hoagland, of, \&c., of the second part, witnesseth."

The substance of the agreement was, that Segur would sell and convey to Hoagland a certain lot and banking-house. After this stipulation, then followed these recitals and covenants, to wit:

"And whereas, the said Segur is now engaged in the business of banking as a private banker in Dover aforesaid; and whereas, the said Hoagland intends to associate himself with other persons to organize a banking association, to be located and to do business in Dover aforesaid, and expects to convey said lot of land and banking-house to said banking association when organized and ready to commence business, to be occupied and used by said association; and whereas, it is a part of the consideration of this sale of said lot and bankinghouse, that said Segur shall withdraw from the business of banking, and not engage in the same at any time within ten years in the borough of Dover aforesaid:

"Now it is further agreed between the said parties, and said Segur doth hereby covenant and agree with the said Hoagland, that as soon as said new banking company or association so expected to be organized, or any banking company to whom the said Hoagland, his heirs or assigns, may hereafter lease. convey or assign said premises and banking-house, or any part of the same, shall commence the business of banking therein, then and from thenceforth the said Segur shall withdraw in good faith, as soon as practicable, from the business of banking in said borough of Dover, and shall abstain from receiving or accepting any money on deposit' as a banker therein; and shall not, at any time for the space of the ten years thereafter, engage directly or indirectly, in the business of banking in said borough of Dover, either as a private banker, a capitalist or as a shareholder or director in or as an officer or employé of any banking company or association, or sarings bank, located in or doing business in said borough of Dover; provided, that nothing herein contained shall be construed as preventing said Segur from being a shareholder in or an officer or employé of any banking company or savings bank which may, at any time, be the owner or occupant of the lot of land hereby agreed to be conveyed, or any portion thereof.

"And it is further agreed and understood that this covenant on the part of said Segur to abandon, abstain from, and not engage in the 
business of banking in said borough of Dover for the period of ten years, is made for the benefit of said Hoagland, as the owner of said lot of land and banking-house, and shall attach to and run with the same in the hands of any heir or heirs, assignee or assignees, grantee or grantees of said Hoagland; and in case of any breach of the same by said Segur, an action may be maintained thereon against him by the person or persons or body corporate who shall, at the time of such breach, be the owner of the fee simple of said lot of land so hereby agreed to be conveyed; and it is further agreed, in order to insure the observance by said Segur of his said covenant to abandon, abstain from, and not engage in the business of banking, for the period aforesaid, in Dover aforesaid, that in case of any breach thereof by him, the damages to be recovered in any action against him for such breach, shall be and they are hereby fixed and liquidated by the parties thereto at the sum of $\$ 10,000$.

"In witness whereof, the parties have hereunto set their hands and seals the day and year first above written.

"[ Signed.]

Anson G. P. Segur. [L. S.]

"H. Hoagland.

[L. S.]"

The declaration also showed a conveyance of the premises in question from Hoagland to the plaintiff, and averred that they were still the owners thereof.

BEASLEY, C. J. ${ }^{88}$ The contention on the part of the defence, on the argument of this demurrer, was, that the right of action disclosed in the record was not resident in the plaintiff. The deed in suit, in its commencement, purports to be made between Segur, of the first part, and Hoagland, of the second part; and it was insisted that when a sealed instrument is so conditioned, the suit must be by the formal party to it. The plaintiff is the grantee of the premises sold to Hoagland, and claims the right to enforce, in its own name, the agrecment, by virtue of the last clause in it, which is to the effect that in case of a breach of the covenant now sued on, the right of action shall be in the owner in fee of the land. Two questions are thus presented to the attention of the court: First, whether, when a deed is in form inter partes, and it contains a covenant to a third person, such third person may sue, in his own name, for a breach of such particula* covenant, it appearing in the instrument to have been the intention to confer such right; and, second, whether such covenant exists, anil such intention appears in the present instrument.

I begin with the first of these propositions.

An examination of the authoritics upon the subject will show that the rule is conclusively settled: that the naked fact that in a deed inter partes there is contained a covenant with a third person, will not enable such person to sue for its breach.

is Part of the opinion is onitted. 
But the question now raised has a further reach. The counsel of the defendant in this case asks the court to say that the deed being inter partes, it is not lawful to make in it a covenant with.a third person, and to give, by an expressed intention to that end, a right to such person to sue for its breach. No precedent has been cited, or has been found, which will stand as a warrant for this contention. $* * *$

[The court held that a covenant could so be made with a third person and that the intent to make the covenant in question with the plaintiff as such third person was sufficiently clearly manifested in the deed in question.]

But again, even if I had yielded to the view so forcibly presented to the consideration of the court, which is directly opposite to that just expressed, and had concluded that the plaintiff was not a party to this agreement, so as to give him an ability, as such, to sue upon it, yet, nevertheless, I should have thought this action maintainable.

This result, in my opinion, would have been justifiable, on the ground that the covenant forming the basis of this suit is, in law, capable of running with the land, and that, if it is to be regarded, technically, as a covenant between the formal parties to the deed, it has passed, with the title to the present plaintiff.

The doctrine with respect to what agreements will so attach to real estate as to devolve with the title, has been a fruitful subject of discussion in the text-books, as well as in judicial opinions, and, since the various resolutions in Spencer's case, has given rise to a long line of decisions, which, it must be admitted, it would be difficult entirely to harmonize. But I think this discord will be found, upon a careful examination of the authorities, to prevail chiefly in other branches of the subject than in the one in which the present case is to be classed. There is such an essential difference, in social effect, between permitting a burthen to be annexed to the transfer of land, and the giving to a benefit such a quality, that the subject will unavoidably run into obscurity, unless the distinction is kept constantly in view. The conspicuous impolicy of allowing land to be trammeled in its transfer, to the extent that previous owners may choose to affect it by their contracts, was pointed out and condemned in the case of Brewer v. Marsha11, 18 N. J. Eq. 337, and 19 N. J. Eq. 537, 97 Am. Dec. 679. In that case, the owner of real estate sold a portion of it, and covenanted with the purchaser that neither he nor his assigns would sell any marl from off the residue of the tract. The suit was against the alience of the vendor, and the decision was that such a burthen would not follow the land into the hands of such alienee of the covenantor. The reason assigned for this conclusion was the public inconvenience that would result if incidents could be annexed to land "as multiform and as innumerable as human caprice." But when we turn our attention to the consideration of those covenants, which, instead of being burthensome to the land, are beneficial to it, we per- 
ceive, at once, that such objection does not apply. Such covenants do not hinder, but rather facilitate the transmission of land from hand to hand, and, therefore, with respect to their transmissibility, the question of public convenience has no place. 'This being the case, it is not easy to sce why any contract, which is of a nature to attach to the land, and which has a beneficial tendency, should not be considered assignable, by act of law, as against the covenantor, with the title. In every instance where the question, in this form, is presented, the suit being between the original covenantor and the alienee of the covenantee, if the making of the covenant be not denied, the sole point for solution would seem to be whether such covenant, in the legal sense, relates to or concerns the land, for, if not, by its quality, it passes as an incident to the property, and is enforceable in the name of the person who is owner at the time of its breach. When the covenantor has been the party sued, and the covenant admittedly related to the land, the alienee of the covenantee being the plaintiff, I think no considered case has held that such action was not maintainable. In the present case, it is conceded that the parties to the suit have these characteristics, but it is denied that the covenants are of a nature to run with the land.

It is insisted that these covenants "relate to future personal acts and omissions of the covenantor; that those acts are not to be done or omitted on the land conveyed, nor on any other land of the grantor or grantee; nor are the covenants with the heirs or assigns of Hoagland" ; and, in support of these objections, the first and second resolutions in Spencer's case are cited.

But none of these positions are sustained, or in any degree sanctioned, by the authority referred to, that authority being merely to the effect that a covenant will not run with the land if it relates to personalty, or if it be merely collateral to the land. But I fail to find that Sir Edward Coke says anything which lends the slightest countenance to the idea that the covenant is not transmissible if it stipulates for "the future personal acts and omissions of the covenantor," or if "those acts are not to be done or omitted on the land conveyed, or on any other land of the grantor or grantee." It is true that he does declare that, in certain cases, the burthen of a covenant will not fall on the assignee of the covenantor, unless such assignee be expressly referred to in the covenant; but as this suit is against the covenantor himself, and not against his assignee, that doctrine can serve no purpose in this connection.

But Lord Coke, in this case cited, states, as one of the judicial resolutions, that a covenant will not run with the land "if the thing to be done be merely collateral to the land, and doth not touch or concern the thing demised in any sort," and, consequently, the inquiry is presented with regard to the nature of the present covenants in relation to the premises convcyed; and this inquiry has been pressed,

Big.RIGITS-29 
with earnestness, on the attention of the court in the brief of the counsel of the defendant. I must say, however, that but for this urgency, it would not have occurred to me that any doubt could be entertained with respect to the question. I understand that a covenant touches and concerns land when its performance confers a direct benefit on the owner of land by reason of its ownership; and, tested by such a definition, the covenant sued on has such a capacity. To be sure of this, we have but to turn to the contract. That agreement is for the sale and conveyance of the premises in question, which are described as a lot upon which is a building, adapted to the business of banking, in the course of erection, and which, it is stated, the defendant is to complete, and which was to include "a counter for the main banking-room," which "had already been ordered" by him. It is then recited that the defendant was then engaged in the business of banking, as a private banker, in Dover; and that Hoagland, the covenantee and grantor of the plaintiff, intended to associate himself with other persons to organize a banking association, to be located and to do business in Dover; and that he expected to convey said lot of land and bankinghouse to said bank association; and that it was a part of the consideration of the sale of said lot and banking-house, that the said defendant would withdraw from the business of banking, and would not engage in the same, at any time within ten years, in the borough of Dover. After this, follow the covenants, which lay the ground of suit, to the purport that the defendant, "as soon as the new banking company or association, so expected to be organized, or any banking company to whom the said Hoagland, his heirs or assigns, may hereafter lease, convey or assign said premises or banking-house, or any part of the same, shall commence the business of banking therein, then and from thenceforth," the said defendant "shall withdraw, in good faith as soon as practicable, from the business of banking," \&c. To this, there is superadded a stipulation that it is understood and agreed that the foregoing covenant is made for the benefit of said Hoagland, as the owner of the land to be conveyed, and is to attach to and run with the same.

In view of these stipulations and recitals, it is undeniably clear that the parties to this contract thought that the covenant in question was one which would appertain to and benefit, not merely the person of the grantee, but'the land itself, which was to become his by a conveyance. Indeed, it was made such an appurtenance to the property that it was to have no effect until the business of banking was commenced upon these particular premises. Now, while it is plain that a mere personal covenant cannot, by the agreement of parties, have its nature so altered as to make it transmissible with land, nevertheless when the question is whether the given covenant does concern certain premises, the fact that such parties considered it to have such quality, should be potent in a decision of the inquiry. Since these parties most manifestly have thought that the stipulation in question gave addi- 
tional value to the property, why, and on what ground, should the court declare that such was not the case? Nor is it perceived that there is any force in the suggestion that this covenant would affect, not only the business done upon these particular premises, but any wher banking business that might be carried on in the vicinity, for the answer to such objection is, that such incidental effects are common to all agreements that in any wise regulate the dealings of men; and that the rule of law requiring the covenant to touch or concern the land, does not require that it shall touch or concern nothing else. In the present instance, this covenant will have an immediate, permanent and beneficial effect upon the use to which the land is to be put, and that is sufficient to annex it to the title. To apprehend how closely this stipulation is related to these premises, we have but to observe that in case of its breach, the party directly, and for aught that the cerrt can know, exclusively injured, will be the owner for the propprty at the time such breach shall occur. There is nothing in the pleadings to show that, upon such violation of this agreement, the original covenantee, or any other person but the plaintiff, has sustained, or can sustain, the least inconvenience or injury. And, finally it should be observed, that under the circumstances of this case, it is necessary to hold that the covenant under consideration, has capacity to run with the land, in order to give damages to the only party actually grieved by its nonperformance.

This conclusion is, I think, amply sustained by the decisions. It is not necessary to review them. The following seem to me directly to the point: The Prior's case, reported in the seventh resolution in spencer's case, 1 Smith's Lead. Cas. 118; Vyvyan v. Arthru's Adm'rs, 1 Barn. \& Cress. 410; Vernon v. Smith, 5 B. \& Ald. 1; Nayor of Congleton, 10 East 130; Norman v. Wells, 17 IVend. (N. Y.) 137; 1 Snitl's Lead. Cas. 142.

Having carefully examined the cases cited in the brief of the counsel of the defendant, I shall dismiss them with the observation that they seem to me plainly to be covenants relating to personalty, or covenants entirely collateral to the land, or cases pertaining to the question when covenants will pass as a burthen with the title.

Another objection taken to this suit is, that the agreement in question, and every part of it, was prospective and executory, and at the time it was entered into, no title to the lands existed, or was transferred to Hoagland, the covenantec.

But I find no authority for this proposition. The adjudications appear, on the contrary, to show very plainly that when a covenant beneficial to land is made, it is not essential to its devolution with the title that the covenantec should have title to the land to which it relates, or that the estate should have come from the covenantor, or should have passed from him, eo instanti, with the inception of the covenant. When, therefore, the covenantee in this case became vested with the title. the corenant, as it touches and concerned the land, 
became an incident to such land, and as such, passed with it, upon conreyance, by act and operation of law.

On the one or other of these grounds, the declaration, in my opinion, must be upheld. ${ }^{78}$

\section{GILMER v. MOBILE \& M. RY. CO.}

(Supreme Court of Alabama, 18s5. 79 Ala. 569, 5S Am. Rep. 623.)

This action was brought by George N. Gilmer, against the Mobile \& Montgomery Railway Company, as the assignee and successor of the Alabama \& Florida Railroad Company, to recover damages for alleged breaches of covenant; and was commenced on the 30th March, 1885. The covenants alleged to have been broken were contained in a written instrument under seal, dated March 7th, 1868, by. which the Alabama \& Florida Railroad Company, "in consideration," as therein recited, "of George N. Gilmer having sold and conveyed to said railroad company, for the sum of one dollar, the right of way and the land for fifty feet on each side of the centre line of said railroad extending through his plantation, and certain other privileges mentioned in the deed of conveyance given by said Gilmer," agreed and bound itself as follows: "The Alabama \& Florida Railroad Company will stop the passenger and freight trains (when proper signals are given) at some convenient point opposite the house of said Gilmer, and receive and discharge (withaut extra charge) passengers and the sacked and baled produce of the farm, or other freight or produce of said farm, when the receiving and delivery of said other freight and produce can be done without seriously interfering with the running of schedule. The further privilege is given said Gilmer to cultivate such parts of said right of way not used by said railroad company, so long as the same may not interfere with the wants and requirements of said railroad company; and further, if at any time the said railroad company should erect a depot on said right of way, the sale of ardent spirits will be strictly prohibited." The complaint claimed that these stipulations were covenants running with the land, and were binding on the defendant as the assignee and successor of said Alabama \& Florida Railroad Company; and alleged specific breaches of each. The court sustained a demurrer to the complaint, on the ground that the covenants were not binding on the defendant as assignee; and the judgment on the demurrers is now assigned as error.

${ }^{70} \mathrm{~A}$. granted to a rallroad a right of way over his land, the ralload covenanting to malntain its roadhed at a certain beight. Held, A.'s successor in title may maintain action agaiust the railroad for breach of the corenant. St. Louls, I. M. \& S. Ry, Y. O'Baugh, 49 Ark. 418, 5 S. W. 711 (1S87).

So as to a covenant by the grantee of a right of way to stop its trains at a designated point. Ford $\mathrm{r}$. Oreson Jilectric Ry. Co., 60 Or. 27s, 117 Yac.

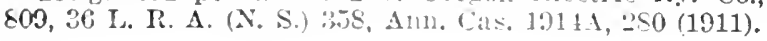


SOMFRVILLE, J. ${ }^{80}$ The action is one at law for the breach of certain covenants entered into with the plaintiff by the Alabama \& Florida Railroad Company, a body corporate, from which the defendant derived title, as assignee, to a strip of land, including the right of way, through the farm of the plaintiff, situated in the county of Lowndes. In March, 1868, the appellant, who was plaintiff in the court below, conveyed to the said assignor of defendant this right of way and land, extending fifty feet on each side of the center line of the railroad track. In consideration of this grant, the said Alabama \& Florida Railroad Company agreed in substance, by a separate instrument, to establish what we may briefly denominate a flag-station on said land, at a convenient point adjacent to the plaintiff's house, where both passenger and freight trains would stop, upon the giving of proper and usual signals, for the transportation of passengers and certain kinds of produce. The plaintiff was to have the right to cultivate so much of this right of way as may not be needed for use by the railroad, and so long as such cultivation did not interfere with its wants and requirements. It was further stipulated that, in the event of a depot being erected on the premises, the sale of ardent spirits would be strictly prohibited.

It is averred that the defendant corporation derived title by succession from the original vendee and covenantor, with full knowledge of the obligations growing out of the contract.

The Circuit Court sustained a demurrer to the complaint, and dismissed the action, on plaintiff's refusal to amend.

There is an agreement of counsel waiving so much of the demurrer as raises any question touching the plaintift's right to bring the action in his name, if it would lie at all upon the facts stated. The consideration of this point we, therefore, pretermit, assuming that the action was properly brought in the name of the plaintiff as husband, for the use of the wife.

The question for decision is, whether the covenants in question, or either of them, so run with the land, as to be of binding obligation at law upon the defendant, as the assignee of the covenantor.

A covenant is said "to run with land" when the liability to perform it, on the one hand, or the right to enforce it, on the other, passes to the vendee, or other assignee of the land. Such covenant must relate to, or, as is more commonly said, "touch and concern the land," and not as merely collateral to it, in order that the assignee of the land may be charged with their benefit or burden. Spencer's Case, 1 Smith, Lead. Cas. 27. They are often called real contracts, because they are annexed or inhere to the realty as part and parcel of it, and "pass from hand to hand with the interest in the realty they are annexed to." 1 Addison Contr. $\S 430$. And no doubt seems to exist as to the rule, that covenants may run witl incorporeal, as well as with corporeal hereditaments, as in the case of tithes and rent-charges, which savor

80 Part of the opinion is omitted. 
of the realty, because they are carved out of and charged on it. 2 Sugden Vend. 482. It is impossible to lay down any fixed rule by which to distingtish in all cases real covenants, which run with land, and are binding as such on heirs, devisees, and assignees, from those which are merely personal, and are binding only on the covenantor and his personal representative. The subject is one full of intricate learning, and the decisions of the courts touching it are greatly conflicting, and far from satisfactory. Among those, however, which have been decided to follow the realty into the hands of an assignee, are covenants of warranty and for quiet enjoyment, covenants by tenants to pay rent, to repair, maintain fences, reside on the premises, or cultivate the demised lands in a particular manner; not to carry on a particular trade on the premises leased or purchased; not to build on adjacent premises, and many others of an analogous character. Among those adjudged to be personal, and not therefore to touch or concern the land, are corenants made by owners of land between whom and the covenantee there is no privity or title or estate; a covenant not to hire persons of a certain description to work in a mill; or a covenant with it stranger not to permit a grist-mill to be erected on the owner's premises; a covenant by the vendor of lands not to permit marl to be sold from adjoining lands; by a lessee of a house to pay so much for every tun of wine sold in the house; or to buy all beer used by him from his lessors or from his successors in trade. Law Real Property (Boone), 317; 1 Addison Contr. $\$ 436 ; 2$ Greenl. Ev. $\$ 240$; 1 Parsons' Contr. 231-233. * * *

A proper application of these principles leads us to the conclusion, that the condition assumed by the Alabama and Florida Railroad Com'pany, the defendant's assignor, by which it was agreed to establish a "Hag-station" on the road adjacent to plaintiff's house, and to permit plaintiff to cultivate the land on which the right of way was granted, imposed a burden on the land itself, and was not a mere personal covenant. It touched and concerned the land itself, and was not collateral to it, because it was to be performed on it, and affected the valwe of the adjacent land of the grantor, being greatly beneficial to it: and was in the nature of compensation by way of rent for the land conveyed, no other consideration having been paicl therefor than that wich was confessedly nominal. 1 Smith, Lead. Cas. 22-27, and note, with cases cited. Its performance or non-performance, also, affected the mode of enjoyment of the granted premises, and their value or quality, so as to render the title acquired by the vendee a subordinate one; and this is one of the tests by which to decide whether the covelant is wherent in the land itself. 1 Addison on Contracts, $\$ 435$. In other words, the covenant of the vendee "qualified the estate which he took, and attached itsclif to that estate." Atlantic Dock Co. v. Leavitt, 54 N. Y. 35 , s. c. 13 Am. Rep. 556 . * * *

The thing to he done ly the covenantor in this case related to the land, and, being annexed to it, the assignee, by accepting possession 
of the land, became bound by the covenant, as one running with the land, without being named in the agreement. Fulton v. Stuart, supra; 'Taylor on Landlord \& Tenant, § 437 ; Spencer's Case, above cited; Morse v. Aldrich, 19 Pick. (Mass.) 449; 1 Add. Contracts, Morgan's ed. $\S 4.55$.

The court below erred in sustaining the demurrer to the complaint; and the judgment must be reversed, and the cause remanded. ${ }^{81}$

\section{ATLANTA, K. \& N. RY. CO. v. McKINNEY.}

(Supreme Court of Georgia, 1906. 124 Ga. 929, 53 S. E. 701, 6 L. R. A. [N. S.] 436, $110 \mathrm{Am}$. St. Rep. 215.)

McKinney brought suit against the Atlanta, Knoxville \& Northern Railway Company, and alleged: On September 13, 1886, Andrew IV. Green conveyed to petitioner the exclusive right to the use and control of all the springs and branches upon a described lot of land in Fannin county, for the purpose of being used on an adjacent lot of land. On November 12,1888, petitioner conveyed to the Marietta \& North Georgin Railroad Company the right to the use of water from the branches and springs on the said lot of land, for the purpose of supplying its water tank at Blue Ridge, Ga., "in consideration of the fact that said Marietta \& North Georgia Railroad Company shall carry and convey sufficient water to the residence of said MIcKinney for the ample use and accommodation of said residence and its occupants." It is further alleged that the Atlanta, Knoxville \& Northern Railway Company purchased all the property, rights, and franchises of the Marietta \& North Georgia Railroad Company at a receiver's sale, and became thereby bound by all the conditions of the above-described deed, and that for more than four years and ever since the purchase of the Marietta \& North Georgia Railroad the defendant has been continuously using the water conveyed in the abovedescribed deed, and that neither the defendant nor its assignor ever carried water to the residence of petitioner. Petitioner claimed, as damages for the breach of the covenant, $\$ 500$ as the cost of conveying the water to his residence as contemplated in the deed, and the value of the use of the water at the rate of $\$ 25$ per year since November 12, 1888, the date of the covenant. The defendant demurred generally to the petition, and specially to that portion seeking damages for

81 Aec.: Parrott v. Atlantic \& N. C. R. Co., 165 N. C. 295, S1 S. L. 348 , Ann. Cas. 1915D, 265 (1914).

A. owned a mill, a dam, and a water power. He conveyed to $X$. the mill and part of the water power, and corenanted to keep the dam in repair, so is to enable X., his heirs and assigns, to use the power so granted. A.'s land and dam came to B., and X.'s mill and power rights to $\mathrm{Y}$. Held, $\mathrm{Y}$. una maintain an action against B. for failure to repair the dam as covenanted. Fitch v. Johnson, 10t Ill. 111 (1ss2). See Mlorse v. Aldrich, ante, p. $4: 9$; Nye v. Hoyle, 120 N. Y. 195, 24 N. 1. 1 (1s90). 
the cost of conveying the water to the petitioner's residence. The special demurrer was sustained, and the general demurrer overruled. To the judgment overruling the general demurrer the defendant excepted.

Совв, P. I. (after stating the foregoing facts.) ${ }^{82}$ The right of action of the petitioner depends upon whether or not the covenant to convey water to his residence is a covenant running with the land. If it is a real covenant, he may recover for its breach against the assignee of the covenantor. If it is only a collateral or personal covenant, he has no cause of action. The determination of a question of this character is usually one of some difficulty. $* * *$ These definitions are founded directly upon Spencer's Case, 5 Coke, 16, 1 Smith's Leading Cases (9th Ed.) 174, or upon authorities derived therefrom. The rule as there laid down is as follows: "When the covenant extends to a thing in esse, parcel of the demise, the thing to be done by force of the covenant is quodammodo annexed and appurtenant to the thing demised, and shall go with the land and shall bind the assignee although he be not bound by express words; but when the covenant extends to a thing which is not in being at the time the demise is made, it cannot be appurtenant or annexed to the thing which hath no being." In the case of Atlanta Con. St. Ry. v. Jackson, 108 Ga. 638, 34 S. E. 184, Mr. Chief Justice Simmons said: "To constitute a covenant running with the land, the covenant 'must have relation to the interest or estate granted, and the act to be done must concern the interest created or conveyed.' 1 Ballard, Real Prop. $\S$ 491. In 2 Kerr on Real Prop. $\S 1218$, it is said: 'Of the covenants in a lease, some run with the land, while others are binding only upon the person. * * * In order that it may run with the land, its performance or nonperformance must affect the nature, quality, or value of the property demised, independent of collateral circumstances, or it must affect the mode of enjoyment, and there must be a privity between the contracting parties.'"

In the present case the thing demised was the right to the use of water from springs and branches upon a certain lot of land for the purpose of supplying a water tank. The covenant, the breach of which is alleged, was the agreement to convey a part of the water to the residence of the plaintiff. Under the rules above laid down, we think it is clear that this is a covenant running with the land. It measures up to every test suggested. It not only relates to the interest or estate conveyed, it is inseparably annexed to and a part of it, a charge upon it. It affects the nature, quality, and value of the thing demised. It qualifies its mode of enjoyment; it restricts its use. It is inextricably woven into the manner in which the grantee shall enjoy the thing demised. "A covcnant by a lessor to supply houses with water at a rate therein mentioned for each house also runs with the

82 Part of the opinion is omitted. 
land, and for a breach of it the assignee of the lessee may maintain an action against the reversioner." 1 Taylor's Land. \& Tenant, 330, citing Jourdain v. Wilson, 4 B. \& A. 266. * * * In the case of Cooke v. Chilcott, L. R. 3 Ch. Div. 694, it is said: "A purchaser of a piece of land with a well or spring upon it covenanted with the vendor, who retained land adjoining intended to be disposed of for building sites, to erect pump or reservoir, and to supply water from the well to all houses built on the vendor's land. Held, that both the benefit and burden of the covenant ran with the land, and that the case was not.within the second resolution of Spencer's Case." See, also, Shaber v. St. Paul Water Co., 30 Minn. 179, 14 N. W. 874. * * *

Another contention of the defendant was that the language of the instrument should not be construed as a covenant to supply to the plaintiff's residence water derived from the water rights conveyed to the defendant, but that, under the instrument, the defendant might supply water from any locality whatever. If this construction were correct, the covenant would undoubtedly be collateral, personal, and independent of the land; but we do not think it a fair construction of the deed. "Covenants are to be so construed as to carry into effect the intention of the parties, which is to be collected from the whole instrunient and from the circumstances surrounding its execution." 11 Cyc. 1051, and citations; Peden v. Chicago Ry. Co., 73 Iowa, 579, 35 N. W. 424, 5 Am. St. Rep. 680. The covenant in question reads: "The said M. McKinney, for and in consideration of the fact that said Marietta \& North Georgia Railway Company shall carry and convey sufficient water to the residence of the said McKinney for the ample use and accommodation of the said residence and its occupants, then and in that event the said M. McKinney grants, sells, and conveys unto said Marietta \& North Georgia Railway Company the right to the free and unrestricted use of water for the supplying of the railroad water-tank at Blue Ridge, in said county, with ample and sufficient water for their use from all the springs and branches for the use of said company," etc. It seems to us apparent that it was the intention of the parties that the water conveyed to the plaintiff's residence should be from the springs and branches which were the subject-matter of the agreement. The grantor reserves what might be said to be the first lien upon the water, and it is only after the needs of his residence are satisfied that the defendant is given the unrestricted use of the branches and springs. It would be unreasonable to hold that the intention of the parties expressed in this instrument was that the water furnished to the plaintiff was to be derived from another locality, and conveyed by separate machinery to the plaintiff's residence. * *

Judgment affirmed. All the Justices concur. ${ }^{83}$

s 3 See Stanislaus Water Co. v. Bachman, 152 Cal. 716, 93 Pac. S5̇, 151. 1R. A. (X. S.) 859 (1908); Hottell v. Farmers' Protective Ass'n, 25 Colo. 67, 53 l'ac. 327, 71 An. St. Rep. 109 (1S9S); Falmel's' High Line Canal it leservoir Co. v. New Hampshire Heal Estate Co., 40 Colo. 467, 92 Pac. 200 (1907); Lydicli v. Baltimore \& O. R. Co., 17 W. Va. 427 (1ss0). 


\section{MILLER v. CLARY et al.}

(Court of Appeals of New Tork, 1913. 210 N. I. 127, 103 N. E. 1114, L. R. A. 1918E, 222, Ann. Cas. 1915B, 872.)

This is an action to construe a deed granting an easement, and to enforce certain covenants relating to the easement. In and prior to the year 1S72, the Phœnix Mills was seised in fee and possessed of certain lands on the Seneca river in the village of Seneca Falls. There was erected on such lands a flouring mill operated by water drawn from the river. The land to the east of the mill property and lower down the river was also owned by the Phœnix Mills. This land, in the year 1S72, the mill company divided into four lots, and on May 1Sth of that year conveyed the easterly lot, which was taken off the easterly end of the land, to one Zalinski. The deed, after describing the property conveyed, continued as follows: "Together with sufficient power (subject to the elements) from a wheel in the Old Stone Mills or Jewett Building to turn a shaft and propel machinery in the basement of any building to be erected on the premises hereby conveyed not requiring more than fifteen horse power, provided, however, that such machinery shall be confined to the basement stories of such building and shall not be used elsewhere nor shall said shaft ever be used for any other purpose than operating machinery in said basement; and provided also that said shaft shall be put up at the sole expense of said party of the second part and shall be properly connected with the shaft rumning from said mill and shall be made and put up in a manner to be approved by the said party of the first part, and said shaft and machinery shall at all times be kept in good condition by said party of the second part and shall be operated in a proper and economical manner, and said power is to be used in common with all other persons who shall be entitled to power from said wheel." Following the clause quoted, the deed contained certain exceptions and reservations, and then the following cavenant on the part of the grantor: "Said party of the first part shall keep said wheel in said mill in good condition, and operate the same economically, and construct and maintain sairl shaft of proper dimensions to the west line of said lot, affording said party of the second part a good connection therewith at his west line."

Subscquently, in the same year, the Phœnix Mills conveyed to different individuals the two lots to the west of the Zalinski lot, and the deed in each instance contained practically the same provisions as the Zalinski deed, except that the grantee agreed to construct and maintain the shaft to transmit power over the land conveyed to him to the adjoining lots on the east thereof. Still later, in the same year, the Phcenix Mills conveyed the fourth lot, which adjoins the mill property, to a fourth person by deed which contained practically the same clauses as the Zalinski decd. 'Thereafter the Phocnix Mills for a time 
transmitted power under the provisions of its deeds aforesaid to lots 1, 2, and 3. No power was transmitted to the fourth lot. Since about the year 1890 no power has been transmitted to any of the lots, and the appliances for conveying the power have been destroyed by the elements or otherwise. In 1873 the Phœnix Mills conveyed the mill property by deed, "excepting and reserving, however, all such rights and privileges as have been conveyed by the party of the first part to" Zalinski and the other grantees aforesaid. Subsequently the property was conveyed to the defendants Clary by deed, containing the same exceptions and reservations.

The plaintiff is, and for several years has been, the owner of all four lots to the east of the mill property conveyed to Zalinski et al. There is now upon the mill property an electric power plant operated by the defendant the Geneva-Seneca Electric Company under lease from the owners. There are several wheels in the power plant which are run by water from the Seneca river. The object of this action is to secure a construction of the covenants and stipulations in the deeds to Zalinski and others, to compel the defendants Clary to keep and observe such covenants and stipulations, and to require said defendants to furnish "power at the plaintiff's buildings and convey such power at their own cost and expense, and by their own appliances, to the plaintiff's buildings." The judgment was in favor of the plaintiff on all points.

Cuddeback, J. ${ }^{84}$ (after stating the facts as above). There can be no question but that the words, "together with sufficient power (subject to the elements) froin a wheel in the Old Stone Mills or Jewett Puilding to turn a shaft and propel machinery" on the grantee's premises, contained in the deeds from the Phonix Mills to Zalinslii and others, constituted the grant of an easement, nor any doubt but that the privilege granted was for the benefit of the land conveyed, and an easement that ran with the land. Nye v. Hoyle, 120 N. Y. 195, 24 N. E. 1.

The question arises on the subsequent covenant to transmit the power, contained in the following provision: "Said party of the first part shall keep said wheel in said mill in good condition and operate the same economically and construct and maintain said shaft of proper dimensions to the west line of said lot, affording said party of the second part a good connection therewith at his west line."

There is now a wheel operated in the defendants' power plant which answers to the language of the deeds, and, therefore, we are not cGr1cerned here with the covenant of the grantor to keep the wheel in good condition and operate the same.

But there is no shaft or other contrivance to carry power from the wheel to the lands conveyed. By the julgment appealed from it is rlecreed that the covenants in the deed of the Phonix Mills to the

64 l'art of the opinion is omitted. 
plaintiff's predecessors in title, whereby the grantor undertook to "construct and maintain a shaft of proper dimensions to the west line of" the plaintiff's land, is a covenant binding on the defendants, and the judgment orders them to comply with and fulfill such covenant.

The covenant to construct and maintain the shaft is known in the law as an affirmative or positive covenant. It compels the covenantor to submit, not merely to some restriction in the use of his property, but compels him to do an act thereon for the benefit of the owner of the dominant estate.

It is the established rule in England that such a covenant does not run with the land, and cannot be enforced against a subsequent owner of the servient estate, either at law or in equity. Haywood v. Brunswick Bldg. Society, 8 Q. B. Div. 403; London \& S. W. Ry. Co. v. Gomm, $20 \mathrm{Ch}$. Div. 562; Austerberry v. Corp. of Oldham, $29 \mathrm{Ch}$. Div. 750; Halsbury, Laws of England, vol. 11, pp. 237, 248. There are, however, certain exceptions to this rule, as covenants to repair fences on boundary lines; to repair private ways, and covenants in leases. Id.

Some of the courts of this country have taken a different view, notably the Massachusetts Supreme Court. In Whittenton Mfg. Co. v. Staples, 164 Mass. 319, 41 N. E. 441, 29 L. R. A. 500, it is held that a stipulation in the deed of a mill site that the grantee and his assigns shail pay one-fifth of the damages caused by flowage from a dam is a covenant running with the land, and binds the grantee, his heirs and assigns. Pomeroy in his work on Equity Jurisprudence takes the same view, namely, that affrmative covenants may be enforced in equity, and criticises the English decisions. 3 Pomeroy, Eq. Jurisprudence (3d Ed.) § 1295. * * *

It has been held in this state that certain positive covenants, which are mainly in line with the covenants excepted by the English courts from the rule adopted there, do run with the land. As, covenants to build fences along boundary lines (Satterly v. Erie R. R. Co., 113 App. Div. 462, 99 N. Y. Supp. 309); covenants relating to party walls (Crawford v. Krollpfeiffer, 195 N. Y. 185, 88 N. E. 29, 133 Am. St. Rep. 783): covenants to provide railway crossings (Day v. N. Y. C. R. R. Co., 31 Barb. 548; Post v. West Shore R. R. Co., 123 N. Y. 580, $26 \mathrm{~N} . \mathrm{E} .7$ ) ; covenants in leases to pay rent or repair buildings on the demised premises (Allen v. Culver, 3 Denio, 284). The cases cited from the reports of this state indicate that the trend of opinion is with the English decisions.

But there is another case on which the plaintiff relies, to wit, Denman v. Prince, 40 Barb. 213. In Dennuan v. Prince the owner of lands on which was situated a gristmill and a sawmill conveyed the gristmill to the plaintiff Denman, and at the same time executed a separate agreement under seal, granting to Denman the use of water to run the gristmill, and covenanting that he would at all times be at an equal expense in keeping up and repairing the dams in the stream from which 
the water was obtained. Later on he conveyed the sawmill to the defendants, subject to the rights and privileges previously conveyed to Denman. Thereafter the plaintiff repaired the dams, and the suit was to recover from the defendants their proportionate part of the expense. The court held that the covenant to share in the costs of repair ran with the land, and was binding on the defendants, and, further, that the parties to the action were tenants in common of the mill privilege, and were jointly using the same; therefore the defendants were bound to contribute to the expense of the necessary repairs made to the dams. The decision in Denman v. Prince is entirely in harmony. with the early English cases.

In Cooke v. Chilcott, 3 Ch. Div. 694, the court held that a covenant by a grantee to erect a pump and reservoir and supply water to all the houses built on the vendor's land was enforceable by an injunction restraining the defendants, who had purchased the land on which the pump and reservoir were located, with notice of the covenant to refrain from allowing the work of pumping to be unperformed. The evil and lasting effect of the decision, which would compel all persons who might thereafter become the owners of the reservoir to forever pump and supply water, led the court to practically overrule Cooke v. Chilcott, and announce the rule, before referred to, that affirmative covenants do not run with the land and cannot be enforced against subsequent purchasers, either at law or in equity. Haywood v. Brunswick Bldg. Society: London \& S. W. Ry. Co. v. Gomm; Austerberry v. Corp. of Oldham, supra.

Except in Gould v. Partridge, 52 App. Div. 40, 64 N. Y. Supp. 870 , which involved the same deeds involved in this action, Denman v. Prince has not been cited, so far as I can find, as an authority on the proposition that a positive covenant runs with the land. Covenants which impose charges on land bind the assigns of the covenantor as equitable obligations. Trustees of Columbia College v. Lynch, $70 \mathrm{~N}$. Y. 440, $26 \mathrm{Am}$. Rep. 615. If, under the circumstances presented by the Denman Case, the defendants had abandoned their sawmill and devoted their lands to. other purposes, it would not have been equitable to compel them thereafter to bear the burden of maintaining the dams in order to provide water for the plaintiff's gristmill. However, in Denman v. Prince the court found that the parties to the action were tenants in common of the mill privilege, and were jointly enjoying the benefit thereof. That may serve to distinguish the case from the case at bar.

I think the rule that affirmative covenants accompanying conveyances of land are not enforceable against subsequent owners is a wise one. It has its limitations, as has been seen, and may require further limitation; but the present case is one in which the rule should be applied.

The plaintiff here has the right, under the grant of the Phœnix Mills, to take power from a wheel in the defendants' power plant when the wheel is in operation. That is an easement, and is a privilege nec- 
essary and convenient to the complete enjoyment of the plaintiff's property, having in mind the purpose for which it was conveyed. But it is not necessary, or even convenient, to the complete enjoyment of the plaintiff's property that the defendants should construct and maintain the shaft by which the power is transmitted. That work the plaintiff can do as well as the defendants, and for the purpose of performing it may enter upon the defendants' property. The only question is: Who shall bear the expense? In that view, the covenant to construct and maintain the shaft was the personal undertaking of the original grantor, and does not run with the land or create an equitable liability on the part of the defendants.

I recommend that the judgment appealed from be modified by striking out the provision that the covenants in the deeds from the Phœnix Mills to Zalinski and others to construct and maintain a shaft from the wheels in the defendants' mill to the plaintiff's building inured to the plaintiff's benefit, and also by striking out the provision that the defendants comply with such covenant, and by inserting a direction that defendants permit the plaintiff to take at and from a wheel in their mill, when the wheel is in operation, the amount of power in the judgment mentioned, and that the judgment as thus modified be affirmed, without costs in this court to either party.

Culien, C. J., and Werner, Hiscock, Chase, Collin, and HoGAN, JJ., concur.

Judgment accordingly. ${ }^{85}$

\section{WIGGINS FERRY CO. v. OHIO \& M. RY. CO.}

(Supreme Court of Illinois, 1S79. 94 IIl. S3.)

[The Wiggins Ferry Company granted to the Ohio \& Mississippi Railroad Company the right to build and maintain upon certain described lands of the grantor, tracks, warehouses, and other structures to be used for railroad purposes, tenendum so long as used for railroad purposes. The consideration was $\$ 1.00$ and a covenant by the grantee

85 In Austerberry v. Oldham, L. R. 29 Ch. Div. 750. 781 (1S85), Lindley, I. J., said: "Does the hurden of this covenant run with the land so as to hind the defendants? The defendants have acquired the road under the trustees, and they are bound by such corenant as runs with the land. Now we come to face the difliculty; does a covenant to repair all this road run with the land-that is, does the burden of it descend upon those to whom the road may be assigned in future? We are not dealing here with a case of landlord and tenant. The authorities which refer to that class of cases have little, if any, bearing upon the case which we have to consider, and I am not prepared to say that any covenant which imposes a burden upon land does run with the land. unless the covenant does, upon the true con. struction of the deed, containing the covenant, amount to either a grant of an easement, or a rent charge, or some estate or interest in the land. A mere corenant to repair, or to do something of that kind, does not seem to me. I confoss, to run with the land in such a way as to bind those who maly acruire it." 
that it would always employ the Wiggins Ferry Co. to transport all its passengers, freight cars, etc, across the Mississippi river to and from St. Louis and Bloody Island. The Ohio \& Mississippi Railway Company later succeeded to the rights of the Ohio \& Mississippi Railroad Company, and refused to employ the plaintiff for the specificd ferry purposes. This action is brought to recover damages resulting from the refusal.]

Scholfield, J. ${ }^{86} * * *$ It remains, then, only io inquire, does the periormance or non-performance of this covenant affect the nature, quality or value of the property demised, independent of collateral circumstances, or the mode of its enjoyment?

It is not shown that the two parcels of lands in which this easement is granted are any part of the ferry of appellant. For aught that appears, these properties are totally distinct and independent of each other, and we are authorized to assume that a sale and conveyance of the one would not necessarily affect the other.

This covenant is not to do anything upon or about the easement granted to the Ohio \& Mississippi Railroad Company, nor does it in anywise affect the parcels of land in which the easement is granted. Its language is: "The said party of the second part will always employ the said IViggins Ferry Company, party of the first part, to transport for the said party of the second part across the said river all persons and property which may be taken across the said river, either way, by the said party of the second part to or from Bloody Island, either for the purpose of being transported on the railroad of said party of the second part, or having been brought to said river upon the said railroad, so that the said party of the first part, their legal representatives or assigns, owners of the said Wiggins Ferry, shall have the profits of the transportation," etc., etc. So, it is the owner of the ferry, and not the owner of the parcels of land, for whose benefit the covenant is made. Hence if appellant had conveyed its ferry to A., and its parcels of land to B., A. alone would have been injured by a breach of the covenant. It is impossible to conceive how the owner of the parcels of land, merely as such, could be injured by a breach of the covenant. It adds nothing to the value of the parcels of land, and gives nothing to him claiming as owner, increly because he is owner. It is all for the benefit of the owners of the feriy, a totally separate and distinct property. It would be difficult to give a better illustration of a purely collateral covenant.

It has bcen said, whether a covenant will or will not run with land does not, however, so much depend on whether it is to be performed on the land itself, as whether it tends directly or necessarily to enhance its value, or render it more beneficial and convenient to those by whom it is owned or occupied. Masury v. Southworth, 9 Ohio St. 340. Following this form of cxpression, the easement here granted

86 The statement of facts is abridged and part of the opinion is omitted. 
Is in the two parcels of land, not in the ferry, while the covenant relates to and affects the ferry only. Undoubtedly the covenant enhances the value of the ferry, or renders it more beneficial, but this has nothing to do with the two parcels of land in which the easement is granted. See Webb v. Russell, 3 Term R. 393, 402; Bally v. Wells, 3 Wilson, 25-29; Hurd v. Curtis, 19 Pick. (Mass.) 459; Brewer v. Marshall, 18 N. J. Eq. 337; 19 N. J. Eq. 537, 547, 97 Am. Dec. 679; Spencer's case, and notes, 1 st part 1 Smith's Leading Cases.

It may be questionable whether this easement, under the allegations before us, legally passed to the assignee, the present appellee, at all, and of course, if it did not, no covenant could run against appellee as being a charge upon that easement. But upon this we express no opinion. We have assumed, without examination, that the declaration sufficiently avers the assignment of the easement; and we have also assumed, as matter of law (of the correctness of which, however, we do not apprehend there can be much doubt), that the easement. is one with which, under a different supposable state of facts, a covenant might run as a covenant running with the land.

Our decision goes no further than the matters specially noticed. For the reasons given, we think the court below properly sustained the demurrer to the declaration. Its judgment is therefore affirmed.

Judgment affirmed. ${ }^{87}$

\section{WOOLISCROFT v. NORTON et al.}

(Supreme Court of Wişconsin, 1S62. 15 Wis. 198.)

Action to recover for work done and materials furnished by the plaintiff in repairing a dam and raceway. The facts, as reported by a referee, were substantially as follows:

A. Hyatt Smith and M. O. Walker were owners of land in Rock county, and of a dam erected thereon across Rock river, and of the power thus created; Smith owning three-fourths and Walker onefourth, undivided. While they were such owners, in 1849, Smith executed to Stevens \& Older a deed of a portion of said land for a mill site, and for 550 square inches of water to be used thereon-this being the first conveyance of any part of said water power by the pro-

$87 \mathrm{~A}$ covenant by a railroad to its grantor of a right of way to give to the grantor a pass over the railroad has been held not to be binding upon its successor in title. Ruddick v. St. Louis, K. \& N. W. Fy. Co., 116 Mo. 25, 22, S. W. 499. 35 Am. St. IRep. 570 (1S93); Eddy v. Hinnant, 82 Tex. 354, 18 S. W. $562(1891)$.

A. owned riparian land, a mill and a dam. He granted to a canal company the right to construct a canal through his land and draw water from the river, the canal comrany covenanting to maintain the dam so that A., his heirs and assigns, should alwis's hive a specified amount of water power. IIeld, a person claining title uniler $A$. camot maintain an action of covenant against the assign of the original (anill company for failure so to keep $u$ p) the dam. Latringer $v$. Virginia 'Tuust (o., 182 N. C. 409, 43 S. E. 910 (190:). 
prietors or either of them. This deed contained a covenant by the grantees that they would pay their ratable share of the expenses of keeping in repair the dam and raceway, "in proportion to the number of square inclies of water by them owned or used;" and that on a failure by them to make such payments, the grantor should have the right to enter upon said lot, and to shut off therefrom all of said water, until such payments should be made; and for that purpose, but no other, all watergates through which such water might pass, were declared to be the property of the grantors, their heirs, etc. Subsequently Older quit-claimed his interest in said grant to Stevens, who afterwards, in December, 1850 , received a deed from Smith \& Walker of additional land and 500 square irches more of water. This deed contained a covenant by Stevens simnlar to that above described. By mesne' conveyances, each containing similar covenants on the part of the grantees, the defendants Norton and Ford became equal owners in common of the land and the right to said 1050 square inches of water, and were such owners when the repairs mentioned in the complaint were made. *** In 1857 , Smith \& Walker employed the plaintiff to make certain repairs mentioned in the complaint; and he did work and furnish materials to the value of $\$ 1,630.62$, and this amount was apportioned among the several owners, lessees and users of the water in accordance with the rule above stated-the sum of $\$ 221.69$ being apportioned to the defendants. After the work was completed and the assessment made, the plaintiff called on Norton, one of the defendants, for payment, and he agreed to pay by giving the note of Norton \& Ford if Ford would consent; but Ford declined to pay or to give the note of the firm as proposed, but offered to set off a note which he held against A. Hyatt Smith, to pay the assessment or such part thereof as it would pay. All parties then called on Smith to obtain his assent to such offset, which he refused.

The referee also found that neither at the time when the work was done and the materials furnished by the plaintiff, nor afterwards, had any formal assignment or transfer of the assessments been made to the plaintiff by the owners of said clam and water power, but the same were handed over to him by A. Hyatt Smith with directions to collect them and apply the money to the payment of said claim for repairs. The referee found also that Norton $\&$ Ford had a valid counterclaim against the plaintiff for $\$ 36.34$.

[The judge found in favor of the plaintiff, but the plaintiff excepted to his method of computing the amount due from the defendants, and took this appeal.?

Cor.E, I. ${ }^{88}$ It appears to us that this suit was properly brought in the name of the plaintiff. He was employed to do the work and make the repairs on behalf of the proprietors of the water power;

88 Iart of the opinion is omitted.

Iirg.RiniIITs-:30 
and although there was no formal assignmert' of the account against the defendants for repairs, still it was in fact given to him with directions to collect and apply the money to the payment of his claim, so that really he is the party in interest. So that the case may be considered as resting substantially on the same grounds and controlled by the same principles of law, as though the proprietors had done the work, and made the assessment for repairs, and brought their suit for a ratable compensation. If the action could be sustained in the latter casc, we cannot see why it cannot now. Could then the proprietors of the water power recover contribution for the repairs, by virtue of the covenants in the deed. $* * *$ The subject of this grant was a mill site, and a certain quantity of water to be used thereon, taken from a dam and raceway called the Janesville water power. The manifest object of the covenant was, to provide adequate means for the due preservation and security of the dam and raceway, which was the common source of power, by compelling the covenantors to pay the proprietors a pro rata share of the expense of repairs in the proportion which the water they used bears to the whole amount used from the power by the proprietors and their several grantees and lessees. This appears to be the plain intent and object of the covenant. The defendants were let into a participation of the common rights and privileges in the power, and were made subject to common duties in respect to its preservation. The grantees and assigns were to contribute towards the expenses of the dam and raceway which were for the common use, in proportion to the water power which they derive therefrom, compared with the other owners thereof. Now the question arises, was this covenant one running with the land, or was it a personal covenant only binding upon the parties who made it? The circuit court held that it was one running with the land conveyed and water granted, and therefore imposed a charge or burden upon the property, binding upon the defendants as assignces of the original grantees. And in this conclusion we think the circuit court was most clearly right. $* * *$

Where a privity of estate exists between the parties, and the covenant is one about or affecting the land devised or granted, and tends directly and necessarily to enhance its value or render it more beneficial to those by whom it is owned or occupied, the covenant is said to be incident to the land and binding upon those in whom it subsequently rests.

Some of the authoritics state the proposition much more broadly, but I have found no case which holds that a covenant which comes within all these conditions was not one real and necessarily running with the land. And within this rule there can Be no doubt that the covenant in this case rums with the land. A privity of estate exists between the parties; the covenant concerns or relates to the property granted; it tends to enhance its value; the benefit of the repairs must directly enure to all interested in the preservation and security of 
the water power which the defendants own in common with others. For it is very apparent that to enable the defendants to enjoy their property, the mill dam and raceway must be kept in good condition. If the water power is destroyed-and it is evident it would be unless the dam and raceway are preserved-the value of the defendants' mill is depreciated, if not destroyed, too. Nor can it, with any justness, be said, that the covenant relates to matters foreign to the property granted. It is directly connected with it. The subject of the grant is a mill site, and an interest in a water power; and a covenant to contribute to the expense of preserving the water power most unquestionably relates to the thing granted. We therefore must hold that the covenant is one connected with or annexed to the property granted, and binding upon the defendants. 'This, we think, is clear upon all the authorities.

['The case was remanded on other grounds.]

\section{FARMERS' \& MERCHANTS' IRRIGATION CO. v. HILL.}

(Supreme Court of Nebraska, 1912. 90 Neb. 847,134 N. W. 929, 39 L. R. A. [N. S.] 79S, Ann. Cas. 19138, 524.)

HAMER, J. ${ }^{89}$ The plaintiff, the Farmers' \& Merchants' Irrigation Company (appellant in this court), commenced an action in the district court of Dawson county against the defendant, S. J. Hill, to recover a judgment for $\$ 750$ and interest for a water maintenance fee for the years 1907, 1908, and 1909. The plaintiff alleged that it owned and operated an irrigation canal and furnished water to lands upon which water rights were held, and that the defendant owned section 5 in township $10 \mathrm{~N}$., of range $21 \mathrm{~W}$., in Dawson county, and that one of the main ditches of the plaintiff passed,through said land; that there was attached to said land a water right which was evidenced by a "water right deed" for 500 acres of said land lying under said ditch, which deed was of record at the time the defendant purchased the land: that in this water right deed there was a provision which required the payment of 50 cents an acre as an annual maintenance fee: that the plaintiff was engaged in furnishing water to water users under its said canal; that the land of the defendant was susceptible of irrigation; that no part of said maintenance fee had been paid; and that there was due the plaintiff from the defendant $\$ 750$ and interest. The defendant answered that he was the present owner of the land, but denied all the other matters alleged.

Upon the trial the plaintiff offered in evidence the deed for the land described in the petition together with the indorsements thereon, all of which were received without objection. There was also offered and

83 Part of the opinion is omitted. 
received in evidence a "water right deed" containing the covenants upon which plaintiff predicates its right of action. The deed for the land is one of general warranty running from the Nikaniss Company to the defendant, and contains only the ordinary and usual covenants in such a deed. The water right deed from the plaintiff to the Nikaniss Company contains the following conditions: "That the said party of the first part ['The Farmers' \& Merchants' Irrigation Co.], for and in consideration of the sum of $\$ 1,750$ to it in hand paid, the receipt whereof is hereby acknowledged, and of the further annual payment hereinafter mentioned and provided for, to be made at the times named in this deed, have sold subject to the limitations and conditions hereinafter named, and by these presents, does sell and convey, unto the said party of the second part [Nikaniss Company], and to its heirs, assigns, and legal representatives, the right to use water, from the canal of the said party of the first part, during the irrigating season of each and every year, in an amount not exceeding the rate of one cubic foot per second of time for each 70 acres of land hereinafter described, to be used upon and for the purpose of irrigating the said land, only, the same being situated in the county of Dawson, state of $\mathrm{Ne}$ braska, to wit: All that part of section 5, in township 10 north, of range 21 west, lying south of the main canal of the the party of the first part (except that part taken up by slough) containing 500 acres. The said party of the second part, its heirs, assigns and legal representatives agree to pay to the party of the first part, its successors and assigns, as a part of the consideration of this grant, annually in advance, on or before the first day of March in each and every year, the further sum of $\$ 250$, the same being in addition to the consideration above expressed, and the amount named is hereby agreed upon as a liquidated sum as compensation to the first party for maintaining and operating said canal which it hereby promises and agrees to do, and the said party of the second part agrees to make said payments well and truly, at the times herein named." * * * .

The deed from the Nikaniss Company to Silas J. Hill is of the date April 6, 1906, and was filed for record May 10, 1906. The "water right deed" from the Farmers' \& Merchants' Irrigation Company to the Nikaniss Company is of the date February 13, 1904, and was filed for record February 24, 1904. On the trial it was stipulated that the plaintiff was a corporation, and that the defendant had paid no part of the maintenance fee claimed by plaintiff in the petition, that the defendant owned the land at the time of the commencement of the action, and that he has owned it at all times since he purchased the same. It was also stipulated for the purposes of the case that at all times mentioned in the petition the plaintiff has been willing and able to furnish water as provided in the "water right deed," but that the defendant at all times refused to recognize any rights or liabilities by reason of such deed, and refused to ask for water or to accept water thereunder. It was also agreed that the "water right deed" was 
duly indexed against the land therein described at the time the same was filed for record.

It is the contention of the plaintiff that the "water right deed" attached to the land and passed with the change of title, and that, therefore, the defendant was liable to pay the maintenance fee for each vear as it matured. It is said in plaintiff's brief that: "Under the rule established by this court the water right deed attached to the land, and cannot be severed from it. The appellee, the owner of the land, is the only person who can receive any benefit from this water right, and he, in turn, should be held liable to pay the annual maintenance fee." Counsel for the plaintiff contends in his brief "the sole question in this case is, Can appellant maintain a cause of action against appellee to recover this maintenance fee, there having been no expressed assumption of the obligation in the deed conveying the land to the apnellee?" The defendant contends that he cannot be held personally liable, and the district court adopted that view and dismissed the case.

The question to be determined is whether the defendant has assumed the obligations of the contract entered into between the irrigation company and the Nikaniss Company, the original owners of the land. The defendant bought the land and received a deed which was in the ordinary form of a warranty deed, and did not mention or refer to the contract sued upon. By the purchase of the land and by receiving the deed, does the defendant assume the contract of his grantor, and is he personally charged with the obligations of such grantor?

It is argued that section 6825 , Ann. St. 1909, obligates the ditch company to keep its canal in repair, and that, therefore, the duty which the l.egislature fixes upon the ditch company creates an obligation on its patrons to provide the funds necessary for the performance of the duty. The contract sought to be enforced is executory. The suit hrought is in personam. It is brought against the person instead of against the thing, and is not a suit against the land to enforce an alIeged lien, but it is an action against the defendant, and the theory upon which it is sought to be maintained of necessity would seem to imply the personal promise of the defendant to pay the money. The conveyance made by the Nikaniss Company to the defendant Hill may. have transferred to him all the property rights which the Nikaniss Company had in the land conveyed, but, if the grantee did not promise in any manner to assume the obligation of his grantor, how can he be hound?

The argument of counsel for plaintiff is that "there was no reservation or suggestion of reservation in the deed from the Nikaniss Company to appellee, Hill. That deed, 'Exhibit B,' it is submitted, carried with it the water right attached to this land as an appurtenance to the land. The acceptance of the deed by appellee Hill from the Vikaniss Company was an acceptance of all the incidents attached to or helonging to the land transferred to appellee (defendant), and charged him with the conditions written therein." The defendant Hill 
is a stranger to the original contract made between the Farmers' \& Merchants' Irrigation Company and the Nikaniss Company. If it may be properly said that the defendant, Hill, received the deed to the land from the Nikaniss Company with notice that the ditch is an easement and with notice of all the rights of the ditch company (Arterburn v. Beard, 86 Neb. 733, 126 N. W. 379), and therefore he is charged with such notice, as is said in Seng v. Payne, 87 Neb. 812, $128 \times$. W. 625, yet it would seem that that does not in any way tend to establish the personal liability of the defendant. Counsel for the plaintiff seems to have been unable to find any case directly in point which supports his contention. * * *

In Lexington Bank v. Salling, 66 Neb. 180, 92 N. W. 318, it is held that the conveyance of land subject to outstanding incumbrances imposes upon the purchaser no obligation to pay such incumbrance. In discussing the case the court said: "It has long been settled in this state that the acceptance of a deed which in express terms conveys land subject to an incumbrance does not impose upon the grantee a personal obligation to pay the debt. He is in such case interested in discharging the incumbrance, but he owes neither the grantor nor the incumbrancer any duty arising ex contractu. The transaction being nothing more than the purchase of an equity of redemption, no implied agreement is deducible from it."

We approach the determination of this case with a full realization of the importance of irrigation to the state. While the great bulk of farming in Nebraska is done upon agricultural lands which are not irrigated, yet a very considerable section must always depend upon the successful application of water to agricultural uses. This section of our state is already prosperous, and is destined to support a dense population. Irrigation is to be encouraged and protected in every legitimate way. While the plaintiff may be obliged to furnish the defendant with water for irrigation purposes if he demands it, and the plaintiff has it, yet the refusal of the defendant to accept the water does not create a personal liability against the defendant. It is contended by the plaintiff that the maintenance fee is by the terms of the "water right deed" made a charge upon the land, and that the defendant by his purchase of the land became personally liable for the payment of such maintenance fee. The trouble with this contention is that neither the terms of his deed nor the several irrigation acts impose upon him any such personal liability. IVe are of opinion that the trial court correctly determined the question before it.

The judgment of the district court is right, and it is affirmed.90

${ }^{90 \mathrm{~A}}$ similar covenant was held to create no personal obligation upon the grantee of the covenantor, but to create a lien upon the land for the price of the water aetually furnished. Fresno Canal Co. v. Rowell, So Cal. 114, 22 Pac. 58, $13 \mathrm{Am}$. St. Tiep. 112 (18s9).

See Consolidated Arizona smelting Co. v. Hinehman, 212 Fed. sï, 129, C. C. A. 267 (1914).

As to the liability of a corenantor after he has conveyed the burdened 


\section{- (C) Party Wall Covenants}

\section{GIBSON v. HOLDEN}

(Supreme Court of Illirois, 1885. 115 1ll. 199, 3 N. E. 2S2, 56 Am. Rep. 146.)

[Ilolden and Armstrong were the owners of adjoining lots in the city of Chicago. Holden was about to build on his lot, and it was desired by both persons that the wall on the side toward Armstrong's lot should be a party wall. On July 3, 1872, they executed a deed which, after reciting the above facts, provided as follows:]

"They therefore agree that said Holden may, in the erection of the improvenents on his property, place one-half in width of the wall of his building upon the property of said Armstrong, that said wall shall be suitable for a party wall, and shall continue to be a party wall forerer. And the said Holden and Armstrong agree to keep, maintain, repair and rebuild said wall, whenever necessary, at the equal joint expense of each. Said wall, when first built, is to be built and paid for by said Holden alone, and whenever said Armstrong uses all or any part of said party wall, he shall first pay to said Holden the cost of one-half of the part of the said wall. ***

"The provisions of this agreement shall be deemed and taken to be covenants rumning with the land, and shall be binding upon the executors, heirs, devisees and assigns of said parties, and shall bind all persons having, at any time, any interest or estate in said land."

[Holden built and paid for the wall. He later conveyed his lot to Limeretta A. Gibson, who continued to own it at the time of this action. The title to Armstrong's lot became vested, by mesne conreyances, in one Kedzie. Kedzie wished to erect a building and use a portion of the party-wall. Being uncertain as to who was entitled to the money, he paid into court one half the cost of that part of the wall. This bill was filed to settle the rights of Gibson and Holden in the money.]

SCHOLIELD, J. ${ }^{91}$ The language of this agreement very clearly hows that this wall was built as a party-wall, and to remain such. It says, after the recital showing the intention of Holden to build the wall, and the mutual desires of the parties that it shall be a partywall on the line between their lots, one-half of the wall resting on the ground of each: "They therefore agree that said Holden may, in the

lremises, sce Perlen r. Clicugo, R. I. \& P. Rr. Co., 73 Iowa, 328, 35 N. W. 4:4. 5 A m. St. Rel. GSo (1S87); Sexaner v. Wilson. 136 Iowa, 357, $113 \mathrm{\Lambda}$. IV. 941, 1.t L. R. A. (N. S.) 155, 15 Ann. Cas. 54 (1907); Hickey v. Jake shore \& M. S. Ry. Co., 51 Obio St. 40,36 N. L. 672, 29 J. R. A. 396, 46 Am. St. Rep. 545 (1S91); Carr v. Lowry's Adm'r, 27 Pa. 257 (1856).

As to the running of envenants annexed to a rent charge, see note 14 to - $r$ Conper, post, p. 566.

01 The statencut of facts is abridged and part of the opinion is omitted. 
erection of the improvements on his property, place one-half in width of the wall of his building upon the property of said Armstrong; that said wall shall be suitable for a party-wall, and shall continue to be a party-wall forever." The word "continue" manifestly means from the time of the building of the wall, for there is no other period indicated to which it can have reference. This view is confirmed by the further language: "And the said Holden and Armstrong agree to keep, maintain, repair, and rebuild said wall." When? The language of the agreement, continuing, answers, "Whenever necessary;" that is to say, at any time from the building of the wall. And this is to be done "at the equal joint expense of each." Had it been intended that the ownership of the wall should be in Holden until such time as Armstrong should pay him for one-half, it would have been the duty of Holden alone, until that time, to have kept, maintained, repaired, and rebuilt the wall; and we are bound to presume that, had such been the intention, language expressing that the wall should be a party wall when or upon condition that Armstrong should pay for one-half, and that thereafter the wall should be kept, maintained, repaired, and rebuilt at the equal joint expense of each, would have been used instead of that which was used. The sharing of the burdens of repair, rebuilding, etc., jointly, is an obvious result of a joint title or ownership, and could never be presumed, in the absence of language admitting of no other reasonable construction, as intended to apply to property whereof the title or ownership was in but one of the parties.

While, however, it is clear that the title or ownership of the wall is joint the moment it is built, and that it so continues, it is also clear that in order to secure Holden for his advances on the joint account in building the wall, the sole possession of the wall shall be in Holden alone; or, in other words, that Armstrong shall not be allowed to use the wall until he shall repay those advances. Armstrong has title to one-half of the wall, but Holden retains the possession of the whole as a security for his debt. There is no language used applicable to a sale. When Armstrong desires to tse the wall, he is not to pay for one-half its value, or a sum to be agreed upon as the price of one-half of the wall, as we should expect in case of a sale; he is simply "to first pay to said Holden the cost of one-half part of said wall." Holden's necessities for the immediate use of the wall are such that he is willing and consents to loan, in effect, to Armstrong so much money for that indefinite time. Cases, therefore, where parties are, by the deed under which they take title, given one-half of a wall as a party-wall, when or upon condition of making payment, and cases in which the owner of one lot has licensed the owner of the adjoining lot to build a wall for himself, resting one-half of it on each lot and reserving the privilege of thereafter purchasing one-half the wall as a party-wall, are not analogous. In all such cases the title to the whole wall may be regarded as appurtenant to the lot of the builder, and so passing 
by every conveyance of it, until the severance of the half by the payment of the purchase money. The sale of the half of the wall does not occur, nor the title to it pass, in those cases, until the payment is made, and so, necessarily, it is constructively a sale by the assignee of so much of the wall. His right to the purchase money is not because he is the assignee of a covenant runining with the land, but because he is the vendor of so much of the wall. ${ }^{02} * * *$

All, therefore, that Holden could have conveyed to another was the title to his lot, and the easement in the haif of the wall resting upon the lot of Armstrong for the support of his half of the wall. We think it quite clear from the language of the agreement that it was never intended that more than this should pass by any conveyance of the lot of Holden. Counsel for appellant, however, contend that the concluding paragraph of the agreement shows that it was intended that the right to receive payment for constructing the haif of the wall resting on the lot of Armstrong should pass by conveyance as an appurtenant to the lot of Holden. That paragraph reads:

"The provisions of this agreement shall be deemed and taken to be covenants running with the land, and shall be binding upon the executors, heirs, devisees, and assigns of said parties, and shall bind all persons having at any time any interest or estate in said land."

It must be apparent to all that this language was not intended to be taken literally; for it would be absurd to suppose that an assignee of Armstrong's lot should be bound for the payment of the one-half of the cost of the wall resting on that lot after the amount had once been paid. And it would seem equally apparent that it could not have been intended that payment should be made to the lot-owner, as such, unless the payment would necessarily have the effect to benefit the lot in some way. Unless such a payment, or rather a payment having such an effect, was intended, there is no conceivable reason why Holden should have desired that one debt rather than another should be paid to his assignee. If the debt could not have that effect, why should he want it transferred to his assignee at all? Why should a debt be transferred by a sale of real estate, unless of that character that it would necessarily affect the value or quality or the enjoyment of the real estate? Where the covenant is not of a nature that the law permits it to be attached to the estate as a covenant running with the land, it cannot

92 "We think that the proper rule, founded upon reason and fundamental principles, is that, unless payment for an interest in said wall is. by the clear terms of the contract, made a condition precedent to the resting of title in the nonbuilder, such title should be held to vest in such nonbuilder at least as soon as, under the terms of such contract, he becomes liable to pay the agreed consideration for such interest therein; that, regardless of the time when the nonbuilder becomes liable for such consideration, the title should he heid to vest in him immediately upon the erection of such wall, if under the terms of such contract he then assumes any responsibilities in relation to such wall, steh as liability to keep sitme in repair or to share in expense of renairs." Hill $\checkmark$ City of Huron. 33 S. D. $324.331,145 \mathrm{~N}$. W. 570,572 (19:1). See also Mickel r. York. 175 Ill. fi2, 51 N. F. S4s (1S9S). 
be made such by agreement of the parties. Masury v. Southworth, 9 Olio St. 340; Glenn v. Canby, 24 Md. 127; Brewer v. Marshall, 18 N. J. Eq. 337; Id., 19 N. J. Eq. 537, 97 Am. Dec. 679; notes to Spencer's Case, 1 Smith, Lead. Cas. (7th Amer. Ed.) pt. 1, 168.

Our conclusion therefore is that the fair construction of this clause of the agreenent will not warrant us in holding that it was intended the right to receive payment for the half of the cost of the wall should pass by a conveyance of Holden's lot, unless the language of the former part of the agreement is susceptible of that construction, and that it was only intended by this clause that such covenants should run with the land of both parties, or of either party, as were, when considered with reference to their subject-matter, practically adapted to the accomplishment of that end, and susceptible, legally, of being enforced as such. $* * *$

It seems impossible to hold that the right to receive payment for the cost of one-half the wall ran with the land. One easement was undoubtedly the consideration of the other. The party-wall was to be built at the joint expense of the lot-owners, but by what particular person the materials were to be procured and brought upon the ground, and the mechanical operation of laying up the wall performed, or by whom this was to be superintended, or by whom the money was to be advanced to make payments, were questions entirely independent of and apart from the ownership of the wall and the character of the easement which the lot-owners had in the part of the wall resting on the lots of each other. The materials might have been furnished, the wall built, and the entire amount paid therefor advanced by a stranger. This was the mere furnishing of so much material and doing of so much work for so much money, or the advancing of so much money to be repair again, and created only the relations of employer and employé, or borrower and lender. The fact that Holden was furnishing materials and doing work for himself on his side of the wall could, by no reasonable construction, affect his relations in regard to the other half of the wall which he was building for Armstrong. There is no cla:m that the money to be paid by Armstrong, or on his half of the wall. was to be expended upon the lot of Holden, or upon the wall gencrally, or that it was to be used in any particular way. As to Holden, the money, when collected, would be like all other money. An assignce would be no more benefited by receiving this money than by receiving money from any other source, or on any other account. To benefit him as landowner, it must, in some way, affect the value or the use of the land. It is not enough that it simply enriches the assignee hy that many dollars. Whether this money should be paid or not, the condition of the wall and of the lot of Holden would remain, in every respect, precisely the same. It would be difficult to give a better illustration of a purely collateral contract or covenant, so far as Holden's rights are affected, than this undertaking to pay for the cost of onehalf of the wall. 
Counsel for appellant strenuously insist that the ruling in Roche v. Liman, 104 Ill. 11, authorizes the plaintiff here to recover. We do not think so. That case states that had an action been brought against Kiclzie, he would have been held liable, but it goes no further. Kedzic took under the agreement, and with notice of it, and before he can have the benefit of the agreement he must comply with its terms. His lot is charged with the burden of paying, that is, in the sense that the wall cannot be used for the benefit of his lot until he does pay; but lliat burden is not to be discharged for the benefit of the adjoining lot, or so as in anywise to affect it. Like a mortgage or deed of trust, the land is, in the sense mentioned, burdened with the payment of a debt; but its payment affects no other land beneficially.

We see no cause to disturb the judgment of the appellate court. It is therefore affirmed.

Judgment affirmed..$^{93}$

\section{CONDUITT v. ROSS.}

(Supreme Court of Indiana, 185.5. 102 Ind. 166, 26 న. E. 195.)

Mitcheld, J. On the 26th day of April, 1875, Julia A. Ross and John Hauck were the owners of adjoining lots in the city of Indianapolis. Pursuant to a written agreement entered into by Mrs. Ross and her husband on the one part, and Mr. Hauck on the other, she placed one-half the width of the south wall of a four-story brick and stone building which she erected on her lot on the north margin of the Hauck lot. After erecting the building she conveyed the lot, with the improvements thereon, to George P. Bissell, reserving, by a stipulation contained in her deed, the right to receive compensation from adjoining property owners for the building, or use of existing party-walls, Subsequently the appellant became the owner of the Hauck lot, and in 1882 commenced the erection of a building thereon, and attached the same to and used the wall erected by Mrs. Ross. Refusing to make payment, this suit was commenced to recover one-half the original cost of the wall. Upon issues made, a trial was had, which resulted in a finding and judgment for the plaintiff.

Counsel for appellant rest their argument for a reversal of this judgment mainly upon the proposition that the agreement between

${ }_{03} \mathrm{Acc}$. where the party wall anreement lacked the tinal covenant contained in the deed in Gibson r. Ilolden: Blocl $r$. Isham, 25 Ind. 37, 92 Am. Dec.: 257 (1867); Cole v. Hughes, 54 N. Y. 444, 13 Am. Rep. 611 (1873); Kenny v. Mackenzie. 12 Ont. App. 346 (1585).

Compare Crater v. IICormicli, + Colo. 196 (1STS).

A. owned a wall stinding wholly on his own land. $X$. had a lease of an adjolning lot. A. by deed leased to $X$. the use of one-half of $A$.'s wall as a party wall for thirty yoars at a specified rent. A. died, and the parcel owned by hin was allotted to li. als one of A.'s heirs. $x$. died, and his leaseholnintrest passed to $\mathrm{Y}$. Ileld, $\mathrm{B}$. may recover the rent from $\mathrm{Y}$. Mackin

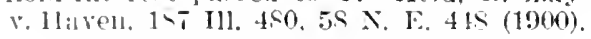


Hauck and Mrs. Ross was purely personal to them, and that Conduitt, by using the wall erected in pursuance thereof, came under no obligation whatever in consequence of such use. They insist further, that, if liable at all, the extent of his liability was the actual value of the wall when used, and not its original cost. The rights and obligations of the parties must be determined by a construction of the agreement already referred to, which is of the following tenor:

"This agreement between John Hauck of the first part, and Julia A. Ross, and Norman M. Ross, her husband, of the second part, witnesseth: That, in consideration that the parties of the second part shall erect a substantial brick wall, twelve inches in thickness, and four stories high, on the line dividing the property of John Hauck and Julia A. Ross, in square 87, in the city of Indianapolis, Marion county, Indiana, which line is twelve feet south of the south line of lot No. 4, in Morris Morris' subdivision of square 87, in the city of Indianapolis, and which wall is to stand six inches in width upon the ground of said Hauck, and six inches upon the ground of said Ross, and is to run back the depth of said Ross' present building, and may at any time be extended further back on the same line the full depth of said lots, by either party, the full consent of said Hauck to the erection of said walls being hereby granted: Now, therefore, said John Hauck hereby binds himself, his heirs, executors, administrators, and assigns, that whenever, after the erection of said wall or walls by the party of the second part, said Hauck, his heirs, executors, administrators, or assigns, sha1l, in any building he or they may erect on the present ground of said Hauck, use said wall, or any part thereof, or attach any part of his or their building thereto, then the said Julia A. Ross shall be paid, without relief from valuation or appraisement laws, the full value of one-half the original cost of said wall or walls. And it is further agreed that neither party shall have the right to so use any part of said wall or walls as to weaken or endanger the same; and that said Hauck, his heirs, executors, administrators, or assigns shall not, in any wise whatever, use or attach to said wall or walls so to be erected by said Ross, until the said value and costs of one-half thereof shall be ascertained, and paid or tendered to said Julia A. Ross. In witness whereof, we have hereunto set our hands and seals, this 26th day of April, 1875. [Signed] John Hauck. '[Seal.] Julia A. Ross. [Seal.] N. M. Ross. [Seal.]"

This agrecment was duly acknowledged, and recorded in the miscellaneous records of Marion county, and it is averred that the appellant had actual notice of it at the time he purchased.

The liability of the appellant depends upon whether the contract set out constituted a continuing covenant, which became annexed to, and ran with, the Hauck lot. If it did, he is liable according to its terms; if it did not, he is liable in this form of action for nothing.

In considering whether a covenant is one which does, or does not, run with land, there are always embraced the following inquiries: 
Is the covenant one which, under any circumstances, may run with land? (2) Was it the intention of the parties, as expressed in the agreement, that it should so run? Doubtless, a covenant which, from its character, might run with the land, may be so restricted in terms. as to make it purely personal, and available to the parties to it, and no other. So, too, a covenant may contain apt words to make it a continuing covenant, yet if its nature or the subject-matter. of it is such that it does not concern some interest or estate in land, either existing or created by it, it cannot run with land. When an instrument conveys or grants an interest or right in land, and at the same time contains a covenant in which a right attached to the estate or interest granted is reserved, or when the grantee covenants that he will do some act on the estate or interest granted which will be beneficial to the grantor, either as respects his remaining interest in the lands out of which an interest is granted, or lands adjacent thereto, such covenant is one which may become annexed to, and run with, the land, and bind its owners successively. When such grant is made, and contains a covenant so expressed as to show that it was reasonably the intent that it should be continuing, it will be construed as a covenant running with the land. A covenant which may run with the land must have relation to the interest or estate granted, and the act to be done must concern the interest created or conveyed. In Bally v. Wells, 3 Wils. 25, it was said: "When the thing to be done, or omitted to be done. concerns the lands or estate, that is the medium which creates the privity between the plairitiff and defendant."

By the contract under consideration, Mrs. Ross acquired the right to enter upon the Hauck lot and erect, and permanently maintain thereon, a party-wall. This was a grant to her of an interest in land, and was of such a character that a perpetual covenant might be annexed to it. Snowden v. Wilas, 19 Ind. 10, 81 Am. Dec. 370; Hazlett v. Sinclair, 76 Ind. 488, 40 Am. Rep. 254, 1 Smith Lead. Cas. (8th Ed.) 161, 162 In consideration of this grant to her, she covenanted to do an act beneficial to the remaining interest of Hauck. That act was the erection of a wall so situated as that one-half of it should rest on the margin of his lot and the other half on hers, thus devoting each estate to the mutual support of the party-wall. She, at the same time, covenanted that when she should be reimbursed onehalf of the cost of the wall, he or his grantees should acquire a reciprocal interest in her lot, and, in legal effect, become owner of onehalf the party-wall. This agreement created what has been aptly termed mutual, or cross, easements in favor of each in the lot of the other. and was an arrangement mutually beneficial to both properties. Fitch $v$ Johnson, 104 111. 111; Roche v. Ullman, Id. 11; Bronson v. Coffin, 108 Mass. 175, 11 Am. Rep. 335; Thomson v. Curtis, 28 Iowa, 229. It contained, therefore, all the elements necessary to a covenant capable of running with the land. Hazlett v. Sinclair, supra: Rich- 
ardson v. Tobey, 121 Mass. 457, 23 Am. Rep. 283; Standish v. Lawrence, 111 Mass. 111; Maine v. Cumston, 98 Mass. 317; Savage v. Mason, 3 Cush. (Mass.) 500; Brown v. McKce, 57 N. Y. 684; Keteltas v Penfold, 4 E. D. Smith (N. Y) 122; Platt v. Eggleston, 20 Ohio St. 414; Masury v. Southworth, 9 Ohio St. 340; Bertram v. Curtis, 31 Iowa, 46; Norfleet v. Cromwell, 70 N."C. 634, 641, 16 Am. Rep. 787.

It is apparent, too, that it was the intention of the parties that the covenant to pay should run with the land. The words used in that connection are those usually and aptly employed for the purpose: "John Hauck hereby binds himself, his heirs, executors, administrators, and assigns, that whenever, after the erection of said wall or walls by the party of the second part, sa1d Hauck, his heirs, executors, administrators, or assigns, shall, in any building he or they may erect," etc., "they will pay," etc. A continuing covenant may exist without the word "assigns," or "grantees," but when these or equivalent words are used, they become persuasive of the intent of the parties. Van Rensselaer v. Hays, 19 N. Y. 68, 75 Am. Dec. 278 It was the manifest purpose of the parties that the right to receive payment for the wall should be personal to Mrs. Ross. It was stipulated that payment should be made to Julia A. Ross. It results that the complaint was sufficient, and that the second paragraph of answer, in which it was alleged that the wall, by reason of injuries sustained from fire, was worth much less than the original cost, was insufficient, and the respective rulings of the court were not erroneous. The covenant being one which ran with the land, when the appellant availed himself of its benefits he became related to it as the original covenantor, and it became the measure of his obligation. We think it is fairly deducible from the complaint that the appellant derived his title through Hauck.

Judgoment affirmed, with $\operatorname{costs.}^{94}$

st Opinion of Mitchell, C. J., on rehearing, is omitted. 


\section{SOUTHIVORTH v. PERRING.}

(Supreme Court of Kansas, 1905. 71 Kan. 755, 81 Pac. 481, 82 Pac. 785, 22 I. R. A. [N. S.] 87,114 Am. St. Rep. 527.)

Mason, J. ${ }^{95}$ In 1885 the respective owners of two adjoining lots entered into a written contract ${ }^{96}$ by the terms of which it was agreed that one of them, who was about to erect a brick and stone building upon his lot, should place one of its walls upon the dividing line, and that when the other should build he should use this wall as a division wall, and pay him half its value. The agreement concluded with these words: "The parties hereto bind and obligate their heirs, executors, administrators and assigns to the fulfillment of all the terms and covenants of this agreement." The building was accordingly erected. In course of time the lot on which the building stood was conveyed to Hiland Southworth, and the other lot to E. L. Perring. In 1901 Perring built upon his property, and made use of the party wall. Southworth then demanded of him pay for half its value, and, upon payment being refused, brought action to enforce it. Judgment was rendered against the plaintıff, who prosecutes error.

95 Parts of the opinions are omitted.

98 The contract is as follows: "This agreement, made and entered into this 22d day of July, A. D. 1SS5, by and between G. W. C. Rohrer and liaggie A. Rohrer, his wife, and J. E. Bonebrake and Elvira A. Bonebrake, his wife, of Abilene. Kansas. parties of the tirst part, and W. S. Hodge and Laura T. Ilodge, his wife, of Abilene, Kansas. parties of the second part, witnesseth: That whereas, the parties of the first part, are the owners of lot seven ( 7 ) and the parties of the second part are the owners of lot six (i) in Henry, Hodge \& Reed's subdivision of Thompson \& MICCoy's addition to the city of Abilene, Dickinson county. Kansas: Now, therefore, the parties of the first part for and in consideration of the promises and agreements of the parties of the second part, hereinafter contained, hereby grant and wive to the parties of the second part the right and privilege to build the west wall of a two story brick and stone building on the line separating said lots in said subdivision from each other; that is to say one half of said west wall of said building to be located on said lot seven (7). Said wall shall he of the following material and dimensions, to wit: The base shall be of stone, and be three feet wide and ten feet high; the first story wall shall be brick, and be sixteen inches wide and sixteen feet high; the second story wall shall be brick, and be twelve inches thick and ten feet high; all of said wall to extend the full length of said lots on said separating line. And the said parties of the first part further promise and agree that when they slall build on their said lot seven (7) they will pay to the said parties of the second part one-hale the ralue of said west wall and use the same as a division wall: the value of the same to be fixed by three appraisers to be selecter, one by the parties of the first part, one by the parties of the secom part, the two so chosen to select a third one. The parties of the second part for and in consideration of the promises and agreements of the parties of the first nart, as herein contained, do hereby promise and agree to build said wall on the location and of the materials and dimensions hereinbefore de. scribed and set out, and, when said parties of the first part build on their said lot, to take one-half of the value of said wall, to be fixed and determined as hereinbefore provided, and permit the sail parties of the first part to use the same as a division wall. 'The parties hereto bind and obligate their heirs, executors, administrators, and assighs to the fultillment of all the terms and covenants of this agreement." 
As appears from this statement, the questions involved are (1) whether the right to compensation provided for in the contract under the circumstances stated remains with the individual who constructed the wall, or has passed to Southworth in virtue of his being the owner of the lot upon which the first building was erected, at the time the wall was made use of by the adjoining proprietor; and (2) whether the liability to pay a part of the value of the wall still exists against the original owner of the second lot, who made the contract, or has shifted to its present owner, who made use of the wall. ***

It is generally conceded to be competent for the parties to make the privilege as well as the duty created by such an agreement follow the ownership of the land, and the disputed question in each case is whether they have done so; the conflict of authority arising upon the interpretation of the language employed. Different conclusions as to the intentions of the parties are reached by different courts upon substantially the same state of facts according to the view taken of the general nature of such contracts. A court that regards them as closely related to the real estate, and inherently adapted to run with it, will be persuaded of the intention of the parties that they should do so upon much less evidence than would convince another court that considers them as essentially personal:

It is easier to find support in reason and authority for holding that the obligation to make payment runs with the land than for holding that the right to receive payment does. The important inquiry in the . present case is therefore whether Southworth is entitled to collect payment for half the value of the wall. If he is not, the judgment must be affirmed. If he is, the same considerations that justify that conclusion will necessarily compel also the determination that Perring is the person who must make the payment, and the judgment must be reversed.

The reasoning in support of the doctrine that the right to demand payment from the second builder passes with each conveyance of the land of the first builder is thus presented in the note in $89 \mathrm{Am}$. St. Rep. 941, to which reference has already been made: "It seems to us that the more reasonable rule is that an agreement between the owners of adjoining premises, whereby one is to build a party wall one-half on the land of each, and the other to pay for one-half of its construction when he uses the wall, creates cross-easements as to each owner, running with the land, with or without notice to the grantee, and is binding on all persons succeeding to the estates to which such easement is appurtenant, and that a purchaser of the estate of an owner so contracting must be required to pay one-half of the cost of the wall, if it is unpaid for at the time of his purchase, and he afterward avails himself of its benefits. [Citing cases.] Under this view, the title to the whole wall may be regarded as appurtenant to the lot of the builder, and so passes by every conveyance of it until the severance of the one-half by the payment of the purchase money. The sale of the one- 
half of the wall does not occur, nor the title to it pass, until the payment is made, and thus necessarily it is constructively a sale by the assignee of so much of the wall. His right to the purchase money is not because he is assignee of a covenant running with the land, necessarily, but because he is a vendor of so much of the wall, for which the party using it is liable. [Citing cases.]" With regard to the effect of the decisions bearing upon the question, the note continues: "Quite a respectable number of well-considered cases maintain the doctrine that the right to that portion of a party wall resting on the lot of an adjoining owner is not personal to the owner of the lot on which the building is erected, but one running with the land, and that a conveyance of the lot on which the building is erected passes to the grantee the right to recover of the adjacent owner the value of one-half of the wall when used by him. [Citing cases.] And this rule has been enforced especially under agreements wherein the covenantor has covenanted for himself, his executors, heirs, or assigns." * * *

Without attempting to declare what general principles relating to the question presented are sustained by the greater number of decisions, we shall decide it upon these considerations: We regard contracts of the character of that here involved as in their nature so related to the real property affected, and so adapted to impose their obligations and bestow their benefits upon the successors in title of the landowners by whom they are made, that the purpose that they shall have that effect is readily to be inferred from the employment of language having any substantial tendency in that direction. In the present case we hold that the use of the clause making the terms of the contract binding upon the heirs, executors, administrators, and assigns of the parties sufficiently indicates that intention. What the effect of the omission of that provision might have been, we do'not now determine.

The judgment is reversed, with directions to render judgment for the plaintiff. All the Justices concurring.

Opinion denying petition for rehearing.

Per Curiam. * * * It must be conceded * * * that none of the cases, in which the right to receive compensation from one using a party wall already built is held to pass to the grantee of the builder, arose upon a contract precisely like the one here involved. Nevertheless the fact remains that the weight of authority supports the view that party wall contracts may be so drawn as to have this effect, and that in each case the question is whether such is the intention of the parties, as shown by the language used. * * *

If the last paragraph [of the party wall contract] as contended by the defendant in error, means only that the personal obligations assumed by the parties shall be binding upon their respective estates, then, as said in the motion for a rehearing, it expresses absolutely nothing that the law does not imply, and is utterly without force. It should

BIg.Rigint- 31 
not be so treated if there is a reasonable and natural construction available that will give it some effect. We interpret it as in substance a stipulation that the covenants of the agreement shall run with the land. It is not expressly said that the benefits of the contract shall accrue to the heirs, executors, administrators, and assigns of the builders of the wall, but there is an express reference to the heirs, executors, administrators, and assigns of all the parties, and the provision that all the terms of the contract shall be binding upon them clearly indicates an intention to establish a permanent status between the respective ormers of the two lots with reference to the party wall. In the body of the contract the reading is that the first parties shall pay the money to the second parties; no mention being made of the heirs, executors, administrators, or assigns of either. But the second parties affirmatively agree not only to build the wall according to certain specifications, but to take one-half the value, to be fixed in a prescribed manner, and to permit the first parties to use it as a division wall. These agreements are by the very letter of the contract made binding upon the heirs, executors, administrators, and assigns of the second parties. This shows that it was within the contemplation of the parties that the payment should be made to the successors in interest of the builders of the wall, quite as explicitly as though their assigns were mentioned each time they were themselves referred to in the contract. ****

The motion for a rehearing is denied. ${ }^{97}$

\section{CRAWFORD v. KROLLPFEIFFER.}

(Court of Appeals of New York. 1909. 195 N. Y. 185. 8s N. F. 29, 13. Am. St. IRep. 78\%.)

Appeal from a judgment of the Appellate Division of the Supreme Court in the First Judicial Department, entered January 22, 1908, affirming a judgment in favor of defendant, entered upon a dismissal of the complaint by the court on trial at Special Term.

niAce.: Savage v. Mason, 3 Cush. (Mass.) 500 (1St9); Sandherg v. Rowland, 51 Wash. 7,97 Pac. 1057, 130 Am. St. Rep. 1077 (190S). See Roche v. Ullinan, 104 IIl. 11 (1S\$2).

"I'rovided alwass. and the above second clause and the rights of using the parts wall therohy conferred shall depend and be contingent upon the said Kantenberger, lis heirs, executors, administrators or assigns, paying or caving to be paid, to the said Brusse, his heirs, executors, administrators or assigns, the one half part of the original cost of said wall." Brusse having erected the wall, conveyed the lot to A., and assigned his claims under the contract to $\mathrm{B}$. IIcld, $\mathrm{A}$. is entitled to collect one-half the cost of the wall from Kantenherger's grantee, who made use of it as a party wall. Adams v. Nohle, 120 Wich. 545, 79 N. W. 810 (1s99). Acc.: Loyal NIystic Legion $\mathrm{v}$. Jones, $73 \mathrm{~N}(\mathrm{H}, 3+2,102 \mathrm{~N}$. W. 621 (1903). Acc, where the language is of promise to pay when the wall is need: Ferguson r. Worrall, 125 Ky. 619,101 S. II. 966. 9 I. I. . . (N. S.) 1261 (1907). See, also, Platt v. Eggleston, 20 Ohio st. $414(1,-i 0)$. 
The plaintiff and Francis Crawford were owners of adjoining parcels of land, and on February 28, 1899, entered into an agreement in writing, plaintiff being party of the first part, and Francis Crawford being party of the second part, which was duly recorded in the office of the register of the county of New York, in and by which it was provided that the plaintiff should forthwith construct a party wall, the center line of which should be the line between the two lots. It was further provided that the entire cost of constructing the wall should be borne by the plaintiff or his assigns, and that "the said party of the second part hereto, or his assigns, shall be at liberty at any time hereafter to use the said wall for all the purposes of a party wall for any house, which he, or his assigns, may erect on said land owned by the said party of the second part, upon payment by the said party of the second part, or his assigns, to the said party of the first part, his legal representatives or assigns, the sum of five hundred dollars in cash, such payment to be made when the wall is used." It was further provided that, should it become necessary to repair or to rebuild the wall after the same slould be used by the party of the sccond part, or his assigns, the cost thereof should be borne equally by the parties, or their representatives, heirs, executors, administrators, or assigns. The final clause of the agreement was as follows: "Fifth. That this agreement shall be binding on and enure to the benefit of the heirs, executors, administrators and assigns of the respective parties hereto, and shall be construed as a covenant running with the land," etc.

The plaintiff built the wall contemplated, in connection with the construction of his building. Francis Crawford died seised of the premises adjoining, and his executors conveyed them to another-subject to the party-wall agreement-who built upon the same, using the wall. The grantee of the executors conveyed the premises so built upon to the defendant, subject to the party-wall agreement. This action was brought to enforce a lien for the amount due under the agreement for the use of the party wall. The complaint was dismissed upon the merits, at the Special Term, and the judgment recovered by the defendant was affirmed by the Appellate Division in the First Department. The plaintiff further appeals to this court.

GrAY, J. (after stating the facts as above). The Appellate Division, in affirming the judgment for the defendant, based its determination upon the ground that the covenant in the party-wall agreement did not run with the land, within the authority of certain decisions of this court, inasmuch as it did not create any privity of estate. This distinction was pointed out that "where the agreement does not contemplate the present construction of a party wall, but authorizes its construction by cither party in the future, the rule is different, and the covenant is said to create a privity of estate and to run with the land." We think that this distinction is one which has been established by our decisions, and that a rule of property has thereby been created 
which should not be departed from. See Mott v. Oppenheimer, 135 N. Y. 312, 31 N. E. 109T, 17 L. R. A. 409, and Sebald v. Mulholland, 155 N. Y. 455,50 N. E. 260.

Prior to the decision in Mott v. Oppenheimer, the rule had become firmly settled that where an owner of land builds a party wall, under an agreement with his adjoining landowner that, when he or his assigns shall use it, he or they should pay the value of the party wall, the corenant of payment was not one which ran with the land. See Cole v. Hughes, 54 N. Y. 444, 13 Am. Rep. 611; Scott v. McMillan, 76 N. I. 141; Hart v. Lyon, 90 N. Y. 663. In the case of Cole v. Hughes, upon which were rested the decisions in Scott v. McMillan ind in Hart v. Lyon, it was held, in substance, that the party-wall agreement, which was entered into for the purpose of permitting one of the parties to erect the wall, created no privity of estate between the contracting parties, but merely a privity of contract, leaving the burden or liability of payment with the original covenantor. Those cases were actions at law to recover one-half of the value of the party wall against subsequent adjoining owners, upon their using the wall, in which the plaintiffs failed to recover. In the last one, of IIart v. Iyon, the corenant for payment was accompanied in the agreement by a further covenant that the expense of repairing or of rebuilding the party wall should be borne equally by the parties, their heirs and assigns. This gave occasion to the court to hold that the latter covenant "should be construed as perpetual and as a covenant rumning with the land, while the other, being personal, could not be so regarded"; thus plainly intimating that there was a distinction to be observed, where the covenant was prospective in imposing a burden upon the land in the hands of its future owner.

When the case of Mott v. Oppenheimer was decided, the rule of the cases referred to was not sought to be disturbed, and the decision proceeded upon the difference in the situation and in the agreement of the parties. There, neither of the parties to the agreement, apparently, was about to build, and they made it with reference to the future. They were adjoining owners of unimproved lots, and through the agreement obtained the necessary authority for the construction of a party wall thereafter by either, or by the successors in interest of either, and for the use of the same by the then adjoining owner upon his paying one-half of the then value of the portion used. subsequently, and when the lands had come into other ownerships, such a party wall was built, and the plaintiff, who had acquired the premises so improved, brought the action against the adjoining landowner, and was given a lien upon the defendant's premises for the value of one-half of the wall. It was held that the covenant of the parties to the agrecment was not personal, and that it concerned the land and became annexed to the estate. "The effect of the contract," it was said, "clearly was to grant, or to create, an interest in the premıses described." 
Later, in the case of Sebald v. Mulholland, 155 N. Y. 455, 4.64, 50 $\therefore$. E. 260, 262, the case of Mott v. Oppenheimer was considered, and, adverting to the fact that it was not proposed, in its decision, to change the rule of the earlier cases, it was held that it was distinguishable in its facts. That distinction was pointed out as being in this; that "the provisions of the agreement in that case related to the future use of the property, and there was no intention to provide for any present or existing situation"; that it was "made with the view that such a contract would be beneficial to the land of both parties, and would bind it when the conditions contemplated should subsequently arise. * * * But in the other cases, *** as well as in the case at bar, the agreement was in effect a personal covenant between the parties." The agreement in Sebald v. Mulholland was made between one, who was "about to erect a building upon his lot," and another, owning the adjoining land, who agreed for himself and "his personal representatives," whenever he or they might desire to use the wall, to pay the due proportionate expense of its construction. The agreement differed from that in Mott v. Oppenheimer, not only in the respect dwelt upon in the opinion, but also in the fact that the covenant of payment was made by the adjoining lot owner for himself and "his personal representatives."

Though I had written the opinion for the court in Mott v. Oppenheimer, I expressed myself as concurring with Judge Martin, who wrote in Sebald v. Mulholland, upon the ground that the contract then in question required a different construction from that in Mott v. Opperiheimer. It was different in the respects noted. The result of this last decision was to establish a test by which it should be ascertained when the covenant in a party-wall agreement ran with the land. The Appellate Division Justices have correctly pronounced upon the rule as it was left by the decisions mentioned, and, as I have said, it being a rule of property, it should stand.

The judgment appealed from should be affirmed.

Cullen, C. J., and Edward T. Bartlett', Vann, Willard Bar't-

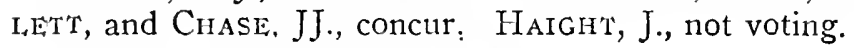

Judgment affirmed, with costs. ${ }^{9 s}$

$98 \Lambda$. and $\mathrm{X}$., owners of adjoining lots, made a party wall agreement. A. erected a wall as provided. $X$. conveyed to $Y$. $X$. used the wall as a party wall. A. brought action against $Y$. for the value of one half the wall, and the case was submitted upon an agreed statement of fact. The court said: "But even if, in accordance with the decision in Cole $\mathrm{v}$. Hughes, $54 \mathrm{~N}$. $\mathrm{Y}$. $44+[13 \mathrm{Am}$. Rep. 611 (1873)], cited for the defendant, the agreement to pay money should be considered a personal covenant only, not running with the land of the grantors, yet the plaintilf clearly had a right of property in the wall which she built in the exercise of the right which liad been granted to ber in that land. Maine v. Cumston, 95 Mass. 317 [1867]; Standish r. Lawrence. 111 Mass. 111 [1S72]. The defendant, having made use of the wall so built, cannot deny the plaintiff's right therein, and is bound to compensate her for such use, either according to the covenant in the deed from his grantors to the plaintiff, or according to the value of the wall. We need not consider what the amount of such compensation slould be, in the absence 


\section{LINCOLN v. BURRAGE.}

(Supreme Judicial Court of Massachusetts, 1901. 177 Mass. 378, 58 N. E. 67, 52 L. R. A. 110.)

Appeal from a decree of the Superior Court sustaining the defendant's demurrer to the declaration. Writ dated July 6, 1899.

'The declaration alleged that the plaintiffs, as executors of the will of Frank N. Thayer, deceased, by virtue of the powers conferred upon them under said will, conveyed to Franklin ' $\mathrm{T}$. Rose by deed dated November 9, 1883, a certain parcel of land in Boston on the conner of Commonwealth Avenue and Hereford Street, bounded westerly on land conveyed by said executors to Richard C. Flower, through the middle of the brick party wall; "that in said deed it was provided as follows: 'Said grantee, by accepting this deed, agrees for himself, and his heirs, and assigns, to pay to said executors, or their successors in said trust from time to time, the value at the time of use of so much of said party wall standing on the described premises, including the piling and foundations under the same, as he or they may at any time use.'

"It the time of said conveyance there stood upon the premises described in said deed, one half of a party wall constructed by the said Thayer at his own expense, but said premises were not otherwise built upon, and so remained until the same were purchased by the defendant.

"Thereafter, on or about January 17, 1899, the defendant purchased the said lot of land, and also the adjoining lot conveyed by said executors to said Flower, as aforesaid, and the same were conveyed to her, subject to the agreement above recited.

"The defendant then procceded to tear down the divelling house crected on the said adjoining lot, and to construct a building covering

ot asrement betwern the parties to this action, because these parties, in the "aso statud, have theluselres assessed the amount, hy agreeing upon the sum whin the plaintiff shall recover if she ean maintain her action." lichardson v. Tolney, 121 Mass, 457, 459, 28 . Im. Rep. 283 (1877).

špr, nlso, Ilving v. Tmmbut1, [1900] 2 Q. L. 129 (1899).

"Where a party will is erected by agrcement, resting in part on the lands of 1 wo adjoining ownels, with a covenant that the owner erecting the wall shall lave conyunsation for a portion of the expense from the other owner when the latter slall male use of the wall, the obligation to pay arises only when such use is matr. The corenant luns with the land as against a granter of sucl aljuining owner, and the wantee who first avails himself of the hemefits of the wall becomes bound to pay his share under his glantol"s cofenant to the owner, who lias erected such wall, and there is no liahility on the liat of the covenantils grantor, who has made no use of the wall, to pay the stipulated shalle of the expense either to the adjoining own"lill whom the covelint was made and who erected the wall, or to the

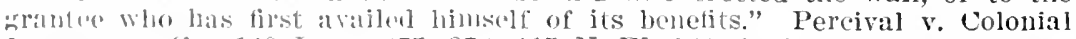

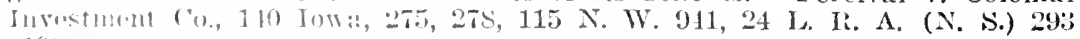
(1) (1)).

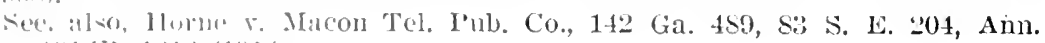
1'as. 1!11;1;, 1:12. (19)11). 
both of the said lots, and to crect a wall upon the said foundations, and in place of the said party wall.

"That the defendant was bound by the terms of said agreement, and having torn down the said party wall for the purpose of erecting a building on said prenises, and having used the piling and foundations under the same, for the purpose of erecting another wall thereon, became liable to the plaintiffs for the value of the whole [one-half] of said party wall, piling and foundations, which, at the time of use thereof, were of the value of $\$ 1,500$."

The defendant demurred to the declaration.

The case was heard in the Superior Court by Bell, J., who sustained the demurrer and ordered judgment for the defendant; and the plaintiffs appealed to this court.

IIormes, C. J.9 ${ }^{99}$ The acceptance by Rose of the conveyance to him implied a promise by him to pay for the party wall at the time of use. Although not a covenant, under our decisions such a promise might be held, in equity, if not at law, to follow the analogy of covenants rumning with the land in a case to which that analogy would apply. Manufacturing Co. v. Staples, 164 Mass. 319, 41 N. E. 441, 29 L. R. A. 500. But it is most unusual to see a covenant under which the rights are held in gross and the burdens go with the land. We suspect that it would be hard to find in the books another case like Middlefield v. Knitting Co., 160 Mass. 267, 272, 35 N. E. 780. Compare, further, Walsh v. Packard, 165 Mass. 189, 192, 42 N. E. 577, 40 L. R. A. 321, 52 Am. St. Rep. 508. Leaving cases of landlord and tenant on one side, commonly, where the burden of a covenant goes with land, the covenant either creates a servitude, or a restriction in the nature of a servitude, in favor of a neighboring parcel, or else is in some way incident to and inseparable from such a servitude, or, if attached to the dominant estate, appears to be the quid pro q11o for the easement enjoyed. Savage v. Mason. 3 Cush. 500; Richardson v. Tobey, 121 Mass. 457, 23 Am. Rep. 283; Norcross v. James, 140 Mass. 188, 191, 2 N. E. 946; King v. Wight, 155 Mass. 4+4, 29 N. I: 644: Manufacturing Co. v. Staples, 164 Mass. 319, 41 N. E. 441, 29 L. R. A. 500.

In the present case Rose's assumpsit did not purport to be for the benefit of the owner for the time being of the adjoining land. The deed which he accepted showed that his grantors had conveyed that land so that they could not annex a promise to it, and disclosed no interest on their part to secure compensation for use of the party wall to their grantee. On the contrary, the stipulation is in favor of the executors making the conveyance, "or the successors in said trust from time to time," showing in the clearest way that the benefit of the promise was intended to be personal, and a postponed compensation to the estate for the use of a wall which the testator had built. This is 
the construction upon which this action is brought. But if the promise is personal on the side of the benefit, no reason whatever is shown for departing from the tradition of the law in order to make it follow the land with its burden, as we already have said. Indeed, the words of Rose's promice are satisfied if they be read as a personal promise to pay whenever he or his assigns may use the wall. Furthermore, it never is to be forgotten that under all circumstances it is an anomaly refuiring explanation when an active duty is other than personal, and is attached to land. See Norcross v. James, 140 Mass. 188-190, 2 ‥ I. 946; Cole v. Hughes, 54 N. Y. 444, 13 Am. Rep. 611. This difficulty is felt so strongly in England that, when a duty to pay for a Irerty wall is recognized between owners who have not contracted together personally, it seems likely that it will be worked out in terms of implied contract, as it was in Irving v. Turnbull, [1900] 2 Q. B. 129. See, also, Maine v. Cumston, 98 Mass. 317, 320; Standish v. Lawrence, 111 Miass. 111, 114; Richardson v. Tobey, 121 Mass. 457, 459, 460, 23 Am. Rep. 283.

The plaintiffs put their argument in the form last suggested. But we do not sce any reason why a change in the fiction should enlarge their rights. In fact, the defendant did not contract with the plaintirifs. Any ground upon which she should be held liable in contract would be a fiction. In the present case, where the plaintiffs have no interest in the property used by the defendant, it is no better to say that a contract is implied than to say that it runs with the land. If a covenant by Rose in the form of the stipulation set forth would not have hound his assigns, even under our law, which permits the burden of such covenants to be transferred, and if, therefore, there was no obligalion on the defendant arising from Rose's simple contract on the analogy to such a covenant, we conceive that we should be unwarranted in saying that a contract by the defendant was to be implied simply from the facts of that same contract by Rose and the defendant's succession to his tiile.

It is not quite clear that there are any further facts which might strengthen the plaintiffs' casc on this latter ground of implied contract. It is not quite clcar that the defendant actually contracted even with her grantor. It does not appear that her grantor was Rose. If both these facts be assumed to have been in the form most favorable for the plaintiffs, while it may be that slight circumstances would be laid hold of to avoid circuity, and to establish a privity of contract between the parties to this suit, stitl it would be difficult to imply a contract in favor of the plaintiffs simply on the ground that a contract was madle with somebody else. In the cases which have gone furthest, the first step has been that both lots have been conveyed under an arrangenent with contemplated reciprocal benefits and burdens belween the two. Maine v. Cumston, Irving v. Turnbull, ubi supra.

Judement ąfintuet. 


\section{Agremientis Not Under Seal}

\section{BURBANK v. PILLSBURY.}

(Supreme Court of New Hampshire, 1869. 4S N. H. 475, 97 Am. Dec. 633.)

['The facts are stated ante, p. 439.]

SmITH, J. ${ }^{\mathbf{1 0 0}}$ If Apphia Martin accepted the deed of Jolnston, containing a stipulation that certain services should be performed by her, she thereby (if she had legal capacity to contract), impliedly promised to perform these services, and an action of assumpsit might have been maintained against her for non-performance. "A deed poll, when accepted by the grantee, becomes the mutual act of the parties, and a stipulation on the part of the grantee, though it cannot be declared upon as his deed, yet by force of his acceptance, is a valid contract on his part, by which a right may be reserved or granted, or upon which a suit may be maintained." This language was used by Shaw, C. J., in Newell v. Hill, 2 Metc. (Mass.) 180, in reference to a deed poll containing a clause almost precisely similar to that now under consideration: and there are various other cases where the same general principle has been enunciated; Goodwin v. Gilbert, 9 Mass. 510; Minor v. Deland, 18 Pick. (Mass.) 266: Pike v. Brown, 7 Cusl. (Mass.) 133; Guild v. Leonard, 18 Pick. (Mass.) 511 ; Maine v. Cumston, 98 Mass. 317, Bigelow, C. J., pp. 319, 320; Atlantic Dock Co. v. Leavitt, 50 Barb. (N. Y.) 135; Huff v. Nickerson, 27 Me. 105. Indeed, there are authorities which go so far as to maintain that an action of covenant will lie against a party who accepts such a deed. It is unnecessary to consider here the correctness of this position: for if the contract entered into by a grantee who accepts such a deed poll as Johnston's is not a technical "covenant," it is none the less a binding obligation, the only dificrence being in the remedy; see 3 Blackstone's Com. 158; and the authorities which hold that an action: of covenant will lie are referred to here only by way of showing that the obligation created by the acceptance of such a dect is so nearly akin to a covenant executed by the grantee that it has been seriously contended that there is not even a technical, much less a substantial, difference between them.

The next question to be considered is whether the obligation thus entered into by the original grantee is binding on her grantees with notice, or, in other words, whether the burden of the agreement runs with the land, so far as those having notice are concerned.

Is the obligation enforceable at bar against the subsequent purchasers with notice?

The arreement related to the land and contemplated acts to be performed upon the land. The word "assigns" is used, and the acts

100 Part of the opinion is omitted. 
to be performed are of a "continuing" nature. Probably the amount of the consideration paid for the original conveyance was less than it would have been if this stipulation had not been inscrted in the acesl. $* * *$

Lpon principle we should say that a subsequent grantee, purchasing with the notice which registry gives of such a stipulation, impliedly cnters into the same engagement as the first vendee, and is liable in assumpsit for non-performance of the stipulation. We think that the first grantee in a deed poll like the present stands on the same footing with a devisee taking property under a devise imposing a burden in favor wf a third party. In Pike v. Brown, 7 Cush. (Mass.) 133, p. 135, Shaw; C. J., cxpressly asserts that a devise "stands on the same footing with a deed poll." In Veazey v. Whitchonse, 10 N. H. 409, it was held that assumpsit could be maintained against the grantee of a devisce for no11-performance of the duties imposed by the devise. The principle of that decision would seem to render the present plaintiff lialle to an action of assumpsit at the suit of Johnston for not maintaining the fence.

Our conclusion is that the stipulation in Johnston's deed is so far binding upon persons holding under that source of title that assumpsit may be maintained against a subsequent grantee with notice (actual or constructive) if he fails to perform the service stipulated for.

If the coverture of Apphia Martin prevented any legal remedy against her, it does not bar the maintenance of an action of assumpsit against her grantees who took the land with notice of the stipulation that they should maintain the fence. ***

Unless the defendant elects to demur, or confess, there must be Judgment for plaintiff. ${ }^{101}$

\section{KENNEDY v. OWEN.}

(supreme Judicial Court of Massachusetts, 1SS4. 136 Mass. 199.)

Contract. The deciaration alleged that the plaintiff, on July 31 , 18.50 , was the owner in fee and occupant of a certain tract of improved land in Greenfield; that the defendant was the owner in fee and occupant of an arljoining tract of improved land; that both of these tracts of land were formerly one undivided lot, of which one Harding C. Windiard was scized in fee; that Woodard, on July 18, 1868, conveyeil to one Jesse A. Coombs the defendant's land, by a deed duly recorded and containing the following condition: "that the said Coombs, his lecirs and ansigns, shall make and maintain all fences around the granted premises:" that afterwards Coombs, under and by virtue of said condition, made and crected a partition fence between

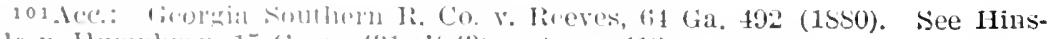

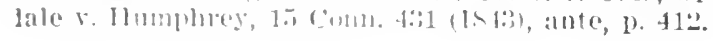


the land so conveyed to him and the remaining part of said lot, which is the same as the plaintiff's land; that said fence was kept up and maintained by Coombs while he remained the owner of said land: that on September 7, 1S68, Coombs conveyed said land in fee to the defendant, by deed duly recorded and containing the following condition: "that the said Owen is to make and maintain all the fences around the granted premises;" that Moodard, on February 7, 1870, by deed duly recorded, conveyed in fee the remaining part of sairl lot, separated by the said fence, to the plaintiff; that, under and by virtue of said condition, the defendant, as owner of said land adjoining the land of the plaintiff, became bound by law to keep up and maintain the fence; that on July 31, 1S80, said fence had become ruinous and out of repair by the neglect and refusal of the defendant to maintain the same, though repeatedly requested to do so; and that the fence so remained out of repair and ummaintained, by the defendant's neglect, during the period of the defendant's ownership of said land, and until she conveyed away her interest therein, on August 14, 18S0. Writ dated March 4, 1882.

The defendant demurred to the declaration, on the ground that it set forth no legal cause of action. The Superior Court sustained the demurrer, and ordered judgment for the defendant; and the plaintiff appealed to this court.

C. Altax, J. The particular question which is presented by the demurrer in this case is settled by the recent decision in Martin $v$. Drinan, 128 Mass. 515, where it was held that a stipulation in a deed poll, that the grantee agreed, for himself, his heirs and assigns, to lieep in repair a building on adjoining land of the grantor, was not a covenant, and did not run with the land, and that an assign of the grantor could not maintain an action of contract against the grantee for a failure to perform the agreement. The present action is in form an action of contract, and the plaintiff is a purchaser from, and assign of, the grantor in the deed which contains the stipulation upon which the plaintiff relies, and, under the decision referred to, cannot maintain an action of contract against the grantee in the deed, especially not against the defendant, who is a purchaser from said grantee.

The plaintiff, however, without apparently adverting to the fact that his action is in form an action of contract, has put his argument upon the broader ground that he is in some form entitled to a remedy against the defendant upon the facts stated in his declaration; and we have considered this broader question, which involves an examination of the nature of the right created by the provision of the deed which is set forth, and of the appropriate remedy for a violation of such right.

The plaintiff avers that the deed of the original grantor, Woodard, was "with the condition following, to wit, that the said Coombs [the grantee], his heirs and assigns, shall make and maintain all fences 
around the granted premiscs;" and that the deed from Coombs to the defendant was with a condition substantially similar. The deed itsclf is not before us, by copy or otherwise, so that we have no opportunity of looking at the language of this special provision, in connection with the rest of the deed. If the plaintiff's averment were to be taken as showing that the deed conveyed an estate on condition subsequent, the question would arise whether the plaintiff could in any form, avail himself of a breach of such condition. But it seems more probable that the provision of the deed was not intended to have that effect, and that it was merely designed to express an obligation or undertaking to make and maintain the fences; and such appears to be the construction put upon it by the plaintiff's counsel. See Ayling v. Kramer, 133 Mass. 12, 13.

It is also clear that the stipulation is not technically a covenant, running with the land. The grantee sealed nothing. In Parish v. Whitney, 3 Gray, 516, it was held that a stipulation in a deed poll, that the grantec, his, heirs and assigns, should erect and perpetually maintain a fence between the land granted and other land of the grantor, did not create an incumbrance on the granted premises, within the meaning of a covenant against incumbrances in a deed subsequently made by the grantee. The court said, that it was not a reservation nut of the estate granted, nor a condition, nor a covenant, running with the land, or otherwisc; but that it was only a personal agreement of the grantee, evidenced by his acceptance of the deed, which might bind him and his legal representatives, but did not affect the estate. That case was criticised in Burbank v. Pilsbury, 48 N. H. 475, 97 Am. Dec. 633, where it was held that such an agreement was of the same effect as an express covenant, signed and sealed by the grantee; that it would run with the land; that it created an incumbrance upon the land; and by implication it was recognized that a subsequent grantee would be liable to the original grantor in an action of assumpsit on the agreement. No question arose there, or could arise, whether an assignec of the grantor could maintain such action. A decision substantially similar was made in Kellogg v. Robinson, 6 Vt. 276, 27 Am. Dec. 550, where the stipulation was regarded as a covenant, or a condition; and it was held that it created an incumbrance on the land, within the meaning of a covenant against incumbrances.

In Bronson v. Coffin, 108 Mass. 175, 11 Am. Rep. 335, it was held that a formal covenant by the grantor, in a deed of portion of his land, that he and his heirs and assigns would make and maintain a fence between the land granted and his remaining land, with a provision that this covenant should be perpetual and obligatory upon all persons who should become owners of the land adjoining to that granted, created an interest in the nature of an easement, and ran with the land, and created an incumbrance upon the land, within the meaning of a covenant against incumbrances in a subsequent deed of such adjoining land; and, in referring to Parish v. Whitney, the 
court, by Mr. Justice Gray, incidentally remarked, "If that decision can be supported, it must be as falling within the rules that no easement in or right affecting real estate can be created by contract of the party, except by deed, and that an agreement not sealed by the party who is to perform it cannot create a covenant or run with the land." The above decisions in New Hampshire and Vermont were cited and commented upon.

In the later case of Martin v. Drinan [128 Mass. 515], as has been seen, it was explicitly held by this court, in an opinion delivered by Chief Justice Gray, that such an agreement, implied or shown by the acceptance of a deed poll, is not a covenant; and Parish v. Whitney was cited, with apparently a full approval of the decision. It is plain that an agreement not under seal cannot, technically speaking, run with the land. ***

It has never been held or considered in Massachusetts, so far as we are aware, that a stipulation like that contained in the deeds on which the plaintiff relies would have the effect to create an easement of this peculiar description, the right to which could be asserted or protected by an action at law. It certainly is not an exception out of the estate granted. It is not strictly a reservation. It appears to be rather a mere personal obligation, imposed upon and assumed by. the grantee, and binding upon him and his legal representatives as an implied contract entered into with the grantor; not amounting to a covenant, or a charge upon the land: but an obligation, which, if enforceable at all against purchasers, is to be enforced against them by a court of equity alone, and having no more force and effect than in case of an express agreement not under seal between two owners of adjoining land.

Being of the opinion, for these reasons, that the judgment of the Superior Court must be affirmed, we do not enter upon the consideration of the grave question, whether even upon the assumption that an easement of this peculiar nature was created by the deed, the plaintiff has a remedy, either at law or in equity, against the defendant, who conveyed away her interest in the premises about two years before the action was brought; there being no averment in the declaration that the plaintiff suffered any actual damage during the time of the defendant's ownership.

Judgment affirmed. 


\title{
CHAPTER V
}

\section{EQUITABLE ENFORCEMENT OF AGREEMENTS RUN- NING WITH THE LAND}

\section{SEC'TION 1.-GENERAL, PRINCIPLES}

TULK v. MOXHAY.

\author{
(Court of Chancery, 1S48. 2 Phil. 774.)
}

In the year $1 S 0 S$ the plaintiff, being then the owner in fee of the vacant piece of ground in Leicester Square, as well as of several of the houses forming the square, sold the piece of ground by the description of "Leicester Square Garden or Pleasure Ground, with the equestrian statue then standing in the centre thereof, and the iron railing and stone work round the same," to one Elms in fee: and the deed of conveyance contained a covenant by Elms, for himself, his heirs, and assigns, with the plaintiff, his heirs, executors, and administrators:

"That Elms, his heirs, and assigns, should, and would from time to time, and at all times thereafter at his and their own costs and charges, keep and maintain the said piece of ground and Square Garlen, and the iron railing round the same in its then form, and in sufficient and proper repair as a Square Garden and Pleasure Ground, in an open state, uncovered with any buildings, in neat and ornamental order; and that it should be lawful for the inhabitants of I-eicester Square, tenants of the plaintiff, on payment of a reasonable rent for the same, to have keys at their own expense and the privilege of admiscion therewith at any time or times into the said Square Garden and Pleasure Ground."

'The piece of land so conveyed passed by divers mesne conveyances into the hands of the defendant, whose purchase deed contained no similar covenant with the vendor: but he admitted that he had purchased with notice of the covenant in the deed of 1808 .

the defendant having manifested an intention to alter the character of the Syture Garden, and asserted a right, if he thought fit, to luild trpon it, the plaintiff, who still remained owner of several houses in the Sifuare, filed this bill for an injunction; and an injunction was granted by the Naster of the Rolls, to restrain the defendant from comverting or using the piece of ground and Square Garden, and the iron railing round the same, to or for any other purpose than as a Square Farden and Pleasure Ground in an open state, and uncovered with buildings.

On a motion, now marle, to discharge that order. 
The Lord Chancelior. ${ }^{1} * * *$ That this court has jurisdiction to enforce a contract between the owner of land and his neighbor purchasing a part of it, that the latter shall either use or abstain from using the land purchased in a particular way, is what I never knew disputed. Here there is no question about the contract; the owner of certain houses in the Square sells the land adjoining, with a covenant from the purchaser not to use it for any other purpose than as a Square Garden. And it is now contended, not that the vendee could violate that contract, but that he might sell the piece of land, and that the purchaser from him may violate it without this court having any power to interfere. If that were so, it would be impossible for an owner of land to sell part of it without incurring the risk of rendering what he retains worthless. It is said that, the covenant being one which does not run with the land, this court cannot enforce it; but the question is, not whether the covenant runs with the land, but whether a party shall be permitted to use the land in a manner inconsistent with the contract entered into by his vendor, and with notice of which he purchased. ${ }^{2}$ Of course, the price would be affected by the covenant, and nothing could be more inequitable than that the original purchaser should be able to sell the property the next day for a greater price, in consideration of the assignee being allowed to escape from the liability which he had himself undertaken.

That the question does not depend upon whether the covenant runs with the land, is evident from this, that if there was a mere agreement and no covenant, this court would enforce it against a party purchasing with notice of it; for if an equity is attached to the property by the owner, no one purchasing with notice of that equity can stand in a different situation from the party from whom he purchased. There are not only cases before the Vice-Chancellor of England, in which he considered that doctrine as not in dispute; but looking at the ground on which Lord Eldon disposed of the case of the Duke of Bedford v. The Trustees of the British Museum, 2 My. \& K. 552, it is impossible to suppose that he entertained any doubt of it.

1 Part of the opinion is omitted.

2 Adjacent owner's made an unsealed agreenent by which a window in the house of the one was to have a certain amount of light from the land of the other. The second owner sold to a third person, who saw the window, but had no actual notice of the agreement. Held, reversing the decision of Hall, V. C., he is not bound by the agreement. Allen v. Seckham, L. R. 11 . Ch. D. 790 (1S7S).

Sre, alio. Bradley v. Walker, 189 N. Y. 291, 299, 33 N. E. 1079 (1593).

"It cannot, I think, be denied that generally speaking a purchaser or mortgagee is bound to inquire into the title of lis vendor or mortgagor, and will be affected with notice of what appears upon the title if he does not so inquire; nor can it, I think, he disputed that this rule applies to a purchaser or nortgagee of leasehold estates, as much as it applies to a purthaser or mortgagee of freeliold estates, or that it applies equally to a tenant for a term of years; and I cannot see my way to hold that a rule which applies in all these cases ought not to be held to apply in the ease of a tenant from year to year." W'ilson v. Hart, L. R. 1 Cli. App. 463,467 (1S66). Compare Carter v. Williams, L. R. 9 Eq. Cas. Gis (1ST0). 
With respect to the observations of Lord Brougham in Keppell v. Bailey [2 M. \& K. 547] he never could have meant to lay down, that this conrt would not enforce an equity attached to land by the owner, unless under such circumstances as would maintain an action at law. If that be the result of his observations, I can only say that I cannot coincide with it.

I think the cases cited before the Vice-Chancellor and this decision of the Naster of the Rolls perfectly right, and, therefore, that this injunction must be refused with costs. ${ }^{3}$

\section{HAYTOOD . BRUNSWICK PERMANENT BENEFIT BUILD- ING SOCIETY.}

(Court of Appeal, 18S1. L. R. 8 Q. B. D. 403.)

This was an action against a building society, the mortgagees of certain land, upon a covenant to build and keep in repair houses erected upon the land. The facts were these:

By an indenture dated the 17th of May, 1866, made between Charles Jackson and Edward Jackson, Charles Jackson granted a plot of land to Edward to the use that Edward should pay Charles an annual chief rent of $£ 11$., and Edivard for himself, his heirs, executors, administrators, and assigns, covenanted with Charles, his executors and assigns, that he Edward, his heirs and assigns, would pay Charles, his heirs and assigns, this rent half-yearly, and would erect and keep in good repair and, when necessary, rcbuild, messuages on the land of the value of double the rent. On the 2nd of March, 1867, Charles Jackson conveyed to Haywood to the use of Haywood, his heirs and assigns, the said chicf rent and all powers and remedies in respect thereof, together with the benefit of the said covenant. Edward Jackson assigned his interest to MacAndrew. MacAndrew by a deed of the 8th of September, 1871, mortgaged the premises in question to certain persons described as the trustees of the Brunswick Building Society in

\footnotetext{
3"It is strenuously urged, in behalf of the defendants and respondents, that there was no privity of estate between the mutual covenantors and covolnanters, in respert of the premises owned by them respectively, and which wre the sulijects of the covenauts and agreements, and that the covelituts did not therefore run with the lands, binding the grantees, and subjertine then to a personal liability thereon. This may be conceded for all the purguses of this artion. It is of no importance whether an action at law cond bo mantained a sainst the grantees of Leers, as upon a corenant running with thr land and binding them. Whether it was a covenant running with the land or a collateral covenant, or a corenant in gross, or whither an action at law could he sustained upon it, is not material as afroting the furisiliction of a conrt of equity, or the right of the owners of the clominant tammont to relief upon a disturbance of the easements." Allem. J., in 'Trustues of' Columbia College v. Lynch, 70 N. Y. 440, 445, 26 A1н. Liep. ti1j (1sit).
} 
fee subject to the rent-charge and covenants above-mentioned. The building society was afterwards incorporated under the Act of 1874, and under the mortgage deed took possession of the land and the buildings on it. It was conceded on the one hand that buildings of the stipulated value had been erected upon the land, and on the other that they had not been kept in repair, and the question was whether, under the circumstances stated, the building society was liable upon the covenant to keep them in repair. No question arose as to their liability to pay the chief rent, as the arrears were paid into court in the action.

The case was tried before Stephen, J., without a jury, at the Manchester Winter Assizes, 1881, who reserved it for further consideration, and after stating the facts as above, gave judgment as follows. ***

The result is that there must be judgment for the plaintiff, with costs. There will be no damages, the parties having agreed that if it is formally decided that the defendants are to put the buildings in repair, they must be repaired to the satisfaction of a gentleman agreed upon.

The defendants appealed.

BRE'TT, L. J.* This appeal must be allowed. I am clearly of opinion, both on principle and on the authority of Milnes v. Branch, 5 M. \& S. 411 , that this action could not be maintained at common law. Milnes v. Branch, 5 M. \& S. 411, must be understood, as it always has been understood, and as Lord St. Leonards (Sug. V. \& P. [14th Ed.] p. 590) understood it, and it will be seen, on a reference to his book, that he considers the effect of it to be that a covenant to build does not run with the rent in the hands of an assignee.

This being so, the question is reduced to an equitable one. Now the equitable doctrine was brought to a focus in Tulk v. Moxhay, $2 \mathrm{Ph}$. 774 , which is the leading case on this subject. It seems to me that that case decided that an assignce taking land subject to a certain class of covenants is bound by such covenants if he has notice of them, and that the class of covenants comprehended within the rule is that covenants restricting the mode of using the land only will be enforced. It may be also, but it is not necessary to decide here, that all covenants also which impose such a burden on the land as can be enforced against the land would be enforced. Be that as it may, a covenant to repair is not restrictive and could not be enforced against the land; therefore such a covenant is within neither rule. It is admitted that there has been no case in which any Court has gone farther than this, and yet if the Court would have been prepared to go farther, such a case would have arisen. The strongest argument to the contrary is, that the reason for no Court having gone farther is that a mandatory injunction was not in former times grantable, whereas it is now; but I cannot help thinking, in spite of this, that if we enlarged the rule as it is

4 Part of the opinions of Brett and Cotton, L. JJ., are unitted. 
contended, we should be making a new equity, which we cannot do. $* * *$

Coт⿰彳亍, L. J. I am of the same opinion on both points. I think that a mere covenant that land shall be improved does not run with the land within the rule in Spencer's Case, 1 Sm. L. C. Sth Ed. at page 89 , so as to give the plaintiff a right to sue at law. I also think that the plaintiff has no remedy in equity. Let us consider the examples in which a Court of Equity has enforced covenants affecting land. WV find that they have been invariably enforced if they have been restrictive, and that with the exception of the covenants in Cooke v. Chilcott, 3 Ch. D. 69 , only restrictive covenants have been enforced. In Tulk v. Moxhay, 2 Ph. 774, the earliest of the cases, Lord Cottenham says, "That this Court has jurisdiction to enforce a contract between the owner of land and his neighbour purchasing a part of it, that the latter shall either use or abstain from using it in a particular way, is what I never knew disputed." In that case the covenant was to use in a particular manner, from which was implied a covenant not to use in any other manner, and the plaintiff obtained an injunction restraining the defendant from using in any other manner, although the covenant was in terms affirmative. At page 778, Lord Cottenham says, "If an equity is attached to property by the owner, no one purchasing with notice of that equity can stand in a different situation from the party from whom he purchased." This lays down the real principle that an equity attaches to the owner of the land. It is possible that the doctrine might be extended to cases where there is an equitable charge which might be enforced against the land, but it is not necessary to decide that now; it is enough to say that with that sole exception the doctrine could not be farther extended. The covenant to repair can only be enforced by making the owner put his hand into his pocket, and there is nothing which would justify us in going that length. *** $*$

[LINDLEY, L. J., delivered a concurring opinion.]

Appeal allowed. ${ }^{5}$

\section{HALL v. EIVIN.}

(Conrt of Aplieal, 15st. I. R. : :T Ch. D. 74.)

The plaintiff, IV. H. Hall, was the owner of a house in Edgware Road, in the parish of Paddington. By an indenture dated the $3 \mathrm{~d}$ of Norember, 1849, the plaintiff granted a lease of the house to G. Tarlington for cighty years. 'The lease contained a covenant by the lessee for himself, his heirs, exccutors, administrators, and assigns, in the following terms: "That he, his executors, administrators, and assigns, shall not at any time during the said term usc, exercise, or carry on in

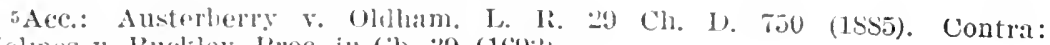
Iolnes r. IBuckley, l'rec. in Ch. $39(169) 2)$.

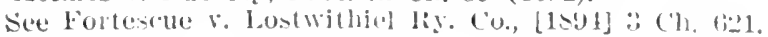


or upon the said hereby demised premises, or permit or suffer any part thereof to be occupied by any person or persons who shall use, occupy, or carry on therein any noisome or offensive trade, business, or employment whatsoever without the like consent in writing of the said IV. H. Hall, his heirs or assigns, first obtained."

By an indenture dated the 11 th of January, 1851, G. Tarlington, demised the premises to $R$. S. Ruddach for the residue of the term of eighty years, except the last three days thereof, by way of mortgage for securing the repayment of a principal sum and interest.

$\mathrm{By}$ an indenture dated the 19th of September, 1865, the executors of. R. S. Ruddach, under the power of sale contained in the mortgage leed, assigned the premises for the residue of the term of eighty years, except the last three days thereof, to the defendant John Ewin.

By an indenture dated the 29th of October, 1885 , the defendant John Ewin demised the premises to the defendant George McNeff for twenty-one years. This lease contained the following covenant by McNeff: "And also shall not at any time during the said term use, exercise, or carry on in or upon the said demised premises any noisome or offensive trade, business, or employment whatsoever without the like consent in writing of the said John Ewin, his executors, administrators, or assigns, first obtained."

In the month of February, 1886, the defendant MiNefi purchased some lions, and opened an exhibition of wild beasts on the premises. He exhibited pictures outside the house, and employed black men to parade in front of it with a going and trumpet, so that the neighbours complained of the nuisance.

The present action was brought by IV. H. Hall and C. Breitbart, who was a carver and gilder, keeping a shop two doors from the premises in question, asking for an injunction to restrain Ewin and MIcNeff from using the premises as an exhibition of wild animals, or otherwise so as to cause a nuisance to the plaintiffs, and also from carrying on upon the premises, or permitting or suffering any part thereof to be occupied by any person carrying on, any noisome or offensive trade or business without the consent in writing of the plaintiff IV. H. Hall.

In his defence the defendant Ewin pleaded that if the allegations in the statement of claim were correct they created no cause of action against him, that none of the acts complained of had been committed by him, and that he had given no consent in writing to the acts complained of ; but, on the contrary, he had done all in his power, save by bringing an action, to induce MicNeff to desist from any acts which might catuse annoyance to the neighbourhood, and that he was not liable for the alleged acts of Micleif.

The existence of the nuisance was sufficiently proved by the eridence. There was no evidence of Ewin having in any way encouraged or consented to the exhibition complained of.

The case was heard on the 3d of May, 1887, before Mr. Justice 
Kekewich. His Lordship was of opinion that although Ewin was not an assignee of the lease, he was equitably bound by the covenant, and that as he had the power to enforce his own covenants against McNeff and to stop the nuisance, he had broken the covenant against suffering the prenises to used for the purpose of carrying on a noisome occupation. He therefore granted the injunction against both of the defendants, with costs. From this judgment the defendant Ewin appealed.

Cotrox, L. J. ${ }^{\circ}$ This is an appeal by the Defendant Ewin against a judgment of MIr. Justice Kekewich, granting an injunction restraining him from the breach of a certain covenant in a lease. Is this right? Ewin is in this position. The plaintiff Hall granted a lease containing the covenant in question, and the lessee made a mortgage of the lease by underlease, and the mortgagee sold his interest under his power of sale to Ewin; therefore Ewin was merely an underlessee and was not bound at law by the covenants in the original lease. He would have been bound if he had taken an assignment of the estate of the lessee under the lease, but he took no such assignment. It is useless to consider whether if Ewin had been bound at law the plaintiff could have maintained an action against him and got damages. If the plaintiff is entitled to relief in this case it must be not on the ground of breach of covenant, but on the ground that he is equitably bound, on the principle laid down in Tulk v. Moxhay, $2 \mathrm{Ph}$. 774, to use the house in conformity with the covenants in the lease. I am of opinion that it would be an extension of the principle of Tulk v. Moxhay to hold him liable to an injunction in such a case as this. The words of the covenant in the original lease are these. [His Lordship read the covenant.] Then what are the facts? The defendant Ewin, who was himself an underlessee, granted an underlease to McNeff, in which there was a covenant that he could not exercise any noisome or offensive trade or business without the consent in writing of Ewin. If the plaintiffs had shewn that Ewin had granted this underlease for the purpose of its being used for an offensive trade or had granted a written license to McNeff so to use it, he would have acted in a way inconsistent with the corenants in the original lease, and I should have had no hesitation in granting an injunction against him; but he has done nothing of the kind, and the case made against him is that by standing by allowing the house to be used for the exhibition of wild beasts, he has acted in violation of the covenant. I give no opinion whether the plaintiff would have had a right of action against him if he had been bound in law by the covenant. There is no doubt that under the principle of Tulk v. Moxhay, $2 \mathrm{Ph}$. 774, if a man had actually done anything in contravention of the covenants of which he had notice, the Court would grant an injunction. As I understand Tulk v. Moxliay, the principle there laid down was that if a man bought an underlease,

6 Statement abridged and part of opinion omitted. 
altlough he was not bound in law by the restrictive covenants of the original lease, yet if he purchased with notice of those covenants the Court of Chancery could not allow him to use the land in contravention of the covenants. That is a sound principle. If a man buys land subject to a restrictive covenant, he regulates the price accordingly, and it would be contrary to equity to allow him to use the land in contravention of the restriction. But here the plaintiff does not seek to restrain Ewin from using the house in a particular way, or from foing something which will enable the tenant so to use it, but to compel him to bring an action against his tenant who is in possession of the house. The principle of Tulk v. Moxhay, has never been carried so far except in a case before Vice Chancellor Malins. Cooke v. Chilcott, 3 Ch. D. 694. The question came practically before the Court of Appeal in Haywood v. Brunswich Permanent Benefit Building Society, $S$ Q. B. D. 403, and the Court there laid down that the principle in Tulk $v$. Moxhay was not to be applied so as to compel a man to do that which will involve him in expense. The covenant in Haywood v. Brunswick Permanent Bcnefit Building Society was to repair buildings on the land, and was therefore as much with reference to the land as the covenant in this case, but the Court would not compel the defendant, who was the assignee of the original grantee, to repair the buildings. There is no evidence in this case that the defendant Ewin has given any license to his tenant to do the act complained of. I think it would be wrong to make an order that would have the effect of compelling him to bring an action, or of making him liable to dlamages if he did not bring an action. It is said that he did nothing to prevent the use of the house in the way complained of. But before the action was brought it appears from the evidence that the clerk of the plaintiff's solicitor called at the house of the defendant Hivin. and that Ewin informed him that he would see McNeff about the matter, and then the plaintiff himsclf puts in evidence a letter from McNeff saying that out of respect to Ewin's wishes he had stopped the pxhibition. It is true that the statement of McNeff, that the exhibition was closed, was false, but the plaintiff has not proved that it was false that Ewin had requested him to stop it. So that on the evidence it stands that there is no proof that the defendant gave permission to his tenant to open the exhibition, but it does appear that he spoke to him and requested him to discontinue it. I think it would be wrong to grant an injunction against Ewin under these circumstances. The injunction against him must therefore be dischargeil. $* * *$

[LINDI.EY and LOPES, L. JJ., delivered concurring opinions.] ${ }^{7}$

iA. leased to B. with a covenant, which was apparently also a condition, that. B. "would not malie or suffer any **** offensire use of the prem. ises." B. subleased to C., who made an impropel use of them. A. entered and forfeital the lease. $\mathrm{H}$, brought ejectment to regain possession of the prenises. Held, he cannot recover possession. The court (Knowlton, J.) 


\section{RANDALL et al. v. LATHAM.}

(Supreme Court of Connecticut, 1869. 36 Conn. 48.)

Bill in equity, to compel the specific performance of an agreement of the respondent with the petitioners' grantor with regard to water from the respondent's raceway for the petitioners' mill; brought to the Superior Court in Windham county.

The respondent was the owner of a water privilege on a stream known as Round Brook, with a grist mill and raceway leading to the same, and, on the 20th of April, 1855, took from one Hiram Thomas a conveyance of a tract of thirty acres adjoining his mill, the grantor remaining the owner of a factory a little below on the same stream. The deed from Thomas to the respondent contained the following provision: "Reserving and excepting the following privileges, to wit: the privilege of the right of way, in common with the said grantee, in the lane from the said bridge to the said turnpike, nearly eleven feet on the westerly side of said lane, making the whole width of said lane twenty-two feet; and also, the said grantor is to have the privilege of drawing the water from the ditch of said Latham's grist mill, at all times when the said Latham, or his successor, is not using sufficient water for the accommodation of the factory below said Latham's mill, and the said Latham and his successor are to keep a spout ten inches square in the inside, at the bottom of said ditch, to which the said grantor shall at all times have access for the purpose of drawing water as aforesaid."

On the 9th day of February, 1866, Thomas conveyed his factory, and the land connected with it, to the petitioner Randall; the deed expressly conveying "all rights and privileges specified in the deed of the grantor to said Joseph B. Latham, dated April 20th, 1855." Randall afterwards conveyed one half the property embraced in his deed to the other petitioner, Harris.

The present petition was dated August 10, 1868. Down to this time the respondent had never put in the spout provided for in the deed of Thomas to him, and on the application of the petitioners, after they became the owners of the Thomas factory, refused to put it in

said: "We are of opinion that the agreement not "to make or suffer" an unlawful use of the premises must be interpreted as a stipulation that there. shall be no unlawful use by the original lessee, or by any person who is occulying under him. It is easy for the lessee to control the use of the property, and to protect the interests of the lessor and of himself in this farticnlal. With this interpretation, effect is given to the word 'suffer.' It way not be loisonible to hold that the covenant makes the lessee liable for an unlawful use of the property by tresuassers, but he may well be held to "suffer" unlawful us" of the property" if he does not take effectual measures to jrevent surh a use by those who occupy by his authority." Mill‥ I'rescott, 16:; Mass. 12, 13, 39 N. L. 409, 410, 47 Am. St. Rep. 4:it (1\$95).

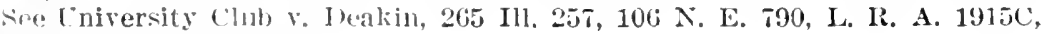
Sist (1914), post, 1. 6i13. 
and denicd their right to require him to do it. The petitioners by their suit sought to compel him to put it in, and claimed the right, under their deed from Thomas, and as owners of the factory bought of him, to draw water for the factory from the respondent's ditch, and by spont put in and maintained by him, and to which they should have constant access and over which they should have control. The ditch itself was never owned by Thomas, and he had no interest in the same beyond that acquired by the provision of his dced to Latham, and the petitioners had no interest beyond that acquired by 'Thomas' deed to Randall.

Upon these facts the case was reserved for the advice of this court.

PARK, J. ${ }^{8}$ In the deed from Thomas to the respondent the grantor reserved from the premises conveyed the right to draw a certain quantity of water at all times when the respondent or his successor should not be using sufficient water for the accommodation of the factory below. The grantor owned a factory below the mill deeded to the respondent, and the reservation was for the benefit of that factory. 'There is a provision in the deed in connection with the reservation that the respondent and his successor should keep a spout ten inches square at the bottom of the ditch leading to his grist mill to which the grantor should at all times have access for the purpose of exercising the right reserved in the deed. The reservation taken in connection with this provision is in effect a reservation of the right to draw water through a spont ten inches square. 'The right reserved is not otherwise limited or lefined. That right was never sold to the respondent, but was subsequently transferred to the petitioners, and is now owned by them in as ample a manner as it formerly was by Thomas. But the deed purports to recruire the respondent to put in the spout upon land not convered, and the question is, whether a court of equity can compel him to do it under the circumstances of the case. That the respondent by accepting the deed containing this provision thereby agreed to perform this duty there can be no doubt. The case of Hinsdale v. Humphrey, 15 Conn. 431, is in point. Sec, also, Townsend v. Ward, 27 Conn. 610; Felch v. Taylor, 13 Pick. (Mass.) 133; Goodwin v. Gilbert, 9 Xass. 510: Burnett v. Lynch, 5 Barn. \& Cress. 589. This duty was a part of the consideration of his deed. The respondent has received tull compensation, and it is difficult to see why he is not bound to perform it. It will be seen that the agreement merely prescribes the mode of exercising the right reserved. Without the agreement Thomas would have had the right to draw the water at some proper place on the land conveyed, but in order that the convenience and interest of both parties might be promoted it was agreed that the orifice should be placed at the botton of the ditch leading to the respondent's grist mill. 'The land of the respondent was selected for the purpose instead of the land conveyed.

8 I'alt of the opinion is omitted. 
The reservation of the right to the water would have carried with it an easement in the land conveyed for the purpose of drawing the water, on the principle that where a right is reserved or conveyed what is necessary for the enjoyment of the right, and without which the right would be useless, passes or is retained by implication. And again, if the agreement had not been made no doubt Thomas would have expressly reserved a place for the orifice. The agreement of the respondent prevented his doing this, and shall the respondent be permitted now to say that he will not perform his agreement when he has obtained the land of Thomas by means of it, and has been and is now in the cnjoyment of the land as his own? If A. agrees to convey to B. a tract of land in consideration that $\mathrm{B}$. will convey to $\mathrm{A}$. an easement in certain other lands, and A. fulfills his part of the agreement and B. goes into possession of the land, there can be no doubt that a court of equity would compel $\mathrm{B}$. to perform his part of the agreement. The respondent therefore can derive no benefit from the fact that the spout was agreed to be placed upon land that Thomas never owned. $* * *$

Again it is claimed that the agreement was a mere chose in action, and did not pass by the deed from Thomas to the petitioners. The deed to the petitioners refers to the deed from Thomas to the respondent, and expressly conveys all the rights and privileges specified in that deed that Thomas had the right to convey. The right to the water was reserved by that deed. That right was manifestly conveyed to the petitioners. By that deed Thomas acquired an easement in the respondent's land to the spout. That right was an equitable interest in the land and was also conveyed. By that deed the respondent agreed with Thomas to put in the spout. The act of putting in the spout is intimately connected with the easement, so much so that the easement could not be enjoyed without the performance of this duty. Thomas had no right to go upon the respondent's land and dig up the soil for the purpose of inserting the spout, neither have the petitioners. The spout was agreed to be placed in the bottom of the ditch leading to the respondent's grist mill. The respondent has the right to select the place in the ditch where it shall be put, and to attend himself to the putting and keeping of it there. For aught that we can discover this may be an important qualification of the right given to Thomas to have it there. A conveyance therefore of the equitable easement carried with it the privilege of the respondent inseparably connected with it. Again, the promise of the respondent to put in the spout cannot be regarded as a separate and independent promise, even if it is a duty onerous to be performed. He agreed not only to grant an easement in his land, but to put it in a condition to be cnjoyed. An easement in that condition he promised Thomas in consideration for the land he conveyed. An equitable easement in that promised condition, Thomas conveyed to the petitioners. Again, if the promise to put in the spout was a chose 
in action, it was transferred to the petitioners by virtue of the statute of 1864. That statute applies to assignments existing when the act was passed as well as to those that should thereafter be made. $* * *$

It is further claimed that the petitioners cannot sustain their bill because the finding does not show that the spout is needed to supply the lower mill with water. We think the respondent is right in this claim. But the want of a finding upon this subject may have been owing to oversight on the part of counsel in neglecting to offer evidence upon a point not in dispute between the parties, and we think the proper course therefore is to advise the Superior Court that if it shall be found on a further hearing of the case that the spout is needed to supply the petitioner's mill with water, the prayer of the petition should be granted. And we so advise.

In this opinion the other judges concurred.

\section{COUNTRYMAN v. DECK.}

(Supreme Court of New York, 18s3. 13 Abb. N. C. 110.)

The plaintiff David F. Countryman and his wife, Emma J., brought this action for a specific performance of an alleged covenant to maintain a fence.

It appeared, that on April 1, 1875, Simpson, owning a farm, conveyed a lot of land out of it to one Woodward, by warranty deed. which contained, after the description of the land, the following words: "Provided always that the party of the second part shall fence and keep fenced the premises above described."

Woodward entered upon the lot, and fenced it. He afterwards conveyed to defendant.

Simpson died, and his daughter, Emma J. Countryman, and two sons, succeeded to his title to the farm. The two sons afterwards conveyed their interests to plaintiffs, who thus become the owners of the entire Simpson farm. Defendant refused to keep the fence about his lot in repair, and this action was brought to compel him to do it, the fence having become too dilapidated to serve the ordinary purpose of a fence.

9 A., who owned a reservoir and several mill privileges upon the stream below, which was supplied by the reservoir, conveyed one of the sites with water privileges to $\mathbf{B}$. in fee. The deed contained a stipulation that $\mathbf{B}$. and his assigns should pay one-fith of the flowage damage caused by the dam. In a hill in eyuity by A.'s successors against L.'s assigns to recover this one-fifth. it was held that the stipulation created a right in $A$. and its successors, that could be enforced against the land in the hands of $B$.' $s$ assigus, but not as a personal obligation. Whittenton Mfg. Co. v. Staples, 164 Mass. 319,41 N. E. 441,29 L. F. A. 500 (1S9J).

See Rochester Lodge, No. 21. .1. F. \& A. M., v. Graham, 65 Minn. 457, 6s N. W. 79,37 L. R. A. 404 (1\$96). 
RUMSEY, J. ${ }^{10}$ [After holding that the proviso was equivalent to a covenant by the grantee:] The only remaining question is as to the relief to be given to the plaintiffs. The duty of the defendant is to keep up the fence, and the plaintiffs are not called upon to do it (Beach v. Crain, 2 N. Y. 86, 49 Am. Dec. 369). The covenant is a continuous one, and plaintiffs cannot get the full benefit of it if they are put to a suit for damages each time the defendant fails to perform.

There is no such uncertainty about it as to forbid a decree for specific performance. In Jones v. Seligman ( 81 N. Y. 190), the duty imposed upon a railroad company to build a fence was decreed to be performed, and in People v. R. \& S. L. R. R. Co. (76 N. Y. 29.4), performance of the like duty was compelled by mandamus. If the building or repair of a fence may be compelled when the duty is imposed by statute, there is no reason why it may not be decreed when it is assumed by contract. The judgment should be that defendant keep the fence in repair where it adjoins the premises of the plaintiffs, with costs to plaintifis. ${ }^{11}$

\section{NORCROSS et al. v. JAMES et al.}

(Aup)reme Judicial Court of Massachusetts, 1SS5. 140 Mass. 1SS, 2 N. E. 946.)

Holmes, J. One Kibbe conveyed to one Flynt a valuable quarry of six acres, bounded by other land of the grantor, with covenants as follows: "And I do, for myself, my heirs, executors, and administrators, covenant with the said Flynt, his heirs and assigns, that I am lawfully seized in fee of the afore-granted premises; that they are free of all incumbrances; that I will not open or work, or allow any person or persons to open or work, any quarry or quarries on my farm or premises in said Long Meadow." By mesne conveyances the plaintiffs have become possessed of the quarry conveyed to Flynt, and the defendants of the surrounding land referred to in the covenant. The defendants are quarrying stone in their land like that quarried by the plaintiffs: and the plaintiffs bring their bill for an injunction. The liscussion of the question under what circumstances a land-owner is cntitled to rights created by way of covenant with a former owner of the land has been much confused since the time of Lord Coke, by neglecting a distinction, which he stated with perfect clearness, between those rights which run only with the estate in the land and those which are said to be attached to the land itself: "So note a diversity be-

10 Part of the opinion is omitted.

11 Certain land was allotted to $\mathrm{A}$. in fee under an inclosure act, the award providiug that $A$. and his assigns shouid inaintain a division ditch and hedge between the lot awarded and an adjoining lot. The defendant luad aconired A.'s land, and had broken down the hedge and filled the ditch. Ifeld, the plaintiff, as cwner of the adjoining lot. is entitled to an injunction ordering the defendant to restore the ditch and hedge. Lidwell v. Holden, (63) 1. T. ( 
wween a use or warranty and the like things annexed to the estate of the land in privity, and commons, advowsons, and other hereditaments annexed to the possession of the land." Chudleigh's Case, 1 Coke, 122b; s. c. 1 Poph. 70, 71.

Rights of the class represented by the ancient warranty, and now by the usual covenants for title, are pure matters of contract, and from a very early date down to comparatively modern times, lawyers have been perplexed with the question, how an assignee could sue upon a contract to which he was not a party. West, Symboleog. I, § 35 ; Wing. Max. 44, pl. 20, 55, pl. 10; Co. Litt. 117a; Sir Moyle Finch's Case, 4 Inst. 85. But an heir could sue upon a warranty of his ancestor, because for that purpose he was eadem persona cum antecessore. See Y. B. 20 \& 21 Edw. I, 232, (Rolle's Ed.;) Oates v. Frith, Hob. 130; Bain v. Cooper, 1 Dowl. Pr. Cas. (N. S.) 11, 14. And the conception was gradually extended in a qualified way to assigns, where they were mentioned in the deed. Bract. fol. 17b; 67a, 380b; 381 ; Iilcta. III, c. 14, $\S 6 ; 1$ Britt. (Nich. Ed.) 255, 256; Y. B. 20 Edw. I, 232-234, (Rolle's Ed.;) Fitz. Abr. "Covenant," pl. 2S; Vin. Abr. "Voucher," N, p. 59; Y. B. 14 Hen. IV, 56; 20 Hen. VI. 6, 34b; Old Natura Brevium, "Covenant," 67, B, C, in Rastell's Law Tracts Ed. 1534; Di. E Student, I, c. S; F. N. B. 145, A; Co. Litt. 3S4b; Com. Dig. "Covenant," B 3; Middlemore v. Goodale, Cro. Car. 503, 505; s. c. IV. Jones, 406; Philpot v. Hoare, 2 Atk. 219. But in order that an assignce should be so far identified in law with the original covenantee lie must have the same estate,-that is, the same status or inheritance,-and thus the same persona quoad the contract. But, as will be seen, the privity of estate which is thus required is privity of cstate with the original covenantee, not with the original covenantor; and this is the only privity of which there is anything said in the ancient books. See further, Y. B. 21 \& 22 Edw. I, 148, (Rolle's Ed.;) 14 Ilen. IV, pl. 5. Of course we are not now speaking of cases of landlord and tenant, and it will be seen that the doctrine has no necessary connection with tenure. F. N. B. 134, E. We may add that the burden of an ordinary warranty in fee did not fall upon assigns. although it might upon an heir, as representing the person of his ancestor. Y. B. 32 \& 33 Edw. I, 516, (Rolle's Ed.)

On the other hand, if the rights in question were of the class to which commons belonged, and of which easements are the most conspicuous type, these rights, whether created by prescription, grant, or covenant, when once acquired were attached to the land, and went with it, irrespective of privity, into all hands, even those of a clisseizor. "So a disscizor, abator, intruder, or the lord by escheat, etc., shall have them as things annexed to the land." Chudleigh's Case, ubi supra. See 1 Pritt. (Nich. Ed.) 361; Kcilw. 145, 146, pl. 15; F. N. B. 180, $\mathrm{N}$; Sir 11. Nevil's Case, Plowd. 377, 381. In like manner, when, as was usual, although not invariable, the duty was regarded as falling upon land, the burden of the covenant or grint went with the servient 
land into all hands, and of course there was no need to mention assigns. See cases supra et infra. The phrase consecrated to cases where privity was not necessary was transit terra cum onere. Bract. fol. 382, a, b; Fleta, VI, c. 23, § 17. See Y. B. 29 Edw. I, 360, (Rolle's Ed.;) Keilw. 113, pl. 45. And it was said that "a covenant which runs and rests with the land lies for or against the assignee at common law, quia transit terra cum onere, although the assignee be not named in the covenant." Hyde v. Dean of Windsor, Cro. Eliz. 552; Id. 457; s. c., Co. R. 24a; Moore, 399.

It is not necessary to consider whether possession of the land alone would have been sufficient to maintain the action of covenant. It is enough for our present purposes that it carried the right of property. Neither is it necessary to consider the difficulties that have sometimes arisen in distinguishing rights of this latter class from pure matters of contract, by reason of their having embraced active duties as well as those purely passive and negative ones, which are plainly interests carved out of a servient estate and matters of grant. The most conspicuous example is Pakenham's Case, Y. B. 42 Edw. III, 3 pl. 14, where the plaintiff recovered in covenant as terra-tenant, although not heir, upon a covenant or prescriptive duty to sing in the chapel of his manor. Spencer's Case, 5 Coke, 16a, 17b. Another which has been recognized in this commonwealth is the quasi easement to have fences maintained. Bronson v. Coffin, 108 Mass. 175, 185, 11 Am. Rep. 335; s. c. 118 Mass. 156 . Repairs were dealt with on the same footing. They were likened to estovers and other rights of common. 5 Coke, $2+$ a, b; Hyde v. Dean of Windsor, ubi supra. See F. N. B. 127; Spencer's Case, ubi supra; Ewre v. Strickland, Cro. Car. 240; Brett v. Cumberland, 1 Rolle, 359, 360; and other examples might be given. See Bract. 382, a, b; Fleta, VI, c. 23, § 17; Y. B. 20 Edw. I, 360 ; Keilw. 2a, pl. 2; Y. B. 6 Hen. VII, 14b, pl. 2; Co. Litt. 3841, $385 \mathrm{a}$; Cockson v. Cock, Cro. Jac. 125; Bush v. Cole, 12 Mod. 24; s. c., 1 Salk. 196; 1 Show. 388; Carth. 232; Sale v. Kitchingham, 10 Mod. 158. The cases are generally landlord and tenant cases; but that fact has nothing to do with the principles laid down.

When it is said, in this class of cases, that there must be a privity of estate between the covenantor and the covenantee, it only means that the covenant must impose such a burden on the land of the covenantor as to be in substance, or to carry with it, a grant of an easement or quasi easement, or must be in aid of such a grant, (Bronson v. Coffin, ubi supra,) which is generally true, although, as has been shown, not invariably, (Pakenham's Case, ubi supra,) and although not quite reconcilable with all the old cases, except by somewhat hypothetical historical explanation. But the expression "privity of estate," in this sense, is of modern use, and has been carried over from the cases of warranty, where it was used with a wholly different meaning.

In the main, the line between the two classes of cases distinguished by Lord Coke is sufficiently clear; and it is enough to say that the pres- 
ent covernant falls into the second class, if either. Notwithstanding its placc among the covenants for title, it purports to create a pure negative restriction on the use of land, and we will take it as intended to do so for the benefit of the land conveyed. The restriction is in form within the equitable doctrine of notice. Whitney v. Union Ry. Co., 11 Gray, 359, 71 An. Dec. 715; Parker v. Nightingale, 6 Allen, 341, 83 Am. Dec. 632. Sce Tulk v. Moxhay, 2 Phil. 774; Haywood v. Brunswick Euilding Soc., S Q. B. Div. 403; London \& S. W. Ry. Co. v. Comm, 20 Ch. Div. 562; Austerberry v. Oldham, 29 Ch. Div. 750. But as the deed is recorded, it does not matter whether the plaintiff's case is discussed on this footing or on that of easement.

The question remains, whether, even if we make the further assumption that the covenant was valid as a contract between the parties, it is of a kind which the law permits to be attached to land in such a sense as to restrict the use of one parcel in all hands for the benefit of whoever may hold the other, whatever the principle invoked; for equity will no more enforce every restriction that can be devised than the common law will recognize as creating an easement every grant purporting to limit the use of land in favor of other land. The principle of policy applied to affirmative covenants, applies also to negative ones. They must "touch and concern" or "extend to the support of the thing" conveyed. 5 Coke, 16a; Id. 24b. They must be "for the bencfit of the estate." Cockson v. Cock, Cro. Jac. 125. Or, as it is said more broadly, new and unusual incidents cannot be attached to land by way either of benefit or of burden. Keppell v. Bailey, 2 Mylne $\&$ K. 517, 535; Ackroyd v. Smith, 10 C. B. 164; Hill v. Tupper, 2 Hurl. \& C. 121.

The covenant under consideration, as it stands on the report, falls outside the limits of this rule, even in the narrower form. In what way does it extend to the support of the plaintiff's quarry? It does not make the use or occupation of it more convenient. It does not in any way affect the use or occupation; it simply tends indirectly to increase its value, by excluding a competitor from the market for its products. If it be asked what is the difference in principle between an easement to have land unbuilt upon, such as was recognized in Brooks v. Reynolds, 106 Mass. 31, and an easement to have a quarry left unopened, the answer is that, whether a difference of degree or of kind, the distinction is plain between a grant or covenant that looks to direct physical advantage in the occupation of the dominant estate, such as light and air, and one which only concerns it in the indirect way which we have mentioned. The scope of the covenant and the circumsiances show that it is not directed to the quiet enjoyment of the dominant land.

Again, this covenant illustrates the further meaning of the rule against unusual incidents. If it is of a nature to be attached to land, as the plaintiff contends, it crcates an easement of monopoly,- -an easement not to be competed with,- and in that interest alone a right 
to prohibit one owner from exercising the usual incidents of property. It is true that a man could accomplish the same results by buying the whole land and regulating production. But it does not follow because you can do a thing in one way that you can do it in all; and we think that if this covenant were regarded as one which bound all subsequent owners of the land to keep its products out of commerce, there would be much greater difficulty in sustaining its validity than if it be treated as merely personal in its burden. Whether that is its true construction as well as its only legal operation, and whether, so construed, it is or is not valid, are matters on which we express no opinion. Bill dismissed. ${ }^{12}$

12Acc.: Bill by the covenantee against the assignee of the covenantor, liettle liver R. Co. v. Eastern Ry. Co., of Minnesota, 41 Minn. 461, $43 \mathrm{~N}$. W. 409,6 I. R. A. 111 (18§9); Tardy v. Creasy, 81 Va, 553, 59 Am. Rep. 676 (1S86) ; assignce of covenantee against assigmee of covenantor, Brewer v. Marshall, 19 N. J. Eq. 537, 97 Am. Dec, 679 (1868).

One Lewis owned land on the Illinois river and ran a ferry across the river: he conveyed to the grantor of the appellee in this case another piece of land on the river with a stipulation in the deed that the grantee, his heirs and assigns, should not establish a ferry thereon without the consent of Lewis, his heirs and assigns. The appellee ran a ferry from the second lifece without the consent of Lewis or of the appellant who had purchased from Lewis the first mentioned lot. Appellant sought an injunction. The conrt granted the injunction, saying, per Craig, J.: "Appellee purchased with notice of the agreement in the deed under which bis grantor derived title, as the decd had been unon record for many years, and it can not be claimed he was misled or in any manner deceived, and, under the authorities cited, it is within the power of a court of equity to enforce the contract upon which, alone, Iewis, the original owner, parted with the title to the liand, and compel anpellee to abide by its terms and conditions. It would lie a strange doctrine, indeed, to hold that an owner of real estate could not convey a part, and restrict its use in such a manner as not to impair or lessen in value the portion retained. We are aware of no restriction upoil the light of an owner to convey unon such terms and conditions as he may see proner, and as may be acceptable to the grantee, except that the right should be exercised with proper regard to public policy, and that the converance should not be made in restraint of trade. When a vendee pur'hases with full notice of a valid agreement. betreen his vendor and the original owner, concerning the manner in which the property is to be occufied, it is but a reasoniahle and equitable requirement to hold him bound to alide by the contract under which the land was conveyed. We are, therefore, of opinion, that the provision in the deed prohibiting the use of the eight acre tract for ferry purposes, is obligatory upon appellee, and it was within the power of a court of equity to enjoin bim from using the land in a manner and for a purpose actually prohihited by the terms of one of the (trecls which is a link in the chain of title under which he holds the land." l're v. l'artridge, S2 I1l. 267, 272. (1876).

Acc.: IRolbins v. Webh, 68 Ala. 393 (18S0); covenanteo against assignee of covenantor. Hodge v. Sloan, 107 N. Y. 244,17 N. E. 335, 1 Am. St. Kep. S16 (1S57); Stines v. Dorman, 25 Ohio St. 580 (1874).

See, also, Kenpell v. lailey, 2 M. \& K. 517 (1834); 'Taylor v. Owen, 2 Blackf. (1nd.) :301, 20 An. Dec. 115 (1530), ante, p. 380; Lymn v. Mt. Savage

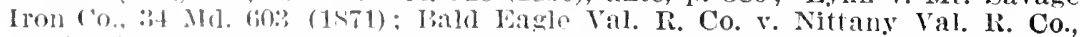
171 I'a. 2S4, 33 Atl. 239, 29 L. R. A. 4.2, 50 Am. St. Kep. 507 (1S95). 


\title{
SECTION 2.-RUNNING OF BENEFIT AND BURDEN
}

\author{
MASTER v. HANSARD.
}

\author{
(Court of Appeal, 1S76. L. R. 4. Ch. D. 718.)
}

By indenture dated the 1st of December, 1853, Hansard and Rogers demised to one Masters a piece of ground at the Anerley Road, Penge, with a building upon it known as the Crystal Palace Hotel, for the term of ninety-nine years, from the 24 th of June, 1852. The deed contained a covenant by Masters that he, his executors, administrators, or assigns, would not during the term do anything upon the premises which might be an annoyance to the neighbourhood or to the lessees or tenants of the lessors, their heirs or assigns, or diminish the value of the adjacent property, nor should nor would erect or build, or cause or permit to be erected or built, upon the said piece or parcel of ground thereby demised any dwelling-house, outbuilding, coach-house, stable, or other building nearer than twenty feet to the Anerley Road, and also should not nor would during the term erect or cause or permit to be erected upon the demised ground any other messuage, building, or erection whatsoever without first submitting the plans thereof to the lessors, their assigns, and obtaining their approval of the same.

On the 14 th of May, 1858, Hansard and Rogers demised to Hantleran adjoining piece of ground with two houses thereon, for ninety-four years, from the 24 th of June, 1857 . This lease contained a negative covenant on the part of the lessee identical in its terms with the above negative covenant contained in the lease to Masters. It did not appear that Hantler when he took this lease knew anything of the terms of the lease to Masters.

After divers mesne assignments, the leasehold interest created by the lease to Masters was, by indenture dated the 12th of October, 1S7, assigned to the Crystal Palace Hotel Company. The leasehold interest created by the lease of 1858 had in the meantime become vested in the plaintiff. Miss Master.

In 1876 the Crystal Palace Hotel Company, determined to enlarge the hotel by adding a new wing, and on the 10th of March, 1876, wrote to the lessors asking their permission to extend the hotel as shewn by the plan. It was not in dispute that the additional building was one the erection of which could have been restrained as unduly interfering with the plaintiff's lights had they been ancient lights. 'The plaintiff complained to the lessors, who stated that the buildings would be proceeded with. The plaintiff thereupon conmenced her action against the lessors and the Crystal Palace Hotel Company, claiming that the lessors might be restrained from giving their approval to the plans, or 
their consent to the erection of any buildings which would interfere with the access of light to the plaintiff's house; that the defendants might be restrained from erecting or permitting to continue erected on the lands of which the company were the tenants the building then in course of erection or any other buildings which would interfere with the access of light to the plaintiff's house, or diminish the value of the house, and for damages and further relief.

Vice Chancellor Bacon held that the plaintiff could not claim to have the restrictive covenant enforced in her favour, but directed an inquiry as to damages. The Crystal Palace Hotel Company appealed. The appeal was heard on the 25 th November, 1876.

JAmes, L. J. I am of opinion that this decree cannot be sustained. The defendants, the Crystal Palace Hotel Company, are owners of a property under a demise for a term of years, and are erecting on it a building which may lawfully be erected unless they have put themselves under an obligation not to do so. The plaintiff is the owner of an adjoining property under another demise for a term of years from the same lessors, of later date than that of the defendants; he therefore cannot have acquired any right against them, except under some grant which could lawfully be made. Now, the lessors could not grant anything so as to derogate from the rights of their prior grantee. The respondent, therefore, was obliged to rest his case on the covenants entered into by the defendants' predecessor in title with the grantor, and the question is whether those covenants bring the case within the rule which says that the owner of two tenements who grants one of them cannot derogate from his own grant by anything he does on the property which he reserves, the property granted becoming entitled to easements known as easements derived by the disposition of the owner of two tenements. The plaintiff contends that though the grantor when he made the grant under which the plaintiff claims had ceased to be the owner of the defendants' tenement, he had a right which he could have used in such a way as to prevent the plaintiff's enjoyment of his property being interfered with in any way in which the grantor would not have been allowed to interfere with it if he had retained the defendants' property, and that this interest brings the case within the rule as to the owner of two tenements. It would be a novel extension of that doctrine to hold that not only a grantor cannot do anything to derogate from his own grant, but that he is obliged to take active steps to prevent other persons from doing what he might not himself do. It cannot, in my opinion, be said, that a right under a covenant is properly within the meaning of this rule. Then the plaintiff says: "You, my lessor, could, under the covenants entered into with you by your other lessee, have prevented this erection; you had and have that right; you have granted me a piece of ground witl a house on it, and you ought to enforce those covenants for my benefit." Now, when the plaintiff took his lease he had no knowledge of the nature of the title to the adjoining property; all he knew was that the piece of property 
adjoining his had once been part of the same estate; he knew nothing of the covenant; the grant to him contains no notice of it, and it would be strange to say that a man who has taken a covenant for his own benefit can be prevented from dealing with it for his own benefit because he has granted parcels of the land to other people. The covenant is not mentioned in the plaintiff's lease, and it cannot have been the intention of the parties thus to restrict the use of a covenant which was entered into, not for the benefit of the adjoining land, but for the benefit of the owner of the estate, that he might be able to make the most of it. It would be too great an extension of the doctrine of implied obligation to raise by implication a right in the nature of an equitable assignment of the benefit of the covenant. There was no bargain as to enforcing the covenant for the benefit of the plaintiff, and we cannot imply one. ${ }^{13}$

\section{RENALS v. COWLISHAW.}

(High Court of Justice, Chancery Division, 187S. L. R. 9 Ch. D. 125.)

By an indenture dated the 29th of September, 1845, Messrs. Hoby, Winterbotham, and Russell, as the devisees in trust for sale of a mansion-house and residential property known as the Mill Hill estate, and of certain pieces of land adjoining thereto, sold and conveyed two of these adjoining pieces of land to one Francis Shaw, in fee, and Shaw thereby for himself, his heirs, executors, and administrators, covenanted with Hoby, Winterbotham, and Russell, their heirs, executors, administrators, and assigns, not to build upon the lands thereby conveyed within a certain distance from a particular road leading "to the Mill Hill house and property belonging to the said trustee"; that the garden walls or palisades to be set up along the side of the said road should stand back a certain distance from the centre of the road; that any house to be built on the land adjoining the road should be of a certain value, and of an elevation at least equal to that of the houses on a particular road; and that no trade or business should be carried on in any such houses or buildings, but that the same should be used as private dwelling-houses only. The conveyance did not state that this covenant was for the protection of the residential property, or in ref-

13 Baggallay and Bramwell, L. JJ., delivered concurring opinions.

$A$. leased one of a row of shops to $B$. and covenanted that he would not lease any of the other shops for the purpose of the trade of a greengrocer. B. assigned his lease to $C$. A. leased another shop to $X$., with a covenant by $\mathrm{X}$. that he would use the premises as an oil warehouse only. $\mathrm{X}$. Iater began to use it as a greengrocery. C. brought action against $A$. and $X$. for an injunction to restrain $\mathrm{A}$. from letting or continuing to let the premises to $\mathrm{X}$. to be used as a greengrocery or from permitting them to be so used, and to restrain $\mathrm{X}$. from so using them. Heid, C. has no cause of action against either defendant. Ashby 5 . Wilson, [1900] 1 Ch. 66 (1899). See, also, Kemp v. Birr, L. R. 5 Ch. D. 549 (1.877); University Club of Chicago v. Deakin, 265 Ill. 257,106 N. E. 790 , L. R. A. 1915C, $8 \check{4}$ (1914), post, p. 613. 
erence to the other adjoining pieces of land, or make any statement or reference thereto.

The same trustees also sold about this time other pieces of lands adjoining the Mill Hill estate; and the conveyance to the purchaser in each case contained restrictive covenants similar to those above mentioned. It was alleged by the plaintiffs in their statement of claim that the intention of all the restrictive covenants was to protect and maintain the value of the Mill Hill estate, and to secure the continuance of the surrounding neighborhood as purely residential in character.

The trustees, in December, 1854, sold and conveyed the Mill Hill estate to T. P. Bainbrigge in fee, and, Bainbrigge having died, his devisees in trust, in September, 1870, sold and conveyed the same estate to the plaintiffs as tenants in common in fee.

In neither of these two conveyances were there covenants similar to those in the conveyance to Shaw, but there was in the conveyance to the plaintiffs a covenant by them with their vendors not to build a public-house or carry on offensive trades upon a particular portion of the property conveyed to them. Neither of the two conveyances recited or mentioned in any way the conveyance or sale to Shaw, or the existence of any restrictive covenant entered into by Shaw or by Gadsby, nor did either of them recite or mention the sales or conveyances of the other pieces of land sold as above mentioned.

There had also been a devolution title with regard to the lands sold to Shaw, for after his death Mary Shaw, the person entitled under his will, in August, 1867, sold and conveyed part of the lands comprised in the indenture of September, 1845, to John Gadsby in fee, who, in his conveyance, entered into covenants with Mary Shaw, her heirs, executors, and administrators, substantially identical mutatis mutandis with the restrictive covenants contained in the indenture of the 29th of September, 1845. And subsequently the lands so conveyed to Gadsby were sold and conveyed (with certain buildings erected thereon) by Gadsby, or persons deriving title through him, to the defendants as tenants in common in fee.

The plaintiffs alleged that the defendants were carrying on upon their lands and in contravention of the restrictive covenants first above mentioned, the trade of wheelwrights, smiths, and bent timber manufacturers, and had erected a high chimney which emitted thick black smoke, and that those acts were destructive of the residential character of the neighborhood, and had deteriorated the value and amenity of the Mill Hill estate. By their action they claimed an injunction to restrain the defendants from carrying on any trade or business upon their lands, and from permitting the buildings erected thereon to be used otherwise than as private houses, and from contravening in any manner the restrictive covenants contained in the indenture of September, 1845 .

The principal question argued, and that on which the decision turned, was as to the right of the plaintiffs to sue upon these covenants. 
It appeared that no contract had been entered into or representations made, either upon the occasion of the purchase by Bainbrigge from the trustees, or upon the purchase from Bainbrigge by the plaintiffs, that the purchaser should have the benefit of the covenants entered into by Shaw with the trustees. ***

HALL, V. C. I think this case is governed by Keates v. Lyon, by Child v. Douglas, Kay, 560; 5 D., M. \& G. 739, as ultimately decided by Vice Chancellor Wood, 2 Jur. (N. S.) 950, who, after granting an interlocutory injunction in the first instance, refused to grant the plaintiff an injunction at the hearing, and by the case of Master v. Hansard [4 Ch. D. 724].

'The law as to the burden of and the persons entitled to the benefit of covenants in conveyances in fee, was certainly not in a satisfactory state; but it is now well settled that the burden of a covenant entered into by a grantee in fee for himself, his heirs, and assigns, although not running with the land at law so as to give a legal remedy against the owner thereof for the time beings is binding upon the owner of it for the time being, in equity, having notice thereof. Who, then (other than the original covenantee), is entitled to the benefit of the covenant? From the cases of Mann v. Stephens, $15 \mathrm{Sim} .377$, Western v. Macdermott, Law Rep. 2 Ch. 72, and Coles v. Sims, Kay, 56; 5 D., M. \& G. 1, it may, I think, be considered as determined that any one who has acquired land, being one of scveral lots laid out for sale as building plots where the court is satisfied that it was the intention that each one of the severdl purchasers should be bound by and should, as against the others, have the benefit of the covenants entered into by each of the purchasers, is entitled to the benefit of the covenant; and that this right, that is, the benefit of the covenant, enures to the assign of the first purchaser, in other words, runs with the land of such purchaser. This right exists not only where the several parties execute a mutual deed of covenant, but wherever a mutual contract can be sufficiently established. A purchaser may also be entitled to the benefit of a restrictive covenant entered into with his vendor by another or others where his vendor has contracted with him that he shall be the assign of it, that is, have the benefit of the covenant. And such covenant need not be express, but may be collected from the transaction of sale and purchase. In considering this, the expressed or otherwise apparent purpose or object of the covenant, in reference to its being intended to be annexed to other property, or to its being only obtained to enable the covenantee more advantageously to deal with his property, is important to be attended to. Whether the purchaser is the purchaser of all the land retained by his vendor when the covenant was entered into, is also important. If he is not, it may be important to take into consideration whether his vendor has sold off part of the land so retained, and if he has done so, whether or not he has so sold subject to a similar covenant: whether the purchaser 
claiming the benefit of the covenant has entered into a similar covenant may not be so important.

The plaintiffs in this case, in their statement of claim, rest their case upon their being "assigns" of the Mill Hill estate, and they say that as the vendors to Shaw were the owners of that estate when they sold to Shaw a parcel of land adjoining it, the restrictive covenants entered into by the purchaser of that parcel of land must be taken to have been entered into with them for the purpose of protecting the Mill Hill estate, which they retained; and, therefore, that the benefit of that restrictive covenant goes to the assign of that estate, irrespective of whether or not any representation that such a covenant had been entered into by a purchaser from the vendors was made to such assigns, and without any contract by the vendors that that purchaser should have the benefit of that covenant. The argument must, it would seem, go to this length, viz., that in such a case a purchaser becomes entitled to the covenant even although he did not know of the existence of the covenant, and that although the purchaser is not (as the purchasers in the present case were not), purchaser of all the property retained by the vendor upon the occasion of the conveyance containing the covenants. It appears to me that the three cases to which I have referred show that this is not the law of this Court; and that in order to enable a purchaser as an assign (such purchaser not being an assign of all that the vendor retained when he executed the conveyance containing the covenants, and that conveyance not showing that the benefit of the covenant was intended to enure for the time being of each portion of the estate so retained or of the portion of the estate of which the plaintiff is assign), to claim the benefit of a restrictive covenant, this, at least, must appear, that the assign acquircd his property with the benefit of the covenant, that is, it must appear that the benefit of the covenant was part of the subject-matter of the purchase. Lord Justice Bramwell, in Master v. Hansard, 4 Ch. D. 724, said: "I am satisfied that the restrictive covenant was not put in for the benefit of this particular property, but for the benefit of the lessors to enable them to make the most of the property which they retained." In the present case I think that the covenants were put in with a like object. If it had appeared in the conveyance to Bainbrigge that there were such restrictive covenants in conveyances-already executed, and expressly or otherwise that Bainbrigge was to have the benefit of them, he and the plaintiffs, as claiming through him, would have been entitled to the benefit of them. But there being in the conveyance to Bainbrigge no reference to the existence of such covenants by recital of the conveyances containing them or otherwise, the plaintiffs cannot be treated as entitled to the benefit of them. This action must be dismissed with costs. ${ }^{14}$

14Affirmed L. R. 11 Ch. D. 866 (1879).

Acc.: Berryman v. Hotel Savoy Co., 160 Cal. 559, 117 Pac. 677, 37 L. R. A. (N. S.) 5 (1911); Badger v. Boardman, 16 Gray (Mass.) 559 (1860); Mc- 
WEIL v. HILL.

(Supreme Court of Alabama, 1915. 193 Ala. 407, 69 South. 438.)

SAYRE, J. ${ }^{15}$ Appellee, Hill, owns the lot, 50 by 165 feet, on the southwest corner of Perry street and Jeff Davis avenue, in the city of Miontgomery. On the lot is a residence which stands $471 / 2$ feet from the line of Perry street, on which the property fronts. Appellee was preparing to move his house nearer to the Perry street line, when appellant, Weil, who owns. and occupies the lot next south of appellant's [appellee's] lot, filed this bill to enjoin the operation.

There are two branches to appellee's title. On May 1, 1909, he took a warranty deed from Mrs. Winn, in which the property conveyed is described as fronting 50 feet on Perry and running back 165 feet on Jeff Davis. Ten days later he took from Sloane Young and his wife, Cora, a deed of all their right, title, and interest, "both in expectancy and in reversion," in and to the rear 35 fect of the same lot, which part Young had purchased from one Rugely, and to which, for convenience, we will refer as the Rugely lot. Prior to September 25, 1901, in pursuance of an understanding between Young and Josie W. Hubbard, who afterwards became Mrs. Winn, and in anticipation of the deed to be presently mentioned, the latter had moved her house on the lot she then owned back on a line with the house now occupied by appellant on the adjacent lot, and then on the last-mentioned date Young, his wife joining in the deed, on the recited consideration of $\$ 1$ and "the covenants and agreements" contained in the deed, conveyed the Rugely lot to Josie W. Hubbard by a deed containing, after a description of the property and customary words of conveyance, the following clause or stipulation:

"But it is covenanted and agreed by the said Josie W. Hubbard, her heirs, legal representatives, and assignees, and it is made a covenant running with said land, that no house or other structure shall ever be erected on the lot immediately east of the lot hereby conveyed on the southwest corner of Perry street and Jeff Davis avenue, nearer or closer to the said Perry street than the house now standing on the said lot, the front of which is, to wit, forty-seven and one-half feet west of the west line of said Perry street, and a violation of this covenant shall immediately work a reversion to the grantors herein, their heirs and assignces, of the land hereby conveyed: Provided, however, that should the residence, as now occupied by us, be rebuilt, remodeled, moved, or in other respects be changed or altered, so as to place same or other permanent improvements on said lot nearer to said Perry street than now located, then this obligation shall be by such change in location of said house or buildings on said lot so modified as

Nichol v. Townsend, 73 N. J. Fq. 276, 67 Atl. 938 (1907); Hutchinson v. Thomas, 190 Pa. '242, 42 Atl. 681 (1899).

15 Part of the oyinion is omitted. 
to require only that the house and other improvements on the lot of said Josie W. Hubbard shall maintain, with such changes or improvements as may be made lipon the premises owned by us, the same relative position to the said Perry street as is now established."

This deed was recorded in July, 1906, thus putting appellee upon notice of it, and upon the quoted clause appellant bases his claim of right to the injunction sought. His theory is that the clause should be held effectual in equity by way of estoppel or implied covenant to impose upon the lot previously owned by Josie W. Hubbard the burden of a perpetual building restriction, a negative easement or servitude, appurtenant to Mrs. Young's adjacent lot, now owned by him, and binding upon any purchaser of the Hubbard lot having notice-this, though the instrument of conveyance containing the clause was not subscribed by the grantee and would fix a servitude on property not the subject of conveyance for the benefit of the property of a grantor whose interest in the property conveyed was nothing more than an inchoate right of dower.

The title by which appellant claims to have acceded to the right in question has two branches also. Cora Young and husband mortgaged the lot to the 'Travelers' Insurance Company on June 27, 1899. It will be observed that this was before the execution of the deed containing the clause. This mortgage was foreclosed on April 5, 1906, and appellant became the purchaser and received a deed from the person executing the power. This title is stated in the bill, but we do not consider that it affects the question under consideration. In the meantime-that is, on December 28, 1901-Cora and Sloane Young had conveyed the lot to J. H. Clisby, "together with all improvements and appurtenances thereunto belonging." In 1908 Clisby conveyed the lot to Weil, describing it by metes and bounds, and to this description adding words and figures which, with slight changes to avoid confusion, may be quoted as follows:

"Being the same property described in the mortgage of Cora Young and Sloane Young, her husband, to the 'Travelers' Insurance Company, date June 27, 1899, recorded in Mortgage Book 160, page 272, in the office of the judge of probate of Montgomery county, Ala., except one picce thereof heretofore released therefrom as described in Deed Book 45 , page 307 , with an alleyway ten feet wide running into said property from the south side of Jeff Davis avenue."

There was no other mention of appurtenances.

It was held in the court below on these facts that appellant's case was deroid of equity, and from the decree dismissing his bill this appeal has been taken.

In determining the intention expressed by the deed of September 25,1901 , we must look to the terms of the deed itsclf, and then, if there be any doubt, to the relation between the properties and the circumstances of the parties at the time so far as disclosed by the bill, to the end that grod sense and sound equity may be applied in the 
case. Appellant assumed, of course, the burden of stating facts that would show the intent to create a right in the nature of an easement over the land of the grantee, that the intent had been so expressed as to become binding on land, and his accession to the right; but, the right appearing, the court will not presume that it was intended to be in gross, or personal to the grantor, if it can fairly be construed as appurtenant to his land; and one test, approved by experience and common sense, is that the restriction would naturally operate to enhance the value of the grantor's adjacent property, whether retained by then or conveyed to another. "If this be so, it is a strong circumstance to indicate that the restriction was not intended for the mere personal benefit of the grantor, but as a permanent servitude beneficial to the owner of the land, whocver he may be, and appendant to the premises." McMahon v. Williams, 79 Ala. 289. And, besides, in this case, from the language of the clause itself, considered apart from the stipulation for a "reversion," it is apparent that the parties intended that the advantage contracted for should be permanent and appurtenant to the grantors' adjacent land-this, for one reason, among others, that the covenant was made "a covenant running with said land." Appellee would refer these words to the land granted and deny their application to the adjacent lot previously owned by the grantee. But on looking to the substance of things it is seen that appellee's application would render the words insensible. If an easement was created running with any land, it runs with the land upon which it was fastened as a burden. It would be quite anomalous to destroy the entire beneficial meaning of the covenant on the sole consideration that the parties made an inapt use of the single word of reference, "said." Nor, on the other hand, was the easement made personal by reason of the fact that it was not expressly limited to the "heirs" of the grantors, since it appeared otherwise from the deed that the right to enjoy the easement was not limited to the lifetime of the grantors therein-this, in view of the statute which provides that words of inheritance are not necessary to the creation of a fee. Code, $\S 3396$; Jones on Easements, $\S 45$.

There can be no doubt, aside from what effect may be given to the provision for a "reversion," that Josie Hubbard, by her acceptance of the deed to the Rugely lot, containing the clause in question, agreed for herself, her heirs, legal representatives, and assigns, that no house or other structure should ever be erected on the lot she previously owned nearer to Perry street than the house then standing on the lot.

But appellee insists that the clause as a whole amounted to nothing more than a condition upon the grantee's title in the Rugely lot, and that the condition has been extinguished by the unity of the condition and the fee which has been effected by the quitclaim deed of the Youngs to him. Unmistakably the clause does connect the covenant with the condition, and makes it manifest that the condition was in- 
serted to secure the advantage expressed in the covenant. Nor is it to be escaped that the stipulation was so framed that a violation of the covenant would operate immediately, and therefore without the necessity for an entry, to determine the estate granted. The clear legal effect was to create a conditional limitation upon the fee granted, leaving in the grantors a possibility of reverter conditioned upon an unobstructed flow of light and air and view across the front of the adjacent Hubbard lot. But the covenant and the condition, though thus conrected, affected different estates. The condition affected the title to the Rugely lot and inured to the benefit of the grantors, their heirs and assigns. The covenant imposed upon the front $471 / 2$ feet of the Hubbard lot a servitude for the benefit of, and annexed to, the grantors' adjacent lot. This servitude was the real consideration for the grant. The condition, imposed for security, was an incorporeal hereditament in the grantors, the legal title to which would pass only by express grant. But the easement, as we have seen, passed by a grant of the land to which it was appurtenant. There is no reason, therefore, why the extinguishment by the Youngs of the condition upon one title should affect the servitude appurtenant to the other which had previously passed by their deed to Clisby. An existing easement appurtenant to land passes by the deed of the owner of the land to his grantee and follows the land without any mention whatever. Jones on Easements, $\S \S 22,23$, and authorities cited. * * *

It is next insisted that a covenant purporting to reserve an easement in favor of one other than the grantor is void. It is true that an easement cannot in strict law be made the subject of a reservation or exception, for it does not issue out of land as a profit, nor is it parcel of the land. But it is to be observed, in line with what we have previously said and the authorities cited above, that in equity at least the effort is to construe and enforce contracts according to the true intention of the parties so long as they violate no principle of public policy, and such a reservation or exception is construed precisely as if it were a counter grant by the grantee, and thus, in a case like this, effect is given to the plain terms of the contract. Goold v. G. W. Deep Coal Co., 2 De G., J. \& S. 600; Dyer v. Sanford, 9 Metc. (Mass.) 395, 43 Am. Dec. 399. In this bill there is no attempt to enforce an easement created by reservation or exception. The effort is to enforce a notional counter grant, or a covenant implied by the grantee's acceptance of the benefits of the deed to him, and the court of chancery will compel performance, whether the servitude bargained for is imposed upon the land granted or other land of the grantee so situated with respect to land of the grantor as that the former may naturally and reasonably be made servient to the latter. ${ }^{16}$ Mrs. Young joined in the conveyance, and though her interest in the tract conveyed was only an

16 See Rogers v. Hosegood, [1900] 2 Ch. 388; Hays v. St. Yaul M. L. Church, 196 Ill. 633, 6i N. E. 1010 (1902). 
inchoate right of dower, her release constituted a valuable consideration for her execution of the deed. Gordon v. Tweedy, 71 Ala. 202.

These considerations lead us to conclude that the decree denying appellant's right to the easement in question, and dismissing his bill for want of equity, was error.

Reversed and remanded.

Anderson, C. J., and McCletilan and Gardner, JJ., concur. ${ }^{17}$

PARKER v. NIGH'TINGALE.

(Supreme .Iudicial Court of Massachusetts, 1863. 6 Allen, 341, 83 Am. Dec. 632.)

Bill in equity, setting forth that before the erection of houses upon Hayward Place in the city of Boston, the land upon and adjoining the same was owned by Lemuel Hayward; that upon his decease it was arranged among his heirs that the said land should be laid out into a court or street, to be occupied exclusively for dwelling-houses; that for this purpose the land was surveyed and laid out into a court, with house lots of convenient size, and numbered, following the course of the court; that this agreement was made to facilitate the sale and

17Acc.: Peck v. Conway, 119 Mass. 546 (1876); Codman v. Bradley, 201 Mass. 361, 87 N. E. 591 (1909); Coughlin v. Barlier, 46 Mo. App. 54 (1891); Hills v. Miller, 3 Paige (N. Y.) 254, 24 Am. Dec. 218 (1832) ; Coudert v. Sayre, 46 N. J. Eq. 386, 19 Atl. 190 (1S90); Clark v. Martin, 49 Pa. 289 (1865).

See Judd v. Robinson, 41 Colo. 222, 92 Pac. 724, 124 Am. St. Rep. 128, 14 Ann. Cas. 1018 (1907).

"When the benefit has been once clearly annexed to one piece of land, it passes by assignment of that land, and may be sajd to run with it, in contemplation as well of equity as of law, without proof of special bargain or representation on the assignment. In such a case it runs, not becanse the conscience of either party is affected, but because the purchaser has bought something which inhered in or was annexed to the land bought. This is the reason why, in dealing with the burden, the purchaser's conscience is not affected by notice of covenants which were part of the original bargain on the first sale, but were merely personal and collateral, while it is affected by notice of those which touch and concern the land. The covenant must be one that is capable of running with the land before the question of the purchaser's consrience and the equity affecting it can come into discussion. When, as in Renals v. Cowlishaw, 9 Ch. D. 125 [1878], there is no indication in the original converance, or in the circumstances attending it, that the burden of the restrictive covenant is imposed for the benefit of the land reserved, or any particular part of it, then it becomes necessary to examine the circumstances under which any part of the land reserved is sold, in order to see whether a benefit, not originally annexed to it, has become annexed to it on the sale, so that the purchaser is decmed to have bought it with the land, and this can hardly be the case when the purchasel did not know of the existence of the restrictive covenant. But when, as here, it has been once annexed to the land rescrved, then it is not necessary to spell an intention out of surrounding facts, such as the existence of il building scheme, statements of auctions, and such like circumstances, and the presumption must be that it passes on a sale of that land, unless there is something to rebut it, and the purchaser's ignorance of the existence of the covount does not defeat the presumption." Farwell, J., in logers v. Hosegood, [1900] 2 Ch. 388, 407. 
enhance the value of the lots, by rendering them quiet and desirable places of abode; that it was further agreed among the heirs, and those who represented such as were not sui juris, that in conveying the lots the grantees should be laid under an express obligation or duty, by way of condition or limitation of the use thereof, that "no other building, except one of brick or stone, of not less than three stories in height, and for a dwelling-house only," should be erected by them; that the deeds of all the lots were made upon this condition, and the same was either repeated or referred to in the subsequent conveyances thereof; that lot No. 2 was set to Charles Hayward, one of the heirs, and, being under the control of trustees, was by them conveyed in 1822, upon condition "that no other building shall be erected or built on the lot except one of brick or stone, not less than three stories in height, and for a dwelling-house only," and the same came by intermediate conveyances to James Nightingale, one of the defendants, who now owns the same; that early in 1862 said Nightingale leased said premises, consisting of a three story dwelling-house, and conrenient and comfortable accessory erections, to Frederick Loeber, the other defendant; that the plaintiffs believe and charge the fact to be that the said lease contains the same condition above recited, but they also insist that said Loeber is bound by the conditions of the tenure of his lessor, whether he had actual knowledge thereof or not; * * * that Loeber has since used the place as a restaurant, having large numbers of noisy and boisterous persons in and about the same, and has thus rendered Hayward Place almost unfit for quiet and comfortable residences; and that the plaintiff Parker, in behalf of himself and eleven others who were named, being each the proprietor of a lot on Hayward Place, with a dwelling-house thereon of the description above set forth, has brought this bill. The titles of some of the plaintiffs were set forth in detail. The prayer was for an injunction against such use of the premises, and for other and further relief.

The defendants filed a general demurrer, and the case was thereupon reserved for the determination of the whole court.

BIGELOW, C. J. ${ }^{18}$ A court of chancery will recognize and enforce agreements concerning the occupation and mode of use of real estate, although they are not expressed with technical accuracy, as exceptions or reservations out of a grant not binding as covenants real running with the land. Nor is it at all material that such stipulations should be binding at law, or that any privity of estate should subsist between parties in order to render them obligatory, and to warrant equitable relief in case of their infraction. A corenant, though in gross at law, may nevertheless be binding in equity, even to the extent of fastening a servitude or easement on real property, or of securing to the owner of one parcel of land a privilege, or, as it is sometimes called, "a right to an amenity" in the use of an adjoining parcel, by

18 The statement of facts is abridged and part of the opinion is omitted. 
which his own estate may be enhanced in value or rendered more agreeable as a place of residence. $* * *$

This brings us to a consideration of the most important and difficult question raised by the demurrer, which is, whether the present plaintiffs, or any of them, set forth in the bill any such claim or title as will enable them to enforce this restriction on the use and occupation of the premises in controversy as against the defendants. A satisfactory answer to this inquiry will, we think, be found in the fact, which is sufficiently apparent from the allegations in the bill, that the purpose intended to be accomplished by the restrictions inserted in the deeds of the estate now owned and occupied by the defendants was for the benefit and advantage of other owners of lots situated on the same street or court. Indeed it could have been designed for no other purpose. If we lay aside all the facts alleged in the bill which rest in parol evidence only, and look exclusively to the history of the title as shown by the deeds, the conclusion is unavoidable that the original grantors, in whom the title to the entire tract now owned by the several parties to this suit in different parcels was vested, intended, by limiting the use of the several lots and prescribing the kind of structures which are to be erected by the grantees thereon, to establish a permanent regulation and restriction by which to prevent each parcel from being appropriated to a purpose which might enure to the injury of any other parcel, or render it less agreeable as a place of residence. By excluding all erections for the purposes of trade, and appropriating each lot to a prescribed use as a dwelling-house, the entire neighborhood comprised within the limits of the original tract laid out for a street or court was secured against annoyances arising from occupations which would impair the value of the several lots as places of residence. Thus a right or privilege or'amenity in each lot was permanently secured to the owners of all the other lots. While each was restrained in the use of his own estate, he had the benefit of a like restraint imposed on all the other estates. That this restriction or limitation was not imposed by the original grantors for their own benefit or advantage, and cannot be considered as personal to them, is manifest from the fact that they retained no right or interest in any of the parcels of land. The whole tract was conveyed by them. It does not appear that they retained the occupancy or ownership of any of the lots or of any adjoining estate, by means of which they could derive any personal benefit or advantage from the restrictions. But even if they had, it would not change the result; because, by uniting in a scheme or joint enterprise for the division of the estate into lots or parcels on a street or court laid out by them, and annexing to the conveyance of each lot a restriction on its use, by the observance of which each parcel would be occupied for a similar purpose with every other, the legal inference is, in the absence of any evidence to the contrary, that the intention was to secure to each estate the benefit or advantage which might arise from the specific mode 
in which the adjoining premises were to be improved and occupied. The effect of such a restriction, inserted in contemporaneous conveyances of the several parcels under the circumstances alleged in the bill, was to confer on each owner a right or interest in the nature of a servitude in all the lots situated on the same street which were conveyed subject to the restriction. Thus it entered into the consideration which each purchaser paid for his land, either by enhancing its price in view of the benefit secured to him in the restraint imposed on adjoining owners, or by lessening its value in consequence of the limitation affixed to its use. In this view of the case, it is quite immaterial to determine the precise legal nature or quality of the restriction in question. In strictness, perhaps, the right or interest created by the restrictions, being a qualification of the fee, did not pass out of the original grantors, and now remains vested in them or their heirs. But if so, they hold it only as a dry trust, in which they have no beneficial use or enjoyment, the entire usufruct being in their grantees and their assigns now holding the estates, for whose use and benefit it was intended. Such being the case, then the latter are proper parties to enforce the restriction; and the former, not having any present interest in it, need not be parties to the proceeding. The same result would follow, if the restriction be construed as in the nature of a covenant by each grantee with the other owners of estates on the court, or others holding under a similar restriction. In either view, the present plaintiffs, having a common interest in the subject matter of the bill, and a right to ask for the same remedy against the defendants, are rightly joined as parties. Story, Eq. P1. $\S \S 121,126$; Adair v. New River Co., 11 Ves. 429, 444; Gray v. Chaplin, 2 Sim. \& Stu. 267.

\section{Demurrer overruled. ${ }^{19}$}

18 Acc.: Nottingham Rrick Co. v. Butler, L. R. 16 Q. B. D. 778 (188(i); De Gray v. Monmouth Beach Club House, 50 N. J. Eq. 329, 24 Atl. 388 (1892); Tallmadge v. East River Bank, 26 N. Y. 105 (1862).

The same principle was applied to the relation of landlord and tenant in IIudson v. Cripps, [1896] 1 Ch. 265 (1895).

"In the present case, I think, no one can doubt that the object of the covenants in the deeds from Mercein was to secure all the purchasers of lots in the block, agalinst an offensive use of any other of those lots. And if lots No. 12 and 13 had been conveyed to the defendants, or to those under whom they claim, while Mercein was still the owner of lot No. 11, I am not sure that any technical difficulty would have arisen in the maintaining an action at law, upon the covenants of the grantees of the two first mentioned lots by the complainant as the subsequent purchaser of lot No. 11, and the assignee of the covenants for an easement for the benefit of that lot. But as No. 11 was first conveyed, and the mutual covenants in the deed refer to that lot only, and not to other lots which still remained in the hands of Mercein, the subsequent purchasers from him of lots No. 12 and 13, would have taken their lots entirely discharged of the easement in favor of No. 11, had it not been for their covenants in their own deeds for the benefit of the "neighbor'ing inhabitants;" that is, the owners of other lots in the block. Although the complainant could not maintain a suit at law on that covenant in his own name, and would, perhaps, be only entitled to nominal damages if the suit was brought in the name of Mercein, this court 


\section{CLARK v. McGEE.}

(Supreme Court of Illinois, 1১96. 159 Ill. 518, 42 N. E. 965.)

This was a bill in equity brought by Melville Clark in the circuit court of Cook county against John McGee to enjoin the erection of a certain building, and asking for a removal of the building. Upon filing the bill, a temporary injunction was granted. The defendant appeared and put in an answer to the original bill, and entered a motion to dissolve the injunction. The court denied the motion. Thereupon MIcGee removed the building in process of erection, and commenced the erection of another building. The complainant then filed a supplemental bill.

[This bill alleged in substance: That one Dray owned a tract of land in Chicago extending from Seventy-Second street to SeventyThird street on both sides of Rhodes avenue. That he platted this land and divided it into house lots, nineteen on each side of the avenue, lot 38 being at the southwest corner of Seventy-Second street and Rhodes avenue. This lot was sold to one Taylor, who in turn conveyed it to complainant.] That at the time Dray made his said subdivision, and pursuant to a general scheme or plan adopted by him, and for the benefit of all future owners of lots in said subdivision. Dray conveyed all lots in said subdivision subject to certain restrictions inserted by Dray in the deeds to the different purchasers of lots in said subdivision. That all of the deeds for said lots, except possibly two or three of the lots, in said subdivision, contained said restrictions, and that the purchasers of the lots in which said restrictions are not stated in the deeds bought said lots with actual notice of such restrictions. That the owners of the said two or three lots concerning which no restrictions are contained in the deeds to them had actual notice that the lots so purchased by them were subject to similar conditions and restrictions, as to the kind and cost of buildings, and the amount of frontage such buildings should occupy, as were contained in the deeds where such restrictions were mentioned. That John McGee was the owner of the north one-half of lot 36 , and all of lot 37 , in Dray's Cottage Grove Addition, which has a frontage of 45 feet on Rhodes avenue, and is immediately south of and adjoining the property so owned by complainant, and that McGee obtained title to lot 37 and the north one-half of lot 36 by deed from Dray and wife dated February 15, 1890, and recorded in recorder's office of said Cook county, in Book 3189, page 189. That the said deed to McGee contained the following expressed conditions, which were a part of the consideration therefor: "First. No house shall be erccted upon a less portion

can give full effect to the corenant by a suit in the name of the party for whose benefit and protection the covenant was intended. See Bleecker $\nabla$. Bingham, 3 Paige's Rep. 246 [1S:2]." McCoun, V. C., in Barrow v. Richard, 8 Paige (N. Y.) $351,359,35$ Am. Dec. 713 (1S40). 
of the aforesaid premises than a frontage of 45 feet. Second. No house shall be erected upon said premises at a less cost than $\$ 2,000$, and be built less than 25 feet back from the front line of said premises." That in the conveyance of lot 20, in said subdivision, Dray inserted a similar provision to that in the deed to McGee, except that it was provided in such deed that no house should be erected on said lot 20 upon a less portion of the said premises than a frontage of $44^{65} / 100$ feet. That in the conveyance of lots 21 to 29 , inclusive, and lots 31 , 32,33 , and 34 , similar restrictions to those contained in said deed to McGee were inserted, except the frontage for each house was to be 30 feet and the cost of each house not less than $\$ 2,000$. And that in the deed to Taylor from Dray and wife, from whom Taylor derived title, similar restrictions were made, except that the house to be erected on such lot should not be erected on a less frontage than 44 feet, and that such house should not cost less than $\$ 2,500$. That said property was situated in a good residence district. It was also alleged that since the filing of the original bill McGee tore down the frame shanty erected by him on his property, and had then in process of erection a onestory cottage having an eight-inch brick wall, the same being set on posts about two feet from the ground; that said building would not cost when completed to exceed $\$ 700$. "That it was being constructed of cheap and inferior material, and is shabby-looking in every respect, and was being erected by McGee with full knowledge on his part that the same was contrary to and in violation of the express covenants contained in the deed to him. The defendant to the supplemental bill appeared, and entered a motion to dismiss. The court, on hearing the motion, allowed the motion, and dismissed the bill.

CRAIG, C. J. ${ }^{20}$ (after stating the facts). Walter S. Dray, who owned a tract of land in Chicago consisting of five acres, laid it off into 38 lots, 19 on each side of that part of Rhodes avenue lying between Seventy-Second and Seventy-Third streets. He surveyed and platted the property. The plat was acknowledged as required by law, and recorded in the recorder's office of Cook county. 'The plat shows the size of the various lots, the streets upon which they are located, the dimensions and numbers of the respective lots; but the plat contains nothing showing or tending to show an intention on the part of the proprietor of the subdivision to impose any condition or restriction whatever upon purchasers, in reference to the mode or manner in which they should use, improve, or erect buildings on the respective lots which might be purchased. No deed executed by the proprietor of the subdivision contained any covenant on his part that in the sale of any of the lots embraced in the subdivision he would impose any restriction on purchasers in regard to buildings to be erected by purchasers on the lots; nor does it appear that the proprietor ever entered into any contract under which he obligated himself to impose any:

20 The statement of facts is abridged and part of the opinion is omitted. 
restriction on purchasers. As will be seen from the following plat, the defendant's premises adjoin the lot owned by the complainant on the north. The south one-half of lot 36 and all of 35 lie directly south of the south line of defendant's lot, as indicated by the plat.

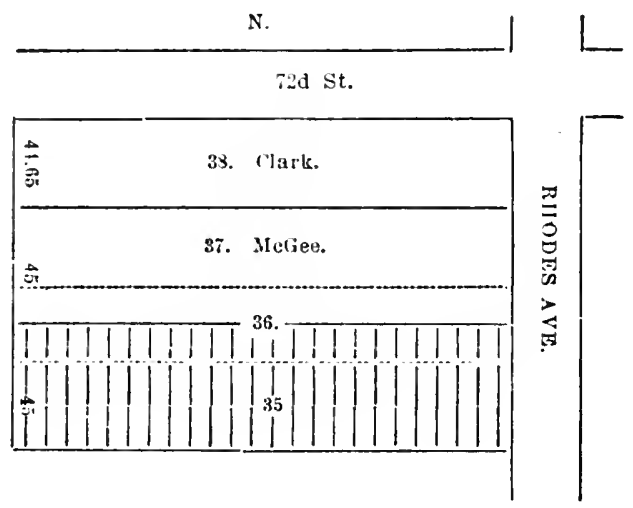

As has been seen, the deed under which McGee obtained title to the premises occupied by him from Walter S. Dray contained a provision that no house shall be erected upon a less portion of the premises than a frontage of 45 feet. No house shall be erected upon the premises at a less cost than $\$ 2,000$ and be built less than 25 feet back from the front line of said premises. And the question presented by this record is whether the adjoining lot owner, Clark, can maintain a bill to prevent the erection of a building contrary to the provision of the deed. We think it well settled by the authorities that where a grantor of two adjoining lots conveys one, and incorporates in the deed of the lot conveyed a covenant restricting the right of the grantee to build in a certain specified manner, which covenant is intended for the benefit of the other lot held by the grantor, a subsequent conveyance of the lot retained will pass or transfer the covenant to the grantee or grantees of such lot as an easement for the benefit of the lot, and the grantee may enforce the covenant against the owner of the other lot in an appropriate action. Coughlin v. Barker, 46 Mo. App. 61, and cases there cited. Hutchinson v. Ulrich, 145 I11. 336. 34 N. E. 556, 21 L. R. A. 391. The law is also well settled, "where a tract of land is subdivided into lots, and these lots are conveyed to separate purchasers, subject to conditions that are of a nature to operate as inducements to the purchase, and to give to each purchaser the henefit of a general plan of building or occupation, so that each shall have attached to his own lot a right in the nature of an easement or incorporeal hereditament in the lots of the others, a right is thereby acquired by each grantee which he may enforce against any other grantee." Sharp v. Ropes, 110 Mass. 385.

It is claimed in this case, as we understand the argument, that the 
complainant is entitled to relief, on the ground that Dray, the original proprictor of the tract of land, laid it off into 38 lots, adopted a general scheme or plan under which all the lots conveyed were to be subject to certain restrictions, which restrictions were intended for the benefit of the several lot owners. We do not concur in this view. There is nothing in the record to show that the restriction placed on the deed to the defendant was part of a general plan adopted by Dray, the proprietor, for the benefit of the lots embraced in his Cottage Grove Addition to Park Manor. In the conveyance of the lots by Walter S. Dray, no two of the deeds executed by him contained the same restriction. They were similar, but not the same. Moreover, for two or three of the lots conveyed they contained no restrictions whatever. The absence of the building restrictions from record of the deeds executed by Dray, as well as the variance in the terms and conditions of the restrictions embraced in the other deeds, destroyed the uniformity essential to establish a general plan. See Dana v. Wentworth, 111 Mass. 293; Sharp v. Ropes, supra; Jewell v. Lee, 14 Allen (Mass.) 145, 92 Am. Dec. 744; Badger v. Boardman, 16 Gray (Mass.) 559, and Coughlin v. Barker, supra.

Had a general plan or scheme been adopted in this case by the proprietor of the addition, and uniformly adhered to in the conveyance of the lots, the complainant might be entitled to maintain a bill, but such was not the case. The judgment of the circuit court will be affirmed.

\section{Affirmed. ${ }^{21}$}

21 Acc.: Summers v. Beeler, 90 Md. 474, 45 Atl. 19, 48 I. R. A. 54, 78 Am. St. Rep. 446 (1S99); Sharp v. Ropes, 110 Mass. 381 (1S72); Equitable Life Assur. Soc. of United States v. Brennan, 148 N. I. 661, 43 N. E. 173 (1896).

"The evidence shows the adoption of such general plan of improvement in this case, and that all of the lands conveyed by the land company, or by the Coast Land Improrement Company, its suecessors in title, on Allen avenue (witl one exception) hare been conreyed with a restriction as to the building line of not less than 40 feet. On the second block east of the block now in question, lots Nos. S2 and 83 were conveyed by the land company, with a 25-feet restriction, instead of 40 feet; but this was because lot No. 81 , next adjoining these on the east was never owned by the land company, and upon this latter lot a house had already been built by a prior owner up to the 25-feet line. This exeeption as to Nos. 82 and 83 cannot be considered a change of the general plan of the company. And althongh different building lines vere adonted for different avenues, the line adopted for each street is the general plan or scheme for that street, upon which purchasers upon the street or arenue have a right to rely." Emery, V. C., in Morlow v. Hasselman, 69 ‥ J. Eq. 612, 614, 81 Atl. 369 (1905). Acc.: Allen v. Detroit, 167 Mich. 464,133 N. W. :317, 36 I. R. A. (N. S.) 890 (1911).

"rhe deliberate continued intention of all parties from 1860 onwards was that this building scheme should continue in force and be operative on all parties. Then it is said that the whole scheme is inconsistent and cannot have been intended, because there was power in the vendor to deal with property undisposed of withont referenve to this deed. That is an argument which has not heen brousht for the first time here. So far as I am aware it is an arrument that has never prevaied. I do not deny that the insertion of such : power is an element to be considered, but out of many building schenes which I have seru I think I am right in this remark, that it is al- 


\title{
WINFIELD v. HENNING.
}

\author{
(Court of Chancery of New Jersey, 1870. 21 N. J. Eq. 1S8.)
}

The Chancelior. The complainant owns a house and lot on the south side of South Fifth street, formerly called also Gilbert street, in Jersey City. The defendant owns a house and lot adjoining it on the west, and on the corner of South Fif th street and Coles street. These lots are part of a tract of one hundred feet square, at the southeast corner of Coles street and South Fifth street, which was conveyed by the devisees of John B. Coles to Keeney and Wheeler, on the first of May, 1854. In the deed the premises were designated by numbers, as four lots fronting on South Fifth or Gilbert street, and the deed contained this provision: "It being expressly understood and agreed that the houses which may be erected on Gilbert street, shall be set back ten feet from the southerly line of said street."

In May, 1857, Keeney conveyed his interest in this tract to Wheeler, who afterwards erected on it five two story houses of twenty feet front on South Fifth street, ten feet from the south line of the street. After they were built, in May, 1858, he conveyed the house and lot of the complainant to a grantee, through whom the complainant derives title, and one year after this he conveyed the house and lot of the defendant to a grantee, through whom the defendant claims title. The stipulation as to the placing houses ten feet from the street, is not contained in any deed after that to Keeney and Wheeler. The

tosether exceptional not to see some power reserved to the vendor to abstract certain property from the scheme. On the face of the scheme, which all the parties were content with, they were told that they entered into this huilding scheme with the knowledge that the vendors might, if they were so ildvised, on the one hand give consent to the erection of a public-house next door to the man who bought the lot, and on the other hand release any unsold property from the covenants. I cannot see that that has any real imvortance in the case." Cozens-Hardy, M. R.. in Elliston v. Reacher, [1908] 2 Ch. 665, 672. See, also, Schreiber v. Creed, 10 Sim. 9, 33 (1S39); Everett $\checkmark$ liemington, [1892] 3 Ch. 14 S.

A. leased a large tract of land to the B. Company, a corporation, for 99 rears, renewable forever'; to be sold in building lots, the lessor reserving ine large lot for himself. It was agreed between $\mathrm{A}$. and the company, inter alia, that no land was to he sold or leased without a stipulation that the lessee should build speedily; that no buildings should be erected unless the designs were approved hy the directors of the company. Lots were then sold or leased by the company. Several years later the lessor died and the company bought in his lot and his reversionary interest. On a bill for speaifie performance by the company against a defendant who had contracted to purchase one of the lots, but who refused upon the ground that the company could not give a clear title, Held, the company could give a title free from the oblication to build speedily, but not from the obligation to build a structure whose design had been approved by the directors, and hence could not compel the defendint to accept the title. Peabody Heights Co. of Paltimore City v. Willson. S- Nfd. 186, 32 Atl. 3S6, 1077, 36 L. R. A. 393 (1ธ95). See, also, Keates v. Ixon, L. R. 4 Ch. App. 218 (1869); Electric City Iand \& Improvement Co. $\mathrm{v}$. West lidge Coal Co., 157 Pa. 500, 41 Atl. 458 (1898). 
grantors in that decd owned a large number of lots in the vicinity, some of which were on the opposite side of the street, and retained them after the deed to Keeney and Wheeler.

The defendant, in May, 1870, commenced erecting an addition to the dwelling house on his lot, which would occupy the ten feet between it and the street, by which the westerly view or prospect from the front of the complainant's house is cut off. The injunction restrains the defendant from proceeding with, or completing that building.

The two questions in the case are, whether the defendant is bound by the stipulation or covenant in the deed from the Coles family, and if he is, whether the complainant has any right to compel its performance.

The provision or covenant in the deed is not like that in Spencer's Case, 5 Rep. 16, as was urged on the argument. It does not relate to something collateral to the land, but to the land conveyed itself. In that case the covenant was to erect a brick wall on an adjoining lot. Nor does it relate to a thing not in esse, as a wall to be built; but it relates to the ten feet of the tract next to the street, and the negative stipulation not to erect houses on that is, in its legal effect, to keep it free from buildings; this is the only legal effect of the covenant; it does not oblige the grantees or their assigns to erect buildings at that distance, or to erect any houses at all.

The stipulation names no one as bound, neither the grantees, their heirs or assigns, but it is annexed to the land and the grant of it, and must therefore be coextensive with the estate granted, which is to them, their heirs and assigns. In a suit by the grantors there would be no question but that this stipulation would be enforced against any owner of this tract, or any part of it, who derived his title through this deed.

The question whether the complainant is entitled to enforce this stipulation, is not so clear. If any purchaser of the other lots retained by the Coles family at the giving of this deed, and injured by this erection, was the complainant, the authorities are numerous and decided, that he would be entitled to the benefit of this stipulation. Tulk v. Moxhay, 11 Beav. 571 ; s. c., 2 Phil. 774: Barron v. Richard, 3 Edw. Ch. (N. Y.) 96; Hills v. Miller, 3 Paige (N. Y.) 254, 24 Am. Dec. 218.

But in this case both parties derive title from the covenantors, and not from the covenantee, and the question is, whether they are bound to each other by the covenants which Wheeler entered into with the Coles family, for the benefit of the property which they retained. An action at law could not be maintained by the complainant against the defendant on such covenant. But in equity their position is different. Both parties are bound to the grantors in the Coles deed to keep this front free from buildings; each is subject to the easement over his lot, in favor of those subsequently deriving title from Coles, and each is equitably and justly entitled to the advantage which the ob- 
servance of this stipulation by his neighbor may be to him. If all were relieved from the encumbrance, none perhaps could complain. But to be restrained from extending his own building to the street, and to have his neighbor on each side project in front of him, would be a much greater grievance to any of these lot owners, than was contained in the stipulation in the deed through which he derived title; and he has no power to compel the grantors to enforce the covenant. It seems equitable that this court should, at his instance, compel the observance of this covenant. This view is supported by the dictum of Lord Romilly, in a case heard before him at the Rolls, in 1866, Western v. Macdermot, 1 Eq. Cases (L. R.) 507, and by a decision of the Supreme Court of Rhode Island, Greene v. Creighton, 7 R. I. 1.

This easement was in existence at the time of the conveyance of the complainant's lot by Wheeler, who still retained the lot of the defendant, which was the dominant tenement; and this space being left open in compliance with a covenant or stipulation binding on both lots it might be held to be an apparent and continuous easement, to which the part retained was thus made subject.

The motion to dissolve must be denied. ${ }^{22}$

\section{FORMBY v. BARKER.}

\section{(Court of Appeal, 1903. [1903] 2 Ch. 539.)}

Appeal from a decision of the Vice Chancellor of the County Palatine of Lancaster (Sir S. Hall).

The action was brought to restrain the defendant from committing a breach of a restrictive covenant relating to land.

The plaintiff was the administratrix with the will annexed of $R . H$. Formby, the covenantee, and he by his will gave and bequeathed all his property to her.

By a deed dated July 27, 1868, land, situated at Forniby in the county of Lancaster (including. some land coloured pink on a plan drawn upon the deed), was conveyed by R. H. Formby and his mortgagees to the Mutual Land Company, Limited, in fee simple.

The deed contained the following covenant by the company, for themselves, their successors and assigns, with R. H. Formby, his heirs, executors, and administrators, "that they $* * *$ shall not nor will erect, build, or make on the land coloured pink and fronting Raven Road any beerhouse or shop or any hotel of less annual value than $£ 50 . " * * *$

The deed comprised the whole of the land belonging to $\mathrm{R}$. H. Form1by in the neighbourhood.

22 Contra: King v. Dickson, L. R. 40 Ch. D. 596 (1S\$9); Korn v. Campbell, 192 N. Y. 490,85 N. E. 657,37 L. R. A. (N. S.) 1, 127 Ain. St. Rep. 9:J (1908). 
This deed was never executed by the land company, but they entered into possession under the deed of the land comprised in it.

The defendant was an assignce from the land company of part of the land coloured pink and abutting on Raven Road. He acquired the land with notice of the above covenant.

R. H. Formby died on October S, 1884, and letters of administration with the will annexed were, on January 30,1899 , granted to Caroline Formby, his widow, the plaintiff, to whom by his will he had given all his property.

In 1902 the defendant commenced to erect on part of the land coloured pink and abutting upon Raven Road two shops, and threatened and intended to complete the same. These shops were not beerhouses or beershops, but were ordinary shops unconnected with the sale of beer.

The action was commenced on September 20,1902, and the plaintiff claimed an injunction to restrain the defendant from erecting, building, or making any shop upon the land coloured pink and abutting on Raven Road. She claimed also damages and costs.

Hall, V. C., held on the construction of the covenant that it applied only to a beershop, and that the erection of any other shop would not be a breach. The Vice-Chancellor also held that, even if there should be a breach, the plaintiff could not maintain an action in respect of a breach committed after the death of the covenantee.

The plaintiff appealed.

Vaughan Willians, L. J., ${ }^{23}$ read the following judgment: The plaintiff sues in her individual capacity and aiso as administratrix with the will annexed of R. H. Formby, deceased. ***

I think we ought to read "shop" as meaning "beershop."

This view really puts an end to the plaintiff's case. But, as another defence was raised and was discussed by the learned Vice Chancellor, I think it right to deal with that point also.

The learned Vice Chancellor expressed an opinion that, even if the plaintiff's construction of the covenant was right, and there had been a breach of the covenant, nevertheless the plaintiff was not entitled to sue-that is, was not entitled to sue either as personal representative of R. H. Formby or as residuary devisee under his will.

I agree with the conclusion of the Vice Chancellor that there is notling in the point made by the defendant of the non-execution of the deed by the company other than this-that there is no legal covenant. I have no doubt that the land company took the estate conveyed subject to the condition contained in the covenant, and I have no doubt that Formby during his life could have enforced that condition, and, as I am inclined to think, even by an action for damages.

Before dealing with the question of the plaintiff's right to sue, I 
wish to point out that that which R. H. Formby conveyed was his whole estate, and that he had no contiguous estate which would be benefited by the covenant in question. Moreover, there is in the deed no re-entry clause under which the vendor could go in as of his old estate, or, indeed, as of any estate.

In my judgment this covenant is a personal covenant, but I do not think that, having regard to the opinions of the judges delivered in the House of Lords in Becklam v. Drake, 2 H. L. C. 579 , the right of action, which, in my judgment, would have vested in $R$. H. Formby on a breach in his lifetime, is of such a character that a breach after his death would not give to his personal representative a right of action against the covenantors, the land company.

The maxim "Actio personalis moritur cum persona" has no application to any breaches of contract, except those which constitute a mere personal wrong and, with that exception, all rights of action for hreaches of contract pass to the executors, and in an action for breach of covenant or condition proof of damage is not essential, and, in my judgment, there has been in this case, if the plaintiff's construction of the covenant is right, a plain breach of the covenant, which breach is not a mere personal wrong.

I make these observations to dispose of the argument addressed to us on the maxim "Actio personalis moritur cum persona." But this still leaves the difficulty that the defendant is not a party to the deed, and that there is plainly no covenant running with land on which the defendant could be sued at law. It becomes necessary, therefore, to see whether an action for an injunction can be brought, upon the principle established by the judgment of Lord Cottenham, L. C., in Tulk v. Moxhay, 2 Ph. 774. Now in the marginal note of that case it is said: "A covenant between vendor and purchaser, on the sale of land, that the purchaser and his assigns shall use or abstain from using the land in a particular way, will be enforced in equity against ail subsequent purchasers with notice, independently of the question whether it be one which runs with the land so as to be binding upon subsequent purchasers at law." But at the beginning of the Lord Chancellor's judgment he said, $2 \mathrm{Ph}$. 777: “'That this Court has jurisdiction to enforce a contract between the owner of the land and his neighbour purchasing a part of it, that the latter shall either use or abstain from using the land purchased in a particular way is what I never knew disputed." These words do not cover the present case, because the land company did not purchase a part only of the vendor's land, but the whole of it. It becomes necessary, therefore, to ascertain whether the principle of Tulk v. Moxhay, $2 \mathrm{Ph}$. 774, applies to a case in which the vendor sells his whole estate. I have not been able to find in any case in which, after the sale of the whole of an estate in land, the benefit of a restrictive covenant has been enforced by injunction against an assignee of the purchaser at the instance of a plaintiff having no land retained by the vendor, although there are cases 
in which restrictive covenants seem to have been enforced at the instance of plaintiffs, other than the vendor, for the benefit of whose land it appears from the terms of the covenant or can be inferred from surrounding circumstances, that the covenant was intended to operate. In all other cases the restrictive covenant would seem to be a mere personal covenant collateral to the conveyance. It is a covenant which cannot run with the land, either at law or in equity, and therefore the burden of the covenant cannot be enforced against an assignee of the purchaser.

But it is said that the doctrine of Tulk v. Moxhay, $2 \mathrm{Ph} .774$, is independent of the question whether there is in law or in equity a covenant running with the land, and that the doctrine is based upon obligations on the conscience of a person taking an estate with notice of a restrictive covenant binding it. The answer, I think, is to be found in a passage in the judgment of Collins, L. J., in Rogers v. Hosegood, [1900] 2 Ch. 388, 407. He said: "These authorities establish the proposition that, when the benefit has been once clearly annexed to one piece of land, it passes by assignment of that land, and may be said to run with it, in contemplation as well of equity as of law, without proof of special bargain or representation on the assignment. Ir. such a case it runs, not because the conscience of either party is affected, but because the purchaser has bought something which inhered in or was annexed to the land bought. This is the reason why, in dealing with the burden, the purchaser's conscience is not affected by notice of covenants which were part of the original bargain on the first sale, but were merely personal and collateral, while it is affected by notice of those which touch and concern the land. The covenant must be one that is capable of running with the land, before the question of the purchaser's conscience and the equity affecting it can come into discussion."

It seems to me that in the passage I have just read Collins, L. J., assumes that the doctrine of Tulk v. Moxhay, $2 \mathrm{Ph}$. 774, will not apply to a contract which is merely personal and collateral. In my judgment the covenant in the present case is merely personal and collateral; it has not been entered into for the benefit of any land of the vendor, or of any land designated in the conveyance; it is a covenant which, in my judgment, would not pass to the heirs of the vendor, notwithstanding the words of the covenant are, "covenant with the said R. H. Formby, his heirs, executors, and administrators." There is no land designated to which the word "heirs" can be applied. R. H. Formby could have sued the purchasers for breaches in his lifetime, and I think that his executrix could have sued the purchasers for breaches after his death, but I do not think that the executrix can sue the assignee of the purchasers. There is no contractual privity and no relation of "dominancy" and "serviency" of land which will enable an action to be brought against a person not a party to the orig- 
inal contract, nor do I think that the benefit of this covenant could be dealt with by a devise.

'There is the following passage in the judgment of Jessel, M. R., in London \& South Western Ry. Co. v. Gomm (1882) 20 Ch. D. 562, 583 : "The doctrine of Tulk v. Moxhay, $2 \mathrm{Ph}$. 774, rightly considered, appears to me to be either an extension in equity of the doctrine of Spencer's Case, 5 Rep. 16a, to another line of cases, or else an extension in equity of the doctrine of negative easements; such, for instance, as a right to the access of light, which prevents the owner of the scrvient tenement from building so as to obstruct the light." Again, Jessel, M. R., said: "This is an equitable doctrine, establishing an exception to the rules of common law which did not treat such a covenant as running with the land, and it does not matter whether it proceeds on analogy to a covenant running with the land or on analogy to an easement."

I think that in both these paragraphs Jessel, M. R., whether describing the doctrine of Tulk v. Moxhay, $2 \mathrm{Ph} .774$, as an extension of Spencer's Case, 5 Rep. 16a, or of the equitable doctrine of negative easements, regards it as something arising from the relation of two estates one to the other. $* * *$

I think that for the reasons which I have given the decision of the Vice Chancellor was right on both points, and that the appeal should be dismissed with costs.

[Romer and Stirling, L. JJ., delivered concurring opinions.] ${ }^{24}$

VAN SANT et al. v. ROSE et al.

(Supreme Court of Illinois, 1913. 260 Ill. 401, 103 N. E. 194, 49 L. R. A. [N. S.] 186.)

FARMER, J. ${ }^{25}$ Defendants in error (hereafter referred to as complainants) filed the bill in this-case to enjoin plaintiffs in error (hercafter called defendants) from erecting a flat building on the premises described, in violation of restrictive covenants in the deed from complainants to defendants.

24Ace: Dana r. Wentworth, 111 Mass. 291 (1S73).

A. owned land through which he wished to lay out a street. He applied to the London County Council, the plaintiff, for its consent, under the Lo1(lon Building Act, to lay out such street. This consent was given in return for a covenant executed by $A$. for his heirs and assigns not to build across the end of the new street without the consent of the plaintiff, the purpose being to facilitate an extension of the street if the plaintiff should later desire so to do. A. subsequently sold the land to the defendant, who bought with notice of the covenant. The defendant started to ercet buildings across the end of the street without the plaintiff's consent. The plaintiff owned no neigliboring land for the benefit of which the covenant was imposed. Held, the plaintiff is not entitled to enjoin the erection of the building. London County Council r. Allen, [1914] 3 Kr. B. G42.

Compare Los Angeles Terminal Land Co. v. Muir, 130 Cal. 36, 6S Pac. 30 s $(1902)$.

25 l'art of the opinion is omitted. 
It appears from the allegations of the bill that complainants were seized in fee simple of lot 1 and the north 43.86 feet of lot 2 , in block 14, in Cochran's second addition to Edgewater, Cook county, Ill., and on or about December 16,1904, conveyed said premises, by deed bearing date September 6, 1901, to Frank A. Rose; the deed containing the following restrictive covenants: "It is hereby expressly covenanted and agreed that neither said party of the second part, nor his heirs, executors, administrators, or assigns, shall erect any fence, inclosure, or obstruction to view on said lots within thirty (30) feet of the front or side street line of said lots for a period of ten years from the date hereof, and shall not build any wall of any building erected on said lots within said thirty (30) feet of the front or side street line of said lots for a period of twenty years from the date hereof, without the written consent of said party of the first part. *** It is hereby expressly covenanted and agreed that neither said party of the second part, nor his heirs, executors, administrators, or assigns, shall build or cause to be built on said lots any building known as a flat or tenement building, hereby covenanting to erect thereupon only a single private dwelling house (excepting the stable as aforesaid) for a period of twenty years from this date." The bill alleged that Frank A. Rose, through an intermediary, has conveyed the premises to his wife, Alvida A: Rose, and that said defendants, Alvida A. and Frank A. Rose, were about to erect on the premises a large apartment house or flat building, and place the north wall thereof substantially on the lot line, all in disregard of the covenants and reservations in the deed from the complainants.

Defendants did not deny their intention to violate the covenants and restrictions as alleged in the bill.

There is no dispute that covenants of the character here involved are lawful and valid, and are in the class of covenants courts of equity will enforce by enjoining their breach. Nevertheless, it is insisted that this case affords -no ground for equitable relief, because it does not appear from the bill that complainants own any neighboring land to be affected in any way by a breach of the covenants. Counsel on both sides have filed voluminous briefs, in which they have cited and extensively discussed many cases decided by the courts of this country and of England having more or less bearing upon this question. They are not altogether harmonious, and in most of them the precise question here presented was not involved. In our opinion the rule contended for by defendants cannot be applied in this case. Complainants are the original covenantees. Alvida A. Rose is not the original covenantor, but she received her title, through an intermediary, from her husband. The deed to her husband containing the covenants was on record, and she had notice of them. She is in no better position to resist the enforccment of the covenants than her husband would have been, and is to be treated, and will be referred to hereafter, the same as if she were the covenantor. We must assume 
that the covenants formed a part of the consideration for the conveyance, and that complainants were unwilling to part with the land without the restrictions in the deed. As absolute control over the property was denied the purchaser by the restrictions assented to, he presumably paid less for it than he would otherwise have been required to pay. At all events, the restrictions were mutually agreed to. They are plain and unambiguous, and there is no pretense that there was any concealment of any fact when they were agreed to. Can defendants now violate or disregard the contract, on the ground that its performance will be of no benefit to complainants? ***

True, a bill to enjoin the breach of restrictive covenants cannot be maintained by one having no connection with or interest in their enforcement; but we cannot agree that complainants had no interest. 'They were the original covenantees, and by their conveyance of the property reserved an interest in it. They conveyed the property subject to that interest. They had a right to reserve such interest, and this right was not dependent upon the covenantees having other property in the vicinity that would be affected by a breach of the covenants, or that they should in any other manner sustain damages thereby. This court has held, in harmony with the prevailing rule in other jurisdictions, that the right to enjoin the breach of restrictive covenants does not depend upon whether the covenantee will be damaged by the breach: but the mere breach is sufficient ground for interference by injunction. Bispham's Principles of Equity (4th - Ed.) par. 461; Consolidated Coal Co. v. Schmisseur, 135 I11. 371, 25 N. E. 795 ; Hartman v. Wells, 257 I11. 167, 100 N. E. 500, Ann. Cas. 1914A, 901. It would seem inconsistent, then, to say, as the covenantees had no other land in the neighborhood, they had no interest in the performance of the corenants. The only purpose their having other land in the vicinity could serve would be to show that they would be injuriously affected-that is, damaged-by a violation of the contract. But, as their right does not necessarily depend upon their being damaged by the breach, it would seem it would not necessarily depend upon their owning other land in the vicinity. Bispham, in the paragraph above referred to, says it is no answer to an action of this kind to say the breach will inflict no injury upon the complainant, or even that it will be a positive benefit. In Steward v. Winters, 4 Sandf. Ch. (N. Y.) 587 (a suit to enjoin the breach of restrictive covenants in a lease), it was contended the breach would cause no injury, and also that the plaintiff had an adequate remedy at law for damages. The court held the grantor or lessor of land had a right to insist upon such covenants as he pleased touching the use and mode of enjoyment of the land, "and is not to be defeated, when the covenant is broken, by the opinion of any number of persons that the breach occasions him no substantial injury." That case was cited, and the opinion quoted from with approval in the Schmisseur and Hartman Cases, supra. Kerr on Injunctions (4th Ed.) p. 370, says: "If there is a negative covenant," 
said Lord Cairns, in Doherty v. Alman (L.), 'the court has no discretion to exercise. If parties for valuable consideration, with their eyes open, contract that a particular thing shall not be done, all that a court of equity has to do is to say, by way of injunction, that the thing shall not be done. In such a case the injunction does nothing more than give the sanction of the process of the court to that which already is the contract between the parties. It is not, then, a question of the balance of convenience or inconvenience or of the amount of damage or injury; it is the specific performance by the court of that negative bargain which the parties have made, with their eyes open, between themselves." * * *

Judgment affirmed.

LEIVIS v. GOLLNER et ux.

(Court of Appeals of New York, 1s91. 129 N. Y. :27, 29 N. E. \$1, 26 Am. st. Rep. 516.)

[One Golher was a builder of flats. He secured a contract for a piece of land in a neighborhood devoted to private residences and announced his intention of erecting a large flat building thereon. The. trial court found as a fact that such a building in that locality would cause injury and damage to the other premises. Gollner was finally induced by the plaintiff, upon a consideration of $\$ 24,500$, which gave him a net profit of $\$ 6,000$, to sell out his interest in the land, and to make an oral contract "not to construct any flats in the plaintiff's immediate neighborhood or to trouble him any more." Immediately after selling out upon these terms Gollner secured a contract for another lot in the same neighborhood and began the erection thereon of another large flat building. Upon litigation being threatened, he conveyed to his wife his equity in the lot, worth $\$ 2,000$, and the foundations of the building, which had involved a large expenditure. The consideration for this was certain equities owned by her worth $\$ 700$. Gollner then, as the agent and architect of his wife nominally and in form, continued the construction of the flat building. Mrs. Gollner knew all the facts and took title for the purpose of aiding her husband in his plan. The plaintiff brought suit against the two Gollners to enjoin the construction of the flat buildings. Judgment below was for the defendants, and the plaintiff appeals.]

FInch, J. ${ }^{28} * * *$ I think we should first examine the situation, as between plaintiff and Gollner, upon the supposition that the latter had remained owner of the land and was himself engaged in violating his contract, and ask of ourselves the question whether in such event it would have been possible for equity to interfere, or whether the objections and difficulties suggested by the respondents would have proved insupcrable.

26 Part of the oplinion is onitted. 
['The court decided that Gollner himself could have been enjoined from breaking the agreement.]

But Gollner did not remain the owner of his new purchase, and that brings us to the difficulty which the courts below deemed insurmountable, and which needs to be thoughtfully considered. They reasoned that the new vendee could not be affected except through or by the purchase of the land, and so only when the land carried with it as an inseparable attachment the burden of the contract; that when the contract was made there was no land to which it did or could attach; and so the agreement remained wholly personal to Gollner, and did not affect or bind his wife. I do not see the contract in that way. Gollner might have fulfilled it by omitting to buy or lease any land within the prescribed limits, but his agreement left him at liberty to do so or nat, as he pleased, but required that, if he did so purchase or lease, he should not erect upon the land so owned or possessed the prohibited structures. The moment he bought or leased any such land he came under an obligation not to use it in a particular way; the land in his hands necessarily became restricted and limited in the use of which it was capable; and as much so, though bought of another, as if it had come from the contractor who imposed the restraint as vendor. I do not see why the equitable rights of the plaintiff did not attach to the land when bought, if it came, as it did, within the scope of the contract. Why should it affect the result that the obligation and the land ownership were not simultaneous, or that the latter came from a vendor who did not restrict when the contractor could and did? In the case of a mortgage the lien may attach to and bind after-acquired property, or cover future and later advances, as between the parties themselves, and that is permitted because they have so agreed and their contract contemplates that precise result. In like manner I think the agreement under discussion was, in substance and effect, that whatever land the defendant Gollner might thereafter possess in that immediate neighborhood should be restricted in its use by him, and should not be devoted to the construction of tenements or flats. In other words, when. he bought the land the plaintiff's equitable rights at once atached to it, and became a burden upon it so long as Gollner owned it, so that apparently the contract ceases to be merely and purely personal because it affects and was intended to affect the use and occupation of Gollner's after-acquired land in that neighborhood.

But, if the contract remains technically a personal one, I think the reasonable and settled doctrine is that the contract equity is so attached to the use of the land which is its subject-matter as to follow the land itself into the hands of a purchascr with full knowledge of all the facts, who buys with his eyes open to the existing equity, and more especially when he buys for the express purpose of defeating and evading that equity. It has been held that the equity resulting from a valid agreement, although the latter was not a covenant running with the land, ur a legal exception or reservation out of it, but stood solely upon the 
ground of a personal contract dictating the mode of user, would nevertheless go with the land into the hands of a purchaser with notice, and who did not buy innocently or in good faith. Whitney v. Railway Co., 11 Gray (Mass.) 363. In Hodge v. Sloan, 107 N. Y. 250, 17 N. E. 335, 1 Am. St. Rep. 816, we substantially affirmed that doctrine, holding that a purchaser without restriction in his deed, but from one who was restricted by a personal covenant not running with the land or binding his assigns, yet with notice of the facts, is bound by the restriction in a court of equity; Judge Danforth describing the character of the agreement thus: "It is restrictive, not collateral to the land, but relates to its use."

It is true, and should be noted, that in these cases the restrictions followed the line of title and were imposed by the original owners and vendors of the land, while here they were not so imposed, but came from one never an owner of the land, but deriving his right from a contract with one who did become such owner. But why should that difference change the result? The original owner's right rests upon one consideration, and that of the stranger to the title upon another, but each one equally good and worthy of equitable regard. In Parker v. Nightingale, 6 Allen (Mass.) 344, it is declared not to be in the least material that the restrictive stipulations should be binding at law, or that any privity of estate should subsist between parties in order to render them obligatory, and to warrant equitable relief in case of their infraction. I think that doctrine is sound and just. The source of the restriction would seem to be immaterial, if itself binding, and founded upon sufficient consideration; and a breach is no greater wrong to a privy in estate than to a stranger validly contracting about its use. Nor can the vendee in bad faith stand upon such a difference. Equity has no compassion for a fraud, and he who buys in aid of one, with full knowledge of what is right, but with purpose to defeat it, should not escape the hand of equity by a criticism upon the origin of the restriction violated.

If these views are correct it will follow that plaintiff should have been awarded the relief which he sought. The judgment should be reversed, and a new trial granted, costs to abide the event. All concur, except Rugrer, C. J., and ANDREIVs, J., not voting. ${ }^{27}$

27 Compare Millbourn v. Lyons, [1914] 1 Ch. D. 34, [1914] 2 Ch. D. 231.

$\Delta$ person in de facto occupancs of the premises with notice of the covenants maly lie enjoined from a breach thereof. Mander v. Falcke, [1891] 2 Cl. 554. See Seaward v. Paterson, [1897] 1 Ch. 545. 


\section{MCCLURE v. LEAYCRAFT.}

(Court of Appeals of New York, 1905. 1S3 N. Y. 36, 75 N. E. 961, 5 Ann. (as. 45.)

[The plaintiff and the defendant were owners of neighboring lots of land in the city of New York. Both derived title from a common source and both were subject to a covenant running until December S, 1911, forbidding the erection of apartment buildings. The defendant started to erect an apartment building upon his land and the plain. tiff sought an injunction.

The trial court made the following findings of fact:]

"Tenth. That at the time when the conveyances hereinbefore set forth were made and entered into, the real property in the vicinity of the property hereinbefore described was occupied exclusively by small private dwellings, and was classed as a private residential district, and such houses were built solely for one family and occupied by one family, and there were no places of business, flats, tenements, or apartment houses in the immediate neighborhood of the property affected by the said covenants.

"Eleventh. That since the making of the said covenants, and within the period of about 10 years last past, great changes have occurred in the neighborhood and in the class of buildings erected upon the property in said neighborhood, and in the immediate vicinity of the premises owned by the plaintiff and the defendant, and there has been erected upon such property, including the three corners directly opposite to defendant's premises, large apartment houses having a great many apartments therein, several on each floor and several stories in height, and which are occupied on the ground floor by places of business and used for business purposes. Numerous flats or tenement houses have been built on the block fronting on 145th street between St. Nicholas and Bradhurst avenues, which is in the vicinity of plaintiff's and defendant's property.

"Fourteenth. That the erection upon the said land of the said apartment house which the defendant proposes to erect thereon will not decrease the fee value of the plaintiff's premises, or of the land and dwellings within the tract hereinbefore described, but will increase the value thereof, and the use of the same as an apartment house will not make the neighborhood undesirable nor decrease the values of the adjoining property.

"Fifteenth. That the change which has taken place in the character of the neighborhood has made the property, including the tract hereinbefore described, especially the land owned by the defendant, undesirable for the erection of a private dwelling thereon.

"Sixteenth. That by reason of the change in the character of the neighborhood and of the immediate vicinity of plaintiff's property and defendant's property the same has been so altered as to render inex- 
pedient the observation of the said covenants, and it would be inequitable to enforce the covenants hereinbefore set forth against the defendant, as the enforcement of the same would cause him great damage and would not benefit the owners of the adjoining property."

The complaint was dismissed on the merits, for the reason, among others, "that the character and condition of the neighborhood have so changed since the making of the said agreements that it would be inequitable to enforce a covenant prohibiting the erection of a structure such as the defendant proposes to erect, and equitable relief enjoining the defendant from erecting the said structure should be refused." Upon appeal to the Appellate Division the judgment of the Special Term was reversed, and a new trial ordered. The defendant appealed to this court.

VANx, J. ${ }^{28} * * *$ Assuming that the defendant was about to violate the covenant, the question is whether, upon the facts found and approved by the courts below relating to the radical change in the situation of the property affected by the covenant, a court of equity was bound to refuse equitable relief in the form of an injunction and to leave the injured party to recover his damages in an action at law. If the granting or withholding of a permanent injunction is within the absolute discretion of the Supreme Court, the exercise of that discretion by the Appellate Division in favor of the plaintiff is beyond our power to review; but if the facts found compet the conclusion, as matter of law, that an injunction should be refused, as inequitable, the order of reversal was wrong, and the judgment rendered by the trial court should be restored.

While a temporary injunction involves discretion, a permanent injunction does not, when the facts conclusively show that it would be inequitable and unjust. A court of equity will not do an inequitable thing. It is not bound by the rigid rules of the common law, but is founded to do justice, when the courts of law, with their less plastic remedies, are unable to afford the exact relief which the facts require. Its fundamental principle, as its name implies, is equity. It withholds its remedies if the result would be unjust, but freely grants them to prevent injustice when the other courts are helpless. It cannot set aside a binding contract; but when the effect would be inequitable, owing to facts arising after the date of the agreement and not within the contemplation of the parties at the time it was made, it refuses to enforce the contract and remands the party complaining to his remedy at law through the recovery of damages.

These principles were applied by this court in an important case which we regard as analogous and controlling. Trustees of Columbia College v. Thacher, 87 N. Y. 311, 41 Am. Rep. 365. In that case adjoining landowners in the city of New York had entered into reciprocal covenants restricting the use of their respective lands to the

28 Part of the oninion is omitterl. 
sole purpose of a private residence and expressly excluding "any kind of manufactory, trade, or business whatsoever." After the lapse of nearly 20 years the defendant permitted a building upon his land, which was bound by the covenant, to be used for the business of a tailor, a milliner, an insurance agent, a dealer in newspapers, and a tobacconist. After the commencement of an action by the other landowner to restrain sucl use, an elevated railway was built and a station located in the street in front of the premises of both parties. It was found as a fact that the "railway and station affect the premises injuriousiy and render them less profitable for the purpose of a dwelling house, but do not render their use for business purposes indispensable to their practicable and profitable use and occupation. The said railway and station, however, do not injuriously affect all the property fronting on Fiftieth street and included in the said covenant, but only a comparatively small part thereof." The trial court awarded a permanent injunction, and the General Term affirmed the judgment; but the Court of Appeals reversed and dismissed the complaint on the ground that a contingency, not within the contemplation of the parties, had frustrated the scheme devised by them and rendered the enforcement of the covenant oppressive and inequitable. This court obviously held that an injunction, under the circumstances, was not within the absolute discretion of the Supreme Court; for otherwise, according to its uniform rule of action, it would not have reversed the judgment or dismissed the complaint.

The opinion of Judge Danforth, concurred in by all the members of the court, declared that there was a, clear breach of the covenant, which, under ordinary circumstances, would entitle the plaintiff to an injunction; but, he said, "though the contract was just and fair when made, the interference of the court should be denied if subsequent events have made performance by the defendant so onerous that its enforcement would impose great hardship upon him and cause little or no benefit to the plaintiff. Willard v. Tayloe, 8 Wall. 557, 19 L. Ed. 501 ; 'Thomson v. Harcourt, case 66, p. 415, vol. 2, Brown's Parliamentary Reports; Davis v. Hone, 2 Sch. \& Lef. 340; Baily v. De Crespigny, L. R. [4 O. B.] 180; Clarke v. Rochester, Lockport \& Niagara Falls Railroad Company, 18 Barb. 350."

After reviewing the authorities cited, the learned judge continued: "In the case before us, the plaintiffs rely upon no circumstance of equity, but put their claim to relief upon the covenant and the violation of its conditions by the defendant. They have established by their complaint and proof, a clear legal cause of action. If damages have been sustained, they must, in any proper action, be allowed. But, on the other hand, the defendant has exhibited such change in the condition of the adjacent property, and its character for use, as leaves no ground for equitable interference if the discretion of the court is to be governed by the principles I have stated, or the cases which those prin- 
ciples have controlled. * * * The road was authorized by the Legislature, and, by reason of it, there has been imposed upon the property a condition of things which frustrates the scheme devised by the parties and deprives the property of the benefit which might otherwise accrue from its observance. This new condition has already affected, in various ways and degrees, the uses of property in its neighborhood and property values. It has made the defendant's property unsuitable for the use to which by the covenant of his grantor it was appropriated, and if, in face of its enactment and the contingencies flowing from it, the covenant can stand anywhere, it surely cannot in a court of equity."

This case was followed in Stokes v. Stokes, 155 N. Y. 581, 590, 50 N. E. 342 ; Amerman v. Deane, 132 N. Y. 355, 359, 30 N. E. 741, 28 Am. St. Rep. 584; Conger v. N. Y., W. S. \& B. R. R. Co., 120 N. Y. 29, 32, 23 N. E. 983; Page v. Murray, 46 N. J. Eq. 325, 331, 19 Atl. 11. See, also, Jewell v. Lee, 96 Mass. (14 Allen) 145, 92 Am. Dec. 744; Taylor v. Longworthb 14 Pet. 172, 174, 10 L. Ed. 405; Duke of Bedford v. Trustees British Museum, 2 My. \& K. 552; Sayers v. Collyer, 24 L. R. (Ch. Div.) 170.

So long as the Columbia College Case stands, the judgment appealed from cannot; for the same principle controls both. In each the changed condition was wholly owing to the lawful action of third parties, which made the allowance of an injunction inequitable and oppressive. Indeed, an injunction in the case before us would be more oppressive than in the case cited; for it is expressly found, and the finding is final here, that the proposed erection would actually increase the value of the plaintiff's premises, while the enforcement of the covenant, without benefiting any one, would cause great damage to the defendant. It is a reasonable inference from the evidence that the rent roll of the defendant's land, with such dwelling houses on it as would rent to the best advantage, would not exceed $\$ 4,500$ a year, while an apartment house such as he proposes to erect would rent for over $\$ 40,000$ a year. Nineteen of the twenty-five years which bounded the life of the covenant in question have passed, and the object of the parties in making it has been defeated by the unexpected action of persons not under the control of the defendant.

Under the circumstances now existing the covenant is no longer effective for the purpose in view by the parties when they made it, and the enforccment thereof cannot restore the neighborhood to its former condition by making it desirable for private residences. If the building restriction were of substantial value to the dominant estate, a court of equity might enforce it, even if the result would be a serious injury to the servient estate; but it will not extend its strong arm to harm one party without helping the other, for that would be unjust. An injunction that bears heavily on the defendant without benefiting the plaintiff will always be withheld as oppressive. No injustice is done, for the damages sustained can be recovered in an action at law, 
and the material change of circumstances so affects the interests of the parties as to make that remedy just to both.

We think that both reason and authority require a reversal of the order of the Appellate Division, but exact justice calls for a modification of the judgment of the Special Term. As that court found that the proposed erection would cause no damage to the plaintiff, its judgment might be held a bar to an action at law, unless it expressly appeared that it was without prejudice to that remedy for the recovery of all damages sustained. We therefore reverse the order appealed from, and so modify the judgment of the Special Term as to declare that it is without prejudice to an action at law, and, as thus modified, we affirm it, without costs in this court or in the Appellate Division to either party.

Cullen, C. J., and Gray, Bartlett, and Werner, JJ., concur. O'Brifis and Haigils, JJ., absent.

Order reversed, etc. ${ }^{2 \theta}$

\section{LOUD v. PENDERGAST.}

(Supreme Judicjal Court of Massachusetts, 1910. 206 1lass. 122, $92 \mathrm{~N}$. E. 40.)

RuGG, J. This is a suit to restrain the alleged violation of a building restriction. A tract of land called "Shirley Park" was laid out in 1895 with streets, and the lots were sold subject to the restriction imposed as a general scheme for the common benefit, that "all buildings shall be set back from the street line at least ten feet." The plaintiff and defendant each own one of these lots, which are adjacent. Each has erected a building on her lot. A small part of the main body of the defendant's house at one corner and a bay window, extending from the ground through the second story, and a piazza and steps are within the restricted area. These constituted a violation of the restriction. Reardon v. Murphy, 163 Mass. 501, 40 N. E. 854: Bagnall v. Davies, 140 Mass. 76, 2 N. E. 786; Linzee v. Mixer, 101 Mass. 512; Sanborn v. Rice, 129 Mass. 387; Payson v. Burnham, 141 Mass. 547, 6 N. E. 708 .

20 Acc.: Jackson v. Stevenson, 156 Mass. 496, 31 N. E. 691, 32 Am. St. 'Rep. 476 (1892).

Compare Brown v. IIuher, 80 Ohio St. 183.88 N. E. 322.28 L. R. A. (N. S.) 70.7 (1909); I andell v. Hamilton, 175 Pa. 327, 34 Atl. 663, 34 L. R. A. יㅡㄱ (1S96).

"A per:on who is entitled to the benefit of a restrletlve covenant may, by his ccloluct or omissions, put himself in such an altered relation to the jorson hound by it, as makes it manifestly unjust for him to ask a court to insist on its enforcement by injunction. * * In the present case we do not decide that a mere alteration in the character of the neighhorhood would he suffielent; liecause there is no evidence that such alteration was cavsed by the plaintiff." Bowen, L. J., in Sayers v. Collyer, L IR us on D. 108 , 108 (1884).

Big.Rights-35 
It is urged that the plaintiff is not entitled to relief because she has been guilty of laches, because she has herself violated the same restrictions in such a way that she comes into court with unclean hands, and because the original scheme has been so generally violated in the neighborhood as to make it unconscionable to enforce the restriction against this defendant.

Relief in equity in cases of this nature is granted only when sought with promptness, and where active diligence has been exercised throughout respecting the matter of complaint. Conscience, requires that one should not stand by in silence, while another makes considerable expenditures in good faith under an assumed right, and then ask a court to enforce compliance with the restrictions at great loss, when seasonable notice or other appropriate action might have prevented the wrong complained of. Stewart v. Finkelstone, 206 Mass. 28, 92 N. E. 37, 28 L. R. A. (N. S.) 634, 138 Am. St. Rep. 370, and cases cited.

Where a plaintiff has violated the very restriction he seeks to enforce to substantially the same extent and in the same general way as has the defendant, and there is no material difference in kind or degree between them, a court of equity will not ordinarily interfere. Bacon v. Sandberg, 179 Mass. 396, 60. N. E. 936; Scollard v. Normile, 181 Mass. 412, 63 N. E. 941. Such a plaintiff is not in a position justly to complain, for he does not come into court with clean hands respecting the precise subject as to which he invokes relief, nor has he complied with the maxim that he who seeks equity must do equity. Butterick Publishing Co. v. Fisher, 203 Mass. 122, 89 N. E. 189, 133 Am. St. Rep. 283. This rule is applied in other jurisdictions. Olcott v. Knapp, 96 App. Div. 281, 89 N. Y. Supp. 201 ; s. c., 185 N. Y. 584 , is N. E. 1108; Landell v. Hamilton, 177 Pa. 23, 35 Atl. 242; Ocean City Ass'n v. Headley, 62 Ñ. J. Eq. 322, 50 At1. 78; Ewertsen v. Gerstenberg, 186 I11. $34+, 57$ N. E. 1051, 51 L. R. A. 310; Brutsche v. Bowers, 122 Iowa, 226, 97 N. W. 1076.30

$30 \mathrm{~A}$. laid ont a tract of land in building lots and conveyed four adjoining lots to P., with a covenant that they should be used only for residence purbuses. IF. sold to C., who knew of the restriction. In sales then made orer a perion of years, A. conveyed several of the other lots to various purchasers with no restrictions. C. started to erect a business building upon his lots. A. still owned a few lots. Held, A. cammot enjoin C. Duncan $:$ Central I'ass. My. Co., $85 \mathrm{Ky} .525,4 \mathrm{~S}$. W. 228 (1S57). Acc.: Jenks v. LaWlowski, 95 IIich. 110. 56 N. W. 1105,22 L. R. A. S63, 39 Am. St. Rep. 52: (1593). See Oshorne v. Lradley, [1003] 2 Ch. 446 ; Reilly v. Otto, 10 S Iich. 380,66 N. W. 228 (1896).

Lots were sold subject to a restriction that "no building or structure" should be placed on the lots within 13 feet of $B$. street. The plaintiff and the defendant had each actuired title to one of these lots. The defendant had erected a small building within 12 feet of $B$. street. On bill by the plaintiff to enforce the restriction the court said: "Lastly, it is urged in defense that the plaintiffs cannot come into a court of equity for redress, because they have infringes the restrictions by allowing projections from the houses into the slitre of $1: 3$ fret hetween the houses and the line of beacon street. These projections collist of lay windows, piazzas, and steps. 
Where there has been no uniform observance of the restrictions and stubstantially all the landowners have so conducted themselves as to indicate an abandonment of the right, which is in the nature of an easement, to lave the neigliborhood kept to the standard established by the original plan and where the enforcement of the restriction agrinst the defendant will not tend materially to restore to the district the character impressed upon it by the scheme, and the infraction complained of does not diminish the value of other estates, then it would be inequitable and oppressive to compel at great loss a compliance with the restrictions. Jackson v. Stevenson, 156 Mass. 496, 31 N. E. 691, 32 An. St. Rep. 476; Baptist Social Union v. Boston Lniversity, 183 Mass. 202, 66 N. E. $714 .^{31}$ There is added force

It appears to be settled in this commonwealth that a plaintiff is not prerented from obtaining relief by the fact that he has not objected to a violation of a restriction by some one in the neighborhood other than the defentlant. Linze v. Mixer, 101 Mass. 512. 531 [1S69]; Payson v. Burnham, 111 Mass. 547, 556,6 N. E. 70s [18s6]. See, also, Knight v. Simmonds, [1S96] ICh. 294; German v. Chapman, 7 Ch. Div. 271, 278 [1877]. When a breach of restriction or of a covenant has been committed by the plaintiti, the case stands somewhat differently. Whether a court of equity will or will not aid the mlaintiff in such a case depends largely upon the question whether there has been such a material and substantial breach as will enable the court to say that it ought not to interfere. Kerr, Inj. (3d Ed.) 431; Western ․ Maclermot. L. I. 1 Eq. 499 [1866]; Id., 2 Cl. App. 72 [1866]; Jackson v. Winnifrith, ti Law T. (N. S.) 243 [1SS2]; Chitty v. Bray, 48 Law T. (N. S.) 660 [1585]. In the case before us it may be assumed that the plaintilfs, by their conduct in respect to their own houses, could not invoke the aid of a inurt of rquity to prevent the defendants from erecting a piazza, bay winlow. or steps extcnding into the restricted space; but the building of a separate house in this space is something the plaintiffs have not done, and, as this bulleling violates the first restriction, we see no reason why the plaintifts slmuld not he allowed to enforce their rights in equits without consirlering whether the defendants have not also violated some of the other restrietions. Evins v. Mary A. Ridalle Co. (N. J. Ch.) 43 Atl. 894 [1899]." La1hrop, J., in Bacon $r$ S. Sindberg, 179 Mass. 396, 399, 60 N. E. 936 (1901).

Compare Curtis v. Rubin. 244 Ill. S\&, 91 N. E. 84,135 Am. St. Rep. 807 (1910). Soe, also, Iandell v. Hamilton, 177 Pa. 23, 35 Atl. 242 (1896).

31 Ace.: Curtis v. Rubin, ante, p. 547.

"As to the territory southwesterly of Ninth street, which has been defined as the residential district, I entertain the view that the six riolations of thr covenant rointed out by defendant caunot be considered as sufficient evidence to indicate the abandonment of the original plan in the district where nearly $t 00$ hullings have been erected in conformity to the plan. The extremely small percentage of the hreaches of the rovenant which defendant has pointed out rather tends to the estallishment of the fact that it has heew the defined prurpose of the property holders in that district to ablhere to the preservation of the original plan sought to be preserved by the covenant. I think it also clear that the equitable right of complainant to the enforcement of the covenint in qunstion is not impaired by isolated breaches of the covenant in locations where such breaches can in no way he salil to affect the desirability of complainants property. It is not to lir expretef that the courts will be appealed to for the preservation of the cellemal seheme in localitios wher a commanint is without interest. It is only whon the interest of a property wwer is affected that, in my judgment,

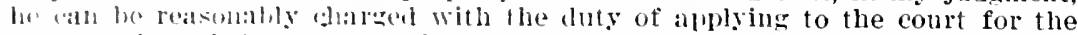
weservation of the cenoril selheme." leaming. v. C., in Iarton $x$. slifer, 72

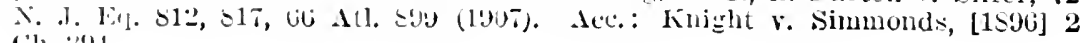
(h. 2!) 1 . 
to the argument drawn from these cases when as in the present case under Rev. Laws, c. $134, \S 20$, the restriction will expire after 30 years, about one-half of which has already run.

The facts as to which these principles are to be applied were found by the superior court. As the evidence upon which they rest is not reported they must be assumed to be true. They are, in substance, as follows: On many of the lots in Shirley Park buildings, completed and occupied for several years prior to the acts here complained of, have been erected within 10 feet of the street lines without objection from the plaintiff or any one else. The plaintiff bought her lot in 1900, and in 1903 built a one-story building flush with the street line. This building was removed in 1907, and in its place a three-story building was erected, the main part of which encroached a few inches upon the prohibited 10 feet and bay windows on which project into it over 3 feet. She also erected a wooden signboard measuring 4 feet by 9 feet, one end of which is within a foot of the street line. See Nussey v. Provincial Bill Posting Co., 1909, 1 Ch. 734. In December, 1908, the batten boards were set for the house upon the defendarıt's lot, standing within 3 feet of the street line, and these remained about 2 months. On February 18, 1909, excavation of the cellar began, and the foundation, including that of the bay, was completed March 11th, and the house was boarded in March 20th, and work continued until the 9th of April following, when the house was substantially finished on the outside with the exception of painting and a little work on the piazza. On the last date process was served in this suit. The defendant's house stands with reference to the restrictions in material respects the same as the plaintiff's. The defendant assumed that she had a right thus to build, relying upon the position of the plaintiff's building and upon the general disregard of restrictions by others. The plaintiff was in her building every day during the progress of the work, and although she often saw the defendant and her husband, who was her agent and daily upon her premises, made no protest to either of them, and did not consult counsel until April 6th. The erections complained of cause no pecuniary damage to the plaintiff, and do not diminish the market value of her estate. The enforcement of the restriction against the defendant will make her house less commodious and attractive and would cause thus her substantial loss. This narration demonstrates that taking all the facts together the plaintiff has failed to establish a right to equitable relief under the governing rules of law which we have stated. The decree dismissing the bill is to be so modified as to include the costs of this appeal, and as so modified is to be affirmed.

So ordered. 


\title{
CHAPTER VI
}

\section{RENTS ${ }^{2}$}

\section{SECTION 1.-GENERAL NA'TURE OF RENTS}

\author{
WALKER'S CASE.
}

(Court of Queen's Bench, 1587. 3 Coke, 22a.)

The case was in effect: Walker leased certain lands to Harris for years, the lessee assigned all his interest to another, Walker brought an action of debt against Harris for rent behind, after the assign-

${ }^{1}$ The payment of rent was not in its origin considered to be the discharge of a personal or contract duty that the tenant owed the lord; rent was regarded as property interest that the lord had in the speeitied return; and the obligation was somewhat metaphorically stated as being owed by the land rather than by the tenant as an individual. Thls feudal theory of rent is shown by the forms of action that were used to protect and vindicate the lord's right to rent. If the tenant had a freehold interest in the land and refused to pay the rent reserved, the lord was regarded as being disseised of the rent, and his action to regain the seisin of the rent was similar to that which he would have brought in order to regain the seisin of the land from a person who had wrongfully ousted him therefrom.

If the tenaut's estate in the land was less than freehold, the theory as to the nature of rent remained the same, although the action which was used to enforce the lord's right to the rent was different. Since in these circumstances the lord bad no seisin of the rent isee Prescott v. Boucher, $2 \mathrm{~B}$. \& Ad. $4 \$ 9$ [18:i2]), a refusil by the tenint could not be a disseisin, and consequently a real action could not he hrought by the lord. The proper form of action for the recovery of the rent in this state of facts was debt. 'The use of this aetion, however, shows that the tenant was regarded as wrongfully retaining something. i. e., the rent, to the return of which the owner of the reversion to which the rent was incident, was properly entitled. For a similar reason the action of debt also lay against a fireelold tenant after the expiration of his estate.

Another method that the lord had for enforeing the pasment of the rent from his tenant was by distress. This was the privilece that the lord had, whenever the rent was in arrear, of seizing any chattels that might be found upon the demised land and detaining them until the rent was paid. This privilege was not limited to the chattels of the tenant; a fact which also indicates that the obliqation was resarded as that of the land. Thls right of distress was not in its origin limited to the enforcement of the basinent of rent, but was a general method of compelling the performance of various fendal obligations, althougl its most common use was to enforce the paymert of rent. Except where created by contract, however, the right of distress exlsted only in the ease where a relation of tenure existed hetween the one levying the distress and the one against whom it was levied.

Thus far the rent diseussed has lieen of a kind that existed only in the case of a tenure relation; it is technically callod a rent service. Rents might, however, be created independent of a temure. One case of this sort results from Quia Emrtores (1290), hy which tenure was abolished between feoffor and feoterer in a conveynure in fee simple. If, prior to the statute, .., owning land, conveged it to li. in fee, there would be a relation of tenure 
ment, and whether the action were maintainable or not, was the question. ${ }^{2} * * *$

On great deliberation and conference with others, it was adjudged by Wray, L. C. J., Sir Thomas Gawdy, and the whole court of King's Bench, that the action would lie after such assignment.

And first for the apprehending of the true reason of this case, and of all the other cases, which have been urged on the other side, (for the law always, and in all cases, is consonant to itself,) it is to be known, that as to the matter now in question, there are three manner of privities, scil. privity in respect of estate only, privity in respect to contract only, and privity in respect of estate and contract together: privity of estate only; as if the lessor grants over his reversion (or if the reversion escheat) between the grantee (or the lord by escheat) and the lessee is privity in estate only, so between the lessor and the assignee of the lessee, for no contract was made between them. Privity of contract only, is personal privity, and extends only to the person of the lessor and to the person of the lessee, as in the case at bar, when the lessee assigned over his interest, notwithstanding his assignment the privity of contract remained between them, although the privity of estate be removed by the act of the lessee himself; and the reason thereof is,

First, because the lessee himself shall not prevent by his own act such remedy which the lessor hath against him by his own contract, but when the lessor grants over his reversion, there, against his own grant, he cannot have a remedy, because he hath granted the reversion to another, to which the rent is incident.

Secondly, the lessee may grant the term to a poor man, who shall not be able to manure the land, and who will, for need or for malice, suffer the land to lie fresh, and then the lessor will be without rem-

between $A$. and $B$. If a rent was reserved upon the conveyance, it rould be dependent upon the tenure and would consequently be a rent serrice. If such a converance was made after Quia Emptores, there would be no tenure between A. and B., and consequently the rent reserved would not be a rent service. Other cases of rent not dependent upon tenure are where a lerson owning land, grants a rent out of it to a third person, in fee, or for life or sears; or where a person having in land a reversion to which a rent service is incident conveys the rent to a third person, retaining the reversion.

As aircady stated the right of distress was incident to a tenure relation. Since in none of these last mentioned cases was there a tenure relation between the owner of the rent and the holder of the land whence the rent was derived, the only method of enforcing his right that the owner of the rent had, was by action. The rent was conseruently known as dry rent, or rent sec. The parties might, however, by deed, create as an incident to the rent the right to distrain for it although there was no tenure. In this case the rent was known as a rent charge.

See, in general, as to the forms of action for the recovers of rents, "2 Pollock and Maitland, History of the English Law (2d Ed.) p. 125 and fol.; 10 Harvard Law lieview, p. 78 and fol.; 11 Harvard Law Review, 1; 13 Law Quart. Rev. 2ss; Amer. Lectures on Legall History, p. 167.

2 Part of the case is omitted. 
edy either by distress or by action of debt, which would be inconvenient, and in effect concerns every man; (for, for most part, every man is a lessor or a lessee) and for these two reasons all the cases of entry by wrong eviction, suspension and apportiomment of rent are answered: for in such cases either it is the act of the lessor himself, or the act of a stranger; and in none of the said cases the sole act of the lessee himself shall prevent the lessor of his remedy, and introduce such inconveniences, as hath been said.

The third privity is of contract and estate together, as between the lessor and the lessee himself. * * *

Note, reader, so great was the authority and consequence of this judgment, that after this time, not only the point adjudged hath been always affirmed, but also all the differences in this case taken by Wray, C. J., and the court have been adjudged, as you may learn by the cases following. Hil. 36 Eliz., in the King's Bench, Rot. 420, between Ungle and Glover ${ }^{3}$ it was adjudged, that if the lessee for years assigns over his interest, and the lessor by deed indented and enrolled according to the statute bargains and sells the reversion to another, that the bargainee shall not have an action of debt against the lessee, for there is no privity betwixt them. But it was unanimously agreed by Popham, Ch. Justice, Clench, Gawdy, and Fenner, Justices, that after the assignment the lessor himself might have an action of debt against the lessee for rent due after the assignment.

Also it was said, if the lessee assigns over his term, the lessor may charge the lessee or his assignee at his election; and therefore if the lessor accepts the rent of the assignee, he hath determined his election, and shall not have an action against the lessee afterwards for rent due after the assignment, ${ }^{4}$ no more than if the lord once accepts the rent of the feoffee, he shall not avow on the feoffor: and by these judgments and resolutions you will the better understand your books; between which prima facie seems to be some diversity of opinions. Vide 44 E. 3, 5, and 44 Ass. 18, 9 H. 6, 52, by Paston, which agree with the judgment of Sir Christopher IVray. See 8 Eliz. Dyer, 247, and the quære there made, is now well resolved.

3 leported I'oph. 55; Cro. Eliz. 328.

4Ace: Marsh v. Mrace, Cro. Jac. 324 (1614); Iodge No. 2 v. White, : 0 Ohio St. 569, 27 Am. Rep. 492 (1876). Compare Manley v. Dupuy, 2 Whapt. (1'a.) 162 (1537).

A. leased to $\mathrm{X}$. $\mathrm{X}$. assigned to $\mathrm{Y}$., who assigned to $\mathrm{Z}$. Held, $\mathrm{Y}$. is not liable for rent accruing after his assignment to $Z$. Hartman $v$. Thompson, 104 Mil. 259, 65 Atl. 117, 118 Am. St. Rep. 422, 10 Ann. Cas. 92 (1906).

An assignee of part of the premises is liable only for a proportionate part of the rent. Babcock r. Scoville, 56 Ill. 461 (1570); Board of St. Louis I'ublic Schools r. Boatmen's Ins. \& Trust Co., 5 Mo. App. 91 (1878); Hogg v. Reynolds. 61 Noh. 758. S6 N. W. 479. s7 Am. St. Rep. 522 (1901). 


\section{ST. 4 ANNE (1705) c. $16, \S \S 9,10$.}

St. 4 Anne, c. 16, $\S 9$ : Be it further enacted by the authority aforesaid, that from and after the said first day of Trinity term [1706] all grants or conveyances thereafter to be made by fine or otherwise of any manors or rents or of the reversion or remainder of any messuages or lands shall be good and effectual to all intents and purposes without any attornment of the tenants of any such manors or of the land out of which such rent shall be issuing or of the particular tenants upon whose particular estates any such reversions or remainders shall and may be expectant or depending as if their attornment had been had and made.

$\S 10$ : Provided nevertheless that no stich tenant shall be prejudiced or damaged by payment of any rent to any such grantor or conusor or by breach of any condition for nonpayment of rent before notice shall be given to him of such grant by the conusee or grantee.

\section{BANK OF PENNSYLVANIA v. WISE.}

(Supreme Court of Pennsylvania, 1834. 3 Watts, 394.)

[Writ of Error.]

KENNEDY, J. ${ }^{5}$ The only question to be decided in this case is, whether the purchaser at sheriff's sale of the lessor's title and interest to and in a house and lot of ground, which had been regularly taken in execution, condemned and sold by the sheriff, be entitled to demand and receive from the lessee, the tenant in possession, the whole of $\$ 212.50$, being a half year's rent; which became payable fourteen days after the purchasers had paid the purchase-money to the sheriff and received from him his deed, duly executed and acknowledged, consummating the sale.

In this case the sheriff, on the 1st day of January, 1831, sold the house and lot to Thomas Elder and Jacob M. Haldeman, two of the defendants, for $\$ 9750$; and after having received from them the purchase-money on the 18th day of same month, executed and delivered to them in due form, a deed of conveyance for the same; of which immediate notice was given by the purchasers to the President, Directors and Company of the Bank of Pennsylvania, who were in possession of the house and lot under a lease from George Fisher, the defendant in the judgment and execution under which the sale had been made. The lease was for a term of five years, commencing with the 1st day of August, 1828 , at a rent of $\$ 425$ per annum, payable half yearly. On the 1st of Fchruary following the delivery of the deed by the sheriff to the purchasers, $\$ 212.50$, a half year's rent

- The statement of facts and part of the olvinion are omitted. 
fell due; and on the 4th of March ensuing, they by their bailiff, John Wise, the other defendant, distrained for it; upon which the writ of replevin commencing this action was sued out by the plaintiffs, and the property distrained on was replevied.

For the fourteen days, that is, the time which elapsed from the delivery of the sheriff's deed to the purchasers, until the 1st day of February, 1831, when the first half year's rent became payable after the sale, the plaintiffs were willing to pay the purchasers such proportion of the rent as that time bore to one hundred and eighty-four days, which is the whole number of days in the half year, but for the residue they say that they are bound to account to the defendant in the execution, as he continued to be their landlord and the owner of the reversion to the 18 th of January, 1831.

The idea of apportioning the rent that becomes payable after the purchaser of a reversionary interest in fee at a sheriff's sale has paid the purchase-money and received his deed of conveyance for it, between him and the defendant in the execution as whose estate it was sold, is unknown to the law, and cannot be reconciled with any of its analogous and fixed principles.

The only reasun of the least plausibility that can be alleged for apportioning the rent according to time, between the defendant in the execution and the purchaser at sheriff's sale $* * *$ would be to say, that it did not properly and truly form any part of the subjectmatter or estate sold by the sheriff; that the defendant in the execution had received no consideration, and the prrchaser had paid none for it. But by inquiring into, and ascertaining what was really sold and bought at the sheriff's sale, it will be seen that there is no ground whatever for such a suggestion, and that it is a great misapprehension of the matter to suppose it; for we shall find that the purchaser at sheriff's sale not only purchased, but must be considered as having paid for, and as being invested with, a right to demand and receive all the rents which shall become payable, according to the terms of the lease, after the time that his title to his purchase became perfect, by his payment of the purchase-money, and receipt of the sheriff's deed. A right to demand and receive all such rents formed the very heart and essence of his purchase, seeing it was merely a reversionary interest.

It will appear that there is no proposition better established in the law, than, that without an express reservation, an assignment or transfer of the reversion, where rent is becoming payable at certain periods to the reversioner, carries with it the right to demand and receive the rent which shall become payable afterwards.

Littleton, in section two hundred and twenty-eight, says, that by a grant of the reversion the rent passeth; and my Lord Coke, in his commentary upon it, tells us, that "the reason thereof is because the rent is incident to the reversion, and passeth away by the grant of 
the reversion, as with the superior, without saying cum pertinentiis." 1 Inst. 151b; Shep. Touch. 89. And in Co. Litt. 215b, it is laid down that "both assignees in deed, and assignees in law, shall have the rent, because the rent, being reserved of the inheritance to him and his heirs, is incident to the reversion and goeth with the same." Indeed Noy lays it down as a maxim, that by a grant of the reversion the rents pass. ${ }^{\circ}$ Noy's Maxims, ch. 21, Rents, p. 41. * * *

The rent is so closely, so inseparably I may say, connected with the reversion, that, without some positive act of the lessor, it is ever considered as following the reversion and belonging to it until it has become actually and completely payable. Hence, if the person entitled to receive the rent outlives the day on which it becomes due, and then dies, it will go to his executor or administrator as a part of his personal estate; but if he die on the day preceding the day of payment, the rent will go to the heir as incident to the reversion, and as part of the real estate. 3 Cruise's Dig. tit. 28, Rents, ch. 1, sect. 59, New York Ed. of 1827 .

It was a great mistake in the court [in West v. Sink, 2 Yeates 274] to say *** that rent which had not become payable was a present debt to be paid in future; which means a debt that the party is positively and absolutely bound to pay, arising upon a consideration which is passed; as in the case of an obligation or a bond given for the payment of a certain sum of money at a future day; or a promise made to pay a certain sum of money at a subsequent day, as the price agreed to be given for goods bought and received by the promisor of the promisee; but if it be a promise or covenant to pay a certain sum of money to another at a future day, as a compensation for his building in the mean time, a house of certain dimensions for the party promising or covenanting to pay, it cannot be called debitum in presenti quamvis sit solvendum in futuro because it is manifest from the very nature of this last engagement, that no duty or obligation whatever can exist or arise to pay the money unless the house shall be built, which may or may not be done. See Co. Litt. 292b. So the consideration for the payment of rent is the enjoyment of the thing demised

'ACc.: English v. Kéey, 39 Ala. 113 (1S63); Dixon v. Niccolls, 39 Ill. 37:, s9 Am. Dee. 312 (1S66); Alten v. Hall, 66 Neb. S4, 92 N. W. 171 (1902); Gibbs v. lives. 39 Temn. (2 Head) 437 (1S59). See Alien v. Van Houton, 19 N. J. Law, 47 (1S12).

A. leased premises to $x$. for two sears at an annual rent of one balf the wheat raised on the premises. After payment of the first year's rent, A. drew an order on $\mathrm{X}$. in favor of $\mathrm{B}$. payable out of the rent. This order was accepted hy $\mathrm{X}$. A.'s reversionary interest was then bought at an execution sale by $C$. 'The second ycar's rent later lecame due, and $\mathrm{X}$. paid $\mathrm{C}$. all of it excent that covered by the acceptance. In an action by $\mathbf{B}$. against $\mathbf{X}$. upon the acceptance, it was stipulated that if all the second year's rent was on these fircts due to $\mathrm{C}$., and that the payment of the acceptance could not be erchited $\mathrm{X}$. against $\mathrm{C}$., julgment should be rendered for $\mathrm{X}$. Held, $\mathrm{X}$. is entitled to judgment. Marlin v. Martin, 7 Md. 368, 61 Am. Dec. 36-1 (1855). Compare Dreyfus v. Hirt, S2 Cal. 6:21, 23 Pac. 133 (1S90). 
which is executory, and therefore uncertain, but must first be complete before any obligation or duty to pay the rent can arise. Lord Chief Baron Gilbert, says "rent service is something given by way of retribution to the lessor for the land demised by him to the tenant, and consequently, the lessor's title to the rent is founded upon this, that the land demised is enjoyed by the tenant during the term included in the contract, for the tenant can make no return for a thing he has not; if therefore the tenant be deprived of the thing letten the obligation to pay the rent ceases, because such obligation had its force only from the consideration, which was the enjoyment of the thing demised." Gilb. on Rents, 145; Vaughan v. Blanchard, 4 Dall. 124, 1 L. Ed. 769; 2 Roll. Abr. tit. Rent, O; Dyett v. Pendleton, 8 Cow. (N. Y.) 727. Hence if the tenant or lessee shall be evicted from the land demised by the lessor, or by a third person, under a title paramount to that of the lessor, at any time before the rent shall have become actually payable, he will thereby be discharged from the payment of it entirely, and there shall be no apportionment of it. In Clun's Case, 10 Co. 128, it is laid down, that "the rent reserved is to be paid out of the profits of the land, and is not due until the profits are taken by the lessee;" and for this reason it was there held, "that if the land is evicted, or if the lease determines before the legal time of payment no rent shall be paid; for there shall never be an apportionment in respect of part of the time, as there shall be upon an eviction of part of the land." So little of the character of a present debt or duty has rent which has not become payable, that a release of all demands (which is perhaps the most comprehensive term that could be used to embrace anything of the kind, Co. Litt. 291b), given by the lessor to the tenant does not discharge it. Collings v. Harding, Cro. Eliz. 606; Trevil v. Ingram, 2 Mod. 282; Henri v. Hanson, 1 Leo. 99; Ingram v. Bray, 2 Leo. 210; Stevens v. Snowe, 2 Salk. 57S. And Littleton, in section five hundred and thirteen, says, that a release of all actions by the lessor to the lessee will be no bar to an action of debt brought afterwards for rent which became payable subsequently; and the reason assigned therefor by Lord Coke is, "because it was neither debitum non solvendum at the time of the release made, for it is to be paid out of the profits of the land, and if the land be evicted from the lessee before the rent became due, the rent is avoided." Co. Litt. 292b.

Rent cannot be likened to interest, which is said to be due cle die in diem, because that is allowed for the delay of payment of the principal that is already due. Hay v. Palmer. 2 P. Wms. 502; Banner v. I.owe, 13 Ves. 135 . Under this view of the nature of rent, that by the terms of the lease has not become payable, it is evident that the court in West v. Sink, mistook the meaning and import of the term "due" when applied to it, because from the foregoing autlorities. it appears that rent in legal parlance is never considered to be due until 
it has become actually payable. In fine that the words "due" and "payable," when applied to rent are convertible terms; and that they are so in common acceptation, and in the general understanding of mankind, will not be, as I think it never has been, denied.

I therefore consider the judgment of the court below fully sustained by law, reason and authority.

Judgment affirmed.

\section{ROCKINGHAM et al. v. PENRICE et al.}

\section{(Court of Chancery, 1711. 1 P. Wms. 177.)}

Sir James Oxenden before marriage, and in consideration of $\mathfrak{E 1 0 , -}$ 000 portion, settled an estate upon his lady (the plaintiff the Lord Rockingham's sister) for her life for her jointure, with a power for himself to make leases at the usual rent.

Accordingly Sir James made leases pursuant to the power of several parts of the land comprised in this settlement, reserving the rent at Lady Day and Michaelmas, and died upon Michaelmas Day between three and four in the afternoon, and before sun-set. And one of these several lessees, to whom the leases were made, paid his rent (being \pm 18 ) unto Sir James Oxenden in the morning of the said Michaelmas Day; but the other tenants had not paid their rent, the arrears whereof came to about $£ 500$.

Hereupon the sole question was, whether these arrears did belong to the defendants, the executors of Sir James Oxenden the lessor, or to the jointress?

For the former it was insisted, that when Michaelmas Day came, the rent was due on that day, and therefore, according to Clun's Case, 10 Co. $127, \mathrm{~b}$, if on Michaelmas Day, being the rent day, the tenant pays the rent in the morning to the lessor, who dies before noon, this payment, though voluntary, is a good payment against all but the King; so that it is not material that the payment was not compulsive, or that there was no remedy for it by debt or distress: in regard it appears by that book, that the payment, though voluntary, is notwithstanding good against the heir. And the case in 1 Saunders, 287, of Baskerville versus Mayo, was by the counsel denied to be law, where it is said to be the opinion of Hale, C. J., that if one leases for years, rendering rent, and dies on the rent day after sun-set and before midnight, this rent shall go to the heir, and not to the executor, for that (as it is there said) thougl a convenient time before sun-set is the proper time to demand the rent, yet it is not due until "the end of the day, videlicet, twelve of the clock at night," which they objected was not law; since at furthest, the rent was due from the tenant to the lessor at sun-set; for a convenient time before sun-set, for the 
telling the money, was the time for the landlord to demand his rent; upon non-payment of which, the lease might be avoided.

But it would be absurd to say, the lessee should forfeit the lease for non-payment of the rent, before it was due; and a case was cited betwixt Bellasis and Cole, at the assizes at Durham before Mr. Justice 'Iracy, where one granted a rent-charge for life, payable at Lady Day and Michaelmas; the grantee died on Michaelmas Day after sunset; and the question was, whether the executor of the grantee should have the rent? And for that the grantee lived until after, sun-set, which was the legal time for demanding the rent, though he died before twelve of the clock at night, yet it was held by that judge, that this rent should go to the executor. Besides, it was observed, that according to the other construction, if the jointress in the present case, should live but one half-year after the death of the husband, she might have a whole year's rent, which would be unreasonable.

But on the other side it was argued, and solemnly decreed by the Master of the Rolls, that the lessor, in the principal case, dying before sun-set, and there being no remedy for the lessor against the lessee, before his [the lessor's] death, to compel the payment of this halfyear's rent; and upon the authority of Clun's Case, the half-year's rent reserved payable at Michaelmas, should, upon the death of the lessor before sun-set, go to the jointress, who then had the reversion;

But that as to the $£ 18$. rent paid by one of the tenants to the lessor upon Michaelmas Day in the morning, this was a good payment as to the lessee the tenant, and he should not be compelled to pay the same over again; but that the executors of Sir James, that received this half-year's rent, should pay and account for the same unto Lady Oxenden the jointress.

Q. As to the last point; for if the $£ 18$. rent was a good payment at law, (as certainly it was, according to Clun's Case) why must it not be so in equity?

See the case of Lord Strafford versus Lady Wentworth, where Sir Henry Johnson tenant for life, remainder to his wife Lady Wentworth for life, made a lease at will rendering rent; and died on Michaelmas Day betwixt three and four in the afternoon, and before sun-set; and Lord Strafford, as administrator to Sir Henry Johnson claiming the rent,

Lord Chancellor Macclesfield held Lord Strafford well intitled thereto; and cited the above mentioned case of Cole versus Bellasis, and said there was a diversity betwixt a rent incident to a reversion that must go somewhere, (if not to the executor, then to the heir) and where the rent was to go nowhere, unless to the executor; in the latter case, if the lessor lived to the beginning of that day, at which time, a voluntary payment of the rent might be made, this would be sufficient to intitle the executor or administrator to the rent, rather than that it should be lost; for it would be strange, if the tenant should pay the 
rent to none; and as that case was, the person in remainder (viz. the jointress) could have no pretence to the rent, it being a lease at will, and consequently such as could have no continuance with respect to her. ${ }^{7}$

\section{HARMER v. BEAN.}

(Nisi Prius, 1853. 3 C. \& K. 307.)

Action for the use of a messuage of the plaintiff. Plea: Never indebted.

It appeared on the part of the plaintiff that the defendant had rented a house of the plaintiff, at a rent of $£ 20$. a year, payable quarterly, and that all the rent had been paid up to Michaelmas, 1851, and that after that a sum of $£ 2$. had been paid and $£ 4$. more recovered under a distress.

For the defendant it was proposed to show that the reversion of this house was not in the plaintiff, and that he was not entitled to receive the rent due at and after Michaelmas, 1852; and that on the 10th November, 1852, the plaintiff had obtained a judgment in the County Court against the defendant for $f 6.14 \mathrm{~s}$. for arrears of this rent.

On the part of the defendant a lease by deed from the plaintiff to Mr. Frederick Ford, of the house in question and other property, was put in; it was dated on the 4th of August, 1852, and was for twentyone years, commencing at Midsummer, 1852. * * *

PARKE, B. (in summing up). It appears that all the rent was paid up to Michaelmas, 1851, and the plaintiff is entitled to receive for all rent due after that till Midsummer, 1852; for we find that in August, 1852, the plaintiff granted a lease under seal of this property to $\mathrm{Mr}$. Ford for twenty-one years, and in consequence of this being done the reversion was transferred to $\mathrm{Mr}$. Ford, and the plaintiff cannot recover for any of this rent due afterwards. The learned judge of the County

'A., tenant for life, leased premises to $\mathrm{X}$. for fifty years, rent payable on the quarterly feast days or within thirteen weeks after each of said feast days. A. died after a feast day, but within the thirteen weeks. Held, there can be no recovery of the rent for that quarter. Clun v. Fisher, Cro. Jac. 809 (1612).

"When a tenant for life, who shall have demised any lands, shall die on or after the day when any rent became due and payable, his executors or administrators may recover from the under tenant, the whole rent due; if he die before the day when any rent is to become due, they may recover the proportion of rent which accrued before hls death." 1 Rev. St. N. Y. p. $747, \& 22(1829)$.

A. owned land in fee, subject to a lease expiring May 1, 1S55, the rent being payable quarterly. He dier in 1852, devising the land to his wite for life, with a residuary devise to $B$. in fee. His wife married $\mathrm{X}$. and dieit $A$ pril 5,1855 , making $X$. her execntor. $X$. collected the final quarter's rent due May 1, 1855. B. bronght action against $\mathrm{X}$. to recover the entire quarter's rent so collected. Mlell. B. is entitled to judgment. Marshall v. Nose ly, 21 N. Y. 280 (1S60). See, also, Jemuor v. Mlolgin, 1 P. Wins. 392 (171s). 
Court thought that the reversion was not transferred by the lease, but he was mistaken. ${ }^{8}$ That takes off all after Midsummer, 1852. ***

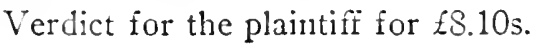

\section{DAMREN v. AMERICAN LIGHT \& POWER CO.}

(Supreme Court of Maine, 1s9S. 91 Me. 334, 40 Atl. 63.)

Haskel, J, J. ${ }^{9}$ Assumpsit for rent. The first count declares for rent from November 20, 1894, to August S, 1895. The case is on report, to be decided upon so much of the evidence "as competent and legally admissible."

One Charles Gay, being the owner of a building and water power connected therewith, leased the same to defeindant. Gay became an insolvent debtor, and on the Sth of August, 1895, his assignees conveyed all the right, title, and interest which Gay had in the premises when he became insolvent to the plaintiff, including the lease, rent being in arrear from that day to the day of the conveyance. Thereafterwards, on the 17 th of January, 1896, the assignees assigned such rent to the plaintiff.

Rent in arrear is a chose in action, and does not pass by a conveyance of the reversion. IVinslow v. Rand, 29 Me. 362; Burden v. Thayer, 3 Metc. (Mass.) 76, 37 Am. Dec. 117; Insurance Co. v. Wilson, 10 Metc. (Mass.) 126.

An assignment of rent reserved under a lease gives the assignee an action in his own name for rent subsequently accruing. Kendall v. Carland, 5 Cush. (Mass.) 75; Hunt v. Thompson, 2 Allen (Mass.) $3+1$; Harmon v. Flanagan, 123 Mass. 288; Beal v. Spring Co., 125

s.ec.: Horn v. Beard. [1912] 8 K. B. 181; McDonald v. Hanlon, 79 Cal. 442, 21 Pac. Se1 (1\$59); Hendriekson r. Beeson, 21 Neb. 61, 31 N. W. 266 $(1 S \subseteq \pi)$.

$\mathrm{X}$. was tenant from yoar to year under A., his tenaney having begun at Midsummer. In May, $\dot{Y}$. took a parol lease from $A$. of the same premises for a year, to begin at vidsmmer. $Y$. demanded the fall and winter quarter rents from $\mathrm{X}$., and on his refusal to pay distrained. $\mathrm{X}$. sued $\mathrm{X}$. for an illegal distraint. IIeld. Y.'s lease being by parol, the distraint is illegal. Brawley r. Wade, McClell. 664 (1824). Sce Bordereaux v. Walker,

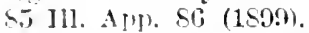

A. leasid land to $X$., the lease expiring September 29, 1869. During this term $A$. executed an indenture of lease of the same premises to $Y$. for a period of 17 years from September 29, 1869. After the execution of the lease to Y., X. refused to pay rent to A. Held, A. ragy distrain, Smith $r$. Day, ‥ M. \& W. GSt (1S:3); and if $\mathrm{X}$. holds over after the expiration of his term A. may recover a statutory penalty. B]atehford v. Cole, 5 C. B. N. S. 514 (1s58); ur damages, 'Thomas $v$. Wightman, 129 11l. App. 305 (1906); or lossession. Eells v. Morse, 20s N. Y. 10\%, 101 N. E. 803 (1913). But compare l'endergast $v$. Young. 21 N. II. 234 (15.0); United Merchants' Realty \& Improvement Co. v. lioth, $193 \times$. $\% 570$, s6 $\mathrm{x}$. E. 544 (1008). See, also,

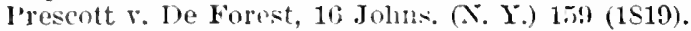

- The statement of facts and part of the opinion are omitted. 
Mass. 157, 28 Am. Rep. 216. No case can be found where an assignee of a lease or of rent reserved has been permitted, at common law, to sue in his own name for rent in arrear at the time of the assignment.

The conveyance of the reversion and of the lease was August $S$, 1895. It passed the title that day of estate held by their insolvent on the 20th of November, 1894. It cannot be construed as a grant or assignment, taking effect the previous November, when the debtor was adjudged insolvent. The part of the grant referring to that date was mere description of the estate conveyed. The rent meantime had accrued to the assignees, and payment to them would have discharged the rent. It had become separated from the land, and was a chose in action recoverable only at common law in the name of the assignees. Whether that rent be held as assigned to the plaintiff under the conveyance of August 8th, or the subséquent assignment of it in the following January, makes no difference, as it was a chose in action to be sued for in the names of the assignees in insolvency only. ${ }^{10}$

Under Rev. St. c. 82, § 130, an assignee of choses in action, not negotiable, may sue in his own name to recover the same, but "shall file with his writ the assignment or a copy thereof." No assignment was so filed in this case, but both the conveyance of August 8th and the assignment of the following January, when offered in evidence, were objected to, and under the stipulations cannot be considered if not legally admissible. This question has been decided in Bank v. Gooding, 87 Me. 338, 32 At1. 967, where it is squarely held that such assignments not filed with the writ are not admissible in evidence against objection. The claim sued in the first count cannot, therefore, be recovered in this action.

The second count declares for rent from August 8 to November 20, 1895. On the former date the lease had been assigned to plaintiff, so that rent accruing afterwards may be recovered by plaintiff in his own name. The lease was terminated on the 20th of November, 1895, by plaintiff taking possession for nonpayment of rent. The rent was payable monthly on the 1st day of each month, so that all plaintiff can recover in any event is rent for August, September, and October. The November rent had not accrued, and therefore cannot be recovered. Nicholson v. Munigle, 6 Allen (Mass.) 215. ***

Defendant defaulted for $\$ 49.98$ and interest from date of writ. $* * *$

10 See Midgley $\nabla$. Lovelace. Carth. $2 \varepsilon 9$ (1693); Thornton v. Strauss, 7! Ala. 164 (1855); Burden 5 . Thayer, 3 Metc. (Mass.) 76, 37 Am. Dec. 117 (1S41); Farmers' \& Mechanics' Bank v. Ege, 9 Watts (Pa.) $4366,36 \mathrm{Am}$. Dec. $130(1840)$. 


\section{ARDS v. WATKINS.}

(Court of Queen's Bench, 1595, 1590. Cro. Eliz. 637, 651.)

Upon demurrer the case was, lessee for thirty years of a parcel of land called Shortwood, lets it for twenty-eight years, rendering $£ 34$. rent per annum; and after deviseth $£ 28$. parcel of that rent to his three sons, severally to every of them a third part. One of them brings debt for his part of the rent: and, whether this action lay, or not? was the question.

Gawdy and Fenner held, that the action well lay; for there is no doubt but that rent may be devised, and be divided from the reversion; for it is not merely a thing in action, but quasi an inheritance, as Knowles' Case is, Dyer, 5b; and in 24 Hen. 8 Rysden's Case, Dyer, $4 \mathrm{~b}$. If lessee grants over all his term in part of the land, yet it is chargeable in an action with the entire rent; for he by his act cannot apportion it. And by the grant of part, the lessee is not compellable to attorn; for then he should be liable to two actions, or two distresses. But the devise is quasi an act of law, which shall inure without attornment, and shall make a suffrcient privity, and so it may be well apportioned by this means. Wherefore, \&c.

Popham and Clench e contra. For as the lessee by his own act shall not divide the lessor's contract, nor apportion his action; so likewise the law favours the lessee, that the act of the lessor shall not charge him with divers actions, or double distresses, but upon his voluntary attornment: and the contract being entire cannot be apportioned.

But Popham agreed, that the rent was well devisable, and by that means severable from the reversion. And although a thing in action camnot be transferred over, nor be devised; yet a contract, which arisetl from an interest in land, or which is an interest, may be well transferred over. Wherefore, \&ic.

\section{Adjournatur.}

The case was now moved again; and Gawdy and Fenner, and Clench agreeing with them, held, that the devise was good, and well severable: for as to that objection, that a mischief may happen to the tenant, that he shall be subject to two actions and distresses, that is his own fault; for if he pays his rent, he shall avoid it: and the same mischief is, where he deviseth part of the reversion and rent, which is agreed on the other part to be well enough; and although a contract, or a thing in action, cannot be transferred nor divided, yet rent only may be. For it is a thing in possession; for he doth not grant the action, but the law gives it as incident to the rent. And Huntley's Case, 10 Eliz. Dyer, 326, is express, where a devise was of a reversion upon a lease for years, with the rent to a man and his sister, and the heirs of their bodies: the sister dies without issue; the brother dies having issue; the heir had the moiety of the rent. 
Poplam e contra. For the difference will be, when part of a reversion and rent is granted, that is good; but when the rent is severed from the reversion, it is otherwise: for then it is but in nature of an annuity, which cannot be granted by parcels, but entirely; but an annuity or rent only are grantable over, because they are things of continuance, and are not personal. And the reason of Huntley's Case, 10 Eliz. Dyer, 326, is, because the rent is divided with the reversion. But notwithstanding, in regard three of them agreed, he consented that judgment should be entered for the plaintiff.

Note. That in the argument of this case, a case was cited in this Court, Easter Term, 28 Eliz. Roll. 344, where a devise was of an entire reversion and rent, which was void for a third part; because it was holden in capite, and debt was brought for two parts of the rent, and adjudged maintainable. ${ }^{11}$

\section{NEWCOMB v. HARVEY.}

\section{(Court of King's Bench, 1690. Carth. 161.)}

The plaintiff being lessee for years assigned over his whole term, by indenture, to the defendant, rendering rent, and an action of debt was now brought for the rent in arrear.

The defendant pleaded non concessit \& hoc, \&c.

And upon a demurrer to this plea, it was objected in behalf of the defendant, that this action would not lie, because the sum reserved was not properly any rent, but a sum in gross, the plaintiff having assigned over his whole term, and by consequence had no reversion, and therefore the action ought to be for a sum in gross upon the contract, (and not debt for rent) and that would not lie till the last day expires.

11Acc.: That the right to rent may be severed from the reversion. Robins $v$. Cox. 1 Lev. 22 (1661); Brownson v. IRoy, 133 Mich. 617, 95 N. W. 710 (1903); Moffat v. Smith, 4 N. Y. 126 (1550).

A. leased land to $X$. for years, reserving a rent. A. left the rent by will to B. B. died. In a contest between B.'s heir and B.'s executor, held, the latter is entitled to the future rent. Knolle's Case, Dyer, 56 (1534).

A. leased land to $\mathbf{X}$. for years, reserving a rent. A. mortgaged the premises to $\mathrm{B}$. The mortrage contained this clause: $B$. "is to receive all the rents to be derived from said lease * * * and this deed shall operate as an assignment of the interest of the said $A$. in said lease." $B$. sued $x$. in lis own mame for rent accruing after the execution of the mortgage. The court held the action maintainable, saying: "The doctrine of the common law, that choses in action are not assiguable, does not obtain with us." Watson v. Hunkins, 13 Iowa, 517 (1562).

The lessor may convey the reversion, but retain the right to the reut. Crosby v. Ionn, 13 111. 625 (1852); Goodwin r. Hudson, 60 Ind. 117 (1877).

See Cheathan v. J. W. Beck Co., 96 Ark. 280, 131 S. W. 699 (1910).

If the reversion in parts of the leased premises is conveyed to separate. grantees, the rent is diviled proportionately, and each grantee may recover his proportionate part of the rent. Swansea v. Thomas, 10 Q. B. D. 48 (1SS2); Worthington v. Coolie, 56 Md. 51 (18s1); Linton v. Hart, 25 Ya. 19:3,

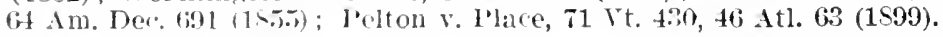


To which it was answered, and so resolved per Curiam, that this is rent, tho' the plaintiff had no reversion; for if a rent is reserved upon a feoffment in fee, there is no reversion in the feoffer; but yet this is a rent, and recoverable by the name of a rent upon the contract, and so it shall be in the principal case.

Moreover, if the defendant had assigned over the term to another, an action of debt would lie for the plaintiff against the second assignee.

The plaintiff had judgment. ${ }^{22}$

\section{WILSTON v. PILKNEY.}

\section{(Court of King's Bench, 1673. 1 Vent. 242.)}

In debt for rent the plaintiff declared, that the dean and chapter of, $\& c$. demised to the defendant for life; by force of which he entered and demised the land to the plaintiff for years, by virtue of which he was possessed, and afterwards granted to the defendant, reserving a rent, for which he brings his action.

To this declaration the defendant demurs. ${ }^{13} * * *$

Thirdly, as to the matter, that the reservation was void, it being upon a suriender by parol. A rent cannot be reserved upon a feoffment by parol; so where lessee for life or years assigns over his whole interest, $12 \mathrm{H} .4,14 ; 9 \mathrm{H} .6,43 ; 12 \mathrm{H} .4,17$. Also no rent can be reserved upon a conveyance that works an extinguishment, unless by deed, where it is good upon the contract. Peto's Case, 3 Cro. 101 , is, that a surrender drowns the interest to all intents and purposes between the parties. Dyer, 251. The tenant for life agreed with him in reversion, that he should have his land for the annual rent of 20s. 'tis doubted there whether this amounts to a surrender, there being no deed or livery. But in 2 Roll. 497, 'tis said, if it had been a surrender the reservation had been void.

As to the matter, the Court resolved for the plaintiff. For

1. The reservation was good by the contract, tho' without deed. And so it. was adjudged in this Court in Manly's Case, that tenant for years might assign his whole term by parol, rendering rent; so in the case of Purcas and Owen, 23 Car. But it was doubted, whether an action would lie until the last day were past. 'Tis all one where the grant is made to him in reversion, which is not actually, but consequentially a surrender by operation of law, before which the contract is perfected, upon which the rent arises. 7 E. 4, is, that the lessee may surrender upon condition; and there is no reason, why a rent can-

12A. leases to $\mathrm{X}$. for years. $\mathrm{X}$. ascigns his whole term to $\mathrm{Y}$., reserving a rent. $X$. assigns his right to the rent to $M$. Held, M. may sue $Y$. in debt in his own name for the lent so reserved. Williams v. Hayward, $1 \mathrm{E}$. E E. 1040 (1859); Clark r. Coughlan, 3 Ir. L. R. 427 (1841); Patten V. Deshon, 1 Gray (Mass.) 325 (1S54).

13 Part of the opinion is omitted. 
not be created upon it as well as a condition. If it were in the case of tenant for life, a deed were requisite as well for a rent as a condition, in respect of the freehold, but that is not so in the case of tenant for years.

\section{LOYD v. LANGFORD.}

(Court of Common Pleas, 1677. 2 Mod. 174.)

A special verdict. The case was: A. being a tenant in fee of lands, demised the same to $B$. for seven years. B. re-demised the same lands to $\mathrm{A}$. for the said term of seven years, reserving twenty pounds rent per annum. A. dies; his wife enters as guardian to the heir of A. her son, and receives the profits. B. brings debt against her as executrix de son tort, in the debet et detinet.

The question was, whether this action would lie or not?

Baldwin, Serjeant, who argued for the plaintiff, held, that it did lie; for though the rent reserved in this case did not attend the reversion, because the lessee had assigned over all his term, yet an action of debt will lie for that rent upon the contract. Cro. Jac. 487. Witton v. Bye, 45 Edw. 3, pl. 8. 20 Edw. 4, pl. 13. Covenant will lie upon the words "yielding and paying." If then here is a good rent reserved, the wife, who received the profits, becomes executrix de son tort, and so is liable to the payment. It hath been held, that there cannot be an executor de son tort of a term, but the modern opinions are otherwise.

Pemberton, Serjeant, for the defendant, would not undertake to answer these points which were argued on the other side, but admitted them to be plain against him; for he did not doubt but that debt would lie upon the contract, where the whole term was assigned, and that there may be an executor de son tort of a term. But he said, that which was the principal point in the case was not stirred: the question was, whether an action of debt will lie against the defendant as executor de son tort, where there is no term at all? for it is plain there was none in being in this case; because when the lessee re-demised his whole term to the lessor, that was a surrender in law, and as fully as if it had been actually surrendered: and therefore this was quite different from the case, where lessee for years makes an assignment of his whole term to a stranger, debt will lie upon the contract there, because an interest passes to him in reversion; and as to this purpose a term is in esse by the contract of the parties, and so it would here against the first lessor, who was lessee upon the re-demise: but now because of the surrender, the heir is entitled to enter, and the mother, who is the defendant, enters in his right as guardian, which she may lawfully do. If, therefore debt only lies upon the contract of the testator, as in truth it doth where the whole term is gone, the plaintiff cannot charge any one as executor de son tort in 
the debet et detinet. And the whole term is gone here by the re-demise, which is an absolute surrender, and not upon condition; for in such case the surrender might have entered for non-performance, and so it might have been revived.

And of this opinion was the whole Court in both points, and would not hear any farther argument in the case. The plaintiff having no remedy at law, the Court told him that he might seek for relief in Chancery; if he thought fit.

\section{ST. 4 GEORGE II, c. $28, \S 5$.}

And whereas the remedy for recovering rents seck, rents of assize, and chief rents, are tedious and difficult, be it therefore enacted by the authority aforesaid, That from and after the twenty-fourth day of June one thousand seven hundred and thirty-one, all and every person or persons, bodies politic and corporate, shall and may have the like remedy by distress, and by impounding and selling the same, in cases of rent seck, rents of assize, and chief rents, which have been duly answered or paid for the space of three years, within the space of twenty years before the first day of this present session of Parliament, or shall be hereafter created, as in case of rent reserved upon lease; any law or usage to the contrary notwithstanding.

\section{- v. COOPER.}

(Court of Common Pleas, 1768. 2 Wils. 375.)

In replevin, the defendant avows under a distress for rent due from the plaintiff to him upon an assignment of a lease of a term for years to the plaintiff, in which assignment there is no clause of distress; the single question is, Whether this is such a rent for which a distress lies, there being no reversion in the defendant. It was said for the defendant, that although rent be incident to the reversion, yet it is not an inseparable incident, and therefore it may be severed from the reversion; and although there is no clause of distress in the assignment of the term, yet the rent reserved thercupon may be considered as a rent-seck, and distrained for by the statute 4 Geo. 2 . c. 28 , sec. 5 , and that it appears clearly to be the intent of the parties that the plaintiff should pay rent to the defendant: this case was so clear, that the court gave judgment for the plaintiff without hearing his counsel.

Curia. There are two ways of creating rent; the owner of the lands either grants a rent out of it; or grants the lands and reserves a rent; there is no such thing as a rent-seck, rent-service or rentcharge issuing out of a term for years. Bro. Dette, pl. 39, cites 43 Ed. 3, 4, per Fynchden Ch. Justice C. B. If a man hath a term for years, and grants all his estate of the term rendering certain rent, he 
cannot distrain if the rent be in arrear; this case is law and in point; therefore if the avowant will recover what is owing to him from the plaintiff, he must bring his action upon the contract.

Judgment for the plaintiff per totam curiam. ${ }^{\mathbf{1 4}}$

\section{WEBB v. RUSSELL.}

(Court of King's Bench, 1789. 3 Term R. 393.)

This was an action of covenant. The declaration stated an indenture of 26 th October, 1780 , by which William Stokes, and R. Webb who was described to be the mortgagee of the premises in question, demised them to the defendant for 11 years, from the 29th September then last, at the yearly rent of $£ 200$. payable to Stokes or his assigns; in which were contained covenants on the part of the defendant with Stokes and his assigns (inter alia) to pay the rent, and to keep the premises in repair. It then stated that $R$. Webb at the time of the lease was possessed of the premises for the residue then to come and unexpired of a term of 99 years, commencing on the 24th of June, 1770, subject to an equity of redemption by Stokes on payment of a certain sum with interest to $\mathrm{R}$. Webb. That the defendant entered on 26th October, 1780 , and became possessed for the term of 11 years, the reversion thereof for the term of 99 years belonging to $\mathrm{R}$. Webb, subject to such equity of redemption, and the further reversion in fee belonging to one G. Medley. It then stated that by indentures of lease and release of the $23 \mathrm{~d}$ and 24th March, 1781, Medley granted the reversion in fee, expectant on the determination of the terms for 99 years, to Stokes and Morgan Thomas; who, by indentures of lease and release, dated 26th and 27th March, 1781, and made between Stokes and Thomas of the first part, R. Webb of the second part, and Makepeace Thackeray of the third part, granted it to Thackeray his heirs and assigns in trust for R. Webb his heirs and assigns, subject to a proviso for redemption on payment of a certain sum of interest by Stokes to $\mathrm{R}$. Webb on a day therein mentioned and since past. That on the 30th May, 1785, R. Webb died, having first made his will; by which

14Acc.: Yarmenter v. Webber, S Taunt. $59: 3$ (1S18); Lewis $\nabla$. Baker, [1905] 1 Ch. 46: Prescott r. De Forest, 16 Johns. (N. Y.) 159 (1S1!): Fge v. Ege, 5 Watts (Pa.) 134 (18,6). Compare Doe v. Bateman, 2 B. \& Ald. 16s (1818). See note to The King v. Wilson, 5 Man. \& Ry. 140, 157 (1529).

It seems that by the common law of England neither the burden of a covenant for the payment of a rent charge in fee nor the right to enforce such a covenant runs with the land or the rent. See Brewster v. Kidgill, 12 Mod. 166 (169s); Milnes v. Branch, 5 M. \& S. 411 (1S16). The rule is otherwise in some jurisdictions in the United States. See Van Rensselaer $v$. Read, 26 N. Y. 5̇́s (1S63); Tyler v. Heidorn, 46 Barb. (N. Y.) 439 (1s66); Streaper $\nabla$. Fisher, 1 liawle (Pa.) 155, $18 \mathrm{Am}$. Dec. 604 (1S29); Juvenal v. l'atterson, 10 I'a. 282 (1849): Springer v. I'hillips, 71 I'a. 60 (1S7'2); scott v. Lunt, 7 Pet. 596, S L. Ed. 797 (1833). Compare Raby v. Reeres, 112 X. C. $6.58,16$ S. E. 790 (1893). 
he bequeathed to the plaintiff all his worldly estate, and appointed her sole executrix; that she proved the will, took upon herself the burthen of the execution of it, assented to the said bequest, and claimed to have the reversion of the premises for the residue of the term of 99 years, (stubject to Stoke's equity of redemption) and the money thereupon securcl to R. Webb, as legatee; and by virtue of that bequest, assent, and claim, she became possessed of the said reversion for the residue of the term of 99 years, subject, \&c. That by indentures of lease and release, dated 12th and 13th February, 1787, and made. between Thackeray of the first part, Stokes of the second part, and the plaintiff of the third part, Thackeray and Stokes granted and released to the plaintiff the reversion of the premises in fee, freed and discharged from all right and equity of redemption whatsoever, by virtue whereof she became and was and still is seised in fee of the reversion of the premises, immediately expectant on the determination of the term of 11 years. The declaration concluded with setting forth two breaches of covenant; the one for non-payment of one year and one quarter's rent, due at Lady-day, 1788; and the other for not keeping the premises in repair.

To this there was a general demurrer; and joinder.

Lord Frivion, Ch. J., now delivered the opinion of the Judges then in Court.

I cannot conceive why the plaintiff has introduced into her declaration many facts there stated. If there were no other objection against the plaintiff's recovering in this action, the pleader has raised some difficulty to himself by stating that the plaintiff, who was executrix, assented to the legacy to herself, and took the term in her own right; for in some views of this question, the action possibly might have been sustained, if the plaintiff had sued as executrix; because nothing is clearer than that a term which is taken in alieno jure is not merged in a reversion acquired suo jure.

It is extremely well settled at common law, without referring to the statute $32 \mathrm{H} .8$, c. 34, that covenants which run with the land will pass to the person to whom the land descends. And that statute enacted, for the benefit of the grantees of reversions, that they should have the like advantages against the lessees, their executors, \&c., by entry for nonjayment of the rent; and should have and enjoy all and every such advantages, benefits, and remedies, by action only for not performing other conditions, covenants, or agreements, contained in the leases, against the lessees, as the lesssors or grantors had. The statute also contains a clause, giving the lessees the same remedy against the grantees of the reversion which they might have had against their grantors. Therefore under this statute the grantees or assignees stand in the same situation, and have the same remedy against their lessees, as the heirs at law of individuals, or the successors (in the case of corporations), had before the statute. It becomes therefore necessary to enauire whether this action of covenant could have been maintained by 
the heirs of the person from whom the plaintiff derives her title. I have already observed upon the introduction of one fact into this case, which might have been omitted; there is also another, which deserves some observation here. It is stated that Stokes was only a mortgagor, who had parted with his whole term to the mortgagee; and the declaration goes on to state that the whole interest which was vested in him he had transferred to the mortgagee. Therefore, in point of law, I cannot conceive how this covenant made with Stokes can be said to run with the land; for Stokes is stated in the declaration to have no interest whatever in the land, and yet both the implied covenant, "arising from the yielding and paying," and also the express covenants are entered into with Stokes. It is not sufficient that a covenant is concerning the land, but, in order to make it run with the land, there must be a privity of estate between the covenanting parties. But here Stokes had no interest in the land of which a court of law could take notice; though he had an equity of redemption, an interest which a court of equity would take notice of. These therefore were collateral covenants. And though a party may covenant with a stranger to pay a certain rent in consideration of a benefit to be derived under a third person, yet such a covenant cannot run with the land.

But even supposing that these covenants had been entered into (not with Stokes but) with Webb, who had an interest in the land, the subsequent transaction, which is stated in the declaration, puts an end to this question. It appears that the person entitled to the reversion of the 99 years term, expectant on the determination of the 11 years term created by the lease, afterwards acquired in her own person the absolute inheritance of the land; in consequence of which the reversion attendant on the lease granted to the tenant no longer existed. Another estate, totally different, arose by the extinguishment of the intervening estate. Many cases were cited on this subject; one of which, Moor, 94, is very applicable. There a person made a lease for 100 years, and the lessee made an underlease for 20 years, rendering rent, with a clause of re-entry; afterwards the original lessor granted the reversion in fee, and the grantee purchased the reversion of the term; and it was held that the grantee should not have either the rent, or the power of re-entry; for the reversion of the term, to which they were incident, was extinguished in the reversion in fee. And though this case was only determined at the assizes, yet it was afterwards recognized in the Court.

Considering then that these are covenants entered into with a stranger that do not run with the land, considering also that the rent is incident to the reversion out of which the term is carved, and that that reversion is gone, it seems to me, with all the inclination which we have to support the action, (and we have hitherto delayed giving judgment in the hopes of being able to find some ground, on which the plaintiff's demand might be sustained) that it cannot be supported. The defence which is made is of a most unrighteous and unconscien- 
tious nature: but unfortunately for the plaintiff the mode which she has taken to enforce her demand cannot be supported; and consequently there must be

Judgment for the defendant. ${ }^{15}$

\section{McMURPHY v. MINOT.}

(Supreme Court of New Hampshire, 1827. 4 N. H. 251.)

This was an action of covenant broken on an indenture made the 12th July, 1811, by which the plaintiff demised to Seth Daniels, a certain tract of land to hold during her natural life, and the said Daniels covenanted with the plaintiff to pay her, on the first day of May, annually, a rent of $\$ 30$.

The action was brought against the defendant, as assignee of Daniels, for the said rent from 1st May, 1817, to the 1st May, 1825, and was submitted to the decision of the court upon the following statement of facts.

The indenture was made as stated in the declaration, and Daniels having entered under it, afterwards conveyed all his estate to one Gilman Dudley, who, on the 3d April, 1822, conveyed the land to the defendant in fee and in mortgage. Dudley remained in possession and took the profits until his death in October, 1822, and after his decease his administratrix remained in possession, taking the profits until April, 1824. On the 16th April, 1824, a tenant entered upon part of the land under an agreement with the defendant to pay rent to him in case the land was not redeemed.

On the 23d April, 1825, the administratrix of Gilman Dudley conveyed to the defendant the right in equity to redeem the land mortgaged as aforesaid, and the defendant's said tenant has been in possession of the whole tract from that time to the commencement of this action, on the 22d March, 1826.

All the interest which the plaintiff ever had in the land was an estate for her own life, and the reversion was in Daniels.

Richardson, C. J. ${ }^{18}$ It has been urged in behalf of the defendant in this case that the plaintiff is not entitled to recover any thing, bcause the rent was never demanded of Minot. The law on this point is well settled. When a lessor proceeds for a forfeiture or to enforce a penalty he must show a demand of a rent on the very day it was payable. But in an action of covenant no demand is necessary. 18 Johns. (N. Y.) 477, Remsen v. Conklin; Com. Dig. "Rent," D, 4; 2 N. H. 163, Coon v. Brickett.

We are therefore of opinion that this objection to the action cannot prevail.

15Acc.: Threer v. Barton, Noore, 94 (1570). See Thorn v. Woollcombe, 3 B. \& Ad. 586 (1832).

16 Part of the opinion is omitted. 
It has also been urged that this action cannot be maintained, because the particular estate and the reversion having become united in the same person, the particular estate is merged and the rent extinguished. Had the rent in this case been incident to the reversion it is clear that this action could not be maintained. 2 N. H. 454 , York v. Jones. But it is well settled that the rent is not inseparably incident to a reversion. Coke, Litt. 143, and 47, a; 2 Bl. Com. 176.

Rent may be reserved upon a grant of a man's whole estate in which case there can be no reversion.

The case of Webb v. Russell, 7 D. \& E. 393, which has been cited by the defendant's counsel does apply in this case. It was there held that where rent is incident to a particular reversion, when that particular reversion is merged, the rent is extinguished. But in this case the rent was never incident to the reversion. The plaintiff granted her whole estate reserving a rent, and she had no reversion to which it could be incident.

In order to maintain this ground it must be shown that when he who has a reversion takes a lease of the particular estate and covenants to pay rent, such rent is extinguished by the union of the particular estate and the reversion. But this proposition cannot be sustained by any reason or authority, and we are of opinion that this ground of defence fails altogether.

In considering this case, the question occurred to us whether the liability of the defendant could be affected by the circumstance that the rent was reserved upon a grant of the freehold, while the conveyance to him was in fee. But we find that it has been decided that covenant will lie against the assignee of part of an estate for not repairing his part, for it is divisible and follows the land. Cro. Car. 222, Congham v. King; 2 East, 580.

And we are not able to discover any reason why he who takes a larger estate should not be bound by a covenant running with a less estate which is parcel of the larger.

On behalf of the plaintiff it has been argued that the defendant is liable in this action, not only for the rent which has become due since he became owner of the land, but the rent which became due before that time.

The cases which have been cited by the defendant's counsel seem to show that the law is not so.

It is another argument in favor of the defendant, that when the action is against an assignee, it is usual to allege in assigning the brcach of the covenant, that the breach happened after the assignment. 2 Chitty's Pl. 191; Lilly, 134; 6 Johns. (N. Y.) 105; Dubois v. Van Orden; Carthew, 177; 2 Ventris, 231.

It is said in Woodfall, 274 and 338, that an assignee is liable for arrearages of rent incurred before, as well as during his enjoyment; but he cites no case in which it has been so decided, and offers no argument in support of the propositions, and we are of opinion that this 
is not law, and there must be judgment for the plaintiff for the rent which has become due since the 3d of April, 1822.

Judgment for the plaintiff.

\section{SMILEY et al. v. VAN IVINKLE et al.}

(Supreme Court of California, 1856. 6 Cal. 605.)

This was an action against P. W. Van Winkle, H. W. Halleck and $\mathrm{A}$. C. Peachy, for the rent of certain premises leased by plaintiffs to Joln Middleton, the lease being by him assigned to Henry Haight, by whom it was assigned to J. L. Folsom; the defendants being appointed executors of the latter shortly after his death, and having held the premises as such executors for the time for which the rent is sought to be recovered.

The complaint sets forth in full the lease from the plaintiffs to John Middleton, in which it is recited that the property is demised to him for the unexpired term of a lease thereof made to the plaintiffs by J. L. Folsom. The lease to Middleton employs the usual words of demise, and contains a reservation of rent and covenant of re-entry for conditions broken. The defence set up is that the defendants have only occupied the premises as executors of Folsom, and that the accounts of plaintiffs for rent have been presented and allowed, to be paid in due course of administration, and that the defendants are not liable therefor, de bonis propriis. The Court below entered judgment for the defendants. Plaintiffs appealed.

'The opinion of the Court was delivered by Mr. Chief Justice MurRAY. Mr. Justice HeydenfeidT and Mr. Justice TiRry concurred.

The question presented by this case, say the learned counsel for the appellants, is, "whether executors who have entered into and possessed a leasehold estate of which their testator was assignee, are liable for the rents accruing during the possession as assignees de bonis propriis."

Were this the only question, we would have no difficulty in deciding it in the affirmative, but the facts of the case present a somewhat different inquiry.

The conveyance by Smiley et al., although it employs words ordinarily used in a demise, and contains a reservation of rent and the right of re-cutry upon covenants broken, is not an underletting or sub-lease, but is considered in law as an assignment of their whole interest, as there remains in them no reversion of the estate; for it is one of the essentials of a lease, that it should contain a reversion in favor of the party from whom the grant or assurance proceeds.

If this position be correct, and we are satisficd it cannot be successfully controverted, then the instrument. which was possibly intended for a demise by the parties, in reality operatcd a conveyance of the entire estate of the lessees to Middleton, through whom, by sundry 
mesne conveyances, it afterwards returned to the grantor, and was merged in fee and thereby extinguished. No action will lie against the executors, although it might have been otherwise, had there been no merger.

Judgment affirmed.

\section{BEAL v. BOSTON CAR SPRING CO.}

(Supreme Judicial Court of Massachusetts, 1878. 125 Mass. 157, 28 Am. Rep. 216.)

Contract for rent due under a written lease made by Heyer Brothers to the defendant for the term of five years from April 1, 1874, and by Heyer Brothers assigned to the plaintiff.

At the trial in the Superior Court, before Allen, J., it appeared in evidence that the premises described in the lease of Heyer Brothers to the defendant constituted a part of the same premises which Heyer - Brothers held under and by virtue of a lease to them for a term of ten years from April 1, 1874, made by the plaintiff, who was the owner of the premises; that on February 7, 1877, when the plaintiff received the assignment from Heyer Brothers of their lease to the defendant, he executed upon the back of the original lease from himself to Heyer Brothers the following instrument: "Boston, February 7, 1877. The within-named lessor, in consideration of the assignment to him of certain underleases made by the within-named lessees of parts of the premises demised in the within lease, and of one dollar to him paid by the within-named lessees, doth hereby release and forever discharge the said lessees, their heirs, executors and administrators, of and from all claims, demands and causes of action of and concerning the within lease, and especially all claims by him for rent thereunder; and said lessees do hereby surrender and yield up the said lease and the premises within described to said lessor, and such surrender is hereby accepted by him, but without prejudice to the leases of parts of the premises assigned to him as above mentioned." It further appeared that the terms of this instrument were carried out, and that Heyer Brothers ceased to occupy the premises.

The defendant offered to show that it had not been in the occupation of the premises since February 7. This evidence was objected to as being immaterial, and was excluded.

The defendant contended and asked the judge to rule that if, by the arrangement entered into between the plaintiff and Heyer Brothers, the original lease was on February 7, 1877, given up, discharged or vacated, and the tenancy of Heyer Brothers thereupon ceased, and the plaintiff resumed control of the premises, and Heyer Brothers at the same time assigned and transferred to the plaintiff the underlease before then held by the defendant from them; and if the defendant, when informed of this, ceased to have anything further to do with the 
premíses, and refused to recognize as longer subsisting or continuing in force the underlease given to them by Heyer Brothers, or to become liable to the plaintiff as assignee thereof in any way, the plaintiff could not maintain his action.

The judge refused so to rule, but ruled that the plaintiff was entitled to recover; and directed the jury to return a verdict for the plaintiff. The defendant alleged exceptions.

ENDICOT', J. The plaintiff, being the owner of the estate leased the same for the term of ten years to Heyer Brothers; and they, on the same day, leased a part of the premises to the defendant for a term of five years. It is to be inferred from the subsequent agreement between the plaintiff and Heyer Brothers that other underleases were made. Before the expiration of the underlease to the defendant, Heyer Brothers assigned it to the plaintiff; who at the same time indorsed on the original lease to Heyer Brothers an agreement releasing them from rent and accepting the surrender of their lease and the premises, "but without prejudice to the leases of parts of the premises assigned to hirn." This agreement was made in consideration of the assignment to the plaintiff of the underleases by Heyer Brothers.

The intention of the parties is plain. Heyer Brothers having made underleases of parts of the premises which the plaintiff was willing to take, and desiring also to surrender the reversion in the leases to the plaintiff, which he was willing to accept, the underleases were assigned, including the defendant's, and the surrender of the original lease accepted without prejudice to the underleases. They evidently did not intend that the rights of the plaintiff under the assignment, or the estates of the sub-lessees, should be destroyed by the surrender, for the language of the acceptance carefully provides for both. The purpose was to put the plaintiff precisely in the position of Heyer Brothers. This intention, as expressed in the papers they have executed, will be carried out, if consistent with the rules of lav, and we are of opinion that it is.

The plaintiff brings this action, as assignee of the lease, to recover upon the defendant's covenant to pay rent; and it is well settled that when a lease is assigned without the reversion, the privity of contract is transferred, and the assignee may sue in his own name for the rent accruing after the assignment. Kendall v. Carland, 5 Cush. 74; Hunt v. Thompson, 2 Allen, 341. The only objection suggested to the plaintiff's right to recover is the surrender of the lease of Heyer Brothers to the plaintiff; and the claim is, that the rent due from the defendant is an incident of the reversion in Heyer Brothers, and, the reversion having been extinguished by the surrender, all remedies incident to it are taken away. But rent is not necessarily an incident to the reversion, so that it cannot by the acts or agreements of the parties be separated from it. In a general grant of the reversion, the rent will pass as incident to it. Burden v. Thayer, 3 Metc. 76, 37 Am. Dec. 117. But the reversion nay be granted and the rent re- 
served, or the rent may be assigned, reserving the reversion, if 'such is the intention of the parties as expressed in the words they use. Lord Coke says that fealty is an incident inseparably annexed to the reversion, and the donor or lessor cannot grant the reversion and save to himself the fealty; but the rent he may except, because the rent, though it be an incident, yet is not inseparably incident. Co. Lit. 143a, 151b; 3 Cruise, Dig. 337; Demarest v. Willard, 8 Cow. (N. Y.) 206. Heyer Brothers therefore could have granted their reversion, or surrendered it to the plaintiff and reserved the rent accruing upon the under leases. In such a case, their relations to the sub-lessees would not be changed by the grant or surrender of the reversion, and they could have recovered rent of this defendant upon the covenants of its lease. Having that estate reserved in the premises, they could have assigned it to a third party or to the plaintiff, and the assignment would have been good, and the defendant would have been bound to pay to the assignee rent for the estate held under its lease. This form of proceeding was not adopted by the parties, but the same result was accomplished. As the assignments were simultaneous with the surrender, Heyer Brothers did not in terms reserve the rent to themselves, but the plaintiff accepted the surrender in consideration of the assignment, with the express stipulation that it should not prejudice the underleases assigned to him; that is, should not invalidate the assignment, or affect the rights of the parties holding the leases.

The case is not presented, what would be the rights of Heyer Brothers against this defendant; or what would be the rights of the plaintiff, if he had not taken an assignment of the underleases, and had accepted a surrender without qualification. The two cases of Grundin v. Carter, 99 Mass. 15, and Webb v. Russell, 3 T. R. 393, relied on in support of the proposition of the defendant, have no application to the facts here presented.

Exceptions overruled. ${ }^{17}$

$17 \mathrm{~A}$. leased premises to B., who subleased to C. B. surrendered his reversion to A. C. then paid A. a month's rent. Held, this establishes the relation of landlord and tenant between $A$. and C., according to the terms of the B.-C. lease. McDonald r. Mar, 96 Mo. App. 236.69 S. W. 1059 (1902). See, also, Bailey r. Richardson, 66 Cal. 416, 5 I'ac. 910 (1S85); Appleton v. Ames, 150 Mass. 34,22 N. E. 69, 5 L. R. A. 206 (1Ss9); Latta r. Weiss, 131 Mo. 20,30 S. W. 1005 (1895); Krider v. Ramsey, 79 N. C. 354 (1S7S); Hessel v. Jolnnson, 129 Pa. 173, 18 Atl. 754, 5 L. R. A. 851, 15 Am. St. Rep. 716 (1S89). Compare Rochester Lodge No. 21, A. F. \& A. M., F. Graham, 65 Minn. 457, 68 N. W. 79,37 L. R. A. 404 (1S96). 


\title{
SECTION 2.-SUSPENSION AND APPORTIONMENT OF RENT'S
}

\author{
WHITE et al. v. MOLYNEUX.
}

\author{
(Supreme Court of Georgia, 1S47. 2 Ga. 124.)
}

\begin{abstract}
NisBet, J. ${ }^{18} * * *$ This was an action for rent, to which the defendant pleaded the destruction of the house rented, by fire. Upon motion the Court ordered the plea to be stricken out, and error is assigned upon that decision. We consider this question as conclusively settled in England and the United States, if authority can settle anything. It is well settled, that neither a court of law, nor of equity, will relieve against an express contract to pay rent upon the ground that the premises have been destroyed by fire, or the King's enemies, or any casualty whatever, unless that is an express stipulation to that effect. Inevitable accident will excuse a party from a penalty, but will not relieve him from his covenant to perform. 1 Dyer, 33 a; 3
\end{abstract} Kent, 468.

And an eviction of the tenant upon a title paramount to the landlord's, will excuse the tenant from payment of rent. Idem, Auct.; also, Crabb's Law of Real Property, t. p. 152; Gilb. Rents, 145.

By the law of Scctland, upon the hire of property, a loss or injury to that property, which is not occasioned by the fault or negligence of the hirer, falls upon the owner; and the lessee is entitled to an abatement of the rent in proportion to any partial destruction of the strbject. 1 Bell's Com. 452. A similar doctrine prevails in Louisiana. Civil Code of Louisiana, art. 2667. And in France by the Code of Napoléon. Code Nap. art. 1722. Puffendorff considers this a plain principle of natural law, founded in eternal justice. Puff. book 5 , ch. 6 , sec. 2 . By the civil law the prætor would exempt the tenant from paying rent, or modify the obligation according to equity, when the property was destroyed by fire, inundation or violence, or the crops failed by bad seasons. Dig. 19, 2, 15, 2; Code, 4, 65, S. In a case in England, Brown v. Quitter, Lord Northman thought it very clear, that a man should not pay rent for what he cannot enjoy, if occasioned by an accident which he did not undertake to meet. Amb. R. 619. Indeed the Courts of Equity in England for a long time struggled against a contrary doctrine. See Harrison v. North, $1 \mathrm{Ch}$. Cas. 83; Steel v. Wright, 1 T. R. 708, note. The question whether a Court of Equity would grant relief against a landlord's claim for

18 The statement of facts and part of the opinion are omitted. 
rent has been set at rest in England, in Hare v. Grove, 3 Anst. R. 687, and Holtzapffel v. Baker, 18 Ves. Jr. 115, and Leeds v. Chatham, 1 Simon, i46. See also, Lamott v. Sterett, 1 Har. \& J. (Md.) 42.

The reason in equity is, that in case of the destruction of the property, the loss of the rent must fall somewhere, and there is no more equity that the landlord should bear it than the tenant, when the tenant has expressly agreed to pay it, and when the landlord must bear the loss of the property destroyed. Equity considers the calamity mutual. She will not interfere to relieve against the express contract of the tenant. So that, notwithstanding the opinion of Puffendorff, the authority of the civil law, and even some adjudications in England and in this country, we consider the rule established as we at first laid it down.

As early as the reign of Henry VIII this question was mooted at law, and in the case of Taverner it was left unsettled. 1 Dyer's R. 55 , 56. In the reign of Charles I, the Court of King's Bench held, that where the rentor had been driven from the premises by public enemies, viz. Prince Rupert and his soldiers, he could not plead it in bar of the rent. Chancellor Kent, after reviewing the authorities, declares: "It is well settled that, upon an express contract to pay rent, the loss of the premises by fire, or inundation, or external violence, will not exempt the party from his obligation to pay rent." Hallett v. Wylie, 3 John. (N. Y.) 44 ; 4 Taunt. R. 45; Pollard v. Shaaffer, 1 Dall. 210, 1 L. Ed. 104; Fowler v. Bott, 6 Mass. 63; Wagner v. White, 4 Har. \& J. (Md.) 564; Gates v. Green, 4 Paige (N. Y.) 355, 27 Am. Dec. 68; 3 Kent, 466; 1 Dyer R. 33; 6 T. R. 650; 6 T. R. 750; 2 Stra. R. 763; 1 Story, Com. secs. 101, 102.

The reasons upon which the decisions at law have gone, are, that it is competent for a party, in his contract, to stipulate against payment in case of fire, or other casualty, or violence; and, having failed to do so, he cannot take advantage of his laches. The contract is an executed one; the tenant is in the position of a purchaser of the premises for the term; he is let into the possession, and the landlord has no right to enter or in any way molest him. And, as in all other express, unconditional contracts, both parties must abide their solemn act.

The rule, too, is not without foundation in policy. It secures, on the part of the tenant, that carefulness and vigilance which is necessary to the safety of the owner's property whilst he is out of possession, and whilst it is under the absolute control of one who has only a temporary interest in it. If the destruction by fire would excuse the payment of rent, then might the tenant, so far as pecuniary interest is concerned, become careless to protect it. The owner would be left to rely upon the tenant's sense of moral obligation, which unfortunately is not, in all me11, so just or so strong as to constrain them to do right. Indeed there are men to be found base enough to burn down 
a house, to get rid of the payment of rent, if their interest might thereby be subserved. The contrary of this rule would therefore operate in restraint of renting.

Let the judgment of the Court below be affirmed. ${ }^{10}$

\section{WATTLES v. SOUTH OMAHA ICE \& COAL CO.}

(Supreme Court of Nebraska, 1897. 50 Neb. 251. 69 N. W. 785, 36 L. K. A. 424,61 Am. St. Rep. 554.)

[The plaintiff leased to one Cotton a tract of land with six ice houses on it adjacent to a lake, reserving a rent of $\$ 100$ per month. Cotton assigned his interest to the defendant, who took possession of the premises and began using them for the purpose of its ice business. During the term the ice houses were totally destroyed by a violent hurricane. The land with the ice houses was worth $\$ 1,200$ a year rental; without them it was worth $\$ 600$ a year rental. The plaintiff claimed the rent as reserved by the lease; the defendant insisted that it was entitled to an apportionment of the rent until the buildings were rebuilt by the lessor. The case was submitted upon an agreed statement of fact.]

RAGAN, C. ${ }^{20}$ [After holding that the lessee was under no obligation to rebuild the ice houses:]

A lease for real estate is not a bargain and sale for a given time of the lessor's interest in the leased premises. It is rather a hiring or letting of property for a certain time, and for a named consideration; and, when a lessee covenants to pay rent for a term, the consideration for that covenant is his right to the use and occupancy of the thing leased. In the covenant of a lessee to pay at stated times certain sums of money for the rent-that is, for the privilege or the right to use and occupy the leased premises-is involved the condition that such leased property shall be in existence, and be capable of being used and enjoyed by the lessee. The promise to pay a stated sum of money as rent for leased premises for a certain term is based upon the presumption that the leased premises shall exist for the term. In the case at bar if the lessee had been evicted from part of the demised

19 Acc.: Monk v. Cooper, 2 Str. 763 (1727), corenant; Baker r. Holtpzatfel, 4 Taunt. 45 (1S11), assumpsit for use and occupation; Fowler $\nabla$. Bott, 6 Mass. 63 (1809); Arbenz v. Exley, 52 W. Va. 476, 44 S. E. 149, 61 L. R. A. 957 (1903).

"A lease for sears is a sale of the demised premises for the term. * * The rent is, in effect, the price or purchase money to be paid for the ownership of the premises during the term, and their destruction or any depreciation of their value, happening without fault of the lessor, is mo ibatement of his price. but entirely the loss of the purchaser." Sewall, J., 12 Fowler r. Bott, supra.

See Felix v. Griffiths, 56 Ohio St. 39, 45 N. E. 1092 (1S97).

20 Part of the opinions are omitted.

Brg.Rigits-:3i 
premises by the holder of a title paramount to that of the lessor's, the lessee would be entitled to an apportionment of the rent. Tayl. Landl. $\&$ Ten. $\S 387$, and cases there cited.

Under the exception established to the rule, had the entire leased premises been washed away by a flood, the relation of landlord and tenant existing between the parties to this suit would have from that moment ceased. This relation would not have been terminated by the act of the parties, but by operation of law; and the lessee would have been relieved from the payment of rent accruing thereafter, upon the principle that the consideration for his promise to pay such rent had failed. If we look to the subject-matter of the lease under consideration, and the language employed by the parties in making the contract, we cannot say that either of these parties, at the time they made this lease, had in contemplation the fact that the leased premises, or any part thereof, might be destroyed by a hurricane. They did not contract with reference to such a casualty. To use the language of McKean, C. J., in Pollard v. Shaffer, supra, had the lessor been asked at the time this lease was made, "Is it your intention to hold the lessee liable for the entire rent reserved in case the leased buildings shall be destroyed by cyclone?" he doubtless would have answered that he had never considered that contingency. If the question had bcen asked the lessee whether it was his intention to pay the entire $\$ 6,000$ rent even if one-half of the leased property should be destroyed before the expiration of the term, it is very probable that he would have said that he had no such an intention. Yet, in construing this contract, we must, if possible, give effect to the intention of the parties, notwithstanding the common-law rule of construction. To us it seems that the lessor, in effect, said to the lessee: "I own this tract of land, and these ice houses. They are in good repair. They are fit for the purposes of harvesting and storing ice. I will hire them to you for five years if you will pay me twelve hundred dollars per year, and keep the premises in good repair." To this the lessee assented. This was an offer and a promise upon the part of the lessor to furnish for the entire time the hired property. It was a promise and a covenant upon the part of the lessee to pay the monthly installments of rent for the right to use and occupy the hired property, if it existed. But it was not a proposition on the part of the lessor to quitclaim his right to the use and occupancy of the leased premises to the lessee for five years, in consideration of $\$ 6,000$ paid or to be paid by the latter. $* * *$

We reach the conclusion that the common-law rule of construction under consideration is not in force in this state, and formulate the rule as follows: Wherc a substantial portion of leased premises is destroyed without the fault of the lessee, he is entitled to an apportionment of the rent covenanted to be paid and accruing thereafter, in the absence of an express assumption by him of the risk of such 
destruction. The decree appealed from is reversed, and the cause remanded, with instructions to the district court to enter a decree in accordance with this opinion. Reversed and remanded.

Invise, C. (dissenting). $* * *$ We think the law is exactly stated in a very exhaustive opinion by Willard, J., in Coogan v. Parker, 2 S. C. 255 , to the effect that, where there is a substantial destruction of the subject-matter of the lease by act of God or the public enemy, the tenant may elect to rescind, and, on surrendering, shall be discharged from the payment of the rent; but unless he èlect to rescind by surrender, or offer to surrender, he must pay the rent according to his covenant, and that, in determining what amounts to a substantial destruction of the subject-matter, the nature of the premises and the use which the parties intended should be made thereof are to be considered. This doctrine reconciles cases supporting the general rule announced with those holding that where a room in a building is let, and the building is destroyed, the rent is extinguished, because in such a case there has been a complete eviction or surrender. Where, however, there has been only a partial destruction, and the lessee sees fit to continue the lease, and remain in possession, he must so do according to its terms, and pay the rent reserved.

Post, C. J., and Ryan, C., concur in the foregoing dissenting opinion. ${ }^{21}$

\section{GRAVES v. BERDAN.}

(Court of Appeals of New York, 1863. 26 N. Y. 49S.)

Action begun in the City Court of Brooklyn to recover rent. In May, 1856, defendant leased from plaintiff, for a term of years, rooms and passage-ways in the basement, and on the second floor of the City Central Hall, in Brooklyn, at the yearly rent of $\$ 2,700$, payable quarterly. The building was also occupied by other lessees of apartments. On May 6, 1857, the building was destroyed by fire. Soon after, plaintiff entered upon the land and removed the ruins of the building, and defendant removed the machinery, brickwork and materials which he had put in, and plaintiff afterward erected a building one story high, upon a portion of the same ground, beneath a part of the premises leased to defendant, but not reaching up to, encroaching upon, or including any part of the space leased to defendant. After the fire the premises (except as above stated) remained vacant, and were not used or occupied by either party. The lease contained no stipulation on the part of either landlord or tenant for rebuilding. The court ordered judgment for plaintiff, and on appeal to the Supreme Court, the judgment was reversed and plaintiff appealed.

21Acc.: Coogan v. Parker, 2 S. C. 255, 16 Am. Rep. 659 (1S71). 
Rosekrans, J. ${ }^{22}$ The opinion delivered by Justice Emott in this case, in the Supreme Court, is a correct exposition of the law applicable to it, and for the reasons stated therein, the judgment should be affirmed. The case of Stockwell v. Hunter, 11 Metc. (Mass.) 448, 45 Am. Dec. 220, may be added to the authorities cited by Justice Emott to show that a lease of basement rooms, or chambers, in a building of several stories in height, without any stipulation, by the lessor or lessee, for rebuilding, in case of fire'or other casualties, gives the lessee no interest in the land upon which the building stands, and that if the whole building is destroyed by fire, the lessee's interest in the demised rooms is terminated, and the lessor may, after the destruction of the building, enter upon the soil and rebuild upon the ruins of the former edifice.

It may be added that at common law, where the interest of the lessee in a part of the demised premises was destroyed by the act of God, so that it was incapable of any beneficial enjoyment, the rent might be apportioned. In Rolle's Abr. 236, it is said that if the sea break in and overflow a part of the demised premises, the rent shall be apportioned, for though the soil remains to the tenant, yet, as the sea is open to every one, he has no exclusive right to fish there. A distinction is taken between an overflow of the land by the sea, and fresh water, because, though the land be covered with fresh water, the right of taking the fish is vested exclusively in the lessee, and in that case the rent will not be apportioned. In the latter case the tenant has a beneficial enjoyment, to some extent, of the demised premises, but in the former he has none, and if the use be entirely destroyed and lost, it is reasonable that the rent should be abated, because the title to the rent is founded on the presumption that the tenant can enjoy the demised premises during the term. Com. Landl. \& Ten. 218; Cillb. Rents, 182.

Where the lessee takes an interest in the soil upon which a buildin's stands, if the building is destroyed by fire, he may use the land upon which it stood, beneficially, to some extent, without the building, or he nay rebuild the edifice; but where he takes no interest in the soil, as in the case of a demise of a basement, or of upper rooms in the building, he cannot enjoy the premises in any manner after the destruction of the building, nor can he rebuild the edifice. He cannot have the exclusive enjoyment of the vacant space formerly occupied by the demised rooms. The effect of the destruction of the building, in such a case, is analogous to the effect of the destruction of demised premises by the encroachments of the sea, mentioned in Rolle's Abr.; and the established rule for the abatement or apportionment of the rent should be applied in the former as well as in the latter case. The same reason exists for its application in both cases.

22 Dissenting opinion of Wright, J., is omitted. 
But even if the lessee's interest in the demised apartment, in a case like this, was not terminated by the total destruction of the building, it may be doubted whether the lessor could recover rent so long as he failed to give to the demised upper rooms the support necessary to them for special enjoyment. The rule seems to be settled in England, that where a house is divided into different floors or stories, each occupied by difierent owners, the proprietor of the ground floor is bound, by the nature and condition of his properiy, without any servitude, not only to bear the weight of the upper story, but to repair his own property so that it may be able to bear such weight. 'The proprietor of the ground story is obliged to uphold it for the support of the upper story. Humphrey v. Brogden, 12 Q. B. $739 ; 1$ Eng. Law \&. Eq. 241; Rowbothem v. Wilson, 36 Eng. Law \& Eq. 236; Harris v. Roberts, 6 El. \& B1. 643; 7 El. \& B1. 625. In the case last cited the duty of such support is recognized as a general commonlaw right. In a lease of upper roons by the owner of the entire building, a covenant should be inplied on the part of the lessor to give such support to the upper rooms as is necessary for their beneficial enjoyment. It has been decided in this court that the statute forbidding the implication of covenants in conveyances of real estate, does not apply to leases for years. Mayor, etc., v. Maybee, 13 N. Y. 151, 64 Am. Dec. 538 ; Vernam v. Smith, 15 N. Y. 332, 333.

The judgment should be affirmed. ${ }^{23}$

Denio, C. J., and Selden, Balcom and Marvin, JJ., concur.

\section{FITCHBURG CO'TTON MANUFAC'TORY CORPORATION v. MELVEN et al.}

(Supreme Judichal Court of Massachusetts, 181S. 15 Mass. 268.)

This was an action of covenant broken, upon an indenture made by and between plaintiffs and the defendants on the 10th of June, 1816, by which the plaintiffs demised to the defendants certain buildings and mill privileges, with tools and machinery in the buildings, for the manufacture of woollen cloths, for the term of three years from the date of the indenture, "yielding and paying therefor the rent of $\$ 275$

23Acc.: McMillan v. Solomon. 42 Ala. 356, 94 Am. Dec. 654 (1S6S). Compare Izon v. Gorton, 5 Bing. N. C. 501 (15:9); 'Taylor r. Caldwell, 3 B. \& s. S.6 (1S63) ; Roberts v. Lynn Ice Co., 187 Mass. 502, 73 N. E. 523 (1905).

If after such destruction the lessee attempts to occupy the same space, he may be evicted therefrom. Winton $v$. Cornish, 5 Ohiu, 177 (153\%); Harrington v. Watson, 11 Or. 143, 3 I'ac. 173, 50 Am. Rep. 465 (1853).

A. executed to B. a "lease" of "the river front and lauding in front of" certain lots owued by A. in Memphis. A flood in the river washed aray all of A.'s land but a narrow strip, wholly destroyed the landing, and rendered the formation of a landing or the wooring of boats impossible. Held, $B$. is no longer liable for the rent reserved. Waite v. O'Neil, 76 Fed. 40s, $22 \mathrm{C}$. C. A. 248, 24 L. R. A. 550 (1S96). 
annually during the term aforesaid." The breach was alleged in the non-payment of one year's rent, due on the 10th of June, 1817.

The defendants pleaded, in bar that, before the making of the indenture, the plaintiffs had mortgaged all the demised premises, excepting tools and machinery, to one Edmund Cushing, to secure the payment of their promissory note to him; and that on the $2 \mathrm{~d}$ of November, 1816, the said note being then due and unpaid, Cushing entered for the condition broken, and evicted the defendants. The same facts were pleaded in a second plea, in bar of damages, except for a ratable and meet sum for the rent of the tools and machinery; and in a third plea, in bar of damages for the rent of that part of the demised premises which had been mortgaged, for any time after the $2 \mathrm{~d}$ of November, 1816 . The plaintiffs demurred to each of these pleas; and the defendants joined in demurrer.

JACrson, J. We are all of opinion that the first plea in bar is good, and that the plaintiffs are not entitled to recover anything in this action. If the rent had been payable quarterly, the sum due for the first quarter might have been recovered, notwithstanding the subsequent eviction; but as the tenants were evicted before the first day of payment, no rent can be recovered upon the indenture.

The result is not influenced by the circumstance that Cushing, who evicted the defendants, was a mortgagee. It is enough that he entered under a title paramount to that of the lessors. If the lease had heen made before the mortgage, Cushing would have bcen assignee of the reversion, and in that character entitled to all the rents payable by force of the indenture, excepting only such as might have been paid by the lessees before notice of the assignment. He could not, in that case, have evicted the tenants, but would have held subject to their lease. But when the lease is made, as in this case after the mortgage, it does not bind the mortgagee, nor in any manner affect his right. There is no privity between him and the lessee, and no right in him to demand the rent reserved by the lease. He may consider the lessee as a trespasser or a disseisor, and may maintain an ejectment or writ of entry against him. The lessee stands in the situation of the mortgagor; and as the mortgagee cannot recover the back rents against the mortgagor, when he is left in possession, it seems to be the better opinion that he could not recover, in the like case, against the lessee of the mortgagor.

It may often happen that the lessee will suffer a loss, by being evicted, that would overbalance the advantage of holding the premises for a part of the term. In such a case, equity would concur with the rule of law which prohibits an apportionment of the rent. But if the lessee has derived a substantial.benefit from the use of the estate demised, although he does not hold it for the whole term, equity would require that he should pay a quantum meruit. If the lessors, in the present case, have any claim on that ground, their only remedy must be an action of assumpsit; as in the analogous case of a charter- 
party of affreightment. In that case, when the ship is prevented by the perils of the sea from carrying the goods to the destined port, and they are received by the owner at an intermediate place, the latter is not liable to an action of covenant on the charter-party; but it was thought, in a case of that kind, that he might be held, in an action of assumpsit, to pay a reasonable compensation for the services of the ship owner, as far as they were performed, and so far as he was benefited by them.

Some doubts have arisen, whether the plaintiffs may not recover in this action for the rent or use of the tools and machinery, which were not included in the mortgage to Cushing. When a part of the land is evicted, and the residue is enjoyed by the lessee, it is a discharge only in proportion to the value of the land evicted. But in the case at bar, the tools and machinery cannot be considered as a distinct, substantial part of the estate demised. They are in the nature of mere appurtenances to the mill and the buildings, and to be used in them for the manufacture of woollen cloth. They would apparently have been of no use to the defendants, unless in connection with the buildings; and the eviction of these latter seems, therefore, to amount to an eviction of the tools and machinery likewise. The plaintiffs may probably recover a reasonable compensation for the loan or use of the tools and machinery, in an action of assumpsit; but they cannot recover it in this action.

PER CuRIaM. Defendants' plea in bar good. ${ }^{2+}$

\section{SEABROOK v. MOYER.}

\section{(Supreme Court of Pennsylvania, 1S79. SS Pa. 417.)}

MERCUR, J. ${ }^{25}$ This was an action of debt for the rent of certain premises demised by plaintiff to defendant. The term was for three years from January 1st, 1874 , at an annual rental of $\$ 3,000$ payable monthly. The narr. contained two counts, one on a demise at $\$ 250 \mathrm{a}$ month, the other for use and occupation. The premises leased consisted of a building fronting on Market street, with a right of way over an alley, of three feet two inches in width, between the leased building

24Acc.: Friend v. Oil Well Supply Co., 165 Pa. 652, 30 Atl. 1134 (1595).

A: leascd to $B$., with a corenant and condition against using the premises for purposes forbidden by the insurance policies. B. subleased to $\mathrm{C}$., who subieased to D.; both subleases haring the same provisions as the head lease. D. violated tine provisions. A. trought ejectment against B., C., and D., and recovered judgment. D. thereupon abandoned the premises, learing the key with $C$. In an action by $C$. against $D$. for rent subsequently accruing, held, the eviction is a defense. Home Life Ins. Co. of Brooklyn $\mathrm{r}$. Sherman, $46^{\circ}$ N. Y. $370(1871)$.

See, also, Leopold v. Judson, 75 Ill. 536 (1S74); Russell v. Fabyan. 27 N. II. 529 (1S53); 28 N. H. 543, 61 Am. Dec. 629 (1S54); Giles v. Comstock, 4 X. Y. 270, 53 Am. Dec. 374 (1550).

25 The statement of facts is omitted. 
and the adjoining property. The defendant took possession and paid the rent up to 1 st February, 1875. In that month the adjoining ownerbegan to build, and in so doing he constructed a party-wall on eleven inches of his alley-way, thus reducing its width and also the width of the rooms in the second and third story of the building. This taking by the adjoining owner was by virtue of a written agreement entered into between him and the plaintiff before the execution of the lease between plaintiff and defendant. By the terms of that agreement the plaintiff and adjoiner had each relinquished to the other the right of way over the alley. In so far as the defendant was not deprived of the premises by this interference of the adjoining owner, he remained in possession of the building, but refused to pay any rent, claiming it to be such an eviction as discharged him from all obligation to pay. The plaintiff claimed the defendant remained liable on a quantum meruit for use and occupation. The court below ordered a judgment of nonsuit to be entered. That is assigned for error.

It is a well-settled rule that if a landlord wrongfully dispossesses his tenant of any portion of the demised premises the rent for the whole is thereby suspended. In the present case, the plaintiff committed no act after possession taken under the lease, by which his tenant was deprived of any part of the demised premises. On the contrary the evidence shows that he tried to prevent the eviction. His offence consisted in demising premises to the defendant to a portion of which he had no title at the time. The eviction of the defendant was by virtue of a title paramount to the title of his landlord. It matters not that the plaintiff previously held it. At the time the lease was executed and the relation of landlord and tenant between the parties was created, the outstanding title of the adjoiner was as superior to the title of the plaintiff as if he had never held it. If the defendant had been evicted by paramount title from the whole premises, he would have been discharged from the payment of the whole rent, after that time. But an eviction by such title, from a part only of the demised premises, when the tenant continues in possession of the remaining part, using and enjoying it, does not work a suspension of all subsequent rent. He remains liable to the payment of such proportion of the rent as the value of the part retained bears to the whole. On having been evicted from a part he might have removed from the residue and thereby wholly relieved himself from the payment of future rent: failing to do so, he became liable to a just apportionment. 'This conclusion is fully sustained in 'Taylor on Landlord and Tenant, § 378, and the English and American cases there cited.

Our own cases recognize the same rule when the landlord conveys a part of the demised premises during the term and possession of the tenant, and the vendee has entered and evicted the tenant from the part thus conveyed. By retaining possession of the remaining part he becomes liable to pay for the use of the portion thus retained. It is held not to be such a wrong ful eviction by the landlord as to release the 
tenant from paying a just compensation for that which he continues to enjoy: Reed v. Ward, 22 Pa. 144; Linton v. Hart, 25 Pa. 193, 64 Am. Dec. 691. The learned judge therefore erred in ordering a judgment of nonsuit.

Judgment reversed and a procedendo awarded. ${ }^{20}$

\section{PARKS v. CITY OF BOSTON.}

(Supreme Judicial Court of Massachusetts, 1834. 15 Pick. 198.)

This was a complaint presented to the Court of Common Pleas, praying that a jury might be empannelled to assess the damages sustained by the complainant in consequence of the taking of 313 square feet of land by the mayor and aldermen of Boston, on July 13, 1829, for the purpose of widening Doane street in that city.

The respondents admitted the taking of the land, but traversed the allegation in the complaint, that the complainant was damaged in his property thereby, and tendered an issue thereon, which was joined.

In the course of the trial, the respondents, in order to show that the complainant was not entitled to recover the full value of the land at the time when it was taken, and that they were liable to pay one Enoch Patterson, who had preferred a complaint against them, for the loss of the use of the land taken, from the time when it was taken until January 1, 1832, proved the execution of a lease of the land taken and of other lands, which was made by the complainant to Patterson before the taking of the land, by virtue of which lease Patterson was entitled to hold such lands for the term of three years from January 1,1829 , at an annual rent of $\$ 725$; and thereupon they contended, that, inasmuch as the complainant would be entitled to recover such rent of Patterson during the continuance of the lease, a deduction should be made by the jury on this account, from the value of the land. The judge instructed the jury, that part of the land leased having been taken by law for the use of the public, without the consent of the complainant or Patterson, the lease was thereby determined;

26Acc.: Stevenson v. Lombard, 2 Fast. jij (1S02); Fifth Are. Bldg. Co. v, Kernochan, 221 N. Y. 370,117 N. L. 579 (1917).

"The question is, Whether the rent be apportionable in this action of corenant by the lessor against the assignee of the lessee? It clearly is so in an action of debt or upon an avowry in replevin, by all the authorities; and the only question Is, Whether it be so in corenant? In covenant as between lessor and lessee, where the action is personal, and upon a mere privi$t y$ of coutract, and on that account transitory as any other personal contract is, the rent is not apportionable." Sterenson v. Lombard, 2 East, 579 (1802).

Compare Swansea v. Thomas, I. R. 10 Q. B. D. 48, 52 (1S82). See l'oston v. Jones, 37 N. C. 350 . 38 Am. Dec. 653 (1S42).

As to the method of computing proportionate values, see Tomlinson v. Day, 2 Brod. \& B. 680 (1821); Carter v. Burr, 39 Barh. (Y. Y.) 59 (1S62). 
that the complainant could not compel Patterson to pay such rent; that the city would not be liable to pay Patterson any damages on account of his having covenanted to pay the rent to the complainant; and that the complainant was entitled to recover against the city the $\mathrm{f}$ ull value of the land taken, as if it had not been leased.

To this ruling the respondents excepted. $* * *$

Shaw, C. J. ${ }^{27} * * *$ But I presume this supposed effect of determining the term is thought to result from the other branch of this opinion, which is, that by the act of thus taking away a part of the leased estate, the tenant would be exempted from the payment of the reserved rent, and therefore the landlord ought to receive an equivalent in his compensation from the public. If such were the effect, the inference would undoubtedly be correct.

But upon what principle can it be maintained, that a lessee under such circumstances would be exempted from the payment of the stipulated rent? The lessee takes his term, just as every other owner of real estate takes title, subject to the right and power of the public to take it or a part of it, for public use, whenever the public necessity and convenience may require it. Such a right is no incumbrance; such a taking is no breach of the covenant of the lessor for quiet enjoyment. The lessee then holds and enjoys exactly what was granted him, as a consideration for the reserved rent; which is, the whole use and beneficial enjoyment of the estate leased, subject to the sovereign right of eminent domain on the part of the public. If he has suffered any loss or diminution in the actual enjoyment of this use, it is not by the act or sufferance of the landlord; but it is by the act of the public, against whom the law has provided him an ample remedy. If he is compelled to pay the full compensation for the estate actually diminished in value, this is an element in computing the compensation which he is to receive from the public. In this view, it becomes unimportant, in settling the principle we are now discussing, whether the taking for public use diminishes the leased premises, little or much, in quantity or in value; all this will be taken into consideration in assessing the damages, which the lessce may sustain.

But it was contended on the part of the complainant, and authorities were cited to show, that where a covenant is to do any act, lawful at the time the covenant is made, but which becomes unlawful afterwards, the covenantor is excused from the performance. This principle is correct, but I cannot perceive that it has any application to the present case. For instance, if one should covenant with the owner of a lot of land to build a warehouse upon it, at a future time, and before the time a street should be laid over it, so that it would become unlawful to build upon it, the covenant would be repealed; and it would probably follow, that the corresponding covenant on the other side to pay for such building would be considered repealed also. But

${ }_{27}$ The statement of facts is abridged and part of the opipion is omitted. 
nothing renders it unlawful for the tenant in the present case, to use, occupy and enjoy the leased premises, subject only to the public easement. To the extent of the property not taken he has still the beneficial use; if its value is diminished by the taking, to that extent he has his compensation from the public, and thus he has still an equivalent for his rent paid.

Upon these grounds, we are of opinion, that the lease from the complainant to Patterson was not dissolved by the act or taking part of the leased premises to widen a public street; that Patterson, notwithstanding such taking, continued liable to pay the reserved rent, during the term which remained unexpired $; 28$ and that the jury should have been instructed to take that fact into consideration, in estimating the damages which the complainant had sustained, by such taking.

The result is, that the exceptions taken by the city are sustained, that the verdict in the writ below is set aside, and that the cause is to be tried at the bar of this Court.

\section{BIDDLE v. HUSSMAN et al.}

\section{(Supreme Court of Missouri, 1S56. 23 Mo. 597.)}

[The plaintiff owned a lot in the city of St. Louis. He leased this to the defendant for a term of years, reserving rent. During the term, part of the land was condemned by the city of St. Louis and appropriated to public uses. The plaintiff brought action for the rent reserved, accruing after the condemnation and appropriation, and a judgment was obtained below for the whole rent. The defendant appealed.]

LEONARD, J. * * * The judgment must be reversed and another trial had. The question will then come up as to the effect of the subsequent condemnation of the lot upon the respective rights of the landlord and tenant. The interests of both these parties in the lot were equally within the protection of our constitution. Both were owners within the meaning of the statute authorizing the condemnation, so that the interest of neither could be taken without a just compensation. If the rights of the parties had remained as they were originally before the making of the deed to the city, and the whole of the leased premises had been applied to the public use, we think the condemnation would have divested all rights of private property in the lot, and have thus extinguished the whole rent issuing out of it. ${ }^{29}$ The con-

28 Acc.: Stubbings v. Village of Evanston, 136 Ill. 37,26 N. E. 57T, 11 L. R. A. $\$ 39,29 \mathrm{Am}$. St. Rep. 300 (1ৎ91); Gluck v. Baltimore, S1 iId. 315, 3: Atl. 515,48 An. St. Rep. 515 (1S95).

29 Acc.: Corrigan v. City of Chicago, 144 Ill. 537,33 N. E. 746, 21 L. R. A. 212 (1893); O'Brien v. Ball, 119 Mass. 2S (1874); Lodge v. Martin, 31 App. Div. $13,52 \mathrm{~N}$. Y. Supp. 385 (189S). Contra: Foote v. City of Cincinnati, 11 Ohio, 408, $38 \mathrm{Am}$. Dec. 737 (1S42). 
demnation was a reassumption by the state of her original title to the land under her right of eminent domain. It was a revocation of the landlord's title, and may well be considered as extinguishing all rights depending upon the continuance of that title. This revocation was effected by law without the fault of either party, and could only be upon a just compensation to both parties, according to their respective rights in the property. The landlord was entitled to the present value of his reversion, and of the rents that were to become due to him during the continuance of the term, and the tenant to the present value of his leasehold interest over and above the rents payable during the term. The public, upon the resumption of the land, must pay the present value of the property, which is to be distributed between the landlord and tenant according to their respective interests. Ellis v. Welch, 6 Mass. 250, 4 Am. Dec. 122. In the present case, however, only part of the lot was taken, and the effect of this partial application, we think, was to apportion the rent, extinguishing it in respect to the part taken, and leaving it subsisting as to the residue. This was so held in the case of Cuthbert v. Kuhn, 3 Whart. (Pa.) 357, $31 \mathrm{Am}$. Dec. 513, although a different view of the matter seems to have prevailed in Parks v. Boston, 15 Pick. 198. We concur, however, in the last case, so far as it holds that the condemnation of part of the leased premises does not extinguish the whole rent; and that seems to have been the matter to which the attention of the court was mainly directed, although the case, perhaps, may be considered as laying down the doctrine that in such a case there can be no apportionment, but that the tenant must continue liabie under his personal contract to pay the whole rent, and be indemnified against this continuing liability in an additional compensation to be allowed him by the public on that account. 'The condemnation of the whole lot, it must be admitted, discharges the lot from the rent, so that the rent ceases thereafter to issue out of the land. If the rent must be considered as still subsisting on account of the personal obligations of the original lessee to pay it, the lessor, in case of the insolvency of the former, might justly complain that he had been deprived of his rights without compensation. And so, in like manner, wie think the consideration [condemnation] of part of the lot discharges it from a proportionate part of the rent, and extinguishes it accordingly. ${ }^{30}$ This apportionment must be made by the jury, who will determine whether any thing, and how much, is due, and have reference, in making their estimate, to the real value of what is left to the tenant, and not to the quantity; and the plaintiff will recover accordingly. Gilbert on Rents, 190.

\section{Judgment reversed. ${ }^{31}$}

80 Acc. : Board of Levee Com'rs v. Johnson, 66 Miss. 248, 6 South. 199 (1889). See Folts v. Huntley, 7 Wend. (N. Y.) 210 (1831).

31 Compare lihode Island Itospital Trust Co. v. Hayden, 20 R. I. 54\%, 40 Atl. 421,42 I. R. A. 107 (1808). 


\section{LAWRENCE v. WHITE.}

(Supreme Court of Georgia, 1909. 131 Ga. 840, 63 S. E. 631, t9 L. R. A. [N. S.] 966,15 Ann. Cas. 1097.)

Janes B. White leased to Bryan Lawrence a hotel in the city of Augusta known as the "Albion Hotel" for the term of five years, to begin on the opening of the hotel for the reception of guests not later than April 20, 1901, with privilege of renewal. The stipulated rent was $\$ 10,000$ per annum, payable in monthly installments of $\$ 833.33$. The only portions of the written contract of lease which need be set out are as follows: "The leased premises consist of the corridor, office, bar, barber shop, cigar stand, billiard room, on the first floor. * * * "The lease was renewed after the first term for five years more.

On August 6, 1907 (Laws 1907, p. 81). an act passed by the Legislature was approved prohibiting the manufacture or sale of alcoholic, spirituous, malt, or intoxicating liquors in the state after the expiration of that year. After this act became operative, the lessee claimed that he was entitled to an apportionment and reduction of the rent, because of his inability to further conduct the business of a bar in the hotel. * * * The lessor declined to allow any abatement in the rent, and sued out a distress warrant for the past-due rent at the monthly rate stipulated,. and also a dispossessory warrant, for the purpose of evicting the lessee from the premises on account of the failure and refusal to pay the rent without abatement. The lessee thereupon filed an equitable petition, claiming an abatement of the rent to be made in proportion of the diminution in rental value because of the legal impossibility of operating a barroom on the premises, and praying that the lessor be enjoined from prosecuting the actions at law commenced by him, and for process and general relief. *** On the hẹaring of the application for interlocutory injunction it was denied, and Lawrence excepted.

Lumpkin, J.32 1. The question in this case is whether the lessee of a hotel, including a barroom, was entitled to a reduction or proportional abatement of the agreed rental because during the term of the lease the Legislature of the state enacted a law prohibiting the sale of alcoholic, spirituous, malt, or intoxicating liquors, and thus the bar could no longer be used for that purpose. The adjudicated cases with unusual uniformity answer this question in the negative, though they do not all give the same reasons for the ruling.

It has been very generally held that the enforcement of public offcers of restrictions or conditions in regard to the use of leased premises does not amount to an eviction of the tenant. *** ['The court here cited and discussed Taylor v. Finnigan, 189 Mass. 568, 76 N. E.

82 The statement of facts is abridged and part of the opinion is omitted. 
203, 2 L. R. A. (N. S.) 973; Abadie v. Berges, 41 La. Ann. 281, 6 South. 529; Teller v. Boyle, 132 Pa. 56, 18 Atl. 1069; Baughman v. Portman (Ky.) 14 S. W. 342; Houston Ice \& Brewing Co. v. Keenan, 99 Tex. 79, 88 S. W. 197 ; Miller v. Maguire, 18 R.'I. 770, 30 Atl. 966; Kerley v. Mayer, 10 Misc. Rep. 718, 31 N. Y. Supp. 818; Newby v. Sharpe, L. R. 8 Ch. Div. 39; Nicholls v. Byrne, 11 La. 170; Gazlay v. Williams, 210 U. S. 41, 28 Sup. Ct. 687, 52 L. Ed. 950; Fleming v. King, 100 Ga. 449, 28 S. E. 239 ; Fitzgerald v. Witchard, $130 \mathrm{Ga}$. 552, 61 S. E. 227, 16 L. R. A. (N. S.) 519.]

It was urged that the lease now involved specifically named the bar, and that its operation was a material consideration entering into the lease of the hotel. * * * The mere use of the word "bar" in the lease did not amount to a covenant or warranty on the part of the landlord that the law would continue to allow the tenant to conduct the business of keeping a bar and selling liquors, or a covenant by the tenant that he would do so. * * *

It was argued that as to the bar the tenancy was terminated; and cases were cited to the effect that where an apartment in a building is rented, and the building is destroyed, the tenancy ceases (Gavan v. Norcross, 117 Ga. 356, 360, 43 S. E. 771); also, to sustain the contention that, if there is a substantial destruction of the subject-matter of the lease by the act of God or the public enemy, rent ceases (9 Cyc. $631)$; that eviction by the landlord results in suspension of rent, eviction by another from a portion of the premises, under paramount title, entitles the lessee to an apportionment of rent (24 Cyc. 1186-7); that, according to some authorities, if part of the premises are taken by condemnation under the power of eminent domain, the rent may be apportioned, and that to the general rule that a party to a contract is not discharged by subsequent impossibility of performance there is an exception where the performance becomes impossible by law ( 9 Cyc. 629-631; Civ. Code 1895, § 3725). These propositions, as abstract rules, do not require discussion. They do not aid the plaintiff in error, because they do not apply to the facts of this case. Neither the leased premises nor any part of them have been destroyed. No act of Providence or of the public enemy has affected the status. The only act complained of is that of the Georgia Legislature. There has becn no eviction of the tenant from the premises by the landlord or by one holding paramotunt title, and no condemnation of any part of them. Nor has the law prevented the carrying out of the written contract between these parties. An underlying error in the contention of the plaintiff in error arises from dealing with the contract of lease as different from what it really was. The landlord leased to the tenant a certain hotel, including a barroom, cigar stand, etc. The tenant contracted to pay certain rent, that the premises should be used for hotel purposes alone, and that it should be a first-class hotel, with other agreements not material now to recite.

The argument for the plaintiff in error treats the lease, so far as re- 
lates to the barroom, as a lease of the "bar privilege" or the right to sell liquor. Such is not the effect of the written lease. The landlord leased the premises to the lessee. So far as he was concerned as landlord, under the law as it then stood, he gave the lessee the privilege of using a portion of them for a bar or of subrenting. But he did not contract or warrant that the law would remain unchanged, or that there should be any diminution of rent, if a change occurred. It may be unfortunate for the lessee that he did not anticipate the possibility of the passage of a prohibition law and provide for such a contingency; but that he did not do so does not alter the contract as made. The lessee is still entitled to the occupancy and use of the premises. The landlord, who had nothing to do with making the sale of liquor by the lessee impossible under the law, is entitled to his rent. The law has not made it impossible to perform the contract of rental of premises. That must not be confused with the prohibition by law of selling liquor on the rented premises. See, on incidental injury from police laws, Menken v. City of Atlanta, $78 \mathrm{Ga} .668,2$ S. E. 559; State v. Griffin, 69 N. H. 1, 39 Atl. 260, 41 L. R. A. 177, 76 Am. St. Rep. 139.

Julgment affirmed.

\section{CIBEL \& HILLS' CASE.}

(Court of Common Pleas, 15ss. 1 Leon. 110.)

A lease was made of a certain house and land rendering rent, and another sum, nomine pœnæ; and for the nomine pœnæ the lessor 1)rought an action of debt; the lessee pleaded, that the lessor had entered into parcel of the land demised, upon which they were at issue. and found for the plaintiff: and now the lessor brought debt for the rent reserved upon the same lease: to which the defendant pleaded, ut supra, scil. an entry into parcel of the land demised: and issue was joyned upon it; and one of the jury was challenged, and withdrawn hecause he was one of the former jury: and the issue now was, whether the said Cibel the lessor, expulit \& amovit $\&$ adhuc extra tenet, the said Hills. And to prove the same, it was given in evidence on the defendint's part, that upon the land demised there was a brick-kill, and theretipon a little small cottage, and that the lessor entered, and went to the said cottage and took some of the bricks and untiled the said cottage: but of the other side it was said, that the lessor had reserved to himself the bricks and tiles aforesaid, which in truth were there ready made at the time of the lease made, and that he did not untile the brick-kill house, but that it fell by tempest, and so the plaintiff did nothing but came upon the land to carry away his own goods: and also he had used the said bricks and tiles upon the reparation of the house. And as to the extra tenet, which is parcel of the issue, the lessor did not continue upon the land, but went off it, and relinquished the pos- 
session: but as to this last point, it seemed to the court, that it is not material if the plaintiff continued his possession there or not, for if he once doth anything which amounts to an entry, although that he depart presently, yet the possession is in him sufficient to suspend the rent, and he shall be said, extra tenere the defendant the lessee, until he hath done an act which doth amount to a re-entry. And afterwards to prove a re-entry, it was given in evidence on the plaintiff's part, that the defendant put in his cattel in the field where the brick-kill was, and that the cattel did estray into the place where the defendant had supposed that the plaintiff had entered. And by ANDERSON, Justice, the same is not any re-entry to revive the rent, because they were not put into the same place by the lessee himself, but went there of their own accord. And such also was the opinion of Justice PEriam.

\section{i ROLLE'S ABRIDGMENT, 940, EXTINGUISHMENT, N, 1, 2.}

If a man leases a rectory for years reserving a rent and upon part of the glebe in a corner of the close is a sheep cote and the lessor enters and destroys this and the lessee re-enters and then the rent is in arrear, the rent is suspended notwithstanding the re-entry of the lessee in the toft; for part of the profit of the thing leased is taken from the lessee, namely, his house, and this by the act of the lessor. M. 37 El. [1595] B. R., per Popham and Gawdy.

If the lessor of a wood or orchard rendering rent cuts them down and the lessee re-enters, still the rent is suspended: quære as to this.

\section{CARRELL v. READ.}

(Court of Queen's Bench, 1595. Owen, 65.)

A lease for years was made of divers fenny grounds in Cambridge ss, and the lessee covenanted to defend the ground, for being surrounded with water, and to drain the water out of other lands that were demised to him in the said county. And upon an action of covenant for not performing, the defendant pleaded that the plaintiff had entered in the land demised. And adjudged no plea by the Court, because the covenant was not in respect that the lessee should enjoy the land, nor was it a covenant adhering to the land, but to a collat$\epsilon$ ral thing; but if it had been in respect of enjoying the land, there it is a good plea to say that the plaintiff had entered, but where the thing to be done is collaterall, it is otherwise, and also if he did plead such plea, yet it is not a bar, unlesse he holds him out of possession. Coke, lib. 3, 221; 4 Ed. 3, 29. The lord shall not have a cessavit after entry in parcel. 10 Ed. 4, 11 ; 35 H. 6; Bar. 162; 19 Ed. 4, 2."3

8.3Acc.: Newton r. Allin, 1 Q. P. 518 (1S41); Morrison P. Chadwick, 7 C. B. $266(1849)$. 
PAGE v. PARR.

(Cpper Beuch, 1654. Styles, 432.)

Page brought an action of covenant upon a covenant conteined in an indenture of a demise for years, for the not paying the rent reserved by the indenture, according to the covenant. The defendant pleads in bar that the plaintiff entered into part of the land demised before the rent due, for which the action was brought, and so had suspended his rent: the plaintiff replyed, the defendant did re-enter, and so was possessed as in his former estate, and to this replication the defendant demurred, and for cause he shewed, that here was no confession and avoidance, or traverse of the plea in bar.

Roll, Chief Justice. Have you shewed that he continued in possession until the rent grew due; for you ought to shew that he entered and was possessed until after the rent-day, but here you have only said that he was possessed in his former right, therefore nil capiat per billam, nisi.

\section{SMITH v. RAIEIGH.}

(Nisi Prius, 1814. 3 Camp. 513.)

Assumpsit for the use and occupation of a house and garden. Plea. the general issue.

It appeared, that after the defendant had agreed to take the premises at an entire rent, and possession had been delivered to him, the plaintiff railed off a part of the garden, and built a privy upon it, for the use of a number of his other tenants. The defendant thereupon returned the keys to him.

LoRd ELLFNBorougir ruled, that this amounted to an eviction from part of the demised premises; which the taking being single, and the rent entire, he considered a complete answer to the action.

Plaintiff non-suited. ${ }^{\text {4 }}$

¿4 This case was recognized by Dallas. J.. in Stokes v. Cooper, Worcester Lent Assizes, 1S14, in which the rule was laid down that, after eviction from part, the landlord cannot recorer unon the original contract, and the tenant, by giring up possession of the residue, is entirely discharged, but that, if the tenant, after the eviction, continues in possession of the residue, he may be linble upon a quantum meruit. V'ide Dalston v. Reeve, Ld. Raym. 77 (1697); Clun's Case, 10 Rep. $12 \mathrm{~S}$ (1613).-[Rcp.]

Big.RIGIITS-38 


\section{BENNETT v. BITTLE et al.}

(Supreme Court of Pennsylvania, 1834. 4 Rawle, 339.)

Error to the Court of Common Pleas of Delaware County.

In the court below, an action of replevin was brought by Lewis Bennett, the plaintiff in error, against William Bittle and Josiah Moore, the defendants in error, in which Moore made cognizance as the bailiff of Bittle, who avowed for rent in arrear. The plaintiff replied, no rent in arrear, and an eviction of part of the premises leased.

On the trial, the defendants gave in evidence a lease from William Bittle to Lewis Bennett, dated the 9th of February, 1830, of which the following are the material parts:

"Be it remembered, that William Bittle has leased to Lewis Bennett, the messuage, tenement or tavern-house, barn, sheds, \&c. with four lots of land, on the north-east side of the Westchester road, in the township of Haverford, and county of Delaware, known by the name of the Spread Eagle Tavern, to hold the same for one year from the first day of April next ensuing, the said Lewis Bennett yieTding and paying to the said William Bittle, the rent or sum of three hundred and seventy-five dollars, together with the price of the license for keeping the public house, and all the taxes that may be levied upon the said premises for the year 1829. It is further agreed to pay the rent half yearly."

After having proved that Bennett went into possession of the premises, under this lease, soon after the middle of April, 1830, and remained in possession until the last of March, 1831, the defendants closed their case.

The plaintiff then exanined several witnesses, from whose evidence it appeared, that about the first May, 1830, two men and a boy employed by Bittle, hauled manure out of the barnyard. They were hauling it the greater part of one day, and they afterwards returned to haul more. Bennett was not at home on the first day. He afterwards reproved Bittle for taking away the manure, who replied, he would do as he pleased. Some further dispute then took place between them. Bittle. also turned cattle into the barn lot; one day seven, and the next day ten, and kept them there more than two weeks, putting them in in the morning, and taking them out at night. Bennett forbade his putting cattle into the lot, and told him he should charge him the same that he did for drove cattle. Bennett used the barn and lot, but each insisted that they were his. * * *

When the evidence was closed, the president judge delivered to the jury the following charge.

"In the course of the argument the court has been asked by the plaintiff's counsel to instruct the jury, 'That any entry on the premises demised against the will or wishes of the tenant, is an eviction in point of law, and suspends the rent.' I cannot so instruct the jury. If 
such were the law, and if Mr. Bittle had entered the tavern of Mr. Bennett, after having been forbidden-had walked over his field, or without leave had walked into the little orchard and carried away a basket of apples or fine peaches, or in short committed any other trespass, it would, according to this position, be an eviction, and suspend the whole rent. But the law is not so; in this, as in every other instance, it is more consonant to reason; it declares, that if the landlord takes the high-handed measure of entering upon the lands he has leased to his tenant, and ejects, expels, evicts, or turns out the terant, and prevents him from enjoying and using the land, or a portion of it, which he had solemnly leased to him, thus preventing the tenant's enjoyment of the premises, in respect of which rent was to be paid, that would be an eviction which would suspend the rent; so that the inquiry with this jury will be whether Bittle did eject from, and dispossess Bennett, and thus evict him of any particular portion of the premises really demised to him, and for which the rent was to be paid; or whether Bittle merely did other wrongs short of eviction and expulsion, such as trespasses in the field or barnyard. If the former, the rent for that half year is wholly suspended; and if the latter only, it affords the tenant no such defence." * * *

Kenvedy, J. ${ }^{35} * * *$ An entry of the lessor, without an expulsion of the lessee from at least some part of the demised premises, is insufficient to produce a suspension of the rent; it follows, that the court below were right in refusing to charge the jury as requested by the counsel of the pitintiff, and in directing them that nothing short of an eviction or expulsion from at least a portion of the demised premises, would be sufficient for that purpose. Whether an eviction was proved or not, was left entirely as a matter of fact to be decided by the jury, upon which I cannot perceive that the president of the court in delivering the charge, ventured to intimate an opinion. $\mathrm{He}$ seems to have met, very fully and fairly the proposition contended for by the counsel of the plaintiff. And it was perhaps owing to a conviction resting on the mind of the plaintiff's counsel at the time, that his evidence at most tended only to prove a mere entry by the defendant against the will and consent of the plaintiff, that he was induced to contend as he did, that such an entry amounted in law to an eviction. For if he had conceived that his evidence was, under any view that might be taken of it by the jury, sufficient to establish any thing beyond such entry, as for instance, an exclusion or holding of the plaintiff out of the possession and enjoyment of any part of the demised premises, he ought to have shaped his proposition according$1 \mathrm{y}$, and to have asked the instruction of the court to the jury in regard to it; and in this way, it is more than probable, some of those things, which it has been alleged on the argument that the court in 
explanation of what in law amounted to an eviction ought to have told the jury, would have been mentioned by the court to them. But as the proposition of the plaintiff's counsel did not require any such illustration, there was nothing improper on the part of the court in omitting it.

The judgment of the Court below is affirmed. ${ }^{38}$

\section{PRIDGEON v. EXCELSIOR BOAT CLUB.}

(Supreme Court of Michigan, 1887. 66 Mich. 326, 33 N. W. 502.)

SHERwOOD, J. The plaintiff sued the defendant in this case for the use of a water lot on the Detroit river, claiming four months' rent due him on the lease under which the defendant occupied, ending December 31, 1885. The rental was the sum of $\$ 25$ per month. By the terms of the lease the lot extended to the channel bank of the river, and included "all and singular the benefits, liberties, and privileges belonging and appertaining to the premises." The defense was eviction during the last month of the term for which rent was claimed to be due. The plaintiff obtained judgment before the justice where the suit was commenced, and on appeal a like result was obtained, and the defendant brings error.

The facts which the defendant claims amount to an eviction are substantially as follows: The premises were rented by lease to be used for a boathouse; that the only method of going to and from the river was from the front of the slip; that the latter part of November, 1886, the plaintiff caused his propellor to be moored at the docks on either side of the slip, and in front of defendant's premises, completely shutting off ingress and egress to the same, thereby depriving the defendant of the particular and only use for which the premises were rented; that the defendant requested the plaintiff to remove the propeller that they might have access to their property, but the plaintiff neglected so to do, and that the defendant had not any beneficial enjoyment of the property during the time the blockade by the propeller continued. It is claimed by counsel for the defendant that these facts constitute such an eviction as will suspend the right of payment of rent during their continuance; and this is the only question made in the case.

We think counsel are correct in this position. If the facts stated are true, the action of the plaintiff in the premises was a substantial eviction of the defendant from a part, if not the whole, of the rented lot. The subject cannot be discussed except in connection with the object and purpose for which the lot was rented and occupied. The

${ }^{3{ }^{8} A c c .:}$ Harrison's Case, Clayton, 34 (1635) ; Roper v. Lloyd, T. Jones, 14S (1678). See Way v. Myers, 64 Ga. 760 (1Ss0); Hayward v. Ramge, 33 Neb. 836,51 N. W. $299(1892)$. 
disturbance of the lessee's beneficial enjoyment of the water front of the prenises amounts to an eviction, actual, if any exists, and not constructive. The right to enter upon the land leased was of no interest or benefit to the defendant, only as it furnished a water front upon which the club could store its boats, and launch and land the same unobstructed.

In a case like the present the technical rule which requires the element either of absolute expulsion from the property by the landlord, or abandonment by the tenant, to be included in the act of eviction, does not and ought not to be applied. A party should be held evicted when the act of the landlord is of such a character as to deprive the tenant, or has the effect of depriving him, of the beneficial use and enjoyment of the whole or any part of the demised property, to the extent he is thus deprived. Upton v. Townsend, 17 C. B. 30; Peck v. Hiler, 24 Barb. (N. Y.) 178; Briggs v. HIall, 4 Leigh (Va.) 484 , 26 Am. Dec. 326; Dobbins v. Duquid, 65 Ill. 464: Lynch v. Baldwin, 69 Ill. 210; Royce v. Guggenheim, 106 Mass. 201, \& Am. Rep. 322: Bentley v. Sill, 35 Ill. 414: Dyett v. Pendleton, 8 Cow. (N. Y.) 727; Crommelin v. Thiess, 31 Ala. 412, 70 Am. Dec. 499; Randall v. Alburtis, 1 Hilt. (N. Y.) 283; Lawrence v. French, 25 Wend. (N. Y.) 443 ; Jackson v. Eddy, 12 Mo. 209; Shumway v. Collins, 6 Gray (Mass.) 232: Christopher v. Austin, 11 N. Y. 216. And in such case, when the eviction is by the landlord, the rent is suspended during the time of such disturbance. Wood, Landl. \& Ten. 793; Tayl. Landl. \& Ten. $\S 378,379$; Vaughan v. Blanchard, 4 Dall. 125, 1 L. Ed. 769 : Neale v. Mackenzie, 2 Cromp., M. \& R. 84; Blair v. Claxton, $18 \mathrm{~N}$. Y. 529; Griffith v. Hodges, 1 Car. \& P. 419; Hoeveler v. Fleming, 91 Pa. 322; Leishmain v. White, 1 Allen (Mass.) 489; Hayner v. Smith, 63 I11. 430, 14 Am. Rep. 124.

The defense claimed in this case is not that the plaintiff did acts tending to diminish the enjoyment of the leased rights and property. but that what he did deprived the defendant of them altogether, and which, it would seem from the record, was substantially done. We think the judgment should be reversed, and a new trial granted.

Cimamprin and Morse, JJ., concurred.

Campeert, C. J., did not sit. $^{37}$

3r Acc.: Hunter $\nabla$. Reiley, 43 N. J. Law, 490 (1SS1); American Tract Socirty $r$. Jones, 76 Misc. Rep. 236.134 N. Y. Supp. 611 (1912).

A. leased the basement and first floor of a three-story building to $X$., reserving rent, the fee of the street being owned by the alouttor subject to the nublic easement. During the term A. erected a building upon an adjacent lot owned bs him and for three months deposited building material upon the street and sidewalk in front of the premises leased to $X$, and tore up and fenced off the siclewalk adjacent. $\mathrm{X}$. continued in occupation of the preniscs. Held, $X$. is not llable for the rent of the premises during the said three montlis. Edmison v. Lowry, 3 S. D. $77,52 \mathrm{~N}$. IV. 583,17 L. R. A. 275, 44 Am. St. Rep. 774 (1S92). Compare Meeker v. Spalsbury, 60 X. I. Iaw, (60, 48 Atl. 1026 11901); Hancock v. Austin, post, p. 636, and footnotc thereto. 


\section{SMITH v. McENANY.}

(Supreme Judicial Court of Massachusetts, 1S97. 170 Mass. 26, 4 S N. E. 7\$1, 64 Am. St. Rep. 272.)

Holmes, J. This is an action upon a lease for rent and for breach of a covenant to repair. There also is a count on an account annexed, for use and occupation, etc., but nothing turns on it. The defense is an eviction. The land is a lot in the city of Boston, the part concerned being covered by a shed which was used by the defendant to store wagons. The eviction relied on was the building of a permanent brick wall for a building on adjoining land belonging to the plaintiff's husband, which encroached 9 inches, by the plaintiff's admission, or, as his witness testified, from measurements, $131 / 2$ inches, or, as the defendant said, 2 feet, for 34 feet along the back of the shed. The wall was built with the plaintiff's assent, and with knowledge that it encroached on the demised premises. The judge ruled that the defendant had a right to treat this as an eviction determining the lease. The plaintiff asked to have the ruling so qualified as to make the question depend upon whether the wall made the premises "uninhabitable for the purpose for which they were hired, materially changing the character and beneficial enjoyment thereof." This was refused, and the plaintiff excepted. The bill of exceptions is unnecessarily complicated by the insertion of evidence of waiver and other matters, but the only question before us is the one stated, and we have stated all the facts which are necessary for its decision.

The refusal was right. It is settled in this state, in accordance with the law of England, that a wrongful eviction of the tenant by the landlord from a part of the premises suspends the rent under the lease. The main reason which is given for the decisions is that the enjoyment of the whole consideration is the foundation of the debt and the condition of the covenant, and that the obligation to pay cannot be apportioned. Shumway v. Collins, 6 Gray, 227, 232; Leishman v. White, 1 Allen, 489; Royce v. Guggenheim, 106 Mass. 201, 202, 8 Am. Rep. 322; Smith v. Raleigh, 3 Camp. 513; Watson v. Waud, 8 Exch. 335, 339. It also is said that the landlord shall not apportion his own wrong, following an expression in some of the older English books. Royce v. Guggenheim, supra; Colburn v. Morrill, 117 Mass. 262, 19 Am. Rep. 415 ; Mirick v. Hoppin, 118 Mass. 582, 587. But this does not so much explain the rule as suggest the limitation that there may be an apportionment when the eviction is by title paramount or when the lessor"s entry is rightful. Fillebrown v. Hoar, 124 Mass. 580, 583; Neale v. Mackenzie, 1 Mees. \& W. 747, 758; Christopher v. Austin, 11 N. Y. 216, 218; Hodgkins v. Robson, 1 Vent. 276; Id., Poll. 141; Id., 3 Keb. 557 ; Co. Litt. 148b; Gilb. Rents, 151 et seq. It leaves open the question why the landlord may not show that his wrong extended only to a part of the premises. No doubt the ques- 
tion equally may be asked why the lease is construed to exclude apportionment, and it may be that this is partly due to the traditional doctrine that the rent issues out of the land, and that the whole rent is charged on every part of the land. Gilbert, Rents, 178, 179, gives this as one ground why the lessor shall not discharge any part from the burden and continue to charge the rest, coupled with considerations partly of a feudal nature. See, also, Walker's Case, 3 Coke, 22a, 22b; Hodgkins v. Thornborough, Poll. 141, 143; Neale v. Mackenzic, 1 Mees. \& W. 747, 763. But the same view naturally would be taken if the question arose now for the first time. The land is hired as one whole. If by his own fault the landlord withdraws a part of it he cannot recover either on the lease or outside of it for the occupation of the residue. ${ }^{39}$ Leishman v. White, 1 Allen, 489. See Fuller v. Ruby, 10 Gray, 285, 289; Keener, Quasi Cont. 215.

It follows from the nature of the reason for the decisions which we have stated that, when the tenant proves a wrongful deforcement by the landlord from an appreciable part of the premises, no inquiry is open as to the greater or less importance of the parcel from which the tenant is deforced. Outside the rule de minimis, the degree of interference with the use and enjoyment of the premises is important only in the case of acts not physically excluding the tenant, but alleged to have an equally serious practical effect, just as the intent is important only in the case of acts not necessarily amounting to an entry and deforcement of the tenant. Skally v. Shute, 132 Mass. 367. The inquiry is for the purpose of settling whether the landlord's acts had the alleged effect; that is, whether the tenant is evicted from any portion of the land. If that is admitted, the rent is suspended because, by the terms of the instrument as construed, the tenant has made it an absolute condition that he should have the whole of the demised premises, at least as against willful interference on the landlord's part. A case somewhat like the present is Upton v. Townsend, 17 C. B. 30, 74. See, also, Sherman v. Williams, 113 Mass. 481, 485, 18 Am. Rep. 522.39

38 "To the claim on the covenant [for rent] the answer is the eviction; to the demand for use and occupation the answer is that the defendant holds under his lease; so that in neither aspect of the case can the plaintiff maintain his action." Bigelow, J., in Leishman v. White, 1 Allen (Mass.) 489, 490 (1S61). Contra: Anderson v. Winton, 136 Ala. 422, 34 South. 96: (1902). Compare Collins v. Karatopsky, 36 Ark. 316 (1Ss0).

${ }^{39 A c c .: ~ M o r r i s ~ v . ~ K e t t l e, ~} 57 \mathrm{~N}$. J. Law, 21S, 30 Atl. 879 (1S94); Christopher v. Austin, 11 N. Y. 216 (1851). Compare Hayner v. Smith, 63 111. 430, $14 \mathrm{Am}$. Rep. $124(1872)$.

A. leased premises to $B$. at a specified monthly rental. The rent being four dars in arrears $A$. filed a bill against $B$. alleging that $B$. was insolrent and was removing his assets from the state and asking the appointment of a receiver. A temporary receiver was appointed, who took possession of the leased premises and the property thereon and ousted $\mathbf{B}$. therefrom until several weeks later, when the receivershil was discharged; it not appearing that $B$. was insolvent. In an action by $A$. against $B$. for rent, the above facts were alleged as an eviction, suspending the obligation to pay 
We must repeat that we do not understand any question, except the one which we have dealt with, to be before us. An eviction like the present does not necessarily end the lease (Leishman v. White, 1 Allen, 489, 490), or other obligations of the tenant under it, such as the covenant to repair (Carrel v. Read, Cro. Eliz. 374; Snelling v. Stagg, Buller, N. P. 165; Morrison v. Chadwick, 7 C. B. 266; Newton v. Allin, 1 Q. B. 518).

Exceptions overruled.

\section{PENDLETON v. DYETT.}

\section{DYETT v. PENDLETON.}

(Supreme Court of New York, 1825. 4 Cow. 581. On Writ of Error in Court for Correction of Errors, 1826. S Cow. 727.)

Covenant for rent upon a lease dated October 15th, 1818, given by the plaintiff to the defendant, for the term of two, three, five, or eight years, but not for a less term than two years, of two rooms, or the whole of the second floor, and two rooms chosen by the defendant on the third foor of a certain house or store in Beaver street, corner of William strect, in the city of New York, at a rent of $\$ 425$ per annum, which the defendant covenanted to pay, and entered into possession of the demised premises.

The defendant pleaded, 1st, non est factum;

2. That before any of the rent became due, to wit, on, \&c. the plaintiff entered upon the demised premises, and ejected, expelled, put out

rent. The court held that these facts did not constitute a defense, sajing. per Fish, C. J.: "In the present case it cannot be said that there was an actual expulsion of the defendant from the rented premises by the plaintiff itself. Was the appointment of a temporary receiver upon the application of the plaintiff, and the taking of possession of the leased premises by him under the order of the court and at the instance of the plaintiti, such an ace, under the circumstances abore set forth, as indicated an intention on the part of the plaintiff to deprive the defendant of the enjoyment of the rented premises? We think not. The evident purpose of the plaintiff in ipplying for the appointment of a receiver, taking the averments in the answer and offered amendments as true, was to secure its alleged rights and the parment of the restal claimed to be due it by the defendant. * * * The taking possession of the leased premises, under the circumstances, should therefore be held not to be an eviction of the defendant by the plain. tiff, but merely an auxiliary measure frequently incident to the character of cases such as the one in which the recelver was appointed, for the purpose of preserving temporarily the status, and not with an intention on the part of the landlord, the plaintiff, that the tenant, the defendant, should no longer continue to hold the premises." Potts-Thompson Liquor Co. v. Capital City Tobacco Co., 137 Ga. 64S, 74 S. E. 279 (1912).

A. leased a shop to $X$., the entrance of which was known to be over the street line. The city later ordered $A$. to remove the entrance, which ne did, only in pursuance of the order. In an action by $A$. against $X$. for subsequently accruing rent, held, this is not an eriction, so as to suspend the rent. Duhain $r$. Mcrmod. Jaccard \& King Jewelry Co., 211 N. Y. 364, 105 ․ E. 657, Ann. Cas. 1915C, 404 (191t). Compare Taylor v. Finnegan, 189 Mass. 568, 76 N. E. $20 \%$, 2 L. R. A. (N. S.) 973 (1905); Barns v. Wilson, 116 Pa. 303,9 Atl. 437 (1ss7). 
and amoved the defendant, and kept and continued him so ejected, expelled and amoved from thence hitherto.

Replication, denying the expulsion and issue.

The cause was tried at the New York Circuit, June 19th, 1S23, before Iidwards, C. Judge.

On the trial, the counsel for the defendant produced receipts for rent to the 1st February, 1820, and offered to prove that about that time the plaintiff introduced into the house demised, lewd women or prosti. tutes, and continued this practice from time to time and at sundry times, keeping and detaining them in there all night for the purpose of prostitution; that such women would frequently enter the house in the day time, and, after staying all night, would leave it by day light in the morning; that the plaintiff sometimes introduced other men into the house, who, together, with him, kept company with the lewd women or prostitutes during the night; that on such occasions, the plaintiff and the women, being in company in certain parts of the louse not included in the lease, but adjacent and in the plaintiff's occupation, were accustomed to make a great deal of indecent noise and disturbance, the women often screaming extravagantly so. as to be heard throughout the house, and by the near neighbors; and frequently using obscene and vulgar language, so loud as to be understood at a considerable distance; that such noise and riotous proceedings being frecuently continued all night, greatly disturbed the rest of persons sleeping in other parts of the house, and particularly in the parts demised; that these practices were matter of conversation and reproach in the neighborhood; and were of a nature to draw, and did draw, odium and infamy upon the house as being a place of ill fame, so that it was no longer reputable for moral or decent persons to dwell or enter there; that all these practices were by the procurement or permission and concurrence of the plaintiff. That the defendant, being a person of good and respectable character, was compelled by the repetition of these practices to leave the house, and did leave it for that cause, about the beginning of March, 1820; and did not return. That a respectable man by the name of Fox, to whom part of the house had been underlet, left it for the same cause.

This evidence was objected to, and overruled by the Judge as inadmissible upon the isste; and the defendant's counsel excepted. Verdict for the plaintiff, damages $\$ 362.52$.

Curia, per Suthierland, J. Eviction of the whole, or any part of the demised premises, is a good plea in bar to an action either of debt or covenant for the rent. In this, all the authorities agree. (Cruise, Dig. tit. 2S, Rents, ch. 3. Woodfall, 412-13. 1 Saund. 204, n. 2, and cases there cited.) The plea in this case is unexceptionable in point of form. It is according to the established precedents. (Salmon v. Smith, 1 Saund. 203, 4, n. 2.) It states that the plaintiff, (who was the defendant's lessor,) entered into and upon the demised premises, and ejected, expelled, put out and amoved the said defendant from the 
possession thereof, and kept and continued him so ejected, expelled, \&c. from thence hitherto. The only question in the case, is, whether the evidence offered by the defendant, and which was rejected by the Judge who tried the cause, supported the plea, or was of a character which ought to have been submitted to the jury, for them to decide whether it made out the fact of eviction or not. No actual ouster or turning out of possession is pretended. The proof offered does not show an entry by the lessor upon the premises. It does not make out even a trespass. The acts complained of as amounting to an eviction, were committed in a different part of the same house, with which the demised premises had no connection, except that the approach to each was by a common entrance. They operated not upon the physical safety of the tenant, or the physical condition of the demised premises; but upon the moral sense and feeling of the defendant. The acts were exceptionable in themselves; and, if they could not be abated, the defendant had not only a moral right, but it was his moral duty, to abandon the scene of riot and prostitution. But they could have been abated. The law afforded a prompt and sufficient remedy. The police of the city, upon the complaint of the defendant, would have instantly taken the plaintiff and his associates into custody, and punished them by fine and imprisonment as of ten as the offence was repeated. There was no moral necessity therefore for abandoning the premises. Suppose the plaintiff had been in the habit of exhibiting himself either in the common passage or in the street opposite the premises in question, in indecent attitudes, or in a state of offensive nakedness, so that the defendant and his family could not leave his house without witnessing the disgusting exhibition; would this cause have supported a plea of eviction? They would both stand upon the footing of nuisances, which the plaintiff or any other citizen might cause to be abated. But if, instead of taking that course, he should abandon his house, it must be considered a voluntary and not a compulsory act.

But I apprehend there can be no eviction, without an actual entry. Such is the form of the plea, and the proof must sustain it. The very definition of the term eviction, is an expulsion of the lessee out of all or some part of the demised premises; and Sergeant Williams says, that to occasion a suspension of the rent, the plea must state an eviction or expulsion of the lessee by the lessor, and a keeping him out of possession, until after the rent became due; otherwise it will be bad. (1 Saund. 204, n. 2.) If a constructive expulsion, without entry, may constitute an eviction, which will operate as a suspension of the rent, why is the averment of an entry contained in all the precedents and why do all the cases agree, that without such averment the plea would be bad? 'Thus, in Timbrell v. Bullock, (Styles, 446,) it is said that, to make a suspension of rent reserved upon a lease for years, the lessor must oust the lessee of part of the thing let, at least, and hold him out until after the lay on which the rent is made payable by the lease; 
and if the lessee re-enters the rent is revived. A re-entry presupposes an actual ouster or expulsion.

Hunt $v$. Cope, (1 Cowp. 242,) is a strong case. There the defendant plcaded that the lessor, with force and arms, entered upon the demised premiscs and demolished a summer house, (being a part of the premises,) by means whereor the tenant had been deprived of the use of the summer house, \&c. This plea was held to be bad, because it. did not aver an actual eviction or expulsion of the lessee. The defendant's counsel urged that the facts in the plea amounted to an eviction, on the ground that an actual entry was stated and a destruction of a portion of the premises; and if an eviction could be constructively pleaded, this would seem to be good. But all the Court leld it bad, and Aston, J., says, all the cases in the books suppose the lessee to be put out of possession. Therefore, merely saying that he was deprived of the enjoyment of the premises is not sufficient. If it is nccessary to state, in terms, that the lessee was turned out of possession, in order to make a good plea of eviction, it would seem to follow that the proof in support of the plea must be substantially of the same character. Lord Mansfield, in Hunt v. Cope, says that the facts there stated, might have been sufficient for the jury to have found for the defendant under a good plea of eviction. But there, it will be recollected, an actual entry, and a physical destruction of a portion of the premises are averred; and if an actual ouster can be inferred from circumstances, it surely might in that case; yet Lord Mansfield considers it as matter of doubt.

In the case before us, there was not only no actual entry, but no assertion either express or implicd of a right of entry on the part of the lessor or of any other right or control over the denised premises. The disturbance suffered by the lessee was the consequence of conduct on the part of the lessor, which partook of the nature of a nuisance, and which he had the power of abating at pleasure. He was not, therefore, constrained by any necessity, either moral or physical, to abandon the premises; and, in judgment of law, so far as this action is concerned, his abandonment must be considered voluntary. The evidence offered was properly rejected by the Judge. The motion for a new trial must be denied.

New trial rcfused.

\section{[On Writ of Error.]}

Spliscrir. Senator. ${ }^{40}$ It seems to be conceded that the only plea which could be interposed by the defcudant below, to let in the defence which he offered, if any would answer that purpose, was, that the plaintiff had entered in and upon the demised premises, and ejected and put out the defendant. Such a plea was filed; and it contended

40 Part of the opinion of Spencer, Senator, and the opinion of Cary, Colden, and Allen, Senators, are omitted. 
on the one side, that it must be literally proved, and an actual entry and expulsion established; while on the other side it is insisted, that a constructive entry and expulsion is sufficient, and that the facts which tended to prove it, should have been left to the jury. It is true that "pleading is the formal mode of alleging that on the record, which would be the support or defence of the party on evidence," as de- fined by Buller, J., in 1 Term Rep. 159; and the same learned judge immediately after draws the correct distinction: "whether the evidence in each particular case is a sufficient foundation for that support or defence, is a question that does not arise upon pleading, but upon the trial of the issue afterwards." In pleading, the legal effect of the facts is stated, not the facts themselves. The form of the plea, therefore, does not determine the kind of evidence necessary to establish it. To support a plea that the defendant never promised, he may prove a payment, or a performance of his undertaking, or some matters which excused him from its performance.

There are many similar cases, where the proof of one fact justifies the legal conclusion of another fact. This, then, is a question of principle, whether the evidence offered by the defendant below tended in any manner to establish a constructive entry and eviction by the plaintiff; for if it did, it should have been left to the jury to decide on its effect.

To determine this, it seems only necessary to inquire what are the conditions express or implied, on which the defendant was to pay the rent. The agreement set forth in the plea, contains a covenant that the defendant shall have "peaceable, quiet and indisputable possession" of the premises. This is, in its nature, a condition precedent to the payment of rent; and whether the possession was peaceable and quiet, was clearly a question of fact for the jury. Such conduct of the lessor as was offered to be proved in this case, went directly to that point; and without saying at present, whether it was or was not sufficient to establish a legal disturbance, it is enough that it tended to that end, and should have been received, subject to such advice as the judge might give to the jury.

The opinion of the supreme court proceeds upon the ground that there must be an actual physical eviction, to bar the plaintiffs; and in most of the cases cited, such eviction was proved; and all of them show that such is the form of the plea. But the forms of pleading given, and the cases cited, do not establish" the principle on which the recovery of rent is refused, but merely furnish illustrations of that principle, and exemplifications of its application. The principle itself is deeper and more extensive than the cases. It is thus stated by Baron Gilbert, in his essay on Rents, p. 145: "A rent is something given by way of retribution to the lessor, for the land demised by him to the tenant, and consequently the lessor's title to the rent is founded upon this: that the land demised, is enjoyed by the tenant during the term included in the contract; for the tenant can make no return for thing 
he has not. If, therefore, the tenant be deprived of the thing letten, the obligation to pay the rent ceases, because such obligation has its force only from the consideration, which was the enjoyment of the thing demised." And from this principle, the inference is drawn, that the lessor is not entitled to recover rent in the following cases: 1st. If the lands demised be recovered by a third person, by a superior title, the tenant is discharged from the payment of rent after eviction by such recovery. $2 \mathrm{~d}$. If a part only of the lands be recovered by a third person, such eviction is a discharge only of so much of the rent as is in proportion to the value of the land evicted. 3d. If the lessor expel the tenant from the premises, the rent ceases. 4th. If the lessor expel the tenant from a part only of the premises, the tenant is discharged from the payment of the whole rent; and the reason for the rule why there shall be no apportionment of the rent in this case as well' as in that of an eviction by a stranger, is, that it is the wrongful act of the lessor himself, "that no man may be encouraged to injure or disturb his tenant in his possession, whom, by the policy of the feudal law, he ought to protect and defend."

This distinction, which is as perfectly well settled as any to be found in our books, establishes the great principle that a tenant shall not be required to pay rent, even for the part of the premises which he retains, if he has been evicted from the other part by the landlord. As to the part retained, this is deemed such a disturbance, such an injury to its beneficial enjoyment, such a diminution of the consideration upon which the contract is founded, that the law refuses its aid to coerce the payment of any rent. Here then, is a case where actual entry and physical eviction are not necessary to exonerate the tenant from the payment of rent; and if the principle be correct as applied to a part of the premises, why should not the same principle equally apply to the whole property demised, where there has been an obstruction to its beneficial enjoyment, and a diminution of the consideration of the contract, by the acts of the landlord, although those acts do not amount to a physical eviction? If physical eviction be not necessary in the one case, to discharge the rent of the part retained, why should it be essential in the other, to discharge the rent of the whole? If I have not deceived mysclf, the distinction referred to settles and recognizes the principle for which the plaintiff in errof contends, that there may be a constructive eviction produced by the acts of the landlord.

An eviction cannot be more than an ouster; and we have the anthority of Lord Mansfield for saying that there may be a constructive ouster. In Cowper, 217, he remarks, "Some ambiguity seems to have arisen from the term actual ouster, as if it meant some act accompanied by real force, and as if a turning out by the shoulders were necessary; but that is not so: a man can come in by rightful possession, and yet hold over adversely without a title," \&c.

We regard cases as containing the evidence of the law, as evincing the rule of decision: and they are consultcd to ascertain the principle 
on which that rule is founded. The review of the cases now made, shows that the principle on which a tenant is required to pay rent, is the beneficial enjoyment of the premises, unmolested in any way by the landlord. It is a universal principle in all cases of contract, that a party who deprives another of the consideration on which his obligation was founded, can never recover damages for its non-fulfilment. The total failure to the consideration, especially when produced by the act of the plaintiff, is a valid defence to an action, except in certain cases, where a seal is technically held to conclude the party. This is the great and fundamental principle which led the courts to deny the lessor's right to recover rent where he had deprived the tenant of the consideration of his covenant, by turning him out of the possession of the demised premises. It must be wholly immaterial by what acts that failure of consideration has been produced; and only inquiry being, has it failed by the conduct of the lessor? 'This is a question of fact, and to establish it the proof offered in this case was certainly competent. I do not feel called upon to say that those facts would have been alone sufficient. Of that the jury were to judge, at least, in the first instance; and the question whether they amounted to a full and complete legal defence, might have been presented in another shape. The only question for our decision is, whether that testimony ought to have been received at all? Believing that it tended to establish a constructive eviction and expulsion against the consent of the tenant: that it tended to prove a disturbance of his quiet possession, and a failure of the consideration on which only the tenant was obliged to pay rent, I am of the opinion that it ought to have been received; and that, therefore, the judgment of the supreme court should be reversed, with the directions to issue a venire de novo. $* * *$

A majority were for reversal. Whereupon it was ordered, that the judgment of the supreme court be reversed; and that a venire de nova should issue in the court below. ${ }^{41}$

\section{EDGERTON v. PAGE.}

(Court of Appeals of New York, 1S59. 20 N. Y. 281.)

Appeal from the Common Pleas of the city and county of New York. Action to recover one quarter's rent of the first floor of brick building No. 8 Fulton street in said city, for the quarter ending May 1st, 1855, leased by the plaintiff to the defendant for one year from May 1st, 1854 , at a yearly rent of $\$ 1,500$, payable quarterly on the first days of August, November, February and May. The defendant in his answer set out a copy of the lease, by which it appeared that the defendant was to have the privilege of renewal for one year at the same rent.

41 See Alger v. Kennedy, 49 Vt. 109, 24 Am. IRep. 117 (1576). Compare Wnlf v. Eppenstein, 71 Or. 1, 140 Pac. 751 (1914). 
The answer alleged that this privilege was one of the main inducements on the part of the defendant to the taking of the lease, and one of the principal causes of its value. The answer further alleged that the plaintifi, between the first days of February and May, 1855, was the occupant of the entire upper part of the building in question, and also of the adjoining building; that between those days, and while the defendant occupied the demised premises, the plaintiff wantonly, maliciously and negligently permitted certain water pipes, coming down through the rear of the building and communicating with a sewer under the demised premises, and which pipes were used for carrying off the waste water from the upper. stories of the building, to get out of order and leak: and that the plaintiff knowing this, maliciously and negligently permitted large quantities of water and filth to flow through the pipes which leaked therefrom into the denised premises, injuring the property of the defendant, deposited therein, to the amount of $\$ 390$, interfering with and depriving the defendant of the beneficial enjoyment of the premises: that the plaintiff could, by ordinary care and prudence, have prevented the injury, and that the defendant requested the plaintiff to repair the pipes or abstain from their use which he neglected to do: that the defendant was injured to the amount of $\$ 250$ in the prosecution of the business during the quarter in question. The answer further alleged, that at divers times during the quarter in question, large quantities of water, filthy and otherwise, were thrown out by the plaintiff and his servants, from the rear windows of the portion of the building occupied by the plaintiff, so negligently and maliciously as to run into the demised premises, by which the defendant was injured to the amount of $\$ 150$ : that the defendant was compelled, by the injuries, to abandon the possession of the premises on or about 1st of May, 1855, thereby losing the benefit and being deprived of the privilege of renewal created by the lease which he intended to avail himself of but for said injuries. The answer insists upon the facts as a defence to the action, and also as a counterclaim. The plaintiff demurred to the answer and assigned several causes, among them that the facts did not constitute a defence, nor a counter-claim available to the defendant in the action. The cause was heard at special term, and judgment given for the defendant upon the demurrer. The plaintiff appealed; the court at general term reversed the judgment, and gave judgment for the plaintiff, from which the defendant appealed to this court.

Grover, J. The demurrer presents two questions: First, whether the facts alleged in the answer constitute a defense; second, whether they constitute a counter-claim, available to the defendant by way of recoupment or otherwise in this action. The rule has long been settled, that a wrongful eviction of the tenant by the landlord, from the whole or any part of the demised premises, before the rent becomes due, precludes a recovery thereof until the possession is restored. Christopher v. Austin, 11 N. Y. 217. Whether this eviction must be 
actual by the forcible removal of the tenant by the landlord from the demised premises or a portion thereof, was not settled in this State until the case of Dyett v. Pendleton, 8 Cow. $72 \mathrm{~S}$. In that case, the principle was established by the Court for the Correction of Errors, that when the lessor created a nuisance in the vicinity of the demised premises, or was guilty of acts that precluded the tenant from a beneficial enjoyment of the premises, in consequence of which the tenant abanconed the possession before the rent became due, the lessor's action for the recovery of the rent was barred, although the lessor had not forcibly turned the tenant out of possession. Ever since that case, this has been considered as a settled rule of law binding upon all the courts of the State. Such act of the lessor accompanied by an abandonment of possession by the lessee, is deemed a virtual expulsion of the tenant, and, equally with an actual expulsion, bars the recovery of rent. The reason of the rule is, that the tenant has been deprived of the enjoyment of the demised premises by the wrongful act of the landlord; and thus the consideration of his agreement to pay rent has failed. In case of eviction from a portion of the premises, the law will not apportion the rent in favor of the wrongdoer.

In this case, the answer shows that the defendant continued to occupy the premises for the whole time for which the rent demanded accrued. In this, the case differs from Dyett v. Pendleton (supra). I cannot see upon what principle the landlord should be absolutely barred from a recovery of rent, when his wrongful acts stop short of depriving the tenant of the possession of any portion of the premises. The injury inflicted may be to an amount much larger than the whole rent, or it may be of a trifling character. In all the cases where it has been held that the rent was extinguished or suspended, the tenant has been deprived, in whole or in part, of the possession by the wrongful act of the landlord, either actually or constructively. There is no authority extending the rule beyond this class of cases. It would be grossly unjust to permit a tenant to continue in the possession of the premises, and shield himself from the payment of rent by reason of the wrongful acts of the landlord impairing the value of the use of the premises to a much smaller amount than the rent. This must be the result of the rule claimed by the defendant. The moment it is conceded that the injury must be equal to the amount of the rent, the rule is destroyed. It would then only be a recoupment to the extent of the injury. In Ogilvie v. Hull (5 Hill, 52), Nelson, Ch. J., in giving the opinion of the court, says: That no general principle is better settled, or more uniformly adhered to, than that there must be an entry and expulsion of the tenant by the landlord, or some deliberate disturbance of the possession depriving the tenant of the beneficial enjoyment of the demised premises, to operate a suspension or extinguishment of the rent. The rule contended for by the defendant is a very different one, suspending or extinguishing the rent whenever the enjoyment, in consequence of the tortious acts of the lessor, becomes 
less beneficial than it otherwise would have been. The true rule, from all the authorities, is that while the tenant remains in possession of the entire premises demised, his obligation to pay rent continues. ${ }^{42}$

The remaining question is whether a counter-claim, arising from the facts contained in the answer, is available to the defendant in this action. By section 149 of the Code, the defendant is permitted to include in his answer new matter, constituting a counter-claim. Section 150 defines the class of demands which are embraced in section 149, as counter-claims. A counter-claim must be 1st, a cause of action arising out of the contract or transaction set forth in the complaint as the foundation of the plaintiff's claim, or connected with the subject of the action; or $2 \mathrm{~d}$, in an action arising on contract, any other cause of action arising also on contract and existing at the commencement of the action. The demand of the defendant, set out in the answer, does not arise out of the contract set forth in the complaint. That contract is for the payment of rent, upon a lease of the demised premises. The defendant's demands arise from the wrongful acts of the plaintiff in permitting water to leak and run into the premises, and in causing or permitting it to be thrown upon the premises and property of the defendant. These acts are entirely independent of the contract of leasing upon which the action is brought. The demands are not connected with the subject of the action; that is, the rent agreed to be paid for the use of the premises. The defendant's demands are for a series of injuries to his property deposited upon the premises, and for impairing the value of the possession. It would be a very liberal construction to hold that in an action for rent, injuries from trespasses committed by the lessor upon the demised premises might be interposed as a counterclaim. The acts of the plaintiff in this case are of a similar nature. They are either acts of trespass or negligence, from which the injuries to the defendant accrued. Such a construction could only be supported by the idea, that the subject of the action was the value of the use of the premises. But when there is an agreement as to the amount of rent, that value is immaterial. Unless the acts of the defendant amount to a breach of the contract of letting, they are not connected with the subject of the action. In the case of The Mayor, etc., of New York v. Mabie, 13 N. Y. 151, 64 Am. Dec. 538 , it was held by this court that a covenant for quiet enjoyment by the lessor was implied in a lease under seal, for a term not exceeding

42 Compare Lumpkin v. Prorident Loan Soc., Inc., 15 Ga. App. 816, s4 s. E. 216 (1915). See Halligan v. Wade, 21 Ill. 470, 74 Am. Dec. 108 (1559): De Witt v. Pierson, 112 Mass. 8, 1T Am. Rep. 58 (1S73).

A. leased a building to B. B. subleased portions to C. and D. Owing to A.'s wrongful failure to keep the roof in repair, that part occupied by $\mathbf{b}$. became untenantable, and $B$. abandoned the premises. Held, B. is entitled against $A$. to have the rent proportionally reduced. Dolph $\nabla$. Barrs, 165 Mo. App. 659, 148 S. W. 196 (1912).

Compare Weiss v. Zenith Realty Co., 129 Minn. 486, 152 N. W. 869 (1915). Brg.Rights-39 
three years, since as well as before the Revised Statutes; that this covenant was broken by an interference with possession by the lessor under a claim of right; consequently, that damages sustained from such acts might be recovered in an action for rent. It was remarked by Denio, J., in giving the opinion in that case, that it is not, however, every mere trespass by the lessor upon the demised premises which will amount to a breach of this covenant; although the covenantor cannot avail himself of the subterfuge, that his entry was unlawful, and he, therefore, a trespasser, to avoid the consequences of his own wrong, still, to support the action of covenant, the entry must be made under an assumption of title. For this, the learned judge cites Platt on Covenants, 319, 320. There is nothing in the answer in this case tending to show that any of the acts of the defendant were done under any claim of right whatever. They did not, therefore, amount to a breach of the contract created by the lease, and the injuries sustained by the defendant do not, therefore, constitute a counter-claim connected with the subject of the action. The judgment should be affirmed.

Judgment affirmed.

\section{BASS v. ROLLINS.}

(Supreme Court of Minnesota, 189-. 63 Minn. 226, 65 N. W. 348.)

START, C. J. Action to recover $\$ 50$ for two months' rent. Trial by the court without a jury, and judgment for the defendant, from which the plaintiff appealed. The here material facts, as found by the court, are that on November 1, 1894, the plaintiff leased to the defendant a certain apartment for a monthly rental of $\$ 25$, payable in advance on the first secular day of each month; that it was a part of the agreement of such leasing that the plaintiff should furnish to the defendant proper and sufficient heat while he was occupying the demised premises; that at times during the month of December, 1894, and up to the 6th day of February, 1895, the plaintiff failed to provide such heat, although repeatedly notified by the defendant so to do, but kept the premises during such times, at such a low temperature as to render the same unfit for occupancy; and that, by reason of such failure, the defendant was compelled to and did vacate the premises on the 6th day of February, 1895. The defendant paid all rent except for the month of February.

We concede, for the purposes of this case, without so deciding, that the agreement to furnish to the defendant sufficient heat was not a condition precedent to the payment of rent, but the trial court has not found that the defendant, by remaining in possession of the premises after February 1st, elected to keep them for that month. Nor can such fact be inferred from the facts found by the court. In this respect the case differs from Flint v. Sweeney, 49 Minn. 509, $52 \mathrm{~N}$. W. 136 , which was a case where the condition of the demised premises 
had not materially changed for several months, and it was held that the lessee, by continuing the occupancy of the premises after the end of the current month, elected to remain for another month, and was liable for that month's rent. In the case at bar it was only at times that the lessor failed to furnish a proper amount of heat. It was a mere neglect of duty, which the lessor might have corrected at any time, and the lessee did not, as a matter of law, elect to keep the premises for the month of February if the lessor did not keep them warmed, and he had a right to vacate them upon the lessor's failure to do so. The court found that, on the 6th day of February, the defendant was compelled to and did vacate the premises, for the reason that they were unfit for occupancy by reason of the plaintiff's failure to keep them warm. This amounted to an eviction by the plaintiff, and he is not entitled to recover for rent accruing after such eviction. It is not an answer to this proposition to say that $\$ 25$ was due for rent six days before the eviction, for, stuppose that, on the 1st day of February, the premises were properly heated, and the defendant paid the month's rent on that day, but on the next day the plaintiff, having received the rent, had shut off the heat, and thereby forced the defendant to vacate February 6th, and he had thereupon brought an action for daniage, would he not have been entitled to recover at least $\$ 20$ for the rent, which he had paid in advance for the four-fifths of a month that he did not occupy the premises? But the $\$ 25$ was not paid. Then, why should the plaintiff recover in this action that which, if the defendant had paid on the due day, he could recover back from the plaintiff? It may be suggested that this line of reasoning would lead to the conclusion that the plaintiff was entitled to recover for one-fifth of a month's rent, $\$ 5$. This point is not raised by the plaintiff. Her claim is that she was entitled to at least a full month's rent. If her claim was only for $\$ 5$, the maxim "de minimis" would be applicable, in this court, to it.

Judgment affirmed. ${ }^{48}$

\section{STEWVART v. CHILDS CO.}

(Court of Frrors and Appeals of Ner Jersey, 1914. S6 N. J. Law, (41S, 92 Atl. 392, L. R. A. 1915C, 649.)

BLACK, J. The error complained of by the appellant in this case is the ruling of the trial court directing a verdict for the plaintiff. The suit was instituted in the Hudson circuit court to recover rent, due under a written lease for the premises No. 53 Newark avenue, Jersey City. The lease was dated the 26 th day of December, 1901 ; the term

43 Acc.: Jackson v. Paterno, 58 Mise. Rep. 201, 108 N. Y. Supp. 1073 (190S).

See Delmar Investment Co. v. Blumentield, 11S Mo. App. 308, $94 \mathrm{~S}$. W. \$23 (1906i) : Metropole Const. Co. r. Hartigan, S.3 N. J. Law. 409, \$5 Atl. 313 (1912); West side Sav. Bank v. Newton, 76 พ. Y. 616 (1S79). 
commencing on the 1st day of February, 1902, ending on the 1st day of May, 1922, at the yearly rental of $\$ 3,000$. The lease contained these covenants: By the tenant: "That the tenant shall pay the rent aforesaid as the same shall fall due." By the landlord: "The basement shall be waterproof, and not less than 7 feet high. And he does hereby guarantee that he will at all times during the said lease keep the said cellar waterproof at his own expense." The evidence of the defendant showed that there was a breach of the above covenant on the part of the landlord to keep the cellar waterproof during the term of the lease. The trial court held that the two covenants were independent. The breach of the covenant to keep the cellar waterproof was not a defense to an action for rent. The judge at the trial, therefore, directed a verdict for $\$ 4,350$ in favor of the plaintiff. It is this ruling of the trial judge which the defendant alleges is erroneous in. law, and seeks to have the judgment reversed.

The defendant contends, to use the words of the brief, that the failure of the landlord to do what is lawfully required of him, either by the terms of the lease or otherwise, which renders the demised premises unfit for the purpose for which they are leased, or which seriously interferes with the beneficial enjoyment thereof, in consequence of which the tenant abandons the premises, constitutes an eviction by construction of law, and releases the tenant from the obligation under the lease to pay rent accruing thereafter, while the plaintiff contends that the failure by the landlord to perform his guaranty does not constitute an eviction in fact or constructively.

There are numerous cases in this and other jurisdictions illustrating the principle of eviction, both actual and constructive, applied as a defense, to an action for the nonpayment of rent. Chief Justice Tarvis, in the case of Upton v. Townend and Greenless, 17 C. B. 30, 51, after speaking of a physical expulsion or a motion, in reference to a constructive eviction, said:

"I think it may be taken to mean this: Not a mere trespass and nothing more, but something of a grave and permanent character done by the landlord with the intention of depriving the tenant of the enjoyment of the demised premises."

This definition of a constructive eviction was cited with approval by our Supreme Court in the cases of Meeker v. Spalsbury, 66 N. J. Law, 63, 48 Atl. 1026; Metropole Construction Co. v. Hartigan, 83 N. J. Law, 411, 85 Atl. 313.

The record shows that the premises were fitted for and used as a Childs restaurant. Soon after the place was opened for business, there was water in the basement, which was taken care of, by the tenant, with a hand pump; that at times it got two feet deep; that the tenant moved out of the premises in May, 1904, and resumed again in November, 1904. From 1905 to 1909 the premises were sublet. The tenant abandoned the premises in 1909. In October, 1910, there were three feet of water in the cellar. The presence of the water in the cellar 
was wholly due to the fact that the walls and foundations were not waterproof. The cellar was necessary for the conduct of the business of the defendant. The cellar was used in part for storage, but mainly for the steam apparatus that perfects the coffee. There is no evidence that the landlord in any way was responsible for the water in the cellar, except that the walls and foundations were not waterproof, according to the guaranty. The facts in the record, on which the judge at the trial was called upon to moke a ruling, tested by the rule above cited, fall short of making out either an actual or constructive eviction. We are unable to find in the record any evidence that shows that the landlord, or by his procurement, did anything with the intention of depriving the tenant of the enjoyment of the premises. A breach of lis covenant was not a defense to the action. The ruling of the trial court in directing a verdict for the plaintiff was not error.

No error appearing in the record, the judgment is affirmed. ${ }^{44}$

\section{UNIVERSITY CLUB OF CHICAGO v. DEAKIN.}

(Supreme Court of Illinois, 1914. 265 Ill. 257, 106 N. E. 790, L. R. A. 1915C, 854.)

Cooke, J. Defendant in error, the University Club of Chicago, brought suit in the municipal court of Chicago against Earl H. Deakin, the plaintiff in error, to recover rent alleged to be due under a lease. A trial was had before the court without a jury and resulted in a judgment for $\$ 2,007.66$. Deakin prosecuted an appeal to the Appellate Court for the First District, where the judgment of the municipal court was affirmed. A writ of certiorari having been granted by this court, the record has been brought here for review.

On March 31, 1909, defendant in error leased to plaintiff in error, for a term of one year, a storeroom in its building at the corner of Michigan avenue and Monroe street, in the city of Chicago, at a rental of $\$ 5,000$ for the year. 'The lease provided that plaintiff in error should use the room for a jewelry and art shop and for no other purpose. It also contained the following clause, numbered 12 :

4 Compare Skally v. Shute, 132 Mass. 307 (1S82).

"While the breach of the landlord's agreement to make repairs or improvements for the benefit of the tenaut may not relieve the tenant in possession from his liability to pily rent, nevertheless where the failure to repair amounts to a constructive eriction, the tenant will be justitied in learing the premises and his liability for rent will thereupon terminate. * * It has been said that constructive eviction results when the lessor renders the enjoyment of the premises impossible. or diminishes such enjoyment to a material degree." Jaggard. J., in liea v. Algren, $101 \mathrm{H}$ inn. $316,317,116$ N. W. 580, 124 Am. St. Rep. 627 (1008). Acc.: Bissell r. Liovd, 100 Ill. 214 (1S51): Piper v. Fletcher, 115 lowa, 263, 88 N. W. 380 (1901), Compare Lewis v. Chisholm, GS Ga. 40 (1s81); Lincoln Trust Co. v. Nathan. 175 Mo. 32, 74 S. W. 1007 (1008) ; Arbenz v. Exley, Watkins \& Co., 52 W. Va. 476,44 S. E. 149,61 L. R. A. 957 (1903). 
"Lessor hereby agrees during the term of this lease not to rent any other store in said University Club building to any tenant making a specialty of the sale of Japanese or Chinese goods or pearls."

Shortly after this lease was made defendant in error leased to one Sandberg, for one year, a room in the University Club building, two doors from the corner at a rental of $\$ 2,500$. The following provision was inserted in the Sandberg lease:

"It is further distinctly understood and agreed by and between the parties hereto that at no time during the term of this lease will the lessee herein use the demised premises for a collateral loan or pawnshop or make a specialty therein of the sale of pearls."

On May 1, 1909, being the first day of the term of the lease, plaintiff in error took possession of the premises and thereafter paid the rent, in monthly installments, for May and June. During the latter part of June plaintiff in error, through his attorney, sought to obtain from defendant in error a cancellation of his lease on the ground that by leasing a room in the University Club building to Sandberg and permitting him to display and sell pearls therein defendant in error had violated the provision of plaintiff in crror's lease above quoted, and that for such violation plaintiff in error was entitled to terminate the lease. Defendant in error refused to cancel the lease, and on June 30th plaintiff in error vacated the premises, surrendered the keys, and refused to pay any further installments of rent. This suit was brought to enforce payment of subsequent installments of rent accruing under the lease for the time the premises remained unoccupicd after June 30 th.

The evidence offered by plaintiff in error tended to show that Sandberg had made a specialty of the sale of pearls in connection with the conduct of his general jewelry business ever since he took possession of the room leased to him, and that plaintiff in error vacated the premises and surrendered possession because of the failure of defendant in error to enforce the twelfth clause of his lease. The evidence offered by defendant in error tended to prove that Sandberg had not made a specialty of the sale of pearls, and that when plaintiff in error first made known his desire to assign or cancel his lease he gave as his only reason that his health was failing and that he had been advised by his physician to leave the city of Chicago.

Propositions were submitted to the court by both. parties to be held as the law of the case. The court held, at the request of plaintiff in error, that the lease sued upon was a bilateral contract, and upon a breach of an essential covenant thercof by the lessor the lessee had a right to refuse further to be bound by its terms and to surrender possession of the premises, and that a breach of the twelfth clause of the lcase would be a good defense to an action for rent if the tenant surrendered possession of the premises within a reasonable time after discovery of the breach. The court refused to hold as law propositions submitted by defendant in error stating the converse of 
the propositions so held at the request of plaintiff in error. The court properly held that the lease in question was a bilateral contract. It was executed by both parties and contained covenants to be performed by each of them. The propositions so held with reference to the effect of a breach of the twelfth clause of the lease also correctly stated the law. $\mathrm{By}$ holding these propositions the court properly construed the twelfth clause as a vital provision of the lease and held that a breach of that provision by the lessor would entitle the lessee to rescind. Where there is a failure to comply with a particular provision of a contract and there is no agreement that the breach of that term shall operate as a discharge, it is always a question for the courts to determine whether or not the default is in a matter which is vital to the contract. City of Belleville v. Citizens' Horse Railway Co., 152 Ill. 171, 38 N. E. 584, 26 L. R. A. 681; People v. Central Union Telephone Co., 232 Ill. 260, 83 N. E. 829. While there was no provision in this contract that plaintiff in error should have the option to terminate it if the terms of the twelfth clause were not cbserved, it is apparent that it was the intention of the parties to constitute this one of the vital provisions of the lease. It was concerning a matter in reference to which the parties had a perfect right to contract, and it will be presumed that plaintiff in error would not have entered into the contract if this clause had not been made a part of it. It is such an essential provision of the contract that a breach of it would warrant plaintiff in error in rescinding the contract and surrendering possession of the premises.

The court was not asked to make any finding of fact, and there is nothing in the record to indicate that the judgment is based upon any finding of fact. Whether Sandberg had, in fact, made a specialty of the sale of pearls was one of the controverted questions in the case. One of the propositions submitted by defendant in error and held by the court stated that the conduct of a general jewelry business was not "making a specialty of the sale of pearls," within the meaning of the words quoted as they were used in the twelfth clause of plaintiff in error's lease. This cannot be construed as a holding that Sandberg did not, in fact, in addition to his conduct of a general jewelry business, make a specialty of the sale of pearls.

The following proposition was submitted by defendant in error and held by the court as the law of the case:

"That plaintiff perforned all the obligations imposed upon it by its covenant that it would not rent any other store in its building to a tenant making a specialty of the sale of pearls, by incorporating in its lease to the second tenant that said second tenant should not make a specialty of the sale of pearls in the demised premises."

From a consideration of all the propositions of law held and refused, it appears that the judgment of the trial court was reached from the application of the proposition just quoted to the facts in the case. The court erred in holding this proposition as the law. By 
covenanting with plaintiff in error not to rent any other store in this building, during the term of plaintiff in error's lease, to any tenant making a specialty of the sale of pearls, defendant in error assumed an obligation which could not be discharged by simply inserting in the contract with the second tenant a covenant that such tenant should not make a specialty of the sale of pearls. It was incumbent upon it to do more than to insert this provision in the second lease. By the terms of its contract with plaintiff in error it agreed that no other portion of its premises should be leased to any one engaged in the prohibited line of business, and, if it failed to prevent any subsequent tenant from engaging in the business of making a specialty of the sale of pearls, it did so at the risk of plaintiff in error terminating his lease and surrendering possession of the premises.

This precise question has never been passed upon by this court, so far as we are able to ascertain. Defendant in error cites and relies upon Lucente v. Davis, $101 \mathrm{Md}$. 526, 61 Atl. 622, which supports its theory. We cannot yield our assent to the doctrine there announced. Defendant in error cannot escape its obligation by the mere insertion of a clause in the lease with the second tenant prohibiting him from engaging in the line of business named. Plaintiff in error contracted for the exclusive right to engage in this particular business in that building. There was no privity between him and Sandberg, and he was powerless to enforce the provisions of the contract between defendant in error and Sandberg. It is idle to say that an action for damages for a breach of contract would afford him ample remedy. He contracted with defendant in error for the sole right to engage in this specialty in its building, and, if defendant in error saw fit to ignore that provision of the contract and suffer a breach of the same, plaintiff in error had the right to terminate his lease, surrender possession of the premises, and refuse to further perform on his part the provisions of the contract.

For the errors indicated, the judgment of the Appellate Court and the judgment of the municipal court are reversed, and the cause is remanded to the municipal court for a new trial.

Reversed and remanded. ${ }^{45}$

45 See Iucente v. Davis, 101 Md. 526, 61 Atl. 622 (1905). Compare Hall v. Ewin, 37 Ch. D. 74 (1857), ante, p. 49. 


\title{
SECTION 3.-FAILURE TO OBTAIN POSSESSION
}

\author{
NEALE v. MACKENZIE.
}

(Exchequer Chamber, 1836. 1 Nees. \& W. 747.)

[On writ of error to the Court of Exchequer.]

LORD DENMAN, C. J.48 This is an action of trespass for entering the plaintiff's dwelling-house, and taking his goods.

The declaration is dated the 25th of April, 1834. The defendant, on the 24th of May, 1834, pleaded that he, being seised of the dwelling-house and certain other premises, demised the same to the plaintiff for one year from the 25 th of June, 1833, at the rent of $70 l$., payable quarterly; that the plaintiff accepted the lease, and, by virtue of the said demise, entered into and upon the said demised premises, and thereupon became and yet was possessed thereof for the said term so granted to him as aforesaid; and, until the 25th of December, 1833 , and from thence until and at the time when \&c., held and enjoyed the dwelling-house and premises by virtue of the said demise; that, on the said 25th of December, 1833, 35l. of the rent was in arrear. wherefore the defendant entered and made a distress for the same.

The plaintiff, on the 6th of December, 1834, replied that one Adam Charlton, before the demise in the plea mentioned, and from thence and still was in possession of eight acres of land of the said demised premises, under and by virtue of a demise theretofore made by the defendant to him, which demise was then and from thence had been and still was in full force and undetermined, whereby the plaintiff did not and could not enter into the possession of, or hold or enjoy the said lastmentioned land, so being parcel of the demised premises in the plea mentioned; and although he had been willing and desirous of entering, he had been kept out of possession by Adam Charlton by virtue of the demise to him, and the plaintiff had been prevented from holding and receiving the profits.

The rejoinder alleges that the plaintiff, at the time of his entering on the demised premises, had notice that Adam Charlton was in possession of the eight acres as tenant to the defendant, under a demise for a term then unexpired.

To this rejoinder there is a special demurrer, for inconsistency with the plea and departure therefrom.

The question to be determined is, whether the replication be an answer to the plea.

It has been argued that the impediment to the plaintiff's obtaining possession of the eight acres demised to Adam Charlton by the de-

10 The statement of facts is omitted. 
fendant previously to the demise made to the plaintiff, is in the nature of an eviction. On one side it is contended that it is analogous to an eviction by title paramount, the right of Adam Charlton being prior to the demise made by the lessor, and to the title acquired under that demise by the lessee; and on the other side, that it is analogous to an eviction by the tortious act of the lessor, since the impediment arises from the wrongful act of the lessor himself in demising land which he had already parted with; and is not to be distinguished in principle from the case of an entry upon the lessee under a demise made by the lessor to a stranger immediately after possession taken by the lessee.

If the former of these views be adopted, the rent will be apportionable, and the distress justified by the plea:-for it is clear that a person may distrain for apportionable rent; and, if the defendant was entitled to distrain at all, the action of trespass cannot be maintained. If the latter view be correct, the defendant was not entitled to distrain at all, so long as the plaintiff was kept out of possession of any part by his wrongful act.

But, we are of opinion that the impediment to the plaintiff's taking possession in this case, is not analogous to an eviction:-for it appears to us that no interest in the eight acres previously demised to Adam Charlton passed to the plaintiff by the demise subsequently made to him. The demise to Adam Charlton covered the whole time during which the rent distrained for accrued.

But it has been supposed, that notwithstanding the demise to Adam Charlton, by which the defendant had parted with his right of possession in the eight acres, the plaintiff by his subsequent lease took an interesse termini in these eight acres for the period of his own lease, viz., one year, so as to give him a right to a term for all that period, and to the possession on the determination of the prior lease by efflux of time, or by any other lawful mode, whenever and in whatever way it should be determined; and that the existence of the prior demise being the impediment by which alone the plaintiff was prevented from obtaining possession under the demise to him, the case must be governed by the same principle as that of an eviction by title paramount: and, if any interest in the eight acres did pass to the plaintiff under the demise to him, we might possibly be disposed to accede to this view of the case; considering that eviction by title paramount means eviction by a title superior to the titles both of lessor and lessee; against which neither is enabled to make a defence.

It appears to us, however, upon authority which we do not feel ourselves at liberty to dispute, that the denise to the plaintiff of the eight acres in question was wholly void.

It has been already observed that the demise to Charlton, made previously to the demise to the plaintiff, covers the whole of the plaintiff's term; or at least the whole period for which the distress was made. Now, it is expressly laid down in Bacon's Abr., Leases, (N.,) (which is 
to be considered as the language of Lord Chief Baron Gilbert,) as follows: "If one make a lease to $\mathrm{A}$. for ten years, and the same day make a parol lease to $B$. for ten years of the same lands, this second lease is absolutely void, and can never take effect either as a future interesse termini, or as a reversionary interest, though the first lessee should forfeit or otherwise determine his estate, or though the first lease were on condition, and the condition broken within ten years; neither shall the lessor have the rent reserved upon such second lease, but such second lease is absolutely void, as if none such had been made. 'The reason whereof is, because the first lease being made for ten years, the lessor during that time had nothing to do with the possession, or to contract with any other for it; and the second lease being made the same day, and for no longer term than the first ten years, would not pass any interest as a future interesse termini certainly; for, the first lessee had the whole interest during that time; and his forfeiture or determination of it sooner, which was perfectly contingent and accidental, shall never make good the second lease as a future interesse termini, when at the time of making thereof it was absolutely void for want of a power in the lessor to contract for it: and as a reversionary interest it cannot be good for want of a deed." And a little further on, "But now, if such second lease had been made for twenty years, then it had been good as a future interesse termini for the last ten years, and void for the first ten years for the reasons before given, but for the last ten years it had been good; because, when the first ten years were elapsed, the second lessee might then execute and reduce into possession by entry as well as if it had been at first made in possession; for, it had been good for the whole twenty years if the first lease had not stood in the way, and that can stand in the way no longer than it continues, and therefore, by its termination, lets in the second lease; but, as a grant of the reversion such second lease could not be good for want of a deed, for the reasons before given, neither could any attornment help it or let in the second lease, till the first ten years ran out by effusion of time." And afterwards it is said that if, after a lease for ten years, a second lease by deed poll were made for twenty years, it might take effect with attornment as a grant of the reversion, or, if no attornment could be had, "yet it would enure as a future interesse termini for the last ten years, and would be absolutely void for the first ten years, as much as if it had been made by parol."

It has been remarked that the doctrine here laid down is derived from the argument of counsel in the case of Bracebridge v. Clowse, in Plowd. 421: but it may be answered, that although the matter introduced into Bacon's Abridgment is first distinctly found in the argument set forth at length in Plowden, it now stands upon the authority of Lord Chief Baron Gilbert. Moreover, the point immediately under consideration in this case is confirmed by the opinion of Gawdy, J., in Dove v. Willcot, Cro. Eliz. 160, who say's, "If a lease be made for two 
years, and after the lessor let the land for four years, this is but a lease for two years, although the first lessee surrender, for he had no power to contract for the first two years at the beginning; but otherwise when the estate is determinable upon an uncertainty;" and cites Plowd. Comment. Smith \& Stapleton's case, which is the case where the argument is fully stated-fo. 432.

It may be remarked also that in Comyns's Digest, title Estates (G. 13 ,) it is said that a lease which cannot take effect in interest, except by possibility, if it be not an estoppel, shall be void; as, if tenant in fee leases by parol to A. for nine years, and the same day to B. for nine years, the lease to $\mathrm{B}$. shall be void. For this he cites Plowden, 432 , and though this statement be only part of the language of the apprentice who argued the case of Smith v. Stapleton, Chief Baron Comyns, by introducing it in this general way, must be considered as adopting it in some degree at least as authority: in what is said by Gawdy, as referred to in Cro. Eliz. 160, there is afterwards added Smith v. Stapleton, Plow. 426, though it is not clear whether this be his language or that of the reporter.

The same doctrine, as far as regards a second parol lease for years after a former lease for years, appears to have been treated as clear law in various books; though the effect of such a lease made after a prior lease for life, has been the subject of discussion. See Bro. Abr., Lease, pl. 35, 48; Plowden, 521, note of the reporter. Welchden v. Elkington, Plowd. 521; Plowden's Quæries, 122 and 161; Sir Hugh Cholmondeley's case, Moore, 344, in the argument of Cook, Attorney-General. So, in Watt v. Maydewell, Hutton, 105-"If a man make a lease for twenty-one years and after makes a lease for twenty-one years by parol, that is merely void; but if the second lease had been by deed, and he had procured the former lessee to attorn, he shall have the reversion." Edward v. Staler, Hardr. 345, arguendo. So Sheppard's Touchst. $275 \mathrm{~b}$ : "If the second lease be for the same or a less time, as, if the first lease be for twenty years, and the second lease be for twenty or for ten years, to begin at the same time, these second leases are for the most part void;" but if the second lease be by fine, deed indented or poll, it may pass the reversion with attornment when attornment is necessary, and without if not necessary. But, if the second lease be by word of mouth it is otherwise:" "And if the second lease be by fine, or deed indented, then it may work by way of estoppel hoth against the lessor and the lessee; so that, if the first lease happen by any means, as, by surrender or otherwise, to determine before it be run out, then the second lessee shall have it."

Upon these authorities, therefore, we feel ourselves obliged to hold that the lease to the plaintiff was utterly void, so far as regarded the eight acres demised to Charlton.

If that be so, we are unable to distinguish the case in principle from that of Gardiner v. Williamson, 2 Barn. \& Adolph. 336, where the tithes of a parish, together with a messuage used as a homestead for 
collecting the tithes, having been demised by parol at a rent of $200 l$. per annum and a distress made for arrears, the Court of King's Bench held that an action of trespass would lie, because the demise of the tithes, being by parol, was void. There was no valid demise, it was said, of the whole subject matter, nor any distinct rent reserved for that part of it upon which there might have been a legal distress. That case was the stronger, because it was contended that the whole rent must be taken to be issuable out of the corporeal hereditament, upon which alone a distress could be made. And accordingly, in a case of a lease by indenture, Dyer is reported to have held, (Moore, 50,) that, if lands at common law and copyhold lands are leased by indenture rendering rent, all the rent is issuing out of the lands at common law; for the lessor had no power to make such a lease of copyhold, wherefore as to this the lease is utterly void; but it is added, that if a man lets lands, parcel of which he is seised of by disseisin, then the rent is issuing out of all the land, and by the entry of the disseisee the rent shall be apportioned, because the lease of this was not void but voidable. In this last case the tenant took an interest, and enjoyed all the lands demised till the time of his being evicted from a parcel thereof by the disseisee, and was therefore liable in respect of such interest and enjoyment to a portion of the rent. In the case before the court, which is not the case of a demise by indenture, the rent is reserved in respect of all the land professed to be demised, and to be issuing out of the whole and every part thereof; and as the plaintiff, as to a portion of the land comprised in the demise, (which might be great or small, as far as the principle is concerned,) has taken no interest, and had no enjoyment, and is not bound by any estoppel, we are of opinion that the distress made by the defendant is not justifiable, either in respect to the whole rent reserved or any portion of it.

It may further be observed, that, even supposing the plaintiff to have taken an interesse termini in the eight acres, capable of being executed by entry in case the demise to Charlton should happen to be forfeited or surrendered, yet, as that demise to Charlton was in force at the commencement of the plaintiff's tenancy, and continued during the whole period, in respect of which the distress has been made, no demise of those eight acres to the plaintiff ever took effect; and, consequently, no right to any rent in respect of those eight acres has ever come into existence. And we are not aware of any case where an entire rent reserved has been held to be apportionable, in which the tenant has not been at some period subject to the entire rent by virtue of the demise. Here, the right of apportionment is not founded upon any eviction, or other matter occurring subsequently to the demise, but upon an original defect in the demise itself by which the entire rent was reserved. In this respect it is strictly analogous to Gardiner v. Williamson.

In the case of Tomlinson v. Day, 5 Moore, 558, which has been referred to, the landlord did not claim an apportioned part of an entire rent, 
either by avowry for a distress or by action for the rent. It was an action for use and occupation, in which he was allowed to make use of an agreement for a lease, (according to the express provision of the statute 11 Geo. 2, c. 19, s. 14, "as evidence of the quantum of damages to be recovered;" and, as the defendant had been interrupted in the full enjoyment of what had been agreed for, the plaintiff was held "entitled to recover a reasonable compensation for the property enjoyed by the defendant as an equivalent for rent." The interruption to the defendant's right of exclusive sporting was indeed compared by Lord Chief Justice Dallas and Mr. Justice Richardson to an eviction; but, if it was an eviction, it was clearly an eviction by title paramount. The agreement for exclusive sporting was not void on account of the landlord having made a prior agreement to let it to some other person; but it was defeated, because other persons interfered who had a right superior to that of the landlord. Supposing the circumstances, therefore, to amount to an eviction, it would be a case of apportionment according to the acknowledged rule; and would not assist the argument in favour of the defendant.

Upon the whole, therefore, we are of opinion that the judgment of the Court of Exchequer ought to be reversed.

Judgment reversed.

\section{LAWRENCE v. FRENCH.}

(Supreme Court of New York, 1S41. 25 Wend. 443.)

This was an action of replevin, tried at the Albany circuit in June, 1839 , before the Hon. John P. Cushman, one of the circuit judges.

The plaintiff, on the 12th December, 1835, took a lease of the defendant of a building in the city of Albany called the Exchange Coffee House, for the term of one year from the first day of May, 1836 , at an annual rent of $\$ 1,050$, payable quarterly. He had, since May, 1834, been in possession of the whole of the premises demised, except one room in the corner of the building, which was occupied by one Candy. On the first day of May, 1836, Candy, under a prior lease from the defendant, at an annual rent of $\$ 400$, continued in the occupation of the room; and the plaintiff continued to occupy all the residue of the building, until 17th January, 1837; when the defendant issued a distress warrant, claining $\$ 487.50$ to be.due to him from the plaintiff from three quarters' rent, estimating the rent by deducting $\$ 400$ from the annual rent reserved in the lease to the plaintiff; thus charging the plaintiff with an annual rent of only $\$ 650$, for three-fourths of which sum the warrant was issued. The property of the plaintiff was distrained to the amount of $\$ 487.50$; and the plaintiff sued out a writ of replevin. It was conceded by the plaintiff that $\$ 650$ per annum was a fair price for the use of that portion of the premises occupied by him; but he insisted that the defendant, 
not laving put him into possession of the whole of the demised prenises, had no authority by law to distrain for the rent reserved, or any part thereof; and so requested the judge to charge the jury. The judge refused so to charge; and on the contrary instructed the jury that the defendant had a lawful right to make the distress for the sum demanded, and was entitled to their verdict. The jury accordingly found a verdict for the defendant, with six cents damages and six cents costs; found the rent to be $\$ 487.50$, and the value of the property at the same sum; and assessed the damages of the defendant at $\$ 10$, for the detention of the property. The plaintiff having excepted to the charge of the judge, moved for a new trial.

Nelson, C. J.47 It is a familiar rule of law, that if the landlord enter wrongfully upon, or prevent the tenant from the enjoyment of, a part of the demised premises, it suspends the whole rent, until possession is restored. His title is founded upon this, that the land leased is enjoyed by the tenant during the term; if, therefore, he be deprived of it, the obligation to pay ceases. The rule is otherwise where a part is recovered by title paramount to the lessor's; for, in that case he is not so far considered in fault, as that it should deprive him of a return for the part remaining. The law, therefore, directs an apportionment of the rent. 6 Bacon's Abr. 44, tit. Rent, L.; Gilbert on Rents, 173; Comyn's Land. \& Ten. 214-219; Bradby on Dist. 24-3. But as between lessor and lessee, an eviction from part by the former, or any person claiming through him, will operate a suspension of the whole. Comyn's Land. \& Ten. 524; 2 Saund. Pl. \& Ev. 630. There are some cases illustrating this principle to which I will refer. ***

The case of Ludwell v. Newman, 6 T. R. 458, in principle, comes near the present one. It was an action on a covenant of quiet enjoyment in a lease. The breach was, that the plaintiff could not obtain the possession; that he applied to the tenant to attorn, who refused; an action of ejectment was brought, and defeated by a previous lease of the defendant, given the month before; by reason of all which the plaintiff was prevented from enjoying the term, \&c. The second count was like the first, except it omitted the application to attorn, and proceedings in ejectment. Defective pleas were put in to each count, to which there were demurrers. One objection taken to the pleas was this: they stated the plaintiff might lawfully have enjoyed during the first half year; when it appeared by the declaration, that he could not have entered at any time on account of the prior lease. The court held, that the defendant's covenant of quiet enjoyment meant a legal entry and enjoyment, without the permission of any other person; which could not take place on account of the prior subsisting lease granted to $R$. See Platt on Cov. 327. The case decides that the lessee is not bound to test his right of entry by suit, as

47 Part of the opinion is omitted. 
the only legal evidence of a breach of the covenant; nor need he commit a trespass by an actual entry. Platt on Cov. 327; Hob. 12; 2 Bacon, 66, B.

In Tomlinson v. Day, 2 Brod. \& Bing. 680 , the defendant took a farm under an agreement, by which the plaintiff stipulated that he should enjoy the exclusive right of sporting over the manor in which the farm lay, and should occupy the glebe land of the parish; rent $£ 450$. The agreement, though acknowledged and recognized by the defendant, had never been signed by him; but he occupied the farm for some time. The chief inducement in taking it, was the privilege of sporting; but it turned out the plaintiff had no power to grant the privilege, and the defendant was in fact warned off by the occupiers of the manor. Neither did he get possession of the glebe. In an action for use and occupation, the court held that an eviction of a part of the subject matter of the demise had been proved, and allowed a recovery for no more than the annual value of the farm. Though the rule for a time seems to have been inflexible, that in these cases the whole rent should be suspended till possession was restored, the last case referred to shows, that if the tenant occupies part, he may be charged for such occupation upon a quantum meruit. * * *

The result of all these cases, I think, shows that the defendant here has deprived himself of the remedy by distress. The eviction from part of the demised premises, by means of his prior lease, defeated the contract; and though the tenant is still liable by reason of his occupation of the residue, the holding is not strictly under the original agreement, but an implied obligation arises to pay the worth of them at the time specified therein. No fixed rent is due, and therefore distress is not the appropriate remedy. It would be unjust to allow it here, as the party himself has put it out of the power of the tenant, to tender the amount. His rights will be sufficiently protected by allowing the usual redress, where no specific rent has been agreed on. 5 Barn. \& Ald. 322.

New trial granted..

\section{FRIEND v. OIL WELL SUPPLY CO.}

(Supreme Court of Pennsylvania, 1897. 179 Pa. 290, 36 At1. 219.)

STERRETT, C. J.48 There is practically no controversy as to any of the matcrial facts in this case. On March 12, 1892, by written agreement, plaintiff leased to defendant company, for one year from July 1, 1892, "all that portion of Eagle Rolling Mill" described therein, for the yearly rent of $\$ 6,000$, payable monthly, etc. Prior to the date of said lease, the rolling mill had been occupied by the Oliver Iron \& Steel Company under lease from plaintiff which expired on

48 Part of the opinion is omitted. 
July 1, 1892. By and with the consent of their lessor, that company had sublet part of said property to the defendant company, and it had entered upon the demised premises, and was in possession thereof prior to March 12,1892, and continued in possession until July 1, 1893, the expiration of the first-mentioned lease. This suit was brought to recover the one year's rent due under that lease. The defense was eviction by the Pittsburg, Cincinnati, Chicago \& St. Louis Railway Company under paramount title, etc.

The railroad bridge or viaduct referred to by the court below was erected prior to 1865 , and, having been destroyed by fire, was rebuilt in 1885. From the date of its original construction until the present time it has stood on the same abutments, etc. The right of way, for that part of the railroad, etc., was acquired by condemnation proceedings in the district court of Allegheny county at No. 115, July term. 1855 , in connection with the release of James Wood, then owner of the Eagle Rolling Mill property, executed December 2, 1864, and duly recorded, etc. For the consideration therein set forth, said Wood, for himself, his heirs, executors, administrators, and assigns, granted and released unto the then owners of the railroad, their successors and assigns, forever, the right of way for their railroad tracks, bridges, and abutments, as the same are now located through, over, and upon a certain tract of ground, and over a certain rolling mill, situate on the south side of the Monongahela river, at or near Saw Mill run, "being all the rights, liberties, and privileges secured by the Pittsburg \& Steubenville Railroad Company by virtue of divers proceedings had in the district court of Allegheny county at No. 115, July term, 1855 , the said record and proceedings being taken and made as part of this release." He also released them "from all claims for damages by reason of the location of the said railroad and bridge of the said companies, through, over, or upon the tract aforesaid."

The perpetual servitude thus imposed upon a portion of the rolling mill property, with all its incidental rights of maintenance, repair, reconstruction, etc., pertaining thereto, has been continuous, open. and manifest to all who had anything to do with the property; and its effect on the servient property must have been contemplated by both lessor and lessee when the lease in question was executed. With this bridge or viaduct, constituting a section of the railroad there upon the ground, the defendant went into possession as the subtenant of the Oliver Iron \& Steel Company, and afterwards took the new lease from the plaintiff. It cannot be doubted that the defendant was fully aware of the open and visible servitude to which the demised property then was, and would continue to be, subject, while in its possession as lessee. It is well settled that, where a continuous and apparent easement or servitude is imposed upon land, a purchaser of the servient property, in the absence of an express reservation or agreement on the stibject, takes the property subject to the easement Big.Rights-40 
or servitude. Cannon v. Boyd, 73 Pa. 179; Geible v. Smith, $146 \mathrm{~Pa}$. 276, 23 Atl. 437, 28 Am. St. Rep. 796; Ormsby v. Pinkerton, 159 $\mathrm{Pa} .458,28 \mathrm{Atl}$. 300. This principle is not restricted to cases between the owner of the servient and the owner of the dominant property. Eby v. Elder, $122 \mathrm{~Pa}$. 342, $15 \mathrm{Atl}$. 423. In that case the defense interposed to a purchase-money mortgage was that the land purchased was incumbered by a private right of way, and it was held that "if, when land is conveyed, it is openly and plainly subject to an easement of way, the existence of the easement will be no defense to the payment of the purchase money, as a breach of the covenant against incumbrances implied from the words 'grant, bargain and sell." "*** Other authorities to the same effect might be cited, but those above referred to are sufficient.

The soundness of the underlying principle therein recognized cannot be questioned, nor is there any valid reason why the same principle should not be applied in cases between lessor and lessee, where it is clearly shown that the latter was fully aware of the fact that the demised premises, or part thereof, was subject to an open, notorious, and permanent servitude or easement, such as the railway viaduct, etc., in this case. In such cases, unless something to the contrary appears, it is fair to assume that the parties contracted with reference to the then existing condition of the premises, and that the lease was made and accepted subject to the railway company's right of way over some of the buildings composing the rolling-mill plant, together with all the incidental rights pertaining to such an easement. It so happened that the railway company found it necessary, during a few months of defendant's term, to exercise some of those incidental rights in repairing and practically reconstructing its viaduct. In consequence of this, the defendant was more or less inconvenienced and deprived of the beneficial enjoyment of a part of the premises during that time; but that result was neither the fault of the plaintiff nor a matter over which he had any control. If an unreasonable time was con- sumed in the work of reconstruction, or if anything to defendant's injury was done by the railway company, in excess of the authority acquired by the condemnation proceedings and release aforesaid, defendant company's remedy, if any it has, would be against the wrongdoer, and not against the plaintiff.

It is unnecessary to consider the plaintiff's further answer to the defense against the payment of rent, viz. "that there was no eviction in this case." It follows, from what has been said, that there was no error in directing the jury to find for the plaintiff the full amount of his claim. The authorities mainly relied on by the learned counsel for defendant are inapplicable to the undisputed facts of this case. Judgment affirmed. ${ }^{49}$

49 See Duncan v. Granas, 166 Cal. 41, 134 Pac. 979 (1913); Tunis v. Grandy, 22 Grat. (Va.) 109 (1572). 


\section{MOORE v. MANSFIELD et al.}

(Supreme Judicial Court of Massachusetts, 190:. 182 Mass. 302, 65 N. E. 39S, 94 Am. St. Rep. 65T.)

Holmes, C. J. This is a bill to reach and apply the proceeds of a judgment recovered by the defendant to the payment of a debt alleged to be due to the plaintiff for use and occupation. The bill was dismissed by the Chief Justice of the Superior Court, and the facts found by him were reported under the statute, substantially as follows: The defendant hired of the plaintiff an entire house by a parol lease, and took possession. At the time, the attic was locked and contained goods belonging to the plaintiff. The defendant did not find this out at first, but when he did he asked for the key and the use of the attic but never got it while he occupied the house. The judge found that there was a partial eviction and dismissed the bill, seemingly on this ground and the further one that the equitable process given by Rev. Laws, c. $159, \S 3, \mathrm{cl} .7$, to reach and apply certain property "in payment of a debt," would not be available upon a claim for an unascertained amount for use and occupation. The question is whether the facts found show the decree to have been wrong.

We say nothing about the latter ground inasmuch as we are of opinion that the former is good in substance, so far as appears from any facts stated in the report. The plaintiff contends that there was no eviction because the defendant never had possession of the room. Townsend v. Wharf Co., 117 Mass. 501; Vanderpool v. Smith, 1 Daly (N. Y.) 311. If the question were material, it would raise the difficulty that while the defendant had possession of the whole land and of the room on the outside considered as an enclosed cube, yet if the analogy of the cases on larceny by carriers breaking bulk were followed, he would not have possession of the contents of the room; and, by the same argument, perhaps not of the inside of the room itself. Y. B. 13 Ed. IV, 9, pl. 5; Fairfax, J., in Keilway, 160, pl. 2; 8 Edw. II, 275; s. c. Fitz. Abr. "Detinue," pl. 59; 2 Bish. Cr. Law (8th Ed.) $\S \S 834,860$.

The true reason appears from the old books. Perhaps possession by the tenant would be presumed until the landlord's refusal gave an expressly adverse character to the landlord's conduct, inasmuch as the tenant lawfully might have unlocked the door. But it does not matter whether the refusal to give up the room was a failure to perform the whole contract from the beginning, or a partial eviction after performance at the outset. The difference would be material onty if there were a question of waiver involved. But there is no such question in the case. The tenant entered not knowing that the room was locked, and no fact later than the entry is recited which implied a waiver. All that appears is that the failure to open the room continued during the tenancy, and that the tenant insisted upon his 
rights. There being no waiver the plaintiff could not recover on the express contract because he had not furnished the stipulated consideration, and he could not recover upon an implied one for the benefit actually received because the failure to furnish the whole was due to his own willful fault. Leishman v. White, 1 Allen, 489; Royce v. Guggenheim, 106 Mass. 201, 202, 8 Am. Rep. 322; Smith v. McEnany, 170 Mass. 26, 48 N. E. 781, 64 Am. St. Rep. 272. It may be that in this class of cases the old common law is adhered to a littlo more rigidly than in some others. See Gillis v. Cobe, 177 Mass. 584, 59 N. E. 455. The absence of a written lease makes no difference. Colburn v. Morrill, 117 Mass. 262, 264, 19 Am. Rep. 415.

The distinction taken by Tayl. Landl. \& T. (8th Ed.) § 379, between eviction and refusal to put the tenant in possession of some privilege which he ought to have enjoyed, very likely is sound with regard to the cases which the author cited and had in mind, that is to say, with regard to cases where the tenant entered and occupied the demised premises, and there was a subsequent failure to perform a covenant for an improvement or one affecting the enjoyment of the premises. Etheridge v. Osborn, 12 Wend. (N. Y.) 529; News Co. v. Brown, 103 Ill. 317, 320. See, also, Allen v. Pell, 4 Wend. (N. Y.) 505. And so it might be where there was a known failure at the outset to give possession of all the stipulated land and the entry of the tenant showed a waiver of compliance with the strict terms of the lease.

Decree affirmed. ${ }^{50}$

\section{SMITH v. BARBER.}

(Supreme Court of New. York, Appellate Dirision, First Department, 1906. 112 App. Div. 1S7, $9 S$ N. Y. Supp. 365.)

IngraHAM, J.51 The action was brought to recover the rent reserved by a lease, whereby the plaintiff leased certain premises to the defendant, together with the costs of certain improvements on the premises, which was, under the lease, to be paid by the tenant. On the trial the court excluded evidence offered by the defendant to sustain the defense set up in the answer, and directed a verdict for the plaintiff. Exceptions were taken to these rulings and they were ordered to be heard here in the first instance. The lease is annexed to the complaint. By it the plaintiff leased to the defendant the office on the first floor fronting on Wall and New streets, and a portion of the second floor fronting on Wall and New streets, in a building in course of erection at the corner of Wall and New streets in the city of New York, to be used as offices for the business of the Equitable Trust

soAcc.: McClurg v. Price, 59 Pa. 420, 98 Am. Dec. 356 (1869). See Sullivan v. Schmitt, 93 App. Div. 469, S7 N. Y. Supp. 714 (1904); Penny v. Fellner, 6 Okl. 3S6, 50 Pac. 123 (1894).

61 Part of the opinion is omitted. 
Company, and for no other purpose, "beginning February 1, 1900, and expiring May 1, 1910, at a yearly rental of thirty-seven thousand five hundred $(37,500)$ dollars," payable in equal monthly payments in advance. The lease provided:

"No compensation or claim shall be made by the tenant by reason of inconvenience or annoyance arising from the necessity of repairing any portion of the building, however the necessity may occur. * * * And it is further understood and agreed that the landlord will fit up the herein demised premises in a proper and suitable manner for the transaction of a banking and trust company business, the cost of which in excess of the sum of four thousand $(4,000)$ dollars is to be paid by the tenant.

This lease was dated September 27, 1899, and the term was to commence on February 1, 1900. The action was brought to recover the rent from February 1, 1900, to September 1, 1900, and also for the cost of fitting up the denised premises in excess of the sum of $\$ 4,000$; to wit, $\$ 11,068.73 . * * *$

On the trial the plaintiff was allowed to amend his complaint, and subsequently the defendant was allowed to amend * * * paragraph 12 of his answer so that the same read:

"That on the first day of February, 1900, and for a long time thereafter, plaintiff was in possession of said premises by his tenants, agents, servants, contractors, and employés, engaged in the construction, completion, and fitting up of the same. That said tenants in possession of said premises held the same under a lease made by the plaintiff to them prior to the making of the lease annexed to the complaint herein, and said tenants were holding such possession under title paramount to the defendant herein, and the plaintiff thereby excluded the defendant from possession of a portion of the demised prenises."

On the trial the defendant admitted that the rent sued for had been demanded and not paid. The following facts were then stipulated by counsel:

"At the time the parties to this action entered into the lease, a portion of the first floor of the premises covered by the lease was occupied by Seligsberg \& Company. Said lease had been made by the plaintiff to Seligsberg \& Company on or about May 1, 1899, for a term expiring May 1, 1900. The lease was an oral lease. The plaintiff was notified that the defendant would require Seligsberg \& Company to vacate the premises on the 1st of February, 1900. The occupancy of the premises by Seligsberg \& Company delayed the completion of the improvements in the premises, and some of the work could not be finished until they vacated on that date. The improvements made by the plaintiff in fitting up the premises pursuant to the lease herein were not completed on February 1, 1900, and not until about the 1st of June, 1900 , when they were completed." 
The plaintiff, while conceding these facts, objected to their competency under the answer, and this objection was sustained, and defendant excepted. $* * *$

The real question presented on this appeal is whether the defendant was entitled to prove as a defense to the action that the improvements upon the premises were not completed.prior to February 1, 1900, and that from February to May, 1900, other tenants were in possession of the premises leased to the defendant under an oral lease made by the plaintiff prior to the execution of the lease in question for one year from May 1, 1899. This case was before this court upon a former appeal from an order setting aside a verdict in favor of the plaintiff, and granting a new trial. 96 App. Div. 236, 89 N. Y. Supp. 317. Although there was some discussion in the opinion as to the rights of the plaintiff and the defendant under this lease, it does not seem that that question was decided. The court held that certain evidence which was admitted had no bearing upon the question of whether the defendant on February 1, 1900, waived his right to rescind the contract, or thereafter acted with reference to the premises so that the jury could have inferred, by assuming dominion over the premises, he elected to continue in possession under the lease; that, in view of the course which the trial took, the evidence which was improperly admitted, and the erroneous theory upon which the case was submitted to the jury, the conclusion was that the trial judge was justified in setting aside the verdict, and granting a new trial, and that order was therefore affirmed. The court, however, in discussing the question as to the liability of the defendant for this rent, said:

"The acceptance of the lease, therefore, under which the defendant obtained the right to the use of the entire premises from the first of February, did not render him liable for the rent, where a substantial portion thereof was held by another tenant under a valid lease from the plaintiff, and where, as here, the defendant never went into actual occupancy of any portion of the premises. Having notified the plaintiff of the obligation resting upon him of getting Seligsberg \& Company out, and no action having been taken, so far as appears, by the plaintiff to that end, the defendant, had he so elected, would have had the legal right on the first of February to notify the plaintiff that he regarded the lease as terminated and canceled. Upon that date, when the term was to begin, the defendant was legally put to his election, and it was entirely competent for the plaintiff to show, as was attempted to be shown, that not only had the defendant not elected to terminate the lease, but that his acts were such that they are to be legally construed into a waiver of the condition precedent to his liability for rent, namely, his obtaining complete possession."

The court then says: "Where a person enters into possession of a portion of the premises, he is liable for the rent of the whole; and if he has not full possession he cannot refuse to pay the rent, but his 
remedy for his damages arising from the failure to receive full possession is either by way of counterclaim to the original action for rent, or by way of an independent action."

The observation here would seem to indicate that it was the opinion of the court that the defendant would be liable for rent for the period, unless he proved that he elected to terminate the lease. The law in this statc in relation to the obligation of the tenant to pay rent after the beginning of the term does not depend upon the possession by the tcnant of the demised premises. If the tenant acquire a perfect title to the premises by virtue of the lease, which would include the right of possession, then he is bound under his covenant to pay rent, regardless of the question whether or not he actually obtained possession of the prenises. Gardner v. Keteltas, 3 Hill, 330, 38 Am. Dec. 637, where Nelson, Chief Justice, says:

"All that either of the covenants mentioned exact of the lessor is that he shall have such a title to the premises at the time as shall enable him to give a free, unincumbered lease for the term demised. There is no warranty, express or implied, against the acts of strangers. Hence, if the lessee be ousted by one who has no title, the law leaves him to his remedy against the wrongdoer, and will not judge that the lessor covenanted against the wrongful acts of strangers, unless the covenant be full and express to the purpose. * * * I admit the covenant of quiet enjoyment means to insure the lessee a legal right to enter and enjoy the premises, and if he is prevented from entering into the possession by a person already in under a paramount title the action may be sustained. That was decided in Ludwell v. Newman, 6 T. R. 458. In such a case no ouster or expulsion is necessary on which to predicate a suit, as the lessee is not bound to enter and commit a trespass." * * *

These cases all recognize the rule that where a third party is in possession of the demised premises, claining possession under a title paramount to the title of the lessor, and the tenant is thereby excluded from possession of the premises, there can be no recovery for rent under the covenant in the lease. The amendment of the defendant's answer, whereby the defendant as a defense alleged that the tenants in possession of the premises held the same under a lease made by the plaintiff to them prior to the making of the lease to the defendant, and that the said tenants were holding such possession under a title paramount to the defendant herein, and plaintiff thereby excluded the defendant from a portion of the premises, was a good answer for a demiand for rent of the premises during the period that the defendant was excluded from the premises. It was, therefore, competent for the defendant to prove under this answer that at the time the term commenced the premises were occupied by Seligsberg \& Co. under a lease from the plaintiff which extended to the 1st of May, thrce months after the defendant's term commenced, and that the defendant never occupied these leased premises. 
I think, therefore, that the exceptions should be sustained, and a new trial ordered, with costs to the defendant to abide the event. ${ }^{52}$

O'Brinn, P. J., and McLaughlin, Clarke, and Houghton, JJ., concurred.

\title{
SECTION 4.-WHAT PAYMENTS ARE RENTS
}

\author{
Y. B. 12 H. 8. MICH. [1520] pl. 5.
}

Note that it was agreed: If one makes a lease of goods and land for a year and the land is recovered against him but he keeps the goods until the end of the term the rent shall be apportioned.

\section{EMMOTT v. COLE.}

(Court of Queen's Bench, 1591. Cro. Eliz. 255.) ss

Debt upon an obligation made ult' March, 29 Eliz. The condition was, to perform all covenants, conditions, articles, agreements and clauses in an indenture bearing the same date. The defendant pleads the indenture, which was a lease for years of certain lands and stock of cattle to the defendant and to Tolfry, rendering twenty pounds rent per annum, and all the covenants and other clauses in it wère concerning the land; and pleads, that long time before the lessor had any thing in it, one $\mathrm{C}$. was seised of the land in fee, and acknowledged a statute to J. S. and that after the lease made, viz. 29 May, 29 Eliz. the conusee sued execution, and all the land was delivered in execution (so they were thereof evicted); and that after the date of the indenture, until execution sued, he and Tolfry had performed all the covenants, conditions, agreements and clauses in the said indenture. Upon this plea it was demurred in law.

The matter in law was, if a lease be made of lands and goods rendering rent, if the land be evicted, whether all the rent shall be gone, or there shall be an apportionment in regard of the goods; and so the non-payment of the portion for the rent be a forfeiture of the bond. And he said there shall be an apportionment, 12 Hen. 8, pl.

B 2 Compare United States Restaurant \& Realty Co. v. Schulte, 67 Misc. Rep. 633, 124 N. Y. Supp. 835 (1910).

A. leased premises to $B$, occupation to begin at a specified date. On that date a former sublessee, whose lease had expired, was in possession of part of the demised premises and continued to occupy this part. Held, in an action by $A$. against $B$. for the rent reserved this fact is no defense to A.'s action. Ward v. Edesheimer, 17 N. Y. Supp. 173 (1S92). See Little v. Hudg. ins, 117 Ark. 272, 174 S. IV. 520 (1913).

68 Part of the opinion is omitted. 
11 ; 35 Hen. 8 , Dyer, 56 , if the goods be evicted thiere shall be an apportionment; and so e converso.

Curia contra in omnibus. ***

For the matter in law, there shall be no apportionment, for the rent issueth out of the land, and follows it; and so Wray, Chief Justice, said it hath been heretofore adjudged. And it was here adjudged that the plaintiff shall be barred. ${ }^{54}$

\section{NEWMAN v. ANDERTON.}

(Coúrt of Common Bench, 1S06. 2 Bos. \& P. [N. R.] 224.)

Replevin. The plaintiff in his declaration complained that the defendant took certain goods and chattels of the plaintiff in a bed-room and shop, and unjustly detained them, against sureties and pledges. The defendant avowed the taking in the bed-room, because "the plaintiff, for the space of 16 weeks and more next before, and ending, \&c enjoyed the said bed-room, in which, \&c. together with a certain other room and apartment, also being in and part and parcel of the said dwelling-house in the declaration mentioned, with certain furniture and effects with which the said bed-room in which, \&c. and the said other room and apartment, with the appurtenants, were furnished under a demise thereof theretofore made by the defendant to the plaintiff, at the weekly rent of 13s. of lawful money of Great Britain, payable weekly on the Thursday in every week, and during all that time held the same of the defendant by virtue of the said demise, as his tenant thereof." And because $£ 12$. were in arrear, avowed the taking and prayed a return.

The plaintiff took judgment for so much as related to the shop; and as to the avowry, pleaded that he did not hold the said bed-room together with the said other room and apartment in the said declaration mentioned, and certain furniture and effects with which the said other room and apartment were furnished under a demise thereof theretofore made by the defendant to the plaintiff, at the weekly rent of 13s. payable on the Thursday in every week in manner and form, \&c.

On this plea issue was joined.

At the trial before Sir James Mansfield, Ch. J., at the Westminster sittings after last Hilary term, a verdict was found for the defendant.

[Rule nisi to set aside the verdict.]

Sir James Mansfield, C. I. Cases like this must have very often occurred, and yet it does not appear that the right of distress has ever before been called in question. The difficulty of the case consists in this, that in London and other towns it scarcely ever happens that any house is let without some goods being let with it, and yet one

54 See Le Taverner's Case, Dyer, 56a (1543); liead 7 . Lawnse, Dyer, 212b (1562). 
rent is always reserved. In the case of a brew-house it is common to let the utensils with it, and yet I never heard it doubted that the landlord might destrain for rent. Whether the goods be worth five shillings or five hundred pounds the case must be the same. We will inquire into the matter, and give our opinion in a few days.

Cur. adv. vult.

On this day Sir James Mansfield, C. J., said:

Upon this question no authorities have been cited either on the one side or the other. But it must occur constantly that the value of demised premises is increased by the goods upon the premises, and yet the rent reserved still continues to issue out of the house or land, and not out of the goods; for rent cannot issue out of goods. In Spencer's case, 5 Co. 17 , it is resolved that if a man lease sheep or other stock of cattle, or any other personal goods, for any time, and the lessee covenants for him and his assigns at the end of the time to deliver the like cattle or goods as good as the things letten were, or such price for them, and the lessee assigns the sheep over, this covenant shall not bind the assignee; for it is but a personal contract; and it is added "the same law, if a man demises a house and land for years with a stock or sum of money, rendering rent, and the lessee covenants for him, his executors, administrators, and assigns, to deliver the stock or sum of money at the end of the term, yet the assignee shall not be charged with this covenant, for although the rent reserved was increased in respect of the stock or sum, yet the rent did not issue out of the stock or sum, but out of the land only." The material words in that resolution are those which declare that where land is leased with stock upon it, the rent still continues to issue out of the land only. In that case, therefore, as well as any other, the person to whom the rent is due may distrain for the same; and consequently the landlord here, who was not paid his rent, has pursued his legal remedy of distress, though the rent issued out of ready furnished lodgings.

Rule discharged. ${ }^{55}$

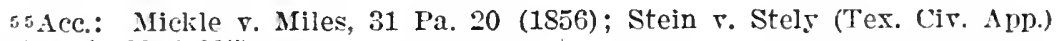
32 S. W: 782 (1S95).

See Farrell v. Dickinson, 6 B. \& C. 251 (182T); Armstrong v. Cummings, 58 How. Prac. (N. Y.) 331 (1880).

Compare Cranston r. Rogers, 83 Ga. 750,10 S. E. 364 (ISS9). 


\section{SALMON et al. v. MAT'THEWS.}

(Court of Exchequer, 1841. 8 Mrees. \& IV. 827.)

Assumpsit by the assignees of a bankrupt for the use and occupation of a house and the use of the furniture. Plea, non assumpsit. * * *

Alderson, B. In this case, we think both rules ought to be discharged.

This was an action for the rent of a ready furnished house. The house had been mortgaged in fee, but the mortgagor had remained in possession, and had let the house as a ready furnished house to the defendant. After this the mortgagor became bankrupt, and then, by the assent of his assignees, let the house by the week to the defendant. After three weeks' occupation, the mortgagee gave notice to the tenant to pay the rent to him; and it was paid. The present action was brought by the assignees of the bankrupt to recover the rent. At the trial the jury, by the direction of Lord Abinger, found a verdict for the plaintiff for $£ 40$, being, as was admitted, a proper verdict, if the assignees were entitled to any compensation in respect of the furniture which belonged to them.

My brother Adams, on behalf of the defendant, applied for leave to enter a verdict for the defendant, on the ground that, under this letting, the mortgagee was entitled to the whole rent. On the other hand, Mr. Hill applied to increase the damages to $£ S 2$, being the amount of the whole rent, which, as he contended, belonged to the assignees of the bankrupt.

IVe think the verdict is right: for either the rent may be apportioned, according to the case of Dubytofte v. Curteene, Cro. Jac. 453, cited by Saunders, in his argument in the Dean and Chapter of Windsor v. Gover, 2 Saund. 303; or, if not, it is clear that, upon the entry of the mortgagee claiming the house, and having no interest in the furniture, a new agreement may be inferred by the jury to take the house at a reasonable rent from the mortgagee, and to pay a reasonable amount as a compensation for the use of the furniture to the assignees.

If so, both rules are to be discharged, and both without costs. We mention this to prevent the costs of these rules being costs in the cause, which would not be just.

Rules discharged. ${ }^{58}$

56 Acc.: Buffum v. Deane, 4 Gras (Mass.) 385 (1555); Newton v. Speare Laundering Co., 19 R. I. 546, 37 Atl. 11 (1S96). Contra: Fay v. Holloran, 35 Barb. (N. Y.) 295 (1861).

A. leased to $\lambda$. a mill and a miller (a supposed slave); the slave had previously been formally emancipated by $A$. and left $X$.'s service. Held, in an action by $A$. for the rent, $x$. is entitled to an apportionment. Newton $v$. Wilson. 3 Hen. \& M. (Va.) 470 (1809).

A. leased to $\mathrm{X}$. a furnished louse, reserving a rent. The house and furniture were destroyed by fire without $\mathrm{X}$.'s fault. Held, $\mathbf{X}$. continues liable for the rent reserved. Bussman v. (amster. 72 Pa. 285 (1572). Cuntra: Whitaker v. IIawley, 25 Kan. 6it, 37 dw. IRep. $27 t$ (1ss1). 


\title{
HANCOCK v. AUSTIN.
}

\author{
(Court of Common Pleas, 1863. 14 C. B. [N. S.] 634.)
}

This was an action for an illegal and excessive distress, with a count for the conversion of the plaintiff's goods, to wit, lace-machines.

The cause was tried before Erle, C. J., at the last Summer Assizes at Derby. . The facts were as follows: The defendant was possessed of a factory consisting of several rooms in which he let "standings" for lace-machines, supplying the steam-power by which they were put in motion, and reserving to himself the right of entering the rooms for the purpose of oiling the bearings of the shafting,- - portions of the same room being sometimes allotted to different persons. In or e of these rooms the plaintiff had hired standing for three lace-mact.ines, and power, for which he was to pay 12s. per week. The rent being in arrear, and the plaintiff having gone out and locked the door of the room where the machines were, the defendant placed a ladder to the window (which was fastened with an ordinary hasp), and his son, without breaking anything, opened the window and got into the room, when the plaintiff entered by the door and distrained the machines, and afterwards sold them.

ERLE, C. J. ${ }^{57}$ This is an action brought for the conversion of three lace-machines, of the value, as the jury have found, of $£ 150$., which were seized and sold by the defendant. The defendant had leave to move to reduce the verdict to $f 40$. if the court should be of opinion that under the circumstances the defendant had a right to distrain; inasmuch as in that case he would not be liable as a trespassir, but only to such damages as the plaintiff might have sustained from any illegality in the mode of taking or disposing of the distress. But, if the defendant had no right to distrain, he must pay the full value of the goods taken. $* * *$ The first question is, whether there was any distrainable rent, there being no demise of the room, but only a bargain for standing for the plaintiff's machines. I am clearly of opinion that the stipulated sum of $12 \mathrm{~s}$. a week was not a rent issuing out of the realty, but only a payment for a privilege or easement. In no sense can it be called rent, or distrainable for as rent: but the owner of the factory is put to his action to enforce payment of the agreed sum. $* * *$ It follows, therefore, that the defendant has been guilty of a trespass, and must pay the value of the goods. ${ }^{68}$

B7 The statement of facts is abridged and part of the opinion of Erle, C. J., and the opinion of Villiams, J., are omitted.

$68 \mathrm{~A}$. demised to $\mathrm{x}$. part of a specified room and power to drive lacemaking machines, at a specified rent. Held, A. may distrain for rent in arrear. Selby v. Graves, L. R. 3 C. P. 594 (1868).

$A$. leased land to $X$., with an easement of way over other lands of $A$. In an action by A.'s assignee agrainst $\mathrm{X}$. for rent reserved under the lease, held, a plea that before the aecrual of the said rent the plaintiff evieted and has since kept out the defendant from the way so demised is bad on demur- 
FIRST NAT. BANK OF SIOUX CITY v. FLYNN.

(Supreme Court of Iowa, 1902. 117 Iowa, 493, 91 N. W. 784.)

Action to recover rent alleged to be due under a lease, and to enforce a landlord's lien therefor against the L. Humbert Company. One Flynn, as trustee in bankruptcy of defendant company, sought to controvert plaintiff's right to a lien, and judgment was rendered for plaintiff establishing its lien as to a portion of the land clained, from which judgment plaintiff and Flynn, trustee, prosecute separate appeals. Affirmed on plaintiff's appeal, and reversed on the appeal of the trustee.

MCCLAIN, J. ${ }^{6 \theta} * * *$ The trial court received. evidence tending to show that, while the lease was executed six months from June 1,1899 , at the agreed rental of $\$ 122.30$ per month, as a matter of fact the amount of rent to be paid was determined by adding to the real rental value of the premises, which, under a previous lease, had been $\$ 50$ a month, such additional sum as that the payment for the rent under the lease would satisfy not only the real rental value of the premises, but arrearages of rent to the amount of some $\$ 433$; and the amount to be paid per month under the lease for each month was simply one-sixth of a total amount agreed upon in satisfaction of indebtedness for arrearage rent and rent for the six months for which the lease was executed. It is contended for plaintiff that parol evidence showing these facts was not admissible, on the ground that it was thereby attempted to vary the terms of a written instrument. But it is certainly competent in any case to show what the real consideration for a contract is, even though the contract is in writing and recites the consideration; , and on the issue as to whether plaintiff was entitled to a lien under this lease for $\$ 733$ it was proper to admit evidence to show that the rent agreed to be paid by the terms of the lease was not the real rental for the use of the premises, but included additional indebtedness, for which plaintiff was attempting to secure a lien by means of the recitals of the lease. As between plaintiff and the trustee in bankruptcy, it was material only to determine for what amount plaintiff was entitled to a lien, and on that question the recitals of the lease could not be conclusive. It is well settled that a landlord cannot assert a lien for other indebtedness than that arising from the renting of the premises for the time covered by the lease, and that, if he attempts to do so in such way as to render it impracticable to determine what amount is due for the lease of the premises, he forfeits his entire lien. Smith v. Dayton, 94 Iowa, 102, 62 N. W. 650: Ladner v. Balsley, 103 Iowa, 674, 72 N. W. 787; In re Wolf (D. C.) 99 Fed. 74.

rer. Williams . Hayward. 1 F. \& E. 1040 (1959). See Buzzard $\nabla$. Capel, 8 B. \& C. 141 (1S28): Tomlinson v. Day, 5 Moo. 558 (18:21); Carter F. Burr, 39 Barb. (N. Y.) 59 (1S62).

$\because \theta$ Part of the opinion is omitted. 
That is exactly what the plaintiff did in this case. Having a claim against the L. Humbert Company for $\$ 433$, it attempted to lump that amount in with a charge for the rental of the premises for six months, and thereby secure a landlord's lien under the last lease for a much larger amount than that for which the premises were actually rented. The trial court assumed that the real rent charged for the premises under the last lease was $\$ 50$ per month, the rate at which the premises had been rented under the previous lease, and gave plaintiff a judgment under his landlord's attachment for that amount. But this, we think, was error. It does not appear that the parties agreed on a rental of $\$ 50$ per month, but, rather, that they made a contract by which, if the tenant should pay $\$ 122.30$ each month for six months, he would satisfy the claim of the plaintiff for delinquent rent under the previous lease, and have the use of the premises under the new lease. The representative of plaintiff who made the contract of lease testified as a witness that the premises, with slight repairs, might have been rented for $\$ 75$ a month; and whether or not it was the purpose of plaintiff to throw off a part of the claim which it held for delinquent rent under the old lease, and charge a higher rental for the premises during the new lease, does not appear. It is enough to say that the plaintiff so managed the transaction that it was not agreed what the rental under the new lease actually was, and, as plaintiff is not entitled, as against the creditors of the bankrupt, to enforce its lien for more than the real rental, it should have been held to have forfeited its lien by this attempt to make a new lease cover the payment of antecedent indebtedness. The lower court erred, therefore, in recognizing plaintiff's lien as to any portion of the proceeds of the attached property. ${ }^{60}$

${ }^{0} 0 \Lambda$ cc., that failure to pay a contract debt cannot be distrained for as for a rent: Paxton v. Kennedy, 70 Miss. 865,12 South. 546 (1893). See Smith v. Mapleback, 1 T. R. 441 (17S6); Donellan v. Read, 3 B. \& Ad. 899 (1832); Miners' Bank of Pottsville v. Heilner, $47 \mathrm{~Pa} .452$ (1861).

"It is said that the payment of taxes is part of the return made by the defendant to his landlord for the use of the property, and, therefore, properly comes under the definition of rent. But in one sense the performance of every covenant on the part of the lessee is a return made by the tenant for the use of the land. Yet it would hardly be contended that money stipulated to be expended in repairs or for insurance, or in the way of improveinents, was any portion of the rent. Taxes, being payable annually, anproad, it is true. to the icea and character of rent, which is a certain yearly return reserved to the landlord in money, or kind, or service for the enjoyment of the freehold; but they are distinguishable from rent in this, that they are uncertain both as to amount and time of payment, and are payable not to the landlord, but to the government, and are imposed for the benefit of the public, and the landlord may, by the terms of his agreement with the tenant, be reliered from their layment; taxes are not, on that account, any more rent than the expenditure of money for insurance under a corenant to that effect on the part of the lessee." Slosson, J., in Garner v. Hannah, 15 N. Y. Super. Ct. 262, 266 (1857).

Complare Neamle v. Kelly, 146 Ill. 460 , 34 N. E. 947 (1893); Gedge v. schoenterger, s.; Ky. 91 (1-4.5).

See, also, Constantine v. Wise, 31 N. Y. Suirer. Ct. 239 (1869). 


\section{CHAPTER VII}

\section{WASTE}

\section{SECTION 1.-GENERAL PRINCIPLES OF WASTE}

ST. 52 HEN. III, ST. OF MARLBOROUGH .[MARLBRIDGE] (1267), c. 23, § 2: Also fermors, during their terms, shall not make waste, sale nor exile of house, woods, and men, nor of anything belonging to the tenements that they have to ferm without special license had by writing of covenant, making mention that they may do it; which thing, if they do, and thereof be convict, they shall yield full damage, and shall be punished by amerciament grievously.

ST. 6 EDIV. I, S'T. OF GLOUCESTER (1278), c. 5: It is provided also that a man from henceforth shall have a writ of waste in the Chancery against him that holdeth by law of England, or otherwise for term of life, or for term of years, or a woman in dower; and he which shall be attainted of waste shall lose the thing that he hath wasted, and moreover shall recompence thrice so much as the waste shall be taxed at.

\section{COKE'S LITTLETON, 53a et seq.}

An action of wast doth lie against tenant by the curtesie, tenant in dower, tenant for life, for yeares, or halfe a yeare, or gardian in chivalry, by him that hath the immediate estate of inheritance, for wast or destruction in houses, gardens, woods, trees, or in lands, meadows, \&c. or in exile of men to the disherison of him in the reversion or remainder. There be two kinds of waste, viz. voluntary or actuall, and permissive. Wast may be done in houses, by pulling or prostrating them down, or by suffering the same to be uncovered, whereby the spars or rafters, plaunchers, or other timber of the house are rotten. But if the house be uncovered when the tenant commeth in, it is no wast in the tenant to suffer the same to fall downe. But though the house be ruinous at the tenant's coming in, yet if he pull it downe, it is wast unlesse he reedifie it againe. Also if glasse windows (tho' glased by the tenant himsclfe) be broken downe, or carried away, it is wast, for the glasse is part of his house. And so it is of wainscot, benches, doores, windowes, furnaces, and the like, annexed or fixed to the house either by him in the reversion, or the tenant. 
Though there be no timber growing upon the ground, yet the tenant at his perill must keepe the houses from wasting. If the tenant doe or suffer waste to be done in houses, yet if he repaire them before any action brought, there lieth no action of waste against him, but he cannot plead, quod non fecit vastum, but the speciall matter.

A wall uncovered when the tenant commeth in, is no wast if it be suffered to decay. If the tenant cut downe or destroy any fruit trees growing in the garden or orchard, it is waste; but if such trees grow upon any of the ground which the tenant holdeth out of the garden or orchard, it is no waste.

If the tenant build a new house, it is waste, and if he suffered it to be wasted, it is a new waste. If the house fall downe by tempest, or be burnt by lightning, or prostrated by enemies or the like, without a default of the tenant, or was ruinous at his comming in, and fall downe, the tenant may build the same againe with such materialls as remaines, and with other timber which he may take growing on the ground for his habitation, but he must not make the house larger then it was. If the house be discovered by tempest, the tenant must in convenient time repaire it.

If the tenant of a dove-house, warren, parke, vivary, estangues, or the like do take so many, as such sufficient store be not left as he found when he came in, this is waste; and to suffer the pale to decay, whereby the deere is dispersed, is waste.

And it is to be observed, that there is wast, destruction and exile. Wast properly is in houses, gardens, (as is aforesaid) in timber trees, (viz. oak, ash, and elme, and these be timber trees in all places) either by cutting of them downe, or topping of them or doing any act whereby the timber may decay. Also in countries where timber is scant, and beeches or the like are converted to building for the habitation of man, or the like, they are all accounted timber. If the tenant cut down timber trees, or such as are accounted timber, as is aforesaid, this is wast; and if he suffer the young germins to be destroyed, this is destruction. So it is, if the tenant cut down underwood, (as he may by law) yet if he suffer the young germins to be destroyed, or if he stub up the same, this is destruction.

Cutting down of willowes, beech, birch, aspe, maple, or the like, standing in the defence and safeguard of the house, is destruction. If there be a quickset fence of white thorne, if the tenant stub it up, or suffer it to be destroyed, this is destruction; and for all these and the like destructions an action of wast lyeth. The cutting of dead wood, that is, "ubi arbores sunt aridæ, mortuæ, cavæ, non existentes maremium, nec portantus fructus, hex folia in rstate," is no wast; but turning of trees to coles for fewell, when there is sufficient dead wood, is wast.

If the tenant suffer the houses to be wasted, and then fell down timber to repaire the same, this is a double wast. Digging for gravel, line, clay, brick, earth, stone, or the like, or for mines of mettall, coale, 
or the like, hidden in the earth, and were not open when the tenant came in, is wast; but the tenant may dig for gravell or clay for the reparation of the house, as well as he may take convenient timber trees.

It is wast to suffer a wall of the sea to be in decay so as by the flowing and reflowing of the sea, the meadow or marsh is surrounded, whereby the same becomes unprofitable; but if it be surrounded, suddenly by the rage or violence of the sea, occasioned by winds, tempest, or the like, without any default in the tenant, this is no wast punishable. So it is, if the tenant repaire not the bankes or walls against rivers, or other waters, whereby the meadows or marshes be surrounded, and become rushy and unprofitable.

If the tenant convert arable land into wood, or e converso, or meadow into arable, it is waste, for it changeth not onely the course of his husbandry, but the proofe of his evidence.

The tenant may take sufficient wood to repaire the walls, pales, fences, hedges, and ditches, as he found them; but he can make no new: and he may take also sufficient plowbote, firebote, and other housbote.

The tenant cutteth downe trees for reparations and selleth them, and after buyeth them againe, and imploys them about necessary reparations, yet it is wast by the vendition: he cannot sell trees, and with the money cover the house: burning of the house by negligence or mischance is waste.

A prohibition of waste did lye against tenant by the curtesie, tenant in clower, and a gardian in chivalry, by the common law, but not against tenant for life or yeares, because they came in by their own act, and he might have provided that no waste should be done. ***

There is waste of a small value, as Bracton saith, "Nisi vastum ita modicum sit propter quod non sit inquisitio facienda." Yet trees to the value of three shillings and foure pence hath beene adjudged wast, and many things together may make waste to a value.

In many cases a tenant for life or years may fell down timber to make reparations albeit he be not compellable thereunto, and shall not be punished for the same in any action of waste. As if a house be ruinous at the time of the lease made, if the lessee suffer the house to fall down he is not punishable, for he is not bound by law to repaire the house in that case. And yet if he cut down timber upon the ground so letten, and repaire it, he may well justifie it; and the reason is, for that the law doth favour the supportation or maintenance of houses of habitation for mankind. *** A man hath land in which there is a mine of coales, or of the like, and maketh a lease of the land (without mentioning any mines) for life or for yeares, the lessee for such mines as were open at the time of the lease made, may digge and take the profits thereof. But he cannot digge for any new mine that was not open at the time of the lease made, for that should be adjudged waste. And if there be open mines and the owner make a lease of BIG.RIGIITS-41 
the land, with the mines therein, this shall extend to the open mines onely, and not to any hidden mine: but if there be no open mine, and the lease is made of the land together with all mines therein, there the lessee may digge for mines, and enjoy the benefit thereof, otherwise those words should be void. I have been the more spacious concerning this learning of waste, for that it is most necessary to be knowne of all men.

\section{COLE v. GREEN.}

(King's Bench and House of Lords, 1671. 1 Ler. 309.)1

Waste in the Hustings London, on a Lease for Years of a BrewHouse in London. The Defendant pleads no Waste, and Issue thereon; and on the Evidence it appeared, That the Defendant took down the Brew-House, and erected several Houses in the Place, and improved the Rent from $£ 120$. to $f 200$. per Annum; And by the Direction of Howel, Deputy Recorder, before whom the Cause was tried; for that thereby the Nature of the Thing, and the Evidence thereof was altered, the Jury found it Waste, and gave single Damages $£ 200$. which were trebled to $f 600$. But then Judgment was arrested, on Motion before Sir William Wilde, the Recorder himself, for the Insufficiency of the Verdict. * * * Rule made for a new Trial; whereupon the Jury, in respect of the Melioration, or Improvement, by the Direction of Sir William Wylde, before whom the new Trial was, gave a Verdict for the Defendant, and Judgment was thereupon given for the Defendant.

On which Judgment Cole brought a Writ of Error before Vaughn Chief Justice of the Common Pleas, Hale Chief Baron, Turner, and Rainsford, and Moreton Justices. * * * And upon this all the Judges agreed, and reversed the Judginent, and gave Judgment for the Plaintiff on the first Verdict.

On which Judgment of Reversal the Defendant brought a Writ of Error in the House of Peers.

[The House of Lords affirmed the judgment and it was remanded for execution, whereupon the defendant sought an injunction to stay the execution.]

In regard there had been one Verdict for the Plaintiff, and another for the Defendant, the Lord Keeper Bridgman, after all those Proceedings, directed a new Trial at the King's Bench Bar, to try in a feigned Issue, Whether Waste of not? And on the Trial before Hale, then Chief Justice, it was resolved to be Waste notwithstanding the melioration, by Reason of the Alteration of the Nature of the Thing,

1 The case is also reported 2 Saund. 252 (1671), where the lease is stated to have been for 51 rears. 
and of the Evidence thereof; and the Jury gave their Verdict accordingly, and 100 Marks single Damages, which trebled, amounted to $£ 200$. which the Chancery compelled Cole to take.

\section{KEEPERS AND GOVERNORS OF THE POSSESSIONS, E'TC., OF HARROW SCHOOL v. ALDERTON.}

(Court of Common Pleas, 1800. 2 Bos. \& P. 86.)

This was an action of waste on the statute of Gloucester, for ploughing up three closes of meadow land, and converting the same into garden ground, and building thereupon, to the damage of the Plaintiffs £500. Plea, Not guilty.

The cause was tried before Heath, J., at the Westminster sittings after last Trinity Term, when the jury found a verdict for the Plaintiff with three farthings damages, being one farthing for each close.

In the Michaelmas Term following, Cockell, Serjt., obtained a Rule, calling on the Plaintiff to shew cause why the judgment should not be entered up for the Defendant, on account of the smallness of the damages recovered, on the principle that de minimis non curat lex; and cited in support of the application Bro. Abr. tit. Waste, pl. 123, Co. Lit. 54, a. 2 Inst. 306. Cro. Car. 414. 452. Finch's Law, lib. 1 cap. 3. s. 34. adopted 3 Black. Com. 228. Vin. Abr. tit. Waste N. and Buller's N. P. 120.

Shepherd, Serjt., now shewed cause. There are two species of waste, that which consists in the abuse of the thing in which the waste is committed, and the consequent deterioration of its value; and that which changes the nature of the thing itself. In waste of the first kind, if the damage be very small, it may be right that no action should lie, because the deterioration is the essence of the waste. But where the waste consists in the alteration of the property, that alteration is the essence of the waste. If then the amount of pecuniary damage be the criterion of this kith of waste also, the distinction will no longer exist; for it will then be the deterioration of value, and not the alteration of the property, which will constitute the waste.

LoRd Erdoon, Ch. J. I confess, that when this application was first made, I was not aware, that under the circumstances of the case the Defendant was entitled to demand judgment: but my Brother HEaTu has satisfied me, that the application is supported by the current of authorities. I do not, indeed, see precisely on what ground those decisions have proceeded; thóngh I can easily conceive many cases in which it may be extremely unconscientious for a Plaintiff to take advantage of his judgment, where such small damages have been recovered as in this case. As, if the owner of land suffer his temant to lay out money upon the premises, and then bring an action of waste to recover possession when the land may have been improved to ten times 
the original value. The cases do not appear to authorize the distinction contended for by my Brother Shepherd. Whether the waste committed be by alteration of the property, or by deterioration, still the jury, in estimating the damages, take into consideration the injury which the Plaintiff has sustained; and in this case the jury have estimated the damage which these Plaintiffs have sustained, by the alteration of their property at three farthings only. The Courts of Common Law seem to have entertained a sort of equitable jurisdiction in cases of this kind.

HeAtn, J. This doctrine prevailed as early as the time of Bracton, who wrote before the statute of Gloucester. With respect to the distinction taken, there is no reason why pecuniary damages should not be assessed for the alteration of property as well as for the deterioration. Thus, if a tenant convert a furze-brake in which game have bred into arable or pasture, by which its real value would be improved, but its value to the landlord depreciated, it would be the business of the jury to assess damages to the landlord thereon.

RookE, J. I am of the same opinion.

Rule absolute. ${ }^{2}$

\section{OWEN v. HYDE.}

(Supreme Court of Tennessee, 1834. 6 Yerg. [14 Tenn.] 334, 27 Am. Dec. 467.)

This is an action for waste, prosecuted by the plaintiff, who is entitled to the reversion of part of the dower estate of the defendant. The declaration alleges, that the waste was committed by removing the timber from fifteen acres of the dower estate.

The proof shows that Henry Hyde died intestate, seized and poscessed of seven hundred and fifty-six acres of land, leaving his widow (the defendant) and eight children. The widow's dower was laid off according to law; and soon afterwards commissioners were appointed by the county court to divide the land amongst the children. The whole tract, including the dower, was laid off into eight lots; one of the lots, of seventy-six and a half acres, was set apart for Charlotte Hyde, one of the children of the intestate. She intermarried with Cummings, and they sold and conveyed to the plaintiff.

2 Contra: Provost of Queen's College v. Hallett, 14 East, 459 (1811).

A. was a tenant for life of two meadows. He took down the fences, built a road through the land, and drained it (in so doing changing the surface of the land), and ding cellars and erected wooden houses on the land. The jury found that, even if the houses were taken off, the land would be worth more for agricultural purposes as a result of A.'s acts. Held, A. Is not liable to B., the remaindermutn in fee, for waste. Pynchon v. Stearns, 11 Metc. (Mass.) 304, 45 Am. Dec. 207 (1846). Compare Young v. Spencer, 10 Barn. \& C. 145 (1529); sce Jones v. Chappell, L. K. 20 Iq. 539 (1575); West Ham Central Charity Board v. East London Waterworks Co., [1900] 1 C'n. 
About one half of this lot was embraced within the portion set apart for the dower. The dower estate contained upwards of one hundred acres of cleared land, the greater part of which was much worn. The fifteen acres complained of, was part of the dower estate, which was included in the lot belonging to the plaintiff, and which was cleared for the purposes of cultivation. It was the best land and the most convenient for farming purposes of any of the timbered land on the dower estate. The defendant had but a small force, and there was a sufficient quantity of land cleared upon the dower estate for her support before she cleared the fifteen acres. A portion of the timber cut from the lot of Charlotte was used to erect fences on other lots of the dower estate. The timber cut off was valuable, worth three or four hundred dollars; but there was timber enough left, for the permanent use of the dower estate. The court charged the jury, among other things not excepted to, "that though there may be a sufficient quantity of cleared land for the support of the dowager and her family on the dower estate, yet she may go in and clear land and cut down timber for the purpose of cultivation, provided she leaves wood and timber sufficient for the permanent use of the dower estate."

GREEN, J., delivered the opinion of the court.

The question here is, whether the Judge erred in his charge to the jury.

In order to the formation of a correct opinion in this cause, it is proper to remark, that whatever may be said in relation to the defendant's rights and liabilities must be understood as relating to the whole dower estate. She was not bound to notice any division which may have been made of the reversionary interest among the heirs; she took the dower estate as it was assigned to her with the rights and liabilities which attach to that as a whole; and although she may have destroyed all the timber which was on that part of one of the lots included in her dower, yet, if the dower estate was not injured, but benefited thereby, she would not be guilty of waste; for that is the great criterion by which to determine whether waste has been committed, as that only which does a lasting damage to the inheritance, or depreciates its value, is waste. It is clear, that the cutting timber and clearing land instead of being waste would of ten greatly enhance the value of the inheritance. In this country, where so large a portion of the lands are wild, and yet in forest, it is often of great advantage to the estate to destroy the timber and reduce the land to a state of cultivation. 3 Dane's Ab. 214, 215; 4 Kent 76-7.

It is not a question then, whether the dowager cut the timber from this fifteen acres as a necessary means of support, but it is, did she materially injure the dower estate thereby; if so, she would be liable to an action for waste, but if not, although the clearing was not necessary for her support, and although she may have done it for the purposes of profit, she is not liable. If the cleared land on 
the dower estate was old and worn, and if the proportion of wood land was such as that a prudent farmer would have considered it best to reduce a portion of it to cultivation, whereby to relieve the old land from excess of culture, and thus enhance the value of the whole dower estate, such clearing would not be waste, provided, "sufficient timber for the permanent use of the dower estate" were left. Jackson v. Brownson, 7 Johns. (N. Y.) 227, 5 Am. Dec. 258; 4 Kent, 76.

In respect to the privilege of a tenant for life, in the destruction of timber, the law must necessarily be varied in this country from the English doctrine. There, we could not well conceive of the destruction of timber without attaching to it the idea of an injury to the estate, as timber is scarce, and forest trees are planted and raised for fuel and for timber, it is of too much value to permit its unnecessary destruction. That not being the state of things here, but on the contrary, as a benefit often results to the estate from clearing away the timber, it would be absurd to apply the rigid principles of the English law to a state of things wholly variant from theirs.

We are, therefore of opinion there was no error in the charge of the court, and order the judgment to be affirmed.

Judgment affirmed. ${ }^{3}$

\section{DAVIS v. GILLIAM et al.}

(Supreme Court of North Carolina, 1848. 40 N. C. 308.)

Appeal from an interlocutory decree of the Court of Equity of Martin county, at the Fall Term, 1848, perpetuating an injunction theretofore granted in the cause, his Honor Judge Caldwell presiding.

The bill is to restrain waste; and upon the bill and answer the case is this. Maer and wife were seised in possession of land in fee in her right and had issue; and a judgment was had against Maer and on a fieri facias the land was purchased by the defendant in 1833 . In 1838. Naer and wife assigned the reversion to the plaintiff; and, in April, 1848, Maer and wife being still living, this bill was filed for an account of the proceeds of timber, shingles and staves, made of the oak and cypress timber, that had been felled on the land and sold, and for an injunction against cutting any more for sale. The land consists of two tracts. One of them contains 100 acres, of which the defendant had about 40 in cultivation. The residue thereof is what is called swamp, on the Roanoke, which lies so low, that, for the greater part of the year, it is covered by water, and in its natural state, is unfit for agricultural cultivation, if the timber on it were all felled.

sAcc: Keeler v. Eastman, 11 vt. 293 (1839); Wilkinson v. Wllkinson, 59 Wis. $557,18 \mathrm{~N}$. W. 527 (1851). Compare Dashwood v. Maguiac, [1804] 3 Ch. 306. 
The other tract contains 250 acres, of which 150 consists of high land, and 100 acres of swamp like the other. On the highland there was once a field of 40 acres in cultivation; but it was exhausted and turned out some years before the defendant purchased, and is still in that state. The residue of the high land is broken and of but little value for cultivation; but it has on it oak and other timber, fit for staves and boards. The swamp on each tract is heavily timbered with cypress and other growths; and in 1846, the defendant sold cypress timber from the first tract, to the value of $\$ 100$, and in 1847 and in 1848 , he felled cypress in the swamp of the other tract, of which he made shingles, and red oaks on the high land of that tract, of which he made staves, to the value of about $\$ 900$ - of which he had sold a part and was about to sell the other part, when the bill was filed. The timber thus felled is not of one twentieth part of the value of all the timber on the several tracts, and there is a great abundance left for fencing, fire wood and the like. But the defendant insists on the right to continue the cutting of the timber on the swamp land, and also to some extent more on the high land.

On the hearing, the injunction was perpetuated and an account ordered; but the defendant was allowed to appeal.

RUFFIN, C. J.* The husband was dispunishable for waste, because, while in possession, he was not tenant for life in his own right, but was seised with his wife in fee in her right. Besides, the wife, in whom the inheritance was, could not sue him. But it is otherwise with the defendant. For, although he purchased the husband's estate, his seisin and possession are several, and he is strictly a tenant for the life of the husband.

The case is similar to that mentioned by Lord Coke of tenant in tail after possibility of issue extinct, who was not liable for waste in respect that he once had the inheritance in him. But the privilege was personal, and his feoffee was but tenant for life, and as such, liable for waste.

The question, then, is, whether the acts done and contemplated by the defendant amount to waste. We think they do, and the plaintiff had the right to the decree, both as to the injunction and the account. Of course the question is to be treated, as embracing the case of dower as well as curtesy. *** A tenant for a limited period, or a particular estate, cannot rightfully so treat the estate as to destroy the value of the reversion, or materially reduce it below what it would be, regard being had merely to the postponement of the enjoyment. The tenant may use the astate, but not so as to take from it its intrinsic worth.

We should hold, as the state of the country now is, that a tenant for life of land, entirely wild, might clear as much of it for cultiva-

4 Part of the opinion is omitted. 
tion as a prudent owner of the fee would, and might sell the timber that grew on that part of the land. Clearing for cultivation has, according to the decisions, peculiar claims for protection; and a sale of the timber from the field cleared may be justly made, in compensation for clearing and bringing it into cultivation. ${ }^{5}$ But it seems altogether unjust, that a particular tenant should take off the timber, without any adequate compensation to the estate for the loss of it. For he takes, in that case, not the product of the estate arising in his own time, but he takes that, which nature has been elaborating through ages, being a part of the inheritance itself, and that, too, which imparts to it its chief value. As in the case of the mine, how is it possible to apportion the timber between the tenant for life and the remainder-man, since it is altogether uncertain, what the duration of the life will be? If a tenant for life can claim a share of the trees for sale, as a part of the profits, then the whole might be taken from the owner of the inheritance, when there happens to be a succession of life estates limited. It is said, however, that, unless he be allowed to take some of the timber, his estate will be of no value, when the land is swamp, not fit for cultivation or that cannot be made so without great expense in drains and dikes. That, we suppose, could not altei ${ }^{\circ}$ the principle. But this case does not call for a decisive answer to that suggestion. For, in the first place, the greater part of the sales have been of shingles and staves made of timber felled on the high land on one of the tracts; and, in the next place, one half of one of the tracts and three fifths of the other are arable, and, consequently, the timber on the swamp might by a prudent proprietor be preserved as a provision that would enable him to reduce to actual cultivation the whole of those portions of the land, which are arable. Certainly a tenant for life cannot insist on being allowed to make the greatest possible profit out of the land that can be made in his time. Indeed, he ought not, for the sake merely of enhancing his profits and without any view to the cultivation of any parts of the land, to cut the timber in which the chief value of the fee consists, and thus leave the exhausted or barren parts of the land, which are arable or might be made so, to the reversioner, with only timber enough on the several

¿ $\Lambda$ dowress, in order to get firewood for the dower house, which she was occupying, paid a person fur cutting and drawing the wood by allowing him to take an equal amount for his own benefit. Held, this was waste as to the wood so allowed to be taken by the cutter for himself. Johnson $v$. Johnson, 18 N. H. 594 (1847). See Darcy v. Askwith, Hob. 234 (1618); Padelfold v. Padelford, 7 Pick. (Mass.) 152 (1S2\$).

A dowress sold to a third person the right to occupy the dower land and to cut enongh wood for one rire, it being known at the time of the sale that the purchaser did not intend to occupy the house. The purchaser diu not oceupy the house; he cut in a prudent manner and used elsewhere somewhat less wood than would have been necessary to heat the dower house. IIeld, the dowress is guilty of waste. Fuller v. Wason, 7 N. H. 311 (15:3t); see Cook v. Couk, 11 Gray (Mass.) 123 (1SüS). 
tracts to fence those worthless parts. That would really be to give to the particular estate the kernell, and the shell to the fee.

Per Curiam. Decree affirmed with costs. ${ }^{\circ}$

\section{GAINES et al: v. GREEN POND IRON MINING CO. et al.}

(Court of Errors and Appeals of New Jersey, 18s1. 33 N. J. Eq. 603.)

VAN Syckei, J. ${ }^{\top}$ The bill in this cause was filed by the complainants as owners of the remainder in fee of a large tract of wild lands in the county of Morris, to restrain the defendants, who, it is alleged, have only a life estate in said lands, from cutting timber and working the iron mines on said premises, and also praying for an account.

The land in question is very rough and mountainous, and almost all of it unfit for cultivation. On it there is a thin covering of wood and timber, with a large deposit of valuable iron ore underlying it. About the year 1812, Dr. Graham, then owner of the fee, excavated the iron ore for the purpose of manufacturing copperas, sulphur being combined with it in such proportions as made it available for that purpose. He made at least two openings, from ten to fifteen feet deep, out of which the ore was raised, and carried on this business for several years. There was erected upon the premises a building used for pounding the ores, and other apparatus for treating them. There was no digging for ore from the time Dr. Graham quit working (about 1812 or 1814) until about forty years ago, when a small quantity of ore was taken out and tested at two different forges in the neighborhood, and was considered to be without value as iron ore, on account of the sulphur it contained. From that time there has been no mining upon these premises until the Green Pond Iron Company commenced its operations in 1872.

By the strict rule of the common law, the opening and working of a mine by a tenant for years, not opened in the lifetime of the previous tenant in fee, was, equally with the cutting of timber, an undoubted waste of the estate. In Hoby v. Hoby, 1 Vern. 218, the widow was

BAcc.: Warlen County v. Gans, 80 Miss. 76, 31 South. 539 (1902); Protlitt v. Henderson, 29 Mo. 325 (1S60); Jackson v. Brownson, 7 Johns. (N. Y.) 227, 5 Am. Dec. 258 (1810).

In 1882 the plaintiff county leased to the defendant for 99 years for a lump sum of $\$ \$ 35$ forty acres of land covered with timber which constituted its only ralue, the land being unfit for cultivation. The defendant began to cut the timber; the plaintiff sought an injunction. Held, on a rehearing, overruling the first decision in the case, the injunction should issue. Moss Point Lumber Co. v. Harrison County, S9 Miss. 44S, 42 South. 290, S73 (1907).

As to rights in trees blown down, see Bateman $\mathbf{v}$. Hotchkin, 31 Beav. 4sci (1862), post, p. 6S7.

? Part of the opinion is omitted. 
held to be dowable of a coal work. It was resolved in Saunders' Case, 5 Coke, 12, that if a man hath land in part of which there is a coal mine open, and he leases the land to one for life, or for years, the lessee may dig in it, for inasmuch as the mine is open at the time, and he leases all the land, it shall be intended that his intent is as general as his lease."

The tenant for life, subject to waste, cannot open a new mine. Whitfield v. Beuitt, 2 P. Wms. 242.

And if a lease of land be made, and some mines are open and some not, the open mines only can be wrought. Astry v. Ballard, 2 Lev. 185.

But a tenant for life may open the earth in new places in pursuit of an old vein of coals, when the coal mine had been opened before he came in possession of the estate. Clavering v. Clavering, $2 \mathrm{P}$. Wms. isS. $* * *$

This subject was carefully considered by Lord Romilly, in Bagot v. Bagot, 32 Beav. 509, where he says:

"With respect to the abandoned, or, as they are called in the pleadings and evidence, the dormant mines, I am of opinion that it has not been shown that he committed waste in working those mines. It is always a question of degree to be established by evidence, whether the working of a mine which has been formerly worked, is waste or not. There is no doubt that a tenant for life, though impeachable for waste, may properly work an open mine. A mine not worked for twelve months, or two years, previously to the tenant for life coming into possession, must still be considered an open mine. A mine which has not been worked for one hundred years cannot, I think, be properly so treated. My present opinion is, that a mine which had not been worked for twenty or thirty years, from the loss of profit attending the working, might, without committing waste, be worked again by a succeeding tenant for life. But, if the working of the mine had been abandoned by the owner of the inheritance many years previously, with a view to some advantage which he considered would accompany such discontinuance, apart from the profits to be made from the sale of the mineral, I doubt whether a succeeding tenant for life could properly treat that as an open mine."

In Elias v. Griffith, L. R. 4 App. Cas. 465, Lord Selborne says:

"Upon the questions of law which were argued at the bar, I think it unnecessary to make more than two remarks. The first is, that I am not at present prepared to hold that there can be no such thing as an open mine or quarry, which a tenant for life, or other owner of an estate impeachable for waste, may work, unless the produce of such mine or quarry has bcen previously carried to market and sold. No doubt if a mine or quarry has been worked for commercial profit, that must, ordinarily, be decisive of the right to continue working; and, on the other hand, if minerals have been worked or used for some. definite and restricted purpose (e. g., for the purpose of fuel or repair to some particular tenements), that would not alone give any 
such right. But if there has been a working and use of minerals not limited to any special or restricted purpose, I find nothing in the older authorities to justify the introduction of sale as a necessary cr1terion of the difference between a mine or quarry which is, and one which is not, to be considered open in a legal sense. None of the dicta which are to be found in some of the more modern cases (each of which turned upon its own particular circumstances) can have been intended to introduce a condition or qualification not previously known, into the law of mines.

"The other observation which I desire to make is, that when a mine or quarry is once open, so that the owner of an estate impeachable for waste may work it, I do not consider that the sinking a new pit on the same vein, or breaking ground in a new place on the same rock, is necessarily the opening of a new mine or quarry; and for this, anthority is to be found in the cases which were cited at the bar, of Clavering v. Clavering, Bagot v. Bagot, and Lord Cowley v. Wellesley."

In Elias v. Griffith, L. R. 8 Ch. Div. 521, Lord Cotton remarked that:

"To enable a termor, or tenant for life punishable for waste, to work mines, it must be shown that the owner of the inheritance, or those acting by his authority, have commenced the working of the mines with a view to making a profit from the working and sale of what is part of the inheritance. When this is established, though no profit has in fact been made, the mine is open in such a sense as to justify the continuance of the working by a termor."

The case of Clavering v. Clavering, $2 \mathrm{P}$. Wms. 38S, which recognizes the right of the life tenant to open new pits or shafts for the working of an old vein of coal, has never been overruled in the English courts.

These citations show that, in England, the life tenant has a right to use a mine for his own profit, where the owner of the fee, in his lifetime has opened it, even though he may have discontinued working upon it for a long period of years.

The rule by which the right of the life tenant is to be tested is not the length of time that may have elapsed since the last working of the mines, but it depends upon whether the owner of the fee merely discontinued the work for want of capital, or because it did not prove profitable, or for any other like reason, or whether he abandoned it with an executed intention to devote the land to some other use. * * *

The American cases have modified the law of waste, to adapt it to the circumstances of a new and growing country, in order to encourage the tenant for life in making a reasonable use of wild and undeveloped lands. Hastings v. Crunckleton, 3 Yeates $(\mathrm{Pa})$.261 ; Findlay v. Smith, 6 Munf. (Va.) 134, 8 Am. Dec. 733; Ballentine v. Poyner, 3 N. C. 110; Neel v. Neel, 19 Pa. 323; Irwin v. Covode, 24 Pa. 162. 
In Neel v. Neel, a coal mine had been opened ana worked for family use, and for the benefit of the neighbors, but a very inconsiderable quantity had been taken out. In that case, Judge Lowrie said:

"It seems, in this case, that the author of the gift had sometimes sold coal out of the pits, but I do not conceive this to be material. It is sufficient that he opened them and derived any profit from them, even if it were only private. And the decisions refer to coal mines, iron mines, \&c., and the tenant for life may work them, even though the working of them may have been discontinued before the death of him through whom the estate comes, and, if necessary to the proper working of them, to make new openings in the ground."

In support of these views he cites the English and American cases, and expresses himself without reference to the statute of 1848 .

Chancellor Kent says :

"The American doctrine on the subject of waste is somewhat varied from the English law, and is more enlarged and better accommodated to the circumstances of a new and growing country." 4 Comm. 76.

The cases referred to will show a strong inclination to amplify the privileges of the life tenant.

In a country like this, where there are such vast bodies of unimproved lands, which would otherwise lie dormant in the hands of the life tenant, public policy requires that the doctrine of waste should be liberalized, and the decisions have uniformly been in that direction.

The present case illustrates the hardship of a close rule in favor of the fee. The life estate vested in 1860, and there is an expectancy of twenty years more of this life. A construction of the law which locks up the land from all beneficial use for so long a period, and gives the life owner only the privilege of paying the land tax, should not be favored.

When the property is unimproved land, not adaptable to any other beneficial use than that of mining, the right of the life tenant to use it reasonably for such purpose, has some support in the adjudications in this country, and is certainly not without reason to uphold it.

To maintain the right of the appellant in this case, it is not necessary to broaden the rule to that extent.

The openings in this case were such as, under the English cases, will establish the right in the life estate to pursue the workings upon the veins which had been opened.

It is sufficient to show that openings were made and ore taken ont with a view to profit, and it is wholly immaterial whether the ore was used in the manufacture of copperas or for some other commercial purpose.

The evidence shows a mere cessation of the work, not such an abandonment, in the legal sense of that term, as will defeat the right of the life tenart. The length of time during which cessation continued is immaterial, so long as the fact of abandonment is not established. 
The decree of the chancellor, so far as it denies the right of the appellants to work the veins of ore upon which the openings had been made in the lifetime of the owner of the fee, and so far as it enjoins such work, should be reversed, and in other respects affirmed.

Decree unanimously reversed. ${ }^{8}$

\section{KLIE et al. v. VON BROOCK et al.}

(Court of Clancery of New Jersey, 1S97. 56 N. J. Eq. 18, 37 Atl. 469.)

[The complainants owned two adjoining and connecting buildings. They occupied the first floor of the easterly one as a saloon. The other building had been erected by the complainants for the purpose of being used as a restaurant by the defendant, and after it was completed it was leased to him for five years with a covenant not to sell liquors upon the premises. The defendant, shortly after he took possession under the lease, obtained from the Hoboken Land Improvement Company a lease of a building adjoining the restaurant building on the west and using a party wall in common with the restaurant building. The defendant intended to use this building for saloon purposes in conjunction with the restaurant and obtained from the Hoboken Company permission to make an opening in the party wall and began so to do. The complainants objected, but before they could obtain an injunction the defendant completed the opening. The complainants now file this bill, setting forth the above facts and asking for an injunction compelling the defendant to restore the party wall to its former condition.]

Pitney, V. C. ${ }^{0} * * *$ There remains the third question, namely, that of waste. The defendants obtained permission from the Hoboken Land Improvement Company to cut the doorway through the partition wall, but, clearly, that company could not give them the right to do so without the permission of the complainants, who owned onehalf of the wall. And the result is the same whether we consider that ownership as of the partioular one-half which was on their side of the line, or as the undivided one-half of the whole. The question, then, is whether or not, under the terms of the lease, the defendants acquired such a right in the premises as authorized them to make the opening. The opening, as first made, was between four and five feet wide,

8 See, in addition to the cases cited in the opinion, Owings 7 . Emery, 6 Gill (Md.) 260 (1847) ; Billings v. Taylor, 10 Pick. (Mass.) 460, $20 \mathrm{Am}$. Dee. 533 (1830) ; Coates v. Cheever, 1 Cow. (N. Y.) 460 (1823).

A. was tenant for life of land under which there were large beds of clay. A. granted to $B$. the right to excavate the clay therefrom in large quantities. and $\mathrm{B}$. began so to do. Held, the remainderman in fee may enjoin this ;rarating. University v. Tucker, 31 W. Va. 621, 8 S. F. 410 (188S). Acc.: Isom v. Rex Crude Oil Co., 147 Cal. 659, 82 Pac. 317 (1905), statute.

See Freer v. Stotenbur, 34 How. Prac. (N. Y.) 440 (1S66).

- Part of the opinion is omitted. 
and seven or eight feet high. The bricks and mortar were actually removed, and these composed an essential part of the building itself.

Now, it seems to me too plain for argument that such an abstraction amounted to waste at the common law. It was a "spoil" and "destruction" pro tanto of the building. 2 Bouv. Law Dict. tit. "Waste"; 6 Jac. Law Dict. tit. "Waste," p. 393, and at page 399, where the author uses this language, citing authorities: "If a lessee flings down a wall between a parlor and a chamber, by which he makes a parlor more large, it is waste. It cannot be intended for the benefit of the lessor, nor is it in the power of the lessee to transpose a house. So, if he pulls down a partition between chamber and chamber, it is waste. Or if a lessee pulls down a hall or parlor, and makes a stable of it, it is waste. If a lessee pulls down a garret overhead, and makes it all in one and the same thing, it is waste. Breaking of a wall covered with thatch, and of a pale of timber covered, is waste." To the same effect precisely are 7 Bac. Abr. tit. "Waste," at $* 256$; Tayl. Landl. \& Ten. \& 348; Kerr, Inj. *250, *251, where the author says: "An alteration of buildings which changes their nature and character is waste, even although the value of the premises be thereby increased. Thus the converting two chambers into one, or e converso, or the converting a hand mill into a horse mill, or a corn mill into a fulling mill, or a malt mill to a corn mill, or a logwood mill to a cotton mill have been held to be waste. So, also, the conversion of a private house into a shop is waste. So, also, may the building of a new house, where there was one before, be waste, if it impair the evidence of title." * * *

In my judgment, the test in such a case is not alone whether a material injury is done to the building, but whether it is altered in a material manner, and to an extent beyond what is fairly implied from the terms of the original contract of letting. It is said by the treatise writers, and authorities are cited for the position, that the severity of the ancient rule of waste has been relaxed, and that many alterations are now held not waste which in ancient times would have been held as waste. I have examined the cases which are said to illustrate this modification, and my conclusion is that in most of them a permission by the owner to the tenant to alter and change the building is either found in the terms of the demise, or is to be implied from the circumstances of the case. *** So I should say that if a building be erected and let for an hotel, and through oversight or miscalculation some mistakc in the interior arrangements occurs, which materially interferes with its beneficial use for that purpose, and requires a change, it is probable that the right to make such a change could properly be inferred from the circumstances. An illustration is found in this case. At the special request of the tenants, the landlord divided the basement into two parts by a cross wall of brick, not a part of the original plan, and not necessary for the support of the building. This was done in order to keep the heat of the range in the kitchen from penetrating to the front part of the bascment. When the building came into actual use, it was 
found that this wall was an injury, rather than a benefit, and was, in whole or in part, removed by the defendants. They assert that it was done with the consent of the landlords, but the landlords deny this. Be that as it may, I think it was not waste, and its removal was not relied upon as a part of complainants' case. * * *

These considerations lead to the conclusion that the case is not covered by any well-considered authority in which tenants have been held justified in changes of this character. ${ }^{10} * * *$

\section{MEIiMS et al. v. PABST BREWVING CO.}

(Supreme Court of Wisconsin, 1899. 104 Wis. 7, 79 N. W. 75S, 46 L. R. A. 478.)

This is an action for waste, brought by reversioners against the defendant, which is the owner of an estate for the life of another in a quarter of an acre of land in the city of Milwaukee. The waste claimed is the destruction of a dwelling house upon the land, and the grading of the same down to the level of the street. The complaint demands double damages, under section 3176, Rev. St. 1898, The quarter of an acre of land in question is situated upon Virginia street, in the city of Milwaukee, and was the homestead of one Charles T. Melms, deceased. The house thereon was a large brick building, built by Nelms in the year 1864 , and cost more than $\$ 20,000$. At the time of the building of the house, Melms owned the adjoining real estate, and also owned a brewèry upon a part of the premises. Charles 'T. Melms died in the year 1869, leaving his estate involved in financial difficulties. After his decease, both the brewery and the homestead were sold and conveyed to the Pabst Brewing Company, but it was held in the action of Melms v. Brewing Co., 93 Wis. 140, 66 N. W. 244, that the brewing company only acquired Mrs. Melms' life estate in the homestead, and that the plaintiffs in this action were the owners of the fee, subject to such life estate. As to the brewery property, it was held in an action under the same title, decided at the same time, and reported in 93 IVis. 153, 66 N. IV. 518, 57 Am. St. Rep. 899, that the brewing company acquired the full title in fee. The homestead consists of a piece of land 90 feet square, in the center of which the aforesaid dwelling house stood; and this parcel is connected with Virginia street on the south by a strip 45 feet wide and 60 feet long, making an exact quarter of an acre.

It clearly appears by the evidence that after the purchase of this land by the brewing company the general character of real estate upon Virginia street about the homestead rapidly changed, so that soon after

10 For the final decree in this case. see post, p. 681.

Acc.: Davenport v. Magoon, 13 Or. :3, 4 Pac. 299, 57 Am. Rep. 1 (18s4). see Agate v. Lowenbein, 57 N. Y. 601 (1S74). 
the year 1890 it became wholly undesirable and unprofitable as residence property. Factories and railway tracks increased in the vicinity, and the balance of the property was built up with brewing buildings, until the quarter of an acre homestead in question became an isolated lot and building, standing from 20 to 30 feet above the level of the street, the balance of the property having been graded down in order to fit it for business purposes. The evidence shows without material dispute that, owing to these circumstances, the residence, which was at one time a handsome and desirable one, became of no practical value, and would not rent for enough to pay taxes and insurance thereon; whereas, if the property were cut down to the level of the street, so that it was capable of being used as business property, it would again be useful, and its value would be largely enhanced. Under these circumstances, and prior to the judgment in the former action, the defendant removed the building, and graded down the property to about the level of the street, and these are the acts which it is claimed constitute waste.

The action was tried before the court without a jury, and the court found, in addition to the facts above stated, that the removal of the building and grading down of the earth was done by the defendant in 1891 and 1892, believing itself to be the owner in fee simple of the property, and that by said acts the estate of the plaintiffs in the property was substantially increased, and that the plaintiffs have been in no way injured thereby. Upon these findings the complaint was dismissed, and the plaintiffs appeal.

Winslow, J. ${ }^{11}$ Our statutes recognize waste, and provide a remedy by action, and the recovery of double damages therefor (Rev. St. 1898, $\S 3170$ et seq.); but they do not define it. It may be either voluntary or permissive, and may be of houses, gardens, orchards, lands, or woods (Id. $\$ 3171)$; but, in order to ascertain whether a given act constitutes waste or not, recourse must be had to the common law as expounded by the text-books and decisions. In the present case a large dwelling house, expensive when constructed, has been destroyed, and the ground has been graded down, by the owner of the life estate, in order to make the property serve business purposes. That these acts would constitute waste under ordinary circumstances cannot be doubted. ***

This element will be found in all the definitions of waste, namely, that it must be an act resulting in permanent injury to the inheritance or future estate. It has been frequently said that this injury may consist either in diminishing the value of the inheritance, or increasing its burdens, or in destroying the identity of the property, or impairing the evidence of title. The last element of injury so enumerated, while a cogent and persuasive one in former times, has lost most, if not all. of its force, at the present tine. It was important when titles were not registered, and descriptions of land were frequently dependent upon

11 l'art of the opinion is omitted. 
natural monuments, or the uses to which the land was put; but since the universal adoption of accurate surveys, and the establishment of the system of recording conveyances, there can be few acts which will impair any evidence of title. Doherty v: Allman, supra [3 App. Cas. 709]; Bewes, Waste, pp. 129, 130, et seq.

But the principle that the reversioner or remainder-man is ordinarily entitled to receive the identical estate, or, in other words, that the identity of the property is not to be destroyed, still remains, and it has been said that changes in the nature of buildings, though enhancing the value of the property, will constitute waste if they change the identity of the estate. Brock v. Dole, supra [66 Wis. 142, 28 N. W. 334]. This principle was enforced in the last-named case, where it was held that a tenant from year to year of a room in a frame building would be enjoined from constructing a chimney in the building against the objection of his landlord. The importance of this rule to the landlord or owner of the future estate cannot be denied. Especially is it valuable and essential to the protection of a landlord who rents his premises for a short time. He has fitted his premises for certain uses. He leases them for such uses, and he is entitled to receive them back at the end of the term still fitted for those uses; and he may well say that he does not choose to have a different property returned to him from that which he leased, even if, upon the taking of testimony, it might be found of greater value by reason of the change. Many cases will be found sustaining this rule; and that it is a wholesome rule of law, operating to prevent lawless acts on the part of tenants, cannot be doubted, nor is it intended to depart therefrom in this decision. The case now before us, however, bears little likeness to such a case, and contains elements so radically different from those present in Brock v. Dole that we cannot regard that case as controlling this one.

There are no contract relations in the present case. The defendants are the grantees of a life estate, and their rights may continue for a number of years. The evidence shows that the property became valueless for the purpose of residence property as the result of the growth and development of a great city. Busincss and manufacturing interests advanced and surrounded the once elegant mansion, until it stood isolated and alone, standing upon just enough ground to support it, and surrounded by factories and railway tracks, absolutely undesirable as a residence, and incapable of any use as business property. Here was a complete change of conditions, not produced by the tenant, but resulting from causes which none could control. Can it be reasonably or logically said that this entire change of condition is to be completely ignored, and the ironclad rule applied that the tenant can make no change in the uses of the property because he will destroy its identity? Must the tenant stand by, and preserve the useless dwelling house, so that he may at some future time turn it over to the reversioner, equally useless? Certainly, all the analogies are to the contrary.

Big.Rights-42 
Suppose an orchard to have become permanently unproductive through disease or death of the trees, and the land to have become far more valuable, by reason of new conditions, as a vegetable garden or wheat field, is the life tenant to be compelled to preserve or renew the useless orchard, and forego the advantages to be derived from a different use? Or suppose a farm to have become absolutely unprofitable by reason of change of market conditions as a grain farm, but very valuable as a tobacco plantation, would it be waste for the life tenant to change the use accordingly, and remodel a now useless barn or granary into a tobacco shed? All these questions naturally suggest their own answer, and it is certainly difficult to see why, if change of conditions is so potent in the case of timber, orchards, or kind of crops, it should be of no effect in the case of buildings similarly affected. ***

In the absence of any contract, express or implied, to use the property for a specified purpose, or to return it in the same condition in which it was received, a radical and permanent change of surrounding conditions, such as is presented in the case before us, must always be an important, and sometimes a controlling, consideration upon the question whether a physical change in the use of the buildings constitutes waste. In the present case this consideration was regarded by the trial court as controlling, and we are satisfied that this is the right view. This case is not to be construed as justifying a tenant in making substantial changes in the leasehold property, or the buildings thereon, to suit his own whim or convenience, because, perchance, he may be able to show that the change is in some degree beneficial. Under all ordinary circumstances the landlord or reversioner, even in the absence of any contract, is entitled to receive the property at the close of the tenancy substantially in the condition in which it was when the tenant received it; but when, as here, there has occurred a complete and permanent change of surrounding conditions, which has deprived the property of its value and usefulness as previously used, the question whether a life tenant, not bound by contract to restore the property in the same condition in which he received it, has been guilty of waste in making changes necessary to make the property useful, is a question of fact for the jury under proper instructions, or for the court, where, as in the present case, the question is tried by the court.

Judgment affirmed. ${ }^{12}$

$12 \mathrm{~A}$., a widow, to whom the homestead, an adobe house, had been set off for life, began to tear it down for the purpose of replacing it with a better building. Held, since it appears that the present building has some value, A. nay be enjoined by the remainderman from tearing it down. Dooly . Stringham. 4 Utah, 107, 7 Pac. 405 (1S85). Compare Crowe $\nabla$. Wilson, 65 Md. 479,5 Atl. 427,57 Am. Rep. 343 (1SS6). 


\title{
COUNTESS OF SALOP v. CROMPTON.
}

\author{
(Court of Queen's Bench, 1599. Cro. Eliz. 777, 784.)
}

Action: on the case. Whereas the plaintiff, 20th February, 34 Eliz. let to the defendant a house, a stable, and three barns in Shirland, habendum to him at will; and the defendant entered accordingly; and afterward, 20th January, 36 Eliz. being so possessed, tam negligenter et improvide kept his fire in the said house, that through default of good keeping thereof, the said house, stable, and barns were burnt down, to her damage, \&c.

The defendant pleaded not guilty; and after verdict it was moved in arrest of judgment, that this action lies not against a tenant at will, who burns the houses by negligence: for against a tenant for life or years, or other particular tenant who comes in by demise of the party, an action lies not for waste at the common law. By the statute, an action is given against tenant for life or years, but tenant at will remains as at the common law; and there is not any remedy against him for voluntary or negligent waste. On the other part it was said, that although waste lies not for a negligent or permissive waste (for it is not given by any statute, because the estate of tenant for will is uncertain, and by reason of the uncertainty he is not bound to repair it), yet for a valuntary negligence which destroys the thing denised, or for a voluntary negligence whereby the thing demised is lost, an action well lies; as Lit. fol. 15, is, that trespass lies where tenant at will cuts down the trees; as it lies against a shepherd who destroys the sheep committed to him. So 12 Edw. 4, pl. 18, if a bailiff of goods waste them, action upon the case lies; and 14 Hen. 8, and 48 Edw' 3, pl. 25. Brook, "Action sur le case," 25, and Mich. 3 Hen. 8, Roll. 655, The Earl of Oxford v. Marning, an action on the case was brought, supposing that the plaintiff was tenant for life, reversion to the King in fee; and the defendant was tenant at will to the plaintiff, and cut down sixty oaks, and carried them away, by reason whereof the King recovered the place wasted, and treble damages against the now plaintiff; but no judgment can be found therein. Another precedent was cited. Mich. 22 Hen. 7, Roll. 320, Cricost v. Nichols, where tenant for years made a lease of parcel thereof for a less term of years to the defendant; an action upon the case was brought against the defendant, for negligently burning his house: but there is not any judgment to be found therein. Wherefore, \&c.

But all the Court held in this case, that for the negligent burning, this nor any other action lies; for he comes in by the act of the party, and it was his folly that he did not provide for his remedy.

But Popham and Fenner agreed, that if lessee at will cuts down trees, an action of trespass well lies, because he voluntarily destroyed the thing demised: so where a shepherd kills the sheep. But for this 
negligent keeping of his fire, whereby his house was burned, no action lies. Wherefore it was adjudged for the defendant.

This case was now moved again, and all the justices resolved, that the action lay not for this negligent waste.

But Gawdy allowed that if tenant at will burnt, or pulled down the houses voluntarily, that trespass lay, because the privity of the lease is determined by this act done, which his estate permits not; which is the reason of the case in $2 \& 3 \mathrm{Ph}$. \& Mary, 121, and $15 \mathrm{Edw} .4$, pl. 20, and 2 Hen. 7, pl. 11, that if a bailiff destroys the thing delivered, trespass lies; and where a shepherd will not keep his sheep, but suffers them to be drowned, action upon the case lies, because he there took upon him the charge. But here he takes not any charge upon him, but to occupy, and pay his rent; and none will affirm, if a lessee at will suffers his house to fall down, that an action should lie against him; for he is not bound to repair it.

To this difference of voluntary and permissive waste, Popham, Clench, and Fenner, agreed. And Popham said, there was difference betwixt an interest and an authority: for if a man hath an authority to do a thing in general, action of trespass lies; but where a man hath an interest during that time, his misfeasance shall not be punished by a general writ of trespass. But as it hath been said, if a tenant at will cuts down the trees, or pulls down the houses, a general action of trespass lies; for thereby his interest is determined, and he is become a stranger, for that he voluntarily had done such an act, which could not be done by his interest, and determines the will. Wherefore judgment was given accordingly. ${ }^{13}$

18.Acc.: Panton v. Isham, 3 Lev. 359 (1702); Lothrop v. Thayer, 13s Mass. 466, $52 \mathrm{Am}$. Rep. $2 S 6$ (1SS5). In this latter case, Field, J., said (13s Mass, 474, $52 \mathrm{Am}$. Rep. 292): "The law of negligence has been largely dereloped in recent times, and it is argued that there is no sound reason why it should not be apllied in the same manner to real property as to personal, and to tenancies at will as well as to tenancies for a term. It may well be doubted whether the existing condition of the law of negligence is altogether satisfactory, and whether it rouid be wise to establish an unlimited liability to his landlord, on the part of every tenant at will of real property. for every injury occasioned by any act of negligence of himself or his servants, in the use of the property. However this may be, we do not feel at liberty to overturn long-established rules of law gorerning real property. We are not in this case requiled to consider the consequences of the negligent setting or guarding of fires, set for other purposes than such as are necessary to render the tenement fit for occupation, and in other places than those constructed or intended for the use of fires in beating the premises let. It is competent for landlords and tenarts to make in writing any stipulations they see fit. When there is no writing, and the tenant talses the precarious estate of a tenancy at will, we think it has been generally understood that the tenant is not liable for the burning of the tenement let, occasioned by his negligence or that of his servants in the keeping of fires set for the purpose of heating the premises, and in the places designed for that purpose, so that they may be fit for occupation. The fact that no action can be found to have been maintained for this cause is strong evidence of this. The ancient law has been acquiesced in, and, conseiously or 


\title{
In re CARTWRIGHT.
}

\author{
AVIS v. NEWMAN. \\ (Chancery Division, 1889. L. R. 41 Ch. D. 532.)
}

\section{Adjourned summons.}

John Cartwright, who died in 1850 , by his will, dated in that year, devised land in the county of Suffolk unto and to the use of his daughter Mary Anne Cartwright and her assigns for and during the term of her natural life, and from and immediately after her decease to the use of her children, if any, in manner therein mentioned, and if all such children should have departed this life without issue at the time of the decease of his daughter and on failure of her issue, he devised the land to the deiendant Newman, his heirs and assigns for ever. The will contained no provisions touching the liability of the testator's daughter for waste.

Mary Anne Cartwright died a spinster on the 15th of December, 1888, and the plaintiff Avis was her executor. At the time of her death the buildings, gates, and fences on the devised land were in a dilapidated condition owing to the necessary repairs not having been done, and the probable cost of the works necessary to place the property in repair was estimated by a surveyor to be $£ 166.12 \mathrm{~s}$. $9 \mathrm{~d}$. The defendant claimed this sum from the plaintiff, who, on the 28th of March, 1889, took out an originating summons to have it determined whether any and what sum should be allowed and paid to the defendant as compensation in respect of waste suffered by Mary Anne Cartwright during her estate in the premises.

KAY, J. (without calling upon counsel for the plaintiff). I am much obliged to you, Mr. Druce, for your argument, to which I have listened with very considerable interest. The result appears to be this: Sir James Mansfield was clearly of opinion that an action for permissive waste would not lie even against a tenant for years. That is clearly shewn in the case of Gibson v. Wells, 1 B. \& P. N. R. 290. which was followed at later dates in Herne v. Bembow, 4 Taunt. 764, and Jones v. Hill, 7 Ibid. 392, and in the recent case of Barnes v. Dowling in the Law Times Reports; and when the point was brought before the Lord Chancellor (Lord Cranworth) in the case of Powys v. Blagrave, his Lordship, 4 D. M. \& G. 458, said this: "Then it was argued, independently of the trust, that it is the duty of a tenant for life to repair-'Equitas sequitur legem.' But even legal liability now is very doubtful." And he referred to Gibson v. Wells, 1 B. \& P. N. R. 290, and Herne v. Bembow, 4 Taunt. 764. His Lordship there de-

unconsciously, the cost of insurance to the landlord, or the value of the risk, enters into the amount of the rent."

Compare Wainscott $r$. Silvers, 13 Ind. 497 (1S.59); Coale v. Hanuibal St. J. R. Co., 60 Mo. 227 (1S75). 
cided most certainly that in equity no interference whatever would be made on the ground of permissive waste by a tenant for life. Now, in that state of the authorities, this consideration is to be added. Since the Statutes of Marlbridge and of Gloucester there must have been hundreds of thousands of tenants for life who have died leaving their estates in a condition of great dilapidation. Not once, so far as legal records go, have damages been recovered against the estate of a tenant for life on that ground. To ask me in that state of the authorities to hold that a tenant for life is liable for permissive waste to a remainderman is to my mind a proposition altogether startling. I should not think of coming to such a decision without direct authority upon the point. Such authority as there is seems to me to be against the contention, and in opposition to the positive decisions in Gibson v. Wells, Herne v. Bembow, and Jones v. Hill, 7 Taunt. 392, there are only to be found certain dicta of Baron Parke and the late Lord Justice Lush which seem to amount to this, that the words of the statutes of Marlbridge and Gloucester are sufficient to include the case of permissive waste, at any rate where there is an obligation on the person who has the particular estate not to permit waste, whether that obligation does or does not exist at the common law in the case of a tenant for life. But at the present day it would certainly require either an Act of Parliament or a very deliberate decision of a Court of great authority to establish the law that a tenant for life is liable to a remainderman in case he should have permitted the buildings on the land to fall into a state of dilapidation. I therefore think that this claim must be disallowed. ${ }^{14}$

\section{MORRIS v. CAIRNCROSS.}

(Common Pleas Division of the High Court of Justice of Ontario, 1907. 14 Ont. L. R. 544.)

This was an action for a declaration that a certain lease was void, and not binding on the plaintiffs, and for other relief.

The plaintiffs were the grandchildren and heirs-at-law of Mary Gallagher, who died in 1870, having first made her will whereby she devised certain lands situate at the corner of Church and Ann streets, in the city of Toronto, then owned by her in fee simple, amongst other lands, to her son Robert Atkinson Gallagher for life; and appointed William Mulock and John Oliver her executors.

14Acc.: In re Parry, [1900] 1 Ch. 160; Patterson v. Central Canada Loan \& Savings Co., 29 Ont. 134 (1S9S), action at law.

"A tenant for life is required to keep the buildings in which he may have a life estate from going to decay, by using ordinary care; but he is not required to expend any extraordinary sums." Eastman, J., in Wilson v. Edmonds, 24 N. II. 517, 545 (1852). See Sherrill v. Connor, 107 N. C. 630, 12 S. E. $588(1890)$. 
In accordance with the terms of the will, R. A. Gallagher entered into possession of the lands; and on the 1st October, 1895, John Oliver and R. A. Gallagher assumed to make a lease of the lands to the defendant for the term of twenty-one years, at an annual rental of $\$ 120$ who went into and continued in, possession of the same. On February 6th, 1905, R. A. Gallagher died.

The plaintiffs contended that on his death they became entitled to an estate in fee simple in the lands, and that John Oliver and R. A. Gallagher had therefore no power to make a lease of the lands for a longer term than the life of R. A. Gallagher. That the Settled Estates Act, 58 Vict. ch. 20, sec. 42 (O.), did not apply, as the lease was not made in conformity with that Act, in that it was not an ordinary lease as contemplated by that Act, but was in effect a building lease, and was made without impeachment of waste, and that the rent rescrved by the lease was not the best rent that could have been reasonably obtained therefor, but was an inadequate and insufficient rental, and that even if the lease were made in conformity with the provisions of the Settled Estates Act, it was not binding upon or good as against the plaintiffs.

The plaintiffs proved that, on the death of the life tenant, $R$. A. Gallagher, they had repudiated the lease, and had demanded possession from the defendant, but that he neglected and refused to deliver up the possession, claiming that the lease to him was a valid lease.

The plaintiffs asked for a declaration that the lease was void, and not binding upon them, and also to have it declared that the defendant had excluded them from the possession, and to have such possession delivered over to them, and claiming mesne profits or damages, and costs.

The action was tried before Boyd, C., at the non-jury sittings at 'Toronto, on May 15, 1906.

Boyd, C. ${ }^{15}$ In leases for years under the Settled Esstates Act, 1895, 58 Vict. ch. 20, sec. $42(\mathrm{O})$, it is essential that they be not made "without impeachment of waste." In other words, the terms of the lease must be such as not to affect or vary the common law liability of the lessee for waste. The tenant must not be relieved from any duty the omission of which would constitute waste.

[The Chancellor dismissed the action and the plaintiffs appealed.]

MerediTH, C. J. [after considering certain objections of the plaintiff's to the lease]. The other ground of objection on this branch of the case-that the demise is without impeachment of waste-is based upon the proposition that the covenants to repair and to repair according to notice are qualified by the exceptions in the covenant to leave the premises in good repair, namely, "reasonable wear and tear and damage by fire or tempest," and that, bcing so qualified the effect of them is that the lessee is freed from liability for waste, for which, as

15 Parts of the opinions of Boyd, C., and Meredith, C. J., are omitted. 
was contended, both voluntary and permissive, a tenant for years is answerable. $* * *$

There remain to be considered two questions:

(1) Whether a tenant for years is answerable for permissive waste;

(2) If answerable, whether the terms of the lease are such as to relieve the respondent from any liability which otherwise he would be under for permissive waste.

I would have been justified in resting my decision as to the existence of the liability upon Yellowly v. Gower, 11 Exch. 274, had it not been that it was argued that the authority of that case had been shaken, if not destroyed, by subsequent decisions and by the effect of the Judicature Act, and that if I had come to that conclusion it would still be necessary to ascertain what are the nature and extent of the liability of a tenant for years for the state and condition of the demised premises.

Yellowly v. Gower was decided in 1855 by the Court of Exchequer the judgment of the Court being delivered by Baron Parke, and was supposed, as the text writers say, to have "stifled the doubt" that had before existed as to the liability of a tenant for years for permissive waste.

This doubt, as Baron Parke points out, was raised by three cases in the Common Pleas: Gibson v. Wells (1805) 1 Bos. \& P. N. R. 290; Herne v. Bembow (1813) 4 Taunt. 764; and Jones v. 'Hill (1817) 7 Taunt. 392; and as to them he said, at p. 292: "Upon examining these cases, none of which appears to be well reported, the Court seems to have contemplated the case only of a tenant at will in the two first cases, and in the last no such proposition is stated that a tenant for years is not liable for permissive waste."

The opinion of the Court was stated in no uncertain terms (at p. 292): "We conceive that there is no doubt of the liability of tenants for terms of years, for they are clearly put on the same footing as tenants for life, both as to voluntary and permissive waste. ***"

The declaration in Herne v. Bembow was in case in the nature of waste, and it would seem that the decision turned upon the form of the action, for the Court is reported to have said (at p. 765): "Whatcver duties the law casts on the tenant, the law will raise an assumpsit from him to perform (if there be no covenant in his lease for the performance), but that is a very different case from a declaration framed in tort like this." * * *

The learned Chancellor declined to follow Yellowly v. Gower and Davies v. Davies, 38 Ch. D. 499. He had already, in Patterson v. The Central Canada Loan and Savings Co., 29 O. R. 134, adopting the view of Kay, J., in In re Cartwright, Avis v. Newman, 41 Ch. D. 532, determined that a tenant for life was not impeachable for permissive waste, and that determination logically required the same holding as 
to a tenant for years, for tenants for years are by the statutes put on the same footing as tenants for life.

I am, with great respect, of opinion that even if In re Cartwright was well decided, we ought to follow Yellowly v. Gower, followed as it was by Kekewich, J., in Davies v. Davies, unless the Judicature Act makes it necessary to follow the rule in equity which undoubtedly was not to interpose its aid in the case of permissive waste.

This rule of equity was not based upon any different view as to the legal liability from that entertained by Courts of common law, and I do not find anywhere any clear statement of the reason for its adoption.

The rule is referred to in Lord Castleniain v. Lord Craven (1733) 22 Vin. Abr. 523, by the Master of the Rolls, who said that "as to repairs, the Court never interposes in case of permissive waste, either to prohibit or give satisfaction, as it does in case of wilful waste." $* * *$

The rule probably had its origin in the difficulty which Courts of equity found in enforcing by their process the performance of the tenant's duty, and in the absence of jurisdiction to give relief by mandatory injunction, that jurisdiction being strictly confined to cases where the remedy by damages was inadequate for the purposes of justice, and the restoring of things to their former condition was the only remedy which would meet the requirements of the case. Kerr on Injunctions (4th Ed.) p. 31. * * *

The most that can be said as to the course of Courts of equity in regard to claims for permissive waste is that they did not actively interfere where the estates were legal, but left the claimant to his remedy at law, and that they did not interfere where the estates were equitable, and I see in this course nothing that involves. any conflict or variance between the rules of equity and the rules of common law as to the remedy by a legal remainderman for permissive waste by a legal tenant for life or for years.

If the question were as to the liability of a tenant for life, we would he bound by Patterson v. The Central Canada L. \& S. Co., to hold that such a tenant is not liable. The effect of that decision and of my conclusion in this case leads to the illogical result, so far as a decision of a Divisional Court can be said to settle the law, that though by the statutes both classes of tenants are put on the same footing as to waste, tenants for years are liable for permissive waste, but tenants for life are not; and were it not for that consideration, I should have refrained from adding anything further on this branch of the case.

Apart from Barnes v. Dowling. 44 L. T. N. S. 809, the only English case supporting the view of the Divisional Court in Patterson v. The Central Canada L. \& S. Co., is In re Cartwright, Avis v. Newman, 41 Ch. D. 532.

The main ground of Mrr. Justice Kay's decision is stated on p. 536: "Since the Statutes of Marlbridge and of Gloucester there must have 
been hundreds of thousands of tenants for life who have died leaving their estate in a condition of great dilapidation. Not once, so far as legal records go, have damages been recovered against the estate of a tenant for life on that ground. To ask me in that state of the authorities to hold that a tenant for life is liable for permissive waste to a remainderman is to my mind a proposition altogether startling. I should not think of coming to such a decision without direct authority upon the point."

For an able criticism of this judgment, I refer again to the article on Permissive Waste in the Solicitors' Journal [vol. 33, p. 743], and to Mr. Labatt's article in the Canada Law Journal, vol. 37, p. 535 et seq.

Text writers and others have suggested reasons for the absence of adjudged cases since the time of Charles $I$. In the notes on In re Cartwright, in the Law Quarterly Review, vol. 5; at p. 449, it is suggested that this may be explained by the rule "actio personalis," and Mr. Smith, in his Lectures on the Law of Landlord and Tenant (2d Ed.) p. 266, speaking of tenants for years, says that the reason of the "paucity of information is, that in practice a case rarely, if ever, occurs in which it is necessary to inquire what the general law is on the subject; for every lease of any importance contains stipulations upon the subject of repairs, and where those are inserted they supersede the law, as it would stand without them; and of course, therefore, the question of what that law is, in the absence of express stipulations, rarely if ever occurs."

These reasons appear to me to afford a satisfactory explanation of the absence of decided cases as to both tenants for life and tenants for years.

That down to the time of Charles I cases did occur in which the question arose is beyond question, and there is abundant authority in the earlier cases to support the statement of Lord Coke that the statutes applied to permissive as well as to voluntary waste.

The early cases are referred to and commented upon by Mr. Bewes at pp. 211-216 of his book, and the principle he deduces from them is that "a tenant is not in general responsible for permissive waste where not followed by actual, substantial damage to the premises." P. 213.

It appcars to me, however, that the cases establish that as far as liability of tenants for life and for years for waste is concerned, there is no difference between permissive and voluntary waste, and that the questions which have arisen were not as to the existence of the liability but as to what acts or omissions of the tenant constitute waste, and that the result of the cases is that the tenant is not liable for mere wear and tear, but that he is liable for his failure to make such repairs as are necessary to prevent the decay or destruction of the premises as where. a small breach is made in the roof of a building by tempest and the tenant permits it to remain unrepaired, and the roof is afterwards blown off or the house blown down for want of repair- 
ing the breach, 6 Eliz., Moore, p. 62 , case 173 ; or where the tenant neglects to paint or plaster a chamber of the house, which results in the timbers of the house becoming putrid, Corbet v. Stonehouse, 9 Car., 2 Rolle Abr. 816-7; or neglects to scour a ditch, which results in the groundsels of the house becoming putrified, Sticklehorne v. Hatchman, 28 Eliz. Owen, p. 43.

An independent inquiry into the question, fortified by the result of this examination of the principal cases, in England, Ireland and the United States, and of the opinions of text writers and commentators, leads me to the conclusion that Yellowly v. Gower was rightly decided, and that its authority has not been impugned or affected by any subsequent case, or displaced by the provisions of the Judicature Act, and I may point out that the Commissioners by whom the Laws of England introduced into this Province by the Constitutional Act of 1792, 32 Geo. III, ch. 1, were revised and consolidated, must have reached the same conclusion as that to which I have come, for as revised the Statute of Marlbridge reads: "Lessees making or suffering waste on the demised premises without license of the lessors shall be liable for the full damage so sustained." R. S. O. 1897, ch. 330, sec. 23; Ibid. ch. 342, sec. 22.

There remains to be considered the question whether the modifications of the covenants in the lease to which I have referred have the effect of relieving the respondent from any liability which but for them he would have been subject to for permissive waste; and I am of opinion that they do not. ***

The result is that in my opinion the appeal fails and should be dismissed with costs. $^{16}$

\section{CHALMERS et al. v. SMITH et al.}

(Supreme Judicial Court of Massachusetts, 1S91. 152 Mass. 561, 26 N. E. $95,11$ L. I. A. 760.$)$

Tort, with a count in contract, to recover for loss by the fall of a barn in South Hadley. The declaration was as follows:

"Count in tort. And the plaintiffs say the defendants became and were tenants to the plaintiffs of a certain barn and premises of the plaintiffs, situated in said South Hadley, which said defendants hired for the storage of hay, and when so occupying and using said barn and premises as such tenants they wrongfully and unlawfully, and without the license and against the will of the said plaintiffs, stored and filled the barn floors, passageways, and stables of said barn with meal, grain, and fertilizers, all of which were quite weighty, and having also filled the remaining space in the barn with hay and grain,

16 See Iiatch v. Stamper, 42 Conn. 28 (1S75); Libbey v. Tolford, $4 S$ Me. 316, 76 Am. Dec. 229 (1S61); Moore v. Townshend, 39 N. J. Law, 285 (1S69); Windon v. Stewart, $43 \mathrm{~W}$. Va. 711,28 S. E. $776(1897)$. 
so that the entire space in the barn was filled or nearly filled with material and substance much too weighty, and said barn not having been constructed or calculated to sustain such a quantity of heavy grain, and substances as the defendants placed therein; and said defendants so overloaded said barn as aforesaid that the floor gave way. The timbers, braces, and supports of said barn were drawn out of place and broken. The scaffold and roof were broken down, and the entire building badly damaged by reason of the enormous weight so wrongfully and unjustly and improperly placed therein by said defendants. By means of which damage said plaintiffs have lost and will lose the use and rental of said barn, and have been and will be put to great loss and expense to repair the same.

"Count in contract. And the plaintiffs say that the defendants became and were tenants to the plaintiffs of a certain barn and premises of the plaintiffs situated in said South Hadley, which they hired for the storage of hay, upon the terms that the defendants should during the said tenancy use the said barn and premises in a tenantlike and proper manner, and the defendants during the said tenancy used the said barn and premises in an untenant-like and improper manner, filling the stable and barn floors with a large quantity of grain, meal and fertilizers, in addition to the large quantity of hay and grain stored by said defendants in other parts of the barn, so that said barn was overloaded, and the floors and scaffolds and roof broke down, the timbers and supports were broken, and the barn badly damaged, by reason of which the plaintiffs have lost and will lose the rental of the same, and will be put to great expense to repair the same.

"The count in contract is joined with the count in tort, being deemed doubtful to which of these classes the above cause of action belongs, and both being for one and the same cause of action."

Trial in the Superior Court, before Barker, J., who, after a verdict for the plaintiffs, reported the case for the determination of this court, in substance as follows.

The plaintiffs purchased the land on which the barn mentioned in the declaration stood on July 19, 1887. The defendants, as copartners, occupied the barn under an oral lease from the former owners at the time of the purchase, and continued in occupation under that lease until its term expired, July 1, 1888. In June, 1888, the defendants, by an oral bargain, hired the barn of the plaintiffs for another year from July 1, 1888, at a rent of seventy-five dollars. On the morning of July 31,1888 , the barn fell, its floors settling and many of its beams being broken. The plaintiffs-contended and offered evidence tending to show that the barn fell from overloading, and that the weight put into it by the defendants was excessive, and improperly distributed. But the defendants denied this, and contended and offered evidence tending to show that the accident was caused by the defective construction of the barn. It also appeared in evidence, that the defendants remained in occupation of the barn until July 1, 18S9, and 
that they had paid the rent for the full term before this action was brougint.

When the plaintiffs rested their case, the defendants moved for a verdict, on the ground that the action could not be maintained upon the pleadings and evidence, but the judge overruled the motion; and the defendants excepted.

The judge submitted the case to the jury upon instructions, to which no exception was taken, which allowed them to find for the plaintiffs, if they found in fact that the fall of the barn was caused by an apparently unreasonable use of it by the defendants.

If the case was properly submitted to the jury, judgment was to be entered for the plaintiffs; otherwise, such disposition of the case was to be made as might be proper.

Knowlton, J. The jury have found that the defendants unreasonably used the plaintiff's barn by putting into it a weight which was apparently and in fact excessive. This was something more than a mere omission, which would constitute permissive waste. It was a positive unreasonable act, of a kind likely to cause injury to the plaintiff's property. Such an act which results in damage is voluntary waste on the part of a tenant who is guilty of it. A tenant at will who commits voluntary waste is liable to his landlord in an action of trespass quare clausum. His act terminates his right as a tenant, and entitles the landlord to treat him as a trespasser in doing it. Starr v. Jackson, 11 Mass. 519; Lienow v. Ritchie, 8 Pick. 235 ; Daniels v. Pond, 21 Pick. 367, 32 Am. Dec. 269; Lothrop v. Thayer, 138 Mass. 473, $52 \mathrm{Am}$. Rep. 286. A tenant at will, as well as a tenant for life or for years, is under an implied agreement to use the premises in a tenant-like manner, and not by his voluntary act unnecessarily to injure them. While this agreement does not include an obligation on the part of a tenant at will to repair defects resulting from the action of the elements, or from a reasonable use of the premises, or from an unavoidable accident, it creates a liability in an action on contract for a wrongful act in violation of it. 1 Add. Cont. (8th Ed.) 383; Holford v. Dunnett, 7 Mees. \& W. 348; United States v. Bostwick, 94 U. S. 53, 66, 24 L. Ed. 65.

The acceptance of rent by the plaintiff for the full term was not necessarily a waiver of their right to recover damages for a breach of this contract. It was merely evidence for the consideration of the jury upon the question whether there was a waiver. A liability in damages for an act of this kind may well be enforced in an action of contract, notwithstanding that the rent has, been fully paid. Upon the facts which the jury must have found the action can be maintained on the second count, and the ruling of the presiding justice was therefore correct. Whether the plaintiffs waived their right to maintain an action of trespass quare clausum, by permitting the defendants to be in possession of the premises and accepting rent for a long time after the building fell, or whether the defects in pleading 
in the first count, treating it as a count in trespass, could be taken advantage of by the defendants' request for a ruling at the close of the evidence, it is unnecessary to decide.

Judgment for the plaintiffs. ${ }^{17}$

\section{EARLE v. ARBOGAST et al.}

(Supreme Court of Pennsylvania, 1897. 1S0 Pa. 409, 36 Atl. 923.)

Trespass by lessor to recover damages from lessees for injuries to buildings while in their possession under the lease. Before Albright, P. J.

At the trial it appeared that the premises in question had been leased by the plaintiff to the defendants by parol for one year, with no agreenient to repair or to deliver the premises in good order and condition at the end of the term. The property had been used by the lessor as a soap factory, and this use was continued by the defendants. The only new appliance which the defendants used was a rendering tank, which exploded and caused the injuries for which suit was brought. It was ciaimed by the plaintiff that the explosion was caused by the vent pipe of the tank becoming clogged. It was also averred by him that the tank was not strong enough to withstand the pressure of steam that was put upon it.

Verdict and judgment for defendants. Plaintiff appealed.

FELL, J. ${ }^{18}$ Generally, in the absence of an express covenant on the subject, the law implies a covenant on the part of the lessee so to treat the demised premises that they may revert to the lessor unimpaired, except by usual wear and tear, and uninjured by any willful or negligent act of the lessee. The implied covenant does not, however, extend to the loss of buildings by fire, flood, or tempest, or enemies, which it was not in the power of the lessee to prevent, and there is no implied covenant that the lessee shall restore buildings which have been destroyed by accident without fault on his part. Jack. \& G. Landl. \& Ten. §§ 964, 965; Tayl. Landl. \& Ten. § 343; Cooley, Torts, p. 335 ; Long, v. Fitzimmons, 1 Watts \& S. 530; United States v. Bostwick, 94 U. S. 53, 24 L. Ed. 65.

Tenants by the curtesy and in dower were responsible at common law, and tenants for life and for years whose estates were created by the acts of the parties were responsible under statute as for permissive waste until relieved by the statute of 6 Anne, c. 31, where the property was destroyed by 'unavoidable accident, not the act of God or the public enemy. The statute of 6 Anne, c. 31, which saved the tenant from liability for the consequences of accidental fires, has never been in force in this state, and it has been formally adopted by few,

17 Compare Horsefall v. Mather, İolt's N. P. 7 (1815).

18 The statement of iacts is abridged. 
if any, of the other states except New Jersey. Chancellor Kent (4 Kent, Comm. 82) says: "Perhaps the universal silence of our courts upon the stoject of any such responsibility of the tenant for accidental fires is presumptive evidence that the doctrine of permissive waste has never been introduced and carried to that extent in the common-law jurisprudence of the United States." In United States v. Bostwick, supra, it was held that the implied covenant of the tenant is not to repair generally, but so to use the property as to make repairs unnecessary as far as possible, and that it is a covenant against voluntary waste only. It is said in the opinion by Waite, C. J.: "It has never been so construed as to make a tenant answerable for accidental damages, nor to bind him to rebuild if the buildings are burned down, or otherwise destroyed by accident."

The statement in the opinion in Long v. Fitzimmons, supra, that a tenant, where there is no covenant to that effect, is not bound to restore buildings that have been burned down, or become ruinous by other accident, without default on his part, may be a dictum only, but it is in harmony with the trend of decisions of the courts of other states and of the federal courts, and it has been accepted and acted upon by the courts of this state, and it is a correct statement of the law. There could be no recovery without proof of the defendant's negligence, and the burden of proof rested upon the plaintiff. The lease was in parol, for one year, with no agreement to repair or to deliver the premises in good order and condition at the end of the term. No new or different use was made of the building by the tenants. It was used by them for the purpose for which it had been leased, and for which it had been fitted with machinery, and used by the lessor. The only new appliance used was the rendering tank which exploded. In the use of the property leased the defendants were under an implied duty not to negligently injure it. The standard of their duty was reasonable care.

The mere fact of the explosion did not throw upon them the burden of proving that they were not negligent. The burden of proof was with the plaintiff throughout the trial. He was not bound, in the first instance, to prove more than enough to raise a presumption of negligence on the part of the defendants. Proof of the explosion and of the attendant circumstances might have furnished sufficient ground for a reasonable inference of negligence to have made out a prima facie case; but he could not rest his case upon a bare presumption, based only upon the fact that the explosion occurred. The answers to the third, fourth, and fifth points affirmed these propositions, and are free from error.

The assignments which complain of the charge cannot be sustained. An inadequate presentation of the case, when the omission to charge leaves the jury without direction on important questions involved, or plainly tend's to mislead them, is ground for reversal. In this case the charge was clear and full. The omission now complained of 
was in not calling the attention of the jury to some features of the case which counsel at the time did not deem of sufficient importance to mention, and which may have been discovered only by a critical analysis of the charge made since the trial.

The judgment is affirmed. ${ }^{19}$

\section{ROGERS v. ATLANTIC, G. \& P. CO.}

(Court of Appeals of New York, 1915. 213 N. Ý. 246, 107 N. E. 661, L. R. A. 1916A, 787, Ann. Cas. 1916C, 877.)

Miliek, J. ${ }^{20}$ The plaintiff, a life tenant, has recovered a judgment for all of the damages, both to the life estate and to the inheritance, caused by a fire set by the defendant, a canal contractor, on adjoining lands of the estate, and negligently allowed to spread

19 See, as to the liability of a tenant for years for loss by fire, Dorr $\nabla$. Harkness, 49 N. J. Law, 571, 10 Atl. 400, 60 Am. Rep. 656 (1887); Moore v. Parker, 91 N. C. 275 (1SS 1$)$.

As to the liability of a tenant under a covenant to return the premises in good condition where they have been destroyed by tire, compare Nave v. Berry, 22 Ala. 352 (1S53); Levey v. Djess, 51 Miss. 501 (1875); Maggort v. Hansbarger, 8 Leigh (Va.) 532 (1837); Armstrong v. Maybee, 17 Wash. 24, 48 Pac. 737, 61 Am. St. Rep. 895 (1S97).

Plaintiff leased premises to the defendants, an express company, for a term of years. The premises were damaged by the explosion thereon of a package of nitroglycerine received by the defendants without knowledge of its contents, which exploded without the fault of the defendants. Plaintiff brought action against the defendants to recover for the damage so caused. The court, by Sawyer, J., said: "As to the waste on the premises demised to the defendants, I adopt the views expressed by the district judse, in his opinion on the demurrer, and I need not repeat the reasoning here. [Case No. 10,773a (1S6S).] Whether the waste complained of is technically permissive, or commissive, I think it falls within the provisions of the statute. And on the facts found, I think the defendants liable, although, as will hereafter alpear, there was, in my judgment, no negligence on their part. There was, doubtless, fault on the part of those who delivered the explosive substance to defendants for carriage over their express route, without informing them of the dangerons character of the article, for which they may be liable to defendants. The rule seems to be established, that, with respect to liability for waste, the tenant is in a position analogous to that of a common carrier, and without some special agreement to the contrary, responsible for all waste, however or by whom committed, except it be occasioned by act ot God, the public enemy, or the act of the reversioner himself. $4 \mathrm{Kent}$, Comm. 77; Attersoll v. Stevens, 1 Taunt. 183 [1S0S]; Cook v. Champlain Transp. Co., 1 Denio, 91 [1S45]; 2 Elen, Inj. 198, and notes. In White $\mathbf{v}$. Wagner, 4 IIar. \& J. [MI.] 373, 7 Am. Dec. 67t [1818], this doctrine was carried out in an extreme case. The tenant is held responsible to the landlord, and left to his remedy over against the delinquent party. The liability does not devend on mere negligence, but it is imposed on the same grounds of public policy as those npon which the strict liabilities of common carriers are made to rest." Parrott v. Barney, 2 Abb. U. S. 197, 207, Fed. Cas. No. 10,773 (1870).

See Attersoll $\nabla$. Stevens, 1 Taunt. 193 (1S08); White v. Wagner, 4 Har. \& J. (Md.) 37., 7 Am. Dec. 674 (1S1S); Regan v. Luthy (Com. Pl.) 11 N. $\dot{\text {. }}$ Supp. 709 (1S90).

$\because$ Part of the opinion is omitted. 
to the lands of the plaintiff. The single question involved in this appeal is whether the recovery should have been limited to the damages to the life estate. The right of the plaintiff to recover all of the damages has thus far been maintained on the ground that she is liable to the remaindermen for any injury to the inheritance not caused by them, the act of God, or the public enemy. No case is known in which a tenant has been subjected to such a rule of liability, and the proposition is so startling as to demand examination before it is made the ground of a decision by us.

This is an action for negligence against a stranger both to the life estate and the remainder, and it may well be doubted whether the doctrine of waste has any application at all to it. Waste is thus defined by Bouvier :

"Spoil or destruction done or permitted to lands, houses, or other corporeal hereditaments, by the tenant thereof, to the prejudice of the heir or of him in reversion or remainder. Permissive waste consists in the mere neglect or omission to do what will prevent injury; as to suffer a house to go to decay for the want of repair. And it may be incurred in respect to the soil, as well as to the buildings, trees, fences, or live stock on the premises. Voluntary waste consists in the commission of some destructive act; as in pulling down a house or ploughing up a flower garden." "There are two kinds of waste, viz., voluntary or actual, and negligent or permissive. Voluntary waste may be done by pulling down or prostrating houses, or cutting down timber trees; negligent waste may be suffering houses to be uncovered, whereby the spars or rafters, planches or other timber of the house are rotted." Bacon's Abridgment, vol. 10, p. 422.

In the popular sense, any injury may be waste, but it is not waste in the legal sense, unless caused in such manner as to be within the legal definition of either commissive or permissive waste.

The rule contended for is based on Lord Coke's interpretation of two English statutes passed in the thirteenth century, the statute of Marlbridge, 52 Henry III, c. 24, and the statute of Gloucester, 6 Edward I, c. 5. ***

Lord Coke gives two reasons for allowing the reversioner to recover of the tenant for waste committed by a stranger :

(1) "For it is presumed in law that the former may withstand it" (2 Inst. 145, 146); and (2) "for he in the reversion cannot have any remedy but against the tenant" (2 Inst. 303.)

.It may be open to some question whether by "stranger" he did not mean the assignce of the tenant, against whom he said that the heir could not maintain an action for waste. 2 Inst. 300 . But, at any rate, it is plain that under that head he referred to voluntary, not permissive, waste. The Court of Chancery did not interfere to prohibit permissive waste. In Lord Castlemain v. Lord Craven, the Master of the Rolls said:

Big.RIgHTs- 43 
"But, as to repairs, the court never interposes in case of permissive waste, either to prohibit or give satisfaction, as it does in case of willful waste." 22 Vin. Abr. 523.

Certainly there is no basis for any presumption that the tenant could have prevented such an injury as was done in this case. One of the reasons given for likening the liability of a tenant to that of a common carrier is that it is imposed to prevent collusion. Attersoll v. Stevens, 1 Taunt. 183, 198. That reason cannot apply with any force except to cases of voluntary waste. Lord Coke does except the case of injuries done by the enemies of the king, and by tempest, lightning, and the like, but in that connection he also instances a case in which it was adjudged:

"That if thieves burn the house of tenant for life, without evil keeping of lessees for lives fire, the lessee shall not be punished therefor in an action of waste." 2 Inst. 303.

In Halsbury's Laws of England (volume 18, p. 499) it is said:

"Lessees for years, or from year to year, or for any other period, are liable for voluntary waste, whether committed by themselves. or any other person, for, if committed by another, it is their duty, and they are presumed to be able, to withstand it."

The case in 1 Taunton, supra, is the one generally cited as the leading case in support of the proposition that the tenant is liable for waste committed by a stranger, but that was a case of voluntary waste, the removal of clay.

Even assuming that by the rule of the ancient common law an injury caused by the negligent act of a stranger both to the estate for life or years and to the reversion or remainder amounted to waste, for which the tenant for life or years was responsible, the reasons for the rule given by Lord Coke either no longer exist or do not apply to the facts of this case. The ancient common-law forms of action have been abolished, and the impediment of the common law against the maintenance of ain action for waste by reversioner or remaindermen in case there was an intervening estate (2 Inst. 301; Coke upon Littleton, vol. 3 , p. *243) was removed in this state by chapter $246, \S 47$, of the Laws of 1811, which provided:

"That it shall and may be lawful for any person or persons seised of an estate in remainder or reversion, to maintain an action of waste or trespass for any injury done to the inheritance, notwithstanding any intervening estate for life or for years." * * *

Certain other statutes affecting the obligation of tenants remain to be considered. The statute of 6 Anne, c. 31, relieved an owner from liability for an accidental fire starting in his house or chamber, and the statute of 14 George III, c. 78, extended the exemption to such fires starting anywhere on one's estate. Primarily, those statutes were intended to relieve from the rigorous rule of the ancient law which made a person liable for the consequences of a fire originating upon his own premises and spreading to his neighbor's. But they are broad 
enough to affect the liability of a tenant to reversioner or remainderman, and have been so construed (see 4 Kent, *82), and they have been held to be part of the law of this state. Lansing v. Stone, 37 Barb. 15. And see Hoffman v. King, 160 N. Y. 618, at page 622, 55 N. E. 401, 46 L. R. A. 672, 73 Am. St. Rep. 715. Whilst a fire is not accidental, within the meaning of those statutes, if caused by the negligence of the tenant, or his servants (Filliter v. Plippard, 11 Ad. \& E. [N. S.] 347), and the statute literally applies only to a fire beginning on one's premises, there is no substantial reason for making a distinction as to the liability of a tenant between an accidental fire and one caused by the negligence of strangers, or between a fire accidentally beginning on the premises and one spreading thereto from adjoining premises.

By chapter 345 of the Laws of 1860 (now section 227 of the Real Property Law [Consol. Laws, c. 50]) a lessee or occupant of a building is relieved from the obligation to pay rent in case it is destroyed or rendered untenantable by the elements or any other cause without any fault or neglect on his part. In the absence of covenant, no obligation rests upon either the landlord or the tenant to rebuild in such case. Smith v. Kerr, 108 N. Y. 31, 15 N. E. 70, 2 Am. St. Rep. 362. The law would be in an anomalous state if a tenant, though under no obligation to rebuild or to pay rent, were still answerable in damages, or if, though not liable for the injury or destruction of buildings without his fault, he were still liable for other injuries to the premises, though equally without fault. Those statutes do not in terms apply to a case like this, doubtless for the reason that no one had ever attempted to hold a tenant responsible in such case. The written and the unwritten law should be consistent, and the whole body of law governing the obligations of tenants should by analogy be made to harmonize with the said statutory rules.

Moreover, the statutes of Marlbridge and Gloucester were superseded in this state by chapter 6 of the Laws of 1787, which provided:

"That no tenant for life or years or for any other term shall during the term make or suffer any waste $* * *$ without special license in writing making mention that he may do it $* * *$ and whoever shall be convicted of waste shall lose the thing or place wasted and shall recompense thrice so much as the damage shall be taxed at by the jury."

That statute was substantially re-enacted by 2 R. S. 334, and is now cmbodied in section 1651 et seq. of the Code of Civil Procedure. Whilst the construction given a similar statute of earlier times may have weight, our own statute should be construed according to the social conditions of its time, and should not be controlled by the construction of a statute passed in the thirteenth century.

It thts appears that there is no binding decision of this court upon the point whether an injury by the negligent acts of third parties is waste, for which the tenant is liable to the reversioner or remainder- 
man, and the consequences of holding such a doctrine would be too serious to justify us in resting the right of the plaintiff to recover upon it.

The doctrine has only been invoked in this state to permit the tenant to recover from the wrongdoer. Cook v. Champlain Transportation Co., supra [1 Denio, 91] ; Austin v. Hudson R. R. R. Co., supra [25 N. Y. 334]; Dix v. Jaquay, 94 App. Div. 554, 88 N. Y. Supp. 228; United Traction Co. v. Ferguson Contracting Co., 117 App. Div. 305, 102 N. Y. Supp. 190. And it may well be that a rule so long recognized may be adhered to without adopting the reason originally assigned for it. In Dix v. Jaquay, supra, the Appellate Division in the Third Department naturally followed the Cook Case, but in a well-reasoned opinion Mr. Justice (now Presiding Justice) Smith suggested what appears to us to be a much better reason for maintaining the rule than that assigned in the Cook Case. Notwithstanding the removal of the impediments of the ancient common law, there will be many cases in which, for practical reasons, the tenant alone can compel redress from the wrongdoer, and it should not be open to the latter to escape liability by asserting the rights of a third party, under whom he does not claim. The tenant has not only possession, but an interest in the premises, in this case a life estate, and there is equal, if not greater, reason for allowing a full recovery by him as for allowing a depositary, who has no interest, but only possession, to recover for the conversion of, or an injury to, the deposit. A bailee, though not liable to the bailor, may recover for the wrongful act of a third party resulting in the loss of, or injury to, the subject of the bailment. Kellogg v. Sweeney, 1 Lans. 397; Id., 46 N. Y: 291, 7 Am. Rep. 333. And see Mechanics' \& T. Bank v. F. \& M. Bank, 60 N. Y. 40; Russell v. Butterfield, 21 Wend. 300; Faulkner v. Brown, 13 Wend. 63; Finn v. Western Railroad Co., 112 Mass. 524, 17 Am. Rep. 128; Johnson v. Holyoke, 105 Mass. 80; Chamberlain v. West, 37 Minn. 54, $33 \mathrm{~N}$. W. 114. If the bailee recovers, he holds the recovery as trustee for the bailor. A recovery by either bailor or bailee will bar an action by the other. First Commercial Bank of Pontiac v. Valentine, 209 N. Y. 145, and citations at page 150, 102 N. E. 544, Ann. Cas. 1913D, 1104; Woodman v. Nottingham, 49 N. H. 387, 6 Am. Rep. 526. The principle is the same as that applied in Madison Square Bank v. Pierce, 137 N. Y. 444, 33 N. E. 557, 20 L. R. A. 335, 33 Am. St. Rep. 751, in which it was held that the payce might recover from the maker the full cmount of a promissory note, notwithstanding an indorser had paid part; the plaintiff in such case becoming trustee for the indorser of so much of the so covery as represents the amount paid by the latter.

The recovery in this case might be treated as a substitute pro tanto for the land damaged, as would be the case of the proceeds of a sale (see Ackerman v. Gorton, $67 \mathrm{~N} . \mathrm{Y} .63$ ); the plaintiff being entitled to the life use of it, and becoming trustee of the principal for the 
remaindermen. See Snith v. Van Ostrand, 64 N. Y. 278; Leggett v. Stevens, 185 N. Y. 70, at page 76,77 N. E. 874 . The recovery might be apportioned between life tenant and remaindermen according to their respective interests, and the court might require the life tenant, if intrusted with the principal, to give security. See Matter of Camp, 126 N. Y. 377, 27 N. E. 799; Matter of McDougall, 141 N. Y. 21,35 N. E. 961 . It is for the court to make proper provision for the protection of the rights of remaindermen. The wrongdoer is only concerned in being protected from a second suit, and we are of the opinion that it must be held, as a necessary corollary to the proposition that the life tenant may recover all the damages, that such a recovery will bar an action by the remaindermen.

The judgment should be affirmed, with costs.

Werner, Hiscock, Chiase, Collin, Hogan, and Cardozo, JJ., concur.

Judgment affirmed. ${ }^{21}$

\section{SECTION 2.-REMEDIES FOR WASTE}

CO. LIT. 53b.

No person shall have an action of wast, unlesse he hath the immediate state of inheritance. ${ }^{22} * * *$ If the tenant doth wast, and he in the reversion dyeth, the heyre shall not have an action of waste for the waste done in the life of the ancestor. *** And so if lessee for yeares doth waste, and dyeth, an action of wast lyeth not against the executor or administrator for waste done before their time. But if two coparceners be of a reversion, and waste is committed, and the one of them die, the aunt and the neece shall joine in an action of waste.

Note, after wast done there is a speciall regard to be had to the continuance of the reversion in the same state that it was at the time of the waste done; for if after the waste he granteth it over, though he taketh backe the whole estate again, yet is the wast dispunishable. So if he grant the reversion to the use of himselfe and his wife, and of his heires, yet the wast is dispunishable, and so of the like; because the estate of the reversion continueth not, but is altered, and consequently the action of waste for waste done before (which consists in privity) is gone.

21Acc: Sampson v. Grogan, 21 R. I. 174, 42 Atl. 712, 44 L. R. A. 711 (1899). See Miller v. Shields, 55 Ind. 71 (1S76).

The life tenant may recover entire damages against the tort-feasor, for the reason that the former is liable to the remainderman as for waste. Willey v. Laraway, 64 Vt. 559, 25 Atl. 436 (1S92).

22 see IIunt v. Fiall, 37 Mre. 363 (1853). 
If a lease be made to $\mathrm{A}$. for life, the remainder to $\mathrm{B}$. for life, the remainder to $\mathrm{C}$. in fee, in this case where it is said in the Register, and in F. N. B. that an action of wast doth lie, it is to be understood after the death or surrender of $B$. in the meane remainder, for during his life no action of waste doth lie.

But if a lease for life be made, the remainder for yeares, the remainder in fee, an action doth lie prescntly during the terme in remainder, for the meane terme for yeares is no impediment.

But if a man make a lease for life or yeares, and after granteth the reversion for yeares, the lessor shall have no action of waste during the yeares, for he himself hath granted away the reversion, in respect whereof he is to maintaine his action. Otherwise it is, if he had made a lease in reversion, which had been but a future interest; for there an action of wast lieth during the terme, and so is the booke to be understood, and the terme shall be saved in that case.

\section{ANONYMOUS.}

(Court of Chancery, 1599. Noore, 554, pl. 74S.)

By EGERTON, Keeper of the Great Seal; that he had seen a precedent in the time of Richard II, that where there is tenant for life, the remainder for life, the remainder over in fee, by which waste in the first tenant for life is dispunishable by the common law: still it has been decreed in Chancery by the advice of the judges upon complaint of him in remainder in fee that the first tenant shall not commit waste and an injunction was granted. ${ }^{23}$

UDAL,v. UDAL.

(Court of King's Bench, 1648. Aleyn S1.)

[Estates were limited as follows: To Sir William Udal in tail, remainder to the defendant for life, remainder to his first and other sons in tail, remainder to $W$. U. for life, with like remainder to his sons in tail, remainder to the plaintiff in tail. Sir Willjam Udal died without issue; the defendant (neither himself nor W. U. having any sons) entered and cut down timber and some years later sold part of it, the plaintiff seized the rest, the defendant retook it and sold it, and the plaintiff brought trover.]

And (the case being argued Trin. Pasch. ult. and this term) it was resolved by Bacon and Roll. 1. That if there be tenant for life, the

23Acc: 1 Rolle, Abr. 377, Chancerie R. 13 (semble); Farrant v. Lovel, 3 Atk. 723 (1750); Dennett v. Dennett, 43 N. H. 499 (1S62). 
remainder for life, and tenant for life cut down timber trees, he that hath the inheritance may seise them, although he cannot have an action of waste during the life of him in remainder; for 1 . The particular tenant hath not the absolute property in the trees, but only a special interest in them, so long as they continue annexed to the land. And therefore a termer cannot grant away his term excepting the trees, but the exception is void, for that he cannot have a distinct interest in then but only relative to the land. ${ }^{24} * * *$ Mainard said it was adjudged, Mich. 14 E. 2 , in a case not printed, that where he in reversion upon an estate for life granted his reversion for life, and the tenant for life made waste, and then the grantee of the reversion dyed, that an action of waste would lye against the tenant for life, which proves that the cutting down of the trees by the tenant was tortious.

It was resolved that the mean remainders in contingency, though of an estate of inheritance, alter not the case; for an estate in contingency is no estate till the contingency happen: and therefore it was agreed that the plaintiff might have had an action of waste in this case, had there not been a remainder for life in esse, notwithstanding the mean contingent remainders.

It was resolved that a trover and conversion in this case, would lye for all the timber trees though the plaintiff never seized parcel of them, for by the cutting down of them an absolute property was vested in the plaintiff, unless they had been cut down for reparations and so imployed in convenient time. $* * *$ And judgment was given for the plaintiff.

Quxre in the case cited, if a lessor should bring trover against a stranger for trees cut by him, if this should be a bar to an action of waste for the trees. And if there were cause for reparations, what remedy hath the lessee for his loss, for it should seem that he will be liable to an action of waste for not repairing, although the lessor recovers for the trees.

\section{PERROT v. PERRO'T.}

(Court of Chancery, 1744. 3 Atk. 94.)

There was a limitation in a settlement to the defendant for life, to trustees to preserve contingent remainders, to his first and every other son in tail, remainder to plaintiff for life (remainder to trustees to preserve contingent remainders), with remainder to his first and every son in tail, reversion in fee to the defendant.

The first tenant for life (before he had any son born) cuts down tim-

24 I'art of the case is omitted. 
ber, the plaintiff, who is the second tenant for life, brings his bill for an injunction to stay waste.

Mr. Attorney General for the plaintiff shewed cause why the injunction for restraining the defendant from committing any further waste should not be dissolved.

It was insisted by Mr. Solicitor General, for the defendant, that the timber which he has cut down, are decayed trees, and will be the worsc for standing, and that it is of service to the publick, that they should be cut down; and that it is very notorious that timber, especially oak, when it is come to perfection, decays much faster in the next twenty years, than it improves in goodness the twenty years immediately preceding.

That as the defendant has exercised this power in such a restrained manner, and confined himself merely to decayed timber, which grows worse every day, that this court will not interpose, especially as the plaintiff is not entitled to come into this court, as he has not the immediate remainder, and besides has no remedy at law.

LORD CHANCELIOR. The question here does not concern the interest of the publick, unless it had been in the case of the King's forests and chases; for this is merely a private interest in the parties; and it is by accident that no action at law can be maintained against the defendant, because no person can bring it, but who has the immediate remainder.

Consider too in how many cases this court has interposed to prevent waste.

Suppose here the trustees to preserve contingent remainders harl brought a bill against the defendant to stay waste for the benefit of the contingent remainders (vide Whitfield v. Bewit, 2 Cox's P. W. 240, note 1; Garth v. Cotton, post [3 Atk.] 751; Williams v. Duke of Bolton, 3 Cox's P. W. 268, note 3.) I am of opinion they might have supported it, but here it is the second tenant for life (vide Roswell's case, 1 Roll's Ab. 377, pl. 13; 3 P. W. 268, note), who has done it, and though he has no right to the timber, yet if the defendant, the first tenant for life, should die without sons, the plaintiff will have an interest in the mast and shade of the timber.

The case of Welbeck Park, which has been mentioned, was a very particular one, because there, by the accident of a tempest, the timber was blown down, and was merely the act of God.

But this is not the present case, for there a bare tenant for life takes upon him to cut down timber, and it is not pretended that they are pollards only: and though the defendant's counsel have attempted to make a distinction between cutting down young timber trees that are not come to their full growth and decayed timber, I know of no such distinction, either in law or equity.

Therefore upon the authority of those cases which have been very numcrous in this court, of interposing to stay waste in the tenant for 
life, where no action can be maintained against him at law, as the plaintiff has not the immediate remainder, the injunction must be continued till the hearing. (Reg. Lib. B, 1743, fol. 432.) ${ }^{26}$

\section{KLIE et al. v. VON BROOCK et al.}

(Court of Chancery of New Jersey, 1897. 56 N. J. Eq. 18, 37 Atl. 469.)

[The facts of the case are stated ante, p. 653.]

PITNEY, V. C. *** As to the remedy. In the prayer of complainants' bill they ask that the defendants may be ordered either to restore the opening in the party wall, or to give security for its restoration at the end of the term. By thus praying for alternate relief, I understand that the complainants did not intend to give to the defendants an option of submitting to the latter remedy, but simply to ask that the court should give it if the first remedy of immediate restoration was not considered by the court proper and equitable. The defendants, by their answer, and at the hearing, offered to give security for restoration at the end of the term, but complainants, at the hearing, insisted upon immediate restoration. It is well settled that complainants are entitled to immediate relief, and are not obliged to wait until the end of the term. Agate v. Lowenbein, 57 N. Y. 604, and cases cited at page 612 et seq. In the present case the waste was committed against the known wishes and protest of complainants, and with such haste that it was substantially completed before complainants could obtain preventive relief from this court. It further sufficiently appears that the carrying out of defendants' plan will be inconsistent with the spirit, if not the letter, of the agreement. The intention was that the restaurant should be conducted in such a manner as to increase the patronage of complainants' liquor saloon, and should not be, in any sense, a competitor for their business. The compiainants allege in their bill that the intention of defendants is to keep a rival liquor saloon in No. 39. This is not denied by defendants in their answer. In fact, they say they propose to keep an hotel there. If so, and a passageway is kept open between the two buildings, patrons of the restaurant in No. 35 may possibly be served with intoxicants from a bar in No. 39 without a breach of the letter of the agreement. This consideration shows the motive, or one of the motives, behind complainants' action, and it cannot be affirmed that it is unworthy or inequitable.

The authorities justify the use of a mandatory injunction in such cases. The leading case is Vane v. Lord Barnard, 2 Vern. 738, known as the "Raby Castle Case." This was followed by Rolt v. Lord Somerville (1737), decided by Lord Hardwicke, and reported in 2 Eq. Cas. Abr., at page 759 , where there was a cutting of trees, and also pulling

25 Acc.: Kane v. Vaudenburgh, 1 Johns. Ch. (N. Y.) 11 (181f). 
down houses and buildings. The prayer was that the premises might be restored. Lord Hardwicke said that he could not compel the restoration of the trees; but he said, "Yet, as to the pulling down the houses and buildings and laying the lead pipes, they may be restored or put in as good condition again,"-citing with approbation, the case of Vane v. Lord Barnard. I think the present a proper case for immediate restoration.

I will advise a decree that the defendants be restrained from permitting the opening in the party wall made by them on or about May 10,1896 , to remain in its present condition, or from permitting the party wall between the leased premises and those of the Hoboken Land Improvement Company on the west to be in any other condition than it was prior to the opening made herein, by the defendants; and, further, if complainants desire themselves to do the work of restoration, then that the defendants be restrained from preventing the complainants from so doing at a reasonable time and in a reasonable manner; and the court will name a special master, under whose supervision the work of restoration shall be done, if the parties cannot agree thereupon. The provision for restoration may also include the window opening upon the area if the brickwork has not already been restored to its original condition. ${ }^{26}$

\section{DICKINSON v. MAYOR AND CITY COUNCIL OF BALTI- MORE.}

(Court of Appeals of Maryland, 187S. 4S Mrd. 583, 30 Am. Rep. 492.)

STEWART, J., ${ }^{27}$ delivered the opinion of the Court.

The appellant had leased to the appellee or its agent, a certain store or cellar, in the City of Baltimore, for the term of three years; the term had expired and the property was surrendered to her.

Waste thereon, or injury thereto, being alleged to have been committed by the appellee during the tenancy, this action was brought for the recovery of damages therefor.

During the pendency of the action the appellant conveyed the property to the appellee.

This alienation was relied upon as a sufficient defence to the action, the appellee insisting that to enable the appellant to recover, it was necessary not only that she should hold the reversionary interest when the waste was done, but at the time of the recovery.

28 Equity will ordinarily enjoin the commission of waste where an action at law would also lie. Onslow v. — , 16 Ves. 173 (1809); Douglass v. Wiggins, 1 Johns. Cr. 435 (1815); Davis v. Gilliam, ante, p. 646; Davenport v. Magoon, 13 Or. 3, 4 Pac. 299, 57 Am. Rep. 1 (18s4).

Equity will not enjoin meliorating waste. Doherty v. Allman, L.'R. 3 A. C. 709 (1.S7S).

2: The statoment of facts and part of the opinion are omitted. 
The Superior Court entertained this view, and so ruled, in which we think there was error.

The right of the appellant otherwise to recover, seems not to have been questioned.

The law in regard to ancient and modern remedies for waste, is well stated in note 7, Greene v. Cole, 3 IVms. Saunders, 252.

The action of waste as formerly known was a mixed action, being partly real and partly personal, and consisted in privity, and by it the owner of the inheritance in reversion, or remainder, in fee or tail, recovered against the tenant in dower, tenant by the curtesy or guardian in chivalry, the thing or place upon which the waste was committed, and also damages for the injury. It was therefore necessary that the plaintiff should be entitled to the property upon which the waste was committed, not only at the time of the waste, but when the recovery was had. There can be no doubt therefore, that the action of waste could only be brought by the person having the inheritance at the time when the waste was committed to his prejudice by the respective tenants aforesaid, and being confined in its operation, to the proprietor of the inheritance and the tenant of the land, between whom there existed a relation of privity to some extent according to the nature of the tenure, if after the waste, the inheritance was alienated, and that privity broken up, the action of waste was gone. Coke upon Lit. 53a.

By the Statute of Marlbridge, 52 Henry 3, ch. 23, and of Statute $6 \mathrm{Ed}$. 1, ch. 5, the action of waste was given a wider range, and could be brotght against lessee for life or years, or against the assignee of the same for waste done after the assignment. 1 Sharswood's Blackstone, 283; 2 Blackstone's Com. 178, n. 7; Greene v. Cole, 3 Saunders Rep. 252, n. 7.

To avoid the defective and inadequate remedy afforded by this action, as known to the common law, or as modified by the Statutes of Marlbridge and Gloucester, and to provide an effectual remedy or method of recovery against tenant or stranger, where no privity existed, better adapted to the exigencies of the case, the action on the case in the nature of waste, as it is denominated, was devised: which enables the party who has been injured in his reversionary right, to recover damages for the same, and whether he has become repossessed of the property after the injury, or has transferred the same, does not affect the clain for the damages committed to his property at the time it belonged to him. It extends to every case where one who has any reversionary interest or estate in the premises suffers by the tortious act of the actual tenant or occupant. The transfer of the estate afterwards cannot operate to condone the wrong.

It is an equitable action and not discomntenanced by any technical consideration, but must be sustained in all cases, and against all persons, who are by the common law or under the statutes aforesaicl, 
liable to the action of waste. White v. Wagner, 4 Har. \& J., 373, 7 Am. Dec. 674, per Justice Johnson.

It can be brought by a party in remainder for life or years, as in fee or tail, who held the interest at the time of the injury. McLaughlin v. Long, 5 Har. \& J. 113.

It entitles the party to recover for the actual damage committed, with costs, against any one who commits the wrong, whether lessee or stranger. 1 Wash. on Real Property, 153; 4 Kent, Com. 83; Taylor's Landlord and Tenant, sec. 688; Addison on Torts, 245. ***

That privity is no longer necessary is well established, for the action may be brought against a stranger.

Upon what sound principle can it be held, because the reversioner of the estate, after the waste committed, has alienated her interest, (whether to the party committing the waste or to another, can make no difference,) she is to be precluded from a recovery? We know of none.

If the plaintiff here held the reversionary interest in the property at the times the alleged waste was committed, she is entitled to recover for the same; and her alienation of the property subsequently, or during the pendency of the suit for damages, cannot operate to defeat her right of recovery.

Judgment reversed, and new trial ordered. ${ }^{\mathbf{2 8}}$

\section{SCHERMERHORN v. BUELI.}

(Supreme Court of New York, 1847. 4 Denio, 422.)

Error to Genesee C. P. Schermerhorn sued Buell in the court below, and declared in trespass. One count was for cutting and carrying away trees; and one count was simply for taking and carrying away. The case was as follows: On the 24th of May, 1837, the plaintiff by a lease, not under seal, demised to the defendant a lot of land containing 96 acres, for the term of six years commencing on the 1st of November following, for the yearly rent of $\$ 150$, which rent the defendant agreed to pay, with all taxes, \&c. The lease contained a clause as follows: "All of the timber in the southeast corner, of about five acres, suitable and proper for fuel, to be left and not cleared." The lot was wild and uncultivated at the date of the lease. It was called "oak openings." The defendant entered, and cleared and cultivated most of the land: and on the five acres in the southeast corner of the lot he cut some trees which were suitable and proper for fuel and carried away the timber. For that wrong this action was brought. The suit was commenced before the term granted by the lease haci expired, and while the defendant was in possession. The court be-

28 Acc.: Robinson $v$. Wheeler, 25 N. Y. 252 (1S62). See Bacon v. Smith, 1 Q. B. 345 (1841); Dupree v. Dupree, 49 N. C. 387,69 Am. Dec. 757 (1857). 
low held that the plaintiff could not maintain trespass, and directed the jury to find a verdict for the defendant, which they did, and judgment was rendered in his favor. The plaintiff brings error on a bill of exceptions.

Bronson, C. J. When the lessor excepts the trees on the demised premises, they do not pass with the land, and he may enter, cut and carry them away; and he can maintain trespass against the tenant, if he cuts them. (1 Saund. 322, n. 5; 1 Ld. Raym. 551, 552; Cro. Eliz. 17, 18; Vin. Abr. Trees, (A.) pl. 6; Bac. Abr. Trespass, (C.) 3; Bullen v. Denning, 5 Barn. \& Cress. 842.) But in this case, I am not able to see that the trees were excepted. When there is any doubt about the meaning of an exception in a lease, the words, being considered those of the lessor, are construed favorably for the lessee. (Bullen v. Denning, 5 Barn. \& Cress. 842; Cardigan v. Armitage, 2 id. 197.) The clause in this lease in relation to the timber on the five acres in the southeast corner of the lot is not even in the form of an exception; and nothing more can be made of it than an agreement between the parties that the timber on the five acres should "be left, and not cleared," or cut off. The defendant is bound by the agreement, and must answer for breaking it; but it does not limit the extent of the grant. The whole lot, with all the timber upon it, passed by the demise. Without the clause, the law would have imposed the duty of preserving a portion of the timber; and it might have been proper to save it in different parts of the lot, and to an extent either greater or less than five acres in the whole, as the rules of good husbandry should decide. But the parties have settled that matter by contract, saying where and to what extent the timbers should be preserved. The case then stands on the same principle as though there had been no such clause in the lease, and the law had decided that the timber on the five acres should not be cut. In either case, the interest in the trees, for all the purposes of shade and fruit, would pass with the land to the lessee; but the general property in the trees would remain in the lessor. And if the tenant improperly cut the timber, his interest in it is thereby determined; and the landlord may have an action of waste, an action on the case in the nature of waste, or an action on the contract, where there is one touching the subject, ${ }^{29}$ for the injury done to the land; or he may have an action of trover for the wood which has been severed from the freehold. $^{30}$ (Berry v. Heard, Cro. Car. 242; Palmer, 327, and W. Jones, 255, S. C. ; Com. Dig. Biens, (H.) Trees; Vin. Abr. Maeresme, (A.) pl. 2, 3; 1 Chit. Pl. 160, ed. of 1837.)

The question here is, whether the landlord may not also have trespass for the carrying away and conversion of the wood after the trees

20 See Chalmers v. Smith, ante, p. 667.

so Brook v. Rogers, 101 Ala. 111, 13 South. 356 (1S93). So also replevin. Richardson ₹. York, 14 Me. 216 (1837); Warren County v. Gans, 80 Miss 76, 31 South. 539 (1902). 
had been cut. It was laid down long ago, and I do not find that the doctrine has ever been denied, that if lessee for years cuts down timber trees and lets them lie, and after carries them away, so that the taking and carrying away be not as one continued act, but that there be some time for the distinct property of a divided chattel to settle in the lessor, that an action of trespass vi et armis will lie against the lessee. (Udal v. Udal, Aleyn, 81; Vin. Abr. Trees, (A.) pl. 7 ; and tit. Trespass, (S.) pl. 10; 1 Chit. Pl. 206, ed. of 1837.) It is true, that trespass for an injury to real property which is occupied at the time, can only be maintained by the person in actual possession. I cannot now call to mind more than two exceptions to this general rule. One, where the wrong is done by a tenant at will, in which case the injury amounts to a determination of the will and of his possession. The other exception is, where the wrong was done by a disseisor, and the disseissee afterwards regains the possession. In that case the disseissee is deemed in law to have had the possession from the beginning. (Holmes v. Seely, 19 Wend. 507; Tobey v. Webster, 3 Johns. 468; Phillips -v. Covert, 7 Johns. 1; 3 Black. Com. 210.)

But the point under consideration is not whether the lessor can maintain trespass against the lessee for an injury to the freehold; but whether he can have that action for carrying away and converting the trees after they have been wrongfully severed from the freehold. Upon the authorities already cited, the action may be supported; and, as I think, without violating any legal principle. The interest which the lessee had in the trees is deternined by the wrongful act of cutting them down; and the general property which the lessor had before, subject to the rights of the lessee, has now become absolute. The trees have become mere personal chattels, and the lessor is the general owner, and entitled to immediate possession. $\mathrm{He}$ is in a condition to maintain trespass against any one who takes and carries away the property. It is said, that as the lessee is in the rightful possession of the land, the lessor has no right to enter upon it for the purpose of carrying away the trees after they have been cut down. That may be so; and the lessor may not be able to maintain trespass so long as the trees remain on the land. But the right to the possession of the chattel may be complete, although there may be no right to enter upon the land of another for the purpose of taking it. As the lessor has the right, both of property and possession, in the trees, he may sue whenever they are carried away and converted to the use of another.

Whether the trees were cut at one time, and carried away at another, was, upon the evidence, a question for the jury.

Judgment reversed. ${ }^{31}$

31 It has been held that the reversioner may maintain trespass d. b. a. against a stranger wrongfully cutting and carrying away the wood. Bullily. r. Uolbenre. 7 Conn. 232 (1S2S); Lane v. Thompison, 43 x. H. 320 (1Sfj]). Sec, also, Rogers v. Atlantic, G. \& P. Co., ante, p. 672.

If the tenant wrongfully cuts timber and sells it to a third person who 


\section{B.'TEMAN v. HOTCHKIN.}

(Court of Clancery, 1S62. 31 Beav. 4SE.)

A question arose as to the right of a tenant for life impeachable for waste to a fund derived partly from wood blown down by a storm.

The question was brought before the Master of the Rolls in Chambers, who gave the following opinion in writing:

"That in the case of waste committed by a tenant for life by cutting timber, the produce of the sale of it is part of the inheritance, and as the tenant for life can gain no advantage by his own wrongful act, the produce is invested and accumulated, for the benefit of the first estate of inheritance.

"In the case of timber blown down by a storm, there is no waste, becalise, it is the act of God, but the produce of the sale of it belongs to the inlheritance, that is, the money must be invested in consols, and the interest paid to the tenant for life."

Mr. Speed, for the plaintiff, contended that timber "whenever it is severed by the act of God, as by tempest, or by a trespasser and by wrong, it belongs to him who has the first estate of inheritance."

Mr. C. Hall, for the tenant for life, claimed the benefit of all the windfalls. He argued that there was a question as to what part of the fund arose from wood to which a tenant for life impeachable for waste was entitled to cut. That what was timber depended on local custom, and that a tenant for life was entitled to thinnings, and to timber cut periodically or planted, as fir, for the protection of young timber.

The Master of the Rolls [Sir John Romiliy]. I am of opinion that the tenant for life is entitled to have the benefit of the sale of all such trees felled by the wind as he would be entitled to cut himself, and to all fair and proper thinnings, and to all coppices cut periodically in the nature of crops.

There must be an inquiry to ascertain what part of the fund is derived from timber or cuttings within that description. ${ }^{32}$

buys in good faith, the reversioner may maintain trover against the third person, Mooers v. Wait, 3 Wend. (N. Y.) 104, 20 Am. Dee. 667 (1529); or replevy the wood, Hill v. Burgess, 37 S. C. 604, 15 S. E. 963 (189:).

32 Compare Tuolier v. Annesley, 5 Sim. 235 (1832); Stonebraker v. Zollickoffer, 52 Md. 154, 86 Aw. Iep. 364 (1879); Shult v. Barker, 12 Serg. \& 1 . (1'a.) 272 (152t). 


\section{SECTION 3.-EQUITABLE WASTE.}

\section{LEWIS BOWLES' CASE.}

(Court of King's Bench, 1615. 11 Coke, 79b.)

Lewis Bowles, Esq., brought an action upon the case upon trover, against Haseldine Bury the younger, (which began in the King's Bench, Hil. 10 Jacobi Regis, Rot. 1319,) and declared, that he was possessed of thirty cart loads of timber, and lost them, and that they came into the hands of the defendant, and that he $20 \mathrm{Feb}$. anno $9 \mathrm{Jac}$. Regis, at Norton, in the county of Hertford, converted them to his own use; and upon not guilty pleaded, the jury gave a special verdict to this effect. Thomas Bowles, Esq. grandfather of the said Lewis, was seised of the manor of Norton-Bury, in the said county in fee, and, 1 Sept. anno 12, by indenture, betwixt him on the one part, and William Hide, and Leonard Hide of the other part, in consideration of a marriage to be had betwixt the said Thomas Bowles and Anne, daughter of the said William Hide, \&c. covenanted, that after the said marriage had and solemnized, that the said Thomas, his heirs and assigns, would stand seized of the said manor of Norton-Bury, to the use of the said Thomas and Anne, for the term of their lives, and without impeachment of waste, and after their deceases, to the use of their first issue male, and to the heirs male of such issue lawfully begotten, and so over to the second, third, and fourth issue male, \&c. and for want of such issue, to the use of the heirs males of the body of the said Thomas and Anne lawfully begotten; and for want of such issue, to the use of Thomas Bowles, son and heir apparent of Thomas Bowles the grandfather, and the heirs males of his body issuing, and for want of such issue, to the use of the heirs of the body of the said Thomas and Anne lawfully issuing. Which marriage was solemnized accordingly, and the said Thomas the grandfather, and Anne, had issue Joln; and afterwards the said Thomas the grandfather died without any issue on the body of Anne, but the said John: after whose death the said Anne entered into the said manor, and was thereof seised, with the said remainder over, as aforesaid, and afterwards the said John Bowles died, and afterwards Thomas the son conveyed by fine his remainder to the use of Lewis Bowles the plaintiff, and Diana his wife, and heirs males of his body; and the said Anne being so seised of the said manor, with the remainder over as aforesaid, viz. 20 Feb. an. Reg. Jac. reg. 9. a barn, parcel of the said manor per vim ventorum et tempestat' penitus subvers. et ad terram deject' fuit, and that the said thirty cart loads of timber, in the declaration mentioned, were parcel of the said barn, and that the said timber was sound and fit for building, wherefore the defendant, 
as servant of the said Anne, and by her command took the said timber, and carried it out of the limits of the said manor to Radial, in the same county; and afterwards the said Anne, 24 Feb. anno 9. Jac. Reg. made her last will, and thereof made Robert Osborne and Leon. Hide. Knts. her executors, and died, after whose death the plaintiff seized the said timber, and afterward the defendant, by the command of the said executors, converted it to his use; and if upon the whole matter the defendant was guilty or not, the jury prayed the opinion of the Court.

And in this case two questions were moved. 1. If upon the whole natter the wife should be tenant in tail after possibility, or that she should have the privilege of a tenant in tail after possibility, sc. to do waste, \&c. 2. Admitting that she should not have the privilege, \&c. if the clause of "without impcachment of waste," shall give her property in the timber so blown down by the wind.

That tenant in tail, after possibility, has a greater pre-eminence and privilege, in respect of the quality of his estate, than tenant for life, but he has not a greater quantity of estate than tenant for life; in respect of the quality of his estate, it tastes much of the quality of an estate in tail, out of which it is derived: and, therefore, 1 . She shall not be punished for waste..$^{33} * * *$

The clause of "without impeachment of waste" gives a power to the lessee, which will produce an interest in him if he executes his power during the privity of his estate; and therefore to examine it in reason. 1. These words absque impetitione vasti, are as much as to say, without any demand for waste: for impetitio is derived from in and peto, and petere is to demand, petitio is a demand, and sine impetitione is without any manner of demand or impeachment: then this word demand is of a large extent ; for if a man disseises me of my land, or takes my goods, if I release to him all actions, yet I may enter into the land, or take my goods, as Lit. holds, fol. 115. and therewith agree 19 Ass. 3. 19 H. 6, 4b. $21 \mathrm{H} .7,23 \mathrm{~b} .30 \mathrm{E} .3,19$, for by the release of the action, the right or interest is not released, but if in such case I release all demands, that will bar me, not only of my action, but also of my entry and seisure, and of the right of my land, and of the property of my goods; as it was resolved in Chauncy's case, 34 H. 8. Br. Release 90.2 H. 7, 6b. the King made one sheriff sine computo, thereby he shall have the revenues which belong to his office to ccllect to his own use. But if the words had been absque impetit' vasti per aliquod breve de vasto, then the action only would be discharged, and not the property in the trees, but that the lessor after the fall of them might seise them: and this difference appears in 3 Edw. 3, 44a, b, in Walter Idle's case, where a lease was made without being impeached, or impleaded for waste, upon which it was col-

$\$ 3$ See Sterens v. Rose, 69 Mich. 259, 37 N. W. 205 (18sS).

Big.Rights- 44 
lected that thesc words "without being impleaded," without these words "without being impeached for waste," were not sufficient to bar the lessor of his property, and that if the lessor had granted that the lessee might do waste, he thereby had power not only to do waste, but also to convert it to his own use; and that the words of the said Act of Marlebridge, and the statute de Praerogativa Regis, c. 16. do prove where it is said, that the King shall have annum, diem, et vastum, sc. which is as much as to say, that he shall have the trees, \&c. at his own disposition.

It was said, that the continual and constant opinion of all ages was, that those words gave power to the lessee to do waste to liis own house, and it would be dangerous now to recede from it, and as it is said in $38 \mathrm{Edw} .3$, 1a, by the Judges (so we say in this case) we will not change the law which has been always used. ***

But the said privilege of without impeachment of waste, is annexed to the privity of estate, 3 Edw. 3, 44, by Shard and Stone; if one who has a particular estate without impeachment of waste, changes his estate, he loses his advantage, $5 \mathrm{Hen} .5,9 \mathrm{a}$. If a man makes a lease for years without impeachment of waste, and afterwards he confirms the land to him for his life, now he shall be charged for waste, 28 Hen. 8, Dyer, 10b. If a lease is made to one for the term of another's life, without impeachment of waste, the remainder to him for his own life, now he is punishable for waste, for the first estate is gone and drowned. ***

Lastly, it was resolved, that the said woman by force of the said clause of without impeachment of waste, had such power and privilege, that though in the case at $\mathrm{Bar}$ no waste be done, because the house was blown down per vim venti without her fault, yet she should have the timber which was parcel of the house, and also the timber trees which are blown down with the wind; and when they are severed from the inheritance either by the act of the party or of the law, and become chattels, the whole property of them is in the tenant for life, by force of the said clause of "without impeachment for waste." And for this cause judgment was given per omnes justiciarios una voce, quod querens nihil caperet per billam. ${ }^{34}$

\section{ROL_LE'S ABRIDG. 380, CHANCERIE T. 3.}

If a lessee for years without impeachment of waste, about the end of his term intends to cut down all the timber trees, an injunction lies out of a court of equity upon this matter to stop the felling of the trees, notwithstanding the agreement of the parties; because it is contrary to public good to destroy the trees and the suit is to hinder and prevent this and not to have damages after the act is done. Michelmas,

34 Part of the case is omitted. 
14 Car. [1638] B. R. in the said Salway case, stated by Brampton that this was the Bishop of Winton's case which was referred from Chancery to the judges and by their advice an injunction was granted for the reason aforesaid. ${ }^{35}$

\section{CLEMEN'T v. WHEELER et al.}

(Supreme Court of New Hampshire, 1852. 25 N. H. 361.)

In equity. The bill stated the following case:

The plaintiff, Rodney Clement, is the son of Samuel W. Clement. who died testate, on the 10th of May, 1838, owning his homestead farm, in Salem, containing one hundred acres, and ten acres of wood land in Windham.

By his will, he devised the occupation and improvement of all his real estate to his wife, Elizabeth, during her natural life, without impeachment of waste. To the plaintiff he devised one fourth part of all the real estate of which he might die seized and possessed, but not to come into possession of the same until the death of his wife; and he made a similar devise of the remaining three-fourths to Samuel Clement, a brother of the plaintiff. Samuel died intestate and unmarried, on the 16th of February, 18t6, leaving his mother, Elizabeth, the plaintiff, and two sisters, his heirs at law, whiereby the plaintiff became seized of seven-sixteenths of the land described.

Elizabeth Clement is still living, and on the 13th of September, 1846. she released all her interest in the homestead farm and the wood land to Delia D. Clement, her daughter, who, in the year 1847, married Day Wheeler, and Wheeler and his wife have, both before and since the marriage occupied the land, which has upon it a large quantity of valuable timber. Wheeler and his wife have already cut off a portion of the timber, and threaten to cut the remainder, and are offering to sell it. $* * *$

Gilchisist, C. J. ${ }^{36}$ It is unnecessary to refer to the allegations in the bill and answer, farther than to show what the facts were at the tine the bill was filed, in order to ascertain whether the plaintiff ha:l any reasonable ground for complaint. But an inquiry is necessary. to a certain extent, into the merits, because the result has a bearing upon the question of costs.

Elizabeth Clement was tenant for life, without impeachment of waste. Such is the allegation in the bill, and the admission in the answer. It is relevant to the question now before us, to inquire what such a tenant may legally do.

Chancery will interpose where the tenint affects the inheritance in an unreasonable and unconscientious manner, even though the lease be

35 Acc.: Pishop v. Webb, 1 P. Wms. 527 (171S); Day v. Merry, 16 Vez. 375 (1S10); Duncombe v. Felt, S1 Mich. 392,45 N. W. 1004 (1s:)0).

80 The statement of facts is abridged and part of the of inion is omittod. 
granted without impeachment of waste. Perrot v. Perrot, 3 Atk. 94; Aston v. Aston, 1 Ves. 264. These cases are referred to, as containing the law on this point, by Chancellor Kent, in the case of Kane v. Vandenburgh, 1 Johns. Ch. (N. Y.) 11. At common law, timber cut by the tenant for life, belonged to the owner of the inheritance, and the words in the lease, "without impeachment of waste," had the effect of transferring to the lessee the property in the timber. Mooers v. IVait, 3 Wend. (N. Y.) 104, 20 Am. Dec. 667; Payne v. Dor, 1 T. R. 55. And in general the words absque impetitione vasti, that is, "without challenge or impeachment of waste," enable the tenant for life to cut down timber and convert it to his own use. By the statute of Marlbridge, ch. 23, it appears that lessees for life could not rightfully sell the trees or pull down the houses, unless the lessor had by deed granted them the power to do so. When that act was passed the clause "without impeachment of waste" was in use, "which proves that it was to such purpose that the lessee might commit waste, and dispose it to his own use, which he could not do without such clause." Bowles' Case, 11 Co. Rep. 81.

But the extensive power given to the tenant for life by this clause may be exercised by him contrary to conscience, and in an unreasonable manner. It will, therefore, be so far restrained that he will not be allowed to commit malicious waste, so as to destroy the estate, which is called equitable waste. A leading authority upon this point is Vane v. Lord Barnard, 2 Vernon, 738, commonly called "Lord Barnard's Case." The defendant, on the marriage of the plaintiff, his eldest son, settled Raby Castle on himself for life, without impeachment of waste, remainder to his son for life, and to his first and other sons in tail made.

Afterwards, having taken some displeasure against his son, the defendant got two hundred workmen together, and of a sudden, in a few days, stripped the castle of the lead, iron, glass doors and boards, $\& c$, to the value of $\{3,000$. The son then filed a bill for an injunction to stay waste, stating that the defendant had proceeded to demolish the castle, and had pulled down one of the rooms and sold the timber, lead, iron, and other materials, and converted the money, being a considerable sum, to his own use. "The joists on which the floors were laid being each a whole oak tree, the said castle being heretofore very strongly built, and made use of for a fortification," Lord Cowper immediately granted an injunction to stay the commission of waste in pulling down the castle, and afterwards decreed that the injunction should be continued, and that the castle should be repaired. And the court will restrain the tenant for life, without impeachment of waste, from committing equitable waste by cutting timber, planted or left standing, for the shelter or ornament of a mansion-house or grounds. Packington v. Packington, 3 Atk. 215; Strathmore v. Bowes, 2 Brown, Ch. C. 88. 'This principle has been extended from the ornament of the house to out-houses and grounds. then to plantations, vistas, avenues, 
and to all the rides about the estate for ten miles round. ${ }^{37}$ Lord Eldon, Devonshire v. Sandys, note, 6 Ves. 110; Sir William Grant, Mahon v. Stanhope, 3 Madd. 523, note. The remedy by injunction is applicable to every species of waste, it being to prevent a known and certain injury. Hawley v. Clowes, 2 Johns. Ch. (N. Y.) 122.

The defendants in the present case derive their title from Mrs. Elizabeth Clement, the devisee under the will, having a conveyance of all her interest in the land. They may exercise all the rights which their grantor possessed, but of course would be liable for exceeding the powers given them by her conveyance. In the case of Coffin v. Coffin, Jac. 70, the defendant, J. P. Coffin, who was tenant for life, without impeachment of waste, assigned his life interest to one Rowe, who was also a defendant, and Rowe was about to fell certain timber, but was restrained by injunction.

Now the defendants do not, upon the facts admitted, come within any class of persons who would, upon the authorities, be restrained by injunction from committing waste. It does not appear that they have done any acts which a tenant for life, without impeachment of waste, may not lawfully do.

37 "The doctrine of the Court is extremely well settled. If the object in planting timber, or in leaving timber standing, is ornament, whether that object is effected, whether the effect is truly ornamental, or the most absurd exhibition that ever was produced, this Court will protect that timber: and the protection is not confined to trees planted, or left standing, as ornamental to a house or park; nor does it depend on the distance from the mansion.

"In framing the issue another thing also must be attended to; by whom the trees were planted or left standing for ornament: as, if they had been planted by a tenant for life without impeachment of waste, unless afterwards left standing with that view by some person haring the inheritance. they would not be entitled to this protection.

"The question is not, whether the timber is, or is not, ornamental; but the fact to be determined is, that it was planted for ornament; or, if not originally planted for ornament, was, as we express it, left standing for ormament by some person, having the absolute power of disposition. If such a proprietor had even the bad taste to plant or leave standing, a rouple of yew trees cut in the shape of peacocks on the road side, I do not shrink from what I laid down in The Marquis of Downshire v. Iady Sandys [6 Ves. Jr. 108 (1801)] * * * that they must be protected, until some person, having the same absolute power of disposition with more correct taste, comes into possession; and this doctrine applies in the same manner to a pleasant ride, although at the distance of two miles from the mansion house; but I do not agree, that a mere tenant for life, coming into possession, can vary the estate. That can be done only by some person having the absolute dominion over it."

Tord Chancellor Eldon in Wombell v. Belasyse, 6 Ves. Jr. 109, note (1825).

38 Acc.: Burges v. Lamb, 16 Ves. 174 (1S09); Findlay v. Smith, 6 Mrunf. (Va.) 134, 8 Am. Dec. 733 (1818).

A tenant in tall cannot be enjoined from either legal or equitable waste. Skelton v. Skelton, 2 Swanst. 170 (1677); Atty. Gen. v. Marlborough, 3 Mad. 498, 542 (1818). See Williams v. Williams, 15 Ves. 419 (1808); Willans v. Williams, 12 Fast, 209 (1810).

A. was tenant in fee, with an executory devise over to B. in fee if $\mathbf{A}$. should die without issue. Held, B. may enjoin A. from cutting the ornamental timber. Turner v. Wright, 2 De G., F. \& J. 224 (1860). Compare Robinson v. Litton, 3 Atk. 209 (1744). 


\section{LUSHINGTON v. BOLDERO.}

\section{(Rolls Court, 1851. 15 Beav. 1.)}

In 1785 the testator devised Aspeden Hall and other estates to Charles Boldero for life, without impeachment of waste, with remainder to his first and other sons in tail, with similar limitations to IVilliam Boldero for life, without impeachment of waste, with remainder to his first and other sons in tail, with remainder to Henry Lushington for life, without impeachment of waste, with remainder to his first and other sons in tail, with divers remainders over.

In 1812 Charles Boldero and Henry Lushington, and their partners, became bankrupt, and the assignees under their joint commission having proceeded to commit equitable waste by felling ornamental timber, this bill was, in 1813, filed by the eldest son of Henry Lushington, who was then and is now the first tenant in tail in esse. The Plaintiff established his claim (see Lushington v. Boldero, 6 Mad. 149; and G. Cooper, 216), and the assignees were ordered to pay into Court $66379.4 \mathrm{~s}$., the value of the timber and interest, to an account intituled, "The Account of Timber felled by the Defendants, the Assignees of the Estate of Messrs. Boldero, Lushington \& Co., Bankrupts." This was done; and it was directed to accumulate, and be subject to the further order of the Court. By accumulation, the fund in Court now exceeded $£ 26,000$.

William Boldero died "several years since," without having been married. In 1850 Charles Boldero being still living, and ninety-five years of age, but having no issue, the Plaintiff, the first tenant in tail in esse, presented his petition for payment to him of the fund in Court. The case came before Lord Langdale on the 4th of 'November, 1850, when his Lordship thought that the case could not be decided until it had been ascertained that Charles Boldero, who was living, should have no issue, and his Lordship therefore ordered the petition to stand over until after the death of Charles Boldero.

Charles Boldero died in August, 1851, and the application for payment was now again renewed.

Ties Master of the Rolis [Sir John Romilly]. I shall first consider what would have been the effect if Charles Boldero had himself done this act. He was tenant for life without impeachment of waste, and having cut ornamental timber, the Court compelled him to pay into Court the amount for which the timber was sold; and, omitting all questions respecting intermediate life-estates, the question now is, whether he or the reversioner was entitled to the income of that fund. The equitable doctrine applicable to this and other similar cases is this: that no person shall obtain any advantage by his own wrong. But it is manifest that the tenant for life may obtain very considerable advantage from his own wrong, if he were to cut down timber and obtain the interest of the fund; his income for life would 
be thereby increased beyond what it would have been if the timber had not been cut.

It has been observed, that in all the reported cases the rule has been applied to the corpus of the fund; but that, I think, ought not to vary my judgment, because it depends upon this equitable and just principle, that no man shall obtain a benefit by his own wrongful act: the authorities, therefore, which lay down the principle in cases of corpus only, are equally applicable to any species of interest to be derived by a wrongful act.

It is then said, that this is a case in which the Court does not impose a forfeiture, but only requires restitution; and that to deprive the tenant for life of the income, it would be to inflict a penalty upon him, inasmuch as he would have had the enjoyment and advantage of the shade and mast of the timber if it had not been cut. But this he deprives himself of by his own wrongful act, and for this reason the Court refuses to give him any substitution or remuneration. It is also material to bear in mind that if the timber had not been cut it would have increased in value for the benefit of the reversioner, but that has been rendered impossible by the tenant for life having improperly cut it. If, therefore, it is impossible for the Court to ascertain what portion of the interest ought to be attributed to the estate of the reversioner, and what portion to the enjoyment of the tenant for life, it is the tenant for life who has himself put the Court into that situation, and made it incapable of arriving at a just conclusion. It is not a case in which the Court can act on the principle of restitution. The case put, by way of analogy, of a tenant for life selling out the fund, and being compelled to restore it, is inapplicable, because the tenant for life cannot in this case restore the subjectmatter.

There may be a great number of cases in which the timber would become of great value when the reversion fell in; and it is impossible for the Court to ascertain what portion of it would have been enjoyed by the reversioner if the wrongful act had not been committed. Undoubtedly the tenant for life does in some cases directly gain an advantage, but it is not by reason of his own act. Thus, where by the act of God a large quantity of timber is blown down by a storm, the produce is laid out in the purchase of stock, and the interest of the fund is paid to the successive tenants for life. So, upon the same principle, when timber is decaying, and it cannot benefit the reversioner to allow it to remain standing, the Court, having ascertained that it is for the benefit of all parties, orders the timber to be cut down, and the produce to be invested, and the interest of the fund to be paid to the tenants for life in succession.

When, however, the tenant for life has committed the wrongful act which produces the fund, the Court will not allow him to gain any benefit from it; but the reversioner takes the benefit arising from an accretion of the fund, in lieu of the accretion of the timber. 
Can I look at this case in any different point of view, because the assignees, and not the tenant for life, have done the wrongful act? The assignees stand for these purposes exactly in the same situation as the tenants for life; they are bound by the same equities, and are exactly in the same position, and the same observations apply to both. Nor am I able to separate, or to distinguish the case of Sir Henry Lushington from that of Charles Boldero; because, if the two tenants for life had concurred together, and had agreed between themselves that the one in possession should cut the timber, and that they should divide the produce in certain proportions, the Court would have prevented either of them from gaining any benefit from the wrongful act which they concurred in performing. Here they are the assignees of both; and I am unable to find any principle which says that the assignees must not stand exactly in the same situation as the tenants for life would stand, and be bound by exactly the same equities. If Charles Boldero had died immediately afterwards, and Sir Henry Lushington had survived for a very long period, and the income of the proceeds of the timber had been applied during that period in payment of the joint creditors, they would have obtained a great benefit from the wrongful act of the assignees. I must hold them in exactly the same position as if the wrongful act had been committed by Sir Henry Lushington alone. I cannot separate the characters of the assignees; they are assignees for the joint creditors and of the joint estate; and I consider that I must treat the case exactly in the same way as if the two tenants for life, one only being in possession, had concurred in the wrongful act of cutting the timber.

It was suggested that I should suppose the possible case of the commission having been superseded; and I was asked whether the tenant for life, Sir Henry Lushington, who is perfectly innocent in the matter, ought to be prejudiced by the wrongful act committed by his assignees. It would be hard if it were to be so; but I do not consider that question at present, because it does not arise before me. But, if the question did arise, it is manifest that the remark would apply, just as much to the case of Mr. Charles Boldero's estate as to that of Sir Henry Lushington; nor can I find anything whatever in the fiduciary character of the assignees, who, in matters of this description, stand in exactly the same position as the tenants for life, to prevent their being held liable precisely in the same manner as the tenants for life themselves. They have themselves done this wrongful act; and neither they nor the persons for whom they are trustees can gain any advantage by reason of it.

I am of opinion, therefore, that, upon the petition, I must make an order according to the prayer. ${ }^{89}$

\footnotetext{
$39 \mathrm{~A}$. was tenant for life, unimpeachable for waste; the ornamental timber was growing so thickly that some of the older and decaylng timber was stunting the growth of the younger timber. A. cut this older timber. IIeld, he is entitled to the proceeds from the sale thereof. Baker $\mathbf{v}$. Se
} 
The assignees appealed to the Lords Justices, but a compronise was, a fter argument, effected.

REPORTER'S NOTE.-In the argument of this case, both before Lord Langdale and Sir John Romilly, two authorities which are in point were overlooked. In Rolt v. Lord Somerville ${ }^{* 0}$ Lady Somerville was tenant for life, without impeachment of waste, with remainder to the Plaintiff Rolt for life, without impeachment of waste, with several remainders over. Lord Somerville cut down several groves of trees planted for the shelter and ornament of the mansion, and did other waste. Rolt, the tenant for life, filed a bill to compel the Defendant to account for the monies thus raised. To this the Defendant demurred, and insisted that "the Plaintiff could not call him to an account because he was not a remainderman of the inheritance." Lord Hardwicke observed, "I cannot say the Plaintiff is entitled to a satisfaction for the timber, which is a damage to the inheritance;" and the demurrer was allowed as to satisfaction on account of the timber.

The second case is that of the Marquis of Ormonde v. Kynnersley, or Butler v. Kynnersley, ${ }^{41}$ decided by Sir John Leach and afterwards by Lord Lyndhurst.

In that case, equitable waste was, in 1805 , committed by Clement Kynnersley, who was then in possession as the tenant for life, without impeachment of waste. The estate was limited in remainder to his first and other sons in tail, with remainder to the Marchioness of Ormonde and Job H. P. Clarke for life, in a moiety, with remainder, as to the whole, to her first and other sons in tail, with an ultimate remainder to Job H. P. Clarke in fee. Neither Clement Kynnersley nor the Marchioness of Ormonde had any issue, and Job H. P. Clarke had therefore the first vested estate of inheritance.

Upon a bill by the Marchioness of Ormonde for an account of the timber, a decree was, in the first instance, made by Sir John Leach for an account of the timber (6th May, 1820).

There was a reference to arbitration; and on a motion to enforce the award (1824), it was suggested, that "the representative of Job H. P. Clarke (if any one) was entitled to the proceeds of the timber cut down." The cause was reheard by Sir John Leach (23d April, 1825), who dismissed the bill, on the ground that the right to the money vested in Job H. P. Clarke. The cause then went by appeal to the House of Lords (1828), and was remitted to Chancery, with liberty to appeal; and, ultimately (20th April, 1830), Lord Lyndhurst dismissed the appeal with costs, on the ground that the trees belonged

bright, I. R. 13 Ch. D. 179 (1S79). See, also, Gent v. Harrison, H. R. V. John's Rep. 517 (1859).

102 Eq. Ca. Ab. 759 (1737).

417 Law J. (O. S.) Ch. 150 (1829), and 8 Law J. (O. S.) Ch. 67 (1S.30), and reported on other points in 5 Madd. 369 (1S20), 2 Sim. \& St. 15 (1s24), and 2 Bli. (N. S.) 374 (1S2S). 
to Job H. P. Clarke, as the person entitled to the first vested estate of inheritance, and that the Plaintiff had no interest.

It is to be observed, that the decision of the Marquess of Ormoride v. Kynnersley is scarcely reconcilable, first, with the order for the investment and accumulation in Lushington $\mathrm{v}$. Boldero, instead of for immediate payment to the Plaintiff, the owner of the first estate of inheritance; nor secondly, with Wellesley v. Wellesley, ${ }^{42}$ where, instead of directing payment to the Plaintiff, the fund was paid into Court, and formed part of the settlement fund. ***

\section{In re BARRING'TON.}

\section{GAMLEN v. LYON.}

\section{(Chancery Division, 1S\$6. L. R. 33 Ch. D. 523.)}

Originating summons.

Francis Lyon Barrington was owner in fee of certain coal mines at Binchester in the county of Durham, but not of the surface above such mines. These coal mines were worked at certain royalties under a lease granted by $\mathrm{Mr}$. Barrington for a term of thirty-one years from the 1st of May, 1872. By his will, dated the 1st of December, 1876, Mr. Barrington devised his collieries at Binchester (subject to a mortgage and an anntity) to trustees upon trust for the Dowager Viscountess Barrington for life without impeachment of waste, and after her death for the defendant, the Hon. Francis Bowes Lyon, for life without impeachment of waste, with limitations over. The testator died on the 15th of January, 1877, and Lady Barrington died on the 23d of March, 1883.

During her lifetime and after her death certain of the coal was got by the owners of neighbouring collieries working by instroke from their collieries, such neighbouring owners having inadvertently thus trespassed beyond their proper boundaries. This working began in October, 1882; the mistake was discovered in December, 1884, when the working was discontinued, and the neighbouring owners subsequently paid the sum of $£ 839.7 \mathrm{~s}$. $2 \mathrm{~d}$. as compensation for the coal which they had thus gotten.

A line of railway belonging to the North Eastern Railway Company passes across the surface of the lands over a portion of the Binchester collieries. In the month of June, 1884, the lessees of those collieries gave notice to the railway company that they were desirous of working and taking away the coal lying under and adjoining a portion of the railway. The company gave a counter-notice that this coal was required for the support of the railway, and they ultimately paid compensation moneys for the coal so left unworked, of which the sum of 
$£ 136$. 0s. 2d. was apportioned as being paid in respect of the lessor's interest therein.

This was an originating summons taken out by the trustees of the will for the purpose of having the respective rights of themselves, $\mathrm{Mr}$. F. B. Lyon, the equitable tenant for life in possession, and Viscount Barrington, as the executor of Lady Barrington, the late equitable tenant for life, in these two sums of $£ 839.7 \mathrm{~s}$. 2d. and $£ 136$. Os. 2d. determined by the Court.

KAY, J., after stating the facts with reference to the coal won by the innocent trespass of the owners of adjoining collieries, continued:

The question is to whom the moneys in respcct of such trespass belong. The point seems to be completely determined by authority. No doubt, if a tenant for life who is impeachable of waste improperly commits waste by cutting trees or digging minerals, such trees or minerals when severed become at once the property of the owner of the first cstate of inheritance in esse. Uvedall v. Uvedall, 2 Roll. Abr. 119; Whitficld v. Bewit, 2 P. Wms. 240; Bewick v. Whitfield, 3 Ibid. 267. And in such case an intermediate tenant for life without impeachment of waste cannot recover the proceeds in trover. Pigot v. Bullock, 1 Ves. 479,484 . The reason for this seems to be that he had no right to the timber cut before his estate came into possession.

The same law applies if the timber be severed by the act of God, as by tempest, or by a trespasser. See Bewick v. Whitfield.

On the other hand, if the severance be in the lifetime of a tenant for life who is unimpeachable of waste the severed portion of the inheritance belongs to such tenant for life. In an Anonymous Case in Moseley, page 238, the Master of the Rolls stated: "It is now settled at law that if a stranger cut down timber, or commit any other waste, it belongs to the tenant for life, who is dispunishable of waste, and not to the remainderman in tail, or in fee." This was followed by Lord Chicf Justice Mansfield in Pyne v. Dor, 1 T. R. 55. 56, who said, "that a tenant for life without impeachment of waste, has a right to the trees the moment they are cut down."

And in Bagot v. Bagot, 32 Beav. 509, and on appeal 33 L. J. (Ch.) 122 , note, the law as to timber and minerals is treated as being precisely identical.

I am, therefore, of opinion that the proceeds of the minerals worked during the respective lifetimes of Lady Barrington and the defendant belong to her estate and to the defendant respectively.

Another question arises thus: A railway belonging to the North Eastern Railway Company passes over a portion of the mine. In June, 1884, the lessees gave to the railway company notice that they were desirous of working the coal lying under and adjoining a portion of the railway. A counter-notice was given, and eventually a compensation to be paid by the railway company was assessed at $£ 514.17$ s. 11d., of which the lessor's proportion was to be $£ 136.0$ s. 2 d.

I have to determine under the 74th section of the Lands Clauses Act 
who is entitled to the latter sum. I quite agree that under that section it is the duty of the Court to consider all the circumstances, and if the coal for which compensation was thus received was of such an extent that by no possibility it could be gotten during the lifetime of the existing tenant for life it seems to me that might be a circumstance which the Court might have to regard in determining the relative rights of the tenant for life and the remainderman; but nothing of that kind occurs here, and I am of opinion that in this case the tenant for life is entitled to the $£ 136$. Os. $2 \mathrm{~d}$., being that part of the compensation which is allotted to the lessor. 


\section{CHAPTER VIII}

\section{PUBLIC RIGHTS}

\section{SECTION 1.-STREAMS}

\section{BROWN v. CHADBOURNE.}

(Supreme Judicial Court of Maine, 1849. 31 Me. 9, 50 Am. Dec. 641.)

Case for maintaining a dam across Little river, and thereby obstructing the passage of the plaintiff's logs. It is a fresh water river, three miles long, flowing from Boyden's lake to tide water. Its width varies from seven or eight feet to three or four rods. The defendant owns land on both sides of the river, and has a dam and mills there, and a large quantity of his logs were resting upon the dam. The plaintiff had a quantity of logs in the river, for the purpose of being driven to his mill, below the defendant's dam. But they were prevented from passing, by means of the mass of the defendant's logs above his dam. The defendant was requested to remove the obstruction, or provide some passage way for the plaintiff's logs, but declined to do so, insisting that the plaintiff had no right to drive $\operatorname{logs}$ on that part of the stream, and forbidding him to drive them. The plaintiff thereupon boomed the defendant's logs, and opened and repaired some old sluice ways, belonging to the defendant, around the dam, and drove his logs through the same.

To recover for the hindrances and expenses in getting his logs by the dam, the plaintiff brings his suit.

The defendant contended that, at the place where his lands lay, the river is wholly his property; that the public have no right of passing or using it, and that the plaintiff had no right to run logs there. ***

Welis, J. ${ }^{1}$ This is an action on the case for erecting and maintaining a dam across a stream, called Little river, and obstructing the passage of the water, and the plaintiff's logs.

The river is about three miles in length and runs from Boyden's lake to the tide waters. It varies in its width, from seven or eight feet, to three or four rods, and it has been used many years for floating logs and rafts, and sometimes boats. Within twenty years, several dams and mills have been erected upon it.

The plaintiff disclaimed the right to recover upon the ground of

1 The statement of facts is abridged and part of the opinion is omitted. 
prescription or user, but claimed it because the stream was a public one in its natural state.

The jury were instructed that, it being a fresh water stream, the presumption is that it is private property, and the burden is on the plaintiff to establish the contrary, by satisfactory proof, that it is a navigable or floatable river, and in its natural condition capable of being used for running logs.

The rule of the common law, that riparian proprietors own to the thread of fresh water rivers, has been adopted in this and many other States of the Union. Berry v. Carle, 3 Greenl. 269; Spring v. Russell et al., 7 Greenl. 273.

The first question that arises is, it being conceded that the bed of the river belongs to the owners of the land on either side, can a right to the use of its waters be obtained, unless that use has been continued twenty years, the ordinary length of time for the acquisition of an easement? ***

If a stream could be subject to public servitude by long use only, many large rivers in newly settled States, and some in the interior of this State, would be altogether under the control and dominion of the owners of their beds, and the community would be deprived of the use of those rivers which nature has plainly declared to be public highways. The true test, therefore, to be applied in such cases, is whether a stream is inherently and in its nature capable of being used for the purposes of commerce, for the floating of vessels, boats, rafts or logs. When a stream possesses such a character, then the easement exists, leaving to the owners of the bed all other modes of use not inconsistent with it. For in this State, the rights of public use have never been carried so far as to place fresh water streams on the same ground as those in which the tide ebbs and flows, and which alone are considered strictly navigable at common law, and to exclude the owners of the banks and beds from all property in them. In some of the States of the Union such a rule has been established by judicial decisions, and in others by legislative acts. ${ }^{2}$

2 "Navigation was, from the first settlement of the province, an inherent and paramount right of the people. But we did not retain the commonlaw definition of navigable streams. At common law, those rivers only are (alled navigable in which the tide ebbs and flows. All rivers entirely above the influence of the tide, if they are so large as to admit navigation, and to le of public use for the passage of vessels, boats, ete., may be, as well as those which ebb and flow, under the servitude of the public interest, and are used as public highways by water. 'There be some streams or rivers,' says Lord Hale, "that are private not only in property or ownership, but also in use, as little streams and rivers that are not a common passage for the ling's people. Again, there be other rivers, as well fresh as salt, that are of common or pullic use for the carriage of boats and lighters; and these, whether they are fresh or salt, whether they flow and retlow or not, are prima facie, pullici juris, common highways for man, goods, or both, from one inland town or another." IIargrave's Tracts, De Jure Maris, e. : The common-law definition of navigalle livers affects, therefore, rather the proprietorship in the soil or bed of the river than the right of navigation. 
It is contended, that to show Little river is public, it is not enough to prove that logs may be floated down at certain seasons of the year, when it is affected by a freshet, but that it should have that capacity in its natural and ordinary state, at all seasons of the year.

In the test which has been mentioned, to determine whether a stream should be considered public, none of the authorities, from which it is derived, requires the stream to possess the quality of being capable of use during the whole year. A distinguishing criterion consists in its fitness to answer the wants of those whose business require its use. Its perfect adaptation to such use may not exist at all times, although the right to it may continue and be exercised whenever an opportunity occurs. In many rivers where the tide ebbs and flows, the public are deprived of their use for navigation during the reflux of their waters. A way over which one has a right to pass, may be periodically covered with water. In high northern latitudes, most fresh water rivers are frozen over during several months of the year. Even some tide waters are incapable of any beneficial use for purposes of commerce in the season of winter, owing to the accumulation of ice. $* * *$

Most of the great rivers of this State, in some portions of their passage, are so much impeded by rocks, falls and other obstructions, that logs cannot be floated in them any great distance, at what might be called an ordinary state of water. It is only in the spring and fall, and occasionally at other times, when their channels are filled with water, that they are capable of floating timber to market. They generally remain in this condition a sufficient length of time to answer the purposes of a common highway, and their fitness and character as such cannot be destroyed because they cannot be used in their ordinary state.

A test so rigid and severe as that required by the instruction requested, would annihilate the public character of all our fresh rivers, for many miles in their course, from their sources towards the ocean. The timber floated upon our waters to market is of great value, and neither the law nor the public policy requires the adoption of a rule which would so greatly limit their use for that purpose.

This was secured to the public in all streams competent to sustain it, whether they were, legally speaking, navigable or were not. But in Pennsyvania we have followed the civil-law definition of narigable rivers, rather than that of the common law, and we hold as navigable not only those streams which are subject to tides, but all rivers calable of being navigated; that is, navigable in the common sense of the term. Instead of granting the soil usque ad filum, we hare bounded our grants at low water on all such rivers, and have retained, as eminent domain, for the use of all citizens. whatever of soil and water were found between the lines that desuive the low water. In this we have defrarted not only from the common law of bigland, but from the law of most, though not all our sister states." Woodwarl, J., in Flanacan r. City of Philadelplia, 42 I'a. "210, 202 (1S6:). See, also, Mcilanus r. Carmichael, 3 Iowa, 1 (15コ̈). 
The right to the use of the stream in question must prevail, whenever it may be exercised at any state of the water.

Another instruction requested to be given was, that "the plaintiff has no right to use the banks of this stream for driving logs, and if such use is necessary for driving logs, the plaintiff has no right to drive this stream."

This request is manifestly too broad, and could not with propriety be given. When the stream overflows its banks, it carries some of the timber with it, and when it subsides, the timber is left upon the uplands. But in such cases, the timber is not lost to its owners, who have a right by our law to enter upon the uplands and remove it. This subject has been regulated by the statute (chapter $67, \S 11$ ), by which the owners of timber may enter upon the land and remove it within a certain time, by tendering to the owner or occupier of the land a reasonable compensation for his damages. The banks of the stream may therefore be used for driving logs.

No request was made to instruct the jury, that if the stream was incapable of being used, without traveling upon its banks to propel the logs, there could be no public servitude in it.

The instruction given to the jury was, "That if it was necessary to go on the banks more or less, for the purpose of driving logs in Little river, that fact would not take from the stream its public character, if they found it capable in other respects of being used as a public stream." It belonged to the jury to determine whether the river possessed those requisites, which would give it the character of the public stream, and if they found it to be so, it could not be deprived of that character by the acts of those who might use it. In narrow places it might at times be blocked up, or it might, as has been stated, overflow. The necessity of going upon the banks in such instances to effect a floating of the logs would not prevent the river from being public. The inquiry related to the capacity of the river, and that could not be altogether decided by what those using it might find necessary at times to do. Some might find it absolutely necessary in their mode of driving logs to commit trespasses on the adjoining lands, but their unlawful acts could not affect the stream, if it was really and intrinsically capable of public use.

If the plaintiff and others were in the habit of going upon the banks of Little river to drive their logs, it does not appear but that they might have confined themselves to its waters, though it might be more inconvenient for them so to have done. Their want of care in the use of the river, creating a necessity to commit trespasses to relieve their property, would not prevent it from being public nor justify the defendant in obstructing it. They would be responsible in damages for any trespasses committed. ${ }^{3}$

8 See Hooper v. Hohson, 57 Ne. 273, 99 Am. Dec. 769 (1869); Carter v. 'Thurston, $5 \mathrm{~S}$ N. H. 104, 42 Am. Rep. $58+$ (1S77); Haines v. Hall, 17 Or. 165, 20 I'ac. S31, 3 L. I. A. 609 (1SSS); Olson v. Merrill, 42 Wis. 203 (1S77). 
The public are not entitled to tow on the banks of ancient navigable rivers, at common laiv. Ball v. Herbert, 3 T. R. 253. And where a river cannot be used without towing, or going upon its banks to propel what is floating, such fact would evince its want of capacity, in itself, for public use.

Sometines the flow of rivers is broken by cataracts and falls, while in most of their course, there is a smooth current, and they are of great utility in the transportation of property. Where such.obstructions exist to so great extent, as to require the use of the shores, to carry property by them, though in those places they might not have a public character, yet for many miles above and below them, they might be capable of a beneficial use for trade and commerce, and thereby be public. These obstructions may occur at long or short intervals, leaving other portions of the streams clearly public.

It is further contended by the defendant, that if the dam was an unlawful obstruction the plaintiff had no right to run his logs through the defendant's sluice, built on his land, and recover damages for repairing it, although such course would be less detrimental than the destruction of the dam, but that he should have cut away the defendant's dam.

If a man has a right of way over another's land, unless the owner of the land is bound by prescription or his own grant to repair the way, he cannot justify going over the adjoining land, when the way is impassable by the overflowing of a river, but if public highways are out of repair or impassable, as by a flood, there is a temporary right of way over the adjoining land. 2 Black. Com. 36; 3 Kent's Com. 424.

Those obstructions, which prevent a passage while they remain, are insurmountable.

It is said by Buller, J., in Ball v. Herbert, "that if a river should happen to be choked up by mud, that would not give the public a right to cut another passage through the adjoining lands" The right of ways is in the waters, and the defendant had no authority to prevent its exercise. He could, by law, erect and continue his dam and mills, but was bound to provide a way of passige for the plaintiff's logs. He obstructed the river improperly by his dam and logs. The plaintiff must either have left his property and lost its whole value, carried it by the dam, repaired the sluice and run the logs through it, or have removed such portion of the dam, as would have afforded a passage. He adopted that course, which was least injurious to the defendant.

The plaintiff would have had the right to enter upon the defendant's land to remove the obstruction. Colburn v. Richards, 13 Mass. 420, 7 Am. Dec. 160; Inhabitants of Arundel v. McCulloch, 10 Mass. 70.

The plaintiff might not be bound to repair the sluice, but having done so to obviate the difficulty created by the defendant, there does not appear to be any reason, why he should be held to have taken

Big.RIgIITS- 45 
that course, which would have produced a greater injury to the defendant. Miller v. Mariner's Church, 7 Greenl. 51, 20 Am. Dec. 341.

Both the motion for a new trial and the exceptions are overruled, and there nust be judgment on the verdict. ${ }^{4}$

\section{THUNDER BAY RIVER BOOMING CO. v. SPEECHLY et al.}

(Supreme Court of Michigan, 1575. 31 Mich. 336, 1S Am. liep. 184.)

[The plaintiffs owned and operated a sawmill on Thunder Bay river. The mill was run by water power furnished by a dam on the river. The defendants owned a millsite and dam five miles higher up the river, but were chiefly engaged in floating lumber down the river. Between the defendants' and the plaintiffs' dams were shallows. After June the natural flow of the river was not sufficiently great to carry logs over these shallows. In order to get a sufficient head of water for this purpose the defendants had been in the habit of raising the height of the dam by superstructures until they accumulated a large head of water and then letting it out suddenly. The result was that the plaintiff's mill was first deprived of a sufficient head of water to continue operations, and then so flooded with water that the

4Acc.: Moore $\nabla$. Sanborne, 2 Micll. 519, 59 Am. Dec. 209 (1853); Smith $r$. Fonda. 64 Miss. 551, 1 South. 757 (1S86); Commissioners of Burke County v. Catawba Lumber Co., 116 N. C. 731,21 S. E. 941, 47 Am. St. Rep. S2! (1S9.5).

"The precise character of this stream is not stated, nor does it appeal" anywhere in the record. * * * We are led to infer, from what is stated, that it is an inconsiderable stream. nearly or wholly dry in the summer season, and carrying a volume of water sufficiently powerful to float logs or rafts only in seasons of freshets, and then for a few days or weeks only. * * * The principle is distinctly asserted [in Brown v. Chadbourne] that the public have the right to the free use of all streams which are susceptible of any valuable floatare. And to this cxtent is the claim of the defendant in error. He claims, if Big creck, which, from its mouth to its source, is mivate property, bought of the United States and paid for, and which may exhibit for the greater poltion of the year but a dry bed of gravel and sand, and which has teen crossed by fences and bridges, and occupied by other structures reared by the owners, is, notwithstanding, when a frestuet occul's of one week's duration, subject to be cntered upon by the public. and to be applopriated to floating logs, to the destruction of fences, bridges or other necessary structures, and in defiance of the proprietors of the same. We eannot sanction a doctrine fraught in its application with such consetuences. However neccssary it may be in the great lumbering states of Iaine and Michigan, that private rights should yield to the prevailing interest, no such necessity exists in this state, and we shall be careful that the rights of its citizeus shall not be wrongfully invaded upon such pretences as are set forth in this record, and sustained by such considerations as influenced the julgments of the coults whose opinions we have considercl." Hreese, J., in llublard v. Pell, 54 Ill. 110, 114, 118, 5 Am. Rep. 9s $(1870)$

Sre, also. Jewis v. Coffee County, 77 Ala. 190. 54 Am. Rep. $5 \bar{j}$ (1SS'1); Molgan v. King, 35 N. I. 454,91 Am. Dec, is (1)6i). 
wheels would not work, and the plaintiff was forced to close his mill. 'This action is brought to recover the damages so caused.]

COOLEY, J. ${ }^{3}$.[after stating the foregoing facts:] * * * This statement will be stufficient to show the bearing of the legal questions presented in the court below. That court was requested to charge the jury, that defendants had a right to use the water of the river to lloat logs, and if there was an insufficient supply to float logs during the montlis of June, July, and August, 1872. then defendants had a right to raise a head of water at the 'Trowbridge dam, to assist in running the logs on the rapids, and if they detained the water no longer than was necessary for the proper enjoyment of that right, then plaintiffs were not entitled to recover. This request was refused, and the court on the contrary instructed the jury, that the plaintiffs had a right as riparian proprietors, to have the water of the river flow into and through their pond in its usual and ordinary mode of flowing, and that any detention of water by defendants for the sole purpose of securing a flood, in such a manner that it could not be used by the plaintiffs in the operation of their mill, was unreasonable and unlawful as to them, and entitled them to compensation for the resulting damages. The jury returned a verdict for the plaintiffs.

The position taken by the defendants, and which they insist upon here, is, that Thunder Bay river is a public stream, navigable for the jurpose of floating and booming logs, and that any rights of riparian proprietors are subservient to the right of the public to make use of the stream as a public highway; that defendants had a right to detain the water in the Trowbridge dam to assist in running the logs jammed upon the rapids, and that they could not be liable for so doing, prorided they detained the water no longer than was needful for that purpose, and exercised their right reasonably, with a due regard to the rights of others. And it is this claim which presents the principal question for otr consideration.

That Thunder Bay river must be regarded as a public highway for the purpose of running logs, must be considered as determined by the previous arljudication of this court. Moore v. Sanborne, 2 Mich. 519, 59 Am. Dec. 209. But that case falls short of solving the difficulties presented by this, for, while that only determines that a stream may be public and navigable, which is capable of being used for floating logs for a considerable portion of the year, the question presented by this is, whether such a stream is to be considered navigable and subject to the public easement at a time when, in its natural condition, it is entirely incapalle of being made use of, even for the restricted llavigation which was held to be of common right in the case referred to. There is obviously a very broad distinction between a stream being held to be public and navigable while it is capable of being used by the public for any important purpose of carriage by water, and the

G Part of the opinion is omitted. 
same stream being held to be so when the whole capacity for use is created by artificial means, and by abridging what, but for the resort to these artificial means, would be the unquestionable rights of riparian proprietors on the stream below. ***

The doctrine, then, which we derive from the cases is, that a.stream may be a public highway for floatage when it is capable in its ordinary and natural stage in the seasons of high water of valuable public use. The inference sought to be drawn from it is, that a navigable stream must, in contemplation of law, be navigable at all times, and under all circumstances; that there can be no such thing as a highway which is only open to the public use periodically, but that when once the public character of the way is established, the right of the public to the easement is paramount to all private rights, and that nothing done to facilitate the public use can be the foundation of a right of action unless in itself unreasonable, when the due subordination of private to public rights in the stream is considered and properly allowed for. But no such inference is warranted by the decisions. The highway they recognize is one sui generis, and in which the public rights spring from peculiar facts. It is a public highway by nature, but one which is such only periodically, and while the natural condition permits of a public use. During that time the public right of floatage and the private right of the riparian proprietors must each be exercised with due consideration for the other, and any injury which the latter receives in consequence of a proper use of the stream for floatage he must submit to as incident to his situation upon navigable waters. Middleton v. Booming Co., 27 Mich. 533.

But at periods when there is no highway at all, there is no ground for asserting a right to create a highway by means which appropriate or destroy private rights. The doctrine that this may be done without compensation to parties injured is at war with all our ideas of property and of constitutional rights. The most that can be said of this stream, during the seasons of low water, is, that it is capable of being made occasionally navigable by appropriating for the purpose the water to the natural flow of which the riparian proprietors are entitled. It is highly probable, in view of the large interests which are concerned in the floatage, that the general public good would be subserved by so doing, but this fact can have no bearing upon the legal question. It is often the case that the public good would be subserved by forcing a public way through private possessions, but it neither should be nor can be done under any circumstances without observing the only condition on which it can be permitted in constitutional government, namely, that the private proprietor be compensated for the value which he surrenders to the public. We do not question the right of the legislature to provide for the taking of riparian rights for this purpose, but no attempt had been made in this case to resort to a legal appropriation, and the reliance of the booming company is exclusively upon a public right of navigation, though the capacity for navigation does not 
exist by nature, is only created by artificial means, and can neither be created nor enjoyed without appropriating to the use of the company the valuable riparian rights which the plaintiffs acquired by the purchase of lands over which the stream runs; this appropriation without compensation is no more admissible than would be the taking of lind for an ordinary highway or a railroad. As was remarked in Morgan v. King, 35 N. Y. 460, 91 Am. Dec. 58, the question of public right in a case like this is to be decided without reference to the effect which artificial inprovements have had in the navigable capacity of the river; in other words, the public right is measured by the capacity of the stream for valuable public use in its natural condition; and any attempt to create capacity at other times at the expense of private interests can be justified only on an assessment and payment of compensation.

The judgment must be affirmed, with costs.

Graves, C. J., and Campbeli, J., concurred.

Christiancy, J., did not sit in this case.

\section{COBB v. BENNETT.}

(Supreme Court of Pennsylvania, 1874. 75 Pa. 326, 15 Am. Rep. 752.)

This was an action of trespass vi et armis brought June 20th, 1870, by David Bennett against David Cobb, master and agent for the owners of the schooner "Sarah."

The cause of action was that the defendant wantonly ran his vessel into the fishing-net of the plaintiff and greatly injured it.

The case was tried February Sth, 1872, before Lynd, J.

The plaintiff testified that he was the lessee of a fishery on the New Jcrsey side of the river Delaware and duly licensed. He further testified that on the 17th of May, 1870, he had his nets laid out about $31 / 2$ o'clock a. m., with a boat with a light in it, lying about 200 feet from low-water nark; he had about thirty or thirty-five men employed. About that time the "Sarah" was seen approaching and when about 400 or 500 yards below the nets, his son rowed towards the vesscl in which there was a light, he heard his son hail the vessel to go to the westward, plaintiff rowed down to the vessel and told the captain of the vessel, that if he would "go about" he would clear the nets; he did not go about, "he continued his course until he struck

- A. erected a legal dam on a stream, leaving a sluiceway as wide and with as much water as the original channel. IIeld, although the river, because of the dam, has a greater carrying capacity, a person floating logs is entitled to no more water at the dam than would naturally be there, had there been no dam. Pearson v. Rolfe, 66 Me. $3 S 0$ (1Ss4). Compare Volk v. Eldred, 23 Wls. 410 (1S6s).

See, also, Luopman r. Blodgett, 70 Mich. 610, 38 N. W. 649, 14 Am. St. Rep. 527 (185s). 
my net; he damaged my net, tore my lines; he let go his anchor in. side the net on the fishing grounds; $* * *$ he lay the first time at anchor half an hour. **** I told him to stand over towards Tinicum Island; he did so and then went about, came back and anchored on our grounds; $* * *$ he remained four hours at anchor the second time."

The plaintiff then testified as to the damage which he had sustained by reason of the vessel injuring his net. He also testified that the defendant without injury to himself might have avoided running into the net, if he had changed the course of his vessel after he had been notified: ***

[The verdict was for the plaintiff and the defendant took out a writ of error.]

AGNEW, C. J. We discover no error in the portions of the charge assigned for error. They may all be comprised in the following instruction: "I charge as a question of law he [the defendant] was bound to shorten his tack, if he could have thereby avoided the nets, without prejudice to the reasonable prosecution of his voyage." This was said in view of the facts in evidence on the part of the plaintiff, that the defendant was notified of the position of the net of the plaintiff; pointed to the light which marked that position; and requested to change his course so as not to foul it, and that this could be done conveniently. The judge had already said: "But there is another right in the river, that of navigation, which is superior to the right of fishing, and wher they interfere, that of fishing nust give way to the right of navigation." He had also said: "Those exercising the rights of navigation will not be excused, if they are sufficiently warned, unless they make a reasonable effort to avoid them."

Now, surely, it is not error to say, that when the mariner is warned of his approach toward the net of the fisherman, he should change the course of his vessel, if he can do so without prejudice to the reasonable prosecution of his voyage. The entire point of the charge is contained in this qualification, and hence it was not doing full justice to the charge to onit the qualifying words in the assignment. What would be a reasonable prosecution of the voyage would depend on the attendant circumstances, and upon this a special instruction might have been called for. Without the qualification there would have been error, for we must agree that the mariner is not bound to shorten his tack, merely because a net is stretched across his course. A vessel is entitled to take her course in the navigation of the river, and to hold it without regard to the fisherman's net, provided the master act without wantonness or malice, and do no unnecessary damage. This is an obvious consequence of the superior right of navigation. But this, we think, was the very doctrine of the charge, and the exception contained in the qualification in view of the facts in evidence.

7 The statement of fucts is abridged. 
If the mariner, warned of the position of the net and requested to change his tack, may do so "without prejudice to the reasonable prosecution of his voyage," can we say he is exercising his superior right of navigation justly, and in the spirit of the maxim, "sic utere tuo ut alienum non ladas," if, indifferent to the inferior right, he recklessly holds on his way and fouls and injures the fisherman's net? Certainly we cannot say this, for in effect it would be to say a fisherman has no rights whatever; that being no right which another may disregard under all circumstances.

In view of the legislation, both of Pennsylvania and New Jersey, the usages of fishing, and the decisions in our own state, there is a right of fishing in the Delaware, though subordinate to the right of navigation, which cannot be unnecessarily impeded by it. Fisheries attached to the riparian ownership are valuable, and command high rents. This subject will be found to be discussed at great length and with much research, by our brother Sharswood, in the case of Tinicum Fishing Co. v. Carter, $61 \mathrm{~Pa} .21,100 \mathrm{Am}$. Dec. 597. It therefore needs no further discussion here. The right of fishery is an acknowledged one, though it is entirely subordinate to those of navigation. and we intend in this opinion to lay down no principles which would burden commerce or restrict the navigator's rights, beyond that which his evident duty to others would justly require. Indeed, the question upon the charge comes down to this: Is it wantonness when a mariner, warned of the net, seeing the light marking its position, and requested to avoid it, yet, indifferent to the interests of the fisherman, keeps on his course, when a reasonable pursuit of his voyage would not be prejudiced by avoiding the net? Wantonness is reckless sport, wilfully unrestrained action, running immoderately into excess. If a man will do an injury, when he may reasonably avoid doing so, without inconvenience to himself, can it be said he is blameless? Is it not worse than wantonness, is it not rather malice, when he may, without prejudice to the reasonable enjoyment of his own right, desist from an injury to another, and yet will persist in committing it?

Now, unless we deny this proposition we cannot reverse. If there were anything exceptional in the facts or contradictions in the evidence, it was in the power of the defendant to ask specific instructions upon the precise state of the facts as appearing on either side. If by reason of the veering of the wind to the north-east, the running of the tide with the course of the vessel, the want of men on deck at the moment, or other sufficient cause, it would have been difficult, or even unreasonably inconvenient, to shorten the tack of the vessel, or change its course, the instruction might have been asked that in such a case the master was not bound to luff or to shorten tack. We agree with the counsel of the plaintiff in error, that the interests of navigation are all-important to a port like that of Philadelphia, and are not required to give way to the minor and subordinate right of fishing. 
But in the absence of a call for instruction on the point so much insisted upon in the argument, we cannot say the court erred in the general instructions contained in the charge. There was evidence of malice sufficient to take the case to the jury, to whom it belonged, and not to the court, to say whether the language used, "to hell with vour net," was a mere superfiuity of maritime civility, or was indicative of malice.

Judgment affirmed. ${ }^{8}$

\section{POLIOCK v. CLEVELAND SHIP BUILDING CO.}

(Supreme Court of Ohio, 1897. 56 Ohio St. 655, 47 N. E. 582.)

[The plaintifi and defendant were adjoining riparian owners upon the Cuyahoga river, a navigable stream. The defendant built and repaired boats and had a 700 -foot dock running the length of its river frontage. The plaintiff made no use of his land, and it was unimproved. In repairing vessels, and in putting the boilers and machinery in vessels that it built, the defendant made use of a derrick erected so near to the line of the plaintiff's property that as the vessels

8. contracted to cut and float to a specified point timber belonging to $\mathbf{B}$. He began cutting operations in the fall. Duriug the winter the defendant stored in a river sereral hundred thousand feet of logs of the preceding year's cut, so that they blocked the mouth of the tributary river down which A. expected to float the logs cut by him. As a consequence $A$. Tas unable to get out the logs. In an action by $\mathbf{A}$. against the defendant for the damage so caused, the court said: "The defendants had as much right as the llaintiff to use Moose river for driving purposes. If they fairly occupied the river first with their logs, they could claim precedence, and the plaintiti would need wait, prorided they used reasonable diligence and efforts to propel their drive. They were under no obligation to hold up, and let the llaintiff put his loss in ahead. or even in the midst of their drire. If the plaintiff reaclied the rivel later than the defeudants, he would be obliged to wait and his loss would he damnum absque injuria. If the defendants, in such case, used reasomale diligence and efforts, they would not be responsible, even thounh they made temporary delays for purposes of booming. etc. * * Temporary delays and rests may be justitiable in the driving of logs if thes are not unreasonable in time or place. But when larties deliberately, and without compulsion by nature, select a particular portion of a river as a place for a season's storage of their logs and thus completely block up another's entrance into the common highway, we think they ale excceding this right, and are legally liable for damages thereby caused. Partics desiring to use any part of a river for such storage should select such places as will least olstruct others in their use of the river. * * In this casc it is urged that there was no other place where the left-over logs could have heen safely kelut during the winter. It was perhaps the most convenient place, but the evidence does not satisfy us that it was the only safe place. We think the logs could, with some extra care and expense perliaps, have been safcly stored where they would not have obstructed the Tom Fletcher stream." Emery, J., in McPheters v. Moose Iiver Log Driving Co., is Me. 329, 333, 5 Atl. 270 (1856).

See, further, as to reasonablencss in the use of the stream, Harold $v$. Jones, 86 Ala. 274, 5 South. 198, \& I. R. A. 406 (1858); St. Clond Waterl'ower \& Mill Co. v. Mississippi \& li. li. Bonm Co., 43 Minn. 380, 45 N. W. 714 (1\&90). 
were moored it was frequently necessary to make them project 25 to 75 feet along the plaintiff's river frontage, and to carry lines from their projecting ends across the plaintiff's land to piles in the defendant's land. No actual damage was caused to the plaintiff by the defendant's acts. The plaintiff frequently requested the defendant to desist from these practices and after its repeated refusals brought suit for an injunction. The injunction was denied and the plaintiff appealed.]

SpEAr, J. ${ }^{\bullet}$ [after stating the facts]. The inquiry presents two questions: (1) Were the acts of the conpany in moving vessels in front of plaintiff's land for the purpose of repairs to old vessels, and of putting in boilers, engines, and machinery in new vessels, trespasses? (2) Were its acts in carrying lines across the river bank of plaintiff trespasses for which injunction will lie?

The right of ownership to the center of the stream by one owning land abutting on a navigable river is not in dispute. It was declared by this court in Gavit v. Chambers, 3 Ohio, 497, that "he who owns the lands upon both banks owns the entire river., subject only to the easement of navigation; and he who owns the land upon one bank only owns to the middle of the river, subject to this same easement." * * *

We now inquire, was the mooring of boats by the company in the part of the water of the river which is over plaintiff's land, for the purpose of repairing or completing such vessels, the pursuit of a strictly private manufacturing business thereon, as is claimed by plaintiff? Or was it but an incident of navigation and commerce, as claimed by defendant? If the latter, the judgment of the circuit court is right in this particular, and as to this should be affirmed. If the former, the jurlgment is wrong and should be reversed, for, whatever may be the rule elscwhere, in Ohio it is established that repeated acts of trespass, which in time would ripen into a prescriptive right, although the damage for each trespass is but nominal, will entitle the aggrieved party to an injunction. And it seems to be also established that the owner of the fee of a highway may have trespass, founded upon his possession, against a stranger, for any acts of trespass committed upon it, not justified or excused under the public right, and if he neglects to sue, but submits, adverse possession under claim of right would in time ripen into a prescriptive right. Having the exclusive seisin and possession of the soil of the highway, subject only to the easement of the public, he may lose his right of seisin and possession by being deprived and barred by the statute of limitations. Tootle v. Clifton, 22 Ohio St. 247, 10 Am. Rep. 732; Washb. Easem. 10; Read v. Leeds, 19 Conn. 182. This brings us to the inquiry as to what is fairly embraced within the meaning of the term "easement of navigation." One dictionary meaning of navigation is, "the science or art of conducting a ship from one place to another," and this definition is quoted by plaintiff's coun-

- Part of the opinion is omitted. 
sel as applying here. Another definition is, "the science or art of ascertaining the position and directing the course of vessels, especially at sea, by astronomical observations or calculations; nautical science or art." Still another is, "shipping," which would embrace the conduct of ships generally. Clearly the term "easement of navigation" should not be construed in any narrow, scientific sense, but, having in mind that the reservation of the easement by the state is for the benefit of the public in its use of the highway, it shibuld receive a construction in harmony with the nature of the uses of the water by the public, and the objects of a public nature to be accomplished by such uses. Those objects relate to trade and commerce, which is the interchange of goods or products between nations,or individuals by means of transportation, or, as applied to commerce, on the water, by means of navigation. "Commerce,". says Chief Justice Marshall in Gibbons v. Ogden, 9 Wheat. 1, 6 L. Ed. 23, "is traffic, but it is something more; it is intercourse." Commerce, then, is the object; navigation, the instrument or incident. In other words, navigation is the means by which commerce is accomplished, and it is for the purpose of aiding commerce that navigation is encouraged and protected. When the term "easement of navigation" is used, therefore, it carries with it the idea of navigation for the purposes above expressed; so that whatever relates to commerce, or is incident to it, is embraced in the term. ***

Vessels cannot be operated or moved without getting out of repair, and hence stopping for repairs becomes one of the incidents of their use. It would not be reasonable, from the standpoint either of expense or convenience, to compel such vessels to seek a slip or a drydock on every occasion when repairs are needed,-at last, when such repairs can be made without interference with other craft plying the same waters, and without injury to riparian owners. It follows from the foregoing that the use made by defendant of the waters of the Cuyahoga river for the repair of vessels was an incident to the right of navigation and commerce, and hence a public use and a proper use.

The question of the right to moor vessels in front of plaintiff's property, outside the dock line, while the machinery was being put in, presents greater difficulties. The point is thought to turn upon whether or not an independent contract for putting in such machinery would be a maritime contract. "A ship," says Mr. Benedict in his work on Admiralty (section 215), "is a locomotive machine adapted to transportation over rivers, seas, and oceans." In this sense, the vessels moored by defendant, awaiting cngines and bollers, were ships. They were. machines upon the water, would float, and were capable of being moved and propelled on the water, and were so floating on the water, and intended as aid to commerce. $* * *$

Without taking space for general discussion, our conclusion is that the work of placing engine and boilers into the vessels of defendant, as they lay moored partly in front of plaintiff's land, whether done by an independent contractor or by the defendant itself, was a maritime 
purpose,- an incident to navigation and commerce, which the defendant, as one of the public, had the right to pursue in the legitimate use of the highway, so long as such use did not unreasonably impede narigation. 'The mooring of vessels there, though they did overlap in front of plaintiff's land, did not constitute trespasses; and the plaintiff, under the facts found, has no standing in a court of equity to enjoin such use. There was therefore no error in the refusal of the circuit court to allow an injunction as to this, the main branch of the case.

2. The carrying of lines across the river bank of plaintiff presents a wholly different question. Those acts invaded the real property of plaintiff, the title to which is not qualified by any right in the public. It is absolute. It was the judgment of the circuit court that such acts resulted in no real damage to plaintiff, and that, by reason of the record in this case, their repetition, no matter for what duration of time, could not ripen into a right by prescription, and hence plaintiff was not entitled to any relief. WVe are unable to agree with this conclusion. The acts complained of were trespasses. It is by no means clear that they would not, if pursued long enough, grow into a prescriptive right. It is not necessary to ascertain this with positiveness. It is enough that, if there be any doubt, the risk should not be imposed upon the plaintiff. And it is no hardship upon defendant to say that, if it needs to use plaintiff's land, it can do as other people do in like circumstances, -obtain a right to such use by negotiation. The very fact that the trespasses are in themselves trifling, and the damage, if any, so snall that suits at law to recover would be impracticable, affords an additional reason for granting an injunction. As to this ground of complaint the judgment of me circuit court will be reversed, and judgment entered for plaintiff in error.

Judgment reversed. ${ }^{10}$

$10 \mathrm{Acc} .:$ That the mere projecting orer the boundary line of a ressel moored for loading and unloading is not actionable: Original Hartlepool Co. v. Gibbs, I. R. 5 Ch. D. 713 (1877). Compare Harrington v. Edwards. 17 Wis. 5S6, 84 Am. Dec. 768 (1S63); Delaware River Steamboat Co. v. Burlington \& B. Steam Ferry Co., 81 Pa. 103 (1S76); The IVm. H. Brinstield (D. C.) 39 Fed. 215 (1S 9 ). Ace.: That there is no right of mooring to or landing on riparian land of a third person: Ensminger $r$. People ex rel. Trover. 47 Ill. 3S4. 95 Am. Dec. 495 (1868); Bainbridge r. Sherlock, 29 Ind. $864,95 \mathrm{Am}$. Dec. 644 (1S68).

A. anchored coal harges in a navigable river opposite B.'s land and on B.'s side of the river, and kept them there for over two years. B.'s land was not in use. Ileld, B. has a right of action against A. Wall $r$. Pittsburgh Harbor Co., 152 Pa. 427, 25 Atl. 647, 34 Am. St. Rep. 667 (is93). 


\section{WILLOW RIVER CLUB v. WADE.}

(Supreme Court of Wisconsin, 189S. 100 Wis. 86,76 N. W. 273, 42 L. R. A. 305.)

Cassoday, C. J. ${ }^{11}$ This is an action for trespass to recover $\$ 20$ damages for taking fish, commenced in justice court. The defendant answered to the effect that he had a right to take the fish, and that the title to land would come in question, and gave the requisite bond, and the case was thereupon transferred to the circuit court, where the cause was tried. *** At the close of the evidence the court directed a verdict in favor of the defendant, and from the judgment entered thereon plaintiff brings this appeal.

The precise question presented by the facts stated is whether the defendant, by stepping from a public highway into a boat upon the river, and while floating thereon, catching the fish in question from the river by hook and line, committed a trespass upon the premises of the plaintiff. The proper solution of the question depends upon the proper determination of one or more other questions discussed at the bar. Counsel for the plaintiff is undoubtedly correct in claiming that at common law the public right of fishery in rivers was confined to such portions of the rivers as were covered by the ebb and flow of the sea, and that the right of fishing in fresh-water rivers was exclusively in the abutting landowners. ***

This court has held from the beginning that the owners of the bank of a navigable stream by purchase from the United States, even when meandered, were prestumed to be such owners to the middle of the stream in front of such purchase. ***

Upon the undisputed evidence and the adjudications mentioned, we must hold that the Willow river is a public navigable stream, fitted for useful commerce and transportation of persons and property thereon. Being such, it necessarily follows, from the principles of law stated, that, notwithstanding the plaintiff has title to the bed of the river, nevertheless it holds the same in trust for the use of the public.

The question recurs whether the public right of fishery is included in, or an incident of, such public right of navigation. In other words, has the plaintiff, as riparian owner, the exclusive right to take fish from the river? The plaintiff certainly has no property in the particles of water flowing in the stream, any more than it has in the air that floats over its land. Its rights in that respect are confined to their use and in preserving their purity while passing. Lawson v. Mowry, 52 Wis. 234, 235, 9 N. W. 280. So, the fish in the stream were not the property of the plaintiff at common law, any more than the birds that flew over its land. State v. Roberts, 59 N. H. 256, 47 Am. Rep. 199; Ang. Water Courses (7th Ed.) § 65a, and cases there cited; State v. Welch, 66 N. H. 178, 28 Atl. 21.

11 Parts of the opinions are omitted. 
As indicated, the public right of fishery in tidal rivers was maintained, at common law, in England, before the use of stean,- - when vessels could only be carried up the river by the flow of the sea, and down the river by the ebb of the sea,-and consequently when the ebb and flow of the tide practically measured the navigability of the stream. For the same reason, the public should have the right to fish in all the public navigable waters of the state, including all public navigable rivers and streams of the state. The supreme court of the United States, in a recent case, partially adopting the language of the New Hampshire case cited, has declared that, "at common law, the right of fishing in navigable waters was common to all. The taking and selling of certain kinds of fish and game at certain seasons of the year tended to the destruction of the privilege or right by the destruction consequent upon the unrestrained exercise of the right. This is regarded as injurious to the community, and therefore it is within the authority of the legislature to impose restriction and limitation upon the time and manner of taking fish and game considered valuable as articles of food or merchandise. For this purpose fish and game laws are enacted. The power to enact such laws has long been exercised, and so beneficially for the public that it ought not now to be called into question." Lawton v. Steele, 152 U. S. 138, 139, 14 Sup. Ct. 501, 38 I. Ed. 385.

In this state the legislature has expressly declared that "all fish in the public waters of the state of Wisconsin are hereby declared to be the property of the state and may be taken for the use of the individual and become his property at any time and in any manner not prohibited by the laws of this state." Laws 1893 , c. $307, \S 20$. Public navigable streams are certainly "public waters," within the meaning of that act. Since the defendant kept within the banks of the river,-within the limits of the public highway,--his fishing was nothing more than the exercise of a right common to the public. We must hold that the Willow river was a public navigable stream, and the defendant was not guilty of trespass by going upon it, as he did, catching the fish in question.

The judgment of the circuit court is affirmed. ${ }^{12}$

12 "The idea is sometimes entertained that the right to pass along a public navigable river carries with it the right to fish in it, but so far as regards non-tidal rivers this is not so. No lawyer could take that view. Yersons using a navigable highway no more acquire thereby a right to tish there than persons passing along a public highway on land acquire a right to shoot upon it." North, J., in Smith r. Andrews, [1891] 2 Ch. 678, 695. Acc.: Adams v. Pease, 2 Conn. $4 \$ 1$ (1S18); Hooker $r$. Cummings, 20 Johns. (X. Y.) $90,11 \mathrm{Am}$. Dec. 249 (1S:2); Queen v. Robertson, 6 Can. S. C. 52 (18S2),

There is no right of fishing unon rivers nonnavigable in fact. Beach v. Mforgan, 67 N. H. 529, 41 Atl. 349, 6S Am. St. Rep. 692 (1893); Grittith v. Holman, 23 Wash. 347, 63 Pac. 239, 54 L. R. A. 178, 83 Am. St. Rep. S21 (1900). So as to lakes which are not comnected with navigable waters and the beds of which are th private ownership. Albright $\mathbf{r}$. Cortright, $64 \mathrm{~N}$. J. Law, 330, 45 Atl. 684,48 L. R. A. 616, 81 Aln. St. Rep. 504 (1899); Lem- 
Pinney, J., dissenting.

Marshal, J, I concur with the decision of the court, but regard the opinion of the Chief Justice as being so framed as to lead to the belief that the common right of fishing in navigable streams in this state is a mere incident to the right of navigation, and that defendant is not liable because he was navigating the stream in a boat at the time of the act complained of; in short, that he was where he had a right to be in the exercise of the right of navigation, and therefore that he was not a trespasser upon the plaintiff's lands. In my judgment the right of fishing in navigable waters is common to all, and exercisable, so far as it can be done without trespass on the banks thereof, whether the person exercising such right be at the time navigating the stream in a boat or otherwise floating upon the surface of the water, or traveling upon the bed in the shallows, or anywhere in any manner, between the lines of ordinary high-water mark. That is, that the common-law doctrine of navigble waters, with all the incidents and characteristics of such waters, has been extended to include all streams navigable in fact, through the location of the title to the beds of such streams in the state originally for that very purpose, and that though such title, by force of state policy, has passed from it to private ownership, such ownership is of such a qualified character as not to in any way interfere with the character of the streams as public waters; not public in the sense of such rivers as at common law were merely subject to the right of passage, but public by the common-law test of navigability.

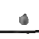 \\ SECTION 2.-HIGHWAYS}

GOODTITLE ex dem. CHESTER v. ALKER \& ELMES.

(Court of King's Bench, 1757. 1 Burr. 133.)

[The lessor of the plaintiff was the owner of a parcel of land over which there was a public highway. The defendant wrongfully erected a fence that enclosed part of this land, and retained possession of this part. 'This action of ejectment was brought in respect of the strip so enclosed.]

beck $\nabla$. Nye, 47 Ohio St. 336, 24 N. E. 686, 8 L. R. A. 578, 21 Am. St. Rep. 828 (1890). Compare Beckman v. Kreamer, 43 Ill. 447, $92 \mathrm{Am}$. Dec. 146 (1867). As to the public right of fishing in the Great Lakes, see Linculn v. Davis, 53 Mich. 375,19 N. W. 103, 51 Am. St. Rep. 116 (18S4); Sterling v. Jackson, 69 Mich. 4SS, 37 N. W. 845, 13 Am. st. Rep. 405 (1SSS); Sloan v. Biemiller, 34 Ohio St. 492 (1878). 
Mansieled, C. J. * * * * 13 As to the Question "Whether an ejectment will lie, by the owner of the soil, for land which is subject to passage over it as the King's highway?"

1 Ro. Abr. 392. letter B. pl. 1, 2. is express-"That the King has nothing but the passage for himself and his people: but the freehold and all profits belong to the owner of the soil." So do all the trees upon it, and mines under it (which may be extremely valuable.) The owner may carry water in pipes under it. The owner may get his soil discharged of this servitude or easement of a way over it, by a writ of ad quod damnum.

It is like the property in a market or fair.

There is no reason why he should not have a right to all remedies for the frechold; subject still indeed to the servitude or easement. An assize would lie, if he should be disseised of it: an action of trespass would lie, for an injury done to it.

I find by the case of Selman v. Courtney, Tr. 13, 14 G. 2. that a point which had been before the Court of Exchequer in the case of the Dutchess of Marlborough v. Gray, M. 2 G. 2. is now settled; viz. "That its being a highway cannot be given in evidence by the defendant, upon the general issue:" which proves that the ownership of the soil is not in the King. I see no ground why the owner of the soil may not bring ejectment, as well as trespass. It would be very inconvenient, to say that in this case he should have no specific legal remedy: and that his only relief should be repeated actions of damages, for trees and mines, salt springs, and other profits under ground. 'Tis truc indeed that he must recover the land, subject to the way: but surely he ought to have a specific remedy, to recover the land itself ; notwithstanding its being subject to an easement upon it. * * *

[Foster and DENison, JJ., concurred.]

Judgment for the plaintiff. ${ }^{14}$

\section{STACKPOLE et al. v. HEALY.}

(Supreme Judicial Court of Massachusetts, 1819. 16 Mass. 33, 8 Am. Dec. 121.)

Trespass for breaking and entering the close of the plaintiffs. The declaration contains two counts. The first alleges that the defendant on, \&c. with force and arms broke and entered the close of the plaintiffs in Waterville, bounded, \&c. and with cows ate up consumed and depastured the grass and corn then and there growing, of the val-

13 Part of the opinion is omitted.

14Acc.: Postal 'Telegraph-Cable Co. r. Eaton, 170 Ill. 513, 49 N. E. 365 , 39 L. R. A. 722, 62 Am. St. Rep. 390 (189i). Contra: Cincinnati v. White, (i Pet. 431,8 L L Ed. 452 (1832).

A. Went on a public highway, the fee of which was owned by B., and there hunted. Held, he may be indicted under a statute for committing "a tresfass upon the land of" B. "by being thereon in the pursuit of game." Rex. v. I'ratt, 4 El. \& Bl. sio (1S5.j). 
ue, \&c. The second count alleges a like trespass in that part of the same close, over which the publick highway runs.

The defendant pleads not guilty as to the force, \&c. and as to the residue of the trespass in the first count, he pleads in bar, that over and across the place in which, \&c. there is, and at the said several times when, \&c. and before and ever since has been a publick highway, in and over every part of which he and all other the inhabitants of Waterville have, and ever since the same hath been a publick highway, have had a right with their cows, to pass, repass and graze: and at the said several times when, \&c. the said $\mathrm{H}$. with his said cows were of right passing, repassing and grazing, in and upon the said highway. And as to the supposed trespasses upon that part of the said close not covered by the said highway, but which lay contiguous thereto, being the remaining part of the locus in quo, that just before the several times when, \&c. his said cows, being of right on said highway passing, repassing and grazing, without the consent of the defendant escaped therefrom into the said remaining part, through the fences of the plaintiffs, which they were bound to keep in good and sufficient repair, and which were not then in such repair, but altogether ruinous: and so said cows escaped through the default of the plaintiffs. And as to the second count, he justifies as in that part of the former plea respecting the part of the close covered by the highway.

The plaintiffs demur generally to both the pleas in bar, and the defendant joins in demurrer.

Putnan, J. ${ }^{15}$ The principal question intended to be presented in this case is, whether the people of this commonwealth have a right to use the lands for the purpose of grazing, which have been laid out as highways. I hold it to be clear that the publick have no other right, but that of passing and repassing; and that the title to the land, and all the profits to be derived from it, consistently with, and subject to, the right of way, remain in the owner of the soil. The owner may maintain trespass for any injury to the soil, which is not incidental to the right of passage acquired by the people. The land covered by a highway may be recovered in ejectment. Lord Mansfield, in delivering the opinion of the court in the case last referred to cites with approbation from 1 Roll. Abr. 392, that the king has nothing in an highway, but a passage for himself and his people; but the freehold and all the profits belong to the owner of the soil. His Lordship adds, "so do all the trees upon it, and the mines under it, which may be extremely valuable:" and Mr. Justice Foster observes, "the owner of the soil has all above and under ground, except only a right of passage for the king and his people."

This has been the settled law, ccrtainly ever since, the time of Edw. 4. The only case, which seemed to the contrary, was that of Sir

15 Part of the opinion is omitted. 
Bouchier Wray, mentioned in the last cited case, which Lord Mansfield said was so loosely remembered, and so imperfectly reported, as to deserve no regard. The old authorities are cited by Viner, Chimin priv. B, and particularly $8 \mathrm{Edw} .4,9$, pl. 7, where this was held to be the law by all the justices.

These principles have also been recognized in this court. In the case of Perley v. Chandler, 6 Mass. 454, 4 Am. Dec. 159, Chicf Justice Parsons states the opinion of the court, that every use to which the land may be applied, and all the profits which may be derived from it, consistently with the continuance of the easement, the owner can lawfully claim. And in a late case it was held, that one might recover the land, subject to the way, in a writ of entry.

It is not lawful therefore for the publick to put their cattle into the highway to graze. For wherever one would justify taking the property of another, in virtue of a license or of a way, he must plead and prove that he pursued the authority, or used the way as a way, and not for any other purpose. So in $22 \mathrm{Edw} .4,8$, pl. 24, it was said by one of the court, that "if one drive a herd of cattle along the highway, where trees, or wheat or any other kind of corn is growing, if one of the beasts take a parcel of the corn, if it be against the will of the driver, he may well justify; for the law will intend that a man cannot govern them at all times as he would: but if he permitted them, or continued them \&c. then it is otherwise."

In the case at bar, the defendant put his cattle into the way to graze, and not merely to pass along the way. All the injury, which is necessarily done by the passing, all the involuntary damages done by the traveller, must be borne by the owner of the soil. But he is entitled to damages for the excess.

The statute of 1799 , c. 61 , allows the inhabitants of towns to order that neat cattle, horses or horse kind, mules or asses, shall not go at large, without a keeper, under a penalty \&c. Hence it was argued, that the legislature admit, or take it as a settled custom or law, that horses may be suffered to go at large on the higlıways, and of course feed upon the grass there growing.

Ve have seen how clear the conmon law is upon this subject, and that it has been adopted here. Now if the legislature intended such a material alteration as has been contended for, is it to be supposed that they would not have expressed themselves clearly, and not merely by doubtful implication? But did they mean to touch rights protected by the common law? I may ask another question; could they do so, if they were disposed, (which is a case never to be supposed,) without making compensation to the owner? Take the case of a fruit tree standing in the road, but in a situation to afford a convenient shade to the traveller, an ornament and not a nuisance to the way, and yielding an annual profit to the owner of the soil. Now the legislature might, if they thought it expedient, provide by law tinat for

BIG.RIGHTS- 46 
the future the soil of all highways that should be laid out should be vested in the publick, and compensate the owners accordingly. But what constitutional right would they have to devest the owners of the soil of rights remaining, in respect to ways theretofore laid out?

Take the case of a mine under the way, which the owner of the soil may profitably and conveniently work, consistently with the free passage of the people over it. Clearly before the statutes referred to the property remained in the owner of the soil. Can he be divested without compensation? If the legislature can divest him of the trees and herbage, I see no reason why they may not do the same as to all profits, and rights, and property under the way. We do not believe that the legislature would do this, if they had the power. There is no inducement to it. The accommodation desired by the publick is to pass and repass with ease. So it is expressed in the colony law of 1639: "all country highways shall be such as may be most easy and safe for travellers." The pasturage never made any part of the inducement, or reason for laying out highways. And upon the discontinuance of a highway, it never was doubted that the soil belonged to the former owner or his heirs, discharged of the easement.

Upon consideration of the whole matter, we are of opinion that the common law doctrine has been adopted in this commonwealth, and continues unaltered by statute. The defendant therefore cannot justify turning his cattle into the highway for the purpose of grazing; he having no other right there but of passage.

The remaining question is, whether the owner of land, adjoining a highway, unfenced, may maintain trespass against one, who had put his cattle into the highway to graze, because the cattle escaped into the adjoining land, and there ate the plaintiff's grass. And we are of opinion, on the authority of the case of Dovaston v. Payne before cited, and the reason and law applicable to the case, that such action may well be maintained. In the case referred to, the defendant pleaded that his cattle, being in the highway, escaped into the plaintiff's close for want of a sufficient fence. And it was held clearly a bad plea: for the defendant ought to plead and prove that they were passing the highway, and that the defendant was using the same as a highway, and not otherwise. So is the pleading in Herne 828. Defendant said, "he was driving his cow along the highway, from which she escaped into the plaintiff's close for want of fence; and that the defendant followed her and drove her back: and that the cow casually and snatchingly, and against the will of the defendant, sparingly did Dite the grass while returning," \&c.

In Dovaston v. Payne Justice Buller states the question, whether trespass or not, to depend on the fact whether the defendant was passing or using the road as a highway, or whether the cattle were in the road as trespassers.

This depends upon a rule of the common law well settled, that a man is not obliged to fence against any cattle, but such as may be right- 
fully on the adjoining close. The statutes of this commonwealth have not altered that rule; and closes, which are adjoining the highways, are left as at common law.

Now the cattle of the defendant were not rightfully in the highway for the purpose of grazing. If they had escaped from the owner, without any default on his part, he could well have justified. But in such case, he must plead that the beasts were in his view, and escaped, and that he made fresh pursuit. If a man will leave his land unfenced against the highway, he must submit himiself to bear all the casual damages, which may arise involuntarily on the part of travellers. But those who use highways are not to convert the right of passing into a right to take the herbage, which belongs to the owner of the soil.

Defendant's pleas in bar adjudged bad. ${ }^{16}$

\section{BARBER v. PENLEY. \\ (Chancery Dirision, 1893. [1593] 2 Ch. 447.)}

This was a motion for an interlocutory injunction, treated as the trial of an action.

The plaintiff had a lease for twenty-one years, granted in August, 1892, of premises known as Waterloo Chambers, Wych Street, Strand, which she used as a common lodging-house for men of the working classes. The only access to her premises was by a door adjoining the pit entrance to the Globe Theatre.

The defendant was lessee of the Globe Theatre. Shortly before the issue of the writ, he had commenced the performance of a play called Charley's Aunt, which had become at once extremely popular. The doors of the theatre were opened for the evening performances at $7: 30 \mathrm{p}$. m., and crowds of persons collected every evening in the street outside the pit entrance, previously to the opening of the doors. The crowd began to collect about 5:30 p. m., and, as the Judge held on the evidence at the time of the issue of the writ, during the two hours previous to the opening of the doors, occupied the pavement

16 Acc.: Woodruff v. Neal, 28 Conn. 165 (1559).

For other users of the highway that constitute a violation of the rights of the owner of the soil, see Harrison v: Rutland, [1593] 1 Q. B. 142, loitering ou the highway to prevent the owner's use of his own land; Hickman $\therefore$ Maisey, [1900] 1 Q. B. 752, using the highway as an observation post to spy upon the owner; Codman v. Erans, 5 Allen, 308, 81 Am. Dec. 748 (1S6:), building overhanging bay window; Lewis v. Jones, 1 Ya. 336, $44 \mathrm{Am}$. Dec. ¿is (1S45), stacking timber. See, also, leople v. Foss, so Mich. 559, $45 \mathrm{~N}$. W. 480,8 L. R. A. 472, 20 Am. St. Rep. 532 (1S90); State v. Lavis, so N. C. 251,30 Am. Rep. 86 (1879).

The question as to how far or under what circumstances State or municipal authorities may authorize the use of a street for purposes such as the laying of pipes, erection of electric liglst and other yoles, laying of cal $r$ tracks, etr.; withont compensating the alutting owner, who lias title to the street is dealt with in Ilall's Cases on Constitutional law, p. 75 i et seq. 
in front of the plaintiff's premises in such way as to obstruct access to them, notwithstanding that policemen had been employed at the expense of the defendant to preserve order.

The plaintiff complained that, by reason of such obstruction, her customers were impeded in getting to her house at the hour when, after their day's work, they were in the habit of seeking lodgings. The evidence shewed also that both parties had made representations to the police authorities, and that previously to the hearing of this motion additional policemen had been employed, and the pavement in front of the premises was then kept entirely clear. The motion before the Court was for an injunction till trial, to restrain the defendant from carrying on the Globe Theatre, so as (by causing crowds to assemble or otherwise) to obstruct the access to or egress from the plaintiff's premises, Waterloo Chambers.

North, J. ${ }^{17}$ stated the nature of the action, and continued:

It was said that the plaintiff had taken these premises with the knowledge that there was the theatre next door, which is quite true, and that is a matter which is deserving of consideration. A person who deliberately goes next door to a theatre cannot expect to have precisely the same amenities in Wych Street that the lessee of a private house in a street occupied by private houses only in the West End would expect; but still such a lessee has a right to expect that no nuisance shall be committed to the prejudice of such person. The collection of playgoers in the street would to some extent be a public nuisance, if a nuisance at all; but certainly it would be a private nuisance to the plaintiff, in respect of which, if proved, the plaintiff would have a right of action.

[After considering the evidence as to the obstruction, on which he considered, that when the writ was issued there was, previously to the opening of the door of the theatre, such obstruction as to render access to the plaintiff's premises very difficult, his Lordship continued:]

* * * Then there is another case in the same volume-Rex v. Jones, 3 Camp. 230 - where it was held to be an indictable offense for a timber merchant to cut logs of timber in the street adjoining his timber-yard, and Lord Ellenborough said: "If an unreasonable time is occupied in the operation of delivering beer from a brewer's dray into the cellar of a publican, this is certainly a nuisance. A cart or waggon may be unloaded at a gateway; but this must be done with promptness." Then he gives other illustrations. Then at the end, speaking of the particular case before him, he says: "I cannot bring myself to doubt of the guilt of the present defendant. He is not to eke out the inconvenience of his own premises by taking in the public highway into his timber-yard; and if the street be narrow, he must remove to a more commodious situation for carrying on his business." * * * Lord Justice Giffard says (Law Rep. 4 Ch. 397): "In 
Inchbald v. Robinson the whole of the case made by the bill is, that the circus will draw together a great crowd of disorderly persons. The evidence in support of this allegation is insufficient, and if an injunction in such a case wcre to be granted and upheld, it would prevent the setting up near a dwelling-house of any exhibition likely to be attended by a large number of people."

It was said that this was an authority to shew that the plaintiff would have no right to complain of the nuisance caused by persons coming to and going from the theatre; but, in my opinion, that does not apply to the case I have to deal with. It is not here a coming to and going from that is complained of; it is the nuisance caused by those who intend ultimately to get into the theatre collecting in the street outside the theatre and remaining there, which is quite a different thing from coming to or going from it. There is no complaint here of the use of the theatre, either as regards persons who come to it without having to stop in the street so as to be a nuisance to the plaintiff, nor is there any complaint made here of the persons who are going away from the theatre at the end of the performance. It was also said that there was a distinction between outdoor and indoor performances, that this case was an authority to that effect. That there may be a distinction in detail and result I can quite understand; but I do not see where the distinction in principle is. If a defendant does within his premises what causes a nuisance outside, it does not matter whether the nuisance is caused by what goes on inside being actually visible cutside and so causing the crowd to collect, or whether, by reason of what is going on, or what is about to go on inside, he causes the crowd to collect. It seems to me the principle of both is the same, though the application is somewhat different.

Then it is said that the defendant could not prevent a crowd from gathering. and that it was a police matter. It does appear that the refendant did from the first tell the police that assistance would be necessary to regulate the crowds; but I find that the plaintiff did that also, and, although that was done, no such interference took place as prevented the arising of the nuisance complained of. I think the defendant's own evidence confirms the plaintiff's evidence as to crowds that collected, because he himself says that, although at half-past five there is no crowd to complain of, it is not until half-past six that a large number of persons then collect, and I take it that is an admission that from that time onwards at any rate there were such persnns. As regards the defendant's suggestion that he could not help it, if in point of fact the nuisance exists which is caused by him, not with an object to cause that nuisance, but by reason of the entertainment he carries on, and to which he invites the public to come, it seems to me that it is a case in which either he must discontinue his performance or the nuisance must be prevented. In this case the police have taken the matter into their control, and it is clear from the affidarit of the plaintiff in reply that they can effectually prevent 
the nuisance. The affidavit in reply says there has been no subject of complaint whatever since a recent date subsequent to the commencement of the action, and there it appears that the police have taken control and have prevented a nuisance arising. It is said the defendant ought to prevent this; but he cannot do it-of course he has no control over the streets, he cannot put persons in the street to regulate the crowds, and one of the first things the police would do would be to prevent the interference by other persons with the traffic of the sireet. Still, this nuisance did exist, and in my opinion the plaintiff is entitled to be relieved from it.

But in this case I do not propose to grant any injunction. In the first place I do not think it necessary; no injunction is wanted now, because, as the plaintiff's own affidavit, to which I have just referred, says, the nuisance has been put a stop to. *** If he [the defendant] had claimed a right to obstruct I certainly should have granted an injunction. As he does not claim that right, I do not think an injunction is necessary, and therefore I do not propose to grant it. Then there is another reason why I should not do so. As I have said, I have not the least doubt that the police will do all that is necessary; but, supposing that there was a great fire or a great demonstration or anything else that caused extraordinary and sudden demand upon the services of the police, and the police could not be there to prevent the crowd, and it did happen on some particular occasion that there was a nuisance, I do not intend to expose the defendant to a motion to commit by reason of such an accidental interference with the plaintiff's rights.

The result is, that I do not think it necessary to grant an injunction, and I do not propose to do so; but in my opinion the plaintiff was justified in bringing the action, and, therefore, the order will be: "It appearing from the plaintiff's affidavit in reply" (referring to it) "that the nuisance has been discontinued, the Court doth not think fit to make any order except that the plaintiff's costs of the action shall be taxed and paid by the defendant." 18

\section{TUCKER et al. v. ELDRED et al.}

(Supreme Court of Rhode Island, 1860. 6 R. I. 404.)

Trespass for breaking and entering the close of the plaintiffs in South Kingston, and cutting down the trees, wood, timber, and brushwood of the plaintiffs, and burying the same under the ground.

The case, which had been appealed from the court of common pleas, was tried, under the general issue in this court, at the February term

18 See Graves v. Shattuck, 35 N. H. 257, 69 Am. Dec. 536 (1557); Callanan v. Gilman, 107 N. Y. 360,14 N. E. 264, 1 Am. St. Rep. 831 (1887); Raymond v. Keseberg, $\$ 4$ Wis. 302,54 N. W. 612,19 L. R. A. 6t3 (1S93). 
for the County of Washington, 1860, with a jury, when it appeared, that the town of South Kingston, having laid out a highway through the farm of the plaintiffs, and having paid the damages assessed against them therefor, under the statute, the defendants, who were the townsergeant and his assistants, in opening and making the same through a space of some thirty-nine rods long by three rods wide of woodland, cut down the trees of the plaintiffs growing thereon, and used, as materials in building the road in the swampy places, the wood and brush so cut on the land of the plaintiffs taken for the road.

The jury assessed the plaintiffs' damages at thirty dollars; the verdict being, by agreement, subject to the opinion of the court, upon the question of law: Whether trees and brushwood growing upon land condemned to the uses of a highway, are, under the statute, included in the condemnation and estimate of damages, or, when removed by the surveyor for the purpose of opening and building the new highway, are to be left for the use of the owner of the land?

Brarton, J. The question submitted to the determination of the court in this case, is whether a surveyor of highways is justified in law, not merely in cutting and removing timber standing or growing within the line of the highway newly laid out, and which straitens, hinders, or incommodes the public in traveling, but in using the timber grown there in the construction of the way?

By the general rules of law, the public have but an easement upon the land lying within the lines of the highway. Notwithstanding the laying out of the highway and the condemnation of the land to the use of the public for travel, the title to the soil, and all the profits thercof consistent with the existence of the easement, remain in the original owner. He has a right to the freehold and to all the profits which may be derived from it, consistently with the right of passage of the public,-to all mines beneath the surface, to all trees, grass, and pasturage upon and above the surface. Goodtitle v. Aiken, 1 Burr. 133; Sterens v. Whistler, 11 East, 51; Doe v. Wilkinson, 3 B. \& C. 413: Perley v. Chandler, 6 Mass. 454, 4 Am. Dec. 159; Jackson v. Hathaway, 15 Johns. (N. Y.) 447, 8 Am. Dec. 263; Gidney v. Earl, 12 Vend. ( $\mathrm{N}$. Y.) 9S. Our statutes (ch. $43, \S \mathrm{S}$, ch. 44 , $\$ 17$, of the Rev. Sts.) provide, that upon the laying out and establishment of a highway, everything upon the land which shall in any way straiten, hinder, or incommode the travel, may be removed therefrom; as buildings, fences, trees, or other thing whatsoever. This right the law would imply without the statute; since upon the passing of the easement to the public, everything reasonably necessary to its enjoyment passes with it.

This power is necessarily vested in the surveyor of highways, who is appointed by law to keep the way in repair for the convenience of the public. He, therefore, nay remove the trees, if they in any way interfere with the travel; but the right to remove gives him no property in them. 
There seems to be no difference in this respect, certainly no material difference, between a public and a private way. In the one case, the easement is for the benefit of the general public; in the other, for that of an individual; but in neither case does any property in the land, or its incidents, pass from the owner of the soil; and the individual, in the one case, and the public in the other, are to make and maintain the way in proper condition for travel, at his or their own expense. If the way may be made cheaper with timber than with earth, it must be provided by them; and if they will take that which is another's for this purpose, they do it at their peril.

Ir is said, indeed, that in the assessment of damages for the laying out, the use of the wood is made an item of these damages. The damages for which the statute provides, are, "the damages which the owners of the land shall sustain by means of such highway passing through their lands;" that is, the damages which they may suffer from the right of the public continually to pass over their lands,- the adaptation of the soil to that passage,- the removal of everything therefrom which may interfere with the travel, and the fact that they must, by such use, be deprived, to a great extent, of the profit of the soil; the growth of timber thereon being one source of profit. These damages are necessarily assessed before the land is entered upon for the purpose of making the way; and, therefore, cannot be for all the injury, necessary or unnecessary, which may be actually done by the surveyor or other person, in making the way, and opening it for travel. The assessment can only be for such damages as necessarily will be done to the owner of the land in order that the public might be enabled conveniently to pass over the land. The use of the timber in the construction of the way is certainly not reasonably necessary to the passage of the public; though the removal of it from the path may be, and would be. Until such necessity is shown, no reason is shown why the value of the timber should be an item of damages to be awarded to the owner of the land.

The same reason is equally conclusive against the right of a surveyor of highways, in the course of repairing or amending the same, from doing more in relation to the timber growing within the lines of the highway, than to cut down and remove it, so that it shall not impede the travel. According to the agreement, therefore, judgment must be entered upon the verdict. ${ }^{18}$

19 Compare Aurora v. Fox, 78 Ind. 1 (1S81); Stretch v. Cassopolis, 125 Micb. 167,84 N. W. 51, 51 L. R. A. 345, 84 Am. St. Rep. 567 (1900); Rich v. Minneapolis, 37 Minn. 423, 35 N. W. 2, 5 Am. St. Rep. 861 (1S57); Cole v. Drew, 44 Vt. $49, \mathrm{~S}$ Am. Rep. 363 (1871). 


\section{MOREY v. FITZGERALD.}

(Supreme Court of Vermont, 18s4. 56 Vt. $4 \$ 7,48$ Am. Rep. 811.)

ROWELL, J. The evidence on the part of the plaintiff tended to show that for about six years next before the commencement of this suit, the defendant was in the habit of driving his horse and carriage outside of said pent-road on to plaintiff's meadow, thereby cutting up the soil thereof and trampling down the grass then and there growing; but the particular times when said supposed trespasses were committed were left wholly indefinite. The defendant justified, for that at the said several times when, etc., said road was dangerous and impassable, wherefore he drove extra viam, as he lawfully might. The plaintiff's evidence being thus indefinite as to the said times when, it was competent, and indeed necessary, for the defendant to meet it with evidence as to the general bad condition of the road equally indefinite as to time.

The exceptions state that "there was no evidence tending to show that the gate was on the plaintiff's land except as herein stated," but it is not therein stated that there was such evidence. In the charge the court say it does not conclusively appear that it was on plaintiff's land; but this cannot be taken as showing that there was evidence tending to show that it was on his land. This remark of the court is made incidentally only, and by way of giving a reason for its ruling that plaintiff could not recover for the removal of the gate. Hence there was no apparent error in the court's refusal to comply with plaintiff's first request, nor in the charge on the subject-matter thereof.

The court complied with the plaintiff's seventh request, but refused to comply with his second, third, fourth, fifth, and sixth requests; and the main question arises on the exceptions to such refusal and to the charge in respect thereto.

It is a maxim that private mischief shall be endured rather than a public inconvenience. That regard be had to the public welfare, is the highest law. Hence, if a public highway be out of repair and impassable, a traveller may lawfully go over the adjoining land, since it is for the public good that there should be at all times free passage along the highways for all the subjects of the State. In such case, an interference with private property is obviously dictated and justified summa necessitate, by the immediate urgency of the occasion, and a due regard to the public safety or convenience. Broom Leg. Max. 2; Lord Mansfield, C. J., in Taylor v. Whitehead, Dougl. 749; Lord Ellenborough, C. J., in Bullard v. Harrison, 4 M. \& S. 393. But such obstruction must be from sudden and temporary causes, and of such a character as to render the road founderous and impracticabie.

The leading case in this country on the subject is Campbell v. Race, 7 Cush. 408. in which the highway was obstructed and rendered im[assable by snowdrifts. But such a right, having its origin in neces- 
sity, must be limited by the necessity that creates it, and does not exist from convenience merely, nor when, by the exercise of due care, after notice of obstructions, other ways may be used and traveling extra viam thereby avoided. It is to be confined to cases of necessity arising from sudden and recent causes that have occasioned temporary and impassable obstructions in the way.

But it is said that the obstructions in this case were not sudden, unforeseen, and temporary, but continuous, notorious, and permanent; and great stress is laid on the phrase, "unexpected and unforeseen occurrences," used by the court in Campbell v. Race. But the obstruction in that case was of the same kind as one of the obstructions in this case, and of the same nature as to being uncxpected and unforeseen as the others. Surely, the formation of ice or the occurrence of a washout in a highway is just as unexpected and unforeseen as a snowdrift, and in this latitude none of them are unexpected at ccrtain seasons of the year, or unforseen except in the sense that the precise time of their visitation cannot be foreknown.

And although the defendant knew of the founderous condition of the road before he attempted to pass over it, he was not thereby deprived of the right he otherwise would have had to travel it. One has a right to travel highways when he is not thereunto impelled by imperious necessity as well as when he is, provided always that he uses them for the purposes for which they are constructed and maintained. But when one knows that a highway is so obstructed as to necessitate a divergence therefrom on to adjoining land in order to get past founderous portions thereof, it is his duty to the adjoining land-owner to go some other way if there be one reasonably available to him, rather than thus to deviate. But this case does not show that there was another way available to the defendant. All that is shown, is, that there was no evidence tending to show that defendant could not have gone some other way and thus have avoided going upon plaintiff's land. But this is not enough. Every reasonable intendment is to be made in favor of the correctness of the judgment below; and it is a cardinal principle, too often lost sight of by counsel, that error is not to be sought after, but nust be made affirmatively to appear.

The defendant's evidence tended to show that the obstructions were formidable though temporary in their character; and the court charged the jury that if they found them to be what the defendant's evidence tended to show them, and dangerous to pass over, the defendant was not bound to remove them; and in this there was no error. If the obstruction is such that to remove it would materially delay the traveler in his journey, and impose upon him any considerable labor, no duty of removal is upon him. Besides, his right to cast quantities of earth and stones into a washout, or to cast and throw material out of the way, and perhaps on to adjoining land, may in many cases be fairly doubtful, to say the least. So unless the obstruction can be readily and easily removed by the travcler, he is not bound to remove it, 
lut may lawfully travel extra viam, doing as little damage as possible. 'Tlie obstacles that the defendant's testimony tended to show impeded the way were obviously not of this character; but the jury inust have found them to have been dangerous.

It is further objected that defendant should have taken measures to have the road repaired or have provided himself another way. But 110 such duty rested upon him. It was the duty of the town to keep the road in good and sufficient repair at all seasons of the year; and because it did not perform that duty, it did not devolve in any part upon the defendant, nor impose upon him the duty of providing himself another way. The road was still a highway, and the defendant had a right to travel it as such, and in so doing he was in the exercise of a public right.

It is further objected that these obstructions were too long in the way to be deemed temporary, but are fairly to be deemed permanent. 1:ut it is the nature and character of the obstruction rather than the time of its duration that is determinative in this respect. Snow and ice are temporary in their character, although often uncomfortably permancut in their duration. So washouts that impede and obstruct travel may justly be deemed to be temporary; for it is the duty of towns to make them so, and the common course that they are.

The charge was justly applicable to the case as disclosed by the evidence, and we find no error in it nor in the refusal to charge as requested.

Judgment affirmed. ${ }^{20}$

20 In addition to the cases cited in the opinion, see Aruold $\mathbf{v}$. Holbrook, I. Ii. \& Q. B. 96 (1S73); State v. Brown, 109 N. C. 802 , 13 S. E. 940 (1S91). 



\section{INDEX}

[THE FIGURES REFER TO PAGES]

ADVERTISEMENTS,

Right to affix to party walls, 236 note.

ARTIFICIAL WATER COURSES,

Rights in, 253 Wood, 256 Mason, 261 note.

ASPHAIT,

Rights in, 54 note.

ASSIGNEE,

Liability of, for breaches of covenants in leases, 389 Mason, 391 note.

Of lessee, at common law, 338 Brool, 338 Thursby, 339 Sugden.

Of lessor, at common law, 338 Brook, 338 Thursby, 339 Sugden.

Of part interest in lease, liability of, 395 Congham, 395 Holford.

of part interest in reversion, rights of, 404 Attoe, 405 Twynam, 407 Demarest.

Of unsealed instruments, liability of, 410 Buckworth, 412 Hinsdale, 414 Standen, 489 Burbank, 490 Kennedy.

Rights of, 419 note.

When must be mentioned to make covenant run, 341 Spencer, 342 note, 343 Masury, 349 Purvis, 351 note, 442 Brown, 445 note. See Assignment.

\section{ASSIGNMIEN'T,}

Covenant against, when broken, $35 \mathrm{~S}$ Williams, 361 note.

Corenantee's rights, effect of, on, 391 Mascal, 392 Stoddard, 393 Wills.

Covenantor's liability, effect of, on, 383 Brett, 384 Wall, 384 Washington, 387 Jones, 388 note.

Of covenantee's rights, 378 note, 423 note, 502 Randall.

Of interests in leases not under seal, 416 Bickford, $418 \mathrm{Cobb}, 419$ note.

Of lease, effect on rent, 549 Walker.

of reversion, effect on reut, 558 Harmer, 559 Damren, 559 note.

Sublease, distinguished from, 395 Holford, 396 Earl, 398 McNeil, 404 note.

ASYLUM,

Right of, to use stream, 77 Filbert.

BRANCHES PROJECTING,

Right to remove, 3 note.

BREACH,

Continuing, right of action for, 391 Mascal, 392 Stoddard. 393 Wills.

What is, 384 Washington, 387 Jones, 388 note.

\section{BUILDINGS,}

Altering, when waste, 653 Klie, 655 Melms.

Damage to, right of leversioner to recover for, 143 Green.

When recoverable, 36 Rolle, $40 \mathrm{Smith}, 46$ Foley, 49 Charless.

Destruction of, as affecting rent, 575 White, 577 Wattles, 579 Grares.

Prescriptive right to support of, 36 Bonomi, 39 note. CITY.

Right of, to stream, for domestic user, 79 Canton, 82 note.

COMPFTITION,

Agreenents restraining, when run, 448 Natlonal, 506 Norcross, 510 note.

Bia.Riants

(733) 
COVENANTS,

Assignee, of lease with, at common law, 338 Brook, 338 Thursby, 339 Sugden.

Of reversion with, at common law, 338 Brook, 338 Thursby, 339 Sugden.

Burden of, do not run, when, 458 Miller, 462 note, 462 Wiggins, 467 Farmers.

Chattels, do not run with, 420 Allen, 422 note.

Esse, in, things not, relating to, 341 Spencer, 342 note, 343 Masury, 349 Purvis, 351 note.

Fee, conveyances in.

Assigns, need not be mentioned, 442 Brown, 445 note.

Privity, what constitutes, 429 Morse, 431 note, 432 Hurd, 435 Horn, 438 note, 439 Burbank.

What run, 427 Palsenham, 448 National, 452 Gilmer, 455 note, 455 Atlanta, 458 Miller, 462 note, 462 Wiggins, 464 Wooliscroft, 467 Far'mers.

Fence, to maintain, 270 Bronson.

Lessee by, effect on, of eviction, 592 Carrell, 598 Smith.

What run, 352 Cockson, 352 note, 353 Mayor, 355 note, 358 note, 358 Williams, 364 Vyvyan, 367 Gower, 369 Northern, 373 note.

Who may enforce, 352 note, 355 Thruston, 358 note, 361 Vernon, $36 \pm$ Vyvyan.

Lessor, by, what run, 373 Jourdain, 374 Woodall, 376 Hollander, 379 Thomas, 379 note, 380 Dewar.

Who may enforce, 373 note, 374 Woodall, 376 Hollander, 380 Dewar.

Iiability as on, in deed poll, 412 Hinsdale, 489 Burbank, 490 Kennedy.

Party wall when run, 471 Gibson, 475 Conduitt, 479 Southworth, 482 Crawford, 486 Lincoln.

Rent charge, to pav, 566 note.

See Assignee, Assignments.

CusTom,

Easement acquirable by, 180 Abbott, 181 Graham.

Profit not acquirable by, 176 Smith.

DAM,

Lower riparian's right to have maintained, 259 Matheson, 262 Kray.

Upper riparian's right to maintain, 54 Embrey, 61 Dumont.

DAMAGES,

Comparative, as element in granting injunction, 23 Hennessy, 29 Madison.

Land, to, how estimated, 49 note.

When recoverable by reversioner, 140 Baxter, 144 note.

Nominal, disturbance of possession, in, 1 Pfeiffer.

Nuisances, in, 32 Sturges, 35 note.

Subsidence of land, in, $40 \mathrm{Smith}, 41$ note.

DITCHES

Water in, as personal property, 266 note.

DOMESTIC USER OF STREAM,

it Filbert, 79 Canton, 82 note.

DRAINAGE,

Easement of, 209 Wood, 221 Durfee.

License for, revocable, 304 Hewlins, 328 Wlseman.

EASEMENTS,

Affirmative, 268 Rider, 270 Bronson, 273 Castner.

Appurtenant, not sererable, 194 Cadwalader, 197 note.

Continuance of, right of servient to, 253 Wood, 256 Mason, 259 Matheson 262 Kray.

Contract to give, 316 Frogley.

Custornary, 180 Abbott, 181 Graham. 
EASEMENTS-Continued,

Damage to, by servient, 221 Durfee, 222 note.

Dominant estnte, change in character of, 207 White, 209 Wood.

Dr:ıinage, 209 Wood, 221 Durfee.

Exclusive, 230 note.

Extinguishment of, see Extinguishment.

Fencing, 270 bronson, 273 Castuer.

Gross, in, 185 Acliroyd, 187 Boatman, 190 Standard, 193 note.

Interference with, 222 At torney General, 225 Bitcllo, 227 note.

Loration of, 220 note.

Nature of, 197 IIill.

Prescriptive, extent of, 201 Williams, 203 Parks, 205 note.

Repair of, 216 Edgett, 218 Dudgeon, 219 note, 268 Rider.

Struetures, in, 240 Shirley, 212 note, 243 Douglas.

See Party Walls.

User, change in as affecting, 207 White, 213 Gray, 215 note.

Varieties of, 200 note.

Water pipes, for, 213 Grar.

Way, scope of, 201 Howell, 201 Williams, 20 ? note. 205 Watson, 207 White, 218 Dudgeon, 227 note, 22S Pittsburgh, 230 Atlantic.

Water courses, artificial, in, 253 Wood, 256 Mason.

\section{EJECTILNT,}

For overhanging wire, 3 Butler.

EMIBANKMINTS.

Obstructing water, liability for, 102 note.

EMINENT DOMAIN,

Efrect on rent of taking by, 5S5 Parks, 587 Biddle.

EQUITABLE ENFORCEMENT OF AGREEMENTS RELATING TO LAND, Aftirmative agreement, 496 Haywood, 498 Hall.

Benefit, when runs, 511 Hansard, 513 note, 513 Renals, 517 Weil, 521 note, 521 Parker, 525 Clark, 528 note, 529 Winfield, 531 Formby, 535 note, 53. Van Sant.

Burden, when runs, 513 Renals, 517 Teil, 525 Clark, 53 s Gollner.

Dominint estate, need for, 531 Formby, 535 note, 535 Vau Sant.

Notice, 495 note.

Privity, 496 note.

Reason for, 494 Tulk, 496 Haywood.

Suppressing competition, 506 Norcross, 510 note.

When refused, $5 \pm 1$ IeClure, $5+5$ Loud, 546 note, 547 note.

ESSE,

Iu, corenant relating to things not, when runs, 341 Spencer, 343 Masuryi 349 Purvis.

EVICTION,

Constructive, when, 600 Pendleton, 606 Egerton, 610 Bass, 611 Stewart, 613 University.

FXTINGUISIMENT OF FASEMENTS,

Abandonment, by, 277 Mciore, $2 \$ 0$ note, 280 Crain, 286 Pratt, 291 note, 294 Fitzpatrick.

Arceptance of new casement, by, 295 Fitzpatrick, 299 note.

Adverse user by servient, by, 293 .Jennison, 295 note.

Cluange in dominant estate, by, 277 Moore.

Comluet of dominant incompatible with easement, by, 2S0 Crain, ss: Dillman.

Estoppel, by, 295 Erowne, 298 note.

Excessire user, ly, 28t irc Cullough.

License, by, 290 Winter.

Merger of estates, by, 299 Ritger.

Nonuser. by, 277 Moore, 286 I'ratt.

Obstruction by sorvient, by, 290 Winter, 291 Rogers, 293 Jennison.

I'arol, by. 2:2 note. 
FEE, Corenant to convey by lessor, whether runs, 374 Woodall, 376 Hollander. FEXCE,

Easement oblication to maintain, 270 Bronson, 273 Castner.

Obstruction of way, by, 227 note.

Equitable enforcement of obligation to, 505 Countryman.

\section{GAS,}

Escaping, illness caused by, when actionable, 12 note.

Natural, rights in, 136 Hague, 139 note.

\section{HIGHWATS.}

Deviation from, 729 Mores.

Obstrution of, 723 Barber.

Ownership of, $71 \mathrm{~s}$ Goodtitle.

Pasturing cattle on, 719 Stackpole.

Public use of, what is, 719 Stackpole. 723 note.

Timber cut from, ownership of, 726 Tucker.

HEAT,

Failure to furnish, as constructive eviction, 610 Bass.

INCORPOREAL INTERESTS,

Leases of, 426 note, 636 Hancock, 636 note.

INDEMNIFY,

Corenant to, when runs, $36 \ni$ Northern, 373 note.

INJUNCTION,

Discretion as to issuance of. 23 Hennessy, 29 Madison.

Trespass, against, 8 Richards.

IASCRE,

Corenar.t to, when runs, 343 Masury, 361 Vernon.

INTEREST,

License coupled with, when irrerocable, 316 note.

IRRIGATION,

Streams, use of, for, 54 Embrey, 64 Meng.

I.AND,

Buildings on, how far entitled to support, 36 Rolle, 40 Smith, 46 Foley, 49 Charless.

Care, degree of in excavating, 46 Foley, 49 Charless, 52 note.

Damages to, how estimated, 46 Foley, 49 note.

Recovery for, by reversioner, 140 Baxter.

Neighboring, what is, 42 Birmingham.

Riparian, what is, 71 Jones.

Subsidence of, when actionable, 40 Smith, 41 note.

Support of, nature of right to, 36 Bondmi, 39 note, 42 Birmingham.

IEASE,

Assignment of, distinguished from sublease, 395 Holford, 396 Earl, 398

MeNeil, $40+$ note.

Part, assignment of, 395 Congham, 395 Holford.

LEVANT AND COUCHANT,

Defined, 161 Cole.

\section{LICENSE,}

Easement, to extinguish, when irrevocable, 290 winter.

Frauds, stitute of, not within, 303 Wood.

Interest, roujled with a, 316 note.

Irrevocable, when, 303 Wood, 315 Rerick, 322 note, 331 Hurst.

Iease, contraster] with, 313 note, sil6 note.

Niture of interest reated by, üt Hewlins, 309 Wood, 218 Rerick, 328

Wiseman, :31 Ilurst. 
[The figures refer to pages]

LICENSE-Continued,

Revocable, when, 304 IIewlins, 309 Wood, 313 Drake, 323 St. Louis, 328 Wiseman.

Revocation of, by conveyance, 313 Drake.

Riparian right, to extinguish, irrerocable, 305 Liggins.

Timber, for removal of, 313 Drake.

\section{LICENSEE,}

Right of action against third persons, 336 Miller.

LOCOMOTIVE,

Use of stream to supply, 68 Garwood.

"MAKE OR SUFFER,"

498 Hall, 501 note.

MERGER,

Right to rent lost by, 566 Webb. 569 McNurphy, 571 Smiley, 572 Beal.

Waste, action of, effect of, on, 682 Dickinson.

MINES.

Opening, when waste, 649 Gaines.

MONEY,

Running of covenant for, payment of, 464 Wooliscroft, 467 Farmers.

NECESSITY,

Way of, when ceases, 302 note.

NEGLIGENCE,

Buildings, in damage to. 46 Foley, 119 Fitzpatrick, 120 note.

Fences, in damage to, 275 note.

Land, in damage to, 49 Charless, 52 note.

Nuisance, in, 29 note.

Party walls, in raising, 235 note.

Underground waters, in damage to, 129 note, 132 Kinnaird, 134 note.

Waste, in, 659 Countess, 660 note, 667 Chalmers, 670 Earle, 672 Atlantic.

NOTICE TO ADJACENT OWNER, '

When necessary in excavating, 49 Charless, 52 note.

NUISANCE,

Action for, by whom maintainable, 11 Kavanagh.

Dust as, 21 note.

Hospital as, 21 Stotler, 23 note.

Injunction asainst, whether discretionary, 23 Hennessy, 29 Madison.

Negligence, not an element in, 29 note.

Neighborhood. character of. in determining, 13 Ross, 21 note.

Noise as, 17 Romer, 21 note, 23 Hennessy.

Pigpen as, 23 note.

Prescriptive right to maintain, 32 Sturges, 35 note.

Priority in location of, immaterial, 34 note.

Property, damage to, as, 23 Hennessy, 29 note.

Reversioner's right to sue with respect to, 141 Simpson, 145 Park, 146 not.-

Saloon as, 23 note.

Sanitarium as, 23 note.

Smoke as, 12 Ross.

Stallion, breeding place of, as, 23 note.

Vibrítion as, 23 Henness 5 , 32 Sturges.

OIL,

Rights in, 140 note.

PARTY WALISS,

Advertisements, right to affix to, 236 note.

Covenants relating to, 471 Gibson, 475 Conduitt, 479 Southworth, 482 Craw ford, 486, Líncoln.

Destruction, effect of, on easement in, 242 note, 246 Sherred.

Big.Rigits -47 
PARTY WALLS-Continued,

Easements in, 232 Brooks, 236 note.

Quasi contractual right to recorer for cost of, 246 Sherred, 249 Spaulding, 252 note, 485 note.

Raise, when may, 232 Brooks, 235 note.

Tear down. when may, 237 Putzel.

Windows, insertion in, 236 note.

PONDS.

Rights in, 97 Schaefer, 99 note.

POSSESSION,

How giren bs sheriff, 3 Butler.

Injunction to protect, 8 Richards.

Violation of, actionable, 1 Pfeiffer.

Arm projecting is, 3 note.

Branches projecting are, 3 note.

Cares projecting are, 2 Smith.

Wire orerbanging is, 3 Butler.

POWER,

Corenant to supply, when runs. 458 Miller.

PRESCRIPTION,

Air, none in, 33 Webb.

Nuisance, right to, by, 32 Sturges, 34 note, 35 note.

Streams, when right acquired in, by, 73 Messinger, 74 note, 86 note, 88 Stockport.

Underground waters, none in, 124 note.

PRIVITY

What constitutes, 429 IIorse, 431 note, 432 Hurd, 435 Horn, 438 note, 439 Burbank.

\section{PROFIT,}

Appurtenant, 167 Hall, 173 Huntington, 176 note.

Assignment of, 153 Mountjoy, 155 Tottel.

Customary, none, 176 Smith.

Division of, 163 Rotherham, 164 Cole, 167 Hall.

Easement, distinguished from, 177 Race.

Exclusive, 154 Dowglass, 155 Grubb, 157 note, 158 Cald

Extent of, 153 Mountioy, 154 Dowglass.

.Extinction of, 163 Rotherham, 164 note, 164 Cole, 167 Hall.

Grant of, 155 Tottel.

Gross, in. 155 Grubb. 164 Drurs, 176 note.

Prescription for, 154 Dowglass, 154 note.

Severance of, from dominant estate, 164 Drury, 164 note, 165 Phillips, 167 Hall.

PROHIBITION STATUTE,

Effect of, on rent of hotel, 589 Lawrence.

PROPERTY,

Damage to, as nuisance, 23 Hennessy.

Real, defined, 3 Butler.

QUASI CONTRACT,

Right to recover for cost of party wall, in, 246 Sherred, 249 Spaulding, 252 note, 485 note.

RAILROAD,

Ijability of, for obstructing mater, 102 note.

Right of way, nature of, 228 Pittsburgh, 230 Atlantic.

Right to usè water for locomotives, 68 Garwood.

RENT,

Actions for, 562 Harvey, 563 Wilston, 564 Ioyd, 565 St. Geo. II, 565 Anon. Apportionment of, 575 White, 577 Wattles, 632 Anon., 632 Emmott, 633 Anderton, 635 Salmon. 
RENT-Continued,

Assignment of, 561 Ards, 562 note.

Attornment, 552 St. 4 Anne.

Chattels, payment for use of, not, 632 Emmott, 633 Anderton.

Constructire eviction suspending, 600 Pendleton, 606 Egerton, 610 Lass, 611 stewart, 613 Unirersity.

Contract debt not, 637 First, 638 note.

Covenant to pay, when runs, 364 Vyryan.

Destruction of premises extinguishing, 575 White, 577 Wattles, 579 Grares, 581 note.

Distraint for, 549 note, 565 Anon., 633 Anderton, 636 Hancock.

Divided when, 561 Ards.

Eninent domain, takiñg by, extinguishing. 5S5 Parks, 587 Biddle, 597 note.

Exelusion from premises suspending, $59 t$ Pridgeon.

Extinguishment of, 566 Webb, 569 MeMurphy, 571 Smiley, 579 Graves, 585 Parks, 5S7 Biddle.

Guaranty of payment of, 420 Allen, 424 Walsh.

Kinds of, distinguished, 549 note.

Lessee, assignment by, 383 Brett, 384 Wall. 549 Walker.

Lessor, eriction b5, suspending, 591 Cibel, 592 Rolle, 592 Carrell. 593 Page, $593 \mathrm{Smith}, 593$ note, $59 \mathrm{~S}$ Smith.

Merger, loss of, by, 566 Webb, 5f9 McMurphy, 5il Smiley, 572 Beal.

Not divisible in time, 552 Bank, 556 Rochinglkam, 558 note.

I'rior valid lease, effect of, on, 617 Neale, 622 Lawrence, 621 Friend, 627 Moore, 628 Smith.

Prohibition statute, effect of, on rent of hotel, 599 Lawrence.

Rescrved on lease of lessor's entire interest, 562 Newcombe, 563 Wilston, 56.4 Ioyd. 565 Anon., 569 Me.Iurphy, 571 Smiley.

Reversion, assiqnment of, effect on, 555 Harmer, 5ig Damren, 559 note.

Superinr title, eviction by, suspenis, 581 Fitrhburs, 5ss Seabrook.

Suciension of, 5\$1 Fitchburg, 55. Seabrook, 591 Cibel. 592 Rolle, 593 Page. 503 Smith, 506 Prillgeon, 600 Penlleton, 610 Barr, 613 University.

Trespiss by lessor, effect of, on, 591 Bennett.

When due, 552 Bank, 554 note.

REPAIR,

Covenant to, 3so Dewar, 383 Prett.

Vasement obligation to, 268 Rider.

REVERSION,

A sigmment of part interest in, 404 Attoe, 405 Twrnam, 407 Demarest.

of unsealed lease, right of assignee of, 416 Bickford, 415 Cobb.

REVERSIONER,

Recovery by, for, damage to building, 143 Green.

Damage to land, 140 Baxter.

Diversion of water, 144 note.

Nuisance, 141 Slmpson, 145 Park, 146 note, 147 Miller.

RIPARIAN IAND,

What is, 71 Jones.

SAIYMILI,

When may discharge in stream, S3 Hayes, SG note, S7 note.

SEMIILUID SUMSTANCES,

Right of support in, 54 note.

\section{STREAMS,}

Abandonment of rights in, 259 Matheson, 262 Kray.

A rid states, law in, relating to, 71 note.

Covenant resulating use oi, 432 Hurd, 435 Horn, 43 sote.

Dam, right to, 61 Dumont.

Detention or', 61 Dumont, 63 note, 262 Lray. 
STREAMS-Continued,

Diversion of, 58 Webb, 68 Garwood, 69 Gillis, 71 note, 259 Matheson.

Action by reversioner for, 144 note.

Right of lower riparian to have continued, 256 Mason, 259 Matheson, 262 Kray.

Docking, light to use for, 712 Pollock, 715 note.

Domestic user of, 77 Filbert, 79 Canton, 82 note.

Evapolation of, by user, 54 Embrey, 61 Dumont.

Fishing, public right of, in, 709 Cobb, 716 Willow, 717 note.

Injunction, to prevent diversion of, 76 note.

Irrigation, use of, for, 54 Embrey, 64 Meng.

Locomotives, use of, for, 68 Garwood.

Navigation in, public right of, 701 Brown, 706 Thunder, 706 note, 709 Cobb, 712 note.

Nonriparian, use of, by, 68 Garwood, 69 Gillis, 71 note, 71 Jones, SS Stock. port, 92 note.

Pollution of, 83 Hayes, 86 note, 87 note.

Preseriptive rights in, 73 Messinger, 74 note.

Riparians, who entitled as, 71 Jones. 88 Storkport, 92 note.

Right in, nature of, 54 Embrey, 58 Webb, 64 Meng, 75 New York, 76 note.

Underground, rights in, 135 Hale, 136 note.

SUBIJEASE,

Distinguished from assignment, 395 Holford, 390 Earl, $398 \mathrm{MCNeil,} 404$ note.

SURETY,

For rent, liability of, 420 Allen, 424 Walsh.

TAXES,

Covenant to par, when runs, 367 Gower, 369 note.

Scope of, $3 \$ 9$ Masor, 393 Wills.

TICKET,

As license, 309 Wood, 313 note.

TIMBER,

Cutting, when waste, 644 Owen, 646 Davis, 649 nnte, 678 Tdal, 684 Schermerhorn, 688 Bowles, 690 Rolle, 691 Clement, 693 note, $69 \pm$ Lushington.

TRAINS,

Corenant to stop, when runs, 452 Gilmer.

TRESPASS,

Injunction to prevent, 8 Richards.

To realty, what is, 1 Pfeiffer, 2 Smith, 3 note.

TASTE,

Altering buildings as, 653 Klie, 655 Melms.

Cutting thmber as, 644 Owen, 646 Davis, 649 note.

Defined, 639 Coke.

Equitable, what is, 6ss Bowles, 690 Rolle, 691 Clement, 693 note.

Injunction against, 678 Anon., 679 rerrot, 681 Klie, 682 note, 690 Rolle, C91 Clement, 693 note.

Life tenant, when liable for, 661 Cartwright, 672 Atlantic, 691 Clement, 693 note.

Meliorating, 642 Cole.

Merger, as affecting liability for, GS2 Dickinson.

Miuing as, 649 Gaines.

Negligent, 659 Countess, 660 note, 667 Chalmers, 670 Earle, 672 Atlantic.

Nominal, 643 Keepers, 644 note.

Permissive, 659 Countess, 661 Cartwright, 662 Morris.

Produets of, right to, 678 Udal, 684 Schermerhorn, 6S7 Bateman, 691 Luslington, 697 note, 698 Barrington.

Tail, tenaut in, not liable for equitable, 688 Lowles. 
WASTL-Continued,

Will, tenant at, liability for, 659 Countess, 660 note, 667 Chalmers.

Years, tenant for, liability for, 662 Morris, 670 Earle, 672 note, 690 Rolle.

WA'llis,

Corchant to supply, when runs, 373 Jourdain: 455 Atlanta.

litches, in, as personal property, 266 note.

Iivert, license to, when irrevocable, 305 Liggins.

Flood, obstruction of, 102 note.

Rights in, 99 Thompson.

I'ipes, easement to use, 213 Gray.

light to, acquirable by custom, 177 Race.

surface, artificial structures affecting, 116 IIurdman, 119 Fitzpatrick. Concentration of, 109 Yerex, 111 note, 111 Manteufel, 113 note.

Viversion of, 113 note, 114 Bowlsby.

Flood, distinguished from, 99 T'hompson, 102 note.

Negligence in changing course of, 119 Fitzpatrick, 120 note.

Oustructions of, 103 Barkeley, 107 Gormley.

Ponds, not, 97 Schaefer, 99 note.

Streams, distinguished from, 93 Eulrich, 95 note, 95 Macomber, 97 note.

Underground, diversion of, 121 Acton, 124 note, 125 Meeker.

Pollution of, 132 Kinnaird, 134 note.

Reasonable use of, 12:5 Meeker. 129 note, 130 Merrick, 131 note.

WAY, streams, rights in, 135 Hale, 136 note.

Easement of, departure from, 218 Dudgeon.

Extent of. 201 Howell, 201 Williams, 205 Watson. 207 White.

Interference with, by servient, 221 note, 222 Attorney General, 225 Bitello, 227 note.

Railroal, 22 Sittsburgh, 230 Atlantic.

WINDOWS, See Extinguishment of Easements.

WIIRL,

In party walls, 236 note.

Orerhanging, ejectment for, 3 Butler. 






C1

4.

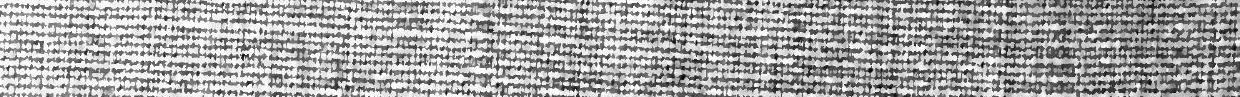

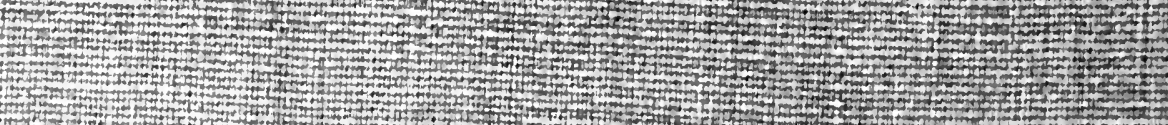
(1)

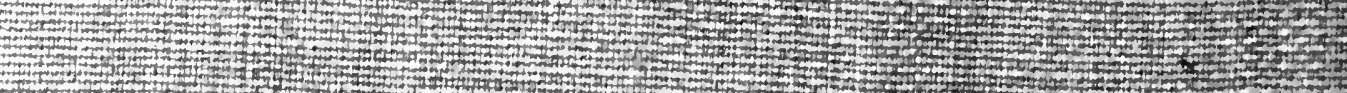

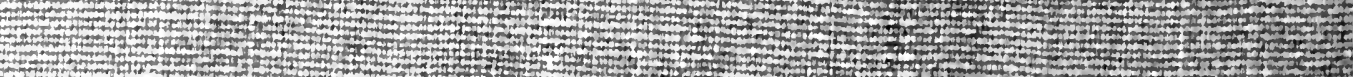

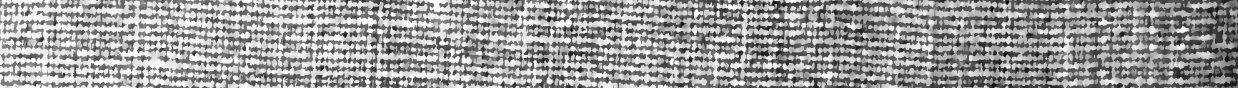

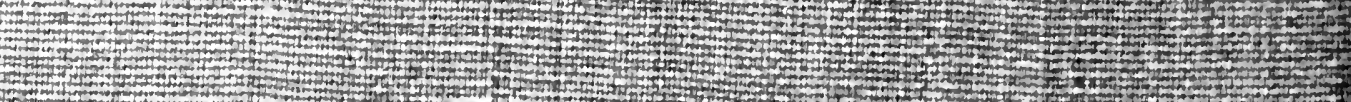

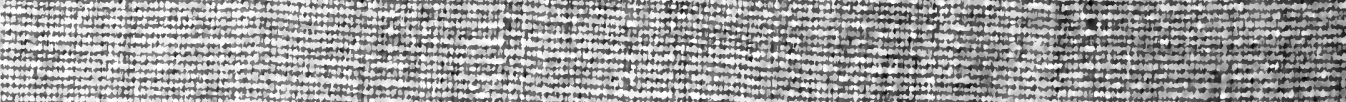

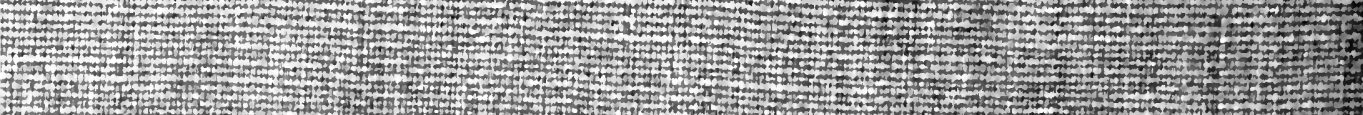

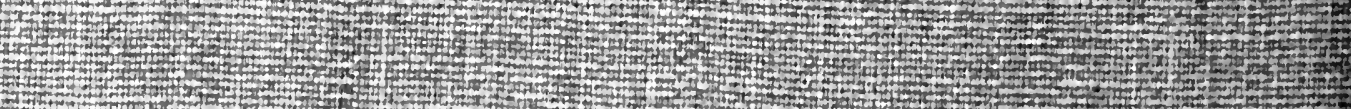

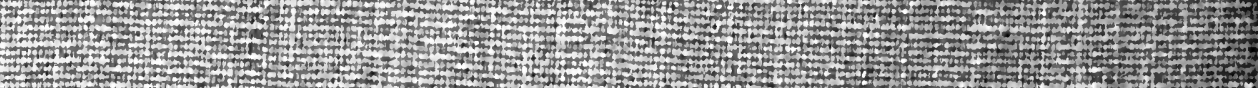

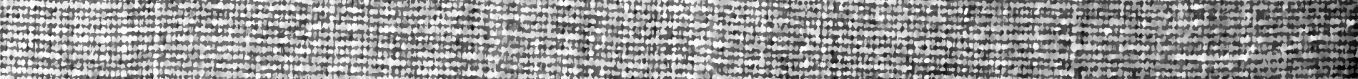

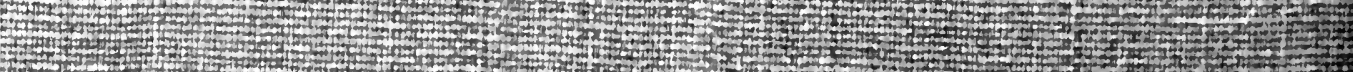

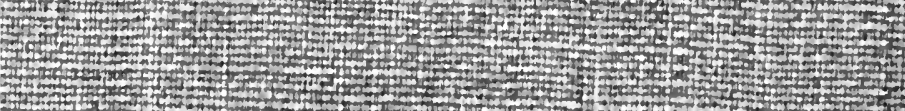

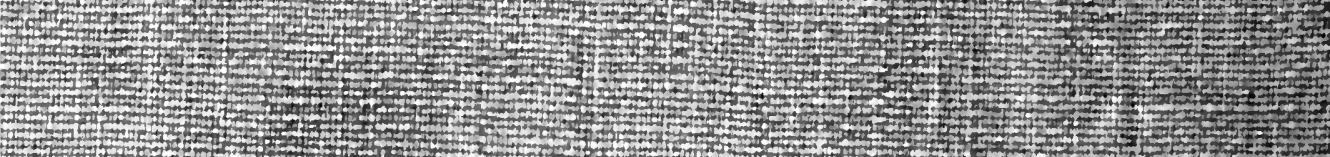

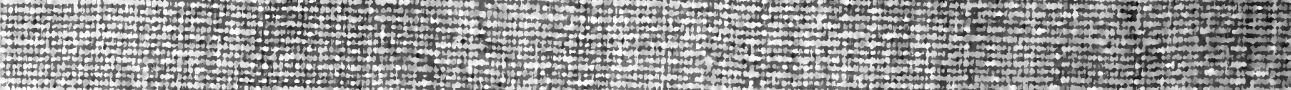

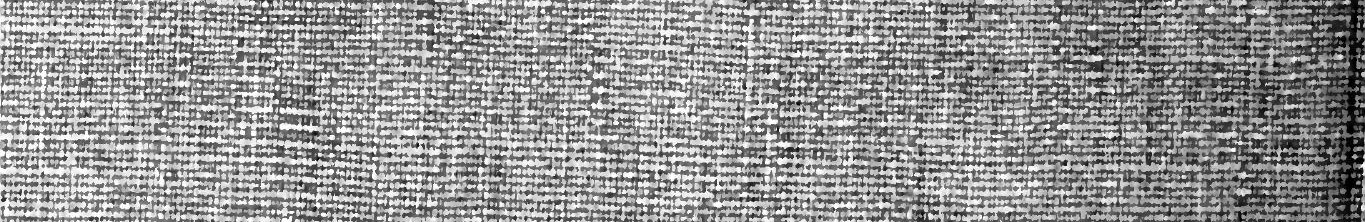

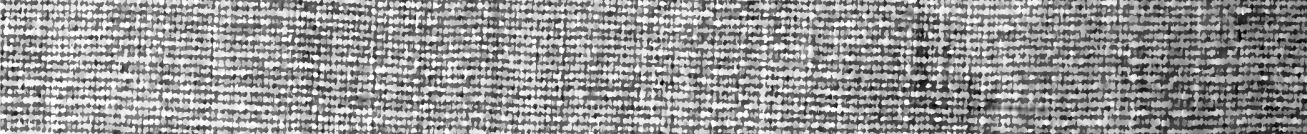

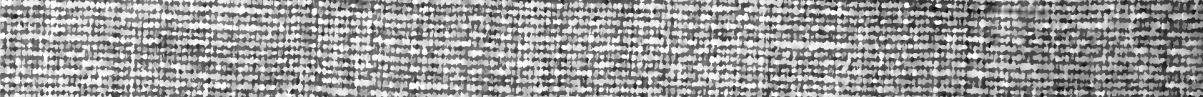

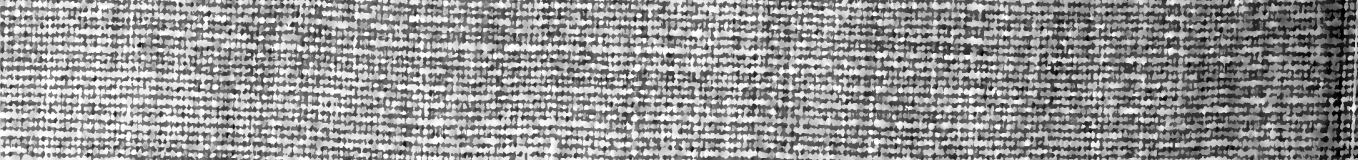
1.7.

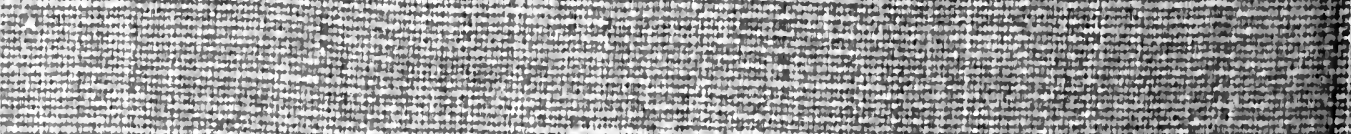

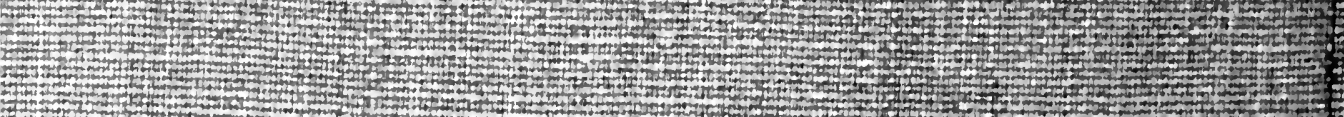

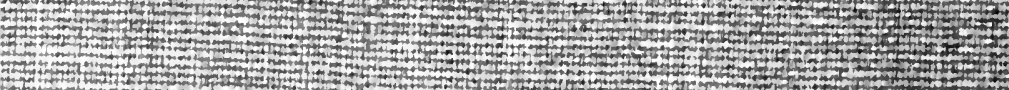
2.

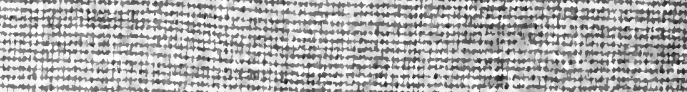

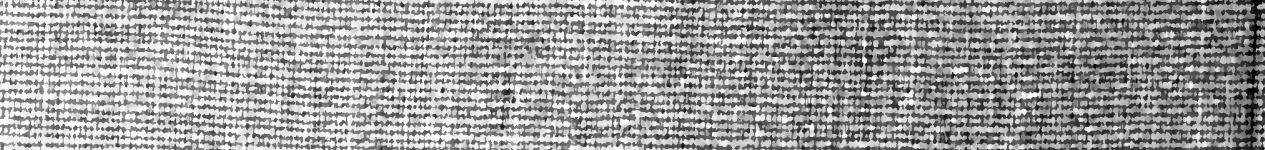
r.

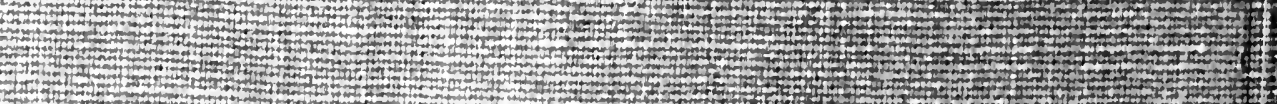

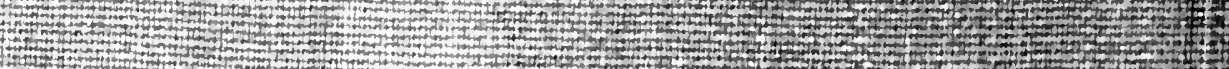

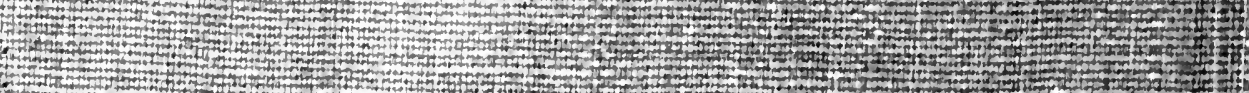

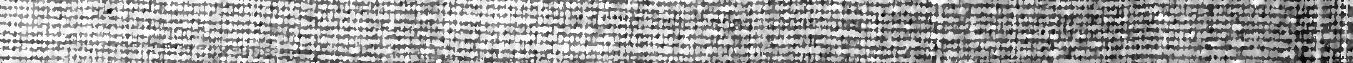

